\title{
INTERNATIONAL GONFERENGE ON EURASIAN ECONOMIES 2010
}





\section{T.C. BEYKENT UNIVERSITY}

\section{INTERNATIONAL GONFERENGE ON EURASIAN ECONOMIES 2010}

Istanbul - Turkey 4-5 November 2010 


\title{
INTERNATIONAL CONFERENCE \\ ON EURASIAN ECONOMIES
}

2010

\author{
Editors: \\ Selahattin Sarı, \\ E. Ayşen Hiç Gencer, \\ Alp H. Gencer
}

Copyright (C) 2010

Beykent University

ALL RIGHTS RESERVED.

This book contains material protected under International and Federal Copyright Laws and Treaties. Any unauthorized reprint or use of this material is prohibited. No part of this book may be reproduced or transmitted in any form or by any means, electronic or mechanical, including photocopying, recording, or by any information storage and retrieval system without express written permission from the author / publisher.

Typesetting: Alp H. Gencer

Printing: Şanofset

We gratefully acknowledge support by Istanbul 2010 European Capital of Culture Agency in financing of the printing of this book. 


\section{RECTOR'S ADDRESS}

Dear Colleagues and Dear Guests,

It is a great pleasure to welcome you all to the International Conference on Eurasian Economies 2010 at Beykent University, for which preparations were started with great zeal by the Department of Economics about a year ago, and which hopefully will be the first of a series of conferences to be held in different Eurasian countries each time, with a projection that aims at broadening academic interest regarding economic and social issues faced by the Eurasian economies during the transition process in the era of globalization by reaching to a more extensive and more diverse audience every year.

I would hereby like to inform you briefly about Beykent University, which was established in 1997 by Adem Çelik - Beykent Educational Foundation as a foundation university with public entity. Beykent University started courses in the 1997-1998 academic year at the Beylikdüzü Campus. In the 2002-2003 academic year, the ŞişliAyazağa Campus became operational. Education expanded to the Taksim Campus in the 2008-2009 academic year. Today, Beykent University has 34 undergraduate programs, 31 graduate programs, 2 post-graduate programs, 38 associate programs and 2 distance learning programs that are organized in 7 schools, 2 institutes and a vocation school. The language of instruction at Beykent University is Turkish and English. I can proudly declare that Beykent University is a dynamic institution with about 11,000 students, $20 \%$ of whom are on scholarship, with a renowned and esteemed faculty, with highly skilled staff, with state-of-the-art equipment and with a continual quest for improving intellectual and social atmosphere. Since its foundation Beykent University targeted at becoming one of the top worldwide universities, each and every member works in a family environment with great enthusiasm and excellence for accomplishing this vision.

On behalf of Beykent University, I would like to thank all the members of the Beykent family for the diligent efforts they have put forth in the realization of the International Conference on Eurasian Economies 2010; and I would like to express great appreciation and honor to all of you, academicians and researchers from all around the world for sharing your valuable work with us, hoping that all your presentations and discussions at this international event will provide a significant contribution to the world literature in the field of economics and will shed light to the decisions of policymakers. 


\section{FOREWORD}

Dear Authors, Dear Colleagues, Dear Guests,

We are pleased and honored to present to you this proceedings book of the International Conference on Eurasian Economies 2010 that was initiated by the Economics Department of Beykent University with an aspiration to make it a traditional annual international academic event. We hope that the International Conference on Eurasian Economies will provide a closer link between Eurasia and the world of science.

At a significant geographic and cultural point on which many cultures and ideas intersected throughout history, Turkey today carries out the distinctive mission of constituting a bridge between Asian and European countries in the era of globalization. By organizing this first conference in Istanbul, where Asia and Europe meet at the Bosphorus, we aimed at providing a forum for academicians and decisionmakers from all over the world to discuss and develop policies concerning current and future economic and social issues of Eurasia. We also hoped that the importance of Turkey will be highlighted in the economic development process of Eurasia under globalization. In the long run, we believe that effective policies will be developed and proposed via forthcoming conferences to be held in different countries in collaboration with different universities and various institutions.

The topics of the International Conference on Eurasian Economies 2010 cover a wide variety of general subjects in the light of economic and social policies that have immediate impacts on the region such as: Economic ties of Eurasian countries with other countries or country groups in today's global world, including trade, tourism and transportation; challenges and strategies regarding economic growth and development in Eurasian economies taking into account energy and natural resources management; policies targeting at development and level of regulation vs. deregulation of financial institutions and markets based on the experience of the 2008 global financial crisis.

Following our call for papers to the International Conference on Eurasian Economies 2010 worldwide at universities, institutions and academic research networks focusing on Eurasian economies, we received over 120 abstracts from 30 different countries. Of these studies, 67 presentations from 20 different countries are discussed at the International Conference on Eurasian Economies 2010. We wish that all of these valuable studies and following discussions will provide significant benefits to future research on Eurasian economies.

We would hereby like to convey our genuine thanks to all of you who have contributed to the conference by submitting and presenting your important work andor by taking active part in the discussion sessions. In addition, we would like to express our gratitude to the distinguished members of the scientific board for their dedicated efforts in the review process of these submissions, as well as to the outstanding session chairs for their excellence in leading the discussions. We proudly would like to offer our special thanks to the eminent members of the advisory board for making this conference possible. We also deliver our great appreciation to the 
organizing committee as well as to the web and print designers for their meticulous team-work. Of course, we would like to remark happily the help and interest on the part of all our students at Beykent University.

Moreover, we would like to gratefully mention our indebtedness to the academic and administrative personnel at the Department of Economics and Administrative Sciences, as well as to the staff at the Publicity and Public Relations Department, at the Support Services Department and at the Budget Department for kindly contributing to the conference in every way in their capacity.

We are also grateful to the Agency of Istanbul 2010 European Capital of Culture and to the Promotion Fund of Prime Ministry for their support in the organization and preparation of this conference and its events.

Last but not least, we would like to state our sincere respects to the Chairman of the Board of Trustees, Adem Çelik, and to the members of the Board of Trustees, to the Rectorate, to the Board of Directors, to the Secretary General.

Prof. Dr. Selahattin Sart

Chair of Organizing Committee,

International Conference on

Eurasian Economies
Prof. Dr. Ahmed Güner Sayar

Chair of Economics Department, Beykent University 


\section{ADVISORY BOARD}

- Prof. Dr. Mehmet Emin Karahan (Rector, Beykent University)

- Prof. Dr. Selahattin Sarı (Vice Rector, Beykent University)

- Prof. Dr. Erol Eren (Dean, Faculty of Economic and Administrative Sciences, Beykent University)

- Prof. Dr. Ahmed Güner Sayar (Chair, Department of Economics, Beykent University)

\section{ORGANIZING COMMITTEE}

- Prof. Dr. Selahattin Sarı

- Prof. Dr. Ahmed Güner Sayar

- Asst. Prof. Dr. E. Ayşen Hiç Gencer

- Asst. Prof. Dr. Mustafa Ercilasun

- Asst. Prof. Dr. İlyas Sözen

- Asst. Prof. Dr. Özgür Ömer Ersin

- Asst. Prof. Dr. Fatih Macit

- Asst. Prof. Dr. Perihan Paksoy

- Ph.D. Candidate Bekir Aşık

- Ph.D. Candidate Volkan Öngel

\section{WEB \& PRINT DESIGN}

- Dr. Alp H. Gencer

- Assoc. Prof. Dr. Larysa Zakharova 


\section{SCIENTIFIC BOARD}

- Prof. Dr. Şahin Akkaya (Istanbul University, Turkey)

- Prof. Dr. Ahmet Aksoy (Gazi University, Turkey)

- Prof. Dr. Serdar Altınok (Gazi University, Turkey)

- Prof. Dr. Sudi Apak (Beykent University, Turkey)

- Prof. Dr. Hanifi Aslan (Uludağ University, Turkey)

- Assoc. Prof. Dr. Ahmet Ay (Selçuk University, Turkey)

- Prof. Dr. Metin Balcı (Aydın University, Turkey)

- Assoc. Prof. Dr. Mehmet Balcılar (Eastern Mediterranean University, Cyprus)

- Prof. Dr. Cem Behar (Boğaziçi University, Turkey)

- Prof. Dr. Damira Bektenova (Slavian University, Kyrgyzstan)

- Prof. Dr. Melike Bildirici (Yıldız Technical University, Turkey)

- Prof. Dr. Faik Bilgili (Erciyes University, Turkey)

- Prof. Dr. Ersan Bocutoğlu (Karadeniz Technical University, Turkey)

- Prof. Dr. Cumabek Cailov (Kyrgyz Economic Research Center, Kyrgyzstan)

- Prof. Dr. Seyfullah Çevik (Gediz University, Turkey)

- Prof. Dr. İrfan Civcir (Ankara University, Turkey)

- Prof. Dr. Nevin Coşar (Yıldız Technical University, Turkey)

- Prof. Dr. Selçuk Emsen (Erzurum Atatürk University, Turkey)

- Assoc. Prof. Dr. Alpay Filiztekin (Sabancı University, Turkey)

- Prof. Dr. Saziye Gazioğlu (Middle East Technical University, Turkey)

- Prof. Dr. Cevat Gerni (Gebze Institute of Technology, Turkey)

- Prof. Dr. Ahmet Gökçen (Istanbul University, Turkey)

- Prof. Dr. Muhsin Halis (Sakarya University, Turkey)

- Prof. Dr. Süreyya Hiç (Kocaeli University, Turkey)

- Prof. Dr. Mükerrem Hiç (Beykent University, Turkey)

- Prof. Dr. Ahmet Incekara (Istanbul University, Turkey)

- Assoc. Prof. Dr. Metin Karadağ (Ege University, Turkey)

- Prof. Dr. Ridvan Karluk (Eskişehir Anadolu University, Turkey)

- Prof. Dr. Mehmet Kaytaz (Işık University, Turkey)

- Prof. Dr. Nuriddin Kayumov (Tajikistan Academy of Sciences, Tajikistan)

- Prof. Dr. Gülten Kazgan (Bilgi University, Turkey)

- Prof. Dr. Recep Kök (Dokuz Eylül University, Turkey)

- Prof. Dr. Turar Koychuev (Kyrgyz-Turkish Manas University, Kyrgyzstan)

- Prof. Dr. Suat Oktar (Marmara University, Turkey)

- Prof. Dr. Ali Ozgüven (Kültür University, Turkey)

- Prof. Dr. Jusup Pirimbaev (Kyrgyz-Turkish Manas University, Kyrgyzstan)

- Prof. Dr. Süreyya Sakınç (Celal Bayar University, Turkey)

- Prof. Dr. Recep Tarı (Kocaeli University, Turkey)

- Prof. Dr. Muammer Tekeoğlu (Cukurova University, Turkey)

- Prof. Dr. Sübidey Togan (Bilkent University, Turkey)

- Prof. Dr. Münevver Turanlı (Istanbul Commerce University, Turkey)

- Prof. Dr. Bahadir Umurzakov (Russian Economic Academy, Russia)

- Prof. Dr. Halit Yanıkkaya (Gebze Institute of Technology, Turkey)

- Prof. Dr. Ahmet Yörük (Kadir Has University, Turkey)

- Prof. Dr. Ahmet Yüksel (Beykent University, Turkey) 


\section{Contents}

\section{OPENING SESSION}

\section{Keynote Address}

Major Current Economic and Political Problems Facing Eurasian Countries .1

- Prof. Dr. Mükerrem Hiç, Beykent University, Turkey

SESSION 1A: Küresel Kriz

Session Chair: Prof. Dr. Erol Eren

Küresel Kriz Sonrası Türk Cumhuriyetleri Ekonomileri ve Türkiye ile Ticari İlişkileri .5

- Assoc. Prof. Dr. Müslüme Narin, Gazi University, Turkey

- Assoc. Prof. Dr. Akın Marşap, Istanbul Aydin University, Turkey

2008 Küresel Kriz Bağlamında Baltık ve Bağımsız Devletler Topluluklarının Karşılaştırmalı Ekonomik Performansları

- Mr. Savaş Erdoğan, Selçuk University, Turkey

- Assoc. Prof. Dr. Ahmet Ay, Selçuk University, Turkey

- Mr. Mustafa Gerçeker, Selçuk University, Turkey

2008 Küresel Krizinin Avrasya Ülkelerinin Ekonomileri Üzerindeki Etkileri.

- Mr. Bilal Özer, Okan University, Turkey

- Mr. Alper Karaağaç, Okan University, Turkey

- Mr. Ismail Önden, Okan University, Turkey

Rusya'nın Serbest Piyasa Anlayışı ve Küresel Kriz

- Asst. Prof. Dr. İsmail Hakkı İșcan, Bilecik University, Turkey

- Mrs. Yıldız Zeliha Hatipoğlu, Bilecik University, Turkey

SESSION 1B: Growth \& Development

Session Chair: Prof. Dr. Sudi Apak

The Impact of Globalization on Eurasian Economies: Prospects for Development in the 21st

Century......

- Prof. Dr. Berch Berberoglu, University of Nevada, Reno, United States of America

Who is Better Equipped for Globalization in Eurasia? A Seven-Country Analysis.

- Prof. Dr. Tansu Barker, Brock University, Canada

Some Major Causes of Current Economic Crises and Leadership Strategies

- Prof. Dr. Asım Şen, Beykent University, Turkey

Convergence Across Kazakh Regions

- Ph.D. Candidate Miriam Frey, University of Regensburg, Germany

- Ph.D. Candidate Carmen Wieslhuber, University of Regensburg, Germany 
SESSION 1C: Uluslararası İlişkiler Session Chair: Prof. Dr. Cevat Gerni

Avrasya Bağlamında Türklerin Misyonu ve Küreselleşme İdeolojisi .64

- Prof. Dr. Recep Kök, Dokuz Eylül University, Turkey

Küresel Dünyada Orta Asya Türk Cumhuriyetlerinin Konumu .75

- Mrs. Esra Karapınar, Zirve University, Turkey

Avrasya Ekonomik Topluluğu: Bir İktisadi İşbirlliği Alternatifi. .82

- Prof. Dr. Jusup Pirimbayev, Kyrgyz-Turkish Manas University, Kyrgyzstan

- Dr. Junus Ganiyev, Kyrgyz-Turkish Manas University, Kyrgyzstan

Türkiye İçin Alternatif Bir Dış Ticaret Pazarı : Avrasya Ekonomik Topluluğu. .86

- Ph.D. Candidate Volkan Öngel, Beykent Üniversitesi, Turkey

SESSION 2A: Global Crisis

Session Chair: Prof. Dr. Gülten Kazgan

Foreign Capital in Russia and Hong Kong: Postmortem of International Financial Crisis .92

- Prof. Dr. Şaziye Gazioğlu, University of Aberdeen, United Kingdom

- Ph.D. Candidate Ülkem Başdaş, Middle East Technical University, Turkey

Credit Behaviour of Banks in the European Union in the Wake of Global Economic Crisis.....98

- Prof. Dr. Stanislav Polouček, VŠB-Technical University of Ostrava, Czech Republic

Economic Crisis in Kazakhstan. 106

- Assoc. Prof. Dr. Abu Mukhammedov, University of International Business, Kazakhstan

- Ph.D. Candidate Madina Kairbekova, Eurasian Market Institute, Russia

The Present Global Crisis and Its Effect on the Turkish Economy..... 110

- Dr. Özlen Hiç Birol, Boğazici University, Turkey

SESSION 2B: Büyüme ve Gelişme

Session Chair: Prof. Dr. Muhittin Karabulut

Sektörel Büyüme Oranları Arasındaki Karşılıklı İlişki.

- Mr. Ismail Önden, Okan University, Turkey

- Mr. Bilal Özer, Okan University, Turkey

- Mr. Alper Karaağaç, Okan University, Turkey

Türkiye'nin Doğu Bölgeleri ve Sahil-Batı Bölgeleri arasında Toplu Göç Süreci.... 121

- Asst. Prof. Dr. Tahsin Bakırtaş, Sakarya University, Turkey

- Dr. Orhan Kandemir, Kastamonu University, Turkey 
Demokrasi ve Ekonomik Kalkınma: 1992 Sonrası Orta Asya Türk Cumhuriyetleri için Bir Analiz.

- Ph.D. Candidate Ali Pişkin, Doğuş University, Turkey

- Ph.D. Candidate Dinçer Dedeoğlu, Bahçeşehir University, Turkey

Orta Asya Cumhuriyetlerinde Yolsuzluk ve İktisadi Özgürlük (2001-2008).

- Asst. Prof. Dr. İlyas Sözen, Beykent University, Turkey

- Asst. Prof. Dr. Ahmet Alkan Çelik, Beykent University, Turkey

- Prof. Dr. Selahattin Sarı, Beykent University, Turkey

SESSION 2C: International Relations

Session Chair: Prof. Dr. Mithat Baydur

Geoeconomic Ties of Eurasian Countries with the United States, European Union, Russia and

China.

- Mrs. Ruxandra Ionela Chiran, Bucharest Academy of Economic Studies, Romania

Turkey as an EU Member as Seen by EU, Russia and USA in Integration Networks prospect

- Ph.D. Candidate Anna Akutina, Catania University, Italy

A comparative analysis of remittance behaviour between East European and North African migrants

- Prof. Dr. Monica Roman, Bucharest Academy of Economic Studies, Romania

- Ph.D. Candidate Bogdan Ileanu, Bucharest Academy of Economic Studies, Romania

- Prof. Dr. Mihai Roman, Bucharest Academy of Economic Studies, Romania

Migrants' Remittances in Romania and Balkan Countries: A Macro-Economic Perspective. .160

- Prof. Dr. Zizi Goschin, Bucharest Academy of Economic Studies, Romania

- Ph.D. Candidate Aura Popa, Bucharest Academy of Economic Studies, Romania

- Prof. Dr. Mihai Roman, Bucharest Academy of Economic Studies, Romania

SESSION 3A: Küresel Kriz ve Finans

Session Chair: Prof. Dr. Şahin Akkaya

2008 Küresel Krizi ve Sonrası Avrasya Ekonomilerinde Finans Sektörü.

- Dr. Naci Yılmaz, İş Bankası, Turkey

- Dr. Bora Selçuk, Kadir Has Universitesi, Turkey

Gelişmekte Olan Ülkelerde Küreselleşme, Uluslararası Sermaye Hareketleri ve Finansal Krizler Arasındaki İlişki.

- Asst. Prof. Dr. Ayfer Gedikli, Kırklareli University, Turkey

Hisse Senedi Fiyatları İle Döviz Kuru Arasındaki Dinamik İlişkinin Belirlenmesi: Avrasya

Örneği.

- Dr. Bekir Elmas, Erzurum Atatürk University, Turkey

- Ph.D. Candidate Ömer Esen, Erzurum Atatürk University, Turkey 
SESSION 3B: Growth \& Development

Session Chair: Prof. Dr. Ahmed Güner Sayar

Effects of Foreign Direct Investment on Growth in Turkey.

- Prof. Dr. Melike Bildirici , Yıldız Technical University, Turkey

- Dr. Elçin Aykaç Alp, Yıldız Technical University, Turkey

- Ph.D. Candidate Fazıl Kayıkçı, Yıldız Technical University, Turkey

European Enlargement Policy for the Western Balkans: Case of Montenegro

- Prof. Dr. Gordana Djurovic, University of Montenegro, Montenegro

- Prof. Dr. Danijela Jacimovic, University of Montenegro, Montenegro

Does the Law of One Price Hold in a High-Inflation Environment? A Tale of Two Cities in

Turkey

- Dr. Sule Akkoyunlu, ETH Zurich, Switzerland

- Mr. Boriss Siliverstovs, ETH Zurich, Switzerland

SESSION 3C: Enerji ve Endüstri

Session Chair: Prof. Dr. Ahmet Yörük

Avrasya Ülkeleri Açısından Yenileşen Dengeli Enerji Yönetiminde Paylaşılan Stratejik

Yaklaşımlar.

- Assoc. Prof. Dr. Akın Marşap, Istanbul Aydin University, Turkey

- Assoc. Prof. Dr. Müslüme Narin, Gazi University, Turkey

- Asst. Prof. Dr. Irfan Özcan, Akdeniz University, Turkey

Avrasya Enerji Birliği Mümkün mü?

- Ph.D. Candidate Ceyhun Haydaroğlu, Bilecik University, Turkey

- Ph.D. Candidate Çağdaş Zarplı, Bilecik University, Turkey

Girdi-Çıktı Analizi Yaklaşımıyla Kırgızistan İmalat Sanayinin İncelenmesi (2005-2008)

- Asst. Prof. Dr. Tuncer Ozdil, Kyrgyz-Turkish Manas University, Kyrgyzstan

- Mrs. Ainura Turdalieva, Kyrgyz-Turkish Manas University, Kyrgyzstan

SESSION 4A: Finance

Session Chair: Prof. Dr. Mehmet Kaytaz

Causality Relations between Foreign Direct Investment and Portfolio Investment Volatility. 232

- Ph.D. Candidate Giray Gözgör, Dogus University, Turkey

- Asst. Prof. Dr. Ömer Yaman Erzurumlu, Doğus University, Turkey

Political Risk and Foreigners' Trading: Evidence from Turkey's Emerging Stock Market......240

- Mrs. Deniz İkizlerli, Durham University, United Kingdom

- Assoc. Prof. Dr. Numan Ulku, Central European University, Hungary 
Globalization and Formation of National Pension System Concept in Ukraine: Practice, Problems and Future Trends.

- Dr. Nataliya Rad, Donetsk National University of Economics and Trade, Ukraine

The Determinants of Net Interest Margin in Conventional and Islamic Banks in Indonesia...252

- Mr. Ascarya Ascarya, Central Bank of Indonasia, Indonesia

- Mrs. Diana Yumanita, Central Bank of Indonasia, Indonesia

SESSION 4B: Development

Session Chair: Prof. Dr. Süreyya Hiç

Tradition and Poverty Reduction - Mahalla and its Significance in Development Process in

Tajikistan

- Ph.D. Candidate Anna Cieslewska, University of Warsaw, Poland

The Innovation Zone As A Strategic Element In National Economy. .264

- Assoc. Prof. Dr. Vidadi Zeynalov, Azerbaijan State Economic University, Azerbaijan

SESSION 4C: Energy

Session Chair: Prof. Dr. Ersan Bocutoğlu

The Dependency Game and Potential Gains in Energy Sector of Eurasia

- Asst. Prof. Dr. Yeşim Reel, Marmara University, Turkey

The Economy and Security of Energy in the Eurasian Region.

- Mr. Alper Karaağaç, Okan University, Turkey

- Mr. Ismail Önden, Okan University, Turkey

- Mr. Bilal Özer, Okan University, Turkey

The Nabucco Project within Context of Energy Supply Security and International Politics...282 - Asst. Prof. Dr. Gökhan Özkan, Yalova University, Turkey

The Role of Turkey in the Energy Supply of EU: A Cost and Benefits Analysys

- Asst. Prof. Dr. Abdulkadir Develi, Bayburt University, Turkey

- Assoc. Prof. Dr. Ahmet Ay, Selçuk University, Turkey

- Assoc. Prof. Dr. Zeynep Karaçor, Selçuk University, Turkey

SESSION 5A: International Trade

Session Chair: Prof. Dr. Şaziye Gazioğlu

Exports, Imports and Economic Growth in Iran: An Application of Bounds Test Approach to

Cointegration.

- Asst. Prof. Dr. Hassan Heidari, Urmia University, Iran

- Mrs. Narmin Davoudi, Urmia University, Iran

A Study of the Effects of Non-oil Exports on Iranian Economic Growth.

- Dr. Naser Ali Yadollahzadeh Tabari, Islamic Azad University, Iran

- Ph.D. Candidate Mohammad Nasrollahi, Islamic Azad University, Iran 
An Analysis of Trade Integration in the Commonwealth of Independent States Region

- Dr. Nuray Terzi, Marmara University, Turkey

- Dr. Erdem Turgan, Marmara University, Turkey

Competitiveness of Turkey in Eurasia: A Comparison with CIS Countries.

- Asst. Prof. Dr. Hacer Simay Karaalp, Pamukkale University, Turkey

SESSION 5B: İşletme ve Turizm

Session Chair: Prof. Dr. Melike Bildirici

Rekabet Politikası Ekseninde Avrasya Ekonomileri

- Asst. Prof. Dr. M. Okan Taşar, Selçuk University, Turkey

- Asst. Prof. Dr. Savaş Çevik, Selçuk University, Turkey

Türk Cumhuriyetlerinin Ulusal Güçlerinin Entegrasyon İçi ve Küresel Düzeyde Pazarlanması

- Prof. Dr. Muhittin Karabulut, Beykent University, Turkey

- Asst. Prof. Dr. Tuğba Karabulut, Istanbul Commerce University, Turkey

Turizm Sektörünün İstihdam Yaratmadaki Yeri ve 2009 Krizinin Türkiye Turizm İstihdamına

Etkileri.

- Ph.D. Candidate Didar Sarı, Sakarya University, Turkey

- Ph.D. Candidate Zefure Uçar, Sakarya University, Turkey

Ekonomik Kriz Dönemlerinde Turizm ve Seyahat Endüstrisinin Tutumu.

- Asst. Prof. Dr. Perihan Paksoy, Beykent University, Turkey

- Asst. Prof. Dr. Nurdan Çolakoğlu, Beykent University, Turkey

SESSION 5C: Глобальный кризис

Session Chair: Prof. Dr. Turar Koychuev

Кыргызстан: трудный путь к оздоровлению.

- Prof. Dr. Turar Koychuev, Kyrgyz-Turkish Manas University, Kyrgyzstan

Банковская система Украины в условиях преодоления последствий мирового экономического кризиса

- Dr. Valentina Orlova, Donetsk National University of Economics and Trade, Ukraine

Развитие здравоохранения и экономический рос

- Assoc. Prof. Dr. Damira Japarova, Kyrgyz-Turkish Manas University, Kyrgyzstan

Новый Подход к Инвестиционным Коэффициентам.

- Prof. Dr. Anarkül Urdaletova, Kyrgyz-Turkish Manas University, Kyrgyzstan

- Prof. Dr. Sirgak Kıdıraliyev, American University of Central Asia, Kyrgyzstan 
SESSION 6A: Uluslararası Ticaret

Session Chair: Prof. Dr. Ali Ozgüven

Türkiye'nin Orta Asya Ülkeleriyle Ticareti: Almanya ve İran'la Karşılaştırmalı Bir Analiz...379

- Asst. Prof. Dr. Abdullatif Ceviker, Gaziantep University, Turkey

- Asst. Prof. Dr. H. Murat Mutlu, Gaziantep University, Turkey

- Mr. İsmail Taş, Gaziantep University, Turkey

Türkiye ile Orta Asya Türk Cumhuriyetleri Arasındaki Endüstri-Içi Ticaretin Analizi .386

- Dr. Murat Ozan Başkol, Uludağ University, Turkey

Geçiş Sürecindeki Türk Cumhuriyetlerinde Ekonomik Büyüme ve İhracat İlişkileri.....

- Prof. Dr. Selahattin Sarı, Beykent University, Turkey

- Prof. Dr. Cevat Gerni, Gebze Institute of Technology, Turkey

- Assoc. Prof. Dr. Mustafa Kemal Değer, Karadeniz Technical University, Turkey

- Prof. Dr. Ömer Selçuk Emsen, Erzurum Atatürk University, Turkey

Türkiye-Ermenistan Sınır Kapısının Açılmasının Türkiye ve Ermenistan Ekonomileri

Üzerindeki Muhtemel Etkileri Üzerine Bir Araştırma.

- Prof. Dr. Ersan Bocutoğlu, Karadeniz Technical University, Turkey

- Mr. Emre Bulut, Karadeniz Technical University, Turkey

SESSION 6B: Microeconomics

Session Chair: Assoc. Prof. Dr. Alpay Filiztekin

A Study on the Entry Strategies of Turkish Companies to Emerging Economies

- Asst. Prof. Dr. Duygu Anil Keskin, Istanbul University, Turkey

- Prof. Dr. Ibrahim Anil, Marmara University, Turkey

- Prof. Dr. Cem Canel, University of North Carolina, Wilmington, United States of America

Competition in the Banking Sector in the Czech Republic.....

- Assoc. Prof. Dr. Daniel Stavarek, Silesian University, Czech Republic

- Ph.D. Candidate Iveta Rapkova, Silesian University, Czech Republic

Global Crisis And Its Effects In The Developed And Emergent Countries - "The Bottom Of

The Pyramid" As An Innovation Resource.

- Mrs. Irma Shyle, Polytechnic University of Tirana, Albania

- Dr. Elenica Pjero, University of Ismail Qemali, Albania

Is Origin Denomination an Important Marketing Strategy? The Case of Spanish Wine Industry

- Prof. Dr. Luis Navarro, Universidad de Zaragoza, Spain

- Asst. Prof. Dr. Jesus Pastor, Universidad de Zaragoza, Spain

- Prof. Dr. Ana Clara Pastor, Universidad de Zaragoza, Spain

- Mr. Adrian Archanco, Universidad de Zaragoza, Spain 
SESSION 6C: Food \& Agriculture

Session Chair: Prof. Dr. Emin Özbaş

Global Food Prices, Agricultural Transformation and Food Security in Central Asia.....

- Dr. Kamiljon Akramov, International Food Policy Research Institute, United States of America

The Management Of The Agricultural Structure Of Russia While Maintaining Food Security In The Era Of Globalization.

- Prof. Dr. Irina Soldatova, South Federal University, Russia

- Prof. Dr. Viktor Ovchinnikov, South Federal University, Russia

- Prof. Dr. Michail Chernishev, South Federal University, Russia

- Prof. Dr. Nicolay Kuznesov, Rostov State University of Economics, Russia

Food Demand Analysis of Indonesian Households: Do They Eat Better or Smoke when They

Get Richer?.

- Ph.D. Candidate Evita Hanie Pangaribowo, University of Bonn, Germany

Cooperatives in the Agriculture of Germany: Position and Perspectives under the Conditions of Globalization. 453

- Ph.D. Candidate Igor Tonkoshkurov, Khakassia State University named after Nikolaj

Katanov, Russia 


\title{
Major Current Economic and Political Problems Facing Eurasian Countries
}

\author{
Mükerrem Hiç, Beykent University
}

\section{Introductory}

Political and economic developments and problems are either directly or indirectly linked to each other. Hence, I would be dealing here with both. But the problems are so serious, numerous and complicated that I will be content with only submitting a list of these problems without deepening on any. It should also be stressed that Eurasia itself as a geographical entity covers a very large number of countries with different historical, political and economic backgrounds. Hence, we may have to think about different regions or groups of countries. On the European side, even the EU is not homogeneous today. We have the United Kingdom, Scandinavian countries, developed continental European countries, Iberian countries, the Balkans and Eastern European countries. Even in simple developmental terms, we have at least two tiers, a first tier of democratically and economically developed countries, and the second tier those with less experience in democracy and less economically developed. In Asia, on the other hand, we have such big countries as Russia, China, Japan and India, as well as such regional groups as South-East Asian countries, Central Asian Turkic-origin countries, Caucasian, Afghanistan and Pakistan also including Bangladesh, and Middle-Eastern, with Iran as a separate politico-economic entity. Similarly, Turkey, at the cross-roads between Europe, Asia and the Middle-East, is another, but different unique case.

\section{Major Political Problems}

Eurasian countries and the world as a whole recently passed through the following major political developments, changes and upheavals:

- Following Perestroika and Glasnost (1985), the demolition of the Berlin Wall (1989), re-unification of Germany (1990) and the collapse of Soviet Socialist Union (1991), by which latter event member countries in Eastern Europe and the Balkans gained their independence. They all have adopted democracy and market economy.

- But due to lack of previous experience with democracy and, in some cases due to lack of sufficient mass education, democracy as well as economic management is far from satisfactory in many of these countries. This evaluation applies to Russia as well, particularly for democracy.

- On the surface, the collapse of the Soviet Union turned the bi-polar world to monopolar. But the USA, as remaining super-power soon learned that she is not overpowerful; there are strong limits and restraints to her use of military power and diplomatic persuasion. In fact, there is now talk of a multi-polar world in process, with the USA still the most dominant.

- Another concomitant political and economic development was the enlargement and the deepening of the EU. By taking in most of the Balkan and Eastern European countries, the number of EU members now reached 27. A serious effort at economic deepening was first the "Single Market", and more recently the "Euro". But the EU is, however, still far from becoming a "United States of Europe", like the USA, politically and militarily.

- Still another Eurasian and world development is the strengthening of the religious factor in the EU and Europe. This is compounded by Islamic terror, Islamic fundamentalism, as well as difficulties of adaptation of Muslim immigrants to their host EU countries. 
- Communism as a political and economic regime, on the other hand. seems to be withering away, permanently. At present we have only 5 countries that are "people's republic", that is, communist. Of the five, China seems to retain only the dictatorship, but implement a mixed economic regime that is open to the world and encourages the private sector and foreign private capital flow with, however, prudent interventionism and excessive (neo-Mercantilist) protectionism. The rest of the 4 remaining communist countries, of which 3 are in South-East Asia, are too small to flare up any major political upheaval, even the erratic North Korea. And all are set to go the way of China in the future.

- The recent years also found Eurasia with persistent specific political problems pertaining directly to two or a limited number of countries. These include the Israeli-Palestinian problem in the Middle-East; Iraqi occupation by the USA and present withdrawal efforts; Kashmir problem between India and Pakistan; NagornoKarabagh issue between Armenia and Azerbaijan; the Chechen problem in Russia; and the Russian-Georgian-Abkhazian problem, not mentioning the internal problems of China.

\section{Major Economic Problems}

In the global economic area, on the other hand, again we have very important developments and serious problems, many still in transition.

- $\quad$ Since the years 1970s most of the less developed countries (LDCs) had turned away from a closed economy model, import-substitution industrialization, interventionism and protectionism towards outward-orientation, market economy and encouragement of private sector and foreign private capital flow. Following this change in mentality, hence economic policies, the world entered since 1990s what is called a globalization process. Globalization involves vast movements of foreign private capital (direct private investments), short and long term financial funds, as well as legal and illegal movement of workers, the first two not only within developed countries (DCs) and from DCs to LDCs, but also within LDCs and from LDCs to DCs.

- Globalization was aided by the recent technological breakthrough of computers, internet and related technologies. Indeed, one may safely foresee that this technological innovation is destined to shape our future in all aspects. The magnitude of its effects will be comparable to the industrial revolution of the 18th century, the invention of the steam engine and of electricity.

- As a result of globalization, growth rates of all countries rose, those of LDCs more than those of DCs. This signified that globalization is a "win-win" situation and not a "zero-sum game".

- As a result of growth, while we had only two groups of countries after World War II, the DCs and the LDCs, today we have several tiers of countries with respect to per capita income level, as well as total GNP level.

- Using the latter criterion we now have the BRICs (Brazil, Russia, India and China) with very high total GNP. That of China, has become second only to the USA, surpassing Japan and others. Next we have the "emerging markets" that attract large amounts of financial funds and DPIs. Turkey today is rated as an emerging market.

- But globalization also gave rise to serious, in fact, grave economic problems. Firstly, many countries, such as Russia, Turkey, Argentina faced serious economic crises on a single-country basis because of wrong economic policies pursued. But then, in 1997-98 the South-East Asian countries, again because of economic 
mismanagement, gave rise to a global financial crisis which was quickly prevented by IMF aid and a strong US economy at the time. Followingly, globalization process started to pick up speed again.

- But a much more serious global economic crisis erupted in September 2008. It emanated first in the USA financial sector (mortgage or financial crisis) creating a deep recession, then went on to spread to the DCs and thence to LDCs and the entire world. The ensuing global financial crisis and global recession, which was the worst the world faced, second only to the 1929 Great Depression, was alleviated by means of drastic financial aid to the financial sector and aid to the automotive sector as well as macro monetary policies, tax policies and extensive government expenditure programs. The latter-mentioned macro economic policies were all Keynesian in essence. The entire world and major countries acted in cooperation when taking these measures. And it is noteworthy that the medium of cooperation resorted to was not G8 but G20, that is, 20 countries with the largest GNP. Hence, the group includes the BRICs as well as Turkey.

- The negative effect of the drastic measures taken to prevent the global economic crisis will continue for some more time in the future. But a second dip, initially feared, will likely not come to pass.

- It is interesting that the 2008 global crisis will also not likely revert the world away from globalization. Definitely, there had been precipitous declines in the level of global flows initially, but they are picking up again. Similarly, as the base for globalization, the market economy will also remain in essence despite the contrary remarks made by the French president. The world as a whole will not move towards a French-type dirigiste, that is, interventionist economic model. Emerging markets, however, will have to be cautious today about letting in "hot money" as well as those funds that do not create domestic production and employment possibilities.

- On the global scene again, energy supply will still continue to present problems. Petroleum and natural gas is unevenly distributed between countries, while petroleum exploration, production (extraction) is, for a long time, monopolistic. Increased economic growth worldwide raises the world demand for energy but progress in alternative energy sources is unsatisfactory. Energy-saving, on the other hand, is insufficient. Nuclear energy is one way out but it is rightly considered prohibitive because it can easily be turned into a powerful military weapon.

\section{Major Political and Economic Problems Turkey is Facing}

Major political and economic problems Turkey is facing today is listed below in brief:

- Deficiencies and insufficiencies in the practice and implementation of democracy.

- The question of insufficient general cultural level.

- Corruption and partisanship affecting the economy as well as social justice negatively.

- The Kurdish and the PKK problem in conjunction with Iraq, the USA and the EU.

- The impasse and dichotomy with regard to Armenia and Azerbaijani relations.

- The question whether the strengthening of religiousness poses a threat to laicism or is absorbed and is absorbable within the principle of laicism.

- The slackening in Turkey's relations and membership negotiations with the EU; the negative role of the unresolved Cyprus issue; the question whether the EU played fair in the prolongation of this issue.

- Recent turn of Turkey towards Iran, Islamic Middle-Eastern countries as well as Russia. The recent political antagonism towards Israel. The question, is all of this an 
evidence that Turkey is changing her axis, or is the change dictated merely by economic conditions, the fact that the economy of the EU, Turkey's major economic partner, lost altitude on account of the recent global economic crisis.

- Turkey as a route to European energy supply versus alternative routes that avoid Turkey.

- Too much reliance on hot money and flow of funds that do not create production, employment and export opportunities for the Turkish economy. 


\title{
Küresel Kriz Sonrası Türk Cumhuriyetleri Ekonomileri ve Türkiye ile Ticari İlişkileri
}

\author{
Müslüme Narin, Gazi Üniversitesi \\ Akın Marşap, İstanbul Aydın Üniversitesi
}

\section{Abstract \\ Economies of Turkic Republics After 2008 Global Crisis and Their Commercial Relations with Turkey}

In 2008, world economy has faced with the largest crisis, since the great depression in 1929 . The economic crisis, which started at financial markets, has turned into dramatic occasion in the second half of 2008 and got under control real economy. As a result of globalism, this crisis has affected developing economies as much as developed economies. Growth rate of Turk Republics and Turkey has decreased with the effect of the crisis.

The aim of this paper is to analyze Turkic Republics economies after global crisis and their commercial relations with Turkey. By this way, first the causes of the global crisis and its effects on world economy will be focused and then, all of the economical situation of the Turkic Republics and global crisis has affected on its will be discussed. Finally, Turkic Republics commercial relations with Turkey will be inquired.

JEL Codes: E, F

\section{Giriș}

1980'li y1llardan itibaren dünyada uygulanan serbestleşme hareketleri ve finansal sistemlerde gerçekleştirilen yenilikler, ülke ekonomilerini önemli derecede etkiler hâle gelmiştir. Teknolojik ilerlemeyle birlikte bilgiye daha kolay ve düşük maliyetle ulaşılabilmesi, bilginin daha etkin kullanımını sağlamış, risk ve getiri beklentilerine göre birçok finansal ürün geliştirilmiştir. Finansal ürünlerdeki çeşitlilik, bir yandan risk tercihlerini genişletmiş, öte yandan katılımcı sayısını artırarak piyasanın büyümesine yol açmıştır. Böylece tüm ülkelerin finansal sistemleri birbirine bağlı hâle gelmiş, ABD odaklı küresel piyasalar oluşmuştur. Dolayısıyla bir ülkede yaşanan sıkıntı, küresel krizde olduğu gibi, küresel sistem içerisinde tüm piyasalara yansımaktadır. Eğer ekonomik sıkıntı yaşayan ülke ABD ise krizin etkisi çok daha büyük olmaktadır. Öte yandan bankacılık kesiminde son yıllarda yaşanan aşırı rekabet, zaman zaman yanlış kararların alınmasına da yol açmıştır. ABD'de son yıllarda bankacılık kesimi, büyük boyutlarda düşük nitelikli ipotekli konut kredileri kullandırmıştır. Bu kredilerin geri ödemelerinde yaşanan sorunlar, finansal krizin doğmasına yol açmıştır. 2007 yılı ortalarında finansal piyasalarda başlayan kriz, 2008 yılının ikinci yarısından itibaren reel sektörü de etkisi altına alarak gelişmiş ve gelişmekte olan tüm ülkelere yayılmıştır. Bu kriz, Türkiye'yi ve Türk cumhuriyetlerini de etkilemiştir. Krizin etkisi Türkiye üzerinde çok büyük ölçüde hissedilirken, Türk cumhuriyetlerinde bu etki daha düşük olmuştur.

Çalışmanın amacı, küresel kriz sonrası Türk cumhuriyetleri ekonomileri ve bu ülkelerin Türkiye ile ticari ilişkilerini incelemektir. Bu doğrultuda, öncelikle küresel krizin çıkış nedenleri ve dünya ekonomisi üzerine etkileri ele alınacak, daha sonra Türk cumhuriyetlerinin genel ekonomik durumları ve krizin etkileri incelenecek, son olarak da Türk cumhuriyetleri ile Türkiye'nin ticari ilişkilerine yer verilecektir.

\section{Küresel Krizin Çıkış Nedenleri ve Dünya Ekonomisi Üzerine Etkileri}

Son küresel krizle dünya ekonomisi, 1929 bunalımından bu yana en büyük krizle karş1 
karşıya gelmiştir. 2007 yılı ortalarında ABD konut piyasasında başlayan sorunlar giderek büyümüș, 2008 yılının ikinci yarısında finansal piyasalardan sonra reel sektörü de etkisi altına almıștır. Gelişmiş ülkelerde bașlayan kriz, tüm dünyaya yayılarak küresel bir boyut kazanmıștır. Krizin nedenleri; likidite bolluğu ve ipotekli konut kredilerinin yapısının bozulması, konut fiyatlarındaki aşırı artışlar, menkul değerleștirme ve menkul değerlerin fonlanmasında yaşanan sorunlar, șeffaflık eksikliği, kredi türev piyasalarının genișlemesi, kredi derecelendirme kuruluşlarının etkinliğindeki yetersizlik ve düzenleyici denetleyici kuruluşların müdahalede gecikmesi olarak sıralanabilir.

Küresel kriz, tüm dünya ülkelerinin büyüme oranlarının hızla düşmesine yol açmıştır. Bunun yanı sıra sanayi üretimi, ticaret hacmi ve sabit yatırım harcamaları da büyük ölçüde düşmüştür. Buna bağlı olarak da istihdam azalmış, diğer bir deyişle işsizlik artmıştır.

Büyüme oranları, ihracat ve yatırımlar üzerine etkileri: Finansal krizin reel ekonomiye yansıması nedeniyle tüm dünyada büyüme oranları düşmüştür. 2007 yılının son çeyreğinden itibaren küresel düzeyde düşmeye başlayan büyüme oranları 2008 yılının üçüncü çeyreğinde negatife dönmüş, 2009 yılı ilk çeyreğinde -\%6,27'lik küçülme ile dip yapmıştır. Bu daralma gelişmiş ülkelerde -\%8,31 iken, yükselen ve gelişmekte olan ekonomilerde -\%3,11 olmuştur. Ancak 2009 yılının ikinci çeyreğinden itibaren tüm dünyada bir toparlanma süreci başlamış, büyüme oranları pozitife dönmüştür. 2010 yılının ilk çeyreğinde Asya ülkelerindeki yüksek büyüme oranları nedeniyle, dünya ekonomisi yıllık üzerinden yaklaşık $\% 5$ büyüme gerçekleşmiştir (Şekil 1).

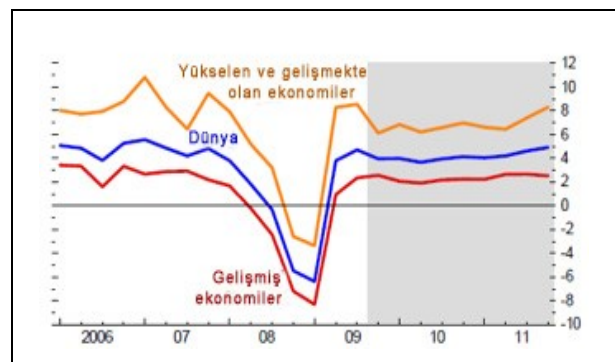

Kaynak: IMF, 2010a ve 2010b: 1.

Şekil 1. Küresel GSYïH büyüme oranı

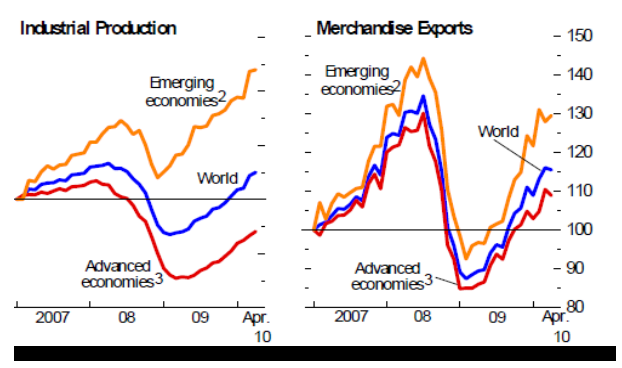

Kaynak: IMF, 2010b: 3.

Şekil 2. Sanayi üretimi ve mal ihracat indeksi

Reel ekonomik faaliyetlere ilişkin küresel göstergelerde de iyileşmeler görülmektedir. 2009 yılının ikinci yarısından itibaren düzelmeye başlayan küresel sanayi üretimi ve mal ticareti, 2010 yılının ilk çeyreğinde de büyümüş ve bu büyüme çift haneli rakamlara ulaşmıştır (Şekil 2, $2007=100$ ). 2007 y1lında \%7,2 olan dünya ticaret hacmi, 2008'de \%3'e düşmüş, 2009 y1lında ise -\%14,4 oranında küçülmüştür. 2009 yılının ikinci yarısından itibaren artmaya başlayan dünya ticaret hacminin 2010 'da \%4,3, 2011 yılında ise \%6,2 olacağı öngörülmektedir. 2009 yılına kadar düşen hem emtia fiyatları hem de petrol fiyatları, tekrar yükselmeye başlamıştır. Yapılan projeksiyonlara göre; bu fiyatların, 2010 ve 2011 yıllarında biraz artacağ belirtilmektedir (World Bank, 2010a: 17).

Sabit yatırımlar da birçok bölgede büyük ölçüde düşmüştür. Bu düşüş 2009 yılında Avrupa ve Merkezi Asya'da -\%16, Latin Amerika ve Karayipler'de -\%14,6 olmuştur. Dünya genelinde yatırımı azalan ülkeler, ticari ve yatırım bankaları ile yakın bağı olan, ihracatı dolaylı olarak düşen ve dolayısıyla finansal krizden doğrudan etkilenen ülkelerdir. Büyük cari açıkları bulunan bazı ülkelerin yatırımlarındaki daralma çok daha fazla olmuştur. 2008 yılının son çeyreğinde yüksek gelirli ülkelerin yatırımı ortalama \%4,4 düşmüştür (World Bank, 2010b: 12, $19,27,36,45)$.

İşsizlik oranlarında artışlar: Küresel krizle birlikte işsizlik oranları da büyük ölçüde artmıştır (Şekil 3). Küresel ekonomide 2009 yılının ikinci yarısından itibaren büyüme görülmesine karşın, işgücü piyasasındaki iyileşme çok küçük düzeyde kalmıştır. İşgücü piyasalarında 2009 yılı için küresel işsizlik oranının \%6,6 ile \%6,9 aralığında olacağı 
öngörülmektedir. 2004-2005 döneminden itibaren düşen küresel işsizlik oran1, 2008 yılında artmaya başlamıştır. Ancak 2009 yılında işsiz sayısında çok büyük bir artış olduğu görülmüş̧ür. İşsiz sayısının 2009 yılında 212 milyon kişi olduğu tahmin edilmektedir. 2009 yılı için tahmin edilen işsizlik sayısı gerçekleşirse, krizin başladığı 2007 yılından itibaren 34 milyon kişi işsiz kalmış olacaktır (ILO, 2010: 9). Bölgesel olarak 2008-2009 döneminde işsizlik oranlarındaki en büyük artış \%2,3 ile gelişmiş ülkeler ile Avrupa birliği ülkelerinde görülmüş̧ür. Bu artış, Orta ve Güneydoğu Avrupa'da \%2, Latin Amerika ve Karayipler'de $\% 1,2$ olmuştur. 2009 yılında küresel işsiz sayısının üçte ikisi de bu üç bölgede bulunmaktadır. Diğer bölgelerde işsizlik oranındaki artış $\% 0,5$ gibi düşük düzeyde gerçekleşmiştir. Gelişmiş ülkeler ve Avrupa Birliği ülkelerinde 2007 yılında \%5,7 olan işsizlik oranı, 2008'de \%6'ya çıkmıştır. Bu oranın 2009 yılında \%8,4'e çıkması beklenmektedir (ILO, 2010: 9). Ayrıca küresel krizden önce genç işsizlerin hem sayısı hem de oranı azalmıştır. Ancak krizle birlikte yeniden artış göstermiştir (Şekil 4).

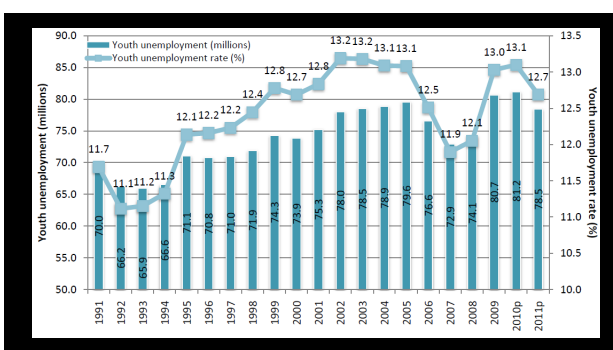

Kaynak: ILO, 2010: 10.

Şekil 3. Küresel işsizlik trendleri



Kaynak: ILO, 2010: 18.

Şekil 4. Küresel genç işsiz işsizlik oranı

Enflasyonist etki: Küresel krizle birlikte dünyada hem ortalama enflasyon (headline inflation) hem de çekirdek enflasyon artmaya başlamıştır (Şekil 5). Ancak 2007 ve 2008 yılında enflasyondaki artış, yalnızca finansal krizden kaynaklanmamıştır.



Kaynak: IMF, 2010b: 6.

\section{Şekil 5. Küresel enflasyon (tüketici fiyat endeksindeki on iki aylık değişim)}

$\mathrm{Bu}$ dönemde hem gıda ürünleri hem de petrol fiyatlarındaki artışlar, önemli ölçüde enflasyonist etki yaratmıştır. Özellikle enerji talebi hızla artan gelişmekte olan ülkelerde enflasyon, daha hızlı yükselmiştir (IMF, 2010a: 31). Bununla birlikte enflasyon beklentileri ve kapasite kullanım oranlarının düşük olmasının enflasyon üzerinde baskı yaratmayacağ öngörülmektedir. $\mathrm{Bu}$ doğrultuda gelişmiş ekonomilerde enerji fiyatlarındaki artışa bağlı olarak 2010 yılında ortalama enflasyonun artması beklenmektedir. Yükselen ve gelişmekte olan ülkelerde ise 2010 yılında enflasyonun \%6,3 düzeyine çıkması, 2011 yılında ise $\% 5$ düzeyinde gerçekleşmesi beklenmektedir (IMF, 2010b: 6). 


\section{Türk Cumhuriyetlerinin Genel Ekonomik Durumları ve Küresel Krizin Etkileri}

Sovyetler Birliği’nin dağılmasından sonra bağımsızlığına kavuşan Azerbaycan, Kazakistan, Kırgızistan, Özbekistan ve Türkmenistan'dan oluşan Türk cumhuriyetleri, 2000'li y1llardan itibaren hızlı bir biçimde büyüme göstermişlerdir. Bu ülkelerin büyüme oranları 2008 yılında en üst düzeye çıkmışken, yaşanan küresel kriz yüzünden 2009 yılında bu ülkelerin büyüme oranları düşmüştür (Tablo 1). Enflasyon oranlarında hafif artışlar (Tablo 2) gerçekleşmiş ve cari işlemler dengesi Kazakistan ve Türkmenistan'da açık vermiş, diğer ülkelerde ise cari işlemler fazlalı̆̆ azalma eğilimine girmiştir (Tablo 3). Küresel krize karşın bu ülkelere yabancı sermaye girişleri devam etmiştir (Tablo 4). 2009 yılı itibariyle Azerbaycan'a 9.044 milyon, Kazakistan'a 72.333 milyon, Kırgızistan'a 1.075 milyon, Türkmenistan'a 6.130 milyon ve Özbekistan'a 3.638 milyon dolarlık toplam yabancı sermaye yatırımı yapılmıştır. Bu yatırımlar, genel olarak gelişmiş ülkeler tarafından gerçekleştirilmiştir. Azerbaycan, Kazakistan ve Türkmenistan'a yönelik yatırımlar ise ağırlıklı olarak petrol ve doğal gaza olmuştur (UNCTAD, 2010: 176).

Azerbaycan: Ekonomisi petrol ihracatına önemli ölçüde bağlı olan Azerbaycan, 2008 yılına kadar yüksek büyüme hızlarına sahip olmuş ve 2008 yılında \%20,8 büyüme göstermiştir. Azerbaycan'ın son yıllardaki hızlı büyümesi, önemli ölçüde 2008 yılı ortalarına kadar hızla artan petrol fiyatları olmuştur. Petrol fiyatlarındaki düşmenin sonucu petrol gelirlerindeki azalma, küresel krizin etkisini daha da şiddetlendirmiştir. Ancak Azerbaycan petrol üretimini artırarak petrol gelirini artırmış ve 2009 yılında büyüme oranı \%9,3 olmuştur (World Bank, 2010b: 7). Bölgedeki diğer Türk cumhuriyetlerine göre Azerbaycan, krizden çok daha az etkilenmiștir. Krizin Azerbaycan üzerine etkisi, düşük petrol gelirleri yüzünden olmuștur. Küresel krizin üstesinden gelebilmek için ülkenin uyguladığı para politikalarının ve özel sektöre yönelik desteklerinin olumlu etkileri olmuştur (World Bank, 2010c). 2006 yılına kadar artan ve bu yıldan itibaren düşmeye başlayan enflasyon oranının, yapılan projeksiyonlara göre 2010 ve 2011 yıllarında daha da düşmesi beklenmektedir. Ayrıca kriz yüzünden cari işlemler fazlası biraz azalmıştır. Petrol fiyatlarındaki düşme nedeniyle, Azerbaycan petrol üretimini artırmış, bu nedenle de cari işlemler dengesi çok fazla etkilenmemiştir. Küresel krize karşın ülkeye yabancı sermaye girişleri, 2008 yılından itibaren artmıştır.

$\begin{array}{cccccccccccc}\text { Ülkeler } & 2002 & 2003 & 2004 & 2005 & 2006 & 2007 & 2008 & 2009 & 2010 & 2011 & 2015 \\ \text { Azerbaycan } & 8,1 & 10,5 & 10,2 & 26,4 & 34,5 & 25,0 & 10,8 & 9,3 & 2,7 & 0,6 & 0,7 \\ \text { Kazakistan } & 9,8 & 9,3 & 9,6 & 9,7 & 10,7 & 8,9 & 3,2 & 1,2 & 2,4 & 4,2 & 6,5 \\ \text { Kirgizistan } & 0,0 & 7,0 & 7,0 & -0,2 & 3,1 & 8,5 & 8,4 & 2,3 & 4,6 & 5,3 & 3,4 \\ \text { Özbekistan } & 4,0 & 4,2 & 7,7 & 7,0 & 7,3 & 9,5 & 9,0 & 8,1 & 8,0 & 7,0 & 6,0 \\ \text { Türkmen. } & 15,8 & 17,1 & 14,7 & 13,0 & 11,4 & 11,6 & 10,5 & 4,1 & 12,0 & 12,2 & 6,9 \\ \text { Türkiye } & 6,2 & 5,3 & 9,4 & 8,4 & 6,9 & 4,7 & 0,7 & -4,7 & 5,2 & 3,4 & 4,0\end{array}$

Tablo 1. Türk cumhuriyetlerinin büyüme oranları (\%)

Kazakistan: 2000 yılından 2007 yılına kadar ortalama \%10 civarında büyüyen Kazakistan'ın, 2009 yılında büyüme oranı küresel krizin de etkisiyle düşmüştür. Azerbaycan gibi Kazakistan'ın da ekonomisi önemli ölçüde petrol ihracatına, dolayısıyla petrol gelirlerine bağlıdır. 2008 yılı ortalarından itibaren petrol gelirlerindeki düşme, küresel krizin etkisini daha da artırmıştır (World Bank, 2010b: 7). Kazakistan'da büyüme oranı negatif olmamış, ancak 2007 yılında \%8,9 olan büyüme oranı, 2008'de \%3,2 ve 2009'da \%1,2 düzeyine düşmüştür. 2008 yılına kadar artan, 2009 yılında düşerek \%7,3 düzeyine inen enflasyonun, 2010, 2011 ve 2015 yıllarında da düşeceği öngörülmektedir. Ayrıca kriz yüzünden cari işlemler fazlası biraz azalmıştır. Kazakistan'ın 2002 yılından 2007 yılına kadar açık veren cari işlemler dengesi, 2008 yılındaki petrol fiyatlarındaki artış nedeniyle fazla vermiştir. Ancak hem petrol fiyatlarındaki düşme, hem de küresel krizin etkisiyle açık veren cari işlemler dengesinin, 2011 ve 2015 yıllarında da açık vermeye devam edeceği öngörülmektedir. Türk cumhuriyetleri 
içerisinde en çok yabancı sermaye girişine sahip bir ülke konumundaki Kazakistan'a, krizin etkisiyle yabancı sermaye girişi de 2009 yılında azalmıştır.

\begin{tabular}{cccccccccccc} 
Ülkeler & 2002 & 2003 & 2004 & 2005 & 2006 & 2007 & 2008 & 2009 & \multicolumn{3}{c}{ Projeksiyonlar } \\
Azerbaycan & 2,8 & 2,2 & 6,7 & 9,7 & 8,4 & 16,6 & 20,8 & 1,5 & 4,7 & 3,5 & 3,0 \\
Kazakistan & 5,9 & 6,6 & 7,1 & 7,9 & 8,7 & 10,8 & 17,1 & 7,3 & 7,3 & 6,6 & 6,0 \\
Kurgizistan & 2,1 & 3,1 & 4,1 & 4,3 & 5,6 & 10,2 & 24,5 & 6,8 & 8,4 & 7,6 & 8,0 \\
Özbekistan & 27,3 & 11,6 & 6,6 & 10,0 & 14,2 & 12,3 & 12,7 & 14,1 & 9,2 & 9,4 & 7,0 \\
Türkmenis. & 8,8 & 5,6 & 5,9 & 10,7 & 8,2 & 6,3 & 14,5 & $-2,7$ & 5,0 & 5,4 & 4,5 \\
Türkiye & 45,1 & 25,3 & 8,6 & 8,2 & 9,6 & 8,8 & 10,4 & 6,3 & 9,7 & 5,7 & 4,0
\end{tabular}

Kaynak: IMF, 2010a: 165

\section{Tablo 2. Türk cumhuriyetlerinin enflasyon oranları (tüketici fiyatları) (\%)}

Kırgızistan: 2007 yılında düşük büyüme hızına sahip olan Kırgızistan, 2007 ve 2008 yıllarında yaklaşık \%8,5 oranında büyümüştür. Kırgızistan'ın finans sektörünü sınırlı düzeyde etkileyen küresel kriz, ülkenin ekonomisini büyük ölçüde etkilemiş ve 2009 yılında büyüme oranını \%2,3 düzeyine düşürmüştür. 2008 yılına kadar artan enflasyon oranı da krizle birlikte düşerek, 2009 yılında \%6,8 olmuştur. 2006 yılından bu yana cari işlemler dengesi açığ 1 veren ülkenin, 2009 yılında fazla verdiği görülmektedir. Bu gelişmede düşen petrol fiyatları etkili olmuştur. Petrol ve doğal gaz kaynakları bulunmadığı için, ülkeye çok fazla yabancı sermaye girişi de yoktur. Çok düşük düzeyde gerçekleşen yabancı sermaye girişi, kriz nedeniyle 2009 yılında iyice düşmüştür.

Özbekistan: Küresel kriz Özbekistan'1 fazla etkilememiş, büyüme oranında küçük bir düşme olmasına karşın, 2009 yılında \%8,1 oranında büyümüştür. Enflasyon biraz artmakla birlikte istikrarlı kalmış, cari işlemler dengesi fazlalığı da 2009 yılında azalmıştır. Özbekistan'ın 2010 yılında da \%8 büyüyeceği öngörülmektedir. Bunda 2009 yılının başından bu yana uluslararası enerji fiyatlarındaki canlanmanın da etkisiyle büyük boyutlu kamu altyapı inşaatlarının payı olduğu belirtilmektedir (World Bank, 2010b: 10). Özbekistan hükümeti, 2009-2012 döneminde ortalama büyüme hızını \%4 civarında tutabilmek amacıyla, 2008 yılının sonu ile 2009 yılının başında anti kriz programı uygulamıştır. Özbekistan'ın küresel finansal piyasalarla bağlarının sınırlı olması nedeniyle, küresel krizin etkilerini azaltmak için önemli finansal desteklere gerek kalmamıştır. Ancak hükümetin çabaları, finansal sektördeki riskleri yönetmek, cari açıkları azaltmak ve enflasyonu düşürmek ve uzun dönemde ekonomik büyümeyi gerçekleştirmek amacına yönelik olmuştur (World Bank, 2010c). Öte yandan ülkeye giren yabancı sermaye, Kırgızistan'daki gibi, düşük düzeyde olup 2009 yılında 750 milyon dolarlık yabancı sermaye girişi söz konusudur.

\begin{tabular}{|c|c|c|c|c|c|c|c|c|c|c|c|}
\hline \multirow{2}{*}{ Ülkeler } & \multirow{2}{*}{2002} & \multirow{2}{*}{2003} & \multirow{2}{*}{2004} & \multirow{2}{*}{2005} & \multirow{2}{*}{2006} & \multirow{2}{*}{2007} & \multirow{2}{*}{2008} & \multirow{2}{*}{2009} & \multicolumn{3}{|c|}{ Projeksivonlar } \\
\hline & & & & & & & & & 2010 & 2011 & 2015 \\
\hline Azerbaycan & $-\overline{12,3}$ & $\begin{array}{c}- \\
27.8\end{array}$ & $\begin{array}{c}- \\
29,8\end{array}$ & 1,3 & 17,6 & 27,3 & 35,5 & 23,6 & 25,3 & 24,2 & 23,7 \\
\hline Kazakistan & $-4,2$ & $-0,9$ & 0,8 & $-1,8$ & $-2,5$ & $-7,9$ & 4,6 & $-3,1$ & 0,7 & $-0,2$ & $-0,9$ \\
\hline Kırgızistan & $-4,0$ & 1,7 & 4,9 & 2,8 & $-3,1$ & $-0,2$ & $-8,1$ & 3,5 & $-15,4$ & $-12,5$ & $-3,9$ \\
\hline Özbekistan & 1,2 & 5,8 & 7,2 & 7,7 & 9,1 & 7,3 & 12,5 & 5,1 & 5,1 & 5,0 & 4,9 \\
\hline Türkmenis. & 6,7 & 2,7 & 0,6 & 5,1 & 15,7 & 15,5 & 18,7 & $-9,7$ & $-8,7$ & 1,3 & 18,3 \\
\hline Türkiye & $-0,3$ & $-2,5$ & $-3,7$ & $-4,6$ & $-6,0$ & $-5,8$ & $-5,7$ & $-2,3$ & $-4,0$ & $-4,4$ & $-4,7$ \\
\hline
\end{tabular}

Kaynak: IMF, 2010a: 174.

\section{Tablo 3. Türk cumhuriyetlerinin cari işlemler dengesi (\%)}

Türkmenistan: Doğal gaz zengini olan Türkmenistan'ın, 2003 yılından itibaren büyüme oranı giderek düşme eğilimine girmiş ve 2008 yılında \%10,5 oranında büyümüştür. Ancak Nisan 2009'da doğal gaz boru hattının patlaması sonrası Rusya ile doğal gaz fiyatları konusunda anlaşmazlık yaşamış ve doğal gaz ihracatını durdurmuştur. Bir yandan doğal gaz sevkiyatında yaşanan sorunlar, öte yandan küresel krizin etkileri, Türkmenistan'ın 2009 yılında büyüme oranını \%4,1'e düşürmüştür. Aynı zamanda ihracattaki büyük düşüş, cari işlemler dengesinin açık vermesine yol açmıştır (Tablo 3). Yükselen gıda fiyatları, yakıt ve ulaşım 
fiyatlarının uyumlaştırılması ve döviz kurunun erken etkileri yüzünden enflasyon 2008 yılında iki haneli hale gelen gelmiştir. Ancak istikrarlı döviz kuru ve düşük ithalat fiyatları nedeniyle 2009 yılında düşerek -\%2,7 olarak gerçekleşmiştir. Yabancı sermaye girişleri yıllar itibariyle artarak, 2009 yılında 1.355 milyon dolar olarak gerçekleşmiştir.

\begin{tabular}{ccccccccc} 
& \multicolumn{9}{c}{ DYSY girişleri } & \multicolumn{5}{c}{ DYSY çıkışlar1 } \\
ÜLKELER & 2006 & 2007 & 2008 & 2009 & 2006 & 2007 & 2008 & 2009 \\
Azerbaycan & -601 & -4.749 & 14 & 473 & - & 286 & 556 & 326 \\
Kazakistan & 6.278 & 11.096 & 15.775 & 12.649 & -385 & 3.142 & 1.001 & 3.119 \\
Kırgızistan & 182 & 208 & 265 & 60 & - & - & - & -3 \\
Özbekistan & 195 & 705 & 711 & 750 & - & - & - & - \\
Türkmenistan & 731 & 804 & 820 & 1.355 & - & - & - & - \\
Türkiye & 20.185 & 22.023 & 18.148 & 7.611 & 924 & 2.104 & 2.532 & 1.551
\end{tabular}

\section{Tablo 4. Yabancı sermaye yatırımları (milyon dolar)}

Türkiye: 2001 krizinden sonra Türkiye, yapısal dönüşüm ve yüksek büyüme dönemine girmiştir. 2002 yılındaki canlanmanın ardından 2003-2007 beş yıllık dönemde yıllık ortalama \%7 civarında büyümüştür. Ancak Türkiye ekonomisi 2008-2009 küresel finansal krizden hem ticari, hem de finansal olarak büyük ölçüde etkilenmiştir. Dolayısıyla 2008 yılında \%0,7 büyüyen Türkiye ekonomisi, 2009 yılında -\%4,7 oranında daralmıştır. Özellikle 2009 yılının ilk çeyreğinde tüm makro göstergeler negatif değerlere ulaşmış, ihracat gelirleri de üçte bir oranında düşmüştür. Benzer şekilde özel kesim yatırımları da etkilenmiş ve 2009 ilk çeyreğinde büyük ölçüde azalmıştır. Dış ve iç talep yetersizliği nedeniyle enflasyon oranı, \%6,3 düzeyine inmiştir (World Bank, 2010c). Diğer Türk cumhuriyetlerinden farklı olarak Türkiye'de cari işlemler dengesi yıllardır sürekli açık vermektedir (Tablo 3). Yabancı sermaye girişi 2007 yılına kadar artan Türkiye'de 2008 yılında biraz azalmış (18,3 milyar dolar), ancak krizin etkisiyle 2009 yılında çok daha büyük ölçüde düşerek yaklaşık 7,7 milyar dolara ulaşmıştır (Tablo 4). Ayrıca Türkiye'ye birikimli toplamı yaklaşık 1990 yılında 11,2 milyar dolarlık, 2000 yılında 19,2 milyar dolarlık yabancı sermaye yatırımı yapılmıştır. 2009 yılında ise bu yatırımının birikimli toplamı 77,7 milyar dolara yükselmiştir. Öte yandan Türkiye'nin başka ülkelere yönelik yapmış olduğu yabancı sermaye yatırımı aynı yıllarda sırasıyla birikimli olarak 1,2 milyar, 3,7 milyar ve 14,8 milyar dolar olmuştur (UNCTAD, 2010: 174). Türkiye, 2008 yılı da dâhil olmak üzere birikimli toplamı yaklaşık 13.2 milyar doları bulan yabancı sermaye yatırımı yapmıştır. $\mathrm{Bu}$ yatırımların 3,9 milyar dolarlık bölümü (\%30) Türk cumhuriyetlerine yöneliktir. Türk cumhuriyetlerine yapılan yatırımların dağılımı ise şöyledir: Azerbaycan'a \%79, Kazakistan'a \%17, Kırgızistan'a \%0,6, Özbekistan'a \%1,5, Türkmenistan'a \%1,5'tur (Central Bank of the Republic of Turkey, 2008: 43).

İşsizlik oranları: Küresel krizin Türk cumhuriyetlerinde reel sektör üzerine etkisi düşük olduğu için, işsizlik oranlarında bir artış yaşanmamıştır. Aksine Kırgızistan ve Türkiye dışında diğer ülkelerde işsizlik oranları düşmüştür (Tablo 5). Türkmenistan'a ilişkin veri bulunamadığından değerlendirme dışı bırakılmıştır.

$\begin{array}{cccccccc}\text { Ülkeler } & 2003 & 2004 & 2005 & 2006 & 2007 & 2008 & 2009 \\ \text { Azerbaycan(1) } & 1,31 & 1,35 & 1,35 & 1,26 & 1,18 & 1,03 & 0,95 \\ \text { Kazakistan (2) } & 8,8 & 8,4 & 8,1 & 7,8 & 7,3 & 6,6 & 6,6 \\ \text { Kırgizistan (3) } & 8,9 & 9,0 & 9,7 & 9,3 & 8,1 & 11,0 & 9,7 \\ \text { Özbekistan (4) } & 0,5 & 0,6 & 0,7 & 3,0 & 0,8 & 1,0 & 1,1 \\ \text { Türkiye (5) } & 6,5 & 5,9 & 9,7 & 9,1 & 9,3 & 10,3 & 13,6\end{array}$

Kaynak: (1) The State Statistical Committee of the Republic of Azerbaijan, 2010, (2) The Agency of Statistics of the Republic of Kazakhstan, 2010, (3) National Statistical Committe of Kyrgyz Republic, 2010, (4) CIA, 2010, (5) TÜİK, 2010.

Tablo 5. Türk cumhuriyetlerinde işsizlik oranları (\%) 


\section{Türk Cumhuriyetleri ile Türkiye'nin Ticari İlişkileri}

Türkiye ile Türk cumhuriyetlerinin 2009 yılında yapmış oldukları ihracat ve ithalat verileri ile en çok ihracat ve ithalat yaptıkları ülkeler ve mallar Tablo 6'da görülmektedir. Bu ülkelerin 2009 yılında toplam dış ticaret hacmi yaklaşık 400 milyar dolar olmasına karşın, aralarındaki dış ticaret düşük düzeydedir. 2005 yılı verileriyle yapılan bir çalışmada (Narin, 2007), Türk cumhuriyetlerinin en çok ihracat ve ithalat yaptıkları ülkeler içerisinde ilk üçte Rusya'nın yer aldığı belirtilmiştir. Oysa aradan geçen 4 y1l içerisinde bu ülkelerin Rusya ile dış ticaret bağlarının hâlâ devam ettiği, ancak dış ticaret paylarının giderek düştüğü görülmektedir.

\begin{tabular}{|c|c|c|c|c|c|c|}
\hline Ülkeler & $\begin{array}{l}\text { İhracat } \\
2009\end{array}$ & $\begin{array}{l}\text { İthalat } \\
2009\end{array}$ & $\begin{array}{c}\text { En çok } \\
\text { ihracat } \\
\text { yaptığ1 } \\
\text { ülkeler (\%) }\end{array}$ & $\begin{array}{c}\text { En çok } \\
\text { ithalat } \\
\text { yaptığ1 } \\
\text { ülkeler (\%) }\end{array}$ & $\begin{array}{l}\text { Başlica ihraç } \\
\text { malları }\end{array}$ & $\begin{array}{l}\text { Başlıca ithal } \\
\text { malları }\end{array}$ \\
\hline $\begin{array}{c}\text { Azerbay } \\
\text { can (1) }\end{array}$ & 14.698 & 6.120 & $\begin{array}{c}\text { İtalya } 25,8 ; \\
\text { ABD } 11,9 \\
\text { Fransa 9; } \\
\text { Türkiye } 0,7 \\
\end{array}$ & $\begin{array}{c}\text { Rusya 17,5; } \\
\text { Türkiye } \\
14,8 \\
\text { Almanya } 9\end{array}$ & $\begin{array}{l}\text { Petrol ür.,örgü } \\
\text { için kullanılan } \\
\text { bitkiler, } \\
\text { ulaş.Araç }\end{array}$ & $\begin{array}{l}\text { Mak.tec.ulaş. } \\
\text { araç. } \\
\text { temel met. } \\
\text { çeşitli eşyalar }\end{array}$ \\
\hline $\begin{array}{c}\text { Kazakist } \\
\text { an (2) }\end{array}$ & 71.184 & 37.889 & $\begin{array}{c}\text { EU27 39,4; } \\
\text { Çin 16,4 } \\
\text { Rusya 6,8; } \\
\text { Türkiye } 2,9 \\
\end{array}$ & $\begin{array}{c}\text { Rusya 28,6; } \\
\text { Çin 26,7 } \\
\text { EU27 25,5; } \\
\text { Türkiye 2,1 }\end{array}$ & $\begin{array}{l}\text { Petrol-gaz, } \\
\text { demir, } \\
\text { kimya }\end{array}$ & $\begin{array}{l}\text { Mak.tec.,hafif } \\
\text { araç., } \\
\text { petrol ürünleri }\end{array}$ \\
\hline $\begin{array}{l}\text { Kirgizist } \\
\text { an (3) }\end{array}$ & 1.152 & 5.192 & $\begin{array}{c}\text { Rusya 26,3; } \\
\text { İşviçre 25,5 } \\
\text { Özbekistan } \\
\text { 15,9; } \\
\text { Türkiye 2,2 }\end{array}$ & $\begin{array}{c}\text { Çin 58,1; } \\
\text { Rusya18,8 } \\
\text { Kazakistan } \\
5,8 ; \\
\text { Türkiye 2,7 }\end{array}$ & $\begin{array}{c}\text { Pamuk, gida, } \\
\text { hidroelektrik, } \\
\text { makine, } \\
\text { ayakkab1 }\end{array}$ & $\begin{array}{l}\text { Petrol ve doğal } \\
\text { gaz, makine ve } \\
\text { teçhizat, } \\
\text { kimyasal ürün, } \\
\text { gıda ma. }\end{array}$ \\
\hline $\begin{array}{c}\text { Özbekis } \\
\tan (4)\end{array}$ & 4.628 & 7.551 & $\begin{array}{c}\text { Ukrayna } \\
31,1 ; \text { Rusya } \\
13,6 \\
\text { EU27 7,9; } \\
\text { Türkiye } 7,3 \\
\end{array}$ & $\begin{array}{l}\text { Rusya 23,6; } \\
\text { Çin } 20,5 \\
\text { EU27 17,9; } \\
\text { Türkiye } 3,7 \\
\end{array}$ & $\begin{array}{l}\text { Pamuk, altın, } \\
\text { enerji ürünleri, } \\
\text { mineraller, } \\
\text { tekstil, gida } \\
\text { ürünleri }\end{array}$ & $\begin{array}{c}\text { Makine ve } \\
\text { ekipman, gida } \\
\text { mad., kimyasal } \\
\text { ürün., metaller }\end{array}$ \\
\hline $\begin{array}{l}\text { Türkme } \\
\text { nis.(4) }\end{array}$ & 2.718 & 5.758 & $\begin{array}{c}\text { EU27 24,3; } \\
\text { Ukrayna } \\
23,5 \\
\text { Türkiye 9,9 }\end{array}$ & $\begin{array}{c}\text { EU27 19,7; } \\
\text { Çin 18,3 } \\
\text { Rusya 16,5; } \\
\text { Türkiye } \\
\underline{16,3}\end{array}$ & $\begin{array}{c}\text { Doğal gaz, ham } \\
\text { petrol, } \\
\text { petrokimya, } \\
\text { tekstil, pamuk }\end{array}$ & $\begin{array}{l}\text { Makine ve } \\
\text { ekipman, } \\
\text { kimyasal ürün, } \\
\text { gida m. }\end{array}$ \\
\hline $\begin{array}{l}\text { Türkiye } \\
\text { (5) }\end{array}$ & 102.139 & 140.869 & $\begin{array}{c}\text { EU27 46,2; } \\
\text { Irak 5,1 } \\
\text { İsviçre 4,1 }\end{array}$ & $\begin{array}{c}\text { EU27 40,5 } \\
\text { Rusya 14,1 } \\
\text { ABD 6,2 }\end{array}$ & $\begin{array}{l}\text { Giyim, gida, } \\
\text { tekstil, metal, } \\
\text { ulaşım araçları } \\
\text { imalatı }\end{array}$ & $\begin{array}{c}\text { Makine, } \\
\text { kimyasal ürün, } \\
\text { yarı mamul, } \\
\text { petrol, doğal } \\
\text { gaz }\end{array}$ \\
\hline
\end{tabular}

Kaynak: (1) The State Statistical Committee of the Republic of Azerbaijan, 2010, (2) The Agency of Statistics of the Republic of Kazakhstan, 2010. (3) National Statistical Committe of Kyrgyz Republic, 2010; (4) CIA, 2010, (5) DTM (2010), (6) European Commission, 2010.

\section{Tablo 6. Türk cumhuriyetlerinin diş ticareti (milyon dolar) ve dış ticarete konu olan mallart ve diş ticaret ortakları}

Türk cumhuriyetlerinin Türkiye ile diş ticaretleri genel olarak çok düşük düzeydedir. Ancak 2003-2008 döneminde düşük düzeyde de olsa artmıştır. Türkiye'nin 2009 yılında toplam ihracatı içerisinde Türk Cumhuriyetleri'ne yapmış olduğu ihracatın payı \%3,33; ithalatın payı ise $\% 2,04$ düzeyindedir.

Türk cumhuriyetlerinin Türkiye ile diş ticaretleri genel olarak çok düşük düzeydedir. Ancak 2003-2008 döneminde düşük düzeyde de olsa artmıştır (Tablo 7). Ancak küresel krizin etkisiyle 2009 yılında, bu ülkelerde hem ihracat hem de ithalat düşmüştür (Tablo 8). 


\begin{tabular}{|c|c|c|c|c|c|c|c|c|c|c|c|c|c|}
\hline Y11 & $\begin{array}{l}\text { Türkiye } \\
\text { toplam } \\
\text { ihracat }\end{array}$ & $\begin{array}{c}\text { Türk } \\
\text { C. } \\
\text { İhracat }\end{array}$ & $\%$ & Azer. & $\%$ & $\begin{array}{c}\text { Kaza } \\
\text { k }\end{array}$ & $\%$ & $\begin{array}{c}\text { Kirg1 } \\
\text { Z }\end{array}$ & $\%$ & $\begin{array}{c}\text { Özbe } \\
\text { k. }\end{array}$ & $\%$ & $\begin{array}{c}\text { Türk } \\
\text { m }\end{array}$ & $\%$ \\
\hline 003 & 47.253 & 898 & 1,90 & 315 & 0,67 & 234 & 0,50 & 41 & 0,09 & 138 & 0,29 & 170 & 0,36 \\
\hline 00 & 63.167 & 1.195 & 1,89 & 404 & 0,64 & 356 & 0,56 & 75 & 0,12 & 14 & 0,23 & 215 &, 34 \\
\hline 2005 & 73.476 & 1.410 & 1,92 & 528 & 0,72 & 460 & 0,63 & 90 & 0,12 & 151 & 0,21 & 181 &, 25 \\
\hline 2006 & 85.535 & 1.981 & 2,32 & 695 & 0,81 & 697 & 0,81 & 132 & 0,15 & 176 & 0,21 & 281 & 0,3 \\
\hline 2007 & 107.272 & 2.875 & 2,68 & 1.048 & 0,98 & 1.080 & 1,01 & 181 & 0,17 & 226 & 0,21 & 340 &, 32 \\
\hline 2008 & 132.027 & 3.750 & 2,84 & 1.668 & 1,26 & 891 & 0,67 & 191 & 0,14 & 337 & 0,26 & 663 &, 50 \\
\hline 2009 & 102.135 & 3.398 & 3,33 & 1.400 & 1,37 & 634 & 0,62 & 140 & 0,14 & 279 & 0,27 & 945 & 0,9 \\
\hline
\end{tabular}

Tablo 7. Türkiye'nin Türk cumhuriyetlerine ihracatı (Milyon Dolar)

$\begin{array}{cccccccccccccc}\text { Y1l } & \begin{array}{c}\text { Türkiye } \\ \text { Toplam } \\ \text { İthalat }\end{array} & \begin{array}{c}\text { Türk } \\ \text { cum. } \\ \text { İthalat }\end{array} & \% & \text { Azer. } & \% & \begin{array}{c}\text { Kaza } \\ \text { k. }\end{array} & \% & \text { Kırgız } & \% & \begin{array}{c}\text { Öz } \\ \text { bek }\end{array} & \% & \begin{array}{c}\text { Tür } \\ \text { km }\end{array} & \% \\ 2003 & 69.340 & 625 & 0,90 & 123 & 0,18 & 267 & 0,39 & 11 & 0,02 & 100 & 0,14 & 124 & 0,18 \\ 2004 & 97.540 & 946 & 0,97 & 136 & 0,14 & 442 & 0,45 & 13 & 0,01 & 179 & 0,18 & 176 & 0,18 \\ 2005 & 116.774 & 1.268 & 1,09 & 272 & 0,23 & 559 & 0,48 & 14 & 0,01 & 262 & 0,22 & 161 & 0,14 \\ 2006 & 139.576 & 1.969 & 1,41 & 341 & 0,24 & 994 & 0,71 & 28 & 0,02 & 416 & 0,30 & 190 & 0,14 \\ 2007 & 170.063 & 2.670 & 1,57 & 330 & 0,19 & 1.284 & 0,76 & 45 & 0,03 & 614 & 0,36 & 397 & 0,23 \\ 2008 & 201.964 & 4.278 & 2,12 & 928 & 0,46 & 2.332 & 1,15 & 48 & 0,02 & 581 & 0,29 & 389 & 0,19 \\ 2009 & 140.924 & 2.874 & 2,04 & 753 & 0,53 & 1.349 & 0,96 & 31 & 0,02 & 413 & 0,29 & 328 & 0,23\end{array}$

\section{Tablo 8. Türkiye'nin Türk cumhuriyetlerinden ithalatı (Milyon Dolar)}

\section{Sonuç}

2000'li yıllardan itibaren hızlı büyüme gösteren Türk cumhuriyetleri, 2008-2009 küresel krizinden çok fazla etkilenmemiştir. 2009 yılında büyüme oranları kısmen düşmüş olmasına karşın, Kazakistan dışında bu düşüşün çok da önemli olmadığı görülmektedir. Türk cumhuriyetlerinin ekonomilerindeki bu olumlu gelişmede en büyük etken, bu ülkelerin sahip oldukları enerji kaynaklarıdır. Petrol ve doğal gazın fiyatlarındaki değişmelere bağlı olarak, özellikle Azerbaycan ve Kazakistan'ın ihracat gelirleri etkilenmiş ve dolayısıyla cari işlemler dengesi açık/fazlasıyla karşılaşmışlardır. Bu ülkelere yönelik doğrudan yabancı sermaye yatırımları, daha çok enerji kaynaklarına yapılan yatırımlar olması nedeniyle Kazakistan ve Azerbaycan'a yönelmiştir. Bu nedenle diğer Türk cumhuriyetlerine yapılan yatırımlar çok düşük düzeyde kalmıştır.

$\mathrm{Bu}$ ülkelerin hem ihracatları hem de ithalatları zaman içinde artmıştır. En önemli ihraç ürünleri petrol ve doğal gaz, pamuk, altın ve gıda ürünleri, en önemli ihraç ürünleri ise ağırlıklı olarak makine ve teçhizattır. Türkiye ile dış ticareti zaman içerisinde artmasına karşın, hâlâ son derece düşük düzeydedir. Türk cumhuriyetleri, küresel krizden çok fazla etkilenmemiş, 2009 yılında büyüme oranı bir önceki yıla göre biraz düşmüştür. Krizden sonra büyüme oranı büyük ölçüde düşen ülkeler, Kazakistan ile Türkmenistan'dır. Bunun da temel nedeni, dünya piyasalarında petrol ve doğal gaz fiyatlarındaki düşmedir. En önemli ihraç ürünü olan petrol ve doğal gaz fiyatlarındaki düşme, ihracat gelirlerini azaltmış ve büyüme oranlarını düşürmüştür. Yaşanan kriz, Türk cumhuriyetlerinin Türkiye ile olan ticari ilişkilerini pek etkilememiştir.

\section{Kaynakça}

- Central Bank of the Republic of Turkey (2008), International Investment Position Report, December 2008, http://www.tcmb.gov.tr/odemedenge/report2008.html, (02.09.2010).

- CIA World Factbook (2010), Countries of the World, 
http://www.theodora.com/wfb/\#CURRENT, (31.08.2010).

- European Commission (2010), European Union and its main trading partners, http://ec.europa.eu/trade/creating-opportunities/bilateral-relations/statistics/, (31.08.2010).

- $\quad$ ILO (2010), Global Employment Trends, January 2010, http://www.ilo.org/wcmsp5/groups/public/---ed_emp/---emp_elm/--trends/documents/publication/wcms_120471.pdf, (15.08.2010); Global Employment Trends for Younth, Agust 2010: Special issue on the impact of the global economic crisis on youth, http://www.ilo.org/wcmsp5/groups/public/---ed_emp/---emp_elm/--trends/documents/publication/wcms_143349.pdf, (28.08.2010).

- IMF (2010a), World Economic Outlook April 2010, Rebalancing Growth, http://www.imf.org/external/pubs/ft/weo/2010/01/, (21.08.2010).

- IMF (2010b), World Economic Outlook Update, Restoring Confidence without Harming Recovery, July 7, 2010, http://www.imf.org/external/pubs/ft/weo/2010/update/02/index.htm, (15.08.2010).

- IMF (2010c), World Economic and Financial Surveys, Regional Economic Outlook, May 2010, http://www.imf.org/external/pubs/ft/reo/2010/mcd/eng/mreo0510.pdf - 2503k - PDF, (22.08.2010).

- National Statistical Committe of Kyrgyz Republic (2010), Economic and Financial Data for Kyrgyz Republic, http://www.stat.kg/nsdp/index.htm, (31.08.2010).

- The Agency of Statistics of the Republic of Kazakhstan (2010), Labour, http://www.eng.stat.kz/digital/Labour/Pages/default.aspx, (31.08.2010).

- The State Statistical Committee of the Republic of Azerbaijan (2010), Azerbaijan in figures, http://www.azstat.org/publications/azfigures/2010/en/index.shtml, (31.08.2010).

- TÜİK (2010), İstatistikler, http://www.tuik.gov.tr/Start.do, (31.08.2010).

- UNCTAD, World Investment Report 2009, http://www.unctad.org/Templates/webflyer.asp? docid=11904\&intItemID=1397\&lang=1\&mode=downloads, (30.08.2010).

- UNCTAD, World Investment Report 2010, http://www.unctad.org/Templates/webflyer.asp? docid=13423\&intItemID=5539\&lang=1\&mode=downloads, (30.08.2010).

- World Bank (2010a), Global Economic Prospects: Crisis, Finance, and Growth 2010, Published February 2010 by World Bank ISBN: 0-8213-8226-8 ISBN13: 978-0-8213-8226-4 SKU: 18226, http://publications.worldbank.org/ecommerce/catalog/product?item_id=9547035, (05.08.2010).

- World Bank (2010b), Global Economic Prospects Summer 2010: Regional Annex, http://siteresources.worldbank.org/INTGEP2010/Resources/FullReportGEPSummer2010.pdf, (18.08.2010).

- World Bank (2010c), Countries in Europe and Central Asia, http://web.worldbank.org/WBSITE/EXTERNAL/COUNTRIES/ECAEXT/0,,content MDK:21776903 menuPK:5026204 pagePK:146736 piPK:146830 theSitePK:25859 9,00.html, (31.08.2010). 


\title{
An Analysis Of 2008 Global Crisis Through Comparative Economic Performance On The Commonwealth Of Independent States And Baltic States
}

\author{
Savaş Erdoğan, Selçuk Üniversitesi \\ Ahmet Ay, Selçuk Üniversitesi \\ Mustafa Gerçeker, Selçuk Üniversitesi
}

\begin{abstract}
In this research, EU members Baltic States (Estonia, Latvia and Lithuania) and Commonwealth of Independent States (CIS) countries Azerbaijan, Kazakhstan and Turkmenistan analyasis comperatively with the TOPSIS Method during 2001-2009 years. This research prove that 2008 and 2009 years of all countries, as expressed global financial crises period, economic performance decreased very sharply.
\end{abstract}

JEL Codes: C30 - R10

\section{Giriş}

1992 yılında Sovyet Sosyalist Cumhuriyet Birliği'nin (SSCB) dağılmasında sonra, çok sayıda ülke kendi bağımsızlığını ilan etmiştir. Bu bağımsızlık sonrası ülkeler SSCB'nin etkisinden bir an önce kurtulmak için dünya ekonomisi ile entegre olma eğilimi içerisine girmişlerdir. Ülkelerin dünya ülkeleri ile bütünleşme çabası içerisinde yapmış oldukları politikalar nedeniyle bu ülkeler geçiş ekonomileri olarak adlandırılmaktadır. Geçiş ekonomileri olarak ifade edilen ülkeler, Doğu Avrupa Bloğu ile Orta Asya ve Kafkas olmak üzere farklı bölgelere ayrılmaktadır. Bu çalışmada, doğu bloğu ülkeler içerisinde yer alan Baltık Ülkeleri (Estonya, Letonya, Litvanya) ile Bağımsız Devletler Topluluğu olarak ifade edilen Azerbaycan, Kazakistan ve Türkmenistan ekonomilerinin 2001-2009 yılları arasındaki ekonomik performansları Topsis metodu yardımı ile test edilmiştir.

\section{Baltık ve BDT Ülkelerinin Ekonomik Değerlendirmesi}

Gerek Baltık gerekse Bağımsız Devletler Topluluğu (BDT) olarak ifade edilen ve SSCB'den ayrılan ülkelerin, bağımsızlıklarını ilan ettikleri ilk yıllar haricinde dünya ekonomisi ile entegre olma süreçleri kolay olmuştur. Özellikle bu ülkelerin gayri safi milli hasılaları (GSMH), dış ticaret hacimleri ve doğrudan yabancı sermaye yatırımlarındaki hızlı artışlar 2000'li yıllarda belirgin hale gelmiştir.

Çalışmamızdaki analize konu olan Baltık ülkeleri Estonya, Letonya ve Litvanya'nın Avrupa Birliğine giriş yılı olan 2004 yılından itibaren ekonomik gelişmeleri hız kazanmıştır. Bu ülkelerin 2000 ve 2008 yılları kıyaslandığında yaklaşık olarak GSMH'ları 4,5 kat artış göstermiştir. Bu ülkelerin artış hızları aynı iken, grafiksel olarak meydana gelen artış trendlerde benzerlik göstermektedir (Grafik 1). 2009 kriz yılında ise belirgin bir şekilde ülke ekonomileri daralma eğilimi göstermiştir. 


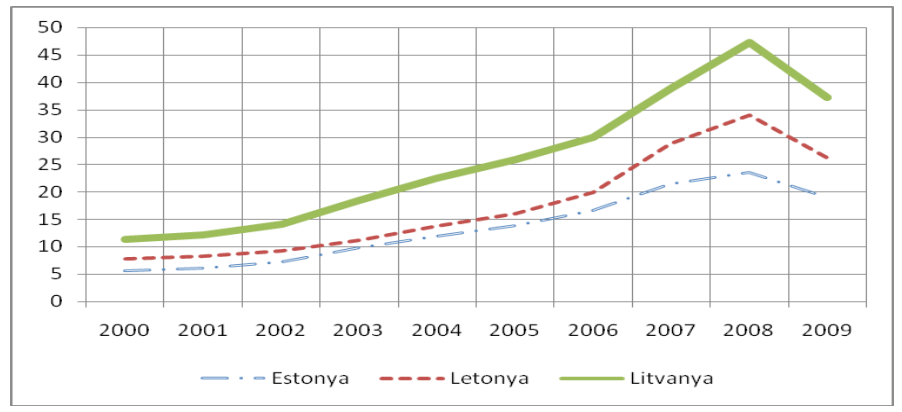

\section{Grafik 1: Baltık Ülkelerinin 2000-2009 Yılları Arasındaki GSMH Değerleri}

Bağımsız Devletler Topluluğu ülkelerinden Azerbaycan, Kazakistan ve Türkmenistan ise sahip oldukları doğalgaz ve petrol rezervleri sayesinde son dönemlerde dünya ülkeleri ile daha kolay entegre olmuşlardır. Bu durum, ülkelerin daha hzılı büyümesine olanak sağlamıştır. Şöyleki 2000 yılı ile 2008 yılı karşılaştırıldığında bu ülkelerin GSMH'sındaki cari düzeydeki artış şaşırtıcı derecede hızlı olmuştur. Bu dönemler arasında GSMH; Azerbaycan'da 9, Kazakistan'da 8 ve Türkmenistan'da ise 5 kat artış göstermiştir. Özellikle Kazakistan ve Azerbaycan ekonomisindeki GSMH artışı değer olarak göze çarpmaktadır. Azerbaycan'ın 2000 yılı GSMH's1 5 milyar dolar civarında iken, 2008 yılında 46 milyar dolara, Kazakistan'ın 2000 yılı GSMH'sı yaklaşık 18 milyar dolar iken 2008 yılında 133 milyar dolara yükselmiştir (Garfik 2).

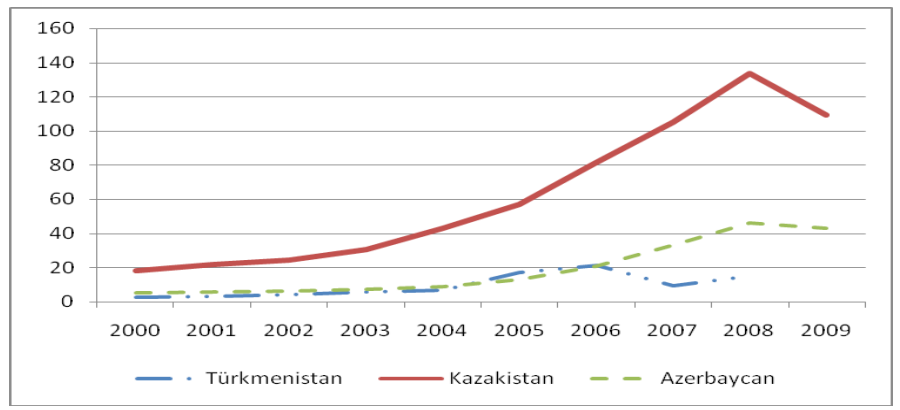

Grafik 2: BDT Ülkelerinin 2000-2009 Yılları Arasındaki GSMH Değerleri

$\mathrm{Bu}$ ülkelerin dışa açılma durumları incelendiğinde, Baltık ülkelerinin dış ticaret hacminin 2000 yılında ekonomik büyüme ile birlikte artış gösterdiği görülmektedir. Ama bu ülkelerin ortak noktaları bu dönemler arasında sürekli dış ticaret açığı vermeleri olmuştur. Ayrıca söz konusu ülkelerin 2004 yılında AB üyesi olması, doğrudan yabancı sermaye akımlarını da, 2004 yılından itibaren olumlu yönde etkilemiş ve belirgin bir artış söz konusu olmuştur.

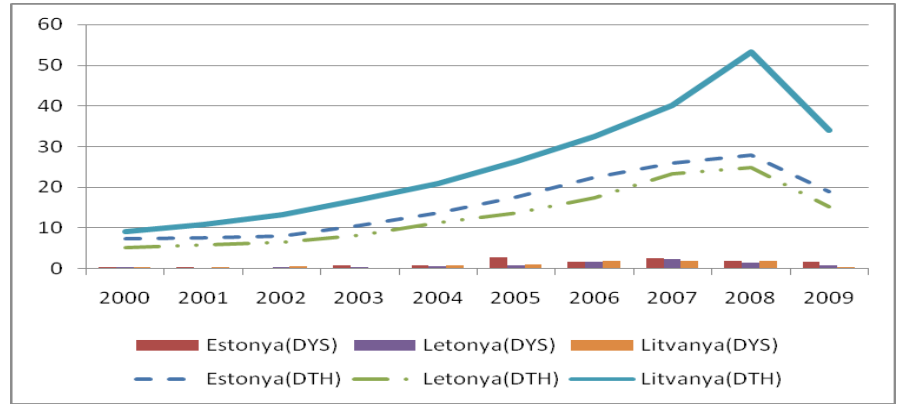

Grafik 3: Baltık ülkelerinin Dış Ticaret Hacmi ve Doğrudan Yabancı Sermaye Hareketleri 
BDT ülkeleri, sahip oldukları petrol ve doğalgaz rezervleri ile 2000'li yıllarda ihracatları ve ithalatları daha fazla artış göstermiştir. Ama bu artışlarda ihracatın artış hızı ithalatın artış hızından daha fazla olmuş ve bunun sonucunda BDT ülkeleri söz konusu dönem içerisinde sürekli dış ticaret fazlası elde etmişlerdir. Doğrudan yabancı sermaye hareketlerine bakıldığında, özellikle Kazakistan ekonomisinde ciddi derecede bir artıș söz konusu olmuștur. Azerbaycan ekonomisinde 2006 ve 2007 yılı için yabancı sermaye çıkışları gerçekleşmiştir.

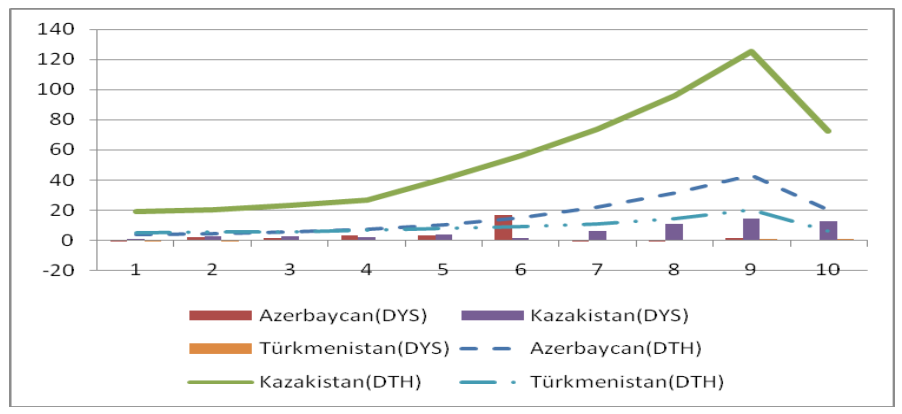

Grafik 4: BDT Ülkelerinin Dış Ticaret Hacmi ve Doğrudan Yabancı Sermaye Hareketleri (Milyar Dolar)

\section{Veriler ve Metodolojik Analiz}

Çalışmada kullanılan 2001 - 2009 yıllarına ait "Ekonomik Büyüme (EG), Enflasyon oranı (ENF), İhracat (EXP), İthalat (IMP) ve Doğrudan Yabancı Sermaye Yatırımı (FDI)" verileri, dünya bankasının "databank.worldbank.org" veri tabanından temin edilmiş olup, 2009 verileri ise, unctad.org internet sitesinden "World Investment Report 2010" veri tabanı ile çalışmada adı geçen ülkelerin merkez bankalarının internet sitelerinden temin edilmiştir. Ülkelerin ekonomik yapılarının yani büyüklüklerinin farklı olması nedeni ile çalışmada kullanılan veriler yıllar itibari ile yüzdesel değişmeler alınarak yapılmıştır.

Çalışmada, ülkelerin ekonomik performansını ölçmek için kullanılan performans denklemi (P) veriler için kullanılan belirli bir ağırlık ölçütü (w) ile elde edilen bir fonksiyondur. Bu fonksiyon (i) belli bir yılı ifade etmek üzere;

$$
\mathrm{P}(\mathrm{i})=\mathrm{w}_{1} \mathrm{EG}+\mathrm{w}_{2} \mathrm{ENF}+\mathrm{w}_{3} \mathrm{EXP}+\mathrm{w}_{4} \mathrm{IMP}+\mathrm{w}_{5} \mathrm{FDI} \quad(\mathrm{i}=1,2,3,4
$$

şeklinde tanımlanmaktadır.

Ülkenin ekonomik performans kriterini ölçmek için çok kriterli karar verme yöntemlerinden TOPSISS metodu kullanılmıştır. Baltık ve BDT Ülkelerinin ekonomik performansının ölçülmesi için kullanılan bu yöntem; Eleren ve Karagül'ün 2008 yılında yapmış olduğu Türkiye'nin ekonomik performansını araştıran çalışmasından yola çıkılarak yapılmıştır.

$\mathrm{Bu}$ yöntemle, beş değişkene dayalı tek bir performans puanının hesaplanması ve buna göre performans büyüklüklerinin sıralanabilmesi amaçlanmıștır. Bu yöntem uygulanırken kullanılan veriler, ülke ekonomilerinin görece büyüklükleri birbirinden farklı olduğu için cari değerler üzerinden ele alınmayıp, yıllar itibari ile yüzdesel değișimler olarak kullanılmıştır. Ayrıca bu yöntemin uygulanması durumunda, ülkelerin bu değişkenlere verdiği tepkilerin aynı olduğu, yani ağırlandırılmış derecelerin 1 olduğu varsayılmıştır.

\subsection{Topsis Yöntemi}

Topsis Yöntemi, Hwang ve Yoon tarafindan çok kriterli karar verme tekniği olarak geliştirilmiştir (Shyjith vd. 2008). Yöntemin temeli, pozitif ideal çözüme en yakın mesafe ve negatif ideal çözüme en uzak mesafedeki alternatifi seçmeye dayanmaktadır. Topsis yönteminin yapılış aşamaları aşağıdaki şekildedir (www. deu.edu.tr/userweb/k.yaralioglu/dosyalar/TOPSIS_yontemi.doc ). 
I - Karar matrisinin oluşturulması (A).

$A=\left\lfloor a_{i j}\right\rfloor_{m x n}$ şeklinde verilen karar matrisinde m karar noktası sayısını, $\mathrm{n}$ ise değerlendirme faktörü sayısını ifade etmek üzere, oluşturulan A matrisi i alternatifinin j kriterine göre gerçek değerini ifade etmektedir.

II - Standart karar matrisinin oluşturulması (R ).

Standart karar matrisi, A matrisinden yola çıkarak ve aşağıdaki formül kullanılarak hesaplanır.

$$
R_{i j}=\frac{a_{i j}}{\sqrt{\sum_{k=1}^{m} a_{k j}^{2}}}
$$

III - Ağırlıklı standart karar matrisin oluşturulması (V).

Değerlendirme faktörüne ilişkin ağırlık dereceleri (w) belirlenir. Bu değerler ile V matrisi $\mathrm{V}=\mathrm{W}_{\mathrm{i}} \cdot \mathrm{R}_{\mathrm{ij}}$ matrisi oluşturulur.

IV- Ağırlıklı standart karar verme matrisinden yola çıkarak, ideal $\mathrm{A}^{+}$ve negatif ideal $\mathrm{A}^{-}$ çözümleri oluşturulur. Pozitif ideal çözüm, ağırlıklı standart karar matrisinin en iyi performans değerinden oluşurken negatif ideal çözüm ise en kötü değerlerden oluşur. Bu en iyi ve en kötü değerler kullanılarak $\mathrm{J}^{+}$maksimizasyon ve $\mathrm{J}^{-}$minimizasyon değeri elde edilmektedir.

$$
\begin{aligned}
& A^{+}=\left\{\left(\max v_{i j} \mid j \in J\right\}\right. \\
& A^{-}=\left\{\left(\min v_{i j} \mid j \in J\right\}\right.
\end{aligned}
$$

V - J alternatif ideal çözümden uzaklığı ideal ayırım $\mathrm{S}^{+}$, negatif ideal çözümden uzaklığ negatif ideal ayırımı $\mathrm{S}^{`}$ sırası ile aşağıdaki formüllerden faydalanarak yapılır.

$$
S^{+}=\sqrt{\sum_{j=1}^{n}\left(v_{i j}-v^{+}{ }_{j}\right)^{2}} \quad \text { ve } \quad S^{-}=\sqrt{\sum_{j=1}^{n}\left(v_{i j}-v^{-}{ }_{j}\right)^{2}}
$$

VI - pozitif ve negatif ideal ayırımlardan yola çıkarak, $C=\frac{S^{-}}{S^{+}+S^{-}}$formülü yardımı ile ideal çözüme göreli yakınlık hesaplanır. C değeri 0 ve 1 dâhil olmak üzere bu aralıklarda yer alır. C değeri bire yakınlaşması pozitif ideal çözüme, sıfıra yakınlaşması negatif ideal çözüme yakınlaştığını gösterir. Böylece bire yakın olan değer daha iyi performansı ifade eder.

\subsection{Bulgular}

Estonya, Letonya, Litvanya (Batlık ülkeleri) ile Azerbaycan, Kazakistan ve Türkmenistan (BDT) ülkelerine ait 2001 - 2009 yıllarına ait ekonomik performans, aşağıdaki denklem yardımı ile ifade edilmektedir.

$$
\mathrm{P}(\mathrm{i})=\mathrm{w}_{1} \mathrm{EG}+\mathrm{w}_{2} \mathrm{ENF}+\mathrm{w}_{3} \mathrm{EXP}+\mathrm{w}_{4} \mathrm{IMP}+\mathrm{w}_{5} \mathrm{FDI} \quad(\mathrm{i}=1,2,3,4
$$

Buna göre, denklemi oluşturan performans değişkenleri Ekonomik Büyüme (EG), Enflasyon Oranı (ENF), İhracat (EXP), İthalat (IMP) ve Doğrudan Yabancı Sermaye Yatırımı (FDI) olarak tanımlanmaktadır. Bu verilere ait karar matrisi verilerin değerleri ile oluşturulur.

$\mathrm{Bu}$ karar matrisinden yola çıkarak, standart karar matrisi oluşturulur. Bu matriste ağırlık derecesini ifade eden $\mathrm{w}$ değeri 1 olarak alınmıştır.

Faktör değerlerden (sütunlardan) yola çıkarak performansı en iyi olan (yani en yüksek) değer ve en kötü olan (yani en düşük) değerler seçilir. Bu seçim yapılırken ekonomik performansta yüksek ve düşük değerlerin iyi ya da kötü olmasına bakılır. Maksimum ve minimum değerler ile pozitif ve negatif ideal çözümden uzaklığı ifade eden S matrisi oluşturulur. İdeal çözümün 
ifade edildiği ülkelere ait performans değerleri grafikleri aşağıda gösterilmiştir.

$\mathrm{Bu}$ grafiklerde, ülkelerin yıllar itibari ile ekonomik performans değerleri ve 2001-2009 dönemine ait ortalama performans değeri gösterilmiştir. Ülkelerin tek tek analiz edilmesi durumunda, Türkmenistan 2002, 2005 ve 2006 yıllarında ortalama değerden daha yüksek bir performans göstermiştir. Kazakistan ekonomisi ise, 2001, 2004, 2006, 2007 ve 2008 yıllarında ortalama değerden daha yüksek veya aynı derecede performans göstermiştir. Azerbaycan ekonomisi ise, 2001,2002, 20042005 ve 2007 yıllarında ortalama değere eş değer ya da daha yüksek performans göstermiştir. Baltık ülkelerinde ise, özellikle Letonya ekonomisi dikkat çekmektedir. Bu ülke, kriz dönemleri haricinde $(2008$, 2009) ortalama değerin üzerinde seyretmiştir. Estonya ülkesi ise, 2003, 2005 ve 2007 yıllarında ortalama değerin üzerine çıkmıştır. Litvanya ekonomisinin ekonomik performansı ise, 2004 yılı haricinde genellikle ortalama değerde seyretmiştir. Bütün bu ülkelere bakıldığında, küresel mali kriz dönemlerini ifade eden 2008 ve 2009 yıllarında ekonomik performanslarının düştüğ̈̈ görülmektedir. Bu demek oluyor ki, küresel mali kriz ile ülkelere ait bu değişkenler ele alındığında söz konusu ekonomilerin geçmiş dönemlere göre daralma gösterdiği sonucuna ulaşılmaktadır.

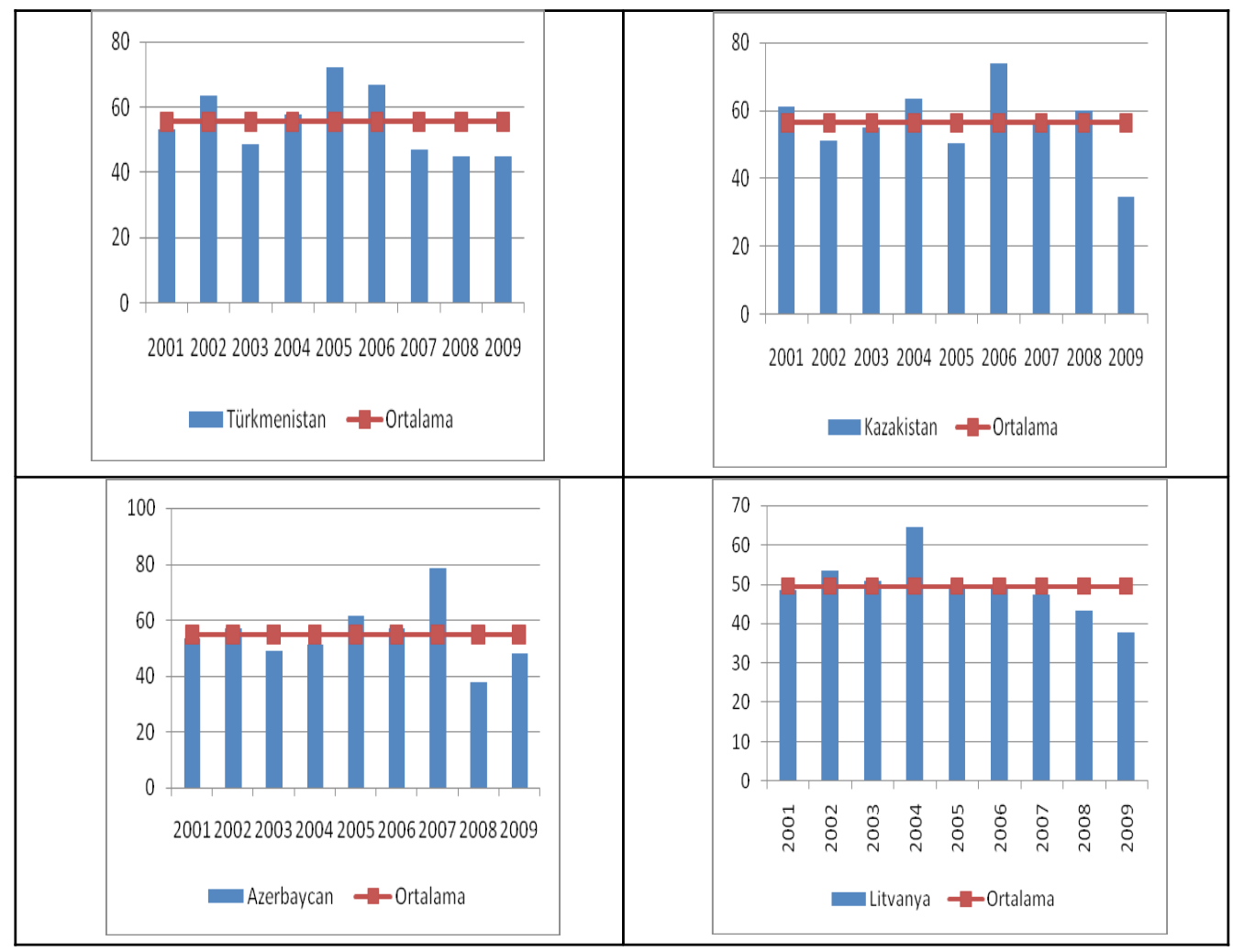




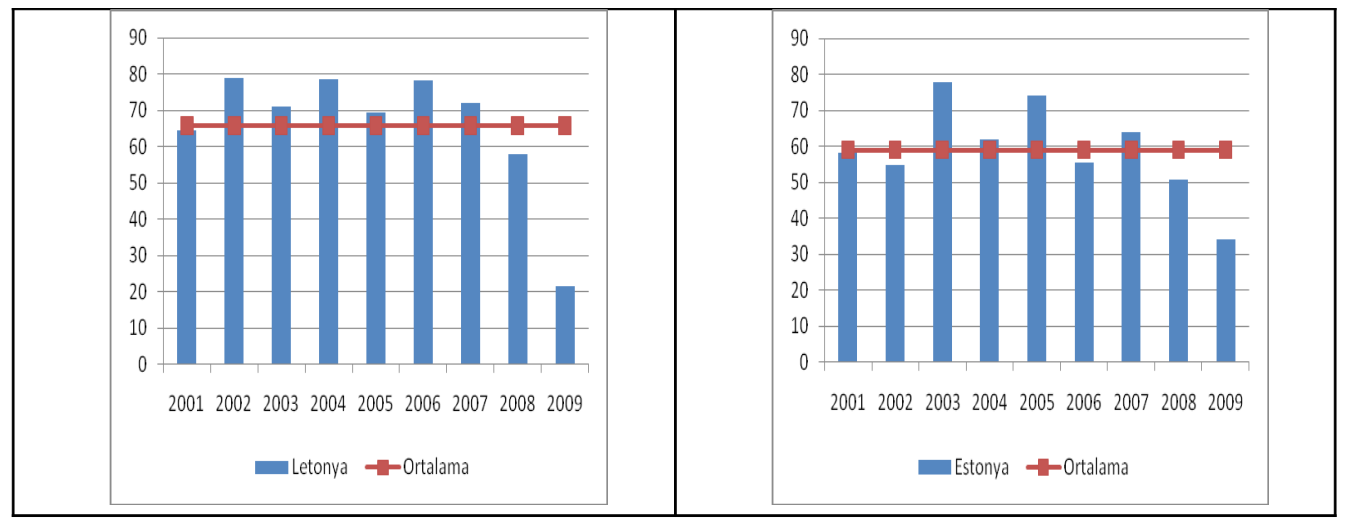

Grafik 5: İdeal Çözümden Uzakliğı Gösteren Matrise Ait Grafikler ve Ortalama Performans Değerleri

Ülkelere ait ekonomik performanslar beraberce ele alındığında, aşağıdaki tablo ortaya çıkmaktadır. Grafiğe göre, genellikle BDT ülkelerinden Kazakistan ve Azerbeycan'ın Baltık Ülkelerinde ise Letonya ve Estonya'nın ekonomik performansları dikkat çekmektedir. Ülkelere ait ekonomik performanslar mali kriz döneminde düşüş göstermiştir. Kriz döneminde ülkelerin performanslarının düşmesine rağmen, dışa açıklık derecesi düşük ve nispeten küçük ekonomilerin daha az zarar gördüğü görülebilmektedir. İthalat, ihracat ve doğrudan yabanc1 sermaye hareketlerinin yüksek olduğu ülkelerde ise mali kriz döneminde ekonomik performanslarının daha fazla düşüş gösterdiği gözlemlenmiştir (Grafik 6). Aşağıda histogram şeklinde ifade edilen ülkelerin yıllara göre ekonomik performans değerleri ve ülke sıralamaları ayrıntılı bir şekilde EK 1'deki dairesel grafiklerde gösterilmiştir.

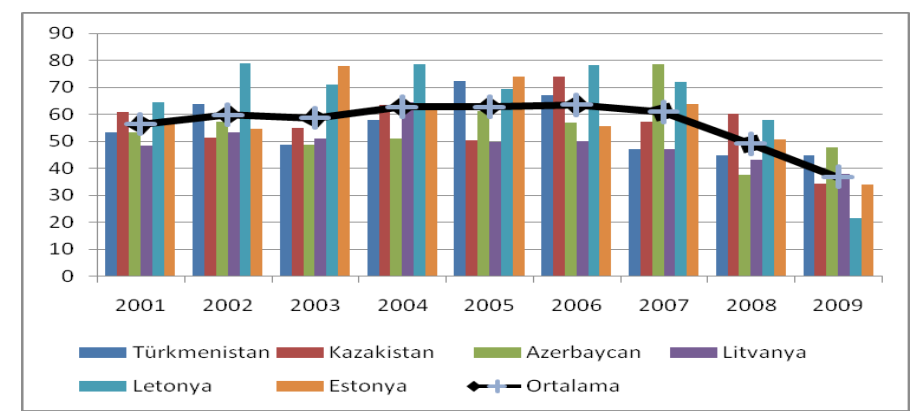

Grafik 6: Baltık ve BDT Ülkelerinin Yıllık Ortalama Değere Göre Performansları

\section{Sonuç ve Değerlendirme}

2007 yılının sonlarında başta Amerika da ortaya çıkan küresel mali kriz kısa süre içinde tüm dünya ülkelerini etkisi altına almıştır. Özellikle ABD gibi gelişmiş olan diğer ülkeleri (AB ülkeleri) bu küresel krizden önemli derecede etkilenmiştir. Dünya ekonomisine yöne veren bu ülkelerin durgunluk yaşamış olması direkt olarak diğer ülkeleri de etkilemiştir. Bu bağlamda, kürsel mali krizin çalışmamıza konu olan Baltık ve BDT ülkelerinin ekonomik performanslarını nasıl etkilediği karşılaştırmalı olarak, 2001 - 2009 yılları arasında TOPSíS yöntemi yardımı ile analiz edilmiştir. Bu yöntem ile ülkelerin yıllar itibari ile önemli ekonomik göstergeleri ele alınmıştır. Bu göstergeler ülkelerin GSMH'sı, ihracat, ithalat, enflasyon oranı 
ve doğrudan yabancı sermaye yatırım değerleri olarak inceleme yapılmıştır. Bu veriler yardımı ile yapılan analizde küresel mali krizin ülkelerin ekonomik performanslarını olumsuz yönde etkilediği ortaya çıkmıștır. Zira kriz öncesi bu ülkelerde ekonomik performans yüzde 50'lerin çok çok üzerine çıkmasına rağmen kriz yılında ise yüzde 20 ile 45 aralığında oluşmuştur. 20082009 dönemini ifade eden kriz öncesi dönem ele alındığında, ekonomik performansı yüksek olan ülkelerin kriz döneminde ise yüzdesel olarak çok düşük performanslar ortaya çıkmıștır. Analize konu olan değişkenler ele alındığında bu duruma neden olan faktör, ülkelerin dışa açıklık dereceleri ile doğrusal orantı içinde olduğunu göstermektedir.

\section{Kaynakça}

- Shyjith, vd, 2002. "Multi-criteria decision-making approach to evaluate optimum maintenance strategy in textile industry", Journal of Quality in Maintenance Engineering, Vol. 14; No. 4, pp.375 - 386.

- Alagöz, vd, 2004. "Türk Cumhuriyetleri İle İlişkilerimize Ekonomik Açıdan Bir Yaklaşım”, Selçuk Üniversitesi, Sosyal Bilimler Enstitüsü Dergisi, Sayı:12, ss:59-74

• Elener, vd, 2008. "1986 - 2006 Türkiye Ekonomisinin Performans değerlendirmesi”, Celal Bayar Üniv. Yöentim ve Ekonomi Dergisi, Cilt: 15 Sayı: 1.

- $\quad$ Altınok, vd, 2006. "Türkiye İle Türk Cumhuriyetleri Arasındaki Ticari ilişki, mevcut Durum, Geleceğe Yönelik Önlem ve Öneriler”, Ülkümüz Dergisi, Sempozyum bildirileri, Cilt:1.

- Ay, vd. 2008. Geçiş Ekonomileri. Edt.: İbrahim Örnek, Seyhan Taş ve Metin Yildırım, ss. 143 - 190, Bursa.

- World Economic Outlook October 2009. Sustaining the Recovery International Monetary Fund, http://www.imf.org/external/pubs/ft/weo/2009/02/pdf/text.pdf

- Topsis Yöntemi, 2010. www. deu.edu.tr/userweb/k.yaralioglu/dosyalar/TOPSİS_yontemi.doc

- Worldbank, 2010. http://databank.worldbank.org/ddp/home.do

- World Investment Report, 2010. http://www.unctad.org/Templates/Page.asp? intItemID $=3198 \&$ lang $=1$

- Economimc Statistic, 2010. http://www.economywatch.com/economicstatistics/country/

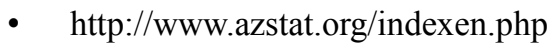

- http://www.bankofestonia.info/dynamic/itp1/itp_report_1a.jsp? reference $=545 \&$ startDay $=1 \&$ startMonth $=1 \&$ startYear $=2008 \&$ endDay $=1 \&$ endMonth $=$ $12 \&$ endYear $=2009 \&$ reference $=544 \&$ class Name $=$ EPSTAT $1 \&$ step $=11 \&$ nrOfQuarter $=0$ \& commtype $=1 \&$ lang $=$ en \&submit $=$ SHOW

- $\quad$ http://www.lb.lt/statistics/statbrowser.aspx? nccharset $=1978$ BE4D\&lang $=$ en\&orient $=$ vert\&date_type $=4 \&$ Year $0=2006 \&$ Year $1=20$ $10 \& 12 \mathrm{MONTHS}=1 \&$ group $=7234$

- $\quad$ http://www.bank.lv/LMB/LMB en.php? table level $0=19 \&$ table level $1=$ \&tables $=3$ \&lang=2 \&period- $\mathrm{f}=2009$ \&period$\mathrm{t}=2010$ \&periodiskums $=1 \&$ currency $=3$ \&bopsy lim $=0$ \&mervieniba $=2$

- $\quad$ http://www.nationalbank.kz/?docid=199 
Ek 1. Yıllar İtibari ile Ülkelerin Performans Değer Stralaması

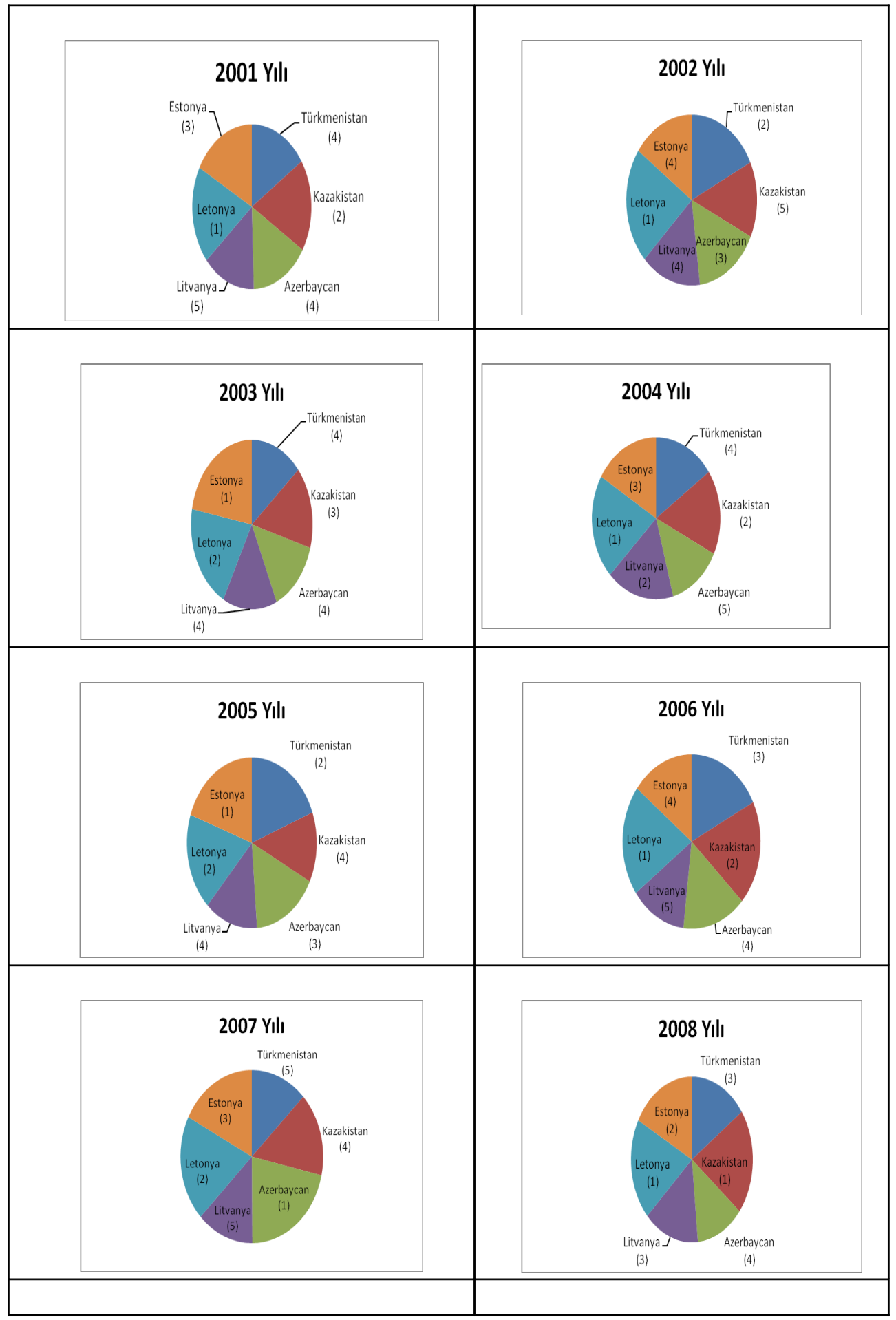




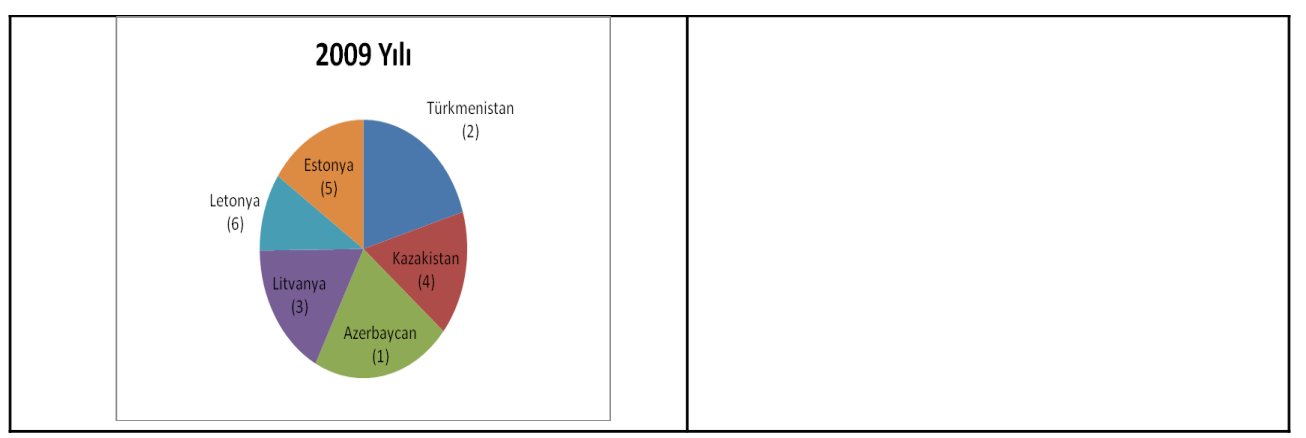




\title{
2008 Küresel Krizinin Avrasya Ülkelerinin Ekonomileri Üzerindeki Etkileri
}

\author{
Bilal Özer, Okan Üniversitesi \\ Alper Karaağaç, Okan Üniversitesi \\ İsmail Önden, Okan Üniversitesi
}

\begin{abstract}
The Effects Of 2008 Global Crisis On Eurasian Countries' Economies

With the ongoing technological progress new transportation and communication channels have emerged, and interactions between people and therefore states has increased significantly. As a consequence of this development the concept of globalization, meaning the disappearance of the boundaries between states, has arisen. Thus the process of integration between the economies of states has started, which increased the dependency and interaction of the state economies. Hence, an economics crisis appearing in a particular state effects all of the countries integrated to this integrated system.

In this study it is aimed to research that in what degree the Eurasian economies are integrated to the world economy, and affected from the recent economic crisis. The changes of the growth rates of the economies of Eurasian states during the crisis have been considered in order to employ them in the analysis of these affects. Moreover, by considering the basic economic indicators of those states such as unemployment rate, consumer price index, budget deficit, current deficit, it is aimed that to reach a general view of those states economic positions.
\end{abstract}

JEL code: F20

\section{Giriş}

Ülkeler arasındaki etkileşim, gelişen, çeşitlenen ulaşım ve iletişim kanalları (Fischer, 2003a) sayesinde geçmişle karşılaştırıldığında çok önemli derecede artış göstermiştir. Bu etkileşim her geçen gün yeni ekonomilerin dünyaya entegre olması (Reich, 1998) ile daha da artmaktadır. Böylece ülkeler arasındaki ticari, kültürel ve sosyal sınırlar kalkmaktadır (Fischer, 2003b). Buna bağlı olarak küreselleşme adı verilen, ülkelerin ekonomik yönden birbirlerine bağımlı oldukları bütünleşik bir sistem ortaya çıkmıştır. Küreselleşmenin sonucu olarak, bu sistemin içindeki bir ülkede yaşanan krizin bu sisteme entegre olan tüm ülkeleri etkileyeceği öngörülebilir (Eğilmez, 2009).

Çalışma, 2008 küresel krizinin Avrasya ülkelerinin ekonomilerini ne derecede etkilediğinin ortaya konulmasını amaçlamaktadır. Bu bağlamda seçilmiş olan ülke ekonomilerinin gayri safi yurtiçi hasıla, tüketici fiyatları, ithalat - ihracat, doğrudan yabancı yatırımı, cari açık, toplam dış borç verilerinin kriz öncesi, süreci ve sonrasındaki değişimlerini tespit etmek, bu değişimleri analiz ederek krizin ülke ekonomilerine ne şekilde etki ettiğini ortaya koymak amaçlanmaktadır. Bu analizler sonucu, seçilen Avrasya ülkelerinin ekonomilerinin dünya ekonomileriyle ne derecede bağımlılık gösterdiği tespit edilmeye çalışılmıştır.

\section{Metodoloji}

Çalışma belli ekonomik göstergeler baz alınarak 2008 küresel krizinin Avrasya ülkelerini ne şekilde etkilediğinin belirlenmesini amaçlamaktadır. Buradan hareketle Avrasya ülkelerinin küreselleşme denilen bütünleşik sisteme ne derece bağlı olduklarının, dünyanın bir ucunda yaşanan bir krizin bu ülkeler üzerinde ne kadar etkili olabileceğinin bulunması amaçlanmaktadır. $\mathrm{Bu}$ bağlamda analiz edilecek ülkeler, bu ülkelere ait belli ekonomik göstergeler seçilmiş ve bu yönde veri toplama işlemi gerçekleştirilmiştir. 


\section{Veri}

Coğrafi, jeopolitik ve yeraltı kaynakları bakımından ele alınan Rusya, Ukrayna, Belarus, Moldova, Kazakistan, ve Azerbaycan'ın gayri safi yurtiçi hasıla, tüketici fiyatları, ithalat ihracat, doğrudan yabancı yatırımı, toplam dış borç, cari açık oranlarında 2008 küresel krizi öncesi, süreci ve sonrasında yaşanan değişimleri yansıtan veriler göz önüne alınarak veri toplanmıştır.

\subsection{Veri Toplama}

Veri toplama sürecinde 2008 küresel krizinin öncesi, süreci ve sonrasını içeren 2007, 2008, 2009 yıllarına ait veriler Dünya Bankası ve IMF gibi güvenilir kurumların internet sitelerinden elde edilmiştir.

\subsection{Veri Analizi}

Araştırma kapsamında değerlendirilecek olan ülkelerin ekonomik durumlarını gösteren verilerin 2007, 2008, 2009 yıllarındaki değişim oranları araştırılmış ve aşağıdaki tablo (Tablo 1) oluşturulmuştur.

\begin{tabular}{|c|c|c|c|c|c|c|c|}
\hline & & Rusya & Ukrayna & Kazakistan & Moldova & Azerbaycan & Belarus \\
\hline \multirow{3}{*}{$\begin{array}{c}\text { GSYH } \\
\text { Değişimi } \\
\text { (Yıllık \% } \\
\text { değişimi) }\end{array}$} & 2007 & 8,1 & 7,9 & 8,9 & 3 & 25 & 8,6 \\
\hline & 2008 & 5,6 & 2,1 & 3,2 & 7,8 & 10,8 & 10 \\
\hline & 2009 & $-7,9$ & $-15,1$ & 1,2 & $-6,5$ & 9,3 & 0,2 \\
\hline \multirow{3}{*}{$\begin{array}{l}\text { Tüketici } \\
\text { Fiyatları } \\
\text { (Yıllık \% } \\
\text { değișimi) }\end{array}$} & 2007 & 11,9 & 16,6 & 18,8 & 13,1 & 19,5 & 12,1 \\
\hline & 2008 & 13,3 & 22,3 & 9,5 & 7,3 & 15,4 & 13,3 \\
\hline & 2009 & 8,8 & 12,3 & 6,2 & 0,4 & 0,9 & 10,1 \\
\hline \multirow{3}{*}{$\begin{array}{l}\text { Ihracat } \\
\text { (Yıllık \% } \\
\text { değişimi) }\end{array}$} & 2007 & 16,8 & 27,4 & 24,7 & 30,9 & 61,4 & 24,2 \\
\hline & 2008 & 33,1 & 33,8 & 48,9 & 24,3 & 42,7 & 34,2 \\
\hline & 2009 & $-35,7$ & $-36,6$ & $-38,9$ & $-19,3$ & $-28,8$ & $-33,1$ \\
\hline \multirow{3}{*}{$\begin{array}{c}\text { İthalat } \\
\text { (Yıllık \% } \\
\text { değişimi) }\end{array}$} & 2007 & 36 & 35,4 & 37,9 & 37,5 & 15,9 & 28,1 \\
\hline & 2008 & 30,6 & 38,5 & 15,6 & 32,1 & 21,7 & 36,9 \\
\hline & 2009 & $-34,3$ & $-43,7$ & $-25,2$ & $-30,1$ & $-13,6$ & $-27,2$ \\
\hline \multirow{3}{*}{$\begin{array}{c}\text { Doğrudan } \\
\text { Yabancı } \\
\text { Yatırımı } \\
\text { (Yıllık \% } \\
\text { değişimi) }\end{array}$} & 2007 & & 6,5 & 8 & 131,3 & $-15,4$ & 404,2 \\
\hline & 2008 & & 5,5 & 14,8 & 32,3 & $-1,2$ & 21,4 \\
\hline & 2009 & & 4 & 9,5 & $-88,5$ & 0,3 & $-15,7$ \\
\hline \multirow{3}{*}{$\begin{array}{c}\text { Cari Açık } \\
\text { (GSYH'a } \\
\text { oranı - \%) }\end{array}$} & 2007 & $-7,6$ & 0,7 & 4,3 & 14,3 & 27,3 & 6,1 \\
\hline & 2008 & $-7,8$ & 3,2 & $-7,8$ & 15,5 & 35,5 & 7,8 \\
\hline & 2009 & $-5,8$ & $-4,5$ & 0,1 & 7,7 & 23,6 & 11,9 \\
\hline \multirow{3}{*}{$\begin{array}{l}\text { Toplam Dış } \\
\text { Borç (Yıllık } \\
\text { \% değişimi) }\end{array}$} & 2007 & 4,6 & 5,5 & 2,6 & $-1,6$ & $-6,7$ & 9,2 \\
\hline & 2008 & $-7,4$ & 0,3 & $-14,5$ & $-6,8$ & $-2,2$ & $-2,6$ \\
\hline & 2009 & 9,5 & 31,6 & 24,2 & 12,1 & 0,8 & 19,2 \\
\hline
\end{tabular}

Tablo 1 : Seçilmiş ülkeler ve ekonomik göstergeleri

\subsubsection{Rusya}

Yukarıdaki tablo incelendiğinde 2007 yılında GSYH'1 \%8,1 oranında artan Rusya'nın 2008 yılında \%5,6 ile artış oranında bir azalma göze çarpmaktadır ve 2009 yılında GSYH'ın \%7,9 azalmasıyla krizin etkilerinin iyice hissedildiği anlaşılmaktadır. Tüketici fiyatları incelenen yılların herbirinde artış göstermiştir ancak 2009 yılındaki artış miktarı önceki yıllardan daha düşük seviyede gerçekleşmiştir. İhracat ve ithalatta 2007 - 2008 yıllarında yaşanan büyük artışın ardından 2009 yılına gelindiğinde \%30'un üzerinde düşüş gerçekleşmiştir. Bu durum 
küresel krizin Rusya'yı derinden etkilediğini göstermektedir. İthalat ve ihracattaki değişim oranları birbirine paralel olduğundan cari açıkta önemli bir değişiklik yaşanmamıştır. Ancak 2008 'de azalan diş borç 2009'da \%9,5 oranında artmıştır. Genel olarak oranlardaki değişimlere bakıldığında Rusya'nın 2008 küresel ekonomik krizinden önemli derecede etkilendiği söylenebilir.

\subsubsection{Ukrayna}

Ukrayna'nın GSYH'ı 2008 yılında artış göstermiş olsada 2007 yılına göre düşük seviyede gerçekleșmiştir. 2009 y1lında ise \%15,1 gibi ciddi bir oranda düşüş göstermiștir. Bu durum krizin Ukrayna'yı ciddi anlamda etkilediğini ișaret etmektedir. Tüketici fiyatlarındaki değișim Rusya ile paralel olarak gerçekleşmiştir. İthalat ve ihracatta 2007 - 2008 yıllarında \%30'un üzerinde ciddi artışlar yaşanmasına rağmen 2009 yılında sırasıyla \%43 ve \%36 oranlarında büyük düşüşler gerçekleșmiștir. Kriz döneminde ve sonrasında doğrudan yabancı yatırımı azalan oranlarda artıs göstermeye devam etmiștir. 2007 - 2008 yıllarında cari açık vermeyen Ukrayna 2009 yılında GSYH'ın \%4,5'i oranında açık vermiștir. Toplam dıș borç da kriz sonrası \%31,6 ile önemli bir artış göstermiştir. Tüm veriler incelendiğinde Ukrayna'nın krizden gözle görünür derecede etkilendiği söylenebilir.

\subsubsection{Kazakistan}

Kazakistan'ın GSYH'ı incelenen yılların tümünde artış göstermiştir ancak artış hızı giderek azalmıştır. Yani Kazakistan kriz döneminde büyüme hızını azaltarak büyümeye devam etmiştir. Tüketici fiyatlarındaki değișim de GSYH'a paralel olarak gerçekleșmiștir. İhracat krizin başladı̆̆ 2008 yılında \%48,9 ile çok büyük bir artış göstermiștir. 2009 y1lına gelindiğinde ise kriz etkisini göstermiștir ve \%38,9 gibi önemli bir düşüş meydana gelmiştir. İthalat ise 2008 yılında 2007 yılına göre daha düsük bir oranda artış göstermiștir ve 2009 yılında \%25'lik önemli bir düșüs gerçekleșmiștir. Doğrudan yabancı yatırımı 2008 ve 2009 yıllarında 2007 yılına göre daha yüksek oranlarda gerçekleşmiştir. 2007 yılında cari fazla veren Kazakistan, 2008 yılında \%7,8'lik bir cari açık vermiștir. 2009'da ise bu dengeye ulaşmıștır. 2008 yılında azalan dış borç 2009 yılında önemli bir artış göstermiştir. Genel olarak incelendiğinde Kazakistan, Rusya ve Ukrayna'ya oranla krizden daha az etkilenmiştir.

\subsubsection{Moldova}

Moldova'nın GSYH'1 krizin başladığı 2008 yılında 2007 yılına göre daha fazla artış göstermiştir. Ancak 2009 yllında yaşanan \%6,5'lik düşüş krizin etkilerinin geç hissedildiğini göstermektedir. $\mathrm{Bu}$ yıllarda tüketici fiyatlarındaki değişim sıfıra yaklaşmıştır. İhracat ve ithalattaki değişimler birbirine paralel olarak gerçekleşmiştir ve kriz öncesi önemli artışlar gösterdikten sonra kriz sonrasında düşüş yaşamışlardır. Ancak ithalattaki değişimler daha sert olmuştur. 2007 yılında \%131 gibi çok ciddi bir oranda artan yabancı yatırımı, 2008 yılında \%32'lik bir artış yaşamış, sonrasında 2009 yılında ise \%88'lik büyük bir düşüş gerçekleştirmiştir. Cari açıkta çok önemli bir değişiklik yaşanmamıştır. 2007 ve 2008 yıllarında azalan dış borç, 2009 yılında \%12'lik bir artış göstermiştir. Oranlardaki değişimlere bakıldığında Moldova'nın da krizden önemli derecede etkilendiği söylenebilir.

\subsubsection{Azerbaycan}

GSYH'ın artış oranı 2008 ve 2009 yıllarında 2007 yılına göre azalmış olsada 2009 yılında yaşanan \%9,3'lük artış kriz sonrası için çok ciddi bir orandır. Yani Azerbaycan kriz süresi ve sonrasında hızla büyümeye devam etmiştir. Tüketici fiyatlarındaki değişim giderek azalmış ve 2009 yılında \%1'in altına düşmüştür. İhracat 2007 - 2008 yıllarında \%61 ve \%42 oranında çok büyük artış göstermiştir. 2009 yılında yaşanan \%28'lik düşüş, bu artışlar göz önüne alındığında çok önemli görünmemektedir. İthalat da benzer şekilde kriz sonrasında azalmıştır ancak ithalatta yaşanan değişimler ihracattaki kadar sert olmamıştır. 2007 yılında \%15 oranında azalan doğrudan yabancı yatırımı, 2008 yılında \%1,2'lik bir azalış göstermiş, 2009 yılında ise $\% 0,3$ 'lük küçük bir artış gerçekleştirmiştir. Kriz sonrası cari açık oranı düşüş göstermiştir. Toplam dış borçta ise küçük bir artış yaşanmıştır. Tüm bu oranlara bakıldığında Azerbaycan'ın kriz sürecinde ve sonrasında büyümesini devam ettirdiği ancak büyüme hızının yavaşladığ 1 
söylenebilir.

\subsubsection{Belarus}

Belarus'un GSYH'1 2007 ve 2008 yıllarında \%8,6 ve \%10 oranlarında artış gösterirken 2009 yılında \%0,2 gibi çok küçük bir artış gerçekleştirmiştir. Bu durum Belarus'un büyüme hızının kriz sonrası önemli derecede yavaşladığını göstermektedir. Tüketici fiyatlarındaki artış oranı önemli bir değișiklik göstermemiștir. İthalat ve ihracat incelenen diğer ülkelerde olduğu gibi 2007 ve 2008 yıllarında artmış, 2009 yılında ise düşüş göstermiștir. Belarus'a yapılan doğrudan yabancı yatırımı 2007 yılında \%404 oranında artmıștır. Bu çok ciddi bir rakam olduğu için 2008 yılında, normal şartlarda yüksek kabul edilebilecek ancak bir önceki yıla göre düşük kalan \%21,4'lük bir artış gerçekleşmiştir. 2009 yılında ise krizin de etkisiyle \%15,7'lik bir düşüş yaşanmıştır. Cari açık kriz süresince artış göstermiştir. Toplam dış borç 2008 yılında azalmasına rağmen, 2009 yılında yaklaşık \%20'lik ciddi bir artış göstermiştir. Eldeki verilere genel olarak bakıldığında 2008 küresel krizinin Belarus'u çok derinden etkilemediği, Azerbaycan'da olduğu gibi büyüme hızını yavaşlattığı söylenebilir.

\section{Sonuç ve Değerlendirme}

Sonuç olarak incelenen 6 ülkeye bakıldığında Rusya ve Ukrayna'nın 2008 küresel krizinden ciddi anlamda etkilendikleri, Moldova'nın ise Rusya ve Ukrayna'ya oranla daha az etkilendiği görülmektedir. Azerbaycan, Kazakistan ve Belarus'un oranlarındaki değişim hızı azalsada krize rağmen büyümelerini sürdürdükleri göze çarpmaktadır. Özellikle Azerbaycan'ın kriz sonrası 2009 yılında \%9,3'lük GSYH artışı dikkati çekmektedir. Buradan hareketle göreli olarak daha büyük ekonomilere sahip olan Rusya ve Ukrayna'nın küresel ekonomiye diğer 4 ülkeye oranla daha fazla entegre oldukları kanısına varılmaktadır. Daha küçük ekonomilere sahip diğer ülkelerin ekonomilerinin ise küresel bütünleșik sisteme tam bağımlı olmadıkları, bu nedenle küresel krizden daha düşük oranlarda etkilendikleri anlaşılmaktadır.

İleriki çalışmalarda 2009 yılı sonrası açıklanan verilerle, kullanılan veri ve ülke sayısı da arttırılarak daha kapsamlı bir çalışma yapılması amaçlanmaktadır. Bir ölçek hazırlanarak ve veriler yardımıyla puanlama yapılarak ülkelerin sayısal olarak derecelendirilmesi planlanmaktadır.

\section{References}

- Fischer, 2003a. "Globalization and Its Challenges", American Economic Review, p. 5.

- Reich, 1998. "What is Globalization? Four Possible Answers", p. 21.

- Fischer, 2003b. "Globalization and Its Challenges", American Economic Review, p. 3.

- Eğilmez, 2009. Küresel Finans Krizi. Remzi Kitabevi, İstanbul.

- World Bank, 2010. Data and statistics, http://web.worldbank.org/WBSITE/EXTERNAL/COUNTRIES/ECAEXT/RUSSIAN FEDERATIONEXTN/0, contentMDK:21032960 menuPK:989684 pagePK:1497618 $\sim$ piPK:217854 theSitePK:305600,00.html

- World Bank, 2010. Data and statistics, http://web.worldbank.org/WBSITE/EXTERNAL/COUNTRIES/ECAEXT/UKRAINE EXTN/0.,contentMDK:20147755 menuPK:328559 pagePK:1497618 piPK:217854 -theSitePK:328533,00.html

- World Bank, 2010. Data and statistics, http://www.worldbank.org.kz/WBSITE/EXTERNAL/COUNTRIES/ECAEXT/KAZA KHSTANEXTN/0, contentMDK:20212143 menuPK:361895 pagePK:1497618 piP $\underline{\mathrm{K}: 217854 \sim \text { theSitePK:361869,00.html }}$

- World Bank, 2010. Data and statistics, http://web.worldbank.org/WBSITE/EXTERNAL/COUNTRIES/ECAEXT/MOLDOV 
AEXTN/0, contentMDK:20190402 menuPK:302276 pagePK:1497618 piPK:21785 4 theSitePK:302251,00.html

- World Bank, 2010. Data and statistics, http://web.worldbank.org/WBSITE/EXTERNAL/COUNTRIES/ECAEXT/AZERBAI JANEXTN/0, menuPK:301939 pagePK:141132 piPK:141109 theSitePK:301914,00 $\underline{\text { html }}$

- World Bank, 2010. Data and statistics, http://web.worldbank.org/WBSITE/EXTERNAL/COUNTRIES/ECAEXT/BELARUS EXTN/0,menuPK:328457 pagePK:141132 piPK:141109 theSitePK:328431,00.htm 1

- IMF, 2010. IMF Country report, http://www.imf.org/external/pubs/ft/scr/2010/cr10246.pdf

- IMF, 2010. IMF Country report, http://www.imf.org/external/pubs/ft/scr/2010/cr10262.pdf

- IMF, 2010. IMF Country report, http://www.imf.org/external/pubs/ft/scr/2010/cr10241.pdf

- IMF, 2010. IMF Country report, http://www.imf.org/external/pubs/ft/scr/2010/cr10234.pdf

- IMF, 2010. IMF Country report, http://www.imf.org/external/pubs/ft/scr/2010/cr10113.pdf

- IMF, 2010. IMF Country report, http://www.imf.org/external/pubs/ft/scr/2010/cr1089.pdf 


\title{
Rusya'nın Serbest Piyasa Anlayışı ve Küresel Kriz
}

\author{
İsmail Hakkı İşcan, Bilecik University \\ Yıldız Zeliha Hatipoğlu, Bilecik University
}

\begin{abstract}
Russia's Free Market Perception and The Global Crisis

The answer of why Russia is not affected from today's global crisis, considerably, is crucial. Since 1990, Russia has been liberalizing its markets rapidly, has decreased implementations which are deterrent for open market significantly until these days. By 2000's Russia, has entered to a new term in which economic profit and instrument depending on energy sources are commented as basic priorities and instruments at foreign policy. In this study Russia's free market applications with this new era are dealt with and results of these applications are found out with the framework of 2008 global crisis.
\end{abstract}

JEL Codes: G01, F43

\section{Giriş}

Özellikle Soğuk Savaş döneminde "kapitalizm" veya daha sonraları "serbest piyasa ekonomisi" kavramları ile paralel ele alınan ve son zaman literatüründe çoğunlukla "piyasa ekonomisi" kavramı ile ifade edilen anlayış aslında siyasal çoğulculuğun, kişisel hak ve özgürlüklerin hem siyasi (konuşma, din ve vicdan, seçme ve seçilme özgürlükleri) hem de ekonomik (teşebbüs-tercih özgürlüğü) manada sağlandığı bir ortamda ekonomik güce sahip bireylerin sınırsız özgürlük içinde birbirleriyle rekabetini öngören ve devleti piyasada istemeyen bir uygulayışı anlatmaktadır. 1989'da Sovyetler Birliği ve sosyalizmin çökmesiyle birlikte günümüzde bu anlayışın alternatifi artık söz konusu değildir.

Rusya dahil geçiş ekonomilerinde piyasa ekonomisinin oluşturulması sürecinde devlet etkin görev almaktadır. Zira piyasa ekonomisine dönüşümde kaynak yetersizliği, kurumsal ve kültürel eksiklik, dönüşümdeki ekonomilerde devleti önemli ve aktif sorumluluklarla karşı karşıya bırakmaktadır. Bu ülkelere 1980'li yılların sonu itibarıyla, Uluslar arası Para Fonu (IMF) ve Dünya Bankası (DB) gibi çeşitli uluslar arası kuruluşlar önderliğinde önerilen ekonomi politikaları, bir takım nedenlerle bu ülkeleri önemli maliyetlerle karşı karşıya bırakmıştır. Bu ülkelerin mal, emek ve sermaye piyasalarının gelişmiş ekonomilerin uygulama alanına açılması, başlangıçta küresel ölçekte reel üretimin artmasına ve sonrasında enflasyonun zamanla uluslar arası düzeyde hızlanmasına neden olmuştur. 1970'lerde gelişmiş batılı ülkelerin krizi aşmak adına 1980'li yılların sonunda yeni gelişen ve elbette dağılma sonrası eski sosyalist ülkelerin oluşturduğu geçiş ekonomilerinde uygulanan piyasa ekonomisi odaklı politikaları, sermaye birikim sürecinde meydana getirdiği etkiyle çeşitli borç krizlerine ve 1990-2002 döneminde ise büyük oranlarda sermaye girişi ve çıkışına neden olduğu için finansal krizlere yol açmıştır. Bu çalışmada geçiş ekonomileri için öngörülen değerlendirme kriterlerinden hareketle, bu grup ülke ekonomileri ve dünya ekonomisi içerisinde önemli ekonomik ve siyasi güce sahip Rusya'nın ekonomik yapısı incelenerek siyasi iradenin serbest piyasa ekonomisine geçişte ortaya koyduğu politikalar irdelenecektir.

\section{8 sonrası Rusya Ekonomisi}

1992 yılı başında fiyatların serbest bırakılmasıla enflasyon oranı y1llık \%2500'lere kadar yükselmiştir. Enflasyon oranı ancak 1997 yılında dış ticarette yaşanan serbestleşmeye bağlı olarak \%11 düzeyine inebilmiştir. (DPT, 1998) 1998 yılında yaşanan krizden çıkışın IMF yardımının artırılmasının yanında, kamu harcamalarının tamamını ve ihracatın da \% 70'e varan kısmını oluşturan petrolün fiyatının artmasıyla gerçekleştiği Rusya' da toparlanma süreci, 1998 
y1lında \%85'lere varan enflasyonun 2000 yılı sonunda \% 20'lere gerilemesiyle kesin bir hal almıştır (Özel, 2005).

2000 yılı Mart ayında Boris Yeltsin'in istifasının ardından Rusya Federasyonu'nun yeni Başkanı olan ve halen yönetimde bulunan Vladimir Putin, piyasa ekonomisine geçiş sürecinin devamını sağlamak adına reform sürecini devam ettirmiştir. Putin, reform sürecinde genel olarak sosyal politikaların geliştirilmesi, vergi reformu, teşebbüslerin önündeki bürokratik engellerin kaldırılması, monopollerin düzenlenmesi, bürokrasinin iyileştirilmesi, finans piyasalarının geliştirilmesi ve bütçe reformu gibi düzenlemelere gitmiştir. Çalışmanın, 2000 yılı sonrası geçiş sürecinin değerlendirildiği bu bölümde, geçiş sürecinin içeriği 4 başlık altında incelenmektedir. $\mathrm{Bu}$ süreç liberalizasyon, makroekonomik istikrar, yeniden yapılanmaözelleştirme ve yasal ve kurumsal reformları içermektedir. Bu incelemede, Dünya Bankası'nın 2000-2007 arasında Rusya ile ilgili yayınladığı raporlar kullanılmaktadır.

Liberalizasyon: $\mathrm{Bu}$ süreçte hedeflenen şey, fiyatların çok daha serbestleştirilmiş piyasada belirlenebilmesi ve ticari engellerin ortadan kaldırılmasıdır. Rusya bu çerçevede 1992 yılında fiyatları serbestleştirmiş ancak bu durum önemli ölçüde enflasyonist etki doğurmuştur. Diğer taraftan ticaretin serbestleşmesi ve engellerin kaldırılması başlığı altında Putin yönetiminin temel hedefi, dünya ile entegre olmuş bir ticaret anlayışıdır. Bu doğrultuda Putin, Dünya Ticaret Örgütü (WTO) ile üyelik sürecine büyük bir önem vermektedir. Rusya diş ticaretinde 2008 küresel krizine kadar gelinen süreçte oluşan hacim yüksekliği, Rusya ekonomisinde sadece yapılan reform ve düzenlemelerden değil, bunun yanında daha çok üretkenliğin üzerindeki ücret seviyesi dolayısıyla artan tüketim talebiyle de açılanabilmektedir. Dünya Bankası'nın Rusya ile ilgili bu dönem (2000-2007) raporları tarandığında genel olarak ihracatın önemli bir kısmının (\% 70'i) doğal kaynaklardan oluştuğu görülmektedir. Dolayısıyla petrol fiyatlarındaki artış, Rusya'nın ihracat gelirlerinde önemli bir yükselişe neden olmaktadır. İthalattaki artışsa, hem tüketici kaynaklı olmakta, hem de Ruble'nin artan değeri neticesinde ucuzlayan ithal sermaye mallarına olan talep artışından kaynaklanmaktadır. Doğal kaynak bağımlısı tipik bir ekonomide olduğu gibi, Rusya'da da reel döviz kuruna yukarı yönlü bir baskı oluşmakta ve yerli üreticiler, kendilerini ithal yarışı ve artan üretim maliyetleri arasında sıkışmış olarak bulmaktadır. Doğal kaynak tabanlı ihracat artışı yaşanırken, rekabete tabi olmayan ve bir yandan da artan gelirle artış gösteren hizmet talebi de, buna ayak uydurmaktadır (Dünya Bankası, 2002).

Makroekonomik İstikrar: Teoride, serbestleşme ile birlikte başarılı bir geçiş süreci için makroekonomik istikrarın sağlanması, böylece düşük enflasyon ve sıkı bütçe çerçevesinde sınırlandırılmış devlet anlayışı ile para politikasının bağımsız olan Merkez Bankası tarafından yürütülmesi, hem tüketici hem de yatırımcı için öngörülebilir ve güvenilir bir ekonomi iklimi oluşturacaktır. Ekonomide devletin payının minimuma indirildiği, yeni girişim ve KOBİ'lerin ekonomik büyümeyi sürüklediği geçiş ekonomilerinde, sürdürülebilir ekonomik büyüme ancak bu şekilde sağlanabilecektir.

Rusya ekonomisi 1998 krizinde \%5,3 oranında küçülme yaşadıktan sonra, hızlı bir büyüme sürecine girmiştir. 1998 'de 10 dolara kadar gerileyen petrol fiyatlarının artan trendi, doğal kaynak bağımlısı ekonominin büyüme kaynağı olmuştur. Döviz rezervlerinin artışı ve enflasyonun \%85'lerden 2000 yılında \% 20'lere gerilemesi de, krizden çıkışı kesinleştirmiştir (Özel, 2005). Bundan sonra Rusya, doğal kaynak fiyatları üzerinden toparlanan ekonomik bir yönelime girmiştir. 2003 'te $\% 7,2$ 'lik büyümenin, doğrudan ve dolaylı olarak $\% 4,2$ 'si petrol etkisinden kaynaklanırken, 2004'te bu etki \% 7,3'lük büyümenin \% 5'i düzeyindedir. Büyümeyi hedefleyen ekonomiler için, bunu destekleyen bir diğer önemli unsur, IMF'nin de makroekonomik istikrarın başlangıcı saydığı enflasyonla mücadeledir. 1998 Krizi sonrasında çabuk toparlanan Rusya ekonomisinde, enflasyonla mücadelede iyi bir yol kat edilmiş, artan petrol gelirleriyle rezerv artışı ve kamu bütçe disiplini sağlanabilmiştir.

Makroekonomik istikrarın enflasyon ayağında, Rusya Merkez Bankası'nın tutumu da önem kazanmaktadır. Rusya Merkez Bankası, 20 Aralık 1991'de kurularak diğer hükümet kurumlarından bağımsız Ruble'nin korunması ve istikrarının sağlanması yükümlülükleri ile 
görevlendirilmiştir. Bu anlamda Ruble'nin istikrarı ve para arzının kontrolü, fiyat istikrarını sağlayacaktır. Diğer yandan, henüz derin bir finansal piyasaya sahip olmayan Rusya' da Merkez Bankası ancak esnek para politikası ve nominal döviz kuruna müdahale ederek çekirdek enflasyonla mücadele edebilecektir. Bu aynı zamanda spekülasyona da neden olabilecek bir politikadır. Rusya'da yıldan yıla yükselen ücret seviyesi dolayısıyla artan talep ve kapasite kısıtı ile karşı karşıya kalan endüstrilerin artan bu talebe cevap verememeleri yanında değerli Ruble'nin ithalatı ucuz hale getirerek teşvik etmesi üreticileri zor durumda bırakacak sonuçlar meydana getirmiştir. Ayrıca ücretlerin artış trendi, enerji fiyatlarındaki artışlarla birlikte henüz teknoloji seviyesinin yaygın olarak yüksek olmadığı endüstrilerin genelinde maliyetleri de artırmıştır. Bu ortamda 2006 yılında artmaya başlayan enflasyona karşı hükümet, kamu harcamalarını kısmak ve kamu kesimi ücret seviyesini aşağıya çekmek gibi bazı daraltıcı politikalarla tedbir almış ve ilk kez kısa vadeli programlar yerine, öngörülebilir ve güvenilir bir ekonomik ortam yaratmak adına orta vadeli ekonomik program hazırlama çabası içerisine girmiştir.

Ödemeler dengesini değerlendirdiğimizde, diğer geçiş ekonomilerinin aksine Rusya ekonomisinin sermaye ihraç eden ekonomiler arasında yer aldığını görmekteyiz. Faizler düşük seyretse de, yatırım ortamında iyileşmenin günden güne artışı, doğrudan yabancı yatırımları olduğu gibi sabit yatırımları da artırmaktadır. 2001 yılında notunu B3'ten B2'ye, durağandan pozitife çevirmiş olan Moody's'in yatırım yapılabilir seviyesinde görmediği Rusya ekonomisinin bu görünümü ancak 2005 yılında S\&P ve Fitch gibi diğer iki önemli uluslar arası derecelendirme kuruluşu vasıtasıyla değiştirilmiş ve yatırım yapılabilir notu yükseltilmiştir. Ödemeler dengesinde sermaye çıkışlarının aksine olumlu etki, bütçe fazlası ve rezerv artışından gelmektedir. Fakat bu iki kalemin de dış etkenlere örneğin petrol fiyatlarına bağlı oluşu, dengeyi kırılgan hale getirmektedir. Mali bütçe fazlası ve enflasyonun düşmesinin yanında artan yabancı rezervler, ekonominin ve Merkez Bankası'nın elini rahatlatmıştır. Fakat yatırım tarafında yabancı doğrudan yatırım yerine çoğunlukla portföy ve diğer yatırım kalemlerinde yani "sıcak para" da görülen artış, ödemeler dengesini çok daha fazla kırılgan hale getirmektedir.

Yeniden Yapılanma ve Özelleștirme: Serbest piyasa ekonomisinin yapısına uygun olarak, serbest ticaretin ve finansal sistemin derinleşmesi, geçiş ekonomilerine sunulan hedeflerden birisidir. Özelleştirme sayesinde ekonomide devletin azalan payına karşın özel sektörün, ekonomik kararları verirken yeniden yapılanmayla dönüşümü ve gelişimi sağlıklı bir şekilde gerçekleştirilecektir. Ampirik çalışmalar, özelleştirmenin ekonomiler için faydalı olduğunu zira özel şirketlerin kamu teşekküllerinden daha verimli çalıştıklarını göstermektedir. Fakat Rusya' da yabancı yatırımcıdan uzak olan özelleştirme süreci, olumlu olmaktan çok olumsuz etki yapmıştır (Sprenger, 2009). Rusya'daki özelleştirme konusunda yukarda kısmen değinildiği gibi hızlı bir süreç yaşanmış, Yeltsin'in 1992'de başlattı̆̆ özelleştirme programı 1998'de devlet işletmelerinin \%80'inin özelleştirilmesi ile sonuçlanmıştır.

Rusya'da özelleştirme programı, farklı dönemlerde farklı stratejilerle gerçekleştirilmiştir. 1992-94 yılları arasında "MPP-Mass Privatisation Programme" -Büyük Özelleştirme Programı- kapsamında gerçekleştirilen özelleştirmeler, 1993-95 yılları arasında, 'LeaseBuyout" -Kiralama-Satınalma yöntemiyle yapılmıştır. Bu yöntemde MPP yönteminden daha yüksek miktarda satın almalar gerçekleştirilmiştir. Bir diğer yöntem ise "Loans-for-shares" olarak anılan yöntemdir. Bu yöntem, ticari bankaların şirketlerden federal bütçe adına pay satın almalarını içeriyordu. Lukoil, Yukos, Sidanko, United Energy Systems, Svyasinvest gibi holding şirketler, bu yöntemle 1995-1997 yıları arasında özelleştirilmişlerdir. Yöntem, zirvedeki şirketlerin kontrolünü zayıflatırken yasal olmayan yollardan para aktarımını da teşvik etmekteydi (Sprenger, 2002)

2000'li yıllarda Putin'in ilk döneminde yönetim, siyasilerle sıkı bağları olan oligarklara çeşitli teşvikler sağlamış, siyasi bağlantıları ve medyayla olan yoğun ilişkileri neticesinde Putin'in hükümete girmesini sağlayan bu oligarklar bir nevi ödüllendirilmiştir. Fakat 2004 sonrasında Gorbachov ve Yeltsin'den farklı olarak aslında otoriter rejim yanlısı olan Putin, 
özelleştirme yerine yeniden kamulaştırma yolunu tercih etmiştir. 2003 yılında petrol imalat sektörünün \%10’u kamudayken, 2007 yılında kamunun elindeki pay \%55'e çıkmıştır. Yukos'un Putin'i ikinci seçimlerde desteklemeyeceğini açıklaması üzerine cezalandırılması ise Rusya'da o dönemde özelleștirmenin geldiği son noktayı göstermekteydi. Yukos, devlet şirketi olan Rosneft'e geçirilmiş, bunu Sibneft'in devlet şirketi Gazprom'a satılması takip etmiştir (Aslund, 2007).

Yasal ve Kurumsal Reformlar: Ekonomide iş ortamının oluşturulması, yatırım ikliminin iyileştirilmesi ve özel sektörün ekonomiden aldığı payın artırılması adına serbest piyasa koşullarının sağlanması, Putin yönetiminin en önemli amaçları arasındadır. Özel mülkiyet ve hukukun üstünlüğü, liberal bir düzen içinde gerekli koşullar olup, girişimcilerin yatırım yapması ve rekabetin geliştirilmesi açısından iflas yasası, rekabet yasası, vb. düzenlemeler, gereklilik halini almaktadır. Bu doğrultuda Putin yönetimi, 2001 yılında mevcut yönetmelikleri geliştiren programın kabulüyle, serbest piyasa şartlarını sağlamayı hedeflemiştir. Bu konuda önemli yasal ve kurumsal değişiklikler yapılmış ve tüm bu çabalar sonucunda kriz sonrasında 1999-2001 yılları arasında 700.000 girişimci piyasaya girmiş, kayıtlı girişimci sayısı 4,3 milyona ulaşmıştır. Rusya'nın iş ortamına dair en temel sıkıntısı teşebbüs sayısının diğer gelişmekte olan ülkelerden daha az olmasındadır. Rusya'da diğer geçiş ekonomilerinden farklı olarak büyümenin kaynağ 1 yeni girişim ve firmalardan gelmemektedir. Rus ekonomisinin Sovyet döneminden kalan mirası ve kaynak bağımlılığ gibi yapısal sorunlar yanında kişisel bağlantıların yüksek oranda kullanıldığı iş ortamında yolsuzluk algısının da önemli düzeyde artmış olması, Rusya'da piyasa ekonomisi için önemli olumsuzluklar arasındadır (Frye, 2010).

2004 yılı Kasım ayında Mortgage Reformu'nun gerçekleştirilmesi, popülist yanının olmasıyla birlikte yine de finansal piyasaları ve mali aracılığı geliştiren ve bu anlamda yatırım iklimine katkısı olan gelişmeler arasında sıralanabilir. Ayrıca 2005-2008 yılları için hazırlanan bütçede, yönetim reformunun yanında bankacılık sektörüne yönelik de önemli düzenlemeler getirildiği görülmektedir.

\section{Global Krizi Bağlamında Rusya Ekonomisine İlişkin Değerlendirmeler}

Petrol fiyatlarına hayli bağımlı yapısı ile Rus ekonomisi, 2008 global krizinden, tüm dünya ülkeleri gibi etkilenmiştir. Fakat diğer geçiş ekonomileri gibi Rusya da 2008 sonunda derinleşen bir etki ve 2009'da yeniden toparlanmayı görmüştür. Rusya ekonomisi ile ilgili bu bölümde yapılan tespitler Dünya Bankası'nın bu ülkeyle ilgili 2008-2010 yıllarında yayınladığı raporlardan elde edilmiştir.

Makroekonomik istikrar bölümünde Rusya'nın 2008 krizi öncesi bir geçiş ekonomisi olarak analizine yer vermiştik. Yüksek büyüme oranlarını yakalayan Putin yönetimindeki Rus ekonomisi, yüksek petrol fiyatları ve ihracat gelirleriyle rezerv fazlası ve piyasa istikrarını sağlamış, olumlu bir ekonomik tablo görünümündeydi. Fakat yer yer bahsettiğimiz düşük emek verimliliği, yetersiz altyapı, enerji kullanımında verimsizlik, yüksek kaynak bağımlılığı ve artan kamu harcamalarının, Rusya ekonomisinde global kriz öncesinde bazı sektörlerde daralmaya sebep olduğu anlaşılmaktadır (Aslund, 2010). Fakat büyük bir kriz çağrışımı olmayan bu gelişmelerin dışında 2007 yılı Temmuz-Ağustos döneminde mortgage kağıtlarında ve aktiflerinde ortaya çıkan riskin yükselmesiyle ABD'de çıkan ve sonrasında Avrupa'yı da sarsan kriz, petrol fiyatlarının düşmesi, ihracatın azalması ve sermaye çıkışıyla gecikmeli olarak Rusya ekonomisini de etkilemiştir (EBRD, 2009).

2008 yılı başında Rusya ekonomisinde dengeli bir ekonomik büyüme sağlanmış olsa da 2000 yılı sonrasında ekonomide kronikleşen verimlilik artışından daha fazla olan ücret artışı anlayışı, üretim kapasitesi kısıtı ve enflasyon artışı gibi bazı sorunlar hala devam etmekteydi. 2007 sonunda $\% 8$ olarak belirlenen enflasyon hedefi \%11,6 düzeyinde gerçekleşmiştir. Bununla birlikte artan ve \%81'e kadar çıkan kapasite kullanımıyla birlikte işsizlik, 1994'ten bu yana en düşük seviyesine inmiştir. 2007'de piyasalarda sterilizasyonun gerçekleşmemesi kredileri 
genişleterek, tüketici talebini artıran önemli bir unsur olmuştur.

Rusya'da bankacılık sisteminde tüketici mevduatlarının yüksek oranda kamu teşekkülü bankalarda tutulması, bu bankalar dışında yabancı aktiflere bağlı sistemi kırılgan hale getirmektedir. 2008 yılı Kasım ayında zayıflamaya başlayan kısa dönem makroekonomik göstergeler krizin geldiğini açılarken ekonomide var olan rezervler ve mali yönetim ise krizin derinleşmesini önlemiştir. Krize ilk tepki diğer birçok ülkede olduğu gibi yabancı sermayenin kaçış1 olmuştur. 2008'in III. çeyreğinde, toplam sermaye akışı, \% 40 azalmıştır. Bir diğer etmense 144 \$'a kadar çıkmış olan petrol fiyatının 55 \$'a kadar gerilemesidir. Yine aynı dönemde global güven eksikliği, finansal piyasalarda önemli ölçüde değer kaybına neden olmuştur. Rusya ekonomisinin büyüme kaynağı olan talebin düşmesiyle de yatırımlar, \% 19,1 'den hızla \%13'e gerilemiştir. Ortalama reel ücret seviyesinde de 2007 y1lına göre \% 16,2 'den $\% 12,8$ 'e gerileme yaşanmıştır.

Rusya'da özel finans kurumlarının kısa vadeli borçları toplam kısa vadeli borçlar içerisinde düşük oranda olsa da \%40'lık bir paya sahiptir. Bu da Rusya'daki finansal yapıyı kırılgan hale getirmektedir. Dış borçlar III. çeyrekte yoğunlaşmış olmasına rağmen sistemik bir risk içermemekte, hükümetin önemli ve büyük ölçekli bankaları desteklemesi, sistemi çöküş riskinden korumaktaydı. Bu konuda yaşanan önemli bir diğer gelişme ise Merkez Bankası'nın daha esnek bir döviz kuru politikası ile artık enflasyon hedeflemesine gitmesidir. Ayrıca gerektiğinde piyasaya likidite sağlaması, güven vermenin yanında bankaların dış borç ödemelerinde ellerini rahatlatan bir diğer gelişme olmuştur. 2009'da da yeniden sermayelendirme ve doğrudan desteklerle bankacılık ve finans sektörü korunmuştur.

2009 yılında tahmin edilenden daha fazla gerileyen dünya ekonomisi içerisinde Rusya'da da talebin gerilemesiyle üretim aynı yılın ilk yarısında \%16 oranında gerilemiştir. İşsizlik \% 8'lere çıkmış, tüm bunlarla birlikte likidite sorunu ve yatırımların \%2,3 düşüşü ekonomik büyümeyi geriye çekmiştir. Likidite sıkıntısına karşın 2008 yılı Eylül ayında para politikasının gevşetilmesi de global kriz ortamında sınırlı etki doğurmuştur. 2009 yılında döviz rezervi kaybını önlemek için para politikası sıkılaştırılmış, döviz rezervleri 2008 yılı Eylül ayındaki 580 milyar \$'dan 2009 yılı Mart'ında 380 milyar \$'a gerilemiştir. Petrol fiyatlarının düşüşü ve vergi gelirlerinin azalması GSYİH'nın \%8'ine tekabül eden bütçe açığına sebep olmuştur. Fakat 2009'un ilk yarısında dış ticaret ve petrol fiyatlarının çökmesinin şoku atlatıldıktan sonra bütçe fazla vermeye başlamıştır. Yine 2009'un başında likidite sıkıntısı çekilen özel sektörde dış borç oranının azaldığı gözlenmektedir.

Tüm gelişmekte olan ülkelerde olduğu gibi, Rusya ekonomisinde de toparlanma 2009'un ikinci yarısında yavaş da olsa artan emtia fiyatları, borsalar ve mali destekle yükselen talep sayesinde başlamıştır. İmalat sektörü ve petrol fiyatlarının toparlanmasıyla da dış ticaret dengesinde iyileşme başlamış, üstelik rublenin değer kaybetmesiyle ithalat önceki yıllara oranla düşmüştür. 2010 yılı başında, yabancı sermaye akımı hızlanmış, özellikle tahvil alımlarında artış görülmüştür. 2009 yılı sonunda iç talebin artmaya başlamasıyla ticari olmayan sektörlerde de toparlanma başlamıştır. Fakat toparlanmanın sınırını kredi ve işsizlik kısıtları belirlemektedir. Kriz sırasında yarı zamanlı istihdam ve ücretsiz izinlerin arttı̆̆ 1 gözlenmiştir. 2009 yılı sonunda yarı zamanlı çalışan sayısı, 2008 yılına göre azalış kaydetmiştir. Yine aynı dönemde sermaye akımının da arttığı gözlenmiştir.

Dünya Bankası'nın yayınlanan son Temmuz-2010 raporuna göre Rusya ekonomisi, işsizlik oranları ve yabancı sermaye kısıtı dışında iyi bir performansa sahiptir. Mali politikaların büyümenin motoru haline geldiği bu krizde toparlanan petrol ve emtia fiyatları, Rusya ekonomisinde büyüme hızını negatiften pozitife çıkarmıştır. Ayrıca güçlü mali pozisyonu ve borç durumu neticesinde Rusya, Avrupa'da derinleşen krizden sınırlı bir şekilde etkilenmektedir. İlk çeyrekte Rusya ekonomisi \%2,9 büyüme kaydederken, sanayi üretimi $\% 10,8$ gerilemenin ardından \%6,9 pozitif büyümeyi yakalamıştır. Artan ücretler sayesinde iç talep toparlanmaya devam ederken, yatırımlarda 2009 yılının aynı dönemine göre dünya konjonktüründe devam eden belirsizlik neticesinde $\% 4,7$ oranında düşüş görülmüştür. Ödemeler dengesi fazla kaydederken, rezervler artmış fakat işsizlik aynı oranda kalmıştır. 
Nisan ayında 1998'den bu yana ilk tahvil ihracı, Eurobond piyasalarında gerçekleştirilmiştir. Ağustos ayı içerisinde Rusya ekonomisinin genel tutumunun dışında büyük kamu şirketlerinden Rosneft'in özelleştirileceği haberi dünyada ses getirirken Rusya ekonomisinde bu durum, teşviklerin ve devlet payının arttığı bu dönemde serbestleşmeye yönelik önemli bir adım olarak nitelendirilebilir.

Rusya Ekonomisi V. Putin'in dolaylı (Başbakan düzeyinde) veya doğrudan (Başkan düzeyinde) iktidar olduğu dönemde piyasa ekonomisi oluşturmak adına önemli adımlar atmıştır. Ancak bu adımların ekonomik yönetim adına gelişmekte olan ülkelerde yapılan uygulamalardan önemli farklılıkları söz konusudur. Çalışmanın son bölümünde özellikle Rusya ekonomisinde alınan bu kararların teknik olarak açıklaması yapılarak Rusya ekonomisinin son 2008 küresel krizden neden çok daha az etkilendiğinin veya en azından krizden nasıl hızla çıkabildiğinin cevabı verilmeye çalışılmıştır. Rusya ekonomisinde hidrokarbon rezervleri ekonomide ve dış politikada önemli bir baskı aracı haline getiren Putin yönetimi, serbest piyasa kurumlarını ve mevzuatını oluştururken bu tutumunun bir devamı niteliğinde ipleri asla kendi elinden bırakmamıştır. Bu elbette Rusya ekonomisinin piyasa ekonomisi algısı açısından eleştirilebilir bir yöndür. Ancak batı ekonomilerinde piyasa ekonomisi anlayışı ve uygulamalarının çeşitli dönemlerde küresel veya bölgesel düzeyde gerçekleşen krizlerde temel etken olduğu gerçeği, bu anlayışın sorgulanmasını gerekli kılmaktadır. Bunu yaparken de Rusya ekonomisinde Putin dönemi takip edilen açılım ve piyasa ekonomisi uygulamalarında olduğu gibi devletin piyasa düzenlemeleri dışında tutulamayacağını ve en azından denetim ve düzenlemelerle piyasaya müdahale edilmesi gerektiği sonucu elde edilmektedir.

\section{Kaynakça}

- $\quad$ DPT, 1998. Rusya Krizi ve Türkiye Üzerine Muhtemel Etkileri, Devlet Planlama Teşkilatı Yıllık Programlar ve Koordinasyon Genel Müdürlüğü, Ağustos. http://ekutup.dpt.gov.tr/dunya/rusya.pdf, (Er.Tar: 10.07.2010)

- Özel, Saruhan, (2005), Global Finans Krizi, Deniz Kitabevi, İstanbul.

- World Bank, 2002. Transition: The First Ten Years: Analysis and Lessons For Eastern Europe and The Former Soviet Union, The World Bank, Washington.D.C.

- Sprenger, Carsten, 2009. The Choice of Ownership St ruct ure: Evidence from Russian Mass Privatization, EFA 2005 Moscow Meetings, ICEF Working Paper Moskova.

- Sprenger, Carsten, 2002. Ownership and Corporate Governance in Russian Industry: A Survey, European Bank, Working Paper, No:70.

- Aslund, Anders, 2007. Russia's Capitalist Revolution, Peterson Institute For International Economics, Washington D.C.

- Frye, Timothy 2010. Corruption and Rule of Law, Russia After the Global Crisis, (Ed: Anders Aslund, Sergei Guriev and Andrew Kuchins), Peterson Institute For International Economics, Washington D.C., ss.79-94.

- Aslund, Anders 2010. The Post-Soviet Space: An Obituary, Russia After the Global Crisis, (Ed: Anders Aslund, Sergei Guriev and Andrew Kuchins), Peterson Institute For International Economics, Washington D.C., ss. 223-240.

- $\quad$ EBRD, 2009. Transition Report - 2009, EBRD, http://transitionreport.co.uk/TRO/b/transition-report/volume2009/issue1, (Er.Tar: 05.08.2010) 


\title{
The Impact of Globalization on Eurasian Economies: Prospects for Development in the 21st Century
}

\author{
Berch Berberoğlu, University of Nevada, Reno
}

\begin{abstract}
The post-Soviet transformation of Eurasian economies over the past two decades has taken place within the context of the globalization process that has affected many countries around the world. Globalization of capital and transformation of these countries in a market-oriented direction through privatization and joint-ventures with foreign capital has had varied effects in growth and development of Eurasian economies. These developments have taken place at various rates and at varying speeds, depending on the country, especially when one contrasts those in Central Asia with other countries in more developed regions of Eurasia, such as Turkey. In Turkey, a hybrid model of development has evolved over several decades -- one that is built on a strong economic base inherited from the past, where heavy state intervention in the economy has led to the development of a viable industrial infrastructure upon which private capital has expanded and benefited immensely. Thus, the Turkish economy can serve as a model for other Eurasian economies that lack the necessary industrial and financial base, but are able to address the region's economic problems through a partnership with Turkey. Although a common characteristic of Eurasian economies is the adoption of neoliberal economic policies and integration into the global economy, which often has a negative impact on national economies, a careful approach in engaging with the global economy with heavy state support to guide through the process (as in China) could result in a positive outcome that fosters growth and development of the Eurasian region in the twenty-first century.
\end{abstract}

JEL Codes: F5, O1

\section{Introduction}

The Eurasian region, stretching from Turkey in the West to the borders of China in the East, is one of the most important strategic regions of the world in the age of neoliberal globalization. The countries making up the core of this region - Kazakhstan, Turkmenistan, Kyrgyzstan, Uzbekistan, Tajikistan, and Azerbaijan, as well as Turkey - provide a rich mix of abundant natural resources, such as oil, natural gas, metals and minerals, industrial and agricultural infrastructure inherited from earlier periods, and a skilled work force trained under mass production in industry, agriculture, and other vital sectors of the economy.

\subsection{The Soviet Legacy and the Transition to Market Economy in Eurasia}

Given their historic experience under state-directed socialist development during the Soviet period, all of these countries, except Turkey, were once republics of the USSR, but have been evolving for nearly two decades now as independent nation-states allied with one or another of the major powers that have strategic interests in the region. Thus, Russia, China, the United States, as well as other regional powers (such as Iran, India, and Turkey), have had and continue to have influence and impact on the development path pursued by these countries in the post-Soviet era (Kleveman 2004; Hiro 2009) - one that is dominated by the forces of neoliberal globalization (the transnational corporations) and by the process that facilitates the transformation of these economies along the capitalist path (privatization of state-owned enterprises as part of the process of neoliberal globalization).

The end result of this process is the gradual integration of previously state-centered socialist economies into the global capitalist system through a variety of means (joint-ventures with foreign capital, leasing of extractive industries, and privatization and outright sale of stateowned firms to transnational corporations). Developments along these lines over the past two decades have led to the rise and consolidation of the power of local and foreign capitalist 
interests, hence to the transformation of their internal social, economic, and political structure in the direction of autocratic capitalist states (Olcott 2005).

\subsection{The Special Case of Turkey}

In contrast, while Turkey has also followed a similar neoliberal economic path tied to the global economy, the political outcome of this process in that country has been quite different due to a variety of reasons that are specific to Turkey's historic context: (1) the legacy of statism (devletçilik) adopted in the early decades of the republic, and (2) the more recent rise of political Islam based on the emergence of a rival economic force (the newly rising Anatolian bourgeoisie) with broader neoliberal economic interests and linkages that go beyond a narrow religious outlook and toward greater integration into the institutions of Western economic power - i.e., the European Union (Boratav 1974; Aydin 2005). Thus, Turkey looking to the West and linking to the East has provided a combination of possibilities for social, political, and economic change that has placed the country in a unique position situated as a regional power broker that will have an important influence on countries of the Eurasian region, as this region goes through new and yet uncharted social, political, and economic transformations in the coming years.

\section{Neoliberal Globalization: Its Nature, Dynamics, and Contradictions}

Over the course of the past two decades of global economic transformations facilitated by the collapse of the former Soviet Union and the rise and spread of neoliberal capitalist globalization around the world, economies of the Eurasian countries have experienced the impact of this process in various ways. Before assessing the nature and depth of this impact, however, we must first examine the dynamics and contradictions of neoliberal globalization.

\subsection{Main Characteristics of Neoliberal Globalization}

A central feature of neoliberal globalization, besides its speed and intensity, is the increased privatization of various spheres of the economy and society, with a relative decline in the power and ability of the state and other political institutions to control their national economies relative to earlier periods. Under the current wave of neoliberal globalization, the state in the advanced capitalist societies (and increasingly in the less-developed ones) has lost some of its traditional power in controlling and regulating the various spheres of society, especially the economy, but also other areas such as communications, information technology, and education, where privatization has become more and more prevalent. Thus, under the current phase of neoliberal globalization, the transnational corporations have become more visible and have increasingly taken center stage in effecting changes in the global political economy (Waters 1995; Halliday 2001).

Neoliberal globalization, much as during earlier stages of capitalism, is facilitated by transnational capital and is driven by the logic of profit for the private accumulation of capital. It is, in essence, the highest and most pervasive phase of transnational capitalism operating on a world scale. It is in this sense the most widespread and penetrating manifestation of global economic expansion that has profound social, political, cultural, and ideological impact on societies around the world (Golding and Harris 1997; Lechner and Boli 2004).

\section{$2.2 \quad$ Economic Basis}

The export of capital by the transnational corporations to the less-developed countries around the world has historically been part of the process of economic expansion worldwide that has led to the growth of giant capitalist conglomerates, cartels, and trusts that have come to dominate the world economy over the course of the twentieth century (Magdoff 1992; Amin 1997; Petras and Veltmeyer 2001). This has facilitated the rapid accumulation of capital by the transnationals at global proportions, a process that stimulates further capital accumulation worldwide, hence further domination of the global economy by the transnationals (Siebert 
2000; Munck 2002; Sklair 2002). It is this economic essence of globalization, then, that sets into motion the social, political and ideological contexts in which global capitalism prospers.

\subsection{Social Impact}

The global expansion of capital has been transforming social relations along capitalist lines, as the main class divisions in society have become wage-labor and capital. The transformation of societies around the world through this process leads to the integration of an increasing number of countries into the global economy by which they are subordinated to the transnationals, especially in terms of the exploitation of low-wage labor. As women workers increasingly constitute bulk of the low-wage laboring population worldwide, the exploitation of the working class in this way takes on a gendered dimension (Barndt 1999; Afshar and Barrientos 1999; Rai 2001).

The global domination of capital over wage-labor in this process of worldwide capitalist expansion fosters the subordination of the working class to the dictates of the transnationals who are the very source of the emerging inequalities in income, wealth, and power. These inequalities, in time, lead to contradictions and conflict in the social sphere, when class divisions become solidified to a point when class struggles between the opposing class forces begin to surface (Beams 1998; Petras and Veltmeyer 2001).

\subsection{Political Dynamics}

In the political sphere, power remains in the hands of the transnational and local capitalist classes and is exercised through the capitalist state. The control of the state and major political institutions of society by these powerful capitalist forces has led to the erosion of democratic governance and given rise to political corruption and authoritarian rule (Palast 2002; Hertz 2002). However, rather than representing the unified interests of a newly emergent global capitalist class, the imperial state of the transnationals advances only the interests of its own capitalists, as against its rivals to secure the supremacy of the transnationals over the global capitalist economy (Cohn et. al. 2000; Halliday 2001; Petras and Veltmeyer 2007).

Despite a temporary commercial, monetary, and even military union, however, the leading imperial state (currently the United States) continues to dominate the world and dictates its terms over other states, thus giving rise to competition and rivalry between the major global capitalist powers (Hook 2001; Weber 2001). While this competition takes place at the monopoly level, between rival transnational corporations as well as their states, it nevertheless affects the structure of social relations in general and has a direct impact on society worldwide.

As the varied dynamics of neoliberal capitalist globalization and its impact on society more and more becomes regulated by the imperial state, it is within the parameters of the state's role in legitimizing and protecting the interests of global capital that we come to understand the relationship of the imperial state to the neoliberal globalization project.

\section{Neoliberal Globalization and the Imperial State}

With the globalization of capital during the twentieth century, the leading capitalist state of the advanced capitalist economies (the United States) has come to assume greater responsibility in organizing and leading the global capitalist system, thus adopting the role of an imperial state charged with the control and rationalization of the global political economy to advance transnational capitalist interests (Beams 1998; Halliday 2001). It is within this context of the role of the advanced capitalist state that the imperial state confronts the contradictions of neoliberal globalization.

\subsection{Crisis of the Imperial State}

The globalization of capital - through the worldwide expansion of transnational corporations - has had a decisive effect on the role and functions of the imperial state, and brought to the 
fore new and more pervasive contradictions, leading to a crisis of management and legitimacy of capitalism on a worldwide basis. This has been the result of developments in the latest stage of global capitalist expansion, in which the monopoly fraction of the capitalist class in the advanced capitalist countries, especially the United States, has secured a thorough control of the state apparatus to advance its interests at home and abroad (Parenti 2002). And this has precipitated the crisis of the advanced capitalist/imperial state on a global scale.

The crisis of the imperial state manifests itself at different levels, ranging from international conflicts (economic rivalry, disintegration of regional political and military alliances, the inability to suppress nationalist movements and revolution, and military intervention and war) to domestic economic problems (trade and budget deficits, monetary and fiscal crisis, unemployment, recession, etc.) to national political crises (factional struggles within the capitalist class, problems of legitimacy, repression of working class and mass movements, militarization of the polity and society, and so on) (Perlo 1988; Parenti 2002).

\subsection{Competition and Crises in the Global Economy}

The growing prospects of economic rivalry between the major capitalist powers, backed up by their states, are effecting changes in their relations that render the global political economy an increasingly unstable character. Competition between the United States and the European Union (and China), representing the interests of their own respective elites are leading them on a collision course for world supremacy, manifested in struggles for markets, raw materials, spheres of influence in geo-political - as well as economic - terms, which may in fact lead to a new balance of forces, and consequently new alliances that would have serious political implications in global power-politics.

As the continuing economic ascendance of the major capitalist rivals of the United States help establish the former's prominent position in the global economy in a more entrenched way, pressures will build toward the politicization and militarization of these states from within, where the leading class forces bent on dominating the world economy will press forward with the necessary political and military corollary of their growing economic power in the global capitalist system (Hart 1992; Falk 1999). And this eventuality threatens the global economy with continued crises in the early decades of the twenty-first century.

\subsection{The Shifting Balance of Forces in the Global Political Economy}

These developments in the global political economy will bring shifts in the balance of forces among the major powers and lead to the forging of new and yet untested international alliances for world supremacy and domination in the twenty-first century. Such alliances will bring key powers such as Russia and China into play in a new and complicated relationship that holds the key for the success or failure of the newly rising imperial centers that will emerge as the decisive forces changing the global economic, political, and military equation in the early decades of the twenty-first century.

Thus, the contradictions and conflicts imbedded in relations between the rival imperial states of the major capitalist powers will again surface as an important component of international relations in the years ahead. And it is in this context of the changes that are taking place on a world scale that the imperial state is beginning to address the current crisis of global capitalism to maintain its rule.

\section{The Impact of Neoliberal Globalization on Eurasian Economies}

Becoming more and more integrated into the modalities of neoliberal globalization led by the transnational corporations, the economies of Central Asian states have become an appendages of the transnational oil companies that have greatly impacted the nature and rate of economic growth and its effects on various segments of the population in each of the countries making up this region. 


\subsection{Oil, Transnationals, and National Economies}

Neoliberal globalization has come to play a central role in determining the type of investment and production (mainly oil, natural gas, metals, minerals, and other natural resources extracted for export) geared to the needs of the global economy rather than the local, national economy. Thus, vast amounts of capital has been invested in oil and other extractive industries across Central Asia with the aim of exporting these vital resources crucial for the industrial engine of advanced capitalist countries and producing high rates of profit for the transnationals (Kleveman, 2004; LeVine 2007), while leaving much of the rest of the local economy unaffected and idle that result in high rates of unemployment and underemployment, poverty, and declining living standards, except for those directly involved in top levels of the state bureaucracy.

\subsection{Corruption, Inequality, and Poverty}

The economic inequities and shortfalls created by the neoliberal policies propagated by the dominant powers and their institutions are exacerbated by Central Asian governments that are working in line with the interests of the transnationals through the corrupt policies and practices that are in their own and their collaborators' interests and not the well being of their people (Olcott 2005; Hiro 2009). Thus, creating gainful employment based on skills acquired by quality education are things reserved only to a minority of the population directly linked to the political bureaucracy of the state and its immediate beneficiaries, while broad segments of the population go without access to any of the benefits accrued by the sale or transfer of vast national resources to the transnational oil monopolies. The neoliberal privatization policies in this situation come to serve both foreign and local capitalist interests that feed into the perpetual cycle of corrupt practices that local bureaucrats engage in to expand their wealth and political clout over the population, hence perpetuating inequalities that divide these societies further along class lines, thus widening the gap between the rich and the poor (Sahadeho and Zanca 2007).

The polarization and conflict that neoliberal globalization has brought to Central Asia in the wake of the recent post-Soviet transformations have thus left their mark as a model that is contrary to the interests of the people of Central Asia and the broader Eurasian region - a situation that requires us to explore alternative paths of development that may be more in line with the needs and aspirations of the Central Asian people.

\section{$5 \quad$ Paths of Development for the Eurasian Economies}

Given the failure of neoliberal globalization to effect positive change in Eurasian economies over the past two decades of post-Soviet transition to a market-oriented capitalist economy across Central Asia, it would be instructive to explore alternative paths of development that would make a contribution to growth and development of these economies based on some recent examples that provide a promise for the future. Russia, China, and India on the one hand and Turkey on the other have provided paths out of alternatives to current neoliberal policies that have failed so miserably. But, ultimately, the prospects for change and development in Central Asia depend on the nature and policies of the states that are responsible for the success or failure of such policies.

\subsection{Russia, China, and India}

Given both the proximity and historic relationship of these three giants of north, east, and south Asia with their growth and expansion in the midst of neoliberal forces that are always ready to derail efforts at independent development, Russia, China and India have been quite successful in escaping imperialist pressures to incorporate these economies into the global economy controlled and dominated by the transnational corporations of the advanced capitalist states, most notably the United States (Chellaney 2006; Friere and Kanet 2010). On the 
contrary, India with its heavy investment in infrastructure and industrial production and China through its state-controlled export-oriented production and trade, and Russia holding on to its vast economic base, have succeeded in escaping subordination to the neoliberal capitalist forces. On the contrary, through strong state intervention and planning, these three economies and states have succeeded in managing their entry to the world economy in promoting their own interests, even if this was done through a complex web of joint-ventures, state enterprises, and private investment schemes.

While the experience of Russia, China, and India show that a strong independent state committed to advancing their national interests can provide an alternative model of development within the context of globalization and the global capitalist system, the sheer size and magnitude of their economies may not be an appropriate model for the Central Asian economies to follow, even if the latter were able to avoid problems associated with corruption and cronyism that many Central Asian states have experienced during the past two decades of transition to a capitalist economy. Given the wholesale surrender of Central Asian states of their economies to the forces of neoliberal capitalist globalization and transnational corporate control, there seem to be little or no chance for these states to emerge as independent states to re-negotiate the terms of their relationship with the transnationals and global capital, unless a major rupture takes place that changes the direction of these economies and societies in a big way.

\subsection{Turkey}

Turkey's links to the Central Asian states go back a long time in history and its cultural and linguistic ties have served to open up possible economic relations that are of mutual benefit within the context of establishing and expanding a Eurasian zone of economic cooperation based on the Turkish model that may be more applicable than that of Russia, China, and India. However, as in other cases, Turkey, too, went through a period of heavy state intervention into its economy in the 1930s that established the basis of its industrial growth and expansion in later years when the economy evolved from a state-directed, planned economy to a private neoliberal economy based on the privatization of state enterprises and public assets. The long history of state-regulated economy that provided the infrastructure and industrial base during the initial stages of its development is the basis of its more recent success in making headway even while working within the parameters of a neoliberal capitalist globalization that has come to define and set limits to its relative autonomy in economic and state policy.

The distinguishing feature of the Turkish model and its adoptability to Central Asia as an extension of the wider Eurasian region is the affinity of the two regions to the historic presence of heavy state intervention that set the stage in one case for the expanded production that followed, while failing to do so in the other, leading the latter to take a different path that led to its ultimate failure. Thus, while the statist (devletçilik) or state-capitalist period through statecentered development projects produced big economic dividends in Turkey during the Atatürk era and built the basis of a strong industrial economy in Turkey that flourished in subsequent decades (Boratav 1974), the state-socialist infrastructure of Soviet era industrialization failed to translate into a strong economy in the post-Soviet transition to capitalist market economy due to heavy corruption, opportunism, and self-aggrandizement personified by the personality cults developed to serve narrow elite interests (as exemplified by the despotic regimes that have ruled this region for nearly two decades).

Perhaps the promise of the application of the Turkish model to these states would be the strengthening of ties between the countries of Central Asia and Turkey for greater cooperation, investment, and collaborative projects geared to national development that are of mutual benefit, while curbing the negative impact of the forces of neoliberal globalization that are already in the region and are destined to derail such efforts to prevent independent national economic development that may come to challenge their newly entrenched interests. 


\section{The Prospects for Economic Development in Eurasia}

What are the prospects, then, for the economic development of countries spanning the Eurasian region? What would it take to set these countries on the correct path of development that meets the needs of their people and generate genuine development that is both sustainable and beneficial to their people? These are not easy questions to answer, nor are the answers easy to delineate. But, given the vast natural and mineral resources of the region, and given the great potential for their development for national use, the prospects for development of these states in the near to medium term remains quite high. In fact, further economic collaboration between Turkey and the countries of this region in the form of economic alliances that facilitate aid and investment may lead to greater links that play a critical role in promoting change. Such change, first in the economy, and later in other spheres of society, may set the Central Asian states on the road to economic recovery in the early to mid twenty-first century.

\section{References}

- Afshar and Barrientos, 1999. Women, Globalization and Fragmentation in the Developing World. Palgrave.

- Amin, 1997. Capitalism in the Age of Globalization. Zed Books, London.

- Aydin, 2005. The Political Economy of Turkey. Pluto Press, London.

- Barndt, 1999. Women Working the Nafta Food Chain: Women, Food \& Globalization. Sumach Press, Toronto.

- Beams, 1998. The Significance and Implications of Globalization. Mehring Books, Southfield, MI.

- Boratav, 1974. Türkiye'de Devletçilik (Statism in Turkey). Gerçek Yayınevi, Istanbul.

- Chellaney, 2006. Asian Juggernaut: The Rise of China, India, and Japan. Harper Collins, New York.

- Cohn, et al. 2000. Power in the Global Era: Grounding Globalization. Palgrave Macmillan, New York.

- Falk 1999. Predatory Globalization: A Critique. Blackwell, Malden, MA.

- Golding and Harris, 1997. Beyond Cultural Imperialism. Sage Publications, Thousand Oaks, CA.

- Halliday, 2001. The World at 2000. St. Martin=s Press, New York.

- Hart, 1992. Rival Capitalists. Cornell University Press, Ithaca, NY.

- Hertz, 2002. Silent Takeover: Global Capitalism and the Death of Democracy. Free Press, New York.

- Hiro 2009. Inside Central Asia. The Overlook Press, New York.

- Hook, et al., 2001. Political Economy of Japanese Globalization. Routledge, New York.

- Kleveman, 2004. The New Great Game: Blood and Oil in Central Asia. Grove Press, New York.

- $\quad$ Lechner and Boli, 2004. The Globalization Reader, $2^{\text {nd }}$ ed. Blackwell, Malden, MA.

- LeVine, 2007. The Oil and the Glory: The Pursuit of Empire and Fortune on the Caspian Sea. Random House.

- Magdoff, 1992. Globalization: To What End? Monthly Review Press, New York.

- Munck, 2002. Globalization and Labor: The New Great Transformation. Zed Books, London. 
- Olcott 2005, Central Asia's Second Chance. Carnegie Endowment for International Peace, Washington, DC.

- Palast, 2002. The Best Democracy Money Can Buy. Pluto, London.

- Parenti, 2002. Democracy For the Few, Seventh Edition. St. Martin=s Press, New York

- Perlo, 1988. Super Profits and Crises: Modern U.S. Capitalism. International Publishers, New York.

- Petras and Veltmeyer. 2001. Globalization Unmasked: Imperialism in the $21^{\text {st }}$ Century. Zed Books, London.

- Petras and Veltmeyer, 2007. Multinationals on Trial: Foreign Investment Matters. Ashgate, Aldershot, U.K.

- Rai, 2001. Gender and the Political Economy of Development. Polity Press, Cambridge.

- Siebert, 2000. Globalization and Labor. Kiel Inst of World Economics, Kiel, Germany.

- Sklair, 2002. Globalization: Capitalism and Its Alternatives. Oxford University Press, New York.

- Waters. 1995. Globalization: The Reader. Routledge, New York.

- Weber, 2001. Globalization and the European Political Economy. Columbia University Press, New York. 


\title{
Who is Better Equipped for Globalization in Eurasia? A Seven-Country Analysis
}

\author{
Tansu Barker, Brock University, Canada
}

\begin{abstract}
Globalization is a long-term transformation of the nation-state that interconnects it to other states. We characterize globalization as a multifaceted concept that has economic, political as well as social dimensions. The countries that are included in this study are Azerbaijan, Kazakhstan, Kyrgyzstan, Tajikistan, Turkey, Turkmenistan and Uzbekistan. In order to make meaningful comparisons and establish a benchmark, we also include Austria as a highly globalized and land-locked country.

The purpose of the study is to provide a measure of the "readiness" of these countries to become more global based on selected economic, political and social variables. With very few exceptions, countries are no longer able to isolate themselves and seek to be self-sufficient. Hence, countries and their governments must accept the reality of globalization and the pressure it creates to look beyond national borders.
\end{abstract}

JEL codes: M16, O53

\section{Facts about Sampled Countries}

The following table attempts to introduce some representative facts that might provide the background to interpret the globalization findings in the rest of the paper. While it is not a comprehensive list of characteristics, the information is meant to cover some of the more pertinent facts regarding globalization.

\begin{tabular}{|l|l|l|l|l|l|l|l|l|}
\hline Variable & Azerb & Kazak & Kyrgyz & Tajik & Turkey & Turkmen & Uzbek & Austria \\
\hline Population & 9.1 & 16.2 & 5.5 & 7.4 & 72.5 & 5.1 & 27.6 & 8.4 \\
\hline Area & 86.6 & 2275 & 200 & 143.1 & 739 & 488 & 447.4 & 83.9 \\
\hline GDP (PPP) & 9564 & 11693 & 2253 & 2103 & 12476 & 5971 & 2806 & 38839 \\
\hline GINI & 36.5 & 28.8 & 30.3 & 32.6 & 41 & 40.8 & 36.8 & 26 \\
\hline Urban \% & 52 & 58 & 36 & 26 & 69 & 49 & 37 & 67 \\
\hline HDI & .787 & .804 & .710 & .688 & .806 & .739 & .710 & .955 \\
\hline Exports & 38.3 & 66.6 & 1.7 & 1.4 & 111.1 & 9.9 & 10 & 137 \\
\hline Vulnerabil. & 5.4 & 4.6 & 6.3 & 6.3 & 7.5 & 5.4 & 4.6 & 1.3 \\
\hline Democracy & 3.31 & 3.62 & 4.08 & 2.45 & 5.7 & 1.83 & 1.85 & 8.69 \\
\hline
\end{tabular}

\section{Table 1 - Country Statistics}

The countries included in this paper represent much diversity in terms of their size, economic and social characteristics. Therefore, the tentative conclusions presented in this paper should be taken as a starting point for what might be a promising approach rather than indisputable conclusions. Future refinements in the selection and weighting of the variables used in this study are expected to improve the results considerably.

These countries exhibit significant diversity along economic, political and social dimensions. Therefore, extreme care must be exercised in interpreting even index numbers that provide a certain degree of protection over comparing absolute figures across the seven countries. Next, we provide brief comments about each country (Wikipedia, 2010) to supplement Table 1 where HDI is a function of life expectancy, education and standard of living and Gini coefficient is a measure of the inequality of distribution of income, a value of 0 expressing total equality and 1 maximal inequality.

Azerbaijan: It is a secular presidential republic established in 1991. Approximately $95 \%$ of 
the population of Azerbaijan is Muslim. Rich in oil and natural gas, Azerbaijan is considered to be important in terms of oil exploration and development. It is a member of IMF.

Kazakhstan: Landlocked country is the ninth largest in the world. Sixty-three percent of the population is Kazakhs with $24 \%$ Russians. Kazakh and Russian are the official languages. While it is an important exporter of uranium and rich in mineral deposits, crude oil and natural gas lead the economy.

Kyrgyzstan: Parliamentary republic where $69 \%$ of the population are Kyrgyz, $14 \%$ are Uzbek and 9\% Russian. Agriculture is the leading economic activity with substantial mineral reserves. It exports hydroelectric energy but imports oil and gas.

Tajikistan: It is a presidential republic that shares language, culture and history with Iran and Pakistan. The economy is dependent on cotton and aluminum. Despite its modest economic means, the literacy rate is estimated to be $99.5 \%$.

Turkmenistan: It possesses the world's fourth largest reserves of natural gas resources and is the tenth largest grower of cotton. The ethnic composition of Turkmenistan is $85 \%$ Turkmen and $89 \%$ are Moslems. Its debt burden, level of poverty, unemployment and limitations on "freedoms" present difficulties.

Uzbekistan: It is a presidential republic where $80 \%$ of the population is Uzbeks. Economy relies mainly on cotton, gold, uranium, potassium and natural gas. Import substitution is an officially declared policy. Uzbekistan has a 99.3\% literacy rate among adults older than 15 and $34.1 \%$ of its people are younger than 14 .

Turkey: It is a democratic, secular, constitutional republic. Given its strategic location, large economy and army, Turkey is classified as a regional power and is a member of G-20. It is the fourth largest ship building country in the world. Other key sectors of the economy are banking, construction, home appliances, textiles, petrochemical products, food, mining, iron and steel, machine industry and automotive. Only $7 \%$ of the population is older than 65 years old.

Austria: It is a federal parliamentary republic. It is one of the richest countries in the world. Austria produces $63 \%$ of its energy through renewable sources and has banned nuclear stations. $74 \%$ are Roman Catholics and $89 \%$ are native Austrians speakers. It has a highly developed social market economy with strong labor unions.

\section{Dimensions of Globalization}

Defining globalization is not a straight forward matter. While the debate continues and there is certainly no unanimity, business people tend to associate globalization with lowering of trade and cultural barriers whereby national markets move toward merging into more similar markets. Marketers talk about global marketing strategy in terms of a single strategy for their offerings for the entire global market with the proviso that modifications must be made to accommodate environmental differences. One popular textbook (Hill and McKaig, 2009, p.9) defines globalization as "the shift toward a more integrated and interdependent world economy". This approach generally depicts globalization in a favorable light and links it to improvements in economic welfare.

Others (Bevan and Gitsham, 2009) suggest a sociological approach that seems to challenge these favorable certainties and points toward far less organizational security. They claim that the sociological approach to globalization appears to have been more accurate at predicting the complexity of globalization than an economic approach. The sociological approach may be understood as the increasing interdependence of world society such that what happens on the other side of the world affects us directly in an immediate way far more profoundly than in previous generations (Giddens, 1999). Parker (1999, pg. 234) suggests that globalization is experienced subjectively as a "growing sense that events occurring throughout the world are converging rapidly to shape a single integrated world where economic, social, cultural, 
technical, business, and other influences cross traditional borders and boundaries such as nations, national cultures, time, space and industries with increasing ease". On the other hand, Martens, et. al, (2010) argue that "socio-cultural factors not only change as a result of globalization, but also can be causes, as well as challenges to the process of globalization itself".

Dorn (2009) contends that "the fundamental determinant of development is not natural resources or capital investment but the choice of institutions, which depends heavily on the government's development strategy". This is a crucial way of portraying globalization beyond the traditional economic or business perspective that emphasizes the political and social aspects. In considering the impact of political influence on globalization, we can broadly separate the governments into two groups, namely, those pursuing export promotion versus import substitution. Justin Lin (referenced in Dorn, 2009) calls the import substitution strategy "a comparative-advantage-defying (CAD) strategy" whereby the fastest way to catch up with developed countries was to employ Soviet-style planning, raise trade barriers and protect infant industries. This perspective that has been quite influential in many of the countries included in the current study highlights the importance of paying particular attention the political dimension of globalization.

Based on the previous discussion, we have fashioned our study after the KOF model (Dreher, 2006) that treats the economic, political and social dimensions of globalization separately as presented in Table 2. The KOF (2009) model employs a weighted average approach where the weights assigned to the economic, political and social dimension are $38 \%, 23 \%$ and $39 \%$, respectively. Next, we provide a brief description of the methodology used to calculate each dimension.

\begin{tabular}{|l|c|c|c|c|}
\hline Country & Globalization & Economic & Political & Social \\
\hline Azerb & $55.2(4)$ & 58.8 & 55.6 & 51.3 \\
\hline Kazak & $60.8(2)$ & 69.8 & 67.8 & 48 \\
\hline Kyrgyz & $59(3)$ & 61.2 & 67.5 & 51.5 \\
\hline Tajik & $34.5(7)$ & 34.8 & 43 & 29.2 \\
\hline Turkey & $64.9(1)$ & 64 & 93 & 48 \\
\hline Turkmen & $38.7(6)$ & 38.7 & 38.4 & 38.9 \\
\hline Uzbek & $40.3(5)$ & 40.6 & 45.7 & 36.8 \\
\hline Austria & 92.5 & 89.3 & 96.9 & 92.8 \\
\hline Bulgaria & 75.4 & 84.1 & 87.6 & 59.5 \\
\hline Romania & 71.5 & 75.1 & 92.4 & 55 \\
\hline ASIA & 61.9 & 61.9 & 62 & 50.9 \\
\hline
\end{tabular}

Table 2 - KOF Indexes

Economic globalization is based on "flows" such as trade as percentage of GDP, foreign direct investment and "trade restrictions" such as import barriers and import taxes. Equal weight is assigned to flows and trade restrictions in calculating the economic globalization index.

Social globalization includes personal contact (34\%) through telephone traffic and foreign population, information flows (34\%) including TV and internet usage and cultural proximity (32\%) based on number of IKEA, McDonalds outlets and trade in books. Martens et. al,. (2010) make the critical observation that "socio-cultural factors not only change as a result of globalisation, but also can be causes, as well as challenges to the process of globalisation itself".

Political globalization is based on embassies in the Country $(25 \%)$, membership in international organizations (28\%), participation in U.N. Security Council Missions (22\%) and international treaties $(25 \%)$. 
Clearly, the indices include many subjective preferences both in the variables used to operationalize certain concepts as well as the weights that are assigned to them. We employ these and other data with caution and the caveat that the choices made may not have the same impact on every country. Hence, it is more appropriate to look at the relative positioning of the countries rather than the absolute figures that are calculated.

Globalization is not a panacea for advancement and has its share of criticism. Globalization has the potential to allow powerful countries to overrun the cultural, economic and political systems of smaller and less powerful countries leading to Americanization, McDonaldization or creolization of the world. Critics of globalization call for more transparency, egalitarianism, respect for human rights, dignity, the environment and fair trade.

\section{Alternative Globalization Index Calculations}

The overall globalization index calculated by Dreher (2009) based on the relative weights of $38 \%, 23 \%$ and $39 \%$ assigned to the economic, political and social indexes produces the results presented in the second column of Table 2.

\begin{tabular}{|l|c|c|c|c|}
\hline Country & $\begin{array}{c}\text { Globalization } \\
\text { Index }\end{array}$ & Econ. Driven & $\begin{array}{c}\text { Politically } \\
\text { Driven }\end{array}$ & $\begin{array}{c}\text { Socially } \\
\text { Driven }\end{array}$ \\
\hline Azerb & $55.2(4)$ & $56.8(4)$ & $56.1(4)$ & $54.1(4)$ \\
\hline Kazak & $60.8(2)$ & $66.8(2)$ & $66.4(2)$ & $58.3(2)$ \\
\hline Kyrgyz & $59(3)$ & $62.8(3)$ & $64.0(3)$ & $58.2(2)$ \\
\hline Tajik & $34.5(7)$ & $37.5(7)$ & $39.2(6)$ & $34.5(6)$ \\
\hline Turkey & $64.9(1)$ & $74.0(1)$ & $79.8(1)$ & $64.7(1)$ \\
\hline Turkmen & $38.7(6)$ & $38.6(6)$ & $38.5(7)$ & $38.7(7)$ \\
\hline Uzbek & $40.3(5)$ & $42.3(5)$ & $43.3(5)$ & $40.2(5)$ \\
\hline Austria & 92.5 & 92.7 & 94.2 & 93.3 \\
\hline
\end{tabular}

Table 3 - Globalization Indexes

Our discussions with colleagues and business leaders suggested quite strongly that the three weights used to generate the KOF globalization index (Table 2, col. 2) are worthy of further consideration. In particular, the point that was made strongly was that the environmental context of different countries may shift the balance of power from one of the dimension of globalization to another. Prompted by these discussions, we have undertaken to calculate several additional globalization indexes to investigate the political, social and economic components of the overall globalization index. Therefore, we present the following three scenarios:

Scenario I, Globalization driven by Economic Factors: The traditional approach to studying globalization from the business perspective is to assign more importance to economic factors that allow a country to be more competitive and to interact with other countries. In this scenario, we assigned a weight of $50 \%$ to the economy. The remaining weights are $40 \%$ political and $10 \%$ social. The reasoning is that, especially, in developing countries the political landscape is likely to be far more influential than the social factors. A higher weight assigned to the economic factors may be seen to suggest a weaker link between the economic and political than might be expected realistically in this group of countries. The results are presented under column 3 of Table 2 .

The relative rankings of the countries remain unchanged compared to the KOF overall globalization index. Turkey is still at the top of the list with Tajikistan having the lowest propensity to globalize based on emphasizing economic factors. While six of the seven countries have improved their index under this scenario, the fact remains that there is a big apparent gap between them and other developed countries as represented by Austria.

Scenario II, Globalization driven by Political Factors: The weights of the political, 
economic and social factors are $60 \%, 30 \%$ and $10 \%$, respectively. While the order of the top five countries remains the same, Tajikistan and Turkmenistan switched places at the bottom. Turkey appears to have a higher political will to become more globalized ahead of its economic potential. To a lesser degree the same observation applies to Kyrgyzstan, Uzbekistan, Tajikistan and Austria. This observation lends mild support to the view that political factors might be as important as the economic factors and may be somewhat more in certain countries.

Scenario III, Globalization driven by Social Factors: In this scenario, social factors have a weight of $50 \%$, followed by $30 \%$ political and $20 \%$ economic factors. The rankings are consistent with the previous scenarios. However, six of the seven countries have lower social indexes compared to their own political and economic indexes. Furthermore, the gap with Austria has widened here considerably. This raises the potentially crucial question of the balance between the three sets of factors in terms of readiness to become more global. Can weaknesses in one area be compensated by strengths in other areas?

We conducted a second analysis under this scenario by switching the weights of political and social factors to $20 \%$ and $30 \%$, respectively. The rankings did not change at all. The absolute magnitude of the revised index changed by less than 1 point for seven of the eight countries. The only notable change was for Turkey (64.7 down to 61.8) when the weight of the political component was reduced to $20 \%$ as a result of its high (93) value.

We included the two newest members of EU, Bulgaria and Romania, as a further point of reference. Compared to Bulgaria and Romania, only Turkey exceeds Bulgaria in terms of its political index. Given that these two countries are not considered to be powerhouses of globalization, the Eurasian countries have to make significant improvements socially, politically and economically. As an example, the ten countries that joined the EU in 2004 present consistent indexes with an average globalization index of 80.4. The Vulnerability Index (Table 1) also highlights the need for better balance as it is a blended measure of various economic (Gini), political (unrest, trust) and social (ethnic fragmentation) indicators.

Recognizing that comparisons against other Asian countries might be more meaningful, we calculated average indexes for Asia excluding the seven countries of interest. Turkey does better in all areas except the social index that is slightly lower. Kazakhstan is ahead of the Asian average economically and socially. Kyrgyzstan only has a higher social index. The results do not favor the Eurasian countries.

In conclusion, the Eurasian countries have much ground to cover and significant progress to make regarding all aspects of globalization. Azerbaijan, Tajikistan, Turkmenistan and Uzbekistan are behind the Asian average in all categories and face significant challenges if they wish to embrace globalization. Kazakhstan and Kyrgyzstan have certain advantages behind Turkey. However, their achievements and potential in certain areas of globalization seem to be mitigated by a lack of consistent performance in other areas. The indisputable fact remains that, as exemplified by Austria, even Bulgaria and Romania have achieved a higher level of consistency and uniform performance along globalization dimensions except the social index, which is still higher than the Eurasian countries. The fact remains that out of 195 countries included in the KOF index; only 21 have a social index greater than $80 \%$ with Switzerland leading the pack at $95 \%$. Singapore has the highest social index in Asia at $79.9 \%$. Perhaps, Bevan and Gitsham (2009) are right in stating the "sociological approach to globalization appears to have been more accurate at predicting the complexity of globalization than an economic approach". 


\section{References}

- Bevan and Gitsham, 2009. "Context, Complexity and Connectedness: Dimensions of Globalization Revealed", Corporate Governance, 9, p. 435.

- Dreher, 2006. "Does Globalization Affect Growth? Evidence from a New Index of Globalization", Applied Economics, 38, p. 1091.

- Dorn, 2009. "Economic Development and Transition: Thought, Strategy, and Viability, Cato Journal, 29, p. 600.

- Hill and McKaig, 2009. Global Business Today. McGraw-Hill, New York. 2. Canadian. Ed.

- KOF, 2009. Globalization Index, http://globalization.kof.ethz.ch.

- Martens et. al, 2010. "Globalisation, the Global Village and the Civil Society", Futures, 42, p. 575.

- Parker, 1999. "Evolution and Revolution: From International Business to Globalization", in Clegg, S.R., Hardy, C. and Nord, W.R. (Eds), Managing Organizations: Current Issues, (1999), Sage, p. 234.

- Wikipedia, 2010. http://en. Wikipedia.org/wiki/country name. 


\title{
Some Major Causes of Current Economic Crises and Leadership Strategies
}

\author{
Asım Şen, Beykent University
}

\begin{abstract}
This paper argues that economic inequality is one of the major causes of the current economic crises and provides some appropriate leadership strategies for solving them. Inequality is defined as unequal opportunities for economical activities among the people of a nation and among the nations of the world. The major cause of most current economic crises is the income and wealth inequality which are generated mainly by the economic growth. Leaders in the past and currently could not utilize appropriate strategies to solve the inequality problems and consequently the economic crisis grew and reached the current levels.

In order to solve the current economic crises it is necessary to eliminate the economic inequality problems and establish fair and sustainable economic growth. The leadership strategies play crucial role for this process. These strategies included in this paper are establishing the local and global shared vision for all; balancing the income and wealth distribution; providing the equal opportunities for education and employment; sharing the production and consumption; and maintaining the fair and sustainable globalization and economic growth.
\end{abstract}

JEL Codes: O4, E2.

\section{Introduction}

The current local and global economic crises are often expressed with some economic activities such as bank failures, personal and corporate bankruptcies, rising unemployment and lowering income and wealth, declining production capacity, difficulties of paying back some of the credits, rising debts for some people, organizations and nations. This study considers also hunger, poverty, and per capita income, lack of health care and education, life expectance, infant mortality, environmental destructions, depletion of the world's resources part of the economic crises. People in different organizations and nations have been affected by some or more of these economic crises throughout the world.

The economic crises can not be explained by the crises of only some corporations, banks and the people affected in developed and developing nations alone. But, all the poor people in developed, developing, and underdeveloped nations should also be included in the definition of the economic crises. More than 1.1 billion poor people in East Asia, Latin America, South Asia, Sub-Saharan Africa, Middle East, and other regions of the world live in extreme poverty (poverty defined as $\$ 2$ a day, moderate poverty about $\$ 1.5$ a day, and extreme poverty $\$ 1$ or less than $\$ 1$ a day). Their economic crises of hunger and poverty which generate misery and anxiety for their life have not been included in the definition of the recent economic crisis. In fact, their economic crises have been with humanity for a long time not just for recently. It is therefore, more accrued and fair to include economic crises of many people of the world into the definition of economic crises.

The economic crises in the past and more recently were developed, mainly, during the economic growth. The economic growth is the main source of the income and wealth of a society which has been rising with the increasing production. In capitalist economies, declining in production reduces investment, employment, personnel incomes, savings, consumptions, and increases the personal debt of the consumers. Without employment, many individuals can not pay their debts and many banks can not collect their loans. Consequently, the total demand declines which stagnates investment, production and causes the economic crises in many organizations and nations. 
Recently, the presidents of many nations have been utilizing some strategies to find a solution for the current economic crises in developed and developing nations. However, these strategies are mostly attempting to generate short term employment by providing small amount of capital for some investors, householders, and bailout some of the troubled banks and corporations. These strategies may generate some limited employment and small demand for the short term, but will not solve the economic crises in the long term. In fact, many experts are predicting that, in spite of these strategies, the economic crises will have a "second dip". In order to find a viable solution for the economic crises, it is necessary to understand the root causes of the economic crises, and then design appropriate strategies to solve them.

This paper argues that unfair and unsustainable economic growth has been the main source of the economic crises. However, the inappropriate leadership strategies in the past and currently played a major role in this process. It is therefore necessary to change the contemporary leadership strategies to eliminate the current economic crises.

The main objective of this paper is to present some evidences that economic inequality causes the current economic crises and establish some appropriate leadership strategies that might be useful for solving them.

\section{The Root Causes of Economic Crises}

The economic growth is the major objective of the capitalist economy and the main source of human prosperity. This process can be explained with some of the major economic activities that are essential for producing goods and services to satisfy the human needs and wants. These major economic activities that generate economic growth include the investment, employment, income, consumption and saving. The rate of economic growth, partly, depends on the relationship of these activities and the size of the raw materials that they use and the demand for the goods and services that they produce.

In capitalist economies, the investors utilize the limited resources to satisfy the existent demand for making profit. In an organization, in a chain reaction, the investment generates employment; employment generates income for labors and investors. Some of these incomes are spent for the consumption and some of them are saved for further investment. When there is enough demand, investors use the opportunity and the raw materials to produce goods and services to satisfy the existent demand in a free market. As a result of continuation of this process, the economy grows and the people of organizations and nations get prosperous. Therefore the investors, employees, consumers, governments, and most other people like to have economic growth.

However, the recent economic crises have shown that the market is not that free; it is partly controlled and directed by the leadership strategies. These strategies are mostly based on maximizing the personal interests of the owners and leaders of the business organizations. The interest of the employees, consumers and most people are often neglected. These kinds of unfair and biased strategies have been causing income and wealth inequalities within and between nations. These inequalities provide the economic power for the leaders and the owners and generate economic crises for the employees. The decisions of distributing the benefits of the organizations, determine the rate of salaries and the duration of employment. These decisions are made by the leaders who are elected or appointed by the owners. Therefore, they have been favoring the owners' objectives and securing their own employment.

Growing economies and rising world population have been generating another kind of inequality between finite world resources and rising demand for them by destroying the environment and depleting the finite resources. These kinds of inequalities are also causing some economic crises for everyone especially the poor people who are dependent on the environmental resources for their livelihood. 


\subsection{Some Data for Economic Growth, Inequalities and Economic Crises}

During the period of twentieth century and early part of the twenty-first century, economic growth of the world has been phenomenal. But, its growth rate and distributions of the benefits and costs, among people of organizations and nations, have been unequal and causing economic crises.

During the last six decades, the economic growth of global economy which is now more than five times the size it was in 1950, has not brought about equivalent progress of fulfilling basic human needs to adequate food, access to health care and education, and decent employment. In a world of nearly 6.7 billion people, 4 billion of them still live in poverty and 1.1 billion live in extreme poverty (Jackson, 2009; Collier, 2007).

The economic growth in terms of world income or world per capita income, and the world population have been growing exponentially since 1800 (Sachs, 2008). But, the growth rate and its benefits have been distributed unequally within and between nations. The group of 7 developed nations (G7) consisting of the United States, the United Kingdom, France, Italy, Germany, Canada, and Japan have managed to grow several times faster than the developing nations and live longer, healthier and more prosperous. During 1970s and 1980s the G7 was the world's dominant economic power through their relatively high economic growth (Marber, 2009).

During 1980s, 1990s, and 2000s some of the developing nations called the Emerging 7 (E7) consisting of China, Russia, India, Indonesia, Mexico, Brazil, and South Korea, and other G20 nations also obtained relatively high economic growth (Marber, 2009).

The G7 nations having combined 700 million people produced \$25 trillion worth of economic output in terms of purchasing power parity (PPP). The E7 nations having combined about 3 billion population, more than 4 times of the G7 nations, produced about $\$ 19$ trillion in 2009. It is estimated that these figures will be about $\$ 67$ trillion for G7 nations and $\$ 105$ trillion for E7 nations by 2050 (Marber, 2009).

According to United Nations Human Development Index (HDI) the lower and middle income nations' was about 20 to 32 percent of that high income nations' in 1960. These figures went up respectively 34 to 62 percent by 1993 and 65 to 85 percent by 2006 (Marber, 2009).

The growth rate of one sixth of the world population achieved high income; two thirds with a modest rates of economic growth; and one sixth of humanity stuck in extreme poverty with very low and most with negative rates of economic growth during the period of 1820 to 2001 (Sachs, 2005).

The richest 20 percent of the world population earn 74 percent of the global income and the 20 percent poorest earn only the 2 percent. The life expectancy is about 50 years, whereas 70 to 80 years in other countries, infant mortality is 14 years, whereas 4 years in other countries, health and social problems are relatively much higher, level of education and literacy is lower, homicides and crime rates are higher, in these countries with a low national income per capita; Human Development Report's Index is about 0.8-1.0, whereas 0.2-0.5 in other countries (Wilkinson and Pickett, 2009).

The inequality of wealth accumulation is also severe in the U.S. The top 1 percent of population owned 46 percent of total financial assets, the next 9 percent owned 36 percent and the rest 90 percent owned 18 percent. Top 10 percent of population owned 82 percent of total financial assets, 91 percent of total corporate and business assets and 75 percent of the total wealth in 1997. The rich person on average has 230 times more wealth than a large majority of Americans. About 5 percent of the population owned the 95 percent of the wealth and 95 percent of the population owned only 5 percent of the wealth (Brouver, 1998; Sachs, 2005).

If the distribution of income and wealth generated by the economic growth remains so unequal, the economic crises will grow and more people will be in poverty by the middle of this century when population expected to rise over 9 billion (Jackson, 2009). 


\subsection{Some Unfair Leadership Strategies and Economic Crises}

Leaders in the past and currently could not provide necessary strategies to eliminate the inequality problems and establish a fair and sustainable economic growth. The leaders of most corporations and governments want growing gross national product (GNP) through economic growth. The economic growth provides opportunities for leaders of many corporations to maximize their profits and strengthens the leaders of many governments' political positions through increasing gross national product.

But the leadership strategies for distributing the benefits of economic growth have not been fair. Their strategies have been favoring mostly the interests of the investors and the owners of the organizations. These kinds of strategies make the inequality of income and wealth between rich and poor even worse. They influence and play the major role for making the main decisions for employment, level of salaries, and sharing the outcomes of the organizations. Most of these decisions satisfy the interests of their affiliated groups (stockholders, investors, and politicians) and their own.

The leaders who are elected by the board of trustees (BOT) of the stockholders or appointed by the owners in many organizations have been favoring mainly the interests of the stockholders and the owners (Derber, 1998; Estes, 1996; Galbraith, 1998; Thurow, 1989; Reich, 2007). The leaders of the governments have also been supporting, mainly, the interests of the corporations who support them financially and politically. Thus the interests of the employees and the customers have been neglected (Batra, 1996; Blair, 1994). These kinds of leadership strategies increase the economic inequality and cause the economic crises.

Some of the real world practices support these arguments. The recent enormous economic growth has generated severe income and wealth inequalities for people within and between nations. The income of some major American companies' CEOs were 25 to 30 times more than the typical workers' wages during the 1950s and 1960s. This figure grew up to 40 times in 1980 and 100 times in 1990 and 350 times in 2007 (Wilkinson and Pickett, 2009). Average pay of CEO in the U.S. rose 57 percent between 1990 and 2000, while the average worker pay rose 37 percent in the same period. CEO salaries tripled in France, Italy, and Britain and doubled in Germany during 1984-1992.

Since 1976, inequality between real wage workers has soared in U.S. Workers' wage index fell 14 percent by 1995, while executives' jumped 150 percent (Batra, 1996). This ratio increased to 690 in U.S. in 2000. Salaries of CEO's of Fortune 500 went up from 35 to 157 times that of production workers (Blair, 1994; Rose, 1994 -1995).

The leaders and owners of many organizations and nations, who are the major agents of the causes of the current economic crises, can also play a major role for solving them. Some of the leadership strategies for this purpose are presented below.

\section{Some Leadership Strategies for Solving the Economic Crises}

There is a Turkish saying that "fish starts smelling from the head". Elimination of the sources and solving the recent economic crises should start first with the leaders of organizations and governments throughout the world. Currently, the leaders of many organizations and governments are utilizing some strategies to avoid world wide economic recession. These strategies may generate some limited employment and increase the total economic demand for the short term, but will not be effective for solving the economic crises in the long term.

In order to eliminate the sources of inequality and solve the current economic crisis for a short and long term, it is necessary to start democratizing and globalizing contemporary leadership practices. The leaders at every level of organizations and governments throughout the world should think and act fairly and ethically for local and global economic affairs to solve these crises.

The leaders of the organizations, unions and the governments should work together locally 
and globally to include the employees and the consumers in the major decisions of the organizations. This kind of industrial democratization will establish equality of income and wealth among people and maintain fair globalization and sustainable environment. The industrial democratization will also provide equal economic opportunities for everyone to participate in political activities. Without industrial democratization we can not have political democratization. The following sections provide some of the leadership strategies for this purpose and may help to solve the current economic crises.

\subsection{Strategy of Developing Local and Global Shared Vision}

In order to solve common local and global economic crisis we need to develop leadership strategies that are based on "we, the united" rather than "we and they, the divided". This is possible through establishing a leadership strategy with a shared vision for every organization, nation and the world.

The vision of most organizations has been the profit maximization based on the argument that the social responsibility of an organization is to make money for the shareholders and the owners (Friedman, 1970). Data indicate that the profits of most organizations have not been shared fairly by all the stakeholders. Most of the gains went to the owners, the stockholders and the leaders who make the major organizational decisions.

Local and global economic crisis are common to all nations. In order to solve the common and global problems, it is necessary to establish the shared vision and joint strategies and efforts. Historical and the contemporary global events indicate that even the most powerful nations can not solve the global problems alone. The global problems require globally joint efforts for a fair solution.

The shared vision of the organizations and nations should be to achieve the quality (prosperity) with equality (equal opportunity), and liberty (personal freedom and national independence) throughout the world.

In order to establish the shared vision the leaders and the citizens of each organization and nation have to work together for having quality with equality and liberty for everyone. This can be established through democratization of leadership practices through group decision making, sharing the benefits and costs of the economic growth, securing the employment in organizations and nations (Sen, 2003).

The process of building and implementing the shared vision has to be the major responsibility and duty of the leaders. They have to respect freedom, independence, and rights of all the stakeholders of organizations and nations. They should cooperate to solve common problems for local and global peace, prosperity and happiness. Organizational and global unity, understanding, respect and care for one another are necessary for solving the contemporary economic crisis at local and global levels. Shared vision will help to establish and strengthen the unity and cooperation among all the stakeholders locally and globally. A quality without equality generates economic, social, and political crises (Chasin, 1997).

\subsection{Strategy of Balancing Income and Wealth Distribution}

During the recent economic crises, the income of many corporate leaders and the profits of many corporations and banks are increasing despite the huge layoffs and the households' debts. It seems that the economic crises have been increasing the income and wealth of the high income groups and lowering the income and wealth of the low income groups. The leaders of organizations and governments have to adopt strategies and policies to balance the income and wealth between high and low income groups.

Leaders of the organizations should balance the high and low income by increasing the income of low income groups and lowering the income of the high income groups. There is of course no theory for determining the lower and upper level limits of the salaries. But, in order to eliminate the inequality and maintain the economic stability, the current ratio of average 
high incomes to low incomes should be reduced. In 1990s, this ratio was about 6 to 1 in USA, 3 to 1 in some Scandinavian nations including Sweden, Belgium and Netherlands (Marber, 2009). The inequality is the lowest in these nations. The ratio of 3 to 1 that they maintained should be a good measure to reduce the incomes of the high income groups and increase the incomes of the low income groups.

The progressive tax programs for high income, capital gains, land, and inheritance for luxury goods and services have to be used for eliminating the income and wealth inequality. These kinds of practices have been very effective for reducing the income and wealth inequality in many Scandinavian countries which have relatively very low inequality (Sachs, 2005; Wilkinson and Pickett, 2009; Jackson, 2009; Speth, 2008).

The corporate leaders should also adopt the programs such as profit sharing, gain sharing and employee stock ownership program (ESOP) to become an owner of the organization. Employee ownership plans saved many companies from bankruptcy and increased he productivity over time (Adams and Hansen, 1992; Blair, 1995).

Many organizations in Japan, Germany, and France, who are given relatively more voice in their employees, get better equality than the U.S. In these countries employees are considered long-term stakeholders of the companies and are permitted to participate in major management decisions. These kinds of participative decisions, sharing the organization's responsibility and the benefits will increase the employee loyalty, eliminate the inequality and increase the prosperity of all stakeholders.

\subsection{Strategy of Providing Equal Opportunities for Education and Employment}

Knowledge, skills and values are the main determinants of income and wealth generation and accumulation. The workers completed six years of education earn 50 percent more than the workers who do not attend school. The gap widens 120 percent for an employee with 12 years education and exceeds 200 percent for those with university diploma (Haussmann, 1998). These figures imply that income inequality arises from education distribution pattern for the employment. People who do not have good economic conditions to go to good schools for a good education mostly end up with low paying jobs and have low income. Thus the inequality in education generates inequality of income and wealth.

During the period of 1990-1995 average corporate layoffs were about 500, 000 in U.S.A. These figures were increased during the last decades and many corporations are planning to have larger layoffs because of the recent economic crises. Many corporations are forcing their employees to work longer hours even during the weekends. Leaders of every organization and government should try to provide equal opportunities for every citizen to eliminate the income inequality and increase the job security.

The yearly military spending of U.S. could provide university scholarship for 30 million students (Marber, 2009). The U.S. military easily cut back without jeopardizing its security. The military spending in many developed and developing nations are similar to or worse than the U.S.A. The leaders in the U.S. and in many other nations should cut down the defense spending and increase the financial helps for those who can not afford education.

The leaders of every public and private organization should also provide and maintain equal opportunities for employment. Hiring for short them purposes and firing when the profits are low is not productive and increase economic crises. The leadership practices should provide opportunities for sharing and securing the employment for a long term. This will increase the moral, loyalty and productivity of the employees. This in turn increases the returns and decrease the inequality and economic crises. Thus providing equal opportunities for education and securing employment are essential for eliminating the current economic crises.

The leaders should also provide opportunities for sharing and securing the jobs with a long term employment. Two third of the Japanese organizations are providing life time employment for their employees (Sen, 1982). Long term employment will increase the employees' moral, 
loyalty and productivity. This in turn increases the organizations' returns and decreases the inequality and economic crises.

\subsection{Strategy of Sharing and Maintaining the Sustainable Production and Consumption}

The inequality gap of production and consumption between developed and developing nations is very high. The developed nations including the U.S., Japan, Germany, France, Italy and the UK provided 71 percent and the 16 big twenty nations and other developing nations 21 percent of the total world's output in 1993. They also consumed the largest portion of the goods and services of the world (Knox and Agnew, 1998).

The richest 20 percent of the world's population consumes 86 percent of all the goods and services. The poorest 20 percent consume only 1.3 percent. Meanwhile more than 1.1 billion people leave on less than $\$ 1$ a day (Collier, 2007).

The production and consumption are increasing with an increasing population of the world while the world's resources are decreasing (Marber, 2009; Sachs, 2008). Increasing production and consumption and decreasing limited world's resources are causing economic instability and environmental problems.

In order to solve inequality and economic crisis, the leaders and the people throughout the world need a radical change in production and consumption activities. This process requires some attitude adjustment, pain, and sacrifice which will resolve the economic crises by slowing down the high level of production and consumption. We can not afford production and consumption that the environment can not provide sustainably.

In order to reduce the inequality gap and maintain fair and sustainable production and consumption, the developed nations should focus on new frontier technologies. They can support the new R\&D, innovations, new knowledge and skills required for these production technologies. Meanwhile developing nations should focus on developing the standardized technologies where they have comparative advantages of production. This process will increase their share of production and consumption for the goods and services that developed nations produce. They will mutually gain from this process through increasing employment and reducing economic crises locally and globally and generate win-win situation for both developed and developing nations.

The local and global leaders of both developed and developing nations should create an environment in which a sustainable production and consumption is possible. The agreements of global partnership for sustainable development are discussed in international meeting in Doha in 2001, in Mexico in 2002 and in other international meetings. These kinds of global agreements should be increased to establish the global cooperation for sustainable production and consumption.

The leaders should establish new organizations to provide credit for investment and education similar to Muhammad Yunus' microfinance revolution through Grameen Bank (Mohammed, 2007).

The leaders of organizations and nations should start giving up wasteful production and unfair consumption and adopt sustainable production and consumption. For this, it is necessary to decrease spending today and increase saving for tomorrow. Small changes in our lifestyle today may provide quality with equality and security for tomorrow.

\subsection{Establishing Fair Globalization and Sustainable Economic Growth}

Many industrial organizations and nations have been obtaining major benefits from the globalization. However, the major benefiters from the globalization have been the main developed nations including U.S.A., Germany and Japan (Isaak, 2005; Stiglitz and Charlton, 2005; Marber, 2009). The nations engaged in globalization increased their income and wealth considerably (Carney, 1995; Marber, 1998; Garten, 1997). Some of the newly developing 
countries (NICs) also increased their economic growth considerably through globalization. However, the distribution of the benefits among the nations is quite unequal.

Limited world resources can not supply this huge and continuously increasing global production sustainably. The environment has been giving warning signals that it can not supply continuously growing demand of the increasing world population (Marber, 2009: Jackson, 2009; Sachs, 2009). These problems will not solve themselves. The leaders should act collectively and abandon the individual self-serving interests and adopt fair globalization and sustainable economic growth. We can obtain prosperity without ever increasing economic growth by establishing sustainable system of energy, land, and resources that avert environmental hazards; stabilize the world population through voluntary reduction of fertility. We can end the extreme poverty in both poor and rich countries if we act collectively and fairly.

Theories of comparative advantages suggest that, nations could improve welfare of the population through globalization (Smith, 1776; Ricardo, 1981). The leaders of both developed and developing nations should act together to improve their comparative advantages through developing educational, technological, economical, and managerial conditions. The nations that developed these conditions jointly can improve their comparative advantages mutually and benefit from the globalization fairly. The leaders should act jointly to revise the biased rules and policies of the international agreements such as United Nations, World Bank, World Health Organization, World Trade Organization, and establish the shared vision with the new principles, rules and regulations to generate quality with equality for all and sustainability of the environment. The leaders of local and global public and private organizations need a genuine and urgent cooperation for establishing a fair globalization and sustainable economic growth to eliminate economic crises.

\section{Conclusion}

The inequality of income and wealth within and between nations and the inequality between supply and demand of the world resources have been generating economic crises through rising economic growth and world population. The past and current leadership strategies could not resolve the current economic crises. Contrarily some of these strategies helped the economic crises grow and reach to the present level. Many experts and scientists are warning us that if these crises will not be solved, growing inequalities and economic crises will be much worse and threaten human life in the near future (Marber, 2009; Sachs, 2008; Wilkinson and Pickett, 2009; Jackson, 2009).

For a long term solution, the leaders and the owners should abandon the self-serving biased profit maximizing visions of the organizations and nations and adopt the shared vision with the participative leadership strategies. The shared vision for individual, organization and nation should be maximizing the welfare with equality and liberty. The leaders, owners, and the employees of each organization and nation have to work together for establishing the shared vision to have quality with equality and liberty for everyone.

The leaders and the owners of the organizations have to adopt leadership strategies through maximizing everyone interests including all the stakeholders of organizations and consumers rather than maximizing the profit. Most of the organizations in Japan, Germany, and in Scandinavian nations have been utilizing leadership strategies to provide more benefits for the society rather than maximizing the profit. Most of the organizations in Japan use participative leadership strategies to generate quality with equality. The Management Consul in Germany makes the major organizational decisions which determine the major benefits including the salaries, employment and the French benefits jointly and fairly. The fifty percent of the members of the Consul are made by the employee representatives who are elected by the employees. These kinds of strategies can be used for reducing the inequality and economic crises. 
The leaders should also adopt policies to increase spending on the social services of the poor families for schooling, health and child care and community services. The evidence in some Scandinavian nations suggests that the high level spending in the social-welfare states rather than military is very effective in reducing the inequality and promoting prosperity. The socialwelfare states have achieved high level of income, low rate of poverty, and a more equal distribution of income than the practices of capitalist economies.

The existent science and technologies of the world are capable for solving the inequality and economic crises. All we need a common good will to do it. The leaders act collectively to revise the biased rules and agreements of the international institutions and establish new principles, fair policies, rules and regulations to generate quality for all with equality and freedom. The leaders need to establish a genuine and urgent cooperation for fair globalization and sustainable growth for eliminating the inequality and economic crises.

The government leaders should increase tax on the high income and wealth holders, and on inheritance, luxury goods and services, second houses and cars and other luxury consumption items to eliminate the income and wealth inequalities.

In spite of recent economic crises, many corporations and banks announced high profits. The government leaders should increase corporate taxes on high profit making corporations and banks, and reduce on small business owners who are having economic crises. They should provide credit and other financial helps for the new entrepreneurs to establish new business which will generate new employment. They should also adopt policies to reduce military spending and political campaigning.

The government and organization leaders can not solve the inequality and economic crises alone. The employees and the consumers should also participate solving these problems. The employees should increase their knowledge and skills to generate more value for their organization through increasing productivity. This will increase their job security and outcome of the organizations.

The employees should also organize and unionize to increase their participation in managerial decisions, and the bargaining powers for negotiating their employment, salaries and the French benefits.

The employees, managers, and leaders should also share the costs of their organizations. The wages of the workers, and salaries of the managers and the leaders should not be increased during the economic crises; they should be decreased for a short time if it is necessary to save their employment and the organizations continuity.

Finally, the consumers should try to cut down their consumptions for non essential and luxury goods, and services. They should also increase charities and help poor anyway they can for eliminating their economic crises. The finite resources can not supply the ever increasing consumption of the people. We should be fair for sharing and consuming the world resources now and in the future. There is an old saying that, the world may come to an end if one rich eats and the poor looks on.

\section{References}

- $\quad$ Adams, Frank T. and Gary B. Hansen, 1992. Putting Democracy to Work. San Berrett-Kohler Publisher, San Francisco.

- Batra, Ravi, 1996. The Great American Deception. John Wiley, New York.

- Blair, Margaret M. Winter, 1994. "CEO Pay: Why Such Contention Issue”. The Brookings Review. The Brookings Institution, Washington D.C., p. 23.

- Brouwer, Steve, 1998. Sharing the Pie. Henry Holt and Company, New York.

- Carney, Martin, et.al., 1993. The New Global Economy in the Information Age. Pennsylvania State University, Universiy Park. 
- Chasin, H. B, 1997. Inequality and Violence in the United States. Humanities Press, NJ.

- Collier, Paul, 2007. The Bottom Billion. Oxford University Press, Oxford.

- Cumhuriyet, April 9, 2010. Bilim Teknoloji. Turkiye'de Gelir ve Yasam Kosullari Arastirmalari. pp. 10-11.

- Derber, C., 1998. Corporation State. St. Martin's Press, New York.

- Jackson, Tim, 2009. Prosperity without Growth: Economics for a Finite Planet. Earthscan, London.

- Estes, R., 1996. Tyranny of the Bottom Line. Berrett-Koehler Publisher, San Francisco.

- Feenberg, Daniel R. and James M. Poterba, December, 1992. "Income Inequality and the Income of Very High Income Taxes". NBER Working Paper No: 4229.

- Friedman, M., 1970. The Social Responsibility of Business is to Increase its Profits. In T.L. Beauchamp and N. Bowie (Eds.), in Ethical Theory and Business. Prentice Hall, Englewood Cliffs NJ.

- Galbraith, K. J., 1998. Created Unequal: The Crisis of American Pay. The Free Press, New York.

- Garten, Jeffrey E.,1997. The Big Ten: The Big Emerging Markets and How They Will Change Our Lives. Basic Books, New York.

- Haussmann, Ricardo, 1998. Inter-American Development Bank. The John Hopkins University Press, New York.

- Isaak, Robert A., 2005. The Globalization Gap. Prentice Hall, New York.

- Kloby, Jerry, 1990. Inequality, Power and Development. Humanity Books, New York.

- Knox, Paul and John Agnew, 1998. The Geography of the World Economy. John Wiley, New York.

- Marber, Peter, 2009. Seeing the Elephant. John Wiley and Sons, Inc., New York.

- Marber, Peter, 1998. From Third World To World Class. Addison Wesley Longman, Inc., Reading, MA.

- $\quad$ Reich, R.B., 2009. Super Capitalism. Vintage Books, New York.

- Ricardo, David, 1981. Principal of Political Economy, and Taxation. Cambridge University Press, Cambridge.

- $\quad$ Rose, Nancy I., Winter 1994-95. Executive Compensation, NBER Reporter.

- Sachs, Jeffrey D., 2008. Common Wealth: Economics for a Crowded Planet. Oxford University Press, New York.

- Sachs, Jeffrey D., 2005. The End of Poverty. Penguin Group (USA), New York.

- Smith, Adam, 1976. Wealth of Nations. Modern Library, New York.

- Speth G. James, 2008. The Bridge at the Edge of the World. Yale University Press, New Haven.

- Stiglitz E. Joseph and Andrew Charlton, 2005. Fair Trade for All. How Trade Promote Development. Oxford University Press, New York.

- Şen, Asım, 2009. Leadership for Twenty-First Century: Lessons from Ataturk's Leadership. Book Surge Publishing, Las Vegas, NV.

- Şen, Asım, 2003. Democratic Management: Total Quality with Liberty and 
Equality. University Press of America, Inc., New York.

- SSen, Asım, 1982. Science, Technology and Development: Lessons from Japan. METU Faculty of Administrative Sciences, Ankara.

- Yunus, Muhammad, 2007. Creating World without Poverty. Public Affairs, New York.

- Thurow, Lester C., 1996. The Future of Capitalism. William Morrow and Company, Inc., New York.

- Wilkinson Richard and Kate Pickett, 2009. The Spirit Level: Why Greater Equality Makes Societies Stronger. Bloomsbury Press, New York. 


\title{
Convergence Across Kazakh Regions
}

\author{
Miriam Frey, University of Regensburg \\ Carmen Wieslhuber, University of Regensburg
}

\begin{abstract}
Even though Kazakhstan is one of the most successful transition countries in Central Asia it has been neglected in the literature on regional convergence. This paper fills the gap with an empirical analysis of the convergence process on the regional level using annual gross regional product (GRP) data for the period 1998-2008 for the 16 Kazakh regions. Sigma convergence implies that the dispersion of per capita GRP, measured as the standard deviation of per capita GRP across regions, declines over time. Given the growing variation in per capita GRP over time this phenomenon cannot be found for Kazakhstan. In the neoclassical growth model, under the assumption of similar steady states, the growth rate of per capita GRP is negatively related to the initial level of per capita GRP. Surprisingly, we do not find this relation for the Kazakh regions. The data show that there is no evidence for absolute beta convergence. In contrast, the Kazakh regions even seem to diverge.
\end{abstract}

JEL codes: O40, O53

\section{Introduction}

Studies on regional convergence within or across countries were already done for a broad range of regions. The most popular work is probably the one by Barro et al. (1991), who identified absolute and conditional beta convergence for the US. An example of a former Soviet Union country can be found in Solanko (2008), who looks at regional convergence in Russia. However, to the best of our knowledge, non of them deals with the former Soviet Union countries in Central Asia. The reason might be the insufficient or even missing data on these countries, especially on the regional level.

Kazakhstan is the biggest among the five former Soviet Union countries in Central Asia. As it is a transition and developing country and in addition well endowed with oil, it is of special interest for studies on regional growth and convergence.

There are already several studies which use regional data for Kazakhstan to work on growth and income distribution. In his work on poverty reduction Agrawal (2008) shows that provinces with higher growth rates achieved a faster decline in poverty. O'Hara and Gentile (2009) instead focus on the regional distribution of Kazakhstan's rising GDP during the postSoviet period. Though, there is no information on regional convergence. The objective of this analysis is to close this gap.

The paper is structured as follows. In section 2 the data used for the empirical analysis is described. Section 3 briefly repeats the theoretical concepts of $\sigma$ - and $\beta$-convergence. This theory is empirically tested in section 4 . The paper concludes with the overview of the main results and some ideas for further research.

\section{Data Description}

Per capita personal income is broadly used in the majority of empirical work done on convergence. However, due to the lack of these data on regional level, we use the gross regional product (GRP) per capita for our analysis. This variable measures factor incomes derived from production within a region. In their paper on convergence Barro and Sala-iMartin (1992) stated that the empirical results for personal income are almost equal to those for GRP. The data in US-Dollar at PPP (purchasing power parity) are drawn from the National Human Development Report 2009. It includes data for the 16 Kazakh regions (oblasts) for the period 1990-2008. 
As in 1997 the capital of Kazakhstan was moved from Almaty to Astana, which subsequently was treated as a distinct region, we have a complete data set for the 16 regions only for the period 1997-2008. Another peculiarity of the Kazakh regional data is that in 1997 an administrative reform was implemented where some regions were redefined. Consequently 1998 is the first year for which data for the regions in today's structure are available. Therefore we decided to start our analysis with the year 1998 to avoid additional aggregation or disaggregation biases, which might occur in the data before 1998.

In addition we used the data for Uzbekistan as well, because a group of regions with similar steady states is not necessarily defined by country borders. An example for this would be the North and South Italian regions. GRP data on the 14 Uzbek regions are taken from the National Human Development Report 2007. As the GRP data sets for Kazakhstan and Uzbekistan are both in US-Dollar at PPP they can easily be merged.

\section{Theoretical background of convergence analysis}

Generally spoken the idea of convergence is an outcome of the neoclassical growth theory done for example by Solow (1956). Basic framework conditions for such a model are a perfect market and linearity in the aggregated production function (Barro und Sala-i-Martin, 2004). In literature two different concepts are distinguished. The first concept is the so called $\beta$ convergence, which is based on the fact that poor regions tend to grow faster than rich ones and per capita income of the former, would catch up with the latter. The main assumption here is that there is a common steady state across the analyzed countries or regions. The second concept is called $\sigma$-convergence which will be explained in detail in the following paragraph.

\section{1 $\sigma$-convergence}

Following Barro and Sala-i-Martin (2004) $\sigma$-convergence is defined in terms of the level of income dispersion. In principle $\sigma$-convergence prevails if the cross sectional dispersion of the GRP per capita declines over time. In this paper it is measured by the standard deviation of the annual $\log$ of GRP.

\section{$3.2 \beta$-convergence}

Countries or regions with similar technologies and preferences tend to have identical steady states. In this framework poor regions tend to grow faster then rich ones. The theory behind this is known as absolute or unconditional $\beta$-convergence theory. The initially poorer regions tend to grow faster than the initially rich ones due to diminishing returns on capital given a common steady state as the basic underlying assumption. The correlation between the initial level of per capita GRP and its average growth rate is represented by the following equation:

$$
\operatorname{h}\left(\frac{y_{i, t}}{y_{i, t}}\right)\left(\frac{1}{T}\right)=a_{i, t}+b^{*} \operatorname{h}\left(y_{i, E}\right)+u_{i z}
$$

On the left hand side in the above equation we have the average annual growth rate of the per capita GRP. On the right hand side refers to the level of per capita GRP, subscript denotes the year and subscript the region. indicates the length of the observed time period. The error term is distributed independently with mean 0 and variance. Roughly spoken, if the log of the initial GRP per capita is negatively related to the respective average annual growth rate, absolute $\beta$ convergence is said to be present. $\beta$, which is included in $b$ as we will show later can be interpreted as the speed of convergence, which is approximately $2 \%$ according to empirical estimations. 


\section{Empirical results}

\section{1 $\sigma$-convergence}

As indicated above the existence of $\sigma$-convergence implies that the dispersion of per capita product, measured as the standard deviation of per capita GRP across regions, declines over time.

Figure 1 shows the cross-sectional standard deviation (i.e. sigma convergence) of the log of per capita GRP for the period 1998 to 2008. The solid line graphs the movement of $\sigma$ convergence, including all Kazakh regions. The dashed line describes the $\sigma$-convergence within the sub-set of regions, which are well endowed with oil. These are Aktyubinsk, Atyrau, Kyzylorda, Mangistau, and Western Kazakhstan. Regions without oil are represented by the third line.

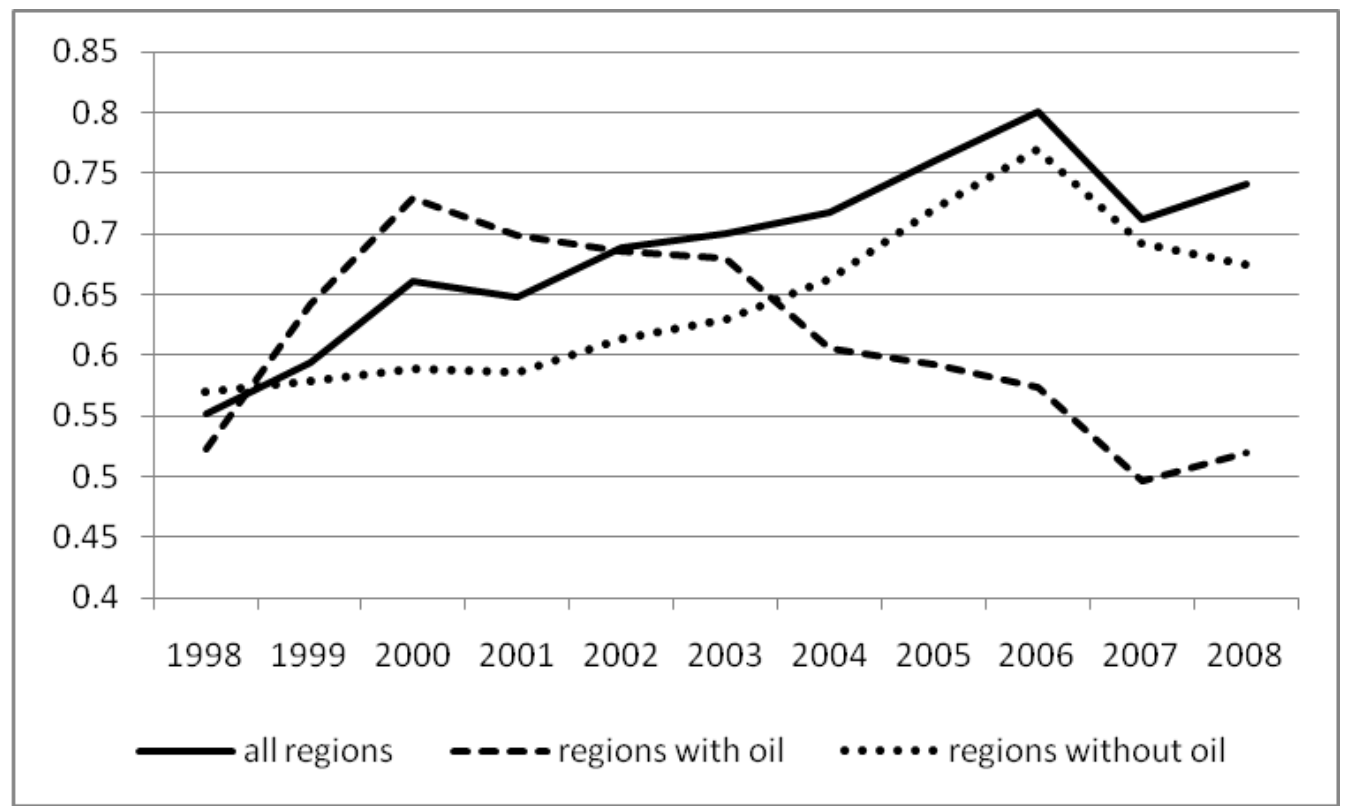

Figure 1. Standard deviation of the log of per capita GRP across Kazakh regions, 1998-2008

The lines can be interpreted in the following way. As the variation in per capita GRP is growing over time (except in 2001 and 2007), no $\sigma$-convergence across all Kazakh regions seems to be present. As the trend for all regions coincides with the one for the regions without oil, $\sigma$-convergence could also not be established for these regions.

In contrast, there is evidence for $\sigma$-convergence across the oil regions. The variation in per capita GRP in these regions grows steeply during the first two years, but declines steadily in the following years. In 2007 it even goes below the starting level. The reason for this might be that according to Najman et al. (2005) Atyrau and Mangistau have traditionally been the main oil producers whereas Aktyubinsk, Kyzylorda and Western Kazakhstan are three relatively new oil-producing regions, which were only explored during the last decade. That is why the latter caught up with Atyrau and Mangistau between 2000 and 2007 while expanding the oil production gradually.

\subsection{Absolute $\beta$-convergence}

The focus of the $\beta$-convergence is the speed of adjustment. To get this immediately it is necessary to estimate a non-linear equation which is represented by the following equation: 


\section{$\operatorname{h}\left(\frac{y_{i z z}}{y_{i z-1}}\right)\left(\frac{1}{T}\right)=a_{i z}-\left(1-e^{-p}\right) h\left(y_{i z-1}\right)+u_{i z}$}

On the left hand side we have again the average annual growth rate and on the right hand side of the non-linear estimation equation we use the parameter matching those from the theoretical paragraph. Here is the parameter estimating the rate of the technological progress which should decline with a rising time interval. Again the time interval is indicated by $\mathrm{T}$. Hence the weight of the initial growth rate is higher if the time span is shorter.

Estimating the equation like it is presented in the theoretical part with OLS leeds to the same result, but the speed of convergence has then to be calculated separately with the following equation:

$$
b=-\left(\frac{1}{T}\right)\left[1-e^{-\rho r}\right]
$$

The univariate non-linear regression equation is estimated with the above mentioned data for the 16 Kazakh regions for the period 2000-2005. We also did some robustness checks using different time periods and received similar results. To do further checks on the robustness of our results, we added the regions of Uzbekistan and estimated the equation again with 30 observations. The underlying assumption is that the Kazakh and Uzbek regions have the same steady state.

(1)

Kazakhstan
(2)

Kazakhstan \&

Uzbekistan

$$
(-1,14)
$$

\begin{tabular}{ccc} 
Observations & 16 & 30 \\
R-squared & 78 & 265 \\
\hline
\end{tabular}

$$
\text { *** } \mathrm{p}<0.01,{ }^{* *} \mathrm{p}<0.05,{ }^{*} \mathrm{p}<0.1
$$

\section{Table 1. Results of non-linear estimations}

The results of our estimations are shown in table 1 . The beta coefficient has a negative sign but is not statistically significant different from zero. The negative sign would indicate that there is no absolute $\beta$-convergence across Kazakh regions. The beta coefficient of the full sample estimation, including Uzbekistan, is significantly different form zero and again negative. So there seems not to be any evidence for absolute $\beta$-convergence across these regions. This can be interpreted as an evidence for the correctness of our results for Kazakhstan, namely, that there is no regional $\beta$-convergence across Kazakh regions. This outcome coincides with the result of the $\sigma$-convergence.

\section{Conclusion}

In this paper we have shown that there is no evidence for regional $\sigma$ - and absolute $\beta$ convergence in Kazakhstan so far. The only evidence for $\sigma$-convergence can be seen if we look solely at the oil producing regions. This indicates that oil plays an important role in the convergence process, which leads us to the missing concept of conditional $\beta$-convergence, where additional explanatory variables are introduced as proxies for different steady states. As a next step we will have a closer look at the conditional $\beta$-convergence across Kazakh regions. 


\section{References}

- Agrawal, Pradeep, 2008. "Economic Growth and Poverty Reduction: Evidence from Kazakhstan“, Asian Development Review, vol. 24, no. 2, 90-115.

- Barro, Robert J., et al., 1991. "Convergence across States and Regions”, Brooking Papers on Economic Activity, no. 1, 107-182.

- Barro, Robert J., and Sala-i-Martin, Xavier, 1992. "Convergence”, Journal of Political Economy, 100(2):223-251.

- Barro, Robert J., and Sala-i-Martin, Xavier, 2004. Economic Growth. The MIT Press, Cambridge (Massachusetts).

- $\quad$ Najman, Boris et al., 2005. "How are Oil Revenues redistributed in an Oil Economy?", The University of Adelaide, School of Economics, Working Paper 200518.

- O‘Hara, Sarah, and Gentile, Michael, 2009. "Household Incomes in Central Asia: The Case of Post-Soviet Kazakhstan“, Eurasian Geography and Economics, 2009, 50, no. 3, pp. 327-347.

- Solanko, Laura, 2008. "Unequal fortunes: a note on income convergence across Russian regions", Post-Communist Economies, vol. 20, September 2008, 287-301.

- Solow, Robert M., 1956. "A Contribution to the Theory of Economic Growth", Quarterly Journal of Economics, vol. 70, 65-94.

- UNDP, 2007/2008. Education in Uzbekistan: matching supply and demand. Report UNDP Uzbekistan, United Nations Development Programme, Tashkent 2007/2008.

- UNDP, 2009. From exclusion to equality: realising the rights of persons with disabilities in Kazakhstan. Report UNDP Kazakhstan, United Nations Development Programme, Kazakhstan 2009. 


\title{
Avrasya Bağlamında Türklerin Misyonu ve Küreselleşme İdeolojisi
}

\author{
Recep Kök, Dokuz Eylül Üniversitesi
}

\begin{abstract}
Turkish Misson and Globalization Ideology in Terms of Eurasia

Evaluating globalization fact with West Ideology which dictate to society, In Eurasia generally and in Turkey specifically, Turkey's geopolitical and strategical importance about Eurasia constantly increase. The aim of this study is firstly to consider historical framework and literature side of globalization in short within the boundaries of this study. Then, the necessity of strategy with Turkish Mission's references from globalization ideology reflections on world state system is presented.
\end{abstract}

JEL Code: Z13

\section{Giriş}

Avrasya genelinde ve Türkiye özelinde topluma dikte edilen Batı İdeolojisi küreselleşme olgusu ile birlikte değerlendirildiğinde, jeopolitik ve stratejik önemi haiz Türkiye'nin Avrasya bağlamındaki önemi giderek daha da artmaktadır. Yakındoğu, Orta Asya ve Balkanları içine alan Türk Avrasyası'nın üzerinde yürütülen stratejiyi, küreselleşme olgusundan bağımsız ele almak tavus kuşu misali başımızı kuma gömmek gibidir. Küreselleşmenin kavramsal çerçevesi ile eyleme dayanan algı boyutu çoğu zaman paraodoksal bir olgudur ve bu coğrafyadaki "havuç" politikasının önemli bir aracıdır. Nitekim, yakın tarihte ortaya çıkan ulus devletler yapılanması içinde de imparatorluk benzeri dünya kaynaklarına hakimiyet stratejisi kurulmak istendiği içindir ki, bu strateji küreselleşme adı altında yeni kavramlarla desteklenmekte ve yeni oluşum sürecine de temel bir zemin yaratmaktadır.

Küreselleşmenin açıklanmasına yönelik politik, ekonomik ve kültürel açılardan birçok yaklaşım olmakla birlikte bu olgunun sürükleyici dinamiğini ekonomik ilişkilerde aramak gerekir (Bauman, 1999; Giddens, 1998; Hopkins-Wallerstein, 1999; Wallerstein, 1974, 1979, 2004; Robertson, 1992, 1999; Rodric, 1997; Waters, 2001; Steger, 2003). Küreselleşme Dünya-Sistem bağlamıyla ulusal devlet sınırlarını aşıp bir sarmal halinde dünya hâkimiyeti stratejisinin koruyucu kuşağı olark mı işlenmektedir? Dünya güç dengelerini kontrol etmek 1steyen devletlerin dikte etmek istediği bir evrenselleşme ideoljisi midir? Özetle, yeni emperyalizm olarak tanımlanabilir mi (Bukharin,1999; Rupert, 2000; Mittelman, 2005; Steger, 2003, 2009; Ritzer, 2004; Robinson, 2004, 2007; Sklaire, 2005; Mooney ve Evans, 2007)? Daha birçok benzeri sorunun cevabı farklı tez başlıklarıyla araştırılmalıdır. Bu çalışmanın amacı, tebliğ sınırları içinde öncelikle "küreselleşme"nin tarihsel çerçevesi ve literatür yönünü kısaca incelemek, ardından küreselleşme ideolojisinin dünya devlet-sistemi üzerindeki yansımalardan hareketle Türk Misyonu'nun refaransları bağlamlı bir stratejinin gerekliliğini ortaya koymaktır. Çalışma aşağıdaki şekilde planlanmıştır. Birinci kısımda, küreselleşme ve yeni emperyalizmin dinamikleri ele alınacak; ikinci kısımda yeni emperyalizm bağlamlı olmak üzere dünya kaynaklarını kontrol etme genelinin ve Türkiye'ye yönelik tehdit senaryolar özelinin uluslararası kurumsal yapısı ortaya konulacaktır. Üçüncü kısımda ise batı ideolojisinin Türk Milleti'nin tarih içindeki rolüne yönelik nihai saldırısının arka planına yer verilecektir. Sonuç olarak Türkiye ve akraba devletler topluluğunun birlikte hareket etmesini amaçlayan ortak bir strateji oluşturmanın gerekliliği tartışmaya açılacaktır.

\section{Küreselleşme, Evrenselleşme, Uluslararasılaşma ve Empeyalizm}

Steger'e göre toplumsal bir öğenin küresellik ve evrensellik kazanma süreci önemli sonuçlar 
doğurmaktadır ve Globalizm tutarlı önermelerden kurulu bir sistemdir. Bu sistem beş temel iddia içermektedir (Yalçınkaya,s.54): Bunlar sırasıyla,

-Küreselleşme , piyasaları liberalleştirir ve bütünleştirir.

-Küreselleşme kaçınılmaz ve geri döndürülemezdir.

-Küreselleşmeyi insanlar değil, piyasalar ve teknoloji yönlendirir.

-Küreselleşme herkese yarar sağlamaktadır.

-Küreselleşme dünya demokrasisinin yayılmasını hızlandırır.

Bu iddiaların doğruluğu dünya deneyimlerine bağlı olarak tartışılmalıdır. Yanlışlanabilirliği doğrulanabilirliğinden daha güçlü olan önermeler dayatmacı yaklaşımlarla ve belli güç odaklarının ideolojik savına dönüştüğünde, bilimsellik öğeleri yerini bilimsel olmayan dogma öğelere bırakır. Bu tartışma sade bir kavram tartışması olmaktan çıkar, çıkar çatışmalarının gölgesinde üretilen bilimin ışı ğında "tarihin sonu" dayatmasıyla zayıfların güçlülere teslim olmasına yönelik bir çağrı halini alır.

Kanaatimize göre evrensel olan ancak insanın doğası ve tabiatın hareket kanunları ile açıklanabilir iken; küresel olan bu doğanın hayata geçirilişine yönelik uygulamalar bütünüdür ve sonradan kazanılanlardır. Her iki güdünün mütehharik sinerji gücüne dönüşmüşşsekli de ideolojidir ve dünyada sistem bağlamıyla emparyalizm olarak tezahür etmektedir. İnsan olma niteliklerinin ortak yönü felsefi düzlemde insanîlik kavramıyla çözümlenebilir. Her bir fert bu çözümlemeyi ister kendi içinde ister teşkilat veya bir organizasyon altında toplum düzleminin ötesine taşınan ve yüce amaçlarla örtüşen insanlık lehine kazanımlara dönüştürürse evrensel bir sonuca hizmet etmiş olur. Nitekim Bauman da uygarlaşma, gelişme, yakınlaşma kavramlarına bağlı olarak insanın bir düzen kurma çabasını, birlik içinde yaşama ve dünyayı eskisinden daha farklı kılma doğrultusundaki değişim ve iyileştirmeler olarak algılamakta ve bunların küresel çapta yaygınlaştırılması gerektiğini savunmaktadır. Ancak, siyasi tarih olayları veya eylemsel boyut değerlendirildiğinde toplumsal olgu ve olaylar göstermektedir ki her zaman insanlık için yararlı olma amacı ve kararlılığı öncelikli değildir. Bazı toplumsal ögeler dünya çapında yaygınlaştıkça karşılıklı bağımlılıkların ortaya çıkması özellikle de teşkilatlar-devletlerarası bağlantıların artması bir bütünleşme sürecni doğurmaktadır. Bu süreçte küresellik kazanan ögeler, insan tarafından mutasyona uğratılmış, başka bir deyimle maniple edilmiş şeyler olarak evrensellikten sapmış ögelerdir. Dolayısıyla her evrensel olan şey küresel olabilir, ancak her küresel olan şey evrensel degildir.

Uluslararsılaşma birey-toplum, toplum-devlet ve devletlerarası ekonomik, politik veya kültürel karşılıklı bağımlıktan doğan bir süreçtir. Robinson karşılıklı bağımlılığın belirlediği coğrafyanın önemine dikkat çekmekte; coğrafi bağlamdaki ulusal sınırların ötesinin, ekonomik faaliyetlerin niteliksel ve niceliksel yönden gelşimesine yol açtığını belirtmektedir. Ekonomi literatüründen bilinen iki yanlı (bilatereal) veya çok taraflı (multiliteral) bu süreçler uluslarasılaşma olgusunun temel kaynağını oluşturmaktadır. Ekonomiler açık bir sisteme tabi olduğu sürece ilişkiler farklılıklardan beslenmekte; karar birimlerinin birbirlerine olan ihtiyacı tek tek ilişki düzeyinde olsa bile karşılıklı etkileşimin doğurduğu ulus-toplum ve ve ulus devlet çatısı uluslararası iktisadın çatısı altında şekillenmektedir. Bu durum yukarıda belirtilen kürelleşme ile ilişkilendirildiğinde ulus-ötesileşmenin doğurduğu sürecin ulus - devlet yapısını zayıflatttığı bilinmektedir. Nitekim ulus-ötesi (transnational- ulus aşkın) deneyimler arttıkça ulus devletler işlevlerinin bir kısmını ulus-üstü (supra-national) kurumsallaşma olgusuna terketmektedirler. Robinson'un ifadesiyle uluslarasılaşmaya özgü niceliksel genişleme, daha farklı bir boyutla işlevsel bütünleşme (functional integration) bağlamlı niteliksel genişleme (qualitative extension) doğurmaktadır. Dolayısıyla ulus-ötesileşme, uluslararsılaşmadan ziyade küreselliğin bütünsel anlamına bağlı olarak, dünya çapında yaratılan bir kontrol ağına dönüşmektedir.

Bu bağlamda, Sklair küreselleşmeyi açıklamaya yönelik üçtür yaklaşıma yer vermektedir. Bunlar, uluslararsılaşma, globalizm ve ulus-ötesileşme dir: Uluslararasılaşma devlet merkezli (state-centrist) bir anlayıştır. Güçlü ve zayıf devletler arasındaki merkez- çevre ve yarı çevre 
yaklaşımını çağrıştırmaktadır. Globalizm devlet merkezlilik görüşüne karşı tezdir. $\mathrm{Bu}$ tez, devletler yerine tanımlanmasında güçlükler çekilen ancak, piyasa güçleri kavramıyla açıklanan sınırsız bir dünya söylemine sahip piyasa globalizmi dir. Ulus-ötesileșme ise ululararasılaşma ve piyasa glabalizminin sentezinden oluşan küresel bir sistemle açıklanabilen ekonomik, kültürel ve politik ulus-ötesi pratiklerle belirlenen bir süreçtir. $\mathrm{Bu}$ olgu tarihsel çerçevede "kapitalist küresellleşme" olarak tanımlanmaktadır (Yalçınkaya, s.22). Bu durumda "sosyalist küreselleșme", islâmik küreselleșme den söz edilebilirmi? Bir toplumsal ögenin küresellik kazanması sosyo-ekonomik bir sistem olarak geçerlilik kazandığı ve bir iddia taşıdığ sürece bir ideoloji olarak yaşayabilir. Sklair'e göre "sınıfsal kutuplaşma" ve "ekolojik sürdürülemezlik" kısıtı altında işleyen kapitalist küreselleşme, işbirliği ve katılımcılığa dayalı demokrasi sürecinin ardından bir geçiș aşamasına bağlı olarak "sosyalist küreselleșme" ye dönüşebilecektir. Bu görüş temelde Marksist öğretiyi çağrıștırmaktadır. Nitekim Kazgan, Emparyalizm teorisinin, Marksizmin, kapitalist evrimi izleyen teorisi olduğunu özellikle ikinci dunya savașının ardından gelen Piyasa Globalizminin "neo-emparyalizm" olgusunu ortaya çıkarttığını iddia etmektedir. Bu iddia esasen Lenin öncesi emperyalizm teorisyenlerinin (John A. Hobson, Rosa Luksemburg, Rudolf Hilferding gibi) ve Lenin'in tekellerin ve finansal sermayenin egemenliğinin kurulmuş bulunduğu, sermaye ihracının belirgin önem kazandığ dünyanın uluslararası tröstler arasında paylaşılmasının başlamış bulunduğu, dünyanın bütün topraklarının kapitalist devletler arasında paylaşılmasının tamamlanmıs olduğu kapitalizmin son gelișmesi" görüșü ile örtüșmektedir (Yalçınkaya, ss. 25-28). Günümüzde de Bukharin'in ișaret ettiği "ticari, endüstriyel, finansal sekliyle ortaya çıkan kapitalist evrim" halen uluslararasılaşma niteliğiyle örtüşen ve küreselleşmeye yönelik tamamlama sürecine hizmet eden bir sistemin varlığını çağrıştırmaktadır.

\section{Küreselleșme Stratejisi, Yeni Emperyalizm ve Türkiye}

Türkiye ekonomisinin büyüme sürecini değerlendirmek ve öncelikle de krize yol açan ve basit bir tanımla, ekonomide refah ve bunalım dönemlerinin birbirini izleme süreci olarak açıklanan konjonktürel nedenleri bilmek veya reel ekonomi ile parasal ekonomi arasındaki örtüşme ve sapmaların nedenlerini, içine sürüklendiğimiz olumsuz şartlar çerçevesinde ele almak gerekir. Üretim güçleri ile finansal piyasalar arasındaki kopukluk, bir siyasal modelsizlikten mi kaynaklanmıștır? Yaşanan olaylar neden mali piyasaların ötesine geçmiștir, ya da krizler nereden beslenmektir ki büyüme, istihdam ve hayat standardı üzerindeki reel etkiler (negatif) süreklilik kazanmıș ve zaman zaman $(1960,1980,2003)$ hükümeti olușturan siyasal partilerin parlamento dışı kalmasına yol açmıştır? Dünya ekonomisini tehdit eden "virüsler", hangi şartlarda ortaya çıkıp özellikle de gelişmekte olan ülkeler için çözümsüzlük "sendromları"na dönüşmüştür? Bu sürecin "konvansiyonel desteği”" küreselleşme olgusunda mı aranmalıdır? Nitekim, Türkiye açısından sadece Nisan 1994, Kasım 2000 ve Şubat 2001 finansal krizlerinin; dünya ölçeğinde 1929, 1945-1947, 2008 yılı krizlerinin ardıl etkileri ve şiddeti dikkate alındığında ortaya çıkan "yeni dünya düzeni” ve yoksullaşan kitlelerin konumu ve doğabilecek sonuçları hangi tepkiler konsepti içinde algılanmalıdır? Ülkemizle ilgili tartışılan tehdit ve firsat stratejilerinden yol gösterici bir 1 șı bulma ve kendi 1șı ğımızla yolumuzu aydınlatma şansımız nedir? Böyle bir şans mevcut ise bunun itici güçleri nelerdir?

1980’li yıllara kadarda akademik açıdan büyük bir önem arz etmeyen küreselleşme kavramı, 1990'lı yıllardan itibaren yaygın bir şekilde kullanılmaya başlanmıştır. Bu kavramın ideolojik bir güvensizlik çağrıştırmasının temel nedeni, Batı kültürünün ve kapitalist toplumun yayılmasını haklı çıkartan ve dünyayı değiştirme iddiasını taşıyan güçlü dünyalıların yarattı̆̆ı ortamdan kaynaklanmaktadır. Kuşku penceresinden baktığımızda bize göre küreselleşme, sosyal ve kültürel düzenlemeler üzerinde coğrafi engellerin kalktığı ve iktisadi anlamda insanların kayıp ve kazançlarındaki farklılaşmanın şiddetinin arttığı; diğer bir deyişle ortaya çıkan nisbi dengesizliğin daha da fark edildiği sosyal bir yıkım sürecidir.

Geleneksel emperyalizme gelince, devlet sistemleri çerçevesinde milliyet/ulus kavramlarını 
içinde kaybetme eğilimini yücelten bir devletin, bir başka devlet ya da bölge üzerinde ekonomik ve kültürel plânda etkin olma, kaynakları kontrol etme veya en azından denetleme yönündeki çabalar bütünüdür.. Devletler, dünyada var olan toprak, insan, üretim ve tüm sermaye güçleri üzerinde sürekli etkinlik kurma ve iktidarlar savaşında önde bulunmayı bağımsızlıklarının vazgeçilmez bir şartı olarak gördükleri sürece, kendi ayrıcalıklarını genişletmek için her zaman bir biriyle yarışmışlardır. Özellikle kapitalistleşme süreciyle birlikte devletler, yeni pazarlar ve yeni tabiî kaynaklara hükmetme amacıyla, dünyanın az gelișmiş ya da gelișmekte olan ülkeler ve bölgesel hassasiyetlerini istismar edebilme doğrultusunda "çağcıl” yaklașımlar geliștirip, küresel ölçekteki egemenlik sınırlarını genişletmektir. $\mathrm{Bu}$ gelișmenin tarihi, "tekelleșme" süreci ile hızlanmış, 1870'ten sonra sistematik emperyalizm çağı başlamıștır. Nitekim Birinci ve İkinci Dünya Savaşları ve içinde yaşadığımız son elli yıldaki lokal operasyonların hemen hemen tamamını bu çerçeveye yerleştirerek analiz etmek, daha sağlıklı sosyal teorilerin kurulmasına katkı sağlayabilecektir.

Yirminci yüzyılın başlarında üzerinde çalışılmaya başlanan emperyalizm teorisi, sömürgelerin ulus devlet olmaya başladığı İkinci Dünya Savaşı sonrasında, yeni boyutlar kazanmıştır. Gerçekten günümüzde kuramsal olarak henüz mükemmelleşememiş olmasına karşın 1960'larda ortaya atılan Yeni Emperyalizm-Yeni Sömürgecilik anlayışı, klasik emperyalizm teorilerinde bulunmayan bir hususu gündeme getirmiştir: Çok Uluslu Şirketlerin ve uluslararası bazı kuruluşların rehberliğinde Türkiye ve benzeri ülkeleri borçlandırarak kendine bağlama yöntemleri geliştirilmiştir. Ancak, "karşılıklı bağımlılık" anlayışının en gelişmiş ülkeler için bile geçerli olduğu günümüz dünyasında, bu yeni sömürgecilik anlayışının boyutlarını kesin olarak öngörmek oldukça zordur. Çünkü, devletlerin özerkliği ve işlevleri uluslarüstü trendlerin etkisiyle aşınmaya uğramaktadır. Küresel/Global değişime karşı duyarlılıklar ortaya konulsa da, bu güne kadar kilit birim olarak bilinen devletlerin yerine konabilecek ekonomik ve siyasal bütünleşmeler giderek ağılığını hissettirmektedir. Ekonomik emperyalizm ve uluslararası kaynak tahsisinde çok yönlü değişkenlerin rol oynadığı artık bilinen gerçeklerdir. "Ulus-üstü sistemin" gelişmesiyle birlikte bir çok yabancı şirket dahil olduğu koruyucu egemen güçleri devreye sokarak dünyanın doğal kaynaklarını kontrol etmeye yönelik hatta büsbütün ele geçirecek çareler geliştirmişlerdir. Son on yıl içinde hazırlanan senaryoların beklenen uzantıları çerçevesinde dünya savaşı eşiğinden dönüldüğü günlerde, 'Irak petrol rezervleri Allah'ın Amerikan halkına bir bahşidir' diyen ABD Başkanı Bush'un ifadelerinden dünya kamu oyuna aktarılan mesaj oldukça ibret vericidir.

İngiltere'deki Orijinal Sanayi Devrimi'nden beri (1790) özellikle gelişmekte olan ülkeler, W.W.Rostow'un “dayanıklı büyüme hamlesi” diye adlandırdığı süreçten geçip, 1960'lı yıllardaki zenginleşmiş batı kulübünü doğurur iken hiçbir yeni ülkenin bu kulübe katılmasına izin verilmemiştir. Dünya sistemini 1945-1960 donemi için analiz eden ve 1990-2025 dönemi için de beklentilerini ortaya koyan Wallerstein'e göre biçimsel olarak sadece iki gerçek ihtimaliyet vardır: Birisi dünya sisteminin, sürekli gereken ayarlamalarla birlikte kapitalist dünya ekonomisi olarak son beş yüzyıldır işlediği gibi işlemeye devam edeceğidir. Bunun anlamı, Kontratieff çevirimin tekrar yukarıya döneceği ve bunun daha uzun olan hegemonik çevirimin tekrar yeniden yapılanma sürecine gireceğidir. İkicisi, 1970'lerde görülmeye başlayan hegemonik bir düşüşün kaçınılmaz sonucu olarak belirsiz sistemik bir kaos döneminin başlayacağıdır. Ortaya çıkan sistemik krize bağlı olarak çatallaşmanın doğmasıdır. Nitekim Hegemonik çöküş merkez bölgede yer alanlar için önce öncü ürunler (yüksek teknolojiye dayalı mallar) alanında rekabetçi olabilmenin yolları aranır. Hakimiyet oluşturan ürünlere yönelik işgücünü ödüllendirmeye yönelik formüller bulunur. Böyle bir dönem hegemonik üstünlük için uzun bir mücadele gerektirirken zirvede kalma bu safhayla çakışırsa bu süreç dünya savaşına yol açabilir (Hopkins, ss. 284-286), Nitekim Birinci Dünya ile Üçüncü Dünya arasındaki bölünmenin kalıcı olduğu sanılmakta iken, birinci dalga ile Asya'nın kaplanları (Hong Kong, Singapur, Tayvan ve Güney Kore) ortaya çıkmış; ardından gelen ikinci dalga ile de Güneydoğu Asya'nın yoğun nüfuslu ekonomileri ve Çin'in şaşırtıcı yükselişi karşısında "yeni dünya düzeni”ne farklı bir ivme kazandırmıştır. Yirminci yüzyıl biterken, 
kaplanları ve kaplan olma yolundaki ülkeleri bunalıma götüren "Grizu/Metan Gazı" (kendi tabirim) nasıl birikmişti ya da hangi düzenleyici güç bu birikimi körüklemişti ki, bir "çınkı" ile ard arda gelen patlamalar köklü iktidar değișimine yol açan sonuçlar doğurmuștur (2008 y1lı dünya kriziyle yeniden şekillenen $\mathrm{ABD}$, İngiltere vb. ülkelerdeki iktidar değişimlerinin arka planı hatırlanabilinir).

Ülkemizin iktisadi kalkınma sürecini dikkate alırsak, Türkiye'de yirminci yüzyıl başlarında yaşanılan daha zor şartlara rağmen İkinci Dünya Savaşı'nın getirdiği yeni şartlar içinde sistem ve rejim analizleri ekseninin tam orta noktasından "saat sarkacı" gibi "sağa-sola" nasıl savrulduğumuz bilinmekte birlikte yirminci yüzyılın üçüncü çeyreğine kadar kısmen kendine yeterlilik politikaları (oluşturulabilmiş bilgi birikimi ve sermaye stoku ile) desteğinde 1980'li yıllara gelinmiştir.

Bu yıllarda özellikle gelişmiş batı ülkelerinde finansal piyasalar yeniden düzenlenmiş, yeni piyasa iştirakleri devreye sokulmuş; daralan pazar şartlarını geliştirmek, yavaşlayan büyüme süreçlerini hızlandırmak ve dinamikliğini kaybeden monetarist politikalara işlerlik kazandırmak amacıyla, devletin piyasa ekonomisi işleyişindeki rolü en aza indirgenmek istenmiş ve yeni finansal araçlar geliştirmek suretiyle de, finans piyasaları arasındaki uluslararası yakın bağlar daha da güçlendirilmiştir. Öte yandan, 1970'li yıllarda, uluslararası finans kurumlarının (IMF, Dünya Bankası v.b.) gelişmekte olan ülkelere açtıkları dış krediler, 1980 başlarından itibaren ana para ve faizleri ile birlikte geri dönmeme riski ile karşılaşınca (örneğin, Güney Amerika Ülkelerinde karşılaşılan borç ödeme krizleri) giderek artan uluslararası fon fazlasına daha risksiz bir reel kaynak bulabilme ve bunun araçlarının ne olması gerektiği konusu tartışmaya açılmıştır. Bu tartışmalar bağlamında, OECD konseyinin rekabetin ilerletilmesi ve düzenlenmesi adına 1979 yılındaki deregülasyon politikalarının hayata geçirilmesi önerisi, dünyadaki özelleştirme hareketlerinin uluslararası platformda ele alınmasının nedeni olmuştur. Bu görüş, İMF ve Dünya Bankası tarafından da benimsendiği içindir ki, kamu sektörünün özelleştirilmesi fikrine destek sağlayan özel birimler oluşturulmuştur. $\mathrm{Bu}$ tür birimlerin faaliyeti sonucunda da, üye ülkelerin devletçilik uygulamasının sınırlandırılmasını öneren, İMF programlarının uygulanmasına yönelik ekonomik paketler hazırlanmış ve bu paketler çerçevesinde üye ülkelere mali destek sağlama yolu kolaylaştırılmıştır. Başka bir deyişle, 1970 ve1980'li yıllarda dünyanın geldiği iktisadi konjonktür ve nispeten de netleşen iktisadi sistem ya da siyasal rejim deneyimleri, salt devletçilik fikrinin ideolojik boyutunu önemli ölçüde sarsmıştır.

Daha sonraki y1llarda(1990) Komünizmin çöküşüyle "radikal devrim" tehdidi büsbütün azalınca, Batı Dünyası'nın sunduğu güven şartları altında dış dünyaya yapılan yatırımlar da hızla artmıştır. Nitekim bu dönem de gelişmiş ülkelerdeki faiz oranları istisnai denebilecek ölçülere düşmüş ve çoğu yatırımcılar daha yüksek getiri elde edebilmek için yurt dışına kaynak aktarmaya başlamışlardır. Bu durum yeni mali fırsat alanları sayılmış ve "gelişen piyasalar" doğmuştur. 1990 da gelişmekte olan ülkelere akan özel sermaye tutarı 42 milyar doları bulmuştur. Yukarıda belirtilen gelişmeler çerçevesinde IMF ve Dünya Bankası gibi Resmi Kuruluşların Üçüncü Dünyadaki finanse ettikleri yatırımlar, tüm özel yatırımların toplamını aşmış, 1997' li yıllara gelindiğinde resmi para akışı azalmakla birlikte özel fonların akışı 256 milyar dolara ulaşmıştır.

Dolayısıyla büyük kurtuluş adına büyük kuruluşlar (IMF ve Dünya Bankası) devreye girerek "tekila krizinin" olumsuz etkileri bir kaç yıl içinde azaltılmış ise de şu açık sorunun tartışması bitmemiştir: Şu anda mevcut olan ve gelecekte daha da ağırlaşabilecek bedellere, temel de Türkiye'nin ABD çıkarlarına özel bir önem vermesine meşruiyet kazandırılabilmesi için mi katlanılmaktadır? Nitekim, 1997'li yıllarda dolar - yen arasındaki rekabetle başlayan ya da yukarıda belirtildiği gibi finansal sektörlerin düzenlenmesi ve kontrolündeki yetersizliklerden dolayı derinleşerek devam eden ve 2000 yılında Türkiye'yi de etkisi altına alan krizler incelenirse Türkiye özeline inmeden Asya ülkelerine ilişkin kısa bir değerlendirme yapmak yararlı olacaktır. Özellikle Çin'in ucuz emek gücü sayesinde kazandığı rekabet gücü karşısında, Asya ekonomisinin (Tayland, Malezya, Endonezya, Hong Kong, Güney Kore vb.) uzmanlık 
alanı olarak bilinen mallar üzerindeki ihracatların daraldığı bilinmektedir. Bu daralmanın panik düzeyine ulaşan dalga etkisi Türkiye'ye yansımıştır. Yani, Rusya da başlayan finansal krizle birlikte Türkiye'ye gelen sermaye akımının durması bir yana Türkiye den çıkışlar da başladığı içindir ki, sürüklendiğimiz savaş senaryolarının gölgesi altında krizin derinliğinin nereye varacağını kestirmek mümkün değildir.

Liberal Hayek, kapitalizmi bir denge sistemi olarak görür ve bu sistemdeki krizlerin/bunalımların nedenini de devletin ve özel bankaların bu "nazik sisteme" devresel olarak yaptığı müdahaleler ve kredi hacmindeki aşırı genişleme ile açıklar. Schumpeter'in konjonktür modeli ise, genel iktisadi dengenin bulunduğu bir anda teknolojik veya teknik etkinliğin bu dengedeki etkilerinin araştırılmasına dayandırılır. Ona göre "gelişme", yeniliğin neden olduğu hiç durmayan "değişim" sürecidir ki yeni kombinasyonların ortaya çıkarılması sonucu oluşur. Değişim de "yaratıcı yıkım" sonucu olarak ortaya çıkmaktadır. Yakın dünya tarihi açısından siyasal sistemdeki yaratıcı yıkımı, Türk tarih özelinde de Türkiye Cumhuriyeti Devleti'nin doğuş şartlarıyla açıklamak gerekir. Günümüzde ise yeni dünya düzenin jandarmalığına soyunan ABD’nin tarihe yön verme iddiasını gerçek yüzüyle algıladığımızda, ödenecek bedele ortak olma aceleciliğimiz ve tarihsel evrim içinde görevini doğru yapamama utancı elbet bir gün Türk aydınının kendi kendini sorgulama cesaret ve bilinciyle netleşecektir.

İktisadi sistemlerde yaratıcı yıkım, devamlı olarak eski olan düzenin/sistemin yıkılıp yeni olanın ortaya konmasıyla gerçekleşmektedir. Bu iktisadi modelde, teknik yenilik olmaksızın büyüme, girişimcilik olmaksızın teknik yenilik ve kredi olmaksızın da girişimciliğin olamayacağı savunulur. Schumpeter'e göre "yenilikler" yeni iktisadi süreci ortaya çıkarırken aynı zamanda "ekonominin ateşini" yükseltmekte ve yenilikler birbirini izlerken de birdenbire yavaşlama olacağı için ekonomiler yeni bir durağan dengeye yönelmektedir. Bu bağlamda, gelişmiş ülkeler, sürdürülemez "arz şokları" yaşamamak için gelişmekte olan ülkelere sürekli talep şokları ihraç etmekte (uluslararası kuruluşlar aracılığıyla) ve bu ülkeler de düşürüldükleri döviz-faiz ve enflasyon sarmalı içinde günü kurtarma pahasına bu "küresel" mekanizmanın bir parçası haline gelmektedir. Nitekim Şubat 2003 itibariyle Türkiye'nin diş borç stoku 120 milyar dolara, iç borç stoku 180 katrilyon TL'ye varmış, ülke üretime yönelik verimlilik seviyesinde dünya liginin 51. sırasına düşürülmüş ise yaşanan sendromun derinliğini ve piyasaların paranoya davranışını anlamak kolaylaşmaktadır. Tarihe kayıt düşecek bir gelişmenin şahidi olmaktayız. Hükümet'in savaş tezkeresini TBMM'ne gönderme ihtimali karşısında Dolar fiyatı düşüyor borsa indeksi yükseliyor, pazarlıklar (savaş ekonomisinin bedellerine yönelik) sürecinde tezkerenin gecikeceği ya da tezkerenin gönderilmeyeceği ihtimali haber konusu olduğunda dolar fiyatları yükseliyor, borsa indeksi düşüyor. Piyasalara ilişkin bu paradoksal olgu yukarıda belirtilen sürüklendiğimiz kaosu açıklayabilecek net göstergelerdir.

Schumpeter'e göre aslında kapitalist sistemin sonunu getirecek olan iktisadi buhranlar değil, sistemin yarattı̆̆ 1 refah (dengesiz) artışıdır. ABD örneğinde olduğu gibi hayat standardı yükselip çalışanlar ve liberal ortamda yetişen aydınlardaki maddi tatminsizlik dalgası giderek büyüyen çarpık bölüşüm adaletsizliği ile birleşince ulaşılan refah yerini manevi tatminsizliğe ve prestij arayışına bırakmaktadır. Dolayısıyla nevrotik bir vaka olan hatta başlangıçtaki örgütsel desteği (EL-KAİDE) ABD eksenine bağlanan 11 Eylül U. Bin Ladin hareketi önce "küresel" sisteme meşruiyet kazandırma aracına dönüştürülmekte, esasta ise medyatik güçlerin desteği ile "yeni dünya düzeni”nin değişim süreci olarak takdim edilmektedir.

\section{Avrasya Bağlamında Türklerin Misyonu ve Batı İdeolojisi}

Batı ideolojisi, jeopolitik ve stratejik önem taşıyan Türkiye'nin Avrasya bağlamındaki giderek artan önemine sırt çevirme lüksüne sahip değildir. Bu nedenle Türk Avrasya'sını kontrol edebilmek için iki temel ideolojik yaklaşım geliştirmiştir.

$\mathrm{Bu}$ ideolojilerden birincisi, sert ideolojiler tanımımıza uymakta ve ABD tarafinda temsil edilmekte olan, tarihin yönünü değiştirme iddiasını içeren uygulamalardır. Tek kutuplu bir 
dünya düzeni için Z.Brezinsky’nin ortaya koyduğu, "Carter Doktrini" olarak bilinen bu ideoloji, dünyaya küreselleșme sürecinin itici gücü olarak takdim edilmektedir. Esasta, yükselen Amerika kapitalizminin, yükselmekte olan Çin ve Hint milliyetçiliğini durdurmasına yönelik bir strateji olmakla birlikte Irak müdahalesi ile başlayan bu "önleyici darbe stratejisi" birçok ülkenin mütareke basınları aracılığıyla genetik sektör ve akıllı silahlar" da ki başarının vazgeçilmez bir yansıması şeklinde gösterilmektedir. Yine, bu ideolojinin Huntington'un medeniyetler çatıșmasını referans aldığı da bilinmektedir. Yumuşak ideolojiler kategorisinde ele almak istediğimiz ikinci ideoloji ise, Türkiye'yi Avrupa'ya "demirleme" stratejisi olarak tanımlanabilir. $\mathrm{Bu}$ ideolojinin temel amacı, AB (Avrupa Birliği)'nin yumuşatılmış kurumsal kararlarını, AB düşkünü Türklerin zafiyetinden yararlanarak hayata geçirmektir.

Türkiye'yi bağlayıcılık açısından etkin zeminlerde olup bitenler, çoğu kez ya öteki'nin aklıyla irdelendiği için yanılgılarımızın derinliği bilinmemekte; ya da tarihi unutmak gibi bir hastalığımızdan dolayı tam anlaşılmamaktadır ki, bu durum bulanık gelişmeleri sınırsız alkışlama heveskârlığımızdan dolayı $\mathrm{AB}$ tarafından keşfedilmiş zafiyetimiz şeklinde değerlendirilmektedir.

Aslında, "rasyonel kuruculuğu" esas alan Avrupa, çağdaş medeniyet olarak algıladığı, kendi medeniyetinin merkezini elinde tutan Türkiye'yi tarihî bir rakip olarak görmektedir. Çünkü, yüksek Avrupa medeniyeti (onlara göre) Anadolu'nun uzantısı olan Konya'da (Ege ve Akdeniz de ) doğmuş, Doğu Bizans İmparatorluğu ölçeğinde İstanbul merkezli gelişmiştir. Bu nedenle bu coğrafyanın Türkiye'nin elinde olması, batı açısından dayanılmaz acı bir hatıra olarak akıllarda tutulmakta ve tarihî bir sorun olarak görülmektedir.

Tarih şuuruyla açıklanabilecek ve zamanla aktörlerinin değiştiği bu ideolojilerin özünde, Çin ve Hindistan'dan gelerek Türkistan ara bölgesini geçen, Ön Asya ve Avrupa'yı birbirine bağlayan yoldaki stratejik kaynakları ve bu kaynakları birbirine bağlayan İpek Yolu'nu büsbütün kontrol etme iddiası vardır. Burada, tarihin med-cezirlerini saymazsak bu yolu kontrol altında tutan ve yüksek bir kültürü temsil edenlerin en büyüklerinden olanları da Türk devletleridir. Türk Milleti, yaklaşık bin yıl tarihin kaderine hakim olmuştur. Nitekim, on birinci yüzyıldan bu güne Rey/Isfahan merkezli Büyük Selçuklu İmparatorluğu, Semerkant merkezli Timur İmparatorluğu, İstanbul merkezli Osmanlı İmparatorluğu ve günümüzdeki Ankara merkezli Türkiye Cumhuriyeti devleti ve diğer Türkî Cumhuriyetler tarihte hesap sorulması gereken dönemlerin temsilcisi sayılmaktadır. Bugün, yer altı zenginlikleriyle bilinen bu Avrasya coğrafyası, ayrı devletlerin çatısını oluştursa da tarih şuurundan koparılması gereken nesilleri halâ barındırdığı için vahşi kaplanların iştahını kabartmaktadır. $\mathrm{Bu}$ anlamda "bağımsızlık benim karakterimdir" diyen M. Kemal ATATÜRK'ün ve Cumhuriyeti Kuran Kurmay Kadro'nun ruh dünyasını referans alan bir milletin güçlenmiş varlığı, AB için bir güvensizlik sendromu olarak algılanmakta ve dolayısıyla Türklerin top yekûn mahkûm edilmesini haklı çıkaracak yolların aranmasını gerekli kılmaktadır.

$\mathrm{Bu}$ mülahazayla Avrupa'yı temsil edenler, Türk Avrasya'sının Yeni Avrupa'ya demirlenmesini sağlayacak rasyonel bir yol bulmuşlardır. $\mathrm{Bu}$ yol, Türkler tarafindan başlangıçta uzun, ince, karanlık ve engebeli bir yol olarak algılanmıştır. Ancak, AB'ye üyelik ihtimali, bekleme odalarındaki mazoşist bir zihinsel iğfal sırrını taşıyan cazibeyle sunulduğu için gafletimizin sınırlarını zorlayan uyutma politikası başarılabilir görülmüştür.. Dolayısıyla, kendi halklarına Türkiye'nin uzun vadede AB'ye alınmayacağı teminatını veren düzenlemeler ile Türklerin ikna edilmelerini sağlayan kararlar, eşanlı olarak Anayasal bir çerçeveye (Avrupa Anayasası) oturtulmaktadır. AB'ye göre bu coğrafya parçası hafızalarda canlı tutulurken, hem tarihten miras kalan sorunlar, hem de günümüzdeki ve yakın gelecekteki çıkarlar kendi lehlerine korunmuş olacaktır. İşte düşürüldüğümüz tuzak ve $\mathrm{AB}$ düşkünlüğümüzün arkasındaki gerçek budur.

Bir başka yönüyle yukarıda belirtilen ve Türkiye'yi kıskacına alan bu iki ideoloji, Türkiye’yi üstü örtülü bir anlaşmayla "kırk katır mı yoksa kırk satır mı" tercihine zorlamaktadır. Çünkü çok uluslu Şirket merkezlerinin marifetleriyle (ağırlıklı olarak ABD ve AB sermayesi) dünya kaynaklarının paylaşım rekabeti netleşmekte, dünyaya kabul ettirilecek yol haritaları, 
Bilderberg toplantılarıyla belirlenmekte; gelişmekte olan ülkelerden çağırılan taşeronların katkısıyla oluşan tek kutuplu yönetim mekanizması, küresel bir güç olarak güvence altına alınmaktadır.

Bu bağlamlarıyla tarihin yönünü değiştirmek isteyen bu ideolojiler, uygulama ekseninde aşağıda belirtilen iki temel senaryoyu Türkiye Cumhuriyeti’ne dayatmaktadır:

Bunlardan birincisine göre Türkiye yakın doğuyu kontrol edebilir bir ülke olma potansiyeline sahiptir. Bu kabul çerçevesinde Türkiye, ya ABD'ye manda ölçüsünde bağll olsun ya da AB'nin içine alınmadan AB'ye demir atacak şekilde bağlanılmış bulunsun. Birinci senaryo, Türkiye tarafından kabul görmez ise, uzlaşmanın zorlaştırıldığ süreç Türkiye'nin iknâ edilmesi için zaman kazanma politikasının hâkim olduğu beş on yıllık bir zaman dilimi içinde şekillendirilebilecek senaryodur. Burada, Türkiye ya etnik bir iç savaşa sürüklensin ve bunun siyasal ve hukuki zemini hazırlansın, ya da parçalanmasını haklı hale getirecek sözde Ermeni Soykırımı'nı kabullendirme dahil siyasi planlar uygulansın, ucu açık "demokratik açılım" süreçlerine bağlı olarak bağımsızlık teminatı olan anayasal direnç kırılsın ve yoksullaşan kitlelerin yılgınlığından yararlanılarak devletine küskün, barışık olmayan bir toplum yaratılsin.

Yukarıdaki sert ideolojinin BOP (Büyük Orta Doğu Projesi) çerçevesinde Irak"ta yapıp ettiği bellidir. Bu bildiri çerçevesinde yumuşak ideolojinin serüveni, kısaca değerlendirilirse Avrupa Parlamentosu'nun Türkiye'ye yönelik kararlarına (15 Aralık 2004) ve Avrupa Birliği Zirvesi'nin sonuçlarını (17 Aralık 2004) hatırlamak yeterli olacaktır. Örneğin,

- Patrikhane ve Heybeliada Ruhban Okuluna ilişkin isteklerden söz eden Komisyon kararları "ruhban yetiştirilmesi", "mülkiyet hakları", "okulların açılması" ve "iç yönetim" konularını masum bir yöntemle ele almakta; T.C'nin üniter kimliğini zedeleyecek bir dayatmayla İstanbul'da devlet içinde devlet kurulması sonucunu doğuran yeni Vatikan'lar yaratmak istemektedir.

- Müzakerelerin tamamlanma süreci açık uçludur (AP Karar mad:50, AB Zirvesi mad:23). Böylece, Yunanistan ve Güney Kıbrıs Rum Kesimi (GKRK) ve birkaç ülke bir araya gelerek görüşmeleri kesintiye uğratabilecektir. Bu şartlar altında yapılacak müzakerelerde Türkiye'den ne tür tavizler isteneceğini ve hangi tehdit stratejilerinin ortaya konacağını tahmin etmek güçtür.

- Güneydoğu'da yaşayan yerel nüfusa ilişkin, yönetim reformları, Kürtlerin kültürel haklarının tanınması ve eşit muamelenin hızlı bir şekilde garanti altına alınmasının gerekliliği ve "kürt güçleriyle" uzlaşma sağlamak üzere daha etkin adımlar atmaya yönelik davetler oldukça düşündürücüdür. Nitekim, kürtleri siyasal bir güç olarak muhatap kabul ettirme eğilimi taşıyan ifadeler, sebebi apaçık belli olan ve yılardır destek verildiği bilinen terörist örgütü zımnen de olsa tanıtma çabası olarak anlamlı bulunmalıdır. Burada AB'nin sömürgecilik amacına hizmet eden bu yaklaşımı kamu vicdanından saklanmakta ve günümüzde yükselen talepler yönüyle de Türk-Kürt meselesi sürekli kanatılan bir yara olarak tutulmak istenmektedir. Dolayısıyla birincil düzeyde bölücülük hareketine meşruluk kazandırılmakta ve Türkiye'deki ayrılıkçı güçlerin aktif bir şekilde federasyon talebine ulus- üstü güç olarak destek verilmektedir.

Ancak bilinmelidir ki, Türkiye Cumhuriyeti kendi yurttaşlarına sahip çıkacak dirayette, hukuk devleti olmanın ilkelerini yaşatacak güç ve kararlılıktadır. Çünkü, T.C. ihanete ve gaflete karş̧ kararlılıkla mücadele etmeyi tarihteki deneyimleriyle göstermiş ve bu Cumhuriyeti kuran halk Türktür diyerek, Türkçülük anlayışını insan hakkıyla özdeşleştirmiştir. AB'nin bu konuya yaklaşımı ise iki yüzlülügü ve husumeti yansıtan, küresel emperyalizme karşı yüklenilmiş bir taşeronluktan daha ileri bir şey değildir.

- Avrupa Parlamentosu Kararları çerçevesinde Türkiye'nin “Ermenilere karşı yapılan soykırımı tanıması ve Ermeni halkıyla uzlaşma sürecini teşvik etmesi" şeklindeki talimat önemlidir. Fransa'nın, İsviçre'nin “Türkler Ermenilere Soykırım Yapmamıştır” demeyi cezalandıran bir kanun hükmüne dönüştürmesini birleştirirsek, cesaretin nerelere uzanacağını 
kestirmek güç olmayacaktır.

- Yine, Türkiye'den istenen Ege Denizi'ndeki tavizlerin, Türkiye'yi karalara kapanma noktasına götürülmesi; Yunanistan'ın Ege'deki karasularını 12 mile çıkarması isteği; Rum Yönetiminin "Kıbrıs Cumhuriyeti" olarak tanınması; Adadaki Türk askerlerinin çekilmesi gibi ölçüsüz istekler kabul edilirse, ya Orta Asya’ya kadar çekilmek gerekecektir ya da demirlenmiş Ankara eyaleti olarak Avrupa'yla bütünleşmiş bir uydu cumhuriyet doğacaktır. Nitekim, Türkiye'nin AB'ye giriş sürecinde KKTC'nin ortadan kaldırılmasını esas alan Annan Planı'nın da ötesine geçen bir uygulamayla Güney Kıbrıs Rum Cumhuriyeti’nin Türkiye tarafindan tanınması ön şart olarak ileri sürülmüştür.

- AP Kararlarının Avrasya bağlamlı tavsiye ve dayatmaları incelendiğinde şu hususlar oldukça önemlidir. Bunların en başında petrol ve su rezervleri gelmektedir. Raporda, petrol ve su kaynaklarıyla ilgili bölgesel altyapının yönetimi için Avrupa Birliği politikalarının getirilmesinin gerekçeleri Türkiye'ye dikte edilmektedir. Türkiye açısından sınır ötesi sorunlar, enerji kaynaklarının Avrupa'ya taşınması, çevre ve tüketicilerin korunmasının Avrupa vatandaşları üzerinde olumlu ve kalıcı etkiler yapacağı öne sürülmektedir. Hatta "Türkiye'den Atatürk Barajı'nın yapılması nedeniyle su akışının (Dicle ve Fırat üzerinden) azaldığına" dikkat çekilerek akarsuların adil ve eşit dağılımını sağlayacak, komşuların yer alacağı, AB gözetimli, "Ombudsman ofisinin" kontrolünde uluslar arası konsorsiyumların kurulacağına yönelik imâlarla âdete aba altından sopa gösterilmektedir. Nihayet AB, AP kararıyla (mad: 61) “TBMM ile Türk Hükümeti'ne iletilmesi yönünde talimatlar vermektedir".

Özetle, bu ideolojik yaklaşımlar ve yakın tarihimizde gözlediğimiz olaylar, ABD uygulamalıyla ve $\mathrm{AB}$ kararlarıyla birlikte değerlendirildiğinde, kendi aklımızla ulaştığımız bulgular, kendimize özgün bir yol ve yöntem geliştirmemizi zorunlu kılmaktadır. Türk Milliyetçileri, bugünkü gücünü, tarih şuurundan kopmadan Türkiye Cumhuriyeti'ni kuran iradeden almaktadır. Çünkü Türk milliyetçiliği, tarihin yükünü omuzlara alıp, içine İslam'ın özünü koyup, onu geleceğe taşıyan iradenin adıdır. İnsan hakkını ve onurunu kutsayan bu irade, Türklerin tarihî misyonudur. Türk insanı, bağımsız devlet, haysiyetli millet olma davasını tüm mazlum milletlere taşımayı başarmış ve değişen dünya şartlarını her zaman doğru okuma ferasetine erişmiştir. Özellikle de tarihin her devrinde onur ve istiklal mücadelesinin örneğini sergilemiş, mazlum milletler ve topluluklara önderlik yapmıştır. Ancak, günümüzde tarihî misyonla, pragmatik düzlemde oluşan vizyon uyuşmazlığına da dikkat çekmekte yar vardır.

İçinde bulunduğumuz şartları Avrasya bağlamıyla ve son AB ilişkilerimizle doğru okuduğumuzda $\mathrm{ABD}$ ve $\mathrm{AB}$ tarafından sürüklenmek istediğimiz etnisite çatışmalı ve din paradigmalı stratejiye karşı temel ödevimiz, (Papa XVI. Benedict, in seçimini firsat bilen ABD, Almanya'nın Avrasya üzerinde bağımsız politika oluşturma etkisini kırmak ve haçlı ittifakını yeniden kökleştirmek için Italya ve Fransa'nın muhalefetine rağmen, stratejik bir politikayla Alman kökenli Kardinali seçtirmiş ve kontrolü eline almıştır. Papa XVI. Benedict, göreve başlama törenindeki ilk konuşmasında Yahudilerin, Hıristiyanlarla ortak bir mirası paylaştı̆̆ını söylemiştir) alternatif bir politika geliştirmektir.

\section{Sonuç}

Hiç bir sosyal dava ve emperyal amaç yoktur ki, içinde "insan, tabiat ve iktisat" olmasın. Türk tarih sarkacının yeniden yükseltilebilmesi ve adaletin yeniden tesis edilebilmesi için tüketim açısından "genel refah" üretim açısında ulusal regülasyon modeli olarak düşündüğümüz modelin evrensel belirleyicilerini ortaya koyup bu modelin temel ilkeleri geliştirilmeli ve kendimizi ifade etmenin özgün yolu bulunmalıdır.

Milli varlığımızı ve mukaddesatımızı esas alan fikirler etrafında birleşerek, istiklalimizi koruma ve kollama stratejileriyle donatılmış, Türk irfanıyla beslenen aydınlanmacı bilimsel düşünce sistemini içselleştirmek zarurettir. Türk"ün tarihî misyonunu yeniden diriltmek gibi kutsal bir ödeve olan inancımızı ve kutlu çağrımızı, bu konferans münasebetiyle dünya Türklüğüne ulaştırmak ahlâkî ve insanî bir sorumluluktur. 
Avrasya'ya dayatılan emperyalist stratejilerin ve oluşturulmak istenen tek kutuplu sömürü düzeninin, bölge insanı üzerindeki tahribatını engellemek ve tarihe karşı sorumluluğumuzu yerine getirebilmek için stratejik ve etkin bir bölge teşkilatlanmasına acil ihtiyaç vardır. Bu stratejinin, bu coğrafyada yaşayan Türkî devletlerin benimseyeceği ortak politikaya dönüştürülmesi gerekir. Akraba devletlerden hangisi, bu yeni oluşuma ne kadar odaklanırsa, Avrasya bağlamlı, ulus eksenli, bağımsız akraba devletler topluluğunun kurulmasında o kadar önder olacaktır.

Stratejik ve etkin bir Avrasya Birliği oluşturmanın üç temel ilkesi şudur (“Üç-İ Yaklaşımı”): Birincisi, 'ilim', ikincisi, 'irfan', üçüncüsü ise 'inanç' tır. İlimden kastedilen şey, evrensel değerlerde pay sahibi olma iddiasında olan "insan tipi"nin önce kendini keşfetmeye yönelmesidir. Ancak bu keşif aracılığıyla kalıcı bir adalet ve karşı ideolojilere üstün, sürdürülebilir rekabet kurulabilir. Bu yolla tabiattaki imkânlar sorgulanıp, tabiatla bütünleşme başarılabilir. İkinci ilke "irfan”, esasta bir araç değişken olup "bilgelik" olarak tanımlanabilir. $\mathrm{Bu}$ bilgelik, soyut planda toplum olarak hangi kök değerlere ve tarih şuuruna sahip olduğumuzun bilinmesi; somut planda ise teknolojik ilerleme ve teknolojik değişmeyi gerçekleştirecek metot ve üretim anlayışının kavranmasıdır. Hatta, kültürel anlamda yaşatılması gereken 'mit'in/kızıl elma'nın' hür ve demokratik bir irade ile geleceğe taşınmasıdır. Temel ilkelerden üçüncüsü olan inanç (islamî öz) ve kendine olan güvendir. Tarihî tecrübelerden bilinmektedir ki, iç dünyamızın itici gücüdür ve yeniden harekete geçirilmelidir. Türkiye açısından yakın tarihimizdeki harekete geçişi açıklayabilecek en güzel örnek, Kuvay-1 Milliye Ruhu'dur. Nitekim, büyük Atatürk ve Kurmay Kadrolar'ının idealiyle örtüşen bu ruh, gelecek yüz yılları doğru okuyan entellektüel insan tipine verilebilecek en güzel mesajdır. Bu mesaj, aynı zamanda Mustafa Kemal'in "fikri hür, vicdanı hür, irfanı hür nesiller yetiştirme" idealini hayata geçiren bir vizyon olarak tanımlanabilir.

$\mathrm{Bu}$ vizyonun, doğru algılanması için Konfüçyüs "üstün insan konuşmadan önce eyleme geçer, sonra eylemine göre konuşur" sözünü hatırlanmalıdır. Türk âlemine çağdaş uygarlığ 1 yakalama ve onu aşma hedefini gösteren Büyük Atatürk'ü; doğru okuyup evrensel kuralları içselleştirememek, sadece, dünyadan daha az pay almak(yoksullaşmak) değil; aynı zamanda, tarih şuurunu kaybeden iradî köleler topluluğu halinde yaşamaya razı olmaktır. Şayet razı değilsek siyasete erdemi, üretime verimliliği, girişimciliğe bahadırca yaratıcılığı ve insanca bölüşümü hâkim kılmak mecburiyettir. Kısacası, Türkî Cumhuriyetler'de yaşayan nesiller olarak bizler, İsmail Gaspıralı'nın özdeyişiyle "dilde, fikirde ve işde işbirliği” ilkesini, her bir akraba devletin kendi bağımsızlık çatısı altında istiklâl mücadelesini çağın değerleriyle uyumlu olarak yükseltme ödevini, hiç mi hiç aklımızdan çıkartmamalıyız.

\section{Kaynakça}

- Bauman, 1999. Küreselleşme: Toplumsal Sonuçları. Çeviren: Abdullah, YILMAZ, Ayrıntı Yayınları, İstanbul

- Bukharin, 2009. Emperyalizm ve Dünya Ekonomisi. Çeviren: Uğur Selçuk AKALIN, Bağlam Yayıncılık, İstanbul.

- Giddens, 1998. Modernliğin Sonuçları, Çeviren: Ersin KUŞDİL, Ayrıntı Yayınları, İstanbul.

- Hopkins, 1999. Geçiş Çağı, Çeviren: Nuri ERSOY, vd., Avesta Yayınları.

- Kazgan, 2000. İktisadi Düşünce, Politik İktisadın Evrimi, Remzi Kitabevi, İstanbul.

- Kök, 2000. İktisadi Düşünce: Kavramların Analitik Kavramı, Anadolu Matbaacılık, İzmir.

- Mittelman, 2005. Ideologies and the Globalization Agenda, Rethinking Globalizm, Editor:Manfred STEGER), Rowman\&littlefield, Maryland-ABD.

- Mooney, 2007. Globalization: The Key Concept, Routledge, İngiltere. 
- Ritzer, 2007. Outsoucing:Globalization and Beyond: The Blackwell Companion To Globalization (Editor: George RITZER) Blackwell Publishing, ABD.

- Robertson, 1995. Globalization: Time-Space and Homogene-Heterogeneity, Global Modernities (Editorler: Mike FEATHERSTONE, Scott LASH ve Roland ROBERTSON) Sage publication, Londra.

- Robinson, 2005. Gramsci and Globalzation :From Nation-State to Transnational Hegemony, Critical Review of International Social and Political Philosophy Vol.8 No:4.

- Rodrik, 2007. One Economics, Many recipes: Globalization, Institutions and Economic Growth, Princeton University Press, New-Jersey.

- Sklair, 1999. Competing Conceptions of Globalization, Journal of World-Systems Research, Volume 2, Summer.

- Steger, 2004. Globalism, The New Market Ideology, Rowman \& Littlefield, publisher, Inc Maryland-AB.

- Wallerstein, 1974. The Modern World-System: Capitalist Agriculture and Origins of The European World-Economy in The Sixteenth Century, Academic Press, New York.

- Waters, 1995. Globalization, Routledge, New-York.

- Yalçınkaya, 2010. "Küreselleşme Sürecinin Ekonomi Politikaları Üzerine Etkilerinin Analizi: Türkiye Örneğì, DEU, SBE. 


\title{
Küresel Dünyada Orta Asya Türk Cumhuriyetlerinin Konumu
}

\author{
Esra Karapınar, Zirve University
}

\begin{abstract}
The Place of Central Asian Turkic Republics in the Global World

Globalization process which started at the end of nineteenth century and goes on at the present shows its impacts more in some countries or less in some other countries but this is a process that closes up countries, blots out authorities' immunities, makes them become transparent, and strengthens socio-cultural, political and especially economic relations. After the terms of being introverted and self-sufficiency between First and Second World Wars, struggles to liberalized world trade have been accelerated since 1960, and good and service flows between countries grew both as a volume and value. As a result of liberalization and deregulation politics which appears since 1980, the capital could move easier on the world. So, how has this process felt its effect on the Central Asian Turkic Republics includes Kazakhstan, Turkmenistan, Kyrgyzstan and Uzbekistan that arised in 1991 after dissociation in the Soviet Union because of clearing and reconstruction policy applied and after facility of establishing its own, independent states by earning their national identities to Turkish elements who lived under the sovereignty of Russians for years is given? The aim of study here is to analyse the effects of that globalization wave in the Turkic Republics which spread out all over the world. For this purpose, first of all changes in the Soviet Union 's policy will be considered and reflections of it on the economical life are to be investigated, and then applications and what the course of actions about integration with the World determined by mentioned republics after dissociation are to be discussed.
\end{abstract}

JEL Codes: P10, P20

\section{Küreselleşme ve Sovyet Sosyalist Cumhuriyetler Birliğgi' nin Dağılması}

Globalleşme, globalizasyon ya da uluslararasılaşma olarak ifade edilen küreselleşme, ülkeler arasındaki ekonomik ve siyasal sınırların etkisini kaybettiği, mal-hizmet ve insan trafiğinin daha hareketli hale geldiği, herkesin her yerde olan biten her şeyden anında haberdar olabildiği bir dünyayı betimlemektedir. Küreselleşme süreci, Sovyetler Birliği' nin anlayışının aksine, sonuçlarda bir eşitliği değil başlangıç koşullarında bir eşitliği, fırsat eşitliğini mümkün kılmaktadır. Bu durum ise geriden gelenlerin hızlı büyümesi, aradaki mesafeyi kapatması, yaratıcılık ve yenilikçiliğin önünün açılmasına olanak vermektedir. Küreselleşen dünyadaki devlet anlayışı da farklıdır. Böyle bir dünyada devletten beklenen çeşitliliklere ve bireysel özgürlüklere saygılı, şeffaf, hesap verebilir, gücü ve yetkileri sınırlı, temel amacı vatandaşın refah düzeyini yükseltmek olan, hizmetkar devlettir. (Acar, 2009) Görüldüğü gibi küreselleşme sürecinin siyasi, ekonomik, sosyo-kültürel boyutları olmakla birlikte, tüm bunlar içersinde en büyük öneme sahip olan şüphesiz küreselleşmenin ekonomik boyutudur. Ekonomik açıdan küreselleşme ticaret, finansal akımlar, teknoloji değişimi ile bilginin ve işgücünün hareketliliği yoluyla da dünya ekonomilerinin birbiriyle bütünleşmesi olarak tanımlanabilir (Aktan ve Şen, 1999).

Sovyet Sosyalist Cumhuriyetler Birliği’ nin dağılmasının altında yatan en önemli neden şüphesiz, birliğin çağın gereklerine uygun olarak dünya ile bütünleşmede isteksiz ve geç kalmış olmasıdır. Sovyet ekonomisi, 1930'larda başlayan ağır sanayileşme politikaları ile \%14'lük büyüme hızına ulaşmış ve kısa zamanda bir sanayi devi haline gelmiştir. Ancak 1970'li yıllardan itibaren gerekli modernizasyonun yapılamamış, teknoloji ve kalitede geri planda kalmış, arz-talep dengeleri kurulamamış, tarımda yanlış politikalar uygulanmış, merkezi otorite zayıflamıştır. Daha sonra 1980 'lerde telaffuz edilmeye başlayan ve tüm dünyaya dalga 
dalga yayılan küreselleşme olgusuyla birlikte dünya siyasi ve ekonomik dengelerin yeniden șekillenmesi sonucu sosyalist anlayıșın iflas etmesi ve Rusya etrafında kümelenmiş olan merkezi planlama ekonomilerinin piyasa ekonomilerine dönüşme sürecine girmesiyle yeni bir dönem başlamıștır. Her ne kadar 1985 yılında Gorbaçov' un başkanlığıyla birlikte, glasnost (açıklık) ve perestroika (yeniden yapılanma) politikalarıyla, dıșta batı ile daha uyumlu, ülke içinde de komünist rejimin ișleyișini bozmayacak şekilde sınırlı ölçüde reformlarla birliği daha liberal ve gevşek bağlarla sürdürme çabaları devam etse de, netice itibariyle 1990'l1 yıllara gelindiğinde SSCB' nin fikirlere, insanlara ve mallara karșı yükselttiği duvarlar kendileriyle birlikte yıkılmıștır. Bu yıkıntının ardından yetmiș beș yılını komünist rejimin baskısı altında geçirdikten sonra 1990' li yılların başında, Baltık Cumhuriyetleri ve Doğu Avrupa ülkeleri gibi Orta Asya Türk Cumhuriyetleri (OATC-Kazakistan, Kırgızistan, Türkmenistan, Özbekistan) de bağımsızlıklarını kazanmışlardır. Diğer ülkelere nazaran çok daha uzun yıllar (Örneğin; Polonya 17 y1l, Macaristan 10 y1l, Slovakya 10 yıl, Estonya 27, Letonya 31 y1l...) komünist rejim altında kalan Orta Asya Türk Cumhuriyetleri için bu süreç nispeten daha sancılı olsa da, daha özgür, daha şeffaf, daha demokratik ve daha adil bir dünyanın kapılarını aralayan bir geçiş süreci olmuştur.

\section{Geçiş Sürecindeki Orta Asya Türk Cumhuriyetleri}

$\mathrm{Bu}$ geçiş süreci, aynı zamanda merkezi planlı ekonomik modelden serbest piyasa ekonomisine doğru bir geçiştir. Serbest piyasa ekonomisine geçiş kavramı, temel olarak, ekonomik faaliyetlerin fiyatlar ve piyasa işlemlerinin serbestleştirilmesi, kaynakların en etkin şekilde kullanılacak biçimde yeniden dağıtılması, makro ekonomik istikrar için piyasa ağırlıklı enstrümanların geliştirilmesi, özelleştirmeler vasıtasıyla, ekonomik verimlilik ve etkin bir işletme yönetiminin sağlanması, sıkı bütçe disiplini uygulanarak ekonomik verimliliğin sağlanması, mülkiyet hakları, hukukun üstünlüğ̈̈ ve şeffaf bir pazara giriş düzenlemesi içeren kurumsal ve hukuki bir çerçevenin oluşturulması unsurlarını içermektedir. Bu ekonomiler 1990'lı yıllardan bu yana devletin ekonomik sistemini değiştirmek amacı ile birçok reform uygulamaya çalışmışlardır. Fakat OATC' de geçiş aşamasında yasal çerçevenin geç oluşması piyasaların gelişmesini engellemiştir. Bu ülkeler, piyasa ekonomisi tecrübesi olmadığı için bir takım sorunlarla karşı karșıya kalabilmişlerdir. Bu noktada IMF ve Dünya Bankası tarafından destek sağlansa da istenilen düzeyde olmamıștır.

Orta Asya ülkeleri bağımsızlığını kazanan diğer pek çok ülke gibi başlangıçta büyük bir makroekonomik istikrarsızlıkla karşılaşmışlardır. Bu ülkeler, piyasa ekonomisine geçişte başlangıç şartlarında diğer ekonomilere kıyasla olumsuz sosyal ve ekonomik şartlara sahiptir. Türk cumhuriyetleri ortalama ömür, sağlık, çocuk ölüm oranları ve konut imkânları açısından Sovyet standartlarının altında bulunmaktadır. Ayrıca bu cumhuriyetlerde tarımın ekonomideki payı daha yüksek iken şehirleşme oranı düşük bir seviyede kalmıştır. Uzun yıllar tamamen dışa kapalı bir sistem içerisinde varlıklarını sürdüren OATC' nin, piyasa ekonomisine geçişte hayli zorlandıkları görülmektedir. Var olan teknolojinin eskimesi ve bu teknolojinin yenilenememesi, beşeri sermaye kayıpları, kitlesel göçler, bunların beraberinde bankacılık ve finansal sorunlar, döviz problemlerini gündeme getirmiş ve ekonomik bir çöküntü yaşanmıştır. Sovyet Rusya'nın dağılmasıyla birlikte ekonomik rekabetin sonucu olarak birçok sorun gündeme gelmiş ve bu sorunların üstesinden gelebilmek için reform çalışmaları başlatılmıştır. $\mathrm{Bu}$ sorunların en önemlisi ise piyasa ekonomisinin yerleşmesinde yaşanan güçlüklerdir. Avusturya Ekolü iktisatçılarından Peter Boetkelye ekonomik reformların başarılı olabilmesi için yapılması gerekenleri şöyle açıklamaktadır: "Söylenmesi kolay uygulaması zor olsa da, eski sosyalist planlı ekonomilerin yapması gerekenler açık ve nettir. Ĕğer ortada bir siyasal açıdan tekelci strüktür (political monopoly) varsa bunu demokratik rekabetçi bir düzenle (democratic competition) iktisadi tekel (economic monopoly) varsa bunu rekabetçi firma düzeni (competitive firms) ile eğer ortada kitliklar (shortages) varsa bunu serbest fiyat mekanizması (price mechanism) düzeni ile eğer enflasyon varsa bunu sıkı para politikası ile mali dengesizlik varsa bunu mali çalışmayı teşvik edici politikalarla değiştirmek 
gerekmektedir." Her ne kadar yapılması gereken bu olsa da, bunu uygulamanın özellikle yetmiş beş yılını komünist rejimin baskısı altında geçirmiş, piyasa ekonomisi tecrübesi olmayan OATC' de çok daha zor olduğu muhakkaktır. Bu zorluğu söz konusu ülkelerin piyasa ekonomisine uyumuna baktığımızda da görebiliriz. Kazakistan ve Kırgızistan'da uyumun daha ileri düzeyde olduğu görülürken Türkmenistan ve Özbekistan'da biraz daha karma bir sistem uygulandığı görülmektedir. Ancak Kırgızistan hala ilk ekonomik şokun uzun süren etkisi altındadırlar. Yüksek borçların ağır yükü düşük kişi başına gelirleri ile gelişen ülkelerin en fakir ülkeleri arasında yer almaktadırlar. Piyasa kurumları ve kapasite yapısı bu ülkede yavaş ilerlemiştir. Uygulamada yasal çerçevenin oluşturulmasının piyasa ekonomisinin gelişimi için ön koşul olduğu anlaşılmıştır. Özellikle OATC geçiş aşamasında yasal çerçevenin geç oluşması piyasaların gelişmesini engellemiş̧ir. Diğer taraftan bu yasal çerçeveyi oluşturmada ileri ülkelerde ise (Bazı Batlık Cumhuriyetleri ve Doğu Avrupa ülkeleri) ekonomik performansları daha ileri seviyede olmuştur.

OATC geçiş dönemi başlangıç yıllarında teknik ve finansal yardım konusunda geri planda kalması, dolayısıyla reformların istenilen seviyeye ulaşamaması ve kurumsal çerçevenin oluşturulamaması neticesi serbest piyasa ekonomisine geçmede ve ekonomik büyümede en önemli dinamiklerinden biri olan yabancı sermaye girişinde de aksaklıklar oluşturmuştur. Merkezi planlı ekonomilerin ekonomik yönden kalkınması, dünya ile entegrasyon sürecine girmesi gerekmektedir. Entegrasyonda en kestirme yollardan biride yabancı sermaye yatırımlarını ülkeye çekebilmektir. Gelişen ve küreselleşen dünya ekonomisi içinde, ülkelerin ticaretlerinin uluslararası bir boyuta taşınması kaçınılmaz hale gelmiştir.Yabancı yatırımlar öncelikle ülkeye önemli bir sermaye akışı sağlamaktadır. Yabancı yatırımlar ülkenin yatırım ve tasarruf açığının giderilmesi bakımından önemli bir rol oynamaktadır. Yabancı yatırımlar sermaye sıkıntısı çeken ülkelerde sermaye açı̆̆ının kapatılmasında, ülke üretiminin artırılmasında, istihdam yaratarak işsizliğin azaltılmasında önemli rol oynamaktadır. Ayrıca üretim maliyetlerini düşürmek; ucuz işgücü, taşıma giderlerinden tasarruf sağlamak, düşük vergi avantajlarından faydalanmak, ucuz hammadde kullanılması gibi avantajları da vardır. Ancak geçiş süreci yaşayan OATC'de hukuk sistemindeki aksaklıklar yabancı yatırımcılara her koşulda güvence ortamının sağlanamaması, siyasi istikrarsızlık ve vergi reformun istenilen düzeylerde gerçekleşmemesi neticesi zaman zaman baş gösteren yolsuzluklar yatırımları olumsuz etkilemektedir. Dolaysıyla bu ülkelerde doğrudan sermaye girişlerinin arzu edilen seviyelerde olmaması nedeniyle yatırım avantajlarından da yeterince yararlanamamaktadır. Yabancı yatırımlar ülkeye ileri teknoloji ve know-how transferini kolaylaştırmaktadır. Doğrudan yabancı sermaye ülke ekonomisi için çok önemlidir. Üretim teknolojisinin ögrenilmesinde önemli rol oynamaktadır. Ayrıca istihdam yaratarak kalifiye eleman da yetiştirmektedir. Sovyetler Birliği döneminde üretimin merkezden ve kitle üretimi yapılması KOBI'lerin gelişmesini engellemiştir. Ayrıca üretim yapan sektörlerin ülkeler bazında birbirine bağlı olması Sovyetler Birliğinin dağılmasından sonra bu ülkelerde üretimin durmasına yol açmıştır. Birçok fabrika çalışamaz duruma gelmiş, birçoğu da kapanmak zorunda kalmıştır. Daha fazla yabancı sermayenin çekilebilmesi için sosyal ve siyasal istikrarın sağlanması, enflasyonun düşürülmesi, kayıt dışı ekonominin kayıta alınması, adalet ve hukuk sisteminde gerekli düzenlemelerin yapılması ve kamu kesiminde yeniden yapılanma gereklidir.

\section{3 Ülke Ekonomilerinin Genel Görünümü}

Yüzölçümü olarak Türkiye'nin yaklaşık 4 katı büyüklügünde bir ülke olmasına rağmen nüfusu yalnızca 15 milyon olan Kazakistan, Bağımsız Devletler Topluluğu (BDT) ülkeleri arasında son yıllarda en yüksek ekonomik performansı sergileyen ülke olduğu kadar Orta Asya'nın da en serbest ekonomisi olarak gösterilmektedir. 1991 yılı SSCB dağılmasından sonraki Kazakistan'la günümüzün çağdaş Kazakistan'ı arasında büyük farklılıklar vardır. Bağımsız Kazakistan'ın gelişimi sırasında, on yılı aşkın süreçte bölgedeki en hacimli yabancı doğrudan yatırımlar çekilmiş, çok kısa zamanda kamusal alanda \% 85 özelleştirme gerçekleştirilmiştir. OATC ülkelerinden Kazakistan yabancı sermaye çekmede nispeten daha 
başarılı olmuştur. Kazakistan, keşfedilmiş rezervleri bakımından dünyada 13'üncü sıradadır. En son değerlendirmelere göre, Kazakistan'ın toplam petrol ve gaz rezerv miktarı 23 milyar ton olup, bunun 13 milyar tonu Hazar'da bulunmaktadır. Büyük petrol ve gaz rezervlerine sahip olmakla beraber ülkenin siyasi istikrarı Kazakistan'ı, kişi başına düşen yabancı yatırım bakımından Bağımsız Devletler Topluluğu (BDT) ülkeleri (Azerbaycan, Beyaz Rusya, Ermenistan, Gürcistan, Kazakistan, Kırgızistan, Moldova, Özbekistan, Tacikistan, Türkmenistan, Rusya Federasyonu ve Ukrayna) arasında lider konuma taşımıștır. Petrol ve doğal gaz sektöründeki yatırım ortamı, birtakım elverişli etmenlerle karakterize edilebilir. Birincisi, yabancı yatırım, petrol, lisans alma ve özelleștirme ile ilgili kanunlar, yabancı yatırımcıların doğal kaynak kullanma alanında rahat hareket edebilmeleri için gerekli hukuk esaslarını oluşturmuştur. Ikincisi, vergi ve fiyat sistemleri ve petrol sektöründeki resmi idari yapı basitleştirilmiştir. Üçüncüsü, Kazakistan'ın kıta ortasındaki coğrafik konumu, Avrupa'nın büyük ihraç piyasalarına ulaşım sağlamaktadır. Son yıllarda Kazakistan, daha faal ve başarılı bir şekilde dünya ekonomisine entegre olmaya başlamıştır. Başta petrol ve gaz sektörü olmak üzere yabancı yatırım hacminde artıs görülmektedir. 1994'te Özbekistan ve Kazakistan, bir anlaşma imzalayarak aralarında serbest ticaret alanı kurmuştur. Daha sonra Kırgızistan da bu anlaşmaya taraf olmuştur. Aynı sene Kazakistan, Avrupa Birliği ile işbirliği ve ekonomik ilişkilerin kurulması konusunda anlaşma imzalamıștır. 1996 senesinde Kazakistan, Belarus, Kırgızistan ve Rusya ile daha yakın ekonomik entegrasyon amacıyla Ortak Pazar ve Gümrük Birliği Anlaşmasını imzalamıștır. Rusya Federasyonu, BDT ülkeleri içerisinde Kazakistan'ın en önemli ticari partneri durumundadır. Diğer önemli partnerleri ise Cin, Almanya ve Ukrayna'dır. 1996 yılına kadar Kazakistan toplam dış ticaretinin \%60'1 BDT ülkeleri ile yapılırken, 1997'den itibaren bu ülkenin toplam dış ticaret içindeki ağırlıkları giderek azalmış ve 2000 yılına gelindiğinde, toplam dış ticaretin \%64'ü BDT dışı ülkelerle gerçekleştirilir hale gelmiştir.

Bağımsızlık sonrası dönemde bölgede en çok dikkat çeken ülkelerden biri de hiç kuşkusuz Kırgızistan olmuştur. Orta Asya'nın en küçük ülkesi ve de petrol ve nükleer güç gibi stratejik değerlere sahip olmayan bir ülke olmasına rağmen, ilk milli parayı kullanan, Dünya Ticaret Örgütü'ne ilk üye olan, ekonomik yatırımlara ağırlık vererek, kendisini güvenlik sorunlarından izole etmeye çalışan ve Orta Asya'nın Çin topraklarına açılan önemli kapılarından biri olan, bu küçük Orta Asya ülkesini uluslararası sistemde bölgede çıkar hesapları yapan büyük güçlerin ilgi odağı haline getirmiştir. Büyük enerji ve diğer doğal kaynaklara sahip olan ve bunları piyasa ekonomisine geçiş sürecinde ortaya çıkan olumsuz sonuçları hafifletmek için belli ölçüde kullanan Kazakistan, Özbekistan ve Türkmenistan'dan farklı olarak Kırgızistan Cumhuriyeti bu tür kaynaklara sahip değildir. $\mathrm{Bu}$ olgu, piyasa ekonomisine geçiş yolunun seçiminde ve gerçekleş̧irirken reformların devamlılı̆̆ında siyasi iktidar için belirleyici olmuştur. Bu şartlar Kırgızistan'ı dışa açık ekonomi politikasını tercih etmeye zorlamakta ve ülkenin Gümrük Birliği'ne ve Dünya Ticaret Örgütü'ne girmesinde belirleyici etken olmaktadır. Kırgızistan'ın ihracatının ve ithalatının ülkelere göre dağılımında ilk sıraları BDT ülkelerinin aldığ 1 görülse de, Kırgızistan bağımsızlık sonrası süreçte izlediği dışa açık iktisat politikaları sonucu çok sayıda ülkeyle dış ticaret ilişkisi içine girmiştir. Bağımsızlığın daha üçüncü yılı olan 1994 yılında dış ticaret ilişkisi kurulan ülke sayısı 50' yi aşmış ve günümüzde Kırgızistan 80'den fazla ülke ile dış ticaret ilişkisi içinde bulunmaktadır. Fakat coğrafi konumu itibariyla dezavantajlı bir duruma sahip olan Kırgızistan' in, bu olumsuzluğu giderip kara ticaret hatlarını geliştirdiği zaman bu ilişkilerin daha da büyüyeceği kesindir. Tüm bunlara rağmen Kırgızistan' in henüz istikrarlı ve uzun vadeli bir toparlanmayı gerçekleştirebilecek seviyede ekonomisinin olgunlaşmadığı görülmektedir. Önünde aşması gereken ciddi zorluklar bulunmaktadır. Tarım ve hayvancılığa dayalı bir ekonomik yapıya sahip olan Kırgızistan'da piyasa ekonomisine geçiş sürecinde yaşanan sıkıntılar sonucu üretimin düşmesi beraberinde işsizlik ve yoksulluk getirmiştir. Yoksulluk da ülkenin sosyal barışını tehdit etmekte ve ülkeye yabancı sermaye girişini engellemektedir. Bu da ekonomik kalkınma için dış tasarrufa ihtiyaç duyulan ülkede yoksulluk kısır döngüsüne yol açmaktadır. Ülkede bağımsızlık sonrası 
dönemde, gerek yurt içi tasarrufların yetersizliği ve gerekse dönüşümün tamamlanabilmesi için gerekli olan reformların gerçekleştirilebilmesi açısından ortaya çıkan finansman ihtiyacı zorunlu olarak dış borçlanmayı gerekli kılmıştır. Ancak, dış borçlanmada yıllar itibarıyla meydana gelen artış, yakın gelecekte Kırgızistan'ın bir borç krizi içine düşmesine ve mali istikrarın sürdürülebilirliğini tehlikeye sokacak önemli bir sorun haline gelmiştir.

Özbekistan, Orta Asya'daki coğrafi konumu, ekonomik yapısı, tarım potansiyeli ile ucuz işgücü, elektrik, doğalgaz ve petrol gibi avantajlarıyla yatırımlara çok elverişli bir ülke özelliği taşımaktadır. Özbekistan zengin yeraltı ve yerüstü kaynaklara sahiptir. 100'e yakın mineral, petrol ve enerji kaynakları mevcuttur. Fakat, Eylül 1991'de bağımsızlığın ilanından sonra Özbekistan da diğer BDT ülkelerini de etkileyen ekonomik güçlerin benzerleri ile karşı karşıya kalmıştır. Geçiş sürecinin ilk yıllarında karşılaşılan ve bir kısmı hala devam etmekte olan ekonomik zorlukların arasında, Sovyet sübvansiyonlarının ortadan kalkması, cumhuriyetler arası ticarette çok önemli kayıların meydana gelmesi, hiperenflasyon, azalan üretim, pamuk üretimine bağımlı bir ekonomik yapı, hızlı büyüyen nüfusa yeni iş alanları oluşturma zorunluluğu ve köklü reformlara ihtiyaç duyan bir bankacılık ve finans kesimi gelmektedir. lyi bir potansiyeli olmasına rağmen geçmişte Sovyetler Birliği'nin en fakir bölgelerinden birisi olmuştur. 1992'den sonra gerçek gelir düşmüştür. Özbekistan'da yaşam standartları düşmekte ve fakirlik artmaktadır. Özbekistan BDT ülkeleri içinde yapısını en az değiştiren, reformların en yavaş ilerlediği ülke konumundadır. Özbekistan'ın ekonomi programının temelinde devletin müdahalesi ve reformların aşama aşama yapılması vardır. Özbekistan'ın kullandığı araçlar daha çok sosyal sistemi hatırlatmaktadır. Bir an önce bütün ekonomik yapıyı değiştirmeyi, hızlı serbestleşmeyi, özelleştirmeyi ve makro ekonomik istikrara ulaşmak açısından sıkı para ve maliye politikalarını öneren Uluslar arası Para Fonu (IMF), Özbekistan'ın izlediği ekonomi politikasından memnun değildir. Ancak Özbekistan'ın ekonomi politikasının başlıca amacı sosyalist tipi ekonomiden serbest piyasa ekonomisine dönüşüm değil, tarım ağırlıklı bir ekonomiden sanayileşmiş ve gelişmiş olan bir ülkeye olan dönüşümdür. Bu yüzden Özbekistan açısından serbestleşme olsun, özelleştirme olsun, piyasa kurumlarının oluşturulması veya makro ekonomik istikrar ikinci plandadır ve ancak sanayileşmeye ve kendi kendine yeterliliğe ulaşmak için elverişli oldukları derecede uygundur. Serbest piyasa ekonomisine hızlı geçiş modelini eleştiren Özbekistan yönetimi bir ülkenin geçiş döneminin başlangıcında sahip olduğu başlangıç şartlarının önemli olduğunu vurgulamıştır. Buna göre Özbekistan şartlarında hızlı geçiş değil, emin ve sağlam adımlarla yavaş geçiş daha uygundur. Bu geçişte mutlaka devletin kontrolünde ve devletin eliyle yapılmalıdır. Kademeli geçiş yönteminin tercih edilmesi geçişin doğurduğu ekonomik ve sosyal sorunları hafifletirken, geçiş döneminin hızlı bir geçiş stratejisi izleyen ülkelere kıyasla daha uzun sürmesine yol açmışıır.

Türkmenistan 1991 yılında bağımsızlı̆gını kazandıktan sonra diğer eski SSCB ülkelerinden farklı bir geçiş dönemi yaşamıştır. "Türkmen yönetimi çoğulcu demokratik rejim ve serbest piyasaya geçiş yönünde oldukça tedbirli, toplum alışkanlıklarını sarsmayan, bağımsızlıklarını yeni kazanmış diğer cumhuriyetlere oranla daha yavaş tempoyla gelişen bir reform süreci belirlemiş ve batıll ülkelerin eleştirilerine rağmen bu alandaki tutumunu değiştirmemiştir. Diğer taraftan ise bürokrasinin fazlalığı, nihai kararların devlet başkanı tarafından alınması ve diğer sebepler, yabancı yatırımlar ve ülke ekonomisi için ciddi birer engel oluşturmaktadır. Yabancı sermaye, bankacılık mülkiyet haklarının korunmasına ilişkin yasalar 1992 yılında çıkarılmıştır. Öte yandan vergi, işgücü, sağlık ve güvenliğe ilişkin yasalar yeterli içeriğe sahip değildir.” Türkmenistan, diğer eski Sovyet Cumhuriyetlerine göre SSCB'nin dağılmasından en az etkilenen ülke olmuştur. 1992 ve 1993 yıllarında dünya fiyatlarıyla doğal gaz ihraç edilmesine başlanmasıyla, ülke ekonomisinde ve dış ticaret dengesinde önemli iyileşmeler gözlenmiştir. Gıda üretiminde kendi kendine yeterlilik, yapısal ekonomik değişimin tamamlanması ve yabancı sermayenin ülkeye çekilmesi amaçlarına yönelik piyasa ilişkilerinin ve serbest girişimciliğin geliştirilmesi programın temel hedefleri olarak gösterilmiştir. Türkmenistan diğer geçiş ülkelerinden farklı olarak, yeniden yapılanma sürecini istikrar ve sosyal uzlaşma önceliği üzerine inşa edilecek "kademeli” reform politikasına dayandırmıştır. 


\section{OATC' de Küreselleşme ve Refah İlişkisi}

Küreselleşmenin eşitleyici, farklı ülkeler, ekonomiler ve bireyler arasındaki farkın daha hızlı kapatılmasına olanak sağlayan bir süreç olduğunu belirtmiştik. Peki bu özellik OATC' de ne kadar geçerli? Bunu anlayabilmek için bir ekonomide üretim ve kişi başına gelirin artmasının yanında bazı sosyal göstergelerin de dikkate alınması gerekir. Bu sosyal göstergeler; okuryazarlık oranı, sağlık ve eğitim olanakları, bebek ölüm oranı, çocuk işgücü kullanımı,beklenen ortalama ömür, temiz suya erişim, vb. şeklinde sıralanabilir. Bu göstergeler yardımıyla iktisadi gelişim yanında beşeri gelişim de görülebilir. Aşağıdaki tabloda söz konusu cumhuriyetlerin, 182 ülkenin ekonomik ve sosyal verileri kullanılarak oluşturulan Beşeri Kalkınma Endeksi (HDI)' ndeki değerleri gösterilmiştir.

\begin{tabular}{|c|c|c|c|c|c|c|c|c|c|c|}
\hline & 1992 & 1995 & 1998 & 2001 & 2002 & 2003 & 2004 & 2005 & 2006 & 2007 \\
\hline Kazakistan & 0,798 & 0,695 & 0,754 & 0,765 & 0,750 & 0,761 & 0,774 & 0,794 & 0,800 & 0,804 \\
\hline Kırgızistan & 0,717 & 0,633 & 0,706 & 0,727 & 0,712 & 0,702 & 0,705 & 0,696 & 0,705 & 0,710 \\
\hline Türkmenistan & 0,739 & 0,660 & 0,704 & 0,748 & 0,741 & 0,738 & 0,724 & 0,713 & 0,739 & 0,739 \\
\hline Özbekistan & 0,706 & 0,659 & 0,686 & 0,729 & 0,727 & 0,694 & 0,696 & 0,702 & 0,706 & 0,710 \\
\hline
\end{tabular}

\section{Beşeri Kalkınma Endeksi (HDI) Değerleri}

$\mathrm{Bu}$ tabloya göre en hızlı beşeri gelişmeyi Kazakistan göstermiştir. Hatta Kazakistan 2006 yılına kadar orta gelişmişlik düzeyindeyken 2006 da yüksek gelişmişlik düzeyinde bir ülke konumuna yükselmiș ve 2007' de de bu başarısını korumuștur. Diğer cumhuriyetler Kırgızistan, Türkmenistan ve Özbekistan ise çeşitli iniş ve çıkışlar yaşamıș, istikrarlı bir performans gösterememiștir. En son yayınlanan HDI raporuna göre 182 ülke arasında Kazakistan 82., Türkmenistan 109., Özbekistan 119. ve Kırgızıstan 120. sıray1 almıștır. Bu raporda, 2007 yılına kadar Kazakistan dıșındaki ülkelerin ciddi bir tırmanış sergileyemedikleri ve orta gelişmişlik düzeyinde kalmayı sürdürdükleri görülmektedir.

Ülkelerin Beşeri Kalkınma Endeksi' ndeki değerlerine baktıktan sonra şimdi de Gayrisafi Milli Hasıla (GSMH)larındaki yıllık büyüme oranlarını dünya ortalaması ile karşılaştırarak görelim. Böylece gelirdeki artışın beşeri kalkınmadaki artışla paralel olup olmadığ konusunda da fikir edinebiliriz. Aşağıdaki tabloda yukarıda belirtilen yıllar itibariyle söz konusu ülkelerin GSMH yıllık büyüme oranları ile yine aynı yıllar için dünya ortalamaları verilmiştir.

\begin{tabular}{|c|c|c|c|c|c|c|c|c|c|c|c|}
\hline $\begin{array}{c}\text { GSMH' daki } \\
\text { Büyüme (y1llk \%) }\end{array}$ & 1992 & 1995 & 1998 & 2001 & 2002 & 2003 & 2004 & 2005 & 2006 & 2007 & 2008 \\
\hline Kazakistan & $-5,3$ & $-8,2$ & $-1,9$ & 9,8 & 9,8 & 9,3 & 9,8 & 9,7 & 10,7 & 8,9 & 3,2 \\
\hline Kırgızistan & $-13,8$ & $-5,42$ & 2,1 & 5,4 & $-0,02$ & 7,3 & 7,3 & $-0,18$ & 3,02 & 8,5 & 7,6 \\
\hline Türkmenistan & -5 & -7 & 7 & 20 & 16 & 17 & 17 & 13 & 11 & 12 & 10 \\
\hline Özbekistan & $-11,2$ & $-0,9$ & 4,3 & 3,8 & 4 & 4,2 & 7,7 & 7 & 7,3 & 9,5 & 9 \\
\hline Dünya & 2,13 & 2,91 & 2,31 & 4,13 & 1,89 & 2,68 & 4,09 & 3,48 & 3,96 & 3,84 & 1,07 \\
\hline
\end{tabular}

Gayrisafi Milli Hasıla (GSMH)'daki Yıllık Büyüme Oranları Karşılaştırması

Tablodan da görüldüğü gibi milli hasıladaki büyümelerle beşeri kalkınma arasında bire bir bir ilişki olduğu söylenemez. Zaman zaman doğru orantılı bir gelişme gözlense de her zaman böyle olmamıştır. Yani gelirdeki artışlar her zaman refah seviyesini artırmamıştır. Yine tablodan görüyoruz ki, Orta Asya Türk Cumhuriyetleri genelde dünya ortalamasının oldukça üzerinde bir büyüme performansı göstermiştir. Küreselleşmenin azgelişmiş ve gelişmekte olan ülkeler için belki de en büyük avantajı, hızlı büyüme ve dolayısıyla aradaki mesafeyi daha çabuk kapatabilmeyi mümkün kılmasıdır. Cumhuriyetlerin özellikle 2000' li yıllarda bu avantajı iyi kullandıkları söylenebilir. 
Sonuç olarak küreselleşme, bugünkü haliyle 1980'lerden itibaren hızlanmış, teknoloji, finans ve enforrmasyon alanındaki gelişmelerin etkisiyle bütün dünyayı etkisi altına almış, yararlanmasını bilene yatırım, büyüme ve gelişme firsatı sunarken yararlanmasını bilmeyene, Thomas Friedman' in (1999) deyimiyle "altın deli gömleği” ni giymemekte ssrar edenlere sermaye kaçışı, istikrarsızlık, kriz ve küçülme getiren, şiddete değil rızaya dayalı, bireysel insiyatiflerle karşı konulması, durdurulması ya da tersine döndürülmesi neredeyse imkansız, sınırlardan ve engellerden arınmış bir dünyayı, malların, hizmetlerin, sermayenin ve fikirlerin serbest dolaşımını öngören bir süreçtir (Acar, 2009). Orta Asya Türk Cumhuriyetleri' nin küreselleşme süreci içersindeki dünyadaki yerinin de, sunulan firsatlardan faydalanılabildiği ölçüde, günden güne belirginleştiği söylenebilir. Özellikle Kazakistan' in gösterdiği başarılı performansla süreçten en karlı çıkan ülke olduğu muhakkaktır. Her ne kadar yapılacak daha çok şey olsa da, yine de söz konusu cumhuriyetler 75 yıllık Sovyet esaretinin etkisini yavaş yavaş üzerlerinden atmaktadır. $\mathrm{Bu}$ etkinin tamamen ortadan kaldırılması, serbest piyasa ekonomisinin tam olarak ne kadar zamanda tesis edileceğine bağlıdır. Dünyada daha etkin olmanın, daha yüksek standartlara sahip olmanın ön koşulu budur.

\section{Kaynakça}

- Acar, 2009. Düzleştirici ve Özgürleştirici Bir Süreç Olarak Küreselleşme. Orion Kitapevi, Ankara

- Aktan ve Şen, 1999. Globalleşme, Ekonomik Kriz ve Türkiye. TOSYÖV Yayınları, Ankara

- $\quad$ Balcilar, a.g.m., s. 107

- Bilgin, 2002; www.foreingtrade.gov.tr/ead/DTDERGI/ocakozel/2002

- TIKA, 2004. http://www.tika.gov.tr/Dosyalar/Kazakistan.doc

- Fahri SOLAK; a.g.m., s. 74.

- Güngörmüş, 2005 “Sovyetler Birliği'nin Dağılmasından Sonra Kırgızistan: Sorunlar”, III. Uluslararası Türk Dünyası Sosyal Bilimler Kongresi.

- Koyçumanov, Bobuşev; a.g.m., s.17.

- Canbay; a.g.m. http://www.tdcif.org/sempozyum/poster/6.doc

- Aslantaş, 2002, a.g.m..www.dtm.gov.tr/ead/DTDERG /ocakozel2002/ozbek.htm

- Çelik, 2003, a.g.m., www.isguc.org.

- Somuncuğlu, 2002. Geçiş Döneminde Özbekistan Ekonomisi. Türkler, C:19.Yeni Türkiye Yayınları, Ankara, s. 684.

- Baitzhanova, 2002. Bağımsızlıktan Günümüze Türkmenistan Ekonomisi.Türkler, C:19. Yeni Türkiye Yayınları Ankara, s. 790.

- Yildı, 2005. http://www.kosgeb.com/Ekler/Dosyalar/Yayin/136\%5CTurkmenistan \%20ulke\%20raporu.doc

- Human Development Reports, 1995-2010. http://hdr.undp.org/en/reports/global

- $\quad$ The World Bank, 2010. http://www.worldbank.org.uz/WBSITE/EXTERNAL/COUNTRIES 


\title{
Avrasya Ekonomik Topluluğu: Bir İktisadi İşbirliği Alternatifi
}

\author{
Cusup Pirimbayev, Kırgızistan-Türkiye "Manas" Üniversitesi \\ Cunus Ganiyev, Kırgızistan-Türkiye "Manas" Üniversitesi
}

\section{Abstract \\ Eurasian Economic Community: One of the Alternative Forms of Economic Relations}

Unregulated economic relations in the post-Soviet territory caused an array of socioeconomic problems in these countries. The result of this need was the Treaty establishing the Eurasian Economic Community, signed by five countries of the CIS in 2000. This article will analyze the principles, objectives and main issues of this international organization.

JEL Code: O19, F15

\section{Giriş}

Sovyetler Birliği'nin dağılma kararı ile beraber 1991 yılında Rusya, Beyaz Rusya ve Ukrayna, daha sonra da diğer Sovyet Ülkeleri'nin de katılmasıyla Bağımsız Devletler Topluluğu (BDT) kurulmuştur. BDT, daha çok siyasi örgüt olduğu için söz konusu ülkeler arasındaki iktisadi işbirliği konularını pek ele almamıştır. Hâlbuki herkese belli olduğu gibi, SSCB ülkelerinde Sovyetler döneminde çok sıkı ekonomik ilişkiler söz konusuydu. Bu sistem öyle kurulmuştu ki, ülkelerdeki çoğu fabrikalar tek başına tam üretim yapamazdı, yani her ülkede malların ayrı parçaları üretilerek sonra birleştiriliyordu. 1991'de aniden SSCB'nin dağılma kararıyla beraber böyle ilişkileri devam ettirmek, bir taraftan fiyatların liberalizasyonu sonucu tırmanan yüksek enflasyon, diğer taraftan da siyasi ve diğer iktisadi nedenlerden dolayı imkânsız hale gelmişti ve sonuçta da ilk bağımsızlık döneminde tüm ülkelerde hızlı üretim düşüşü yaşand1.

Söz konusu ülkeler arasındaki iktisadi ilişkiler önemli düzeyde zayıflamış olmasına rağmen, coğrafi, tarihi etkenlerden dolayı söz konusu ülkelerin iktisadi işbirliğinde gelişmeler kaydetmesi tüm ülkeler için yararlı, zorunlu bir durumdur. $\mathrm{Bu}$ doğrultuda etkin bir iktisadi işbirliği örgütüne ihtiyaç olduğu için 2001 yılında Rusya, Beyaz Rusya, Kazakistan, Kırgızistan ve Tacikistan ülkelerini içine alan Avrasya Ekonomik Topluluğu kuruldu. Bu anlaşma, söz konusu ülkeler tarafından 10 Ekim 2000 tarihinde imzalanmıştı. Özbekistan, bu örgüte 2006'da katılmıştı, fakat 2008'de daha çok siyasi nedenlerden dolayı söz konusu örgütü terk etti. 2002'de Moldova ve Ukrayna, 2003'te de Ermenistan gözlemci olarak örgüte katılmışlardır.

Örgütün temel görevleri aşağıdaki gibidir:

- Serbest ticaret ve gümrük birliği doğrultusunda adımlar atmak;

- Sermayenin serbest dolaşımını sağlamak;

- Ortak mali piyasa oluşturmak;

- Söz konusu örgüt çerçevesinde ortak paraya geçme konusunda ilke ve koşullarda anlaşmanın sağlaması;

- Mal ve hizmet ticaretinde ortak kuralların belirlenmesi;

- Ülkeler arası proje programların oluşturulması ve gerçekleştirilmesi;

- Üretim ve girişimcilik faaliyetleri için eşit şartların sağlanması;

- Ulaşım hizmetleri ortak piyasası ve ortak ulaşım sisteminin oluşturulması; 
- Ortak enerji piyasasının oluşturulmasi;

- Ülkelere girecek yabancı yatırımlara eşit şartların sağlanması;

- Örgüt üyesi ülkelerin vatandaşlarına tüm üye ülkelerde eğitim ve sağlık hizmetlerinden yararlanmada eşit hakların sağlanması;

- Ulusal kanun ve düzenlemelerin yakınlaştırılması ve uyumlaştırılması vs. (www.evrazes.com).

Görüldüğü gibi, örgütün temel görevleri ülkeler arası iktisadi işbirliğinin artırılması ve etkinleştirilmesi amacı doğrultusundadır. Belirtmek gereken husus, söz konusu örgüt dışa açık örgüttür ve isteyen herhangi bir ülke örgüte girebilir.

Örgütün temel organları şunlardır: a) Ülkelerarası Konsey; b) Entegrasyon Komitesi; c) Sekretarya; d) Parlamentolar Kurulu; e) Örgüt Yüksek Mahkemesi. Ayrıca, bazı yardımcı organlar da mevcuttur.

Ülkelerarası Konsey örgütün temel organıdır ve ülkelerin cumhurbaşkanı ve başbakanlarından oluşur. Temel konuları görüşür ve cumhurbaşkanları düzeyinde yılda en az bir defa, başbakanlar düzeyinde de en az iki defa toplanır. Kararlar oy birliği ile alınır ve alınan kararların tüm ülkelerde uygulanması zorunludur.

Entegrasyon Komitesi, örgütün sürekli çalışan organıdır. Üye ülkelerin başbakan yardımcılarından oluşur. Konsey toplantısı için gündemin hazırlanması, kararların uygulama denetimi gibi temel görevleri vardır. Kararlar üçte iki oy çokluğuyla alınır, oy sayısı, ülkelerin örgüt bütçesine olan katkısına göre belirlenir.

Sekretarya, Konsey ve Entegrasyon Komitesi'nin faaliyetinin organizasyonu ve bilgi akımından sorumludur. Sekretaryayı idari en yüksek makam olan ve Konsey tarafından seçilen Genel Sekreter yönetir.

Parlamentolar Kurulu, ülke kanunlarının uyumlaştırılması ve alınan kararlara göre kanunların kabul edilmesi konularını görüşür ve ülkelerin milletvekillerinden oluşur.

Yüksek Mahkeme, anlaşmaların aynen gerçekleştirilmesini sağlar ve ülkeler arası iktisadi anlaşmazlıklara çözümler üretir.

Görüldügü gibi, örgüt etkin çalışabilmek için yeterli organ ve altyapıya sahip gözükmektedir. Fakat çeşitli iktisadi ve siyasi nedenlerden dolayı bugüne kadar pek başarıya ulaşamadığ açıktır. Rusya, Beyaz Rusya ve Kazakistan'ı dâhil eden gümrük birliği, Beyaz Rusya'nın bazı nedenlerden dolayı durdurması sonucu şu anda sadece iki ülke arasında faaliyet göstermektedir.

\begin{tabular}{|c|c|c|c|c|c|}
\hline & Rusya & Kazakistan & $\begin{array}{c}\text { Beyaz } \\
\text { Rusya }\end{array}$ & Kurgızistan & Tacikistan \\
\hline $\begin{array}{c}\text { GSYIH, } \\
\text { milyar ABD doları }\end{array}$ & 1679,48 & 133,44 & 60,31 & 5,06 & 5,13 \\
\hline $\begin{array}{c}\text { GSYİH Büyüme } \\
\text { Oranı, \% }\end{array}$ & 5,60 & 3,20 & 10,00 & 7,60 & 7,90 \\
\hline $\begin{array}{c}\text { Kişi Başına GSYİH, } \\
\text { dolar }\end{array}$ & 11831,50 & 8513,10 & 6230,10 & 958,40 & 751,00 \\
\hline Nüfus, milyon kişi & 141,95 & 15,67 & 9,68 & 5,28 & 6,84 \\
\hline İhracat, milyar dolar & 517,65 & 76,34 & 37,27 & 2,86 & 0,86 \\
\hline İthalat, milyar dolar & 369,09 & 49,27 & 41,72 & 4,73 & 2,99 \\
\hline Üretimdeki payı: & & & & & \\
\hline Tarım, \% & 5,50 & 5,70 & 9,80 & 29,80 & 18,00 \\
\hline Sanayi, \% & 37,20 & 43,30 & 44,40 & 19,70 & 22,90 \\
\hline Hizmet, \% & 57,30 & 51,00 & 45,80 & 50,60 & 59,00 \\
\hline
\end{tabular}

Tablo 1. Avrasya Ekonomik Topluluğu Ülkeleri'nin Temel Sosyo-Ekonomik Göstergeleri (2008). Kaynak: World Development Indicators, www.worldbank.org, 01/09/2010 
Tablodan görüldüğü gibi, doğal kaynakların da etkisiyle Rusya, Kazakistan ve Beyaz Rusya'da sanayinin üretimdeki payı diğer iki ülkeye göre çok daha yüksektir ve tarımın payı ise çok daha düşüktür. Hizmet sektörünün üretimdeki payı yaklaşık Beyaz Rusya hariç diğer ülkelerde yaklaşık aynı seviyededir. Yani ülkelerin dıș ticarette tamamlayıcılık kriteri açısından durumu pek zayıftır. Diğer taraftan ülkelerin gelişmişlik düzeyindeki farklılıkların da etkisiyle ülkeler arası ticaretin önemli kısmı doğal kaynaklar ve tarım ürünlerinden oluşmaktadır.

\begin{tabular}{|c|c|c|c|c|c|c|}
\hline & \multicolumn{2}{|c|}{ Diş Ticaret Hacmi } & \multicolumn{2}{c|}{ İhracat } & \multicolumn{2}{c|}{ Ithalat } \\
\cline { 2 - 7 } & $\mathbf{2 0 0 8}$ & $\mathbf{2 0 0 9}$ & $\mathbf{2 0 0 8}$ & $\mathbf{2 0 0 9}$ & $\mathbf{2 0 0 8}$ & $\mathbf{2 0 0 9}$ \\
\hline Beyaz Rusya & 31,8 & 32,7 & 20,2 & 19,2 & 43,2 & 46,1 \\
\hline Kazakistan & 18,9 & 17,6 & 11,8 & 9,9 & 25,9 & 25,4 \\
\hline Rusya & 49,3 & 49,7 & 68,0 & 70,9 & 30,9 & 28,5 \\
\hline Toplam & 100,0 & 100,0 & 100,0 & 100,0 & 100,0 & 100,0 \\
\hline
\end{tabular}

Tablo 2. Gümrük Birliği Toplam Ticaretindeki Ülkelerin Paylarl, \%. Kaynak: www.evrazes.com, 01/09/2010

Tablodan görüldüğü gibi, gümrük birliğindeki toplam ihracatın üçte ikisinden fazlası Rusya'ya aittir. İthalatta ise Beyaz Rusya'nın payı büyüktür, yani daha çok Rusya'dan Beyaz Rusya'ya mal akımı olmaktadır.

\begin{tabular}{|c|c|c|c|c|c|c|}
\hline & \multicolumn{2}{|c|}{2000} & \multicolumn{2}{c|}{$\mathbf{2 0 0 7}$} & \multicolumn{2}{c|}{2008} \\
\cline { 2 - 7 } & İhracat & İthalat & İhracat & İthalat & İhracat & İthalat \\
\hline Rusya & 13 & 34 & 15 & 15 & 15 & 14 \\
\hline Beyaz Rusya & 60 & 70 & 46 & 66 & 44 & 66 \\
\hline Kazakistan & 27 & 54 & 17 & 45 & 16 & 46 \\
\hline Kurgizistan & 42 & 54 & 57 & 55 & 48 & 54 \\
\hline Tacikistan & 48 & 83 & 16 & 63 & 16 & 56 \\
\hline
\end{tabular}

Tablo 3. Ülkeler Dış Ticaretindeki BDT Ülkelerinin Payı, \%. Kaynak: www.cisstat.com

Bölge içi ticarete baktığımızda, Kırgızistan ve Beyaz Rusya için BDT önemli bir ticari ortak konumunda iken, diğer ülkeler özellikle Rusya için pek önemli sayılmaz. Rusya'nın hem ihracatında hem de ithalatında BDT'nin payı \%15'ten fazla değil. Kazakistan ve Tacikistan'ın ithalatının yarısına yakını veya daha fazlası BDT'den yapılırken, ihracatının büyük kısmı BDT dışı ülkelere yapılmaktadır. Yani bölge içi ticaret elbette ki istenilen düzeyde değildir.

Bazılarına göre, bu ülke ekonomilerinin iyi gelişmemiş olmaları (Emsen, 2007:14-21) bölge içi ticaretin düşük olmasının temel nedenidir.

Diğer iktisatçılar ise, bölgedeki ticari ilişkilerin olumsuz nedenleri olarak; kara ve demir yollarının etkin ve iyi durumda olmaması, gümrük prosedürlerinin çok zaman alması, gümrük kontrol ve ülke içi mal kontrollerinin uyumlu yürütülmemesi, bilgi (enformasyon) değişiminde etkin sistemin olmayışı, transit vergilerin yüksek olması, resmi olmayan ödemeler ve altyapının iyi gelişmemiş olması (Apostolov, 2007:17-21) gibi faktörleri saymaktadırlar. Bunlara, etkin uluslararası ödeme sisteminin olmaması faktörü de eklenebilir. Ayrıca, son dönemlerdeki dolar kurundaki istikrarsızlıklar uluslararası ticarette risk ve belirsizlikleri artırmakta ve dolayısıyla, negatif etki yaratmaktadır.

Diğer taraftan, uzmanlara göre (Apostolov, 2007:17-21), bölgedeki gümrük tarifelerinin genel düzeyi mukayeseli olarak düşük düzeydedir.

Diğer bir önemli sorun da, ülkeler arası bilgi değişim sisteminin yokluğu ve istatistikî verilerdeki hata ve noksanlar, yani ülkeler arasında istatistiki verilerin uyumsuz olmasıdır. Bunun nedeninin yolsuzluk olduğu öne sürülmektedir (Karatalov, 2008:43-44).

Tüm bu faktörlerin etkisi olmakla beraber, en önemli faktör ülkelerin üretim yapılarının çok büyük benzerlik arz etmesi, yani ülke ekonomilerinin birbirini tamamlayıcı değil, birbiriyle rekabet edici konumda olması dolayısıyladır denilebilir. Dolayısıyla örgüte Türkiye gibi 
ekonomisi büyük ve sanayisi belli düzeyde gelişmiş ülkenin katılması Topluluk ülkelerinin dış ticarette tamamlayıcılık düzeyinin yükselmesine ve önemli gelişmelere yol açabilir ve tüm ülkelerin lehine bir gelişme olacaktır.

$\mathrm{Bu}$ doğrultuda ticarete engel olan problemlerin çözülmesi, lojik merkezlerin kurulması, ülkeler arası ticarette etkin ödeme sisteminin geliştirilmesi ve parasal birlik konusundaki ciddi girişimler gibi adımların yapılması da önemlidir.

Ayrıca krizle mücadelede dayanışmak amacıyla 2008 yılında Avrasya Krizle Mücadele Fonu'nun oluşturulması kararı alınmıştır. Bu fon toplam 10 milyar ABD doları tutarındadır ve onun 7,5 milyar dolarlık kısmını Rusya; 1 milyar dolarlık kısmını Kazakistan'ın vermesi kararlaştırılmıştır (www.vesti.ru, 04.02.2009). Moskova'da 25 Şubat 2010'da yapılan toplantıda da üye ülkelerin söz konusu fondan alabileceği maksimum limitler belirlenmiștir. Ona göre, Beyaz Rusya toplam fon hacminin \%21'ini; Rusya \%37'sini; Kazakistan \%24'ünü; Ermenistan \%13; Kırgızistan \%3; Tacikistan \%2'sini isteyebilecektir. Toplantı sonunda da Kırgızistan 160 milyon dolar kredi istemiş bulunmaktadır. Yakında Beyaz Rusya ve Ermenistan'ın da söz konusu fona yatırım projeleri sunacağı beklenmektedir. Fakat ilk krizle mücadele amaçlı yatırım projeleri değerlendirilecektir (http://www.evrazes.com/news/view/802, 26.02.2010). Bunun gibi faaliyetlerin daha geniş çaplı yapılması, ortak politikaların yürütülmesi, günümüzde Rusya ile Kazakistan arasında faaliyete başlamış bulunan gümrük birliğinin gelişmesi ve üye sayılarının artması, daha geniş coğrafyaya yayılması ve en önemlisi siyasi irade, istek ve kararlılığın olması entegrasyon sürecini hızlandıracaktır. Bu doğrultuda da Türkiye'nin bir Avrasya ülkesi ve Türk Devletleri'nin tecrübeli, daha gelişmiş, büyük ülkesi olarak Topluluğa üye olma konusunun her taraflı değerlendirilmesi iyi olur kanaati söz konusudur.

\section{Kaynaklar}

- Ö.S.Emsen. Paradoks Liberalizatsii Ekonomik Sredney Azii: Neizbejnost Integratsii Kak Odna İz Alternativ. Reforma Dergisi 3(35). Bişkek, 2007. ss. 14-21.

- M. Apostolov. Modernizatsiya Posredstvom Regionalnoy Torgovoy Integrasii $V$ Tselyah Privlecheniya İnvestitsiy i Novıh Tehnologiy. Reforma Dergisi 2(34). Bişkek, 2007. ss. 17-21.

- O. Karatalov. Puti Obrazovaniye Korrupsii ("dvijeniye çernıh deneg”- "kara para"- "aram akça”) v Kırgızstane. Legalizatsiya Dohodov, Poluçennıh Prestupnım Putem, Organizovannıye Finansovıye Pravonaruşeniya i ih Vliyaniye na Ekonomiku Kırgızstana. (konferans, 27 Nisan 2007). KTMÜ ve KC Hükümetine Bağlı Mali Polis. Bişkek, 2008. ss. 43-44.

- $\quad$ www.evrazes.com 


\title{
Türkiye İçin Alternatif Bir Dış Ticaret Pazarı: Avrasya Ekonomik Topluluğu
}

\author{
Volkan Öngel, Beykent Üniversitesi
}

\begin{abstract}
An Alternative Foreign Trade Market for Turkey: The Eurasian Economic Community

The Eurasian Economic Community (EEC) is an international organization that has been created by five Commonwealth of İndependent States countries (Belarus, Kazakhstan, Kyrgyzstan, Russia and Tajikistan) on October 10th,2000. The object of this organization was promote the creation of a customs union and the common economic space. After ten years in 2010, three countries (Belarus, Russia and Kazakhstan) made a custom union agreeament as a second step. And the target is to establish a common economic space by 1 january 2012, a single market for goods, investment and labor. This custom union creates a common market of 170 million people with a $\$ 2$ trillion economy, $\$ 900$ billion trade and 90 billion barrels of oil reserves.

This three countries have a strategic geopolitical position, rich producer goods reservers:especially oil and natural gas. The economic structure of this three countries can be explain as consumer goods importer, producer goods exporter. This is the exact opposite of Europian Union economic structure.

Therefore, this paper argues that The Eurasian Economic Community would be a good forein trade market alternative of EU for Turkey. Hence this paper tries to analyse the trade opportunities of this market for Turkey's export. This paper based on the istatistical foreign trade datas of relevant countries.
\end{abstract}

JEL Codes: F15, F17

\section{Giriş}

20.yy'ın son dönemi Türkiye ekonomisinin ve diş ticaret ilişkilerinin yeniden şekillenmeye başlandığı dönem olarak adlandırılabilmektedir. Soğuk Savaş döneminin bitmesi ve Sovyetler Birliği'nin dağılması Türkiye'nin bu ülke ile yapmış olduğu karşılıklı ticaret yapısının sona ermesine sebep olmuştur. Bu gelişmeler beraberinde Avrasya bölgesinde planlı ekonomiden çıkmış bağımsız devletlerin var olmasına sebep olmuş, uzun yıllar merkezi yönetim ile sürdürülen ticari ilişkiler bir anda ayrı ayrı devletlerle gerçekleştirilmeye başlanmıştır. Aynı dönemde Avrupa Birliği (AB) ve Türkiye arasında yapılan gümrük birliği anlaşmasıyla Türkiye - AB ticareti de yeniden şekillenmeye başlamıştır Yaklaşı 20 yıllık süre sonunda Türkiye toplam dış ticaretinin yarısından fazlasını Avrupa Birliği ve Avrasya Bölgesi olmak üzere iki bölge ile yapar duruma gelmiştir.

Bu çalışmada Sovyet Birliği’nin dağılmasından sonra gerçekleştirilmeye çalışılan bölgesel birliklerden günümüzde en aktif olarak görülen ve mevcut durumda üç üyesi arasında (Kazakistan, Rusya, Belarus) gümrük birliği aşamasına gelmiş olan Avrasya Ekonomik Topluluğu'nun (EURASEC) Türkiye için alternatif bir dış ticaret pazarı olabileceği tartışılacaktır.

Çalışmamızın birinci bölümünde uluslararası ekonomik entegrasyon teorisine kısaca değinilecektir. İkinci bölümde Türkiye'nin iki büyük ticaret ortağı olan Avrupa Birliği (AB) ve EURASEC bölgesi ile 2009 yılında yapmış olduğu toplam ticaret rakamları incelenerek, yapılan ticaretin ana kalemlerine değinilecektir. Son bölümde ise, EURASEC oluşumunun başarı şansı değerlendirilerek mevcut ekonomik yapılar 1şı̆̆ında önermemizin başarı ihtimali değerlendirilecektir. 


\section{Uluslararası Ekonomik Entegrasyon Teorisi}

Literatürde ekonomik entegrasyon (birliktelik) tanımının çeşitli şekillerdeki yapıları kapsayan genel bir tanım olduğu görülebilmektedir. Konu üzerine çalışmalarda bulunan J.Tinberger uluslararası ekonomik birleşme ile uluslararası ekonomik işbirliğinin optimumlaştırılmasını ifade ederken, C. Kindleberger üretim faktörlerinin fiyatlarının eşit duruma getirilmesini tanımın esası olarak kullanmaktadır. (Karluk, 1996) Günümüzde ise genel olarak, ekonomik birleşmenin ayrı ülke ekonomilerinin bir ekonomik bölge oluşturacak şekilde birleştirilmesi olarak tanımlandığı iddia edilebilmektedir.

Ekonomik entegrasyonların (birleşme) genellikle belirli süreçler izlenerek gerçekleştirildiği iddia edilebilmektedir. Üyeleri arasında mal mübadelesine konan tarife ve kota gibi engellerin kaldırılarak malların serbestçe dolaşımının sağlandığı bir anlaşmaya dayanan serbest ticaret bölgesi, ekonomik entegrasyonun ilk aşaması olarak kabul görmektedir. Serbest ticaret bölgesinin üyeleri, üçüncü ülkelerle ilişkilerinde tamamen kendi ulusal çıkarları doğrultusunda hareket edebilmektedirler. Birlik dışındaki ülkelere karşı ortak gümrük tarifesi uygulama yükümlülükleri bulunmamaktadır. (Ertürk, 2010) Ekonomik entegrasyonun ikinci aşaması ise; üye ülkeler arası malların serbest dolaşımını içeren ve de buna ek olarak üye olmayan ülkeler ile yapılan ticarete ortak bir sınırlama sistemi getiren gümrük birliğidir. Gümrük birliğine ek olarak üye ülkeler arasında teşebbüs, sermaye ve işgücünün serbest dolaşımını içeren ortak pazar üçüncü aşama olarak değerlendirilebilir. Ekonomik entegrasyon teorisine göre varılmak istenen son aşama ise, ortak pazarın tüm özelliklerine ek olarak üye ülkelerin ekonomilerini ortak bir merkez bankası, tek para ve vergi sistemi ile ortak bir dış iktisadi politika yolu ile birleștirmek olan ekonomik birliktir. Ekonomik birlik neticesinde mal ve üretim faktörlerinin serbestçe dolaşımına ek olarak, ortak sosyal ve ekonomik politikalarda gerçekleștirildiği görülmektedir. Bu noktada ekonomik entegrasyonun temel amacı olan ticaret hacmini arttırmak yanında, genișletilmiș bir pazar yaratmak sureti ile kalkınma, yaşam standartlarının yükseltilmesi, bölgesel dengesizliklerin giderilmesi, dünyadaki siyasi ve iktisadi olaylarda grubun statüsünün güçlendirilmesi ve problemlere ortak çözümler bulunulması olarak sayılabilecek önemli amaçlara ulașılabileceği söylenebilmektedir. (Kılıç, 2002)

Başarılı bir ekonomik entegrasyon için üye ülkelerin; i. Benzer ekonomik yapılarının olması ii. Üyelerin coğrafi yakınlığının bulunması iii. Üye ülkelerin birbirlerine bitişik bir toprak alanına sahip olmaları iv. Geniş bir toprak alanına sahip olunması v. Küçük ülkelerinde birlik içerisinde yer alması vi. Grup üyelerinin birbirlerinin en iyi müşteri ve tedarikçileri olmaları vii. Oluşan birliğin büyük nüfusa sahip bir pazar olması viii. Birlik üyelerinin dünyada üretim ve ticarette önemli pay sahibi olmaları, ekonomik entegrasyonun başarı şansı ve faydalarını arttıran özellikler olduğu iddia edilebilmektedir. (Kılıç, 2002)

\section{Avrasya Ekonomik Topluluğu ve Türkiye Ticaretinin Analizi}

Avrasya Ekonomik Topluluğu (Eurasian Economic Community - Eurasec), Kazakistan'ın girişimi ile 5 Bağımsız Devletler topluluğu ülkesi, Beyaz Rusya, Kazakistan, Kırgızistan, Rusya Federasyonu ve Tacikistan arasında 10 Ekim 200 tarihinde kurulmuştur. Özbekistan 2006 yılında topluluğa katılmasına rağmen 2008 yılında üyelikten çıkmıştır. Ukrayna, Moldova ve 2003 y1lından beri de Ermenistan gözlemci statüsünde bulunmaktadırlar. (www.eurasianhome.org)

Avrasya bölgesinde özellikle Sovyetler Birliğinin dağılmasından sonra ortaya atılan ekonomik ve siyasal birliklerin çeşitli sebeplerle yürütülemedikleri, yapılan görüşme ve anlaşmaların kağıt üzerinde kalan işlemler olduğu iddia edilebilmektedir. Buna rağmen Avrasya Ekonomik Topluluğunun gelişiminin nispeten başarılı olduğu söylenebilir. Şöyle ki; Üç üye ülke Rusya, Belarus ve Kazakistan arasında 1 Ocak 2010 yılından geçerli olmak üzere bir gümrük birliği kurulmuş bulunmaktadır. 2012 yılı için hedeflenen ise ekonomik entegrasyonun bir ileri aşaması olan ortak pazarın oluşturulmasıdır. 2006 yılı itibari ile 
Eurasian Development Bank adı altında Rusya ve Kazakistan'ın finansal desteği ile kurulmuş olan ve bu iki ülke dıșında Ermenistan, Tacikistan ve Belarus'un üye olduğu Avrasya kalkınma bankası ekonomik kriz döneminde üyelerine önemli destekler sağlamıștır. Ayrıca ekonomiler arasındaki farklılıkların giderilmesi konusunda ve alt yapı eksikliklerinin giderilmesi konularında da ciddi katkılar sağlamaktadır. (www.eabr.org) Bölgenin mevcut jeopolitik konumu ve sahip olunan enerji kaynakları nedeni ile topluluğun hedefleri arasında enerji güvenliğinin ve birlikteliğinin sağlanması için tek enerji alanı oluşturulması olduğu ve bununda ekonomik entegrasyonun başarı şansını arttıran bir unsur olduğu iddia edilebilmektedir. Ayrıca bu tip bir birlikteliğin Merkez Asya ülkeleri için çok gerekli olduğu, özellikle bunun Dünya Ticaret Örgütüne üye olmak konusunda başta Rusya olmak üzere başarılı olamamış Asya ülkeleri için önemli bir alternatif olabileceği düşünülmektedir. (Norling, vd, 2007)

Türkiye'nin dış ticaretinde ağırlıklı olarak yer alan iki önemli bölgenin Avrupa birliği bölgesi ve Avrasya Ekonomik Topluluğu özelinde Avrasya bölgesi olduğu söylenebilir. Bu iki bölge ile Türkiye'nin 2009 yılında yapmış olduğu dış ticaretin analiz ve karşılaştırılması aşağıda yer almaktadır. Aşağıda yer alan tablo 1'de 2009 yılı itibari ile Türkiye - Avrupa Birliği Ülkeleri arasındaki dış ticaret rakamları yer almaktadır.

Tablo 1: 2009 Yılı İtibari ile Türkiye - Avrupa Birliği Ülkeleri Dış Ticareti ( 1000 \$)

\begin{tabular}{|c|c|c|}
\hline Ülke Adı & $\mathrm{r} / 000 \$)$ & $\begin{array}{l}\text { Ülke Ad1 } \\
\text { (Değer / } 000 \text { I) }\end{array}$ \\
\hline Almanya & 9787894 & Almanya \\
\hline Fransa & 6208936 & İtalya \\
\hline İngiltere & 5916598 & Fransa \\
\hline İtalya & 5890617 & İspanya \\
\hline İspanya & 2823621 & İngiltere \\
\hline Romanya & 2216354 & Hollanda \\
\hline Hollanda & 2124127 & Belçika \\
\hline Belçika & 1796386 & Romanya \\
\hline Yunanistan & 1634356 & İsveç \\
\hline Bulgaristan & 1389316 & Polonya \\
\hline Polonya & 1321112 & Avusturya \\
\hline Avustuya & 807163 & Yunanistan \\
\hline İsveç & 748382 & Bulgaristan \\
\hline Danimarka & 678858 & Çek Cumhuriyeti \\
\hline Malta & 655328 & Macaristan \\
\hline Slovenya & 594945 & İrlanda \\
\hline Çek Cumhuriyeti & 489019 & Slovakya \\
\hline Macaristan & 445725 & Finlandiya \\
\hline Portekiz & 409148 & Danimarka \\
\hline İrlanda & 289345 & Portekiz \\
\hline Slovakya & 217327 & Slovenya \\
\hline Finlandiya & 196695 & Malta \\
\hline Litvanya & 151433 & Estonya \\
\hline Estonya & 106015 & Litvanya \\
\hline Letonya & 64978 & Lüksemburg \\
\hline Lüksemburg & 19479 & Letonya \\
\hline Güney Kıbrıs & 1294 & Güney Kıbris \\
\hline AB Toplamı & 46984451 & AB Toplamı \\
\hline Toplam İhracat & 102135006 & Toplam İthalat \\
\hline
\end{tabular}

Kaynak: Türkiye İstatistik Kurumu 2009 Yılı Verileri Kullanılarak Derlenmiştir. 
Yukarıda yer alan tablo 1'de görüldüğü üzere AB üyesi ülkelere Türkiye'nin 2009 yılı ihracatı 47 Milyar \$ civarında gerçekleşmiştir. 2009 yılı toplam ihracatının yaklaşık olarak \% 46'sına tekabül eden bu miktar içerisinde en büyük payı tutan ürün grupları hazır giyim ürünleri, makine ve ulaşım araçları, otomotiv sanayi ürünleri, tarımsal ürünler ve dokumacılık ürünleri olarak gözükmektedir. Bu dağılım göz önüne alındığında Türkiye'nin $\mathrm{AB}$ pazarına ihraç ettiği ürünlerin genel olarak emek yoğun ürünler olduğu anlaşılmaktadır. 57 Milyar \$ civarındaki ithalatın yaklaşı \% 90'lık kısmı ise makine ve ulaşım araçları, kimyasal ürünler, plastik ürünleri, elektrikli cihazlar ve eczacılık ürünlerinden oluşmaktadır. Gümrük birliği içerisinde yer aldığı ve toplam ticaretinin yaklaşık olarak \%46'sını gerçekleştirdiği AB ülkeleri ile yapılan ticareti göz önüne alındığında; Türkiye'nin genel olarak emek yoğun sektörler olan tekstil ve alt kolları, tarım ürünleri ve ithal ara malı girdisine gerek duyduğu sektörlerde ihracatçı konumda olduğu iddia edilebilir. İthalatının kalemlerinin ise neredeyse tamamının endüstriyel ve kimyasal mallardan oluştuğu söylenebilmektedir.

Aşağıda yer alan tablo 2'de 2009 yılı itibari ile Türkiye - Eurasec Ülkeleri içerisinde üye ve gözlemci olarak yer alan Avrasya ülkeleri arasındaki dış ticaret rakamları yer almaktadır.

Tablo 2: 2009 Yılı İtibari ile Türkiye - Eurasec Ülkeleri Dış Ticareti ( 1000 \$)

\begin{tabular}{|c|c|c|}
\hline \multicolumn{2}{|c|}{ Ülke Adı - Ülacat (Değer / 000 \$) Ad1 $\begin{array}{c}\text { - İthalat } \\
\text { (Değer / 000 \$) }\end{array}$} \\
\hline Rusya & 3202327 & Rusya \\
\hline Kazakistan & 633534 & Kazakistan \\
\hline Kırgızistan & 140059 & Tacikistan \\
\hline Tacikistan & 126469 & Belarus \\
\hline Belarus & 119185 & Kırgızistan \\
\hline Ukrayna & 1033447 & Ukrayna \\
\hline Moldavya & 117767 & Moldovya \\
\hline Ermenistan & 2 & Ermenistan \\
\hline Genel Toplam & 5372790 & Genel Toplam \\
\hline Türkiye Toplam İhracatı & 102135006 & Türkiye Toplam İthalat \\
\hline
\end{tabular}

Kaynak: Türkiye İstatistik Kurumu 2009 Yllı Verileri Kullanılarak Derlenmiştir.

Yukarıda yer alan tablo 2'de görüldüğü üzere Türkiye'nin bölge ülkeleri ile 2009 yılındaki ticaret hacmi 30 milyar \$ civarındadır. Fakat bu ticaretin 24.263.529 \$ Türkiye'nin bölge ülkelerinden ithalatı şeklinde gerçekleşirken, sadece 5.372.790 \$'lık ihracat yapmış olduğu görülmektedir. Türkiye'nin ithalat kalemlerine bakıldığında en büyük kalemlerin petrol ve doğal gaz olmak üzere, kömür, demir - çelik, alüminyum, bakır ve bakır ürünleri şeklinde neredeyse tamamına yakınının ara mallar ve hammaddelerden oluştuğu; Türkiye'nin bölge ülkelerine olan ihracatında ise gida, otomotiv, dokumacılık, kimya, makine ve hazır giyim sektörlerinin ağırlıklı olduğu görülebilmektedir.

\section{Sonuç}

Eski Sovyetler birliği üyesi 5 ülke tarafından 2000 yılında kurulmuş olan Avrasya ekonomik topluluğunun günümüzdeki durumu değerlendirildiğinde Rusya, Belarus ve Kazakistan arasında gümrük birliği aşamasına gelinmiş olduğu görülmektedir. Bu gümrük birliği yaklaşık 170 milyon kişilik nüfus ve 2 trilyon dolarlık ekonomiye sahip bir alan oluşturmuş bulunmaktadır. Birliğin toplam ticaretinin 900 milyar dolar civarında olduğu görülmektedir. 2012 yılı için hedeflenen ortak pazarında gerçekleşmesi muhtemel gözükmektedir. Toplam EURASEC bölgesine bakıldığında ise bu rakamların çok daha yukarılara çıktığı 
görülebilmektedir. Ekonomik entegrasyon teorisi ve örneklerine bakıldığında söz konusu birlikteliğin başarı şansının yüksek olduğu iddia edilebilmektedir.

Birlik üyelerinin ekonomik yapılarına bakıldığında genel olarak bu ülkelerin hammadde, ara malı, enerji ihracatçısı olduğu görülmektedir. Ülkelerin ekonomik gelişmeleri ve kalkınmalarının bu temel üzerine oturduğu söylenebilir. Buna karşın özellikle mamul madde ve tüketim malı ithalatı söz konusu ülke ekonomilerinin ortak özelliği olarak görülebilir. $\mathrm{Bu}$ bağlamda bölgenin genel ekonomik yapısının ve buna bağlı olarak da dış ticaret yapısının, yoğunluklu olarak gelişmiş ekonomilerden oluşan Avrupa Birliğinin tam tersi olduğu söylenebilir.

Mevcut ekonomik yapılar göz önüne alındığında Türkiye'nin EURASEC bölgesinin başlıca ithalat ürünleri arasında yer alan gıda, otomotiv, dokumacılık, kimya, makine ve hazır giyim sektörlerinde güçlü olduğu görülmektedir. Perakendecilik sektörünün bölge içerisindeki toplam büyüklüğünün yaklaşık olarak 1 milyar dolar civarında olduğu ve bu tüketimin \% 80'nin ithalatla karşılanmakta olduğu bilinmektedir. Dolayısı ile Türkiye'nin bu ülkelere özellikle perakendecilik sektöründe, gıda, tekstil, konfeksiyon ürünlerinde bölge nüfusu, tüketim eğilimleri ve ihtiyaçları göz önüne alınarak çok daha yüksek miktarlarda ürün satma şansı olduğu söylenebilir. Türkiye için firsat olarak gözüken bir diğer alanda birlik ülkelerinin tamamında var olan alt yapı eksiklikleridir. Bu alanda özellikle inşaat bağlamında Türk firmalarının çok güçlü olduğu ve büyük firsatların mevcut olduğu söylenebilir. Diğer taraftan Türkiye'nin bu bölgeden yaptığı ithalatın \% 95'inden fazlasının petrol ve doğal gaz ağırlık olmak üzere hammadde ve ara malı mamullerden oluştuğu bu sebeple de bu ikili ticaretin geliştirilmesinin Türkiye'nin lehine gelişebileceği iddia edilebilir.

EURASEC ülkeleri ile yapılan ticarette mevcut durumdaki en büyük problemlerden birinin karayolu taşımacılığındaki navlun ve geçiş ücretlerinin yüksek olması olduğu görülmektedir. Bu bağlamda Kars - Tiflis demiryolu hattının ve İstanbul - Almatı konteynır hattının gerekli rehabilitasyonlar yapılarak verimli olarak işletilebilmesi önemli görülmektedir. Gümrük birliği ülkeleri ile mevcut koşullar altında Türkiye'nin $\mathrm{AB}$ gümrük birliği sorumluluklarını da göz önünde bulundurarak karşlıklı gümrük tarifesi ve kota muafiyetlerinin sağlanabilmesinin Türkiye'nin lehine olabileceği düşünülmektedir. Yukarıdaki çözüm önerileri ile birlikte ekonomik gelişmişlik seviyeleri göz önüne alındığında EURASEC bölgesi Türkiye için AB'ye alternatif güçlü bir dış ticaret pazarı olabilecek niteliktedir.

\section{Kaynakça}

- Ertürk, 2010. Uluslararası İktisat. Alfa Basım, İstanbul.

- Karluk, 1996. Uluslararası Ekonomi. Beta Basım, İstanbul.

- Kılıç, 2002. Türkiye-AB İlişkileri ve Gümrük Birliği. Siyasal Kitabevi, Ankara.

- Norling, vd, 2007. "The Virtues and Potential Gains Of Continental Trade in Eurasia", Asian Survey, Vol.47, İssue 3, pp. 351-373.

- Agreement On Foundation Of Eurasian Ecomomic Community (EAEC). http://www.worldtradelaw.net/fta/agreements/eaecfta.pdf

- Dış İlişkiler Kurulu, Şubat 2007. Kazakistan Ülke Bülteni, http://www.deik.org.tr/Lists/Bulten/Attachments/101/kazakistan\%20bulten\%20subat $\% 202007$ TR.pdf

- Diş İlişkiler Kurulu, Mayıs 2009. Kırgızistan Ülke Bülteni, http://www.deik.org.tr/Lists/Bulten/Attachments/147/Kirgizistan-bulten-Mayis $\% 202009$ TR.doc

- Diş İlişkiler Kurulu, Haziran 2009. Tacikistan Ülke Bülteni, http://www.deik.org.tr/Lists/Bulten/Attachments/173/Tacikistan\%20ulke \%20bulteni_mayis_2009 TR.pdf 
- D1ş Ticaret Müsteşarlığı, 2008. Beyaz Rusya Ülke Raporu. www.ambar.com.tr/files.php?force\&file=Beyazrusya $657366152 \ldots$

- Eurasian Development Bank, http://www.eabr.org/eng

- Eurasian Economic Community (EAEC). http://www.eurasianhome.org/xml/t/databases.xml? lang $=$ en \&nic $=$ databases $\&$ intorg $=3 \&$ pid $=25$

- Rusya Ülke Raporu, Nisan 2010. http://www.aiaistanbul.org/files/bilgibankasi/pazarlar/ulkeler/russia_ulkeraporu.pdf

- Türkiye İstatistik Kurumu, 2010. D1ş Ticaret İstatistikleri, http://www.tuik.gov.tr/VeriBilgi.do?tb id=12\&ust id=4 


\title{
Foreign Capital in Russia and Hong Kong: Postmortem of International Financial Crisis
}

\author{
Şaziye Gazioğlu, University of Aberdeen \\ Ülkem Başdaş, Middle East Technical University
}

\begin{abstract}
This paper studies the relation among real stock returns, real capital flows and real exchange rate starting from a theoretical model. The model predicts that the capital inflows affect the real exchange rate and stock returns. Besides, there is an asymmetry between the effect of capital inflows and outflows on real exchange rate causing a "Debt Trap". In this paper, we compare the evidence from Russia and Hong Kong. The empirical findings confirm the theoretical model for all three countries.
\end{abstract}

JEL Codes: E60, F30, G15

\section{Introduction}

International Financial Crisis has been studied to a great extend with the suggestion of various causes. The various theories used to explain the South East Asian, the Russian and the South American crises include the First and the Second generation Models and the Crisis of contagion effect argued that the First and the Second generation models (Eijffinger et al. 2002)do not explain the Asian crisis. However, none of these models formulated a macro model that would give a theoretical base to investigate International financial crisis.

Gazioğlu, Ş. and D. McCausland, (2002), developed the theoretical model and Gazioglu (2003, 2005, 2008) applied to the Turkish data to investigate the reversal effects of capital inflows on a developing country. After the 1980's, Turkey experienced an urgent and quick liberalization of markets where the restrictions on capital flows were eliminated. As Gazioğlu (2008) suggest, the nature of the Turkish economy makes it more volatile with respect to external shocks and more open to crises. Before the 2001 crisis, the South American experience indicated that Turkey might face similar problems in their banking sector (Gazioglu, 2005)).

The aim of this paper is to investigate the relationship between capital flows, banking sector, stock market returns and the crisis over Russia and Hong Kong. In this paper we empirically show that the increase in foreign share in financial services can be an indicator of overall economic performance for the countries which are heavily dependent on capital flows. Furthermore, our study shows that capital flows have a deeper effect on the exchange rate when the flow reversal causes an asymmetric impact. This may cause a debt trap for the home country. Our basic innovation is to have a theoretical base for our empirical work on Russia and Hong Kong. This is contrary to other studies, which are only empirical studies with just two variables, namely, exchange rate and stock market returns. Here we test the validity of the theoretical model for Russia and Hong Kong.

The paper is organized as follows; Section 2 introduces the model to test for the relation between capital flow, stock returns and the exchange rate; Section 3 analyzes the empirical evidence for Russia and Hong Kong; Section 4 concludes.

\section{Model}

\subsection{Theoretical Model}

We use the model developed by Gazioğlu $(2001,2002)$ and tested in Gazioglu $(2003,2005$, and 2008) for the Turkish data. The model solves the profit maximization problem of firm and 
time separable utility function and the maximization problem of a representative domestic consumer. The stock market constraint is given as:

$$
\boldsymbol{V}^{d} \dot{X}^{d} \equiv \boldsymbol{X}^{d} \dot{V}^{d}+X^{d} D^{d}
$$

$V^{d} X^{d}, X^{d} I_{\text {and }} X^{d} D^{d}$ denote the value of domestic firms owned by domestic individuals, domestic proportion of stock market valuation of these shares, and their proportion of dividends respectively.

Gazioğlu (2005) summarizes the equilibrium in economy as follows;

$$
\begin{aligned}
& \dot{X}-\boldsymbol{B H}=\boldsymbol{Y}-A-I+X^{d}\left(\dot{V}^{d} / V^{d}+D^{d} / V^{d}\right)+X^{f}\left(\dot{V}^{f} / V^{f}+D^{f} / V^{f}\right) \\
& +H(\boldsymbol{H}+\dot{E} / E)\left(1+R^{f}\right)
\end{aligned}
$$

Where the balance of payment equation can be given as;

$$
\dot{H}=\Pi-T+H(\mathbf{H}+\dot{E} / E)\left(1+R^{f}\right)
$$

Gazioğlu (2005) states that "net accumulation of assets can be accumulated by a trade surplus and capital gain from holding foreign money in terms of foreign goods", which is shown by equation (3). Then, equation (2) implies the equilibrium condition, where the right hand side is equal to net domestic income minus consumption and the left hand side is the net wealth accumulation. This equilibrium proves that a change in shares under foreign ownership in the domestic stock market is reflected to the domestic economy in terms of domestic debt. Therefore, a foreign shock can affect the domestic market via a change in shares under foreign ownership. The percent of shares under foreign ownership has a vital role in evaluating the sensitivity of the economy to foreign shocks. Greater percentage implies higher sensitivity and a more volatile economy.

Gazioğlu (2005) states the dynamics of the whole system as follows;

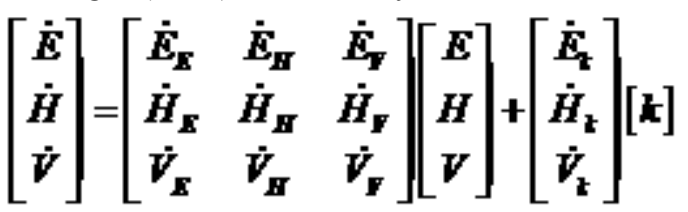

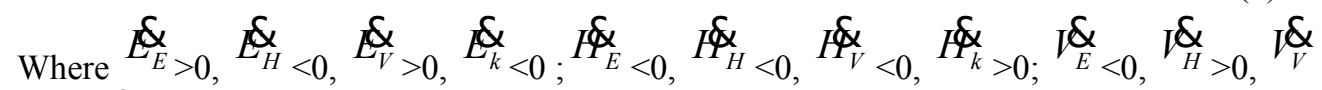

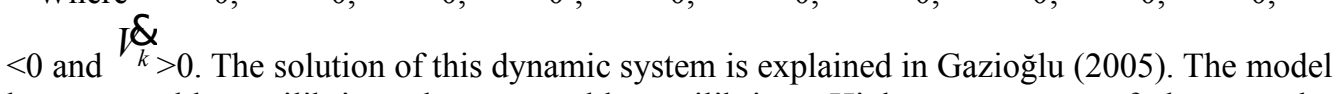
has two stable equilibria and one unstable equilibrium. Higher percentage of shares under foreign ownership causes an asymmetry between the capital inflows and outflows, which leads to the "Ponzi Game" position; the country borrows further to be able to repay debts (Gazioğlu, 2001, 2002, 2003).

\section{Empirical Evidence from Russia and Hong Kong:}

Gazioglu (2008) showed that for Turkey there is a link between the capital flows, real exchange rate and stock returns. Foreign share in the domestic economy is an important parameter affecting the whole economy. Besides, capital outflows have a greater impact than inflows. The case of Turkey can be investigated for other developing or under-developed countries, where there is a reliance on capital flows, or the capital flows captures a significant portion of the economy, or allow mobility of capital without prior construction of regulatory framework. To test our aim Russia and Hong Kong are chosen. In this paper, we test the validity of the model for Russia and Honk Kong. 


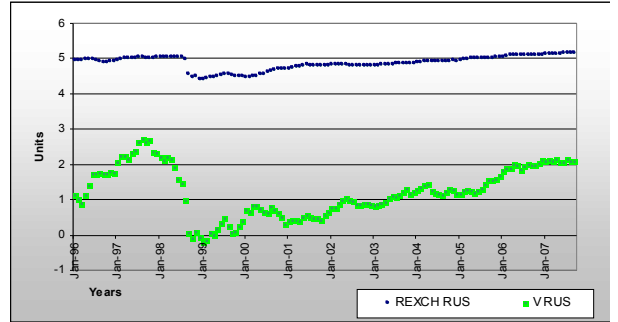

Figure 1 - The Real Effective Exchange Rate and Real Stock Returns in Log for Russia: 1996-2007



Figure 2 - Real Foreign/Liabilities in Log for Russia: 1996-2007

First we discuss the results for Russia. Both the Eigenvalue Test and the Trace Test verify that there is only one cointegrating vector. Estimation of vector via Johansen Estimation is calculated. One per cent increase in RFASS will increase REXCH by nearly 0.095 per cent implying that higher foreign assets will end up with appreciation of the domestic currency. The Stock returns index negatively affects the real effective exchange rate. The dummy variable has a negative sign meaning that, for the crisis period, domestic currency depreciation has been experienced.

For the capital outflow case, one per cent increase of RFLIAB causes a depreciation of 1.979 per cent. Compared to the inflow case (Model 1), capital outflow has a nearly 20 times higher effect on the exchange rate. Considering the coefficients of stock returns in Model 1 and Model 2, the coefficient is more significant for the outflow case. This indicates that capital inflows increase the stock returns and when an economic turbulence occurs it immediately moves out. The impact of capital inflow is higher than stock returns whereas the effect of capital outflow has nearly the same effect as stock returns. This proves the greater importance of capital flows on real exchange rate than of stock returns. The signs of coefficients are in line with the theoretical findings confirming our model.

Comparing the Model 1 and Model 2, it is clear that our theoretical findings are in line with the empirical data. Increase in real foreign assets is invested in stock returns, so that increases the stock returns. Then, a rise in $\mathrm{V}$ causes appreciation of the domestic currency. On the other hand, as mathematically shown in cointegrating vector estimates, RFLIAB has a higher effect on real exchange rate verifying the discussion on the "debt trap". The capital outflow has a deeper effect on real exchange rate than the inflows.

\subsection{Hong Kong:}

We aim to investigate the global direction of capital flows. The Asian crisis seems to have a contagious effect on the Russian Crisis in 1998. We aim to study the effect of 1997-1998 Financial crises on China.

China is one of the biggest economic players in the world because of both its size and importance for attracting foreign direct investment from various countries. High growth rates and high gross domestic product levels are remarkable. Economist Special Report states that China's share of world GDP is already closer to the rich countries. Indeed, the GDP share of EU and the U.S. shows a declining trend starting from the 1980's and reaches to nearly 20 per cent whereas China and the rest of Asia follows an upward trend reaching to above 15 per cent. Japan has less than 10 per cent of the world GDP. Nevertheless, the population of China, nearly 1.3 billion, clearly affects the GDP per capita. The forecasts for 2007 were still expecting high rates for China. According to the recent forecast of Economic Intelligence Unit), the GDP forecasts of China would be $10 \%$ for 2008 and $9.3 \%$ for 2009 after experiencing $11.5 \%$ in 2007. 
The China region, excluding Hong Kong, attracts a remarkable amount of foreign direct investment which mainly flows from the Asia region, especially Hong Kong. Nevertheless, inward flows to Hong Kong are remarkable compared to the flows to China region. Capital flows to the Financial sector and the FDI to the financial sector has similarities with Turkey ((Gazioglu, 2008), (Loewendahl et al, 2001), (Çulha, 2006))

We focus on Hong Kong, which was under the British control in the $19^{\text {th }}$ century. According to the terms of the Sino-British Joint Declaration on the Question of Hong Kong, signed in 1984, Hong Kong became a Special Administrative Region (SAR) of China promising "a high degree of autonomy" for at least 50 years (Economist Intelligence Unit. Hong Kong has lower growth rates, around 5.5 per cent, than China has. Besides, Hong Kong is one of Asia's leading financial centers and the key international financial center servicing China. As emphasized above, it attracts a huge amount of FDI. Consequently, the structure of economy is the basic motivation to test our claim. Another reason is the rising importance of China and Hong Kong within the China region. It is helpful to analyze the linkages of capital flows for this new player for the sake of future economic policies of China, which will affect the world markets deeper and deeper. After the Asian and Russian financial crises 1997-1998, China became the global financial attraction.

\subsection{Evidence from Hong Kong:}

The nominal effective exchange, foreign assets, foreign liabilities of the banking sector and the consumer price index are gathered from the International Monetary Fund International Financial Statistics for 1994:M1- 2006:M12 time period. All Ordinaries Index series is used as the stock returns index. In figure 5, 6, and 7, the real exchange rate, the real stock market returns and capital inflows, and capital outflows are plotted for 1994:M1- 2006:M12. Focusing on the year 1994, there is a considerable rise in real liabilities, depreciation of the home currency and decrease in the stock returns. After 1995, there is an improvement for all variables. Through out 1993 and 1994, the conflicts between Britain and China in politics over reform for Hong Kong (Burns, 1993) continued. (the introduction of the Special Economic Zones in China). The resolution of this conflict might be the underlying causes of attraction of foreign capital to China. It is noticeable from the empirical analysis that the Asian Crisis in 1998 has positive impact on the Hong Kong. Figure 5 shows that the real exchange rate falls between January 1994-1999, but appreciates between 1997-2002. There was no gap between the liabilities and the assets until 1998, and the gap increased afterwards. This can be interpreted as Asian capital moving out, towards the direction of China.

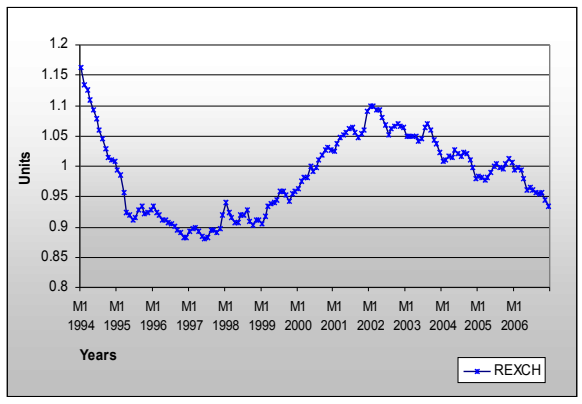

Figure 5 - The Real Effective Exchange Rate for Hong Kong: 1994-2006

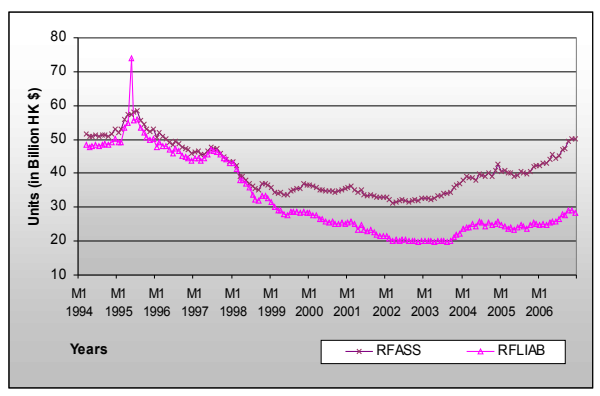

Figure 6 - Real Foreign/Liabilities: for Hong Kong: 1994-2006 


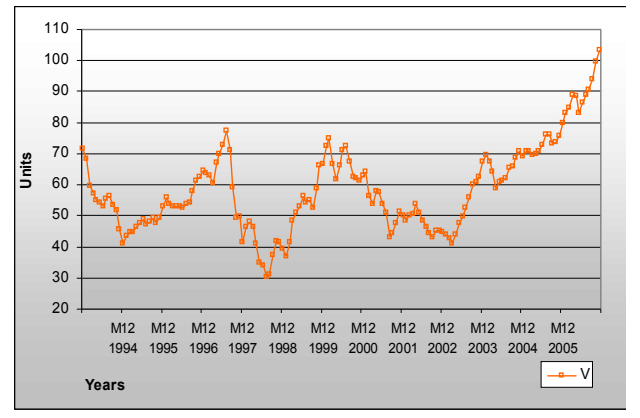

Figure 7 - Real Stock Returns for Hong Kong: 1994-2006
Source: Author's own calculations.

For all variables ADF unit root test is applied and all are integrated of order one. Johansen multivariate technique is applied after including a dummy for 1998. For model 1, a 1\% decrease in stock market returns lead $1.71 \%$ fall (depreciation) of the home currency. Capital inflows into the Banking Sector have very small positive effects. This indicates that capital inflow did not moved into the Banking Sector, has not taken place. We will investigate FDI as an alternative inflow. The sign of DUM $98 \mathrm{HK}$ is positive, indicating that the Hong Kong Dollar still appreciated despite the Asian and Russian crisis. The controversial effect of this dummy variable proves the Asian Crisis improved the economy of Hong Kong contrary to the recession experienced among the Asian countries Gazioglu (2005, 2008). The others (Abeysinghe, 1999) stated that the Asian Crisis transmitted to Hong Kong in very limited manner.

For model 2, capital outflow from banking sector is fairly small. For both Model 1 and 2, we will investigate capital inflow into the stock market and FDI and their reversals.

The basic reason of this finding can be the economic structure of Hong Kong, which greatly differs Russia's. The economy of Hong Kong has ranked the world's freest economy in the Index of Economic Freedom for the 13th consecutive year. Besides, Hong Kong Stock Exchange is one of the largest markets in the world. In 2006 the value of initial public offerings was second highest in the world after London (International Herald Tribune). Accompanied with consecutive high growth rates and developed stock market, the economic performance is comparatively higher for Hong Kong. Consecutively, Hong Kong has not experience the volatility depending on the sudden capital flow shocks as in Turkey or Russia. Rather than the movements of capital, the change in stock returns matter for Hong Kong. Considering the size of the stock market, this finding is not in contrary to our predictions but support the claim that sudden capital flow shocks matter for the countries where there is not enough regulation or institutional framework.

\section{Conclusion:}

This paper considers the relation among real exchange rate, real capital flows and real stock returns for Russia and Hong Kong. The theoretical model of Gazioğlu and McCausland (2002) is empirically tested for Turkey by (Gazioglu, 2003, 2008). The theory predicts that capital inflows via effect on stock returns leads to appreciation, and there is an asymmetry between the effect of inflows and outflows. Our empirical findings from Russia and Hong Kong confirm the theoretical predictions. Comparing the results of Gazioğlu (2008), impact of real liabilities is higher than of real assets meaning that capital outflows has a stronger effect for Turkey and Russia. Furthermore, capital inflow is an important parameter affecting the real exchange rates. Only for Hong Kong the stock returns are more effective than the capital flows because of its exceptional performance of stock markets and overall economy compared to Turkey and Russia. 
Policy implication of this paper relates to capital flows with no restrictions. There is high risk of financial crisis in case of capital reversal. The countries with high foreign investment shares face high risk of financial crisis. Because of the asymmetry, the capital outflows will have deeper effects on exchange rate than capital inflows. These countries are more open to foreign shocks. Some form of capital control possibilities has to be utilized in these countries to be able to smooth the foreign shocks. Further research is needed both to extend the data for other countries and test the theoretical model.

\section{References}

- $\quad$ Abeysinghe, T. ,1999) "Thai Meltdown and Transmission of Recessions within ASEAN4 and NIE4", Paper presented at the conference on International Financial Contagion, How it Spreads, How it Can be Stopped, February 2000, International Monetary Fund, Washington DC

- $\quad$ Eijffinger, S C W; Goderis, Benedickt (2002): "Financial Crises, Monetary Policy and Financial Fragility; A Second-Generation Model of Currency Crises" C.E.P.R. Discussion Papers in its series CEPR Discussion Papers with number 3637

- Burns, J. P. , 1993) "Hong Kong in 1993: The Struggle for Authority Intensifies", Asian Survey, Vol. 34, No. 1, A Survey of Asia in 1993: Part I, pp. 55-63, January.

- Cohen, B., 1998), “The Geography of Money”, Ithaca, NY: Cornell University Press.

- Çulha, A., 2006), "A Structural VAR Analysis of the Determinants of Capital Flows into Turkey", The Central Bank of the Republic of Turkey Research and Monetary Policy Department Working Paper, No.06/05, October.

- Economist (2007), "Reaching For a Renaissance", the Economist Newspaper and the Economist Group, March 292007.

- $\quad$ Eijffinger, S C W; Goderis, Benedickt (2002): "Financial Crises, Monetary Policy and Financial Fragility; A Second-Generation Model of Currency Crises" C.E.P.R. Discussion Papers in its series CEPR Discussion Papers with number 3637

- Gazioğlu, Ş. (2008), "Stock Market Returns in an Emerging Financial Market: Turkish Case Study” Applied Economics, 40(11), pp.1363-1372.

- Gazioğlu, Ş. (2005), "Stock Market, Financial Crisis and Capital Flows in an Emerging Market: Turkish Case Study" in Gazioğlu, S. (eds): Emerging Markets in Financial Crisis: Capital Flow, Saving, Debt and Banking Reform, J-Net Publications, pp. 62-95, 2005.

- Gazioğlu, Ş. and D. McCausland (2002), “A Non-linear Currency Substitution Model of Hysterisis in Debt and Competitiveness", METU Studies in Development, Vol. 29, No. 3-4.

- International Herald Tribune (2006) "Hong Kong surpasses New York in IPOs" (http://www.iht.com/articles/2006/12/25/business/borse.php), published in $25 / 12 / 2005$

- Loewendahl, H. and E. Ertugal-Loewendahl (2001), "Turkey's Performance in Attracting Foreign Direct Investment: Implications of EU Enlargement", ENEPRI Working Paper, No.3, November.

- World Bank (2007), Russian Economic Report 14, the Moscow Office of the World Bank, June. 


\title{
Credit Behaviour of Banks in the European Union in the Wake of Global Economic Crisis ${ }^{1}$
}

\author{
Stanislav Polouček, VSB - Technical University of Ostrava
}

\begin{abstract}
Recent financial crises hit many countries. The impact on Visegrad countries in credit area was not damaging. The main reason was stability and soundness of financial (banking) sectors in these countries and an adequate response of central banks as well as flexible management of commercial banks. Commercial banks, usually daughter companies of western banks, used above all domestic deposits for financing credits. This played a key role in credit area and helped to keep the financial system stable. It is important to underpin that responses to the crisis have been rather heterogeneous in central European countries and there are quite big disparities among Visegrad countries, too. In the paper developments and responses of the commercial banks to the crisis and their stability have been discussed on the basis of deposits, loans of monetary financial institutions to the non-financial sector, households, governments, lending for house purchase and credit for consumption in several EU countries. Net position of banks vis-á-vis foreign banks is taken into account, too.
\end{abstract}

JEL Codes: G01, G21

\section{Introduction}

Rapid financial sector development played a key role in the EU growth and convergence experience. For Visegrad countries (Poland, Hungary, Slovakia, the Czech Republic) foreign capital (in a form of foreign direct investments as well as in a form of various types of credits) was the basis for increasing integration with the rest of the EU. The widespread foreign ownership of banking sectors also contributed to capital inflows and the boom before the crisis (Debrun and Mathisen, p. 12). But in some eastern and central European countries this inflow of capital is considered to be excessive prior to the crises. Strong capital inflows are often associated with boosting credit growth and fuelling asset bubbles. Rapid credit growth is typically followed by an increase in non-performing loans. One can therefore expect foreign investors to be more cautious because of growing risk in countries experiencing a credit boom.

Central banks in Visegrad countries were less active in directly managing credit booms and capital inflows. It is good to say that it was quite difficult to be active for them, partly because of the EU free capital market. However, most central banks in this region took measures to rein in overall credit growth and/or the growth in foreign currency denominated credit (Gardó and Martin, p. 12). In some countries (Hungary, Poland) foreign currency denominated credits to households played an important role during exchange rate turbulences and as a mechanism of contagion of domestic economy - for instance in Poland around $80 \%$ of mortgages were denominated in CHF. High appreciation of PLN in 2007 increased credit risk in banking sector, demanded higher reserves and brought lower liquidity in financial sector.

Recent financial crisis spurred unprecedented government recapitalization programs and liquidity injections by central banks. The ECB and central banks in EU countries also supported liquidity in financial sector but this policy was quite selective. In many EU countries financial sector got an unprecedented government support: on average in the EU the state guarantees in favor of financial institutions were (October 2008-December 2009) more than 20 $\%$ GDP, guarantees effectively used by financial institutions around $8 \%$ of GDP (European Central Bank, 2010b). Only in seven countries (Bulgaria, the Czech Republic, Estonia, Italy, Lithuania, Malta and Romania) no program was approved or effective at all. In Visegrad

Publication of this paper was supported by the Czech Science Foundation within project GACR 402/08/0067 "Financial Integration of the EU New Member States with Eurozone". 
countries measures of central banks were less comprehensive in comparison to most other countries; lower intervention could be attributed to the relatively limited financial stress and sound financial (banking) sector.

The disparities of the effects of the financial crisis are rather large. There were several ways of contagion which worked at different strengths in the different countries. In general there was no or negligible exposure of central European countries to subprime or subprime-related assets (toxic assets). This is the main reason why central European countries performed relatively well until mid-September 2008. But in September 2008 the global economic and financial crisis started to impact foreign investor confidence and asset prices were influenced by an increase in risk aversion. The flight to safety was generally at the expense of the emerging economies: assets were shifted from these countries to more stable currencies and assets. In fact Visegrad countries were not hit hard via this channel. The growth of yield spreads and decline of stock markets were quite mild and short. But all these economies were hit hard via the real economic channels depending on the domestic economic development before the crisis.

Many studies argue that banks are granting less credits in crises because of worsening credibility of companies and growing risk of granted credits. They also argue that financial distress at western parent banks was associated with a significant impact on business lending to central and eastern European firms. In recent crisis banking sectors in several EU countries experienced a strong deceleration in credit and deposit growth and usually increase in nonperforming loans. It is important to underpin that the disparities among countries are rather large. The goal of the paper is to compare development of deposits and several types of loans in several EU countries and three Visegrad countries (the Czech Republic, Slovakia and Poland) and to find and compare how seriously they were hit by financial crisis and credit decrease.

\section{Data and credit development}

The paper is focusing on period January 2006 - June 2010. We use seven sets of monthly data at the end of the period (stocks): total outstanding amounts of deposits of monetary financial institutions (MFI); total outstanding amounts of loans granted by MFI; total outstanding amounts of loans granted by MFI to non-financial corporations; total outstanding amounts of loans granted by MFI to households and non-profit institutions serving households; total outstanding amounts of loans granted by MFI to government; total outstanding amounts of credits to consumption and total outstanding amounts of credits for house purchase. We focus on selected EU countries, namely Austria, Bulgaria, the Czech Republic, Finland, Greece, Hungary, Ireland, Poland, Portugal, Romania and Slovakia.

The development of loans shows no dramatic changes in most countries (Figure 1 and Figure 2) - in some of them (Portugal, Greece, Finland, Bulgaria) we can see lower dynamics after the crisis, but steadily growing amount of loans for the whole period. In Visegrad countries stagnation (Hungary, Slovakia) or growth (Poland, the Czech Republic) followed after a short drop of loans at the break of 2008/2009. The only country with relatively long decrease of loans was Ireland where stagnation starts in May 2008 and a long-term decline in January 2009.

The deposits developed in the same way as strong correlation between loans and deposits confirm (Table 1). In most EU countries loan indicators are strongly correlated with deposit indicators of MFI. Ireland is the only exception, low correlation is also in Slovakia. These data confirm the fact that in most European countries the loans of MFI are basically covered with the deposits and the amount of MFI loans is depending on available domestic sources (deposits) in these countries; it is the supply of deposits that is a limit. It is seen that deposit / loan ratio is relatively stable during the whole period in most countries (Table 2). The exceptions are Poland (loans are covered by deposits until half of 2008 and since then the 
amount of loans is higher than the amount of deposits) and Ireland (the amount of loans is higher than the amount of deposits until December 2008 and since then loans are covered by deposits). It is not possible to say that in countries where deposit / loan ratio is higher than 100 $\%$ the impact of financial crisis was milder than in countries where loans are more financed by outside credits. But in the case of Ireland the break in the deposits / loans ratio can be considered as a loss of confidence in Irish banks and in the case of Poland as a high confidence in Polish banking sector and Polish economy - Poland was the only EU country not experiencing GDP decrease during the recent crisis.

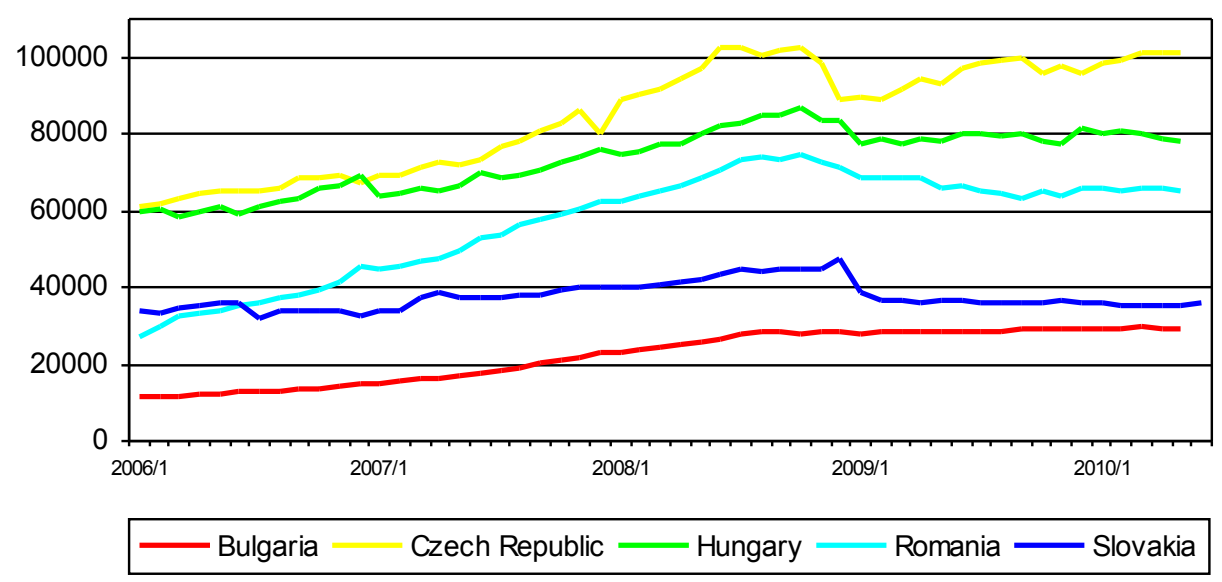

Figure 1. Loans of MFI in selected countries (1) (2006-2010, mil. EUR) Source: ECB



Figure 2. Loans of MFI in selected countries (2) (2006-2010, mil. EUR) Source: ECB

The deposits / loans ratio is often used as an indicator of credit vulnerability and higher values are considered as indicators of more stable financial sector. It really says a lot about the stability of MFI (banks), but nothing about the stability of the whole economy - governments, companies and households can get credit from other sources as well. Situation with huge government debt in Greece confirms this fact as well as relatively strong correlation between loans and deposits and relatively low correlations of loans to non-financial corporation / deposits and loans to household / deposits (Table 1). 


\begin{tabular}{|l|l|l|l|}
\hline & loans / deposits & $\begin{array}{l}\text { loans to non- } \\
\text { financial } \\
\text { corporations / } \\
\text { deposits }\end{array}$ & $\begin{array}{l}\text { loans to } \\
\text { households / } \\
\text { deposits }\end{array}$ \\
\hline Austria & 0,99298392 & 0,96841544 & 0,92834994 \\
\hline Bulgaria & 0,98243153 & 0,97392972 & 0,97538715 \\
\hline Czech Republic & 0,99669811 & 0,95567829 & 0,97980036 \\
\hline Finland & 0,96571379 & 0,95871247 & 0,96964026 \\
\hline Greece & 0,97252362 & 0,84725194 & 0,77758176 \\
\hline Hungary & 0,95068366 & 0,91534938 & 0,93921724 \\
\hline Ireland & 0,75679571 & 0,62420949 & 0,42670957 \\
\hline Poland & 0,97170241 & 0,95977865 & 0,93488103 \\
\hline Portugal & 0,93719882 & 0,98011191 & 0,94211127 \\
\hline Romania & 0,97090102 & 0,98296184 & 0,98178477 \\
\hline Slovakia & 0,88115486 & 0,78502990 & 0,64579222 \\
\hline
\end{tabular}

Table 1. Correlation coefficients between loans and deposits in selected EU countries (monthly data, January 2006-June 2010)

Foreign banks and their daughter companies started in Visegrad countries with loans to large companies, usually daughter companies of western financial conglomerates, financing their activities by their own (foreign) sources. Gradually they expanded into financial services to households and focused on lending and accepting deposits locally. That is why financing loans of MFI by foreign sources was not typical for Visegrad countries (the Czech Republic, Slovakia until the beginning of 2010 and Poland until half of 2007) before the recent financial crisis. Development of net investment position of MFI vis-á-vis foreign banks confirms (Figure 3 - Figure 5) that during the crisis the situation partly changed in Poland and Slovakia, but it stayed the same in the Czech Republic.

In Slovakia an economic development was seriously influenced by euro introduction in January, 2009. The financial sector was healthy and it has not been hit by financial crisis very seriously. Although bank lending standards were tightened throughout 2009, the slowdown of this process towards the year-end represented a moderately positive sign (NBS, 2010a, p. 21). The banks were very careful in financing companies but despite crisis the loans to nonfinancial corporations grew without any interruption until the end of 2008. A mild decrease and stagnation followed. Loans to households including lending for house purchase are permanently growing until now. The credit risk of households was not decreasing (NBS, 2010b, p. 3) but in March 2010 we can record the highest value of credits to households since November 2008. If banks have sources (deposits) they see households as less risky than enterprises. There was a huge but very short drop in total loans (as well as deposits) in January and February 2009 caused by drop in loans to foreign banks and similar drop in credits and deposits taken from foreign banks (Figure 5). Since then the amount of loans is at a standstill despite of mild growth of deposits.

\begin{tabular}{|c|c|c|c|c|c|}
\hline & 2006 & 2007 & 2008 & 2009 & 2010 \\
\hline Austria & 90,95 & 88,41 & 90,55 & 92,41 & 89,81 \\
\hline Bulgaria & 96,76 & 103,14 & 85,23 & 75,15 & 74,72 \\
\hline Czech Republic & 121,14 & 119,40 & 114,89 & 114,10 & 112,83 \\
\hline Finland & 74,28 & 71,74 & 74,36 & 69,43 & 70,18 \\
\hline Greece & 110,47 & 108,52 & 105,17 & 120,39 & 123,84 \\
\hline Hungary & 72,99 & 77,84 & 75,22 & 69,42 & 77,52 \\
\hline Ireland & 90,91 & 87,02 & 84,11 & 104,16 & 108,85 \\
\hline Poland & 122,16 & 115,42 & 101,08 & 90,16 & 92,64 \\
\hline Portugal & 85,59 & 80,69 & 80,46 & 80,09 & 86,17 \\
\hline Romania & 83,08 & 70,42 & 63,15 & 60,64 & 69,72 \\
\hline Slovakia & 104,34 & 108,59 & 104,97 & 107,65 & 114,13 \\
\hline
\end{tabular}


Table 2. Deposit / loan ratio in selected EU countries (in \%, January, 2006-2010)

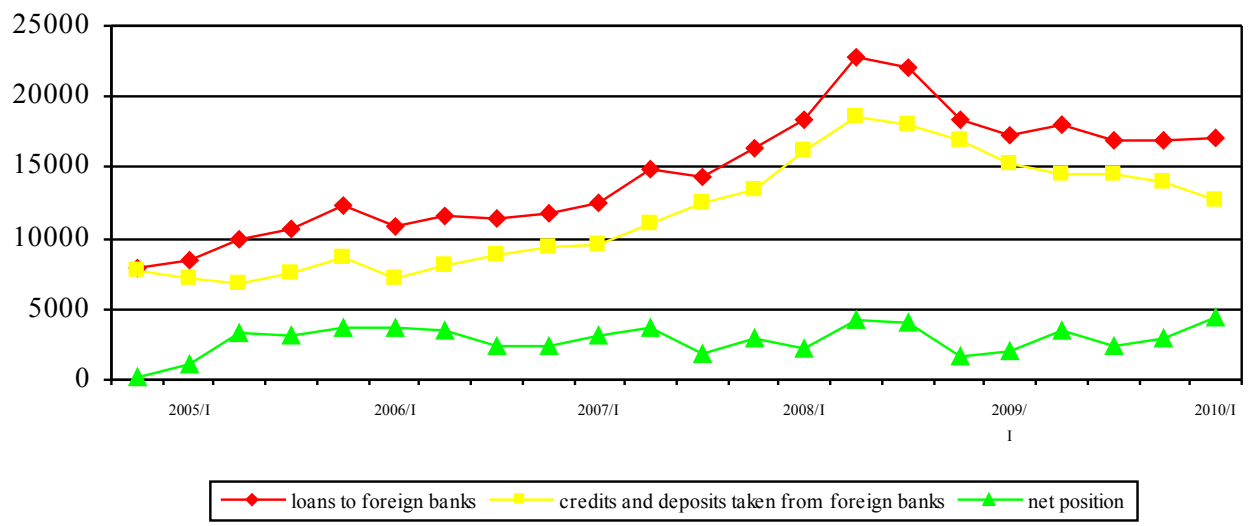

Figure 3. The Czech Republic: net position vis-á-vis foreign banks (2004-2010, mil. EUR) Source: The Czech National Bank

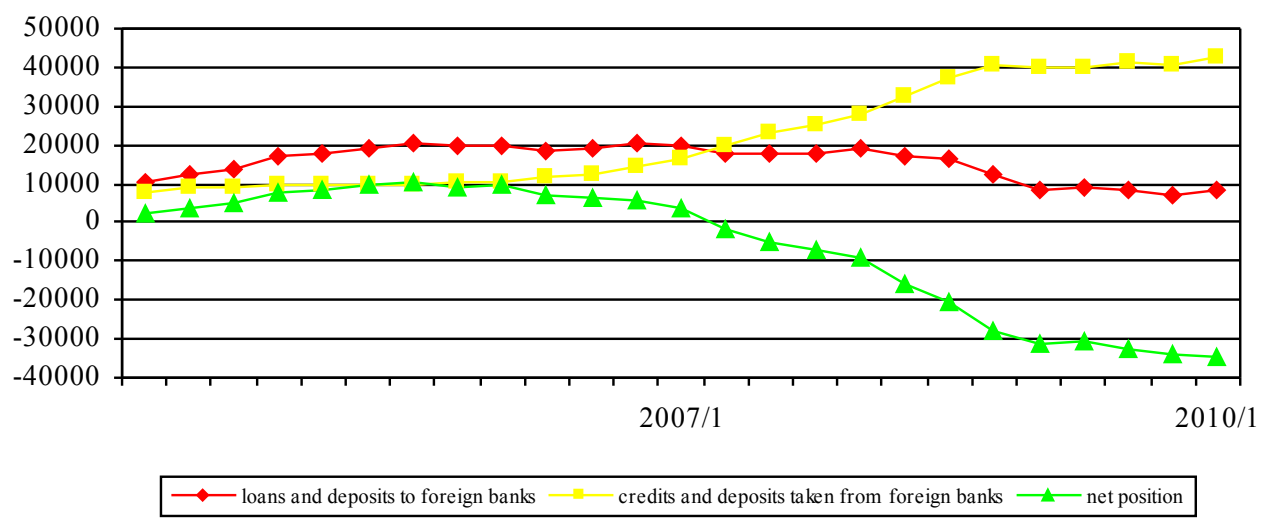

Figure 4. Poland: net position vis-á-vis foreign banks (2004-2010, mil. EUR) Source: The National Bank of Poland

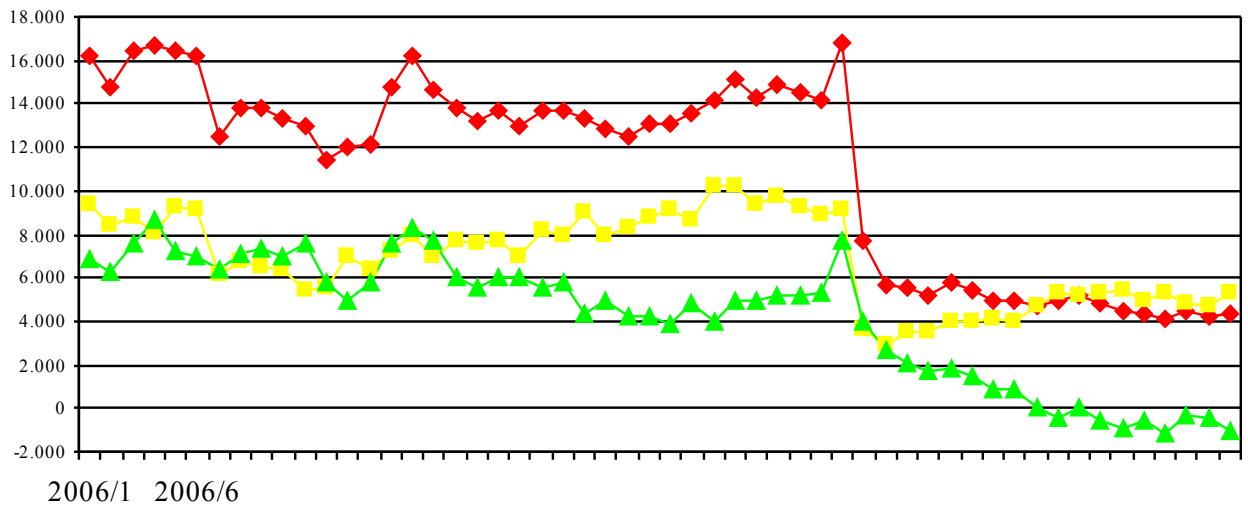

- loans to foreign banks $\longrightarrow$ credits and deposits taken from foreign banks $\longrightarrow$ net position

Figure 5. Slovakia: net position vis-á-vis foreign banks (2006-2010, mil. EUR) Source: The National Bank of Slovakia 
In the Czech Republic MFI loans are growing since 2004; banks started to pay more and more attention to households. While the share of non-financial corporations on credits decreased from more than $70 \%$ at the beginning of 90-ies to 30,75\% (May 2010), during the same period the share of credits to households increased from less than $5 \%$ to $39,02 \%$ (European Central Bank, 2010a). The growth of loans ended in October 2008 but after a two months decline we can see a mild growth of MFI total loans again. In comparison to Slovakia there was a three months decrease in lending for house purchase starting in November 2008 in the Czech Republic and a standstill until now. Most studies argue that a credit boom in central European countries caused growth of asset prices, above all growth of real estates and led to housing price bubble. But in the Czech Republic the size of the housing price overvaluation in $2007 / 2008$ was relatively low, as the rise in property prices in this period was largely explainable by fundamentals (Hlaváček and Komárek, 2009, p. 2).

The Czech Republic is a typical example of a country with mild and short-term impacts of recent financial crisis. The financial (banking) sector remained stable and foreign ownership of banks did not pass contingent difficulties of mother companies on their daughters. Banks became more cautious in risk evaluation of corporations, but loans to households including loans for house purchase are growing. Net position of MFI vis-á-vis foreign banks is stable for the whole period despite of financial crisis. While both loans to foreign banks and credits and deposits taken from foreign banks are growing until the second quarter of 2008, an inverse trend is under way until now (Figure 3).

In Poland financial sector was hit by financial crises very seriously but the impact was quite short. The drop in deposits started in August 2008 and month-by-month decrease finished after 7 months in February 2009. The amount of loans was growing until October 2008 and monthby-month decrease finished already in 4 months in March 2009. In June 2008 another important change happened in Poland: in MFI the amount of deposits started to be lower than the amount of credits. The fact that despite of financial crisis Poland was the only EU country that experienced a permanent GDP growth played an important role in this recovery. In March, 2009 growth of credits to households started based on growing consumption credits and credits to house purchase.

In three Visegrad countries very profitable banking sector became a source of dividends for their foreign owners. Banks also used sources for financing their activities abroad. In Slovakia until the end of 2009 loans to foreign banks were higher than credits and deposits taken from foreign banks. The net position (the difference between deposits taken from foreign banks and loans provided to foreign banks) of banks located in Slovakia changed in the end of 2009 (Figure 5). Permanently growing credits taken from foreign banks and decreasing loans to foreign banks resulted in negative net position starting October 2009. Similar situation appeared in Poland already at the beginning of 2007. In the Czech Republic the surplus of the net position vis-á-vis foreign banks stays for the whole period 2004-2010.

\section{Conclusion}

Most papers are based on an idea that bank lending flows (from advanced countries to the emerging market economies) represented a very important spillover effect of financial crisis and that international banks have been one of the major sources of finance for the catching-up process of the emerging market economies in recent years. Despite of many common features the recent developments have not been homogenous among regions (emerging markets in Asia, Latin America and Central and Eastern Europe) (Hermann and Mihaljek, 2010). Big disparities are among the particular countries in these regions, too.

In three Visegrad countries (Poland, Slovakia and the Czech Republic) that are usually presented as a part of central European countries or central and eastern European countries the sources of their financing from local banks were dominantly local. As comparison of deposits and loans of MFI confirms, as in most EU countries there is for the whole period 2006-2010 
close correlation between loans and deposits of MFI. This is one of main reasons of the stability of financial sector in three Visegrad countries and only mild impact of recent financial crises on their credit areas. The data about various types of credits and credit development do not confirm that firms in the Czech Republic or Romania were more credit constrained than firms in countries like Hungary or Poland because major portions of the banking market are held by the relatively undercapitalized Erste Group and UniCredit Group in comparison with the domestically-owned and well capitalized OTP and PKO (Popov and Udell, 2010, p. 28). At the beginning of the 1990s all former centrally planned countries had inefficient, underdeveloped banking sectors. Foreign banks played a very important role in recapitalizing troubled domestic banks, improving the quality and quantity of financial services, spreading technology and know-how, creating competitive environment in banking industry. Now in all transition countries in Europe banking sector is in hands of foreign capital with no important difference. The share of foreign capital in banking sector was at the end of $200869,2 \%$ in Poland, 81,0 \% in the Czech Republic, 86,4 \% in Hungary and 93,2 \% in Slovakia.

Our data concerning credit area absolutely confirm Gardó and Martin's conclusions. The recent crisis hit much more countries where loan-to-deposit ratio and external debt had been higher. What is important to underpin is that developments have not been homogenous among the countries. Large debt of MFI was not typical for the Czech Republic and Slovakia, depositto-loan ratio was $114,6 \%$ in the Czech Republic and 117,7 \% in Slovakia while it was 91,1\% in Poland (May 2010).

Credit growth in some countries was really elicited with capital inflows (maybe in Poland, but the Polish economy has been permanently growing) but in most countries there is a close relation between deposits and loans. So the growth of loans is above all the result of growing savings - in most countries households as well as companies answered the increasing instability the same way. At the same time the growth of loans is accompanied by serious change in structure of loans in all countries and regions.

The data confirm that stability of financial sector, the stability of banking industry is very high in all three Visegrad countries. Its stability is in close relation to stable development of savings and loans. It is understandable that increase of risks on the market during recent financial crisis influenced behavior of financial institutions. The negative impact on financial stability of financial industry was negligible while the impact on non-financial corporations was not harming nevertheless more serious.

\section{References}

- Barajas and Chami and Cosimano and Hakura, 2010. U.S. Bank Behavior in the Wake of the 2007-2009 Financial Crisis. IMF Working Paper, WP/10/131. IMF, Washington, D.C.

- Debrun and Mathisen, 2010. Europe Moving to Restore Growth and Sustainability. IMF Survey Magazine: Countries \& Regions, May 11.

- European Central Bank, 2010a. Statistical Data Warehouse, http://sdw.ecb.europa.eu/

- European Central Bank, 2010b. The Application of State Aid rules to Government Guarantee Schemes Covering Bank Debt to be Issued after 30 June 2010, http://ec.europa.eu/competition/state_aid/ studies_reports/phase_out_bank_guarantees.pdf

- Gardó and Martin, 2010. The impact of the global economic and financial crisis on central, eastern and south-eastern Europe. A stock-taking exercise. Occasional Paper Series, No. 114 / June 2010. ECB, Frankfurt am Main: 2010.

- Hermann and Mihaljek 2010. The determinants of cross-border bank flows to emerging markets: new empirical evidence on the spread of financial crises. BIS Working Papers, No. 315. BIS, Basel. 
- Hlaváček and Komárek, 2009. Housing Price Bubbles and their Determinants in the Czech Republic and its Regions. Working Paper Series 12/2009. Czech National Bank, Prague.

- NBS, 2010a. Analysis of the Slovak Financial Sector for the Year 2009. 2010. NBS, Bratislava.

- NBS, 2010b. Makroprudenciálna analýza slovenského bankového sektora. Marec 2010. NBS, Bratislava.

- Popov and Udell, 2010. Gross-border Banking and the International Transmission of Financial Distress during the Crisis of 2007-2008. Working Paper Series 1203/June 2010. ECB, Frankfurt. 


\title{
Economic Crisis in Kazakhstan
}

\author{
Abu Mukhammedov, University of International Business, Kazakhstan \\ Madina Kairbekova, Eurasian Market Institute, Russia
}

\begin{abstract}
In the given article the questions of global crisis and its consequences in the Republic of Kazakhstan are opened. It's revealed that influence of the global crisis was rather substantial for the economy of Kazakhstan, that country could avoid some negative phenomena. The questions of passed and current financial system are observed from altered point of view. Also the nuances of oil-producing country are shown from the angle of the global crisis as well as the relations and activity of state institutions as National bank and different funds of well being. The main social and economic events which took place in the country during the crisis and anti-recessionary i.e. stabilization measures taken by the government and some figures of micro economic level as GNP were enumerated.
\end{abstract}

Survey of existing programs of development in Kazakhstan such as "Kazakhstan-2030", , "30 Corporate leaders", "the Program of entering into the fifty advanced countries of the world", "5 Greater affairs" given in brief as programs that partially have not met the expectations yet on the way of performance. And the continuation of searches of a new program like the last strategy of the forced industrial development is viewed.

The seven main priorities of disaffiliation with crisis are opened to discussion as questions of Ways out for Kazakhstan from the economic crisis.

The content of a new economic notion the "Road map" is opened as the later program of the Kazakhstan government. Possible variants of development in the near future for Kazakhstan that could continue to face with a significant complex of risks and probable and possible ways of its further structural reorganization, including in a context of strengthening of influence of external players are taken up.

What is so called 'post-crisis period', what it can be for Kazakhstan as for the globe in a way - that are the questions of the article.

\section{JEL Codes: H12}

First signs of a serious economic crisis in Kazakhstan fall to the second half of 2007. At that time analysts had already predicted that because of crisis of the insurance companies in the USA, practically everyone will declare the moratorium on delivery of mortgage credits during uncertain time, and that in these conditions, who has greater resources on service of corporate sector that will survive. Leaders of retail business can lose almost half of their share. Thus very few people have paid attention to the report of rating agencies.

Moody's report published on August, 15th marks, that "increase of rates in the international debt markets for the long period can complicate refinancing for the Kazakhstan banks involving means abroad". According to Moody's on the end of the first half-year the external debt of the Kazakhstan banks made $\$ 40,7$ billion, or it is more than half of all available obligations. At the same time the agency predicted, if conditions in the global debt markets will worsen considerably and for a long time, and banks will not undertake adequate measures for corresponding management of liquidity, ratings of some banks can appear under negative pressure.

The banking sector of republic which within last several years used not quite absolutely adequate to realities strategy of development focused on external loans and speculative hyper crediting of the population and separate branches of economy began to test especially deep problems. In conditions of absence of access to sources of external loans and preservations of the highest level of external debts, the majority of the Kazakhstan banks has been compelled to reduce strongly the target activity, to optimize directions of activity 
that has caused reduction of crediting of economy and the population with appropriate consequences.

Reduction of external funding volumes has negatively affected on ability of banks to give new credits to borrowers, and promoted decrease in rates of crediting the economy. Necessity of payment and refinancing of large external debts have actually compelled banks with a high degree of debts to reorientation of the activity to service of an external debt. Moreover the demand of the population and economic subjects to the bank products has fallen in view of increase of interest rates and additional payments, and also reduction of depositary base is traced gradual. It was especially strongly observed the further reduction in demand for mortgage crediting in retail sector and the limited demand for consumer crediting. Considering absence of access to external loans, banks have appeared in an original trap of liquidity. For this reason the state has started rendering the purposeful help to the banking sector of the republic which otherwise could face with the facts of separate defaults and bankruptcies. Entering of the state into a number of banks, such as «BTA bank» and «the Alliance Bank», has allowed guaranteeing realization of their obligations and more effective support of economy from their side. At the same time a significant part of the financial assets of support allocated by the state, as a matter of fact, have been used for repayment of their external debts and "have left" the country, and a number of investors has started to consider it as latent "nationalization".

Kazakhstan is one of the first countries which started practical realization of the strategy of the state support of national economy. In difference from some of the states of the world, development of anti-recessionary measures which took long enough time, the country leaders in the middle of the last year autumn has already presented the scale plan of assistance to economy, focused on some directions most strongly touched by economic crisis.

In the accepted joint plan of the Government, National bank and the Agency on regulation and supervision of the financial market and financial organizations (FCA) the volume of stabilization measures has reached 2,17 billion tenge or $\$ 14,5$ billion. The mainframe financed from means of National fund assumes five blocks: stabilization of financial sector; support of housing sector and the mortgage; support of small and average business; development of agro industrial sector; realization of innovative, industrial and infrastructural projects.

Due to decrease by National bank the rates of reservation banks of the second level increase resource base by 350 billion tenge, reduction in tax loading liberates 500 billion tenge for business. Alongside with this the Fund of stressful actives in volume 122 billion tenge will be created. Within 2009-2010 additional financial support at a rate of 600 billion tenge, or $\$ 4$ billion which means reorientation of incomes of raw sector of economy to realization of the expanded stabilization measures, first of all, in bank sector is allocated.

It is indicative, that as a whole the total amount of the state anti-recessionary measures for two years can achieve the volume of $\$ 23-25$ billion, that in relation to volume of GNP is one of the highest parameters in the world. For comparison, Russia directs on antirecessionary measures of $12 \%$ of GNP, and the USA - about $10 \%$. Acceptance of these measures and their practical embodiment has allowed avoiding a collapse of bank system and also purposefully supporting stability of building sector, small and average business spheres.

The key factor which has caused display of negative economic processes is sharp deterioration of a current situation in the export markets, first of all fuel-raw. Considering preservation of dependence of the Kazakhstan economy from receipts of export of hydro carbonic raw material, falling of demand for crude oil and mineral oil on foreign markets on almost 3,5-fold depreciation of oil cost has seriously worsened trading balance of the republic, and also has led to reduction export and tax revenues into the state budget.

Kazakhstan has faced now with a challenge the decision of which it delayed long enough, namely - this is necessity of development of the real sector of economy, independent on fluctuations of the prices for raw material and creating the high value added cost. Fall of oil 
cost and production of mining and smelting sector should become that impulse which will start process viable diversification, despite of crisis.

Everything has led to that authorities of Kazakhstan who hidden the whole year a real state of affairs, at last, have recognized presence of an economic crisis in the country, and quickly started to degreasing National fund means operated by the government by the "Fund of national well-being" Samruk Kazyna" incorporated in joint-stock company on stabilization measures. The fund obtained $\$ 10$ billion in addition $\$ 5$ billion which have been divided between National bank ( $\$ 4$ billion) and «The Fund of, so-called, stressful actives» ( $\$ 1$ billion), which were created ostensibly for the repayment at a discount problem actives of banks of the second level. Then, after the announcement of one more, most likely, the virtual sum at a rate of $\$ 5$ billion, there and then followed the offer to the system formative banks about the repayment at them $25 \%$ of voting shares.

During the struggle against crisis in Kazakhstan a priority was to support of such spheres, as bank sector, an available housing, small and average business, and keeping on afloat the agro-industrial sector. Distribution of the means allocated by the state for stabilization of economy (4 billion US dollars) has been distributed in the ratio 4:1:1:1.

On underdeveloped branches of SME and agrarian sector have started to give out money because of all growing unemployment because of almost $40 \%$ of the active population are occupied in these branches.

Presence of set of existing programs of development in Kazakhstan: "Kazakhstan-2030", "Development of Kazakhstan till 2020", "30 Corporate leaders", "the Program of entering into the fifty advanced countries of the world, "5 Greater affairs" have not found the expected response and now passing to last strategy of the forced industrial development.

After crisis period (if it is possible to name «post crisis time») begins for Kazakhstan with an intensive industrialization. Having named the nearest years as the first five-year period of the state program of the forced industrially-innovative development, the state expects to smooth down that all those newly appeared defects which have come to light during global financial crisis. It is possible to judge them on all to the same priority directions of development of a five-year period.

The first priority of this program - is the development of agriculture and agro processing. Transition from prime slogans by several years earlier from diversification the industries before development agro processing for today is swept up. One of the factors for becoming by a paramount problem is development of agrarian and industrial complex there was an unknown crop nearby 21 million tons of grain and leguminous cultures in 2009.

Following priority - is the development of the building industry and manufacture of building materials. Plans by the end of a five-year period on $80 \%$ to provide needs of the market are quite real, by the truth be required introduction of new capacities.

The third priority - development of oil refining and an infrastructure oil-and-gas sector. Maintenance of the country with gasoline and kerosene completely domestic oil refining factories. Here the role should be played by "KazMunayGaz", stimulating and Chinese shareholders of oil processing factories (OPF) to increase in processing of crude oil. The accelerated development of oil-and-gas sphere basically will depend on development and escalating of potential since 2013 of deposit Kashagan.

Following problem - is the development of metallurgy and manufacture of ready metal products. That's it here, as it will be possible to analyze much on the last years will be depend on the price for a product. Doubling of volume of manufacture and export of production of an iron and steel industry is improbable, even at a good conjuncture in the market and persevering work with managers of the company.

The fifth and sixth priority - is the acceleration of development of the chemical, pharmaceutical and defense industry, development of power, mainly clean. Maintenance of 
more than $50 \%$ of internal consumption of medical products due to a domestic production is quite real in connection with created manufactures at present and expansion of available capacities of the enterprises. Reduction of energy consuming of the country on $10 \%$ by 2015 realize due to introduction of acts for transition to energy supplying.

The seventh priority - development of a transport and telecommunication infrastructure. Transport corridors and the transport units are necessary for reduction of costs, the second ones are available for us and will be modernized (creation of the logistical centers), only good transport infrastructure is necessary for increase in connectivity of regions. Escalating of telecommunication occurs quickly enough, but a lot of operators for creation of a certain competition among them are necessary.

At present the "Road map" program appears the most realistic. Having proved in the past year as the good mechanism for maintenance of the population with temporary work simultaneously hides real unemployment in the country. Providing the amount of 250 thousand person workplaces with the salary of 28 thousand tenge, the people majority from which go on repair works. "Road map" will organize retraining the specialists. During the crisis this program allows to concern not so is critical activity of the government as there is no mass unemployment of the population.

Combining 2 programs of development of the country for 2010 and later, it is possible to reveal following laws:

- In the state obviously there is an opportunity of increasing the number of unemployment, that's why the program "Road map" is realized and new working places on the basis of agrarian and industrial complex are created;

- The post crisis period will smooth out passage of "Road map" and slogans about the forced industrial development;

- Formation of the banking sector, metallurgy, oil-and-gas, chemical industries and other branches will strongly depend on current changes in global economy;

The more quickly there will take place the adaptation to the Customs union of our country the more parameters under all economic characteristics on results will be better to the end of the year.

There are some more variants of one way out for Kazakhstan from the economic crisis. So, one of them assumes, that refinancing earlier given out credits for the same conditions, but for longer periods will allow to avoid many problems. But thus there are also pessimistic forecasts that because of falling many mining branch enterprises there will be not just a stagnation of economy, but the most natural default. That is why there is no reason to expect any positive moments within 2-3 years yet.

Following variant of rescue from all-consuming crisis connected with the new program of development of the United States, in connection with a victory of the candidate over Democratic Party of Barrack Obama. There is also such opinion, that Kazakhstan will be helped by China. Probably, the same China in a neighbour's way will really rescue Kazakhstan, having allocated in addition more two-three tens of billions of dollars.

In the near future the bank sector of Kazakhstan will continue to face with a significant complex of risks which, certainly, will lead to its further structural reorganization, including in a context of strengthening of influence of external players. However the main result should be revision of long-term strategy of development of banks which should be guided by internal resources of the population and the national economy, instead of on external loans which though promote the accelerated capitalization, but simultaneously carry in it uncontrollable challenges.

\section{References}

- Statistical collection of the Republic of Kazakhstan for 2008-2010 


\title{
The Present Global Crisis and Its Effect on the Turkish Economy
}

\author{
Özlen Hiç Birol, Boğaziçi University
}

\begin{abstract}
The global economic crisis first started in the USA in September 2008 as a widespread insolvency problem caused by mortgage debts of households that had become unpayable. The financial crisis, in turn, caused a serious recession. The economic crisis soon spread to other developed countries because their banks held assets of US banks that had become nearly worthless while exports of these countries to the USA decreased significantly. Then it spread to developing countries because direct private investments (DPIs) and financial funds flowing from developed to developing countries declined precipitously while exports of the latter to the former countries also fell down. The developed countries, however, took proper steps to ameliorate the crisis by lowering the interest rates, helping the insolvent banks financially as wel as launching public expenditure programmes. Turkey was one of the worst hit countries because she had been following wrong globalization strategies. Privatization process was corrupt while much of the DPIs went to those fields which did not yield much increase in employment or export potential. But most importantly, Turkey had raised interest rates to abnormally high levels and thereby had vastly expanded her internal and external debts. Hence, as a result of the global economic crises, Turkey suffered a significantly deep fall in her GNP growth rate and a very big increase in her unemployment rate. Though Turkey took several measures to ameliorate the balance of payments deficit and to expand total demand, hence production, the government refrained from making a stand-by agreement with the IMF in order to avoid strict discipline in her government expenditures due to first, local elections and presently, the coming parliamentary elections.
\end{abstract}

JEL Codes: P50, P51

\section{The Present Global Economic Crisis}

The present global financial crisis and global recession emanated in the USA first. The generally accepted date is September 2008 when two giant mortgage firms, Freddie Mac and Fannie Mae faced bankruptcy, followed by American Insurance Group (AIG) and all three received immediate, financial help from the American Treasury with partial nationalization as the quickest way of saving them. Since Lehman Brothers, on the other hand, had breached financial regulations, the government could not move to support it, hence Lehman Bros. went bankrupt. These events proved that the American financial sector faced a deep "insolvency" crisis on account of unpayable mortgage debts of households. These mortgage debts were called "toxic assets" because their presence invalidated the solvency of the financial firms dealing in mortgage credits (mortgage banks). But since the bonds as well as derivatives of mortgage banks were held in the hands of other financial institutions, that is, hedge funds, commercial banks as well as investment banks, the entire American financial sector was drawn into insolvency and crisis.

The mortgage crisis arose because of a number of reasons. One reason was that in order to keep the financial sector as "flexible" as possible, during the Reagan administration (19811989) it was largely deregulated. Secondly, real estate prices were rising continuously during the ' 90 s. This prompted households to increase their mortgage debts, relying on the price rises. They also increased their personal consumption and decreased their personal savings. The mortgage banks, on the other hand, were happy to oblige this demand because it increased their profitability on paper in spite of the fact that a great portion of mortgage debts were to become bad debts. The fall in the prices of real estate in the later years since 1996 changed the entire climate. "Illiquidity" problems in the financial sector had arisen in September 2007 but turned 
into a deep crisis of insolvency by September 2008.

To avoid or otherwise ameliorate the financial crisis, the American Treasury acted swiftly first with partial nationalization, then with an appropriation of a $\$ 700 \mathrm{bn}$. fund, called "Troubled Assets Relief Program" (TARP) to aid financial firms and banks facing illiquidity or insolvency problems on account of bad mortgage debts. FED, in addition, lowered the interest rate considerably in order ease the lending of banks. Furthermore, the FED fund that supports interbank credits was also raised.

In the later years, The US Treasury refrained from partial nationalization of banks and instead increased the equivalent of TARP to $\$ 2$ trillion. Furthermore, banks were subjected to the so-called "stress tests" which investigated the financial strength of banks under simulated adverse economic conditions. Despite these radical measures nearly 200 banks went bankrupt.

The financial crisis also gave rise to a serious recession in the real sectors of the American economy. Therefore, measures were taken by the government, which were Keynesian in essence, to prevent or otherwise ameliorate the recession. The monetary measure was the fall in the interest rate which was to encourage or otherwise prevent a deeper fall in private investments as well as consumption credits, hence private consumption expenditures.

The Treasury, on the other hand, appropriated a considerably large amount of funds for expanding government investment and consumption expenditures to compensate the fall in private expenditures, partially if not fully. The items were selected in accordance with the needs of the economy at the time and included clean energy, social and productive infrastructure as well as health care.

Furthermore, also along Keynesian lines, personal taxes were lowered, particularly those falling on low and mid-income households in order to raise disposable household income, hence private consumption.

All the real sectors of the economy were hit hard by the recession, foremost the automotive sector, following the real estate and construction sector that had been at the center of the economic crisis. But since the automotive sector entails a large area of related sub-sectors, hence employment, the US government decided to lend aid to the two ailing American auto firms, the GM and Chrysler. The government demanded the GM to undertake the right steps of restructuring and also to lower its labor costs. Chrysler was demanded to go ahead with plans to be sold to a foreign company.

The financial crisis as well as the recession spread to other developed countries including the European countries as well as Japan, again because of a number of reasons. Many banks of other developed countries held the bonds, shares and derivatives of American financial institutions which had become nearly worthless, thus leading to financial crises in these countries also. In the second round, both the financial crisis and the decreased exports to the USA gave rise to recession.

The developed countries and the EU fought the financial crisis and recession with measures similar to those undertaken by the USA government and FED. Namely, both national central banks as well as the European Central Bank, the latter with a slight lag, decreased the interest rate. The respective treasuries, on the other hand, partly nationalized banks, mostly lent aid to the illiquid or insolvent banks while also organizing a program of their own to increase government investment and consumption expenditures. They also aided their automotive sector by encouraging and subsidizing sales of new cars to replace old cars.

The economic crisis also hit the developing countries of all levels, including the newly "emerging markets", generally causing balance of payments and recession problems. Firstly, the flow of foreign private capital (DPIs: direct private investments) as well as financial funds (bank credits) from developed countries fell down precipitously. Secondly, most of these countries direct their exports to developed countries. But because the developed countries were in recession, their imports, that is, their demand for exports from less developed countries showed a considerable decline. 
A limited number of countries, however, suffered only slightly from the economic crisis. The list included foremost China which had benefited largely from globalization and flow of direct investments, hence had increased her growth rate and employment level as well as foreign exchange reserves. China was de facto away from socialist central planning and was implementing a mixed economy which accepts private investments and encouragement of direct private investment flows, as well as an open economy model. The second country which did not face a serious crisis was Brazil. The center-left government in Brazil had implemented pragmatic economic policies and had a sound balance of payments as well as budget performance. The third country was India, which did not rely much on exports but on software demand coming particularly from the USA. India had a relatively large mass of engineers working at low salaries compared to the US.

Because all countries cooperated and took the right kind of economic measures, the economic crisis and recession, though very deep, was prevented from developing into a deep depression. For cooperation, G20 rather than G8 was chosen because it included a much larger number of economically important countries, including Brazil, China, India as well as Turkey. Furthermore, the funds at the disposal of IMF were also raised considerably. It will definitely take a long time for the world to move back to normal and in the meanwhile many countries could face serious economic problems. The list includes Greece as well as other small European countries with fragile economies. But, the USA and GB would also be facing long term problems of budget deficits as well as external debt payments. Therefore, though recovery is on the way, it will not be a smooth swift ride back to normalcy. But, over time, market economy and globalization looks likely to prevail rather than reverting to closed economy models and French type of "dirigisme".

\section{The Effects of the Global Crisis on the Turkish Economy}

Turkey was one of the middle-income developing countries, or one of the "emerging markets" worst hit by the global economic crisis, despite denials to the contrary by the government circles. The reason was simple: While the governments of countries like China, Brazil and India had implemented correct globalization strategies that relied on their economic conditions, the Turkish government had followed wrong globalization strategies that left the Turkish economy in a very vulnerable position when the global economic crisis broke out. The only favorable factor was the relative strength of the Turkish banking sector. Following the 1998/1999 and 2001 economic crises and in accordance with the stipulations of the IMF standby agreement, the Turkish government at the time had taken radical steps to strengthen the private banks by means of raising their capital ratio and the ratio of their liquid assets as well as by strictly controlling the credits lent by the banks to the firms owned by the owner of these banks. In addition, Turkish banks cannot hold derivatives of US or European banks, hence did not face the problem faced by the European banks. But otherwise, Turkish economy was vulnerable. Since 2002, in accordance with market economy and stipulations of the IMF standby, the government had pursued programs of privatization as well as encouragement of direct private investments. These policies were certainly in the right direction, but they were wrongly implemented. For instance, privatization was carried on without taking effective steps to reemploy in other sectors the excess personnel the public enterprises employed which the new private owner had to shed. In addition, rumors always arose concerning corruption and partisanship displayed during the privatizations, thus causing considerable loss of government revenue. Secondly, direct private investments were allowed to enter many fields which did not yield an increase in exports, neither in employment. Most private capital that had flown to Turkey was interested in transferring profits back. But the gravest mistake was raising the interest rate to abnormally high levels (above \%20 in nominal and about $10 \%$ in real terms) in order to attract the flow of short and long term external credit. As a result, the total external and internal debt of Turkey increased by about $100 \%$ in between the years 2002 and 2008 . These credits went to the government, municipalities, public banks, private banks as well as private 
firms. Thus, the yearly back payments of credit plus interest to be paid rose very significantly. Moreover, most of the credit thus received was channeled to infra-structural investments by the government and the municipalities hence did not much raise future exports. Such a large flow of foreign exchange in the form of increased financial flows as well as direct private investments artificially lowered the value of the dollar and other foreign exchange currencies. The effect of overvalued TL and under-valued foreign exchange, in turn, was to lower the domestic support prices of Turkish agricultural products. Since the price of basic materials and inputs used, in particular, the price of fuel was raised on account of ever increasing indirect taxes, agricultural production became unprofitable. Hence, during the period 2002-2008 agricultural employment decreased by about 1.5 million while the total absolute level of agricultural production also decreased. This was only slightly compensated by employment rises in other sectors. Thus, during the said period, Turkey experienced a GNP growth accompanied by a slightly rising unemployment rate.

When the global economic crisis broke out, Turkey's exports as well as the flow of external credits and direct private investments fell significantly. Therefore, Turkey had to lower its imports considerably as well. This, in turn, caused investments and production, i.e. GNP to decline because both rely on imported materials and goods.

The Turkish government took several measures to ameliorate the balance of payments difficulties and encourage the growth of production. One such measure was to seek new countries to direct Turkey's exports, other than the EU. These included Russia as well as many Islamic Middle Eastern and African countries. Another measure was to waive the indirect taxes on real estate, the automotive and the whites for a definitive period. Still another measure taken this time by the Turkish Central Bank was to gradually lower down the interest rate.

But the Turkish government deliberately refrained from entering a stand-by agreement with the IMF, declaring they did not need such a support. The fact, however, was that Turkey was going to face general local elections on March 2009 and the government did not want any restrictions on the government and municipality expenditures it would be making before the elections. Negotiations with the IMF were stalled once more in 2010, this time because general parliamentary elections are to be held on July 2011. The IMF had demanded from Turkey discipline in total public expenditures, not only in the government budget but also in the municipalities, public enterprises and other public spending institutions.

Therefore, the effects of the global economic crisis on the Turkish economy were, in fact, very severe. For instance, by November 2009 the ratio of total employment in Turkey had risen to $22 \%$. Of this, $13.6 \%$ were those properly under the category of unemployed because they had applied for work but could not find jobs. 8.4\%, on the other hand, had given up looking for work, hence were nominally under the category of "voluntary" unemployment. By 2007 the rate of growth of GNP had already gone down to 4,6\%. In 2008 Turkey experienced a very big negative growth rate: $-6.5 \%$. In the 3 rd quarter of 2009 , the rate was further down to $-8.4 \%$, but along with relative improvements in the world scene, the Turkish economy started to pick up again by 2010 . Had Turkey, however, gone into an agreement with the IMF she would not have faced such grave falls in the GNP growth rate and increases in unemployment rate, and would have recovered sooner.

\section{Conclusions}

At the time of writing this article, global events still continue to progress. Nonetheless, even at this stage, we may make several observations and draw several conclusions from what has occurred thus far, concerning the global economic crisis, as follows:

- First, broadly speaking, the world has indeed become globalized economically and despite the severe economic crisis faced, it looks certain that globalization will continue; there would be no return to closed economy models. 
- Secondly, the developed counties ameliorated the recession they faced, taking strictly Keynesian macroeconomic monetary and fiscal policies. There should not be, however, a shift to dirigisme, interventionism and protectionism, excepting France.

- Thirdly, it looks as if the adverse long-run effects of the economic crisis and measures taken to eliminate or ameliorate it will continue for a long time. USA would be struggling with a big external debt burden and a large balance of payments deficit; similarly the UK. The EU countries, on the whole, look as if it would take them longer to get out of stagnation, excepting Germany. The less financially disciplined countries in the EU, such as Greece and Southern Europe, make the recovery of EU (and the Euro) still more difficult.

- As many economists observed, some "decoupling" has actually occurred; China, India and Brazil, in particular, rose very fast to healthier economic standing compared to and despite the USA and EU. But, their performance does not seem enough to trigger the rest of the world significantly. The world economy still relies heavily on the robustness of the USA economy plus that of the EU.

Concerning the Turkish economy, on the other hand, the following observations and conclusions can be drawn:

Turkey was severely hit from the global economic crisis because she had implemented wrong economic strategies or otherwise implemented the right globalization strategies wrongly. But immediately following the crises, the Turkish Central Bank corrected its interest rate policy. This reversal plus a strong Turkish banking sector soon took hold. Thus, a deep dive down is about to be compensated completely by now with a fast rise despite the fact that the Turkish government had declined from making stand-by agreement with the IMF.

Has Turkey made a stand-by agreement promptly, the recovery could have surely been even faster, but at least the recovery is nearly complete by now. This is also a result of the "dynamism" of the Turkish economy and the people.

But more correct economic and international policies by the Turkish government can raise the growth rate to even higher levels. These policies include more proper DPI polies, more emphasis on production and exports, elimination of corruption and partisanship, stronger political and economic ties with the USA and the EU.

\section{References}

- Friedman, Thomas L. 2006. The World is Flat. Farrer, Strauss and Gireaux, New York.

- Hiç, Mükerrem (2009) Küresel Ekonomik Kriz ve Türkiye, Beykent Üniv., İstanbul.

- Krugman, Paul, http://www.newsweek.com/search.html?q=paul+krugman

- Rodrik, Dani, 1997. The New Global Economy and Developing Countries: Making Openness Work. Overseas Development Council, Washington D.C., John Hopkins Univ., Press.

- Stiglitz, Joseph E. (2003) Globalization and Its Discontents, W.W. Warton Co., New York.

- UN, Statistics Division 2006 and on, National Account Database, http://unstats.un.org/unsd/snaama/Introduction.asp

- Professional Reviews, Periodicals and Newspapers (for following world news concerning the economic crisis; as well as commentaries by distinguished experts, including N.Roubini, J. Stiglitz, P.Krugman, and directors of IMF, WB and ECB). 


\title{
Sektörel Büyüme Oranları Arasındaki Karşılıklı İlişki
}

\author{
İsmail Önden, Okan University, Turkey \\ Bilal Özer, Okan University, Turkey \\ Alper Karaağaç, Okan University, Turkey
}

\begin{abstract}
Interrelation Between Sectoral Growth Rates

The concept of globalization has arisen from a combination of those developments together with certain political and cultural issues. Economically the term globalization refers to the decrease of borders between states since goods and services, capital, and labour flows from one state to each other easily. This flow makes economic sectors and markets more integrated to each other, and as a result the interaction between them gains significance.

With the emergence of the globalization process, commercial borders such as tariffs, restrictions and heavy duties have been cut out or lightened, since the new integrated economic system requires the borderless flow of factors of production. In such a globalized economic system, the growth or contraction of a specific sector in one country can have an effect on another, since markets are inter-connected and world trade is at its highest levels. Similarly, financial crises affect different sectors of different countries at changing levels, as in the case of the recent world financial crisis.

Within this context the aim of this study is to observe in what degree the global sectors are in interaction with each other. The first part of the study is constituted of specifying the sectors that are going to be observed such as agriculture, manufacturing, services and finance. Secondary and quantitative sectoral data of the major world economic powers and Turkey have been collected. In the next step the classified sectoral data for different countries or country groups is compared and analyzed to represent the sectoral interaction.
\end{abstract}

JEL codes: F20

\section{Giriş}

Dünya çapında iletişim, mevcut firsatların sürekli olarak göz önünde olmasını ve işleri geliştirmeyi sağlamakta, yaşam standartlarını yükseltmektedir. (Levitt, 1993) Uluslararası yayınların çoğu küreselleşme ve uluslararası ticaretin özgürleştirilmesi konusunu destekler niteliktedir, ancak bu durumu sorgulayan (Rodrik, 1997) gibi yayınlar da bulunmaktadır. Ortaya çıkan bu firsatların dünya ekonomilerini birbirlerine yakınlaştıracağı, ülkeler arası ticaret hacmini arttıracağı da bu durumun doğal bir sonucudur.

Artan ticaret hacmi ve yakınlaşan ekonomilerin, dünya ekonomilerinin tepkilere karşı ortak hareket etmeleri sonucunu doğurması beklenir. Çalışma, ülke ekonomilerinin sektörleri bazında bu etkileşimin ne boyutta olduğunu göstermeyi amaçlamaktadır. Bu amaç çerçevesinde ülke tarım ve üretim sektörlerinin katma değerinin yıllık büyümesi ve gayrisafi yurt için hasılasının oranı belirlenmiş ve karşılaştırılmıştır. Bu analize ek olarak, ülkelerin makro göstergelerinden olan yıllık enflasyon, gayrisafi yurtiçi hasıla büyümeleri de ekonomilerin genel olarak nasıl bir seyir izlediğinin belirlenmesi için çalışmada yer almıştır. Çalışma 2005 - 2007 yılları arasındaki ekonomik göstergelere dayanılarak hazırlanmıştır ve küresel krizin öncesindeki veriler dikkate alınarak çalışma gerçekleştirilmiştir.

\section{Metodoloji}

Çalışma ülke sektörlerin birbirleri ile doğru orantılı şekilde hareket edip etmediklerini test etmeyi amaçlamaktadır. Bu bağlamda ilk aşama olarak test edilecek sektörler, ekonomik 
göstergeler ve analiz edilecek ülke ekonomileri olarak Rusya, Türkiye, ABD, Fransa ve Almanya seçilmiştir. Ardından bu ülkelere ait verilerin araştırılması aşamasına geçilmiş ve ilgili veri tabanları taranmıştır. Verilerin temin edilișinden sonra ise ülkelerin sektörleri ve ekonomik göstergelerini baz alan grafikler çizilmiștir. Grafiklerdeki değișim trendleri gözlenerek sektörler ve temel ekonomik göstergeler arasındaki ilişkiler tespit edilmeye çalışılmıştır. Grafiklere göre bir sonuçlar elde edilmiş ve yorumlamalar yapılmıştır ve ileri çalışmalar planlanmıştır.

\section{Veri}

Çalışmada 5 ülke baz alınmıştır. Bu ülkeler, Amerika Birleşik Devletleri, Almanya, Fransa, Rusya ve Türkiye'dir. Amerika Birleşik Devletlerinin seçilme nedeni dünyanın en büyük ekonomisi ve ithalatçısı olmasıdır. Almanya ve Fransa, Avrupa ekonomilerini temsil etmektedir. Rusya, sahip olduğu hidrokarbon rezervi nedeni ile çalışmaya eklenmiştir. Türkiye ise enerji geçiş güzergahında olması nedeni ile stratejik konumu ve gelişen ekonomisi ile gelişen ekonomileri temsil edeceği düşüncesi ile çalışmaya dahil edilmiştir.

Çalışmada tarım ve üretim sektörleri dikkate alınmıştır. Bu sektörlerin seçilmesinin nedeni ekonomilerin gelişmişlik seviyelerinin ölçülmesinde kullanılan verilerin kaynağı olmalarıdır. Genel olarak ekonomik iklimin belirlenmesi için ise enflasyon, gayrisafi yurtiçi hasılanın yıllık büyümesi, ihracat ve ithalatın gayrisafi milli hasılaya oranları seçilmiştir.

\begin{tabular}{|c|c|c|c|c|c|}
\hline Country & Indicator Name & 2005 & 2006 & 2007 & $8^{200}$ \\
\hline \multirow[t]{4}{*}{ United States } & $\begin{array}{l}\text { Inflation, consumer } \\
\text { prices (annual \%) }\end{array}$ & 3,3927468 & 3,2259441 & 2,852672 & 3,8391 \\
\hline & $\begin{array}{c}\text { GDP growth (annual } \\
\% \text { ) }\end{array}$ & 2,9443048 & 2,7787175 & 2,023024 & 0,4 \\
\hline & $\begin{array}{l}\text { Exports of goods and } \\
\text { services (\% of GDP) }\end{array}$ & 10,607323 & 11,289597 & 12,09757 & \\
\hline & $\begin{array}{l}\text { Imports of goods and } \\
\text { services (\% of GDP) }\end{array}$ & 16,378871 & 17,063241 & 17,24836 & \\
\hline \multirow[t]{4}{*}{ France } & $\begin{array}{l}\text { Inflation, consumer } \\
\text { prices (annual \%) }\end{array}$ & 1,8115942 & 1,6014235 & 1,526562 & 2,8124 \\
\hline & $\begin{array}{l}\text { GDP growth (annual } \\
\% \text { ) }\end{array}$ & 1,8959915 & 2,2168177 & 2,324206 & 0,4291 \\
\hline & $\begin{array}{l}\text { Exports of goods and } \\
\text { services (\% of GDP) }\end{array}$ & 26,057085 & 26,740084 & 26,51134 & 26,439 \\
\hline & $\begin{array}{l}\text { Imports of goods and } \\
\text { services (\% of GDP) }\end{array}$ & 26,919102 & 28,041269 & 28,37712 & 28,913 \\
\hline \multirow[t]{4}{*}{ Germany } & $\begin{array}{l}\text { Inflation, consumer } \\
\text { prices (annual \%) }\end{array}$ & 1,5572106 & 1,575 & 2,288949 & 2,6307 \\
\hline & $\begin{array}{l}\text { GDP growth (annual } \\
\% \text { ) }\end{array}$ & 0,7726941 & 2,9603004 & 2,46041 & 1,2697 \\
\hline & $\begin{array}{l}\text { Exports of goods and } \\
\text { services (\% of GDP) }\end{array}$ & 41,07525 & 45,347405 & 46,93508 & 47,244 \\
\hline & $\begin{array}{l}\text { Imports of goods and } \\
\text { services (\% of GDP) }\end{array}$ & 35,74581 & 39,682102 & 39,87866 & 41,044 \\
\hline \multirow[t]{3}{*}{ Turkey } & $\begin{array}{l}\text { Inflation, consumer } \\
\text { prices (annual \%) }\end{array}$ & 10,138405 & 10,510977 & $1^{8,75618}$ & $44^{10,4}$ \\
\hline & $\begin{array}{cc}\text { GDP } \\
(\text { annual \%) }\end{array} \quad$ growth & 8,4016175 & 6,893489 & $9^{4,66857}$ & $8^{0,89}$ \\
\hline & $\begin{array}{l}\text { Exports of goods } \\
\text { and services }(\% \text { of }\end{array}$ & 21,855376 & 22,669907 & $4^{22,3232}$ & $19^{23,9}$ \\
\hline
\end{tabular}




\begin{tabular}{|c|l|c|c|c|c|}
\hline & GDP) & & & & \\
\hline & $\begin{array}{c}\text { Imports of goods and } \\
\text { services (\% of GDP) }\end{array}$ & 25,351504 & 27,58105 & 27,48387 & 28,354 \\
\hline Russia & $\begin{array}{c}\text { Inflation, consumer } \\
\text { prices (annual \%) }\end{array}$ & 12,68334 & 9,6787651 & 9,007227 & 14,108 \\
\hline & $\begin{array}{c}\text { GDP growth (annual } \\
\text { \%) }\end{array}$ & 6,4 & 7,7 & 8,1 & 5,6 \\
\hline & $\begin{array}{c}\text { Exports of goods and } \\
\text { services (\% of GDP) }\end{array}$ & 35,177615 & 33,747654 & 30,33064 & 30,822 \\
\hline & $\begin{array}{c}\text { Imports of goods and } \\
\text { services (\% of GDP) }\end{array}$ & 21,494631 & 21,025889 & 21,71125 & 21,977 \\
\hline
\end{tabular}

Tablo1: Ülkelerin makro ekonomik verileri (World Bank, 2010)

\begin{tabular}{|c|c|c|c|c|c|}
\hline & Indicator Name & 2005 & 2006 & 2007 & 2008 \\
\hline \multirow[t]{2}{*}{$\begin{array}{l}\text { United } \\
\text { States }\end{array}$} & $\begin{array}{l}\text { Agriculture, value added } \\
\text { (annual \% growth) }\end{array}$ & 16,089965 & $-10,432191$ & 3,078203 & \\
\hline & $\begin{array}{c}\text { Manufacturing, value } \\
\text { added (annual \% growth) }\end{array}$ & 1,6225924 & 4,3939302 & 2,9422067 & \\
\hline \multirow[t]{2}{*}{ France } & $\begin{array}{l}\text { Agriculture, value added } \\
\text { (annual \% growth) }\end{array}$ & $-5,4145804$ & $-0,3425578$ & $-2,4142122$ & 2,64777 \\
\hline & $\begin{array}{c}\text { Manufacturing, value } \\
\text { added (annual \% growth) }\end{array}$ & 2,1607712 & $-9,09 \mathrm{E}-05$ & 0,7676454 & $-2,7607$ \\
\hline \multirow[t]{2}{*}{ Germany } & $\begin{array}{l}\text { Agriculture, value added } \\
\text { (annual \% growth) }\end{array}$ & $-16,117276$ & $-3,1821764$ & 4,1420382 & 3,94782 \\
\hline & $\begin{array}{c}\text { Manufacturing, value } \\
\text { added (annual \% growth) }\end{array}$ & 3,3391177 & 7,253929 & 6,1382196 & \\
\hline \multirow[t]{2}{*}{ Turkey } & $\begin{array}{l}\text { Agriculture, value added } \\
\text { (annual \% growth) }\end{array}$ & 7,1838091 & 1,3603217 & $-6,7438798$ & 3,54554 \\
\hline & $\begin{array}{c}\text { Manufacturing, value } \\
\text { added (annual \% growth) }\end{array}$ & 8,1664238 & 8,3936181 & 5,6157018 & 0,75096 \\
\hline \multirow[t]{2}{*}{ Russia } & $\begin{array}{l}\text { Agriculture, value added } \\
\text { (annual \% growth) }\end{array}$ & 1,1 & 3,8 & 2,6 & 8,5 \\
\hline & $\begin{array}{c}\text { Manufacturing, value } \\
\text { added (annual \% growth) }\end{array}$ & & & & \\
\hline
\end{tabular}

Tablo 2: Ülke sektörlerine ait büyüme verileri (World Bank, 2010)

\subsection{Tarım Sektörü}

Tarım sektörünün yıllara göre olan değişimi Şekil 1'de görülmektedir. Tarım sektörü 2008 yılı haricinde ortak şekilde hareket edememiş, sadece 2008 yılında tüm ülkelerin tarım sektörlerinin büyüdüğ ü gözlemlenmiştir. Genel olarak tarım sektöründe ortak bir trend gözlemlenmemiştir. 


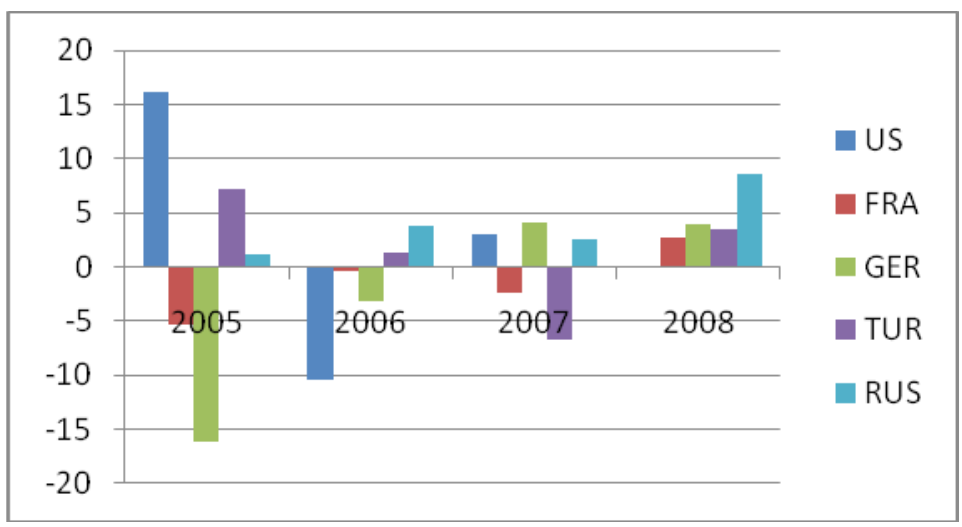

Şekil 1: Tarım sektörünün yıllara göre büyüme yüzdesi

\section{2 Üretim Sektörü}

Üretim sektörü, 2006 yılında Fransa'nın çok küçük oranda küçülmesi göz ardı edilirse, 2008 yılına kadar büyüme düzenli şekilde büyümüştür. Ancak dünyada ekonomik krizin baş gösterdiği 2008 yılında gelişmiş ekonomiler büyüme ivmelerini kaybetmiştir, bu yıl içerisinde Fransa \%2,7 oranında küçülmüştür. Üretim sektörü için ülkeler arasında ortak bir trendin var olduğu söylenebilir.

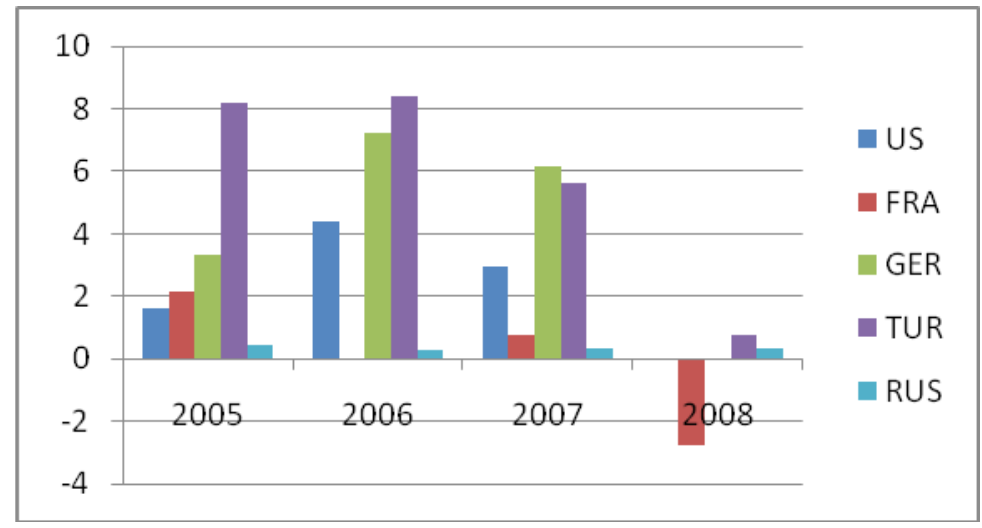

Şekil 2: Üretim sektörünün yıllara göre büyüme yüzdesi

\subsection{Bankacılık Sektörü}

Tablo 3'te Amerika Birleşik Devletleri ve Türkiye'nin bankalarının sahip olduğu aktif büyüklüklerinin yıllara bağlı büyüme oranları görülmekte ve Şekil 3'te de bu büyüme oranları grafik şekilde gözlemlenebilmektedir. Bu grafiğe göre 2008 yılına kadar her iki ülkede de büyüme gözlemlenmektedir. 2009 yılında ABD'nin bankacılık sektörünün aktif büyüklüğü yüzde 3,759 oranında küçülmüştür, bu durum küresel bankacılık krizinin bir etkisi olduğu ifade edilebilir. Aynı yıl, Türkiye'de de büyüme hızı 2008 yılına göre yavaşladığı görülse de, yüzde 16,39 oranında büyüdüğü gözlemlenmiştir.

\begin{tabular}{|c|c|c|c|}
\hline & 2007 & 2008 & 2009 \\
\hline Türkiye & 13,779 & 26,032 & 16,390 \\
\hline ABD & 10,747 & 10,136 & $-3,759$ \\
\hline
\end{tabular}

Tablo 3: Bankacılık sektörü aktifler büyüklükleri değişimi (FDIC, 2010, BDDK, 2006, 2007, 2008, 2009) 


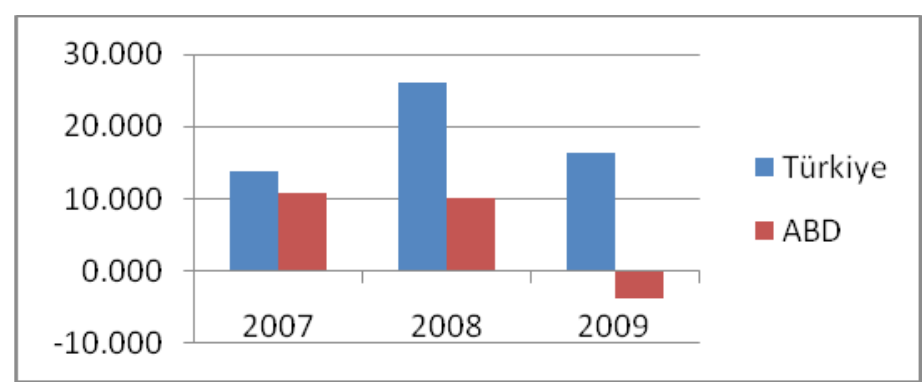

Şekil 3: ABD ve Türkiye bankacılık sektörlerinin aktif büyüklüklerinin yıllara göre değişimi

\section{Sonuç ve İleri Çalış̧alar}

Çalışma sonucu uluslararası bazda sektörler arasında bir etkileşimin var olup olmadığının gözlemlenmesi amaçlanmıştır, bu nedenle ABD, Almanya, Fransa, Türkiye ve Rusya ülkeleri seçilmiş ve üretim, tarım ve bankacılık sektörüne ait veriler değerlendirilmiştir.

Sonuçlara göre tarım sektörünün bağımsız bir trend gösterdiği ve ülkelerin tarım sektörleri arasında bir etkileşim olmadığı görülmektedir. Üretim sektörleri arasında doğru orantı olduğu ve ülkelerin birbirleri ile benzer şekillerde hareket ettikleri gözlemlenmektedir. Bankacılık sektörü için ABD ile Türkiye'nin bankacılık sektörünün aktif büyüklüğü gözlemlenmiş ve genel olarak doğru orantılı olarak hareket ettiği gözlemlenmiştir.

Çalışma 2005 - 2008 yılları arasındaki ekonomik göstergelere dayanılarak hazırlanılmıştır. İleri çalışmalarda, henüz açıklanmamış olan 2008 yılı sonrası veriler de kullanılarak kriz döneminde sektörlerin, ekonomik krize ne şekilde tepki verdikleri ve verdikleri tepkinin birbirleri arasındaki ilişkisi incelenmesi planlanmaktadır.

İleri çalışmanın, mevcut elimizde bulunan çalışmanın genişletilmesi şeklinde gerçekleştirilmesi öngörülmektedir. Var olan verilerin yıl olarak kapsamının genişletilmesi ve daha uzun vadede etkileşim trendlerinin izlenilmesi sektörler arasındaki etkileşimi daha iyi gözler önüne serecektir. Ek olarak, 2009 yılının verileri de göz önüne alınarak kriz sonrasında, sektörlerin nasıl etkilendiğinin gözlemlenmesi amaçlanmaktadır.

\section{References}

- The globalization of markets, Theodore Levitt, sf. 93, 1993

- Rodrik, 1997. Has globalization gone too far?, Instute For National Economics, New York.

- World Bank, 2010. USA, France, Germany, Turkey, Russia, Agriculture, value added (annual \% growth), Manufacturing, value added (annual \% growth), Inflation, consumer prices (annual \%), GDP growth (annual \%), Exports of goods and services ( $\%$ of GDP), Imports of goods and services ( $\%$ of GDP) verileri http://databank.worldbank.org/ddp/home.do? $\underline{\text { Step }=2 \& i d=4 \& \text { hActiveDimensionId }=\text { WDI SERIES }}$

- Federal Deposit Insurance Corporation, 2010, Commercial Bank Assets istatistiği, http://www2.fdic.gov/hsob/hsobRpt.asp

- BDDK, 2009, Bankaların toplam aktif büyüklükleri, http://www.bddk.org.tr/WebSitesi/turkce/Raporlar/Finansal_Piyasalar_Raporlari/7824 FPRAral $\%$ C $4 \%$ B $1 \mathrm{k} 2009$.pdf

- BDDK, 2008. Bankaların toplam aktif büyüklükleri, http://www.bddk.org.tr/WebSitesi/turkce/Raporlar/Finansal Piyasalar Raporlari/6320 
Finansal_Piyasalar_Raporu_Aralik_2008.pdf

- BDDK, 2007. Bankaların toplam aktif büyüklükleri, http://www.bddk.org.tr/WebSitesi/turkce/Raporlar/Finansal_Piyasalar_Raporlari/4816 FPR-Aralik2007.pdf

- BDDK, 2006. Bankaların toplam aktif büyüklükleri, http://www.bddk.org.tr/WebSitesi/turkce/Raporlar/Finansal_Piyasalar_Raporlari/1651 BDDK_FPR_Aralik2006 27042007.pdf 


\title{
Türkiye'nin Doğu Bölgeleri ve Sahil-Batı Bölgeleri Arasında Toplu Göç Süreci
}

\author{
Tahsin Bakırtaş, Sakarya University \\ Orhan Kandemir, Kastamonu University
}

\begin{abstract}
Mass Migration Process between Turkey's Eastern Regions and SeaboardWestern Regions
\end{abstract}

In the study, the aim is to analyze the economic causes of the migration phenomenon that is the most important problem of today's Turkey, and to suggest different policy proposals for the solution of the problem. Within this frame, by accepting sixteen cities that receive high rates of migration according to arithmetical average of 2007-2008 and 2008-2009 periods indicated in the Address-Based Population Registration System as "center of attraction", migration movements from eastern cities and from cities apart from eastern cities (western cities) to these sixteen cities of "center of attraction" were analyzed separately. In order to explain migration that oriented to centers of attraction, a multiple regression model that is convenient with international literature was formed. In this model, the number of enterprise that represents employment opportunity, the number of green card holders that represents poverty related to low income, the number of illiterates that represents lack of education and lastly the number of criminals that represents unrest were taken as independent variables. According to analysis results, independent variables that are used in the model explained migration process in both eastern cities and western cities as above $90 \%$. On the other hand, when the coefficient rates of independent variables are examined, it was revealed that the most important determinant in economic migration is the employment opportunity. Consequently, making only income increasing social aids in regions where migration to other cities takes place is not sufficient; in addition to that, increasing employment opportunities is a healthier and a long-term solution.

JEL Codes: O18, R23, R58

\section{Giriş}

Türkiye'de son yıllardaki en önemli tartışma konularından birisi doğu ve batı-kıyı bölgeleri arasındaki gelişme farklılıkları ve bunun yarattığı göç sorunudur. Ülkedeki doğu bölgelerinden batı-kıyı bölgelerine yönelen göçün iyi analiz edilerek, belirleyicilerinin doğru tespit edilmesi, gerekli önlemlerin alınmasını da kolaylaştıracaktır. Bakırtaş (2009) yaptığı çalışmada, dünya da yaşanan "Kuzey-Güney Çelişkisi”" ya da "Doğu-Batı Çelişkisine" benzer şekilde, Türkiye'de de "Kıyı-Batı ve Dağ-Doğu Çelişkisinin" yaşandığı vurgulamıştır. Bu çelişkinin göstergeleri gelir, tüketim, istihdam, eğitim, sosyal güvence gibi faktörlere bağlı olarak açıklanabilmektedir.

Türkiye'de, göçle nüfusun yığıldığg zengin batı-kıyı bölgeleri tüketim ve istihdam yönünden diğer bölgelere göre oldukça ileri düzeydedir. Buna karşın yoksulluğu temsil eden yeşil kartlı sayısı ve okuma yazma bilmeyen nüfus miktarı başta Güneydoğu ve Ortadoğu Anadolu bölgelerinde olmak üzere kıyı ve batı bölgelerine göre çok daha yüksektir. Geri kalmış bölgelerin toplam tüketimden aldıkları payın düşük olmasının yanında bu bölge halkı eğitim, sağlık gibi insanca yaşamak için gerekli olan alanlara yeterince kaynak ayıramamaktadır. Çünkü gelirleri düşük olan bu bölge insanlarının birinci önceliği karınlarını doyurmaktır. TÜİK' in 2 Aralık 2008 tarih ve 185 sayılı haber bülteninde, düzey 1'e göre 2005-2006-2007 yılları için hane halklarının tüketim amaçlı yaptığı harcamaların payları yayınlanmıştır. Bu bültende yer alan harcamaların bölgesel dağılımı incelendiğinde doğu bölgelerindeki düşük gelirli halkın öncelikli hedefinin gıda harcamaları olduğu görülecektir. Örneğin, İstanbul için gıda ve alkolsüz içeceklerin, bölgenin toplam tüketim harcamaları içindeki payı $\% 21 \mathrm{iken,} \mathrm{bu}$ 
pay Güneydoğu Anadolu'da \%39, Kuzeydoğu Anadolu'da \%30 ve Ortadoğu Anadolu'da \%32'dir. Buna karşın İstanbul bölgesinde eğitim ve sağlığa yapılan harcamaların tüketim harcamaları içindeki payı sırasıyla \%2,5 ve \%2,7 iken, Güneydoğu Anadolu bölgesinde bu pay sırasıyla sadece \%1,1 ve \%1,8'dir. Yoğun şekilde göç veren bu bölgelerde yoksul halkın eğitim ve sağlığa gerekli kaynak ayıramaması yoksulluğu daha da derinleştirmektedir.

Özellikle hızla göç veren bölgeler DPT (2006:37)'nın 2007-2013 yılları için hazırladığ Ulusal Kırsal Kalkınma Stratejisi'nde de belirtildiği gibi genç ve yetenekli işgücünü kaybetmekte, göç süreci sonunda az gelişmiş bölgelerde kalan düşük nitelikli işgücünün girişimcilik kapasitesi de düşük kalmaktadır. Bunun yanında verilen göç nedeniyle bölgedeki efektif talep azalışı da yatırımları azaltmaktadır. Tabii ki bu süreç göç veren bölgelerin geri kalmasına yol açan, işsizlik $\rightarrow$ göç $\rightarrow$ düşük girişimcilik ve düşük talep $\rightarrow$ işsizlik $\rightarrow$ göç şeklindeki kısır döngüyü de beslemektedir.

Bu kısır döngünün en büyük kanıtı; TÜİK tarafından yayımlanan gerek 1995-2000 yıllarını kapsayan Genel Nüfus Sayımında, gerekse Adrese Dayalı Nüfus Kayıt Sistemi (ADNKS)'ne göre yapılan ve 2007-2008 ile 2008-2009 yıllarını kapsayan sayımlarda düzey 1'e göre net göç düzeyi pozitif ve negatif olan bölgelerin aynı olmasıdır. Sırasıyla, sanayi ve turizm yönünden gelişmiş İstanbul, Batı Marmara, Ege, Doğu Marmara, Batı Anadolu ve Akdeniz bölgelerinin net göç düzeyi pozitif iken, bunun aksine görece az gelişmiş Orta Anadolu, Batı Karadeniz, Doğu Karadeniz, Kuzeydoğu Anadolu, Ortadoğu Anadolu ve Güneydoğu Anadolu bölgelerinin net göç oranı negatiftir. Bu durum Türkiye'de göçü önleme konusunda başarı sağlanamadığının bir göstergesidir.

\section{Literatür}

Göç konusuna bilimsel yönden ilk katkıyı yapan ve çalışması İngiltere'nin 1881 yılı nüfus sayımına dayanan Ravenstein (1885)'e göre göçmenler genellikle yüksek gelirli ve hızlı büyüyen büyük ticaret ya da endüstri merkezlerinden birini tercih etmektedir. Bu çalışma göçle ilgili olarak yapılan ilk çalışma olmasına karşın, göçün temel belirleyicileri olan daha yüksek gelir ve daha fazla istihdam imkânının göçü olumlu yönde etkilediğini buna karşın göç maliyetini arttıran mesafesinin göçü olumsuz yönde etkilediğini vurgulaması açısından çok önemlidir. Lee (1966), Ravenstein'in 19. yüzyıl göç kurallarını yeniden inceleyerek revize etmiş ve göç kararında bireylerin yaşadıkları bölgelerin ve gidecekleri bölgelerin artı ve eksi yönlerine göre bir değerlendirme yapacaklarını ifade etmiştir. M.P. Todaro'nın J. R. Haris'le yaptığı (1970:126-142) çalışmada, kır ve kentlerden oluşan “iki sektörlü” bir model kullanılmıştır. Bu çalışmada kırsal kesimde pozitif marjinal üretim olmasına ve kentlerde önemli derecede işsizlik olmasına karşın, kırdan kente iş gücü göçünün gittikçe arttığı vurgulanmıştır. Onlara göre kentsel beklenen gelir kırsal reel gelirden büyük olduğu sürece işgücü göçü devam edecektir. Cebula (2005:267-274) yaptığı çalışmada, 1999-2002 yılları arasında ABD'deki toplam iç göçün ekonomik ve ekonomik olmayan belirleyicilerini incelemiştir. Çalışma sonuçlarına göre eyaletlerin aldığı göçler beklenen ya da cari kişi başına gelirin artan, buna karşın ortalama yaşam maliyetlerinin azalan bir fonksiyonudur. Eyaletlerdeki park alanları, dinlenme ya da eğlence yerleri, sıcaklık düzeyi, batıda bir yerde olması, çok güneş alması gibi ekonomik olmayan faktörler göçü pozitif yönde etkilerken, suç oranları ve tehlikeli atıkların çok olması eyaletlere olan göçü azaltmaktadır. Gallaway ve Vedder (1971:885-897), 1860-1913 tarihleri arasında Büyük Britanya'dan ABD'ne yapılan göçü açıklamak için itici ve çekici faktörleri bir arada değerlendirmişlerdir. Çalışmada göçmenleri ana ülkeden (Büyük Britanya) iten ve göç alan ülkeye (ABD) çeken ekonomik faktörler modele konulmuştur. Göç veren Büyük Britanya'daki görece düşük ücret ve yüksek işsizlik oranları itici faktörler olarak değerlendirilirken, ABD'deki görece yüksek ücret ve düşük işsizlik oranları çekici faktörler olarak değerlendirilmiştir. Hatton (1995) yaptığı çalışmada İngiltere'nin 1870-1913 yılları arasındaki dış göç verilerini kullanarak basit bir zaman serisi modeli kurmuştur. Kullanılan eşbütünleşme regresyon modelinde göç; yurt dış1/yurt içi ücret oranlarına, yurt dış1 istihdam 
oranına, yurt içi istihdam oranına ve göç edilen yerdeki göçmen stokuna bağlı olarak açıklanmıștır. Analizler kısa dönem göç dalgalanmalarının büyük ölçüde istihdam oranlarına bağlı olduğunu buna karşın uzun dönem göç dalgalanmalarının ise büyük ölçüde göreceli ücretlere bağlı olduğunu göstermiştir.

\section{Model ve Veri Seti}

Çalışmada Türkiye'deki iller Ek Tablo 1'de görüldüğü gibi 3 gruba ayrılmıştır. Bu illerden 1. gruptaki iller; ADNKS'ne göre 2007-2008 ve 2008-2009 dönemlerinin ortalamasına göre en çok göç alan ve çekim merkezi konumundaki görece gelişmiş 16 ildir. 2. gruptaki iller en çok göç alan iller arasında yer almayan, Düzey 1'e göre Kuzeydoğu, Ortadoğu ve Güneydoğu Anadolu ile Doğu Karadeniz'de bulunan doğu illeridir. 3. grupta ise 1. ve 2. grupta yer almayan iller yer almaktadır. Yani bu gruptaki iller Kuzeydoğu, Ortadoğu ve Güneydoğu Anadolu ile Doğu Karadeniz Bölgelerin de ve gelişmiş 16 il arasında yer almayan, görece ülkenin batı ve kıyı bölgelerinde yer alan illerdir.

Çalışmada kullanılan model; Türkiye'de 2008-2009 yılları arasında Adrese Dayalı Nüfus Kayıt Sistemi (ADNKS) çerçevesinde tespit edilen iller arası göçü açıklamaya yönelik olarak kurulmuştur. Yukarıda bahsedildiği üzere literatürdeki tüm önemli göç modellerinin temel açıklayıcı değişkenleri istihdam değişkeni ve gelir oranlarıdır. Diğer taraftan özellikle 1990 sonrası dönemde doğu illerinde artan terör olayları doğu batı göçü üzerinde çok etkili olmaktadır. Bunun yanında Türkiye'deki doğu-batı çelişkisinde ileri sürülen en önemli faktörlerden birisi de, doğu illerinde eğitimsizliğin dolayısıyla da yoksulluğun çok yaygın olduğu şeklindedir. Bu çerçevede kurulan çoklu regresyon modelinde; Türkiye'de iller arası göç; istihdam imkânını temsil eden girişim sayısına, düşük geliri dolayısıyla yoksulluğu temsil eden yeşil kartlı sayısına, eğitimsizliği temsil eden okuryazar olmayan sayısına ve son olarak huzursuzluğu temsil eden suçlu sayılarına bağlı olarak açıklanmıştır.

Ek tablo 2'de görülen korelasyon analizlerinde, okuma yazma bilmeyen sayısı ile yeşil kartlı sayısı arasında doğu illeri için \%91 batı illeri için \%65 gibi güçlü bir pozitif korelasyon tespit edilmiştir. Basit korelasyon matrisinde yer alan iki bağımsız değişken arasında basit korelasyon katsayısının oldukça anlamlı ( $r>\% 75)$ olması çoklu bağlantının göstergesidir (Albayrak, 2005:109). Bu nedenle bu değişkenler modelde ayrı ayrı kullanılarak çoklu bağlantı sorunu önlenmiştir. Modelde kullanılan değişkenlerden okuryazar olmayan kişi sayısı ile yeşil kartlı sayısı arasında çok yüksek korelasyon tespit edilmesi eğitimsiz insanların gelirlerinin de düşük olacağ 1 yönündeki görüşlere de uygundur. Kurulan çoklu regresyon modelinin analizlerinde SPSS 13.0 programı kullanılmış olup, regresyon analizinde kullanılan veri seti Ek tablo 4 ve 5 'de verilmiştir.

Çalışmada kullanılan modeller;

$$
\begin{aligned}
& M_{i}=\beta_{0}+\beta_{1} Y_{i}+\beta_{2} G_{i}+\beta_{3} S_{i}+\varepsilon_{i} \\
& M_{i}=\beta_{0}+\beta_{1} \text { OKYZB }_{i}+\beta_{2} G_{i}+\beta_{3} S_{i}+\varepsilon_{i}
\end{aligned}
$$

gibi olup değişkenler aşağıdaki gibi sembolize edilmiştir:

$\mathrm{M}_{\mathrm{i}}=$ 2008-2009 döneminde illerin aldıkları göçün, aynı dönemde göç eden toplam nüfus içindeki yüzdesini,

$\mathrm{YK}_{\mathrm{i}}=$ i. ilde mevcut yeşil kartlı sayısının i. ilin nüfusuna oranı; i. ildeki yoksulluğu,

$\mathrm{OKYZB}_{\mathrm{i}=} 2008$ y1lı itibariyle i. ilde mevcut 15 yaş ve üzeri okuma yazma bilmeyen nüfusun, i. ilin nüfusuna oranı; i. ildeki yetersiz eğitimi,

$\mathrm{Gi}=2008$ yılı itibariyle i. ildeki girişim sayısının Türkiye'deki toplam girişim sayısına oranı; i. ildeki iş bulma ihtimalini ve yapılan yatırımları,

$\mathrm{S}_{\mathrm{i}}=$ İkametgâhı i. ilde olan ve 2008 yılı itibarıyla ceza infaz kurumundan çıkan hükümlülerin sayısının, i. ilin nüfusuna oranı; suçluların yoğun olduğu illeri,

$\varepsilon_{\mathrm{i}}=$ rassal hata terimini ifade etmektedir. 
Modelde kullanılan değişkenlerden; illerin aldıkları göçler (2008-2009 dönemi), okuma yazma bilmeyenlerin sayıları, nüfus verileri, illerdeki iş kayıtlarına göre girișim sayıları ve daimi ikametgâhına göre ceza infaz kurumundan çıkan hükümlülerin sayıları; TÜİK'ten, yeșil kartlıların sayısı; Sağlık Bakanlı̆̆ı'ndan (07.09.2009 tarihi itibariyle yeşil kart sayısı) alınmıştır.

Analizin ilk aşamasında öncelikle çekim merkezi konumunda ki birinci grup illerle ikinci gruptaki doğu illerinin oluşturduğu 45 ilden (bkz. ek tablo 4) oluşan kümeye model uygulanmış, daha sonra birinci ve üçüncü gruptaki iller birleştirilerek elde edilen 52 ilden (bkz. ek tablo 5) oluşan küme üzerinde model tekrarlanmıştır. Her iki kümedeki illerin aldıkları göç rakamlarının göç eden toplam nüfus içindeki yüzdesi (Mi); küme içindeki illere göre hesaplanmış olup, kümenin dışındaki illerden alınan göç rakamları ele alınmamıştır. Burada amaç modelde kullanılan değişkenlerin, doğu illerinden ya da doğu illeri dışındaki illerden çekim merkezlerine olan göç süreci üzerinde farklı etkiye sahip olup olmadıklarını tespit etmektir.

\section{Modelin Tahmini}

Çoklu regresyon analizlerinde doğru tahminlerin yapılabilmesi için bağımsız değişkenler arasında çoklu bağlantının olmaması gerekir. Kurulan modellerde çoklu bağıntı olmadığ 1 basit korelasyon katsayılarına bakılarak tespit edilmiş olup, bu durum ek tablo 3'de görülen VIF değerlerinin 10'dan küçük olması nedeniyle de teyit edilmiştir (Gujarati, 2006; Andrews and A Boyme, 2008:800; Rault ve diğ., 2007: 11; Koçaş, 2007; Albayrak, 2005:109-111).

Çoklu regresyon sonuçlarının görüldüğü ek tablo 3 incelendiğinde, modellerdeki tüm bağımsız değişenlerin işaretlerinin beklendiği gibi çıktığı görülecektir. Bağımlı değişken olan illerin aldığı göç; yeşil kartlı sayısı $\left(\mathrm{YK}_{\mathrm{i}}\right)$ ya da okuma yazma bilmeyenlerin sayısı $\left(\mathrm{OKYZB}_{\mathrm{i}}\right)$ ve suçlu sayısıyla $\left(\mathrm{S}_{\mathrm{i}}\right)$ ters ilişkili olduğu için bu üç değişken tüm modellerde negatif işaretlidir. Buna karşın istihdam imkânını temsil eden girişim sayısı ile illerin aldığı göç arasında tüm modellerde pozitif bir ilişki tespit edilmiştir. Modellerin tümü istatistiksel açıdan \%1 seviyesinde anlamlıdır.

Doğu illerinden çekim merkezi konumundaki illere yönelen göçün çoklu regresyon modellerinden; birinci modelde sabit terim dâhil tüm değişkenler istatistiksel açıdan anlamlıdır. İkinci modelde ise suçlu sayısı hariç tüm değişkenler istatistiksel açıdan anlamlıdır. İki modelde de yine illerin aldıkları göçün en önemli belirleyicisi illerin sağladıkları istihdam imkânlarıdır. İllerin aldıkları göç üzerinde, illerin istihdam imkânını gösteren " $\mathrm{G}_{\mathrm{i}}$ " değişkeninin etkisi 0,968 olup, yeşil kartlı sayısı ve okuma yazma bilmeyenlerin sayısı $(-0,071$ ve $-0,060)$ ile suçlu sayısının etkisinden $(-0,053$ ve $-0,046)$ büyüktür. Dolayısıyla iller arası göçün yaklaşık \%98'ını belirleyen, bu üç değişkenden en önemlileri sırasıyla illerdeki istihdam imkânları, yeşil kartlı sayısı ya da okuma yazma bilmeyenlerin sayısı ile suçlu sayısıdır.

Batı illerinden çekim merkezi konumundaki illere yönelen göçün çoklu regresyon modellerinden; birinci modelde değişkenlerden yeşil kartlıların sayısı hariç diğer tüm değişkenler istatistiksel açıdan anlamlıdır. İkinci modelde ise, tüm değişkenler istatistiksel açıdan anlamlıdır. Yine her iki modelde de illerin aldıkları göç üzerinde, illerin istihdam imkânını gösteren " $\mathrm{G}_{\mathrm{i}}$ " değişkeninin etkisi $(0,926$ ve 0,918$)$ diğer değişkenlerin etkisinden büyüktür. Dolayısıyla iller arası göçün yaklaşı \%94'ünü belirleyen, bu üç değişkenden en önemlileri sırasıyla istihdam imkânı, okuma yazma bilmeyenlerin sayısı ile suçlu sayısıdır.

\section{Sonuç}

Analiz sonuçları göstermiştir ki; Türkiye'de iller arası göç tahmini için kurulan tüm modeller de göç üzerindeki en etkili faktör istihdam imkânını arttıran girişimci sayısıdır. Diğer taraftan doğu illeri ile çekim merkezi konumundaki iller arasındaki göçü açıklayan modellerde istihdam imkânını artıran girişim sayısı, yeşil kartlı sayısı ve okuma yazma bilmeyenlerin sayıları 
istatistiksel açıdan anlamlı bulunmuş olmasına karşın, batı illeri ile çekim merkezi konumundaki iller için oluşturulan modelde yoksulluğu temsil eden yeșil kartlı sayısının istatistiksel olarak anlamsız olduğu görülmüştür. Bunun anlamı yoksulluğun göç veren doğu illeri için, göç veren batı illerine göre daha önemli bir faktör olduğu dolayısıyla doğu illerinde yoksullukla mücadeleye daha fazla önem verilmesinin gerekliliğidir. Dolayısıyla doğu-batı göçünü önlemek için doğu bölgelerinde istihdam imkânlarını artıran kamu ya da özel yatırımların arttırılması, temel eğitim sürecine daha fazla katılım sağlanarak okuma yazma bilmeyenlerin sayısının azaltılması temel hedef olmalıdır. Bu sayede doğu bölgelerinde yoksulluk ve suç işleme oranları da azaltılabilecektir. Sonuç olarak, göç veren bölgelerde sadece gelir arttırıcı sosyal yardımlarda bulunmak yeterli olmayıp, bunun yanında iș bulma imkânlarının da arttırılması çok daha sağlıklı ve uzun vadeli bir çözümdür.

*Bu çalışmanın hazırlanmasında, Orhan Kandemir tarafından Sakarya Üniversitesi, Sosyal Bilimler Enstitüsü İktisat Anabilim Dalı'nda hazırlanan ve danışmanlığını Yrd. Doç. Dr. Tahsin Bakırtaş'ın yaptığı, Mayıs/2010'da sunularak kabul edilen, "İktisadi Gelişme Sürecinde Göç Olgusu: Türkiye Örneği”" adlı doktora tezinden yararlanılmıştır.

\section{Kaynakça}

- Bakırtaş, 2009. “Türkiye'de Yoksulluk Olgusu'nun Yapısal Ekonomik Analizi (19082008)", Yıldız Teknik Üniversitesi, Department of Economıcs, Workıng Papers, http://ideas.repec.org/p/vil/wpaper/0016.html, 13.10.2009.

- TÜIKK (Türkiye İstatistik Kurumu), 2008. "2005-2006-2007 Hane Halk1 Tüketim Harcamaları Bölgesel Sonuçları”, 2 Aralık 2008 Tarih ve 185 Sayll Haber Bülteni, http://www.tuik.gov.tr/OncekiHBArama.do?islem=postmvChoice, 13.10 .2009 .

- $\quad$ DPT, 2006. "Ulusal Kirsal Kalkınma Stratejisi (2007-2013)”, 04.02.2006 tarih ve 26070 Sayll Resmi Gazete, http://ekutup.dpt.gov.tr/bolgesel/strateji/kirsal.pdf, 17.01.2008.

- TÜIKK İnternet Sitesi, http://www.tuik.gov.tr/Start.do

- Ravenstein, 1885. "The Laws of Migration", Journal of the Statistical Society of London, Vol: 48, No:2, s. 167-235.

- Lee, 1966. “A Theory of Migration”, Demograpy, Vol: 3, No:1, s. 47-57.

- Harris and Todaro, 1970. "Migration, Unemployment and Development: A TwoSector Analysis", American Economic Review 60, s.126-142.

- Cebula, 2005. "Internal Migration Determinants: Recent Evidence", International Advances in Economic Research, s. 267-274.

- Gallaway and Vedder, 1971. "Emigration from the United Kingdom to The United States: 1860-1913", The Journal of Economic History, Vol. 31, No. 4 (December), s.885-897.

- Hatton, 1995. “A Model of U.K. Emigration, 1870-1913”, The Review of Economics and Statistics, Vol. 77, No. 3 (August), s. 407-415.

- Albayrak, 2005. "Çoklu Doğrusal Bağlantı Halinde Enküçük Kareler Tekniğinin Alternatifi Yanlı Tahmin Teknikleri ve Bir Uygulama”, ZKÜ Sosyal Bilimler Dergisi, Cilt 1, Sayı 1, s.105-126.

- Gujarati, 2006. Temel Ekonometri, Çev., Ümit Senesen ve Gülay Günlük Senesen, 4. Baskı, Literatür Yayıncılık, İstanbul.

- Andrews and A Boyme, 2008, "Organizational Environments and Public-service Failure: an Empirical Analysis", Environment and Planning C: Government and Policy 2008, Volume 26, s.788-807.

- Rault, A. M. Sova and R. Sova, 2007. "The Endogeneity of Association Agreements and Their Impact on Trade for Eastern Countries: Empirical Evidence for Romania", William Davidson Institute Working Paper Number 868, The William Davidson 
Institute at The University of Michigan, http://papers.ssrn.com/sol3/papers.cfm? abstract_id=1017285, 20.02.2010.

- Koçaş, 2007. "Ekonometrik Rekabet Modelleme, Pazar Tepki Analizi ve Talep Tahmini", (Prepared By: Aykaç, Selcen and Irmak, Melek and Duran, Yasin) İstanbul Ticaret Odast Yayınlart; 2007-74, ISBN: 9789944602648, http://research.sabanciuniv.edu/9528/, 25.08.2009.

- Sağlık Bakanlığı, "Yeşil Kart Kayıtlarının İllere Göre Dağılımı”, (07.09.2009 tarihi itibariyle yeşil kart sayısı), http://ykart.saglik.gov.tr/ykbs/ykbs_ilaktif.jsp, 11.10.2009.

- Kandemir, 2010. İktisadi Gelişme Sürecinde Göç Olgusu: Türkiye Örneği, Sakarya Üniversitesi, Sosyal Bilimler Enstitüsü, İktisat Anabilim Dalı, Yayımlanmamış Doktora Tezi.

Ek Tablo 1. 2007-2008 ve 2008-2009 Dönemlerinde İllerin Aldıkları Göçün Ortalamasının, Aynı Dönemlerde Göç Eden Toplam Göçmenlerin Ortalaması İçindeki Payı (\%)

\begin{tabular}{|c|c|c|c|c|c|c|c|c|}
\hline & \multicolumn{2}{|c|}{$\begin{array}{l}\text { 1. Grup -En çok göç alan iller (çekim } \\
\text { merkezleri) }\end{array}$} & & \multicolumn{2}{|c|}{ 2. Grup-Doğu İlleri } & & \multicolumn{2}{|c|}{ 3. Grup-Batı İlleri } \\
\hline $\begin{array}{c}\text { Sira } \\
\text { no }\end{array}$ & İller & Aldıkları Göç (\%) & Sira no & İller & $\begin{array}{c}\text { Aldıkları Göç } \\
(\%)\end{array}$ & Sira no & İller & $\begin{array}{c}\text { Aldıkl } \\
\text { arı } \\
\text { Göç } \\
(\%)\end{array}$ \\
\hline 1 & İstanbul & 16,9236 & 1 & Diyarbakır & 1,4203 & 1 & Aydın & 1,3945 \\
\hline 2 & Ankara & 7,2044 & 2 & Trabzon & 1,3920 & 2 & Tokat & 1,3801 \\
\hline 3 & İzmir & 5,1759 & 3 & Ordu & 1,2871 & 3 & Kayseri & 1,3545 \\
\hline 4 & Antalya & 3,7186 & 4 & Șanlıurfa & 1,1684 & 4 & Hatay & 1,2860 \\
\hline 5 & Bursa & 3,3163 & 5 & Malatya & 1,1375 & 5 & Sakarya & 1,1018 \\
\hline 6 & Kocaeli & 2,7580 & 6 & Mardin & 1,0177 & 6 & $\begin{array}{l}\text { Kahraman } \\
\text { maraş }\end{array}$ & 0,9902 \\
\hline 7 & Adana & 2,1988 & 7 & Van & 0,9767 & 7 & Denizli & 0,9498 \\
\hline 8 & Mersin & 2,1096 & 8 & Erzurum & 0,9717 & 8 & Sivas & 0,9331 \\
\hline 9 & Konya & 2,0296 & 9 & Giresun & 0,8216 & 9 & \begin{tabular}{|l|} 
Afyonkarah \\
isar
\end{tabular} & 0,8534 \\
\hline 10 & Tekirdağ & 1,8887 & 10 & Batman & 0,7714 & 10 & Isparta & 0,8121 \\
\hline 11 & Samsun & 1,6468 & 11 & Elazığ & 0,6916 & 11 & Zonguldak & 0,7515 \\
\hline 12 & Gaziantep & 1,6242 & 12 & Rize & 0,5694 & 12 & Yozgat & 0,7329 \\
\hline 13 & Balıkesir & 1,5671 & 13 & Ağn1 & 0,5390 & 13 & Çankırı & 0,7282 \\
\hline 14 & Manisa & 1,4872 & 14 & Adiyaman & 0,5375 & 14 & Osmaniye & 0,7234 \\
\hline 15 & Muğla & 1,4255 & 15 & Bitlis & 0,5169 & 15 & Çanakkale & 0,7051 \\
\hline 16 & Eskişehir & 1,4206 & 16 & Erzincan & 0,5087 & 16 & Çorum & 0,6540 \\
\hline & & & 17 & Şırnak & 0,4784 & 17 & Kütahya & 0,6519 \\
\hline & & & 18 & Siirt & 0,4511 & 18 & Yalova & 0,6413 \\
\hline & & & 19 & Muş & 0,4482 & 19 & Kastamonu & 0,6168 \\
\hline & & & 20 & Gümüşhane & 0,3982 & 20 & Niğde & 0,6150 \\
\hline & & & 21 & Kars & 0,3965 & 21 & Kırıkkale & 0,6035 \\
\hline & & & 22 & Bingöl & 0,3539 & 22 & Edirne & 0,5850 \\
\hline & & & 23 & Artvin & 0,2861 & 23 & Amasya & 0,5162 \\
\hline & & & 24 & Hakkari & 0,2686 & 24 & Bolu & 0,5068 \\
\hline & & & 25 & Tunceli & 0,2430 & 25 & Düzce & 0,4983 \\
\hline & & & 26 & Ĭğır & 0,2381 & 26 & Aksaray & 0,4736 \\
\hline & & & 27 & Kilis & 0,2142 & 27 & Kurklareli & 0,4639 \\
\hline & & & 28 & Ardahan & 0,1866 & 28 & Kırşehir & 0,4605 \\
\hline & & & 29 & Bayburt & 0,1352 & 29 & Sinop & 0,4403 \\
\hline & & & & & & 30 & Nevşehir & 0,4101 \\
\hline & & & & & & 31 & Burdur & 0,3950 \\
\hline & & & & & & 32 & Uşak & 0,3849 \\
\hline & & & & & & 33 & Karabük & 0,3746 \\
\hline
\end{tabular}


Kaynak: TÜIKK

\begin{tabular}{|l|l|l|}
\hline 34 & Karaman & 0,3715 \\
\hline 35 & Bilecik & 0,3656 \\
\hline 36 & Bartın & 0,3544 \\
\hline
\end{tabular}

Ek Tablo 2. Basit Korelâsyon Katsayıları

Doğu illeri ile Çekim Merkezi Konumundaki İllerin Göçü İçin Hesaplanan Basit Korelâsyon Katsayıları

\begin{tabular}{|c|c|c|c|c|c|}
\hline & $\mathrm{M}_{\mathrm{i}}$ & $\mathrm{YK}_{\mathrm{i}}$ & $\mathrm{OKYZB}_{\mathrm{i}}$ & $\mathrm{G}_{\mathrm{i}}$ & $\mathrm{S}_{\mathrm{i}}$ \\
\hline $\mathrm{M}_{\mathrm{i}}$ & 1 & $-0,421^{* *}$ & $-0,469 * *$ & $0,991 * *$ & 0,080 \\
\hline $\mathrm{YK}_{\mathrm{i}}$ & $-0,421^{* *}$ & 1 & $0,905^{* *}$ & $-0,395^{* *}$ &,$- 617 * *$ \\
\hline $\mathrm{OKYZB}_{\mathrm{i}}$ & $-0,469 * *$ & $0,905^{* *}$ & 1 & $-0,452^{* *}$ &,$- 611^{* *}$ \\
\hline $\mathrm{G}_{\mathrm{i}}$ & $0,991 * *$ & $-0,395^{* *}$ & $-0,452^{* *}$ & 1 & $-0,092$ \\
\hline $\mathrm{S}_{\mathrm{i}}$ & 0,080 & $-0,617^{* *}$ & $-0,611^{* *}$ & 0,092 & 1 \\
\hline
\end{tabular}

Batı illeri ile Çekim Merkezi Konumundaki İllerin Göçü İçin Hesaplanan Basit Korelâsyon Katsayılar1

\begin{tabular}{|c|c|c|c|c|c|}
\hline & $\mathrm{M}_{\mathrm{i}}$ & $\mathrm{YK}_{\mathrm{i}}$ & $\mathrm{OKYZB}_{\mathrm{i}}$ & $\mathrm{G}_{\mathrm{i}}$ & $\mathrm{S}_{\mathrm{i}}$ \\
\hline $\mathrm{M}_{\mathrm{i}}$ & 1 & $-0,311^{*}$ & $-0,397^{* *}$ & $0,966^{* *}$ & $-0,301^{*}$ \\
\hline $\mathrm{YK}_{\mathrm{i}}$ & $-0,311^{* *}$ & 1 & $0,649^{* *}$ & $-0,276^{*}$ & $-0,222$ \\
\hline $\mathrm{OKYZB}_{\mathrm{i}}$ & $-0,397^{* *}$ & $0,649^{* *}$ & 1 & $-0,348^{*}$ & $-0,104$ \\
\hline $\mathrm{G}_{\mathrm{i}}$ & $0,966^{* *}$ & $-0,276^{*}$ & $-0,348^{*}$ & 1 & $-0,258$ \\
\hline $\mathrm{S}_{\mathrm{i}}$ & $-0,301^{*}$ & $-0,222$ & $-0,104$ & $-0,258$ & 1 \\
\hline
\end{tabular}

**\%1 anlamlılık seviyesini, $* \% 5$ anlamlllık seviyesini belirtir.

Kaynak: Ek Tablo 4 ve 5'e göre hesaplanmıștır.

\section{Ek Tablo 3. Göç Tahmin Sonuçları}

\begin{tabular}{|c|c|c|c|c|}
\hline \multicolumn{5}{|c|}{ Doğu illeri ile Çekim Merkezi Konumundaki İllerin Göç Tahmini } \\
\hline \multicolumn{5}{|c|}{ 1. Model $=\quad M_{i}=\beta_{0}+\beta_{1} Y K_{i}+\beta_{2} G_{i}+\beta_{3} S_{i}+\varepsilon_{i}$} \\
\hline Değişkenler & $\underset{1}{\text { Katsayilar }}$ & Sig & Tolerans & $V I F$ \\
\hline Sabit & $1,524 * *$ & 0,00 & & \\
\hline $\mathrm{YK}_{\mathrm{i}}$ & $-0,071 * *$ & 0,01 & 0,503 & 1,988 \\
\hline $\mathrm{G}_{\mathrm{i}}$ & $0,968 * *$ & 0,00 & 0,806 & 1,240 \\
\hline $\mathrm{S}_{\mathrm{i}}$ & $\begin{array}{l} \\
* \quad 0,053\end{array}$ & 0,04 & 0,591 & 1,691 \\
\hline $\mathrm{R}^{2}$ & 0,98 & & & \\
\hline $\begin{array}{c}\text { Ayarlanmış } \\
\mathrm{R}^{2}\end{array}$ & 0,98 & & & \\
\hline $\begin{array}{l}\text { Anova- } \\
\text { Anlam. }\end{array}$ & 0,00 & & & \\
\hline \multicolumn{5}{|c|}{ Standartlaştırılmuş regresyon katsayılarına göre oluş̧urulan denklem: } \\
\hline \multicolumn{5}{|c|}{$M_{i}=-0,071 Y K_{i}+0,968 G_{i}-0,053 S_{i}$} \\
\hline \multicolumn{5}{|c|}{ 2. $M o d e l=\quad M_{i}=\beta_{0}+\beta_{1} \mathrm{OKYZB}_{\mathrm{i}}+\beta_{2} G_{i}+\beta_{3} S_{i}+\varepsilon_{i}$} \\
\hline Değişkenler & $\underset{1}{\text { Katsayilar }}$ & Sig & Tolerans & VIF \\
\hline Sabit & $1,608^{* *}$ & 0,00 & & \\
\hline $\mathrm{OKYZB}_{\mathrm{i}}$ & $\begin{array}{l} \\
* \quad-0,060\end{array}$ & 0,05 & 0,469 & 2,134 \\
\hline $\mathrm{G}_{\mathrm{i}}$ & $0,968^{* *}$ & 0,00 & 0,742 & 1,348 \\
\hline $\mathrm{S}_{\mathrm{i}}$ & $-0,046$ & 0,09 & 0,584 & 1,714 \\
\hline $\mathrm{R}^{2}$ & 0,98 & & & \\
\hline
\end{tabular}




\begin{tabular}{|c|c|l|l|l|}
\hline $\begin{array}{c}\text { Ayarlanmış } \\
\mathrm{R}^{2}\end{array}$ & 0,98 & & & \\
\hline $\begin{array}{c}\text { Anova- } \\
\text { Anlam. }\end{array}$ & 0,00 & & & \\
\hline
\end{tabular}

Standartlaştırılmış regresyon katsayılarına göre oluşturulan denklem: $M_{i}=-0,060 O K Y Z B_{i}+0,968 G_{i}-0,046 S_{i}$

Batı İlleri ile Çekim Merkezi Konumundaki İllerin Göç Tahmini

1. Model $=\quad M_{i}=\beta_{0}+\beta_{1} Y K_{i}+\beta_{2} G_{i}+\beta_{3} S_{i}+\varepsilon_{i}$

\begin{tabular}{|c|c|c|c|c|}
\hline Değişkenler & $\begin{array}{c}\text { Katsayılar } \\
1\end{array}$ & Sig & Tolerans & VIF \\
\hline Sabit & $1,878^{* *}$ & 0,00 & & \\
\hline $\mathrm{YK}_{\mathrm{i}}$ & $-0,074$ & 0,06 & 0,832 & 1,202 \\
\hline $\mathrm{G}_{\mathrm{i}}$ & $0,926^{* *}$ & 0,00 & 0,817 & 1,225 \\
\hline $\mathrm{S}_{\mathrm{i}}$ & $-0,078$ & 0,05 & 0,840 & 1,190 \\
\hline $\mathrm{R}^{2}$ & 0,94 & & & \\
\hline $\begin{array}{c}\text { Ayarlanmış } \\
\mathrm{R}^{2}\end{array}$ & 0,94 & & & \\
\hline $\begin{array}{c}\text { Anova- } \\
\text { Anlam. }\end{array}$ & 0,00 & & & \\
\hline Standartlastis & & & \\
\hline
\end{tabular}

Standartlaştırılmış regresyon katsayılarına göre oluşturulan denklem:

\begin{tabular}{|c|c|c|c|c|}
\hline \multicolumn{5}{|c|}{$M_{i}=-0,074 Y K_{i}+0,926 G_{i}-0,078 S_{i}$} \\
\hline 2. Model= & $M_{i}=\beta_{0}+$ & KYZ & $\beta_{2} G_{i}+\beta_{3}$ & \\
\hline Değișkenler & $\underset{1}{\text { Katsayılar }}$ & Sig & Tolerans & $V I F$ \\
\hline Sabit & $2,187 * *$ & 0,00 & & \\
\hline OKYZB $_{i}$ & $\begin{array}{ll} & -0,085 \\
& \\
\end{array}$ & 0,03 & 0,839 & 1,192 \\
\hline $\mathrm{G}_{\mathrm{i}}$ & $0,918 * *$ & 0,00 & 0,791 & 1,264 \\
\hline $\mathrm{S}_{\mathrm{i}}$ & $\begin{array}{r} \\
* \quad 0,073 \\
\end{array}$ & 0,05 & 0,891 & 1,123 \\
\hline $\mathrm{R}^{2}$ & 0,94 & & & \\
\hline $\begin{array}{c}\text { Ayarlanmiş } \\
\mathrm{R}^{2}\end{array}$ & 0,94 & & & \\
\hline $\begin{array}{l}\text { Anova- } \\
\text { Anlam. }\end{array}$ & 0,00 & & & \\
\hline
\end{tabular}

Standartlaştırılmış regresyon katsayılarına göre oluşturulan denklem: $M_{i}=-0,085 O K Y Z B_{i}+0,918 G_{i}-0,073 S_{i}$

(1) Bağımsız değişkenlerin katsayıları, standartlaştırılmış regresyon katsayılarıdır.

**\%1 anlamlılık seviyesini, *\%5 anlamlılık seviyesini belirtir. 


\title{
Demokrasi ve Ekonomik Kalkınma: 1992 Sonrası Orta Asya Türk Cumhuriyetleri için Bir Analiz
}

\author{
Ali Pişkin, Doğuş Üniversitesi \\ Dinçer Dedeoğlu, Bahçeşehir Üniversitesi
}

\section{Abstract \\ Democracy and Economic Development: An Analysis for Central Asian Turkic Republics After 1992}

Lipset (1959) had firstly claimed that democracy is not entirely based on social conditions but also it is based on condition of fulfillment of economic development. Following many empirical studies have pointed out the positive relation between democracy and economic development. In this study, basic conditions that are stated as determining variables for the mentioned relation by Barro (1996) are interpreted and debated within the context of data held from International institutes such as the World Bank and the United Nations for Central Asian Turkic Republics after 1992. In the situation that the positive relation occurs, maintenaning of the rule of law, free markets, small government consumption and high human capital are required as instruments of economic policy.

JEL Codes: A13, O53.

\section{Giriș}

Geçtiğimiz son yüzyıl boyunca dünya ekonomileri hızlı bir değişim içerisine girmişlerdir. Bazı ülkeler yaşam standartlarında daha önce benzeri görülmemiş bir biçimde gelişim sağlarken, üçüncü dünya ülkelerinden birçoğu yoksul olarak kalmıştır. Büyümenin sürekliliği veya belirli bölgelerin/ülkelerin gelişim patikası zamana yayılırken-Avrupa ülkeleri 100-150 yıllık bir sürede büyümeye devam etmektedir, Afrika gibi bazı bölgeler gelişmeden yeteri kadar pay alamamıştır. Bu süreçte, ülkelerin politik rejimlerinin de hızla değişime uğradığ görülmektedir. Bazı ülkeler sağlam bir demokrasi ile idare edilmekteyken, bağımsız ülkelerin yarıya yakını da otokrasi ile yönetilmektedir. Ancak, demokrasinin zaman içerisinde yayıldığ dikkatten kaçmamaktadır (Persson ve Tabellini, 2006).

Ekonomik ve politik değişim arasındaki ilişki, 19. yy.dan itibaren araştırmacıların ilgisini çekmeye başlamıştır. $\mathrm{Bu}$ iki dinamik değişkenin nedensel ilişkisi, karşılıklı olarak değerlendirilmiştir; istikrarlı bir demokrasi ekonomik kalkınmayı teşvik etmektedir veya ekonomik kalkınma demokrasinin sağlamlaşmasına neden olmaktadır (Persson ve Tabellini, 2006). Demokrasi alanındaki geliş̧melerin 20. yy.da hız kazanması ile birlikte demokrasi ve ekonomik kalkınma ilişkisi daha önemli bir hale gelmiştir (Doğan, 2005). Bu iliş̧i hakkında henüz teorik ve ampirik çalışmalar yeterli düzeye ulaşmamışken, Lipset (1959) kalkınma seviyesinin demokrasinin sürdürülebilirliği üzerinde pozitif bir etkisi olduğunu iddia etmiştir. Lipset'in çalışmasını takip eden birçok araştırmacı, konuyu farklı açılardan ele almış ve bu ilişkiye dair katkılar sunmuşlardır.

Bu kapsamda, çalışmanın ikinci bölümünde demokrasi ve demokrasinin 20. yy.daki gelişimi açıklanmaktadır. Üçüncü bölümde, demokrasi ve ekonomik kalkınma arasındaki ilişkiyi konu edinen çalışmalar belirtilmekte, dördüncü bölümde ise Barro (1996)'nun çalışmasına dayanılarak Orta Asya Türk Cumhuriyetleri için 1992 sonrasında ilgili verilerin seyri analiz edilmektedir.

\section{Demokrasi ve Demokrasinin 20. Yüzyılda Gelişimi}

Demokrasi, toplumun bütün üyelerinin görüşlerini belirtmeleri için eşit haklara sahip olması 
anlamına gelmektedir. Tarihsel süreçte topluma ait kolektif bir kararın ortaya konulabilmesi amacıyla farklı yöntemler uygulanmıștır; aristokrasi, meritokrasi, oligarși ve monarși gibi. Demokrasi, bu yöntemlerden, bireylere tanıdığı eşit hak nedeniyle ayrılmaktadır. Bu bakımdan demokrasi beș temel düșünceye dayanmaktadır (Beetham, 2005):

1. Toplumdaki bireyler, kolektif kararlar tarafından etkilenen bireysel çıkarlara sahip bulunmaktadır.

2. Herkes, kendileri ve toplum için hangi kararların doğru, hangi kararların yanlış olacağını değerlendirebilmektedir.

3. Uzun dönemde en iyi karar, bütün fikirlerin açıkça ortaya konması ve tartışılması ile alınmaktadır.

4. Tartışmaların neticesinde tek bir kararın alınamaması neticesinde, herkesin eşit şartlarda katıldığı bir oylama sistemi devreye girmektedir.

5. Bir kişi ve bir oy fikri, bireyler arasındaki eşit statüyü güçlendirmektedir.

1960'lı yıllarda, gelişmiş ülkelerin, demokrasi yapısına göre geri kalmış ülkelere yapacakları ekonomik yardımlar ile bu ülkelerde liberal ve demokrat yapının gelişeceği, böylece ekonomik kalkınmanın da hız kazanacağı düşünülmekteydi (Doğan, 2005). 1970'lerde ise demokrasi üçüncü dünya ülkeleri için ikincil öneme sahip bulunmaktaydı. Buna göre birincil öncelik ekonomik kalkınmaydı ve demokrasinin istikrarlı kalkınmayı takip edeceği savunulmaktaydı. $\mathrm{Bu}$ yaklaşım, diktatörlükleri ve askeri yönetimleri meşrulaştırmaktaydı. 1980'lerde ise liberal akımın ön plana çıkması ile serbest piyasa ekonomisinin gerekliliği olarak görülmeye başlanan demokrasi, ekonomik kalkınmanın öncüsü olarak değerlendirilmeye başlamıştır. Bu dönemde, demokrasi üçüncü dünya ülkelerine ithal edilmesi gereken bir politik rejim biçimi olarak dikkate alınmaktaydı. Bu durumda, tartışma konusu olan demokrasinin, ekonomik kalkınma için kolaylaştırıcı bir değişken olup olmadığı üzerinde yoğunlaşmaktaydı (Adejumobi, 2000).

1990’lı yılların başında, Batı Avrupa'da ve Sovyetler Birliği’nde komünist rejimler yıkıldıktan sonra, demokrasi politik idare şekli olarak hızlı bir şekilde yayılmaya başlamıştır. $\mathrm{Bu}$ dönemde, bağımsızlığını kazanan ülkeler için Freedom House'un hazırladığı demokrasi indeksinin ortalaması 1989 'da 0,26 iken 1991'de 0,57 olarak açıklanmıştır (0, demokrasinin olmadığı; 1 tam demokrasinin olduğu durumu ifade etmektedir) (Fidrmuc, 2003). Komünist dönemin sonrasında demokrasinin hâkim olduğu ülke sayısının otokrasi ile idare edilen ülke sayısını aştığı, Grafik 1'de daha iyi görülmektedir. Buna göre, 2000 yılı sonrasında süreç, demokrasinin lehine hareket etmektedir.

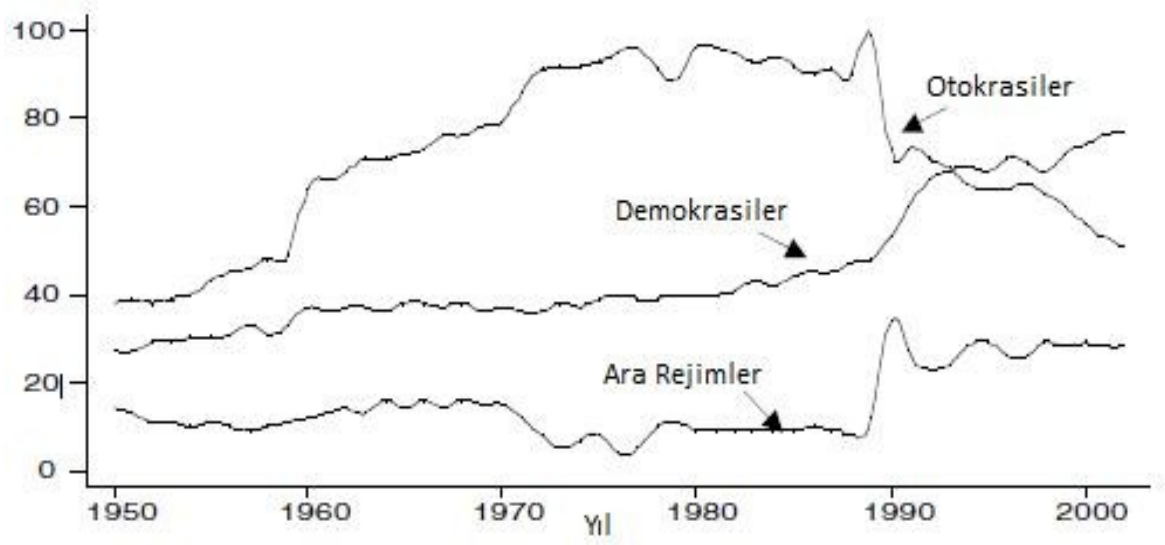

Grafik 1: Rejim Kategorilerinde Küresel Eğilim, 1950-2002 (Helperin, vd, 2005). 
Uzun dönemde başarılı bir ekonomik performansın sağlanabilmesi için gerekli olan temel şartlardan birinin üreticilerin mülkiyet hakkını koruyan kurumların varlığı olduğu konusunda geniş bir fikir birliği mevcut bulunmaktadır. Kurumların, kimlerin haklarını ve bunları nasıl koruyacağı konusu ise politik güç kavramını ortaya çıkartmaktadır. Politik güç, çıkar grupları arasında farklı yönetim biçimlerinde farklı dağılabilmekte; bununla beraber, bu dağılım, demokrasilerde daha eşit olabilmektedir (Acemoglu 2008). Ancak, bir ülkede demokratik kurumların varlığı, o ülkenin her zaman demokratik olmayan ülkelerden daha üstün bir ekonomik performans sergileyeceği anlamına gelmemektedir. Nitekim bu durum savaş sonrası dönemde gözlemlenmiştir (Barro 1999).

\section{Literatür}

Demokrasi ve ekonomik kalkınma birbirini tamamlayan kavramlardır. Refah düzeyi yüksek toplumlarda, ekonominin ve demokrasi istenilen seviyelerde bulunmaktadır. Bu bakımdan, demokrasi ve kalkınma birbirini besleyen kaynaklardır (Ghali, 2003). İktisat literatüründe ise demokrasi ve ekonomik kalkınma arasında pozitif ilişki olduğunu savunan araştırmacılar, ilişkinin yönünü demokratikleşme-ekonomik kalkınma veya ekonomik kalkınmademokratikleşme şeklinde olduğunu belirtmektedir. Ayrıca, bazı çalışmalar sonucunda, ilişkinin negatif veya önemsiz olduğu yönünde çıkarımlar da elde edilmiştir.

İlk defa Lipset (1959), demokrasinin sadece belirli sosyal şartlara dayanmadığını; aynı zamanda ekonomik kalkınmayı sağlayan bazı şartlara da dayandığını savunmuştur. Çalışma, ülkelerin gelir düzeylerinin artması ile demokrasiyi sürdürebileceklerini iddia etmektedir. Coleman (1960), Cutright (1963), Helliwell (1992, 1994), Burkhart ve Lewis-Beck (1994), Lipset (1994), Przeworski vd. (2000), Boix ve Stokes (2003) ve Epstein (2006), çalışmalarında benzer sonuçlara ulaşmışlardır. Buna göre belirtilen ilişkinin yönü; ekonomik kalkınmanın istikrarlı bir biçimde sürdürülmesi ile demokrasinin güçleneceği şeklindedir.

Literatürde, diğer yönlü ilişkinin varlığına ait çalışmalar da bulunmaktadır. Bu görüşe göre demokrasinin sürdürülmesi ile ekonomik kalkınmanın devamlılığı sağlanmaktadır (Borooah ve Paldam, 2007). Demokratik rejimler piyasa yapısının gelişmesi, kalkınmanın istikrarlı bir yapıya kavuşabilmesi için sürekli teknik yenilikler üretmeli ve girișimcilerin önünü açacak uygulamaları hayata geçirmelidir. Yine de demokratikleșme, kalkınma için mutlak değildir; demokrasi ancak rekabeti arttırdığı ve piyasaları genişlettiği ölçüde kalkınmaya olumlu etkide bulunmaktadır (Bhagwati, 2002). Inglehart (1990), Alesina vd. (1996), Londragen ve Poole (1996), Barro (1996, 1999) ve Milanovic (2005) bahsedilen ilișkinin pozitif yönlü olduğunu iddia eden diğer araștırmacılardır.

Neubauer (1967) kalkınmış toplumların daha demokratik olmaları gerektiği şeklindeki ifadenin her zaman doğru olmadığını iddia etmiştir. Kim (1971), Monshipouri ve Samuel (1995), Landman (1999) ve Alfaro (2002) farklı ülke grupları/ülkeler için yaptıkları çalışmalar neticesinde, inceleme yaptıkları vakalar için demokrasi ile ekonomik kalkınma arasında pozitif bir ilişki bulunmadığı sonucuna varmışlardır. Acemoglu vd. (2005) demokrasi ile ekonomik kalkınma arasındaki ilişkinin zayıf olduğunu savunmaktadır.

Barro (1996), demokrasi ve büyüme/kalkınma arasındaki ilişkiyi incelediği çalışmasında, lineer olmayan bir ilișkinin varlığından söz etmektedir. Büyümenin devam etmesi; hukukun üstünlüğüne, serbest piyasanın varlığına, azaltılmıs hükümet harcamalarına ve yüksek beșeri sermayeye bağlı bulunmaktadır. Bu değișkenler ve kiși bașı reel GSYH sabit tutulduğunda, demokrasinin büyüme/kalkınma üzerindeki etkisi negatiftir. Politik özgürlüğün alt seviyelerde olduğu durumlarda demokrasinin büyüme/kalkınma üzerindeki etkisi, politik özgürlüğün tam olduğu durumlara göre daha fazladır. Bu bakımdan kalkınma sürecinde bulunan gelişmekte olan ülkelerde, yaşam standartlarının iyileştirilmesi -GSYH, genel sağlık durumu ve eğitimpolitik özgürlüklerin artma ihtimalini yükseltmektedir.

Barro (1996)'ya göre büyüme çeşitli değişkenlerden etkilenmektedir. Bunlar; GSYH'nin başlangıç seviyesi, beşeri sermayenin başlangıç seviyesi, eğitim harcamaları, doğum oranı, 
hükümet harcamaları, piyasa bozulmaları, yatırım oranı, dış ticaret hacmi ve demokrasi seviyesi olarak belirtilmektedir. Barro, demokrasi ve yaşam standard1 arasındaki etkiyi; büyüme oranı, erkeklerin ilköğretime katılma oranı, kızların ilköğretime katılma oranı ve bebek ölüm oranı ile tespit etmektedir. Bu değișkenlerdeki gelişme, yaşam standartlarını ve demokrasi seviyesini değiştirmekte, demokrasi seviyesi de ekonomik kalkınmayı etkilemektedir.

\section{Orta Asya Türk Cumhuriyetleri'nde Demokrasi ve Kalkınma}

Sovyet Birliği'nin dağılmasından sonraki süreçte bağımsızlığını kazanan ülkelerde çok çeşitli ekonomik sonuçlar ortaya çıkmıştır. Orta Asya Türk Cumhuriyetleri'ni oluşturan Azerbaycan, Kazakistan, Kırgızistan, Türkmenistan ve Özbekistan'ın da aralarında bulunduğu bu ülkelerde, reformların başlangıcından itibaren ekonomik aktivitelerde birtakım daralmalar ortaya çıkmıştır. Bazı ülkelerde geçiş döneminden dolayı resesyonlar yaşanmış, bunlar 2-4 yıl aralığında ortadan kalkmıştır. Bazıları ise yüksek bir ekonomi performansı sergilemiştir (Fidrmuc, 2003).

Tablo 1'de Orta Asya Türk Cumhuriyetleri'nin bağımsızlık sonrası sabit fiyatlarla hesaplanan GSYH büyüme oranı görülmektedir. 1992-1996 yılları arasında beş Türkî Cumhuriyet'in de ekonomileri önemli ölçüde daralmalar yaşamıştır. Bu süreçte daralmadan en az etkilenen ülke Özbekistan olmuştur. 1999 sonrasında büyüme oranları pozitife dönmüştür. Önceki çalışmalarda bahsedildiği gibi başlangıç GSYH seviyesi diğerlerine göre yüksek olan Kazakistan ve Özbekistan, 2000 sonrasında diğer ülkelerin büyüme oranı değişimlerine göre daha istikrarlı bir seyir izlemişlerdir. Barro (1996) büyüme oranı ile demokrasi arasında pozitif yönlü bir ilişki olduğunu belirtmektedir. Bu bakımdan,

-istikrarsız büyüme oranları nedeniyle- Kırgızistan hariç, diğer ülkelerdeki büyümenin demokrasiye olumlu katkı yapacağ 1 düşünülmektedir.

\begin{tabular}{|l|c|c|c|c|c|}
\hline & Azerbaycan & Kazakistan & Kırgizistan & Türkmenistan & Özbekistan \\
\hline $\mathbf{1 9 9 3}$ & $-23,1$ & $-9,2$ & $-15,5$ & $-10,0$ & $-2,3$ \\
\hline $\mathbf{1 9 9 4}$ & $-19,7$ & $-12,6$ & $-20,1$ & $-17,3$ & $-5,2$ \\
\hline $\mathbf{1 9 9 5}$ & $-11,8$ & $-8,2$ & $-5,4$ & $-7,2$ & $-0,9$ \\
\hline $\mathbf{1 9 9 6}$ & 1,3 & 0,5 & 7,1 & $-6,7$ & 1,7 \\
\hline $\mathbf{1 9 9 7}$ & 5,8 & 1,7 & 9,9 & $-11,3$ & 5,2 \\
\hline $\mathbf{1 9 9 8}$ & 10,0 & $-1,9$ & 2,1 & 6,7 & 4,3 \\
\hline $\mathbf{1 9 9 9}$ & 7,4 & 2,7 & 3,7 & 16,5 & 4,3 \\
\hline $\mathbf{2 0 0 0}$ & 11,1 & 9,8 & 5,4 & 18,6 & 3,8 \\
\hline $\mathbf{2 0 0 1}$ & 9,9 & 13,5 & 5,3 & 20,4 & 4,2 \\
\hline $\mathbf{2 0 0 2}$ & 10,6 & 9,8 & 0,0 & 15,8 & 4,0 \\
\hline $\mathbf{2 0 0 3}$ & 11,2 & 9,3 & 7,0 & 17,1 & 4,2 \\
\hline $\mathbf{2 0 0 4}$ & 10,2 & 9,6 & 7,0 & 17,2 & 7,7 \\
\hline $\mathbf{2 0 0 5}$ & 26,4 & 9,7 & $-0,2$ & 13,0 & 7,0 \\
\hline $\mathbf{2 0 0 6}$ & 34,5 & 10,7 & 3,0 & 11,4 & 7,3 \\
\hline $\mathbf{2 0 0 7}$ & 25,0 & 8,9 & 8,5 & 11,6 & 9,5 \\
\hline $\mathbf{2 0 0 8}$ & 10,8 & 3,2 & 7,6 & 9,8 & 9,0 \\
\hline
\end{tabular}

Tablo 1: GSYH büyüme oranl, sabit fiyatlarla, 1993-2008. Kaynak: UNCTAD verilerinden derlenmiştir. 
Tablo 2'de Azerbaycan, Kazakistan ve Kırgızistan için ilköğretimde kızlar ve erkekler için okula devam etme oranları görülmektedir. Türkmenistan için bu veri bulunmamakta, Özbekistan için ise yetersiz veri bulunmaktadır. Azerbaycan'da, başlangıçta, kızların katılım oranı daha yüksek orandadır, sonraki yıllarda oran erkeklerin lehine değișmiștir. Katılım oranları 2003 yılından sonra \%90'nın üzerinde seyretmiștir. Kazakistan'da her iki grubun katılım oranları birbirine yakın seyretmektedir. Kırgızistan'da ise diğer iki ülkeye göre daha düşük katılım oranı izlenmektedir. Bu ülkede, erkek katılımı, kız katılımından her zaman daha yüksek olmakla beraber, iki oran da dalgalı bir seyre sahip bulunmaktadır. Barro (1996)'ya göre kız katılımının artması, demokrasiyi ve dolayısıyla kalkınmayı olumlu etkilemektedir. Erkek katılımının ise negatif bir etkisi vardır. Ancak, daha çok önemli olan ise iki katılım arasındaki farktır. Bu fark ne kadar yüksek olursa, demokrasi ve kalkınma bu durumdan olumsuz etkilenecektir. Bu bakımdan, en avantajlı ülke olarak Kazakistan gözlemlenmektedir.

\begin{tabular}{|c|l|c|c|c|c|c|c|c|c|c|c|}
\cline { 3 - 12 } \multicolumn{2}{c|}{} & $\mathbf{1 9 9 9}$ & $\mathbf{2 0 0 0}$ & $\mathbf{2 0 0 1}$ & $\mathbf{2 0 0 2}$ & $\mathbf{2 0 0 3}$ & $\mathbf{2 0 0 4}$ & $\mathbf{2 0 0 5}$ & $\mathbf{2 0 0 6}$ & $\mathbf{2 0 0 7}$ & $\mathbf{2 0 0 8}$ \\
\hline \multirow{3}{*}{ Azerbaycan } & K1z & 89,3 & 90,5 & 86,6 & 87,1 & 87,0 & 90,9 & 94,7 & 92,9 & 94,6 & 95,3 \\
\cline { 2 - 12 } & Erkek & 88,1 & 88,6 & 88,0 & 88,2 & 89,5 & 92,3 & 96,4 & 95,5 & 96,0 & 96,7 \\
\hline \multirow{3}{*}{ Kazakistan } & K1z & & 87,8 & 89,1 & 91,0 & 91,9 & 92,5 & 90,9 & 90,1 & 90,1 & 90,2 \\
\cline { 2 - 12 } & Erkek & & 86,7 & 89,3 & 91,4 & 92,0 & 92,7 & 91,1 & 90,1 & 90,4 & 90,5 \\
\hline \multirow{2}{*}{ Kirgızistan } & K1z & 87,4 & 86,0 & 85,3 & 85,1 & 84,0 & 88,3 & 84,8 & 84,4 & 83,0 & 83,2 \\
\cline { 2 - 11 } & Erkek & 88,6 & 87,3 & 87,1 & 86,8 & 85,5 & 88,7 & 85,4 & 85,3 & 83,8 & 83,9 \\
\hline \multirow{2}{*}{ Türkmenistan } & K1z & - & - & - & - & - & - & - & - & - & - \\
\cline { 2 - 11 } & Erkek & - & - & - & - & - & - & - & - & - & - \\
\hline \multirow{2}{*}{ Özbekistan } & K1z & - & - & - & - & - & - & - & - & 88,7 & - \\
\cline { 2 - 11 } & Erkek & - & - & - & - & - & - & - & - & 91,1 & - \\
\hline
\end{tabular}

Tablo 2: Illkögrretimde okula devam etme oranı, net \%, 1999-2008. Kaynak: Dünya Bankası.

Bir başka önemli gösterge de canlı doğan her bin bebekte, bebek ölüm sayısıdır. Barro (1996), bu sayı ile kalkınma arasında negatif bir ilişki belirlemektedir. Tablo 3, Orta Asya Türk Cumhuriyetleri için bu veriyi göstermektedir. 2005 yılından sonra düzenli hale gelen verilere göre Türkî Cumhuriyetlerde bebek ölüm sayısı sürekli düşüş kaydetmektedir. Bu durum, olumlu bir seyir olarak kaydedilebilir. Ancak, yine de sayıların daha alt seviyelere çekilmesi kalkınma üzerinde olumlu bir katkı sağlayacaktır.

\begin{tabular}{|c|c|c|c|c|c|c|}
\hline & $\mathbf{1 9 9 5}$ & $\mathbf{2 0 0 0}$ & $\mathbf{2 0 0 5}$ & $\mathbf{2 0 0 6}$ & $\mathbf{2 0 0 7}$ & $\mathbf{2 0 0 8}$ \\
\hline Azerbaycan & 74,9 & 57,6 & 39,9 & 37,1 & 34,4 & 31,9 \\
\hline Kazakistan & 48,0 & 38,4 & 30,7 & 29,4 & 28,0 & 26,9 \\
\hline Kurgızistan & 52,6 & 44,1 & 37,0 & 35,7 & 34,4 & 33,3 \\
\hline Türkmenistan & 70,4 & 59,1 & 48,5 & 46,7 & 44,9 & 43,1 \\
\hline Özbekistan & 57,2 & 52,7 & 39,8 & 37,6 & 35,6 & 33,7 \\
\hline
\end{tabular}

Tablo 3: Bebek ölüm saylsı, her bin canlı doğumda, 1995-2008. Kaynak: Dünya Bankası.

\section{Sonuç}

Demokrasi ile ekonomik kalkınma arasındaki ilişki araştırmacılar tarafından, farklı açılardan ele alınmış ve incelenmiştir. Bu çalışmada ise Barro (1996)'nun araştırmasında belirttiği ve demokrasiyi, dolayısıyla kalkınmayı etkileyen değişkenlerin Orta Asya Türk 
Cumhuriyetleri'ndeki yapısı, 1992 yılı sonrası için ele alınmıştır. Bu değişkenler; büyüme oranı, kızların ve erkeklerin ilköğretim seviyesinde okula katılma oranı ve her bin canlı doğumda bebek ölüm oranıdır.

Sovyetler Birliği'nin yıkılmasından sonraki süreçte, başlangıçta, ekonomiler daralma yaşamıştır. İleriki yıllarda, büyüme oranları iyileşme kaydetmiş, genellikle istikrarlı bir seyre girmiştir. İlköğretim seviyesinde katılım oranı hakkında yıllar ve ülkeler itibari ile yetersiz bilgi bulunmaktadır. Ancak, mevcut bilgiler ile Azerbaycan ve Kazakistan için oranın olumlu olduğu söylenebilmektedir. Her bin canlı doğumda bebek ölüm sayısında ise yıllar itibari ile azalma gözlemlenmektedir. Birlikte değerlendirildiği zaman, Orta Asya Türk Cumhuriyetleri'ndeki genel durumun 1992 'den günümüze kadar daha olumlu bir yapıya kavuştuğu söylenebilmektedir. Demokrasinin daha yüksek seviyelere çıkabilmesi için ilgili değişkenlerde pozitif gelişmelerin sağlanması, ekonomik kalkınmanın istikrarlı bir düzeyde devam etmesine neden olacaktır. Beşeri sermayenin güçlenmesi -sağlık harcamaları ile doğumda hayat süresinin uzaması ve eğitim harcamaları ile okullaşma oranının yükselmesi-, hükümet harcamalarının azalması, piyasa bozucu etkenlerin ortadan kaldırılması, ticaret hacminin genişlemesi ve demokrasinin daha yüksek seviyelere çıkması, kalkınmayı daha da hızlandıracak; demokrasi ve kalkınma birbirini besleyen bir yapıya sahip olacaktır.

\section{Kaynakça}

- Acemoglu, 2008. "Oligarchic versus Democratic Societies", Journal of the European Economic Association, 6(1), p. 1.

- Acemoglu, vd, 2005. Income and Democracy, http://www.nber.org/papers/w11205.

- Adejumobi, 2000. Between Democracy and Development in Africa: What are the the Missing Links?, http://www.worldbank.org/research/abcde/eu_2000/pdffiles/ADEJU MBOI.pdf.

- Alesina, vd, 1996. "Political Insability and Economic Growth", Journal of Economic Growth, 1, 189.

- Alfaro, 2002. "Economic Development and Democracy: Can Modernization Theory Be Upheld in Central America?", in Proceedings of 2. Revista de Ciencias Economicas, p. 20.

- $\quad$ Barro, 1996. "Democracy and Growth", Journal of Economic Growth, 1(1), p. 1.

- Barro, 1999. "Determinants of Democracy", Journal of Political Economy, 107(6), p. 158.

- Beetham, 2005. The Democracy: A Beginner's Guide. Oneworld, England.

- Bhagwati, 2002. "Democracy and Development: Cruel Dilemma or Symbiotic Relationship?", Review of Development Economics, 6(2), p. 151.

- Boix ve Stokes, 2003. "Endogenous Democratization", World Politics, 55, p. 517.

- Borooah ve Paldam, 2007. "Why is the World Short of Democracy? A Cross-country Analysis of Barriers to Representative Government", European Journal of Political Economy, 23, p. 582.

- Burkhart ve Lewis-Beck, 1994. "Comparative Democracy: the Economic Development Thesis", American Political Science Review, 88 (4), p. 903.

- Coleman, 1960. "Conclusion: the Political Systems of the Developing Area", The Politics of Developing Areas. Princeton University Press, USA.

- Cutright, 1963. "National political development: measurement and analysis", American Sociological Review, 28, p. 253.

- Doğan, 2005. "Demokrasi ve Ekonomik Gelişme", Erciyes Üniversitesi İktisadi ve İdari Bilimler Fakültesi Dergisi, 25(2), s. 1. 
- Epstein, 2006. "Democratic transitions", American Journal of Political Science, 50(3), p. 1.

- $\quad$ Fidrmuc, 2003. "Economic Reform, Democracy and Growth During Post-Communist Transition", European Journal of Political Economy, 19(3), p. 583.

- Ghali, vd, 2003. The Interaction Between Democracy and Development. UNESCO, Paris.

- Helliwell, 1992. Empirical linkages between democracy and economic, http://www.nber.org/papers/w4066.pdf.

- Helliwell, 1994. "Empirical Linkages Between Democracy and Economic Growth", British Journal of Political Science, 24, p. 225.

- Inglehart, 1990. Culture Shift in Advanced Industrial Society. Princeton,USA.

- Kim, 1971. "Socio-economic Development and Political Democracy in Japanese Prefectures", The American Political Science Review, 65 (1), p. 184.

- Landman, 1999. "Economic Development and Democracy: the View from Latin America", Political Studies, 47, p. 607.

- $\quad$ Lipset, 1959. "Some Social Requisites of Democracy: Economic Development and Political Legitimacy", American Political Science Review, 53(1), p. 69.

- $\quad$ Lipset, 1994. "The Social Requisites of Democracy Revisited: 1993 Presidential Address", American Sociological Review, 59, p. 1.

- Londragen ve Poole, 1996. "Does High Income Promote Democracy", World Politics, 49, p. 1.

- Milanovic, 2005.Relationship Between Income and Emergence of Democracy Reexamined 1820-2000: A Non-parametric Approach, http://siteresources.worldbank.org/ INTDECINEQ/Resources/przeworski1.pdf.

- Monshipouri ve Samuel, 1995. "Development and Democracy in Pakistan: Tenuous or Plausible Nexus?", Asian Survey, 35 (11), p. 973.

- $\quad$ Neubauer, 1967. "Some conditions of Democracy", The American Political Science Review, 6 (4), p. 1002.

- Persson ve Tabellini, 2006. Democratic capital: The nexus of political and economic change, http://www.nber.org/papers/w12175.

- Przeworski, vd, 2000. Democracy and Development. Political Institutions and Well-Being in the World: 1950-199, Cambridge UP, England. 


\title{
Orta Asya Cumhuriyetlerinde Yolsuzluk ve İktisadi Özgürlük (2001-2008)
}

\author{
İlyas Sözen, Beykent University \\ Ahmet Alkan Çelik, Beykent University \\ Selahattin Sarı, Beykent University
}

\begin{abstract}
The aim of this study is to examine, in the period between two global economic crises, the progress of economic freedom along with corruptions in Central Asian Republics, integrated into the free market economy according to "the Washington Consensus" since late 1990s. According to exportation of natural sources, Azerbaijan, Kazakhstan and Turkmenistan together with Kyrgyzstan, Uzbekistan and Tajikistan all seemed to have entirely different economic structures. Basic macro economic variables, economic liberty indicators and corruption data covering the period of 2001-2008 are to be discussed. In the light of the outcomes of this study, it is observed that, while the social structure in the countries exporting natural sources is stronger, due to the authoritarian structures of the countries in both groups of countries, bureaucratic corruption increases consistently. As Central Asian Republics are in a state of unsuccessful transition into the market economy, the betterment in legislation does not debug the system called "limbo" (neither planned economy nor free market).
\end{abstract}

JEL Codes: P25, P27

\section{Giriş}

1970'lerde yaşanan stagflasyon ve borç krizlerinden sonra devletin piyasa sistemindeki konumunu sorgulayıcı düşünceler ortaya çıkmıştır. Özellikle gelişmiş batı ekonomilerinde, 1980'lerin başından itibaren neo-liberal politikalar uygulanmaya başlanmasıyla beraber; sosyalist ve karma ekonomileri serbest piyasa sistemine yönlendirecek uygun koşullar oluşmuştur. Bu dönemde ortaya konulan "geçiş ekonomileri" kavramı, sosyalist düşüncedeki ekonomilerin piyasa ekonomisine -liberalizm- doğru yol almalarını belirtmektedir.

Piyasa ekonomisi ya da liberalizm, piyasa ajanlarının serbestçe hareket edebildikleri, fiyatların arz ve talep dengesine göre belirlendiği, piyasa dengesinin oluşumuna dışarıdan müdahalenin kabul edilmediği ekonomik yapıdır (Yüce, 2004). Neo-liberal politikalar, 1980'lerin başından itibaren önce gelişmiş ülkelerde -özellikle ABD ve İngiltereuygulanmıştır. Daha sonra, Bretton Woods'ta kurulmuş uluslararası örgütler ile uluslararası sermaye sayesinde, gelişme sürecindeki ülkelerde de 1970'lerin kalkınmacı anlayışı yerine neo-liberal politikalar uygulanmaya başlanmıştır. Uygulanan politikalar arz yanlı iktisadi anlayışta olup temel düşüncesi serbest ticaretin ülkelere refah getireceğidir. 1980'lerdeki neoliberal değişim, yaşanan aksaklıklardan sonra 1990'larda Washington Mutabakatına dönüşmüştür.

Geçiş ekonomileri kavramı sosyalist ekonomik sistemden piyasa ekonomisi sistemine geçişi temsil ettiğinden, geçiş ekonomileri genel olarak Çin ile Sovyet Rusya'nın dağılmasından sonra ortaya çıkan Merkezi ve Orta Avrupa Ülkeleri, Orta Asya Ülkeleri ve Rusya kabul edilmektedir. $\mathrm{Bu}$ ülkelerde, IMF ve Dünya Bankası tarafından uygulanan politikaların yolsuzluk ve iktisadi özgürlük sonuçları farklıdır. Çalışmamızda geçiş ekonomilerinden sadece Orta Asya Cumhuriyetlerinden bahsedilecektir. Altı Orta Asya Türk Cumhuriyetinin, Washington Mutabakatının uygulanmalarından sonraki süreç içinde dünya genelinde yaşanan ekonomik kriz dönemlerinde (2001-2008) yolsuzluk ve iktisadi özgürlük gelişimleri ele alınacaktır. 


\section{Washington Uzlaşması}

1989 yılında J. Williamson Washington mutabakatı (uzlaşması) kavramıyla; gelişmekte olan ülkelerdeki krizlere karşı on maddelik standart reform reçetelerini sunan Washington temelli kurumların (IMF, WB, ABD Hazinesi) ilişkilerini ortaya koymuştur. Williamson, Washington temelli kurumların önceleri kalkınma amaçlı yapılanma içinde olduğunu, daha sonra neoliberallerin söylemlerini kabul ettiğini ve söylemlerinin piyasa temelli politikalara dönüştüğünü belirtmektedir (Williamson, 2000). Artık Washington uzlaşması anıldı̆̆ında akıllara sadece neo-liberal politikalar gelmektedir.

IMF ve WB, 1990'lı yıllardan sonra geçiş ekonomilerinin sorunlarını kabaca şöyle kabul etmektedirler (Altay, 2003);

- Demokrasinin olmayışından kurumsal yapının oluşmaması,

- Tekelleşme sonucunda kalitesiz, verimsiz ve yetersiz üretim,

- Bastırılmış enflasyon ile gelir dağılımının hesaplanamaması ve gelir dağılımı dengesizliği,

- Bireysel mülkiyetin olmayışından dolayı, ticaretin ve talebin yetersizliği,

- Kamu harcamalarının verimli alanlardan çok popülist olması,

- Hukuk alanındaki güvensizlik ve yozlaşma,

- İşsizlik ve verimsizliği teşvik eden sosyal güvenceler.

Washington Uzlaşmasında yukarıdaki sorunlara karşılık ortaya konan maddeler, makro ekonomik istikrar ve liberalleştirme başlığı altında toplanmıştır. Sağlanan uzlaşma tarafindan kabul edilen reçete, 1990'ların başında Lâtin Amerika ülkelerinin ekonomik sorunlarına karşı önerilse de, IMF'in etkisiyle 1990'ların sonunda geçiş ekonomilerine ve gelişmekte olan ülkelerdeki krizlere karşı aynı reçete (standart) sunulmuştur. (Kuczynski ve Williamson, 2003).

Makro Íktisadi İstikrar olarak; Mali ve Parasal Disiplin, Kamu Harcamalarındaki Öncelik, Vergi Reformu ve Rekabetçi Döviz Kuru.

Liberalleştirme olarak; Fiyat Serbestliği, Hükümetin Piyasa Sistemine Müdahalesinin Azaltılması, Finansal Serbestleşme, Ticarî Serbestleşme, Doğrudan Yabancı Sermaye Yatırımları Özelleştirme ve Mülkiyet Hakkı.

Washington Uzlaşmasının, geçiş ekonomileri ve gelişmekte olan ülkeler tarafından kabul edilmesinin iki temel nedeni bulunmaktadır. Bunlardan ilki ithal ikamesine dayalı kalkınmanın 1970'ler sonundaki başarısızlığı, diğeri de ekonomik başarısızlığın telafisinin IMF ve Dünya Bankası gibi uluslararası kurumların desteklediği Ortodoks politikalarla çözeceğine olan inançtır. Bu inancın nedeni ise, serbest piyasa karşısındaki tek rakip Sovyet Rusya'nın dağılma sürecidir. Washington merkezli kurumlar, geçiș ekonomilerinde ve gelişmekte olan ülkelerdeki fakirliğin azaltmasının ve zenginliğin ancak sermaye hesaplarının serbestleştirilmesiyle olacağını savunmaktadır (Williamson, 2000).

Washington Uzlaşması gözetiminde uygulanan politikalar büyümeyi artırmadığı gibi yüksek enflasyona neden olduğu gözlenmiştir. Buna ilaveten fakirliği azaltma amacının gerçekleşmediği gibi ekonomik ve sosyal eşitsizlikte azalmamıştır. Stiglitz'in önderliğinde, 1998 yılından sonra Washington uzlaşmasının başarısız olduğu kabul edilerek, postWashington uzlaşması ortaya konulmuştur (Stiglitz, 1998). Çünkü gelişmiş ülkeler için düşünülüp daha sonra geçiş ekonomilerine uyarlanırken unutulan en önemli konu büyümenin başlangıcıdır. Bu sorunun çözümü için yeni bir anlayış getirilmiştir.

Post-Washington uzlaşması aslında bir önceki uzlaşmanın devamı şeklinde algılanmaktadır. Bir önceki anlaşmada var olan on maddeyi temel alarak eksikleri gidermek için sosyal yönü olan on madde daha eklenmiștir (Rodrik, 2006). 
- Kurumsal Yönetim

- Yolsuzlukla Mücadele

- İş gücü Piyasasında Esneklik

- $\quad$ DTÖ (Dünya Ticaret Örgütü) Anlaşmaları

- Finansal Kodlar ve Denetimler

- Sermaye Hesaplarının Tedbirli Açılımı

- Tek (aracısız) Döviz Kuru Rejimi

- Bağımsız Merkez Bankası/ Enflasyon Hedeflemesi

- Sosyal Güvenlik Fazlas1

- Yoksulluğun Azaltılmasının Hedeflenmesi

Post-Washington Uzlaşması sonucunda geçiş ekonomileri için yolsuzluğun ve kurumsal yapının önemi fark edilmiş̧ir.

\section{Yolsuzluk ve İktisadi Özgürlük}

1996 yılında IMF/Dünya Bankası yıllık toplantısının ardından, gelişmekte olan ülkeler ve geçiş ekonomileri üzerinde yolsuzluk sorunu hakkındaki çalışmalar arttırılmıştır. Yapılan çalışmalarda yolsuzluğun birçok farklı tanımı bulunmaktadır. Ancak Dünya Bankası tarafından kabul edilen en dar anlamıyla "Özel kazançlar için kamu görevlerini kullanma" olarak kabul edilmektedir (Dünya Bankası). 2001 yılında yapılan çalışmada; yolsuzluk üzerine yayınlanmış eserlerin dörtte üçünün politik ve kamu yönetimi üzerine olması (Global Corruption Report, 2001; 229) Dünya Bankası'nın yapmış olduğu dar tanımın genel olarak kabul edildiğini göstermektedir.

Yolsuzluk ile ilgili birçok farklı tanımın olmasının nedeni ise yolsuzlukta farklı faktörlerin etken olmasıdır. Bu faktörler; farklı kültürler, yolsuzluğun farklı sonuçlar vermesi, yolsuzluk türlerinin geniş olmasıdır. Yolsuzluğun; rüşvet, dolandırıcılık, zimmete geçirme, kayırmacılık, irtikâp ve ticari bilgilerin sızdırılması v.b. birçok türü bulunmaktadır.

Yolsuzluk türleri içinde en yaygını ise rüşvettir. Rüşvetin iktisadi nedenleri hakkında birçok çalışma yapılmıştır. Genel olarak rüşvetin iktisadi nedenleri olarak (Gürbüz ve Dikmenli, 2009; 224);

- Yüksek enflasyon ( Maaş/ücretin değerini kaybetmesi)

- Devletin ekonomide ağırlığı ( Bürokratik yapının yüksek oranlı olması)

- Kayıt dışı ekonomi ( Bürokrasinin işlevselliğinin azalması)

- Gelir dağılımı adaletsizliği (Fakirleşmenin artması)

- Medya-ticaret ilişkisi ( Çıkar ilişkisi)

- Siyasetin finansmanı ( Rant dağıtımı)

- Özelleştirmelerin şeffaf olmaması

Çalışmada, Orta Asya Cumhuriyetlerini sınıflandırırken; Ülkelerin Atlas Metoduna göre kişi başına geliri ve 2001 yılından sonra artan doğal kaynak fiyatlarından dolayı doğal kaynak ihraç etmeleri temel alınmıştır.

\begin{tabular}{ccccccc}
\cline { 2 - 7 } & $\begin{array}{c}\text { GDP } \\
(\%)\end{array}$ & $\begin{array}{c}\text { Kişi } \\
\text { Başina } \\
\text { GSMH } \\
\text { (Atlas \$) }\end{array}$ & $\begin{array}{c}\text { Enflasyon } \\
(\%)\end{array}$ & $\begin{array}{c}\text { \%30 Üst } \\
\text { Gelir } \\
\text { Dilimi }(\%)\end{array}$ & $\begin{array}{c}\text { Özelleştirm } \\
\text { e (milyon } \\
\$)\end{array}$ & $\begin{array}{c}\text { DYSY Stoku } \\
(2008 \text { milyon } \\
\text { \$) }\end{array}$ \\
\cline { 2 - 7 } Azerbaycan & 16,36 & 1605 & 8,6 & 48 & 191 & 8557 \\
Kazakistan & 9,3 & 3111 & 9,0 & 64 & 2738 & 59646 \\
Türkmenistan & 14,3 & 1867 & 15,7 & na & na & 8545 \\
\hline Kırgizistan & 4,75 & 457 & 9,2 & 69 & 2 & 1015
\end{tabular}




\begin{tabular}{ccccccc} 
Özbekistan & 6,6 & 584 & 15,3 & 71 & 70 & 101375 \\
Tacikistan & 8,7 & 325 & 7,6 & 66 & 1 & 870 \\
\hline
\end{tabular}

Tablo 1. Temel Makroekonomik Değişkenler. Kaynak: WB, IMF, UN verilerinden derlenmiştir.

Tablo 1'de ilk gruba Azerbaycan, Kazakistan ve Türkmenistan alınırken; ikinci gruba Kırgızistan, Özbekistan ve Tacikistan alınmıştır. Birinci grubun 1997-2001 dönemine kıyasla 2001-2008 döneminde ekonomik büyüme oranlarında iki katına yakın artış yaşanırken; ikinci gruptaki ülkelerde 2001-2008 dönemi 1997-2001 döneminden farklılık görülmemektedir (WB, Data). ilk gruptaki ülkeler yer altı doğal kaynak ihracatı ile 1997 Asya Krizi’nden sonra durumlarını düzeltebilirken diğer gruptaki ülkeler dünya ticaretinde ve ekonomilerinde yaşanan büyüme döneminde bile aynı oranda büyüme hılarına devam etmektedirler. Yeraltı kaynakların ekonomilerdeki etkisi açıç̧a görülmektedir.

Türkmenistan'ın yönetim anlayışından dolayı birçok veriye ulaşılamasa da, bölgede özellikle kişisel gelir ve büyüme açısından giderek artan bir ivmeye sahip olması dikkat çekicidir. Diğer dikkat çeken ülke ise, en fazla yabancı sermaye stokuna sahip Özbekistan'ın yüksek nüfusuna rağmen ekonomisinin ve kişisel gelirinin düşük olmasıdır. Bunda, Özbekistan'ın tarım ülkesi olması ve pamuğa dayalı ihracat sistemi etkilidir.

Orta Asya Cumhuriyetlerinde özelleştirmenin başarılı olduğu tek ülke Kazakistan olması, doğal kaynak zenginliğinden kaynaklandığı iddia edilebilinir. Aynı şekilde Azerbaycan'ın petrol ve doğalgaz, Özbekistan'ın ise altın kaynakları özelleştirme ve yabancı sermayenin ülkeye gelmesinde etkilidir. Ekonominin gelişiminin temel kaynağı tasarruftur. Ancak bu bölge ülkelerinin hem nüfuslarının az olması hem de vatandaşlarının gelirinin düşük olmasından dolayı yabancı sermayeye muhtaçtırlar. Bunlara ilaveten bu ülkelere giren yabancı sermayenin büyük çoğunluğunun petrol v.b. kaynaklara yöneldiğinden, artan para arzı enflasyonu yükseltebilmektedir. Artan enflasyon ise ülkelerdeki gelir dağılımını etkilemektedir. Ülkelerin ekonomileri ne kadar zayıf ve enflasyonu ne kadar yüksek ise ülkedeki zengin kesim ile fakir kesim arasındaki dengenin bozulduğu özellikle Tablo 1'deki yüzde 30'luk dilimin ekonomiden aldığ 1 paylarla ortadadır.

1995 yılından beri Uluslararası Şeffaflık Örgütü tarafından ülkeler yolsuzluk konusunda belli bir sıralamaya tabi tutulmaktadırlar. Örgütün sıralaması kesinlik göstergesi olmasa da, ülkelerdeki rüşvet olgusunu göstermede artık kabul görülmektedir.

\begin{tabular}{ccccccccc} 
& 2001 & 2002 & 2003 & 2004 & 2005 & 2006 & 2007 & 2008 \\
\cline { 2 - 9 } Kazakistan & 73 & 88 & 101 & 124 & 110 & 111 & 155 & 145 \\
Azerbaycan & 84 & 95 & 125 & 140 & 137 & 130 & 150 & 159 \\
Türkmenistan & NA & NA & NA & 139 & 157 & 151 & 166 & 168 \\
\hline Kırgizistan & NA & NA & 118 & 125 & 134 & 145 & 157 & 167 \\
Özbekistan & 74 & 69 & 103 & 114 & 143 & 155 & 176 & 169 \\
Tacikistan & NA & NA & 128 & 138 & 150 & 149 & 160 & 157 \\
\hline Toplam Ülke & 91 & 102 & 133 & 146 & 159 & 163 & 180 & 182
\end{tabular}

Tablo 2. Ülkelerin Yolsuzluk Siralaması. Kaynak:International Transparency Report (2001,2002,2003,2004,2005,2006,2007,2008) verilerinden derlenmiştir.

Tablo 2'de yolsuzluk indeksine 2001 yilında toplam 91 ülke tabi iken, indekse 2008 yilında dünya ülkelerinin tamamına yakınını alınmıştır. Orta Asya Cumhuriyetlerinin yolsuzluk sorunları hem 2001 yılında hem de 2008 yılında açıkça görülmektedir. Yeni ülkeler eklenmesiyle aslen sıralamada farklılık gösterememişlerdir. Örgütün 2004 ile 2008 yolsuzluk raporlarına göre dört yıllık süreçte Kazakistan, Azerbaycan ve Tacikistan aynı puanda iken, Özbekistan, Kırgızistan ve Türkmenistan'da sırasıyla 0,5 0,4 ve 0,2 lik düşüşler göstermişlerdir (Transparency Report, 2004;2008). 
Tablo 1'deki ekonomik yapıları dikkate alındığında, Tacikistan'ın ve Türkmenistan'ın durumları farklılık göstermektedir. Tacikistan'ın gelișmemiș ekonomisinden dolayı rüșvetin ana kaynağı olan rantın el değiștiremediğinden daha gelişmiș Orta Asya Cumhuriyetleri ile aynı konumdadır. Türkmenistan'da ise yolsuzluk sorununun bölgesel olduğu kabul edilmektedir (Factbook). Çünkü ülke de hem doğal kaynak hem de tarım ürünleri ihracatı artmaktadır. Bu alanlarda ekonomik rantı gittikçe yükselen bir ülke konumundadır. Genel olarak bakıldığında ülkeler 1,8-2,2 puan aralığında yolsuzlukta sorunlu ülkeler arasındadır. Bu ülkelerde yolsuzluğun yaygın ve önemli bir sorun olduğu aşikârdır.

Geçiş ekonomileri içindeki Orta Asya ülkelerindeki yolsuzluğun dört ana sorunun var olduğu kabul edilmektedir (Detbier, 2003). Bunlar;

- Politik rejimlerindeki demokrasiye geçişteki sorunlardan dolayı oluşan otokrasi yapı,

- Yerel elitlerin güçlü kontrollerinden dolayı piyasa yapısının gelişememesi,

- Zayıf devlet yapıları,

- Yerel ve bölgesel çatışma ortamının özellikle millet kavramını oluşturmada sorun teşkil ettiği kabul edilmektedir.

Orta Asya Cumhuriyetlerindeki yolsuzluk sorununa, ekonomilerinin gelişmemişliğiyle birlikte yaşanan sert iktisadi değişimin yol açtığı görülmektedir. Bölge ülkelerinin uzun süre planlamacı sistemden, Washington temelleri kurumların yönlendirilmesiyle çok sert bir şekilde serbest piyasa sistemine geçmişlerdir. Aşağıdaki Tablo 3’te bu ülkelerin bu dönüşümlerini on farklı alanda dünya ortalamasına göre puanlar verilmektedir.

\begin{tabular}{|c|c|c|c|c|c|c|c|c|c|c|c|}
\hline & ঠ্ঠ & $\approx$ & 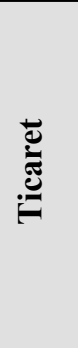 & 离 & 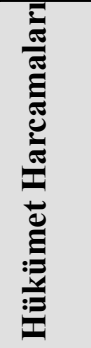 & 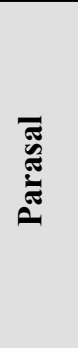 & 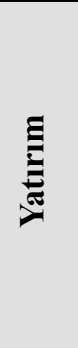 & 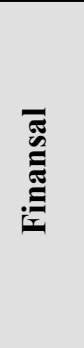 & 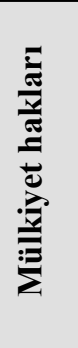 & $\begin{array}{l}\frac{y}{E} \\
\frac{\bar{N}}{\partial} \\
\frac{0}{\partial}\end{array}$ & 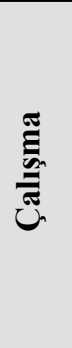 \\
\hline Azerbaycan & 58,8 & 74,6 & 77,1 & 79,5 & 77,5 & 62,7 & 55,0 & 40,0 & 20,0 & 19,0 & 82,5 \\
\hline Kazakistan & 61,0 & 73,5 & 85,9 & 87,9 & 82,1 & 65,6 & 30,0 & 50,0 & 30,0 & 22,0 & 83,1 \\
\hline Türkmenistan & 42,5 & 30,0 & 79,2 & 90,2 & 94,7 & 62,8 & 0,0 & 10,0 & 10,0 & 18,0 & 30,0 \\
\hline Kırgızistan & 61,3 & 76,6 & 75,9 & 92,9 & 80,2 & 62,2 & 50,0 & 50,0 & 25,0 & 18,0 & 82,6 \\
\hline Özbekistan & 47,5 & 67,8 & 65,1 & 88,4 & 72,6 & 62,4 & 10,0 & 10,0 & 20,0 & 18,0 & 61,1 \\
\hline Tacikistan & 53,0 & 57,4 & 82,5 & 88,9 & 78,0 & 58,4 & 25,0 & 40,0 & 25,0 & 20,0 & 54,4 \\
\hline
\end{tabular}

Tablo 3. Ülkelerin İktisadi Özgürlük Puanlaması. Koyu olan rakamlar dünya ortalaması üzerindedir. Kaynak: Heritage Fonu http://www.heritage.org/index/Explore.aspx verilerinden derlenmiştir

Orta Asya Türk Cumhuriyetlerinde yaşanan iktisadi değişim sonucunda genel olarak iş alanındaki özgürlük -Türkmenistan hariç- gelişmiştir. Ticaret alanında, mali anlamdaki özgürleşme ve hükümet harcamaları artan oranda gelişmektedir. Çalışma alanında Türkmenistan diğer ülkelere göre özgürleşmesi düşük orandadır.

Orta Asya Türk Cumhuriyetlerinin sorunları yatırım, mülkiyet hakları ve yolsuzluk olduğu Tablo 3 'te açıkça görülmektedir. Bu sorunlarda, kurumsal gelişim ve ülke vatandaşlarının hayat standartları önemli etkenlerdir. 


\begin{tabular}{|c|c|c|c|c|c|c|}
\hline & 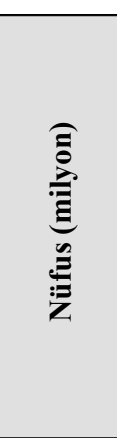 & 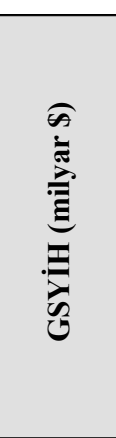 & 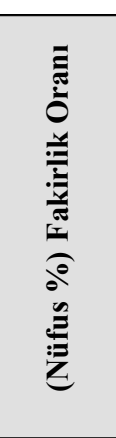 & 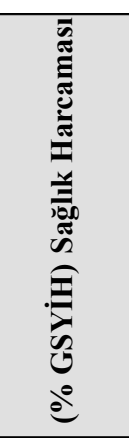 & 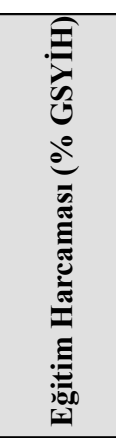 & 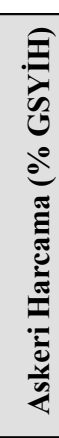 \\
\hline Azerbaycan & $\begin{array}{c}8,4 \\
(2005)\end{array}$ & $\begin{array}{c}78 \\
(2008)\end{array}$ & $\begin{array}{c}<2 \\
(2005)\end{array}$ & $\begin{array}{c}1 \\
(2008)\end{array}$ & $\begin{array}{c}2.6 \\
(2008)\end{array}$ & 2,6 \\
\hline Kazakistan & $\begin{array}{c}15 \\
(2003)\end{array}$ & $\begin{array}{c}175 \\
(2007)\end{array}$ & $\begin{array}{c}17.2 \\
(2003)\end{array}$ & $\begin{array}{c}2.3 \\
(2007)\end{array}$ & $\begin{array}{c}3.6 \\
(2007)\end{array}$ & 1,2 \\
\hline Türkmenistan & 6,5 & $\begin{array}{c}28 \\
(2005)\end{array}$ & na & $\begin{array}{c}4.8 \\
(2005)\end{array}$ & $\begin{array}{c}5.4 \\
(2005)\end{array}$ & na \\
\hline Kurgızistan & $\begin{array}{c}5,1 \\
(2004)\end{array}$ & $\begin{array}{c}12 \\
(2008)\end{array}$ & $\begin{array}{c}51.9 \\
(2004)\end{array}$ & $\begin{array}{c}2.4 \\
(2008)\end{array}$ & $\begin{array}{c}5.2 \\
(2008)\end{array}$ & 2,4 \\
\hline Özbekistan & $\begin{array}{c}25,6 \\
(2003)\end{array}$ & $\begin{array}{c}72 \\
(2007)\end{array}$ & $\begin{array}{c}76.7 \\
(2003)\end{array}$ & $\begin{array}{c}2.4 \\
(2007)\end{array}$ & $\begin{array}{c}8.9 \\
(2007)\end{array}$ & 0,5 \\
\hline Tacikistan & $\begin{array}{c}6,3 \\
(2004)\end{array}$ & $\begin{array}{c}13 \\
(2008)\end{array}$ & $\begin{array}{c}50.8 \\
(2004)\end{array}$ & $\begin{array}{c}1.2 \\
(2008)\end{array}$ & $\begin{array}{c}3.4 \\
(2008)\end{array}$ & 2,1 \\
\hline
\end{tabular}

Tablo 4. Ülkelerin Sosyal Göstergeleri. Kaynak: WB, IMF, EBRD verilerinden derlenmistir.

Tablo 4'ün verilerine göre; doğal kaynak ihraç eden ülkelerde (Türkmenistan hariç) gelir dağılımı daha dengelidir. Ancak fakirliğin ülke ekonomisiyle ilişkisindeki bağlantısızlık Azerbaycan-Özbekistan karşılaştırılmasında görülmektedir. Özbekistan'ın nüfusuna göre yaptığı yatırımların yetersiz olduğu söylenebilir. Orta Asya Cumhuriyetlerinde sosyal gösterge olan eğitim ve sağlık harcamaları yüzde olarak hem dünya ortalamasının çok gerisinde hem de rakamsal olarak çok azdır. Kazakistan eğitim alanında nüfus başına diğer ülkelere göre daha yüksek yatırımda bulunurken, en düşük yatırımları Kırgızistan ve Tacikistan yapmaktadır (Factbook). Askeri harcamalar daha çok sorunlu bölgelerdeki ülkelerde oransal olarak yüksek görülse de diğer harcamalardan çok farklı değildir. Ülkeler az olan kaynaklarını dengeli dağıtmaya çaba göstermektedirler.

\section{Sonuç}

Orta Asya Türk Cumhuriyetlerinin temel sorunu ekonomilerinin gelişmemesinden dolayı ortaya çıkan gelir adaletsizliğinin yolsuzluğa yol açması ve iktisadi sistem değişikliğinin mülkiyet hakları konusunda gelişimi sağlayamamasıdır. Ortaya kapalı bir çember sorunu çıkmaktadır. Sorunun çözümü için kurumsal yapılaşmanın sağlanması gerekmektedir.

Demir'e göre kurumsal yapılaşma kökleri geçmişe dayanan ve insan topluluklarını geleceğe taşıyacak istikrarlı davranış tarzları ve düşünce yapılarıdır (Demir,1996). Bu nedenle istikrarlı bir kurumsal yapı oluşturacak politikaların uygulanması gerekmektedir. Başka bir sistemden piyasa ekonomisine entegre olmaya çalışırken Ortodoks olarak kabul edilen Washington temelli kurumaların politikalarını yirmi yıllık süre boyunca uygulanmaktadır. Ortaya çıkan kurumsal yapılaşma sorunların çözümü için artık farklı yöntemlerin ve iktisadi anlayışların uygulanması gerekmektedir.

$\mathrm{Bu}$ ülkelerdeki kurumsal yapılanmanın önündeki ilk engel, uzun süreli Sovyet Rusya siyasi 
politikasından dolayı, bağımsızlıktan sonra bile ülkelerde çok farklı milletlerin yaşamasından dolayı bir ulus devlet olamamalarıdır. İkinci engel ise, yaşanan iktisadi değişimin çok sert olmasıdır. Değișen sistem ne komünizmi ne de kapitalizmi temsil eden limbo olarak adlandırılan anlayıștır. Bu nedenden dolayı eski alıșkanlıklar devam ettiği gibi, yeni sisteme entegre olmada zorlaşmaktadır. Böylece ülkede yaşayanlar arasında ortak fayda sağlanamadığ 1 gibi sistemde tıkanıklıklara yol açmaktadır. Üçüncü engel ise ülkenin ekonomik yapısının değişimini sağlarken hukuki sistemin gelişiminin sağlanamamasıdır. Özellikle mülkiyet hakkı, kaynak dağılımını etkilediğinden sosyal değişimde temel etkenlerden biridir. Hukuki yapı iktisadi yapının temelini sağladığı unutulmamalıdır.

Orta Asya Türk Cumhuriyetlerinin sorunlarının çözümü için neo-liberal politikaların yerine kurumsal iktisadi anlayışa sahip hukuki alt yapı geliştirilmelidir. Hukuki altyapı ile birlikte hem bürokratlara hem de ülke halkına etik eğitimi ile hak ve görevleri yoğun eğitim programlar sayesinde bir milli ortak fayda ve düşünce oluşturulmalıdır. Özellikle mülkiyet hakkını düzenlemek için iktidar olunması ve hukuki alt yapının geliştirilmesi gerekmektedir. Çünkü bu ülkelerin sorunları artık finansal serbestleşme, çalışma ortamının veya hükümetlerin uygulamalarından ziyade kurumsal ve ahlakidir.

\section{KAYNAKÇA}

- Altay A,2003. "Geçiş Ekonomilerinde Devletin Ekonomik Rolleri Görevleri ve KOBI'lerin Durumu” Maliye Araştırma Merkezi Yayın, No:86, s.11.

- CIA, Factbook, economy and population

- $\quad$ Demir Ö., 1996. Kurumcu İktisat, Vadi yayınları, Ankara, s.173.

- Detbier J-J, 2003. "Corruption in the CIS-7 Countries", in Lucerne Conference of the CIS-7 Initiative, s.10.

- Dünya Bankas1,2010. Introduction to Corruption, Module III info.worldbank.org/etools/library/latestversion.asp?35970

- $\quad$ EBRD Corruption verileri.

- Gürbüz S. ve Dikmenli O., 2009. “Örgütsel açıdan Yolsuzluk: Kavramsal Yönü, Özelliği, İşletme Çevresi, Örgütsel Davranış ve Örgüt Mimarisi Bağlamında Bir İnceleme", Selçuk Üniversitesi sosyal Bilimler Dergisi, Sayı 22, ss.219-237.

- Heritage fonu, http://www.heritage.org/index/Explore.aspx

- IMF International Finance Statistics verileri.

- Kuczynski P. ve Williamson J.,2003. After the Washington Consensus: Restarting Growth and Reform in Latin America, Institute of International Economics, Washington, s.324.

- $\quad$ Rodrik D. 2006, “Goodbye Washington Consensus, Hello Washington Confusion? A Review of the World Bank's Economic Growth in the 1990s: Learning from a Decade of Reform", Journal of Economic Literature, Vol. 44, Issue 4, ss. 973-987.

- Stiglitz J., 1998. "More Instruments and Broader Goals: Moving Toward the PostWashington Consensus", The 1998 WIDER Annual Lecture, Helsinki, Finland.

- Transparency, Global Corruption Report, 2001, Data and Research, s.229

- Transparency, Report 2001,2002,2003,2004,2005,2006,2007,2008.

- UNFID verileri.

- Williamson J., 2000. "What Should World Bank Think About The Washington Consensus?", The World Bank Observer, Vol. 15, 2, s.251.

- Yüce Mehmet, 2004. "Kırgız Cumhuriyetinin Serbest Piyasa Ekonomisine Uyum Sorunu", Ekonomi ve Toplum, Cilt 6, Sayı 1, s.1. 


\title{
Geoeconomic Ties of Eurasian Countries with the United States, European Union, Russia and China
}

\author{
Ruxandra Chiran, Academy of Economic Studies, Bucharest
}

\begin{abstract}
Eurasia represents an area of major strategic interests for USA, Turkey, China, Russia, EU. I examine the interest of this powers to come in a carrefour of energetic and regional security issues and their effects on the regional stability.

There is a geopolitical and geoeconomical dispute over Central Asia, concerning the undefined character of Kazakhstan's role in the region, evolution which I focus on and see if Kazakhstan will manage to set its economic priorities in the European Union's countries.

Russia should develop what some authors refer to as the "geopolitics of cooperation" with three main geoeconomic poles: the West, China, and the Asia-Pacific.

Beijing looks towards Central Asia and beyond as part of a more complex strategy in Eurasia. Its interests are manifested in the "Plan West".

In the attempt to become more of a global actor, the European Union adopted a Strategy for Central Asia in 2007. After three years, it is time to see its progress. I also underline the economic dimension of European Union - Turkey cooperation.

Relations USA - Central Asia on trade and energy levels remain slight. The American projects for an opening into India and Pakistan, with Afghanistan as a transit zone, have failed or have only been realized to a limited degree.
\end{abstract}

JEL Codes: F59, O53

\section{General overview. Central Asia, Transcaucazia, Afghanistan}

Nowadays, the eurasianism, a new form of panslavism, does not have a big audience, politically speaking (it is supported by minor political parties in Rusia and Japan). The projects of reintegrating ex-soviet space (without the Baltic Countries, but eventually including Mongolia) can be considered essays of creating a eurasiatic agenda (including the idea of creating a Eurasian Union, an idea proposed by the president of Kazakhstan, Nursultan Nazarbaiev) ${ }^{1}$.

The Eurasia of the Third Millennium is home to some of the world's largest oil producers, wealthiest investors, and fastest growing economies along with more than half the world's population.

The fragile states of Transcaucazia and Central Asia make the object of a ferocious competition. The purpose: the Caspian oil, the Turkmenistan gas, the Uzbekistan cotton, the Kyrgyzstan gold and other important natural resources located in the region.

The former Soviet states make the object of the Russian leadership's concern about NATO enlargement. The possibility of Georgia and in particular Ukraine joining NATO in the next few years increases Russian feelings of encirclement. The Russians still remember the promise made to Gorbachev in 1990 that NATO would not extend any further eastward than the territory of the former East Germany. The US interest in developing pipeline routes from Central Asia and Transcaucasia that bypass Russia is seen as part of this encirclement.

The Caucasus - both north and south-constitutes an area of direct and vital concern to Moscow, in particular to the Russian military, who remain sensitive to penetration by influence and threats to the territorial integrity of Russia from the other two regional powers, Turkey and Iran.

Afghanistan is in the phase of economic recovery since 2001, "based on large-scale 
international aid, recovery of the agriculture sector, and substantial growth in the services sector" 2 . Furthermore, it has been successful in term of joining to international community, playing a more active role in regional and international organizations and treaties.

Afghanistan has signed bilateral Trade and Economic Cooperation Agreements with Russia and Turkey, bilateral Reciprocal Promotion and Protection of Investments Agreement with Turkey. In 2003 Afghanistan, Iran, and Uzbekistan established a trans-Afghan trade corridor linking Uzbekistan with Chabahar and Bandar-e Abbas. It has also initiated trade relation with overseas countries. The U.S. Department of Commerce estimates U.S. exports to Afghanistan in 2008 were approximately USD 480 million and imports were approximately USD 80 million.

Central Asia has obtained in the last years a unique important role, due to its character of a productive and energy exporter region, due to its position nearby Afghanistan and Pakistan and due to the fact it is an important potential area of transit of merchandises between Europe and East Asia or between Russia and South Asia.

The oil reserves are about 30000 million barrels in Kazakhstan, a country that holds the $11^{\text {th }}$ position in the world, behind Nigeria or Libya but in front of USA. Kazakhstan's oil reserves are the equivalent to the half of Russia's and to the third part of Venezuela's, although they are far away from the Iran's which holds 136000 millions barrels of reserves. Concerning natural gas, we have to notice Turkmenistan with $265 \mathrm{bcm}$ reserves, Kazakhstan with $85 \mathrm{bcm}$ and Uzbekistan with $65 \mathrm{bcm}$. If we sum up the amount of this 3 countries' reserves, we conclude they are $6,3 \%$ of the world reserves, ahead of those of Saudi Arabia, still far away to the ones of Russia $(1680 \mathrm{bcm})$ and to the Iran's $(1045 \mathrm{bcm})$.

For the next decades, the Energy Information Administration of the USA, suggests the percentage of Central Asia in the world oil production, 3,4\% in 2010, will surpass to $4,3 \%$ in 2020 and 2030. On the contrast, its percentage in the world production of natural gas will slightly reduce, from $6,6 \%$ in 2010 to $6,5 \%$ in 2020 and $6,0 \%$ in 2030 .

Nowadays, the majority of hydrocarbons exports of Central Asia goes to Russia, even though a higher and higher percentage goes to China, through the construction of a pipeline from Kazakhstan, two gas pipelines from Turkmenistan, respectively Kazakhstan, the three of them going to Xingjian. It became of an increasingly importance the exports to Turkey through Azerbaijan, with the BTC (Baku-Tblisi-Ceyhan) oil pipeline, the BTE (Baku-Tblisi-Erzurum) gas pipeline, also named SCP (South Caucasus Pipeline), and the BS (Bakú-Supsa) oil pipeline. These exports might become of a bigger potential if the Nabucco gas pipeline becomes functional and if we take into consideration the possible construction of a gas pipeline passing through the Caspian Sea, which will connect the resources of Kazakhstan and Uzbekistan with Azerbaijan, Georgia, Turkey and EU.

\section{Kazakhstan, Economic Leader of Central Asia}

Among the geopolitics and geoeconomics disputes over Central Asia, there is the one concerning the undefined character of Kazakhstan's role in the region.

Since gaining the independence in 1991, the newly independent country of Kazakhstan has pursued a so-called "multi-vectoral" foreign-policy approach, seeking equally good relations with the two large neighbors, Russia and China, as well as with the United States, the European Union, and Turkey.

Kazakhstan is the ninth largest country in the world and shares a border with both Russia and China, and has considerable oil and gas reserves, which it has developed with mainly American investment, but its relationship with the West and the USA in particular is, unlike Azerbaijan across the Caspian Sea, somewhat equivocal.

Kazakhstan is a major success story in Central Asia, having experienced double-digit growth rates between 2000 and 2007. The country has adapted well to a market economy, introducing 
fiscal and monetary reforms and has received large amounts of foreign investment. This success must, in part, be attributable to the considerable assistance from the USA since 1991 when Kazakhstan became independent. In the ten years to 2001 the United States provided "roughly \$874.3 million in technical assistance and investment support in Kazakhstan."3

Due to its geographical position and ethnic composition - nearly 60 percent Asian and 40 percent European - Kazakhstan views itself as a bridge between Europe and Asia. In his 1997 speech, "Kazakhstan 2030," President Nazarbayev spoke of "Eurasianism" and restoring the legendary Silk Road as "a broad channel of trade between European and Asian countries." The Kazakhstan people, located between these big economic regions, should take economic advantage of an expected increase of trade flows through its territory.

Expecting for Russia, EU or USA to strengthened or to initiate form of cooperation with Kazakhstan, China is advancing in this direction. Today, the Chinese-Kazakh commerce represents more than two thirds (about 70\%) of the economic exchanges between Central Asia and China. Beijing represents 15,5\% of the Kazakh foreign trade (compared to Russia's 18,8\% in 2006). The energetic sector is the engine of this partnership. In 1997, and then in 2003, CNPC bought a part of the Kazakh company AktioubeMunaiGaz, owning now $85 \%$ of it. This company exploits almost $15 \%$ of the Kazakh oil, namely the oil-gas fields of Kenkiyak and Zhanazol. In 2003, CNPC has equally bought parts of the oil-gas field of North Bouzachi where the oil reserves are estimated to be between 1 and 1,5 billion barrel. Then in 2005, it took the control of the Canadian company PetroKazakhstan that produces $12 \%$ of the Kazakh oil. CNPC exploits the smaller Kazakh fields from the Turgai basin and from the Kzyl-Orda region and continues its politics of acquiring actives in Kazakhstan. In November 2009, it bought, for 2,6 billion dollars and in joint venture with KazMunaiGas, the Kazakh oil company MangistauMunaiGas, with estimated reserves of 812 million dollars. The Chinese presence in Kazakhstan is undoubtedly significant and in 2008, the Chinese companies have contributed to the production of 20 million oil tones in Kazakhstan, in other words $28 \%$ of the total volume of the Kazakh production. The fields of Tengiz and Kashagan remain to be bought by the Chinese oil companies. The Chinese oil presence in Kazakhstan remains essentially onshore, far away from the promising fields situated in the Caspian Sea.

\section{European Union and Central Asia}

In the attempt to become more of a global actor beyond its near neighborhood, the EU adopted a Strategy for Central Asia in 2007. The current context for the EU's interests in Central Asia oil and gas production is defined in its Strategic Energy Review documents, of which the second was published in November 2008, and which identifies the priority infrastructures needed for the diversification of gas supplies. These are to consist of LNG supply systems, the completion of electricity and gas networks in the EU and its near neighborhood, and the creation of a Southern Corridor for gas supplies from the Caspian and Middle East regions. The urgency of these projects has been spurred by the continuing

concern over the reliability of Russian gas supplies transiting through Ukraine ${ }^{4}$.

For the EU, the access to the Central Asia's natural gas, through Nabucco, will allow the diversification of its suppliers, reducing notably the dependence on Russia and Algeria $(33 \%$, $15 \%$ respectively, of the total imports of EU in 2009), as well as eliminating the problems of the transit through Ukraine of the Russian gas.

Kazakhstan's continuing socioeconomic and political stability make it the EU's most reliable partner in the Central Asian region. Its rising oil exports - almost $80 \%$ of EU imports from Kazakhstan consist of fuel - and geostrategic location make a close and continuing partnership with the EU inevitable ${ }^{5}$.

Issues such as oil export routes and energy security are vital for the EU. Kazakhstan is the EU's biggest trading partner in Central Asia, with bilateral trade worth over $€ 15$ billion. About 
85\% of Kazakhstan's exports to the EU consist of oil and gas. The EU's relationship with Russia can result in a much closer economic and strategic partnership, whereas Kazakhstan's partnership with the EU and participation in many of its programmes could be enhanced further.

Nazarbaev has already indicated a willingness to consider any pipeline routes that could be "profitable for Kazakhstan", while reiterating that it is a partner, and not a competitor with Russia in seeking to diversify its export routes.

A continuing EU engagement can enable Kazakhstan to become more closely involved in extending the Baku-Tbilisi-Ceyhan (BTC) pipeline and possibly use its close ties with Russia to assuage the latter's discontentment over the route.

A closer cooperation between Kazakhstan and the EU is crucial in aiding the development of the Trans-Caspian-Trans-Black Sea energy transit corridor and for the Odessa-Brody pipeline. By aiding a diversification of oil export routes, the EU is keen to ensure a secure supply of oil and help Kazakhstan, Uzbekistan and Turkmenistan to obtain higher export prices , establishing a stronger position vis-à-vis Russia.

The markers of the European dimensions to Kazakhstan's foreign policy are the "Path to Europe" white paper adopted early in 2009 and its OSCE presidency for the year 2010. The 'Path to Europe' is an action plan reminiscent of those produced by the European Union. It has 86 action points, and the Ministry of Foreign Affairs monitors implementation every six months. At the last count in October 200918 actions had been completed and 32 were work in progress. One priority theme is to work for better cohesion between the EU and CIS states.

The state budget of Kazakhstan is now sufficiently rich that the EU should no longer consider it to be a recipient of aid, except for a restricted category of operations, mainly in the education and civil society fields. As regards technical assistance, for which Kazakhstan has big needs, the Commission should explore the model between Kazakhstan and the US (Kazakhstan funds USAID with \$20 million for USAID to procure the needed expert services). The Commission should aim at this same model, providing no funding, but arranging access to European suppliers of expertise, which the TAIEX bureau could help arrange. This would have the double advantage of saving EU funds and allowing Kazakhstan to access European expertise without all the burden of EU regulations for tendering and contracting.

\section{Russia and USA}

Taking advantage of its location in the middle of the Eurasian heartland, Russia cannot orient itself primarily to the West; it should develop what the authors Kolosov and Mironenko refer to as the 'geopolitics of cooperation' rather than confrontation, with three main geoeconomic poles: the West, China, and the Asia-Pacific.

Russian President Dmitry Medvedev recently proclaimed Eurasia a Russian "sphere of exclusive interests." Moscow has backed up those words with every available foreign-policy tool: diplomacy (including recognition of breakaway republics), arms sales, defense pacts, base construction-even regime change.

In what USA concerns, the trade relations between the USA and Central Asia remain slight, as well as at the level of energy: if the Baku-Tbilisi-Ceyhan oil pipeline and the Baku-TbilisiErzerum gas pipeline have opened up the Caucasus to the Turkish Mediterranean, for Central Asia this has meant only a secondary export route for Kazakh oil that is trans-shipped across the Caspian. The American projects hoping for an opening into India and Pakistan, with Afghanistan as a transit zone, have failed far, or have only been realized to a limited degree.

For the USA, Afghanistan is an indispensable pawn on the geostrategic board of the Central Asia. Afghanistan is a geopolitic pivot thanks not for its power or motivations, but for its sensitive geographic situation. 


\section{China}

Over the last decade, the Republic of China is looking towards Central Asia and beyond as part of a more complex strategy in Eurasia. China's interests are now broader and are manifested in its "Plan West," the institutionalization of OCS.

Perhaps the most interesting aspect in the Central Asia's foreign relations is the rapid and multiways approach of China towards the region. The commerce between China and Central Asia is already similar with the one Russia has with the region. It is even bigger with the China's bordering countries: Kazakhstan, Kyrgyzstan and Tajikistan.

China has shown a big interest in energy related issue in Central Asia. Its companies made important companies and wells acquisitions, especially in the Kazakh petrol sector; they made important deals for supplying with Turkmenistan and Uzbekistan, the objective being to ensure new routes and supplying sources, in this way reinforcing its energetic security. China has built an oil pipeline (from Kazakhstan, finished in 2009) and 2 gas pipelines (from Turkmenistan, passing through Uzbekistan and Kazakhstan, finished in December 2009, and from Kazakhstan, finished in January 2010) towards its northwestern region. The projected extension of the Atasu-Alashankou oil pipeline until the Kimkol's fields, will allow the direct connection of the fields controlled by CNPC (China National Petroleum Corporation) in Kazakhstan with Xingjian's refineries.

China's Eurasian portfolio includes road construction projects in Tajikistan and Kyrgyzstan, gas pipelines in Turkmenistan and Kazakhstan, and hydropower plants in Tajikistan and Kyrgyzstan. With USD 2.0 trillion in reserves representing nearly $30 \%$ of foreign exchange reserves worldwide, China enjoys huge financial resources to support its Eurasian ventures.

Energy and energy security are the drivers of China's Eurasian strategy. China represents $1,1 \%$ of the known world oil reserves (14,8 billions barrels) and 1,3\% of the known world gas reserves ( 2460 billions $\mathrm{cm}$ ). China is now the world's second largest oil consumer due to the country's rapid industrialization and urbanization. China's massive economic stimulus package, strategic stockpiling of oil reserves and launch of new refineries are heightening the country's demand for energy. According to the International Energy Agency, China's oil demand will rise to 11.3 million barrels a day by 2015 . The Chinese authorities are aware of the implications of a higher demand compared to its internal resources and namely after 1993, the date China became a net importer of petrol, it demands its enterprises to invest in the producer countries all over the planet, from Africa to Venezuela and especially in the Caspian region. Kazakhstan is becoming China's second economic partner in the ex soviet space, after Russia.

China's commitments of ensuring the region's security have been strengthened by the progressive reinforcement of OCS (Organization Cooperation Shanghai), created in 2001, and from which China, Russia and Central Asia's countries take part (except for Turkmenistan) and of which observers are India, Iran, Mongolia and Pakistan. From China's perspective, the OCS's main objective is the fight against extremism, the separatism and the terrorism, although, in the last years, Beijing is trying to give a more economic side (especially commercial) to the organization.

More general, China has different strategic interests in Central Asia: keeping the stability in its western surroundings, counteracting, the Western influence; controlling the narcotic traffic from Afghanistan; contributing the fight against terrorism (in 2004, the OCS created a RATS, Regional Anti Terrorism Structure, in Tashkent, Uzbekistan); and stopping the spreading of extreme Islamism in the Xingjian region.

\section{Turkey}

In the political-fiction book, "Metal Firtina" (Metal Storm), published in December 2004, the Turkish authors Orkun Uçar and Burak Turna, show Ankara's intentions of limiting the dependence on the USA, and instead approaching to Russia. Turna thinks that the future of 
Turkey is neither in the EU, nor in the American hegemony, but in the Primakov triangle (Russia, India, China) and Central Asia, with a particular attention for Moscow.

There are many observers and political people in Russia and Turkey who directly express, at high levels, the importance that the countries assert themselves as main regional powers, forming together a tight alliance, especially if EU or USA will not satisfy them ${ }^{6}$.

Today the Russian-Turkish commerce is almost three times bigger in volume as the TurkishAmerican commerce. In 1990, the Turkish-Soviet commerce was of 1,7 billion dollars. A decade later it reached 4,5 billion dollars, and in 2007 the Turkish-Russian commerce reached the record of 28 billion dollars. Moreover, for 2008, the estimated amount was of 36 billion dollars. Today Russia has replaced Germany as Turkey's main commercial partner.

The energetic cooperation- for both gas and oil- stands at the basis of Russian-Turkish economic relations. The gas is the main import of Turkey. In 2007, Turkey imported 23,15 billion mc natural gas through the western pipes and Blue Stream, 18\% more than the previous year. Turkey is the third biggest importer of Russian gas, after Germany and Italy and depends on Russia for almost $2 / 3$ of its gas imports. Moreover, Turkey imports 6 million oil barrels annual from Russia, $30 \%$ of the total imported oil and second after the one bought from Iran. Turkey is also Russia's third biggest coal importer, after Ukraine and great Britain, and spent in this sense 717 million dollars in 2007.

But until any other axis of cooperation consolidates, it must not be omitted that for Turkey $\mathrm{EU}$ is the first partner, both for import and for export, whereas for Romania, a recently EU member state, Turkey is the main commercial partner from the non-EU space.

Turkey and EU manage to cover only $28 \%$, respectively $50 \%$ their needs from their energy resources, therefore the need to cooperate in energy related issues such as diversifying its energy suppliers.

After 1991, Turkey has significantly diminished its interest towards its former foreign policy direction - East Mediterranean, and instead it is more and more present in the Black Sea area and Central Asia. Several actions testify the return to some of the traditions of the Sublime Ottoman State's diplomacy: the Turkish State Community and the Black Sea Economic Cooperation (lately known as the Organization of the Black Sea Economic CooperationOBSEC). In 2005, 12 states were part of OBSEC: Turkey, Romania, Ukraine, Russia, Republic of Moldova, Greece, Bulgaria, Azerbaijan, Georgia, Armenia, Albania and Serbia.

For Turkey, the Transcaucasian land has a special interest, being probably priority number 1 in the Turkish geopolitics; and the Caucasus serves as a bridge connecting the country with the Turkish states from Central Asia and Turkish autonomous populations from China and Russia. If the Turkish nationalists' dream was to become true- the creation of a pan-Turk state (Turkestan), then Azerbaijan would be the one to connect the Anatolian Turks with the CentralAsian and Siberian ones.

An Azeri reunification would create the possibility of a direct access, through pipelines, from the Caspian Basin to the Turkish ports in Mediterranean Sea, today impossible to achieve due to the absence of a functional Turkish-Azeri frontier. Russia would loose the control over the important hydrocarbon traffic from the Caspian countries and Turkey would get an appreciable geoeconomic and geostrategic value ${ }^{7}$.

\section{References}

- 1. Serebrian, 2006a, "Dictionar de geopolitica", Polirom, Iasi

- 2. United State Embassy in Kabul, 2009, "Doing Business in Afghanistan: 2009 Country Commercial Guide for U.S. Companies"

- 3. Winston and Young, 2005, "The Caspian Basin, energy reserves and potential conflicts", Library House of Commons, 5/24

- 4. Emerson and Boonstra, 2010, "Monitoring the EU's Central Asia Strategy", 
EUCAM

- 5. Dave, Bhavna, 2007, “The EU and Kazakhstan”, Center for European Policy Studies, 127

- 6. Matthews, $22^{\text {nd }}$ of April 2002, "Europe's Orphan: A Showdown is Brewing Between Turkey and the EU", Newsweek International

- 7. Serebrian, 2006b, "Geopolitica spatiului pontic", Cartier, Chisinau 


\title{
Turkey - as an EU Member as Seen by the EU, Russia and the USA in Integration Networks Prospect
}

\author{
Anna Akutina, Catania University, Italy
}

\begin{abstract}
The strategically positioned Turkey has been playing a significant role connecting Europe and Asia. Its geopolitical and cultural integrity has been suffering historical wounds since early times. Modern Turkish society underlines the necessity to follow the sustainable development course in political, economical, cultural and environmental issues. The future membership in the EU envisages different controversies regarding relations with European members, the USA and Russia, historical partners, which have been pointing on bilateral agreements. The South stream and Nabucco projects are a good opportunity for Turkish diplomacy. The probable EU membership offers an integration with one of the key decision makers and step ahead to positive solutions in several questions: introduction of new quality standards in various production sectors which local small and medium businesses have to withstand improving working conditions and salaries; out-coming immigration flows due to family reunification with relatives already EU citizens, in-coming immigration flows from neighbouring countries which are to joint new job opportunities lacking efficient professional preparation in the country of origin; financial flows need more guaranties for secure long-term investment and strong intellectual competition for technology innovations. Thus Turkey shall bring to the international practise the inherited ethnical religious tolerance and take the important mediating role in relationship with Asian partners, especially in ongoing transport networks.
\end{abstract}

JEL codes: F59, O18

\section{Introduction}

The Economic Development writes the international relations. There are some manifestations, facts, relationships which influence construction and development of a territory. The sequences might go on in the following way: cultural reflection, faiths, religions, production and consumption, levels and quality of cooperation, forming of basic social rules and regulations, customs and traditions,or, as it's defined by Vidal de la Blanche: it's better saying about structures that boils down to the unique of values, institutions and classes. The space in ancient cultures was the road which leads through the world. The space representation is reflected in values and cultural concepts. Alternatively, the culture produces the space, it determines creative presence in the socio-historical texture, it becomes the real space for the full citizenship realization. The view of the "world-culture" explores new trans-communication languages. Describe or recognize the territorial bases of the human subjectivity, fuse the geofactual objectivity with cultural subjectivity, this philosophical approach might give us the sense of space. The stratification of our lives and our experiences is the reconstruction of the space sense, the special perception of subjects is nothing but viaticum for the territorialisation of a cooperative action. The memorial space ends with the distance appearance, alternative to the present visions and sentiments. And in living this distance it might make possible to seize the mobility of forms. The forms which have been realized in roads, ways, networks and communication modes. These forms' realization is like a chess game, which make different subjects and objects meet, react and have sense. Regarding the space, the strategically positioned Turkey has been playing a significant role connecting Europe and Asia. Its geopolitical and cultural integrity has been suffering historical wounds since early times. Today Turkey is the large political and institutional construction with rapidly developing infrastructures, introducing new technologies and the sustainable development principles in economical, political and environmental issues. 


\section{Turkey's Perception in Europe}

Now the modern Turkish society appears as one of the most dynamic space linking the European Union territory and the Asian territory. The space moves people and ideas, moves goods and capitals, and, finally, it organizes the trans-communication, transport networks and flows. Braudel reminds us: the geography, which denies thinking about itself as the world in its expression, must succeed in thinking in terms of space and social realities with the earthed up history. The future Turkish membership in the EU envisages different controversies regarding relations with countries already European members, the USA and Russia, historical partners, which have been pointing on direct bilateral agreements.

How is Europe perceived outside the European territory? Might it be only a geographical space with economical and social essences? The idea to be Europeans and to feel European was born at the beginning of the XVIII century. The idea of being Europeans does not include only territorial belonging to this area it ought to include cultural and social aspects to enjoy proper lineaments. Chabos explains that in forming the concept of "Europe" and the sense of being European due to the complexity of vicissitude, the cultural and oral factors have had absolute even exclusive pre-eminence during the important period of forming. But the European conscience is not the differentiating and contraposition, but social economical and political integrity with cultural and linguistic tolerance. The European Union is subject to the further enlargement. The cultural, social and economical networks define the space. The net space is the new form of space which redefines the distance, cancels the borders as well as historical wounds, but does not cancel geography. Europe is to become the new space with its new borders more distant and flexible within real time. The future membership of Turkey in the European Union proposed by the EU agenda has produced the frontal contraposition evaluating positive and negative after-effects. This is not a new question and some countries had already experienced the procedure of becoming the European member. After many years of the complete disinterest, the idea of including Turkey into Europe seems to have found sustainers able to achieve the goal. At the same time there have been also registered some strong oppositions to the idea who, unfortunately, do not consider the Turkish presence in the European Union as a cultural, social enrichment and a possibility to build up new economical and political ties as relevant and significant. In case Turkey becomes the EU member it will be one the leading political powers as a consequence it will influence the decision making process in pan-European affairs; it will become the leading military power with its military forces, the first demographical power due to the number of citizens. Though no one defines the significant thickness of political and economical cooperation with Turkey which has very positive result in cooperation with the Russian Federation, the USA, and with its Asian partners. Thus Turkish diplomacy possesses keys to negotiations with different economical, political, cultural and social identities.

For example, for the Russian Federation, Turkey is one of the main partners, for the first six months of the current 2010 year the import export volume between Turkey and Russia becomes 12002 million US dollars. At the same time, Turkey enjoys the strong economical relationship with the European Union since 1963, thus for Turkey, the EU is the first export import partner with the following official figures:

1) Turkish export market in 2007 were

i) the $\mathrm{EU}(56.4 \%)$,

ii) Russia (4.4\%),

iii) USA (3.9\%),

iv) United Arab Emirates (3.0\%)

v) $\operatorname{Iraq}(2.6 \%)$.

Textiles and transport equipment dominate EU imports from Turkey, both accounting for about $24 \%$ of the total. Other important imports are machinery (17.7\%) and agricultural 
products $(7.1 \%)$.

2) Imports into Turkey has come from the following key markets:

i) the EU (40.8\%),

ii) Russia (14.0\%),

iii) China (7.9\%),

iv) USA $(4.8 \%)$,

v) $\operatorname{Iran}(3.9 \%)$

vi) Switzerland (3.1\%).

Main EU exports to Turkey are machinery (32.2\%), transport material (18.6\%) and chemical products $(16.9 \%)$.

The trade between Turkey and the USA in 2009 was amounted 11 billion US dollars. "The United States and Turkey enjoy a growing commercial relationship, and this Council provides a great opportunity for our two nations to define and discuss issues that can enhance bilateral commercial relations."

Whilst global economical crises, the bilateral economical cooperation grows up, and Turkey is increasing its economical potentials.

The probable EU membership offers an integration with one of the key decision makers and step ahead to positive solutions in several questions: introduction of new quality standards in various production sectors which local small and medium businesses have to withstand improving working conditions and salaries; out-coming immigration flows due to family reunification with relatives already EU citizens, in-coming immigration flows from neighbouring countries which are to joint new job opportunities lacking efficient professional preparation in the country of origin; financial flows need more guaranties for secure long-term investment and strong intellectual competition for technology innovations. There is no allpurpose solution to the above indicated priorities for the further Turkish development, but the strong cooperation in different projects with different European countries and countries belonging to the South European Region might bring positive results. Thus Turkey shall bring to the international practise the inherited ethnical religious tolerance and take the important mediating role in relationship with Asian partners, especially in ongoing transport networks issues, as the mutual interest for the main international key players is to develop transport networks from West to Est. The future Turkey membership in the European Union is focusing on mutual interests not positions. Even if the position of the European Union countries might vary, the interest to explore Asia and to establish new cooperation goals in economical, social, political and environmental issues is constant.

\section{Turkish Diplomacy}

Turkey is a wise military partner for the NATO countries and, at the same time, its cooperation with Russia and the EU is a good proof to Turkish diplomacy. The Turkish geographical position makes its attractive for cooperation, especially in sustainable transport and communication networks projects. The new geography of space and territory perception seem to be more articulated, complex and influenced by increasing interactivity of the ways and modes of communication within its proper territorial processes and urban and regional centralities. This interactivity underlines the importance of technical organization and economically -financial approach to multilateral collaboration. The continuous evolution of economical and political processes involves variations on local and regional and levels. The processes are urged by public and private sectors aimed by mutual goal of sustainable development in modern transport networks issues respecting the environment. In this frame the following issues are of mutual importance:

- the innovation development of ways and infrastructures; 
- the integration of transport services, infrastructures, telecommunication;

- the development of interconnection and multimodality of transport;

- the development of high speed communications;

- the reorganization of transport vectors;

- the extension of public and private cooperation;

- the sustainability in transport development and mobility;

- the evolution of logistical systems etc.

\section{Conclusions}

The mentioned issues are not to create differences among territories but to strengthen cooperation, as the South stream and the Nabucco projects demonstrate the non-competition in diversity but various approaches to guaranty the permanent energy supply: the central rings of joint countries united by the desire to proceed with their collaboration and forced functionalities. This is only the concatenation of elements, as a Turkish poet Nazim Hikmet might say, the real order is rarely seen with eyes, but it is discovered through the next approximations. The comprehension of the space is connected to the international relationship. That's why it is necessary to reveal the dynamics of sustainability and its fundamental elements which enable each territory to act and to create new history within new borders.

\section{References}

- Braudel F., La storia e le altre scienze sociali, Laterza, 1974,Bari.

- Chabod F., Storia dell'idea d'Europa, Laterza, 1964, Bari.

- Campione G., La composizione visiva del luogo, 2003 Rubbettino Editore.

- Pamuk Orhan, Ecco che cosa la Turchia può offrire all'Europa, La Repubblica, 5 npvembre 2005.

- Ruggiero V., Il Trasporto aereo commerciale europeo, 1984, Napoli, edizioni Scientifiche Italiane.

- Un futuro sostenibile per i trasporti, 2009, Comunità Europea.

- Vidal de la Blanche p., Les conditions geographiques des faits sociaux, in Annales de geographie, 11 Paris.

- U.S.- Turkey business council under secretary Sanchez announces formation, June 29, 2010

- $\quad$ EU -TURKEY http://ec.europa.eu/trade/creating-opportunities/bilateralrelations/countries/turkey/

- О состоянии внешней торговли в I полугодии 2010 года, http://www.gks.ru/bgd/free/b04_03/IssWWW.exe/Stg/d04/166.htm 


\title{
A comparative analysis of remittance behaviour between East European and North African migrants
}

\author{
Monica Roman, Academy of Economic Studies Bucharest \\ Bogdan Ileanu, Academy of Economic Studies Bucharest \\ Mihai Roman, Academy of Economic Studies Bucharest
}

\begin{abstract}
The labour migration in Europe is a phenomenon with multiple effects, both positive and negative. Money sent by emigrants to their families is increasing their quality of life and has positive effects on the family relations; therefore it can be identified an increasing interest in the literature in studying such aspects.

The purpose of the paper is to conduct a comparative analysis of the migrants' propensity to sending money to the origin country.

The study is based on data coming from the National Immigrant Survey of Spain (in Spanish: Encuesta Nacional de Inmigrantes - 2007). A total of 15,475 interviews were carried out. Moroccans, Romanians, and Ecuadorians represent $30 \%$ of the total number of immigrants resident in Spain.

We employ a binary logistic regression model in order to identify the impact of sociodemographical factors on the probability of sending money abroad from Spain. Our aim is to identify cultural discrepancies in remittances sending, according to origin of migrants. We are mainly focusing on two large groups of respondents, which are North African and South Eastern Europe migrants. The variables employed are age of respondent, education, Intention to return in the country of origin, The period spent in Spain, gender of respondent, and the relation with the country of origin defined by the frequency of visits in the country. We identified similar patterns and also significant differences among the two groups.
\end{abstract}

JEL codes: F22, I31, R23

\section{Introduction}

The labour migration in Europe is a phenomenon with multiple effects, both positive and negative. Money sent by emigrants to their families is increasing their quality of life and has positive effects on the family relations. Remittances are also an important source of external funding for developing countries. They rank only behind foreign direct investment, and are much higher in magnitude than total official development assistance. Therefore, it can be identified an increasing interest in the literature in studying such aspects.

According to World Bank Statistics, the top recipients in terms of the share of remittances in GDP in 2008 include many smaller economies such as Tajikistan, Tonga, Moldova, Kyrgyz Republic, Lesotho, Samoa and Lebanon; in these countries remittances exceeded a quarter of the GDP, providing a lifeline to the poor.

Important remittances inflows are found in 2008 in North African countries such are Tunisia (4.9\% of GDP), Algeria, Egypt (5.9\%), Lebanon (23.7 \% of GDP), Syrian Arab Republic (2.2\% of GDP), and Morocco ( $9 \%$ of GDP). In Europe, among the former communist countries -which are the most significant beneficiaries of the money sent by emigrants- we find Romania (5.1\% of GDP), Bulgaria (5.4\% of GDP), Ukraine $(3.2 \%$ of GDP), Serbia (13.9 \% of GDP), Macedonians (4.5\% of GDP), Croatia (2.7 \% of GDP).

Due to increasing role of remittance in the context of financial crisis- a major source of income for households in developing countries-, identifying the true motivations behind remittance behavior is crucial to predict the long term effect of migration on the households and at a macro-level its influence on the sending society overall. Furthermore, the motivations 
behind remittance behavior have significant implications for public policy, especially in countries that rely heavily on remittance from migrants and lack social security transfers or other welfare programs.

The purpose of the paper is to conduct a comparative analysis of the migrants' propensity to send money to the origin country. The remittance behaviour has been proven to be quite diversified in different parts of the world and our primary objective is to explore the similarities and dissimilarities existing between two large groups of emigrants in Spain: Eastern European and North African emigrants. For this purpose, we explore an important data source that is provided by the National Immigrant Survey of Spain.

Within a multivariate context, we seek to uncover the factors that would determine the remittance decision and the magnitude of these factors. Logistic regression is applied in order to establish the significance of origin in decision to remit and then to identify the statistical significant factors that determine emigrants from the two groups to remit.

The rest of the paper is structured as follows. Section 2 offers a brief review of the relevant theories on remittances. Section 3 details the econometric methodology adopted and explains the data set used. In this section are also explained the basic hypothesis. In Section 4 are presented the empirical results and concluding notes complete the paper.

\section{Literature review}

The literature on the remittance behaviour of households is substantial. We have identified two large categories of studies. Firstly, there are some studies that consider the macroeconomic determinants of remittances (see Schiopu and Siegfried, 2006), and are conducted based on macroeconomic data. Secondly, there are studies focusing on the microeconomic determinants of remittance motives and we shall refere to these ones mostly.

The existing debate in remittance literature is determined by the quality of used data. As it was notices by Rapoport and Docquier (2005), "at a macro level, it is not always possible to test appropriately for the macroeconomic impact of remittances because of poor data quality; at a micro level, it is extremely difficult to discriminate between competing theories of remittance".

The Eastern European countries are characterized by a poor quality of data on migration. In Romania, for instance, statistical data on migration captures only the regular emigrants who change their permanent residence. Labour migration is hard to quantify, although in the late years it become the most important component of Romanian migration. In this respect, the macro data on remittances in former communist countries from EE are very few compared to other developing countries.

Considering the methods involved in the existing papers on the determinants of remittances, it is easy to notice that a large variety of methodologies have been used. In recent papers the main methodological distinction is made between modelling the determinants of remittances as a one-stage decision (Tobit, logistic regression analysis) where the decision to remit and the amount of remittances are made together or as a Heckmann two-stage approach (Probit and corrected OLS) where the model separates between the decision to remit and the subsequent decision on how much to remit.

René Houle and Grant Schellenberg (2008) use Logistic regression for remit propensity and OLS regression for the magnitude of the remittances. Heering, van der Erf and, van Wissen (2004) apply logistic regression in order to analyze the migration intensions and its determinants in Morocco. The results of this study support the analytical gender-specific approach of migration intentions among Moroccan non-migrants. Huynh Truong Huy (2009) apply logistic regression in order to analyze the determinants of migration decision in Vietnam, controlling for ethnic groups. Lerch, Dahinden and Wanner (2007) apply logistic regression to analyze the determinants of remittance decision of Serbian Migrants living in Switzerland. The 
same method is used in order to identify the determinants of the amount remitted.

\section{Method and data}

Most previous studies of migration often examined the determinants of decision to remit associated with basic information from both family and individual migrant. As it was mentioned in the previous section, authors such are are Holst and Schrooten (2006), Richard (2001), used the probability model, namely probit or logistic model to estimate the likelihood of decision to migrate or to remit; these are most common techniques for estimating model with a dichotomous dependent variable.

We employ a binary logistic regression model in order to identify the impact of sociodemographical factors on the probability of sending money abroad from Spain.

In our study, the binary dependent variable in the model is whether a person is sending money to the money country or not, specifically 1 denotes the individual is remitting and 0 denotes otherwise. We are mainly focusing on two large groups of respondents, which are North African and South Eastern Europe migrants. The regression model will be predicting the logit, that is, the natural log of the odds of having made one or the other decision. That is,

$$
\ln (O \hat{D} D S)=\ln \left(\frac{\hat{Y}}{1-\hat{Y}}\right)=\hat{a}+\hat{b} X,
$$

where

$\hat{Y}$ is the predicted probability of the event which is coded with 1 (decision to remit) rather than with 0 (decision to not remit),

$1-\hat{Y}$ is the predicted probability of the other decision, and

$\mathrm{X}$ is predictor variable.

In theoretically, the odds are often used to express the predicted change of a unit increase in the corresponding independent variables. For example, if the odd less than one corresponds to decrease; if it is more than one corresponds to increase; and if it is equals to one meaning that unit change in that independent variable does not affect the dependent variable.

The study is based on data coming from the National Immigrant Survey of Spain (in Spanish: Encuesta Nacional de Inmigrantes - 2007).

When looking at the characteristics of migrants according to origin, the ENI points to the existence of two general migratory typologies. On the one hand, persons coming from Andean, African and Eastern European countries have all the earmarks of what might be called 'economic migrants'. They are young, they have come recently, they work in relatively lowskilled jobs and they participate in tightly knit ethnic networks.

On the other hand, immigrants coming from developed countries are quite different, with high levels of education, important proportions of people who have come to Spain to retire.

\section{Results from logistic regressions}

We took into account only the persons older than 16 because in the economic process they are able to have a legal activity. We divided the remaining sample in the two population analyzed in present study. North African migrants include all North African language speakers even if they are not leaving in a North African country. Few categories of emigrants included here are: Moroccans, Tunisians, Algerians, Egyptians, Libyans and Eastern Europeans migrants which include a more heterogeneous population composed in general by Romanians, Bulgarians, Russians, Ukrainians, Moldavians, Serbians, Macedonians, Croatians, and Hungarians.

Our sample includes 15475 observations. The empirical analysis proceeds in two stages 
using SPSS. First, we run a logistic regression using all the observations in the sample. We intend to find out what variables are significant in remittances behaviour and if Nationality has an important influence in migrants' decision to remit.

In the second stage, our core questions is if there are any observable differences between the two important groups of emigrants, in respect with remitting decision: the group of emigrants coming from North Africa and the group of emigrants coming from Eastern European countries.

The set of independent variables involved in the model are:

\section{Income}

To capture the influence of the income of the migrant, the net income from the last month is employed. The values were used as natural logarithms. Income distribution is similar in the two groups, 73,4\% of African migrants have incomes between 500 and 1500 euros and 75,9\% of Europeans have incomes in the same interval.

Age

According to the theoretical literature, the age of the remitter plays an important role. (for instance, Merkle \& Zimmermann 1992).

\section{Education}

The value of the human capital of the migrant is reflected in years of education. If $68,5 \%$ of Eastern Europeans have secondary level of studies finished only $51 \%$ of North African migrants have secondary cycle graduated. On the other hand the percentage of North African migrants which have only the primary education is almost 3 times higher compared to the same percentage of Eastern Europeans migrants.

\section{Gender}

Many empirical studies report a significant influence of gender on remittances. We use a dummy variable to check for this effect here. The variable "gender" is 1 in the case of a female remitter and 0 in the case of a male remitter. There is an equilibrate distribution between men and women in the general sample and among Eastern Europeans migrants. The significant difference is present for North African migrants, where more than $60 \%$ of migrants are men.

\section{Origin}

Nationality, country of origin and the specific migration background might influence the remittances and transfer behavior. The origin of a migrant is captured in the model by the country of birth.

\section{Visits home}

One important basis for remittances is personal contacts to the home country. Here we assume that visits to the country of origin are an important indicator for such personal links. Therefore we expect a positive impact of the visit on remittances. We also control for the future plans of migrants, using a dummy for the decision of moving back in the home country in the next 5 years. We assume that a person with intention to move back will have a smaller probability to remit compared to a person who is willing to remain in Spain.

\section{Household}

A strong argument for remitting is the dimension of the family left in the country of origin. We assume that the propensity to remit is increasing with the number of children living at home and if the wife/husband is there. European migrants have in general smaller number of children than North African families. This difference could be explained by differences regarding tradition and religion. Also the number of children could be an effect of other social characteristics such as marital status and economic power given by income. We may observe that $64 \%$ of North African respondents are married compared to only $53 \%$ of Europeans. 
The length of staying in Spain and the owing an affaire in Spain were included in the logistic regression model, as well. A significant difference between the two categories of migrants could be observed analyzing the period spent in Spain. 96\% of eastern Europeans have less than 10 years spent in Spain, while 22\% of North Africans have more than 20 years.

Foreigners living in Spain are not homogenous group concerning their remittance behavior. In this respect, nationality is a significant factor, as it is shown in table 1.

Tabel 1. Results from logistic regression models

\begin{tabular}{|c|c|c|c|c|c|c|}
\hline \multirow[t]{2}{*}{ Model } & \multicolumn{2}{|c|}{ I. Total sample } & \multicolumn{2}{|c|}{$\begin{array}{l}\text { II. North African } \\
\text { emigrants }\end{array}$} & \multicolumn{2}{|c|}{$\begin{array}{l}\text { III. East Europeans } \\
\text { emigrants }\end{array}$} \\
\hline & B & $\begin{array}{c}\operatorname{Exp}(\mathrm{B} \\
)\end{array}$ & $\mathrm{B}$ & $\operatorname{Exp}(\mathrm{B})$ & B & $\operatorname{Exp}(B)$ \\
\hline lnIncome &, 068 & 1,070 & ,351 & 1,420 &, $285 * *$ & 1,329 \\
\hline gender & ,098 & 1,103 &,$- 579 * * *$ & ,561 &,- 024 & ,977 \\
\hline Bussiness owner & ,408** & 1,504 &,$- 794 * *$ & , 452 & 254 & 1,289 \\
\hline $\begin{array}{l}\text { Lenght of } \\
\text { migration }\end{array}$ &,$- 066 * * *$ & ,936 &,$- 086 * * *$ & ,917 & $\begin{array}{c}-, 090 * * \\
*\end{array}$ & ,914 \\
\hline House owner &,$- 244 * * *$ & ,783 & ,424 & 1,528 & , 150 & 1,162 \\
\hline Future plans &,$- 619 * * *$ & ,538 & , 168 & 1,183 &, 332 & 1,393 \\
\hline Visit number &,$- 022 * * *$ & ,979 &,- 005 & ,995 &,- 002 & ,998 \\
\hline $\begin{array}{l}\text { Wife in origin } \\
\text { country }\end{array}$ &, $774 * * *$ & 2,168 &, $834 * * *$ & 2,303 & ,313 & 1,367 \\
\hline $\begin{array}{l}\text { Children in } \\
\text { origin country }\end{array}$ &, $828 * * *$ & 2,288 &, 703 & 2,020 & $\begin{array}{c}1,478 * * \\
*\end{array}$ & 4,385 \\
\hline Education &,$- 119 * * *$ & 887 & , 107 & 1,113 &,- 052 & ,949 \\
\hline Home country &,$- 201 * * *$ & ,818 & $\mathrm{X}$ & $X$ & $\mathrm{X}$ & $\mathrm{X}$ \\
\hline Constant & $1,620 * * *$ & 5,054 & $-1,049$ & ,237 &,- 941 & ,390 \\
\hline $\begin{array}{c}\text { No of } \\
\text { observations }\end{array}$ & \multicolumn{2}{|c|}{15139} & \multicolumn{2}{|c|}{2187} & \multicolumn{2}{|c|}{1998} \\
\hline $\begin{array}{c}\text { Nagelkerke R } \\
\text { Square }\end{array}$ & \multicolumn{2}{|c|}{0,354} & \multicolumn{2}{|c|}{0,257} & \multicolumn{2}{|c|}{0,148} \\
\hline $\begin{array}{c}\text { Cox \& Snell R } \\
\text { Square }\end{array}$ & \multicolumn{2}{|c|}{0,265} & \multicolumn{2}{|c|}{0,192} & \multicolumn{2}{|c|}{0,108} \\
\hline
\end{tabular}

Gender and income are non-significant factors, when considering the whole sample. All the other factors in logistic regression model are significant. Family connections with home country are the most influential factors. The degree of integration into the society of the host country matters in the whole population.

\section{Conclusions}

Our main findings considering the two observed subpopulations of migrants are: In both cases of the Eastern Europeans and North Africans, family ties are the most important factors that determine remittance propensity. The beneficiary of the remittances is the factor that makes the difference between the two groups. In Europeans case a person is three times more likely to remit if it has children in the origin country, while in North African case a person is more likely to remit if he has a wife in the origin country. In this last case, gender is a 
significant factor in the model and being a male increase the probability to remit. In both cases degree of integration in Spain observed through the length of staying in Spain is a significant negative factor.

We found out that the probability to remit is not dominated by income, which is nonsignificant in the global model. However, it is significant in the East Europeans case. Instead, North African migrants are more entrepreneurship oriented, since in their case owing a business is a significant positive factor in remittances behaviour.

Acknowledgements

This paper was supported by CNCSIS grant no 1829/2008: The Effects of Labor Force Migration and Demographical Structural Changes on Dynamic Economies

\section{References}

- Heering L., van der Erf R., van Wissen, L., 2004. „The Role of Family Networks and Migration Culture in the Continuation of Moroccan Emigration: A Gender Perspective" Journal of Ethnic and Migration Studies Vol. 30, No. 2, March 2004, p. 323-337

- Holst, E., Schrooten M., 2006 „Migration and Money - What determines Remittances? Evidence from Germany" DIW Berlin, SOEP, and University of Flensburg, Berlin

- Houle, R. and Schellenberg, G., „Remittance Behaviours Among Recent Immigrants in Canada", Statistics Canada, Business and Labour Market Analysis

- Huynh Truong Huy, 2009. „Rural to Urban Migration as a Household Decision: Experimental Evidences from the Mekong Delta, Vietnam”, DEPOCEN, Working Paper Series No. 2009/17

- Hoddinott, J., 1992. "A Model of Migration and Remittances Applied to Western Kenya”, Oxford Economic Papers, 46, p. 459-476.

- $\quad$ Lerch M., Dahinden J., Wanner P. 2007. „Remittance Behaviour of Serbian Migrants living in Switzerland", SFM Studies No. 51

- Lucas, Robert E. B., and Oded Stark. 1985. "Motivations to Remit: Evidence from Botswana." The Journal of Political Economy 93(5).

- $\quad$ Merkle, L. and Zimmermann, K. (1992): "Saving and Remittances: Guest Workers in West Germany”, in Klaus Zimmermann (ed.), Migration and Economic Development, Berlin: Springer-Verlag, p.55-75.

- Poirine, B., 1997. “A Theory of Remittances as an Implicit Family Loan Arrangement”, World Development, 25(4), p. 589-611

- $\quad$ Rapoport, Hillel and Frederic Docquier. 2005. "The Economics of Migrants' Remittances." The Institute for the Study of Labor (IZA) Discussion Paper No. 1531.

- $\quad$ Reher, D.; Requena, M. 2009 "The National Immigrant Survey of Spain. A new data source for migration studies in Europe", Demographic Research, 20 (12), p. 253 - 278.

- Schiopu, I., Nikolaus S, 2006. "Determinants of Workers' Remittances: Evidence from the European Neighbouring Region." European Central Bank, Working Papers Series No. 688.

- Stark, Oded, and David E. Bloom. 1985. "The New Economics of Labor Migration." The American Economic Review 75(2): p. 173-178. 


\title{
Migrants' Remittances in Romania and Balkan Countries:A Macro-Economic Perspective
}

\author{
Zizi Goschin, Bucharest Academy of Economic Studies \\ Aura Popa, Bucharest Academy of Economic Studies \\ Mihai Roman, Bucharest Academy of Economic Studies
}

\begin{abstract}
The remittances of international migrants contribute to the well-being of their households of origin and also have an impact at macro-economic level. Out-migration is an effective means for low-income households to quickly overcome shortages of income. The sustenance of poor households might have been more difficult without such remittances. From a macroperspective, remittances contribute to the equalization of the income distribution among households having out-migrants. This study examines the significance of selected macroeconomic and demographic factors associated with remittance behaviour in Romania and several Balkan countries (Bulgaria, Turkey and Albania) as characterized by the propensity to remit and the amount remitted. The extent to which remittances affect the living standard of house-holds left behind is also appraised.

In this respect we used macroeconomic datasets provided by World Bank and national statistical institutes. We develop a model to study the effects of migration and remittances on inequality in the origin communities, by employing regression analysis. Among the main findings is that the evolution of the regional Gross Domestic Product is positively related to the growth of the amount of remittances conveyed through the official network as part of the total amount of remittances.
\end{abstract}

JEL codes: C70, F22, F24

\section{Introduction}

In previous years, benefits from economic globalization have bypassed most developing countries, and as a result international labour migration has taken on a new and special importance. However, the impact of remittances on migrant origins is still a subject that was considerably debated through this period of time. Research all over the world tried to analyse this matter, some of them found that remittances tend to increase income inequailties, whereas others find just the opposite.

In the past few years, there has been a remarkable renaissance in the interest in remittances. This interest has undoubtedly been triggered by a striking increase in remittance flows: after years of relative neglect, they have been rediscovered as a potential source of development finance.

However, the current debate on migration, remittances and development suffers from a number of shortcomings. Also, the current "remittance euphoria" often coincides with a certain perception that it concerns a "new" issue.

\section{A Conceptual Review of the Literature}

In the current world economy, remittances from international labour migration are mostly viewed as a popular response by the Third World failure of both formal and spontaneous means to equalize the income between all the countries. In 1978, Frank and later within one year, Wallerstein considered international migrants just as another example from several flows of the market (commodities, capital, entrepreneurship, inventions, labour) manipulated by international capital in achivieng its goal of controlling the world economy, structuralist seeing migrants just as some „unwiling pawns dependent on forces outside their control that disrupt 
their lives, destroy their livelihoods, and create new cleavages in local economies and societies".

Later, in the 1980s, in the international migration literature, „market triumphalists” such as Peet and Watts (1993) showed that a migrants decision to leave their country is based more on individual families rsponding to primary human needs rathen than being some marionettes of the invisible hand that controls the entire market.

Labour migration represents the temporary or permanent movement of persons from one country to another in the pursuit of employment or education, or to escape an adverse political climate (Goldin and Reinert, 2006).

The growing volume of emigration has called for increased attention both from academics and practitioners. The existing literature dealing with migration issues usually adopts either the perspective of receiving countries (Sassen, 1988), or the causality and impact for migrantsending countries, with remittances playing a major role in this context. Migration and remittances do undoubtedly relieve pressure on the sending countries, compensating for underemployment and generating new opportunities to capture resources through remittances (Gammage, 2006), help alleviate poverty and improve quality of life in poor countries (Ratha, 2004; Skeldon, 2007). On the other hand remittances stimulate imported goods consumption, favour price increases (especially real estate) and land speculation, finally increasing inequality (Aizenman, 2006).

One major direction of investigation in the existing literature on migration and remittances is oriented around poverty as the main explanatory factor of migration. Skeldon (2005) demonstrates that poverty may be considered a root cause of migration. Some scholars argue that migration providing a way out of poverty is likely to be "primarily intra-country", since the poorest cannot afford "the cost and risk" of migration abroad (Skeldon, 2005: 255). Internal migration has received less attention in the literature of migration and development, although in many countries it has played a more significant role than the international migration (DeWind and Haldway, 2005).

Another issue of interest in the debate on migration and remittances concerns the education level of the migrants. Since the brain-drain impairs the quality of labour force and consequently the prospects for development in sending countries, it tends to be the focus of attention both in public debates and in statistics, while unskilled migration is less visible in statistics (Sabogal and Nuñez, 2010). Skilled migration may also bring about benefits through remittances, investments, or transfer of skill and technology across borders (Kageyama, 2008).

While statistical data documents a constant increase in the global volume of migrant remittances, a matter of interest are the unrecorded remittances such as hand-carries by friends and family members, in-kind remittances, consumer goods etc. These informal remittances may reach a high share, up to $50 \%$ of total, in some countries (Puri and Ritzema, 1999). Some studies suggest that unrecorded remittances are going down (Ratha, 2005) owing to better technology and efforts to reduce money laundering.

The increase of total remittances from labour migration in the world triggered the debates on their broader economic impacts on the remittance-receiving countries. One common measure employed in empirical work attempting to capture the income distribution effects of remittances is the Gini inequality index (Stark et al., 1988), but the results of such empirical analysis are contradictory. Ahlburg (1996) and Taylor (1999) reported that remittances had an equalizing effect on income distribution in Tonga and Mexico. On the contrary, Adams (1991), using the same Gini index formula, discovered that remittances contribute to the increase in inequality, mainly because better-off families are more able to pay for the costs of migration (Straubhaar and Vadean, 2006). Similar results were reported, in the Philippines, where as much as $7.5 \%$ rise in rural income inequality in the 1980s was produced by remittances, although their share in the households' income was rather low (Rodriguez, 1998), as well as in Peru (Takenaka and Pren, 2010) and in Yugoslavia, where the remittances generally fueled 
income divergence, the effects varying according to the periods and social categories (Milanovic, 1987).

Straubhaar and Vadean (2006) found two potential explanations for this lack of conclusive evidence on the remittances impact on income inequality in home countries: the diversity in the environments researched in terms of initial inequality and the differences in the methodology as well. The impact of remittances, finally depends on the nature of emigration, as well as on the socioeconomic structure, of the home country (World Bank, 2006, 2008; Beine, Docquier, and Rapoport, 2002).

A more sophisticated approach based on a dynamic model of migration and income distribution (Stark et al., 1986, 1988) revealed that the income distribution effect of remittances depends critically on the migration history and on the distribution of migration opportunities across households. They found an inverse U-shape relationship between migration and income distribution: in the first stage wealthy families benefit from the migration, therefore income inequality upsurges, while in the second stage poor families also acquire information, start migrating and take advantage from remittances, inducing a decrease in inequality.

The extent of the migrant remittances' influence in the home countries is expressed through their multiplier effects. For instance the multiplier effect from the expenditure on remittances in Mexico was 3.25 in 1988 (Durand et al, 1996), but seem to have had very limited impact on productive activities in El Salvador (Gammage, 2006), where remittances have increased the trade deficit, determining higher dependency on imports.

\section{Econometric model}

Following increasing interest and significant public debate on this topic in recent years, our paper addresses two critical research questions: how significant are remittances as a factor of poverty and inequality lowering and what factors influence the volume of remmitance flows.

We address these questions by means of an econometric model using datasets provided by World Bank and national statistical institutes with remittance behaviour in Romania and several Balkan countries, such as Bulgaria, Turkey or Albania, as characterized by the propensity to remit and amount remitted. We develop a model to study the effects of migration and remittances on inequality in the origin communities, by employing regression analysis. Among the main findings is that the evolution of the regional Gross Domestic Product is positively related to the growth of the amount of remittances conveyed through the official network as part of the total amount of remittances. The extent to which remittances affect the living standard of house-holds left behind is also appraised.

First, we have found little data concerning Albania, and only yearly sets. Also another major inconvenience was the period of time that we had to limit our analysis to: from 1994 to 2008 , in order to provide a normal comparability between these four countries. Starting our model from a simple regression, in which the dependent variable is household final consumption on expediture per capita (HFC) (constant 2000 US\$) and the independent ones are remittances (REM), in US\$ milions, the GDP per capita, in constant 2000 US\$, we try to compose a more complex equation, introducing one by one other variables, macro-economic indicators such as: deposit interest rate (DEP) (\%), total unemployment (UNM) (percentage of total labour force), inflation (INF) (at consumer prices, annual \%), patent applications by residents (PAT), consumer price index (CPI) (considered in 2005 equal to 100), and imports (IMP) and exports (EXP) of goods and services (\% of GDP).

Because of too little space for describing each result from all these calculi, we will present and focalize only on those models that were validated from the statistical point of view and that are representative for each country in particular. Therefore, we will summarize the Pearson correlation among variables found for each country in table 2 as follows: 


\begin{tabular}{|l|crrr|}
\hline & Albania & \multicolumn{1}{c}{ Bulgaria } & Romania & Turkey \\
\hline REM & 1,000 & 1,000 & 1,000 & 1,000 \\
GDP & 0,971 & 0,942 & 0,932 & $-0,640$ \\
UNM & NA & $-0,642$ & $-0,399$ & $-0,928$ \\
HFC & 0,870 & 0,947 & 0,883 & $-0,625$ \\
\hline
\end{tabular}

Table 2. Pearson correlation between remittances and the rest of the variables.

Note: In Albania's unemployment case, we didn't have enough data for the entire period, so we decided to omit this variable.

Even though we expected from our literature review, that remittances over import, export and deposit interest rate, more the first one among the two, to have a big influence, from our calculus results there is a very weak correlation and therefore we decided to not take these variables into further consideration, given the following general model in equation (1):

$$
\text { HFCit }=\beta 1 * \text { GDPit }+\beta 2 * \text { IMPit }+\beta 3 * \text { REMit }+\beta 4 * \text { UNMit }+\alpha+\varepsilon i t \text { (1) }
$$

where $t=1994,2008$ and $i=A, B, R, T$ (abbreviated as Albania-A, Bulgaria-B, Romania-R and Turkey-T).

\begin{tabular}{|l|c|c|c|}
\hline & $\begin{array}{c}\text { Coefficients } \\
\text { (T-Statistic) }\end{array}$ & \multicolumn{2}{|c}{} \\
\hline Variable & Albania & Bulgaria & Romania \\
\hline GDP & $0,456^{* *}$ & $0,905^{* * *}$ & $0,701^{* *}$ \\
& $(0,036)$ & $(0,001)$ & $(0,003)$ \\
\hline IMP & $16,245^{* *}$ & $-2,194$ & $16,834^{* * *}$ \\
& $(0,003)$ & $(0,462)$ & $(0,011)$ \\
\hline REM & $-0,219^{*}$ & $-0,018$ & 0,012 \\
& $(0,165)$ & $(0,618)$ & $(0,521)$ \\
\hline UNM & NA & 3,558 & $-17,358$ \\
& & $(0,389)$ & $(0,487)$ \\
\hline Constant & $-180,608$ & $-264,852^{*}$ & $-339,968^{*}$ \\
& $(0,314)$ & $(0,164)$ & $(0,174)$ \\
\hline R-square & 0,960 & 0,997 & 0,990 \\
\hline F-statistic and & $42,829^{* * *}$ & $325,500^{* * *}$ & $125,904^{* * *}$ \\
Prob (F) & $(0,000)$ & $(0,000)$ & $(0,000)$ \\
\hline
\end{tabular}

Table 3. Regression result.

Source: authors' processing based on data issued by the World Bank

*significant at $10 \%, * *$ significant at $5 \%, * * *$ significant at $1 \%$

The results from running the regressions specified in the equation (1) using the data for 1994-2008 period are reported in Table 3. The main result of the empirical estimation of the model is that GDP and imports do exert a strong influence on the household final consumption expenditure per capita in Romania. An increase in the Romanian migrants' remittances also seems to have a positive effect on the household consumption, although the coefficient is not highly significant. The level of unemployment is negatively related to the household consumption, but the low significance levels do not allow for conclusive results. The effect of the imports of goods and services have a strong direct influence over the households being the same for Romania and Albania, but a weaker and negative effect for Turkey and Bulgaria. Even though the model for Albania's case does not have the unemployment variable included because of missing data, the model is nevertheless the best fitted example of the countries, as all the coeffiecients are significant at $10 \%$.

In this paper a retrospective and forward-looking insight into Balkan migrants' remittances 
has been conducted. Specifically, it has mainly been aimed at highlighting their impact on household final consumption expenditure in comparison with the four countries that we chose. We found that GDP and imports do indeed exert a strong influence on the household final consumption expenditure per capita, as well as the Balkan migrants' remittances, as was expected. Some other variables that could be found in several other models which have been the subject of literary reviews were also tested without reaching significance in the final specification of the model that was proposed in this paper. Despite the decline induced by the current economic crisis, remittances still remain high, given that many migrants, even when faced with economic difficulties continue to send money to support their families.

\section{Conclusions}

The lack of longitudinal data on migration, remittances, and economic macro-indicators has necessitated inferring inequality change from static data. In order to ameliorate this problem, we undertook follow-up research on other indicators trying to emphasis some differences and influences that remittances have.

The results are very much alike for these four countries proving that they have similarities at the macro-economic level and the remittances induces important modifications over the same variables, mostly a negative influence on inflation and unemployment, but a positive impact over Gross Domestic Product as was expected. Although the Albanian result is more likely than the Romanian result overall, it seems that Bulgaria and Turkey are not just neighbours, but share almost the same trend related to remittances.

\section{Acknowledgements}

This paper has the support of CNCSIS grant no 1829/2008: The Effects Of Labour Force Migration And Of Demographical Structural Changes On The Dynamic Of Economics, financed under the programme IDEI, PN2.

\section{References}

- Adams, R. H., (1991), „The Effects of International Remittances on Poverty, Inequality and Development in Rural Egypt”, Research Report No. 96. Washington: International Food Policy Research Institute

- Ahlburg, D. A., (1996), „Remittances and the Income Distribution in Tonga”, Population Research and Policy Review, 15(4), p. 391-400

- Aizenman, N., (2006), "Money earned in U.S. pushes up prices in El Salvador." Washington Post, May 14

- Beine, M., Docquier, F. and Rapoport, H., (2002), „Brain Drain and LDCs’ Growth: Winners and Losers", Center for Research on Economic Development and Policy Reform Working Paper 129

- DeWind, J. and Haldway, J., (2005), "Internal and international migration in economic development", Paper presented at the Fourth Coordination Meeting on International Migration, Population Division, Department of Economic and Social Affairs, United Nations

- $\quad$ Durand, J., Parrado, E. and Massey, D. S., (1996), "International migration and development in Mexican communities", Demography 33, p. 249-264

- Frank, A. G., (1978), „Dependent accumulation and underdevelopment”, London: Macmillan Press

- $\quad$ Gammage, S., (2006), "Exporting People and Recruiting Remittances : A Development Strategy for El Salvador?", Latin American Perspectives, Issue 151, Vol. 33, No. 6 
- Goldin, I. and Reinert, K., (2006), „Globalization for Development: Trade, Finance, Aid, Migration, and Poverty", Washington DC: World Bank and MacMillan, p. 14

- Kageyama, A., (2008), "Poverty Alleviation by Migrant Remittances in Sri Lanka", South Asia Research Vol. 28 (1), p.89-108

- Maimbo, S., Adams, R., Aggarwal, R. and Passas, N., (2005), „Migrant Labor Remittances in South Asia", Washington DC: World Bank

- Milanovic, B. (1987), „Remittances and Income Distribution”, Journal of Economic Studies, 14(5), p. 24-37

- $\quad$ Peet, R. and Watts, M, (1993), „Development theory and environment in an age of market triumphalism", Economic Geography, 69, p. 227-253

- Puri, S. and Ritzema, T., (1999), „Migrant Worker Remittances, Micro Finance, and the Informal Economy: Prospects and Issues", Working Paper 21, Geneva: ILO, Social Finance Unit

- Ratha, D., (2004), “Understanding the importance of remittances”, Migration Information. http://www.migrationinformation.org

- Ratha, D., (2005), 'Worker's Remittances: An Important and Stable Source of External Development Finance', in Maimbo, S. M. and Ratha, D. (eds.), Remittances: Development Impact and Future Prospects, Washington DC: The World Bank, p. 1952

- Rodriguez, E., (1998), „International Migration and Income Distribution in the Philippines", Economic Development and Cultural Change, 46(2), p. 329-350

- Sabogal, E. and Núñez, L., (2010), "Sin Papeles: Middle- and Working-Class Peruvians in Santiago and South Florida", Latin American Perspectives, September 2010, vol. 37 (5), p. 88-105

- Sassen, S., (1988), „The Mobility of Labor and Capital: A Study in International Investment and Labor Flow”, Cambridge: Cambridge University Press, p. 6

- Skeldon, R., (2005), „Migration and Poverty: Some Issues in the Context of Asia”, in World Migration 2005: The Costs and Benefits of International Migration, Geneva: International Organization for Migration, p. 253-268

- $\quad$ Stark, O., Taylor, J. E. and Yitzhaki, S., (1986), „Remittances and Inequality”, The Economic Journal, 96(383), p. 722-740

- $\quad$ Stark, O., Taylor, J. E. and Yitzhaki, S. (1988), „Migration Remittances and Inequality: A Sensitivity Analysis Using the Extended Gini Index”, Journal of Development Economics, 28(3), p. 309-322

- Straubhaar, T. and Vadean, F. P., (2006), „International Migrant Remittances and their Role in Development", International Migration Outlook, No. 18, SOPEMI. Paris: OECD

- Skeldon, R., (2007), „On Migration and the Policy Process”, Sussex Centre for Migration Research Working Paper T20

- $\quad$ Takenaka, A. and Pren, K. A., (2010), "Leaving to Get Ahead : Assessing the Relationship between Mobility and Inequality in Peruvian Migration", Latin American Perspectives, Issue 174, Vol. 37 No. 5

- Taylor, J. E., (1999), „The New Economics of Labor Migration and the Role of Remittances", International Migration, 37(1), p. 63-86

- Taylor, E. J., (2004), "Remittances, savings, and development in migrant-sending areas", in Massey, D. and Taylor, J. E. (eds.), International Migration: Prospects and Policies in a Global Market, New York: Oxford University Press, p. 157-173 
- Wallerstein, I., (1979), „The capitalism world economy”, Cambridge: Cambridge University Press

- World Bank, (2006), „The Development Impact of Workers’ Remittances in Latin America", Washington DC

- World Bank, (2008), „Migration and Remittances Factbook 2008”, The International Bank for Development and Reconstruction, TheWorld Bank, Washington DC 


\title{
2008 Küresel Krizi ve Sonrası Avrasya Ekonomilerinde Finans Sektörü
}

\author{
Naci Yılmaz, Türkiye İş Bankas1, Turkey \\ Bora Selçuk, Kadir Has Üniversitesi, Turkey
}

\section{Abstract \\ Finance Sector in the Eurasia Economies During and After the Global Crisis}

As in the other countries around the world, banking systems in Eurasia economies, comprised of Armenia, Azerbaijan, Georgia, Kazakhstan, the Kyrgyz Republic, Tajikistan, Turkmenistan and Uzbekistan, were adversely affected by the 2008 global crisis; A common challenge across most economies is to revive private-sector credit growth. Compared with the high increases of 80 percent in the period immediately prior to the crisis, credit growth has slowed sharply and even turned negative in real terms in a number of economies. Governments in many countries have taken measures to address banking sector stress. The measures for restoring credit growth and thus a high economic growth will be discussed in a part of our work. In the short run, such measures include aiding banks to repair balance sheets and also providing liquidity. In the medium term, measures should promote de-dollarization and the development of local debt markets.

JEL codes: G01, G15

\section{Kriz Sonrası Avrasya Ekonomilerinde Sorunlar ve Canlanma}

Küresel krizle ortaya çıkan şiddetli dışsal şoklar 2009'da Kafkasya ve Orta Asya'yı içinde barındıran Avrasya bölgesini olumsuz etkilemiştir. Bununla birlikte, dışsal şokların ekonomik büyüme üzerindeki olumsuz etkileri alınan önlemlerle hafifletilmiştir. 2010'da, , Küresel ekonomide görülen canlanmayla birlikte Rusya başta Avrasya Bölgesi'nde ekonomik iyileşme beklenmektedir. Bölgede ekonomik büyümenin en güçlü olduğu ülkeler, hükümetlerin destekleyici politikaları terk etmeye başladıkları ve büyümenin belirgin hale geldiği enerji ihracatçıları Türkmenistan ve Özbekistan olmuştur. Kazakistan'da ise nispeten daha yavaş bir büyüme görülmektedir. İyileşmenin henüz belirginlik kazanmadığı enerji ithalatçıları Ermenistan, Gürcistan ve Tacikistan'da sık1 maliye politikaları hedeflenmektedir. Mali kısıtlamalar hükümetlerin hareket alanlarını daraltırken, yapılan yardımlar gerek duyulan mali alanı genişletmektedir.

Avrasya bölgesi 2009'da, mal ve hizmet ihracatında önemli bir gerileme yaşanmıştır. Ayrıca, bölgeye gelen dış kaynak miktarı da 1/3 oranında azalmıştır. Uluslararası finansal piyasalardaki durum, küresel piyasalarla daha fazla bütünleşmiş olan Kazakistan'ı çok etkilemiştir. Ülkede, krizin başlangıcından 2009 sonuna kadar geçen sürede, özel portföy yatırımlarında, ülke dışına büyük bir çıkış gerçekleşirken, Ermenistan ve Gürcistan daha az etkilenmişlerdir. Küresel kriz kaynaklı dışsal şokların ekonomik büyüme üzerindeki olumsuz etkileri, siyasi önlemler ve yapılan yardımlarla hafifletilmiştir. Konjonktüre karşı uygulanan maliye ve para politikaları dışsal şokların etkisini hafifletmiştir. Bölgenin enerji ithalatçısı ülkelerinde kayıplar yapılan yardımlar ve yeni vergilerle finanse edilirken, bölgenin enerji ihracatçısı ülkeleri ise yurt içindeki tasarruflara güvenmişlerdir. Ayrıca, 2009 ilk yarısında dolar ve ruble karşısında ulusal paraların değer yitirmesi, yurtiçi talebi ulusal üretime yeniden yönlendirirken, 2009'da mal ve hizmet ithalatı bir çok Avrasya ülkesinde \%14 ile \%30 arasında azalmıştır. İthalattaki bu azalma düşen petrol fiyatlarından da kaynaklanmıştır. Buna rağmen, enerji ithalatı yapan ülkelerde ekonomik büyüme negatif olmuş; Ermenistan \%14'le en fazla küçülen ekonomi olurken, Gürcistan \%4 küçülmüştür. Kırgızistan ve Tacikistan'da ekonomik büyüme \%2-3 
aralığında gerçekleşmiştir. Bununla beraber, pek çok Avrasya enerji ihracatçısı ülke açısından işler daha iyi gitmiştir (IMF, 2010a).

\begin{tabular}{|l|r|r|r|r|r|r|r|}
\hline & Ortalama & & & & & Tahmini & Tahmini \\
\cline { 2 - 8 } & $\mathbf{2 0 0 0 - 5}$ & $\mathbf{2 0 0 6}$ & $\mathbf{2 0 0 7}$ & $\mathbf{2 0 0 8}$ & $\mathbf{2 0 0 9}$ & $\mathbf{2 0 1 0}$ & $\underline{\mathbf{2 0 1 7}}$ \\
\hline Bölge Ortalaması & 9,4 & 13,6 & 12,4 & 6,5 & 3,5 & 4,3 & 4,7 \\
\hline Azerbaycan & 11,3 & 34,5 & 25 & 10,8 & 9,3 & 2,7 & 0,6 \\
\hline Ermenistan & 11,2 & 13,2 & 13,7 & 6,8 & $-14,4$ & 1,8 & 3 \\
\hline Gürcistan & 6,4 & 9,4 & 12,3 & 2,3 & -4 & 2 & 4 \\
\hline Kazakistan & 10,3 & 10,7 & 8,9 & 3,2 & 1,2 & 2,4 & 4,2 \\
\hline Krgizistan & 4,1 & 3,1 & 8,5 & 8,4 & 2,3 & 4,6 & 5,3 \\
\hline Özbekistan & 5,2 & 7,3 & 9,5 & 9 & 8,1 & 8 & 7 \\
\hline Tadikistan & 9,2 & 7 & 7,8 & 7,9 & 3,4 & 4 & 5 \\
\hline Türkmenistan & 16,6 & 11,4 & 11,6 & 10,5 & 4,1 & 12 & 12,2 \\
\hline
\end{tabular}

Tablo 1. Avrasya Ülkelerinde Reel GSYH Büyümesi (\%) - Kaynak: (IMF, 2010b)

Gelişmeler bölgede erken bir iyileşmenin olduğunu göstermektedir. Pek çok ülkede ihracat 2009 ikinci yarısından itibaren artmaya başlamıştır. Benzer şekilde, yurtdışı kaynaklarda azalmanın yavaşladığını ve hatta 2010 ilk aylarında arttığını gözlenmektedir. Sermaye girişleri olumluya dönse de, hala kriz öncesinden daha düşüktür. Ancak, eğilimler her ülkede tamamen aynı değildir. Bazı ülkelerde bankacılık sektöründeki baskı kredi genişlemesini önleyerek ekonomik canlanmayı yavaşlatmaktadır.

Büyüme belirginleştikçe enerji ihracatçısı ülkeler destekleyici politikaları terk etmeye başlamışlardır. 2010'da Türkmenistan ve Özbekistan'ın sırasıyla \%12 ve \%8 oranında büyümeleri beklenmektedir. Her iki ülkede de, genişleyici mali politikalar devam etmekte olup, daha sıkı politikalar enflasyon baskısının artmasını önlemde yardımcı olabilir. Azerbaycan'da, petrol-dışı ekonomik büyümenin artmasını beklemekte olup, harcamalarda etkinliği artırarak ve orta vadeli mali sağlamlığı temin ederek, petrol-dışı açığın azaltılması hedeflenmektedir. Kazakistan'daki büyümenin \%2'nin az üstünde olacağı beklenmekte olup, 2010 yılına ait bütçesinden 1lımlı genişleyici bir mali politikanın uygulanacağı anlaşılmaktadır. Enerji ihracatçısı ülkeler bakımından, orta vadedeki asıl başarı, büyüme ve istihdam artışında devamlılıktır. Türkmenistan'da ise üretimin önümüzdeki yıllarda artması beklenmektedir. Diğer petrol ve doğal gaz ihracatçısı Özbekistan ise farklı ihraç ürünlerine sahiptir. Ancak, bu iki ülke bölge ülkelerine göre olumsuz iş ortamına sahiptirler (IMF, 2010a).

Mali yönden hareket alanları daraltılmış olan enerji ithalatçısı ülkeler, 2010'da ölçülü ayarlamaların yapıldığı bir maliye politikası hedeflemektedir. Ermenistan ve Gürcistan'da, 2010 'da bütçe açığının GSMH'ya oranı \%2'ye yükselebilir. Kırgızistan'da, son siyasi olayların vergi gelirlerini azaltması beklense de, bütçe üzerindeki ani bir şoka karşı hükümet mali desteklerden yararlanabilir. Yeni başlayan iyileşme ve kriz öncesi dönemin altında kalması muhtemel büyüme oranları nedeniyle, hükümetlerin mali teşvikleri sürebilir. Ancak, bir çok ülkede 2009'a göre desteklerin azalması ve kamu borcunun milli gelire oranının hızla artması, hükümetlerin mali hareket alanlarını daraltmaktadır. Dolayısıyla, ek mali destekler konjonktüre karşı yapılan harcamalara ve orta vadede bölgenin büyüme potansiyelini arttırmak için gerekli olan kamu yatırımlarına imkan sağlayabilir. Enerji ithalatçısı ülkelerde, ödemeler dengesi, milli gelirin \%8 ile \%15'i arasında, yüksek düzeyde açıklar vermektedir. Kısa dönemli borçlanmalar güvenli görülmekle beraber, bu tür büyük açıklar dışsal kırılganlık oluşturabilir. Ermenistan ve Gürcistan'daki doğrudan yabancı yatırımlar ödemeler dengesi açıklarının yarısından fazlasını finanse etmekte olup, merkez bankalarının toplam rezervleri artırmaları beklenmektedir. Doğrudan yabancı yatırımlara daha az güvenen Tacikistan, azalmakta olsa da, imtiyazlı borçlanma dahil desteklerden fayda sağlayabilir.

$\mathrm{Bu}$ ülkelerde, dış borçların milli gelir içindeki payı artmaktadır. Bölgede iyileşme yaşanırken, cari açığı azaltacak ve dış borçları belli bir düzeyde tutabilecek politikalar uygulanmalıdır. Enflasyonun Batılı ülkelerden yüksek, ama Rusya'yla aynı düzeyde (\%10’un 
altında) bulunmasına rağmen, 2010'da tekrar yükselebileceği tahmini vardır. Bu enflasyon fark1, kur rejimine bağlı olarak, büyümenin itici gücü olan dış talepte bir yavaşlamaya yol açarak, 2009'dan başlayan rekabet avantajının kaybedilmesine yol açabilir. Avrasya ülkelerinde kur rejimleri farklılıklar göstermiştir. Kriz süresince, bir çok ülke kur çıpasını terk ederek, kendi paralarının dolar ve rubleye karşı değer yitirmesine izin vermişlerdir. Ermenistan ve Gürcistan sadece aşırı dalgalanmalara müdahale eden esnek bir kur rejimi uygulamakta, kurlar rekabetin devamlılığını sağlayacak şekilde düşmektedir. Azerbaycan ve Türkmenistan dolara dayalı bir çıpayla enflasyon farkını sabitleyerek, rekabet gücünü doların ticaret ortaklarının paralarına karșı hareketlerine bağlamıșlardır. Kazakistan, rekabet gücünü korurken, merkez bankasının yurt içi hedefleri takip etmesine olanak verecek daha geniş bir banda yönelmiştir. Özbekistan ihracatının desteğiyle kurlara daha yavaş bir değer kaybı uygulamıştır.

\section{Kriz ve Sonrasında Avrasya Bankacılık Sistemi}

Dünyanın diğer bölgeleri gibi Avrasya, bölgesindeki bankacılık sistemleri de küresel krizden olumsuz etkilenmiş, kredi genişlemesi hızla yavaşlamıştır. Hükümetler bankacılık sektörünün üzerindeki baskıyı azaltacak önlemler almışlardır. Bu önlemler, kısa vadede, bankaların bilançolarını onarmalarına destek verilmesini ve likidite/sermaye enjeksiyonlarını içermekte, orta vadede, anti-dolarizasyon ve ulusal kredi piyasalarının gelişimini teşvik etmektedir.

\subsection{Kredi Genişlemesini Yeniden Sağlama}

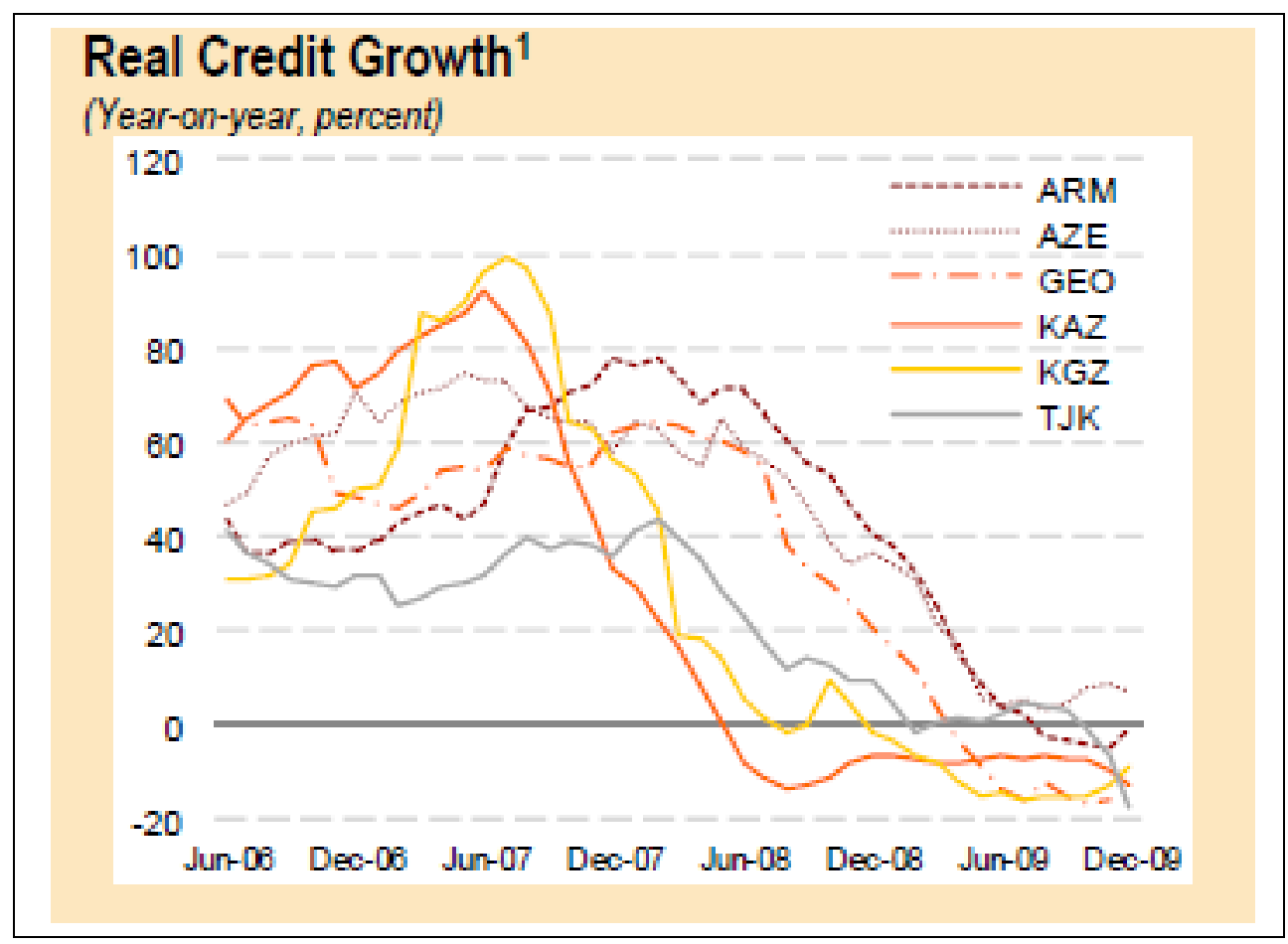

Grafik 1. Avrasya Ülkelerinde Reel Kredi Genişlemesi - Kaynak: (IMF, 2010b)

Kriz öncesi aşırı büyümeden sonra, bölge ülkelerinde kredi genişlemesi önemli ölçüde yavaşlamıştır. Küresel krizin ve sermaye akımlarındaki ani azalışların sonucu olarak, bankaların sorunlu kredilerde artış ve fonlarında keskin bir azalış olmuştur. Bankalar bilançolarını onarmaya odaklanıp, yeni kredi açmaya isteksiz davranmışlardır. Geçmişte krediyle finanse edilmiş yatırımlar uzun süreli yüksek büyümenin önemli itici gücü olduklarından, hükümetler, kredi genişlemesini tekrar sağlamaya çalışmaktadırlar. Küresel 
krizin bölge bankacılık sistemlerini olumsuz etkilediği üç kanal vardır: 1) Ödemeler dengesinde oluşan ağır baskılar bazı ülkelerde ulusal paraların değer kaybına sebep olmuștur. Dolar cinsinden borçlanma ve yüksek kur riski, kurların yükselmesiyle, riske karşı korunmasız borçluların ve banka bilançolarının önemli ölçüde zayıflamasına yol açmıștır. 2) Kriz öncesi aşırı kredi genişlemesini tetikleyen banka mevduatı, işçi dövizleri, dıș borçlanma gibi unsurlarda yaşanan azalma banka fonlarında keskin bir düşüşe yol açmıștır. 3) Kredi talebindeki azalmanın yanı sıra, ekonomik aktivitedeki yavaşlama ve yüksek makro ekonomik belirsizlik nedenleriyle kredi arzında da daralma görülmüştür.

Krizden çıkarken yapılabilecekler şöyle özetlenebilir; 1)Ülkeler krizden çıktıkça, ekonomi iyileştikçe, fonlar tekrar artacak ve makroekonomik belirsizlikler azalacaktır. Ekonomi arz yönlü, ekonomi büyümeye başlayıp özel sektör yatırım projelerine yöneldikçe, talep yönlü kredi genişlemesini de teşvik edebilir. Ayrıca, büyüme odaklı para ve maliye politikaları bu genişlemeyi artırabilir. 2)Ekonomik iyileşmeyi hızlandırmayı hedefleyen politikalar, zararları muhasebeleştirerek bilançoları onarma ve sermaye desteği sağlama sürecinde bankalara yardımcı olmalıdır. 3)Yeterli mali imkanı olan devletin, bankaların kaynak yetersizliğini gidermek amacıyla, geçici likidite enjeksiyonu yapması, yeniden kredi genişlemesine yardımcı olabilir. 4)Orta vadede, ani dalgalanmalar sonucu oluşan kur riskine karşı kırılganlığ azaltmak için dolar kullanımından kaçınma teşvik edilmelidir. Dolar karşıtlığı aynı zamanda para politikasının etkinliğini artırabilir. Bölgede ekonomik istikrarın dolar karşıtlığını olumlu etkilediği görülmüştür. Ayrıca, kur riskine açık borçlulara döviz cinsinden kredi verildiğinde daha yüksek sermaye ayrılmasını zorunlu kılan ve böylece dolaylı kur riskini de dikkate alan düzenlemeler, kur riskinin doğru fiyatlanmasını teşvik edebilir. 5)Bazı ülkelerde, daha esnek bir kur rejimi uygulanması, bankaların, müşterilerin dolar risklerini daha net görmelerini sağlayabilir.6)Yerleşikler ulusal kredi piyasalarının gelişmesiyle ulusal para cinsinden finansal araçlara yönelebilir. Bu piyasalar, bankaların kaynaklarını çeşitlendirmelerine ve bunlarda olabilecek münferit dalgalanmalara karşı kırılganlığın azalmasına da yol açabilir.

IMF, EBRD ve Gürcistan Ulusal Bankası'nın Nisan 2010'da düzenledikleri “Kafkasya ve Avrupa Birliği’nin Doğu Komşularında Sürdürülebilir Kredi Genişlemesi” konferansında, bölge ülkelerinden özel ve kamu sektörü temsilcileri bir araya gelmiş ve şu tespitler yapılmıştır: 1)Bölge ülkelerinde, kredi balonu patlaması süreci yaşanmıştır. Kredilerde görülen ciddi daralma hem arzdaki ve hem de talepteki değişimlerden kaynaklanmıştır. 2)Kısa vadede, ulusal sermaye piyasasının sığlığı, ekonomide yüksek dolar kullanımı ve bankaların yüksek risk iştahı sonucu, para dolaşımı mekanizmasında ortaya çıkan yetersizlik nedeniyle, kredileri canlandırmak için klasik para politikasının etkinliğinin sınırlı olduğunu ifade edebilmiş, yeni seçeneklerin tartışılması gerektiğini ifade etmişlerdir (Glodniuk, 2005). 3)Orta vadede, balonun tekrar patlaması döngüsel hareketinden kaçınmaya ve dolar kullanımının azaltılmasına ihtiyaç olduğu fikri oluştu (IMF,2010a). Bölge ülkeleri, 2008'den önceki yüksek kredi genişlemesiyle değil, ayrıca tarihsel seviyelerinin de üstünde gerekleşen hızlı ve sürekli bir kredi genişlemesi yaşamıştır. Ancak, küresel kriz bölgeyi vurduğunda bu süreç aniden sona ermiştir. 2007'den sonra, reel kredi genişlemesinde, ortalama yüzde 63'lük keskin bir düşüş yaşanmıştır. $\mathrm{Bu}$ azalma, Baltık ülkeleri ile BDT ülkelerinde görülen eğilim ile benzerlik göstermiştir (IMF, 2010b).

\subsection{Küresel Kriz Aracı Olarak Yaygın Dolar Kullanımı}

Bölgede doların yaygın kullanımı artmıştır. 2002-07 döneminde, yabancı para cinsinden mevduat ve kredilerin oranı en düşüğü Kazakistan'da \%40'tan, en yükseği Gürcistan'da \%80'e bir aralıkta gerçekleşmiştir. Ayrıca, bu dönemde, bölge ülkelerinde iyileşen makro ekonomik istikrar ve Ermenistan ile Gürcistan gibi bazı ülkelerde uzun süreli ulusal paranın değer kazanması nedeniyle dolar'dan kaçış süreci başlamıştır. Krize girerken dolar'dan kaçış süreci tamamlanmadığ 1 için bankacılık sistemleri kurdaki ani ve büyük dalgalanmalara karşı kırılgan hale gelmiştir. İki ana tür kırılganlık ortaya çıkmıştır: 1) Bilançoda döviz varlıkları ve yükümlülükleri arasındaki bir uyumsuzluktan kaynaklanan doğrudan kur riski. Böylece, net 
pozisyon açığı olan bankalar, ulusal paranın değer kaybetmesi durumunda, aniden zarar etmişlerdir. 2) Riske karşı iyi korunmayan yurt içi borçlulara yabancı para cinsinden kredi verilmesiyle oluşan dolaylı kur riski. Böylece, kredi alanların döviz borçlarını geri ödemede yetersiz kalmaları ve aktif kalitesinin bozulması sonucu banka bilançoları zayıflamıștır. Krizden önce, sadece Ermenistan bankaları açık pozisyona sahip olduklarından kurlar arttığında doğrudan kur riskine maruz kalmışlardır. Bu açık pozisyon, kriz öncesi kurlar artmadan döviz kredileri ile dengelenmeyen dolar mevduatında görülen ani artıșın sonucudur. Diğer taraftan, geri kalan ülkeler ise dövizde uzun pozisyona sahiptiler. Ancak, altı bölge ülkesinin tamamı, önemli miktarlarda dövizle kredi verdikleri için, dolaylı kur riskine maruz kalmıșlardır. Bu riskin derecesi bankalardan kredi alan reel sektör firmalarının döviz cinsinden nakit akışlarının hacmine göre değişmektedir. Bu nakit akışları (ihracat ve işçi dövizleri toplamı) döviz kredileri ile karșılaştırıldığında, dolaylı kur riskine önemli ölçüde maruz kalındığı görülmektedir (IMF, 2010b).

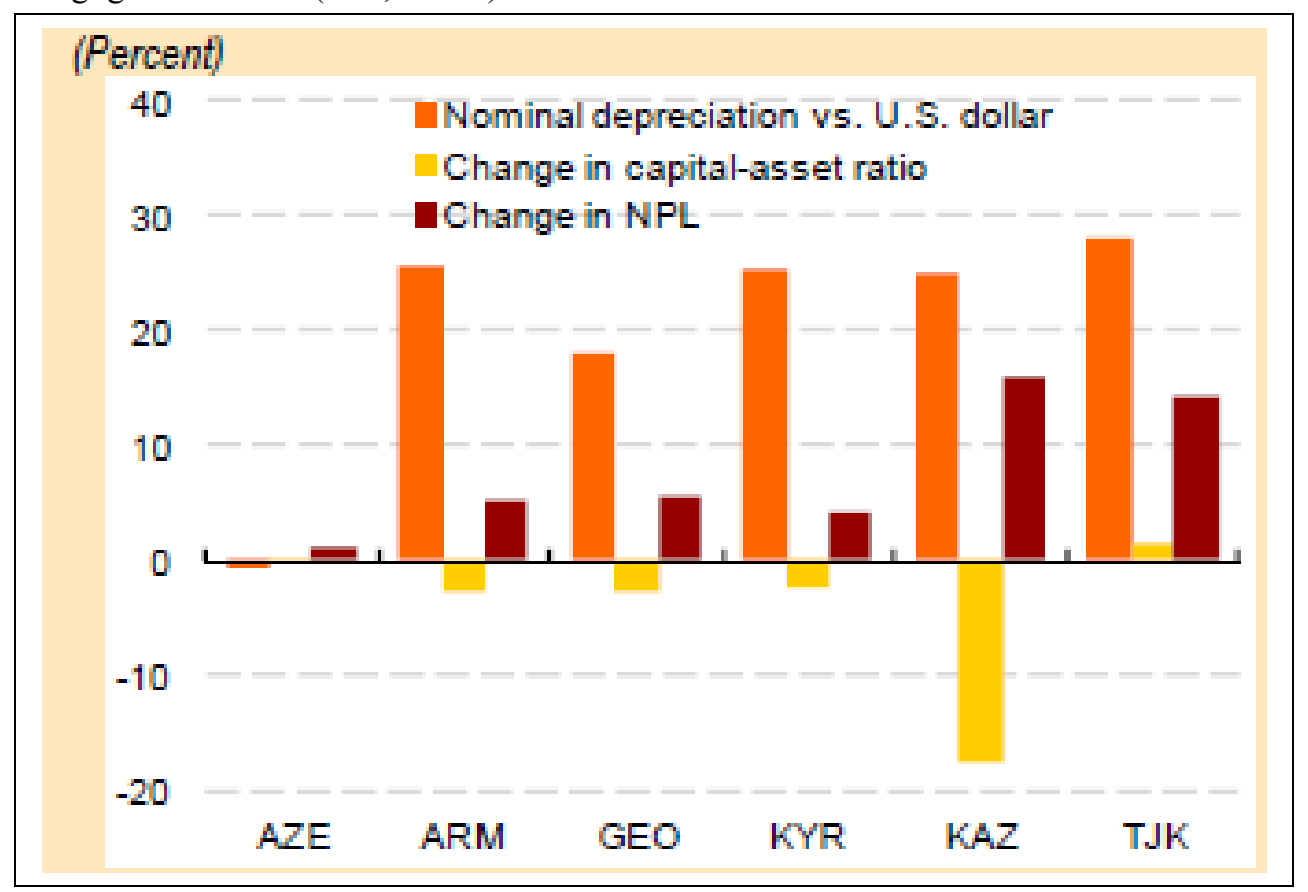

Grafik 2. Kurlar, Sermaye/Aktif Oranı, Sorunlu Kredi Artışı- Kaynak: (IMF, 2010b)

Ruble'nin, 2008 Temmuzu ile 2009 Şubatı arasında, dolara karşı \%55'e varan değer kaybının ardından, Azerbaycan hariç, bölge ülkeleri kendi paralarını \%18-25 arasında devalüe ettiler. Özellikle dolaylı kur riskine maruz kalınmasıyla oluşan bu devalüasyonlar, ekonomik canlılığın azalmasıyla birleşince, banka bilançolarını zayıflattı. Ülkelerin çoğunda, Sermaye/Aktif oranında \%2'den fazla azalışlar ve Sorunlu Krediler/Krediler oranında (NPL) \%4'ten fazla artışlar görülmüştür. Özellikle Kazakistan ve Tacikistan ağır zararlara uğramışlar ve NLP oranları \%14 ile 16 arasında artmıştır. Tacikistan, uluslararası finans kuruluşlarından bankalarına aktarılan sermaye desteğiyle olumsuz etkilerden kurtulmuştur. Azerbaycan'da NLP oranında artış yaşansa da, kurlar istikrarlı tutulduğundan, ani sermaye kaybı gerçekleşmedi (IMF, 2010b).

Kriz, banka fonlarında ciddi azalmalara yol açtı. Fonlardaki azalmanın kredi darlığına önemli etkisi olmuştur. Yurtiçi mevduat azalması kısa süreli kredi darlığının \%20'sini, yurt dış1 fonlardaki azalma $\% 5$ 'ini oluşturdu. Böylece, son 10 yıldır yabancı tasarruflara yönelseler de, bölge bankalarının, asıl fon kaynağı olarak, yurt içi mevduatlara dayanması, kredi daralmasını engelledi. Üretimdeki dalgalanmaların önemli ölçüde kredileri etkilediği görülmüştür. Krizden 
sonra kredilerin daralmasına neden olan iki farklı hareket vardır; Kredi talebinde azalma ve Makro ekonomik kötüleşmeyle birlikte ekonomiye duyulan güvenin kaybolması sonucu kredi arzında azalma.

\subsection{Küresel Kriz Sonrası Önlemler}

Bölge ülkeleri, kredilerin daralması karşısında, kriz karşıtı para politikaları izlemişlerdir. Bankalara doğrudan likidite sağlanması ve mevduat garantisinin artırılması gibi önlemlerin yanı sıra zorunlu karşılık ve politika faiz oranları indirilmiştir. Özel sektöre verilen kredilerin aynı kalması ve kredi faizlerinin politika faizi kadar düşmemiş olması dikkat çekmektedir. Hatta, kredi faizleri Gürcistan'da 78, Azerbaycan'da 232 baz puan artmıștır. Ayrıca, bazı ülkelerde, kur riskini azaltmak için risk azaltmak ve kredi genişlemesini teșvik arasında denge gözeten önlemler alınmıștır. Hükümetler, kredi genișlemesini sağlamak amacıyla, bankaların bilançolarını düzeltmelerine yardımcı olacak politikalar uygulamalı; zararları ortaya koymalı ve sorunlu kredilerle uğraşmalıdır. Devlet fonlama sorunlarının üstesinden gelmek için yapacağ 1 geçici likidite enjeksiyonuyla kredi büyümesini eski haline çevirebilir. Orta vadede, dolar cinsi ișlemlerin azaltılması, kur riskinden kaynaklanan kırılganlıkları azaltabilir. Dolar'dan kaçıș uzun süreli makro ekonomik istikrar dönemleri sağlayabilir. Ayrıca, ulusal kredi piyasalarını geliştirmek ve riske karşı korunmayan kredi borçlularına yabancı para cinsinden açılacak krediler için daha yüksek sermaye karșılığ 1 isteyerek kur riskine karșı uygun fiyatlamayı sağlayıcı şeffaf düzenlemeler yapmak dolardan kaçış sürecini kolaylaştırabilir (IMF, 2009).

\section{Sonuc}

Bölge ülkelerinde, küresel krizle birlikte kredi balonunun patlaması süreci yaşanmıştır. Kredilerde görülen ciddi daralma hem arzdaki ve hem de talepteki değişimlerden kaynaklanmıştır. Kısa vadede, ulusal sermaye piyasasının sığlığı, ekonomide yüksek dolarizasyon ve bankaların yüksek risk iştahı sonucu, kredileri canlandırmak için klasik para politikalarının etkinliği sınırlı kalmıștır. Bölge ülkelerinin büyük cari işlem açıklıklarının, maruz kalınabilecek dış şoklardan kaynaklanan kırılganlıkları azaltmak amacıyla, iyi yönetilmeye ihtiyacı vardır. Krizde artış gösteren ve kredi genişlemesini sınırlayan finansal bask1 bölge ülkelerinde görünümünü olumsuz etkilemiştir. Bankaların bilançolarını düzeltmelerine yardımcı olacak politikalar üretilmelidir. Ayrıca, makro ekonomik istikrarı ve destekleyici yasal düzenlemeleri sürdürerek, dolardan kaçıs sürecine devam etmelidir. Kısa vadede, büyümeyi desteklemek için genişleyici para ve maliye politikaları yanında, likidite enjeksiyonu dahil, yeniden yapılandırma tedbirleri, özel sektöre duyulan güveni canlandırabilir.

\section{KAYNAKÇA}

- (1) Golodniuk. Inna, (2005). "Financial Systems and Financial Reforms in CIS Countries", Center for Social and Economic Research Studies and Analysis No. 306

- (2) IMF, (2010a). "Sees Early Signs of Rebound in Central Asia, Caucasus", IMF Survey Magazine. http://www.imf.org/external/pubs/ft/survey/so/2010/CAR052510A.htm

- (3) IMF, (2010b). Regional Economic Outlook: Middle East and Central Asia. IMF Publication

- (4) IMF, (2010b). World Economic Outlook. IMF Publication

- (5) IMF, (2009). The Implication of the Global Financial Crisis for Low-Income Countries. IMF Publication 


\title{
Gelişmekte Olan Ülkelerde Küreselleșme, Uluslararası Sermaye Hareketleri ve Finansal Krizler Arasındaki İlişki
}

\author{
Ayfer Gedikli, Kırklareli University
}

\begin{abstract}
Relationship Between Globalization, International Capital Inflows and Financial Crisis in Emerging Countries and Alternative Fiscal Policies
\end{abstract}

Globalization which started to improve since 1980's, has caused many beneficial and harmful effects and unexpected changes both in the world economy and in economical structures of countries. Globalization affected not only economical structures but also social life, politics, and even cultures. On the other hand, while globalization was presenting "opportunites" to emerging countries, it also brought heavy risks and severe problems to them. Paralel to those improvements, globalization gave rise to international capital inflows. Emerging countries which have poor economical conditions, found internatinal capital as "life ring" since the capital was their greatest problem for the development of their economies. Unfortunatelly, in a short time, the dream turned into a "nightmare" and finally financial crises came true back to back and they were spreaded all over the world with the domino effect.

In this article, relationship between the globalization, international capital inflows and the financial crises which increased a lot paralel to improvement of globalization will be dicussed. Beside the destructive effects of financial crises on economies, some financial policies to protect from the crises will be suggested.

JEL Code: G15, G01, F36.

\section{Giriș}

1980'li yıllarla birlikte ABD, İngiltere ve Almanya'da işbaşına gelen hükümetlerin aldıkları kararlar doğrultusunda tüm dünya, küreselleşmede yaşanan ivmelenmenin de etkisiyle neoliberal iktisadi akımın etkisi altına girmiştir. Bu süreçte, bu ülkelere, IMF, DB gibi uluslararası kuruluşlar da destek vermiş ve küreselleşmenin eşlik ettiği finansal liberalizasyon eğilimleri de dünya gündemine taşınmıştır. Piyasa engellerinin kaldırılması, ticarette serbestleşme ve uluslararası sermaye hareketlerinin ülkelere giriş çıkışları önündeki engellerin kaldırılması ile karakterize olan finansal liberalleşmenin bir sonucu olarak, 1990'lı yıllarda, uluslararası sermaye hareketleri yoğunlaşarak hız kazanmış ve sermaye gelişmiş ülkelerden (GÜ), gelişmekte olan ülkelere (GOÜ) yönelmiştir. Bu artışta finansal küreselleşme anlayışının GÜ'ler ve GOÜ'ler nezdinde algılanma şekilleri de önemli olmuştur. Bu anlayışa göre, uluslararası piyasalar ile GOÜ piyasaları birbirleri ile bütünleşecekler, bu sayede GOÜ finans piyasalarının daha derin ve daha istikrarlı hale gelmeleriyle GOÜ'lerin kredi notları yükselerek ihtiyacı olan sermayeyi daha fazla çekebileceklerdi. Tasarruf fazlası olan GÜ'lerin sermayesi, tasarruf eksiği ve sermaye ihtiyacı olan GOÜ'lere kayacak; yaşadıkları resesyon dönemi nedeniyle ellerinde bulunan sermaye fazlasını karlı yatırımlara çevirmek için firsat arayan GÜ menşeili sermaye sahipleri daha yüksek faiz geliri elde ederken, GOÜ'ler de ihtiyaçları olan sermayeye kavuşmuş olacaklardı. Ayrıca, finansal küreselleşme sayesinde piyasada sermayenin bolluğu, tüketimi yavaş yavaş arttırarak, derinleşen finansal piyasaları, piyasa disiplinini arttıracaktı. Sonuçta, finansal altyapı daha iyi hale gelecek ve asimetrik bilgi, ters seçim ve ahlaki bozulma sorunlarıla karşılaşma ihtimalini azaltacaktı (Schmukler, 2004:39-40). Taraflar için "Kazan-Kazan" gibi görünen bu süreç, o dönemde kalkınma ve büyüme için gerekli olan sermayenin sıkıntısını çeken ve borç krizi içinde kaynak arayan GOÜ'ler için fazla sorgulanmaya gerek görülmeden hemen kabul edildi. Piyasa engellerinin kaldırılmasına ve 
ticari serbestiye temkinli yaklaşan kimi GOÜ'ler de IMF ve DB tarafından biraz telkin, biraz da zorlamayla sürece dâhil edilmiştir. Sonuçta, 1980'li yıllardan günümüze, özellikle küreselleşmenin de etkisiyle, sermaye hareketliliğinde hızlı bir artış olduğu görülmüştür. Öyle ki, 1980-1990 arası dönemde uluslararası sermaye akımları üç kat artmıș (Santana ve Garcia, 2004:2), 2007 yılının Nisan ayına gelindiğinde ise küresel ekonomide bir günde el değiștiren para miktarı 3,2 trilyon US\$ gibi olağanüstü bir seviyeye ulaşmıştır (BIS, 2007). 2008 Küresel Krizle birlikte yaklașık 200 milyar \$'a gerileyen bu rakamın krizin etkilerinin azalmasıyla birlikte yeniden artması ve beklenmektedir (Hiç, 2009:55). Sermaye sıkıntısı içindeki GOÜ’ler için başlangıçta "sorunsuz finansman kaynağı" gibi algılanan bu durum, büyük bir kısmının vadesi bir haftadan kısa olan söz konusu sermayenin aniden ve yüksek miktarda yön değiştirmesi de bu ülkelerin "finansal kriz" felaketiyle tanıșmasına vesile olmuștur. Yaşanan finansal krizler, temel makroekonomik büyüklüklerde, milli gelir, istihdam, sınâ̂ ve zirai üretim, yatırım gibi fiziksel değerlerde düzensizliğe ve iktisadi faaliyet hacminde zaman içinde tekrarlanan iniș ve çıkışlarla gerilemelere yol açmıștır. Bu ağır şok dalgaları, derin gelir dağılımı eșitsizlikleri olan ve ağırlıkla yoksul halkların yaşadığı bu ülkelerde, krizlerin yükünün yoksul kesim üzerine yüklenilmesine ve yoksulluk seviyesinin son 20 y1lda daha da vahim boyutlara ulaşmasına yol açmıştır. Krizlerin ardından GOÜ'lerin sadece maddi varlıkları zarar görmemiş, kendilerine "pembe tablolarla" takdim edilen küreselleşme sürecine olan inançları ve güvenleri de zedelenmiş, ticarette serbestleşmenin de aleyhlerine yarattığ durum nedeniyle küresel rekabete katılma konusunda cesaretleri de kırılmıştır.

Bu gerçekler 1şığında, bu bildiride küreselleşme sürecinin en yoğun şekilde yaşandığı son çeyrek yüzyılda GOÜ’lerde ardı ardına patlak veren finansal krizler ve baş döndürücü şekilde artan ve tamamen kontrolsüz hale gelen sermaye hareketleri arasındaki ilişki, küreselleşme penceresinden değerlendirilmiş ve bu minvalde, finansal krizlerin önemli bir nedeni olan yabancı sermaye akımlarına yönelik düzenleyici ve kontrol altına alıcı bazı iktisadi politikalar ortaya konulmaya çalışılmıştır.

\section{Finansal Küreselleşme Süreci ve Sermaye Hareketlerindeki Artış}

Bretton Woods sisteminin 1970'lerin başında çökmesi ile sabit kur sistemi yerini dalgalı kur sistemine bırakmıştır. Aynı dönemde ortaya çıkan petrol krizinin etkisiyle oluşan ve Avrupa bankalarında biriken Petro-Dolar/Euro-Dolar denilen fonlar, değerlenmek için kendilerine pazar ararken, GOÜ'lere yönelerek uluslararası bir borç piyasası yaratmışlar ve sermaye de böylece küreselleşmeye başlamıştır (Şenses, 2001:282). 1970'li yılların sonu ve 1980'li yılların başlarında GOÜ'lerin birbiri ardına borç ödeyemez duruma gelmeleri ve uluslararası bankaların zor duruma düşmeleri, bu kaynaktan GOÜ'lere aktarılan fonları iyice azaltmıştır. $\mathrm{Bu}$ sürecin sonunda ortaya çıkan uluslararası borç krizi, uluslararası kuruluşlar güdümünde neoliberal politikaların GOÜ’lerde yaygınlaşmasına ve küreselleşme sürecinin ivmelenmesine yol açmıştır. Sanayileşmiş kapitalist ülkelerde verimlilik artışlarının önemli ölçüde yavaşlaması ve hızla artan dünya petrol fiyatlarının da etkisiyle şiddetlenen stagflasyonist eğilimler bu ülkeleri de sermaye birikim sürecinin sürdürülmesi konusunda yeni arayışlara itmiştir (Şenses, 2004:2). Bu dönemde dünya ekonomisinde banka dengesi giderek büyümüş, küreselleşme süreci içinde, yavaşlayan ekonomik büyümeye paralel olarak krediye talep arttıkça mali sermayenin de gücü artmış, uluslararası piyasalarda yaşanmakta olan fon bolluğu ise kendine karlı plasman alanı oluşturmak için yeni yerler aramaya başlamıştır. Küresel düzeyde faaliyet gösteren ve gittikçe istikrarsızlığı artan bir ortamda kâr peşinde koşan mali sermayenin en önemli gereksinimi, sermaye dolaşımının önündeki engellerin kaldırılması, yabancı sermaye yatırımlarının kolaylaştırılması ve bankaların korunması olmuştur (Schmuklerf, 2004:39).

1980'li y1llarla birlikte Amerika'da Reagan, İngiltere'de Thatcher ve Almanya'da Kohl'un liderliklerini yaptıkları neoliberalizm temsilcisi sağcı partiler iş başına gelmişlerdir. $\mathrm{Bu}$ liderlerin uyguladıkları siyasi ve ekonomik politikalar, son derece varlıklı yatırımcıların ve toplam sayıları binden az olan büyük şirketlerin kısa vadeli çıkarlarını temsil etmiştir. 
Neoklasik teori bağlamındaki finansal liberalleşme düşüncesi, yerli tasarrufların yetersiz kaldığı durumlarda yabancı tasarrufların yerli yatırımlar ve büyüme için önemli bir kaynak oluşturabileceği temeline dayanmaktadır. Paraların konvertabl olması ve cari işlemlerin yanı sıra sermaye hareketlerinin serbestleşmesi (dış finansal serbestlik) sonucunda tasarruflar, sermaye darboğazı çeken ülkelere akacak, bu sayede GOÜ'lerin ekonomik etkinliği artacaktı. Büyüme ve istihdamı gerçekleştirmek için yurtiçi tasarrufları yeterli olmayan GOÜ'lerde faiz oranını yükselterek tasarruf fazlası olan ülkelerin tasarrufları çekilecek ve bu süreç, GOÜ'lerdeki faiz oranları uluslararası faiz oranı seviyesine inene kadar devam edecekti (Duman, 2002:41). Bu minvalde sermaye piyasaları örgütlenmiş ve borsalar kurulmuştur. Ayrıca, iç mali piyasalar da serbestleştirilmiş; dövizle yerli para birbirinin tam ikamesi olmuştur. İş başına gelen neoliberal görüşün temsilcisi hükümetler, yeni oluşan uluslararası rekabet koşullarını bahane ederek, sermaye gruplarının lehine bütün sosyal politikaları gevşetmeye başlamışlardır. GOÜ'lerde alelacele ulusal faiz oranları ve krediler üzerindeki sınırlamalar kaldırılmış ve döviz piyasalarında kurların serbest piyasada oluşumuna terk edilmesi ile uluslararası anlamda sermaye hareketlerinin serbest bırakılmış ve böylece piyasa mekanizmasının etkin işleyişi yolunda gerekli hukuki ve ekonomik düzenlemelere gidilmiştir. Sonuçta ulusal siyasi iktidarların yetkileri sınırlandırılmıştır (Şenses, 2001:282). GOÜ'lerde uygulanan politikalarla ekonomi politikasının iki temel fiyatı, faiz haddi ve döviz kuru, kamu denetiminden arındırılmış, GÜ'lerin etkisine sokulmuştur (Kazgan, 2005:129). 1980-1990 arası dönemde direkt yabancı sermaye akımları üç kat artmış, 19 GÜ'yi kapsayan bir değerlendirmede GSMH'nın yüzdesi olarak uluslararası sermaye akımları 1980'de \%1,2 iken, 1990'da GSMH'nın \%3,1'ine yükselmiştir. Sonraki on yılda da bu ülkelerin GSMH'larının \%9,4'üne ulaşmıştır. Özel sermaye yatırımlarının diğer türleri de 1990'larda \%10,6'dan 2000'de \%32,7'ye yükselmiştir. GOÜ'lerde resmi kurumlarca kontrol edilen sermayenin profilinin 1990'larda önemli ölçüde değiştiğini söyleyebiliriz. Bu ülkelerde özel sermaye akımları GSMH ile ilintili olarak 1990'da \%6,2'den 2000'de \%17,5'e yükselmiştir (World Bank, 2003). Yaşanan süreç içinde siyasi iktidarlardan boşalan otoritenin yerini ÇUŞ’ler ve uluslararası kredi kuruluşları almaya başlamıştır. Bir başka deyişle, devletin bölünemez görevlerinin dışında aktif olmadığı ve giderek küçüldügü̈, buna karşılık özel girişimin dünya ekonomisi ile rekabet koşullarında bütünleştiği bir dünya ekonomisi düzenine doğru bir süreç başlamıştır (Dönmez, 1998:417).

1990’lara gelindiğinde, Sovyetler Bloğunda yaşanan çöküşün ardından iki kutuplu dünya ekonomisi ve buna bağlı politik riskler azalırken küreselleşme hız kazanmış ve küresel ekonomi boyutuyla hacim genişlemesi ortaya çıkmıştır. ÇUŞ'ler ile hızlanan küreselleşme sürecinde, finansal sermaye serbestleşip güçlenirken, ciddi bir reel üretim fazlası ve rekabet ortaya çıkmıştır. GÜ'lerde kurumsal yatırımcıların yönettiği fonlarda büyük artışlar olmuştur. Bilgi ve iletişim teknolojisindeki gelişmeler de fonların dünya ölçeğinde kolayca hareket etmesine olanak sağlamıştır. Ancak GOÜ’lere yönelik fon akımlarının resmi kanallardan çok özel yatırımlar alanına doğru kaymış olması dikkat çekici bir gelişmedir. Ayrıca, geçmişteki durumun tersine, uluslararası sermaye akımlarının ödemeler bilânçosunun cari işlemler bölümü ile olan bağlantısı zayıflamış ve hatta tamamen kaybolmuştur (Seyidoğlu, 2003:142). 1990'lı yıllarda piyasa temelli reformların uygulamaya geçilmesiyle birlikte, GOÜ’lere yapılan sermaye akımları 1970-2000 yılları arasında hızlanarak artmış, 1970'lerde 41 milyar US\$'dan 1997'de 320 milyar \$'a yükselmiştir (Schmuklerf, 2004:40). Tüm dünyada yaşanan uluslararası sermaye akımları 1980-1990 döneminde üç kat artmıştır. 19 GÜ ele alındığında, özel sermaye akımları GSMH yüzdesi olarak 1980'de \%1,2 iken, 1990'da GSMH'nın \%3,1'ine yükselmiştir. UNCTAD verilerine göre 1990-1998 arasında tüm GOÜ’lere toplam 1890.6 milyar US \$ sermaye girişine karşılık 577.2 milyar US \$ çıkış yaşanmış, bunun 1083.6 milyar US \$'lık kısmı 16 GOÜ piyasasına yönelmiştir (UNCTAD, 1999). Sonraki on yılda ise bu ülkelerin GSMH'larının \%9,4'üne ulaşmıştır. Özel sermayenin diğer türevleri ise 1990'da \%10,6 iken 2000'e gelindiğinde \%32,7'ye yükselmiştir (Santana ve Garcia, 2004:2).

Öte yandan, portföy yatırımlarındaki artışta GOÜ'lerin kredi derecesinin dünya düzeyinde 
artması ve yapısal reformlarla yüksek kazanç beklentilerinin artması, bu ülkelere sermaye akımlarının yönlenmesinde etkili olmuștur. Ancak ülkelerin döviz rezerv hareketliliğinin giriș ve çıkıș evrelerindeki "kısa vadecilik" ve ulusal finans piyasalarının giderek daha fazla spekülatif saldırılara açık hale gelmesi sonucunda belirsiz bir risk ortamı ile karşı karşıya kalınmıștır (Yeldan, 2002:7). Bu nedenle, merkez bankaları giderek daha fazla miktarda rezerv tutmaya zorlanmıș, bu da reel fiziksel yatırımlara ayrılabilecek kaynakların giderek daralmasına yol açmıștır. 2008 Küresel krizden sonra ise finans fon ve kredi akımlarında ve direkt özel yatırım akımlarında, büyük azalmalar yaşanmıştır. GÜ’lerden GOÜ'lere yönelik direkt özel sermaye hacmi 2007 yılında 1 trilyon dolara yakın bir rakama ulaşmışken, 2009'da bu rakam 200 milyar dolara gerilemiștir. Ancak bu gerilemenin geçici olduğu, krizin etkileri hafifledikten sonra, tıpkı önceki krizlerde olduğu gibi, küreselleşmenin yeniden hız kazanması ön görülmektedir (Hiç, 2009:55).

\section{Uluslararası Sermaye Hareketlerinden Küresel Finansal Krizlere}

Finansal küreselleşmenin hızlandığı dönemlerde, GÜ'lerde artan likiditenin dış ticaret ve finansal yatırımlar üzerinden hızla GOÜ’lere kaydığı görülmüştür. Yine finansal küreselleşmenin bir sonucu olarak, çok yüksek borçlanmalarla büyük riskler alarak çalışan, yönettikleri fon miktarı 1 trilyon doları aşan, çok hızlı hareket eden ve denetlenemeyen yatırım fonları küresel piyasaların en önemli oyuncuları konumuna gelmişlerdir. GOÜ finansal piyasalarda "kaldıraç etkisi" adı verilen teminat yatırılarak, teminatın birkaç kat üzerinde borçlanılmasıyla aşırı riskler alınan spekülatif yatırımların artması, GOÜ'lerde spekülasyona dayalı piyasa şoklarında artışlara neden olmaktadır. Özellikle sabit kur rejimi uygulayan GOÜ'lerde merkez bankalarının bu fon kuruluşları aracılığıyla ülkeye giren döviz likiditesini toplayarak karşılığında kendi para birimlerinin arzını arttırdıkları sık rastlanır bir durum olmuştur. GOÜ ekonomilerinde yaşanan parasal genişleme, faizlerin ve kârlılık olanaklarının yüksekliği ile birleşince, ülkeye giderek daha yoğun bir kısa süreli sermaye veya portfolyö sermayesinin girmesine neden olmuş, bu da mali varlıkların fiyatlarında spekülâtif şişkinliklere yol açarak dış mali yatırımları daha da özendirici (sürü etkisi) etkide bulunmuş, artan döviz miktarı ise, kuru baskı altına alarak ulusal parayı aşırı değerlendirmiştir (over-valuation) (Seyidoğlu, 2003:144). Sermaye girişlerinin yarattığı canlılık ve döviz kurlarındaki aşırı değerlenme ticaretin yeni durum karşısında bocalamasına, iç piyasada ticarete konu olan ürünler açısından sorunla karşılaşılmasına ve ihracatta azalma görülürken, tüketim malları ithalatında artışların yaşanmasına yol açmıștır (Glick ve Hutchison, 2002:1-2). Bu sürecin devamı ancak yeni dıș sermaye girișlerine bağlı olduğundan, așırı değerlenmiș kur ve yüksek faiz politikaları tüm ekonomiyi tehdit etmeye başlamış, bankacılık sistemi de bundan nasibini alarak sistemin kırılganlığı büyük ölçüde artmıștır. Faiz tavanlarının kalkması ile faiz oranlarının artan volatilitesi, bankaları ciddi faiz riskleri ile karşı karşıya getirmiștir. Regülasyon uygulamaları ile kısa vadeli faizlerin, her zaman uzun vadeli faizlerin altında kalması garantilenirken, finansal liberalizasyon ile birlikte bu garanti ortadan kalkmıș ve vade uyumsuzlukları nedeniyle banka bilançoları daha riskli hale gelmiștir (Duman, 2004:41). Yakın geçmişte GOÜ'lerde yaşanmış olan krizlerin çoğunda ekonomik olayların gelişimi benzer çizgide olmuştur. Öyle ki, günümüzde finansal krizler adeta, yaşanan mali küreselleşmenin ve tüm dünyada egemen olan spekülatif sermaye hareketlerinin doğal bir sonucu olarak görülür hale gelmiştir.

Finansal krizlerde görülen bulaşıcılığın ardında da bu tür spekülatif fonlar vardır. Yatırımların farklı ülke ve bölgelere dağıtılması, birbiriyle coğrafi ilgisi olmayan ülkelerin dahi birbirinin ardı sıra kriz yaşamalarına neden olmaktadır. Bir ülkede ortaya çıkan krizin etkileri hızlı bir biçimde ve kolayca başka ülkelere de sirayet edebilmektedir. 1997 Asya krizinin başladığı ülke olan Tayland'ın IMF'nin direktifleriyle tüm döviz hareketlerini 1990 yılında serbestleştirmesinin ardından dışa açılımının ve finansal liberalizasyon sürecinin 1990'lı yıllarda hızlandığı görülmüş, banka faizlerine uygulanan limitler 1990-1992 döneminde kademeli olarak kaldırılmıştır. Filipinler de tıpkı Tayland gibi, 1990'lı yılların başlarında 
serbest piyasa ekonomisine geçerken, yabancı yatırımcılar önündeki kısıtlamaları kaldırmış, yabancı bankaların yerli bankaların çoğunluk hisselerini alabilmeleri için gerekli düzenlemeleri yapmış ve diş ticarette var olan engelleri kaldırmıştır. Yine aynı dönemde Malezya, Dr. Mahathir'in finansal reformlarıyla ekonomisinin yabancı sermayeye açılımını hızlandırmıştır. $\mathrm{Bu}$ ülkelerin 1990-1996 yılları arasındaki dönemde dış borçlarında patlama yaşanması, Tayland'ın dış borcunun 30 milyar dolardan 113 milyar dolara, Güney Kore'nin 49 milyar dolardan 165 milyar dolara, Malezya'nın 19 milyar dolardan 47 milyar dolara, Endonezya'nın 58 milyar dolardan 136 milyar dolara fırlaması kesinlikle rastlantı değildir. Döviz ve kısa vadeli ruble cinsi Rus bonoları piyasaları faaliyete geçirdikten sonra, Rusya'nın dış borcunun \%50 artarak 170 milyar dolara yükselmesi de tesadüf değildir (Özel, 2005:222). Yaşanan bu liberalleşme ve borçların kısa vadeli finansmanı sürecinin ardından bahsi geçen ülkelerde peşi sira finansal krizler baş göstermiştir.

Öte yandan GOÜ’lerin en önemli ekonomik sorunu olan cari denge açığı kısa vadeli finanse edildiğinde, döviz kuru sistemlerinde yaşanan olumsuzluklar, küresel ekonomik koşullarda yaşanan değişiklikler ve politik çalkantılar gibi hesaplanamayan nedenler döviz talebinin aniden güçlenmesine yol açabilir. Bunun yanında GOÜ’lerde yasal ve kurumsal yetersizlikler, sık sık yapılan seçimlerle birlikte yaşanan hükümet değişiklikleri ve ekonomi politikalarında görülen radikal değişiklikler, sermaye hareketliliğindeki süreci tersine çevirebilmekte ve ekonomiyi finansal dalgalanmalara daha açık hale getirebilmektedir. Bu nedenle "ekonomi ile ilgili beklentiler" hayati önem taşır (Özel, 2005:246).

Ayrıca, yakın tarihli kriz deneyimleri, sermaye hareketleri liberalizasyonunun ardından, hükümetlerin para politikası, faiz oranları ve döviz kurları üzerindeki etkinliklerinin önemli ölçüde zayıfladığını ortaya çıkarmıştır. Üstelik, devletin bu otorite zafiyeti, yanlı tutumu gerekçesiyle yoğun eleştiri alan IMF gibi uluslararası finans kuruluşları veya diğer yabancı finansörler tarafından doldurulmaya çalışılmaktadır. Elbette ki bahsi geçen kurumların kendi menfaatlerine yönelik olarak tercih edecekleri politikalar ülkeye sağlayacağı getiriler açısından paralellik taşımak zorunda değildir. GOÜ'lerde yaşanan kriz deneyimleri, bu tür krizlerle mücadelede ulusal politikaların önemine işaret etmekte ancak, bu ülkelerde bir yandan zaten var olan yapısal ve kurumsal yetersizliklerin üzerine finansal liberalizasyon gereği devletin ağırlı̆̆ının azaltılması, gerekli politikaların uygulanmasının önüne geçmektedir. Diğer yandan, doğasında istikrarsızlık unsurları bulunduran uluslararası sermaye hareketleri önündeki tüm engellerin kaldırılması, GOÜ'lerde mali yapıyı giderek daha dengesiz hale getirerek, oluşan finansal kargaşada krizlerin önlenmesini ve yönetilmesini çok daha güçleştirdiğini göstermektedir (Akyüz ve Cornford, 1999:12).

Son 20-30 yıl içinde neoliberal politikalar doğrultusunda yaşanan finansal küreselleşmenin, başta IMF ve DB olmak üzere kimi uluslararası kurumlar ve bazı GÜ'lerce kalkınmanın ve yoksulluktan kurtulmanın olmazsa olmazı olarak ısrarla sunulması, ağır etkileri yıllarca gitmeyecek finansal krizleri beraberinde getirmiştir. Garip bir çelişki olmakla birlikte, "Sermaye piyasası liberalizasyonu, istikrarsızlı̆ga neden olur fakat her zaman büyümeyi sağlamaz" gerçeği, yaşanan onca finansal krizin (Asya ve Rusya 1997-98, Brezilya 1999, Ekvator 2000, Türkiye 2001, Arjantin 2001 ve Uruguay 2002 krizleri) ardından IMF tarafından yapılan araştırmalarla da doğrulanmış olmasına rağmen, yine aynı kurum tarafından, finansal liberalizasyonu tam uygulamamış olmamakla birlikte dünyanın en fazla büyümeyi başarmış iki ülkesinden biri olan Hindistan'a, sermaye piyasasının liberalizasyonunda halen israrcı olması ise son derece ironiktir (Stiglitz, 2007:72-73). Öte yandan, ABD'de başlayan 2008 Küresel krizin küreselleşme ortamında süratle diğer ülkelere yayılmasının ardından, ümit verici bir gelişme olarak, küresel ilişkilerden istifade edilmenin gerekliliği fark edilmiş, küresel kriz karşısında $\mathrm{AB}, \mathrm{ABD}$, Japonya ve hatta Çin'in de dâhil olmasıyla tam bir ahenk içinde ortak mücadeleye başlanmıştır. Küresel sorunlara karşı küresel mücadele vermenin sorunun hallinde en önemli anahtar olduğu anlaşılmıştır. 15 Ocak 2009'da G20 ülkelerinin katılımıyla gerçekleştirilen toplantıda Stiglitz, Krugman ve Rogoff, krizlere karşı alınacak tedbirlerin tespiti için IMF ve DB'nın mevcut politikalarının yeterli olmayacağını, bunlardan ayrı olarak 
uluslararası finansın, daha ciddi takibe alınmasının gerekli olduğunu belirtmişlerdir. Stiglitz ise yeni ve bugünün şartlarına, ülkelerin bugünkü ekonomik ağırlıklarına daha uygun bir Bretton Woods anlaşmasının gerekliliğini vurgulamıș, Brezilya başbakanı Lula da Silva da yeni bir uluslararası örgüt kurulmasının gerekli olduğunu belirtmiştir (Hiç, 2009:56).

\section{Sermaye Hareketlerini Kontrol Etmeye Yönelik Politikalar}

İstikrarlı küresel finansal bir yapı için makroekonomik reformların gerekliliği artık tüm çevrelerce kabul görmektedir. Ancak, mevcut sistem dolayısıyla, GOÜ’ler üzerine büyük maliyetler bindiren finansal istikrarsızlık bazılarının çıkarlarına hizmet ettiği sürece bu sistem bu şekliyle devam ettirilmek istenecektir. Tüm yaşanan olumsuz deneyimlere rağmen herhangi bir reform çalışmasına başlanmaması durumunda dünya ekonomilerinin belirsiz sonuçlara yol açacak küresel bir finans istikrarsızlığıyla karşı karşıya kalması sürpriz olmayacaktır (Stiglitz, 2007:73)

Öte yandan, yaşanan tüm krizlere ve yaşanmakta olan küresel istikrarsızlığa rağmen, uluslararası finansal bütünleşme eğilimlerindeki artış trendinin önümüzdeki yıllarda da sürmesi beklenmektedir. Bu bağlamda, GOÜ'lerin öncelikli hedefi, uluslararası kısa vadeli sermaye hareketlerinin olumsuz etkilerini azaltacak politikalar geliştirmek olmalıdır. Stiglitz (2000)'e göre, finansal istikrarsızlığın en önemli sebeplerinden biri olan uluslar arası kısa vadeli sermaye hareketleri üzerinde uygulanacak kısıtlama veya kontroller diğer destekleyici politikalarla birlikte değerlendirildiğinde yerel ekonomilerin spekülatif ataklardan izole edilmesini kolaylaştırabilir, ülkede para ve döviz istikrarı bu sayede güçlenebilir. Ayrıca, sermaye hareketleri üzerinde kontrol uygulamasının makroekonomik istikrarsızlığı giderici özelliği olduğu gerçeği uzun zamandır kabul edilmektedir. Bu nedenle GOÜ’lerde sermaye hareketlerinde kontrollerin uygulanmasının yanında, ekonominin uygun piyasa koşulları altında doğru şekilde yönetilmesi de makroekonomik istikrarın sağlanmasında önemlidir.

Kontrolsüz sermaye akımları ile mücadele etmek için her şeyden önce, ülkeye kısa vadeli sermaye girişinin asıl sebebinin ne olduğunun belirlenmesinde fayda vardır. Ülkeye kısa vadeli sermayenin girişini teşvik eden faktörler kamu bütçe açıkları, kamu borç stoku, ülkede uygulanmakta olan faiz oranları, cari açıklar, borsa endeksi, enflasyon seviyesi, büyüme oranı gibi ulusal ekonomiye ilişkin makro değişkenlerdir. Ayrıca, ülke ekonomisinin yönetiminde gerekli olan finansman ihtiyacının uluslararası sermaye hareketleri ile karşılanması da belli ölçülerde zorunluluk ve alternatifsizlik gibi görünmekle birlikte, hükümetlerin tercihlerinin de önemli bir faktör olduğu bir gerçektir. Zira Çin ve Hindistan, IMF ve DB'nın tüm baskılarına rağmen ne piyasa engellerinden ne de kontrollerden vazgeçmemișlerdir. Bu bağlamda devletin uygulanacak piyasa kontrollerinde ve bu değișkenler üzerinden direkt ya da dolaylı olarak yön verici olduğunu söylemek mümkündür. Devletin doğrudan müdahalesi daha çok sermaye girişlerini veya kısıtlanmasını öngören tedbirlerin, yasalar ve uygun vergilerin salınması ile mümkün olabilmektedir (World Bank, 1997). GOÜ’lere yönelik olarak artan sermaye girişleri karşısında alması gereken tedbirler şu șekilde sıralanabilir (World Bank, 1997; Stiglitz, 2000):

GOÜ'ler, ekonomilerini, beklenmedik dış şoklara ve istikrarsızlıklara karşı korumaya yönelik tedbirleri sağlayacak mekanizmalar geliştirmelidir. Zira finansal krize yol açan içsel (finansal piyasalar, finansal kurumlar ve finansal altyapı) ve dışsal (makroekonomik sapmalar ve siyasi konjonktür) sistematik risklerin sebep olabileceği olumsuzluklardan hem finansal sistemi oluşturan unsurlar (piyasalar, kurumlar ve altyapı) hem de reel ekonomi faktörleri (hane halk1, firmalar ve kamu kesimi) olumsuz etkilenebilir. Finansal sistemde yaşanan sapmalar, reel ekonomi üzerinde üretim azalışları, işsizlik, yoksulluk artışı vb makroekonomik sapmalara yol açabileceğinden, özellikle para ve maliye politikaları, finansal krizlere yol açabilecek sistematik finansal risklerin azaltılması ve yönetimi noktasında önem kazanmaktadır. $\mathrm{Bu}$ bağlamda GOÜ'ler, finansal liberalizasyon sürecinde çok fazla risk almaktan kaçınmalı, makro ekonomik yapı güçlendirilmeli, sermaye piyasası ve bankacılık sistemi faal hale getirilerek denetim mekanizmaları ile kontrol edilmelidir. GOÜ'lerin rekabetçi bir serbest piyasa 
ekonomisi oluşturmaları, herşeyden önce makroekonomik dengenin tam olarak sağlanıp maliye ve para politikaları arasında uyumun yakalanması ile mümkündür. Nitekim, neoklasik yaklaşım dahi finansal liberalleşme karşısında, GOÜ'lerde sorun yaşanmaması için öncelikle kamu ve para piyasası dengesinin sağlanmış olması, dış ticaret açığının kapanması gerektiğini vurgulamaktadır. Bu görüșe göre, makro ekonomik denge oluşturulmadan ve para politikaları üzerinden kalkacak müdahalenin yerini alacak araçlar yaratılmadan finansal serbestleşmeye gitmek hatalı görülmektedir. O halde, belli bir evrim içerisinde olmadan ve makro ekonomik dengeler sağlanmadan çok çabuk bir şekilde finansal serbestleşmeye gitmek, krizle karş1 karşıya kalınmasına neden olmaktadır (Duman, 2004:44). Ayrıca bu uluslararası sermaye piyasalarında etkin olmaları, ülkelerin ekonomileri üzerinde olumlu etki yapabilecek uluslararası fonlardan yeterince pay alması ile de direkt ilintilidir. Rekabetçi bir serbest piyasa ve yerinde makroekonomik politikalar, enflasyonun düşük tutulmasını ve verimli yatırımların artmasını sağlayarak, gerek yurt içi gerekse yurt dışı işlemlerdeki risklerin azaltılmasına yardımcı olur. Bu konuda Stiglitz (2000) ise GOÜ'lerin, ülkelerine yönelen fonların olumlu yönlerinden istifade etmek ve olumsuz yönlerini bertaraf etmek amaciyla, kısıtlayıcı ve müdahaleci politikalar yerine, siyasi ve ekonomik istikrarı sağlayıcı, sermaye piyasalarını derinleştirici politikaların ön plana çıkarmasının daha yerinde olacağını savunmaktadır. Finansal serbestleşmeyi takiben yerli bankalar, yurtiçi mevduatlar yanında ülke dışından döviz cinsinden borçlanıp, döviz mevduatları alırken, verdikleri krediler genellikle yerli para cinsinden olmaktadır. $\mathrm{Bu}$ durumda bankalar, sahip oldukları kısa vadeli döviz yükümlülüklerinin, kısa vadede elde edebilecekleri döviz miktarını aşması halinde kolayca uluslararası likidite sıkıntısına düşebilmektedir. Banka krizlerinin \%70’i finansal kesimin serbestleşmesini izleyen beş yıl içinde ortaya çıkmaktadır ve finansal serbestleşme, bütün banka krizlerinin \%67'sinin işaretidir. Diğer yandan bu sonuç, öngörülebilir bankaya hücum modelleri ile tutarlıdır. Zayıf denetime sahip olan bankaların deregülasyonuna eşlik eden örtük ya da açı mevduat garantileri, aşırı borç verme ve aşırı risk alma durumları sonucunda bir finansal krizle sonuçlanabilir. Sistemin düzgün işler hale gelmesi ise sermaye piyasalarının derinleşmesine ve finansal istikrarsızlık riskinin azalmasına yol açar. Sermaye girişleriyle ilişkili olarak, bankalar aracılığıyla ülke ekonomilerinde verilen kredilerin hacmindeki artışlar takip edilmeli, özellikle zayıf bankacılık sistemi nedeniyle riskli kredi sorununa karşı gerekli tedbirler alınmalıdır. Kredi miktarındaki artışlar, para arzındaki artışlardan daha fazla ise merkez bankalarının döviz rezervleri de o ölçüde erimektedir. Böyle bir durumun yaratacağ 1 etki, spekülatif bir saldırı anlamına gelmektedir. Son Güneydoğu Asya krizi yaşanmadan az önce, finansal liberalizasyon sürecinde teşvik edilen sermaye akımları yüksek faiz oranları pahasına bu ülkelere girmiş, Tayland'da GSMH'ın \%12,5'ine ulaşmıştır. Sonuçta kısa vadeli borç miktarları artmış ve finansal kriz gerçekleşmiştir (Duman, 2004:43). Yapılan çalışmaların değerlendirilmesi için hesap verilebilirlik ve şeffaflık prensipleri göz ardı edilmemeli ve birimler arasındaki işbirliği ve güven konularına dikkat edilmelidir. Ayrıca, bu süreçlerin gerçekleştirilmesinde önemli görevler üstlenecek politika oluşturucu kurumları (Merkez Bankası ve düzenleyici kurumlar) güçlendirmek için teknik destek sağlanmalıdır.

Birbirinin tamamlayıcısı durumundaki bu politikalar yanında, dikkat edilmesi gereken bir konu da krizlerin derinleşmesinde en önemli etkilerden birine sahip olan ani sermaye çıkışlarının önüne geçilebilmesidir. Son dönemde sermaye hareketlerinin kontrol edilmesi konusunda yapılan çalışmalarda Kaminsky (2003) ve Cardoso (2003), sermaye hareketlerine getirilecek kontrollerin Şili örneğinde olduğu gibi sermaye girişlerine uygulanmasını önerirken; Krugman, (1998) kontrollerin Malezya örneğinde olduğu gibi sermaye çıkışlarında uygulanmasının daha verimli olabileceğini vurgulamaktadır. Kısa vadeli sermayenin aniden ülkeyi terk etmeleri ülkede piyasa şoklarına yol açabilmesi nedeniyle Nobel ödüllü iktisatçı Tobin'in 1978 yılında geliştirdiği ve kısa vadeyi pahalı hale getirerek, uzun vadeli yatırımları destekleyen Tobin vergisi (döviz dönüşüm vergisi), spekülatif sermaye akımlarının önlenmesi konusunda göz önünde bulundurulabilecek alternatif bir vergi olarak değerlendirilebilir. Vergi aracılığıyla yapılacak kontroller, yerleşik ve yerleşik olmayanların pozisyonlarını farklılaştırmak için ticari bankaların yabancı para pozisyonlarına ya da açık pozisyonlarına 
konulan limitleri, dışardan borçlanabilmek için kuruluşların belirli rating koşullarını sağlamalarını ifade eder. Böylelikle, kısa vadeli portföy yatııılarının caydırılması, daha pahalı hale getirilmesi ve piyasalarda ortaya çıkan ani hareketlenmelerden ülkelerin korunması amaçlanmaktadır. Şili, Kolombiya, Malezya, Brezilya, Tayland ve Slovenya kısa vadeli sermaye hareketlerine sınırlandırma getiren ülkelere örnekler olarak gösterilebilir. Ancak kontrollerin bașarısı her ülkede i aynı olmamıștır. Malezya ve Tayland, sermaye kontrolleri ile sermaye girișlerinin miktar ve bileșimini etkilemeyi başarmış, Kolombiya ve Sili'de sadece sermayenin bileşimi değiştirilebilmiştir. Özellikle Şili, kısa vadeli sermaye hareketlerine getirdiği sınırlamalarla, 1994 ve 1995 Meksika krizinden etkilenmemiștir. Brezilya'da ise finansal piyasaların çok gelişmiş olması ve türev araçlarının yaygın kullanılması ve dolayısıyla vergiden kaçınmanın kolaylaşması nedeniyle başarısız olmuştur. (Duman, 2004:45).

\section{Sonuc}

Neoliberal politikalar sonucunda gelişen mali küreselleşme ile birlikte, son dönemde yaşanan küresel finansal krizler arasında önemli ilişkiler olduğu reddedilemez. 1990'lardan itibaren kısa aralıklarla Meksika'da, Güney Doğu Asya'da, Rusya'da, Brezilya'da, Türkiye'de ve diğer GOÜ'lerde yaşanan finansal krizler, zaten zayıf ve kırılgan ekonomik yapıya sahip olan bu ülkelerde bir yandan önemli refah kayıplarına yol açarken, diğer yandan ekonomik göstergeleri hepten kötüleştirerek etkisi uzun yıllar sürecek mali ve sosyal sorunlar ortaya çıkarmıştır. Uluslararası sermaye hareketlerinin önündeki tüm engellerin kaldırılmasıyla, tüm dünyada küresel finansal sermaye GÜ’lerden GOÜ’lere doğru akmaya başlamıştır. GOÜ'ler için gelişmenin anahtarı durumundaki sermayenin bu ülkelere akması, ilk aşamada son derece katmadeğerli bir süreci işaret etmiştir. Uzun vadeli olarak GOÜ'lere gelen yabancı sermaye, daha çok uzun vadeli yatırımların finansmanında kullanıdığından önemli bir risk teşkil etmezken, gecelik karlar, arbitraj farkları ve kısa vadeli spekülasyon üzerinden kar elde etmek niyetinde olan sermaye finansal krzi sorunun asıl kaynağını teşkil etmiştir. Zira, zayıf makroekonomik yapı üzerine oturtulmuş finansal piyasalarda, özellikle beklenmedik olaylar veya piyasa şokları karşısında sermayenin aniden yön değiştirmesi krizlere yol açabilmektedir. Bu nedenle, bir yandan GOÜ'lere sermaye girişini teşvik edereken, diğer yandan ülkelerin , bu akımların sebep olabileceği risklere karșı korunması ve ekonomilerinin daha stabil hale getirilmesi hayati önem taşımaktadır. Bu minvalde, her şeyden önce, finansal liberalizasyona geçiş ve piyasa engellerinin tamamen kaldırılmasının düşünülmesinden önce ülke ekonomisinin liberalizasyona hazır hale getirildiğinden emin olunması gerekmektedir. Son dönemde en büyük gelişmeyi yakalamıș iki ülke olan Çin ve Hindistan, istikrarlı büyümelerini halen devam eden korumacı piyasa engellerine borçludur. $\mathrm{Bu}$ iki ülke, sağlam bir makroekonomik altyapı ve ticarette küresel rekabete katılabilecek gücü elde etmeden piyasalarını açmamışlardır. Bu nedenle, ülke içinde sistemin işlerliğinin kontrolünü yapacak, belli piyasa engelleri ve kontrollerini uygulacak bir piyasa aygıtına ihtiyaç vardır. Bu noktada neoliberal politikalar gereği görev ve yetki sınırları iyice daraltılan devletlerin yeniden belli yetki ve sorumluluklarla donatılması gerekmektedir. Zira, iyi işleyen bir denetim mekanizması hayati değer taşımaktadır. GOÜ'lerin ekonomilerinde en önemli darboğazı oluşturan sermaye ve dıs borç ikilemi, bu ülkelerin var olan borçlarının yeniden yapılandırılarak daha uzun vadeye yayılması, istikrarsızlığın asıl kaynağı olan ve spekülatif kazanç dıșında başkaca bir beklentisi olmayan kısa vadeli giriș çıkıșların kontrol altına alınması ve kısıtlanması, bunların yerine uzun vadeli ve kalıcı yatırımların finansmanlarında kullanılmak üzere uzun vadeli yabancı sermaye girişini teşvik edici makro ekonomik düzenlemeler ve vergi politikalarının oluşturulması, yukarıda sözü edilen olumsuzluklarından çok daha fazla istikrar sağlayıcı sonuçlar getirebilmektedir. Kısa vadeli sermaye girişine yönelik kontroller ise, sermaye girişlerine ve çıkışlarına yönelik olarak iki farklı şekilde söz konusu olabilir. Şili'de sermaye girişlerine, Malezya'da ise sermaye çıkışlarına uygulanan kontrollerin ekonomide istikrar sağlayıcı ve riski minimize edici özellik sağladığı müşahade edilmiştir. Bu minvalde özellikle spekülatif amaçlı işlemleri daha pahalı hale getirmekle caydırıcı nitelik taşıyan Tobin vergisi de 
sözü edilebilecek bir alternatiftir. Ancak, unutulmamalıdır ki, yukarıda sözü edilen tüm politikaların tek başlarına yeterli olmaları mümkün olmadığı gibi, uygulanacak politikaların bir yandan birbirlerini destekler nitelikte olması gerekirken, yapılan tüm çalışmaların hesap verilebilirlik ilkesi göz önünde bulundurularak yapılması ve diğer yandan tarafsız bir denetim mekanizması ile kontrol edilmesi, çalışmaların hem başarısını hem de güvenilirliğini arttıracaktır.

\section{KAYNAKÇA}

- $\quad$ AKYÜZ, Y. and CORNFORD A., (1999). "Capital Flows to Developing Countries and The Reform of TheInternational Financial System", UNCTAD Discussion Papers. No. 143. pp.1-53.

- $\quad$ BALKANLI, O. (2002)“Küresel Ekonominin Belirleyici Faktörleri Üzerine”, Uludă Üniversitesi, İktisadi ve İdari Bilimler Fakültesi Dergisi, Cilt XXI, ss.13-26

- $\quad$ BIS. (2007), Triennial Central Bank Survey of Foreign Exchange and Derivatives Market Activity in 2007-Financial Results, Bank of International Settlement, Basle.

- CHOMSKY, N. (2000), Halkın Sırtından Kazanç: Neoliberalizm ve Küresel Düzen Çev. Deniz Hakyemez/ Barış Zeren, Om Yayınevi.

• DÖNMEZ, R. (1998), "Vergi Hukuku Açısından Küreselleşme ve Elektronik Ticaret”, Anadolu Üniversitesi İ̈BF Dergisi, Cilt 14, Sayı 1-2.

- DUMAN, K. (2002)“Finansal Krizlerin Nedenleri, Etkileri ve Bankacılık Sektörüne Yansımaları", Finans-Politik\&Ekonomik Yorumlar Dergisi, ss.38-50.

- DUMAN, K.(2004) “Finansal Krizlere Karşı Politika Tercihleri”, Akdeniz Üniversitesi İ̈BF Dergisi, (8) ss.38-61.

• Gelişmiş Ülkeler, Türkiye ve Dönüşüm Ekonomileri”, Dogus Üniversitesi Dergisi, 4 (2) 141-156.

- $\quad$ GLICK, R and HUTCHINSON, M. (2002), "Capital Controls and Exchange Rate Instability in Developing Countries", Pasific Basin Monetary and Economic Studies Working Paper Series, WP No:PB00-05, Federal Reserve Bank of San Francisco.

- HİÇ, M. (2009), Küresel Ekonomik Kriz ve Türkiye, Beykent Üniversitesi Yayınları, İstanbul.

- KAZGAN, G. (2005), Küreselleşme ve Ulusdevlet, Yeni Ekonomik Düzen, İstanbul Bilgi Üniversitesi Yayınlar1, 4. bask1, İstanbul.

- ÖZEL, Saruhan, (2005), Global Finansal Krizler, Deniz Kültür yayınları, No. 13, 1. Basim.

- Plan B Yayınları, İstanbul.

- $\quad$ SANTANA, J. R. and GARCIA, F. (2004) "World Financial Liberalization and Its Effects on Capital Inflows", pp.1-31

http://ideas.repec.org/p/ecm/latm04/101.html.

- SCHMUKLER, S. L. (2004), "Financial Globalization: Gain and Pain for Developing Countries", Federal Reserve Bank of Atlanta Economic Review, Second Quarter, pp.39-66.

- $\quad$ SEYİDOĞLU, H. (2003), "Uluslararası Mali Krizler, IMF Politikaları, Az Gelişmiş Ülkeler, Türkiye ve Dönüşüm Ekonomileri”, Doğuş Üniversitesi İIBF Dergisi.

- $\quad$ SEYİDOĞLU, H.(1996), Uluslararası İktisat, Güzem Yayınları, İstanbul

- $\quad$ STIGLiTZ, J. E. (2000). "Capital Market Liberalization, Economic Growth and 
Instability", World Development Report

- $\quad$ STIGLITZ, J. E. (2007a), Making Globalization Work, W.W. Norton \& Company,NewYork.

- $\quad$ STIGLITZ, J.E. (2007b) “Finansal İkiyüzlülük”, Ekonomik Forum, ss.72-73 www.project-syndicate.org

- ŞENSES, F. (2001), Küresellesmenin Öteki Yüzü: Yoksulluk, 1.Bask1.

- ŞENSES, F.(2004), "Neoliberal Küreselleşme Kalkınma İçin Fırsat mı, Engel mi?”, ERC Working Paper in Economic 04/09, ss.1-28.

- United Nations Conference on Trade and Development (UNCTAD) (1999), Trade and Development Report, Geneva.

- WORLD BANK (1997). "Private Capital Flows To Developing Countries: The Fioad To Financial Integration ", A World Bank Policy Research Report.

- WORLD BANK (2003). World Development Indicators 2002.

- YELDAN, E. (2002) "Neoliberal Küreselleşme İdeolojisinin kalkınma Söylemi Üzerine Değerlendirmeler”, (II. Dünya Sosyal Forumu), Rethinking Economics: Active Growth and Social Policies Under Globalization Conference, Brazil. 


\title{
Hisse Senedi Fiyatları İle Döviz Kuru Arasındaki Dinamik İlişkinin Belirlenmesi; Avrasya Örneği
}

\author{
Bekir Elmas, Atatürk Üniversitesi \\ Ömer Esen, Atatürk Üniversitesi
}

\begin{abstract}
Determining a Dynamic Relationship Between Stock Prices and Exchange Rates: An Empirical Study on Eurasia

The stock price has a close relationship with some macroeconomic variables. As examples of the main macroeconomic variables can be shown that exchange rates, inflation, interest rate, growth rates. This paper empirically examined the relationship between the local stock market indexes and exchange rate (USD) in six Eurasian countries namely Turkey, Germany, France, Netherlands, Russia, France and India. The paper set out by testing existence of a long-term relationship between considered two variables using the Engle-Granger (1987), Johansen $(1988,1995)$ and Johansen-Juselius (1990) cointegration methods. Results of Engle- Granger cointegration test showed that there is no cointegration linkage between two variables under consideration. Furthermore, The Johansen cointegration test found that there is a long-term relationship between two variables (variables in the two countries). Under the VAR (Vector Autoregressive) and VEC (Vector Error Correction) models appllied the Granger causality test, revealed an unidirectional casual relationship between two variables in each of the six countries. In addition as regards the relationship While there is a unidirectional causal relationship running from exchange rate to stock market for four countries. However this relation is casual running from stock market to exchange rate for other two countries. According to the direction of the relationship these results that relationship between stock prices and exchange rate in four countries supports for the "Traditional Approach". Furthermore, this relation also supports for the "Portfolio Approach" for other two countries.

Jel Codes: F31, G10, G15

\section{Giriş}

Hisse senedi fiyatlarının bir takım makro ekonomik değişkenlerden etkilenerek dalgalandığı gözlemlenmektedir. $\mathrm{Bu}$ durum finans literatüründe Etkin Piyasalar Hipotezi ile ifade edilmektedir. Etkin Piyasalar Hipotezi, hisse senedi fiyatlarının hem şirket hem de genel ekonomiden gelen bilgilerle oluştuğunu savunmaktadır. Hipoteze göre, şirket haberlerinin yanında gelen makro ekonomik verilerle hisse fiyatları yeni noktalarına taşınacaktır. Makro ekonomik veriler ülke ekonomisinin ve dünya ekonomisinin gidişatını göstermekte olup, bu gidişattan elbette ki şirketlerde olumlu veya olumsuz yönde etkilenecekler ve bu durum şirketlerin karlarına yansıyacaktır. Hisse senedinin değeri tespit edilirken en çok kullanılan model şimdiki değer veya iskonto edilmiş nakit akımları modelidir. Nakit akımlarından olan kar payları ve iskonto oranı makro ekonomik değişkenlerle yakın ilişki içerisindedir.

Son yıllarda rağbet gören finansal serbestleşme politikalarının doğal bir sonucu olarak, sermaye hareketleri üzerindeki kontrollerin kaldırılması, döviz kurları ile hisse senedi fiyatları arasındaki ilişkilere yönelik çalışmaların önemini artırmıştır. Finansal piyasalarda meydana gelen bu değişmeler alternatif yatırım araçlarının da artmasını beraberinde getirmiştir. Yaşanan bu süreçte döviz kuru, ulusal ekonomiler arasında uyum ve aynı zamanda da ekonomilerin karşılaştırılmasında dengeyi sağlayan önemli makroekonomik bir rolü üstlenmiştir. Bu bağlamda para ve sermaye piyasalarında meydana gelen bu değişmeler ile birlikte, hisse senedi fiyatları ile döviz kuru arasındaki ilişkiye yönelik çalışmaların sayısı da buna paralel olarak artmıştır. 
$\mathrm{Bu}$ alanda yapılan çalışmalara bakıldığında hisse senedi fiyatları ile döviz kuru arasındaki ilişkiyi açıklamakta farklı temel yaklaşımlara dayalı çalışmalar yoğunluk kazansa da, çalışmaların daha çok geleneksel ve portföy yaklaşımları temel alınarak desteklendiği görülmektedir. Böylece hisse senedi fiyatları ile döviz kuru arasındaki ilișki inceleyen çalışmalarda temel alınan "geleneksel" ve "portföy " yaklaşımları, bu ilişkiyi açıklamaya çalışan modellerin başında gelmektedir.

Geleneksel yaklaşım, döviz kurunda meydana gelen bir değişmenin hisse senedi fiyatlarında bir değişmeye neden olacağını savunmaktadır. Yaklaşıma göre, döviz kurunda meydana gelen bir değişme firmaların varlıklarını, yükümlülüklerini, girdi-çıktı maliyetlerini ve rekabet gücünü etkileyecektir. Nihayetinde firmanın karlılığında bir değişme meydana gelecek ve bu durum hisse senedi fiyatına yansıyacaktır (Granger, vd, 1998; Tabak, 2006).

Portföy yaklaşımına göre ise, piyasalarda hisse senedi getirilerini artırmaya ve riskleri azaltmaya yönelik meydana gelen her türlü olay ya da yatırımcıların geleceğe yönelik beklentilerinin pozitif yönde değişmesi, döviz kurunu düşürücü bir etkiye sahipken ulusal paranın değerini de aynı zamanda artmasına neden olabilmektedir. Bu bağlamda hisse senedi fiyatları ile döviz kuru arasında negatif bir ilişki olduğu ve bu ilişki neticesinde hisse senedi fiyatlarından döviz kuruna doğru bir nedensellik ilişkisi olduğunu ileri sürülmektedir. (Granger, vd, 1998; Stavarek, 2005; Nath ve Samanta, 2003; Tabak, 2006).

\section{Literatür İncelemesi}

Bu alanda yapılmış ilk çalışmalardan biri olan, Aggarwal (1981), 1974-1978 dönemini kapsayan hisse senedi fiyatları ile döviz kuru arasındaki ilişkiyi analiz etmiştir. Hisse senedi fiyatlarının, gelecekte gerçekleşmesi beklenen döviz kurunda meydana gelecek değişmeye yönelik bilgilerden etkilenebileceğini ileri sürmektedir. Bu bağlamda yapmış olduğu çalışmada hisse senedi fiyatları ile döviz kuru arasında anlamlı ve pozitif bir ilişki tespit etmiştir. Benzer bir çalışmayı Solnik (1987), gelişmiş sekiz ülkenin verilerini kullanarak yapmış olduğu çalışmada, iki değişken arasında zayıf olmasına karşın pozitif yönlü bir ilişki olduğunu ileri sürmektedir. Phylaktis ve Ravazzolo (2005) ve Dimitrova (2005) 'da iki değişken arasında pozitif bir ilişki olduğu, döviz kurunda meydana gelen bir artışın hisse senedi fiyatlarını artırdığını ileri sürmektedirler.

Literatürde hisse senedi fiyatları ile döviz kuru arasında ileri sürülen pozitif ilişkinin aksini söyleyen çalışmalarda önemli yer tutmaktadır. Bunların başında Soenen ve Hennigar (1988), Kim (2003) ve Hatemi-J ve Irandoust (2002) gelmektedir. Bu çalışmalarda iki değişken arasında güçlü ve negatif bir ilişki olduğu ileri sürülmektedir. Kanas (2000), 'da benzer bir çalışmayı altı sanayileşmiş ülke için yapmıştır. Ele aldığı ülkelerden biri hariç iki değişken arasında negatif ve hisse senedi getirilerinden döviz kuru değişimlerine doğru anlamlı bir nedensellik ilişkisi olduğu sonucuna varılmıştır. Yine aynı şekilde Adjasi, vd., (2008), döviz kurunun hisse senedi fiyatları üzerine etkisini araştırdıkları çalışmalarında, iki değişken arasında negatif bir ilişki ve döviz kurunda meydana gelen bir değişmenin hisse senedi fiyatlarını etkilediği sonucuna varılmıştır. Yapılan incelemelerde ulusal paranın değer kaybetmesi uzun dönemde hisse senedi fiyatlarını artması ile sonuçlanırken kısa dönemde düşürdüğü görülmektedir.

Literatürde bu alanda yapılmış diğer çalışmaların aksine döviz kuru ve hisse senedi fiyatları arasında ilişkinin olmadığını ileri süren çalışmaları da görmek mümkündür. Bahmani-Oskooee ve Sohrabian (1992) ve Nieh ve Lee (2001), yapmış oldukları çalışmalarda değişkenler arasında uzun dönemde bir ilişkinin varlığını ortaya koyamamışlardır. Bununla birlikte kısa dönemde çift yönlü nedensellik ilişkisi olduğunu ileri sürmüştürler. Aynı şekilde Bhattacharya ve Mukherjee (2003), Shew (2008), Rahman ve Uddin (2009), Kutty (2010) ve Zhao (2010) çalışmalarında döviz kuru ile hisse senedi fiyatları arasındaki ilişkiyi analiz etmişleridir. Bu araştırma sonuçlarına göre de ele alınan değişkenler arasında bir nedensellik ilişkisine rastlanılmamıştır. Ayrıca Smyth ve Nandha (2003), dört Güney Asya ülkesinin verilerini 
kullanarak yapmış oldukları çalışmada iki değişken arasında uzun dönemli bir ilişkinin varlığı tespit edilememiştir. Ancak ele aldıkları ülkelerin ikisinde döviz kurundan hisse senedi fiyatlarına doğru tek yönlü bir nedensellik ilişkisi tespit edilmiştir. Diğer iki ülkede ise döviz kuru ve hisse senedi birbirlerinden bağımsız hareket ettikleri ileri sürmektedirler. Abdalla ve Murinde (1997) ve $\mathrm{Wu}$ (2000) ise hisse senesi fiyatları ile döviz kuru arasındaki nedensellik ilişkiyi araştırdıkları çalışmalarda döviz kurundan hisse senedi fiyatlarına doğru tek yönlü bir ilişkiye rastlanmıştır.

\section{Veri Seti}

Bu çalışma ile 6 Avrasya ülkesinde hisse senedi fiyatları ile döviz kuru (USD) arasında nasıl bir ilişkinin olduğu tespit edilme amacı güdülmüştür. Aşağıda Tablo 1'de uygulamaya dahil edilen ülkeler ve diğer açıklayıcı bilgiler sunulmuştur. Aylık verilerin kullanıldığı çalışmada, veri seti Eurostat (European Statistics), Federal Reserve Bank of St. Louis, Russian Trading System Stock Exchange (RTSI), Data of the Central Bank of the Russian Federation, India Bombay Stock Exchange (BSE)'den sağlanmıştır.

\begin{tabular}{cccc}
\hline \hline Kitalar & Ülke & Borsa & Para Birimi \\
\hline \hline Avrupa & Almanya & Frankfurt DAC & Euro \\
Avrupa & Fransa & Paris CAC & Euro \\
Avrupa & Hollanda & Amsterdam AEX & Euro \\
Avrasya & Türkiye & İstanbul İMKB & TL \\
Asya & Rusya & Moskova RTSI & Ruble \\
Asya & Hindistan & Bombay BSE & Rupee \\
\hline \hline
\end{tabular}

Tablo 1: Çalışmaya Alınan Ülkeler ve Diğer Açıklayıcı Bilgiler

\section{Ampirik Bulgular}

Tablo 2'den hisse senedi endeks serilerinin tanımlayıcı istatistiklerini incelediğimizde; oynaklığın en fazla olduğu endeks RTSI endeksi olduğunu, bu endeksi sirasıyla İMKB, BSE, AEX, DAX ve CAC endeksleri izlediği görülmektedir. Endeks serilerinden BSE endeksi dışında normal dağılım gösteren seri bulunmamaktadır. BSE endeks serisinin çarpıklık katsayısı 0'a oldukça yakın olarak -0.52 ve basıklık katsayısı 3'e oldukça yakın 3.89 olarak gerçekleşmiştir. Seri normal dağılıma göre hafif sola çarpık ve hafifte diktir. Normal dağılımı gösteren Jarque-Bera test istatistiği de $(9.552(0.01))$ normal dağılımı doğrulamaktadır. Kur serilerine baktığımızda; oynaklığın en fazla olduğu kur TL/USD kuru olduğunu, bu seriyi sirasıyla RUBLE/USD, RUPEE/USD ve EURO/USD kurlarının izlediği görülmektedir. Kur serilerinden EURO/USD dıșında normal dağılım gösteren seri bulunmamaktadır. EURO/USD serisinin çarpıklık katsayısı 0'a çok yakın olarak 0.06 ve basıklık katsayısı 3'e çok yakın 2.92 olarak gerçekleşmiştir. Normal dağılımı gösteren Jarque-Bera test istatistiği de $(0.113(0.94))$ normal dağılımı doğrulamaktadır.

\begin{tabular}{cccccc}
\hline \hline Getiri Serisi & Maks. & Min. & Std. Sapma & Çarpıklık & Basıklık \\
\hline \hline IMKB & 45.6 & -29.9 & 11.3 & 0.59 & 4.78 \\
DAX & 11.7 & -21.8 & 5.6 & -1.05 & 5.29 \\
CAC & 9.8 & -19.5 & 4.8 & -1.09 & 5.34 \\
AEX & 9.9 & -31.7 & 5.6 & -1.84 & 9.97 \\
RTSI & 45.6 & -44.9 & 12.7 & -0.38 & 5.41 \\
BSE & 24.9 & -27.3 & 8.04 & -0.52 & 3.89 \\
TL/USD & 44.6 & -6.6 & 4.83 & 5.11 & 40.4 \\
EURO/USD & 6.5 & -7.6 & 2.54 & 0.06 & 2.92 \\
RUBLE/USD & 14.3 & -4.74 & 2.18 & 2.81 & 18.8 \\
RUPEE/USD & 6.55 & -4.14 & 1.51 & 1.03 & 7.98 \\
\hline \hline
\end{tabular}




\section{Tablo 2: Serilerin Tanımlayıcı İstatistikleri}

Tablo 3 ADF ve PP birim kök testi sonuçlarını göstermektedir. Tablo 2'de 3 birim kök testi içinde tüm serilerin getirilerinin \%1 önem düzeyinde durağan olduğu görülmektedir.

\begin{tabular}{|c|c|c|c|c|}
\hline \multirow{2}{*}{$\begin{array}{l}\text { Piyasa ve Kur } \\
\text { Endeks }\end{array}$} & \multicolumn{3}{|c|}{ ADF Birim Kök Testi } & \multirow{2}{*}{$\begin{array}{c}\begin{array}{c}\text { PP Birim Kök } \\
\text { Testi }\end{array} \\
\text { Düzey }\end{array}$} \\
\hline & Düzey & \multicolumn{2}{|c|}{ Getiri } & \\
\hline İMKB & $-2.54(1)[.31]$ & $-8.61(0)[.00]^{a}$ & $-2.35(2)[.40]$ & $-8.53(3)[.00]^{\mathrm{a}}$ \\
\hline DAX & $-1.73(1)[.75]$ & $-7.82(0)[.00]^{a}$ & $-1.58(4)[.80]$ & $-7.82(3)[.00]^{a}$ \\
\hline CAC & $-1.65(1)[.77]$ & $-8.45(0)[.00]^{a}$ & $-1.76(6)[.72]$ & $-8.51(3)[.00]^{a}$ \\
\hline AEX & $-1.71(1)[.75]$ & $-8.16(0)[.00]^{a}$ & $-1.62(4)[.78]$ & $-8.16(1)[.00]^{a}$ \\
\hline RTSI & $-1.97(0)[.61]$ & $-9.89(0)[.00]^{a}$ & $-2.17(6)[.50]$ & $-9.89(1)[.00]^{a}$ \\
\hline BSE & $-2.23(0)[.46]$ & $-9.77(0)[.00]^{a}$ & $-2.55(6)[.30]$ & $-9.88(5)[.00]^{a}$ \\
\hline TL/USD & $5.94(11)[.99]$ & $-6.54(0)[.00]^{a}$ & $6.39(7)[.99]$ & $-5.84(9)[.00]^{\mathrm{a}}$ \\
\hline EURO/USD & $-3.08(1)[.12]$ & $-7.74(0)[.00]^{a}$ & $-2.81(0)[.20]$ & $-7.34(9)[.00]^{\mathrm{a}}$ \\
\hline RUBLE/USD & $-2.14(2)[.51]$ & $-4.75(2)[.00]^{a}$ & $-2.11(4)[.53]$ & $-5.83(6)[.00]^{a}$ \\
\hline RUPEE/USD & $-3.55(5)[.03]^{\mathrm{b}}$ & $-7.34(0)[.00]^{\mathrm{a}}$ & $-2.29(6)[.43]$ & $-7.39(1)[.00]^{\mathrm{a}}$ \\
\hline \multicolumn{5}{|l|}{$\begin{array}{l}\text { Kritik Test } \\
\text { Değerleri }\end{array}$} \\
\hline \multicolumn{2}{|c|}{ a\% 1 önem düzeyi } & -4.031309 & & \\
\hline \multicolumn{2}{|c|}{ b\% 5 önem düzeyi } & -3.445308 & & \\
\hline \multicolumn{2}{|c|}{ c\% 10 önem düzeyi } & -3.147545 & & \\
\hline
\end{tabular}

Tablo 3: Birim Kök Testi Sonuçları

Çalışmanın bu aşamasında değişkenler arasında uzun dönemli bir ilişkinin olup olmadığ Engle-Granger (1987) ve Johansen $(1988,1995)$ ve Johansen-Juselius (1990) eş-bütünleşme testleri ile araştırılmıştır. Tablo 4'te Engle-Granger eş-bütünleşme testi sonuçları verilmiştir. Test sonuçlarına göre; değişkenler arasında eş-bütünleşmenin olmadığı yönündeki $\mathrm{H}_{0}$ hipotezi reddedilememektedir. $\mathrm{Bu}$ sonuçlar değişkenler arasında bir eş-bütünleşme vektörünün ve değişkenler arasında bir eş-bütünleşme ilişkisinin bulunmadığını göstermektedir. İkinci olarak Johansen eş-bütünleşme testi ile eş-bütünleşme ilişkisinin varlığı araştırılmaktadır. Johansen eş-bütünleşme testinin ilk aşamasında Schwarz Bilgi Kriterine göre en uygun gecikme uzunluğu bütün değişken çiftleri için "2" olarak tespit edilmiştir. Yapılan eş-bütünleşme testinin sonuçları Tablo 4'te verilmiştir.

\begin{tabular}{lc}
\hline \hline \multicolumn{1}{c}{ Değişken Çifti } & Engle-Granger t-istatistiği \\
\hline \hline IMKB - TL/USD & -1.92 \\
DAX - EURO/USD & -1.67 \\
CAC - EURO/USD & -1.63 \\
AEX - EURO/USD & -1.86 \\
RTSI - RUBLE/USD & -3.26 \\
BSE - RUPEE/USD & -2.09 \\
\hline \hline
\end{tabular}

Tablo 4: Engle-Granger Eş-Bütünleşme Testi Sonuçları

Tablo 5, verilen Johansen eş-bütünleşme testi sonuçları, ele alınan değişken çiftlerinden İMKB-TL/USD ve RUS-RUBLE/USD arasında eş-bütünleşmenin olmadığı yönündeki $\mathrm{H}_{0}$ hipotezinin reddedildiğini ve değişkenler arasında bir eş-bütünleşme vektörünün bulunduğunu göstermektedir. 


\begin{tabular}{cccc}
\hline \hline Değişken Çifti & İz Testi & İhtimaller & Max. Özdeğer \\
\hline \hline IMKKB & 29.542 & $0.000^{*}$ & 26.389 \\
TL/USD & 3.152 & 0.076 & 3.153 \\
DAX & 5.521 & 0.751 & 3.640 \\
EURO/USD & 1.881 & 0.170 & 1.881 \\
CAC & 3.843 & 0.915 & 2.897 \\
EURO/USD & 0.945 & 0.330 & 0.945 \\
AEX & 6.636 & 0.620 & 5.562 \\
EURO/USD & 1.074 & 0.299 & 1.074 \\
RTSI & 15.269 & $0.054^{* * *}$ & 12.700 \\
RUBLE/USD & 2.569 & 0.011 & 2.569 \\
BSE & 5.159 & 0.791 & 5.109 \\
RUPEE/USD & 0.050 & 0.823 & 0.050 \\
\hline \hline
\end{tabular}

Not: 1. Satır değerleriyle $\mathrm{H}_{0}: r=0, r \geq 1$ hipotezi test edilirken, 2. Satır değerleriyle $\mathrm{H}_{0}: r=1, r \geq 2$ hipotezi test edilmektedir. $* \% 1, * * * \% 10$ önem düzeyinde anlamlılığı göstermektedir.

\section{Tablo 5: Johansen Eş-Bütünleşme Testi Sonuçlart}

Buna göre söz konusu değişken çiftleri arasında eş-bütünleşme ilişkisine rastlanırken, diğer değişken çiftleri arasında böyle bir ilişkinin varlığına rastlanamamıştır. Johansen eş-bütünleşme testi sonuçlarına göre, İMKB-TL/USD arasında \%1 önem düzeyinde ve RUS-RUBLE/USD değişken çiftleri arasında \%10 önem düzeyinde uzun dönemli bir ilişki bulunmaktadır.

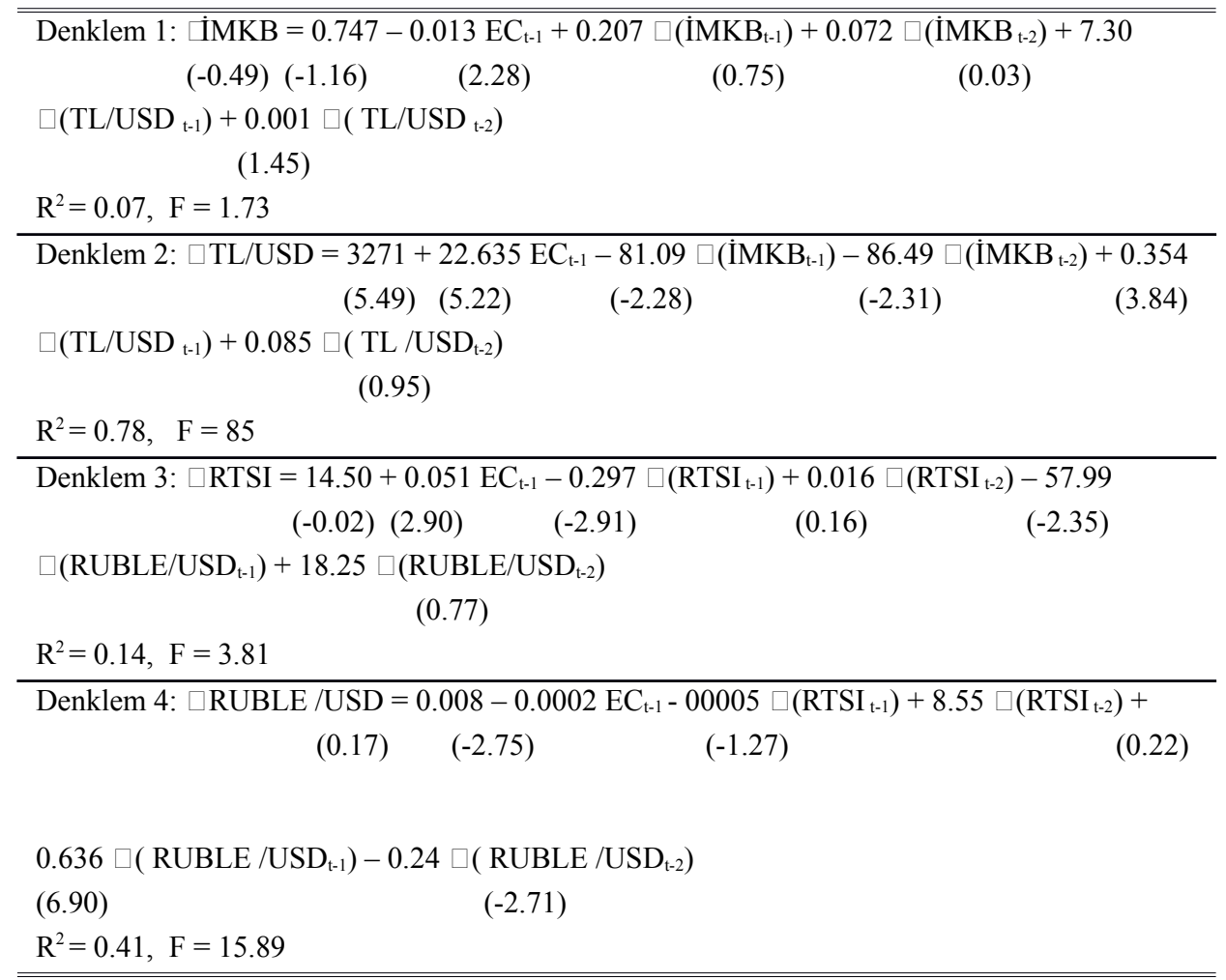


Johansen eş-bütünleşme testine göre, IMKB-TL/USD ve RTSI-RUBLE/USD değişken çiftleri arasında eș-bütünleșme ilișkisi bulunduğu için bu değișkenlerin hata düzeltme modelleri tahmin edilerek Tablo 6'da gösterilmiștir. Kısa dönem ilișkisinde hata düzeltme terimi olan $\mathrm{EC}_{\mathrm{t}-1}$ katsayısı yorumlanır. Hata düzeltme teriminin katsayısının işareti Tablo 6' da gösterildiği gibi denklem 1 ve denklem 4'te "_“" olarak bulunmuștur. Hata düzeltme teriminin katsayısının ișaretinin "_“" olması uzun dönemde birlikte hareket eden seriler arasında kısa dönemde meydana gelen sapmaların ortadan kalktığını ve serilerin uzun dönem denge ilişkisine yakınsadığı anlamına gelir. Dolayısıyla burada yapılan analizlerde hata düzeltme mekanizmasının çalıștığı ve uzun dönemde birlikte hareket eden İMKB-TL/USD ve RTSIRUBLE/USD serilerinde kısa dönemde meydana gelen sapmalar ortadan kalkmakta ve seriler birbirine yakınsamaktadır.

Eş-Bütünleşme ilişkisi olan değişkenler arasında bir hata düzeltme modeli oluşturularak, eşbütünleşme ilişkisi olmayan değişkenler arasında ise doğrudan VAR modeli üzerinden nedensellik ilişkisi tespit edilmektedir.

\begin{tabular}{ccc}
\hline \hline Değişken Çifti & p & Ho \\
\hline \hline IMKB & 1 & IMKB $\neq>$ TL/USD \\
TL/USD & & TL/USD $\neq>$ IMKB \\
DAX & 1 & DAX $\neq>$ EURO/USD \\
EURO/USD & & CAC $\neq>$ EURD $\neq>$ DAX \\
CAC & 2 & EURO/USD $\neq>$ CAC \\
EURO/USD & 1 & AEX $\neq>$ EURO/USD \\
AEX & 2 & EURO/USD $\neq>$ AEX \\
EURO/USD & & RTSI $\neq>$ RUBLE/USD \\
RTSI & & RUBLE/USD $\neq>$ RTSI \\
RUBLE/USD & 1 & BSE $\neq>$ RUPEE/USD \\
BSE & & RUPEE/USD $\neq>$ BSE
\end{tabular}

\footnotetext{
Not: VAR(p) ve ECM(p) modellerinde gecikme uzunlukları Schwarz Bilgi Kriterine göre belirlenmiştir. Parantez içerisindeki rakamlar ilgili $\mathrm{p}$ değerlerini ve * \% 1 önem düzeyinde, ** \% 5 önem düzeyinde, *** \% 10 önem düzeyinde anlamlılı̆̆ göstermektedir.
}

\section{Tablo 7: Granger Nedensellik Analizi Sonuçlart}

Tablo 7, Granger nedensellik analizi sonuçlarını göstermektedir. Analiz sonuçlarına göre, \% 1 önem düzeyinde TL/USD'den İMKB doğru ve EURO/USD'den AEX doğru, \% 5 önem düzeyinde EURO/USD'den CAC doğru ve BSE'den RUPEE/USD doğru, \% 10 önem düzeyinde EURO/USD'den DAX doğru ve RTSI'dan RUBLE/USD doğru bir Granger nedensellik ilişkisinin olmadığı boş hipotezi reddedilmektedir. Böylece değişken çiftlerinin hepsinde tek yönlü bir Granger nedensellik ilişkisi söz konusu olmakla birlikte ilişkinin yönü değişebilmektedir. Bu nedensellik ilişkisi TL/USD- IMKB, EURO/USD-AEX, EURO/USDCAC ile EURO/USD-DAX değişken çiftlerinde döviz kurundan piyasa endeksine doğru iken, BSE-RUPEE/USD ile RUS-RUBLE/USD değişken çiftlerinde ise piyasa endeksinden döviz kuruna doğrudur. Bu durumda 6 değişken çiftinden 4’ünde döviz kurundan piyasa endeksine doğru bir nedensellik ilişkisi, 2'sinde ise piyasa endeksinden döviz kuruna doğru bir nedensellik ilişkisine rastlanmıştır.

\section{Sonuç}

Ekin Piyasalar Hipotezi hisse senedi fiyatlarının hem şirketle ilgili bilgiler hem de makro ekonomik bilgilerle oluştuğunu öngörmektedir. Hipoteze göre makro ekonomik veriler 
gelecekte oluşacak şirket karlarını etkileyeceği için son derece önemlidir. Şirket karlarında bir etkilenme doğal olarak hisse senedi fiyatlarına yansıyacaktır. Bu çalışmada makro ekonomik verilerden olan döviz kurları ile hisse senedi fiyatları arasındaki ilişki incelenmiştir.

Bu çalışmada ilk olarak Türkiye, Almanya, Fransa, Hollanda, Rusya ve Hindistan gibi 6 Avrasya ülkesinde yerel hisse senedi piyasa endeksleri ile döviz kuru (USD) serilerinin tanımlayıcı istatistikleri incelenmiştir. Endeks bazında oynaklığın en fazla olduğu endeks RTSI endeksi olup, bu endeksi sirasiyla İMKB, BSE, AEX, DAX ve CAC endeksleri izlemektedir. Kur serilerinde oynaklığın en fazla olduğu kur TL/USD kuru olup, bu seriyi sirasiyla RUBLE/USD, RUPEE/USD ve EURO/USD kurları izlemektedir. Serilerden sadece BSE endeks serisi ve EURO/USD kur serisi normal dağılım sergilemektedir. Birim kök testi sınamalarında tüm serilerin getirilerinin \%1 önem düzeyinde durağan olduğu görülmektedir. Döviz kuru değişimi ile hisse senedi getirilerinin açıklanabilmesi için bu değişkenlerin eşbütünleşik olması yani uzun dönemde birlikte hareket ediyor olmaları gerekmektedir. Seriler arasındaki uzun dönem ilişkisini belirlemek için yapılan Engle-Granger (1987) eş-bütünleşme testinde herhangi bir eş-bütünleşme ilişkisine rastlanmazken, Johansen eş-bütünleşme testinde ise İMKB-TL/USD değişken çiftleri arasında \%1 önem düzeyinde ve RUS-RUBLE/USD değişken çiftleri arasında \%10 önem düzeyinde uzun dönemli bir ilişki tespit edilmiştir. Johansen eş-bütünleşme testine göre eş-bütünleşme ilişkisi bulunan İMKB-TL/USD ve RTSIRUBLE/USD değişken çiftlerinin kısa dönem ilişkilerinin tespiti için oluşturulan hata düzeltme modellerinde, hata düzeltme terimi olan $\mathrm{EC}_{\mathrm{t}-1}$ katsayısı 2 denklemde "-_"olarak bulunmuştur. $\mathrm{Bu}$ sonuç uzun dönemde birlikte hareket eden 2 serinin arasında kısa dönemde meydana gelen sapmaların ortadan kalktığını ve bu serilerin uzun dönem denge ilişkisine yakınsadığını göstermektedir. Dolayısıyla yapılan analizlerde hata düzeltme mekanizmasının çalıştığı ve uzun dönemde birlikte hareket eden İMKB-TL/USD ve RTSI-RUBLE/USD serilerinde kısa dönemde meydana gelen sapmalar ortadan kalkmakta ve seriler birbirine yakınsamaktadır.

Çalışmada VAR ve VEC modellerine göre yapılan Granger nedensellik testlerinin sonuçlarına göre; \%1 önem düzeyinde TL/USD'den İMKB doğru ve EURO/USD'den AEX doğru, \%5 önem düzeyinde EURO/USD'den CAC doğru ve BSE'den RUPEE/USD doğru, \%10 önem düzeyinde EURO/USD'den DAX doğru ve RTSI'dan RUBLE/USD doğru bir Granger nedensellik ilişkisinin olmadığ 1 boş hipotezi reddedilmektedir. Böylece değişken çiftlerinin hepsinde tek yönlü bir Granger nedensellik ilişkisi söz konusu olmakla birlikte ilişkinin yönü değişebilmektedir. Bu nedensellik ilişkisi TL/USD- İMKB, EURO/USD-AEX, EURO/USD-CAC ile EURO/USD-DAX değişken çiftlerinde döviz kurundan piyasa endeksine doğru iken, BSE-RUPEE/USD ile RUS-RUBLE/USD değişken çiftlerinde ise piyasa endeksinden döviz kuruna doğrudur. Bu durumda 6 değişken çiftinden 4 'ünde döviz kurundan piyasa endeksine doğru bir nedensellik ilişkisi, 2'sinde ise piyasa endeksinden döviz kuruna doğru bir nedensellik ilişkisine rastlanmıştır. Bu sonuçlar; hisse senedi fiyatları ile döviz kuru arasında 4 ülkede "Geleneksel Yaklaşım"ın geçerli olduğunu desteklerken, 2 ülkede ise "Portföy Yaklaşımı"nın geçerli olduğunu desteklemektedir.

\section{Kaynakça}

- Abdalla ve Murinde, 1997. "Exchange Rate And Stock Price Interactions in Emerging Financial Markets: Evidence On India, Korea, Pakistan and The Philippines", Applied Financial Economics, 7: 1, pp.25-35.

- $\quad$ Adjasi, vd., 2008. "Effect of Exchange Rate Volatility on The Ghana Stock Exchange", African Journal of Accounting, Economics, Finance and Banking Research, Vol. 3. No. 3. pp.28-47.

- Aggarwal, 1981. "Exchange Rates and Stock Prices: A Study of U.S. Capital Market under Floating Exchange Rates", Akron Business and Economic Review, Vol. 12, Iss. 3.

- Bahmani-Oskooee ve Sohrabian, 1992. "Stock Prices and the Effective Exchange 
Rate of the Dollar", Applied Economics, Vol. 24, Issue. 4, pp. 459-64.

- Bhattacharya ve Mukherjee, 2003. "Causal Relationship Between Stock Market and Exchange Rate, Foreign Exchange Reserves and Value of Trade Balance: A Case Study For India", Paper presented at the Fifth Annual Conference on Money and Finance in the Indian Economy.

- Dimitrova, 2005. "The Relationship Between Exchange Rates And Stock Prices: Studied in A Multivariate Model", Issues in Political Economy, Vol. 14.

- $\quad$ Nath ve Samanta, 2003."Dynamic Relation Between Exchnage Rate And Stock Prices - A Case For India", 39th Annual Conference Paper of Indian Econometric Society Also Published in NSE News.

- Granger vd., 2000. “A Bivariate Causality between Stock Prices and Exchange Rates: Evidence from Recent Asia Flu”, The Quarterly Review of Economics and Finance, Volume 40, Number 3, pp. 337-354.

- Hatemi-J ve Irandoust, 2002. "On The Causality Between Exchange Rates and Stock Prices: A Note”, Bulletin of Economic Research, Vol. 54, Issue.2, pp. 197-203.

- Kim, 2003. "Dollar Exchange Rate and Stock Price: Evidence From Multivariate Cointegration and Error Correction Model", Review of Financial Economics, Volume 12, Issue 3, p. 301-313.

- Kutty, 2010. "The Relationship Between Exchange Rates And Stock Prices: The Case Of Mexıco", North American Journal of Finance and Banking Research, Vol. 4, No. 4.

- Nieh ve Lee, 2001. "Dynamic Relationship Between Stock Prices and Exchange Rates for G-7 Countries", Quarterly Review of Economics and Finance, 41, 477-490.

- Phylaktis ve Ravazzolo, 2005. "Stock Prices and Exchange Rate Dynamics", Journal of International Money and Finance, Volume 24, Issue 7, pp. 1031-1053.

- Rahman ve Uddin, 2009. "Dynamic Relationship Between Stock Prices And Exchange Rates: Evidence From Three South Asian Countries", International Business Research, Vol.2,No.2,pp.167-174

- Shew, 2008. "Causality Relationship Between Foreign Exchange Rates And Stock Market Close: Evidence in Singapore”, Bryant Economic Research Paper, Vol. 1. No. 11.

- $\quad$ Smyth ve Nandha, 2003. "Bivariate Causality between Exchange Rates and Stock Prices in South Asia", Applied Economics Letters, 10, pp. 699-704.

- Soenen ve Hennigar, 1988. "An Analysis of Exchange Rates and Stock Prices: the U.S. Experience between 1980 and 1986", Akron Business and Economic Review, Vol.19,Iss.4, pp.7-16.

- Solnik, 1987. "Using Financial Prices to Test Exchange Rate Models: A Note", The Journal of Finance, Vol. 42, No. 1, pp. 141-149.

- Stavarek, Daniel, 2005. "Stock Prices and Exchange Rates in The EU And The United States: Evidence On Their Mutual Interactions", Czech Journal of Economics and Finance, Vol. 55, Issue 3-4, pp. 141-161.

- Tabak, 2006. "The Dynamic Realationship Between Stock Prices and Exchnage Rates: Evidence for Brasil”, Bank of Brasil Working Paper Series 124, pp.1-37. 


\title{
Effects of Foreign Direct Investment on Growth in Turkey
}

\author{
Melike Bildirici, Yıldız Technical University \\ Elçin Aykaç Alp \\ Fazıl Kayıkçı, Yıldız Technical University
}

\begin{abstract}
This study aims at analyzing the relationship between Foreign Direct Investment and Growth in Turkey by using Threshold Cointegration. As the studies about the impact of Foreign Direct Investment on growth are surveyed, it is seen that all of them uses liner methods except two. Starting point of these studies that use liner methods are the positive relationship between Growth and Foreign Direct Investment. As such, Y1lmaz and Barbaros (2006) find positive relationship between Foreign Direct Investment and market size in Turkey between 1980 and 2001. Erdal and Tatoğlu (2002) reach the same conclusion for the period of 1980-1998 by using real Gross Domestic Product as a proxy for market size. Deichmann, Karidis and Sayek (2003) find positive linkage between Foreign Direct Investment and Gross Domestic Product in Turkey by using Conditional Logit Model. Bildirici and Bozoklu (2008) find positive relationship between growth and Foreign Direct Investment by using Markov Switching Vector Auto Regression method. Katırcioğlu (2009) analyses the connection between Foreign Direct Investment and economic development by using Auto Regressive Distributed Lag and indicates that economic development causes net Foreign Direct Investment. Darrat and Sarkar (2009) state the affirmative effects of the Foreign Direct Investment on growth as expected theoretically. Bildirici, Bozoklu (2008) find positive relationship between growth and Foreign Direct Investment in Turkey. Bildirici, Alp and Kayıkçı (2010) state the existence of threshold effect for these variables. This study intends to research this effect in historical perspective, using Threshold Cointegration Analysis.
\end{abstract}

JEL codes: C32, F21, F43

\section{Introduction}

While foreign direct investments (FDI) take place in two ways as a complete new investment (Greenfield) by corporate combinations and corporate take over (Merger and Acquisition), each definition carries different implications in itself. The conflict between the preference of foreign companies and the social benefit of host country sets a stage for intervention. Host country prefers new investments rather than corporate combinations.

According to researches which study the effects of foreign capital on the economy, effect of foreign capital on the economy is positive. Studies, which approach to the relationships between FDI and economic growth from the positive perspective, analyze the subject in the context of positive externalities. According to these studies, FDI flow provides direct and indirect profits to the incoming country because it has important positive externalities. This theory can be evaluated in two perspectives. It will be seen that for the relationship between economic growth and FDI, the traditional approach is depended on market imperfection approach (MIA) or industrial organization approach (IOA). In the base of MIA approach there are market imperfections. According to IOA, transferring of technology, marketing skills, management and other sources beyond capital, are essential in the perspective of FDI effect. According to Kindleberber (1969) returns of others are also important and deterministic as well as capital.

When positive externalities are to be evaluated, which are the adoption of foreign technology and know-how, which can happen via licensing agreements, imitation, employee training, the introduction of new processes, and products by foreign firms; and the creation of linkages 
between foreign and domestic firms, these are to enable country's national economy as modern by this way and to encourage economic growth, management and organization level, taxes, balance of payments, the encouragement of justice in income distribution. Blomstrom and Kokko (1998), Gorg and Greenway (2004), Lipsey (2002), Barba Navaretti and Venables (2004), and Alfaro and Rodriguez-Clare (2004) studies have focused on spillover channel of FDI.

The studies which question positive effect; Magnus Blomstom, Robert Lipsey and Mario Zejan (1994) emphasized that positive effect of FDI upon economic growth only appear in higher-income developing countries. Referring market growth, Bondera and White (1968), Schmitz and Bieri (1975), Swedenborg (1979), Lunn (1980), Dunning (1980), Root and Ahmed (1979), Kravis and Lipsey (1982), Nigh (1985), Schneider and Frey (1985), Culem (1988), Wheeler and Mody (1992), Sader (1993), Tsai (1994), Billington (1999), Pistoresi (2000) and Shamsuddin (1994) emphasized the existence of positive effects. Researches which study the effect on labor cost; while Caves (1974), Swedenborg (1979), Nankani (1979), Wheeler and Mody(1992) emphasize positive effect, Goldsrough(1979), Saunders(1982), Flam (1984), Schneider and Frey (1985), Culem (1988), Shamsuddin (1994), Pistoresi (2000) emphasized negative effects. Owen (1982), Gupta (1983), Lukas (1990), Rofle and White (1991), Sader (1993), Tsai (1994) found the effects as unimportant. Krevis and Lipsey (1982), Culem (1988), Edwards (1990), Pistoresi (2000) while emphasizing positive effects in openness matter, Schmitz and Bieri (1972) and Wheeler and Mody (1992) has specified the unimportance of the effect. When the effects have been researched upon exchange rate, while Edwards (1994) emphasizing positive, Caves (1988), Contractor (1990), Froot and Stein (1991), Bionigen (1995) and Bionigen and Freenstra (1996) emphasizig negative effetcs, Calderon and Rossel (1985), Sader (1991), Bloningen (1997) and Tuman and Emmert (1999) decleared the unimportance of effects. For the matters of taxes while Hartman (1984), Grubert and Muti (1991), Hines and Rice (1994), Loree and Guisinger (1995), Guisinger (1995), Cassou (1997), Kemsley (1998), Barrel and Paint (1998), Billington (1999) emphasize negative effects, Swenson (1994) found that the effects are positive. Luiz De Mello (1997), emphasized technological gap between the host and foreign country, and found that with the increase of technological gap the effect will be smaller (Spatz, Nunnenkamp;2004). When Abdul Khaliq and Ilan Noy (2007) studied the effect of FDI upon economic growth as sectoral, has found this effect to be positive on some parts of sectors and negative in most of sectors.

Some studies however, started to question the provision of the effects appearance. According to them; foreign companies may not always contribute to the appearance of effects to the country they come. As it does not provide technology transfer, effort may tend to turn to labor intensive manufacturing. The another important point, as Caves (1971, 1974), Saunders (1982), Gupta (1983), and Kumar (1987) emphasize in their studies, the arising rivalry in the case of specific production effect and the existence of imperfect competition market, is the loss of their advantages and the absence of countries' comparative advantages.

Some part of their studies emphasized the capacities of countries in benefiting from FDI externalities. These studies started to focus on the conditions of local circumstances. Within these local circumstances, development structure of financial markets, education level of country, the level of human capital investment has come to the forefront. Borensztein, De Gregorio, and Lee (1998) and Xu (2000) have axplained the effect of high technology of FDI upon economic growth with human capital investment. Alfaro et.all (2006), Durham (2004), and Hermes and Lensink (2003) tied the benefit of FDI which will provide to the country, to the developed financial markets. Balasubramanyam, Mohammed Salisu and David Sapsford (1996) has indicated that the openness to trade is the base in taking benefit from FDI. There is one important problem in the studies which emphasizes positive externalities between economic growth and FDI, that is the structural differences of foreign countries and calculation errors which are the usage of FDI stocks and flows interchangeably (Spatz, Nunnenkamp;2004). 
In the this study, foreign capital in Turkish economy will be studied in historical perspective; the third part is consists of from the econometric theory while the last part includes the discussions of the results.

\section{Foreign Investments in Turkish Economy}

Foreign investments coming after the establishment of Turkish Republic, took place as corporation and these corporations were generally in food, cement and textile sectors. There are 94 companies that can be considered as foreign capital in 1924. 23 of them are in banking, 11 in electricity, 12 in manufacturing industry, 35 in trading and 6 in marine fields. In the year of 1929, the number of foreign investment companies increased to 114 and 30 billion dollars capital has entered country. For the reasons of the lack of foreign capital, it is important to indicate there are important effects of I. World War, 1929 depression and nationalization. Since 1928, Turkish Government nationalized 24 foreign investment companies. In 1933-45 21 companies were nationalized.

Important developments emerged after 1950 in order to encourage foreign capital which was in low levels because of the effects of II. World War, nationalization and etatism policies. In the eventuation of international monetary fund (IMF) and the participation of Turkey to the World Bank (IBRD), its taking benefit from Marshall Plan, monetary and military help from the USA, Turkish Republic tended to make legislative amendments to make easier for foreign capitals to invest in Turkey (Karluk; 2001). It has been observed that these amendments resulted in forming a restrictive frame for foreign investors especially in 1960s and 1970s (Şenses ve Taymaz; 2003). After 1980 many changes have been made in codes of practice of incentive policies with the aim of encouragement of FDI. By these changes foreign companies were enabled to enter all sectors and access the whole property rights (Öniş (1994) Erdilek (1982). Namely, for the purpose of encouragement of direct investment, foreign investment legislation has been rescheduled after 1980. In the years of 1986, 1992 and 1995, changes made in foreign investment framework decision, the legislation became more liberal and customs unions negotiated with the EU in 1996 and the international arbitration in 1999 inured (TCMB, 2000, 52). Nevertheless, expected increase could not be observed in the movements of foreign capital especially the increase awaited from direct investment. By the consideration of encouragement validated for foreign investment as well, native and foreign companies started to take benefit from encouragement practices equally. Namely, amendments and globalization in 1984 and 1990 periods have been essential in short term and portfolio investments. As a matter of fact, short term and portfolio investments produced important effects after 1990s. Such that, Turkish economy grown in the years when short term and portfolio investments were positive. As a result of inversion of the entrance of short term and portfolio investments by depression in 1994, economy has decreased in 6.1\% (Uygur, 1999). Portfolio and short term investment, inversion of foreign capital can be seen as a cause of depression in 1999 and 2000-01 crises. When the effects of 2001 crises started to be partly overcome, foreign capital began to enter. FDI investment entered these years was very limited.

With the laws concerning international arbitration made in years 2000 and 2001, an ambiance was created where all obstacles for foreign investments were defeated. While in 2002 1,1 billion $\$$ foreign capital entered the country, this amount was 2,8 billion $\$$ in 2004 and this development turned to a remarkable leap and direct investments increased to 20 billion $\$$ in 2006 and 21,9 billion \$ in 2007.

Although a leap has been seen in direct investments between the years 2004-2008, these are the results of privatization rather than new investments. However, these rates were insufficient. As a matter of fact, when FDI dispersion is studied for the years 2005 and 2006, Turkey can be seen in 23rd and 16.th row in turn.

As it can be seen from the Table 1, without considering China and Hong Kong, we can see that industrialized countries took a share from FDI. Although with 9.80 billion \$ capital Turkey 
took place in 23rd row in 2005, and tough rose to 16th row in 2006 by 2010 billion $\$$ capital, when privatizations are considered, it can bee seen that foreign capital investments as a form of new investments were lower and sufficient foreign capital could not be obtained.

When the features of direct foreign capital investments are studied;

The incoming direct investment is as predominantly owner's equity investment. Owner's equity investment which was 3352 billion \$ in 2001, has increased to 21864 billion \$ in 2007 . When the periods 2009 October-May and 2010 October-May are studied, it can be seen that the values are 3861 and 2562 respectively.

When the numbers of firms are studied, an increase is seen after 2000. When there were total 4141 companies between the years 1954-1999 cumulatively, 3352 companies came in 2000, the increase of foreign investment 2004 also was seen here, 2095 companies which came in 2004 reached to 3530 in 2007 . With the effects of crises of 2008 decrease continued also in 2009 and 2010 and 3337, 2987 and 1252 companies were established respectively. In two last years, the number of companies founded was decreased $10 \%$ and $55 \%$ when compared to previous year (Treasury, Turkish Republic:2010).

As per 2010 June, 20386 international investment companies branches were established, 4669 local investment companies participation to international investment took place. In total 24924 international investment companies are operated in our country. The inadequacy of the number is clear (Treasury, Turkish Republic:2010).

Most of the foreign direct capital has come to services sectors as $90.2 \%$ in $2005,90.6 \%$ in 2006, 69.9\% in January-October 2007. Share of production sector as $60.1 \%$ in 2003 persistently decreasing to $8 \%$ until 2006 , increased to $23.6 \%$ in January-October 2007 . The leading sector in capital outflow is manufacturing industry $(89.7 \%$ in $2005,76.7 \%$ in 2006). It decreased to 24\% in January-October 2007 (DPT, 2008). Namely, when sectoral dispersion of foreign capital is studied, finance sector and manufacturing industry stand out.

It is seen that (Table 2) 25055 international firms operate in heading wholesale and retail trade, manufacturing industry, real estate renting and business operation sectors. While chemical materials and products are leading in international investment companies which operate in manufacturing industry, food products, beverages and tobacco manufacturing with textile products follows. However, number of firms operate in the manufacturing sector can still be considered as insufficient when compared to the service sectors.

Approximately $55 \%$ of foreign capitals are centered in Istanbul. Antalya takes second place by $12 \%$, Ankara takes 3rd place by $6 \%$ and Izmir takes fourth place by $5 \%$. It is not possible to mention about a broad based investment in Turkey.

When we look at dispersion of foreign capital according to the countries (Table 3), it is seen that particularly Netherlands, Germany, EU countries and USA take most shares. Asian countries fallow these countries.

As it can be seen when FDI is studied in Turkish economy; it is observed that the incoming investments are insufficient, that they are focused in Istanbul and display an increasing structure in services sector. Total of foreign direct investment in 2001-2007 period is 50.8 billion \$. Total profit transfers are $10 \%$ of direct investments. While this rate is $58 \%$ when profit transfer was in its highest rate in 2004, it is seen that the same rate were decreased to 6$9 \%$ levels between the years 2005 and 2006, and increased to $10 \%$ in 2007 .

\section{Econometric Methodology}

This study based on the usage of TAR cointegration method. The reason of the preference of this method is especially the thought of short term capital flows' openness to threshold effect. Two regimes threshold model can be written as $\gamma$ threshold parameter, 


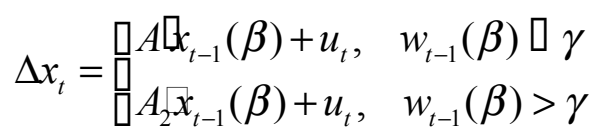

it can also be written as below.

$\Delta x_{t}=A_{1} x_{t-1}(\beta) d_{1 t}(\beta, \gamma)+A_{2} x_{t-1}(\beta) d_{2 t}(\beta, \gamma)+u_{t}$.

$\mathrm{I}($.$) as an indicator function,$

$$
d_{1 t}(\beta, \gamma)=I\left(w_{t-1}(\beta) \square \gamma\right), d_{2 t}(\beta, \gamma)=I\left(w_{t-1}(\beta)>\gamma\right)
$$

There are two regimes defined according to second equation's error term level. A1 and A2 coefficients' matrix are sheltered in these two regime dynamics. 2. model provides all parameters to be changed among these two regimes. In the case of only $0<\mathrm{P}\left(w_{t-1} \leqslant \gamma\right)<1$ threshold effect exists, it will turn to linear coentegration in other cases. By being $\pi_{0}>0$ trimming parameter, it is constructed as it is defined in 3 . equation.

$$
\pi_{0} \leqslant \mathrm{P}\left(w_{t-1} \leqslant \gamma\right) \leqslant 1-\pi_{0},
$$

\section{Data and Econometric Results}

The data used in the study has been taken from Turkish Statistical Institute (TUIK), Central Bank of Turkey (TCMB) electronic data delivery service. Growth data has been calculated as proportional increase in industrial production index. The scope of data is monthly between 1992:01 and 2008:12.

As a measurement of economic growth in this work, industrial production index was taken in terms of GDP growth. Although it is a common application to use GDP as a measurement concerning the works of relating FDI with economic growth, we will take action from industrial production index as the works of Bildirici, Alp and Kayıkçı(2010). There are two reasons for the usage of IPI in economic growth. The first one is that IPI representation can be the measurement of economic growth, because the correlation between IPI and GDP is found as 0.80 . The second is that it is aimed at seeing the FDI effect on industrial production.

The works apply GDP variable, and also use linear models usually. The works conducted for Turkish economy, the works of Bildirici and Bozoklu (2008) and Bildirici, Alp and Kayıçı (2010) are the works which use nonlinear methods. In this study, as in the study of Bildirici, Alp and Kayıkçı (2010) Threshold structure was attached to the main body of the empirical work and TAR Cointegration analysis was applied. By the application of TAR analysis, cointegration analysis will be analyzed by the values under and above threshold level.

\begin{tabular}{|c|c|c|c|c|}
\hline & Test Statistic & $1 \%$ & $5 \%$ & $10 \%$ \\
\hline -D(FDI)- & -12.43681 & -3.465977 & -2.877099 & -2.575143 \\
\hline -D(Growth)- & -5.389460 & -3.467205 & -2.877636 & -2.575430 \\
\hline
\end{tabular}

Table 4: Traditional Unit Root Test Results for FDI and Growth (ADF Test)

As it can be seen from the table, both foreign capital and growth series are integrated of order one. Lag lengths are determined according to AIC information criterion. (Information was previously given that the power of unit root tests might be low in the case of nonlinear structure, and it should be tested with Caner- Hansen (2001) TAR unit root tests which was developed for these cases).

The numbers in brackets in the estimated Threshold VAR models are Eicker - White standard errors. When the models are studied, parameter estimations are statically significant. For parameters $\gamma, \beta$ scan size has been chosen as $300 \times 300$ and estimated co integration relationship as a result of likelihood function has been found as $v_{t}=G_{t-1}+0,35 F D I_{t}$ and 
estimated threshold value has been found as $\hat{\gamma}=-0,69$. Therefore, the first regime arises in the case when foreign capital shown $96 \%$ more decline rather than growth. In the estimated period, first regime comprises $20 \%$ of the observations and is called as extreme regime. Second regime comprises $80 \%$ part which above normal and called as typical regime. Second regime arises in the cases when the difference between foreign capital and growth decreases less than $69 \%$, or becomes stable or decrease.

First regime "extreme regime" $G_{t},-0,35 F D I_{t}-0,69$

Second regime "typical regime" $G_{t}>-0,35 F D I_{t}-0,69$

Estimated VAR model,

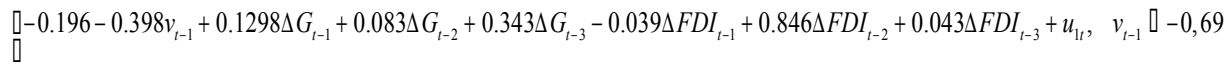

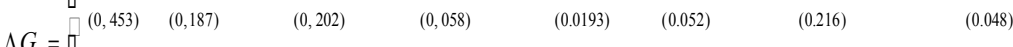

$$
\begin{aligned}
& \Delta G_{t}=0.458-0.315 v_{t-1}-0.358 \Delta G_{t-1}+0.0008 \Delta G_{t-2}+0.103 \Delta G_{t-3}-0.016 \Delta F D I_{t-1}+0.1888 \Delta F D I_{t-2}-0.021 \Delta F D I_{t-3}+u_{2 t}, \quad v_{t-1}>-0.69 \\
& \square(0,148) \quad(0,074) \quad(0,088) \quad(0,023) \quad(0.0975) \quad(0.0206) \quad(0.068) \quad(0.015) \\
& {\left[-1.273-3.66 v_{t-1}-0.617 \Delta G_{t-1}-0.698 \Delta G_{t-2}+0.282 \Delta G_{t-3}-0.348 \Delta F D I_{t-1}+0.879 \Delta F D I_{t-2}-0.221 \Delta F D I_{t-3}+u_{1 t}, \quad v_{t-1}[-0,69\right.}
\end{aligned}
$$

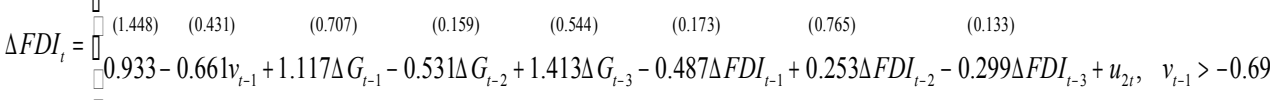

$$
\begin{aligned}
& \begin{array}{llllllll}
(0.654) & (0.293) & (0,331) & (0.119) & (0.440) & (0.133) & (0.286) & (0.112)
\end{array}
\end{aligned}
$$

When the equations are analyzed, it can be seen that in the first regime which observation values comprise $20 \%$ and called as extreme regime, error correction mechanism operates in the first equation and it was insignificant in the second equation. In second regime, it can operate in both equations. Thus, it is concluded that obtained co integration relationship is valid for both regimes.

\section{Conclusion}

In this study, it was analysed the relationship between Foreign Direct Investment and Growth in Turkey by using Threshold Cointegration The relationship shows as a result of analyzing the period of 1992:01-2008:12 that, in the cases in which foreign capital decrease above $70 \%$, there will be $35 \%$ decrease in growth and this is a quite remarkable decline.

Annex
\begin{tabular}{|c|c|c|c|}
\hline Country & 2005 & Country & 2006 \\
\hline 1-England & 193,7 & 1-England & 175,4 \\
\hline 2-U.S.A. & 101 & 2-U.S.A. & 139,5 \\
\hline 3-France & 81,1 & 3-France & 81,1 \\
\hline 4-China & 72,4 & 4-China & 72 \\
\hline 5-Netherlands & 41,6 & 5-Netherlands & 69,5 \\
\hline 6-Germany & 35,9 & 6-Germany & 69 \\
\hline 7-Belgium & 35,9 & 7-Belgium & 42,9 \\
\hline 8-Hong Kong & 33,6 & 8-Hong Kong & 42,9 \\
\hline 9-Canada & 28,9 & 9-Canada & 39,2 \\
\hline 10-Spain & 25 & 10-Spain & 29,3 \\
\hline 23-Turkey & 9,8 & 16-Turkey & 20,1 \\
\hline
\end{tabular}

Table 1. FDI Shares in the World (Billion \$). Source: Under secretariat of Treasury, Turkish Republic 


\begin{tabular}{|c|c|c|c|c|c|c|c|}
\hline & $1954-2004$ & 2005 & 2006 & 2007 & 2008 & 2009 & $\begin{array}{c}1954- \\
2010 \\
\text { June }\end{array}$ \\
\hline & Cumulative & & & & & & Total \\
\hline $\begin{array}{l}\text { Agriculture, hunting, fishing } \\
\text { and forestry }\end{array}$ & 131 & 34 & 42 & 49 & 53 & 60 & 387 \\
\hline Mining and quarrying & 138 & 50 & 48 & 82 & 91 & 71 & 510 \\
\hline Manufacturing & 1937 & 400 & 441 & 497 & 471 & 384 & 4311 \\
\hline $\begin{array}{l}\text { Manufacture of food products } \\
\text { and beverages }\end{array}$ & 233 & 39 & 43 & 38 & 38 & 49 & 481 \\
\hline Manufacture of textiles & 242 & 66 & 50 & 49 & 21 & 18 & 452 \\
\hline $\begin{array}{c}\text { Manufacture of chemicals and } \\
\text { chemical products }\end{array}$ & 232 & 37 & 39 & 58 & 48 & 39 & 483 \\
\hline $\begin{array}{c}\text { Manufacture of machinery and } \\
\text { equipment }\end{array}$ & 145 & 27 & 54 & 46 & 46 & 24 & 353 \\
\hline $\begin{array}{c}\text { Manufacture of motor vehicles, } \\
\text { trailers and semi-trailers }\end{array}$ & 141 & 21 & 17 & 23 & 21 & 18 & 242 \\
\hline Other Manufacturing & 944 & 210 & 238 & 283 & 297 & 236 & 2298 \\
\hline $\begin{array}{l}\text { Electricity, gas and water } \\
\text { supply }\end{array}$ & 89 & 9 & 42 & 75 & 117 & 132 & 514 \\
\hline Construction & 338 & 312 & 404 & 477 & 372 & 302 & 2331 \\
\hline Wholesale and retail trade & 3048 & 708 & 752 & 808 & 791 & 933 & 7491 \\
\hline Hotels and restaurants & 710 & 162 & 194 & 207 & 220 & 174 & 1746 \\
\hline $\begin{array}{c}\text { Transport, storage and } \\
\text { communications }\end{array}$ & 691 & 222 & 266 & 284 & 292 & 268 & 2172 \\
\hline $\begin{array}{l}\text { Real estate, renting and } \\
\text { business activities }\end{array}$ & 658 & 487 & 660 & 828 & 675 & 476 & 4002 \\
\hline $\begin{array}{l}\text { Other community, social and } \\
\text { personal service activities }\end{array}$ & 331 & 167 & 226 & 223 & 255 & 187 & 1294 \\
\hline TOTAL & 8192 & 2551 & 3075 & 3530 & 3337 & 2987 & 25055 \\
\hline
\end{tabular}

Table 2. FDI dispersion According to the Sectors. Source: Under secretariat of Treasury, Turkish Republic

\begin{tabular}{|c|c|c|c|c|c|c|c|}
\hline & $\begin{array}{c}1954- \\
2004\end{array}$ & 2005 & 2006 & 2007 & 2008 & 2009 & $\begin{array}{c}1954- \\
2010 \\
\text { June }\end{array}$ \\
\cline { 2 - 9 } & $\begin{array}{c}\text { Cumulativ } \\
\mathrm{e}\end{array}$ & & & & & & Total \\
\hline European Union (27) & 4182 & 1513 & 1926 & 2027 & 1770 & 1423 & 13417 \\
\hline Germany & 1405 & 462 & 540 & 557 & 584 & 513 & 4256 \\
\hline The Netherlands & 652 & 189 & 257 & 249 & 277 & 146 & 1842 \\
\hline United Kingdom & 536 & 297 & 453 & 436 & 251 & 205 & 2256 \\
\hline Other European Countries & 1589 & 565 & 676 & 785 & 658 & 559 & 5063 \\
\hline Other European Countries & & & & & & & \\
(Exclude EU) & 981 & 311 & 356 & 471 & 528 & 431 & 3305 \\
\hline Africa & 146 & 52 & 42 & 48 & 50 & 66 & 448 \\
\hline North America & 496 & 104 & 132 & 160 & 142 & 148 & 1241 \\
\hline U.S.A. & 453 & 90 & 111 & 127 & 124 & 116 & 1071 \\
\hline Canada & 43 & 14 & 21 & 33 & 18 & 32 & 170 \\
\hline Central-South America And & 54 & 14 & 11 & 20 & 12 & 17 & 134 \\
\hline
\end{tabular}




\begin{tabular}{|c|c|c|c|c|c|c|c|}
\hline Caribbean & & & & & & & \\
\hline $\begin{array}{c}\text { Near and Middle Eastern } \\
\text { Countries }\end{array}$ & 1657 & 375 & 396 & 492 & 564 & 639 & 4464 \\
\hline Azerbaijan & 177 & 54 & 82 & 118 & 131 & 168 & 792 \\
\hline Iraq & 249 & 56 & 70 & 107 & 86 & 106 & 719 \\
\hline Iran & 540 & 118 & 104 & 103 & 140 & 173 & 1308 \\
\hline Other & 691 & 147 & 140 & 164 & 207 & 192 & 1645 \\
\hline Other Asian Countries & 574 & 159 & 163 & 271 & 229 & 239 & 1753 \\
\hline China & 191 & 30 & 24 & 41 & 44 & 43 & 392 \\
\hline South Korea & 74 & 16 & 13 & 23 & 13 & 21 & 167 \\
\hline Other & 309 & 113 & 126 & 207 & 172 & 175 & 1194 \\
\hline Other Countries & 102 & 23 & 49 & 41 & 42 & 24 & 293 \\
\hline TOTAL & 8192 & 2551 & 3075 & 3530 & 3337 & 2987 & 25055 \\
\hline
\end{tabular}

Table 3. FDI dispersion According to the Countries. Source: Under secretariat of Treasury, Turkish Republic

\section{References}

- $\quad$ Alfaro, Chanda, Kalemli-Ozcan and Sayek 2006. "How Does Foreign Direct Investment Promote Economic Growth? Exploring the Effects of Financial Markets on Linkages" http://hbswk.hbs.edu/item/5531.html

- Bandera, and White 1968. "U.S. Direct Investments and Domestic Markets in Europe”, Economia Internazionale. 21, p. 117-133.

- Barrel and Pain 1998. "Real Exchange Rates, Agglomerations, and Irreversibilities: Macroeconomic Policy and FDI in EMU",Oxford Review of Economic Policy 4, p.152-167.

- Billington, 1999. "The Location of Foreign Direct Investment: An Empirical Analysis", Applied Economics. 31, p. $65-76$.

- Bildirici, Aykaç Alp, Ersin and Bozoklu 2010: “íktisatta Kullanılan Doğrusal Olmayan Zaman Serisi Yöntemleri”,Türkmen Kitabevi, İstanbul.

- $\quad$ Bildirici and Bozoklu 2008: "Yabancı Sermayenin Ekonomi Üzerindeki Etkilerinin MS-VAR Yöntemi Kullanılarak Test Edilmesi”, in proceedings of ICAM 2007, Balıkesir.

- Caner, and Hansen 2001: "Treshold autoregressions with a unit root," Econometrica, 69, p. 1555-97.

- Cassou, 1997. "The Link Between Tax Rates and Foreign Direct Investment, Applied Economics". 29, p. 1295 -1301.

- Chakrabarti, 2001. "The Determinants of Foreign Direct Investment: Sensitivity Analyses of Cross-Country Regressions", Kyklos, 54(1), p. 89-113.

- Cheng, and Kwan 2000. "The location of foreign direct investment in Chinese regions, further analysis of labor quality. The Role of foreign direct investment in East Asian economic development", NBER, p. 213-238.

- Coughlin, Terza and Arromdee 1991. "State Characteristics and the Location of Foreign Direct Investment within the United States", The Review of Economics and Statistics, 734, p. 675-83.

- Culem, 1988. “The Locational Determinants of Direct Investments Among Industrialized Countries", European Economic Review, 32, p. 885-904.

- Deichmann Karidis and Sayek 2003. "Foreign Direct Investment in Turkey: Regional 
Determinants", Applied Economics, 35, no.16/10, p. 1767-78.

- Dunning, 1980. "Toward an Eclectic Theory of International Production: Some Empirical Tests", Journal of International Business Studies, 11, p. 9-31.

- Edwards, 1990. "Capital Flows, Foreign Direct Investment, and Debt-Equity Swaps in Developing Countries”, NBER Working Paper No. 3497.

- Erdilek, 1982, "Direct Foreign Investment in Turkish Manufacturing J.C.B. Mohr, Tübingen.

- Flamm, 1984. "The Volatility of Offshore Investment", Journal of Development Economics, 16 p. 231- 248.

- Froot, and Stein 1991. "Exchange Rates and Foreign Direct Investment: An Imperfect Capital Markets Approach”, Quarterly Journal of Economics. 106 p. 1191-1217.

- Goldsbrough,1979."The Role of Foreign Direct Investment in the External Adjustment Process", International Monetary Fund Staff Papers, 26 p. 725 -754.

- Grubert and Mutti 1991. "Taxes, Tariffs and Transfer Pricing in Multinational Corporate Decision Making”, Review of Economics and Statistics, 73 p. 285-293.

- Gupta, 1983. "A Simultaneous Determination of Structure, Conduct and Performance in Canadian Manufacturing", Oxford Economic Papers. 35, p. 281-301.

- Hartman, 1984. "Tax Policy and Foreign Direct Investment in the United States", National Tax Journal. 37, p. 475-487.

- Hines, and Rice 1994. "Fiscal Paradise: Foreign Tax Havens and American Business", The Quarterly Journal of Economics, 109, p. 149-182.

- $\quad$ ITO 2010. "2009 Yılı Yeni Kayıt ve Kapanış Yaptıran Firmalarda Yabancı Yatırımeı ve Sermaye Durumu" Ireport.

- Karluk 2001. “Türkiye'de Yabancı Sermaye Yatırımlarının Ekonomik Büyümeye Katkısı", Ekonomik Istikrar, Yabanc1 Sermaye ve Büyüme, TCMB.

- Khaliq, and Noy. 2007, Foreign Direct Investment and Economic Growth: Empirical Evidence from Sectoral Data in Indonesia,

- Kemsley, 1998. "The Effect of Taxes on Production Location", Journal of Accounting Research, 36 p. 321-341.

- Kindleberger , 1969. “American Business Abroad: Six Lectures on Direct Investment, Fourth Printing", Yale University Press, New Haven.

- Kravis, and Lipsey 1982. "The Location of Overseas Production and Production for Export by U. S. Multinational Firms", Journal of International Economics, 12, p. 201223.

- Loree, and Guisinger 1995. "Policy and Non-Policy Determinants of U.S. Equity Foreign Direct Investment”, Journal of International Business Studies, 26, p. 281300 .

- Lucas. 1993. "On the Determinants of Direct Foreign Investment: Evidence from East and South Asia", World Development, 21, p. 391-406.

- Lunn, 1980. "Determinants of U. S. Direct Investment in the E. E. C.: Further Evidence", European Economic Review, 13, p. 93-101.

- Nankani, 1979. “The Intercountry Distribution of Direct Foreign Investment”. Garland, New York.

- Nigh, 1985. "The Effect of Political Events on United States Direct Foreign Investment: A Pooled Time-series Cross-sectional Analysis", Journal of International Business Studies. 16, p. 1-17. 
- Onyeiwu and Shrestha 2004. "Determinants of Foreign Direct Investment in Africa" Journal of Developing Societies, 20 (1-2), p. 89-106.

- Owen, 1982. "Inter-industry Determinants of Foreign Direct Investments: A Canadian Perspective", in A. M. Rugman ed., New Theories of Multinational Enterprise. London.

- Öniş, 1994. "Liberalization, Transnational Corporations and Foreign Direct Investment in Turkey: The Experience of the 1980s", in Şenses 1994, p. 91-109.

- Pistoresi, 2000. “Investimenti diretti esteri e fattori di localizzazione: L'America Latina e il SudEst asiatico", Rivista di Politica Economica, 90, p. 27-44.

- Root, and Ahmed 1979. "Empirical Determinants of Manufacturing Direct Foreign Investment Developing Countries", Economic Development and Cultural Change, 27 p. $751-767$.

- Sader, 1993. "Privatization and Foreign Investment in the Developing World", World Bank Working Paper No. 1202.

- Saunders, 1982.“The Determinants of Foreign Direct Investment”, Canadian Journal of Economics, 15p77-84.

- Schmitz, and Bieri, 1972. EEC Tariffs and U. S. Direct Investment”, European Economic Review, 3, p.259-270

- Schneider, and Frey 1985. „Economic and Political Determinants of Foreign Direct Investment”, World Development, 13, p. 161-175.

- Shamsuddin, 1994. "Economic Determinants of Foreign Direct Investment in Less Developed Countries", The Pakistan Development Review, 33, p. 41-51.

- Spatz, and Nunnenkamp 2004. "FDI and economic growth in developing economies: how relevant are host-economy and industry characteristics?", Kiel Working Papers, no. 1176.

- Swedenborg, 1979. "The Multinational Operations of Swedish Firms: Analysis of Determinants and Effects", Working Paper, Industrial Institute of Economic and Social Research, Stockholm.

- Swenson, 1994. "The Impact of U. S. Tax Reform on Foreign Direct Investment in the United States", Journal of Public Economics, 54, p. 243-266.

- Tsai, 1994. "Determinants of Foreign Direct Investment and Its Impact on Economic Growth, Journal of Economic Development", 19, p. 137-163.

- Tuman, and Emmert 1999. "Explaining Japanese Foreign Direct Investment in Latin America, 1979 -1992”, Social Science Quarterly, 80, p. 539-555.

- Wheeler and Mody 1992. "International Investment Location Decisions: The Case for U.S. Firms", Journal of International Economics, 33, p. 57-76. 


\title{
European Enlargement Policy for the Western Balkans: Case of Montenegro
}

\author{
Gordana Đurović, University of Montenegro \\ Danijela Jaćimović, University of Montenegro
}

\begin{abstract}
European Union, as mentioned in the Treaty on the EU, is based on the values of respect for human dignity, freedom, democracy, equality, legal state, as well as on the respect for human rights, including persons that belong to national minorities.

Association process to the European Union, in its broadest context, is defined as the fulfillment of so-called Copenhagen criteria. Apart from these basic criteria, in Madrid in 1995, one additional criterion was added, which refers to the harmonization of the administrative, governing and judicial structures with the EU norms.

Having in mind the fifth enlargement experiences, in December 2006 the European Council adopted the so-called Enlargement Consensus. Namely, all future enlargements will be subject to more detailed pre-accession dialogue and more complex negotiation process. In that way process becomes more complex in the very fight for candidate country status, and it is based on the fact that a country has to be "ready in the earlier phase" for obligations stemming from the full-fledged membership in the EU. So that we can now define a new trend in the EU enlargement policy - enlargement plus.

The goal of this study is to analyze enlargement plus process in the Western Balkans region, with special focus on achievements of this process in Montenegro, and on challenges of Montenegro on the EU path.
\end{abstract}

JEL code: F15

\section{Introduction}

As stated in the Treaty on European Union, the EU is founded on the values of respect for human dignity, freedom, democracy, equality, the rule of law, as well as of the respect for human rights including the rights of persons belonging to national minorities. These values are common to all Member States whose society is characterized by pluralism, non-discrimination, tolerance, justice, solidarity and equality between men and women. Building and respect of these values are an important motive for countries interested to enter the EU association process.

For that reason the Union has "in time" defined the accession criteria, getting prepared for the fifth great enlargement to the East. The EU association process in the broadest sense has been defined through the Copenhagen criteria and it is related to the criteria established in Copenhagen in 1993:

1. Stability of democratic institutions, the rule of law, respect for human rights and the protection of minorities;

2. Existence of functional market economy and the ability to deal with the competition pressure and EU market;

3. Ability to accept obligations stemming from the membership, including the goals of the political, economic and monetary union.

Besides these basic criteria defined in 1993, there is one more criterion added in Madrid in 1995 and it is related to adaptation of administrative, governing and judicial structures to EU norms. Fulfilment of the mentioned additional criterion implies full publicity and transparency of work as well as the active role of the Parliament, chambers, trade unions, non-governmental organisations with the aim of realisation of the social consensus and provision of public 
support.

Furthermore, the improved policy of conditionality which following the accession criteria puts the focus on the political accession criteria which were extended in 1997 (one year before the opening of the first round of accession negotiations for the fifth enlargement) with requirements for the more determined fight against corruption and for the independence of jurisdiction.

Having in mind experiences from the fifth enlargement, the European Council adopted the consensus on enlargement in December 2006 (one month before the official accession of Bulgaria and Romania). Thus, all future enlargements of the Union will be subject to a more detailed pre-accession dialogue and more complex negotiation process. The process becomes more complex already in the battle for the status of a candidate country, which means that the country needs to be "prepared beforehand" for obligations deriving from the membership. The accession and accession negotiations, thereby, become more complicated and demanding so that we can talk about a new trend in the EU enlargement policy - enlargement plus.

\section{Characteristics of Montenegrin Integration Path}

Providing above all the economic and political achievements of the fifth enlargement, countries of the Region standing on the threshold of the common European home, including Montenegro, have defined the EU accession process as their strategic priority and „Europeanization" as the engine of all reform processes and positive changes in the society, expecting that the future association policy of Brussels will still be equally stimulating and open for new member states. However, the accession road of these countries will be more complicated and demanding than it was the case so far.

Besides the already existing conditions, the additional conditions or priorities have been settled for the Western Balkan counties. These priorities are related to the stabilisation of each country, along with strengthening of good neighbour cooperation, regional cooperation, return of the refugees, ethnical and religious conciliation, as well as the cooperation with the International War Crimes Tribunal in Hague. All of the mentioned criteria have been consolidated in a document called the Stabilisation and Association Agreement. Thereby, the stabilisation and association process has become the framework for European road and integration of Western Balkans countries into the EU. (Beáta, 2010)

The Stabilisation and Association Process (SAP) is a term for the integral strategic approach of the EU to the Western Balkan countries (a term used in the European Union and includes Croatia, Macedonia, Montenegro, Bosnia and Herzegovina, Albania, Serbia and Kosovo). This is a process that involves an entire series of activities and relations between a concerned Western Balkans state and the EU, as well as the gradual adoption of the EU law. The basic goal of the SAP is the realisation of association of the countries of this region to the European Union, along with establishment of full and permanent stabilisation, not only of individual states but the entire region as well. (Vrbensky, 2008). Important part of the SAP is insisting on the mutual regional cooperation of countries wanting to access the EU, and in the third level of conditionality there are also individual requirements for each country separately. (Gordon, 2009)

Montenegro stands before a long and complicated road from obtaining the candidate status to the full membership. The growing challenge which needs to be approached with utmost attention and has the vital importance for the speed of the integration process is the implementation of the accuis communautaire, or shorter acquis. Harmonisation of the legislation is the EU policy the role of which is accomplishing the goal of harmonising law in Member States to the extent and measure that should provide establishing and functioning of the common market and macro system of the EU as a whole.

The harmonisation is not just a simple formal procedure, or a goal in itself. It is an 
instrument for achieving a broad spectrum of legal-technical, economic and political goals. The trend of growth of the Acquis in the last ten years has been fascinating, which can additionally complicate the situation and slow down the process. Such exponential growth of the volume of EU regulations is directly connected to the expenses of its application in the very member countries, especially in new member countries as well as in those which are still in the accession process. (Gaskell and Persoon, 2010)

Having a goal of facilitating the financial burden of the application of the European legislation, the European Union allocates certain funds from the budget for the IPA programmes. Basic goal of the IPA programme is the support for candidate countries and potential candidate countries, primarily in the area of strengthening of capacities for the adoption of European regulations and standards, the improvement of the business environment, building of democratic institutions, development of the civil society, improvement of the regional and cross-border cooperation, co financing of infrastructural projects, as well as the support directed at the preparation for the use of structural funds (EU Council, 2006). In the EU budget and in the Financial Perspective 2007 - 2013 the support to the EU association process has been included into the priority: $\mathrm{EU}$ as a global player.

\section{Effects and scope of the instrument for pre-accession assistance (IPA)}

Since 2007 the IPA fund has replaced a certain number of EU programmes and mechanisms of the financial assistance for candidate countries and potential candidate countries such as PHARE, PHARE CBC, ISPA, SAPARD, CARDS as well as the financial support for Turkey. This measure is intended for the EU candidate countries including Croatia, Turkey and Macedonia as well as for the potential candidates from the Western Balkans: Albania, Bosnia and Herzegovina, Montenegro, Serbia and Kosovo.

Regarding the candidate countries IPA covers the financial assistance for the transition and institutional reforms, cross-border cooperation, including the relations with other EU Member States and other countries included into IPA programme; for the regional development including transport, environment and economic development; for strengthening of human resources and the fight against the social exclusion and finally, for the rural development initiatives. Candidate countries are obliged to introduce the decentralised system for the IPA funds management, whereas for the potential candidate countries the assistance is provided in a centralised manner. Furthermore, regarding the potential candidates, IPA covers only the assistance for the transition and institutional reforms, as well as for the cross-border cooperation with the EU Member States and other IPA countries.

The IPA fund consists of five different components: support for the transition and institutional building, cross-border and regional cooperation, regional development, human recourse development and rural development. As a potential candidate for the EU membership, Montenegro uses the first and the second component of IPA. The introduction of the decentralised system for the management of funds (OJL, 2010a) and (OJL, 2007b) is in progress.

The overview of allocation of funds assigned to Montenegro and other IPA countries in EUR million, according to the Multi-Annual Indicative Financial Framework - MIFF are given in Table 1.

\begin{tabular}{|c|c|c|c|c|c|c|c|c|c|}
\hline \multirow{2}{*}{ Country } & \multirow{2}{*}{2007} & \multirow{2}{*}{2008} & \multirow{2}{*}{2009} & \multirow{2}{*}{2010} & \multirow{2}{*}{2011} & \multirow{2}{*}{$\begin{array}{l}201 \\
2\end{array}$} & \multicolumn{2}{|c|}{ TOTAL IPA } & \multirow{2}{*}{$\begin{array}{l}\text { Total } \\
\text { IPA/pc }\end{array}$} \\
\hline & & & & & & & $€$ mil & $\%$ & \\
\hline Croatia & 141 & 146.0 & 151.2 & 154.2 & 157 & 160 & 910,22 & 11,0 & 200 \\
\hline Macedonia & 58.5 & 70.2 & 81.8 & 92.3 & 98.7 & 105 & 507,3 & 6,1 & 249 \\
\hline Turkey & 497 & 538.7 & 566.4 & 653.7 & 781 & 899 & 3.94 & 47,7 & 56 \\
\hline
\end{tabular}




\begin{tabular}{|l|l|l|l|l|l|l|l|l|l|}
\hline Albania & 61.0 & 70.7 & 81.2 & 93.2 & 95.0 & 96,9 & 498 & 6,0 & 156 \\
\hline $\begin{array}{l}\text { Bosnia and } \\
\text { Herzegovina }\end{array}$ & 62.1 & 74.8 & 89.1 & 106.0 & 108 & 110 & 550,3 & 6,7 & 140 \\
\hline Montenegro & 31.4 & 32.6 & 33.3 & 34.0 & 34.7 & 35,4 & 201,4 & 2,4 & 320 \\
\hline Serbia & 189 & 190.9 & 194.8 & 198.7 & 202 & 206 & 1.18 & 14,3 & 152 \\
\hline Kosovo & 68.3 & 124.7 & 66.1 & 67.3 & 68.7 & 70 & 465,1 & 5,6 & 221 \\
\hline TOTAL & 1109 & 1.25 & 1.26 & 1.40 & 1.55 & $\begin{array}{l}1.68 \\
5\end{array}$ & $8.253,3$ & 100 & 87 \\
\hline
\end{tabular}

Table 1: Projection of the use of IPA funds by countries for 2007-12 Source: Ministry of European Integration, 2009;

The biggest beneficiary of the IPA funds is certainly Turkey using $47.4 \%$ of IPA national components funds or EUR 3.9 billion, although it has $70 \%$ of the entire population of the IPA countries. That leaves the remaining 52.6\% for the entire Western Balkan region. The amount of these fund varies depending on the IPA-per capita indicator which is the lowest for Turkey $56 € / \mathrm{pc}$, whereas Montenegro is the biggest beneficiary of these funds per capita of its population - $320 € /$ pc.

Montenegro's population makes only $0.66 \%$ of the population of IPA countries, but receives $2.4 \%$ of funds. As the smallest country, Montenegro has the most favourable IPA/pc indicator because it needs the greatest support for strengthening of the necessary administrative capacities for the process of integration and planned reforms. The following table (Table 2) shows the projection of a gradual growth of funds for these purposes by years.

\begin{tabular}{|l|l|l|l|l|l|l|}
\hline Available IPA components & 2007 & 2008 & 2009 & 2010 & 2011 & 2012 \\
\hline $\begin{array}{l}\text { Support to the transition and institutional } \\
\text { building }\end{array}$ & 27,4 & 28,1 & 28,6 & 29,2 & 29,8 & 30,4 \\
\hline Cross-border cooperation & 3,9 & 4,4 & 4,6 & 4,7 & 4,8 & 4,9 \\
\hline TOTAL-€ 201.4 mil & 31,4 & 32,6 & 33,3 & 34,0 & 34,7 & 35,4 \\
\hline
\end{tabular}

Table 2: Projected programme of the pre-accession support for Montenegro Source: Ministry of European Integration, 2009;

Table 2 shows that the most of funds are directed to the support for transition and institutional building. . The total amount of funds allocated to Montenegro in the period 2007 2012 is EUR 201 million, while the annual dynamics moves from EUR 31.4 million in 2007 to EUR 35.4 million in 2012. In three programme years, total investments in the growth of institutional capacities amounted to EUR 16.52 million (without the centralised part which is managed from Brussels) with $1.91 \%$ of co-financing by Montenegro.

\section{Conclusion}

EU has been actively included in the process of reconstruction and stabilisation of the Region since 1995. Today, the regional European integration has a changing dynamics, the process develops slower than expected, it is burdened by many limitations, with a modest positive effect of overflow. Competition in the integration speed has not created a regional synergy and the real improvement of good relationships is not on the expected level.

Montenegro, a small but increasingly stable country with a certain Euro-Atlantic perspective and strong internal consensus for the European integration, begins to play a „leader" role among the potential candidate countries being the first to enter the demanding enlargement plus process, where, clearing the path for all other countries raises its voice against any kind of "Balkans wait room" for the membership. While expecting a decision on the candidate status 
to be prepared in the beginning of the next year (2011) Montenegro works on creating conditions for the beginning of negotiations and the gradual implementation of the European acquis. Transposing and implementation of European regulations is an intensive process in both technical and financial dimension for a small state such as Montenegro. Therefore, using funds from the IPA programme is important for the acceleration of this process.

During the programming of project in 2007, 2008, 2009 and 2010, Montenegro received EUR 131.3 million of IPA funds for the stimulation of democratic and economic reforms in the country, adoption of the European acquis and European standards, more efficient implementation of policies important for business and EU integration, some infrastructural projects as well as the cross-border cooperation. Co-financing of projects has been provided at the level of $50-10 \%$ of co-financing. Infrastructural projects in the area of transport infrastructure are followed also by the loan arrangements with EBRD, EIB and the Council of Europe Development Bank (CEB). Besides the great importance of IPA funds in the accession process, Montenegro and other countries in the region can expect bigger and more significant funds with new and more demanding phases of the integration.

\section{References}

- Beáta, Huszka, 2010. "The Next Enlargement Round - The Balkan Challenge, EU Frontier, Policy Paper No.1, Centre for EU Enlargement Studies, CEUENS, Budapest, 5-6;

(https://cens.ceu.hu/sites/default/files/publications/policypapernoleufrontiershuszka.p df)

- Vrbensky, R., 2008. “Can Development Prevent Conflict? Working Paper WR 02/2008, Centre for Study Global Governance (LSE), 56

- Gordon, C., 2009 "The Stabilization and Association Process in the Western Balkans: An Effective Instrument of Post-conflict Management?” Ethnopolitic, 8:3; 325 - 340.

- Gaskell, S. and Persson Mats, 2010. "Still Out of Control - Measuring Eleven Years of EU Regulation?” Openeurope, Vol 3, 38-44.

- . Council Regulation, 2006. Establishing an Instrument for Pre-Accession Assistance (IPA) (OJ L 210, 31.7; 2-10;

- OJL, 2010. Budget EU 2010, OJL 64, Vol 53, Brassels; 5-20;

- OJL, 2007. Financial Framework 2007-13 revised for Economic Recovery Plan (costant prices 2004); Brussels.

- Ministry of European Integration, 2009. Information on Community Programmes, Podgorica, pg 212; 


\title{
Does the Law of One Price Hold in a High-Inflation Environment? A Tale of Two Cities in Turkey
}

\author{
Sule Akkoyunlu, ETH Zurich \\ Boriss Siliverstovs, ETH Zurich
}

\begin{abstract}
This study addresses price convergence in two cities in Turkey (Istanbul and Ankara) using the annual data over the three quarters of the 20th century (1922-1998), characterized by prevailing high inflation rates for most of the period. In contrast to the rest of the literature addressing convergence in price levels with a typical result of extremely slow convergence rates at best, we argue that convergence is much easier detected in growth rates rather than levels of prices. We suggest using the bounds testing procedure of Pesaran et al. (2001) for this purpose. We find a clear-cut evidence on the existence of a common driving force behind inflation dynamics in Istanbul and Ankara - a finding that is intuitively appealing from the point of view of economic theory.
\end{abstract}

JEL code: C22, C32, C52, E31

Full paper in print. Please contact the author for details. 


\title{
Avrasya Ülkeleri Açısından Yenileșen Dengeli Enerji Yönetiminde Paylaşılan Stratejik Yaklaşımlar
}

\author{
Akın Marşap, İstanbul Aydın Üniversitesi \\ Müslüme Narin, Gazi Üniversitesi \\ İrfan Özcan, Akdeniz Üniversitesi
}

\section{Abstract \\ New Shared Strategic Approaches for Balanced Energy Management in Eurasian Countries}

Energy can play a kind of major role for improving life quality and providing sustainable developments is one of the basic inputs of economic and social progress all of the Eurasian countries. It is necessary for improving of the Eurasia countries to providing continuous clean energy, requires to create a suitable market atmosphere. Energy demand is increasing by quick growing up and increase of population of global economy. Most of the increased of energy demand is going to provide by using fossil fuels that are coal, petroleum and like a natural gas. At the end of using these types of fuels creating greenhouse gas emissions that is creating climate changes so it is a major reason of ecological environmental and climate changes is effecting life securities in all areas. With this threat of global warming becoming increasingly urgent, to provide economic development and expectation in healthy environment for future life quality is bringing usage of clean energy resources in front plan. It is a kind of requirement for providing clean energy we need to transforming a unique understanding of using energy resources most economically and effectively. We need to guidance on how to achieve a clean and competitive energy future usage management in renewable energy is energy generated from natural resources-such as sunlight, wind, rain, tides and geothermal heat-which are renewable for Eurasia countries. In this study, we are evaluating of energy management and alternative and renewable clean energy source management for common strategic approaches for Eurasian countries.

JEL Code: Q, Q4

\section{Giriş}

Avrasya ülkeleri her alanda olduğu gibi enerji yönetiminde de dünya ekonomisi açısından kritik bir rol üstlenmiş bulunmaktadır. Bu önemli süreçte, dünya ekonomisindeki hızlı büyüme, nüfus artışı, sanayileşme ve şehirleşmenin artmasıyla enerji talebi de yükselmektedir. Son yıllarda petrol başta olmak üzere toplam enerji kaynaklarının sağlanmasında net ithalatçı durumunda olan sanayileşmiş ülkeler ile çağdaş enerji hizmetlerinden yararlanmak isteyen Avrasya ülkeleri, enerji güvenliğini sağlamak amaciyla çeşitli alternatif politikalar oluşturmaktadır. Dünya petrol fiyatlarındaki hızlı artış, sera gazı emisyonlarına BM İklim Değişikliği Çerçeve Sözleşmesi (BMiDÇS) ve Kyoto Protokolü çerçevesinde getirilen sınırlamalar, tüm ülkeleri yeni ve yenilenebilir enerji kaynaklarına ve enerji kullanımında verimliliği artıracak önlemlere yöneltmiştir. Dolayısıyla Avrasya ülkeleri açısından da stratejik bir yaklaşımla ele alındığında yenileşen enerji yönetim sisteminin (YEYS) ekonomik büyümeyi gerçekleştirecek biçimde, zamanında, yeterli, güvenilir, rekabet edilebilir fiyatlardan, çevre üzerine yaratacağı etkiler de dikkate alınarak tüketiciye sağlanması hedeflenir. Böylece, enerji, çevre ve iklim ilişkileri, enerjide alternatif enerji kaynaklarına hızlı geçişe yol açarak sürdürülebilir enerji yaklaşımının yerini yenilenebilir enerji yaklaşımı almaya başlamıştır. Çalışmanın amacı, Avrasya ülkeleri açısından fosil yakıt kaynaklarının sınırlı oluşu, bu yakıtların yol açtığ 1 sera gazı emisyonları, bu emisyonların çevre ve insan sağlığ üzerine yarattığı olumsuz etkilerin azaltılması amacıyla geliştirilen çağdaş enerji yönetimindeki 
yeni açılımları incelemektir. Bu doğrultuda önce Avrasya ülkeleri enerji kaynakları, kullanımı ve sera gazları; sonra da temiz ve yenilenebilir enerji politikaları; yaşam kalitesi, iklim ve temiz yenilenebilir enerji yönetimi tartışılacaktır.

\section{Yenileşen Enerji Yönetimi Sistemleri}

Dünya açısından, YEYS stratejileri, çevrenin korunumu, iklim değişimi ve gelecek yönetimi açısından büyük bir önem taşımaktadır. Kısıtlı dünya kaynaklarının korunması, gelecek kuşaklara daha temiz ve sürdürülebilir bir dünya mirası bırakılması açısından, Avrasya ülkeleri YEYS stratejilerinin gelişime açık ortak bir anlayışla ele alınması gerekir.

\subsection{Dünya Enerji Tüketimi}

Hızla artan dünya nüfusu ve büyüyen dünya ekonomisi, enerji kaynaklarına yönelik talebi de hızlı artış göstermekte ve bu talebin karşılanmasında giderek artan sorunlar yaşanmaktadır. 2008 yılında 6,7 milyar olan dünya nüfusunun 2035 y1lında 8,6 milyara (UN Population Division, 2010), dünya birincil enerji talebinin ise 495,2 katrilyon Btu'dan yıllık ortalama \%1,43 artarak 738,7 katrilyon Btu'ya çıkacağı öngörülmektedir (EIA, 2010:1). Dolayısıyla 2007-2035 döneminde dünya nüfusu yaklaşık \%28,4, dünya birincil enerji talebi ise yaklaşık $\% 49$ artacaktır.

Birincil enerji tüketimi içinde en büyük payı petrol, kömür, doğal gaz oluşturmaktadır. Öte yandan dünya enerji tüketiminin 2007 yılında \%85'ini oluşturan fosil yakıtların payı, 2035 yılına doğru biraz düşerek \%80 civarında olacaktır (Tablo 1). Ancak fosil yakıtlar, çevreyi ve insan sağlığını giderek daha fazla tehdit eder hâle gelmiştir. Fosil yakıt kullanımı sonucu ortaya çıkan karbondioksit, karbon monoksit ve kükürt dioksit gibi gazlar, ısının uzaya çıkışını yavaşlatarak sera gazının oluşumuna yol açmaktadır. Özellikle ormanların azalmasıyla bu süreç daha da hızlanmıştır. Sera gazı emisyonu, hava kirliliğine dolayısıyla iklim değişikliğine yol açmaktadır. İklim değişikliği ise su kaynaklarının azalmasına, tarımsal üretkenlikte değişikliğe, orman yangınlarına, kuraklığa, erozyon ve çölleşmeye, ekolojik bozulmalara, bulaşıcı hastalıkların artmasına ve sıcak hava dalgalarına bağlı ölümlere yol açmaktadır. Bu nedenle fosil yakıtlara alternatif olabilecek sürdürülebilir ve yenilenebilir enerji kaynaklarına yönelik araştırmalar ve çalışmalar hızla devam etmektedir. Ancak yaşamın sürdürülebilirliği için enerji kaynaklarının yalnızca sürdürülebilir olması yeterli değil, aynı zamanda ekolojik denge için yenilenebilir olması da gerekmektedir. Dolayısıyla bir yandan hızla artan enerji talebi, öte yandan fosil yakıtların yanması ortaya çıkan sorunlarına çözüm getirmek amacıyla nükleer enerjiye yönelik çalışmalar da hızlanmıştır. İkinci Dünya Savaşı sonrasında barışçıl amaçlarla kullanılmaya başlanan nükleer enerjiye duyulan güven, özellikle 1986 Çernobil reaktör kazasından sonra azalma göstermiş, ancak enerji sorunları yüzünden 2000'li yıllarda yeniden gündeme gelmiştir (Nükleer Enerji Dünyas1, 2010). Nükleer enerjinin enerji tüketiminin 20072035 döneminde yıllık ortalama \%2 artarak, 27,1 katrilyon Btu'dan 47,1 katrilyon Btu'ya çıkacağı ve toplam enerji tüketimi içerisindeki payının da artacağı öngörülmektedir (EIA, 2010: 147). Ağustos 2010 itibariyle 440 işletmede olan, 59 inşa hâlinde bulunan, 149 sipariş verilmiş ya da planlanmış, 344 de önerilmiş nükleer reaktör mevcuttur (World Nuclear Association, 2010).

\begin{tabular}{|c|c|c|c|c|c|c|c|c|}
\hline Enerji Kay.lar1 & 2007 & $\%$ & 2015 & $\%$ & 2025 & $\%$ & 2035 & $\%$ \\
\hline Petrol & 174,7 & 35,3 & 179,3 & 33,0 & 197,2 & 30,9 & 223,6 & 30,3 \\
\hline Doğal gaz & 112,1 & 22,6 & 129,1 & 23,8 & 150,2 & 23,5 & 162,0 & 21,9 \\
\hline Kömür & 132,5 & 26,8 & 139,1 & 25,6 & 167,8 & 26,3 & 206,3 & 27,9 \\
\hline Nükleer & 27,1 & 5,5 & 32,2 & 5,9 & 41,1 & 6,4 & 47,1 & 6,4 \\
\hline Yenilenebilir E. & 48,8 & 9,9 & 63,8 & 11,7 & 82,4 & 12,9 & 99,7 & 13,5 \\
\hline Toplam & 495,2 & 100 & 543,5 & 100 & 638,7 & 00 & 738,7 & 00 \\
\hline
\end{tabular}

Tablo 1. Kaynaklarına göre dünya enerji tüketimi (katrilyon Btu) Kaynak: EIA, $2010: 1$. 


\subsection{Dünyada Karbondioksit Emisyonları}

Fosil yakıtların yakılması sonucu ortaya çıkan $\mathrm{CO}_{2}$ emisyonlarının 2035 yılına kadar artacağ öngörülmektedir. $\mathrm{CO}_{2}$ emisyonları içerisinde petrol ve doğal gazın payı giderek azalırken, kömürün payının arttı̆ğ görülmektedir (Tablo 2). Ağırlıklı olarak fosil yakıtların yanması sonucu ortaya çıkan sera gazlarının yol açtığı iklim değişikliğine çözüm bulmak üzere BMIDÇS ve Kyoto Protokolü gibi uluslararası girişimlere gidilmiştir.

\begin{tabular}{|c|c|c|c|c|c|}
\hline & 1990 & 2007 & 2015 & 2025 & 2035 \\
\hline Petrol & 42,3 & 38,0 & 36,7 & 34,8 & 33,9 \\
\hline Doğal gaz & 32,7 & 20,0 & 21,7 & 21,8 & 20,3 \\
\hline Kömür & 39,0 & 42,0 & 41,6 & 43,4 & 45,8 \\
\hline Toplam (\%) & 100,0 & 100,0 & 100,0 & 100,0 & 100,0 \\
\hline Toplam milyar metrik ton $\mathrm{CO}_{2}$ & 21,49 & 29,69 & 31,51 & 36,45 & 42,38 \\
\hline
\end{tabular}

Tablo 2. Dünyadaki $\mathrm{CO}_{2}$ emisyonları ve enerji kaynaklarına göre payları (\%) Kaynak: EIA, 2010: 124.

21 Mart 1994 tarihinde yürürlüğe giren BMiDÇS'de iklim değişikliğinin ve zararlarının insanlığın ortak kaygısı olduğu, insan etkinliklerinin atmosferdeki sera gazları yoğunluğunu artırdığı ve bunun atmosferde sıcaklık artışıyla sonuçlanarak insanlığa zarar verdiği, küresel sera gazı emisyonunda en büyük payın gelişmiş ülkelerden kaynaklandığı ve iklim değişikliğinin küresel boyutu göz önüne alınarak uluslararası boyutta işbirliğine gereksinim duyulmuştur (Arıkan, 2006). Bu doğrultuda sera gazlarının azaltımıyla ilgili 2005 yılında Montreal'de yapılan 11. Taraflar Toplantısının (COP-11/MOP-1) öncelikli ilgi alanını enerji verimliliği, yenilenebilir enerji, yeni teknolojiler, karbonu yeraltında depolama uygulamaları ve ormanlaştırma oluşturur (UNCCC, 2005). 2005 yılında yürürlüğe giren Kyoto Protokolü ise BMIDÇS'nin sera gazı emisyonlarının azaltılmasına yönelik hukuki açıdan bağlayıcı bir belge özelliğine sahiptir. Bu protokol, ülkelerin ortak ancak farklı sorumlulukları, ulusal ve bölgesel kalkınma öncelikleri, amaçları ve özel koşulları dikkate alınarak, öncelikli olarak gelişmiş sanayileşmiş ülkelerin sera gazı emisyonlarını azaltmaları yönünde yükümlülükler getirir (Narin, 2008). BM Hükümetlerarası İklim Değişikliği Paneli (IPCC)'nin Mart 2007'de “'̇klim Değişikliği 2007: İklim Değişikliğinin Azaltılması” Raporu’nda da sera gazı emisyonlarının sanayileşme öncesi dönemden bu yana sürekli yükseldiği, özellikle 1970-2004 arasında \%80 arttığ ve bu artışı \%28'inin 1990 yılından sonra gerçekleştiği belirtilmektedir. 2004 yılında sera gazı emisyonlarının \%77'sinin insan kaynaklı olduğu, bu emisyonların en çok fosil yakıtların kullanıldığı enerji sektöründen kaynaklandığı vurgulanmıştır. Ayrıca mevcut küresel iklim değişikliğini azaltma politikalarının yetersiz olduğu, 2000-2100 yılları arasında sera gazı emisyonunun azaltımında; enerji tasarrufu ve verimliliğinin, yenilenebilir enerji kaynakları, karbon tutarak depolama teknolojisi ile karbondioksitsiz toprak kullanımının ön plana geçmesi gerektiği belirtilmektedir (IPCC, 2007). Bununla birlikte atmosferdeki $\mathrm{CO}_{2}$ emisyonunun 2030 yılına kadar erişimini hedeflenen "450 İstikrar Durumu” senaryosuna göre 2020 yılına kadar $\mathrm{CO}_{2}$ emisyonunun artacağı, ancak sanayide, binalarda ve taşımacılıkta fosil yakıt kullanımında verimlilik sağlanarak, nükleer ve yenilenebilir enerji kaynaklarının payı artırılarak, elektrik üretiminde ve sanayide ortaya çıkan karbonu yeraltında depolayan teknoloji kullanılarak 2030 yılına kadar 26,4 Gt'ye düşürülebileceği belirtilmektedir (IEA, 2009). Bu gelişmelerden sonra enerji, çevre ve iklim ilişkileri, enerjide alternatif kaynaklara hızla geçerek sürdürülebilir enerji yaklaşımı yerini, yenilenebilir enerji yaklaşımına bırakmaya başlamıştır. Dolayısıyla enerjiye ilişkin klasik yaklaşımın dünyadaki tüm ekonomilere ve dünyaya zararı, temiz enerji ve enerji sektöründeki paradigmaların değişimini gerektirmektedir. İnsanı ve doğayı gözeten sağlıklı bir çevrede yaşamak için, yenilenebilir temiz enerji seçeneklerine yönelmek artık zorunlu hâle gelmiştir. $\mathrm{Bu}$ doğrultuda günümüzde ulusal ve uluslararası düzeydeki enerji çalışmalarının temelini, temiz enerjinin üretimi, depolanması, dağıtımı ve kullanımı oluşturmaktadır. 


\subsection{Temiz ve Yenilenebilir Enerji Politikaları}

Fosil yakıtların çevre kirliliği, sera etkisi, asit yağmurları ve iklim değişiklikleri biçiminde çevreye verdiği zararın artmasıyla, yenilenebilir enerji kaynaklarına yöneliş başlamıştır. Hidrolik, rüzgâr, güneş, jeotermal gibi doğal kaynaklar hem yenilenebilir olma özelliğine sahip hem de temiz enerji olarak karşımıza çıkmaktadır. Toplam enerji tüketimi içerisindeki payı 2007 yılında \%9,8 olan yenilenebilir enerji kaynaklarının, 2035 yılında \%13,5'a çıkacağ 1 öngörülmektedir. Özellikle 2035 yılında dünyada üretilen elektriğin \%35,5'inin yenilenebilir enerji kaynakları ile nükleer enerjiden sağlanması planlanmaktadır (EIA, 2010).

Sera gazı emisyonlarının azaltılmasına yönelik çalışmalardan birisi de enerji verimliliğinin sağlanmasıdır. Enerji verimliliği, enerji girdisinin üretim içindeki payının azaltılması, aynı üretimin daha az enerji kullanımı ile gerçekleştirilmesidir. Bunun için gaz, buhar, 1sı, hava ve elektrikteki enerji kayıplarını önlemek, çeşitli atıkların geri kazanımı ve değerlendirilmesi veya ileri teknoloji ile üretimi düşürmeden enerji talebini azaltmak, daha verimli enerji kaynakları, gelişmiş endüstriyel süreçler, kojenerasyon ve enerji geri kazanımları gibi etkinliği artırıcı önlemler almak gerekmektedir. Enerji kullanımına bağlı olarak ortaya çıkan $\mathrm{CO}_{2}$ emisyonlarındaki eğilimin belirlenmesinde enerji yoğunluğu ve karbon yoğunluğu olmak üzere iki önemli gösterge kullanılmaktadır. Bunlardan birisi enerji yoğunluğu, diğeri karbon yoğunluğudur. Enerji yoğunluğu, birim hâsıla başına birincil ya da nihai enerji tüketimi göstermekte olup, birincil ya da nihai enerji tüketiminin gayri safi yurt içi hâsılaya (GSYİH) bölünmesiyle hesaplanmaktadır. Karbon yoğunluğu, bir birim enerji kullanımı sonucu ortaya çıkan $\mathrm{CO}_{2}$ emisyon miktarını göstermektedir.

Başta gelişmiş ülkeler olmak üzere tüm dünyada enerji verimliliğini sağlamaya yönelik önemli çalışmalar yapılmaktadır. Bu çalışmalardan da olumlu sonuçlar alınmıştır (Narin ve Akdemir, 2006). Bunların dışında enerji yönetiminde çeşitli teknikler ve enerji teknolojileri de kullanılmaktadır. Bunlar kojenerasyon, basınçlı hava (kompresör) uygulamaları ve yüksek verimli motor kullanımı, akışkan yatak, yakıt pilleri, rüzgâr enerjisi teknolojileri, güneş enerjisi teknolojileri, karbonu yeraltında depolama teknolojileri olarak sıralanabilir (Marşap ve Narin, 2008).

\section{Avrasya Ülkelerinde Yenileşen Enerji Stratejileri}

Stratejik yönetim, gelecek odaklı kararlar toplamıdır. Avrasya ülkeleri açısından ortak enerji stratejilerinin erken dönemde kurgulanması, bu yönde atılacak işbirliği içeren adımlar, gelişim ve değişimin öncüsü olacaktır. 285 milyonluk nüfusu barındıran Avrasya bölgesi ülkelerinin toplam millî geliri 2000 yılı sabit fiyatlarıyla yaklaşık 654 milyar dolara ulaşmıştır.

\subsection{Avrasya Ülkelerinde Enerji Tüketimi}

Enerjinin temini açısından Avrasya ülkelerini enerji ihracatçısı ve enerji ithalatçısı olarak iki gruba ayırmak gerekmektedir. Ermenistan, Beyaz Rusya, Estonya, Gürcistan, Kırgızistan, Letonya, Litvanya, Moldova, Tacikistan, Ukrayna enerji ithalatçısı, Azerbaycan, Kazakistan, Rusya, Türkmenistan ve Özbekistan enerji ihracatçısı konumunda olan ülkelerdir. 2008 yılı verilerine göre; dünya nüfusunun \%4,3'ünü barındıran Avrasya ülkelerinin, dünya GSYH'nın \%1,6'sına sahiptir. Dünyadaki enerjinin \%13,7'sini tüketen bu bölgede ortalama olarak kişi başına enerji tüketimi 5,94 TEP'tir. Enerji tüketiminde dünya ortalamasının çok üstünde olduğu görülmektedir. Özellikle Rusya, Kazakistan, Estonya ve Türkmenistan'da kişi başına enerji tüketiminin 4 TEP civarında olduğu görülmektedir. Kişi başına elektrik tüketiminde de 4.660 $\mathrm{kWh}$ ile dünya göstergelerinden fazladır (Tablo 3).

Avrasya ülkelerinin birincil enerji tüketiminin referans senaryoya göre 2007-2035 döneminde yıllık ortalama \%0,6 artacağ 1 öngörülmektedir. Bu artış dünya enerji tüketim artış hızından daha düşük düzeydedir. Bölgede aynı dönemde petrol tüketiminin yıllık ortalama $\% 0,2$, doğal gaz ve kömür tüketiminin yıllık ortalama $\% 0,3$, nükleer enerji tüketiminin yıllık ortalama $\% 2,7$ ve diğer enerji kaynakları tüketiminin yıllık ortalama $\% 1,4$ artacağı 
belirtilmektedir. 2035 yılına kadar petrol, doğal gaz ve kömür tüketiminin artacağı, ancak bu artışın düşük düzeyde gerçekleşeceği görülmektedir. Toplam enerji tüketimi içerisinde en büyük payı $\% 51$ ile doğal gaz oluşturmakta, onu $\% 20$ ile petrol, $\% 16,9$ ile kömür, $\% 7,2$ ile nükleer ve \%4,9 ile diğer enerji kaynakları izlemektedir. Avrasya ülkelerinin enerji tüketimi içerisinde 2007 yılında \%88 olan fosil yakıtların payı, 2035 yılında \%82'ye düşmesi beklenmektedir. $\mathrm{Bu}$ oranlar dünya genelindeki fosil yakıtların toplam enerji tüketimi içerisindeki payından yüksektir (EIA, 2010: 146-147). Fosil yakıt kullanımı sonucu ortaya çıkan $\mathrm{CO}_{2}$ emisyonu, Avrasya ülkelerini de yeni ve yenilenebilir enerji kaynaklarına yöneltmiştir. Bu ülkelerde özellikle nükleer enerjiye yönelik çalışmalar hız kazanmıştır.

\begin{tabular}{|l|r|r|r|r|r|r|r|}
\hline & $\begin{array}{c}\text { Top. } \\
\text { enerji } \\
\text { temini } \\
\text { milyon } \\
\text { TEP }\end{array}$ & $\begin{array}{c}\text { Con } \\
\text { emisyonu } \\
\text { milyon } \\
\text { ton } \mathrm{CO}_{2}\end{array}$ & $\begin{array}{c}\mathrm{K} \text {. B. } \\
\text { enerji } \\
\text { temini } \\
\text { TEP/Kişi }\end{array}$ & $\begin{array}{c}\text { GSYH.B } \\
\text { toplam } \\
\text { enerji } \\
\text { temini }\end{array}$ & $\begin{array}{c}\text { K.B. } \\
\text { elekt. } \\
\text { tüketimi } \\
\mathrm{kWh} / \text { kişi }\end{array}$ & $\begin{array}{c}\text { K. B. } \\
\mathrm{CO}_{2} \text { emi. } \\
\text { ton } \\
\mathrm{CO}_{2} / \text { Kişi }\end{array}$ & $\begin{array}{c}\text { GSYH.B. } \\
\text { emisyon } \\
\mathrm{Kg} \mathrm{CO}_{2} / \\
2000 \\
\text { Dolar }\end{array}$ \\
\hline Dünya & 12.369 & 29.381 & 1,83 & 0,30 & 2.782 & 4,39 & 0,73 \\
\hline Avrasya & $1.691,19$ & 2.476 & 3,65 & 1,59 & 4.660 & 8,53 & 3,71 \\
\hline Ermenistan & 0,80 & 5,26 & 0,97 & 0,64 & 1.578 & 1,71 & 1,12 \\
\hline Azerbaycan & 58,59 & 29,28 & 1,54 & 0,72 & 2.318 & 3,37 & 1,58 \\
\hline Beyaz Rusya & 4,03 & 64,19 & 2,91 & 1,17 & 3.427 & 6,63 & 2,67 \\
\hline Estonya & 4,22 & 17,62 & 4,03 & 0,57 & 6.346 & 13,14 & 1,86 \\
\hline Gürcistan & 1,08 & 4,71 & 0,68 & 0,55 & 1.657 & 1,08 & 0,86 \\
\hline Kazakistan & 148,19 & 201,63 & 4,52 & 1,90 & 4.689 & 12,86 & 5,41 \\
\hline Kurgizistan & 1,19 & 5,92 & 0,54 & 1,44 & 1.449 & 1,12 & 2,99 \\
\hline Letonya & 1,79 & 7,91 & 1,98 & 0,33 & 3.087 & 3,49 & 0,58 \\
\hline Litvanya & 3,85 & 14,24 & 2,73 & 0,46 & 3.557 & 4,24 & 0,71 \\
\hline Moldova & 0,10 & 7,07 & 0,87 & 1,50 & 1.287 & 1,95 & 3,37 \\
\hline Rusya & $1.253,92$ & $1.593,83$ & 4,84 & 1,60 & 6.443 & 11,24 & 3,71 \\
\hline Tacikistan & 1,49 & 3,03 & 0,36 & 1,49 & 2.072 & 0,44 & 1,81 \\
\hline Türkmenistn & 68,63 & 47,29 & 3,74 & 2,19 & 2.280 & 9,41 & 5,52 \\
\hline Ukrayna & 81,29 & 309,58 & 2,94 & 2,55 & 3.534 & 6,69 & 5,79 \\
\hline Özbekistan & 62,02 & 114,92 & 1,85 & 2,20 & 1.646 & 4,21 & 5,01 \\
\hline
\end{tabular}

Tablo 3. Avrasya Ülkelerimde Enerji Göstergeleri (2008) Kaynak: IEA, 2010: 48-57.

\subsection{Avrasya Ülkelerinde Karbondioksit Emisyonları}

Avrasya ülkelerinde enerji kullanımı sonucu ortaya çıkan $\mathrm{CO}_{2}$ emisyonlarının referans senaryoya göre 2007-2035 döneminde yıllık ortalama \%0,3 artacağ dünya ortalamasının altında kalacağı öngörülmektedir (EIA, 2010: 155). Ancak 2008 yılı verilerine göre kişi başına $\mathrm{CO}_{2}$ emisyonu, dünya değerlerinin iki katı olduğu görülmektedir (Tablo 3). Sera gazı emisyonlarını azaltmak amacıyla Avrasya ülkeleri 1998 yılından itibaren Kyoto Protokolü'nü imzalamaya başlamışlardır. Bu ülkelerin tamamı protokolü imzalamasına karşın, yalnıza Letonya'nın onay için \%0,2 emisyona sahip olması ve 2012 yılına kadar bu oranı $-\% 8$ indirmesi gerekmektedir.

\begin{tabular}{|c|c|c|c|c|}
\hline & İmza & Onay & $\begin{array}{c}\text { Yürürlüğe } \\
\text { giriş }\end{array}$ & Emisyon \% \\
\hline Ermenistan & & 25 Nisan 2003 & 16 Şubat 2005 & \\
\hline Azerbaycan & & 28 Eylül 2000 & 16 Şubat 2005 & \\
\hline Beyaz Rusya & & 26 A ğustos 2005 & 24 Kasım 2005 & \\
\hline Estonya & 3 Aralı 1998 & 14 Ekim 2002 & 16 Şubat 2005 & \\
\hline Gürcistan & & 16 Haziran 1999 & 16 Şubat 2005 & \\
\hline Kazakistan & 12 Mart 1999 & 19 Haziran 2009 & 17 Ekim 2009 & \\
\hline Kırgizistan & & 13 May1s 2003 & 16 Şubat 2005 & \\
\hline Letonya & 14 Aralık 1998 & 5 Temmuz 2002 & 16 Şubat 2005 & $0.2 \%$ \\
\hline
\end{tabular}




\begin{tabular}{|c|c|c|c|c|}
\hline Litvanya & 21 Eylül 1998 & 3 Ocak 2003 & 16 Şubat 2005 & \\
\hline Moldova & & 22 Nisan 2003 & 16 Şubat 2005 & \\
\hline Rusya & 11 Mart 1999 & 18 Kasim 2004 & 16 Şubat 2005 & $14.4 \%$ \\
\hline Tacikistan & & 29 Aralık 2008 & 29 Mart 2009 & \\
\hline Türkmenistan & 28 Eylül 1998 & 11 Ocak 1999 & 16 Şubat 2005 & \\
\hline Ukrayna & 15 Mart 1999 & 12 Nisan 2004 & 16 Şubat 2005 & \\
\hline Özbekistan & 20 Aralık 1998 & 2 Ekim 1999 & 16 Şubat 2005 & \\
\hline
\end{tabular}

Tablo 4. Avrasya ülkelerinin Kyoto protokolünü imzalama tarihleri Kaynak: UNFCCC, 2010.

1997 yılında imzalanan Kyoto Protokolünün 25. maddesi; “Ek-1'de yer alan en az 55 ülkenin imzalaması ve bunun Ek-1 ülke emisyonlarının en az \%55'ine karşılık gelmesi durumunda, buna uyduğu tarihten sonraki 90. gün yürürlüğe girer" biçimindedir. \%55 koşulu Rusya'nın 18 Kasım 2004'te anlaşmayı imzalaması ile sağlanmış ve anlaşma 16 Şubat 2005 tarihinde yürürlüğe girmiştir. Bu koşula göre, Rusya’nın emisyon azaltımıyla ilgili bir yükümlülüğü bulunmamaktadır (Tablo 4).

\section{Avrasya Ülkelerinde Yenilenebilir Enerji Politikaları}

Dünyanın diğer ülkelerinde olduğu gibi Avrasya ülkelerinde de iklim değişikliğinin olumsuz etkilerini azaltmak amacıyla yenilenebilir enerji kaynakları ve yeşil teknolojinin diğer formlarını geliştirmeye yönelik çalışmalar giderek artmaktadır. Özellikle yeşil teknoloji, bu konuda büyük destek verebilecektir. Bu ülkelerin bazılarında büyük geleneksel enerji rezervleri bulunmasına karşın, mevsimsel enerji sıkıntısı yaşanabilmekte ve yenilenebilir enerji projelerinin hayata geçirilmesi de önem kazanmaktadır.

Ermenistan: Yenilenebilir enerji kaynaklarının geliştirilmesi için Ermenistan'da yasal düzenlemeler yapılmıştır. Ülkenin umut verici yenilenebilir enerji kaynakları rüzgâr ve biyokütledir. Finansal sermaye yetersizliği ve düşük elektrik fiyatları yüzünden, bu kaynakların geliştirilmesi kaçınılmaz hâle gelmiştir. Ayrıca ülkede hidro güç potansiyeli de yüksektir. Güneş ve jeotermal enerji de kullanılabilecek kaynaklar olmasına karşın, güneş enerjisi büyük ölçekli fotovoltaik (PV) projelerin desteklenmesi için yeterli bulunmamaktadır (EBRD, 2010).

Azerbaycan: Büyük petrol ve doğal gaz rezervlerine sahip olması, ülkenin yenilenebilir enerji kaynaklarını geliştirmesinde caydırıcı bir unsurdur. Sovyetler Birliği döneminde inşa edilen Azerbaycan'ın enerji altyapısı, kamu yatırımlarının düşük olması nedeniyle genellikle kötü koşullardadır. Ülkenin yenilenebilir enerjiye dayalı santralleri için rüzgâr, hidro ve biyokütle büyük potansiyele sahiptir. Toplam rüzgâr enerjisinin teknik potansiyelinin 1500 MW olduğu tahmin edilmektedir. Enerji üretimi için biyokütle ve hidro da önemli potansiyele sahiptir (EBRD, 2010).

Estonya: AB'ye giren Estonya, AB'nin yenilenebilir enerji politikalarından etkilenmektedir. Estonya'da yüksek kamu bilinci ve olumlu yasal düzenlemeler, yenilenebilir enerji için uygun yatırım ortamı sağlamaktadır. 2010 yılı sonuna kadar yenilenebilir enerji kullanımının artırılarak \%67'ye çıkarılması hedeflenmiştir. Bu doğrultuda 1 Temmuz 2003'de yürürlüğe giren Elektrik Piyasası Yasası ile yenilenebilir enerji kaynaklarından üretilen elektrik daha yüksek fiyattan satın alınmıştır. Yenilenebilir enerji kaynaklarının birçoğuna vergi destekleri sağlanmıştır. En umut verici yenilenebilir enerji kaynakları rüzgâr ve biyokütledir (EPRD, 2010).

Beyaz Rusya: 1994 yılında Almanya'nın “Elektrik Besleme Yasası” örnek olarak alınarak, devletin yenilenebilir enerji kaynaklarından üretilen elektrik enerjisini piyasa değerinin üzerinden satın almasına dayalı yasayı çıkarmışıı. Bu yasaya dayanarak, yenilenebilir enerjiye dayalı elektriği yüksek fiyattan satın almıştır. Ancak hükümetin özelleştirmeye yanaşmaması, enerji projelerinin gelişmesini ve dış finansman girişini sınırlandırmıştır. Beyaz Rusya, güneş, 
jeotermal, rüzgâr ve hidro güç kaynaklarında çok düşük potansiyele sahiptir. En önemli yenilenebilir enerji kaynağı odun ve diğer biyokütle kaynaklarıdır (EBRD, 2010). Ancak 2000 MW kapasiteli iki nükleer reaktör inşa edilmesi planlanmaktadır (Tablo 5).

Gürcistan: Siyasi ve ekonomik ortamdaki istikrarsılık, ülkede yenilenebilir enerji kaynaklarına yönelik yatırımların yetersiz kalmasına yol açmıştır. Gürcistan'daki en önemli yenilenebilir enerji kaynakları rüzgâr, jeotermal ve hidro güçtür. 2000 MW'lık rüzgâr enerjisi potansiyeli bulunan Gürcistan, santral kapasitesinin \%50'sini hidro güçten sağlamaktadır. Jeotermal kaynağının kapasitesi 350 MW olup, ispatlanmış rezervi 465 MW civarındadır (EPRD, 2010).

Kazakistan: Önemli ölçüde fosil yakıt rezervlerine sahip olan Kazakistan, elektrik açığı yaşayan bir ülkedir. Kişi başına günlük ortalama $10 \mathrm{kWh}$ elektrik tüketilen bu ülkenin bazı bölgelerinde elektrik tüketimi ortalamanın çok altındadır. Ülke içinde özellikle rüzgâr, güneş ve 1sı pompaları gibi yenilenebilir enerji kullanımları umut verici görünmektedir. Kazakistan yıllık 1,8 TWh rüzgâr gücü, $1 \mathrm{TWh}$ güneş enerjisi ve $170 \mathrm{TWh}$ hidro güç potansiyeline sahiptir. Rüzgâr enerjisi piyasasını geliştirmek amacıyla Kazakistan ile Birleşmiş Milletler Yatırım Programının ortak girişimiyle rüzgâr projesi oluşturulmuştur. Bu projeye göre, öncelikle 2015 yılına kadar toplam 300-500 MW gücünde rüzgâr türbinleri inşa edilecek, 2024 yılına kadar da buna 2000 MW gücünde yeni türbinler eklenecektir. Ayrıca Kazakistan'da güneş enerjisi projeleri de yapılmaktadır. Güneş enerjisini elektriğe dönüştüren fotovoltaik (PV) sektöründe lider bir firmaya da sahiptir. Söz konusu firma ile güneş enerji sistemlerinin temel parçalarının üretimine başlanmaktadır. Ayrıca Ulusal İnnovasyon Fonu'ndan destek alan bir Kazak firması, Almatı'da yıllık toplam $40 \mathrm{MW}$ üretim gücünde bir güneş enerjisi istasyonu inşa etmektedir. Yenilenebilir enerji ürünlerinden biri de 1s1 pompalarıdır. Is1 pompası (heat pump) hem 1sitma hem de soğutma işlevi için kullanılabilen klimadır. Bu pompalar, temel olarak isının bir ortamdan diğerine aktarılması işlemini çift yönlü olarak gerçekleştirmekte ve böylece enerjiyi daha etkin kullanmaktadır. Kazakistan'da 1sı pompaları üretme ve geliştirme üzerine çalışan birkaç firma bulunmaktadır. Örneğin bir donanım fabrikasında 500 1sı pompası kullanarak binanın 1sıtılmasını ve soğutulmasını gerçekleştirmektedir (Carnegie Endowment, 2008).

Kazakistan, bol miktarda petrol ve doğal gaz rezervlerine sahip olmasına karşın, ulusal kalkınma stratejisi doğrultusunda 2030 yılına kadar enerji verimliliği ve enerji tasarrufu sağlamayı hedeflemektedir. Enerji verimliliği politikaları ve programları, Enerji Verimliliği ve İlgili Çevresel Boyut Protokolü’nün odağını oluşturmaktadır. $\mathrm{Bu}$ doğrultuda enerji yoğunluğunun 2020 yılına kadar \%25 azaltılması hedeflenmektedir.

Kırgızistan: Yenilenebilir enerji üzerine yapılan çalışmaların çoğu, ekoloji ve çevre çalışmalarının bir parçasını oluşturmaktadır. Yenilenebilir enerji kaynaklarının kullanımını artırmak amacıyla yasal düzenlemeler yapılmış ve "Yenilenebilir Enerji Kaynakları Yasası" çıkarılmıştır. Ülkede küçük hidro güç santralleri için pilot uygulamalar bulunmaktadır (Carnegie Endowment, 2008). Kırgızistan yenilenebilir enerjiyi geliştirmek için iyi bir potansiyele sahiptir. Önemli ölçüde güneş enerjisine sahip olmasına karşın, güneş projelerini finanse edecek kaynağa sahip olmadığı için bu enerjiden pek yararlanamamaktadır. En yaygın yenilenebilir enerji kaynakları rüzgâr, biyokütle ve hidro'dur. Ülkenin rüzgâr potansiyelinin $1500 \mathrm{MW}$ olduğu tahmin edilmektedir (EBRD, 2010).

Letonya: Avrupa Birliği'ne katılım Letonya için yatırım ortamının oluşmasına ve ekonomik başarının sağlanmasına katkı sağlamıştır. 1998 yılında Enerji Yasası'nı çıkaran Letonya, yenilenebilir enerji kaynaklarından üretilen elektriği yüksek fiyattan satın almaya başlamıştır. 2003 yılında yeni bir tarife sistemine geçmiş ve farklı yenilenebilir enerji kaynağından üretilen elektriğe farklı fiyat uygulamıştır. AB'ye katılmak için Enerji Yasası ile kojenerasyon ve katı atıkla ilgili diğer yasalar kabul edilmiştir. Rüzgâr enerjisinde büyük potansiyele sahip olan Letonya'nın teknik potansiyeli 500 MW'tır. Toplam santral kapasitesinin \%74'ünü hidro güç kapasitesinin oluşturmasına karşın, yeni küçük hidro projeleri oldukça sınırlıdır. Fosil yakıt rezervlerinin sınırlı olması yüzünden biyokütle projeleri oldukça önemlidir. Ancak biyokütle projelerinin önündeki en önemli engel, yüksek yatırım maliyetine sahip olmasıdır. Yüksek 
elektrik fiyatları ve önemli yasal teşvikler nedeniyle Letonya'da yenilenebilir enerji projeleri oldukça ilgi görmektedir (EBRD, 2010).

Litvanya: AB'nin yeni üyelerinden olan Litvanya'da yenilenebilir enerji kaynaklarından üretilen elektriğin uygun fiyatlardan satın alınmasına yönelik yasalar çıkarılmıştır. En önemli yenilenebilir enerji kaynakları biyokütle ve rüzgârdır. Hidro güç çok düşük olup, toplam santral kapasitesinin \%4'ünü oluşturmaktadır. Ancak küçük hidro güç santralleri için bazı firsatlar bulunmaktadır. Litvanya yeni yasal düzenlemelerle yenilenebilir enerjiyi teşvik etmekte, eskiyen termik ve nükleer santralleri kapatmaktadır (EBRD, 2010). Ağustos 2010 itibariyle Litvanya'da 3400 MW kapasiteli 2 nükleer reaktör önerilmektedir (Tablo 5).

Moldova: Enerji kaynakları yönünden Rusya, Ukrayna ve Romanya'ya bağlı olan Moldova net ithalatçı konumundadır. Birincil enerji talebinin yalnızca \%3'ünü yerli kaynaklardan sağlamaktadır. $\mathrm{Bu}$ nedenle Moldova için yenilenebilir enerji kullanımı büyük önem taşımaktadır. Ulusal Enerji Düzenleme Kurumu, elektrik sektörünün yeniden yapılanmasını düzenlemek için kurulmuştur. Ülkede elektrik sektörünün özelleştirilmesi devam etmektedir. Ülkenin rüzgâr enerjisi potansiyeli yaklaşık $1000 \mathrm{MW}$ civarındadır. Hidro güç ise ülkenin santral kapasitesinin yalnızca \%2'sini oluşturmakta, ancak geliştirilmesi için potansiyel bulunmaktadır (EPRD, 2010).

Rusya: ABD, Çin ve Japonya'dan sonra Rusya dördüncü büyük elektrik santrallerine sahiptir. 2008 yılında yaklaşık olarak $914 \mathrm{TWh}$ elektrik üretmiştir. Üretim kapasitesinin yaklaşı \%68'i termik santrallerden, \%21'i hidro, \%10'u nükleer ve \%1'i rüzgâr, jeotermal ve atık 1s1 gibi yenilenebilir enerji kaynaklarından oluşmaktadır (EBRD, 2010). Nükleer enerji santrallerini ilk inşa eden ülke olan Rusya'da, Ağustos 2010 itibariyle toplam kapasitesi 23 GW'a ulaşan 32 nükleer santral faaliyet göstermektedir. Ayrıca 10 inşa halinde, 14 planlanan, 30 önerilen nükleer reaktör bulunmaktadır (Tablo 5). Rusya, yenilenebilir enerji kaynaklarında büyük potansiyele sahiptir. Jeotermal, rüzgâr ve güneş enerjisinden yararlanma olanağ 1 bulunmaktadır.

Tacikistan: En önemli enerji kaynağı kömür olan ülkenin, 12 termik santrali bulunmaktadır. Ülkenin enerji ihtiyacı kömür dışında, petrol, doğal gaz ve hidro güçten sağlanmaktadır. Hidro güç dışında yenilenebilir enerji kaynakları olmamasına karşın, yenilenebilir enerji kaynakları kullanımı ve diğer tip hidro projelerin uygulanması olası görünmektedir. Hidro güç enerji kullanımını artırmak için farklı bölgelere küçük hidro güç santralleri inşa edilmiştir. Ülkenin küçük hidro güç santrallerinden elektrik üretim potansiyeli yıllık 100 TWh'dir. Rüzgâr ve güneş enerjisi potansiyeli olmasına karşın, pilot uygulamalar dışında bu enerji kaynaklarından tam olarak yararlanılamamaktadır (Carnegie Endowment, 2008).

Türkmenistan: Ülkede elektrik santralleri için gerekli kullanılabilir büyük petrol ve doğal gaz yatakları bulunmaktadır. Günümüzde ülkede nüfusun büyük bölümü, devlet desteklediği için kullandığı elektriğe ödeme yapmamaktadır. Bu nedenle yenilenebilir enerji projeleri pek ilgi görmemektedir. Çok büyük rüzgâr ve güneş enerjisi potansiyeli olmasına karşın, bu enerji kaynaklarına yönelik projeler geliştirilmemektedir (EPRD, 2010).

\begin{tabular}{|c|c|c|c|c|c|c|c|c|c|c|}
\hline \multirow{2}{*}{ Ülke } & \multicolumn{2}{|c|}{$\begin{array}{c}\text { Nükleer } \\
\text { Elektrik } \\
\text { Santrali } 2009\end{array}$} & \multicolumn{2}{c|}{$\begin{array}{c}\text { İşletmede olan } \\
\text { reaktörler }\end{array}$} & \multicolumn{2}{c|}{$\begin{array}{c}\text { İnşa } \\
\text { halindeki } \\
\text { reaktörler }\end{array}$} & \multicolumn{2}{c|}{$\begin{array}{c}\text { Planlanan } \\
\text { reaktörler }\end{array}$} & \multicolumn{2}{c|}{$\begin{array}{c}\text { Önerilen } \\
\text { reaktörler }\end{array}$} \\
\cline { 2 - 12 } & $\begin{array}{c}\text { Milyar } \\
\mathrm{kWh}\end{array}$ & $\%$ & No & MW & No & MW & No & MW & No & MW \\
\hline Ermenistan & 2,3 & 45 & 1 & 376 & 0 & 0 & 1 & 1060 & 0 & 0 \\
\hline Beyaz Rus. & 0 & 0 & 0 & 0 & 0 & 0 & 2 & 2000 & 2 & 2000 \\
\hline Kazakistan & 0 & 0 & 0 & 0 & 0 & 0 & 2 & 600 & 2 & 600 \\
\hline Litvanya & 10,0 & 76,2 & 0 & 0 & 0 & 0 & 0 & 0 & 2 & 3400 \\
\hline Rusya & 152,8 & 17,8 & 32 & 23084 & 10 & 8960 & 14 & 16000 & 30 & 28000 \\
\hline Ukrayna & 77,9 & 48,6 & 15 & 13168 & 0 & 0 & 2 & 1900 & 20 & 27000 \\
\hline Dünya & 2560 & 14 & 440 & 375805 & 59 & 60065 & 149 & 163744 & 344 & 365125 \\
\hline
\end{tabular}

Tablo 5. Avrasya Ülkelerinde Nükleer Enerji (2010) Kaynak: World Nuclear Association. 
Ukrayna: Geleneksel olmayan yenilenebilir enerji kaynakları ve küçük hidro güç santrallerini geliştirmek için devletin desteklediği bir programa sahiptir. Yenilenebilir enerji kaynakları için hedef, 2010 yılına kadar santrallerin \%10'una ulaşmaktır. 1996 yılında Ukrayna Cumhurbaşkanı, rüzgâr santrallerinin ulusal öncelikleri olacağını ve 2010 yılına kadar 200 MW'lık rüzgâr santrali kurulacağını bildirmiştir. Bunun 40 MW'lık kısmı gerçekleştirilmiştir. Ukrayna güneş enerjisinde orta düzeyde teknik potansiyele sahiptir. Ayrıca elektrik talebinin \%7'sini hidro güçten sağlamaktadır. $327 \mathrm{MW}$ 'lı potansiyeli olan yeni hidro projeleri vardır. Ukrayna öncelikle 1sı sağlamak için jeotermal kaynaklara sahiptir. Bu kaynağın toplam kurulu gücü 13 MW'tır. Hayvan gübresi, saman ve kereste fabrikası atıklarından oluşan biyokütle potansiyeli ise 4 milyon TEP'tir (EPRD, 2010). Ukrayna'da Ağustos 2010 itibariyle toplam kapasitesi $13 \mathrm{GW}$ olan 15 nükleer santral faaliyet göstermektedir. Ayrıca 2 planlanan, 20 önerilen nükleer reaktör bulunmaktadır.

Özbekistan: Enerji ihtiyacının \%86'sı fosil yakıtlara ve nükleer enerjiye dayanan Özbekistan'ın tek yenilenebilir enerji kaynağı biyoyakıttır. Biyoyakıt, ülkenin enerji tüketiminin \%10,76'sını oluşturmaktadır. Güneş ve rüzgâr enerjisi potansiyeli bulunmasına karşın, yeterince kullanılmamaktadır (Carnegie Endowment, 2008).

Dünyanın diğer ülkelerinde de olduğu gibi, Avrasya ülkelerinde enerji verimliliği ve enerji tasarrufunun sağlanmasına yönelik önemli çalışmalar sürdürülmektedir. Ancak her bir ülkenin hem sahip olduğu doğal kaynakları hem de yakın siyasi geçmişi birbirinden oldukça farklıdır. Dolayısıyla her bir ülkenin enerji durumu ve izlemiş oldukları politikalar da kendine has özellikler taşımaktadır.

\section{Sonuç}

Ekonomik büyüme ve nüfus artı̧̧ı enerji tüketimini artırmış, artan enerji tüketimi de sera gazları, özellikle $\mathrm{CO}_{2}$ emisyonlarını artırarak iklim değişikliğine yol açmıştır. Tüm ülkelerde olduğu gibi Avrasya ülkelerinde de enerji, çevre ve iklim ilişkileri, yenilenebilir enerji kaynaklarına yönelmeyi, enerji verimliliği sağlamayı ve enerji teknolojilerinin kullanımını zorunlu hâle getirmiştir. YEYS açısından yenilenebilir enerji yönetiminin başarılabilmesi için, Avrasya ülkelerinde kurumlar ve ülkelerarası işbirliğine gidilerek küresel ısınmayı önleyecek biçimde hareket edilmesi gerekmektedir. Bunun için fosil yakıt kullanımı azaltılarak, bunun yerine hidrolik, rüzgâr, güneş, jeotermal, biyokütle gibi yenilenebilir enerji kaynaklarının teşvik edilmesi gerekir.

Enerji üretiminde ve temininde sürdürülebilirlik ve yenilenebilirliğin temel stratejileri için; Avrasya ülkelerinde ortak yenilenebilir temiz enerji stratejilerinin işbirliği içinde geliştirilmesi, enerji piyasalarını daha güvenli ve sürekli gelişen bir konuma getirecek ortak stratejilerin benimsenmesi, enerji kaynakları ve iletim hatlarının modernizasyonunda birlikte hareket edilmesi, enerji verimliliği artırılarak Avrasya ortak enerji strateji ve politikaları geliştirilerek küresel enerji stratejileri ile uyumlaştırılması ön plana alınabilir. Bu doğrultuda, Avrasya'da yüksek güneş ve rüzgâr enerjisi potansiyeline sahip ülkeler ya da kentlerde işbirliğine gidilerek, bu kaynaklardan bölgesel olarak yararlanılmasına yönelik projeler geliştirilebilir. Avrasya ülkeleri açısından ortak enerji stratejileri, toplumun ve bireylerin duyarlı davranarak enerji verimliliğini desteklemesi sağlanabilir.

\section{Kaynakça}

- $\quad$ Arıkan, Y. (2006), "Birleşmiş Milletler İklim Değişikliği Çerçeve Sözleşmesi ve Kyoto Protokolü”, Bölgesel Çevre Merkezi, REC Türkiye, Nisan 2006, Ankara, http://iklim.cob.gov.tr/iklim/Files/REC_unfccc.pdf, (31.08.2010).

- Carnegie Endowment (2008), Summary of "Renewable Energy in Central Asia: Enhancing Food Security and Improving Social and Economic Conditions in Remote Locations", Conference Report, November 10, 2008, Tashkent, uzbekistan, http://www.carnegieendowment.org/events/?fa=eventDetail\&id=1252, (15.08.2010). 
- EBRD (2010), Renewable Development Initiative, Country Profiles, http://ebrdrenewables.com/sites/renew/countries/russia/profile.aspx, (15.08.2010).

- $\quad$ EIA (2010), Energy Information Administration, International Energy Outlook 2010, http://www.eia.doe.gov/oiaf/ieo/index.html (31.08.2010).

- IEA (2009) How the Energy Sector can deliver on a Climate Agrement in Copenhagen, Special early excerpt of the World Energy Outlook 2009 for the Bankok UNFCCC meeting, International Energy Agency, http://www.worldenergyoutlook.org/, (25.08.2010).

- IEA (2010), Key World Energy Statistics 2010, http://www.iea.org/publications/free_new_Desc.asp?PUBS_ID=1199, (02.09.2010).

- IPCC, (2007). Working Group III Report "Climate Change 2007: Mitigation of Climate Change", http://www.ipcc.ch/ipccreports/ar4-wg3.htm, (10.08.2010).

- Marşap, A. Narin, M. (2008), “Çağdaş Enerji Yönetiminde Yeni Açılımlar: Ekolojik Çevre, İklim Değişikliği ve Yaşam Kalitesi” VII. Ulusal Temiz Enerji Günleri, 17-21 Aralık 2008, İstanbul.

- $\quad$ Narin, M. ve Akdemir, S. (2006). "Enerji Verimliliği ve Türkiye” UEK-TEK 2006 Uluslararası Ekonomi Konferans1, Türkiye Ekonomi Kurumu 11-13 Eylül 2006, Ankara/ Türkiye.

- Narin, M. (2008), "Fosil Yakıt Kullanımının Çevresel Etkilerinin Azaltılması: Kyoto Protokolü”, Hava Kirliliği ve Kontrolü Ulusal Sempozyumu 2008 Bildiriler Kitabı, 22-25 Ekim 2008, Hatay.

- Nükleer Enerji Dünyası, (2010), Nükleer Enerjinin Tarihçesi, http://www.nukleer.web.tr/, (02.09.2010).

- UN Population Division (2010), World Population Prospects: The 2008 Revision Population Database, http://esa.un.org/unpp/, (03.09.2010).

- UNCCC, (2005). United Nations Climate Change Conference (COP 11 and CMP 1), http://unfccc.int/meetings/cop_11/items/3394.php, (15.08.2010).

- $\quad$ UNCTAD (2010), World Investment Report 2010, http://www.unctad.org/Templates/webflyer.asp? docid $=13423$ \&intItemID=5539\&lang=1\&mode=downloads, (30.08.2010).

- UNFCCC (2010), Status of ratification of the Kyoto Protocol, http://unfecc.int/kyoto_protocol/status_of_ratification/items/2613.php, (02.09.2010).

- World Nuclear Association, (2010), World Nuclear Power Reactors and Uranium Requirements, http://www.world-nuclear.org/info/reactors.html, (02.09.2010). 


\title{
Avrasya Enerji Birliği Mümkün mü?
}

\author{
Ceyhun Haydaroğlu, Bilecik Üniversitesi \\ Çağdaş Zarplı, Bilecik Üniversitesi
}

\begin{abstract}
Is Eurasia Energy Association Possible?

The end of the Soviet hegemony over the Eurasia region after the dissolution of Soviet Union and the terrorist attacks targeting the USA in 11 September 2001, posed a threat for energy transfer. In addition to these, the instable situation in the Middle East brings forward the search for the alternate energy sources. The interest in the energy issue was directed to Eurasia from Middle East. The integration attempts such as energy association between the countries in the Eurasia region, lead up to utilize the resources they have more productively and economic development by promoting the trade within the region. The solution seeking of the countries in Eurasia to the problems in the region and the survival attempts in the growing global competition gave cause for the necessity to make regional cooperation agreements between countries in the region. Considering the fact that the nations in the Eurasia should utilize the resources in the Eurasia in spite of the fact that the USA uses force, the local constituent of Eurasia began to respond. In this context, the object of the study is to develop a point of view for establishing Eurasia Energy Association by discussing the possibility of the integration attempts in the region in a political and economic sense. Solutions will be offered in the following steps with a situation analysis of political and economic conditions necessary for establishing a Eurasia Energy Association, obstacles to establish the desired energy association in the Eurasia region and the encouraging facts.
\end{abstract}

JEL Codes: F15, F59.

\section{Giriș}

Enerji, uluslararası ilişkiler sistemi içerisinde para ve güç kaynağı olarak algılanmaktadır. Enerji kaynaklarının tedarik edilmesi ve hakimiyetinin sağlanması ülkelerin dış politikalarını belirleyen önemli bir faktör olmuştur. Genellikle enerji üretim alanları ile enerji tüketim alanları farklı bölgelerde bulunmaktadır. $\mathrm{Bu}$, beraberinde enerjiye olan talebin artma eğilimi içerisinde olması ülkelerin enerji politikalarını bu sınırlı kaynakları denetim altına alma ve enerji gelirlerinden pay kapma rekabeti içerisine sokmaktadır. Soğuk savaşın sona ermesiyle birlikte uluslararası düzlemde yeni bir dünya düzeni şekillenmeye başlamış ekonomik ve bölgesel çıkar çatışmaları ortaya çıkmış; Avrasya bölgesindeki zengin enerji kaynaklarının kullanımı, tedarik edilmesi ve ulaştırılması ile ilgili çıkar çatışmaları yeni dönem ile birlikte artmıştır.

Avrasya bölgesi zengin enerji kaynakları üzerinde devam eden güç mücadelesi, kaynaklar üzerinde tam hakimiyet gerçekleştirme temelinde, ülkeler arasındaki rekabetten bölgesel ve küresel aktörlerin bir araya gelerek oluşturdukları işbirliğine dayalı rekabete dönüşmüştür. Başlangıçta enerji kaynaklarının çıkarılmasından pay sahibi olunması büyük bir avantaj sağlarken günümüzde enerji kaynaklarını denetim altına alarak bu güce sahip olmak rekabet avantajı getireceğinden bu yöne doğru bir eğilim gözlenmektedir. Bu amaç doğrultusunda enerji kaynaklarına sahip olabilmek için güç mücadelesi içerisine giren taraflar, bu amaca ulaşma doğrultusunda hamlelerini gerçekleştirmektedirler.

Soğuk savaş sonrası dönemde stratejik açıdan önemli bir yeri olan Avrasya bölgesinin hakimiyeti küresel aktörler için vazgeçilmez bir konuma sahiptir. Küresel aktörler, Avrasya bölgesinin zengin enerji kaynaklarını uluslararası piyasalara güvenli ve kendi çıkarları doğrultusunda uygun güzergahlardan ulaştırılması için çeşitli bölgesel işbirliği girişimlerinde bulunmuşlardır. Küresel aktörlerin bölgede etkin güç olma arayışları karşısında Avrasya bölge 
ülkeleri tepkilerini ortaya koymaya başlamışlardır. Bununla birlikte Sovyetler Birliği'nin dağılmasından sonra Avrasya'nın zengin enerji kaynaklarının kendi ulusları arasında paylaşılması gerektiği konusundaki anlayış çerçevesinde bölgesel işbirliği çabaları giderek artmıștır.

Avrasya bölgesinin zengin enerji kaynaklarına sınırsız bir şekilde sahip olmak isteyen ülkeler ve bu ülkelerin gerçekleştirdikleri bütünleşme girişimleri yeni güç odaklarının ortaya çıkmasına neden olmuştur. Bu çalışmanın ilk bölümünde Avrasya bölgesinin petrol ve doğal gaz rezerv ve üretim miktarları, ikinci bölümde ise bölgede oluşturulan bölgesel bütünleşme girişimleri ele alınacaktır. Üçüncü bölümde, Avrasya bölgesinde oluşturulmaya çalışılan çeşitli bütünleşme girişimlerinin önündeki engeller ve sorunlardan bahsedilecek, Avrasya bölgesinin enerji kaynakları üzerinde bölge ülkelerinin ve küresel oyuncuların rolü tartış1lacaktır. Son bölümde ise sonuç kısmı yer alacaktır.

\section{Avrasya Bölgesi Enerji Kaynakları}

Zengin enerji kaynaklarının varlığı, dünyanın bütün küresel güç aktörlerini enerjiye sahip olma dürtüsüyle mücadele içine almakta ve bu aktörlerin bütün ekonomik, siyasi ve askeri imkanlarını ortaya koymalarına neden olmaktadır. Sovyetler Birliği’nin dağılmasıyla birlikte bağımsızlıklarını yeni kazanan cumhuriyetlerin enerji kaynaklarına sahip olması, buna karşın demokrasi ve ekonomi açısından zayıf olmaları, bir yandan dünya ile bütünleşme girişimleri diğer yandan enerji kaynaklarını uluslararası piyasalara ulaştırma konusunda yetersiz kalmaları, küresel aktörlerin bu bölgeye ilgilerinin ve rekabetin artmasına neden olmuştur (Birsel, 2003).

Avrasya bölgesindeki ülkelerde önemli petrol ve doğal gaz rezervleri bulunmasına rağmen, pazara sunumda sorun yaşamaktadırlar. Yeni bir politika arayışı, zengin enerji kaynaklarını kullanmaları doğrultusunda az gelişmiş̧lik olgusundan çıkmalarını ve kendi aralarındaki sorunları çözebilme kabiliyetini ortaya koyan bir anlayış çerçevesinde oluşturulmasını gerektirmektedir. Bölge ülkelerinin bir bölümünde enerji üretimi ya hiç yoktur ya da kendi tüketimlerini karşılayacak boyutta değildir; bir bölümünde ise kendi üretim fazlası bulunmasına karşın bu kaynakları değerlendirebilmek ve uluslararası piyasalara ulaşımını gerçekleştirebilmek için enerji nakil hatları bulunmamaktadır (Emsen ve Karaköy, 2009).

Bağımsızlıklarını yeni kazanan Avrasya bölgesi cumhuriyetlerinin zengin enerji kaynaklarına sahip olması ve bu kaynakların uluslararası piyasalara ulaştııılmasında kullanılan karayolu ve deniz yolu taşımacılığı, boru hatları ve Doğu-Batı enerji koridorunun bulunması, bölgeyi uluslararası diplomasinin ilgi alanı haline getirerek, enerji kaynaklarının elde edilmesi, ulaştırılması ve kullanımı ile ilgili küresel rekabette dikkatleri bu ülkelerin üzerine toplamıştır (Özalp, 2004).

Avrasya bölgesinin petrol kaynakları değerlendirildiğinde 2009 yılı itibariyle dünya rezervlerinin yaklaşı olarak \%9,2'sini, dünya üretiminin ise $\% 16,6$ 'sını oluşturmaktadır. Rusya'nın, bölgede sahip olunan petrol rezerv ve üretimin sırasıly \%5,6'llk ve \%12,9'luk payıyla büyük bir hakimiyeti söz konusudur. Rusya'dan sonra sırasiyla Kazakistan ve Azerbaycan takip etmektedir.

Avrasya bölgesinin doğal gaz rezervleri ve üretimi açısından değerlendirildiğinde dünya rezerv ve üretimin sırasıyla \%30,6'sını ve \%22,6'sını oluşturmaktadır. Bu dağılım içinde petrol rezerv ve üretiminde olduğu gibi Rusya sahip olduğu \%23,7 ve \%17,6'l1k payiyla dünya doğal gaz rezerv ve üretimi içinde birinci sırada yer almaktadır. Bu ülkeyi sırasıyla Kazakistan ve Türkmenistan takip etmektedir.

Özbekistan ve Türkmenistan önemli enerji kaynak rezervlerine sahip olmasına rağmen ihracat potansiyelleri yeterli düzeyde değildir. Bunun nedenleri olarak açık denizlere kıyısı bulunmadığından geçiş güzergahları ve bağımlılık durumları göz önüne alındığında, ürettiği enerji kaynaklarını uluslararası piyasalara sunamamaları veya enerji kaynaklarını yeterli 
sermaye ve teknolojik altyapının olmaması nedeniyle üretememekten kaynaklanan dışa bağımlılık sorunu ortaya çıkmaktadır. $\mathrm{Bu}$ nedenle bölge ülkeleri sahip oldukları enerji kaynaklarının işletilmesi, geliştirilmesi ve ulaşımının sağlanması konularında küresel güçlerle işbirliği arayışı içine girmeleri bir zorunluluk haline gelmiştir (Çelik ve Kalayc1, 2000).

Fosil enerji kaynaklarında bağımlılık oranlarının gereği olarak ülkeler arasında işbirliğine gitmeleri kaçınılmaz görünmektedir. Bölge ülkeleri arasında tarihsel, sosyo-kültürel ve coğrafi bağlılık açısından birbirine benzer özellik taşıyan bu ekonomiler arasında işbirliği arayışının kendileri için hayati önem taşıyan enerji kaynaklarında gerçekleştirilmesi birbirleri ile olan ilişkilerinin gelişimine de katkıda bulunabilmektedir (Öğütçü, 2005).

\section{Avrasya Bölgesinde Bütünleşme Girişimleri}

Avrasya bölgesinde yaşanan sorunlara çözüm arayışları, küresel rekabet içinde ayakta kalabilme mücadeleleri, ülkelerin birbirleri arasında bölgesel işbirliği arayışlarına girmelerini ve anlaşmaların gerçekleştirilmesini zorunlu hale getirmiştir (Kayalar, 2007).

Türkiye'nin öncülüğünde 1992 yılında gerçekleştirilen girişimlerden birini bazı Avrupa ülkeleri ile birlikte Bağımsız Devletler Topluluğu ülkelerini de içeren Karadeniz Ekonomik İşbirliği Teşkilatı oluşturmaktadır. Birlik, Doğu ile Batıyı ekonomik, sosyal ve siyasal bakımdan bir araya getiren bir coğrafyayı kapsamaktadır. Birliğin amacı, bölgede dostluk ve iyi komşuluk ilişkilerinin geliştirilmesiyle barış, istikrar ve refahın sağlanmasına bağlı olarak üye ülkeler arasında etkileşim ve uyumun geliştirilmesidir (Alagöz, vd., 2004).

Üye ülkeler arasında Gümrük Birliği kurulması ve bu bağlamda ortak ekonomik alan oluşturulmasını amaçlayan Avrasya Ekonomik Topluluğu, bölgesel işbirliği anlaşmaları doğrultusundaki girişimlerden en önemlisidir. Topluluk, dünya ekonomisi ve uluslararası ticaret sistemine bütünleşmeyi kolaylaştırmayı, üye ülkelerin üretim seviyelerini birbirine yakınlaştırmayı ve ortak enerji piyasası oluşturmayı da amaçlamaktadır (Dikkaya, 2009).

Orta Asya İşbirliği Örgütü başka bir bölgesel işbirliği anlaşmasıdır. Kuruluş, üye ülkeler arasında ekonomik, siyasal, sosyal ve kültürel alanda işbirliğini; aynı zamanda üye ülkelerin toprak bütünlüğüne yönelik saldırılara karşı da yardımlaşmayı amaçlamaktadır. Ortak Ekonomik Alan Anlaşması bir diğer ekonomik bütünleşme girişimidir. Bu anlaşmanın amacı, üye ülkeler birbirleri arasında mal, hizmet ve sermaye hareketlerini serbestleştirmeyi ve ortak gümrük ve ticaret politikaları uygulamayı hedeflemektedirler. Sovyetler Birliği'nin dağılmasıyla bölgede güvenlik ortamının sağlanması için Ortak Güvenlik Anlaşması imzalanarak, Orta Asya, Batı ve Kafkasya'yı da kapsayacak güvenlik sistemleri oluşturma çalışmalarına girişilmiştir.

Bölgesel istikrarı sağlamaya yönelik bir başka girişim başlangıçta Şanghay Beşlisi adıyla ortaya çıkan ancak sonra yeni katılımlarla Şanghay İş̧irliği Örgütüne dönüşen oluşumdur. Birliğin amacı, bölge ülkeleri arasında sınır anlaşmazlıklarını çözmektir. Bölgesel istikrar ve güvenliği sağlamayı amaçlayan birliğin önemi üye ülkelerin sahip olduğu siyasi, askeri ve ekonomik kapasiteleri göz önüne alındığında ortaya çıkmaktadır. İlk etapta askeri işbirliği şeklinde ortaya çıkan oluşum, Avrasya bölgesinde önemli bir güç merkezi haline gelmiştir (Erol, 2001).

\section{Avrasya Bölgesinde Bütünleşmenin Önündeki Sorunlar}

Avrasya bölgesindeki ülkelerin sınırları sömürgeci devlet tarafından çerçevesi çizilmiş yapay sınırlardır. Sovyet politikasının ürünü olarak "Böl ve Yönet" anlayışına bağlı olarak Türk toplulukları bölünerek etnik cumhuriyetler oluşturulmuştur (Roy, 2000). Bağımsızlıklarını kazanan cumhuriyetler arasındaki sınır çizgileri birbirleri arasında çatışmalara neden olacak biçimde yapay olarak çizilmiştir. Bununla birlikte sadece bölge ülkelerinin kendi arasındaki sınırlar yapay değil; aynı zamanda bölge ülkelerine komşu diğer ülkeler arasındaki sınır çizgileri de yapay şekilde oluşturulmuştur (Henze, 1992). 
Avrasya bölgesi ülkeleri bir yandan giderek güçlenen Çin'in ve Rusya'nın diğer yandan bölge açısından potansiyel bir tehlike oluşturan İran'ın arasında sıkışıp kalmışlardır. Avrasya bölgesinde güvenlik problemlerinin yanı sıra bağımsızlıklarını yeni kazanmaları nedeniyle siyasal, sosyal ve ekonomik sorunlar da ortaya çıkmaktadır. Bunun yanında bölgenin iç istikrarsızlıkları, terörizm gibi potansiyel tehlikeler de bulunmaktadır (Purtaş, 2008).

Güvenlik ihtiyaçları açısından Rusya, Kolektif Güvenlik Anlaşması kapsamında bölge ülkeleri ile sıkı bir bütünleşme çabası içerisine girerken ABD de bölge üzerinde varlığını hissettirmektedir. Avrasya bölgesi ülkeleri hala kendi başlarına güvenliklerini sağlayacak güce ulaşamamışlardır. Bölge ülkeleri arasındaki rekabet ve sorunlar, bölgeyi güçsüz bırakarak bölge dışındaki diğer güçlü devletlerin müdahalesine zemin hazırlamaktadır (Şanlı, 2008).

Avrasya bölgesinde ekonomik işbirliği oldukça zayıf olmakla birlikte piyasa ekonomisi uygulamaları, ekonomik güç ve teknoloji düzeylerinin birbirinden farklı olması nedeniyle ülkelerin gelişmişlik düzeyinin ülkeler arasında farklı olmasını da beraberinde getirmektedir. Avrasya bölgesinde bazı ülkeler serbest bir ekonomik yapıyı benimserken, bazı ülkelerde ise devlet kontrolünün hakim olduğu bir yapının mevcut olması ülkeler arasında hem ekonomik hem de ticari açıdan bir bütünleşme girişimini zorlaştırmaktadır. Aynı zamanda bölge ülkelerinin genel ekonomik yapısının enerji kaynaklarına dayalı olarak şekillendirilmesi bölgesel ticaretin gelişimini de engellemektedir. Ülkeler arasındaki siyasi problemler ise enerji kaynakları ticaretinde sorunların ortaya çıkmasına yol açmaktadır (Somuncuoğlu, 2006).

Avrasya bölgesindeki ülkelerin bölgesel veya küresel aktörler ile yaptıkları stratejik anlaşmalar Avrasya birliğinin oluşumunu engelleyen en önemli engellerden birisidir. Bölge ülkelerinin birbirleri arasındaki anlaşmazlıklar bölgesel işbirliği arayışlarını olumsuz şekilde etkilemektedir. Aynı şekilde bağımsızlığını yeni kazanan cumhuriyetlerin devlet yapısı ve millet anlayışlarını oluşturma çabalarına girişmesi ve uygulamış oldukları rejim yapılarının birbirinden farklı olması bütünleşmeyi zorlaştıran sorunlar olarak ortaya çıkmaktadır. Bölge ülkelerinin küresel aktörler ile mücadele amacı doğrultusunda ortak hareket etmeleri ve ortak bir takım politikalar geliştirmeleri gerekliliği, bölgede bir işbirliğinin kurulmasını zorunluluk haline getirmiştir (Kona, 2001).

Enerji kaynaklarının bölüşülmesinde etki eden ve çözümsüz bir şekilde bekleyen Hazar'ın statüsü belirsizliğini korumaktadır. Hazar'ın statüsünün deniz veya göl olarak kabul edilmesi Hazar'a kıyısı bulunan beş devletin payının bölüşülmesini de etkilemektedir. Hazar'ın statüsü deniz olarak belirlendiğinde Rusya ve İran bundan büyük bir avantaj sağlarken, göl olarak belirlendiğinde ise Azerbaycan, Türkmenistan ve Kazakistan'a yarar sağlamaktadır (Ünüvar, 2004).

Avrasya bölgesinin açık denizlere kıyısının bulunmaması dünya ile bütünleşme noktasında sınırlandırıcı bir rol oynamaktadır. Bununla birlikte hemen hemen tüm ulaştırma yollarının Rusya üzerinden sağlanması, Rusya'yı Avrasya bölgesi ülkelerinin uluslararası piyasalara açılabilmesi için kilit öneme taşımaktadır. Rusya, enerji kaynaklarının ulaşımını sağlayan boru hatları ve kara yolu taşımacılığı sayesinde stratejik bir konuma sahiptir. Bölge ülkeleri arasında ortaya çıkan mevcut ulaştırma sorunları bölgesel bir bütünleşme arayışlarını olumsuz etkilemektedir (Yavuz, 2007).

Avrasya bölgesi enerji kaynaklarının dünya piyasalarına ulaşmasını engelleyen en önemli faktör alt yapının yetersiz olmasıdır. Bu bölgenin mevcut alt yapısını Sovyetler Birliği'nin kendi iç piyasasına göre yapılandırması nedeniyle hemen hemen tüm boru hatları Rusya'dan geçmektedir. Bu nedenle Soğuk Savaş sonrası dönemde kurulan yeni devletlerin transit ülkeler ile kuracakları ilişkiler enerji piyasasının şekillenmesinde önemli bir rol oynayacaktır (Laçiner, 2006).

Avrasya ülkelerinin demokratik kurum ve yapılarının altyapısı yetersizdir. Sovyetler Birliği'nin dağılmasıyla Azerbaycan, Gürcistan, Kazakistan, Kırgızistan, Özbekistan, Tacikistan ve Türkmenistan siyasal anlamda bağımsızlıklarını elde etmişlerdir. Belli bir devlet geleneğine sahip olmayan bu ülkelerin düzgün işleyen demokratik kurum ve kuruluşlara sahip 
olma özelliklerinde yetersizlikler olduğu açıkça görülmektedir. Demokratik altyapıda ortaya çıkan yetersizlikler ekonomik gelişmiş̧liği engelleyebilmektedir (Efegil ve Musaoğlu, 2009).

\section{Sonuç}

Dünyada enerji kaynaklarına sahip olan ülkeler, hem ekonomik hem de siyasi yönden etki altında kalmaktadır. Bu nedenle zengin enerji kaynaklarına sahip olan ülkeler, bir yandan sahip olduğu kaynaklar nedeniyle çeşitli siyasi oyunlarla karşı karşıya gelmekte diğer yandan sahip olduğu enerji kaynaklarını stratejik bir tehdit unsuru olarak kullanmaktadırlar.

Avrasya bölgesinin zengin enerji kaynakları Rusya, İran, Çin, ABD, AB ve diğer güçlerin bu bölge üzerinde nüfuz etme mücadelesine yol açmıştır. Rusya, sahip olduğu zengin enerji kaynakları ile birlikte Avrasya bölgesindeki ülkelerin enerji kaynaklarının taşıma yolları üzerinde bulunması nedeniyle bölge üzerinde yeni bir güç merkezi olmuştur. ABD, Avrasya bölgesindeki zengin petrol ve doğal gaz yataklarına sahip ülkelere yakınlaşması ile bir yandan Ortadoğu petrollerine olan bağımlılığını azaltmak diğer yandan ise Avrasya enerji kaynakları ve boru hatları üzerinde söz sahibi olmak istemektedir. $A B$, enerji güvenliğini sağlamak için enerji çeşitliliğini gerçekleştirmek, bunun yanında hem fosil yakıt rezervlerinin ömürlerinin sınırlı olması hem de petrolde Ortadoğu'ya doğalgazda ise Rusya'ya büyük ölçüde bağımlı olması nedeniyle Avrasya bölgesinin enerji kaynaklarına yönelmiştir.

Sovyetler Birliği'nin dağılmasıyla bağımsızlıklarını kazanan cumhuriyetler, aradan 20 yıl geçmesine, aralarında dil, din, kültür ve tarihi bağların olmasına ve aynı ortak sorunlar ile baş etmeye çalışmalarına rağmen bu bölgede hala bir bölgesel bütünleşmeden bile söz edilememiş olması ilginçtir. Böyle bir ayrışmanın temel faktörlerinden birisini aralarındaki siyasal ve ekonomik gelişmişlik farklılıkları oluşturmaktadır. Günümüzde bölgeler arasındaki benzerliklerden daha fazla, farklılıklar üzerinde durulmaktadır.

Bölge ülkeleri arasındaki ekonomik, siyasi ve sosyal gelişme farklılıkları, ekonomik entegrasyonu engelleyen, ülkelerin korumacı politikalarının yanı sıra bölge ülkeleri arasındaki güvenlik sorunları da aralarında işbirliğinin kurulmasını önleyen unsurdan biridir. Bölgedeki güvenlik sorunlarını etnik milliyetçilik, organize suçlar ve toplumsal sorunlar olarak sınıflandırabiliriz. Bölge ülkeleri arasındaki bütünleşme girişimlerinin önündeki engel olan güvenlik probleminden başka somut olarak görülen devletler arasındaki sınır anlaşmazlıkları gelmektedir.

Avrasya ülkeleri enerji kaynaklarını tamamen çıkar ve fayda ilişkisi açısından değerlendirmekte, ekonomik kalkınmalarını sağlayabilmek için her türlü firsatı değerlendirmeye çalışmaktadırlar. Kendi çıkarları doğrultusunda enerji kaynaklarının çıkarılmasından uluslararası piyasalara ulaştırılmasına kadarki süreçlerin hepsinde imkanlarını sonuna kadar kullanmaktadırlar. Dünyanın önemli küresel aktörleri ise kendilerine avantaj sağlayacak şekilde tüm güçlerini ortaya koymaktadırlar.

Avrasya bölgesindeki ülkelerin aralarında enerji birliği gibi çeşitli bütünleşme girişimlerini gerçekleştirmeleri, mevcut enerji kaynaklarını daha etkin kullanmalarını sağlayarak bölge içi ticaretin gelişmesine ve daha geniş piyasalar için üretimlerini arttırmalarını sağlamaya yardımcı olarak ülkelerin ekonomik gelişmişliğinin artmasına ve Avrasya birliğinin gerçekleştirilmesine önayak olacaktır.

\section{Kaynakça}

- $\quad$ Birsel, 2007. “Avrasya Enerji Kaynaklarında Sınırsız ve Kontrolsüz Hakimiyet”, 2023 Dergisi, 75, s. 32.

- $\quad$ Emsen ve Karaköy, 2009, “Merkezi Asya Ve Kafkas Ekonomilerinde Entegrasyonun Olabilirliği: AB'deki Kömür-Çelik Topluluğu Benzeri Su Ve Enerjide İşbirliği Arayışı”, Ç.Ü. Sosyal Bilimler Enstitüsü Dergisi, 18, s. 195.

• Özalp, 2004. "Büyük Oyunda Hazar Enerji Kaynaklarının Önemi ve Konumu”, 
Panorama Dergisi, 1, s. 1 .

- CÇelik ve Kalayc1, 2000. “Azeri Petrolünün Dünü ve Bugünü”, Avrasya Etütleri Dergisi, 16, s. 121.

- Öğütçü, 2005. Küresel Politikada Orta Asya. Nobel Yayın Dağıtım, Ankara.

- Kayalar, 2007. Avrasya Ülkeleri ile Ticari ve Ekonomik İşbirliği, http://www.kasid.org.tr/ana.php? incmain=icerik/icerik_detay\&incsol=icerik/icerik_sol\&katid=8\&altkatid=7\&icerikid= 11 .

- $\quad$ Alagöz, vd, 2004. “Türk Cumhuriyetleri İle İlişkilerimize Ekonomik Açıdan Bir Yaklaşım”, Selçuk Üniversitesi Sosyal Bilimler Enstitüsü Dergisi, 12, s. 71.

- Dikkaya, 2009. Orta Asya ve Kafkasya Dönüşüm Süreci Ve Uluslararası Ekonomi Politik. Beta Basım, İstanbul.

- Erol, 2001. “Avrasya'da Güç Mücadelesi: Şanghay Beşlisi”, Stratejik Analiz, 14, s. 68.

- Roy, 2000. Yeni Orta Asya ya da Ulusların İmal Edilişi. Metis Yayın, İstanbul.

- Henze, 1992. Whither Turkestan, Rand Paper, California.

- Purtaş, 2008. Orta Asya \& Kafkasya Güç Politikası. USAK Yayınları, Ankara.

- Şanl1, 2008. "Ekonomik Entegrasyon Teorisi Çerçevesinde Avrasya Birliği'nin Olabilirliği”, Atatürk Üniversitesi, İktisadi ve İdari Bilimler Dergisi, 1, s. 26.

- Somuncuoğlu, 2006 “Orta Asya Enerji Oyununda Asya Devleri” 2023 Dergisi, 66, s. 34.

- Kona, 2001. “Orta Asya'da Güç Mücadelesi”, Türk Dünyası Araştırmaları Dergisi, 133, s. 177.

• Ünüvar, 2004. "Yeni Büyük Oyun: Hazar Bölgesinde Rekabet ve Güvenlik Arayışı", Stratejik Öngörü Dergisi, 1, s. 12.

- Y Yavuz, 2007. “Avrasya'da Enerji Eksenli Bitmeyen Büyük Oyun”, 2023 Dergisi, 75, s. 23.

- Laçiner, 2006. "Hazar Enerji Kaynakları ve Enerji-Siyaset İlişkisi”, Orta Asya ve Kafkasya Araştırmaları Dergisi, 1, s. 60.

- Efegil ve Musaoğlu, 2009. Küresel Güç Mücadelesinde Avrasya'nın Değişen Jeopolitiği Yeni Büyük Oyun. Platin Yayınları, Ankara. 


\title{
Girdi-Çıktı Analizi Yaklaşımıyla Kırgızistan İmalat Sanayinin İncelenmesi (2005-2008)
}

\author{
Tuncer Özdil, Kırgızistan-Türkiye Manas Üniversitesi \\ Aynura Turdalieva, Kırgızistan-Türkiye Manas Üniversitesi
}

\begin{abstract}
As is known, there are various economies on the Eurasian continent area, which differ from each other by structure, potential and growth performance. Region's development depends on those economies growth and relationship between them. Viewed from this perspective, it's become actual for Kyrgyzstan to research and evaluate the importance of manufacturing industry contribution to the economy. Given article aimed to study the reached stage in the process of manufacturing industry development, the position in the economy and economic policy tools, recommendations that will bring solutions to the identified problems. Research based on input-output analysis and as basic data used input-output tables prepared for the year 2005 and 2008 by the National Statistics Committee of Kyrgyz Republic. In the paper calculated the linkages among the industrial sector, direct and indirect sectoral demands, defining key sector for Kyrgyzstan's Economy and explained sectoral analysis of production structure. For a better assessment of manufacturing industry, in paper discussed its structure, properties, dynamic aspects of change. The results are as follows: manufacturing industry inadequate in the economy and externally dependent; economy-wide inter-sectoral interaction is weak; manufacture of coke, refined petroleum products; manufacture of chemical products; manufacture of other non-metallic mineral products; manufacture fabricated metal products; manufacture of machinery and equipment calculated as key sectors. Also they are Kyrgyzstan's economy locomotive for economic growth among the other sectors. Therefore, realization of investments will stimulate the production capacity increase of manufacturing industry, strengthening of intersectoral relationships and stable macro-economic planning are important for achieve economic growth.
\end{abstract}

JEL Classification: E23, D57, L52.

\section{Giriş}

Bilindiği gibi, imalat sanayi sanayileşme sürecinin ve dolayısıyla kalkınmanın çekirdeğini oluşturmaktadır. Doğal kaynakları işlemeye dayalı ekonomik büyümenin ülke ekonomisinin temeli olan sanayinin oluşmasına, gelişmesine ve bir bütün olarak piyasa mekanizmalarının ve ekonomik sistemin oluşmasına katkısı çok sınırlı kalmaktadır. İmalat sanayinin gelişmesi üretim türlerinin ve üretim faaliyetlerinin çeşitlendirilmesine, ülkenin sosyal ve ekonomik sorunlarının çözümüne ve ülke ekonomisinin uluslararası rekabet gücünün artmasına ve dünya piyasalarıyla entegre olmasına yol açacaktır. Çalışmamızda Kırgızistan ekomomisi için söz konusu inceleme girdi-çıktı analizi yaklaşımıyla yapılmaktadır. Sektörler arası ilişkileri de kapsayacak şekilde; ileri - geri bağlantı endeksleri hesaplanmakta, sektörlerin yayılma dereceleri ve doğrudan - dolaylı talepler hesaplanarak Hirschman kategorilerine göre kilit sektörler belirlenmekte ve genel olarak sektörel üretim yapısı incelenmektedir. Dış ticaret bakımından da, nihai talep unsurları içerisinde yer alan ihracat vektörü kullanılarak ihracatı karşılamak için gerekli sektörel üretim değerleri hesaplanmaktadır. Buradan elde edilen teknik sonuçlarla sektörün yapısı, kendi içsel dinamikleri ve genel özellikleri birleştirilerek Kırgızistan ekonomisinin kalkınmasına olan potansiyel etkisi değerlendirilmiştir.

\section{Kırgızistan'da İmalat Sanayinin Gelişimi}

1990'lı yılların başlarından bu yana Sovyetler Birliği'nden ayrılmış Orta Asya Cumhuriyetlerinde olduğu gibi Kırgızistan da planlı ekonomiden piyasa ekonomisine geçişin 
sancılarını yaşamaktadır. Geçiş ekonomileri olarak da bilinen kapalı bir ekonomik sistemden yeni çıkan Kırgızistan'da, merkezden planlı ekonomik sistemin yapısından kaynaklanan sorunlar nedeniyle, piyasa mekanizmasına dayalı ekonomik sistem henüz tam anlamıyla uygulanamamaktadır. Diğer Orta Asya Türk Cumhuriyetlerinde olduğu gibi Kırgızistan'da da 1990'lı yıllardan bu yana piyasa mekanizmasına dayalı ekonomik sistemi kurabilmek için bir çok reform uygulanmaya çalıșılmıștır. Ancak geçen 20 yıllık sürede edinilen deneyimler reformların başarısını etkileyen birçok faktörün olduğu şeklindedir. Özellikle eski sistemin genel özellikleri, uygulanan reformların başarısı üzerinde hala önemli etkilerde bulunmaktadır. $\mathrm{Bu}$ özellikler; Sanayi sektöründeki tekelci yapı, Tüketim mallarında kıtlık olgusu ve ürünlerin yetersiz ve kalitesiz oluşu, Bastırılmış enflasyon, Mali dengesizlikler ve gevşek bütçe, Sanayi sektöründe işsizliği teşvik eden sosyal güvenlik uygulamalarının varlığ 1 olarak sayılabilir (Boetke, 2003, s.9). Reformların başarısı kuşkusuz bu unsurların ne ölçüde giderildiği ile ilgilidir. Diğer bir deyişle, bu unsurların sırasıyla piyasa ekonomisi ortamını yaratacak boyuta çekilmesi gerekmektedir. Bu şartlar altında, Kırgızistan İmalat Sanayiinin 2004-08 dönemi üretim yapısı aşağıdaki gibi özetlenebilir. İmalat sanayiini oluşturan sektörlerin üretim hacmi 2005 yılındaki siyasal çalkantıya bağlı olarak oluşan azalma dikkate alınmazsa dönem içerisinde yaklaşık \%66 oranında artmıştır. 2005 yılına göre 2008 yılındaki artış oranı ise \%83'tür. Dönem içerisinde sektörel paylar içerisinde Gıda ve tütün ürünleri üretimi ve Metal anasanayi-Hazır maden ürünleri üretimi sektörleri dikkati çekmektedir. Bu sektörlerin imalat sanayi içindeki payı 2004 yılı için sırasıyla \%18 ve \%55'tir. Bunu \%8 ve \%6'llk payla Diğer metal olmayan mineral üretimi ve Tekstil-konfeksiyon sektörleri izlemektedir. Diğer sektörler çok düşük paylarla yer almaktadırlar. Dönem içerisinde sektörel paylarda ciddi değişiklikler olmamakla birlikte Tekstil-konfeksiyon sektörünün payında artış, Metal anasanayinde ise $\% 55$ 'ten \%49'a azalma vardır. Tarıma dayalı sanayilerden tütün ve gıda sektörüyle metal anasanayii sektörleri dağılma öncesi dönemde de ön plana çıkan sektörler arasında olup dağılma sonrası dönemde de bu sektörler göreceli önemlerini korumaktadırlar (KC, Milli İstatistik Komitesi). Kırgızistan Milli İstatistik verilerine göre, GSYİH'nın faaliyet türüne göre dağılımına bakıldığında da, 2004'te sanayi sektörü \%15'i oluştururken, 2008'de bu oran \% 13 'e gerilemiştir. Sanayi sektörünün tarım ve hizmetler sektörüne göre payının oldukça düşük olduğunu ve dönem içerisinde iyileşmenin sağlanamıyor olmasının önemli bir sorun olduğunu belirtmeliyiz.

İmalat sanayii ihracat ve ithalat açısından değerlendirildiğinde, dönem içerisinde imalat sanayi toplam ihracatı 2004 yılına göre ciddi oranda artış göstermiştir. 2004 yılına göre ihracat artış oranı yaklaşık 7,83 kattır. 2005 yılına göre ihracat artış oranı 8,48 kattır. 2004 yılı için İhracatın sektörel dağılımına bakıldığında da, \%52'lik payla metal anasanayii dikkat çekmektedir. Bu sektörü \%7-\%8 civarı paylarla Tekstil-konfeksiyon, Gıda ve Tütün üretimi, Diğer metal olmayan mineraller üretimi ve \%12'lik payla Petrol damıtma sektörleri izlemektedir. Dönem içerisinde 2008 yılı dağılımına bakıldığında, petrol ürünleri ihracatının payının \%82'ye ulaşarak belirgin biçimde arttığı görülmektedir. Kırgızistan'ın kendi petrolünün olmayışı buna karşılık rafine petrol ürünleri ihracatının artıyor olması ithalata bağımlılı̆̆ 1 daha da arttırmaktadır. İthalatın sektörel dağılımına bakıldığında da, 2004 yılı için rafine petrol ürünleri sektörü $\% 25$ payla dikkat çekmektedir. Bu sektörü \%13 ve \%14'lük paylarla Kimya ve Gıda ve Tütün Ürünleri sektörleri izlemektedir. Diğer imalat sektörlerinin payları genelde \%7-\%8'ler civarındadırlar. Dönem içerisinde ciddi anlamda bir değişiklik olmamakla birlikte, ulaştırma araçları ve donanımı üretimi sektöründe ithalat \%8'den \%16'ya çıkmaktadır. 2004 yılına göre 2008 yılındaki ithalat artış oranı 3,35 kattır. 2005 yılına göre oran 2,71 kattır. Hem ihracat hem ithalattaki hatırı sayılır artışlar dış ticaret açığının daha da artmasına yolaçmıştır.

\section{Kurgızistan İmalat Sanayinin Girdi-Çıktı Yöntemiyle İncelenmesi}

Endüstrilerarası mal ve hizmet akımı çok yönlü ve karmaşık bir yapıya sahiptir. Ulusal ekonominin planlanabilmesi için, her şeyden önce, ekonominin yapısını tanımak ve endüstriler 
arasındaki ilişkileri bilmek gerekir. Bu ilişkilerin belirlenmesinde çeşitli modellere ihtiyaç duyulur. Girdi-Çıktı Analizi de, matematiksel ve istatistiksel analizler yardımıyla, endüstrilerarası ilişkileri tutarlı olarak inceleyen bir modeldir. Bir ekonomik sistemin belirli yapısal özelliklerini tanımlayan bir veriler toplamı ve sistemin belirli bir zaman aralığı içinde belirli bir anındaki davranışını etkileyici ve açıklayıcı analitik bir teknik olarak tanımlanabilir (Todaro, 1987, s.17). Analizin temeli, herhangi bir ülke ekonomisinin kendi içerisinde homojen ya da birbirine benzer mallar üreten endüstrilere bölünebilmesi ve bu endüstrilerin birbirleriyle ve ekonomiyle olan etkileşimlerinin matematiksel ifadesine dayanır. Burada da, imalat sanayiiyle ilgili tüm analizler girdi-çıktı analizi yaklaşımıyla yapılmaktadır (Korum, 1977, Chenery, 1965, Bocutoğlu, 1985).

1991 yılında bağımsızlığını elde ettikten sonra, ekonomide sektörlerarası çözümlemelere yönelik girdi-çıktı analizi çalışmaları 1994 yılında Milli İstatistik Komitesi tarafından başlatılmıştır. Dağılma öncesi dönemde de, eski Sovyetler Birliği’ne bağlı bir cumhuriyet iken, Kırgızistan için 1966 ve 1972 yıllarında girdi-çıktı tablolarının hazırlandığı, ve bu tablolardan elde edilen bilgilerin cumhuriyetin makroekonomik planlamasında kullanıldığı bilinmektedir (Koyçuyev, 1983, s.228.). Ancak dağılma sonrası bu çalışmalarda aksamalar ortaya çıkmıştır. Endüstrilerarası akım tablosu, 1998-2003 yılları arasında yapılan çalışmalarla ilk kez 2003 yılında yayınlanabilmiştir. 2005, 2006 ve 2008 yıllarında 34 sektörlü girdi-çıktı tabloları hazırlanmıştır. Çalışmamızda en son bilgileri içermesi bakımından 2005 ve 2008 yılı girdi-çıktı tabloları kullanılarak imalat sanayinin göreceli konumu, önemi ve dönem içerisindeki yapısal değişimi incelenmeye çalışılmıştır. 2005 ve 2008 yılları endüstrilerarası akım tabloları 34 sektörlü satınalma cari fiyatlarıyla hazırlanmış tablolardır. Tablolarda ihracat bir nihai talep unsuru olarak düşünülerek II. Bölmede kolon vektör olarak yer alırken, ithalatta da, rakip tamamlayıcı ithalat ayrıştırması yapılamadığından, ithalatın tamamen rakip ithalat olduğu varsayımı kabul edilmiş, sektörel ithalata bir arz kaynağı olarak nihai talep unsurları içerisinde eksi (-) değerli kolon vektör olarak yer verilmiştir. Çalışmamızda da hesaplamalar bu durum dikkate alınarak net değerler üzerinden yapılmıştır. Her iki tabloda da tüm sektörler aynı sıra numarasıyla aynı yerde yeralmaktadırlar. 34 Sektör içerisinden 06-15 numaralar arasında kalan sektörler genel olarak imalat sanayini tanımlayan sektörler olmaktadırlar. Bu nedenle çalışmada 06-15 numaralı imalat sektörleri kullanılarak Kırgızistan İmalat Sanayinin ekonomi genelindeki göreceli konumu ve kendi arasındaki ekonomik ve teknolojik ilişkileri açıklanmaya çalışılmıştır. Genel olarak sektörel üretim yapısını inceleyebilmek için girdi-çıktı tablolarında yeralan sektörel üretim, ihracat ve ithalat değerleriyle bunların sektörel dağılımları Tablo 1'de gösterilmiştir. Sektörel üretimin oransal dağılımına bakıldığında, hem 2005 hem de 2008 yıllarında 12 numaralı Metal anasanayi sektörünün payı \% 9,7 ve \%9,3'tür. Bunu ikinci sırada 2005 'te $\%$ 6,2 ve 2008 'de \%5,9 oranlarıyla 06 numaralı Gıda ve Tütün Ürünleri Üretimi sektörü izlemektedir. Ardından 11 numaralı Diğer metal olmayan mineral üretimi sektörü 2005 'te $\% 2,04$ ve 2008 'de \%2,2 paylarla, 07 numaralı Tekstil, Konfeksiyon Deri ve Deri Ürünleri Üretimi 2004 yılı için \%1,72 ve 2008 yılı için \%1,74'lük paylarla dikkati çeken imalat sektörleri olmaktadırlar. İmalat sanayinin ekonomi genelindeki toplam üretim payı 2005 'te $\% 23$ iken 2008 'de \%22,5 civarında olmaktadır. İmalat sanayinin üretim paylarına bakıldığında, dönem içerisinde önde gelen sektörlerin göreceli önemini korumakla birlikte arada sektörel paylarda küçük değişmelerin olduğu görülmektedir. Sektörlerin ihracat payları incelendiğinde, 2005 ve 2008 yılları arasında önemli ölçüde değişmeler vardır. Metal anasanayii 2005 'te \% 35,57, 2008'de \% 23,56'lık paylarla ilk sirada yer almaktadır. 2005'te Kok, Petro-Kimya, Kimya, Lastik ve Plastik Üretimi \% 11,8'lik payla ikinci sıradayken, 2008'de de yerini korumuş, ama sektörel payda ciddi bir azalma ortaya çıkmıştır. 2008'de sektörün ihracat payı $\% 4,3$ olarak gerçekleşmiştir. Diğer sektörlerin payları ise \%5'ten küçüktür. Dönem içerisinde sektörel ihracat paylarında genel olarak azalma eğilimi görülmektedir. Ithalat bakımından ise 2005 'te ilk sirada \% 30,2'lik payla Kok, Petro-Kimya, Kimya, Lastik ve Plastik Üretimi, ikinci sırada \% 13,9'luk payla Makine-Teçhizat Üretimi, ardından \% 10,2'lik payla Gıda ve Tütün Ürünleri Üretimi sektörü gelmektedir. 2008'de ise aynı sıralama ve sektörel paylarda önemli ölçüde azalma eğilimi söz konusudur. İmalat sektörünün genel ekonomi içindeki toplam ithalat 
ve ihracat paylarına bakıldığında hem ihracat hemde ithalat oranlarında gerileme olduğu görülmektedir (Tablo 1).

Girdi-Çıktı analizine göre, elde edilen Leontief ters matrisi nihai talebi oluşturan unsurlara ait kolon vektörlerle çarpıldığında ilgili nihai talep unsurunu karşılayabilmek için gerekli sektörel üretimler bulunabilir (Aydoğuş, 1999, Korum, 1963, Kepenek, 1977). Sektörel ihracatı karşılamak için gerekli sektörel üretimlerin bulunabilmesi için nihai talep unsurları içerisinde yeralan ihracat kolon vektörü ters matris ile çarpılmıştır. Elde edilen sonuçlar tablo 1'de gösterilmiştir. 2005 yılı verilerine göre, 08 Kereste ve Ahşap Doğrama Üretimi, 10 Kok, PetroKimya, Kimya, Lastik ve Plastik Üretimi, 15 Diğer sanayi sektörleri ikincil üretim; 2008'de ise 07 Tekstil, Konfeksiyon Deri ve Deri Ürünleri Üretimi, 08 Kereste ve Ahşap Doğrama Üretimi, 09 Kağıt ve Karton Üretimi, 10 Kok, Petro-Kimya, Kimya, Lastik ve Plastik Üretimi, 12 Maden (metal) sanayi, 13 Hazır (işlenmiş) maden mamulleri üretimi, 14 Makine ve teçhizat üretimi imalat sektörlerinde ihracat için gerekli üretim sektör üretiminden büyük çıkmıştır (Tablo 1). Bunun nedeni ilgili sektörlerde talebin önemli bir kısmının ithalatla karşılanıyor olmasıdır. Bu da ekonomide genel olarak dışa bağımlılık sorununun bulunduğu izlenimini desteklemektedir. Ekonomi genelinde sektörlerarası ilişkilerin çözümlenmesinde ileri ve geri, doğrudan ve dolaylı bağlantı etkileri hesaplanmıştır (Öney, 1983, Kepenek, 1991, Bulmer, 1982). Tablo 2'de görülebileceği gibi, 2005 yılında toplam 10 tane alt imalat sektöründen 6 tanesinin ileri bağlantı endeksi 1'den büyük çıkmıştır. Bu sektörler 06 Gıda ve tütün ürünleri üretimi, 09 Kağıt ve karton üretimi; yayın ve basım, 10 Kok kömürü üretimi; petrol damıtma (rafine); kimya sanayi; lastik ve pls. Ür., 11 Diğer metal olmayan mineral üretimi, 12 Hazır (işlenmiş) maden mamulleri üretimi ve 14 Makina-Teçhizat üretimi alt sektörlerdir. 2008 yılında da, ileri bağlantı endeksi 1'den büyük çıkan sektör sayısı 5'tir. Bu sektörler 07 Tekstil ve Konfeksiyon Sanayi Deri ve Deri Ürünleri Üretimi, 08 Kereste ve Ahşap Doğrama Üretimi, 10 Kok kömürü üretimi; petrol damıtma (rafine); kimya sanayi; lastik ve pls., 12 Maden (metal) anasanayii ve 14 Makine-Teçhizat Üretimi imalat alt sektörleridir. İleri bağlantı etkileri bakımından 06 Gıda ve Tütün ürünleri üretimi sektörü 2008 yılında bağlantı 1'den küçük çıkan sektör olmuştur. Geri bağlantı etkileri bakımından 15 no'lu Diğer sanayi sektörleri ve ikincil işlemeler sektörü dışında tüm alt sektörlerde bağlantı endeksi 1'den büyük çıkmıştır. 2008 yılında ise burada adı geçen sektörün geri bağlantı endeksi 1'den büyük çıkmış, fakat bu kez 14 no'lu Makina-teçhizat üretimi alt sektöründe endeks gerileyerek 1'den küçük çıkmıştır (Tablo $2)$.

Burada hesaplanan endekslerin yorumlanmasında, 1'den küçük endeks sayıları sektörün etkisinin; ortalamanın altında, 1'e eşit endeks sayıları, tam ortalamaya eşit ve 1'den büyük endeks sayıları ise ortalamanın üzerinde olduğu anlamına gelmektedir. 2005 ve 2008 yılları ileri ve geri bağlantı etkileri için hesaplanan yayılma derecelerine bakıldığında tüm sektörlerde katsayıların hepsi 0'dan oldukça fazla büyük çıkmıştır. Buradan genel olarak ekonomi genelinde sektörler arası etkileşimin zayıf olduğunu söyleyebiliriz. İleri ve geri bağlantı etkilerinin en önemli sonuçlarından bir tanesi ekonomik planlamada önemli bir kavram olan kilit sektörlerin belirlenebilmesi olmaktadır. Elde edilen sonuçlara göre 2005 yılında, 10 tane imalat sanayi alt sektöründen 5 tanesi kilit sektör özelliği taşımaktadır. Bunlar: 06. Gıda ve tütün ürünleri üretimi, 09. Kağıt ve karton üretimi; yayın ve basım, 10. Kok kömürü üretimi; petrol damitma (rafine); kimya sanayi; lastik ve pls. Ür., 11. Diğer metal olmayan mineral üretimi, 14. Makine ve teçhizat üretimi, 15. Diğer sanayi sektörleri ve ikincil işlemler sektörleri kilit sektör olma özelliğine sahiptirler. 2008 yılında her iki etkinin yüksek olduğu kilit sektör sayıs1 4'e gerilemekte ve 07.Tekstil ve konfeksiyon sanayi; deri ve deri ürünleri üretimi 08.Kereste ve ahşap doğrama üretimi 10.Kok kömürü üretimi; petrol damıtma (rafine); kimya sanayi; lastik ve pls. Ür. ve 12.Maden (metal) sanayi sektörleri kilit sektör konumuna gelmektedirler. Dönem içerisinde 10 no'lu Kok kömürü üretimi; petrol damıtma (rafine); kimya sanayi; lastik ve pls. Ür. sektörü dışında 2005 'teki tüm kilit sektörler 2008 'de bu özelliklerini yitirmişlerdir. Ancak genel olarak bakıldığında, söz konusu kilit sektörler üretim payları oldukça düşük sanayi sektörleri olmaktadırlar. Bu başı başına ekonominin hızla 
gelişmesinin ve büyümesinin önünde bir engel oluşturmakla birlikte, bu imalat sanayi alt sektörlerinin bu özellikleri nedeniyle geliștirilmesinin önemli olduğunu düşünüyoruz. Burada elde edilen sonuçların yorumlanmasında, ekonomide ithalata olan bağımlılığın ve ithalatın ağırlığının özellikle dikkate alınması gerektiğini belirtmeliyiz. Burada tanımlanan kilit sektörlerin üretim paylarının çok düşük olması ve sektörel üretimlerde ihracatı karşılamak için gerekli üretimin sektör üretiminden çok büyük çıkması ihracat talebinin ithalatla karşılanabileceği düşüncesini akla getirmektedir. Dolayısıyla burada elde edilen sektörel ilişkilerin üretime dayalı olarak değil, tamamen talebe bağlı olarak ortaya çıktığını belirtmeliyiz.

\section{Sonuç}

Kırgızistanda İmalat sanayinin ülke ekonomisi içindeki göreceli payı oldukça düşük çıkmıştır. Sektörel ihracatın önemli bir kısmı ithalatla karşılanmaktadır. Tüm sektörlerde belirgin olarak ithalat payı yüksektir, hatta bazı sektörlerde sektörel ithalat sektörel üretimden daha yüksek çıkmaktadır. Bu durum Kırgızistan ekonomisinin genel olarak ithalata olan bağımlılığın bir göstergesi olarak görülebilir.

Dağılma öncesi Kırgızistan'da enerji üretimi, su kaynaklarının kullanımı, gıda, hafif sanayi, makine ve teçhizat, demir çelik, madencilikte altın çıkarılması ve işlenmesi ile ilgili imalat sektörlerinin önemli olduğu bilinmektedir. Ancak dağılma sonrası ekonomik ve sosyal sistemdeki köklü değişmeler diğer dağılan ülkelerle olan ilişkiler, finansal yetersizlikler sonucu günümüzde bu sektörlerde üretim iyice düşmüş. Bunun yerine talebi karşılamaya dönük ithalat hızla artmıştır. Kilit sektör olarak belirlenen sektörlerin üretim paylarının çok düşük olmakla birlikte bazı sektörlerin payları azalma eğilimlidir. Araştırmanın yapıldığı çok kısa bir dönem içerisinde dahi üretim yapısının çok değişken olduğu görülmektedir. Üretimin önemli bir kısmı ithalatla karşılanmaktadır. Çoğu sektörde, ihracatı karşılamak için gerekli üretim sektörün kendi üretiminden daha çok çıkmıştır. İleri ve geri bağlantı etkilerine göre sektörler arası etkileşim zayıftır. Ekonomi genelinde kilit sektörler üretim yapısına göre değil, iç ve dış talebe göre oluşmaktadır. Tüm bunlar; söz konusu sektörlerin ekonomi üzerinde uzun dönemli olumlu etki yaratması yerine kısa dönemli etkiler yaratmasına yol açmakta, piyasa koşullarına bağlı olarak ekonominin dengesiz büyümesine neden olmaktadır. Sonuç olarak dönem içinde imalat sanayi alt sektörleri; ekonomik büyümeyi sirtlayamayan, lokomotif sektör olma özelliği taşımayan sektörler olarak ortaya çıkmaktadırlar. Sektörlerin ileri ve geri bağlantı etkileri ve yayılma dereceleri incelendiğinde, sektörlerin kendi üretimi için, başka sektörlerden hammadde ve yarımamül talebinin, yani kendisine girdi sağlayan sektörlerde talep yaratma ve diğer sektörler için arz yaratma özeliklerinin çok zayıf ve yetersiz kaldığı anlaşılmaktadır.

Bununla birlikte imalat sanayinde sabit sermaye unsurlarının (amortisman, yenilenme) aşınma katsayıları oldukça yüksektir. 2005 'te $\%$ 53,5 iken 2008 'de bu katsayı $\% 48,8$ 'dir. Sabit sermaye unsurlarının yenilenme oranları ise 2005 'te $\% 16,4,2008$ 'de ise $\% 15,9$ olmuștur (K.C. Milli İstatistik Komitesi). Buradan imalat sanayinin ciddi bir modernizasyona ihtiyaç duyduğu anlaşılmaktadır. Kırgızistan'da sürekli ve kalıcı ekonomik kalkınma ve gelişmeyi sağlamak için üretim kapasitesini arttırıcı yatırımlara ihtiyaç vardır. Bunun için de sermaye gereklidir. Hızla sermaye yetersizliğini önleyecek șekilde ülkeye yabancı sermayeyi çekecek uygun politikalar belirlenmelidir. Ancak bu politikalar belirlenirken yabanc1 sermayenin hangi sektörlerde değerlendirileceği veya yatırımların hangi sektörlere kanalize edilmesi gerektiği

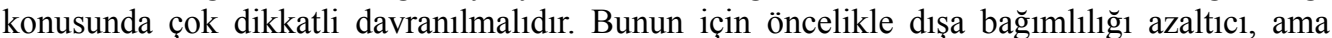
ülkedeki üretim potansiyelini harekete geçirecek sektörlere ağırlık verilmelidir. İlk başlangıçta Tarıma dayalı sanayiler özellikle tekstil ve gıda sektörleri Kırgızistan için avantajlı sektörler olabilir. Bu sektörlere yatırımı teşvik edecek yasal ve idari düzenlemelerin yapılması ve genel olarak ekonomik sistemdeki, piyasalardaki aksaklıkları giderecek düzenlemelerin hızla yaşama geçirilmesi gerekmektedir. Bunun yanısıra tüm ekonomi genelinde olduğu gibi imalat sanayiinde de, kurumsal alt yapısının iyileştirilmesi, üretici ve tüketici arasında ilşkilerinin 
düzenlenmesi ve yönetilmesi rekabetçi fiyatların oluşumunda önemli olacaktır. Modernizasyon ile ilgili AR-GE’ye dayalı sektörel araştırmalar, zamanla innovasyonların uygulanması için zemin hazırlayacak, böylelikle imalat sanayiinde oluşacak gelişmelerle kapasite artışları yeni istihdam olanaklarını ortaya çıkaracak ve bu da işsizlikle mücadelede ciddi avantajlar sağlayacaktır. Bununla birlikte imalat sanayisinin gelişmesi; iç piyasanın genişlemesine, yerli ve yurt dişı üreticilerle rekabet ortamının yaratılmasıyla, ekonominin genel olarak rekabet gücünün de artmasına neden olacaktır. İlk başlangıçta bölgesel ekonomik entegrasyonu artıracak şekilde gerçekleştirilecek bölge ülkeleri ile ekonomik ilişkiler, imalat sanayinin de gelişmesiyle daha da güçlenecek, entegrasyonu bölgeden dünya geneline yayacaktır. $\mathrm{Bu}$ nedenle imalat sanayi mutlaka ekonomide hakettiği konuma getirilmelidir. Ancak bu yolla kalıcı ve sürekli ekonomik büyüme ve kalkınmanın gerçekleştirilebileceği unutulmamalıdır.

\section{Kaynakça}

- Aydoğuş O., 1999. Girdi-Çıktı Modellerine Giriş, Gazi Kitabevi Ankara.

- Bocutoğlu, E., 1985, Girdi - Çıktı Analizine Giriş, Karadeniz Üniversitesi İktisadi ve İdari Bilimler Fakültesi Ders Notları, Yayın No:23, Trabzon.

- Boettke, P., J., 2004, "İs the Transition to the Market too Imported to be left to the market", Erişim: http://www.econ.nvu.edu (12.03.2004)

- Bulmer, T., V., 1982, Input Output Analysis in Developing Countries, John Wiley Sons Ltd. Ş.ti, New-York.

- Chenery H.B, Clark P.E, 1965. Endüstrilerarası İktisat, (Çev. Cemil Çınar), ODTÜ, Ankara.

- Kepenek Y. 1977. Türkiye İmalat Sanayiinin Üretim Yapısı (1963-1973), ODTÜ, Ankara.

- $\quad$ Kepenek Y., 1991.Türk İmalat Sanayiinin Üretim Yapısı, Friedrich Ebert Vakfı Araştırma Sonuçları, İstanbul.

- Korum U., 1963. Input Output Analizi, Sevinç Matbaası, Ankara.

- Korum U., 1977. Türk İmalat Sanayi ve İthal İkamesi : Bir Değerlendirme, Ankara Üniversitesi Siyasal Bilgiler Fakültesi Yayınları No:408, Ankara.

- Koyçuyev T., SSCB Ülkerinde Dengeli Ekonomik Büyüme Özelliklerinin Analizi ve Teorik Problemler, Doktora Tezi, Moskova İktisat Enstitüsü, Moskova-1983.

- Öney E., 1983. İktisadi Planlama, 3. Bask1, A.Ü.S.B.F. Yayın No:526, Ankara.

- Todaro M.P., 1987. Kalkınma Planlaması (Modeller ve Yöntemler), (Çev. Orhan Sezgin), İstanbul.

- K.C. Milli İstatistik Komitesi. 2005-08 Yılları Girdi-Çıktı Sonuç Tabloları, BişkekKırgızistan

- Экономика Кыргызской Республики: Учеб. Пособие. - Б.: КТУМ, 2003. - 487 c.

- Национальный статистический комитет КР. Промышленность Кыргызской Республики 2004-2008. Годовая публикация, Бишкек 2009. 
Tablo 1: 2005 ve 2008 Ylllarl Kırgızistan Ekonomisinin Üretim Yapısı (milyar som)

\begin{tabular}{|c|c|c|c|c|c|c|c|c|}
\hline $\begin{array}{l}\text { Sira } \\
\text { no }\end{array}$ & $\begin{array}{l}\text { Ekonomik } \\
\text { Sektörler }\end{array}$ & Üretim & $\begin{array}{l}\% \\
\text { pay }\end{array}$ & ihracat & $\begin{array}{l}\% \\
\text { pay }\end{array}$ & İthalat & $\begin{array}{l}\% \\
\text { pay }\end{array}$ & $\begin{array}{l}\text { Sektörel } \\
\text { üretimde } \\
\text { ki \% pay }\end{array}$ \\
\hline 06 & $\begin{array}{lll}\text { Gida } & \text { ve } & \text { tütün } \\
\text { ürünleri } & & \\
\end{array}$ & 12642.300 & 6,21 & 1.107.229 & 2,93 & 6.017 .300 & 10,21 & 8,75 \\
\hline 07 & $\begin{array}{l}\text { Tekstil ve } \\
\text { konfeksiyon sanayi; } \\
\text { deri ve deri ürünleri }\end{array}$ & 3.508 .700 & 1,72 & 1.199 .889 & 3,18 & 4.826 .300 & 8,18 & 34,19 \\
\hline 08 & $\begin{array}{l}\text { Kereste ve ahşap } \\
\text { doğrama üretimi }\end{array}$ & 107.100 & 0,05 & 372.905 & 0,98 & 804.900 & 1,36 & 348,18 \\
\hline 09 & $\begin{array}{l}\text { Kağıt ve karton } \\
\text { üretimi; yayın ve } \\
\text { basım }\end{array}$ & 734.400 & 0,36 & 67.005 & 0,17 & 1.155 .600 & 1,96 & 9,12 \\
\hline 10 & $\begin{array}{lr}\text { Kok } & \text { kömürü } \\
\text { üretimi; petrol } \\
\text { damıtma (rafine); } \\
\text { kimya sanayi; lastik } \\
\text { ve pls. ür. }\end{array}$ & 2.695 .000 & 1,32 & 4.477.616 & 11,86 & 17.824 .400 & 30,24 & 166,14 \\
\hline 11 & $\begin{array}{lr}\begin{array}{l}\text { Diğer } \\
\text { olmayan }\end{array} & \text { metal } \\
\text { üretimi } & \text { mineral } \\
\end{array}$ & 4.159 .500 & 2,04 & 345.737 & 0,91 & 605.200 & 1,02 & 8,31 \\
\hline 12 & $\begin{array}{ll}\begin{array}{l}\text { Maden } \\
\text { sanayi }\end{array} \quad \text { (metal) } \\
\end{array}$ & 19.758 .800 & 9,71 & 13.421 .491 & 35,57 & 1.942 .500 & 3,29 & 67,92 \\
\hline 13 & $\begin{array}{l}\text { Hazır (işlenmiş) } \\
\text { maden mamulleri }\end{array}$ & 515.000 & 0,25 & 141.046 & 0,37 & 1.304 .400 & 2,21 & 27,38 \\
\hline 14 & Makine ve teçhizat & 2.429 .900 & 1,19 & 1.485 .185 & 3,93 & 8.215 .400 & 13,94 & 61,12 \\
\hline 15 & 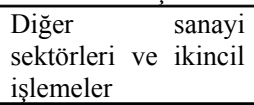 & 280.300 & 0,13 & 442.977 & 1,17 & 631.200 & 1,07 & 158,03 \\
\hline & Toplam & 46.831 .000 & $\begin{array}{r}23,0 \\
1 \\
\end{array}$ & 23.061 .084 & 61,11 & 43.327 .200 & 73,51 & \\
\hline $\begin{array}{l}\text { Sira } \\
\text { no }\end{array}$ & $\begin{array}{l}\text { Ekonomik } \\
\text { Sektörler }\end{array}$ & Üretim & $\begin{array}{l}\% \\
\text { pay }\end{array}$ & ihracat & $\begin{array}{l}\% \\
\text { pay }\end{array}$ & İthalat & $\begin{array}{l}\% \\
\text { pay }\end{array}$ & $\begin{array}{l}\text { Sektörel } \\
\text { üretimde } \\
\text { ki \% pay } \\
\end{array}$ \\
\hline 06 & $\begin{array}{lll}\text { Gida } & \text { ve } & \text { tütün } \\
\text { ürünleri } & & \\
\end{array}$ & 23.395 .900 & 5,95 & 3.590 .079 & 3,62 & 13.527 .400 & 7,57 & 23,77 \\
\hline 07 & $\begin{array}{l}\text { Tekstil ve } \\
\text { konfeksiyon sanayi; } \\
\text { deri ve deri ürünleri }\end{array}$ & 6.952 .300 & 1,76 & 4.348 .028 & 4,39 & 10.636 .800 & 5,95 & 171,29 \\
\hline 08 & $\begin{array}{l}\text { Kereste ve ahşap } \\
\text { doğrama üretimi }\end{array}$ & 213.200 & 0,05 & 32.523 & 0,03 & 2.273 .500 & 1,27 & 175,95 \\
\hline 09 & $\begin{array}{l}\text { Kağıt ve karton } \\
\text { üretimi; yayın ve } \\
\text { basım }\end{array}$ & 1.266 .000 & 0,32 & 277.026 & 0,27 & 1.768 .000 & 0,98 & 184,79 \\
\hline 10 & $\begin{array}{l}\text { Kok kömürü } \\
\text { üretimi; petrol } \\
\text { damıtma (rafine); } \\
\text { kimya sanayi; lastik } \\
\text { ve pls. ür. } \\
\end{array}$ & 5.825 .400 & 1,48 & 3.059 .011 & 3,08 & 43.713 .400 & 24,47 & 727,65 \\
\hline 11 & $\begin{array}{lr}\begin{array}{l}\text { Diğer } \\
\text { olmayan }\end{array} & \text { metal } \\
\text { üretimi } & \text { mineral } \\
\text { ürayal }\end{array}$ & 8.956 .600 & 2,27 & 3.731 .805 & 3,76 & 2.731 .300 & 1,52 & 55,80 \\
\hline 12 & $\begin{array}{ll}\begin{array}{l}\text { Maden } \\
\text { sanayi }\end{array} & \text { (metal) } \\
\end{array}$ & 36.738 .400 & 9,34 & 23.328 .974 & 23,56 & 4.294 .800 & 2,40 & 111,46 \\
\hline 13 & $\begin{array}{l}\text { Hazır (işlenmiş) } \\
\text { maden mamulleri }\end{array}$ & 849.300 & 0,21 & 302.147 & 0,30 & 3.168 .900 & 1,77 & 218,25 \\
\hline 14 & Makine ve teçhizat & 3.101 .800 & 0,78 & 2.286 .742 & 2,30 & 35.910 .200 & 20,10 & 438,83 \\
\hline 15 & 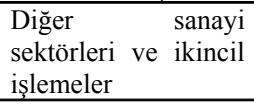 & 1.129 .800 & 0,28 & 735.239 & 0,74 & 1.201 .700 & 0,67 & 77,58 \\
\hline & Toplam & 88.428 .700 & $\begin{array}{r}22,5 \\
0 \\
\end{array}$ & 41.691 .579 & 42,10 & $\begin{array}{r}119.226 .00 \\
0 \\
\end{array}$ & 66,74 & \\
\hline
\end{tabular}


Kaynak; KC, Milli İstatistik Komitesi, Girdi-Çıktı Sonuç Tabloları, 2005-2008.

Tablo 2: 2005 ve 2008 Yılları Kırglzistan Ekonomisi Doğrudan ve Dolaylı İleri ve Geri Bağlantı Etkileri ve Kilit Sektörleri

\begin{tabular}{|c|c|c|c|c|c|c|c|c|}
\hline \multicolumn{9}{|c|}{2005 Y11ı Bağlantı Etkileri, Endeksleri, Yayılma Dereceleri ve Kilit Sektörleri } \\
\hline \multirow[t]{2}{*}{ Sira no } & \multirow[t]{2}{*}{$\begin{array}{l}\text { Ekonomik } \\
\text { Sektörler }\end{array}$} & \multicolumn{2}{|c|}{$\begin{array}{c}\text { Doğrudan ve } \\
\text { Dolaylı Bağlantı } \\
\text { Etkileri }\end{array}$} & \multicolumn{2}{|c|}{$\begin{array}{c}\text { Bağlantı } \\
\text { Endeskleri }\end{array}$} & \multicolumn{2}{|c|}{ Yayılma Dereceleri } & \multirow{2}{*}{$\begin{array}{c}\text { Hirschman } \\
\mathrm{n} \\
\text { Kategorileri }\end{array}$} \\
\hline & & İleri & Geri & İleri & Geri & İleri & Geri & \\
\hline 06 & $\begin{array}{c}\text { Gida ve tütün } \\
\text { ürünleri üretimi }\end{array}$ & 2.6847 & 2.7960 & 1,1728 & 1,2215 & 0.9347 & 2.8785 & 1 \\
\hline 07 & $\begin{array}{c}\text { Tekstil ve } \\
\text { konfeksiyon } \\
\text { sanayi; deri ve } \\
\text { deri ürünleri } \\
\text { üretimi } \\
\end{array}$ & 2.0044 & 2.8212 & 0,8756 & 1,2324 & 4.7711 & 2.8436 & 2 \\
\hline 08 & $\begin{array}{c}\text { Kereste ve } \\
\text { ahşap doğrama } \\
\text { üretimi } \\
\end{array}$ & 1.9958 & 2.5998 & 0,8718 & 1,1357 & 4.1104 & 3.1489 & 2 \\
\hline 09 & $\begin{array}{c}\text { Kağıt ve karton } \\
\text { üretimi; yayın } \\
\text { ve basım } \\
\end{array}$ & 2.3446 & 2.5141 & 1,0242 & 1,0983 & 0.6686 & 3.4100 & 1 \\
\hline 10 & $\begin{array}{c}\text { Kok kömürü } \\
\text { üretimi; petrol } \\
\text { damitma } \\
\text { (rafine); kimya } \\
\text { sanayi; lastik ve } \\
\text { pls. Ür. } \\
\end{array}$ & 8.6310 & 2.7863 & 3,7705 & 1,2172 & 1.3671 & 3.2699 & 1 \\
\hline 11 & $\begin{array}{c}\text { Diğer metal } \\
\text { olmayan mineral } \\
\text { üretimi }\end{array}$ & 2.3514 & 2.6020 & 1,0272 & 1,1367 & 2.7594 & 2.5839 & 1 \\
\hline 12 & $\begin{array}{c}\text { Maden (metal) } \\
\text { sanayi }\end{array}$ & 3.2354 & 2.7047 & 1,4134 & 1,1815 & 1.0157 & 3.3436 & 1 \\
\hline 13 & $\begin{array}{l}\text { Hazır (işlenmiş) } \\
\text { maden } \\
\text { mamulleri } \\
\text { üretimi }\end{array}$ & 1.9143 & 2.8442 & 0,8363 & 1,2425 & 5.1149 & 2.5854 & 2 \\
\hline 14 & $\begin{array}{c}\text { Makine ve } \\
\text { teçhizat üretimi }\end{array}$ & 2.3709 & 2.6294 & 1,0357 & 1,1487 & 2.9562 & 2.7457 & 1 \\
\hline 15 & $\begin{array}{c}\text { Diğer sanayi } \\
\text { sektörleri ve } \\
\text { ikincil işlemeler }\end{array}$ & 1.0007 & 0.3485 & 0,4371 & 0,1522 & 1.0144 & 26.1801 & 4 \\
\hline \multicolumn{9}{|c|}{2008 Yılı Bağlantı Etkileri, Endeksleri, Yayılma Dereceleri ve Kilit Sektörleri } \\
\hline \multirow{2}{*}{ Sira no } & \multirow{2}{*}{$\begin{array}{l}\text { Ekonomik } \\
\text { Sektörler }\end{array}$} & \multicolumn{2}{|c|}{$\begin{array}{c}\text { Doğrudan ve } \\
\text { Dolaylı Bağ. Et. }\end{array}$} & \multicolumn{2}{|c|}{$\begin{array}{c}\text { Bağlantı } \\
\text { Endeskleri }\end{array}$} & \multicolumn{2}{|c|}{ Yayılma Dereceleri } & \multirow{2}{*}{$\begin{array}{c}\text { Hirschman } \\
n \\
\text { Kategorileri }\end{array}$} \\
\hline & & İleri & Geri & İleri & Geri & İleri & Geri & \\
\hline 06 & $\begin{array}{c}\text { Gıda ve tütün } \\
\text { ürünleri üretimi }\end{array}$ & 1.8662 & 2.9765 & 0,7531 & 1,2012 & 3.6529 & 2.8532 & 2 \\
\hline 07 & $\begin{array}{c}\text { Tekstil ve } \\
\text { konfeksiyon } \\
\text { sanayi; deri ve } \\
\text { deri ürünleri } \\
\text { üretimi } \\
\end{array}$ & 3.0772 & 2.5915 & 1,2419 & 1,0458 & 2.2171 & 3.2475 & 1 \\
\hline 08 & $\begin{array}{c}\text { Kereste ve } \\
\text { ahşap doğrama } \\
\text { üretimi } \\
\end{array}$ & 3.1631 & 2.6511 & 1,2765 & 1,0695 & 3.0808 & 3.6639 & 1 \\
\hline 09 & $\begin{array}{l}\text { Kağıt ve karton } \\
\text { üretimi; yayın } \\
\text { ve basım }\end{array}$ & 2.0875 & 2.5886 & 0,8424 & 1,0447 & 3.8063 & 3.1725 & 2 \\
\hline 10 & $\begin{array}{l}\text { Kok kömürü } \\
\text { üretimi; petrol } \\
\text { damitma } \\
\text { (rafine); kimya }\end{array}$ & 10.995 & 2.9399 & 4,4376 & 1,1864 & 0.9018 & 3.3409 & 1 \\
\hline
\end{tabular}




\begin{tabular}{|c|c|c|c|c|c|c|c|c|}
\hline & $\begin{array}{c}\text { sanayi; lastik ve } \\
\text { pls. Ür. }\end{array}$ & & & & & & & \\
\hline 11 & $\begin{array}{c}\text { Diğer metal } \\
\text { olmayan mineral } \\
\text { üretimi }\end{array}$ & 1.5395 & 2.5536 & 0,621 & 1,0306 & 3.9206 & 2.5829 & 2 \\
\hline 12 & $\begin{array}{c}\text { Maden (metal) } \\
\text { sanayi }\end{array}$ & 3.7711 & 2.8398 & 1,5219 & 1,1461 & 2.5129 & 3.3910 & 1 \\
\hline & $\begin{array}{c}\text { Hazır (işlenmiş) } \\
\text { maden } \\
\text { mamulleri } \\
\text { üretimi }\end{array}$ & 1.8139 & 2.9029 & 0,7320 & 1,1715 & 3.7334 & 2.5386 & 2 \\
\hline 14 & $\begin{array}{c}\text { Makine ve } \\
\text { teçhizat üretimi }\end{array}$ & 5.2635 & 2.3619 & 2,1242 & 0,9532 & 1.4377 & 3.2796 & 3 \\
\hline 15 & $\begin{array}{c}\text { Diğer sanayi } \\
\text { sektörleri ve } \\
\text { ikincil işlemeler }\end{array}$ & 1.1143 & 2.7416 & 0,4497 & 1,1064 & 5.2227 & 2.3214 & 3 \\
\hline
\end{tabular}

2005-2008. 


\title{
Causality Relations between Foreign Direct Investment and Portfolio Investment Volatility
}

\author{
Giray Gozgor, Doğuş University \\ Yaman O. Erzurumlu, Doğuş University
}

\begin{abstract}
Following the liberalization of financial markets, Goldstein and Razin (2006) show that there is an information based trade-off between foreign direct investment and foreign portfolio investment, our paper examines the causality relations between foreign direct investment and volatility of foreign portfolio investment. Utilizing monthly and quarterly data set of Czech Republic, Poland, Russia and Turkey, volatility of portfolio investments, which indicated evidence of ARCH effects for all four countries, have been estimated by best fitting GARCH (p,q) models. Further, potential causality has been examined by Granger (1969), Sims (1972) and Toda and Yamamoto (1995) test methods.

Results indicated that, for Russia and Turkey foreign direct investment has a significant cause on portfolio investment volatility. However for Czech Republic and Poland, there is no such significant relationship has been found. Finally further investigation of a possible structural break due to EU membership could not provide such evidence for Czech Republic and Poland in related variables.
\end{abstract}

JEL Codes: C50, F21, F32.

\section{Introduction}

Private equity flows in various forms all have positive effect on the performance of the host country. Foreign Direct Investment (FDI hereafter) and Foreign Portfolio Investment (FPI hereafter) are two of the forms of international investment choices. Between the two, FDI is considered as a crucial component especially for developing countries (Albuquerque, 2003). FDI's contribution to domestic investment and output growth dominates over the contributions of FPI flows (Razin, 2002). Literature suggests two main reasons for the preference for FDI. First, it potentially involves creation of new jobs, transfer of foreign technology and managerial expertise, and larger increases in per capita GDP (Strazicich et al. 2001). Second FDI is suggested to be more stable compared to other forms of foreign investment (Bekaert and Harvey, 1998). Borensztein et al. (1998), Balasubramanyam et al. (1996) and Lichtenberg and van Pottelsberghe de la Potterie (1996) are also found these favorable effects of FDI. This characteristic is persistent both during normal and crisis periods (Sula and Willett, 2009). Nevertheless, although the physical investment is irreversible once made, the flow of funds associated with that investment is not necessarily irreversible (Sarno and Taylor, 1999). Portfolio flows on the other hand consist of liquid assets such as bond and equity investments. That structure of FPIs enables investors to sell their assets more easily and quickly. This makes FPI the primary candidate to be the hottest and the most volatile of all major types of foreign capital flows. Hence, there is vast amount of evidence on the structure and individual behaviors of these two forms of foreign capital. However, to our knowledge not much has been done on the causal relationship between FDI and FPI.

Next section provides a summary of the related literature about the variable and model used. Second section explains the data and the methodology, the third section presents the empirical findings and final section concludes.

\section{Literature Review}

The standard approach states that more volatile form of capital is the one that is more likely 
to leave the country. Hence, conventional wisdom suggests that FDI is the least volatile and short-term funds are more volatile than long term funds (Gabriele et al. 2000). Literature provides empirical evidence mostly in favor of this opinion indicating that FDI is unconditionally less volatile than other flows UNCTAD (1998), World Bank (1999) and Lipsey $(1999,2001)$ and portfolio flows are generally considered the most volatile form of foreign capital flows (Ferreira and Laux, 2009), thus the "hottest" of all (Sula and Willett, 2009). Contrary to this argument Claessens et al. (1995) finds that FDI is as volatile as other types of flows. Levchenko and Mauro (2007) find that while the coefficient of variation for FDI was less than other types of capital flows, its standard deviation is higher than debt and equity portfolio's and bank flows This phenomenon is valid especially in the emerging markets (Teaser and Werner, 1995) and following policy liberalization (Kraay, 1998). Although, Neumann et al. (2009) suggest that high volume high volatility relationship is persistent on the average flow for both direct investment and portfolio flows for both the mature and emerging countries, comparing the standard deviation of the residuals across countries, Broner and Rigobon (2004) find that capital flows to emerging markets are $80 \%$ more volatile than those to mature markets. On the contrary, after investigating as a group of capital flows Bekaert and Harvey (2003) suggest that capital flows to emerging markets are less volatile than developed countries. Neumann et al. (2009) also suggest that the standard deviations of FDI and portfolio flows increase as financial liberalization occur. Bekaert and Harvey (2003) argue that volatility should subside once the large capital inflow has occurred adding that there is always the worry that portfolio flows are not as "sticky" as FDI and may disappear at a whim causing a crisis in the process.

An important indicator of the volatility of a certain type of foreign investment would be the permanent and temporary portions of it. FDI mainly consists of fixed assets. It is highly illiquid, therefore difficult to sell during liquidity crisis. Moreover the driving force behind FDI is long term profitability expectations that are based on the fundamentals of the host country rather than the speculative forces that partially drive relatively shorter term capital flows such as FPI. Sarno and Taylor (1999) argue that the flows that are more likely to have sudden reversals would have large temporary, reversible components. They find that FDI is mostly composed of a permanent component and that FPI flows have a large temporary and reversible component. Moreover, Chuhan et al. (1996) observes that FDI responds less to shocks most likely due to its permanent dominated structure. Lipsey (1999) reports significant differences in volatility between FDI and other net long term flows for developing countries. Thus, we can say that FDI flows are mostly permanent and tend to be more stable whereas FPI displays a temporary dominated and volatile structure.

This structural difference between FDI and FPI is crucial for our model. We construct our model partially based on this unique difference between the structures of two types of foreign investments. Based on the well documented permanent nature of FDI and temporary nature of FPI we model our investigation between FDI measured at level values and the volatility of FPI. Thus, our main objective is to investigate whether there is causality between FDI and the volatility of FPI in a number of Eastern European emerging economies that are still in the process of capital liberalization. Although one could argue that capital liberalization processes in emerging markets are subject to sudden shocks, shock effects to portfolio investment are temporary (Strazicich et al. 2001). Claessens et al. (1995) finds in general the time it takes for unexpected shocks to dissipate is similar for both FDI and portfolio investment. Therefore, our approach would not be significantly affected by possible shocks during the observation period. Neumann et al. (2009) provide preliminary evidence suggesting that portfolio flows appear to show little response to capital liberalization while foreign direct investment flows show significant increases in volatility, particularly for the emerging markets considered. Thus, if flows chase growth expectations, we should expect capital liberalization to be followed by FDI flow.

We investigate whether initial FDI flow sets up an environment for potential FPI follow up. 
Literature provides theoretical and empirical evidence for such a causal structure. There is an information based trade-off between foreign direct investment and portfolio investment. FDI enables the owner to obtain refined information about the firm. Foreign direct investor obtains both the ownership and the control of the domestic firm whereas foreign portfolio investor's gain is limited to the ownership. FDI investors are more informed about the prospects and fundamentals of their projects compared to FPI investors (Razin and Sadka, 2003). This effect generates an advantage, with an added value in the capital market, to foreign direct investors relative to foreign portfolio investors (Goldstein and Razin, 2006). However, literature suggests that FPIs are particularly more susceptible to these kind of informational problems and herding behavior (Sula and Willett, 2009). Informational problems can cause rational herding behavior in financial markets (Calvo and Mendoza, 2000). Mutual fund managers show similar patterns in their trading behavior and tend to invest or leave a market at the same time (Haley, 2001). Moreover, this superiority, the "information value" of FDI relative to FPI poses also a problem of asymmetric information between buyers and sellers of investment projects (Ahmad et al., 2004) which is crucial for the order of FDI and FPI entry to a country. As Goldstein and Razin (2006) point out, if a foreign direct investor chooses to liquidate his or her firm for a reason, potential buyers would underpriced the firm assuming that foreign direct investor has an information advantage. Foreign direct investor would have a low resale price because of asymmetric information between the owner and potential buyers. Thus, one implication of this would be that if the investor wants liquidity then he or she would choose less control vice versa. Albuquerque (2003) also argues FDI overcomes imperfect enforcement mechanism providing a risk sharing form of investment. Higher exit cost, due to the difficulty of reselling a firm signals to the following investors, low probability of early liquidation and potential positive return. Thus, we expect that sensitivity of FPI to information and asymmetric information advantage of FDI by its nature would cause capital liberalization in emerging markets to be followed by foreign direct investment flow followed by short term foreign portfolio investment.

\section{Data and Methodology}

This study is based on the monthly FDI and FPI data, date 2000:01-2009:12 for Turkey and Poland and quarterly data for Czech Republic and Russia date 1995:Q1-2009:Q4. The mentioned data are obtained from Central Bank of related markets. Firstly, under null hypothesis variable has a unit root, the unit root tests suggested by (Kwiatkowski et al., 1992) and (Phillips and Perron, 1988) are tested and it is proved that they are not stationary. Therefore time series' first differences are used. Since we have limited space, the obtained unit root tests results are not included in the study. For showing the volatility of FPI, GARCH (p,q) model is used. GARCH models have been introduced by (Engle, 1982) and have been expanded and generalized by (Bollersev, 1986). The GARCH(p,q) model has been defined by (Bollersev 1986) as:

$$
h_{t}=\omega+\sum_{i=1}^{p} \beta_{i} h_{t-i}+\sum_{j=1}^{q} \alpha_{j} \epsilon_{t-j}^{2}
$$

The $\omega>0$ condition must exists in this model. Along with this in order for the $h_{t}$ value to be positive, it must be $\alpha \geq$ and $\beta \geq 0$ for GARCH (p,q). Also during the GARCH (p,q) process for the variance to be homoscedastic, the following assumption must exist:

$$
\sum_{i=1}^{p} \beta_{i}+\sum_{j=1}^{q} \alpha_{j}<1
$$

The main reason this model is used is that it responds quicker to the shocks than do the other models. For testing whether have on $\mathrm{ARCH}$ effect, optimum $\mathrm{AR}(\mathrm{p})$ and $\mathrm{MA}(\mathrm{q})$ process have been selected by Akaike Information Criteria (AIC) and Bayesian Information Criteria (BIC). It has been approved that selected $\mathrm{AR}(\mathrm{p})$ and $\mathrm{MA}(\mathrm{q})$ process have an $\mathrm{ARCH}$ effect. At this 
point it must be explained that in the GARCH $(p, q)$ model the FPI series have been analyzed for autocorrelation. The lag selection is taken as fifteen, the lag number suggested by (Engle, 2001). In order to show that there is no autocorrelation within the series $Q$ statistics can be used, to show that the specification of the variance equation is correct $\mathrm{Q}^{2}$ statistics can be used, and to show the ARCH effect on the selected lag in the variance equation ARCH-LM test statistics can be used. According to the ARCH-LM test which takes FPI as a basis there is no remaining ARCH effect for both of the variables. Best fitting GARCH $(p, q)$ models selected by Akaike Information Criteria (AIC) and Bayesian Information Criteria (BIC) are GARCH(1,1) model for Poland, Russia and Czech Republic; $\operatorname{GARCH}(1,2)$ model for Turkey. All these results are available upon request. $\operatorname{GARCH}(p, q)$ volatility of FPI can be shown as graphs:
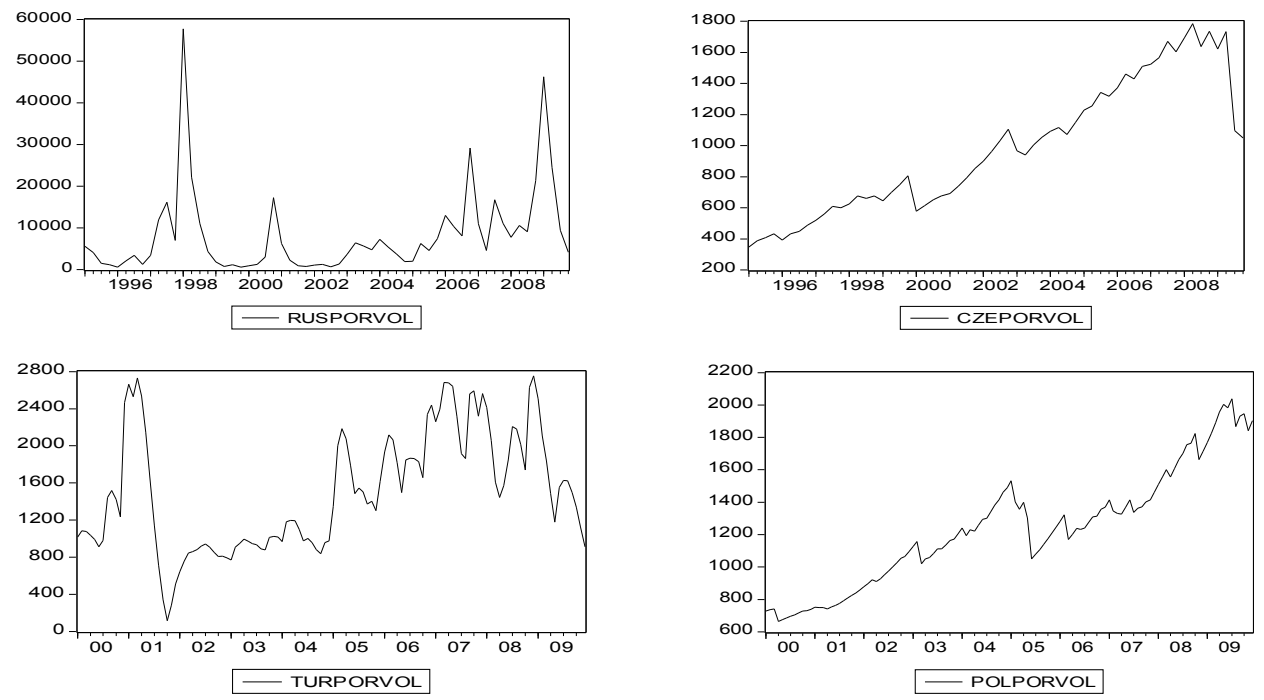

Graph 1: $G A R C H(p, q)$ volatility of FPI.

\section{Empirical Findings}

Potential pairwise causality has been examined by (Granger, 1969), (Sims, 1972) and (Toda and Yamamoto, 1995) test methods. Under null hypothesis FPI Volatility does not Granger Cause FDI and FDI does not Granger Cause FPI Volatility, all of these results can be shown as in Table 1. 


\begin{tabular}{|c|c|c|c|c|c|}
\hline \multirow{7}{*}{ Poland } & \multirow{3}{*}{$\begin{array}{l}\text { FPIVOL does not Granger Cause FDI } \\
\text { FDI does not Granger Cause FPIVOL }\end{array}$} & Lag & $\begin{array}{c}\text { Granger } \\
(1969) \\
\end{array}$ & $\begin{array}{c}\text { Sims } \\
(1972) \\
\end{array}$ & $\begin{array}{c}\mathrm{T}-\mathrm{Y} \\
(1995) \\
\end{array}$ \\
\hline & & \multirow[t]{2}{*}{1} & 0.5904 & 0.5668 & 0.5550 \\
\hline & & & 0.8513 & 0.8172 & 0.8002 \\
\hline & \multirow{2}{*}{$\begin{array}{l}\text { FPIVOL does not Granger Cause FDI } \\
\text { FDI does not Granger Cause FPIVOL }\end{array}$} & \multirow[t]{2}{*}{2} & 0.8257 & 0.7927 & 0.7762 \\
\hline & & & 0.7960 & 0.7642 & 0.7482 \\
\hline & \multirow{2}{*}{$\begin{array}{l}\text { FPIVOL does not Granger Cause FDI } \\
\text { FDI does not Granger Cause FPIVOL }\end{array}$} & \multirow[t]{2}{*}{3} & 0.8016 & 0.7695 & 0.7535 \\
\hline & & & 0.4659 & 0.4473 & 0.4379 \\
\hline \multirow{7}{*}{ Turkey } & \multirow{3}{*}{$\begin{array}{l}\text { FPIVOL does not Granger Cause FDI } \\
\text { FDI does not Granger Cause FPIVOL }\end{array}$} & Lag & $\begin{array}{c}\text { Granger } \\
(1969) \\
\end{array}$ & $\begin{array}{c}\text { Sims } \\
(\mathbf{1 9 7 2 )} \\
\end{array}$ & $\begin{array}{c}\text { T-Y } \\
(1995) \\
\end{array}$ \\
\hline & & \multirow[t]{2}{*}{1} & 0.1975 & 0.1949 & 0.1892 \\
\hline & & & $0.0634 *$ & $0.0609 *$ & $0.0576^{*}$ \\
\hline & \multirow{2}{*}{$\begin{array}{l}\text { FPIVOL does not Granger Cause FDI } \\
\text { FDI does not Granger Cause FPIVOL }\end{array}$} & \multirow[t]{2}{*}{2} & 0.1715 & 0.1668 & 0.1540 \\
\hline & & & 0.1110 & 0.1063 & $0.0961 *$ \\
\hline & \multirow{2}{*}{$\begin{array}{l}\text { FPIVOL does not Granger Cause FDI } \\
\text { FDI does not Granger Cause FPIVOL }\end{array}$} & \multirow[t]{2}{*}{3} & 0.2761 & $\begin{array}{c}0.2704 \\
0.0247^{*}\end{array}$ & 0.2437 \\
\hline & & & $0.0288^{* *}$ & $*$ & $0.0188 * *$ \\
\hline \multirow{7}{*}{$\begin{array}{l}\text { Czech } \\
\text { Rep. }\end{array}$} & \multirow{3}{*}{$\begin{array}{l}\text { FPIVOL does not Granger Cause FDI } \\
\text { FDI does not Granger Cause FPIVOL }\end{array}$} & Lag & $\begin{array}{c}\text { Granger } \\
(1969) \\
\end{array}$ & $\begin{array}{c}\text { Sims } \\
(1972) \\
\end{array}$ & $\begin{array}{c}\mathrm{T}-\mathrm{Y} \\
(1995) \\
\end{array}$ \\
\hline & & \multirow[t]{2}{*}{1} & 0.7348 & 0.7054 & 0.6907 \\
\hline & & & 0.8885 & 0.8530 & 0.8352 \\
\hline & \multirow{2}{*}{$\begin{array}{l}\text { FPIVOL does not Granger Cause FDI } \\
\text { FDI does not Granger Cause FPIVOL }\end{array}$} & \multirow[t]{2}{*}{2} & 0.8194 & 0.7866 & 0.7702 \\
\hline & & & 0.2671 & 0.2564 & 0.2511 \\
\hline & \multirow{2}{*}{$\begin{array}{l}\text { FPIVOL does not Granger Cause FDI } \\
\text { FDI does not Granger Cause FPIVOL }\end{array}$} & \multirow[t]{2}{*}{3} & 0.4859 & 0.4665 & 0.4567 \\
\hline & & & 0.4118 & 0.3953 & 0.3871 \\
\hline \multirow{7}{*}{ Russia } & \multirow{3}{*}{$\begin{array}{l}\text { FPIVOL does not Granger Cause FDI } \\
\text { FDI does not Granger Cause FPIVOL }\end{array}$} & Lag & $\begin{array}{c}\text { Granger } \\
(1969) \\
\end{array}$ & $\begin{array}{c}\text { Sims } \\
(1972) \\
\end{array}$ & $\begin{array}{c}\mathrm{T}-\mathrm{Y} \\
(1995) \\
\end{array}$ \\
\hline & & \multirow[t]{2}{*}{1} & 0.1667 & 0.1611 & 0.1501 \\
\hline & & & $0.0237 * *$ & $0.02 * *$ & $0.0169 * *$ \\
\hline & \multirow{2}{*}{$\begin{array}{l}\text { FPIVOL does not Granger Cause FDI } \\
\text { FDI does not Granger Cause FPIVOL }\end{array}$} & \multirow[t]{2}{*}{2} & 0.8788 & 0.8786 & 0.8677 \\
\hline & & & 0.1284 & 0.1182 & $0.0962 *$ \\
\hline & \multirow{2}{*}{$\begin{array}{l}\text { FPIVOL does not Granger Cause FDI } \\
\text { FDI does not Granger Cause FPIVOL }\end{array}$} & \multirow[t]{2}{*}{3} & 0.9820 & 0.9823 & 0.9785 \\
\hline & & & 0.1237 & 0.1092 & $0.0747^{*}$ \\
\hline
\end{tabular}

Table 1: (Granger, 1969), (Sims, 1972) and (Toda and Yamamoto, 1995) Test Results.

Table shows that rejection of null hypothesis p-values and $* 10 \%, * * 5 \%$ significant.

Because of limited space, the probability values of causality tests results are only shown in the Table 1. Since FPI Volatility under null hypothesis variable has a unit root, the unit root tests suggested by (Kwiatkowski et al., 1992) and (Phillips and Perron, 1988) are tested and it is proved that Czech Republic and Poland series are stationary and Turkey and Russia series are not stationary. It has been showed that all series are not cointegrated; only pairwise causality tests are used. Since defining the maximum lag of twelve, causality tests lag length selected by AIC and BIC and only up to three lags of results are shown in table. It can be said that up to three lags of causality tests' results, there are $10 \%$ and $5 \%$ significant causality 
between FDI and FPI volatility for Turkey and Russia. However, four, six, eight, twelve lag values for Turkey and twelve lag values for Russia are also significant but these results are not added in the Table 1.

Furthermore we investigate possible structural break due to EU membership date beginning 2004:05 for Poland and 2004:Q2 for Czech Republic. Up to twelve lag of pairwise (Granger, 1969), (Sims, 1972) and (Toda and Yamamoto, 1995) tests results are shown that EU membership could not provide such evidence for Czech Republic and Poland in related variables. Under null hypothesizes FPIVOL does not Granger Cause FDI and FDI does not Granger Cause FPIVOL, for Poland date 2000:01-2004:04 minimum probability values of mentioned tests are 0,6799 for lag one and date 2004:05-2009:12 is 0,4721 for lag three. For Czech Republic date 1995:Q1-2004:Q2, minimum probability values of mentioned tests are 0,1722 for lag two and date 2004:Q3-2009:Q4 is 0,3409 for lag two. All these results are also available upon request.

\section{Conclusion}

The permanent structure of FDI and temporary structure of FPI are well documented in the literature. Literature also suggests that following capital liberalization in an emerging market, relative change in FDI flow is more than change in FPI flow. Thus, literature implies that capital liberalization is followed initially by FDI. Moreover, through signaling potential positive return and optimism about the fundamental indicators due to its permanent structure and informational advantage, FDI somewhat paves the way for FPI that is especially sensitive to lack of informational efficiency. Therefore, we examine whether there exists a casual relationship between FDI measured at level and FPI volatility in a number of Eastern European emerging markets.

Our results indicate that, for Russia and Turkey FDI has a significant cause on FPI volatility. This result also support the argument that FDI which does not require a degree of capital liberalization as much as FPI helps overcoming the informational inefficiency to some extent and leads the entry of foreign investment into these emerging markets. Results reveal no such relationship for Czech Republic and Poland. Further partitioning the observation period between post and pre EU membership reveals no change in results. We believe that there are two possible explanations to this. First, informational asymmetry is not as sever e for this group of countries. Second, these two countries have reached a necessary level of capital liberalization at a shorter length of time so FDI could not be a fore runner and cause of FPI.

\section{References}

- $\quad$ Ahmad, Y., Cova, P. and Harrison, R., 2004. "Foreign Direct Investment Versus Portfolio Investment: A Global Games Approach”, University of WisconsinWhitewater Working Paper.

- $\quad$ Albuquerque, R., 2003. "The Composition of International Capital Flows: Risk Sharing Through Foreign Direct Investment”, Journal of International Economics, 61, p. 353-383.

- $\quad$ Balasubramanyam, V.N., Salisu, M. and Sapsford, D., 1996. "Foreign Direct Investment and Growth in EP and IS countries?”, Economic Journal, 106, p. 92-105.

- Bekaert, G. and Harvey, C.R., 1998. "Capital Flows and the Behavior of Emerging Market Equity Returns”, NBER Working Paper Series, 6669.

- Bekaert, G. and Harvey C.R., 2003, "Emerging Markets Finance”, Journal of Empirical Finance, 10, p. 3-55.

- Bollersev, T. (1986). “Generalized Autoregressive Conditional Heteroskedasticity”, 
Journal of Econometrics, 31, p. 307-328.

- Borensztein, E., Gregorio, J. and Lee, J., 1998. "How Does Foreign Direct Investment Affect Growth?", Journal of International Economics, 45, p. 115-135.

- Broner, F.A. and Rigobon, R., 2004. "Why Are Capital Flows So Much More Volatile In Emerging Than In Developed Countries?"Available at SSRN: http://ssrn.com/abstract=884381.

- Calvo, G. and Mendoza, E.G., 2000. "Rational Contagion and the Globalization of Securities Markets", Journal of International Economics, 51, p. 79-113.

- Chuhan, P., Perez-Quiros, G. and Popper, H., 1996. "International Capital Flows: Do Short-Term Investment and Direct Investment Differ?", World Bank Policy Research Working Paper, 1669.

- Claessens, S., Dooley, M.P. and Warner, A., 1995. "Portfolio Capital Flows: Hot or Cold?", The World Economic Review, 9, p. 153-174.

- $\quad$ Engle, R.F. (1982). “Autoregressive Conditional Heteroskedasticity with Estimates of the Variance of United Kingdom Inflation”, Econometrica, 50, p. 987-1007.

- Engle, R.F. (2001). "The Use of ARCH/GARCH Models in Applied Econometrics", Journal of Economic Perspective, 15, p. 157-168.

- $\quad$ Ferreira, A.M. and Laux P.A., 2009. "Portfolio Flows, Volatility and Growth", Journal of International Money and Finance, 28, p. 271-292.

- Gabriele, A., Boratav, K. and Parikh, A., 2000. "Instability and Volatility of Capital Flows to Developing Countries", World Economy, 23, p. 1031-1056.

- Granger, C.W.J., 1969. "Investigating Causal Relations by Econometric Models and Cross Spectral Methods", Econometrica, 37, p. 424-438.

- Goldstein, I. and Razin, A., 2006. “An Information Based Trade-off between Foreign Direct Investment and Foreign Portfolio Investment”, Journal of International Economics, 70, p. 271-295.

- Haley, M.A., 2001. Emerging Market Makers: The Power of Institutional Investors: Financial Globalization and Democracy in Emerging Markets. Macmillan, London, p. 74-90.

- Kraay, A., 1998. "In Search of the Macroeconomic Effects of Capital Account Liberalization", World Bank.Working Paper.

- Kwiatkowski, D., Phillips, P.C.B., Schmidt, P. and Shin, Y. (1992). "Testing the Null Hypothesis of Stationarity against the Alternative of a Unit Root", Journal of Econometrics, 54, p. 159-178.

- $\quad$ Levchenko, A. and Mauro, P., 2007. "Do Some Forms of Financial Flows Help Protect from Sudden Stops?”, World Bank Economic Review, 21, p. 389-411.

- Lichtenberg, F. and van Pottelsberghe de la Potterie, B., 1996. "International R\&D Spillovers: A Re-examination”, NBER Working Paper, 5668.

- $\quad$ Lipsey, R.E., 1999. “The Role of Foreign Direct Investment in International Capital Flows", NBER Working Paper, 7094.

- $\quad$ Lipsey, R.E., 2001. "Foreign Direct Investment in Three Financial Crises", NBER Working Paper, 8084.

- Neumann, R.M., Penl, R. and Tanku, A., 2009. "Volatility of Capital Flows and Financial Liberalization: Do Specific Flows Respond Differently?", International Review of Economics and Finance, 18, p. 488-501.

- $\quad$ Phillips, P.C.B. and Perron, P. (1988). “Testing for a Unit Root in Time Series 
Regression", Biometrika, 75, p. 335-346.

- Razin, A., 2002. "FDI Contribution to Capital Flows and Investment in Capacity", NBER Working Paper, 9204.

- $\quad$ Razin, A. and Sadka, E., 2003. "Gains from FDI Inflows with Incomplete Information”, Economics Letters, 7, p. 71-77.

- Sarno, L. and Taylor, M., 1999. "Hot Money, Accounting Labels and the Permanence of Capital Flows to Developing Countries: An Empirical Investigation", Journal of Development Economics, 59, p. 337-364.

- $\quad$ Sims, C.A., 1972. "Money, Income and Causality”, American Economic Review, 62, p. $540-552$.

- $\quad$ Strazicich, M.C., Co, C.Y. and Lee, J., 2001. "Are Shocks to Foreign Investment in Developing Countries Permanent or Temporary? Evidence from Panel Unit Root Test", Economic Letters, 70, p. 405-421.

- $\quad$ Sula, O. and Willett, T.D., 2009. "The Reversibility of Different Types of Capital Flows to Emerging Markets", Emerging Markets Review, 10, p. 296-310.

- Teaser, L.and Werner, I., 1995. "Home Bias and High Turnover", Journal of International Money and Finance, 14, p. 467-493.

- Toda, H.Y. and Yamamoto, T., 1995. "Statistical Inferences in Vector Autoregressions with Possibly Integrated Processes”, Journal of Econometrics, 66, p. 225-250.

- UNCTAD, 1998. World Investment Report: Trends and Determinants, Overview. United Nations, New York.

- World Bank, 1999. Global Development Finance. The World Bank, Washington DC. 


\title{
Political Risk and Foreigners' Trading: Evidence from An Emerging Stock Market
}

\author{
Deniz İkizlerli, Durham University, UK \\ Numan Ülkü, Central European University Business School, Budapest
}

\begin{abstract}
This paper analyzes the impact of political risk on foreigners' trading in an emerging stock market, using quantified political risk ratings reported by ICRG and foreign flows data compiled by Istanbul Stock Exchange. Besides illuminating the impact of political risk on foreign investors' trading, currently a gap in the literature, we track the differential effect of political risk upgrades and downgrades on market returns. We also repeat the analysis for industry portfolios. The reaction to upgrades is slow and small in magnitude, while the reaction to downgrades is immediate. Foreigners' reaction to political risk seems to vary with the market sensitivity of the industry, except for the tourism sector where their response to political risk is particularly salient.
\end{abstract}

JEL Codes: F21; F30; G15

Political risk has been commonly assumed to be one of the main drivers of emerging stock markets. The earlier evidence on the impact of political risk on stock market returns has mainly been anecdotal because it is difficult to quantify political risk. Several papers in the literature, however, accomplished a systematic analysis by using the ICRG (International Country Risk Guide) indices published by Political Risk Services, in particular the political risk (PR) component. Diamonte et al. (1996) find a significant impact of political risk changes, as measured by ICRG PR ratings, on contemporaneous returns in emerging markets. Average returns in emerging markets experiencing PR upgrades exceed those in emerging markets experiencing political risk downgrades by $11 \%$ a quarter, while the difference is not significant for developed markets. Erb et al. (1996) document a positive contemporaneous relationship between PR changes and returns over 6-month windows, in emerging and developed markets (more significant in the former). However, political risk changes are poor in predicting future 6-month returns. On the other hand, lagged levels of political risk are positively related to future expected returns and fundamental valuation ratios such as book-to-market ratio and dividend yield, which have been used as a proxy for risk. Bilson et al. (2002) controlled for other risk factors that may affect emerging stock market returns, and found that PR bears some additional explanatory power which cannot be captured by many widely-used risk factors.

While the impact of political risk on emerging stock market returns has been investigated, no study has enquired its effect on foreign investors' trading (i.e. foreign flows in stock markets). Given that foreign investors are more vulnerable to political risk, especially in emerging markets, their trading would be expected to respond to PR changes. This paper fills this gap by employing foreign flows data from Turkey, world's $7^{\text {th }}$ largest emerging stock market where political risk has shown substantial variation and always been perceived as an important factor driving stock markets. We use foreign flows data compiled by Istanbul Stock Exchange (ISE) as previous research on foreign investor flows has indicated that accurate data should be compiled at the destination point, and data compiled from a source country or a custody may be biased. Such data are not available for many emerging markets. Moreover, Turkey has never implemented any (partial) restrictions on foreigners' trading, which might confound the analysis. Hence, Turkey presents an ideal case to enquire how foreigners' trading is affected by political risk.

We employ a structural VAR framework that enables to portray the dynamic response of foreigners' trading and stock market returns to changes in PR, and the differential effect of political risk upgrades and downgrades. A further contribution of this paper is to provide an analysis of the impact of political risk on foreigners' trading in different industries as different 
sectors may have differential sensitivity to political risk.

\section{Data and Methodology}

Our data set consists of monthly levels of the ICRG PR index, monthly net foreign flows (defined as foreigners' purchases minus sales, normalized by dividing by market capitalization) and monthly log returns of ISE indices (in local currency) and MSCI World index. For all local indices, we use inflation adjusted returns, calculated as monthly return minus annual CPI inflation divided by 12 , since inflation rates, hence expected nominal returns, exhibit huge variation over our sample period (fell from around 101.6\% in January 1998 to as low as $8.3 \%$ in April 2008).

Political Risk: PR index scores vary within the range 0-100, with a lower score implying higher risk. As the 0-100 range conflicts with the normality assumption, we apply log transformation; and, as it is still nonstationary, we take the first differences. Using first logged difference of the PR index makes sense, because foreign investors may be more sensitive to a 1-point decrease in the PR index, say from 41 to 40, compared to 1-point decrease from 81 to 80 for the same country. A 1-point decrease from 81 to 80 is not likely to spur macroeconomic instability, however a 1-point decrease from 41 to 40 can be perceived as political instability which has the potential to cause macroeconomic instability. By taking the first logarithmic difference of the PR index, a 1-point change at lower levels is given more weight relative to a 1-point change at higher levels. The PR index for Turkey is portrayed in Figure 1 below.

\section{Political Risk (PR)}

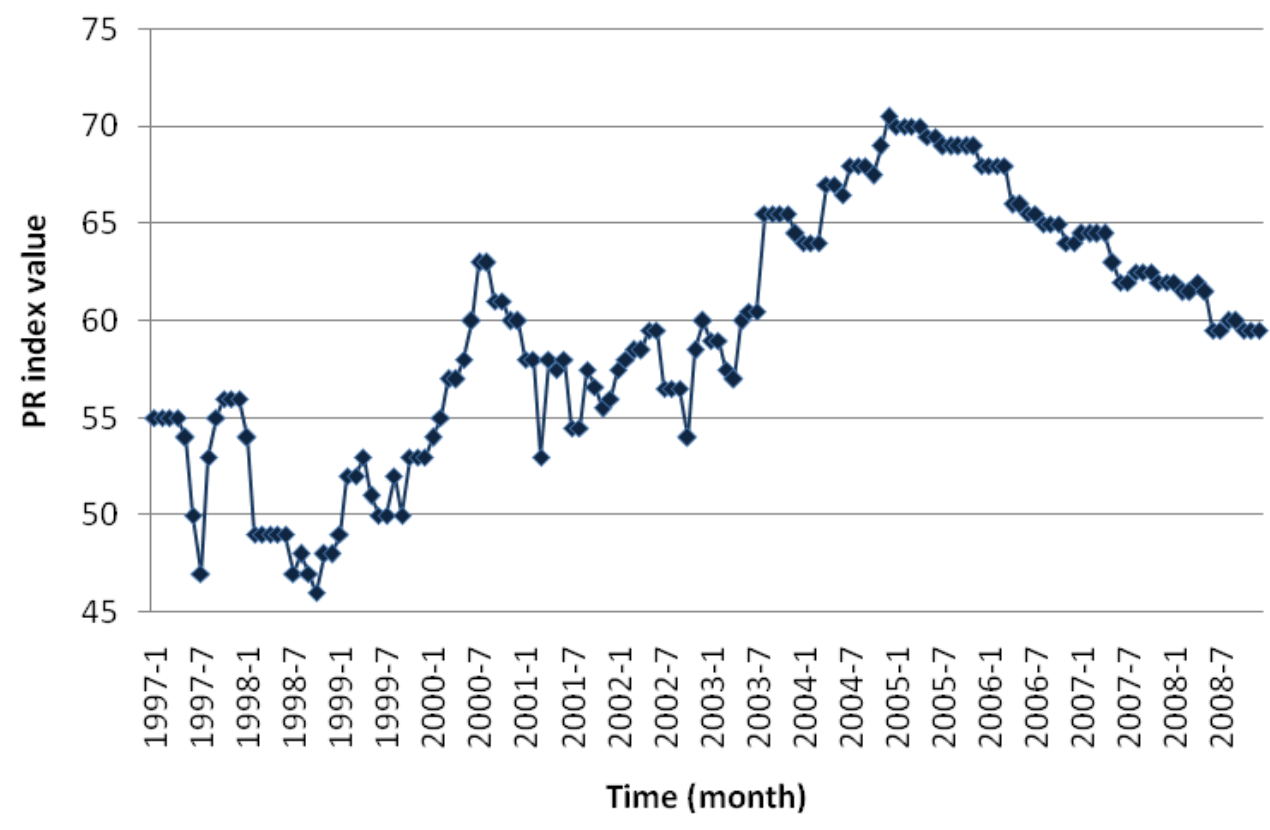

Figure 1: The time series of the political risk index for Turkey

In the first part of the empirical analysis, we use ISE all-share index and marketwide aggregated net foreign flows, to see how political risk affects ISE market returns and foreign investors' trading marketwide. We control for global returns, which strongly affect both ISE returns and foreigners' trading in ISE (see Griffin et al., 2004 and Richards, 2005). We use MSCI World index as a proxy for the global market. Thus, as political risk is a country-specific 
factor, we focus on country-specific (idiosyncratic) component of ISE market returns and foreign flows. Our sample period, dictated by the availability of foreign flows data, starts in January 1997 and goes through December 2008.

In the second part of empirical analysis, we focus on industry portfolios, employing sector indices published by ISE. As these indices are equally-weighted averages, we compute net foreign flows for each industry as the equally-weighted average of normalized net purchases in individual firms. The sample period for industry portfolio analysis is from January 1997 to June 2007. The industries and the number of companies listed in each industry portfolio (in parentheses) as of June 2007 are as follows:

1) Banks (17), 2) Food, Beverage (23), 3) Wood, Paper, Printing (14), 4) Textile, Leather (25), 5) Basic Metal (13), 6) Chemical, Petroleum, Plastic (23), 7) Non-Metal Minerals (24), 8) Tourism (6)

In our structural Vector Autoregression (SVAR) specification, net foreign flows and ISE returns are two endogenous variables in the system which is augmented by PR and MSCI World index returns that are affected only by their own lags. This enables a more accurate characterization of the dynamic interaction between foreign flows, domestic returns and political risk after controlling for world market returns. The advantage of this specification instead of a conventional VAR is that none of the lags of foreign flows and local returns affect the PR and world market returns, but contemporaneous values of them are affected by the instantaneous and lag values of PR and world returns. Thus, political risk and world market returns are treated as exogenous variables. The identified VAR model can be specified as:

\section{$\mathbf{A}(\mathbf{L}) \mathbf{y}(\mathbf{t})=\boldsymbol{\varepsilon}(\mathbf{t})$}

where $A(L)$ is an $n \times n$ matrix polynomial in the lag operator $L, y(t)$ is the $n \times 1$ observation vector, and $(t)$ is the $n \times 1$ vector of structural disturbances ( $\mathrm{n}$ is the number variables in the system).

$$
y(t)=\left[\begin{array}{l}
W(t) \\
P R(t) \\
N F(t) \\
R(t)
\end{array}\right] A(L)=\left[\begin{array}{cccc}
A_{11}(\mathrm{~L}) & 0 & 0 & 0 \\
0 & A_{22}(\mathrm{~L}) & 0 & 0 \\
A_{31}(\mathrm{~L}) & A_{32}(\mathrm{~L}) & A_{33}(\mathrm{~L}) & \mathbf{A}_{34}(\mathrm{~L}) \\
A_{41}(\mathrm{~L}) & A_{42}(\mathrm{~L}) & A_{43}(\mathrm{~L}) & \mathbf{A}_{44}(\mathrm{~L})
\end{array}\right] \varepsilon(t)=\left[\begin{array}{l}
\varepsilon_{1}(t) \\
\varepsilon_{2}(t) \\
\varepsilon_{3}(t) \\
\varepsilon_{4}(t)
\end{array}\right]
$$

W is the world market return, PR is the first difference of the logged PR index, NF is the net purchases of foreigners, and $\mathrm{R}$ is the returns of the relevant ISE index. The assumptions are that is uncorrelated with past $w(t-k)$ for $k>0$, and the coefficient matrix of $\mathrm{L}^{0}, \mathrm{~A}_{0}$, is nonsingular. The block exogeneity is represented by zero entries. The lag order of SVAR is 1 as suggested by both Akaike and Hannan-Quinn information criteria. All the variables entering the system are stationary. The system is estimated via seemingly unrelated regressions (SUR), since the right-hand side variables $\mathrm{W}$ and $\mathrm{PR}$ equations are different. In line with the common treatment in the literature, net flows are assumed to have contemporaneous effect on local returns but not vice versa, thus NF enters prior to R in the Cholesky factorization.

In this setting, our focus is the impulse response of net foreign flows to a shock in PR, after controlling for the effects of world market returns and possible feedback effects from local market returns. Before that, however, we analyse the impact of PR changes on local market returns, by studying the impulse response of ISE returns to shocks in PR.

\section{Results}

We present our results by studying impulse response functions (IRFs). In all IRF graphs to follow, the black line in the middle represents a point estimation of impulse responses together with $90 \%$ bootstrapped confidence bands shown by the upper and lower blue lines. Statistical 
significance is implied when neither of the confidence bands crosses the $\mathrm{x}$-axis.

Figure 2 portrays the response of ISE market returns to a shock in PR. Most of the effect is priced in the instantaneous month and a very small portion is left to the following month after which the response is virtually null. The cumulative effect is significantly positive. This result confirms, under VAR methodology, the findings of earlier articles that changes in PR are significantly associated with contemporaneous returns of emerging stock market indices. Further, it shows that most of the contemporaneous effect in 3- or 6-month intervals takes place within the month during which the shock is observed.

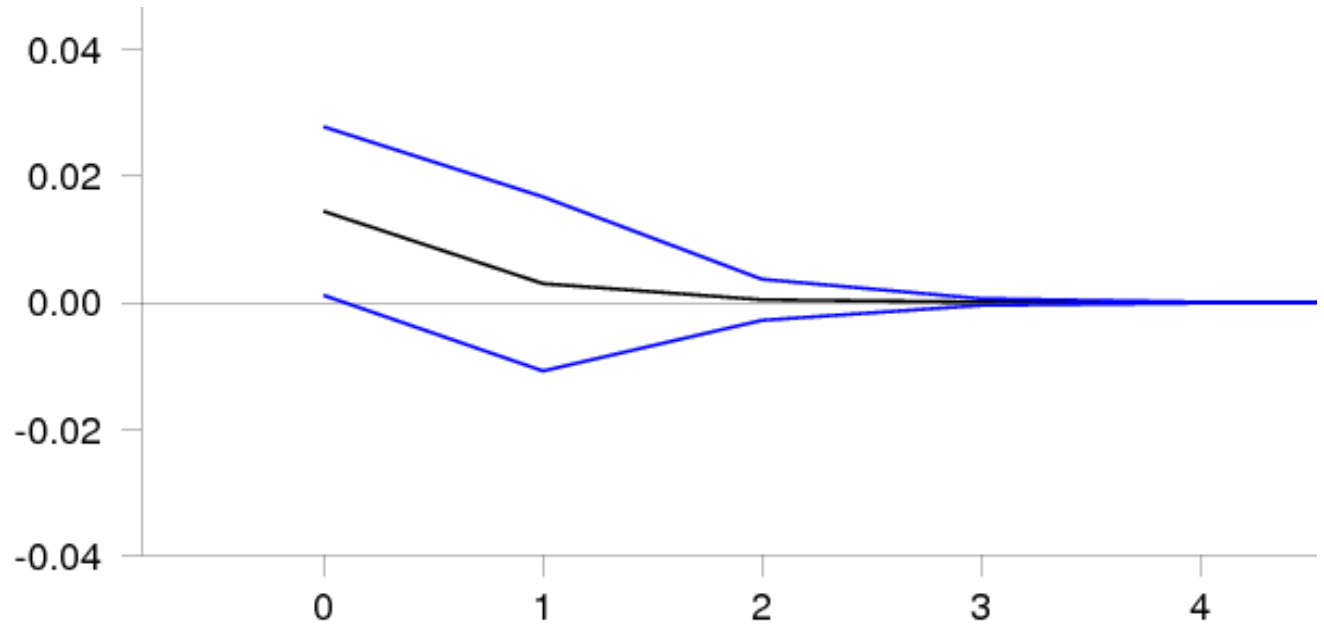

Figure 2: The impulse response of ISE return to a shock in PR

Notes: The line in the center is the impulse response function obtained from VAR model described above, and the blue lines around it represent $90 \%$ confidence interval bands.

In Figure 3 we distinguish the response to upgrades and downgrades using dummy variables that partition changes in PR index as positive and negative shocks. The response to an upgrade is slow, with a nontrivial portion of the response left to the next month, implying some underreaction. In contrast, the response to a downgrade is immediate and stronger.
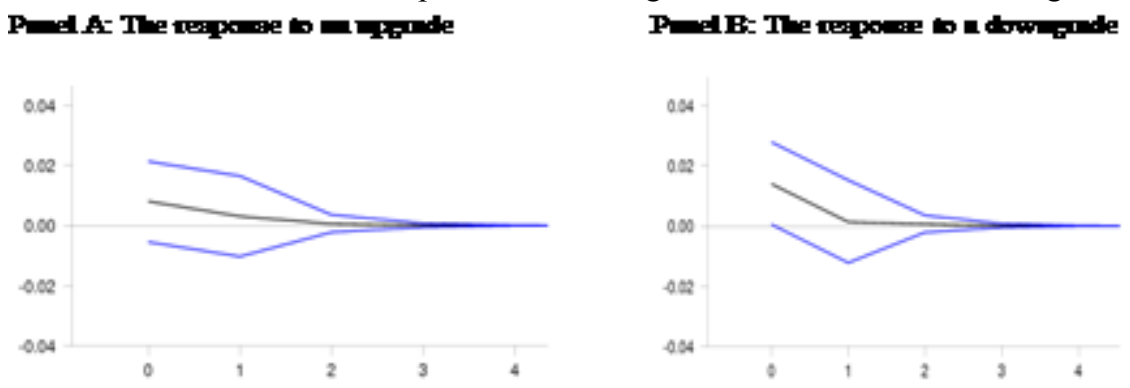

Figure 3: The impulse response of ISE returns to an upgrade and downgrade in PR

Next, we focus on the impact of PR shocks on foreigners' trading. Figure 4 depicts the impulse response of foreigners' net purchases to a shock in PR index. The bulk of foreigners' reaction occurs in the contemporaneous month, while a little more is left to the following month. The cumulative effect is borderline significant.

A variance decomposition analysis based on the same specification suggests that PR can explain approximately $1.5 \%$ and $0.7 \%$ of the forecast error variance in ISE returns and foreign flows, respectively. 


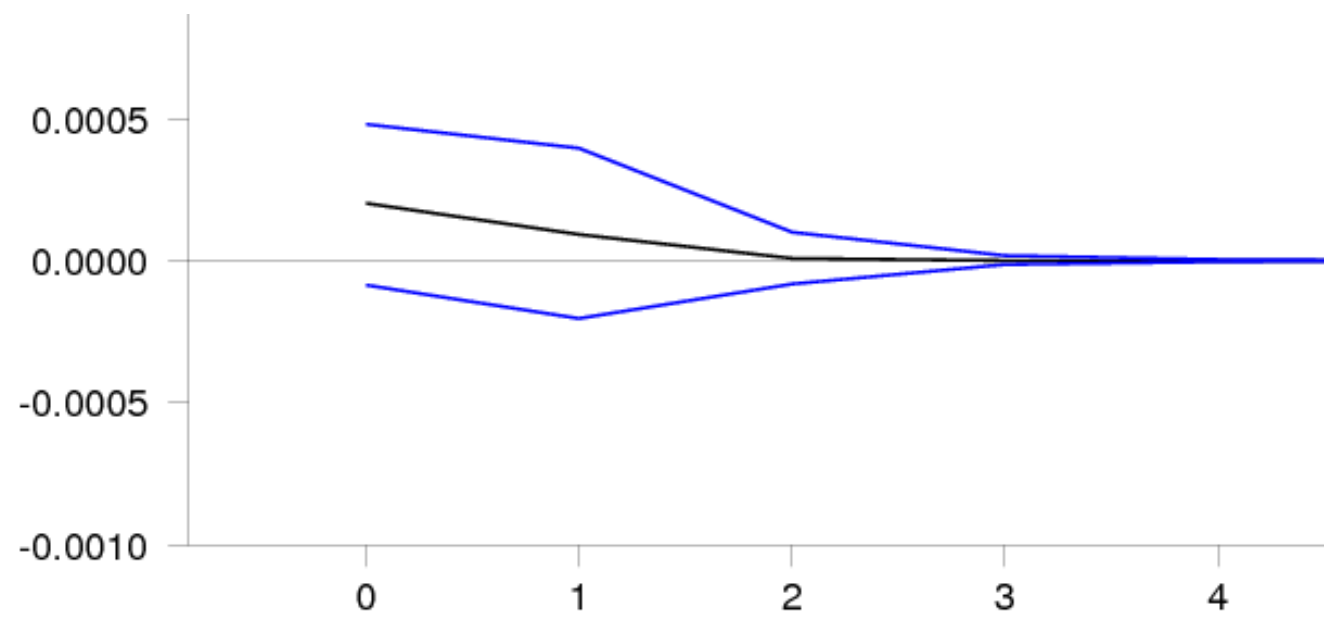

Figure 4: The impulse response of net foreign flows to a shock in PR

Figure 5 below breaks down the response of foreigners' net purchases to an upgrade and downgrade in PR index. The main message is that their reaction to good political news is slow (more of the response takes place in the following month) and of smaller magnitude, while their reaction to bad political news is stronger and immediate. This is consistent with slow build-up and quick loss of confidence. It should be mentioned here that changes in PR index do not exhibit any significant autocorrelation.
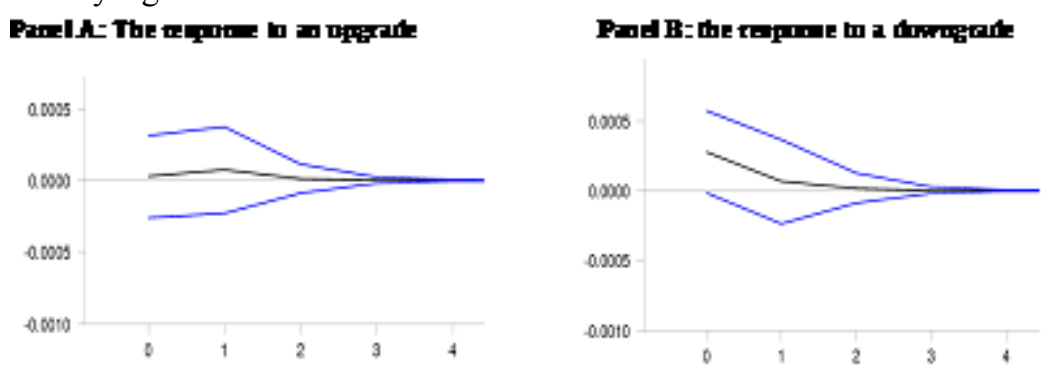

Figure 5: The response of net foreign flows to a positive and negative shock in PR index

\section{Industry Portfolio Results}

First, we note that all industry portfolio returns exhibit a significantly positive contemporaneous relationship to global markets, with the first lag also being borderline significant in most cases (see Panel C in Figures 6-13). The highest world beta is seen in the banking sector. These sensitivities are important as they may affect foreigners' trading in different sectors. The impact of PR on industry portfolio returns is typically positive, but insignificant in many industries. Banking sector returns exhibit the strongest response to PR shocks, followed by wood-paper-printing sector. The impact of PR on chemical-petroleumplastic and non-metal minerals sector returns is negligible. Other industry returns exhibit insignificantly positive relationship to PR (see Panel D in Figures 6-13).

Our main interest is the impact of PR shocks on foreigner's trading in different industries. Below, in Panels A and B of Figures 6-13, are the impulse responses of net foreign purchases (NF) in several industries to a shock global return (WR) and in PR, respectively.

A first interesting observation is that in the food and beverage sector (Figure 7), foreigners act in a contrarian manner to PR. While this industry's returns are weakly positively related to $\mathrm{PR}$, foreigners seem to take advantage of this positive reaction, possibly considering that the 
performance of firms in this sector should not be very sensitive to political risk. The strongest response to political risk in the expected direction is seen in the banking sector. Foreigners' trading in the banking sector also exhibits the strongest response to world returns. In other sectors, the response of net foreign flows to world returns and PR is positive but only marginally significant. Thus, one can contrast banking sector with the food and beverage sector, and argue that foreigners' trading pattern is rationally related to firm's sensitivity to market factors. Generally speaking, the response of net foreign flows to global returns and to PR exhibit parallel variation across industries. Foreigners seem to employ strategies based on sensitivity of industries to market factors.

A notable exception is the tourism sector (Figure 13). It has a significantly positive world beta, however foreigners exhibit little response global market returns, while they exhibit a strong positive response to PR, even though tourism sector returns do not significantly respond to PR. As our data partition market participants as domestic versus foreign investors, the above finding implies a significant difference in the response of foreign and domestic investors in the tourism industry to political risk. A possible explanation is that political risk is perceived differently by international investors. Likewise, the impact of political instability on tourists' decisions (tourism demand) may be evaluated differently. Political instability is documented to have negative influence on tourism industry (Sönmez, 1998), consistent with foreigners' response.

\section{Conclusion}

This article provides the first evidence on the dynamic response of foreigners' trading to political risk shocks in an emerging stock market. Political risk affects foreigners' marketwide trading in the expected direction, but only moderately. Foreigners' response to PR downgrades is immediate and larger in magnitude, while their response to PR upgrades is slow. We also find that the bulk of the effect of PR changes is priced-in within the contemporaneous month, and the response to upgrades is slower.

Foreign investors' reaction to PR changes in different industry portfolios varies mainly with the sensitivity of the industry to market factors (usually in parallel to their reaction to world market returns). They respond positively to PR changes in sectors, such as banking, which are sensitive to market factors. They exhibit contrarian trading with respect to PR changes in food and beverage sector. Given that food and beverage sector returns are positively related to PR, these results suggest that foreigners do not follow herds or pursue naïve feedback trading strategies.

An interesting dimension of these results stems from the fact that our data partition market participants as domestic versus foreign residents. This implies that domestic investors trade in the opposite direction of PR shocks, and more so in industries that are more sensitive to market risk. In other words, domestic traders seem to provide liquidity to foreign investors who trade on information. This suggests that a significant difference exists between foreign and domestic investors' response to political risk. The difference is particularly salient in the tourism sector where foreigners strongly respond to political risk whereas domestic investors seem to be more comfortable with it.

\section{References}

- $\quad$ Bailey W., and P. Chung. 1995. "Exchange Rate Fluctuations, Political Risk, and Stock Returns: Some Evidence From An Emerging Market.” Journal of Financial and Quantitative Analysis 30, 541-562.

- Bilson, C.; T. Brailsford; and V. Hooper. 2002. "The Explanatory Power of Political Risk in Emerging Markets." International Review of Financial Analysis 11, 1-27.

- Chan, Y., and J. Wei. 1996. "Political Risk And Stock Price Volatility: The Case Of 
Hong Kong.” Pacific-Basin Finance Journal 4, 259-275.

- Clara G. and I. Gang. 2010. "Exchange Rate and Political Risks, Again.” Emerging Markets Finance \& Trade 46, no. 3: 46-58.

- Diamonte, R.; J. Liew; and R. Stevens. 1996. "Political Risk in Emerging and Developed Markets." Financial Analysts Journal 52 (May/June): 71-76.

- $\quad$ Erb, C.; C. Harvey; and T. Viskanta. 1996. "Political Risk, Economic Risk and Financial Risk.” Financial Analysts Journal 52 (Nov/Dec): 29-46.

- Griffin, J.M.; F. Nardari; R.M. Stulz,. 2004. “Are Daily Cross-Border Equity Flows Pushed or Pulled?” The Review of Economics and Statistics 86, no. 3: 641-657.

- $\quad$ Kim, H. and J. Mei. 2001. "What Makes The Stock Market Jump? An Analysis of Political Risk on Hong Kong Stock Returns.” Journal of International Money and Finance 20, 1003-1016.

- Richards, A., 2005. Big Fish in Small Ponds: "The Trading Behavior and Price Impact of Foreign Investors in Asian Emerging Equity Markets." Journal of Financial and Quantitative Analysis 40, no. 1: 1-27.

- Sönmez, S. 1998. "Tourism, Terrorism and Political Instability." Annals of Tourism Research 25, 416-456. 


\title{
Globalization and Formation of National Pension System Concept: Practice, Problems and Future Trends
}

\author{
Nataliya Rad, Donetsk National University of Economics and Trade after M. \\ Tugan-Baranovsky, Ukraine
}

\begin{abstract}
The article analyzes some aspects of Ukrainian pension system reforming in the context of globalization processes. It is pointed out that globalization, as a backbone factor, not simply generates integration trends for entities of social-economic development. Gradual elimination of state borders and creation of common free market zone take place. Of dominating importance in today's world is a concept of sustainable development as a process to ensure needs of generations in the long-term outlook. The main place in social development belongs to an individual. This is reflected in respective evaluating indicators. As a basis of Ukrainian pension reforming transition to three-level model of pension system that functions in many countries of the world is assumed. This concept contains potential for implementation of modern social standards of social-economic development. It is also a powerful tool that influences development of society. The results of development of economic and social domains for the period of pension system transformation are analyzed and a frame of problems is specified. Lack of efficient tools for capitalization of pension assets and risk protection accompanying functioning of the national pension system is mentioned. Proposals for improvement of the pension system concept are worked out.
\end{abstract}

JEL codes: G23, G28

\section{Problem definition}

Pension system development is constituent part of transformational processes that occur in Ukraine. Their orientation and character are defined by endogenous and exogenous factors where globalization trends dominate. As the superior type of integration they, under presentday conditions, create valuable opportunities for stable and efficient development of the whole system of public relations. And aggregate information space contributes to expansion of global experience, concepts and standards of development.

Started in 2004 pension system reform has become continuation of implementation of the principles of social state declared in the Constitution of Ukraine (Constitution of Ukraine, 1996). It should be noted that taken as a basis, three-level pension system model is not new. Similar systems are already functioning in different countries. Its concept provides for diversification approach to retirement assets formation within the framework of solidarity and savings systems of compulsory state pension insurance and non-state pension provision system based on insurance principles.

Many scientists and experts devoted their works to studying different aspects of pension system reforming. However, problems related to formation of the optimal model of the national pension system in the context of globalization effects have been investigated not to the full. This explains urgency of research topic.

Thus, object of the article is analysis of particular aspects of Ukraine pension system reforming under the influence of globalization processes; identification of outstanding problems and development of proposals for improvement of approaches to formation of pension reforming concept.

\section{Problem description}

It should be emphasized that current pension reform has integrated nature. And its goals go 
beyond the scope of the raising of living standards of citizens. It is expected that renewed pension system parameters will contribute to activation of economic contacts, formation of investment resources, and transformation of it from economy-burdening institution into complex of impetuses for development.

However, analysis of statistics shows that besides positive dynamics of social indicators one can observe negative nature of a number of indicators that determine development (State Committee of Statistics of Ukraine, 2010) (Fig. 1).

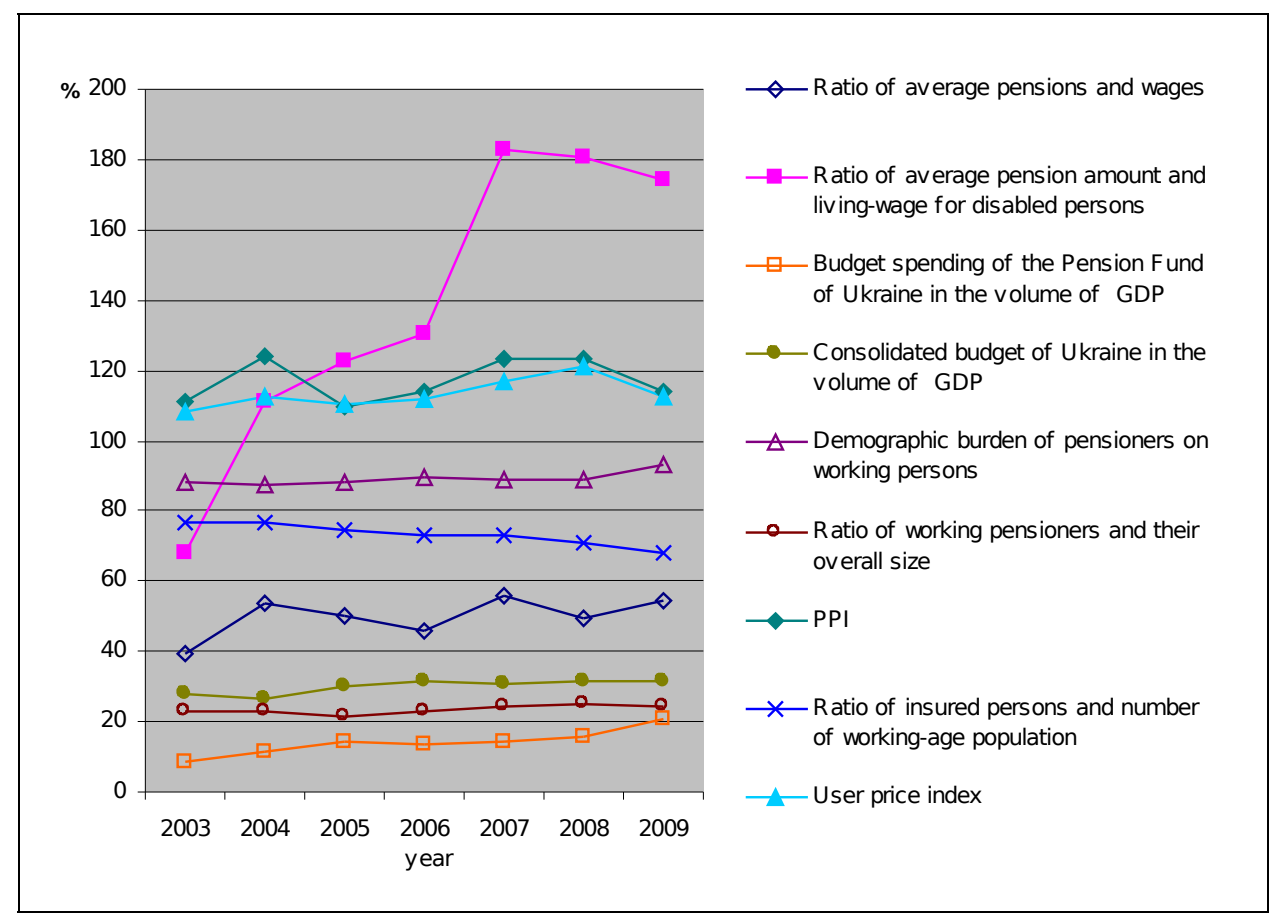

Figure 1. Dynamics of key figures of pension system development in Ukraine for 2003-2009

The above figures indicate continuation of increase in level of load on state economy and financial fragility in the period under consideration.

It is appropriate to emphasize that depending on the dominating components pension relations may be financial, insurance or social. Note that pension relations formed during centuries-long history have taken on stable national features. They are characterized by low level of insurance initiative and traditions, weakening of interfamilial social responsibility and formation of corresponding set of mind.

Current pension reform has taken on pronounced financial-insurance orientation; social essence of pension relations is being evened-out. The result is aversion of transformations alien to pension system participants' set of mind. The illustration of this can be outcomes of polling among 4.3 thousand citizens of different ages and social categories in Donetsk region. According to its data, pension transformations correspond to the views of only $12.4 \%$ of respondents. But $6.1 \%$ of pollees see themselves responsible for formation of retirement assets, and $42.0 \%$ of pollees consider this as duty of state.

Pension system development is defined primarily by economic level of the state and stability of its financial system as a basis for solution of social problems. At the same time, current pension relations penetrate all domains of public life through which manifestation of globalization processes is show in Table 1. 


\begin{tabular}{|c|c|c|c|}
\hline $\begin{array}{l}\text { Domains of } \\
\text { manifestation }\end{array}$ & $\begin{array}{l}\text { What manifestation } \\
\text { consist in }\end{array}$ & $\begin{array}{l}\text { Positive impact } \\
\text { potential }\end{array}$ & $\begin{array}{l}\text { Negative impact } \\
\text { potential }\end{array}$ \\
\hline Economic & $\begin{array}{l}\text { Structural } \\
\text { transformation and } \\
\text { socialization }\end{array}$ & $\begin{array}{l}\text { Growth of } \\
\text { mobility, agents, } \\
\text { role of knowledge, } \\
\text { modernization }\end{array}$ & $\begin{array}{l}\text { Integrity failure, } \\
\text { disbalances }\end{array}$ \\
\hline Financial & $\begin{array}{l}\text { Structural } \\
\text { transformation of } \\
\text { financial systems }\end{array}$ & $\begin{array}{l}\text { Capital migration, } \\
\text { capitalization of } \\
\text { instruments }\end{array}$ & $\begin{array}{l}\text { Instability and } \\
\text { disbalances }\end{array}$ \\
\hline Social & $\begin{array}{l}\text { Raising the role of } \\
\text { individual in } \\
\text { criteria of society } \\
\text { development }\end{array}$ & $\begin{array}{l}\text { Growth of social } \\
\text { standards }\end{array}$ & $\begin{array}{l}\text { Capitalization } \\
\text { social relations }\end{array}$ \\
\hline $\begin{array}{l}\text { Moral, } \\
\text { mental and ethical }\end{array}$ & $\begin{array}{l}\text { Formation of inter- } \\
\text { generational } \\
\text { relations }\end{array}$ & $\begin{array}{l}\text { Capability } \\
\text { improvement }\end{array}$ & $\begin{array}{l}\text { Pragmatism and } \\
\text { earthliness }\end{array}$ \\
\hline
\end{tabular}

Table 1. Basic manifestations of globalization processes through domains of national public environment

It was noted that building of pension system concept means formation of acceptable relation between increasing social needs and capability of state to implement them. For objective assessment of the quality of pension support a number of social standards at the level that ensures dignity and free development of individual have been elaborated by world community (Kapitsa, 2008a). At the same time, updating of intangible indicators such as integral index of human development, Happy Planet index and many others takes place (Kapitsa, 2008b). Building of national standards is based at indicators oriented at costs of living (Kulinich, 2007). This corresponds not in full with Euro-integration priorities for state development and requires harmonization with international standards.

Stressing importance of increasing national development socialization it is desirable to mention strengthening of the crisis of existing theories. Traditionally used models of society development ceased to meet demands made to them by mankind (Popkov, 2007a). Indeed, such criterion for assessment of economic development as profit on laid-down capital does not give any comprehensive characteristic of sustainable development. Criteria for assessment of social development can be neither objective based on infinite growth in prosperity. According to some estimates such categories as social state and welfare state are interpreted today as threat to national and general development process (Popkov, 2007b). Based on the limited nature of natural resources as natural limiting factor, the concept of "Sustainable Development: The Nature - Society -Human Being" stipulates for definite frameworks of economic and social development on a global scale (Popkov, 2007c). It is pointed out that the main subject matter of sustainable development estimate is inter-generational balance of meeting the demands (Kotlikoff ve Burns, 2004). This requires global coordination actions on general global scale. Thus, formation of the concept of pension system under present-day conditions requires determination of its ideology and a place in general long-term perspective development.

Concentrating attention on the urgency of providing sustainable social-economic development, it is desirable to accentuate importance of knowledge development as one of the most efficient tools of global problem solution. V. I. Vernadsky considered scientific idea of mankind among unique natural phenomena, owing to development of which mankind improved and optimized conditions and life support environment at qualitatively new levels (Popkov, 2007d). It should be emphasized that knowledge as a category has no limitations and 
bears in itself powerful development potential. This resource has one very important feature. Depending on goal-oriented character this potential can take either creative or destroying trend. In our opinion, society's immateriality and morality define its qualitative characteristics. Thus, it is the author's opinion that moral component has also to be present in the concept of sustainable development. In accordance with our notion, immateriality in the context of development can be determined as unique human society-inherent phenomenon, which contributes to integrity of the process of society development harmonized within socium and with surrounding vital space.

This seems of current importance because present pension transformations more and more reveal problems of moral character main manifestations of which are given in Table 2.

\begin{tabular}{|c|c|c|}
\hline $\begin{array}{c}\text { Assessment of pensioner's } \\
\text { status }\end{array}$ & Description & $\begin{array}{c}\text { Manifestations and } \\
\text { sequences }\end{array}$ \\
\hline In family & Weak social obligations & $\begin{array}{c}\text { Lack of assistance from } \\
\text { relatives }\end{array}$ \\
\hline By employer & $\begin{array}{c}\text { Discrimination by age } \\
\text { (ageism) }\end{array}$ & $\begin{array}{c}\text { Employment assistance } \\
\text { problems }\end{array}$ \\
\hline By society & Negative image & Absence of demand \\
\hline Personal identification & Low self-appraisal & Dissatisfaction \\
\hline
\end{tabular}

Table 2. Basic problem moral aspects related to formation of the concept of pension system in Ukraine

It should be recognized that the state during pension reformation has not proposed any radical changes in ideology for attitude toward middle age representatives. This is confirmed by polling data according to which $62.2 \%$ of pensioners consider that reformation did not improve their social status. From the above it follows that it is necessary to re-think and correct moral aspects of the reform.

Present-day crisis has shown that practically none of accumulation forms could guarantee preservation of savings for old age. There is no experience of efficient functioning of such instruments in long-term perspective. Thus, in conditions of existing global and national financial risks solidary system, in our opinion, is a more optimal system of guaranteed social protection of citizens. Stereotypes of perception of it and improvement of its elements should be changed.

It was mentioned that world depression has only plaid the role of catalyst in aggravation of internal structural disbalances and antagonisms. It is expected that strengthening of global processes will further propagate variants of their manifestations and ranges (Naumenkov ve Mishchenko, 2009). Therefore absence of harmonious global ideology and balanced concept of development in conformity with national ones will restrict capabilities for efficient overcoming of crisis phenomena doing this situationally and keeping the origins unchangeable.

\section{Conclusions}

Thus, to improve the concept of pension reforming in conditions of active influence of globalization processes, in our opinion, it is necessary:

i. To add moral component to the system of basic criteria of world development.

ii. To form harmonious ideology and concept of world development.

iii. To identify the place of pension system in the national system of development in conformity with global criteria.

Introduction of the proposed measures will make it possible to improve domestic concept of 
pension reforming in correlation with global trends in the context of social-economic development of Ukraine.

\section{References}

- Kapitsa, 2008. World development indicators. MGIMO(U), Moscow.

- Kulinich, 2007. Statistical estimation of social-economic development factors. Znannya, Kuiv.

- Kotlikoff ve Burns, 2004. The coming generational storm: what you need to know about America's economic future. The MIT Press, London.

- Naumenkov ve Mishchenko, 2009. "Problems of Overcoming Negative Influence of Deep Disparities and Formation of New Geo-financial Mechanism", Finances of Ukraine, 160, p. 23.

- Popkov, 2007. Sustainable economic development in conditions of globalization and knowledge economy: conceptual bases of management practice and theory. Economika, Moscow.

- State Committee of Statistics of Ukraine, 2010. Statistical information, http://www.ukrstat.gov.ua/operativ/oper_new.html

- Verkhovna Rada of Ukraine, 1996. Constitution of Ukraine, http://zakon1.rada.gov.ua/cgi-bin/laws/main.cgi?nreg=254\%EA\%2F96-\%E2\%F0 


\title{
Determinants of Bank's Net Interest Margin in Indonesia
}

\author{
Ascarya Ascarya, Central Bank of Indonasia \\ Diana Yumanita, Central Bank of Indonasia
}

\begin{abstract}
Indonesia has adopted dual banking system since 1998, when conventional bank operate side by side with Islamic bank. One measure of bank's performance as intermediary institution to stimulate economic growth is net interest margin (NIM) in conventional bank or net profit-andloss sharing/PLS margin (NPM) in Islamic bank. This study analyses the determinants of NIM and NPM in Indonesia using multivariate analysis and dynamic panel data to see the persistence of large NIM and NPM in the recent past, although policy rate has been decreasing significantly.
\end{abstract}

JEL Codes:: E52, G18, G28

\section{Introduction}

\subsection{Background}

Indonesia's financial system has long been dominated by banking sector. Meanwhile, Indonesia has adopted dual banking system since 1998, when conventional bank operates side by side with Islamic bank. As intermediary, banking sector plays dominant role in productive activities and economic development. Research by Levin (1996) showed that the effectivity of banking intermediary can affect economic growth. One of the indicators is net interest margin (NIM) in conventional bank or net profit-and-loss sharing/PLS margin (NPM) in Islamic bank.

Islamic banks are expected to encourage the growth in real sector as business partner and contribute positively in the realization of sustainable development. By emphasizing the investment paradigm, the main role of Islamic bank is distributing funds to productive financing based on profit-and-loss sharing (PLS) mode of finance.

One indicator of effective banking intermediation is loan to deposit Ratio (LDR) in conventional bank or financing to deposit ratio (FDR) in Islamic bank, which reached $73 \%$ and $90 \%$, respectively, at the end of December 2009. Another indicator is loan / financing to GDP ratio. Based on Bank Indonesia data as of December 2009, loan to GDP and financing to GDP ratios have shown an increasing trend. However, Indonesia's total loan+financing to GDP ratio is much lower than other Asian countries, such as Philipine and Thailand that reached 297\% and $309 \%$, respectively.

Distribution of conventional loan and Islamic financing in real sector can be optimized, if the pricing set by the bank is in accordance to market price or market return. This normal pricing will provide reasonable profit for entrepreneurs who obtain loan from conventional bank or financing from Islamic bank for their businesses. Unreasonable pricing (too high) will distort the market, reduce business interest, and will also reduce the effectiveness of intermediation function of bank. High loan/financing price will make the attempt to encourage the activities in real sector becomes counterproductive.

The pricing of loan/financing in conventional/Islamic banks are determined by their constituent elements, which are cost of fund and spread. Cost of fund is determined by the composite level of return on deposits (demand deposit, saving, and time-deposit), while the spread is determined by interest to cover required reserves, loan loss provisions / loans, operating costs / loans, and pretax profit. Bank loan/financing pricing is influenced by microeconomic factors (internally) and macroeconomic factors (externally). Microeconomic factors include bank size, equity, overhead cost, foreign ownership, competition, reserve 
requirement, and deposit rate (Gelos, 2006), while macroeconomic factors include GDP, inflation, volatility and country risk. Other influencing factors are information, tax, and legal environment.

Up until today, pricing in Islamic bank, either from supply side, which includes PLS nisbah, murabahah margin, ijarah fee, and fee based income rates, or from demand side, which includes demand deposit, saving deposits and time deposits, are still be benchmarked to conventional interest rate prevailed as reference rate in the market. The pricing technique of Islamic bank is also copied from that of conventional bank. However, the movement of PLS return in Islamic bank does not always follow the movement of interest rate in conventional bank.

The margin or spread between PLS funding and financing in Islamic bank is relatively similar to the margin or spread between interest funding and loan in conventional bank. From January - November 2009, Islamic bank PLS margin reached an average of $6.1 \%$, while conventional interest margin reached an average of $6.3 \%$ (see figure 1.3). High and persistent margin between funding and financing does not only happen in Indonesia. Research conducted by Gelos (2006) and Afanasieff and Lhacer (2006) showed a high and persistent margin in Latin America, resulting in low distribution of banking credit. In Brazil, the margin between lending and deposit rates was as high as $38.7 \%$ in 2000. Cihak and Podpiera (2005) showed that high margin (13\% average) also occured in Africa in 2002.

Based on the above mentioned problem of high and persistent interest/PLS margin in Indonesia's conventional/Islamic bank, it is very important to understand the determinants of interest/PLS margin of bank, so that the root cause of the problem can be pin pointed and policy recommendations to solve the problem can be formulated.

\subsection{Objectives}

In detail, this study/research has some objectives to answer the research questions, as follows.

1. To identify the determinants of net interest margin (NIM) of conventional bank, as well as net PLS margin (NPM) of Islamic bank.

2. To identify the causes of persistent high NIM and NPM in conventional bank and Islamic bank, respectively.

\section{Methodology}

The definition of net interest margin in this research refers to the definition suggested by Maudos (2009), financial income and financial expenses to total asset. The observation period in this research is from first quarter 2006 - First quarter 2009 (quarterly). Total banks are 80 commercial banks. Banks in this research cover more than $80 \%$ of share asset to total banking asset, in both conventional and Islamic banking as a whole.

\subsection{Determinants of Net Interest Margin}

To answer the research question about determinant factors that influence net interest margin of bank following bank spread, is by using two step regression approach by Ho and Saunders (1981), Alfanasief (2002), Brock and Suarez (2000), Maudos (2004, 2009). In this approach, bank is assumed to be risk adverse and acted as dealer or intermediary between creditor and debitor. The model considers the credit risks with a process that does not require big expenses. In its operational activities, bank tends to hold non-liquid assets and by then it always manages unbalanced portfolio, due to excess credit demand or insufficient credit supply. Bank determines the deposit's and credit's rate to maximize the profit at the end of period.

Assumption used is that creditor and debitors meet randomly by Poisson process. Ho and Saunders assumed that the functions of credit and deposit rate have specifications of linear 
symmetric as the equation below:

$\lambda_{L}=\alpha-\beta b, \quad \lambda_{D}=\alpha+\beta a$

Where $\mathrm{a}$ and $\mathrm{b}$ are the fees charged by credit and deposit.

The equilibrium of spread can be written down as follow:

$s=a+b=\frac{\alpha}{\beta}+\frac{1}{2} R \sigma_{1}^{2} Q$

Where bank spread consists of two parts, first is $(\alpha / \beta)$, which measures the 'risk neutral spread'. This indicator reflects bank spread when bank faces neutral risks. Risk neutral spread is the ratio of intercept $(\alpha)$ against the slope $(\beta)$ from the symmetric functions of credits and deposits. Ho and Saunders interpreted that the first part is the measurement of market power, as long as bank faces an inelastic demand relative to supply function in market, so that the market power is reflected by giving out a bigger spread.

The second part is to measure the risk premium. It reflects the composition of three components, which are absolute coefficient of risk aversion (R), variation of interest rate on net credit inventories $\left(\sigma_{1}^{2}\right)$ and transaction size between deposits and credit.

In this case, Ho and Saunders (1981) and Alfanasief (2006) built two-step regression to determine the variables that influence bank spread.

\subsection{Econometric Model}

In this section, we describe the empirical approximation of the determinants of net interest margin in the Indonesian conventional banking system. We estimate a regression model of the net interest margin (NIM) (calculated as the difference between financial income and financial costs divided by total asset) as a function of pure spread (PS), bank specific variables (BS) and Macroeconomic Variables.

The model to $b$ estimated is as follows:

$$
N I M_{i t}=\alpha_{i}+\sum_{j=1}^{J} \beta^{j} P S_{i t}^{j}+\sum_{k=1}^{K} \chi^{k} B S_{i t}^{k}+\sum_{l=1}^{L} \delta^{l} M E_{t}+\varepsilon_{i t}
$$

For $\mathrm{t}=1, \ldots \ldots \mathrm{T}$, where $\mathrm{T}$ is the number of periods observed and $\mathrm{i}=1, \ldots \ldots \mathrm{I}$, and $\mathrm{I}$ is the total number of banks. Therefore, subscripts I and t refer to bank I at time t, respectively. Pure spreads are the variables that theoretically determine the margin.

\subsection{Operational Variables}

The variables are proxied empirically as follows:

Table 3.1 Variable Descriptions and data used

\begin{tabular}{|c|c|c|c|}
\hline Variables & Description & Source & Expected Sign \\
\hline \multirow[t]{2}{*}{ Net Interest Margin } & $\begin{array}{l}\text { Calculated as the difference between } \\
\text { financial income and financial costs } \\
\text { divided by total asset }\end{array}$ & $\begin{array}{l}\text { Bank's Monthly } \\
\text { Financial Report }\end{array}$ & \\
\hline & I. $\quad$ Pure Spread & & \\
\hline Market Power & $\begin{array}{l}\text { Proxy of Concentration Degree } \\
\text { (Herfindhal Index) }\end{array}$ & Developed & Positive/Negative \\
\hline Risk Aversion & Ratio of Equity to total assets & Balance Sheet & Positive \\
\hline Size & Logarithm of loans & Balance Sheet & A priori \\
\hline \multirow[t]{2}{*}{$\begin{array}{l}\text { Market } \\
\text { Volatility }\end{array}$} & Market rate standard deviation & Bank Indonesia & Positive \\
\hline & Microeconomic VaI & iables & \\
\hline Operating Cost & Ratio of administrative to total asset & Income Statement & Positive \\
\hline
\end{tabular}




\begin{tabular}{|c|c|c|c|}
\hline Default Risk & Ratio of credit to total asset & Balance Sheet & Positive \\
\hline Liquidity Risk & Ratio of liquid asset to liquid liability & Balance Sheet & Negative \\
\hline implicit return & $\begin{array}{l}\text { Ratio biaya non dana to rata-rata aktiva } \\
\text { produktif }\end{array}$ & $\begin{array}{l}\text { Income Statement } \\
\text { Balance Sheer }\end{array}$ & Positive \\
\hline $\begin{array}{l}\text { Opportunity cost of } \\
\text { bank reserves }\end{array}$ & $\begin{array}{l}\text { Ratio of liquid reserves (proxied by cash } \\
\text { variable) to total asset }\end{array}$ & Balance Sheet & Positive \\
\hline $\begin{array}{l}\text { Quality of } \\
\text { Management } \\
\text { (efficiency) }\end{array}$ & $\begin{array}{l}\text { Ratio of operational cost to operational } \\
\text { revenue }\end{array}$ & Income Statement & Negative \\
\hline Operational Policy & $\begin{array}{l}\text { Ratio of deposit to difference of total asset } \\
\text { and fixed asset }\end{array}$ & Balance Sheet & Positive \\
\hline Implicit Cost & $\begin{array}{l}\text { Difference between noninterest expense } \\
\text { and other operating income in term of total } \\
\text { assets }\end{array}$ & $\begin{array}{l}\text { Income Statement } \\
\text { Balance Sheet }\end{array}$ & Positive \\
\hline $\begin{array}{l}\text { Interaction between } \\
\text { credit and market } \\
\text { risk }\end{array}$ & $\begin{array}{l}\text { Ratio product of nonperforming loans to } \\
\text { loans and market risk }\end{array}$ & Income Statement & Positive \\
\hline $\begin{array}{l}\text { Income } \\
\text { trading }\end{array}$ & Difference of non interest income and fee & Income Statement & Negative \\
\hline $\begin{array}{l}\text { Strategy } \quad \text { cost } \\
\text { subsidy }\end{array}$ & $\begin{array}{l}\text { Ratio of other operation revenue- } \\
\text { operational cost to total asset }\end{array}$ & Income Statement & Negative \\
\hline Ratio of Deposit & Specialization variables & Balance Sheet & \\
\hline \multirow[t]{2}{*}{$\begin{array}{l}\text { Non } \\
\text { Loan }\end{array}$} & Bad debt (collective 4 and 5) & Income Statement & Positive \\
\hline & Macroeconomic V & riables & \\
\hline Inflation & Growth rate of the consumer price index & $\begin{array}{l}\text { Indonesia Bureau of } \\
\text { Statistics }\end{array}$ & Positive \\
\hline PUAB & Daily PUAB & Bank Indonesia & Positive \\
\hline GDP Growth & Output Growth in constant 2002 & $\begin{array}{l}\text { Indonesia Bureau of } \\
\text { Statistics }\end{array}$ & Positive/Negative \\
\hline
\end{tabular}

Note: $\left.{ }^{*}\right)$ Less concentrated and more competitive banks will adjust their credit rate quicker

**) Operational costs considered in MFR, consist of labour cost, education and training cost, research and development cost, rental cost, promotion cost, and maintenance and repair costs.

\section{Result}

The sample used is form by a balanced panel of data from quarterly observations, corresponding to 80 commercial banks for the period between first quarter 2006 and 2009, which represent an average of $80 \%$ of the Indonesian commercial bank. The data obtained from financial report of Bank Indonesia. Table 1 shows the descriptive statistics of the net interest margin and their determinants, as well as the number observations in each year.

The model was estimated with fixed effects in order to capture the influence of specific variables of each bank. The results are presented in table 2 .

Almost the sign of variables are significant with the expected sign.

Table 1. Sample Descriptive Statistic

\begin{tabular}{|c|c|c|c|c|c|c|c|c|c|c|c|c|c|c|c|c|c|c|}
\hline Year & Barks & Statistics & NIM & $\begin{array}{c}\text { Market } \\
\text { Power } \\
\text { (Hefinchl } \\
\text { Inder-Loan) }\end{array}$ & $\begin{array}{c}\text { Pisk } \\
\text { Aversion }\end{array}$ & $\begin{array}{l}\text { Operating } \\
\text { cost }\end{array}$ & Default Pisk & $\begin{array}{l}\text { liquidty } \\
\text { Fsk }\end{array}$ & $\begin{array}{c}\text { impliait } \\
\text { retum }\end{array}$ & $\begin{array}{c}\begin{array}{c}\text { Opproturity } \\
\text { cost of bark } \\
\text { reserves }\end{array} \\
\end{array}$ & $\begin{array}{c}\text { Opporturity } \\
\cos \end{array}$ & $\begin{array}{l}\text { Management } \\
\text { Quality }\end{array}$ & $\begin{array}{l}\text { Operational } \\
\text { Policy }\end{array}$ & $\begin{array}{l}\text { Impliat } \\
\text { Interest }\end{array}$ & $\begin{array}{l}\text { Income } \\
\text { from } \\
\text { trading } \\
\end{array}$ & $\begin{array}{c}\text { Srategy } \\
\text { cost } \\
\text { sulsidy }\end{array}$ & $\begin{array}{l}\text { Ratioof } \\
\text { Deposit }\end{array}$ & $\begin{array}{c}\text { Non } \\
\text { Performing } \\
\text { Loan }\end{array}$ \\
\hline$\overline{2006 \_1}$ & 80 & "Mean & 5.88 & 5.92 & $\begin{array}{l}13.45 \\
\end{array}$ & 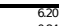 & 54.56 & 38.62 & 422.94 & 3.95 & $\begin{array}{l}19.49 \\
1.29\end{array}$ & 4432.52 & $\begin{array}{l}78.27 \\
1.27\end{array}$ & $\begin{array}{l}9.31 \\
9.37\end{array}$ & $=61.12$ & 2.79 & $\begin{array}{l}75.49 \\
\end{array}$ & 4.122 \\
\hline & & Standard Deviation & & & 11.92 & & 18.21 & 26.59 & & 1.78 & 13.39 & 346.29 & & 3.76 & 145.47 & & 14.78 & 3.79 \\
\hline 2006_2 & 80 & $\begin{array}{l}\text { Mean } \\
\text { Standard Deviztion }\end{array}$ & 5.70 & 5.84 & 13.82 & 6.23 & 54,44 & 39.31 & $\begin{array}{l}44.20 \\
25.55\end{array}$ & 3.88 & 22.68 & 438.29 & 78.38 & 9.17 & 53.12 & 2.80 & 75.64 & 4.17 \\
\hline 20063 & 80 & $\frac{\text { Standard Deviation }}{\text { Mean }}$ & $\frac{2.13}{5.68}$ & 6.14 & $\frac{10.13}{1421}$ & $\frac{0.84}{6.25}$ & $\frac{18.26}{5470}$ & $\frac{25.71}{39.92}$ & $\frac{25.65}{4.59}$ & $\frac{1.77}{3.88}$ & $\frac{\frac{15.81}{23.15}}{x}$ & $\frac{344.30}{442.41}$ & $\frac{16.05}{78.03}$ & $\frac{3.68}{9.11}$ & $\frac{12.373}{55.80}$ & $\frac{2.01}{2.82}$ & $\frac{15.20}{75.29}$ & $\frac{3.67}{4.16}$ \\
\hline & & Standard Deviation & 2.06 & & 10.38 & 0.82 & 17.74 & 25.68 & 27.40 & 1.79 & 15.97 & 339.00 & 15.89 & 3.56 & 130.94 & 1.97 & 14.97 & 3.85 \\
\hline 20064 & 80 & $\begin{array}{l}\text { Mean } \\
\text { Standard Deviation }\end{array}$ & $\begin{array}{l}5.42 \\
2.05\end{array}$ & 6.12 & $\begin{array}{l}13.73 \\
992\end{array}$ & $\begin{array}{l}6.28 \\
0.82\end{array}$ & $\begin{array}{l}53.59 \\
1790\end{array}$ & $\begin{array}{l}40.44 \\
2314\end{array}$ & $\begin{array}{l}44.45 \\
29.34\end{array}$ & $\begin{array}{l}3.82 \\
187\end{array}$ & $\begin{array}{l}23.29 \\
13.38\end{array}$ & $\begin{array}{l}453.20 \\
332.94\end{array}$ & $\begin{array}{l}77.46 \\
1573\end{array}$ & $\begin{array}{l}8.62 \\
3.44\end{array}$ & 55.11 & 2.80 & 74.89 & 3.69 \\
\hline 2007_1 & 80 & $\begin{array}{l}\text { Sododoradevidion } \\
\text { Mean }\end{array}$ & 2.05 & 5.59 & $\begin{array}{l}9.92 \\
14.13 \\
\end{array}$ & $\frac{0.82}{6.29}$ & $\begin{array}{l}17.90 \\
53.15\end{array}$ & $\begin{array}{l}2.14 \\
46.15 \\
\end{array}$ & $\begin{array}{l}2.44 \\
45.02\end{array}$ & $\frac{1.87}{3.85}$ & 27.50 & $\begin{array}{l}325.94 \\
428.59\end{array}$ & 77.71 & $\begin{array}{l}3.44 \\
8.10\end{array}$ & 57.71 & $\frac{1.99}{2.72}$ & $\begin{array}{l}14.06 \\
75.02\end{array}$ & $\frac{3.18}{3.88}$ \\
\hline & & Standard Deviation & 2.17 & & 10.95 & 0.82 & 17.69 & 39.18 & 27.97 & $\begin{array}{l}1.97 \\
\end{array}$ & 16.21 & 314.34 & $\begin{array}{l}16.02 \\
\end{array}$ & 3.09 & 133.63 & 1.93 & 14.98 & 3.20 \\
\hline $2007 \_2$ & 80 & Mean & 5.64 & 5.53 & 14.20 & 6.31 & 5430 & 42.56 & 44.42 & 3.86 & 24.64 & 408.78 & 77.55 & 7.86 & 55.37 & 2.70 & 74.90 & 3.93 \\
\hline & & Standard Deviation & 2.01 & & 111.13 & 0.82 & 17.58 & 32.34 & 30.08 & $\begin{array}{l}1.92 \\
192\end{array}$ & 15.08 & 301.83 & 14.73 & 3.13 & $\frac{12239}{2539}$ & 2.05 & 13.81 & 3.29 \\
\hline $2007 \_3$ & 80 & $\begin{array}{l}\text { Mean } \\
\text { Standard Deviation }\end{array}$ & $\begin{array}{l}5.42 \\
182\end{array}$ & 5.45 & $\begin{array}{l}14,35 \\
1077\end{array}$ & 6.33 & $\begin{array}{l}53.72 \\
17.08\end{array}$ & $\begin{array}{l}45.19 \\
3378\end{array}$ & $\begin{array}{l}44.28 \\
3661\end{array}$ & $\begin{array}{l}3.78 \\
187\end{array}$ & $\begin{array}{l}26.20 \\
1600\end{array}$ & $\begin{array}{l}414.17 \\
30677\end{array}$ & $\begin{array}{l}77.91 \\
14.75\end{array}$ & $\begin{array}{l}7.61 \\
295\end{array}$ & $\begin{array}{r}52.12 \\
11514\end{array}$ & $\begin{array}{l}2.73 \\
1.74\end{array}$ & $\begin{array}{l}75.27 \\
13.64\end{array}$ & $\begin{array}{l}3.66 \\
2.991\end{array}$ \\
\hline$\overline{20074}$ & 80 & & $\frac{1.82}{5.16}$ & 5.59 & $\frac{10.71}{14.37}$ & $\frac{0.84}{6.36}$ & $\frac{17.06}{54.00}$ & & $\frac{36.61}{47.50}$ & $\frac{1.87}{3.64}$ & & & & $\frac{2.95}{7.19}$ & & $\frac{1.64}{2.66}$ & $\frac{13.64}{74.11}$ & $\frac{2.91}{3.01}$ \\
\hline $2001-4$ & & Standard Deviation & $\begin{array}{l}3.91 \\
1.91 \\
\end{array}$ & 3.09 & $\begin{array}{l}12.25 \\
\end{array}$ & $\begin{array}{l}0.85 \\
0.85 \\
-10\end{array}$ & $\begin{array}{l}17.04 \\
17.04\end{array}$ & $\begin{array}{l}13.79 \\
113.79 \\
\end{array}$ & 50.11 & $\begin{array}{l}1.47 \\
1.47 \\
\end{array}$ & 16.86 & $\begin{array}{l}306.25 \\
306\end{array}$ & $\begin{array}{l}15.90 \\
15.90\end{array}$ & 2.49 & $\begin{array}{l}115.31 \\
1151 \\
\end{array}$ & $\begin{array}{l}1.200 \\
1.37 \\
\end{array}$ & 14.80 & 2.51 \\
\hline $2008 \_1$ & 80 & Mean & 5.50 & 5.38 & 13 & 6.39 & 57.05 & 52.58 & 47.75 & 3.79 & 24.04 & 426 & 76.28 & 7.42 & $\begin{array}{l}60.06 \\
1305\end{array}$ & 2.87 & 73.70 & 3.17 \\
\hline 20082 & 80 & $\begin{array}{l}\text { Standard Deviation } \\
\text { Mean }\end{array}$ & $\frac{2.04}{5.46}$ & 5.46 & $\frac{12.55}{1588}$ & $\frac{0.85}{642}$ & $\begin{array}{l}17.94 \\
59.29\end{array}$ & $\frac{135.08}{56.19}$ & $\begin{array}{l}56.30 \\
48.49\end{array}$ & $\frac{1.53}{382}$ & $\frac{16.68}{20.58}$ & $\frac{30}{42}$ & 16.45 & 2.61 & $\frac{135.84}{55.5}$ & 1.49 & $\frac{15.31}{77.40}$ & $\frac{3.10}{3.3 .}$ \\
\hline & & $\begin{array}{l}\text { Stand } \\
\text { Stand Deviation }\end{array}$ & $\begin{array}{l}\begin{array}{l}.46 \\
1.92\end{array} \\
\end{array}$ & & $\begin{array}{l}15.88 \\
13.99\end{array}$ & $\begin{array}{l}6.42 \\
0.87\end{array}$ & $\begin{array}{l}59.29 \\
17.82\end{array}$ & $\begin{array}{r}56.19 \\
19840\end{array}$ & 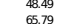 & $\begin{array}{l}3.82 \\
1.47\end{array}$ & $\begin{array}{l}20.58 \\
16.01\end{array}$ & $\begin{array}{l}426.91 \\
294.61\end{array}$ & $\begin{array}{l}75.85 \\
16.40\end{array}$ & $\begin{array}{l}7.27 \\
270\end{array}$ & $\begin{array}{r}5.565 \\
13.70\end{array}$ & $\begin{array}{l}2.87 \\
142\end{array}$ & $\begin{array}{l}773.40 \\
15.70\end{array}$ & $\begin{array}{l}3.03 \\
2.98\end{array}$ \\
\hline 2008 _3 & 80 & & 5.40 & 5.53 & 16.24 & 6.45 & 60.53 & 39.85 & 54.45 & 3.85 & 17.83 & 433 & 74.82 & 7.26 & 58.20 & 2.91 & 245 & 2.93 \\
\hline & & Standard Deviation & 1.79 & & 14.01 & 0.89 & 18.62 & 75.15 & 121.99 & 1.48 & 14.16 & 299. & 16.07 & 2.79 & 135.95 & 1.45 & 15.49 & 3.18 \\
\hline 20084 & 80 & Mean & 5.39 & 5.84 & 16.10 & 6.48 & 59.84 & $\begin{array}{l}57.88 \\
21311 \\
\end{array}$ & 59.60 & 4.11 & 18.38 & 424.50 & 74,44 & 7.68 & 60.15 & 3.06 & 72.05 & 2.97 \\
\hline 20091 & 80 & & $\frac{2.20}{5.49}$ & 650 & 15.47 & $\frac{0.87}{648}$ & $\frac{17.33}{56.65}$ & $\frac{213.11}{77.57}$ & $\frac{124.22}{6.72}$ & $\frac{2.19}{390}$ & $\frac{14.28}{21.64}$ & $\begin{array}{l}289.44 \\
40685\end{array}$ & $\frac{17.16}{7497}$ & $\frac{3.49}{810}$ & $\frac{145.36}{6.62}$ & $\frac{2.14}{2383}$ & $\frac{16.63}{782}$ & $\frac{4.53}{332}$ \\
\hline & & Standard Deviation & 1.95 & & $\begin{array}{l}17.36 \\
\end{array}$ & 0.88 & 16.42 & 224.93 & $\begin{array}{l}014.95 \\
143.95\end{array}$ & 2.01 & $\begin{array}{l}21.64 \\
14.11\end{array}$ & 346.81 & 18.40 & 3.85 & 147.23 & $\begin{array}{l}2.83 \\
2.20\end{array}$ & $\begin{array}{l}72.82 \\
16.99\end{array}$ & $\begin{array}{l}3.32 \\
4.62\end{array}$ \\
\hline
\end{tabular}


Source: Author Calculation based on data from Commercial Bank Financial Report, collected by Bank Indonesia

Table 2. Determinants of the Net Interest Margin

\begin{tabular}{|c|c|c|}
\hline \multicolumn{3}{|l|}{ Dependent Variable: Net Interest Margin } \\
\hline Variable & Coefficient & P-Value \\
\hline NIM (01) & 0.4706 & 0.000 \\
\hline Default Risk & 0.0502 & 0.000 \\
\hline Liquidity Risk & 0.0009 & 0.000 \\
\hline Implicit Return & 0.0000 & 0.929 \\
\hline Operational Cost & 0.0097 & 0.000 \\
\hline Efficiency & 0.0000 & 0.000 \\
\hline Operational Policy & 0.0451 & 0.001 \\
\hline Opportunity Cost of Bank Reserves & 0.2859 & 0.000 \\
\hline Risk Aversion & -0.0017 & 0.569 \\
\hline Implicit Cost & -0.0239 & 0.035 \\
\hline Size & -0.9821 & 0.000 \\
\hline Strategy of Cross Subsidy & 0.1286 & 0.000 \\
\hline Income from Trading & -0.0002 & 0.000 \\
\hline Ratio of deposit & -0.0609 & 0.000 \\
\hline Market Structure (HHI-Loan) & 0.2370 & 0.000 \\
\hline Non Performing Loan & -0.0812 & 0.000 \\
\hline Inflation & -0.0014 & 0.604 \\
\hline Market Rate (PUAB) & -0.0310 & 0.000 \\
\hline Interest Market Volatility & 0.0002 & 0.000 \\
\hline Growth of GDP & 0.0309 & 0.000 \\
\hline _cons & 4.9005 & 0.000 \\
\hline \multirow[t]{5}{*}{ Result } & \multicolumn{2}{|l|}{ Fixed Effect Model } \\
\hline & \multicolumn{2}{|c|}{ No Biased } \\
\hline & \multicolumn{2}{|c|}{ Order 1 = Autocorrelation } \\
\hline & \multicolumn{2}{|c|}{ Order 2 = No Autocorrelation } \\
\hline & \multicolumn{2}{|c|}{ Over identifying restrictions are valid } \\
\hline
\end{tabular}

The result indicates that not all variables that are pure bank spread is statistically significant. The result of market structure is statistically significant, indicating that commercial bank market tends to be concentrated into several big banks. The more concentrated banking in Indonesia, the higher the NIM, where large banks tend to set product prices both funding and lending products.

In general, the coefficients of the independent variables are consistent and statistically significant with that predicted by theoretical models, except for degree of risk aversion. According to the theoretical model degree of risk aversion is one of the variables included in the variables that determine the NIM of banking pure spread, but the estimation shows that the results were not significant. Proxy for this variable is the ratio of capital to total assets.

The estimation of bank-specific variables is also statistically significant with the expected sign, except for the variable liquidity risk, implicit cost, and non performing loan. Liquidity risk was calculated as ratio of liquid assets and liquid liability. Meanwhile, the results of the estimation shows that the more illiquid assets held by banks compared with their obligations, the higher of NIM. The reason behind this result is the market structure of commercial banking in Indonesia. As we mentioned before that the market structure of Indonesian banking tend to be concentrated into several banks mostly five banks. It means that more liquid will push net interest margin.

Variable opportunity cost of bank reserves, which were calculated based on the ratio between the liquid reserve approach with the total assets held by banks have a significant effect on the 
movement of NIM. Overall, estimation results show that NIM banking in Indonesia is determined by market structure or market power, the variable cost opportunity of reserve bank, and cross subsidy strategy. Meanwhile, the economic conditions, such as inflation, growth of GDP, and market rate have statistically significant.

\section{Conclusion}

In Indonesian commercial banking system, market structure, cost opportunity of reserve bank and cross subsidy strategy are the main factors in determining the net interest margin. Meanwhile, the macroeconomic variables have also a contribution in determining net interest margin in commercial banking in Indonesia. The policy implication from the research, that our regulatory should make the commercial banking to become a perfect competition.

\section{Reference}

- $\quad$ Afanasieff, T. Segalla, Priscila M.V. Lhacer and Marcio I. Nakane (2002). "The Determinants of Bank Interest Spread in Brazil.” Paper. Research Department, Banco Central do Brasil.

- Abrao, Ana Carla., Marcio, Costae., Nakane, Marcio I., (2005). Revisiting the Methodology for The Bank Interest Spread Decomposition in Brazil: An Application of The Theory of Cost Allocation, Research Departement, Central Bank of Brazil

- Barajas, Adoflo., Steiner, Roberto., Salazar, Natalia., (1999). Interest Spreads in Banking in Colombia, IMF Staff papers.

- $\quad$ Brock, Philip L., Suarez, Liliana Rojaz., (2000). Understanding the Behavior of Bank Spreads in Latin America, Journal od Development Economics

- Cihak, Martin and Richard Podpiera (2005). Bank Behavior in Developing Countries: Evidence from East Africa, IMF Working Paper.

- Cottarelli, Carlo., Ferri, Giovanni., Generale, Andrea., (1995), Bank Lending Rates and Financial Structure in Italy, IMF Staff Papers

- Gelos, R. Gaston, (2006), Banking Spreads in Latin America, IMF Working Paper

- Gambacorta, Leonardo., (2004), How Do Banks set Interest Rate?, NBER Working Paper Series.

- Muljawan, dkk, (2009), Kajian Konsep Awal Indeksasi Return Sektor Riil Sebagai Acuan Pricing Perbankan Syariah, Direktorat Perbankan Syariah, Bank Indonesia.

- $\quad$ Romansyah, Dadang., (2009), Penentuan Rate Bagi Hasil Deposito Mudharabah Bank Syariah di Indonesia, Analisis Teori dan Praktek, Universitas Paramadina

- S.Y. Ho, Thomas., Saunders, Anthony., (1981), The Determinants of Bank Interest Margins: Theory and Empirical Evidence

- Souza, Nelson, F., Sobrinho, Souza., (2010), Macroeconomics of Bank Interest Spreads: Evidence from Brazil, Ann Finance

- Saaty, L. Thomas., Vargas, Luis G., (2006), Decision Making with The Analytic Network Process, Springer

- Shy, Oz., (2008)., How to Price : A Guide to Pricing Techniques and Yield Management, Cambridge University Press 


\title{
Tradition and Poverty Reduction - Mahalla and its Significance in Development Process in Tajikistan
}

\author{
Anna Cieslewska, University of Warsaw
}

\begin{abstract}
Significance of mahalla as informal social, self-governing institution has increased due to a variety of factors related to the post-transitional changes in Tajikistan. The phenomenon of existence of informal self-government bodies has not been only exclusive to Central Asia or Tajikistan. However, in a case of Central Asia, those institutions have always played significant role in maintaining social order and frequently they are more legitimized in the eyes of local residents than the formally established self-government. Recently, the government of Tajikistan has attempted to incorporate the elements of (indigenous) self-governmental institutions into the formal self-government's structures. Also, international organizations try to integrate mahalla as important element which would facilitate development's process. Identification of potential of this old institution could become a good base for poverty reduction and social programs.
\end{abstract}

JEL Codes: D7, D71, D78

\section{Introduction}

Self-govermentality has long lasting tradition in the cultures of Central Asia. Since centuries the self-government institutions such as mahalla have regulated life of communities. Despite the social changes which were brought by Soviet Union, mahalla played an important function during the whole soviet period, and a real role of Soviet Union in diminishing or reinforcing authority of mahalla is still discussed by scholars, politicians as well as development workers. Unquestionably, this old social institution outlive of the Soviet Union and its significance cannot be marginalized. After gaining independency by Tajikistan, the government sought to incorporate a concept of mahalla into the state system to legitimize its rules as well as to extend control over society. In spite of this, still mahalla has a wider, social recognition than the formal, governmental bodies. It has long-lasting authority in society and its importance was endured by hardship of a civil war (1992-1997), then the afterwards crisis. Despite the common Western view that traditional organization such mahalla cannot be considered as a form of civil society due to its patriarchal as well as segmentary character, mahalla still grasps great admiration of society that is much more bigger than have just recently established civic organizations or formal governmental bodies.

The presented paper considers traditional, central Asian institution - mahalla in a context of social cohesion which would reinforce poverty reduction and social development in Tajikistan. The paper is based on a field study which was conducted from June to September 2010 in the three regions of Tajikstan: the central part of the country - Gissara region, Shurabad district (Khalton region) which borders with Afghanistan, and Khujand region - the North part of the country. Research was carried out by a team of the Polish researchers: Professor Stanislaw Zapasnik, Mariusz Marszewski, PhD, and PhD student Anna Cieslewska.

\section{Institution of Mahalla - short overview}

The literal meaning of a word mahalla in Arabic is district. However, in the context of Central Asia, the original sense of the word "district" does not provide a precise understanding of the concept of mahalla. Apart from mahalla, among a sedentary population of Central Asia, there are other terms which describe a similar phenomenon such as $k u$ (Tajik/Farsi)/(English: road, a part of city), guzar (Tajik/Farsi)/(English: passage) - (a term of guzar is also used to described a small street within mahalla), also elat (tribe, family, country - this name for district 
was used only in Khiva), (Jasiewicz, 2004a) as well as chakar (Tajik) characterized for Sukh region (presently, Uzbekistan). According to Jasiewicz, the term elat, might be evidence of the strong divisions of tribes and ethnic groups in the past within the same territory. The oldest source which mentioned word mahalla, it is a history of Buchara written in twelfth century by Narshahi, although, the same concept was developed before Islamization of Central Asia (Niyazov, 2007a).

The meaning of those terms have been changing over time as well as region. All quoted names imply the integrated cluster of houses based on a different kind of the territorial, professional, family, or/and ethnic relationship, being incorporated into a city, town or settlement where a particular community is living. As Nizajov (2007b) indicates the problem with the precise definition of mahalla is related to its geographical form which is determined by a place where mahalla is built - usually mahallas which are located in a center of city/town are smaller. Mahalla can consists of several dozen or even several hundred houses build along big street with small side streets (organize in a form of quarter), or one, big street which is sometimes divided into two mahallas. Mahalla is also found in a rural area in the bigger settlements; usually all houses located within the border of a village make up one mahalla or a particular settlement is divided into a few smaller entities. Basically, mahalla is the smallest administrative unit which organizes life of community; a concept of mahalla is deeply embedded in collective consciousness of sedentary population of Central Asia as a form of social organization. In my opinion, idea of mahalla influenced social organization almost at the each level - even, in a modern apartment block, there are block committees which are partly followed the model of mahalla; for instance the Tajik $\mathrm{PhD}$ student being asked about her understanding of mahalla, answered that community who are living in a student hostel - it is also a kind of mahalla.

In terms of its social function, mahalla can be defined as a self-governing small community. However, there are very different ways of organizing malalla' society. Area of mahalla can be occupied by one ethnic group, one or more extended families such as avlod (Tajik)/(English: ancestors), qaum (Uzbek/Tajik)/(English: family), (a term varies from region to region); mahalla also can gathered representatives of different ethnic groups. In this case, a name of mahalla could be derived from the biggest ethnic group which is living there e.g.: mahalla Arabon - in the Old Buchara (where mainly, but not only Arabs were living), or if mahalla's vicinity was outnumbered by representatives of a particular professional group then it name was taken from that profession, i.e.: mahalla pachtabofon (mahalla weavers). Mahallas also can be named after mosque, local mazar (Tajk)/(English: cemetery - here a shrine), even waterfall, name of local heroes and the others (Niyazov, 2007c).

A way of functioning mahalla's community is based on the certain rules rooted in tradition, which regulate the social relations of mahalla's dwellers. Certainly, mahalla is indigenous, self governing body.

Prior to the October revolution, mahalla was treated as the semi- administrative unit of the city/town/settlement. The tsarist government administration was interested in maintaining mahalla as a form of self-governing organization which regulated social order at the local level. A head of mahalla, was always elected by its inhabitants, but his candidacy had to be approved by municipal authorities; he was also the lowest administrative representative in the hierarchy of city's administration (Jasiewicz, 2004b) .

Significance of mahalla as informal self-government organization was also recognized by the soviet authorities. In the aftermath of the revolutionary changes, a number of different kinds of the social committees sprang up i.e: in the early twenties meczetkoms and guzarkoms were established with intention to mingle ideas of a new communist ideology with the local tradition. In this way, the new, communist power tried to integrate Central Asians into the Soviet structures. Later then, mahallas committees played a role of important linkage between community and the state. They fulfill both - the traditional social function as well as a new role introduced by the Soviet authorities. For example, Jasiewicz (2004c) indicates that 
mahallas committees, besides its numerous social responsibilities, passed a certain political knowledge aimed at spreading the new, socialistic values among mahallas'dwellers. However, Abdullaeva and Turyaev (2004a) argue that during the Soviet period, the village councils were established as the legitimate, executive body, and mahalla's position decreased.

Nevertheless, a main role of mahalla during the soviet period was to maintaining traditional, social values. I am of the same opinion with Goziev, who points out that mahalla contributed to preserve the Islamic heritage (unpublished paper, 2008b).

From a point of view of the structure, it varies from region to region. However, the traditional mahalla maintains a chaikhana (Tajik)/(English: tea house) - a place for the meetings of community as well as people from outside (i.e.: officials). Sometimes chaikhana used to play a role of the mosque (such situation took place during the soviet period, when majority of mosques were closed). However, in mahallas which posses two institutions, their roles differ; the mosque is a very important place for religious life of the community; there is sometimes mazar (here: shrine) on the territory of mahalla which is important from the point of view of spiritual life of mahalla community. As a mosque is a place of worship accordingly to Islamic faith, and traditionally is attended only by men (women are not allowed to pray in a mosque in most countries of Central Asia), while mazar is a shrine which gathers both men and women; some rituals performed in mazars are rooted in pre-Islamic tradition; mazar also plays important role as a part of collective spirit of a certain community.

Every mahalla has a head (Tajik: raize or amin of mahalla) who traditionally was elected by community. He should be a trustworthy as well as distinct men, responsible for all mahalla's affairs; he has also his deputies (a committee of mahalla). Every side-street has its leaders who closely cooperate with raize/amin of mahalla (they are called raizes of guzare (Tajik)/(English: a head of side-street) or sometimes sardori kucha (Tajik)/(English: an elder of street). Together with the other significant male representatives of community, during the meetings in the mosques or chaikhana, they discuss important issues for community such as collective work (Tajik: hashar), necessary reparations, or the other socially important issues. According to tradition, in mahalla, money is collected to help the poorer members of the community as well as to meet the other social needs such as reparations and so forth (Goziev, unpublished paper, 2008a, Nijazov, 2006d). Hashar can be performed for benefit of whole community i.e.: repairing a public building or for a private purpose such as embroidering fabrics for someone dowry.

In the past in every mahalla, there was an informal institution of the Council of Elders, which played a regulatory role over the community life such as resolving conflicts among community members, mediations and so on. Nowadays, due to a rapid post-transitional changes, influences of elders have been decreasing, and it varies from mahalla to mahalla. However, elders still are asked about recommendations, also in majority mahallas, religious leaders contribute to discussion on important matters - mullas as well as sometimes women religious leader bibi halifa or bibi otum. They usually lead a circle of women who participate in organization of mahalla's rituals, celebration and the forth. Despite the fact that formally, all decisions are taken by a group of significant men and, they are approved by majlis (Arabic)/ (English: place of sitting/assembly) of all male representatives of mahalla, bibi halifa (Tajik.)/bibi otym/bibi mulla (Uzbek) is usually asked about opinion - they represent women's affairs in mahalla. In a case of a lack of women religious leaders, the other women are responsible for women's issues. The fact that majlis is traditionally attended only by men, arouses always controversy among western donors.

One of the most important factors which contributes to consolidation of community is collective participation in celebrations and rituals such as weddings, burials, circumcisions they are very important events of everyday mahalla's life. This fact integrates poor and reach members of community not only at the material level but also in spiritual way. 


\section{Contemporary mahalla in Tajikistan}

During the civil war in Tajikistan, the social recognition of mahalla as self-governing body increased due to decreasing state's activity at the local level. In fact, in many cases, mahalla operates more sufficiently that the formal local self- government (Tajik: jamoat), (jamoats is the smallest administrative unit in Tajikistan, and it consists of a several mahallas). Despite the fact that during the war humanitarian assistance was frequently channeled through jamoats, a role of mahallas' leader in aid delivery was significant as they were able to deal with conflicts in the villages, which increased during these times. Some international organizations channeled humanitarian aid through mahalla's authorities - such action significantly reinforce a position of mahallas' leaders. According to one of my interlocutors: mahalla'leader controlled over the humanitarian food distribution. It was relatively easier to make a pressure on jamoat's authorities to get aid products informally, conversely, due to the fact that mahalla' community is well integrated, it was much more difficult to misappropriate humanitarian aid.

During our research on mahallas in three different regions of Tajikistan, only few times, we had opportunity to observed significant contribution of the state in building new or maintaining old infrastructure. Mainly all reparations and small investments are financed by fund of mahalla with voluntary participation of community's members (hashar). In some cases, international donors contribute to local development. In the region of Gissara, we organized short, informal seminar with the representatives of two mahallas regarding writing project's proposal. The event was initiated by a head of women's local initiative group. Both mahallas undertook many enterprises such as road's reparation (two kilometers), reconstruction of water's channels, constructing water's pipe and the others. Any of those projects were neither facilitated nor financed by the state. All implemented activities were organized and financed only by mahallas's inhabitants. The participants of seminar expressed opinion that the state is too poor to contribute to local development's process and mahalla's community has to rely on itself. I heard such opinion many times during research. Ones I heard the following question from vice-raize mahalla: the bridge in our mahalla was broken - Do you know maybe some international donors who could contribute to its reparation? - frequently, people even do not consider that local formal authorities can provide any form of assistance.

Despite a low state's participation at the local level, authorities attempt to create mechanisms which would integrate mahalla into the state's system. In 2008, a new law was passed "the Law on Self-governing, Social Institutions” (Russian: “Закон Об Органах Общественной Самодеятельности"). According to a new law, civil society institutions such as mahallas are considered as the smallest self-government entities at the local level. Formally, mahalla can be registered as social institution with rights to maintain own banking account, stamp as well as to issue simple documents as certificate of permanent or temporary residency. Moreover, according to the new law in order to resolve social problems, they can cooperate with governmental and non-governmental bodies as well as international organizations operating in Tajikistan. Theoretically, the new law gives mahalla more competencies as well as a space to develop mahallas's social capita. In practice, a real capacity of mahalla is limited, since knowledge of the new law among members of mahallas' committees is inadequate, and majority of them do not understand the mechanism of work with international donors. Also, implementation of the new law encounters difficulties due to the fact that people doubt a real execution of the law.

In addition, the new law regulates activity of mahalla's committee. Mahalla committee plays a role of a representative organ of citizens. Integration of mahalla into the state system could contribute to improve cooperation between local formal self-government and society. However, it should be also indicated that mahalla committees could be a tool of extending control over society; due to the fact that a real contribution of jamoat to mahalls's life is questionable, authorities can use mahalla committees to influence community. The research data indicates that people rarely approached jamoat authorities with their problems. Traditionally, especially 
rural population do not apply to formal authorities to resolve any civil claims (property, religious divorce and the others), (Abdullaeva and Tyuryaev, 2004b).That is why mahallas' committee is a body which goes between community and jamoat. Nevertheless, owing to the different role and function of mahalla and jamoat, it is difficult to diminish a role of the latter. Undoubtedly, due to a lack of funds, the state which is at the local level represented by jamoat does not fulfill its duties, hence, partly its function is replaced by traditional, social institutions such as mahalla. However, still authorities try to avoid decentralization of the state's structures by expanding regulatory framework over life of mahalla's community.

In terms of its function, institution of mahalla tends to be stronger in the villages or smaller settlements than in the bigger urban units. Frequently, in the big cities a main task of mahalla's authorities is limited to collecting money for communal services, and its traditional, customary role is almost disappeared. One of the reasons of such situation is regular movement of inhabitants which results in a low level of community's integration. However, there are also strong mahallas in big cities and weak mahallas in villages.

The fact that mahalla is strong and well integrated in rural areas could be explained by long history of community living in the same place. For instance, we conducted research in the places where common memory of mahallas community dates back to seven hundreds or even one thousand years which means very strong social bonds (of course, due to a variety of reasons people moved during such long period, however, still community has common memory: ancestors, mazars and the like). The second important factor which reinforce of maintaining traditional, social order are religious institutions such as mosque or mazars, especially of those which are tombs of local saints. In one case, qaum of local, Islamic teacher who died in fourteenth century, and who was told to be a famous clairvoyant, has been still living in the village where there is the saint's mazar; some of his ancestors continue spiritual tradition of family as religious leaders.

From the point of view of social structure, the most important is a place of each extended family (avlod, qaum ect.) within a community. As Abdullaeve and Tyuryaev (2004c) indicate, social capita is accumulated by members of family from generation to generation (as well as negative deeds). It means that extended family consists of the living people as well as their ancestors - this fact contributes to strengthen social bonds. For instance, even if, presently, many people migrate to Russia, Kazakhstan and so forth for work, and they have been living abroad for years, they still participate in life of mahalla through linkage with their avlot as well as the other social networks i.e.: groups of the same age (Tajik: jura, dawra) and the like. So, many of them substantially contribute to mahalla funds, even sometimes financing certain enterprises i.e.: in one mahalla in Gissara, a part of water pipe was financed by a businessman living in Russia - a inhabitant of mahalla.

One of the most consolidated factor of mahalla's community is a person of raize mahalla. If raize mahalla has strong leadership skills - mahalla is well integrated. According to the local development worker, a sign of weakness of mahalla is degeneration of traditional order and values which are associated also with a person of raize mahalla. A work of a raize mahalla is unpaid, that is why, there are other advantages of holding this position such as gaining respect of everyone in mahalla. In the past raize was elected by community, whereas, nowadays, a raize is often recommended by local authorities, and he often represents only interests of a certain group of people. During a focus group with women from mahalla at the outer suburbs of Khujand city, I was told that a present raize who is a director of the school was appointed informally by jamoat authorities (during majlis his candidacy was only formally confirmed in an open voting) but he is not good raize because of he does not know the needs of community. According to respondents, good raize is a person who is strongly involved in the community's affairs, he should be experience as well as energetic, cleaver, and also he should possess respect of people.

Potential of indigenous institution such mahalla can be used to facilitate development programs implemented by international organizations. Although, mahalla is frequently 
considered by donors as undemocratic and unequal institution due to its segmentary character which for example disadvantages women in a process of decision making. There are a number of organizations which try to implement of the elements of mahalla structures into their projects by facilitating of mahalla's committees, creating variety of groups or integrating mahalla into the other structures. Though, majority of organizations desire to use mahalla institutions but in the same time they do not take into account the most important aspect of mahalla which is a division of community accordingly to social status, age, gender as well as education or descent from spiritual/religious leaders.

I had opportunity to participate in majlis which was organized by donor - International Funds for Agriculture and Development (IFAD). One of the requirements of the donor, was women' participation in public gatherings which aimed at facilitating a process of decision making. The assembly was organized at premises of the school in the following way: the mahalla elders were sitting in the main place, beside, the middle age men took the sits, then the young men followed; on the veranda which was placed quite far from the main part of the meeting, few women were gathered, and shortly after signing a list for participants, they left the place. One of the local development workers comment on that situation that women's participation in majlis is useless since tradition prevent them from expressing opinion in public. They will do it in home which eventually would influence opinion of their husbands but they would never openly tell what they think in a presence of the other male members of community. My interlocutor added that he personally raised the issue of women's participation during the meeting with donors but it did not cause any change in donor's policy. Above example well illustrate that integrating institution of mahalla could be beneficial for development programs, however, to achieve desirable goal it should be done with full recognition of local conditions. It means that in society with strong division into male and female worlds, merging two of them could not bring a wanted result.

\section{Summary}

Integrating traditional (indigenous) self-governing institution such as mahalla into poverty reduction's programs, could give a great potential for social as well as economic development. Mahalla has always played significant role in maintaining social order, and its informal, unwritten rules are frequently more sustainable and durable that formal codes. Unquestionably, mahalla's institution is inherent in the structures of the Tajik social life by either responding to its needs or controlling its function. A role of value system, traditions and beliefs should be incorporated into modern structures. All those means could be use for benefit of society. That is why, while planning development programs, representatives of international organizations should bear in mind the specific social conditions of each targeted environment.

\section{References}

- Z. Jasiewicz, 2004. Rodzina, społeczność lokalna i grupa etniczna w Polsce i Azji Środkowej. Wydaw. Poznańskie, Poznan

- A.Niyazow, 2007. "Mahalla a tradycje samorządowe w Azji Centralnej”, an excerpt of unpublihed master dissertation. Polish Academy of Science, Warsaw

- S. Goziev, 2008. "Traditional institutions in Tajikistan", unpublished paper

- Abdullaeva, M. and F. Tyuryaev, 2004. Role and place social institutions in a process of development village communities. ASTI, Khujand.

- “Закон республики таджикистан об органах общественной самодеятельности”, 2008. Dushanbe 


\title{
The Innovation Zone As a Strategic Element in the National Economy
}

\author{
Vidadi Z.Zeynalov, Azerbaijan State Economic University
}

\begin{abstract}
In this article is based the necessity of the creation of regional innovation zone on information communication sector for providing sustainable development of Azerbaijan economy, are investigated and given purposes the conception and stages implementation of the innovation zone.
\end{abstract}

JEL Codes: L86, O 31

\section{Zone definition and development trends}

Free special zones have played an important role in advancing economic reform in the developing countries and, particularly, in opening up its economy to the rest of the world. Free zones have existed for centuries. They were originally established to encourage entrepot trade, and mostly took the form of citywide zones located on international trade routes. Examples include Gibraltar (1704), Singapore (1819), Hong Kong (China; 1848), Hamburg (1888), and Copenhagen (1891).

The core definition of a free zone, as well as proposed guidelines and standards for them, are contained in the Revised Kyoto Convention of the World Customs Organization (WCO). Specifically, Annex D and the accompanying guidelines provide standards and recommendations on the treatment of imports to and exports from free zones including territorial limits (free zones are defined as "outside the customs territory" for purposes of the assessment of import duties and taxes); minimal documentation requirements; and issues to be covered by national legislation. Free zones typically allow for duty- and tax-free imports of raw and intermediate materials and, in many cases, capital equipment.

Special economic zones (SEZ) have also evolved into highly specialized facilities, configured to the needs of specific industries and activities. Examples include special zones to promote high technology or science based industries; petrochemical and heavy industry zones relying on cheap energy sources and specialized facilities; financial services zones to promote offshore financial and non-financial activities; software and information communications technology (ICT) zones accommodating software coding and other off-shore ICT services operations; airport-based zones, specifically support aviation and air-based activities; tourism zones to facilitate integrated resort and leisure community development; logistics parks and cargo villages/cities, providing specialized facilities and support services to facilitate trade, supply chain management, and logistics; and others.

A large number of free special zones have been put into operation throughout the world, and more are in the planning process (Akinci, G., Crittle J. 2008). Even though they offer almost similar incentives and facilities, their degree of success differ from one country to another. In the People's Republic of China, Special Economic Zones were founded by the central government under Deng Xiaoping in the early 1980s. The most successful Special Economic Zone in China, Shenzhen, has developed from a small village into a city with a population over 10 million within 20 years.

Following the Chinese examples, Special Economic Zones have been established in several countries, including Brazil, India, Iran, Jordan, Kazakhstan, Pakistan, the Philippines, Poland, Republic of Korea, Russia, Ukraine, United Arab Emirates, Cambodia, North Korea. Currently, Puno, Peru has been slated to become a "Zona Economica" by its president Alan Garcia.

A single SEZ can contain multiple 'specific' zones within its boundaries. The most prominent examples of this layered approach are Subic Bay Freeport Zone in the Philippines, the Aqaba 
Special Economic Zone Authority in Jordan, Sricity Multi-product SEZ and Mundra SEZ in India and According to World Bank estimates of 2007 there are more than 3,000 projects taking place in SEZs in 120 countries worldwide.

Key characteristics of zones in developing and transition countries are:

- Concentration in a few countries. A relatively small number of countries account for the majority of worldwide zone activity. Zones are concentrated in Asia and the Pacific (mainly China), Latin America, and Central and Eastern Europe and Central Asia. In general, less than a dozen countries account for most jobs created within zones and exports generated.

- Concentration in a few product areas. The majority of zone enterprises worldwide are engaged in labor-intensive, assembly-oriented activities such as apparel, textiles, and electrical and electronic goods. In 1999, it was estimated that these activities accounted for more than 80 percent of zone output worldwide. This is less the case today, given the re-cent increase in zones with a diversified output, especially in the CIS. The degree of product specialization tends to be linked to the level of industrial development of the host country. Apparel assembly operations, for example, dominate activity in low-wage countries like Bangladesh, Sri Lanka, Madagascar, and the Dominican Republic. Electronics, electrical and automotive components predominate in middle income countries like Mexico, Malaysia, and Thailand.

- Reliance on a female workforce. Female workers account for 60-70 percent of the zone work-force worldwide, a number that has remained consistent since the inception of EPZs. As economic activity diversifies away from simple assembly operations, the percentage of women in the workforce decreases. In the Malaysian EPZs, for example, 40 percent of the workers are female, down from 60 percent two decades ago.

The Free Special Zones covers a broad range of more specific zone types, including Free Trade Zones (FTZ), Export Processing Zones (EPZ), Free Zones (FZ), Industrial Estates (IE), Free Ports, Urban Enterprise Zones and others (Akinci, G., Crittle J. 2008).

- Free trade zones, also known as commercial free zones and free commercial zones, are small, fenced-in, duty-free areas, offering ware housing, storage, and distribution facilities for trade, transshipment, and re-export operations, located in most ports of entry around the world. A leading example is the Colon Free Zone in Panama.

- Export processing zones, industrial estates offering special incentives and facilities for manufacturing and related activities aimed mostly at export markets, typically take two forms. In the traditional EPZ model, the entire area within the zone is exclusively for export-oriented enterprises licensed under an EPZ regime. Hybrid EPZs, in contrast, are typically sub-divided into a general zone open to all industries regardless of export orientation and a separate EPZ area reserved for export-oriented, EPZregistered enterprises.

- Freeports are generally a much broader concept and typically encompass much larger areas. They accommodate all types of activities, including tourism and retail sales, permit people to reside on site, and provide a much broader set of incentives and benefits. The large-scale freeports in China are a traditional example.

- Enterprise zones are intended to revitalize distressed urban or rural areas through the provision of tax incentives and financial grants. Most zones are in developed countries, for example the United States, France, and the United Kingdom, although South Africa is developing a similar mechanism.

- Single factory EPZ schemes provide incentives to individual enterprises regardless of location; factories do not have to locate within a designated zone to receive incentives and privileges. Leading examples of countries relying exclusively on a single factory 
scheme include Mauritius, Madagascar, Mexico and Fiji; other countries such as Costa Rica, the United States, and Sri Lanka allow both industrial estate-style zones and single factory designations.

- Specialized zones include science/technology parks, regional innovation zones, petrochemical zones, logistic parks, airport-based zones, and so on.

Below we would like specify the regional innovation zones, specifically the development concept and strategy framework of Regional Innovation Zone (RIZ) in Azerbaijan.

Firstly, RIZ provides for establishment of technical parks for development of small-scale and middle-scale innovation entrepreneurship, regional base on manufacturing and export of hardware and software, transformation of the country into an advantageous transit data centre, training of human resources for the information society, introduction of IT in other fields (Akinci, G., Crittle J. 2008).

\section{ICT for sustainable development}

The world has entered the era of a global information society. That means that the technology is becoming the primary source for rapid development due to the knowledge-based economy becoming the main driving force for all development. Therefore, Azerbaijan must continue to secure its place in this new globalized world by successfully developing innovative sectors of its economy. Information Communication Technology (ICT) is deemed as being crucial for achieving sustainable economic development. As a result of a carefully planned approach the Government of Azerbaijan has achieved noteworthy results, both in developing the ICT sector and by implementing innovative and advanced technologies in many fields of the economy. According to the Global Information Technology Report 2007-2008 of the World Economic Forum, Azerbaijan ranks 67 out of 127 countries and in its leading position among the CIS countries has left many major economies behind. The United Nations e-Government Survey 2008 ranked Azerbaijan as first among the countries of the southern Caucasus and in position 89 among the 182 surveyed countries. In Azerbaijan the ICT sector currently is the second most rapidly developing sector of the national economy and thus immediately follows the energy sector. In 2007, Ilham Aliyev, President of the Republic of Azerbaijan, declared ICT as a priority sector of the economy and emphasized the importance of the use of ICT in all sectors of the economy. Revenue growth in the ICT sector has in recent years achieved a rate of 30$35 \%$ p.a. This trend is expected to continue, which means that it will match the revenues generated by the energy sector within a few years and is forecast to overtake it during the period 2018-2020. Within the nonoil sector, the ICT industry is the second largest generator of tax revenues, thereby following the construction industry (MCIT. 2009).

In Azerbaijan the ICT sector currently is the second most rapidly developing sector of the national economy and thus immediately follows the energy sector. Revenue growth in the ICT sector has in recent years achieved a rate of $30-35 \%$ p.a. This trend is expected to continue, which means that it will match the revenues generated by the energy sector within a few years and is forecast to overtake it during the period 2018-2020. Within the nonoil sector, the ICT industry is the second largest generator of tax revenues, thereby following the construction industry. Investments in telecommunication and postal communication in 2008 amounted to \$270.5 million, split into \$52.2 million and \$218.3 million for state-run and privately-owned companies respectively. The country thus is creating long-term opportunities for the manufacture of high-tech equipment. In 2008 alone, manufacturing services generated in the ICT sector displayed an increase of $28.3 \%$. The telecommunication services market has developed strongly in Azerbaijan during the past 5 years. New technologies have become a platform for new services. In order to meet the increasing demand and to modernize the existing public switched telecommunication network (PSTN) the capacity of the PSTN has been increased by $50 \%$, thereby reaching a national penetration level of 16 fixed telephone lines per 100 inhabitants on average. Digital switching has already reached a level of $85 \%$. By 
the end of 2008 and as the first CIS country, Azerbaijan was able to provide telecommunication services to all residential areas in the country. Today villages and settlements having only 2 to 3 households have the possibility to obtain access to up-to-date telecommunication services. This achievement thus can successfully achieve the national "100 Phones for 100 Households" Project. Its successful realization will allow a doubling of telephone penetration and expand broadband communication services further. Currently fixed telephone lines penetration has reached 65.8 per 100 households. Another first for Azerbaijan among CIS countries was the initiation of the installation of the NGN platform, which can be seen as a "leapfrogging" development. The cellular communication market of Azerbaijan has been developing rapidly and remains one of the most attractive investment segments of the national telecommunication market (MCIT. 2009). Over the past five years, mobile coverage has reached $100 \%$ of the population on $80 \%$ of the territory of the country.

The cellular communication market of Azerbaijan is well developed compared to that of most developing countries. Currently there are 75 mobile cellular subscribers per 100 inhabitants and revenues from mobile communications account for approximately $65 \%$ of the total ICT sector revenue. As mobile penetration increases, the mobile content market is also increasing in importance for GSM operators. That market already accounts for approximately 98\% of all cellular communication (including that on the CDMA standard). Demand for bandwidth globally is expanding exponentially due to the growing number of people using online media to gather information by downloading multimedia content and engaging in social networking, businesses redefining their business models and the overall contribution by the development of the "e-society".

To boost the development of an innovative environment for designing and implementing information and other technologies, positioning Azerbaijan as an IT products exporting country, stimulating development of small and medium sized enterprises, attracting foreign direct investment and developing its human resources, the Government of Azerbaijan has initiated a Regional Innovation Zone Project (RIZ) - a special economic zone - for ICT activities. It is also planned to establish innovation and research centers and an International University of Information Technology within the RIZ. The proposed RIZ concept is expected to have an enormously positive impact on the economy of Azerbaijan and will generate significant direct revenues. Major social benefits would be generated both for the urban and rural populations by the positive multiplier effect on numerous economic sectors (for example, tourism, transportation, and banking). It is expected that revenues generated by the ICT sector will match and then exceed those of the energy sector by the year 2020 (MCIT. 2009).

\section{Innovation Zone Concept}

Now getting detailed information about telecommunication sector of country we may research the main objectives, development concept of innovative zone, the future perspectives and next steps on creation of RIZ in Azerbaijan.

The Ministry of Communication and Information Technologies of the Republic of Azerbaijan has conducted a feasibility study to create Regional Innovation Zones with an aim to boost development of the sector and to turn Azerbaijan into a regional information and communication technology hub (US, Department of State). The main objective of the project is to create innovative environment for the production of electronic equipment and software products and exports at the regional level, technical parks for developing small and medium sized innovations from entrepreneur, the international centre for information DATA Center, the promotion of technological innovation through the expansion of small and medium-sized businesses, development of human resources in information and high technology, as well as the creation of an enabling and transparent environment for local, regional and international companies and attract foreign investment into the area. This project is of great importance for Azerbaijan but also for the whole Caspian region as a factor in attracting global investments in 
high technology, to the opening of new jobs and in general economic growth. The regional innovation zone will turn a place for attraction of global high technological investments to Azerbaijan, and the project will be economically robust. Efficiency of the project on creation of a regional innovative zone provides strengthening of local manufacture and activation of export of IT production. Monetary and fiscal privileges will be applied in regional innovative zone for businessmen and also will be opened the way for the Azerbaijani companies to the regional market (ITU, 2009) .

Special economic zones are supposed in Azerbaijan in two directions. The first direction is realization of state orders and the second is manufacture of products for export. Our Republic developed its own concept of the project including the most optimal elements of worldwide best projects. For that the MCIT conducted consultations in the United States, South Korea, and at domestic level. The package of proposals was prepared by US consulting company Booz, Allen\&Hamilton, international and local specialists. As a result, the Ministry came to conclusion that at primary stage RIZ will be restricted with physical zone and in the process of development will turn into virtual cities and turn eventually into virtual zone. Azerbaijan has already passed the Law on Special Economic Zones that creates legal bases for creation of RIZ. Cisco, Intel, HP, Microsoft, Ericsson, and Siemens expressed a desire to take part in this project. It is assumed that the entire territory of the republic will be declared a zone of innovation. This will be a virtual space, but there will be own customs, and possibly tax incentives. Mechanism for providing customs and tax privileges to the virtual space has been worked out. RIZ implies creation of favorable monetary, fiscal, price and other environments for private, state, private local and foreign companies running production, consumption and export of output demanding use of high technologies and services.

Within RIZ it is planned to create educational and research centres, International University of Information Technologies, labs, innovation and survey centres, innovation-oriented small and medium business for which favourable conditions will be created and state support given. This project is directed on creation of the large-scale economic zone providing manufacture and export of production of technological capacity in the country, development of small and medium business, also on attraction of the foreign companies and potential investors in ICT country sector and development of human resources.

There are fundamental motivations and opportunities for developing a RIZ in Azerbaijan:

- The region has a big gap in the ICT industry;

- During Soviet times, and through today, Azerbaijan possesses distinctive intellectual/scientific human capacities;

- The BTC pipeline and its secure and proven international contracting methodologies.

- Azerbaijan is now working to create and sustain a technology platform, business development environment, physical and information infrastructure, and related regulatory, legal and tax planning other initiatives that will provide an attractive, consistent and secure investment and operating environment;

- The Azerbaijan government is ready to share the investment risk (UNPAN).

Currently in the evaluation and planning stage, with assistance from a major global technology consulting firm, the RIZ has five core objectives:

S: Stimulate technology innovation via small and middle scale entrepreneurs;

H: Develop human resources, particularly in IT and high technology areas;

I: Create an international data transit center;

$\mathbf{N}$ : Provide a hospitable, innovative and collaborative environment for new and established domestic, regional and global technology organizations to invest and expand operations in Azerbaijan;

E: Establish an innovative environment that supports and enhances production and regional 
exports of electronic equipment and software products and services.

Each of the five objectives embeds a domestic perspective for the RIZ and SHINES beyond to the World:

SME / Technology Innovation: The RIZ shall assist in stimulating development of small and middle scale entrepreneurs, providing an innovative environment for designing and implementing information and other technologies for application and use in various sectors of the Azerbaijan economy and potentially for the region.

HR Development / IT University: The RIZ shall provide the site, resources, expertise to assist developing human resource capabilities, related training and development activities that are part of the broader national initiative to develop a Regional Information Technology University.

International Data Center: The RIZ shall provide the site, capability and related resources to facilitate the growth of a profitable business that involves the receipt of various forms of information, data or content from entities around the world, add value to this information, return the enhanced information, data or content to its origin and /or redistribute it to the domestic, regional or global marketplace.

New Investments: The RIZ shall provide a hospitable, low risk, innovative collaborative environment for ICT and other domestic, regional and global technology organizations to invest and develop operations to share ideas, information, research and development, work processes and other knowledge-based activities to support the commercial needs and sustained economic, social and technological development of Azerbaijan and regional Markets.

Export Opportunities: The RIZ shall provide an environment that supports and enhances production and export of electronic equipment and software products, services that are produced in Azerbaijan and distributed to regional Markets (Booz Allen Hamilton Briefing Paper)

This actions will consist of the increasing of the special weight of information communication technologies, playing the catalyst role in the diversification process of the country economy, development of the intellectual potential and agitating of the production directing to the innovation, servicing for the development of the regions, increasing of the export potential of the country, making Azerbaijan ICT centre of the region.

\section{References}

- Akinci, G., Crittle J. 2008. Special economic zones performance, lessons learned, and implications for zone development. Washington DC: The World Bank, 2008.-75 p.

- Innovation in the hybrid zone: Knowledge transfer and adaptive boundary-spanning collaboration // Management of Innovation and Technology, 2008. ICMIT 2008. 4th IEEE International Conference on Bangkok. 21-24 Sept. 2008 p.59-64

- $\quad$ MCIT. 2009- ICT Development Report - Baku

- ITU, Country Information, http://www.itu.int/ITU-D/treg/wsis/c6/doc/ Azerbaijan.pdf

- A. Abbasov. Azerbaijan's ICT sector: Dynamic and growing/ http://unpan1.un.org/intradoc/groups/public/documents/gaid/unpan035720.pdf

- US, Department of State, 2009 Investment Climate Statement - Azerbaijan Bureau Of Economic, Energy And Business Affairs, February 2009/ http://www.state.gov/e/eeb/rls/othr/ics/2009/117856.htm 


\title{
The Dependency Game and Potential Gains in Energy Sector of Eurasia
}

\author{
Yeşim Reel, Marmara University
}

\begin{abstract}
The integration of the Eurasian super-continent will potentially have major implications for the Eurasian region, and also for the world economy.

Traditionally, economic integration has ben analyzed and measured mostly with regard to trade and transport linkages. Turning from the most obvious linkages in energy to other areas, the first point to be made is that the collapse of the Former Soviet Union (FSU) had a devastating impact on trade within the former Soviet regional trading bloc known as COMECON (Linn and Tiomkin,2007).

Opening Greater Central Asia to continental trade in energy and goods would give countries in the region greater access to foreign technology and foreign exchange revenue, increase market access. Forecasts about the positive effects of construction and restoration of road corridors suggest there could be enormous gains (Norling and Swanström,2007).

Moreover, potential gains in energy transit are also massive (Pandian,2005).

It is stated that the increasing demand for Eurasian energy is creating a very interesting dependency game involving three groups of countries. The existing dependencies are based on a number of variables (Svedberg,2007).

The aim of this paper is to analyze the current situation, the dependency game and potential gains in Eurasia's energy sector. The current situation's analysis presents a framework which shows Eurasia's energy sector's data, trends and problems. The dependency game indicates the linkages between different countries which are related to the sector, and these countries' positions. The potential gains are important particularly in energy production, energy projects and energy trade for Eursia. Considering all these, first part presents introduction. The second part analyzes the current situation, the dependency game and, gives outcomes of this dependency in the sector. Third part presents the potential gains for this sector. Last part gives a conclusion.
\end{abstract}

JELCodes: Q4

\section{Introduction}

It is stated that the integration of the Eurasian super-continent will potentially have major implications for the Eurasian region, and also for the world economy (Linn and Tiomkin, 2007). Remarkable opportunities have opened on the Eurasian continent. Not only will Greater Central Asia benefit from this, but India, Pakistan, Iran, China, Azerbaijan, and Russia have similar gains to make by engaging the region, including energy.

Opening Greater Central Asia to continental trade in energy and goods would give countries in the region greater access to foreign technology and foreign exchange revenue, increase market access (Norling and Swanström, 2007).

Moreover, potential gains in energy transit are also massive. Whether India's and Pakistan's energy needs are met by building the Turkmenistan-Afghanistan-Pakistan-India pipeline across Afghanistan or the Iran-India-Pakistan pipeline, transit states will benefit substantially. For example, it has been estimated that Pakistan would gain a total of $\$ 14$ billion in 30 years from building the Indo-Iran pipeline (Pandian, 2005).

It is argued that the increasing demand for Eurasian energy is creating a very interesting dependency game involving three groups of countries. The existing dependencies are based on a number of variables (Svedberg, 2007). Therefore it is important to analysis energy sector in 
Eurasia. In order to anaysis the sector, firstly, it is summarized and analyzed the current situation and the dependency game. Secondly it is given the potential gains for this sector. In the end, it is given a conclusion.

\section{The Current Situation and Dependency Game}

\subsection{The Current Situation}

While the breakup of the Soviet Union created a number of different, new stakeholders in pieces of the energy supply system, and a number of formally independent producing states. In particular, almost all Central Asian and Caucasian natural gas (and oil) had to initially pass through the Russian pipeline network to reach foreign customers. Thus Russia, through Gazprom, remained the monopoly supplier of Eurasian gas to Europe.

This situation remained essentially unchanged until the Russian financial collapse of 1998, and the subsequent economic recovery driven by a dramatic rise in oil, and other energy, prices. That crisis brought a change in the government of Russia, and ushered in a new era of rising energy demand and prices.

The Russian state tightened its control over oil and natural gas supplies to the rest of the world, reinforcing its monopoly over oil (Transneft') and gas (Gazprom) export pipelines. In the light of these developments, the European Union has initiated efforts to form a common energy policy and seek ways to diversify energy — and in particular natural gas — supplies. And Russia began looking to develop alternate export routes to lucrative European markets. Thus a complex and changing structure of interdependence has arisen (Ericson,2009).

Based on this knowledge and, also International Energy Annual is considered, it is realized that specially four Eurasian countries, which are Russia, Azerbaijan, Kazakhstan and Ukraine, have crucial role in the region.

Russia holds the world's largest natural gas reserves, the second largest coal reserves, and the eighth largest oil reserves. Russia is also the world's largest exporter of natural gas, the second largest oil exporter and the third largest energy consumer. Russia is a major world oil producer, sometimes producing even more than Saudi Arabia (IEA, 2010).

Azerbaijan is emerging as an important exporter of oil and natural gas and as a transport corridor between Europe and Central Asia. Its strategic location bordering the Caspian Sea has attracted significant international interest in developing its oil and natural gas reserves. Oil production in Azerbaijan more than quadrupled between 1997 and 2008 to 875,000 bbl/d and is expected to increase further. With the startup of the Shah Deniz natural gas and condensate field in 2007, Azerbaijan went from being a net natural gas importer to a net exporter, shipping increasing amounts of natural gas via Turkey to Europe.

Kazakhstan has the second largest oil reserves among the former Soviet republics after Russia as well as the second largest oil production. The country also has large reserves of natural gas and steadily increasing production. With large amounts of associated natural gas at its oil fields, Kazakhstan has the potential to become a net exporter in upcoming years (IEA, 2010).

Table 1, Table 2, Table 3, Table 4 and Table 5 show more detailed information about Azerbaijan, Kazakhstan and Russia on energy data (IEA, 2010).

\begin{tabular}{|c|c|c|c|c|c|}
\hline $\begin{array}{c}\text { Petroleum } \\
\text { (Thousand barrels per day) }\end{array}$ & Azerbaijan & Russia & Kazakhstan & Eurasia & World \\
\hline Total Oil Production & 874.98 & $9,792.33$ & $1,429.95$ & 12,527 & 85,429 \\
\hline Crude Oil Production & 869.56 & $9,356.78$ & $1,345.42$ & 11,927 & 73,652 \\
\hline Consumption & 121.00 & $2,916.00$ & 244.00 & 4,350 & 85,752 \\
\hline Net Export/Imports & 753.98 & $6,876.33$ & $1,185.95$ & 8,177 & -- \\
\hline
\end{tabular}




\begin{tabular}{|c|c|c|c|c|c|}
\hline Total Oil Export to US & 74 & 465 & 12 & 605 & 12,915 \\
\hline Refinery Capacity & 399 & 5,428 & 345 & 8,205 & 85,460 \\
\hline $\begin{array}{c}\text { Proved Reserves(billion } \\
\text { barrels) }\end{array}$ & 7.00 & 60.00 & 30.00 & 99 & 1,332 \\
\hline
\end{tabular}

Table 1. Petroleum Data belongs to Azerbaijan, Russia, Kazakhstan,Eurasia and World in 2008

\begin{tabular}{|c|c|c|c|c|c|}
\hline $\begin{array}{c}\text { Natural Gas } \\
\text { (Billion Cubic Feet) }\end{array}$ & Azerbaijan & Russia & Kazakhstan & Eurasia & World \\
\hline Production & 572 & 23,386 & 398 & 29,939 & 109,789 \\
\hline Consumption & 376 & 16,799 & 409 & 24,318 & 110,262 \\
\hline Net Export/Imports(-) & 196 & 6,586 & -10 & 5,586 & -- \\
\hline $\begin{array}{c}\text { Proved Reserves } \\
\text { (Trillion Cubic Feet) }\end{array}$ & 30 & 1,680 & 100 & 2,015 & 6,212 \\
\hline
\end{tabular}

Table 2. Natural Gas Data belongs to Azerbaijan, Russia, Kazakhstan,Eurasia and World in 2008

\begin{tabular}{|c|c|c|c|c|c|}
\hline $\begin{array}{c}\text { Electricity } \\
\text { (Billion Kilowatthours) }\end{array}$ & Azerbaijan & Russia & Kazakhstan & Eurasia & World \\
\hline Net Generation & 21.95 & 939.41 & 67.75 & 1,376 & 18,010 \\
\hline Net Consumption & 19.67 & 816.01 & 61.80 & 1,193 & 16,385 \\
\hline Installed Capacity (GWe) & 5.21 & 220.91 & 18.73 & 348 & 4,267 \\
\hline
\end{tabular}

Table 3. Electricity Data belongs to Azerbaijan, Russia, Kazakhstan,Eurasia and World in 2006

\begin{tabular}{|c|c|c|c|c|c|}
\hline $\begin{array}{c}\text { Total Primary Energy } \\
\text { (Quadrillion Btu) }\end{array}$ & Azerbaijan & Russia & Kazakhstan & Eurasia & World \\
\hline Production & 1.659 & 53.133 & 5.711 & 70 & 468 \\
\hline Consumption & 0.702 & 30.298 & 2.971 & 46 & 472 \\
\hline $\begin{array}{c}\text { Energy Intensity } \\
\text { Consumption per dollar of } \\
\text { gross domestic product } \\
\text { using purchasing power } \\
\text { parities. } \\
\text { (Btu per 2005 U.S. } \\
\text { Dollars) }\end{array}$ & 13,595 & 16,522 & 20,368 & 17,328 & 7,811 \\
\hline
\end{tabular}

Table 4. Total Primary Data belongs to Azerbaijan, Russia, Kazakhstan,Eurasia and World in 2006

\begin{tabular}{|c|c|c|c|c|c|}
\hline $\begin{array}{c}\text { Coal } \\
\text { (Million Short Tons) }\end{array}$ & Azerbaijan & Russia & Kazakhstan & Eurasia & World \\
\hline Production & 0.000 & 318.591 & 107.838 & 514 & 7,047 \\
\hline Consumption & 0.000 & 230.402 & 77.453 & 410 & 7,019 \\
\hline Net Export/Imports(-) & 0.000 & 85.908 & 31.332 & 103 & -- \\
\hline
\end{tabular}

Table 5. Total Primary Data belongs to Azerbaijan, Russia, Kazakhstan,Eurasia and World in 2007

Ukraine is important to world energy markets because it is a critical transit center for exports of Russian oil and natural gas to Europe, as well as a significant energy consumer. Ukraine's 
gas sector has been dominated by Naftogaz. Ukraine has the seventh-largest amount of coal resources in the world, but underinvestment, and a lack of progress on deregulation have made the country a net coal importer. Ukraine has sufficient generating capacity to supply more than twice its electricity needs, but the country's ageing infrastructure is in need of investment and maintenance (Heifetz, 2009,IMF,2007).

Followings are stated as energy trends in Eurasia:

1)Slow expansion of European and Japanese demand

2)Rapid expansion of import demand in China, India; recovery from depressed levels in FSU

3) Gas demand growing more rapidly than oil demand

4) Rapid growth in electricity demand

5) Rapid expansion of FSU energy exports in recent years, but now slowing down

6) Russia is the main factor on the supply side (Linn and Tiomkin,2008).

EurAsEC (Eurasian Economic Community) countries desperately need investments, because of possesing vast resources. Specially, Russian investments have been made in the energy sector and infrastructure in EurAsEC countries. Some oil and gas production projects are closely associated with joint reconstruction of existing pipelines or construction of new ones for exporting fuel and raw materials. One of the most active Russian players in EurAsEC is LUKoil. It has participated in eleven oil projects in Kazakhstan since 1995, when a contract for the development of the northern part of Kumkol was made. Since that time LUKoil has invested in Kazakhstan's economy over $\$ 4.5$ billion (Heifetz, 2009).

On the other hand, it is stated that the investment cooperation of Russia and other EurAsEC countries encounters a number of problems; the most important of them are given below (Heifetz, 2009):

1. Political opposition to investment expansion.

2. Lack of flexibility in Russian company policy.

3. Increasing competition.

4. There was no progress in multilateral cooperation.

5. Governmental support for the investment expansion of Russian companies and investment cooperation in EurAsEC is inadequate.

Formulation of a common policy for EurAsEC countries towards the use of energy resources and transport services and cooperation in this area are priority economic goals for EurAsEC (Heifetz, 2009). But problems, which are mentioned above, could create important obstacles for the use of energy sources and others.

\subsection{The Dependency Game}

According to Swedberg, the increasing demand for Eurasian energy is creating a very interesting dependency game involving three groups of countries. The countries of the European Union (EU) are dependent on oil and gas from countries in the Commonwealth of Independent States (CIS) for consumption, whereas the CIS countries in general and Russia in particular are dependent on the EU countries for exports. Both the CIS and EU countries are dependent on the Baltic States, Belarus, Ukraine, and Poland for transiting energy from the former to the latter. The transit countries, for their part, are dependent on CIS energy both for domestic consumption and as a source of revenue, as the transit traffic contributes significant shares of their gross domestic product (Svedberg, 2007).

It is believed that this is a game where there must be winners on one side (producers) and losers (consumers) on the other, but it is better understood as a complicated interdependency game where some countries suffer more than others.

Under these conditions, while the introduction and diffusion of energy-saving policies may help, they are unlikely to relieve the upward pressure on prices. Consequently, all actors should 
be concerned about policies that would support and guarantee the flow of supply. While this entails, in the short term, growing general concern for investments in existing and new oilfields and transport infrastructure for energy (oil and gas primarily), there are also pressures for diversifying energy dependence over the longer term. The advantage of high energy prices, on the other hand, gives a leverage to energy producers that they may wish to use against consumers in other areas when there is a conflict of interest (Malle, 2007).

Moreover it is noted that the energy trade in Eurasia is not a zero-sum game but rather an interesting example of regional interdependence. European countries on average import about 43 percent of their total oil and gas consumption. Some countries are more dependent than others. Most of the Central and Eastern European countries are fully dependent on CIS imports for their oil consumption as they have no or very little own production and limited alternative import routes.

The transit countries in between Western Europe and Russia - most notably the Baltic States, Poland,Ukraine, and Belarus - play a crucial role in the dependency game. They are today among the most dependent on Russian energy imports for consumption and revenues and are, at the same time, the energy bridge between Europe and Russia. As much as 80 percent of Russian gas exports are transited through Ukraine and 25 percent of its crude oil exports.

The existing dependencies could be based on a number of variables that are very difficult to fully assess. Most analysts seem to agree that demand will remain high and growing, especially as the demand in the large emerging markets, most notably China, is increasing rapidly. The underlying issues are related to the future supply, infrastructure, and price of oil and gas (Svedberg, 2007).

Swedberg stated that Russia needs Europe for exports and investments. It is therefore more important than ever that Russia and the EU get their act together and agree on a joint energy policy based on mutual dependency. One of the most interesting outcomes of this dependency game is what role the transit countries will play, both in shaping the policy and as future energy bridges (Svedberg, 2007).

Morelli suggested that Russia, with its vast resources, especially gas, will likely continue to be Europe's primary supplier of gas for the indefinite future. For Europe, trying to construct an overall common energy policy with a common external energy strategy, directed especially at Russia, could be critical. Europe's understanding of Russia's dependence on Europe as a stable customer for Russia's energy resources and an eager investor in Russia's economy presents the EU with several options regarding its energy relations with Russia (Morelli, 2006).

\section{The Potential Gains}

Opening Greater Central Asia to continental trade in energy and goods would give countries in the region greater access to foreign technology and foreign exchange revenue, increase market access, and reduce the harmful effects of being landlocked. Forecasts about the positive effects of construction and restoration of road corridors suggest there could be enormous gains (Norling and Swanström, 2007).

Potential gains in energy transit are also massive. Whether India's and Pakistan's energy needs are met by building the Turkmenistan-Afghanistan-Pakistan-India pipeline across Afghanistan or the Iran-India-Pakistan pipeline, transit states will benefit substantially. For example, it has been estimated that Pakistan would gain a total of $\$ 14$ billion in 30 years from building the Indo-Iran pipeline (Pandian, 2005).

Supporting energy projects in the region and regional energy integration promises to have huge potential long-term payoffs; the BTC pipeline is a case in point. The pipeline was feasible because of financial and political backing from the United States and Europe in a project most observers had doomed beforehand. This pipeline not only relieved Azerbaijan from dependence on Russia, but its construction also signified a long-term commitment from the West to 
Azerbaijan's future.

In order to make full use of the potentials that have opened on the Eurasian continent, there is a need to strengthen cooperative mechanisms and make sizable efforts in restoring infrastructure and reducing border inefficiency. The scope of activity cannot be limited to Central Asia alone. Greater Central Asia has equal complementarity with the economies of South Asia and East Asia as with Russia and Europe (Norling and Swanström, 2007).

Klaassen,et al. show on different scenarios about the prospects for Eurasia. According to them, the prospects for Eurasia are ultimately determined by GDP increases, energy intensity changes, technology dynamics and resource availability. Energy demand projections assume that the next decades are characterized by successful reform and restructuring in Eurasia as a whole, leading to sustained investments in the energy sector and economic development that is reflected in the long-term improvement of energy intensities.

Between 1990 and 2050 electricity demand in Eurasia is expected to increase by a factor of five in Asia and by nearly a factor of three in the European part (FSU, EEU and WEU). The challenge therefore is to match the rich energy resources of Eurasia to growing demands. Resources and demands must be matched geographically through trade, transportation networks and energy grids (Klaassen,et al.,1999).

\section{Conclusion}

It is suggested that continental trade in energy and goods would give countries in Eurasia greater access to foreign technology and foreign exchange revenue, increase market access, and reduce the harmful effects of being landlocked.

Since the region possesses vast resources, and EurAsEC countries desperately need investments. Specially, Russian investments have been made in the energy sector and infrastructure in EurAsEC countries. Some oil and gas production projects are closely associated with joint reconstruction of existing pipelines or construction of new ones for exporting fuel and raw materials. Formulation of a common policy for EurAsEC countries towards the use of energy resources and transport services and cooperation in this area are priority economic goals for EurAsEC.

Moreover, it is stated that the increasing demand for Eurasian energy is creating a very interesting dependency game. The existing dependencies between different countries' groups could be based on a number of variables that are very difficult to fully assess. Most analysts seem to agree that demand will remain high and growing, especially as the demand in the large emerging markets. Therefore, Eurasia could have advantage, using linkages and dependency game.

In order to make full use of the potentials that have opened on the Eurasian continent, there is a need to strengthen cooperative mechanisms and make sizable efforts in restoring infrastructure and reducing border inefficiency. For all these, strong and efficient relation should be maintain and, also comprehensive and efficient projects are necessary.

\section{References}

- Ericson, 2009. "Eurasian Natural Gas Pipelines: The Political Economy of Network Interdependence", Eurasian Geography and Economics, 2009, 50, No. 1, p.32, 33.

- Heifetz, 2009 "Russian Direct Investments in EurAsEC and Their Role in Energy and Transport Infrastructure Development in Eurasia", EDB Eurasian Integration Yearbook 2009,www.eabr.org/eng/publications/IntegrationYearbook/index.wbp? article-id= F591B688-BF0D-45FC-9EFD-B31E0E1E4DD7(03.08.2010).

- IEA,2010, International Energy Annual, http://www.eia.doe.gov/country_energy_data.cfm?fibs=AJ (05.08.2010). 
- International Monetary Fund (IMF), 2007. Ukraine: Selected Issues, IMF Country Report No. 07/47, Washington, p.20.

- Klaassen et al.,1999. Towards New Energy Infrastructures in Eurasia: a background paper, Interim Report IR-99-17, December, p.6, 8.

- Linn, and Tiomkin, 2007. Economic Integration of Eurasia- Opportunities and Challenges of Global Significance, Edited by Anders Aslund and Marek Dabrowski, Europe After Enlargement, Cambridge University Press, Cambridge.

- Linn, Johannes and Tiomkin, 2008. "Economic Integration of Eurasia: Opportunities and Challenges of Global Significance", Asia Europe Journal Volume 4 Number 1 April 23 February, p.16.

- Malle, 2007. "Energy and Central Asia: an Overview of Current Issues", Transition Studies Review, 14, p.149,150.

- Morelli, 2006. “The European Union's Energy Security Challenges”, in Congressional Research Service Report for Congress September 11, 2006, Washington, p.12.

- Norling and Swanström, 2007. "The Virtues and Potential Gains of Continental Trade in Eurasia", Asian Survey, 47, p. 351,352, 369. 370-372.

- Pandian,2005. "Energy Trade as a Confidence Building Measure between India and Pakistan: A Study of the Indo-Iran Pipeline Project," Contemporary South Asia 14:3, September, p.314.

- Svedberg, 2007. "Energy in Eurasia: the Dependency Game”,Transition Studies Review, 14 (1): p.195,197, 201. 


\title{
The Economy and Security of Energy in the Eurasian Region
}

\author{
Alper Karaağaç, Okan University \\ İsmail Önden, Okan University \\ Bilal Özer, Okan University
}

\begin{abstract}
The increasing consumption and production trends in the globalizing world require high levels of energy use. Petroleum and natural gas are the two main energy sources. At this point, the Eurasian Region lying between Europe and Asia, has considerable reserves of hydrocarbons, and provides an alternative to the other oil and gas producing areas of the world. The efforts of big countries to gain influence on the newly independent Eurasian countries result with clashing interests, that could lead the world in the future to serious struggles.

In this study, the current and potential reserves of hydrocarbons are examined with their estimated economic values together with the economic and strategic importance. The interests of the major global and regional powers on the region are discussed. The study aims to show the role of energy economics and energy security concepts in the Eurasian region.
\end{abstract}

JEL codes: $\mathrm{P} 28, \mathrm{Q} 40$

\section{Introduction}

Since the Industrial Revolution, taken place in the mid- $18^{\text {th }}$ century, energy is a vital concept to pursue the increasing production and consumption trends. Firstly the primary source of energy production was coal, which then has been largely replaced by crude oil with the Second World War and also natural gas in the last quarter of the $20^{\text {th }}$ century. These two energy sources are hydrocarbons and have a higher priority in contrast to other resources used to generate the adequate energy. The limited supply of these sources causes significant various consequences. One of them is the race of oil and gas dependent countries for securing access to the energy sources in particular areas of the world. Ensuring the sustainability of their future consumption is vital for them. At this point, the Eurasian Region lying between Europe and Asia, has considerable reserves of hydrocarbons, and provides an alternative to the other oil and gas producing areas of the world. Diversification of energy sources means less dependency to one particular area or producer. Even though the current production of the region is less compared to the Middle East, its potential is much more. The efforts of big countries to gain influence on the newly independent Eurasian States result with clashing interests, that could lead the world in the future to serious struggles.

In this study, it is tried to show the current status in the Eurasian Region, in the perspective of energy security. The main policies of the big international and regional powers are discussed along with their clashing interests in order to emphasize the future economic and geopolitical importance of the region.

\section{World Energy Outlook}

Energy resources are subject to wide variation. Since the early times of the history societies used some materials or substances to heat themselves, cook their food or to make production. First they used firewood with these purposes. Than with the industrial revolution coal domination started. Since mid- $20^{\text {th }}$ century crude oil and natural gas are the main energy sources.

Mainly energy sources can be divided into two groups: Renewable and non-renewable energy sources. Renewable sources are sources such as solar energy, wind power, hydraulic 
energy and nuclear energy. Non-renewable sources are fossil fuels like coal, petroleum and natural gas. These are called hydrocarbons. The limited supply of these non-renewable sources creates a dependency problem and in effect the energy security issue arises.

The 6.7 billion people living in the world use energy somehow directly or indirectly. According to the International Energy Agency's Key World Energy Statistics, in 2006, 43.1\% of total world primary energy consumption was from oil. $15.3 \%$ was from natural gas, $8.6 \%$ from coal. The most consuming countries of the world are the OECD countries with $47.3 \%$. China alone consumed $15 \%$ of total world output.

On the production side it is seen that energy sources are not equally distributed among countries and even among continents. This inequitable allocation of fossil fuels is another issue that gives rise to the concept of energy security. It is seen that in $2006,34.4 \%$ of the total world primary energy supply is oil. Then coal is seen with $26 \%$ and natural gas with $20.5 \%$. These are the fossil fuel figures. Nuclear energy has a share of $6.2 \%$ and hydro has a share of $2.2 \%$. The biggest oil producer is Saudi Arabia with 10.7 millions of barrels per day (bbl/d). Russia and the US follow it.

\section{Energy in the Region}

The Eurasian Region is a point of interest due to its rich energy sources and its strategic location. It is a very volatile part of the world in terms of political, economic and social stability. The region connects the Asian and European continents. In the region there are several countries that obtain rich crude oil and natural gas reserves such as Russia, Azerbaijan, Turkmenistan, Kazakhstan and Uzbekistan.

\subsection{Hydrocarbons in the Region}

The Caspian Region, which is a sub-part of Eurasia, has considerable hydrocarbon reserves. At the moment the countries of the Caspian Region are relatively minor world oil and natural gas producers, struggling with difficult economic and political transitions. But, it keeps its importance to world energy markets because of its potential to become a major oil and natural gas exporter over the next decade. The factors that threat the region's potential in energy include a lack of adequate export infrastructure, disagreement over new export routes, and border disputes between the Caspian Sea's littoral states. In the next parts of the paper the energy and geopolitics of the Caspian Region will be emphasized.

\subsection{Crude Oil in the Region}

There are different estimates of the Caspian Region's proved crude oil reserves. Presently the Caspian region is a significant, but not major supplier of crude oil to world markets. Statistics of British Petroleum (BP) and the Energy Information Administration (EIA), US Department of Energy show that the nations in the Caspian Region, notably Azerbaijan, Kazakhstan, and Turkmenistan, own the proved reserves of approximately 17 billion to 49 billion barrels of crude oil accounting to $4 \%$ of world proven reserves. The reserves in Russia and Iran's Caspian littorals are also added to this figure. A possibly additional unproven reserve of 100 to 300 billion barrels is estimated.

The Caspian Region produced 1.9 million barrels per day (bbl/d) including natural gas liquids in 2005, accounting to $2.3 \%$ of total world output. By 2010, EIA expects the countries of the Caspian Region to produce between 2.9 and 3.8 million bbl/d, accounting to between 3.2 and $4.5 \%$ of total world output. To compare, it would exceed the annual production of Venezuela, the largest oil producer of South America. In 2005, 67\% and 22\% of regional total crude oil output came from Kazakhstan and Azerbaijan respectively.

There is a likelihood of much greater additional reserves of crude oil being found in the region. It is estimated that an additional 184 billion barrels of crude oil reserves are possible (EIA, Caspian Sea Region: Survey of Key Oil and Gas Statistics and Forecasts, July 2006). 
This amount is nearly equivalent to the amount currently held by Saudi Arabia, and can account to about $15 \%$ of total world reserves. It is expected that Caspian oil production will double to 4.140 million $\mathrm{bbl} / \mathrm{d}$ by 2010 .

\subsection{Natural Gas in the Region}

The countries surrounding the Caspian Sea, Russia to the north, Kazakhstan and Turkmenistan to the east, Iran to the south, and Azerbaijan to the west, hold some of the largest oil and gas reserves in the world. And together with neighboring Armenia, Georgia, Turkey, Ukraine, and Uzbekistan, they represent important economic, political, and strategic interests for the global energy markets. The Caspian Region's natural gas potential is by some measures more significant than its crude oil potential. Its relative contribution to world gas supplies is larger than that for crude oil. Regional proven natural gas is estimated at 6.55 trillion cubic meters (tcm). Natural gas production from Azerbaijan, Kazakhstan, Turkmenistan and Uzbekistan in 2005 was approximately $0.147 \mathrm{tcm}$. Turkmenistan produced $0.057 \mathrm{tcm}$ of this total yearly production figure. Turkmenistan and Uzbekistan are the region's largest natural gas exporters. By 2010, annual total production is expected to become $0.153 \mathrm{tcm}$.

\section{Major Actors and Their Interests in the Region}

The collapse of the Soviet Union in 1991 has started a new period in the Eurasian Region characterized by a great power rivalry. The situation in the region is described as being a new great game. The political, economic and social gap created by the Soviet disintegration is tried to be filled by different actors. In order to gaining access to the rich hydrocarbon resources and then to secure this access, global and regional powers try to put the region under their own influence. Politics, military force, economic policies, cultural and religious ties are all used for this purpose. The global outlook of the world energy consumption and production patterns pressures this game. Every country that is interested in the region pursues its policies, chooses its partners and takes the necessary measures.

The US sees dependency on imported oil as a threat to national security. Despite its great crude oil production, US energy is depended to imported crude oil because of its great consumption. Accordingly diversifying and securing the sources of this imported oil is a preliminary for the US. With this tendency the Caspian hydrocarbons are considerable alternatives for the US. The US, imports about $60 \%$ of its crude oil importation. Most of this oil comes from Middle East and the Americas. The oil demand of the US is expected to increase $24 \%$ by 2025 relative to today with decreasing home reserves. Therefore new and rich reserves in other parts of the world attract the US to decrease its dependency. Caspian hydrocarbons are hence feasible alternatives. However, Russian, Chinese and, Iranian presence in the region is a barrier to the US. It wants to balance the influence of Russia and China in the region. The neo-cons that have determined the new global strategy of the US after the $9 / 11$ attacks believe that to ensure the global reign of the US, the Caspian Region must be controlled.

In the Soviet Union era, the Caspian Region was the backyard of Moscow. With the collapse of the Union, as the Caspian states became independent, Russia wanted to keep them still as its backyard. When the US started to show its tendency towards the region, Russia developed new doctrines for its policies in the region; close political, military and economic cooperation was foreseen. The Commonwealth of Independent States (CIS) was established as an alternative in 1991 while the Soviet Union was collapsing. The member states that are the former socialist republics joint the CIS as sovereign and independent states. The relationship of Russia and the Caspian states is mostly based on oil and gas. Also, it has historical social ties with the region. In order to have control over the energy sources in the region, it incentives the involvement of Russian energy corporations in the region. With the 9/11 attacks, Russia supported the US in the global fight against terrorism. Russia both wanted to integrate more with the western world 
and also wanted to provide legitimacy to its military operations in Chechnya. However, expectations from the US were not materialized. Anti-Americanism rose again. The US's military presence in some Caspian countries in the form military bases and joint military agreements as well as military aid to Georgia worried Russia. As a response to the rising US involvement in the region and to the unipolar world order, Russia together with China, Kazakhstan, Kyrgyzstan, Tajikistan and Uzbekistan established the Shanghai Cooperation Organization (SCO). Russia tries to be more influential in the global arena, and hence first it would ensure its influence on its near territory. With this purpose it made interventions to the politics of the former Soviet republics. It tried to prevent the color revolutions. In such a time as Iran was sidelined, Russia invited it to join the SCO.

China gives importance to the cooperation with the Caspian states, as the rivalry between the US and Russia gets intense. China can not withdraw itself from the competition on securing energy resources. China's ongoing process of industrialization has made the country one of the major importers of oil and gas. The biggest part of Chinese imported oil comes from the Middle East. But, despite its great reserves of hydrocarbons the Middle East is the world's most chaotic, insecure and turbulent part. Moreover, politically it is a US dominated area. So, Caspian hydrocarbons are a good alternative to China in terms of diversification. From the view point of the Caspian states, the entry of China into the region will provide new oil and gas pipelines and further options for these inland states, since China is a balancing force between Washington and Moscow.

Iran wants to get out of the sidelining policy of the US, and therefore seeks to enhance the cooperation with the Caspian states. The Caspian states also need Iran, because they are landlocked countries. To export their hydrocarbons via tankers, they should have access to the Persian Gulf. Iran is the region's primary port in terms of hydrocarbon transportation.

The emergence of the newly independent states in the Caspian Region attracted Turkey both economically and politically. In the Cold War period because of the Soviet Union dominance over the Caspian Region, Turkey could not pursue effective policies regarding the region. Turkey forms a natural energy bridge between the source countries and consumer markets and stands as a key country in ensuring energy security through diversification of supply sources and routes, considerations that have gained increased significance in Europe today. From the energy security perspective, the Turkish Straits are of particular importance as around $3.7 \%$ of the world's daily oil consumption is shipped through the Turkish Straits. There are many international major pipeline projects that will probably pass through Turkey, one of which is the Nabucco Pipeline Project. From the energy security perspective Turkey has a key role in the region. Despite having insignificant hydrocarbon reserves, due to its "energy bridge" Turkey attracts almost the same interest as the hydrocarbon exporting countries.

\section{Conclusion}

The first oil shocks of the 1970s, started a new era in the field of energy. All countries of the world realized the importance of the energy security concept. World demand for hydrocarbons will increase more and more, as the more nations enter the path of economic development. Owning adequate amounts of hydrocarbons is vital for a country to meet its needs. But, the reserves of energy resources, especially hydrocarbon reserves are unfortunately not equally distributed. The hydrocarbon exporting countries are mostly the underdeveloped and developing countries, whereas major importers are the industrialized, developed countries. This situation brings about the efforts of those developed countries to influence and have control over the hydrocarbon producing states.

In the Eurasian Region, surrounded with rich reserves, many actors are involved in the new great game that was played for the first time in the second half of the 19th century and early 20th century. The indirect result of the first one was two world wars, which ensured Russian (Soviet) control over the region with the Cold War period. However, with the disintegration of 
the Soviet Union in 1991, the great game is restarted. This time with more players involved, the game have already started. Big powers determined their strategies and chose their regional allies. Despite their rich hydrocarbon resources, the relative under development of the Eurasian states together with their aim to integrate to the world after years of Soviet isolation makes them prone to foreign intervention. Also they need adequate capital to improve their energy sector, and this capital is foreign capital. The pipeline politics in the region is very intensive. Caspian energy sources should reach international markets in an effective way, and therefore major pipeline projects are being debated. Including also Turkey the region serves as an energy corridor between the western world and the eastern world.

So much international involvement in the region causes some conflicts and disguised clashes of interests between the players. One side is the US, with Turkey and Azerbaijan being close to US; on the other side there is the Shanghai Cooperation Organization including China, Russia and some Caspian states. Of course Iran should not be forgotten, which is also close to the Shanghai Cooperation Organization. But, even the interests of the countries in the same strategic partnership clashes with each other. Hence, every player will go after its own interests, especially in such an important issue like energy.

What will be the future of the region is not an easily answerable question. But, we have past evidence that the former game ended with two great wars, giving the shape of the world order. It is likely that in the long-run as the clashes of interests will become harsher with the growing demand for energy, the region will might be the homeland of the first spark of a great war over energy resources.

\section{References}

- Ebel and Menon, 2000. Energy and Conflict in Central Asia and the Caucasus. Roman \& Littlefield Publishers, Oxford.

- Bilgin, 2005. Avrasya Enerji Savaşları. IQ Kültür Sanat Yayıncılık, İstanbul

- International Energy Agency, 2008. World Energy Outlook 2008 Edition, http://www.iea.org/publications/free_new_Desc.asp?PUBS_ID $=2056$

- British Petroleum Company (BP), 2010. Statistical Review of World Energy, http://www.bp.com/liveassets/bp_internet/globalbp/globalbp_uk_english/reports_and publications/statistical_energy_review_2008/STAGING/local_assets/2010_downloads /statistical_review_of_world_energy_full_report_2010.pdf

- Martin, 2006. The Meaning of the 21st century. Transworld Publishers, London. 


\title{
The Nabucco Project within Context of Energy Supply Security and International Politics
}

\author{
Gökhan Özkan, Yalova University
}

\begin{abstract}
The Nabucco Project is a project, which aims to transport rich natural gas resources of the Central Asia, the Caucasus and the Middle East to the European market via Turkey. In this study, the Nabucco Project was evaluated within context of the energy supply security concept and international politics. Firstly, interdependence between national power and energy supply security was investigated. How oil and natural gas became strategic raw materials of world politics beyond being primary energy resources of the global economy was examined. It was found that discovery of rich oil and natural gas resources in the Central Asia and the Caucasus after the Cold War turned the region into a focus of interest of the global and regional actors. In this connection, perspectives of the global and regional actors about the Nabucco Project were examined.As a result of analyses and evaluations, it was concluded that the Nabucco Project is a project that can significantly enhance Turkey's geopolitical importance and make Turkey one of the key countries of the east-west energy corridor.
\end{abstract}

JEL Codes: F50, F59, Q34

\section{Introduction}

According to forecasts for global energy consumption, natural gas and oil consumption will continue to increase in the next twenty years. It is estimated that global oil consumption will increase one percent and global natural gas consumption will increase 1,5 percent on average per year so that total increase in energy demand will amount to 45 percent by 2030. (IEA, 2009) Growing energy demand and its economic and political consequences make the energy supply security a more pronounced concept each and every day.

Energy supply security, which is defined as "continuous and stable supply of energy from reliable and different sources in sufficient amounts, at reasonable price and via reliable means of transport", became a priority for the developing and developed countries. The energy supply security became more important for international system dynamics after economic parameters became as important as political and military parameters in the $21^{\text {st }}$ century security perceptions. (Demiray and İşcan, 2008)

Growing importance of energy in world politics multiplied the geopolitical importance of countries and regions rich in hydrocarbon reserves. After the end of the Cold War and the dissolution of the Soviet Union, many countries gained independence in the Central Asia and the Caucasia. Rich hydrocarbon resources in this geography led to competition among the regional and global actors that want to shape the region according to their interests, which led to evaluations that "new great game" started in the region. It is argued that main actors of this "new great game" are Turkey, Russia, Iran, China, Afghanistan and Pakistan as regional powers and the U.S., the E.U. and Japan as global actors. (Amineh and Houweling, 2005)

As energy security and national security became interconnected, the Middle East and the Eurasia, where around 70 percent of the proved oil and natural gas reserves of the world are located became, in Brzezinski's words, the chessboard of the "new great game". Rivalry in the region intensified over the exploitation of these resources as well as the routes these resources will be transported to international markets.

Various projects were developed to transport these resources to international markets. Regional and global actors struggled to realize the pipeline project that is most suitable for their national interests. The Nabucco Project, which will transport the natural gas of the Middle East and the Caspian Region when completed, is one of the most important projects. In this 
study, the Nabucco Project will be evaluated within context of the energy supply security and "the new great game".

\section{Power, Energy Supply Security and the International System}

Energy supply security became one of the most important factors of international power struggles especially after the cut of energy supply was reflected to the international economic and political system as a major shock during the 1973 oil crisis. Regional and global actors of the international system struggle to control both the geography where these resources are located, the exploitation of these resources and the routes that these resources are transported to international markets to enhance their energy supply security. In this connection, oil and natural gas are not simple commodities that are exchanged at international markets. These resources and the geography these resources are located became strategic assets. (Amineh and Houweling, 2005)

It is argued that after the dissolution of the Soviet Union and after the hydrocarbon-rich Central Asian and the Caucasian states gained independence, the Caspian Region became a special focus of the regional and global actors and the "new great game" started in the region. (Dhaka, 2009) Brzezinski (1997) likened the region to a chessboard, on which regional and global actors struggle to protect their geostrategic and economic interests. The importance of the Eurasia increases along with the transformation process of the international system from a unipolar system with the US as the only superpower into a multipolar system with the EU, Russia and China as potential global powers and Turkey and Brazil as regional powers that enhance their global capabilities. (Arıboğan and Bilgin, 2009)

The Eurasian energy geopolitics is defined as the influence, power, and hegemony struggle for the oil and natural gas in the Central Asia and the Caucasus. (Edwards, 2003) It is argued that the West and Russia compete for the control of the hydrocarbon reserves and the export infrastructure in the region. It is argued that the West and Russia struggle to fill the Nabucco and South Stream Pipelines by the Azerbaijan and Turkmenistan natural gas. (German, 2009)

The Middle East and the Eurasia are the richest regions of the world in terms of natural gas and oil. These regions have almost seventy percent of the world oil and natural gas reserves. Turkey's geographic location makes it a natural energy bridge between the Middle East plus the Eurasia, where almost 70 percent of all oil and gas reserves are located, and the European Union countries, some of which have the highest per capita energy consumption levels in the world. (Bozhilova, 2009) Turkey is aware of the importance of its geographic location and uses its geostrategic advantage to be an energy hub. (Saivertz, 2009)

The EU, because of its growing natural gas needs, supports projects that aim to transport the Middle Eastern and Caspian Region natural gas and oil to the EU bypassing Russia such as the Baku-Tiflis-Ceyhan (BTC), Baku-Tiflis-Erzurum (BTE) and the Nabucco. These projects can make Turkey one of the key countries of the east-west energy corridor. In the next section, maybe the most important one of these projects, the Nabucco Project will be evaluated.

\section{The Nabucco Project}

Nabucco is a project that aims to transport the Central Asian, Caucasian and the Middle Eastern natural gas to Europe via Turkey and the Balkans. Since the Nabucco Project aims to diminish the energy dependence of the EU on Russia, it is supported both by the EU and the US. According to Mihail Delyagin, the President of the Russian Global Issues Institute, the Nabucco Project is the US's geopolitical project. Delyagin argues that the US broke off the Caucasia from Russia in terms of strategic relationship by the BTC Pipeline and may be aiming to break off Turkmenistan, Uzbekistan and Kazakhstan by the Nabucco Project. (Özbay, 2009)

One of the main pillars of the EU's policy of diversifying the supplier countries and pipeline routes is the Nabucco Project. If realized, it will be an important step for the EU towards 
diversifying supplier countries and the energy routes. The EU provided financial funds for the Nabucco Project for the first time in the beginning of 2009. In the same year, the Nabucco Intergovernmental Agreement was signed by Turkey and the four European countries (Austria, Hungary, Romania, and Bulgaria). If the Nabucco Project is realized, the EU will have successfully applied its strategy to diversify supplier countries and routes. The EU will be able to provide natural gas from energy routes that pass from the territories of countries other than Russia and will decrease its dependence on Russia.

The Nabucco Project is a project that will enhance Turkey's geopolitical importance as well as lowering the EU's energy dependence on Russia. If the Project is realized, Turkey will be one of the key countries of the east-west corridor. At the same time, the Nabucco Project is a very important project for Turkey, which because of cuts of natural gas supplies from Iran and Russia, wants to diversify the energy supplier countries and the routes by reaching the Middle Eastern and the Caspian Region natural gas.

The Nabucco Project is seen as one of the main pillars of the "new great game". Regional and global actors have different perspectives about the Project parallel to their regional interests and policies as will be analyzed in the next section.

\subsection{Russia}

Russia, the richest country in terms of natural gas reserves, owns 26,6 percent of all the natural gas reserves in the world. Russia is also one of the richest countries in terms of coal and oil reserves. Russia's natural resources made it one of the most important players in the global energy market. As the oil demand and price rose in the last 10-20 years as a consequence of the fast economic growth of the developing countries such as China and India; as energy supply security became a priority for both the developed and developing countries and as the instabilities in the Middle East increased uncertainty; Russia's leverage as one of the richest countries in terms of energy resources grew. It is argued that Russia used this leverage to increase its declining influence after the Cold War and became an energy superpower. (Sevastyanov, 2008)

It is argued that Russia tries to be a monopoly not only on the transportation of its own the hydrocarbon resources but also on the transportation of the hydrocarbon resources of the Caspian Region by using its geostrategic location. (Blank, 2008) It is argued that Russia tries to increase its influence on the Central Asian and the Caucasian countries parallel to its "Near Abroad" policy by using the critical energy infrastructure. Because of this, Russia opposes the western countries' efforts to bypass Russia by linking the supplier countries in the Caspian Region to the Europe via Azerbaijan and Turkey. (Rywkin, 2008)

It is argued that the military clashes between Georgia and Russia should be evaluated within this context. The clashes are evaluated as an example of the differentiation of the security perceptions of the West and Russia since the end of the Cold War. (Alexandrova-Arbatova, 2009) The balance of power in the Caucasus changed substantially after the clashes. (Ekşi, 2009) Further than that, Pabst (2009) argues that the clashes of August 2008 strengthened the movement of balance of power towards east, which started after the global financial crisis.

It is argued that the clashes may affect the pipeline projects supported by the US in the region such as the Nabucco Project negatively. (Cheterian, 2009) It is argued that Russia's objective is to hold the control of the strategic energy export infrastructure rather than to protect its citizens in the South Osetia. (German, 2009) The US authorities criticized the clashes by stating that they perceive them as Russia's efforts to divide Georgia and undermine the South Energy Corridor. (Fried, 2008) In a report prepared by the European Commission, it is stated that the incidents in Georgia show that these are critical times for energy security and the EU should intensify its efforts with regards to energy supply security. (Commission of the European Communities, 2008)

It is argued that since Russia is opposed to the Nabucco Project, which aims to transport the 
Caspian natural gas to Europe bypassing the Russia route, it developed the alternative South Stream Project. (Larrabee, 2009) With this project, the natural gas of the region will be transported to Europe via Russia and the Black Sea bypassing Azerbaijan and Turkey.

\subsection{The United States}

The US, which became the only superpower in the international system after the end of the Cold War, wants to increase its influence over the energy resources to sustain its superpower status. Discovery of oil and natural gas reserves in the Central Asia and the Caucasus caught the attention of the US like other regional and global actors and the US defined the region as strategically vital. The US tried to protect the interests of the powerful energy companies; meanwhile its policies had also a power politics dimension. (Tsantoulis, 2009) The exploitation of the Caspian Region natural gas and oil and the infrastructure to transport these resources became the focus of the US's security policy in the region. (McDermott, 2008)

In the post-Cold War period, control of the Eurasian Heartland, as defined by Mackinder, became one of the priorities of the US foreign policy. (Labban, 2009) It is argued that the US's objective is not only to control the energy resources in the region but also to contain its potential rivals such as China and Russia. (İşeri, 2009) China's increasing influence in the Central Asia is evaluated as one of the issues that the US must be careful about. (Rywkin, 2008)

The US wants the transportation of the region oil and natural gas via the routes that pass over the territories other than the Russia's. In this way, the US tries to diminish Russia's influence in the region. (Larrabee, 2009) The US also tries to prevent Iran, with which it has disagreements over the nuclear energy, from becoming a transit country. In this connection, the US is opposed to Iran's participation in the pipeline projects such as the Nabucco. So, it is argued that the optimal pipeline route for US's strategy is the Azerbaijan-Georgia-Turkey-Europe route and because of this, the US is the strongest supporter of the BTC, BTE and the Nabucco Projects.

\subsection{Iran}

It is expected that the geostrategic importance of Iran, which has the richest natural gas reserves after Russia and which is the second richest country in terms of oil reserves, will increase rapidly in the global energy geopolitics if it can benefit from its natural reserves effectively. (Coşkun, 2009) Nonetheless, because of its technological backwardness and its international disputes with other countries, it faces many obstacles at both exploiting and distributing these resources.

Disagreement among Iran, the US and the EU about nuclear energy restricts cooperation opportunities among these countries with regards to the exploitation and transportation of Iran's natural resources. Iran, which can contribute to the Nabucco Project substantially, is not included in the Project because of the US's political reservations.

Nonetheless, Turkey signed with Iran the "Natural Gas Memorandum of Understanding (MoU)" in 2008 to develop its relations with its neigbour and to diminish its energy dependence on Russia. According to the MoU, a $2000 \mathrm{~km}$. pipeline from Iran's Assaluyeh Region to the Turkish border will be constructed and connected to the pipeline on the Turkish side.

The MoU is important especially with regards to the Nabucco Project. If realized, the transportation of the Iran gas to Europe with the Nabucco Pipeline will be possible. Also, it will be possible to transport the Turkmen gas, which cannot be included in the Nabucco Project because of the uncertainties about the legal status of the Caspian Sea, over the Iranian territories to Turkey. In this way, it will be possible to include the Turkmen gas to the Nabucco Project. It is also estimated that negotiations about the legal status of the Caspian Sea can also go forward if the Turkmen gas was included in the Nabucco Project. 


\subsection{China}

One of the most important players of the new great game in the Central Asia and the Caucasus is China, average economic growth rate of which surpassed eight percent in the last two decades. China makes investments all over the world to provide the energy it needs for its fast growing economy. According to International Energy Agency's forecasts, China's oil demand will surpass 10 million barrels per day by 2020. Since China's resources are not sufficient to meet this demand, it is expected that China will import 80 percent of its energy needs. The Caspian Region, because of its proximity, is seen as a good alternative to meet China's energy demand and because of this China has made big investments in the region. (Ong, 2009)

Chin has developed various projects to exploit and transport the rich natural reserves of the region. The Turkmenistan-Uzbekistan-Kazakhstan-China Natural Gas Pipeline Project, which was developed to transport the Turkmen gas to China, was realized and the first Turkmen gas reached Beijing in February 2010. The transportation of the Uzbek and Kazakh gas on this pipeline is also considered. It is argued that China, taking into account the US preponderance in the high seas, is developing a project that will link the Iranian natural gas and oil to the China-Kazakhstan Pipeline to increase its energy security.

\subsection{The European Union}

Since the EU is a relatively poor region in terms of natural gas reserves and must import most of the natural gas it needs, energy security became a priority for the EU. It imports around 50 percent of the natural gas it needs and around 80 percent of this natural gas is imported from three countries, Russia, Norway and Algeria. The natural gas and oil reserves in the Central Asia and the Caucasus created an alternative for the EU, which tries to diversify the supplier countries and diminish its energy dependence on these countries, particularly Russia. It is argued that the EU's regional policies depend on constituting an energy export infrastructure that bypasses Russia with the support of the US.

The cut of the natural gas supplies from Russia to Europe in 2006 because of the price disagreement between Russia and Ukraine and the recurrence of this problem in the following years directed the EU to take new measures about energy security. One of the biggest steps the EU took was increasing its support for the Nabucco Project and signing of the Nabucco Agreement in July, 2009. It is argued that the military clashes between Russia and Georgia in 2008 and the recurrence of the energy crisis between Russia and Ukraine in 2009 increased the Nabucco Project's momentum. After the energy crisis between Russia and Ukraine in 2009, the EU declared that energy security became a priority.

\section{The Nabucco Project and Turkey}

The geostrategic location of Turkey between the Central Asia, Caucasus and Middle East Regions rich in hydrocarbon reserves and the EU, which is expected to import 75 percent of the energy it consumes by 2020, makes Turkey one of the key countries of the east-west energy corridor and one of the most important actors of the new great game in the region.

The EU decided to take new measures about energy security after the EU's energy dependence on Russia rose and after the problems between Russia and the transit countries repeated and disrupted the European economy. In this connection, Turkey became a key country with respect to transportation of the hydrocarbon resorces of the Middle East and the Caspian Region to Europe via routes that bypass Russia. This intensified the competition between Turkey and Russia as can be seen at the opposition of Russia to the BTC Project. (Öniş and Yilmaz, 2009)

It is argued that the Nabucco Project may lower Russia's role in transporting hydrocarbon resources of the Caspian Region to Europe as the BTC did. If the Nabucco is realized, Turkey will be able to play the energy bridge role by transporting not only the Caspian Region natural 
gas but also the Middle Eastern and the African natural gas.

Pipelines such as the Nabucco, BTC, BTE; while making Turkey an energy corridor and increasing Turkey's geopolitical importance, also increase Turkey's energy supply security. Turkey, similar to the EU countries, is dependent on other countries with respect to energy and it is estimated that its dependence will increase. In this connection, Turkey also follows the policy of diversifying its energy resources, energy supplier countries and the routes.

It is argued that if Turkey becomes one of the key countries in the east-west corridor and if it becomes a strategic country for the EU's energy supply security, Turkey's EU membership negotiations may proceed more positively. (Tekin and Williams, 2009)

\section{Conclusion}

Turkey's unique geostrategic location makes it a Middle Eastern, European and Eurasian country at the same time, which increases Turkey's potential to be one of the key countries of the east-west and south-north energy corridors. Turkey, if it uses its geostrategic leverage to find solutions for the regional problems and to provide stability by using diplomacy and developing new projects, can consolidate its regional power and increase its weight in world politics.

It is argued that Turkey should follow proactive rather than reactive policies while taking into account the strategies of the regional and global actors in the new great game. Turkey can become one of the key countries of both the east-west and north-south energy corridors if it utilizes its geostrategic location in the Middle East and the Caspian Region, which is home to around 70 percent of all proven natural gas and oil reserves of the world.

Maybe the most important project of the east-west energy corridor is the Nabucco Project. If it is realized, Turkey will be one of the key countries for the transportation of not only the Central Asian and Caucasian natural gas, but also the Middle Eastern and African gas. Since energy security became a priority for the EU, Turkey's geostrategic importance for the EU will also increase, Turkey's EU membership negotiations will proceed more positively and Turkey will have hosted the alliance of civilizations at the energy dimension.

\section{References}

- Amineh and Houweling, 2005. "Caspian Energy: Oil and Gas Resources and the Global Market”, in Central Eurasia in Global Politics: Conflict, Security and Development. (eds. Parvizi Amineh ve Henk Housweling) Koninklijke Brill NV, Leiden, p. 82.

- Alexandrova-Arbatova, 2009. "The Impact of the Caucasus Crisis on Regional and European Security", Southeast European and Black Sea Studies, 9 (3), p. 287.

- Arıboğan and Bilgin, 2009. "Yeni Enerji Düzeni Siyaseti (Neopolitik): Jeopolitik’ten Enerjeopolitik'e”, Uluslararası İlişkiler 5 (20) (Özel Sayı: Enerji), p. 109-132.

- Blank, 2008. "What Comes After the Russo-Georgian War? What's at Stake in the CIS”, American Foreign Policy Interests, 30 (6), p. 379-391.

- Bozhilova, 2009. "Energy Security and Regional Cooperation in South-East Europe", Journal of Balkan and Near Eastern Studies, 11 (3), p. 293-311.

- Brzezinski, 1997. The Grand Chessboard: American Primacy and Its Geostrategic Imperatives. Basic Books, New York, s. 30-56.

- Cheterian, 2009. "The August 2008 War in Georgia: From Ethnic Conflict to Border Wars", Central Asian Survey, 28 (2), p. 164.

- Commission of the European Communities, 2008. Green Paper: Towards a Secure, Sustainable and Competitive European Energy Network. Commission of the 
European Communities, Brussels, p. 3.

- C Coşkun, 2009. “Küresel Enerji Jeopolitiği ve İran”, Uluslararası_lilişkiler, 5 (20) (Özel Sayı: Enerji), p. 179-201.

- Demiray and İşcan, 2008. "Uluslararası Sistemde Güvenlik Kavramının Değişimi Ekonomik ve Jeopolitik Arka Planı”, Dumlupınar_Üniversitesi_Sosyal_Bilimler Dergisi, 21, p. 161.

- Dhaka, 2009. "The Geopolitics of Energy Security and the Response to its Challenges by India and Germany", Geopolitics, 14 (2), p. 279.

- Edwards, 2003. "The New Great Game and the New Great Gamers: Disciples of Kipling and Mackinder", Central Asian Survey, 22 (1), p. 83.

- Ekşi, 2009. "Türkiye-Azerbaycan İlişkileri: Söylemden Reelpolitiğe”, Avrasya Etüdleri, 36, p. 110.

- Fried, 2008. "US-Russia Relations in th Aftermath of the Georgia Crisis", Testimony of Daniel Fried, Assistant Secretary of State for European and Eurasian Affairs, before the House Committee on Foreign Affairs, Washington DC, 9 September 2008. http://www.state.gov/p/eur/rls/rm/109363.htm.

- International Energy Agency (IEA), 2009. World Energy Outlook 2009: Executive Summary. IEA, Paris, p. 3.

- İşeri, 2009. "The US Grand Strategy and the Eurasian Heartland in the Twenty-First Century", Geopolitics, 14 (1), p. 27.

- Labban, 2009. "The Struggle for the Heartland: Hybrid Geopolitics in the Transcaspian", Geopolitics, 14 (1), p. 2.

- Larrabee, 2009. "The United States and Security in the Black Sea Region", Southeast European and Black Sea Studies, 9 (3), p. 305.

- McDermott, 2008. "United States and NATO Military Cooperation with Kazakhstan: The Need for a New Approach", The Journal of Slavic Military Studies, 21 (4), p. 616.

- Ong, 2009. "China's Strategic Convergence with Russia", Korean Journal of Defense Analysis, 21 (3), p. 319.

- Öniş and Yılmaz, 2009. "Between Europeanization and Euro-Asianism: Foreign Policy Activism in Turkey during the AKP Era”, Turkish Studies, 10 (1), p. 10.

• Özbay, 2009. "Nabucco'nun Fendi Güney Akım'1 Yendi mi?”, http://www.bilgesam.org/tr/index.php? view $=$ article \&catid=131\%3Aenerji\&id=398\%3Anabucconun-fendi-guney-akimiyendi mi\&format $=$ pdf\&option $=$ com_content $\&$ Itemid $=146$

- Pabst, 2009. "Central Eurasia in the Emerging Global Balance of Power", American Foreign Policy Interests, 31 (3), p. 166.

- Rywkin, 2008. "Russia's Place in the World", American Foreign Policy Interests, 30 (5), p. 311.

- Sevastyanov, 2008. "The More Assertive and Pragmatic New Energy Policy in Putin's Russia: Security Implications for Northeast Asia”, East Asia, 25, p. 35-55.

- Tekin and Williams, 2009. "EU-Russian Relations and Turkey's Role as an Energy Corridor", Europe-Asia Studies, 61 (2), p. 352.

- Tsantoulis, 2009. "Geopolitics, (Sub)regionalism, Discourse and a Troubled 'Power Triangle' in the Black Sea”, Southeast European and Black Sea Studies, 9 (3), p. 249. 


\title{
Role of Turkey in the Energy Supply of EU: Costs and Benefits Analysis
}

\author{
Abdulkadir Develi, Selcuk University \\ Ahmet Ay, Selcuk University \\ Zeynep Karaçor, Selcuk University
}

\begin{abstract}
EU does not have adequate energy resources when it is compared with its grant amount of energy consumption.. Russia is one of the most important traditional suppliers for the EU and is trying to maintain its position in the future. Russia sometimes use energy as political tools as it seen in example of Ukraine Crises. So, diversification of energy resources of EU will provide more competitive energy supply and it strength energy security of EU. Therefore, EU needs to regional cooperation for energy diversification. Caspian region is energy rich region. Therefore Turkey's strategic location makes it a natural "Energy Bridge" between the major oil producing areas in the Middle East and Caspian Sea. This paper tries to examine costs and benefits analyzing between Turkey and EU aspects of energy cooperation. These costs and benefits analyzing also include projects that are under the construction or still project process. Turkey has some benefits from this process. Because pipelines that provide energy to Europe passes though Turkish boundary and Turkey collect transportation fee from these pipelines and also EU has support these project financially. This is also contains cost for EU.
\end{abstract}

JEL codes: Q41, Q42 and Q43

\section{Introduction}

That is eleven September for EU that in 2006, security of European gas supply became a very topical subject following the cuts in Russian supplies to Ukraine in the first days of the year which had the consequence of restricting the availability of supplies to some European countries (Stern, 2006: 3). After that EU tries to diversify its energy resources. Diversifications of energy resources contain same costs and benefits aspects of economy and politics. Moreover, EU has been searching different alternatives like important producers such as Black Sea, Caspian region, Middle East and Gulf regions. Therefore, Turkey is becoming a crucial energy hub to supply needed energy from producer regions and this is strategically important for EU energy security. On the other hand, cooperation on pipeline projects such as Nabucco Project and South European as Ring Project (SERG) is very big opportunity for EU and also for Turkey in terms of strengthening relationship with EU for future member ship of EU (Green Paper, 2006: 1). In terms of EU-Turkey cooperation, the establishment and development of Trans-European (energy) Networks and the promotion of proper interconnection and interoperability of national networks aim to take full advantage of the internal market (European Parliament, 2006: 3). Transportations of gas and petrol from Russia, the Caspian Sea region and the Persian Gulf though from Turkey by ships and tankers contains mutual cost and benefits for EU and Turkey. These cost and benefits can be calculated in terms of political perspective as energy security concept and economic costs and benefits such as pipeline construction and transportation fee aspect of EU and Turkey.

\section{General Energy Demand Analysis of EU}

The energy dependence of the EU on energy imports will increase steadily in the period from 2010 to 2020. The Union's dependency is growing daily. (Bacık, 2006: 294).

High energy costs, inadequate energy resources and growing energy demand makes EU as one of the most important energy region. European gas demand will rise from presently 540 
billion cubic meters $(\mathrm{bcm})$ to around $800 \mathrm{bcm}$ in 2030, rendering Europe the largest gas market in the world. Oil demand will increase, too, from the present 16 million barrels per day (mbd) to $20 \mathrm{mbd}$ in 2030. At the sometime, generic European resources in the North Sea have peaked and will contribute to future European energy supplies only at sharply reduced proportion (Goldthau, 2008: 2).

The Source dependence of OECD Europe will increase from 36\% in 2002 to \%69 in 2030. The bulk of the supply will be concentrated on Russia 33\%, North Africa $27 \%$ and The Middle East 17\% (Weisser, 2007: 2).

Structural specialties of natural gas and dependency on specific regions and especially to Russia make it more important in terms of security of supply. Ukrainian crises had affected deeply European gas supply. The Ukrainian pipeline system, however, is pivotal in supplying gas to Europe and consequences for Europe's gas supply security were quick to follow: from January 1-3, Gasprom's gas supply to France decreased by $25-30 \%$; supply to Austria decreased by $33 \%$; and Italy received approximately $25 \%$ less gas than normal (Spanjer, 2007: 1). However, consumption of natural gas in EU is twice a bigger than petrol; therefore, providing gas security of EU and alternative projects to diversify gas supplies are more important than oil security for EU. EU makes $17 \%$ of total world natural gas consumption. It is estimated that petrol dependence of EU will reach $70 \%$ by 2030 and natural gas dependence will be $80 \%$ about 25 years later. EU has imported its natural demand from specific regions and countries so far. This ratio is $90 \%$ of necessary demand.(EU, 2000:19) Energy import of EU depends on specific regions; for example, $40 \%$ of gas is imported from Russia and $45 \%$ of petrol is imported from OPEC countries (Morelli, 2006: 9). Natural gas was the fastest growing fuel among the fossil fuels used in the EU, increasing by $2.78 \%$ per year between 1990 and 2005 (EU, 2008: 72 ).

The Middle East and North Africa (MENA) are among the leading countries for energy supply of EU. Although Russian reserves are larger than any single MENA country, many of the latter countries have reserve to production ratios exceeding 100 years, suggesting ample potential for exports. MENA countries have always been seen as a huge potential import resource for European gas markets (Stern, 2006: 3).

On the other hand, EU has to pay huge amount money for energy. The PRIMES model includes a detailed calculation of energy related costs and attributes these costs to the end consuming sectors. Cost analysis includes expenses for purchasing energy products, annuity payments corresponding to investment in end-use equipment, operating expenses and spending to improve energy efficiency (e.g. insulation, etc.). The end-user prices of energy products are also estimated by the model on the basis of a detailed cost analysis of supply, which includes import prices of energy products, extraction costs, distribution costs and annuity payments for investment. The determination of end-use costs takes the view that prices reflect total costs plus profits. The total energy related costs increase by $1.85 \%$ per year, during $2005-2030$. This growth is lower than the GDP growth, implying that energy costs as a percentage of GDP decrease in the Baseline scenario.

\begin{tabular}{|c|c|c|c|c|c|}
\hline $\begin{array}{c}\text { Total Cost Related } \\
\text { to Energy in } \\
\text { billion } €\end{array}$ & 978 & 1080 & 1219 & 1516 & 1709 \\
\hline As \% of GDP & 9.73 & 9.87 & 9.81 & 9.66 & 9.15 \\
\hline
\end{tabular}

Table 1: Energy Costs of EU. Source; European Commission, 2008 'Directorate-General For and Energy and Transport' Luxembourg: Office for Official Publications of the European Communities.

As it is understood from table 1 energy costs of EU composed \%9-10 of EU in GDP. And EU has imported most of its energy demand and energy costs of EU getting up because of 
increasing using natural gas consumption. The main responsible for this increase is the price of natural gas which rises more than the average energy price. The prices of oil products follow the world oil price rise (EU, 2008: 77). Therefore, energy diversification of EU will provide different energy from different producer's countries that will be has effect on more competitive market structure.

\section{Role of Turkey in Energy Demand of EU}

Turkey has historically been of great geopolitical importance to states in the regions surrounding it as well as to states more remotely (Tekin and Walterowa, 2007: 1). Turkey's strategic location makes it a natural 'Energy Bridge' between the major energy producing areas in the Middle East and Caspian Sea regions (Devlet, 2005: 1). Turkey is strategic region where $71.8 \%$ world energy sources crossing (BP, 2005). Turkey is an important link in the East-West energy corridor challenging the Caspian and the Middle Eastern energy to Europe and world markets. The Baku-Tbilisi-Ceyhan and Iraq-Ceyhan oil pipe-lines, Turkmenistan-TurkeyEurope, The Shah Sea, The Black Sea and Turkey- Greece natural gas pipelines would provide the EU with alternative routes for energy supply be used to provide energy security of the EU. Turkey is situated at the meeting point of three continents (Asia, Europe and Africa) and stands as a bridge between Asia and Europe (Demirtaş, 2000: 15).

There are currently four trans-boundary gas pipelines that cross Turkey's borders (Özdemir, 2008); from the west, the Russia-Turkey western pipeline, carrying Russian gas, with a capacity of 14 billion cubic meters (bcm) per year, from the north, the Blue Stream pipeline, carrying Russian gas, with a capacity of $16 \mathrm{bcm}$ per year, from the east, the South Caucasus Pipeline, carrying Azerbaijani gas, with a capacity of $8 \mathrm{bcm}$ per year presently, but upgradable to over $20 \mathrm{bcm}$, from the east, the Tebriz-Erzurum pipeline, carrying Iranian gas, with a capacity of $20 \mathrm{bcm}$.

According to Roberts, Turkey's role as a gateway through which gas can enter the European Community is becoming increasingly important as the European Union grapples with the interrelated geopolitical position, many natural gas pipelines have been established and couples of them are still under the projects (Roberts, 2004: 11). But two of these project has more important than other because of their huge potential energy to Europe that is BTC and Nabucco Pipeline projects.

Baku-Tbilisi-Ceyhan (BTC): This project aims at the transportation of crude oil produced in the Caspian Basin, in places such as Azerbaijan and Kazakhstan, by a pipeline to a marine terminal on the Mediterranean coast of Turkey in Ceyhan and then to the world markets by tankers (Babal1, 2005: 30). Within this framework, a major aspect of Turkey's energy strategy is to complete "the East-West Energy Corridor". Total capacity of the $1768 \mathrm{~km}$ long pipeline is 50 million tones of oil per year (or 1 million barrels a day) (İpek, 2006: 2). The pipeline will have an approximate length of 1,100 miles $(1,770 \mathrm{~km})$ and will cost an estimated $\$ 3.6$ billion. Seventy percent of the project (about $\$ 2.6$ billion) will be funded by credit. It was initially planned to be completed in 2005, however due to some delays the first oil is expected to flow through it in the second half of 2006 (Babal, 2005: 46). Role Turkey in this Project is very critical because of providing security of pipeline. Revenue of Turkey for this project per year is 600 million dollars.

Nabucco pipeline project aimed to connect the large gas reserves from the Caspian Sea and the Middle East through Turkey's border to Europe markets. (Unece Gas Centre Report, 2005). The amount of total eligible costs of study will be supported by EC. It is estimated that the project will cost 4.6 billion Euros (The Busness, 2007). When we consider, it is clear that EU separated crucial amount for achieving its own security of supply, the position of Turkey is very important aspect of realization of project. When it is compared with Russia, it is estimated that 30 billion cubic meters of gas will be supplied to Central Europe by the years 2015. The Nabucco project to Europe in 2030 will be provide more energy supply than other energy 
routes (North Africa, North Sea and its domestic production) according to statistics from BP in 2006. So that it is estimated that the Nabucco Project will be world's largest natural gas pipeline with its huge potential in 2030

Another alternative energy source of EU will be South European Gas Ring Project (SERG) 'Turkey - Greece - Italy interconnector project' this project aimed to reaching gas to Europe from Caspian and Middle East gas reserves. However, Turkey has key role in this project, too.

Turkish part of the project cost is 135 million euro and it will be financed by $\% 50$ by EU and $\% 50$ by BOTAS this support that made by EU. Financial economic support will be provided EU for the project. Turkey will have right to take taxes revenue from this project. Length of border is determiner factor for tax revenue. Therefore Turkey will take biggest transportation fee. In this perspective Turkey will have $\% 60$ of taxes revenue of pipeline. So it is estimated that Turkey income will be nearly 400-450 billion euro (Çerçi, 2009:17).

Economic and politic costs and benefits of EU-Turkey energy cooperation are as follows;

- It will be provided to easy and safe access to the consumption center in Europe with existing transmission infrastructure and cost-based transportation tariff on transit pipelines.

- Investment of European gas companies on searching, production and creating potential new business opportunities activities in that area will be provided with these Projects.

- Ensuring long-term energy supply of EU has been relieved energy markets and providing price advantage in visible period for EU that pays extremely high amounts to energy.

- Increasing bilateral trade capacity, establishment of economic interdependence and strong political relation between Middle East and Caspian Region will be achievements of these projects.

- Contribution to supply security by creating diversification of supply routes and dependence of consuming countries to particular region will be reduced by these projects.

- Europeans companies will have opportunity to get position in a very fast-growing market like Turkey.

- Turkey has joined the pipeline projects, founded pipeline construction costs and collect transportation fee from these projects.

- Turkey takes the security of these pipelines.

- EU energy partnership with Turkey is strengthening its position in a process of accession to EU.

- Oil tankers passing through the Straits has the environmental risks. Therefore new pipeline project will diminish this risk.

- The EU has been taken the cost of these projects greatly.

- Benefits from Turkey from pipeline transportation with these projects are that security of supply will be ensuring more effectively with partnership to investment to high capacity transportation infrastructure.

- Creation new infrastructure for inaccessible potential suppliers to take additional amount of energy has been expected with these projects.

- Long-term prices down to attract transit transport comes from the acquisition, the existing transmission infrastructure, the unused capacity as possible to evaluate in the future likely to be encountered take-or-pay problems to overcome export facilities establish that Turkey would receive benefits will be. 
- Decreasing of prices in long term, collecting transportation fee, evaluation of unused capacity of the existing transmission infrastructure capacity as much as possible, composing exportation opportunity to overcome possible problems of take-or-pay problems in the future are benefits of Turkey.

\section{Conclusion}

New pipelines construction cost are so much and EU meets most cost of the new pipeline construction such as Nabucco Project. Although high cost of new pipeline construction, EU has been obtain so many advantages from these projects that can provide more competitive energy market structure with these projects. Because Russian energy company GASPROM is absolute monopole in European markets. Energy security is another point of diversification of EU with last Ukrainian crises and it is still hot topic in EU agenda. Absolutely, new pipeline project needs to strong cooperation with boundaries countries. Turkey show itself as energy bridge countries for energy transferring to Europe. EU-Turkey energy cooperation also includes some costs and benefits aspect of Turkey. Turkey attended to some pipeline project directly and meets these projects financially. Moreover, Turkey has to provide securitization of these pipelines. The EU' s financial cooperation instruments should be mobilized in full to promote the restructuring and development of partner countries' energy sector, regional cooperation, infrastructure interconnection, new pipelines, energy efficiency and renewable energy sources for their mutual benefit. Member states need to support the ongoing bilateral and regional energy cooperation financed by EU, the European Investment Bank, the European Bank for Reconstruction and Development and other international financial institution. Because, EU's \%8-10 of GDP is energy costs. This value is covered most part EU exportation.

The natural gas projects Turkey is involved in and the liberalization process of our energy market, which gives special importance to energy security, make Turkey a Crucial partner for Europe with regards to energy supply diversification. Therefore new project will open new advantages for FDI. The co-operation projects such as, NABUCCO and SERG will be cause rapid alignment of Turkey with EU energy standards. Turkey has opportunity to develop regulations of Natural Gas market with providing more efficient market and improvement infrastructure services for NABUCCO, SERG and BTC

\section{References}

- Bacık, Gökhan, 2006. “Turkey and Pipeline Politics”, Turkish Studies, Vol. 7, No.2, 293-306, June 2006.

- Babalı, Tuncay, 2005. "Implications of The Baku-Tbılısı-Ceyhan Main Oil Pipelıne Project", Perceptions, Winter

- British Petroleum, June 2005. BP Statistical Review of World Energy. London.

- The Business. 2007. Capital of Nabucco, September 20-28, 2007

- Devlet, Nadir, 2005. “Turkey's Energy Policy in the Next Decade”, Perceptions, Winter 2004-2005

- Demirbaş, Ayhan. 2000 "Recent Advances in Biomass Conversion Technologies", Science and Technology, Say1 6

- İpek, Pınar, 2006. “ The Aftermath of Bakû-Tbılısı-Ceyhan Pıpeline: Challenges Ahead for Turkey”, Perceptions, Spring 2006

- Ö̈zdemir, Sahir, 2001. “Avrupa Ekonomik Topluluğu, Avrupa Topluluğu, Avrupa Toplulukları, Avrupa Birliği, Roma Anlaşması, Avrupa Tek Senedi, Avrupa Birliği Antlaşması, Maastricht Anlaşması, Amsterdam

- Anlaşması, Nice Anlaşması", www.dpt.gov.tr/DocObjects/Download/.../KavramlaraIilskinAN.pdf 
- Morelli, Vince L, 2006. “The European Union's Energy Security Challenges, Analyst in European Affairs Foreign Affairs", Defense and Trade Division.

- European Commission 2000. Green Paper: Towards a European Strategy for the Security of Energy Supply. COM 769 final. Brussels.

- European Commission, 2008. Directorate-General For and Energy and Transport' Luxembourg: Office for Official Publications of the European Communities.

- Tekin, Ali and Walterova, Iva, 2007. “Turkey's Geopolitical Role:The Energy Angle”, Middle East Policy, Vol 14, No1 Spring.

- Stern, Jonathan, 2006. The New Security Environment For European Gas: Worsening Jeopolitics and Increasing Global Competition for LNG, Oxford Institute for Energy Studies, October 2006

- Unece Gas Center, December 2005. Report on The Gas Company and Market Structure in The European Part of The Unece Region, Geneva.

- Roberts, John, 2004. "The Turkish Gate: Energy Transit and Security Issues", Centre For European Studies, EU-Turkey Working Papers, No 11.

- Weiner, Myron, 1995. 'Nations: The Problem of Political Developmen", Annuals of American Academy of Political and Social Science, Vol 358, March 1995.

- BOTAŞ, 2009, http://.botaS.gov.tr/icerik/eng/projeler/yurtdisi.asp. 11.11.2009 


\title{
Exports, Imports, and Economic Growth Nexus in Iran: Bounds test approach to Cointegration
}

\author{
Hassan Heidari, Urmia University \\ Narmin Davoidi, Urmia University
}

\begin{abstract}
This paper examines the long-run relationship between exports, imports and economic growth in Iranian economy using annual data over the period of 1960-2007. As Iran is an oilexporting country, and oil-export boom has a direct impact on the import demand function, and it leads to higher levels of consumption that impact on growth, we emphasize the role of the imports variable in this investigation. Moreover, following recent studies about importance of human capital in endogenous growth models, we extend Feder's model (1982) by entering a proxy for human capital. As Iranian economy has been subject to numerous shocks and regime shifts, we apply Bai and Perron (2003) test to detect any possible endogenous structural breaks. Hence, investigating data properties by concerning structural breaks shows that our variables are not in the same order of integration. This property convince us to use Bounds Test approach to cointegration developed by pesaran et, al. (2001) where it can be applied irrespective of order of integration of the variables. Finally, being sure about existence a long-run relationship between variables, ARDL approach and ECM employed to argue about short-run and long-run coefficient. The results reveal that while there is significant positive relationship between exports and economic growth, the effect of imports is insignificant and also human capital has a negative effect on growth both in short and long run.
\end{abstract}

JEL classification: C22; F14

\section{Introduction}

Discussion about relationship between export and economic growth can be traced to about over two centuries, but arguments over this issue still continue, and results are still varied in different countries.

It was common using time series for investigating ELG hypothesis in individual countries. The results of time series studies was not consisted with previous researches on ELG hypothesis, for example, Ahmad and Kwan (1991) rejected the relationship between exports and growth hypothesis for 41 African countries. Also Ahmad and Harnihirum (1996) found no link between exports and growth for all of ASEAN countries. Al-Yousif (1997) in the study for Arab gulf countries using time series found evidence that supports the hypothesis in the short run, but it fails to find any long run relationship. Chang et al (2000) found no support for ELG hypothesis for Taiwan during the fast growth. Furthermore, Ahmad et al (2000) estimated the relationship between exports, growth and foreign debt for Bangladesh, India, Pakistan, Sri lanka and East Asian countries, and reject hypothesis for all countries except Bangladesh. Panayiotis et al (2005) reject the ELG hypothesis for 22 African and Asian countries, using panel cointegration. Vis-à-vis, some time series studies support the ELG hypothesis, like Sengupta (1991) for south -east Asia, Ghartey (1993)'s investigation for Taiwan, USA and Japan, using bootsrap approach, Al-Yousif (1997) for Malaysia, Emiliu (2001) for Costarica, Vohra (2001) for countries like Pakistan, India, Philipin, Malaysia, and Tayland, Hatami (2002) for Japan, Al-mavali (2004) for Egypt, Awokuse and Christopoulos (2009) for Canada, Italy, Japan, UK, and US. Our paper is different from others in following way:

Some researches like Edwards (1993) and Chang et al (2000) imply that most early studies didn't take into account important factors on growth, and it may leads biased results. Most of previous studies neglected the role of imports in ELG hypothesis. Since Iran is a petroleumexporting country, we add imports to the model under examination, because, according to 
Holder and Williams (1997) an oil-export boom has a direct impact on the import demand function. Higher oil price leads to improved trade, and increased level of consumption which are satisfied through higher levels of imports. Moreover, endogenous growth models also emphasize the role of imports in the model. They argue that knowledge from advanced economies spills another countries through imports. In turn, this knowledge spillover enables the economy to achieve increasing returns. (sengupta, 1993)

In this paper, we investigate ELG hypothesis for Iranian economy by concerning role of imports and using bounds test approach to cointegration introduced by Pesaran et al (2001).

As standard unit root tests, such as Augmented Dickey Fuller (ADF) and Philips and Perron (PP) tests, are biased towards the null of a unit root in the presence of structural breaks, we use Perron (1990) and Lee \& Strazicich (2004) tests to address this issue and test the null of unit root in the series. Since existence of structural breaks may cause the series to be integration of different orders, so, to investigate a long-run relation between variables under consideration, this paper applies the bounds test for cointegration within the Autoregressive Distributed Lag (ARDL) modeling approach. This method was developed by Pesaran et al (2001) and can be applied irrespective of the order of integration of the variables.

The paper proceeds as follows: In section II the data and econometric methodology of the paper is presented. Section III, contains the empirical results and discussions and finally, section IV concludes that paper.

\section{Data and econometric methodology}

\subsection{Data}

The study employs real GDP, real exports, real imports, gross capital formation for K, and the average of human capital as a proxy of labor force covering the period 1966-2007 gathered form central bank of Iran and International financial statistics (IFS).

\subsection{The econometric methodology}

We employ different unit root tests to investigate stationarity properties of the series, both with concerning structural breaks and without. There are several unit root tests such as ADF, PP, KPSS, ng-perron, which ignore the structural breaks of the data. In other words, their results are biased in favor of identifying data as integrated. We present results of these tests in table 1. As we see in this table, results are not the same and are therefore, uncertain. In fact, the general conclusion about the order of integration of data through these approaches is very difficult and the non-confidence is high. One of the reasons of these mixed results can be existence of some structural breaks in time series. According to Perron (1990), ignoring the effects of structural breaks can lead to spurious unit root results and improper policy implications.

\begin{tabular}{l|llll}
\hline & $A D F$ & $P P$ & $K P S S$ & Ng-Perron \\
\hline GDP & $\mathrm{I}(1)$ & $\mathrm{I}(1)$ & $\mathrm{I}(1)$ & $\mathrm{I}(1)$ \\
K & $\mathrm{I}(1)$ & $\mathrm{I}(1)$ & $\mathrm{I}(0)$ & $\mathrm{I}(0)$ \\
HU & $\mathrm{I}(1)$ & $\mathrm{I}(1)$ & $\mathrm{I}(1)$ & $\mathrm{I}(1)$ \\
EXP & $\mathrm{I}(1)$ & $\mathrm{I}(1)$ & $\mathrm{I}(0)$ & $\mathrm{I}(1)$ \\
IMP & $\mathrm{I}(1)$ & $\mathrm{I}(1)$ & $\mathrm{I}(0)$ & $\mathrm{I}(1)$ \\
\hline
\end{tabular}

Table 1. Results of common unit root tests

\subsection{About Iranian data}

The Iranian economy has been experienced numerous shocks and regime shifts such as the 1973-75 oil shock, Islamic revolutions in 1979, the destructive eight-year (1980-1988) war 
with Iraq, the freezing of the country's foreign assets, in march 1993 the Iranian government embarked upon the exchange rate unification policy with consultation of the International monetary fund.

Many of these events and policies during the fundamental review leads to structural breaks occurred in several macroeconomic variables.

\subsection{Structural break tests}

One of our purposes must be determine the appropriate structural breaks in data under investigation. Bai and Perron (1998-2003) developed two tests of null hypothesis of no structural break against an unknown number of breaks given from upper bounds. These tests are called double maximum tests ( $D_{\max }$ ): the first is an equal weighted labeled by $U D_{\max }$. The second test, $W D_{\max }$, applies weights to the individual tests such that the marginal Pvalue are equal across the value of breaks. In both of these tests, break points are estimated by using the global minimization of the sum of squared residuals.

More of related tests confirmed at least one structural break for Iranian data. The joint time that has been considered from most tests is 1979 Islamic revolution. Also in addition to this dummy variable, another dummy variable related to 1973-74 oil shock has been added to the model.

\subsection{Unit root test with structural breaks}

To decrease uncertainty of result reported in Table1, that caused by ignoring structural breaks, we continue our investigation by using unit root test with presence of two endogenous structural breaks developed by Lee and Strazicich (2002) which we report the results in Table 2 .

The results, shows that by concerning two possible structural breaks, GDP, human capital and total exports will be stationary.

Although the results of performed tests, don't lead us to make a general and reliable conclusion, but all set of results suggests that, in general, these series are not in the same order. Therefore, investigation of long run relationship using approaches like Engle and Grenger (1987) and Johansen (1991, 1995)-which assumed that underlying variables need to be integrated of order 1 or I(1)-will be difficult. So, to solve this issue, we use bounds test approach introduced by Pesaran et al (2001) which is applicable irrespective of the order of integration of regressors.

\begin{tabular}{|l|c|c|c|c|l|}
\hline Variable & t-statistics & K & TB1 & TB2 & result \\
\hline GDP & $-7.0820^{*}$ & 7 & 1352 & 1364 & $\mathrm{I}(0)$ \\
\hline $\mathrm{Hu}$ & $-7.4917^{*}$ & 7 & 1365 & 1369 & $\mathrm{I}(0)$ \\
\hline $\mathrm{K}$ & -4.7352 & 1 & 1355 & 1362 & $\mathrm{I}(1)$ \\
\hline $\mathrm{Texp}$ & $-8.3775^{*}$ & 8 & 1357 & 1367 & $\mathrm{I}(0)$ \\
\hline $\mathrm{Imp}$ & -5.3827 & 6 & 1361 & 1379 & $\mathrm{I}(1)$ \\
\hline
\end{tabular}

Table 2. Lee and Strazicich unit root test with two breaks

Note: 1) The critical values at 1,5 , and $10 \%$ are-5.823, -5.286 and -4.989 , respectively (Lee \& Strazicich, 2002, p.22)

2)*indicates that the corresponding null is rejected at all levels.

\subsection{Bounds test approach}

Pesaran et al (2001), proposed a new approach to testing for the existence of a long-run relationship which is applicable irrespective of whether the underlying regressors are I(0), I(1) or mutually co integrated. They provide two asymptotic critical value bounds for the F-test for large samples, both in the case where all the regressors are I(1), and when one or more of the 
regressors are individually $\mathrm{I}(0)$. If the computed F-statistics falls outside the critical value bounds, a conclusive inference can be drawn, without needing to know about order of integration of regressors. However, if the F-static falls inside the critical value's band, inference would be inconclusive, and in such case according Bahmani-Oskoaee and Nasir (2004) an efficient way of establishing co integration is by applying the ECM version of the ARDL model. The error correction representation of ARDL model for our modified Feder's model introduced by Pesaran, Shim, and $\operatorname{Smith}(2000)$, is given by the following equation:

$$
\begin{aligned}
& \Delta L n y_{t}=\alpha_{0}+\beta_{1} \ln y_{t-1}+\beta_{2} \ln k_{t-1}+\beta_{3} \ln h u_{t-1}+\beta_{4} \ln t \exp _{t-1}+\beta_{5} \ln i m p_{t-1}+ \\
& \sum_{j=1}^{n} b_{j} \Delta \ln y_{t-j}+\sum_{j=0}^{n} c_{j} \Delta \ln k_{t-j}+\sum_{j=0}^{n} d_{j} \Delta \ln h u_{t-j}+\sum_{j=0}^{n} e_{j} \ln t \exp _{t-j}+\sum_{j=0}^{n} f_{j} \ln i m p_{t-j} \\
& +\delta D U_{57}+\not D_{52}+\varepsilon_{t}
\end{aligned}
$$

Where $\beta_{i}, i=1, \ldots, 5$ is the coefficient of long-run parameters, and $b_{j}, c_{j}, d_{j}, e_{j}, f_{j}$, are the short-run dynamic coefficient of the underlying ARDL.

\section{Empirical results}

Since the application of the unit root tests to the underlying variables-as we argued in previous section- yields mixed results, following the methodology developed in Pesaran et al (2001), we test the existence of a long run real GDP equation involving for variables without worrying about order of integration of them. Moreover, the lag length (p) for this test is based on Schwarz Bayessian (SBC) and Akike information criteria (AIC). The best choice of lag order is one. Table 4 Gives the values of F-statistics for bounds test under 3 different cases depending on whether the model contains a linear trend or not and whether the trend coefficients are restricted. Intercept in these cases are all unrestricted. (See Pesaran et al, 2001, pp. 7-9).

These statistics need to be compared with the critical value bounds provided by Narayan (2005) for small samples. As we see in table3, $F_{\text {IV }}$ lies outside the lower bound at all levels, while at $90 \%$ critical value bounds, $\mathrm{F}_{\mathrm{III}}$ and $\mathrm{F}_{\mathrm{v}}$ are inconclusive. It means that the test outcome is mixed, and we need to estimate ECM version of ARDL model to decide about existing long run equation. (Bahmani-oskooee and Nasir, 2004)

\begin{tabular}{lllllllll}
\hline $\mathrm{K}=4$ & $1 \%$ & & & $5 \%$ & & & $10 \%$ & \\
\cline { 2 - 3 } \cline { 7 - 8 } & $\mathrm{I}(0)$ & $\mathrm{I}(1)$ & & $\mathrm{I}(0)$ & $\mathrm{I}(1)$ & & $\mathrm{I}(0)$ & $\mathrm{I}(1)$ \\
$\mathrm{F}_{\text {IV }}$ & 4.763 & 6.20 & & 3.512 & 4.587 & & 2.985 & 3.862 \\
$\mathrm{~F}_{\mathrm{V}}$ & 5.376 & 7.092 & & 3.958 & 5.226 & & 3.334 & 4.438 \\
$\mathrm{~F}_{\text {III }}$ & 4.428 & 6.250 & & 3.202 & 4.54 & & 2.660 & 3.838 \\
\hline
\end{tabular}

Table 3. Critical value for bounds test

Notes:1) Critical values are from Narayan (2005, pp.1987:1990)

2) $\mathrm{K}$ is the number of regressors for dependent variable in ARDL models, $F_{\text {IV }}$ represents the $F$ statistic of the model with unrestricted intercept and restricted trend, $F_{V}$ represents the $F$ statistic of the model with unrestricted intercept and trend, and $\mathrm{F}_{\mathrm{III}}$ represents the $\mathrm{F}$ statistic of the model with unrestricted intercept and no trend. 


\begin{tabular}{|c|c|c|c|}
\hline \multirow[t]{2}{*}{ Variables } & \multicolumn{2}{|c|}{ with deterministic trend } & $\begin{array}{c}\text { without } \\
\text { deterministic trend }\end{array}$ \\
\hline & $\mathbf{F}_{\text {IV }}$ & $\mathbf{F}_{\mathrm{V}}$ & $\mathbf{F}_{\text {III }}$ \\
\hline $\begin{array}{l}\text { FGDP(GDp|hu, } \\
\text { K,imp,exp,du57,du72) }\end{array}$ & $a^{*} 2.68524$ & $4.4371 b^{*}$ & $3.02339 \mathrm{~b}$ \\
\hline
\end{tabular}

\section{Table 4. Bounds test for cointegration}

Note: $\mathrm{H}_{0}$ : no existence long run.

$\mathrm{a}^{*}$ indicates that the statistic falls outside the lower bound at all levels.

$\mathrm{b}^{*}$ indicates that the statistic falls inside the bands at $5 \%$ level.

$\mathrm{b}^{* *}$ indicates that the statistic falls inside the bands at $10 \%$ level.

\subsection{ARDL and ECM}

To estimate the long run relations, we use ARDL approach discussed in Pesaran and Shin (1999). The optimal order of lags in the model selected based on Schwarz-Bayessian information criteria as suggested by Pesaran et al (2001) will be ARDL $(1,1,0,0,1)$. Results reveal in table 5 .

\begin{tabular}{|l|l|c|}
\hline variable & Coefficient & $\begin{array}{c}\boldsymbol{t} \text { - } \\
\text { statistic }\end{array}$ \\
\hline Lhu & -3.70096 & -0.9655 \\
Lk & 0.33623 & 0.4962 \\
Limp & 0.32913 & 0.72142 \\
Ltexp & 0.82648 & 1.17317 \\
Constant & -1.7876 & -0.1941 \\
\hline
\end{tabular}

\begin{tabular}{|c|c|c|}
\hline \multicolumn{1}{|c|}{ Regresso } & Coefficie & $\boldsymbol{t}$-Ratio \\
\hline $\boldsymbol{n} \boldsymbol{\text { dLhu }}$ & -0.26467 & - \\
& & 0.86543 \\
dLk & 0.15218 & 3.4095 \\
dLimp & -0.01871 & -0.4115 \\
dLtexp & 0.20828 & 10.1970 \\
dDu57 & 0.07616 & 1.9626 \\
dD52 & -0.00304 & -0.1316 \\
Constant & 0.00593 & 0.4655 \\
ECMT(- & -0.10461 & -6.3575 \\
1) & & \\
\hline
\end{tabular}

Table 6. ECM-ARDL

Results find no significant long run coefficient except export. Also we see surprisingly the negative sign of human capital that is not theoretically correct. We also report the short run coefficient estimates obtained from the ECM version of the ARDL model in table 6. As we can see, the error term $\left(\mathrm{EC}_{\mathrm{t}-1}\right)$ in the short run is statistically significant with a correct negative sign, which confirms that a long run equilibrium relationship exists between the variables, but the error correction coefficient is 0.1046 which means that convergence to equilibrium is very slow with only 10 percent of the adjustment occurring in the first year. The short run coefficient of physical capital and export is significant, implies that just these two parameters among other underlying variables effects on GDP.

\section{Conclusion}

We investigated augmented Feder's model for Iranian data, and following endogenous growth theory, imports added to model, and also instead of labor's force, we use human capital as a proxy of labor's force according endogenous growth theory. The results imply that the speed of adjustment of equation is too slow, and the sign of human capital is theoretically incorrect. It means that human capital have negative effect on GDP. There are some reasons for getting this result: human capital is a quality related to labor force, and so in many studies it is 
used by measuring the number of educated people, but there is not enough quality of education in Iran to enter the labor market and basically, graduated labor force don't have enough productivity. Moreover, imports doesn't have any effect on GDP neither in short run or long run. The lack of sufficient professional labor force to make imported technologies indigenous, through imports of industrial goods, is one of the reasons for long term and short term coefficients of imports to be insignificant in the underlying model, but total export has strong and significant impact on GDP.

\section{References}

- $\quad$ Ahmed, Q. M., M. S. Butt, and S. Alam, 2000. "Economic Growth, Export, and External Debt Causality: The Case of Asian Countries", The Pakistan Development Review 39:4, pp. 591-608.

- Ahmed, J., and S. Harnhirun, 1996. "Cointegration and Causality between Exports and Economic Growth: Evidence from the ASEAN Countries", Canadian Journal of Economics, 24, Special Issue, pp. 413-416.

- Ahmad, J. and Kwan, A, 1991. "Causality between exports and economic growth", Economic Letters, 37 (3), pp.243-248.

- $\quad$ Al-Yousif, Y. K, 1997. "Exports and Economic Growth: Some Empirical Evidence from the Arab Gulf Countries", Applied Economics, 29:6, pp. 693-97.

- $\quad$ Awokase,Tituso, 2007. "Causality between export,imports, and economic growth:evidence from transition", economics,Economics Letters, no.94, pp. 389-395.

- Bahmani-Oskooee, M. and Nasir, A, 2004. "ARDL approach to test the productivity bias hypothesis", Review of Development Economics J., 8, pp. 483-488.

- $\quad$ Bai, J., Perron, P, 2003. "Computation and analysis of multiple structural change models", Journal of Applied Econometrics. Vol. 18:1, pp.1-22.

- Bhat, Sham K, 1995. " Export and Economic Growth in India", Artha Vijana, 37:4, 350-358.

- Chang, T. et al, 2000. "Exports, Imports and Income in Taiwan: An Examination of the Export Led Growth Hypothesis", International Economic Journal, 151-160.

- $\quad$ Edwards, Sebastian, 1993. "Openness, Trade liberalization and Growth in developing countries", Journal of Economic Litrature,31:3, 1358-93.

- Emilio. J. Medina-Smith, 2001. "Is the export led growth hypothesis valid for developing countries? A case study of Costa Rica", Policy Issue International Trade and Commodities Study Series, No.7.

- Engle RF, Granger CWJ, 1987. "Cointegration and error correction representation: estimation and testing", Econometrica, 55: 251-276.

- $\quad$ Feder, Gershon, 1982. "On Export and Economic Growth", Journal of Development Economics, 12, 59-73.

- Ghartey, E. E, 1993. "Causal Relationship between Exports and Economic Growth: Some Empirical Evidence in Taiwan, Japan and the U.S", Applied Economics 25, $1145-1152$.

- Hatemi-J, Abdulnasser. (2002) Export performance and economic growth nexus in Japan. Japan and the World Economy. 14, 25-33.

- Johansen, S1991. "Estimation and hypothesis testing of cointegrating vectors Gaussian vector autoregressive models", Econometrica 59: 1551-1580.

- Johansen, S, 1995. "Likelihood-Based Inference in Cointegrated Vector Autoregressive Models", Oxford University Press: Oxford.. 
- $\quad$ Kwiatkowski, D., Philips, P. C. B., Schmidt, P., Shin, Y, 1992. "Testing the null hypothesis of stationary against the alternative of a unit root, how sure are we that economic time series have a unit root?", Journal of Econometrics, 54, 159-178.

- Lee, J. and Strazicich, M, 2003. "Minimum Lagrange Multiplier unit root test with two structural breaks", The Review of Economics and Statistics, 85:4, 1082-1089.

- $\quad$ Narayan, P.K, 2005. "The saving and investment nexus for china: evidence from cointegration tests", Applied Economics, Vol. 37, pp.1979-90.

- $\quad$ Nasser R. Al-Mawali Dr,2004. "Revisting the Trade-Growth Nexus: Further Evidence from Egypt", Review of Middle East Economics and Finance: Vol. 2: 3.

- $\quad \mathrm{Ng}, \mathrm{S}$. and Perron .P,1995. "Unit root tests in ARMA models with Data-Dependent methods for the selection of the truncation lag", Journal of the American Statistical Association, Vol. 90, pp. 268-281.

- $\quad \mathrm{Ng}, \mathrm{S}$. and Perron .P,2001. "Lag length selection and the construction of unit root tests with good size and power", Econometrica, vol. 69(6), pp.1519-1554.

- Perron, P. (1990), Testing for a unit root in a time series with a changing mean, Journal of Business and Economic Statistics, Vol. 8, pp. 153-62.

- $\quad$ Perron, P, 1997. "Further evidence on breaking trend function in macroeconomic variables", Journal of Economics, 80, pp.355-385.

- $\quad$ Pesaran MH, Shin Y,1999. "An autoregressive distributed lag modelling approach to cointegration analysis", Chapter 11 in Econometrics and Economic Theory in the 20th Century: The Ragnar Frisch Centennial Symposium, Strom S (ed.). Cambridge University Press: Cambridge.

- Pesaran MH, Shin Y, Smith RJ, 2000. "Structural analysis of vector error correction models with exogenous I(1) variables", Journal of Econometrics, 97: 293-343.

- $\quad$ Pesaran, M. H., Shin, Y., and Smith, R. J,2001. "Bounds testing approaches to the analysis of level relationships", Journal of Applied Econometrics, 16, 289-326.

- $\quad$ Phillips, P. C. B. and Perron, P, 1988. "Testing for a Unit Root in Time Series Regression", Biometrika, 75, 335-346.

- Reppas, Panayiotis. A, and Christopoulos, Dimitris. K, 2005. "The export-output growth nexus: Evidence from African and Asian countries", Journal of Policy Modeling, 27, 929-940.

- Sengupta, J.; Espana, J,1994. "Exports and Economic Growth in Asian NICs: An Econometric Analysis for Korea", Applied Economics, 26, pp. 41-51. 


\title{
A Study of the Effects of Non-Oil Exports on Iranian Economic Growth
}

\author{
Naser Ali Yadollahzadeh Tabari, Islamic Azad University \\ Mohammad Nasrollahi, Islamic Azad University
}

\begin{abstract}
This paper examines the effects of Iranian non-oil exports on output during the years 19802007. We use an augmented neoclassical production function type and apply VECM methodology to estimate the short and long-run effects. The results show: negative effects of non-oil export on non-Export output, while capital stock and labor force have positive effects on non-Export GDP.
\end{abstract}

JEL Codes: C12, C32.

\section{Introduction}

The relationship between exports and economic growth has been one of the interesting issues for economists in recent decades. The dominant view in the last two decades can be said to be inclined towards the acceptance of 'export-led growth'; however, since export is one of the components of gross domestic product (GDP), a positive correlation between these two variables is not entirely unexpected (Greenaway and Sapsford, 1994). But the advocates of this theory believe that export's aid to national output growth is not only due to increase in export quantity but also because of the creation of greater output capacities, economy of scale, aid to technological improvement and efficient resource allocation due to the pressure from foreign competition.

Export growth is able to provide the necessary basis for a rise in home investment, and also pave the way for greater levels of foreign investment. Moreover export growth also offers motivation for greater profitability whilst also providing cash flow for imports of intermediate and capital goods Fosu (1990). This process will ultimately lead to economic growth. Empirical studies regarding the relationship between exports and output growth can categorized in: (i) cross-sectional and (ii) time-series analysis.

Experimental studies on testing the 'export-led growth' hypothesis carried out in recent decades have not reached similar results and have sometimes been in complete contrast. Although the 'export-led growth' hypothesis is more accepted or supported than others, the short-term relationship between the two variables of export and economic growth has been mainly emphasized (Love, 1994 and Edwards, 1993). Some studies have even challenged the exogenous growth theory and questioned its accuracy for some developing countries (Love 1994, Greenaway and Stansford 1994). Some research work such as those carried out by Michaely (1977), Balassa (1978), Heler \& Porter (1978), Feder (1983), Kavoussi (1984), Ram (1985) and Fosu(1990) have supported the idea that export growth motivates economic growth. However, the strong relationship between export and economic growths does not imply their causality. These researchers assumed that there is a causal relationship between export and GDP growths. However some researchers questioned the results of cross-section studies (e.g. Sheehey (1990) and Pritchett (1996)). They believe the reliability and validity of the findings of cross-sectional studies is doubtful. In these studies, they implicitly assume that countries in question have a common economic structure and follow similar production technology (Shirizai and Manap, 2005). Moreover, the relationship between export and economic growth is a long-run phenomenon that cannot be fully captured by cross-sectional analysis. Using the analysis of time-series data instead of cross-section data is another way of studying causality.

A number of time-series researches were carried out in the 1980s and 1990s. Jung and 
Marshall (1985), Chow (1987), Hesiao (1987), Bahmani Oskooee et al (1991), Dodaro (1993) and Love (1994) are some of the main examples. Using Grenger (1969), Sims (1972) and Hisao's (1987) approach to the causality test, these researchers have not reached a single conclusion implying the 'export-led growth' hypothesis. Although some of them reached some evidence to support the mentioned hypothesis, they lack finality. While these studies found some evidence to support the 'export-led growth' hypothesis, their findings are far from conclusive.

Using Grenger's causality concept, Jung and Marshall (1985) concluded that the 'export-led growth' hypothesis is only supported in 4 of the 37 involved countries. Bahmani Oskooee, Mohtadi, and Shabsigh(1991) reached some evidence in support of the 'export-led growth' hypothesis through Grenger's causality, although these results lack adequate finality. Love(1994) also studied the two motives of growth hypothesis, namely export and the government sector for economic growth through combining Grenger's causality with FPE. He used Heler and Porter's approach (1978) in defining non-export GDP and reached weak evidence in support of the idea that export and government expenditure motivate growth. Using Grenger's approach, Dodaro (1993) studied causality for a larger group including 87 countries but did not reach decisive results showing that export growth motivates GDP growth. However, support for the effect of GDP growth on export growth was also weak, although stronger than previous ones.

On the other hand, some researchers used Sim's approach (1972) to study causality. Using this approach, Chow(1987) studied the causality between export growth and manufactured output growth. He reached the following results: the presence of bilateral causality in Brazil, Hong Kong, Israel, Korea, Singapore and Taiwan; the presence of unilateral causality from export growth to output growth in Mexico; and the lack of causality in Argentina. However, it should be noted that Sim's procedure has the disadvantage that it uses a higher degree of freedom compared to Grenger's test since it includes lead values of a variable in the model(Love and Chandra, 2005).

One of the basic weaknesses of traditional causality studies whether in Grenger's approach (1969) or Sim's (1972) is that they do not examine the co integration properties of time-series variables like exports and GDP. As Grenger (1988) mentioned, if time series are co integrated, traditional causality tests may reach wrong conclusions on causality. Using Engle and Granger's two-step approach (1987) to co-integration and error correction modeling and using quarterly data instead of annul data for 8 studied countries, Bahmani Oskooee and Ales (1993) reached strong experimental evidence for two-way causality between export and GDP growths in 8 out of 9 countries.

\section{Materials and Methods}

The main purpose of this research is to study the long-run relationship between growth and export. In this regard some issues are noticeable; firstly, the time series techniques were used due to cross-section regression limitations; secondly, we used augmented production function including export instead of two-variable causal relationship in order to avoid probable misspecification; thirdly, we divided export into oil and non-oil in order to establish a more precise study of the effects of export on growth( There is a considerable difference between the share of oil and non-oil export in Iran's GDP). According to above-mentioned theoretical and methodological arguments, we use a neoclassical production function:

$$
\mathrm{Y}_{\mathrm{t}}=\mathrm{A}_{\mathrm{t}} \mathrm{L}_{\mathrm{t}}^{\alpha} \mathrm{K}_{\mathrm{t}}^{\beta}
$$

Where $\mathrm{Y}$ is aggregate real output, and $\mathrm{A}, \mathrm{L}$ and $\mathrm{K}$ are the level of total factor productivity, labor force and capital stock respectively. Because we want to investigate if and how non-oil exports affect economic growth through increase in productivity, we assume that the total 
productivity of factors is a function of non-oil export and other exogenous factors, $c_{t}$.

$$
A_{t}=f\left(N O X_{t}, C_{t}\right)=\mathrm{C}_{\mathrm{t}} N O X_{t}^{\delta}
$$

Inserting equation (2) into equation (1), we will have:

$$
\mathrm{Y}_{\mathrm{t}}=\mathrm{C}_{\mathrm{t}} \mathrm{L}_{\mathrm{t}}^{\alpha} \mathrm{K}_{\mathrm{t}}^{\beta} N O X_{t}^{\delta}
$$

Where $\boldsymbol{\alpha} \boldsymbol{\beta}$ and $\boldsymbol{\delta}$ are the elasticity of production with respect to L, K and NOX. We will reach the following estimated linear function by taking the natural logs (L) of both sides of the equation (3):

$$
\mathrm{LY}_{\mathrm{t}}=\mathrm{c}+\alpha \mathrm{LL}_{\mathrm{t}}+\beta \mathrm{LK}_{\mathrm{t}}+\delta \mathrm{L} N O X_{t}+e_{t}
$$

In which all coefficients are constant elasticity, $\mathrm{c}$ is a constant parameter, and $\boldsymbol{e}_{\boldsymbol{t}}$ is the error term which reflects the influence of all the other factors. Therefore, the estimation of $\boldsymbol{\delta}$ measures the effects of non-oil exports productivity on economic growth. However, the problem is that non-oil export- via the national accounting identity- is itself a component of output. Hence, even if there is no positive effect of non-oil export on TFP in the economy, a positive and significant correlation between the exports and aggregate output is inevitable since rapid increase in exports automatically leads to higher GDP growth (Herzer et al, 2003). To remedy this problem, it is necessary to separate the 'economic influence' of exports on output from the influence incorporated 'growth accounting relationship'. For this purpose, we use the net aggregate output of the non-oil export, NXY (NXY=Y-NOX) instead of total output, Y. We will reach the following equation by replacing $\mathrm{Y}$ with $\mathrm{NXY}$ :

$$
\mathrm{LNXY}_{\mathrm{t}}=\mathrm{c}+\alpha \mathrm{LL}_{\mathrm{t}}+\beta \mathrm{LK}_{\mathrm{t}}+\boldsymbol{\delta} \mathrm{LNOX_{t }}+e_{t}
$$

This equation is estimated to determine the impact of increasing non-oil export on economic growth via increases in productivity. However, it should be noted that higher rates of capital formation, labor force growth and non-oil export growth can themselves be due to higher output growth. We will investigate this causal relationship in an empirical analysis using VAR approach.

\section{Results}

This study aims at testing the presence of a long-term relation between involved research variables and also estimating regression model coefficients presented above. Accordingly, needed annual data for the period 1980-2007 was collected from statistics published by IRI Central Bank and Management and Planning Organization. However, it should be noted that monetary variables used in this research (K, NOX. NXY) are evaluated in Iranian Rials at 1997 constant prices.

In the first step we test the variables for unit roots to verify their order of integration. The Augmented Dickey-Fuller (ADF) test was used to determine the integration degree of involved variables. Table (1) shows the results of unit root tests for the variables. 


\begin{tabular}{rcc}
\hline Variable & Levels & First differences \\
\hline LL & $1.62-$ & $* 5.29-$ \\
LK & 1.97 & $* 4.78-$ \\
LNOX & $2.68-$ & $* 5.80-$ \\
LNXY & 2.54 & $* 5.42-$
\end{tabular}

Table 1- ADF tests for unit roots. Note: The critical values of the tests are taken from MacKinnon (1994). The asterisk (*) indicates that the test statistic is significant at 5 percent level.

The results of these tests reveal that all variables are non-stationary in level while all their first- differences are stationary. Thus, all level variables are I(1) since the first- differences are $\mathrm{I}(0)$. In applying Johanson's procedure there is a need to consider two important issues. The first is determining the appropriate lag length, $\mathrm{K}$, of the VAR model that is considered to be $\mathrm{P}=4$ according to LR standard. Then, it is necessary to study the number of co-integrated vectors along with the presence of deterministic components (constant and trend) in the cointegration space. An important aspect of the VECM includes inserting both the levels and differences of variables into the model. The asymptotic distribution of the co-integration test is dependent on the assumption of deterministic components in a given model. The selection between the different models is practically limited to the three following cases: model 2, including intercept in the cointegration relation, model 3 including the presence of deterministic trends in levels (but neither nor an intercept is present in cointegration relation), and model 4 including a trend in the cointegration space. The Pantola principle can be used to choose one model among the three (Ousterio, 2007). Table (2) presents Pantola principle on the basis of Trace statistics and maximum eigenvalue test statistic to choose the appropriate model.

In these conditions, Trace test signifies the presence of one cointegration vector while the maximum eigenvalue test shows the presence of two long-run equilibrium relations between the variables of the system with intercept and no trend (model 3); therefore, the results of trace and maximum eigenvalue tests are different from each other. Cheung and Lie (1993) point out that the Trace test is more robust to both skewness and excess kurtosis in the residuals than the maximal eigenvalue test.

Trace Statistics

\begin{tabular}{cccc}
\hline$r$ & Model 2 & Model 3 & Model 4 \\
\hline 0 & $(\mathbf{5 4 . 0 8 ) 9 7 . 3 8}$ & $(47.86) 67.71$ & $(\mathbf{6 3 . 8 8 ) 1 0 9 . 9 6}$ \\
1 & $(35.19) 47.80$ & $(\mathbf{2 9 . 8 0 ) 2 2 . 9 4}$ & $(\mathbf{4 2 . 9 2 ) 6 1 . 5 1}$ \\
2 & $(\mathbf{2 0 . 2 6 ) 2 9 . 2 3}$ & $(\mathbf{1 5 . 4 9 ) 1 . 2 7}$ & $(\mathbf{2 5 . 8 7 ) 2 1 . 6 4}$ \\
\hline$r$ & \multicolumn{2}{c}{ Maximal Eigenvalue Statistics } & \\
\hline 0 & $(\mathbf{2 8 . 5 9 ) 4 9 . 5 7}$ & Model 3 & Model 4 \\
\hline 1 & $(\mathbf{2 2 . 3 0 ) 2 5 . 5 8}$ & $(\mathbf{2 7 . 5 8 ) 4 4 . 7 7}$ & $(\mathbf{3 2 . 1 2 ) 4 8 . 4 6}$ \\
2 & $(\mathbf{1 5 . 8 9 ) 2 1 . 4 9}$ & $(\mathbf{2 1 . 1 3 ) 2 1 . 6 6}$ & $(\mathbf{2 5 . 8 2 ) 3 9 . 8 7}$ \\
\hline
\end{tabular}

Note: $\mathrm{r}$ is the cointegration rank or the number of cointegrating vectors. Figures in the. parenthesis are the $95 \%$ critical values of the respective test statistics 
Hence, in view of its better properties and given present economic theories, we estimate VECM with model 3 with one cointegration vector.

After determining the number of co-integration vectors, the estimation of the long-run vector involved in the research (normalized on non-export output) is presented in table (3) with regard to theoretical literature.

\begin{tabular}{rccc}
\hline \multicolumn{1}{l}{ Variable } & Estimated Coefficient & LR Statistic & Probability \\
\hline LL & 0.65 & 8.65 & 0.003 \\
LK & 0.53 & 18.82 & 0.000 \\
LNOX & $0.04-$ & 12.97 & 0.000 \\
\hline
\end{tabular}

Note: The restricted cointegrating vector (LNXY-0.65LL-0.53LK+0.04LNOX) is .obtained after normalisation, i.e. after putting the coefficient of LNXY $=1$

\section{Table 3- Results of Long-run Vector Estimates}

As one can see in the above table, both labor force and capital stock variables have positive effects on GDP excluding non-oil export (NXY as dependent variables) while non-oil export has a negative effect on the dependent variable. The question whether above explanatory variables should be entered into the long-term vector related to NXY (GDP excluding non-oil export) can be answered by looking at the likelihood ratio test statistic (LR) which is distributed $\mathcal{X}^{2}$ with $\mathrm{r}$ degree of freedom. The test statistic for NXY are highly significant and thus, it is concluded that LL, LK, and NOX enter into a long-run equilibrium relationship with NXY.

Using error correction coefficients and short-run parameters, the method of how to adjust the variables towards equilibrium can be presented. We used the weak exagenity test in order to determine whether variables in the model are able to push GDP excluding non-oil export(NXY) towards their long-run equilibrium trend. Present adjustment coefficients in error correction model (presented in table 4) show that only changes in GDP excluding non-oil export (NXY) can restore the model to equilibrium in case of deviation from the long-run relation. The estimated model passes diagnostic tests and indicates that the model is fairly stable during the sample period.

\begin{tabular}{rccc}
\hline Variable & Estimated Coefficient & LR Statistic & Probability \\
\hline LL & $0.11-$ & 0.41 & 0.52 \\
LK & $0.18-$ & 1.49 & 0.22 \\
LNOX & $4.95-$ & 0.60 & 0.44 \\
LNXY & $2.64-$ & 23.06 & 0.00 \\
\hline
\end{tabular}

Table 4- Results of ECM Coefficient Vector Estimates

\section{Conclusion}

This paper uses annual time series data from 1980 through 2007 to investigate the relationship between exports and growth. Our findings, based on using Johnson's multivariable approach to co-integration, show that labor force, capital stock, non-oil export and GDP excluding non-oil export are co-integrated in Iran i.e. there is a long-run relationship between these variables. Moreover, the results of estimating long-run coefficients indicate that the coefficient related to labor force and capital stock is, according to theoretical expectations, completely positive and significant. Results also show that the coefficient related to non-oil 
export is, unexpectedly, negative and statistically significant. It means that the rise in non-oil export in Iran's economy decreases economic growth. This probably implies that the rise in non-oil export in Iran's economy leads to decline in total factor productivity and lessens the positive effect of other factors on economic growth. As also Griffin (1989) confirms this fact through regarding the relationship between export and economic growth to be too weak in developing countries even in best conditions and that we can expect export growth to be provide motives for overall economic progress only if there are well-developed relations between export and non-export sectors. In addition, the positive effect of export on overall economic growth is not initiated unless minimum progress level and strong intersectional relations in economy are established. However, it should be considered that the development of manufactured goods probably has more positive and reliable effects on economic growth.

\section{References}

- $\quad$ Asteriou, D. and S. G. Hall, 2007. Applied Econometrics A Modern Approach Using Eviews and Microfit. Palgrave Macmillan.

- Bahmani-Oskooee, M., and J. Alse, 1993. "Export growth and economic growth: An pplication of cointegration and error-correction modeling". Journal of Developing Areas, 27(7): 535-542.

- Bahmani-Oskooee, M., H. Mohtadi, , and G. Shabsigh, 1991. "Exports, growth and causality in LDCs: A reexamination". Journal of Development Economics, 36(October), 405-415.

- Balassa, B. 1978. "Exports and growth: Further evidence". Journal of Development Economics, 5(2): 181-189.

- Cheung, Y. W., \& K. S. Lai,., 1993." Finite sample sizes of Johansen's likelihood ratio tests for cointegration". Oxford Bulletin of Economics and Statistics, 55, 313328.

- Chow, P. C. Y. 1987. "Causality between export growth and industrial development: Empirical evidence from the NICs", Journal of Development Economics, 26, 1 (6): 55-63.

- Dodaro, S. 1993. "Export and growth: A reconsideration of causality". Journal of Developing Areas, 27(1): 227-244.

- Enders, W., 2004. Applied Econometrics Time Series. John Wiley \& Sons. New York.

- $\quad$ Engle, R. F., and C. W. J. Granger, 1987. "Cointegration and error correction: Representation, estimation and testing". Econometrica, 55(3): 251-276.

- $\quad$ Feder, G. 1983." On exports and economic growth". Journal of Development Economics, 5, 59-73.

- Fosu, A. K. 1990. " Exports and economic growth: The African case". World Development, 18,6 (6): 831-35.

- $\quad$ Granger, C.W.J., 1969." Investigating causal relations by econometric models and cross- spectral methods". Econometrica, 37, 424-438.

- Granger, C.W.J. (1988)." Some recent developments in a concept of causality". Journal of Econometrics, 39, 199-211.

- Greenaway, D. and D. Sapsford (1994). What does Liberalisation do for Exports and Growth?

- Weltwirtschaftliches Archiv 130 (1): 152-74.

- Griffin, K., 1989. Alternative Strategy for Economic Development, London, Macmillan Academic and Professional L.T.D. 
- Heller, P. S., and R. C. Porter, 1978. "Exports and growth: An empirical reinvestigation". Journal of Development Economics, 5, 191-193.

- Hsiao, M.W. 1987. "Tests of causality and exogeneity between export growth and economic growth". Journal of Development Economics, 18, 143-159.

- Jung, W. S. and P. J. Marshall, 1985. "Exports, growth and causality in developing countries". Journal of Development Economics, 18, 1 (4/5): 1-12.

- $\quad$ Kavoussi, R. M., 1984." Export expansion and economic growth: Further empirical evidence". Journal of Development Economics, 14, 1/2 (1/2): 241-50.

- Love, J., 1994." Engines of growth: The exports and government sectors". World Economy, 17, 203-218.

- $\quad$ Love, J., \& R. Chandra, 2005." Testing export-led growth in Bangladesh in a multivarate VAR framework". Journal of Asian Economics, 15, 1155-1168.

- Michaely, M., 1977. "Exports and growth: An empirical investigation". Journal of Development Economics, 4, 1 (3): 49-53.

- $\quad$ Pritchett, L., 1996." Measuring outward orientation in LDCs: Can it be done?", Journal of Development Economics, 49(2), 307-335.

- $\quad$ Ram, R., 1985. "Exports and economic growth: Some additional evidence". Economic Development and Cultural Change, 33, 2 (1): 415-25.

- Sheehey, E. J., 1993. "Exports as a factor of production: A consistency test. World Development", 21, 1 (1): 155-60.

- $\quad$ Sims, C.A., 1972. "Money, income and causality". American Economic Review, 62(9), 540-552. 


\title{
An Analysis of Trade Integration in the Commonwealth of Independent States Region
}

\author{
Nuray Terzi, Marmara University \\ Erdem Turgan, Marmara University
}

\begin{abstract}
Most of the countries in Eurasia have significantly re-integrated with the global economy. Economic integration of Eurasia carries a global significance, especially in CIS region. Economic integration proceedes in different areas. One of the major areas is trade integration. Further trade integration can depend on different factors. The aim of this article is to identify trends in the trade integration of the CIS by explaining changes in the commodity composition of foreign trade, and by providing an insight into the trade policy, transport system and trade facility of the CIS region.
\end{abstract}

JEL Codes: F15, F13

\section{Introduction}

In today's economically integrated world, trade matters more than ever before. Most of the countries in Eurasia have significantly re-integrated with the global economy. Economic integration of countries has the potential to improve the economic efficiency and welfare of countries. In this context, economic integration of Eurasia carries a global significance, especially in CIS region. Economic integration process can proceede in different areas. One of the major areas is trade integration. A country's comparative advantage in international trade can vary significantly overtime not only due to differing rates in the accumulation of production factors or changes in technology, but also due to increased trade integration of other countries. The progress of trade integration can be influenced by political and economic forces. Further trade integration can depend on different factors in CIS region. The aim of this article is to to identify trends in the trade integration of the CIS. Following section gives the growth and composition of trade in CIS region. Next section analyzes trade integration in CIS region by explaining trade policy, transport system and trade facility. Last section provides a conclusion.

\section{The Characteristics of Trade in CIS Region}

The Table 1 shows that growth in export takes place among CIS and with the world. Since 2000 , the growth in export in CIS has increased. CIS countries exported around $\$ 137$ billion worth of merchandise to other CIS countries, but exported $\$ 521$ billion to the world in 2008 .

\begin{tabular}{|l|r|r|r|r|r|}
\hline & $\mathbf{2 0 0 0}$ & $\mathbf{2 0 0 1}$ & $\mathbf{2 0 0 2}$ & $\mathbf{2 0 0 3}$ & $\mathbf{2 0 0 4}$ \\
\hline World & 77,280 & 91,298 & 100,114 & 133,957 & 181,541 \\
\hline Among CIS & 29,053 & 32,103 & 30,361 & 39,842 & 54,968 \\
\hline & $\mathbf{2 0 0 5}$ & $\mathbf{2 0 0 6}$ & $\mathbf{2 0 0 7}$ & $\mathbf{2 0 0 8}$ & \\
\hline World & 223,673 & 291,918 & 397,418 & 521,248 & \\
\hline Among CIS & 61,728 & 78,079 & 70,085 & 137,099 & \\
\hline
\end{tabular}

Table 1. Growth in Exports of CIS, 2000-2008, Million US Dollars. Source: UNCTAD

In CIS, trade structure in export is overwhelmingly concentrated in fuels (64\%) while trade structure in import is mainly concentrated in traditional non-energy areas, such as machinery and transport equipment $(40 \%)$, other manufactured goods $(21 \%)$, primary commodities $(15 \%)$ fuels $(\% 11)$ and chemical products (10\%) (Graph 1). 

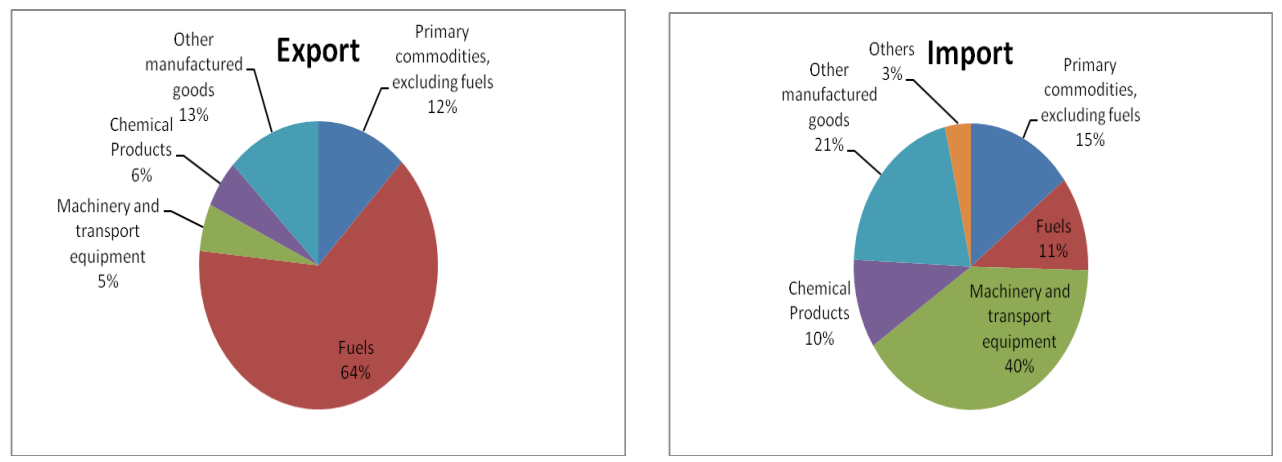

Figure 1. Trade structure by product group in CIS, 2008. Source: UNCTAD.

\section{Trade Integration in CIS Region}

Three main factor is important for further trade integration in CIS. First, trade policy of the countries in the region; second, development of transport system; and third, and trade facilitation across borders. Following section explains these three factors.

\subsection{Trade Policy}

Accession to the World Trade Organization (WTO) has the potential to impact greatly on the economies of member countries. On the one hand acceding countries make commitments to liberalize their markets by reducing tariffs and undertaking a variety of trade reforms. While consumers may gain from lower prices on imported goods, and acceding countries can use WTO membership to better position themselves to attract private investment flows, there are broad implications for domestic productive capacity in the main economic sectors agriculture, industry and services - as well as for growth, human development and poverty reduction. In this regard, critical challenges and opportunities face the 12 Commonwealth of Independent States (CIS) countries, half of which acceded to the WTO relatively recently with the other half in the process of negotiating accession (only Turkmenistan has not applied). (Table 2) They need to join with other countries to strengthen their bargaining position [2,3]

\begin{tabular}{|l|c|l|}
\hline & Application & Current Status \\
\hline Armenia & Nov-93 & Joined in 2003 \\
\hline Azerbaijan & Jul-97 & Ongoing negotiations \\
\hline Belarus & Sep-93 & Ongoing negotiations \\
\hline Georgia & Jul-96 & Joined in 2000 \\
\hline Kazakhstan & Jan-96 & Ongoing negotiations \\
\hline $\begin{array}{c}\text { Kyrgyz } \\
\text { Republic }\end{array}$ & Feb-96 & Joined in 1998 \\
\hline Moldova & Nov-93 & Joined in 2001 \\
\hline Russia & Jun-93 & Ongoing negotiations \\
\hline Tajikistan & May-01 & Ongoing negotiations \\
\hline Turkmenistan & $\ldots$ & $\ldots$ \\
\hline Ukraine & Nov-93 & Joined in 2008 \\
\hline Uzbekistan & Dec-94 & Ongoing negotiations \\
\hline
\end{tabular}

Table 2. WTO Accession Status of the CIS, 2010 [3]

Although WTO membership is a key element of global and regional integration for trade policy, their integration into the world economy and in Eurasia still lacks for now an important impetus (World Trade Organization).

Trade integration can also be pursued on a purely bilateral or regional basis. Table 3 shows 
the bilateral free trade agreements in CIS. Despite their proliferation, in the past many CIS preferential trade agreements remained agreements on paper only. There are several reasons for this. First, the coverage is limited and unclear, which made the agreements either ineffective or irrelevant. Sometimes the most sensitive goods were excluded (e.g., gas and oil for Kazakhstan and the Russian Federation). Exemptions and exceptions were not harmonized across countries and were usually granted on an ad hoc basis, which introduces uncertainties in their application. Second, because these arrangements provide a mechanism to allocate rents, there has been a rise in conflicts of interests, trade disputes, and retaliation, delaying or blocking the implementation of some agreements. Third, the costs of enforcing rules of origin are often higher than the benefits associated with a preferential tariff regime. Therefore, importers often forgo claiming the preferential rates. Fourth, because regional institutions were absent in the past, the regional trade agreements had to be self-enforcing, which weakened their implementation. Finally, the lack of harmonization in levying the value-added tax (VAT) in the past has resulted in numerous trade disputes and provoked suspension of the agreements on particular issues (Tumbarello, 2005).

\begin{tabular}{|c|c|c|c|c|c|c|c|c|c|c|c|c|}
\hline & $\begin{array}{c}\text { Arm } \\
.\end{array}$ & Azer. & Bel. & Geo. & Kaz. & Kyr. & Mol. & Russ & Taji. & Tur. & Ukr. & Uzb. \\
\hline Arm & $*$ & & & 1998 & 2001 & 1994 & 1993 & 1993 & & 1996 & & \\
\hline Azer & & $*$ & & 1996 & 1997 & & 1995 & 1992 & & 1996 & 1995 & 1996 \\
\hline Bel. & & & $*$ & & & & 1993 & 1996 & 1998 & & 1996 & 1993 \\
\hline Geo. & 1995 & 1998 & & $*$ & 1999 & & 1998 & 1994 & & 1996 & 1996 & 1995 \\
\hline Kaz. & & 1997 & 2001 & 1999 & $*$ & 1995 & 1995 & 1992 & & & & 1997 \\
\hline Kyr. & 1994 & & & & 1995 & $*$ & 1995 & 1993 & & & 1998 & 1998 \\
\hline Mol. & 1993 & 1995 & 1993 & 1998 & 1995 & 1995 & $*$ & 1993 & & 1993 & 1995 & 1995 \\
\hline Russ & & 1992 & 1996 & 1994 & 1992 & 1993 & 1993 & $*$ & & & 1993 & 1992 \\
\hline Taji. & & & 1998 & & & & & & $*$ & & & 1996 \\
\hline Tur. & 1996 & 1996 & & 1996 & & & 1993 & & & $*$ & & 1996 \\
\hline Ukr. & & 1995 & 1996 & 1996 & & 1998 & 1995 & 1993 & & & $*$ & 1994 \\
\hline Uzb. & & 1996 & 1993 & 1995 & 1997 & 1998 & 1995 & 1992 & 1996 & 1996 & 1994 & $*$ \\
\hline
\end{tabular}

Table 3. Bilateral Free Trade Agreements in CIS. Source: Tumbarello, 2005.

The CIS countries, because of their central location at the heart of the Eurasia region, are particularly important for permitting and facilitating regional trade integration Eurasia-wide. Table 4 shows the regional trade agreements involving CIS countries. Various reviews of regional trade policy and agreements in the CIS have shown that the high frequency of bilateral, regional and global trade agreements in the CIS, while in principle to be welcome as a recognition of the importance of regional trade integration, in practice has not yet led to effective trade cooperation within the CIS. The principal reasons are two-fold: One reason is the complexity of the overlapping trade agreements which leads to unimplementable trade relations among countries in the region. The second reason is that most of the agreements have actually not been implemented or enforced in practice, either due to a lack of political readiness for cooperation and integration, or because of the weakness of administrative capacity and high incidence of corruption in implementing national trade policies in many of the CIS countries (WTO).

\begin{tabular}{|c|c|c|c|}
\hline CACO (2002) & EAEC (2000) & UES (2003) & GUAM(1997) \\
\hline Russia, & Russia, Kazakhstan, & Ukraine, Belarus, Russia & Georgia, \\
Kazakhstan, & Kyrgystan, Tajikistan, & Kazakhstan, Kyrgystan, & Ukraine, \\
Kyrgystan, & Belarus & Tajikistan & Azerbaijan, \\
Tajikistan, & & & Moldova \\
Uzbekistan & & & \\
\hline
\end{tabular}

Table 4. Regional Trade Agreements Involving CIS Countries.. Source: UNDP Poverty Report 
In addition, some efforts at regional cooperation have been made in the last 10 years and various regional organizations have been created to support these efforts such as SCO, EurasEC, ECO, CAREC, SPECA, etc. (Table 5). However, they remain mostly quite ineffective. Significant efforts would be needed to convert them into an effective institutional framework supporting regional cooperation and integration of Central Asia (Linn, 2009).

\begin{tabular}{|c|c|c|c|c|}
\hline SCO (1996) & $\begin{array}{c}\text { EurAsEC } \\
(2000)\end{array}$ & ECO (1992) & CAREC (1997) & SPECA(1998) \\
\hline China & Belarus & Afghanistan, & Afghanistan, & Kazakhstan \\
Kazakhstan & Kazakhstan & Azerbaijan & Azerbaijan, China, & Kyrgyzstan \\
Kyrgyzstan & Kyrgyzstan & Iran, Kazakhstan & Kyrgyzstan, & Tajikistan \\
Russia & Russia & Kyrgyzstan, & Mongolia, & Turkmenistan \\
Tajikistan & Tajikistan & Pakistan & Tajikistan, & Uzbekistan \\
Uzbekistan & Uzbekistan & Tajikistan, Turkey & Uzbekistan, & Afghanistan \\
& & Uzbekistan & Mongolia, EBRD, & \\
& & & IMF, IDB, ADB, & \\
& & & UNDP,World Bank & \\
\hline
\end{tabular}

Table 5. Regional Organizations Involving CIS Countries. Source: Linn, and Pidufala (2009).

\subsection{The Integration of the Transport System}

The integration of national transport systems is key to the of most of the obstacles that restrict region's attempts to encourage greater use of its international transport corridors for transit. The post-Soviet space has a number of integration groups whose main aim is to overcome these physical and non-physical barriers such as CIS integration initiatives, EurAsEC initiatives, and initiative 1520 (Vinokurov et.al., 2009).

CIS integration initiatives The CIS is coordinating the integration of the transit and transport sectors of EurAsEC member countries. The CIS' transport policy identifies the following priorities[8]:In accordance with the need to promote liberalisation and economic reform, all CIS governments adopt the agreed transport policy. The policy aims to create a common market to which all operators have equal access; to implement an agreed tariff and tax policy; to preserve and extend unified technical and technological standards for the transport sector; and to maintain a unified approach to cooperation with third countries and international organisations; the extension and harmonisation of transport laws by the legislature of the CIS.

EurAsEC initiatives EurAsEC's purpose is to develop Unified Transport System (UTS) and a Transport Union of its member countries. EurAsEC countries(Belarus, Kazakhstan, Kyrgyzstan, Russia and Tajikistan) are committed to jointly pursuing the following goals: [8] Coordination of activities aimed at developing the international transport corridors linking European and Asian countries; the development of transport infrastructure and standardisation of technical and technological parameters across all EurAsEC transport corridors; a coordinated policy to attract foreign investment in transport corridors; refining the legal framework regulating the crossing of borders in EurAsEC; a policy of harmonised tariffs and charges for freight and passenger transport, crossing borders, use of infrastructure; encouraging the establishment of joint ventures engaged in international freight and passenger transportation and forwarding services; coordinating activities to enhance traffic and cargo safety and protect the environment; identifying opportunities to improve multi-modal shipments; finding the optimal location for and building new international logistics centres.

Initiative 1520 In May 2006, the first international 1520 Strategic Partnership rail industry forum was held in Sochi. The forum was created to discuss transport integration in the seventeen countries which use the $1520-\mathrm{mm}$ railway gauge. By the end of 2008, three such forums had been held in Russia. The forums include round-table and panel discussions on a 
wide range of administrative and technical issues, analysts' reports and potential solutions. The forums attract delegates not only from the "1520 Area", but also from Western Europe and the APR, who recognise the huge intercontinental importance of the 1520-mm gauge network and the investment opportunities that the region's transport system represents [8].

\subsection{Trade Facilitation}

According to the World Trade Organization, trade facilitation is the process of "simplification and harmonization of international trade procedures" covering the "activities, practices, and formalities involved in collecting, presenting, communicating and processing data required for the movement of goods in international trade." It relates to a wide range of activities at the border, such as import and export procedures; transport formalities; and payments, insurance, and other financial requirements (Roy,and Banerjee, 2010). Nevertheless, free trade among the CIS is not, as yet, generalized. Non-preferential tariff rates, therefore, maintain all their importance for trade flows, even within the region. As Table 6 below shows, tariffs are still relatively high, not least in the Russian Federation, which is by far the region's largest importer and has tariffs averaging over $10 \%$.

\begin{tabular}{|l|c|c|}
\hline Country & Tariff Year & Simple Average \\
\hline Armenia & 2001 & 3.3 \\
\hline Azarbaijan & 2002 & 10.1 \\
\hline Belarus & 2002 & 11.5 \\
\hline Georgia & 1999 & 9.9 \\
\hline Kyrgyzstan & 2002 & 8.2 \\
\hline Moldova & 2001 & 5.1 \\
\hline Russia & 2002 & 10.3 \\
\hline Tajikistan & 2002 & 8.0 \\
\hline Turkmenistan & 2002 & 5.3 \\
\hline Ukraine & 2002 & 7.9 \\
\hline Uzbekistan & 2001 & 10.6 \\
\hline CIS Average & & $\mathbf{8 . 8}$ \\
\hline
\end{tabular}

Table 6. Simple Average of Tariff. Source: UN, 2005

In addition to tariffs, a number of other obstacles to trade among the CIS countries appear not to have been sufficiently addressed, in spite of the existence of Free Trade Agreements (FTA) For an FTA to function, the elimination of customs duties is not sufficient. Moreover, implementation continues to lag behind, and significant barriers to trade in the CIS region remain. Longer trade routes, insufficient transport infrastructure, customs clearance and transit fees, lengthy and inefficient customs procedures, unofficial payments, need for a modern information system are the other various barriers to trade in the region[10].

\section{Conclusion}

In conclusion, CIS countries have increased their important in Eurasia. The level of export in CIS region has grown and trade structure in export is concentrated in fuels while trade structure in import is concentrated in machinery and transport equipment, primary commodities fuels and chemical products. Although WTO membership is a key element for trade integration for trade policy, their integration into the world economy and in CIS still lacks an important impetus. Many of them is outside of WTO; and bilateral and regional agreements remain mostly ineffective. Several initiativies try to provide the integration of national transport systems. However, they need to develop. In terms of trade facilitation, CIS region has some programs to improve trade facilitation but they still has some problems. In sum, CIS has significant position in a global context, but further trade integration is possible if it is supported by efficient trade policy, improved transport system, and enhanced trade facilitation. 


\section{References}

- Linn, J.2009. "Connecting Central Asia with the World", First Eurasian Emerging Market Forum, Gerzensee, Switzerland, Jan 31-Feb 2.p.9.

- Linn, J. and Pidufala, O. 2009. “The Experience with Regional Economic Cooperation Organizations. Lesson for Central Asia” EDB Eurasian Integration Yearbook, 2009.p.93.

- Linn, Johannes and D. Tiomkin, 2005. “Economic Integration of Eurasia: Opportunities and Challenges of Global Significance" Studies\&Analyses No. 298, In Proceedings of International Conference 'Europe after the Enlargement' Center for Social and Economic Research, Warsaw, 8-9 April.p.1-46.

- $\quad$ Roy, J. And Banerjee, P. 2010. "Connecting South Asia :The centrality of Trade Facilitation for Regional Economic Integration” BeyondSAFTA. p.110.

- Tumbarello, P. 2005. "Regional Trade Integration and WTO Accession: Which is the Right Sequencing ?, An Application to the CIS", IMF, Working Paper, May.p.7.

- UN, 2005. "Building Trade Partnerships in the CIS Region", Document for Information, Trade /2005/17, p.1-18.

- UNCTAD, http://www.unctad.org/Templates/Page.asp?intItemID=1889\&lang=1

- UNDP,http://europeandcis.undp.org/poverty/trade/show/6E1143B5-F203-1EE9B3A7671EB41CA8A3

- Vinokurov, E.,Jadraliyev, M. And Scherbanin, Y. 2009. “The EurAsec Transport Corridors EDB Industry Report”, EDB Eurasian Integration Yearbook 2009. P.186240.

- WTO, http://www.wto.org/english/thewto_e/whatis_e/tif_e/org6_e.htm 


\title{
Competitiveness of Turkey in Eurasia: A Comparison with CIS Countries
}

\author{
Hacer Simay Karaalp, Pamukkale University
}

\begin{abstract}
The main aim of this paper is to examine international competitiveness of Turkey both in world market and CIS (Commonwealth of Independent States) in comparison with Azerbaijan, Belarus, Georgia, Kazakhstan, Kyrgyz Republic, Moldova, Ukraine, Russia and to determine the value of trade between Turkey and CIS countries. The Revealed Comparative Advantage, Grubel-Lloyd (IIT) and Trade Intensity indices were calculated for sixteen commodity groups over the period 1996-2008 by using WTO data. The results suggest that Turkey is more competitive in CIS market and has comparative advantage in various products. Turkey has comparative advantage not only in agricultural products, food, manufactures, automotive products, textile and clothing as the world market but also in chemicals, pharmaceuticals, machinery-transport equipment, office-telecom equipment and telecommunications vis-à-vis CIS countries. CIS countries exhibit similar comparative advantages in the world market. CIS countries have comparative advantage particularly in fuels and mining products, agricultural products, food, iron and steel but in a decreasing trend. The IIT results indicate that while Turkey approaches intra-industry specialization in agricultural products, food and textile but also manufacture products such as iron and steel, telecommunications equipment, machinerytransport and automotive products. CIS countries' economy indicates increasing intra-industry trade in agriculture products, food manufactures, iron and steel. It is found that there is an intense relationship between Turkey and CIS countries except Belarus. Bilateral trade flow between Turkey and Azerbaijan, Kyrgyz Republic and the Georgia is extremely larger than these countries' importance in world trade.
\end{abstract}

JEL Codes: F10, F14, F13

\section{Introduction}

After 1980's many important changes occurred in the world economy with the globalization. Many countries eliminated its borders and entered to global markets. As a result, the size of the world trade in goods and services has dramatically increased with the technological progress. Moreover, financial flows became globalized in the 1990s. However globalization caused various massive changes in economic specialization, income inequality and poverty not only just among the countries but also within countries and regions. World economy has opened to new geographies since the effect of globalization. In addition to old industrial countries new countries attended to the global economy and integrated into the world market. More integrated into the world market and the higher degree of economic liberalization indicates increased growth rates, trade flows and competitiveness. During this period transition countries of the CIS were not left out of the globalization process. After the break up of the USSR in 1991, 15 independent countries established. During this period The Commonwealth of Independent States (CIS) was founded in 1991 after the dissolution of the Soviet Union with the 12 member states (Armenia, Azerbaijan, Belarus, Georgia, Kazakhstan, Kyrgyzstan, Moldova, Russia, Tajikistan, Turkmenistan, Ukraine, and Uzbekistan) which Georgia withdrawal from the CIS in 18th August 2009. Upon its foundation, members adopted the Alma-Ata Declaration, which confirmed the promise of the former republics to cooperate in various fields of external and internal policies, and announced the guarantees for implementation of the international commitments of the former Soviet Union (IONP, 2009).

The main objective of this study is to analyze international competitiveness of Turkey both in world market and CIS (Commonwealth of Independent States) market in comparison with the CIS countries and to determine whether the value and extent of trade between countries and 
trade overlap for the given products. The study covers the 1996-2008 period and sixteen product levels relying mainly on WTO's trade database. All product groups are defined according to Revision 3 of the Standard International Trade Classification (SITC) by WTO. Some countries discarded from the study due to the incomplete data (Tajikistan, Turkmenistan and Uzbekistan) and concentrated instead on Azerbaijan, Armenia, Belarus, Georgia, Kazakhstan, Kyrgyz Republic, Moldova, Tajikistan, Russia and as well as Turkey.

In order to identify the products that hold the most promise of being the leading export sectors, Turkey's comparative advantage vis-à-vis CIS countries and world Balassa's Index of Revealed Comparative Advantage (RCA), to analyze intra and inter-industry specialization of Turkey's and CIS countries' trade Grubel-Lloyd Indices and to determine the value of trade between Turkey and CIS countries Trade Intensity Index and are calculated.

The paper is divided into five main sections. The following section briefly focuses on the economic relations between Turkey and CIS. The third part describes the methodology for assessing Turkey's competitiveness with the CIS countries, Revealed Comparative Advantage (RCA), Grubel-Lloyd Index of Intra-industry Trade (IIT) and Trade Intensity Index will be given. The results of the analysis will be evaluated in the fourth section. Conclusion of the study and inferences will be assessed and interpreted in the final section.

\section{Structure of CIS Foreign Trade and Economic Relations between Turkey and CIS countries}

As a result of the Trade Development Strategy with Neighboring and Region Countries, Turkey started to look for new ways to improve its trade and create a fair trading environment in the Middle East, South East Europe, Black Sea, Caucasus and Central Asia (WTO, 2003). Since 1990's, after the break up of USSR Russia and the Turkic countries have been playing an increasing role in Turkey's external economic relations. Economic relations between Turkey and CIS have increased over the period, especially after 2003. While Turkey's total export to the CIS was $2.663 .908 .726 \$$ (11.47\% of Turkey's total export) and total import form CIS was $3.074 .152 .966 \$$ (7.05\% of Turkey's total import) in 1996. Turkey's export to CIS has increased $423 \%$ from 1996 to 2008 and reached to $13.938 .225 .914 \$$ and import has increased sharply to 42.613.878.879\$ in 2008. The share of export to the CIS countries in Turkey started to increase since 2006 and reached $10.56 \%$ in 2008. Turkey's import from CIS countries increased significantly and constituted $21.10 \%$ and $18.48 \%$ of Turkish world import in 2008 and 2009 respectively (Turkstat, 2010). Russia is the main trade partner of Turkey among the CIS countries which Turkey had 6,483,003,596\$ export and 31,364,476,862\$ import in 2008. Other biggest export and import partners of Turkey are Ukraine, Azerbaijan, Georgia and Kazakhstan. The only CIS country which Turkey has no trade relation is Armenia. The border has been closed since 1993 due to the politic reasons.

Turkish exports to the CIS countries concentrated heavily on the manufactured goods classified chiefly by material (SITC 6) and export of machinery and transport equipment (SITC 7) which has been increasing since 2000 especially to Ukraine, Russia, Uzbekistan, and Kazakhstan, Chemicals and related products (SITC 5) and Miscellaneous manufactured articles (SITC 8). Turkish import from the CIS countries concentrated heavily on manufactured goods classified chiefly by material (SITC 6), Crude materials, inedible, except fuels (SITC 2), Mineral fuels, lubricants and related materials (SITC 3), Food and live animals (SITC 0) (Turkstat, 2010).

\section{Methodology and Data}

\subsection{The Revealed Comparative Advantage Index,}

Revealed Comparative Advantage (RCA) index, as developed by Balassa (1965) compares 
the share of the export of the ith good in a given country's total exports to the share of that export good in world or a set of countries exports. The RCA index can be written as:

RCAij $=($ Xij / Xit $) /($ Xwj / Xwt $)$

where, xij and xwj represents the values of country i's exports of product $j$ and world exports of product $\mathrm{j}$ and where Xit and Xwt refer to the country's total exports and world or set of countries (CIS) total exports. A value of index greater than unity indicates that the country in question has comparative advantage in the product. If the value is less than unity implies that the country has a revealed comparative disadvantage in the product. (Fertö and Hubbard (2003), Havrila and Gunawardana (2003), Utkulu and Seymen (2004)).

\subsection{Grubel-Lloyd Index of Intra-industry Trade}

IIT index proposed by Grubel and Lloyd (1975) is based on measuring the trade overlap for a given industry (Erlat et.al., 2007). Intra-industry exchange produces extra gains from international trade over. It suggests how and to what extent the economy in question is already integrated into the world market and the degree of liberalization that the economy has already realized throughout the economic development process (Y1lmaz, 2003:13). Index is often computed using the following formulae:

$\operatorname{IIT}_{\mathrm{i}}=1-\left(\left|\mathrm{X}_{\mathrm{i}}-\mathrm{M}_{\mathrm{i}}\right| /\left(\mathrm{X}_{\mathrm{i}}+\mathrm{M}_{\mathrm{i}}\right)\right)$

where, $\mathrm{Xi}$ is export of the ith industry and Mi is import of the ith industry. IIT index has a value range between 0 and 1 or 0 and 100 in percentage form. A large value implies greater trade between firms in the same industry.

\subsection{Trade Intensity Index}

The trade intensity index $(\mathrm{T})$ is used to determine whether the value of trade between two countries is greater or smaller than would be expected on the basis of their importance in world trade (Hoekman et.al., 2003).

$\mathrm{Tij}=(\mathrm{xij} / \mathrm{Xit}) /(\mathrm{xwj} / \mathrm{Xwt})$

where, xij and xwj represents the values of country i's exports to country $j$ and of world exports to country $\mathrm{j}$ and Xit and Xwt refer to country i's total exports and total world exports respectively. A value of index more than unity indicates a bilateral trade flow that is larger than expected given the partner country's importance in world trade. An index of more than one implies an 'intense' trade relationship. If the value is less than unity indicates bilateral trade flow is smaller than expected.

\section{Empirical Results}

\subsection{Revealed Comparative Advantage}

According to the results Turkey has revealed comparative advantage in manufactures which has an increasing trend especially after 1999. RCA of Turkish manufacture products was 1.03 in 1996 and increased 1.21 in 2008. The most significant products of Turkish manufacture industry in the world trade are textiles, and clothing, iron and steel which have high revealed comparative advantage during the time period. Although the high value of RCA Turkey's advantages in textile decreased since 2001. The RCA of Turkey in clothing sector was 8.50 in 1996 which is the most competitive sector of the Turkish economy as well as textile, has decreased dramatically since 1996 and declined to 4.57 in 2008. Turkey has a significant and rising comparative advantage in automotive products since 2003 . While automotive products' RCA value was 0.37 in 1996 increased to 1.76 in 2008. Turkey has a decreasing comparative advantage in agricultural products and food in the world trade. The RCA value was 1.90 and 2.21 in 1996, decreased to 1.02 and 1.17 respectively. However Turkey has comparative disadvantage in fuels and mining products, fuels, chemicals (with an increasing trend), pharmaceuticals, machinery and transport equipment (which has an increasing trend, Turkey 
will have comparative advantage in the near future), office and telecom equipment, electronic data processing and office equipment, telecommunications equipment and integrated circuits and electronic components in the world market.

Turkey has comparative advantage in agricultural products, food, manufactures, automotive products, textile and clothing, chemicals, pharmaceuticals, machinery and transport equipment, office and telecom equipment, telecommunications equipment with respect to CIS countries. However comparative advantage of agricultural products, food, pharmaceuticals, office and telecom equipment, telecommunications equipment and clothing products have decreasing trend during the period with RCA value of 2.79, 3.95, 8.23, 2.54, 3.70, 20.50 in 1996 and decreased to $1.68,2.27,3.44,2.12,2.28,12.54$ in 2008. Products which have increasing comparative advantage vis a vis CIS countries are manufactures, chemicals, machinery and transport equipment, automotive products and textile with RCA value of 3.27, 1.37, 2.50, 2.96, 8.78 in 1996 and 3.29, 2.04, 5.86, 14.55,47.58 in 2008.

The most prosperity country among the CIS countries Russia has comparative advantage in fuels and mining products, fuels, iron and steel in a decreasing trend. The RCA of these products was 4.90, 5.23 and 3.38 in 1996 and decreased 3.33, 3.67 and 1.92 in 2008. Ukraine has a decreasing comparative advantage especially in iron and steel. Other competitive sectors are agricultural products and food with an increasing trend during the period with the RCA value of 1.79 and 2.14 in 1996 and 2.02 and 2.32 in 2008 respectively. Whereas Ukraine lost its comparative advantage and has comparative disadvantage in the fuels and mining products. Moldova has revealed comparative advantage in agricultural products and food in a decreasing trend and clothing sector with an increasing trend with RCA 1.41 in 1996 and 7.44 in 2008; textile sector also became competitive since 2005 and its RCA increased to 1.97 in 2008. Belarus has comparative advantage in a set of diverse products which are agricultural products, food, fuels and mining products, fuels, iron and steel, textiles but in a decreasing trend during the period except chemicals (RCA was 137 in 1996, 1.44 in 2008). The RCA of products decreased to $0.96,0.97,1.73,2.11,1.37$ and 1.15 in 2008 respectively. However Belarus lost its comparative advantage in clothing since 2005. Georgia has comparative advantage in agricultural products, food, fuels and mining products, iron and steel during the period in a decreasing trend with the RCA value of 2.91, 3.31, 2.33, 5.42 in 1996 and 2.19, 2.38, 1.06, 5.35 in 2008 respectively. Georgia lost its revealed comparative advantage in fuel since 1999. Kazakhstan has revealed comparative advantage in fuels and mining, fuels and iron and steel in a decreasing trend with a RCA value 3.68, 3.86, 2.26 in 2008 respectively. Moreover Kazakhstan had comparative advantage in agricultural products and food in 1996-97 but have comparative disadvantage since 1998. Fuels and mining and fuels are the most competitive products of Azerbaijan during the period but in a decreasing trend as most of the other CIS countries. Azerbaijan lost its competitiveness in agricultural products vis a vis world market since 1999 as Kazakhstan. Its RCA was 1.14 in 1996 but dropped to 0.22 in 2008. Unfortunately Kyrgyz Republic has not a stable result for its RCA in the time period but nevertheless it has comparative advantage in agricultural products, food (with a decreasing trend) fuels and mining and fuels (for the last three years) with RCA value of 2.37, 2.46, 1.83, 2.08 in 2008. Kyrgyz Republic has become comparative advantage in clothing since 2004 in the world market. Its RCA value was increased 0.54 from 1996 to 3.25 in 2008.

\subsection{Index of Intra-industry Trade}

Turkey only eight of sixteen products (agricultural products, food, manufactures, iron and steel, telecommunications equipment, textiles, machinery transport and automotive after 2001) have IIT which exceed $50 \%$ for the period as a whole. IIT showed an increasing trend throughout the period in food, manufactures, telecommunications equipment and textile. IIT showed an increase from 2001 onwards and reached the level of 0.95 and 0.86 in automotive products and machinery and transport equipment respectively. Turkey approaches intraindustry specialization in automotive products and machinery and transport equipment for the 
last eight years. Russian economy indicates the characteristics of intra-industry mainly in agricultural products, food, manufactures and chemicals. Ukraine's trade in five sectors of production creates the intra-industry type of specialization in agricultural products, food, manufactures, chemicals and Machinery and transport equipment and clothing has an ITT value that exceeds $50 \%$ for the last four years. IIT results for Moldova economy reflects intraindustry specialization only in agricultural products and food increasingly after 2000 and manufactures for 1996-2002. For Belarus ITT showed an increase in agricultural products, food, fuels and mining products, fuels (after 1999), iron and steel, integrated circuits and electronic components (after 1998), automotive products and textiles whereas a decrease in chemicals, machinery and transport equipment. Georgia approaches inter-industry specialization most of the products in the whole period except iron and steel. Value of IIT in agricultural products, food, fuels and mining products was higher for the period 1998-2005. Kazakhstan economy reflects mainly increasing intra-industry specialization in agricultural products, food throughout the period and iron and steel since 2001. The only sector which has higher IIT in Azerbaijan is agricultural products and food for the last six years. Kyrgyz Republic economy indicates intra-industry trade mainly in agricultural products, food and partly in textiles.

\subsection{Trade Intensity}

The results indicate that trade intensity between Turkey and CIS countries over the period is more than unity except Belarus. Trade intensity between Turkey and Russia has decreased throughout the period and indicate a steady decreasing trend after 2003 which was 5.10 in 1996 and dropped to 2.70 in 2008 . A steady intense trade relationship found between Turkey and Ukraine over the whole period between 1996 (3.54) and 2008 (3.11). Over the same period the values of trade intensity between Turkey and Moldova has increased from 3.13 to 4.93 . The trade intensity between Turkey and Georgia decreased from 1996 (37.36) to 2005 (15.58). An intense trade relationship found between Turkey and Kazakhstan which has been decreasing whole period from its highest level in 1997 (10.42) to 2.86 in 2008. After a dramatic decline of the value of trade intensity between Turkey and Azerbaijan from 1996 (58.08) to 2004 (16.77), trade intensity index showed a steady increase from 2005 onwards and reached 26.80 in 2008. Although trade intensity between Turkey and Kyrgyz Republic has irregular trend throughout the period, the results show an 'intense' trade relationship between them.

\section{Conclusions}

The results indicate that Turkey has strong comparative advantage in agricultural products, food, manufactures, textiles, clothing, iron and steel and automotive products especially for the last six years. However Turkey's comparative disadvantage has been decreasing in machinery and transport equipment and chemicals as the significant products for the future periods of Turkey. Therefore Turkey's export structure began to shift from labour and raw intensive goods to capital intensive goods. As it is expected Turkey is more competitive in CIS market than world market and has comparative advantage not only in agricultural products, food, manufactures, automotive products, textile and clothing as the world market but also in chemicals, pharmaceuticals, machinery and transport equipment, office and telecom equipment, telecommunications equipment. Products which have increasing comparative advantage vis a vis CIS countries are manufactures, chemicals, machinery and transport equipment, automotive products and textile. Although Turkey's comparative advantage in textile decreases in world market, its comparative advantage increase significantly with respect to CIS throughout the period.

CIS countries exhibit similar comparative advantages in the world market. In cross-country comparisons CIS countries have comparative advantage particularly in fuels and mining products, agricultural products, food, fuels, iron and steel but their dominance and positive contribution to the export performance have been decreasing or losing in the considering 
period. While Russia, Belarus, Georgia, Kazakhstan and Azerbaijan have a decreasing comparative advantage in fuels and mining products, Ukraine lost its competitiveness and Kyrgyz Republic became competitive for the last three years. Similarly Russia, Belarus, Kazakhstan and Azerbaijan have a decreasing comparative advantage in fuels and Georgia lost its comparative advantage whereas Kyrgyz Republic has been comparative advantage since 2006. Countries which have decreasing comparative advantage in iron and steel are Russia, Ukraine, Belarus, Georgia and Kazakhstan. While most of the CIS countries have decreasing comparative advantage in agricultural products such as Moldova, Belarus, Georgia or lost their competitiveness such as Kazakhstan and Azerbaijan; Kyrgyz Republic has increasing comparative advantage after 2005. Ukraine and Kyrgyz Republic has increasing comparative advantage in food sector whereas Moldova, Belarus and Georgia have decreasing comparative advantage. While Belarus lost its comparative advantage in clothing and textile, its comparative advantage increased in chemicals, on the other hand Moldova has increasing comparative advantage both in clothing and textile and Kyrgyz Republic also became competitive in clothing after 2005.

The IIT index results indicate that Turkey approaches intra-industry specialization not only raw materials (agricultural products and food) and labour intensive good textile but also capital intensive manufacture products such as iron and steel, telecommunications equipment, machinery transport and automotive products especially after 2001. ITT values reveal that Turkish economy has increasing inter-industry specialization mainly in capital intensive manufacture products and food. CIS countries' economy indicates the characteristics of increasing intra-industry trade in agriculture products and food (for Russia, Ukraine, Moldova, Belarus, Kazakhstan and Azerbaijan), manufactures (for Russia, Ukraine and Moldova) iron and steel (for Belarus, Georgia and Kazakhstan). Textile, fuels, automobile products, fuel and mining are sectors which an increase observed in their IIT index only in Belarus. Economic liberalization and integrations increase IIT level of the countries. Increasing value of ITT in manufacture goods imply the economic development and gains from the world trade.

It is found that there is an intense relationship throughout the period between Turkey and CIS countries with the exception of Belarus that implies an 'intense' trade relationship larger than the countries importance in world trade. Bilateral trade flow between Turkey and Azerbaijan, Kyrgyz Republic and the Georgia is extremely larger than these countries' importance in world trade. While trade intensity between Turkey and Russia, Ukraine, Kazakhstan decreased over the period, it is increased between Turkey and Moldova. To sum up the index results indicate that Turkey is one of the important trade partners of the CIS countries after the dissolution of the Soviet Union except Belarus.

\section{References}

- Balassa, 1965. "Trade Liberalization and 'Revealed' Comparative Advantage", The Manchester School, 33, p. 99-123.

- $\quad$ Erlat, Erlat, and Şenoğlu, 2007. "Measuring Vertical And Horizontal Intra-Industry Trade: The Case for Turkey", presented at the 6th International Conference of the Middle East Economic Association, March 14-16, 2007, Zayed University, Dubai, p.1

- $\quad$ Fertö and Hubbard, 2003. "Revealed Comparative Advantage and Competitiveness in Hungarian Agri-Food Sectors", The World Economy, 26, p. 250

- Grubel and Lloyd, 1971. "The Empirical Measurement of Intra-Industry Trade." Economic Record, 47, p.494 517.

- Havrila, and Gunawardana, 2003. "Analyzing Comparative Advantage and Competitiveness: An Application to Australia's Textile and Clothing Industries", Australian Economic Papers, 42, p.108

- Hoekman et.al., 2003). 
- Turk Stat, 2010. "Foreign Trade Statistics", http://www.TUİ.gov.tr/disticaretapp/Basla.do

- Utkulu and Seymen, 2004. "Revealed comparative advantage and competitiveness: Evidence for Turkey vis-a' -vis the EU 15", presented at the European Study Group 6th Annual Conference, Nottingham, p.8

- WTO, 2003. Trade Policy Review Turkey Report by the Government, , 19 November, p.29

- WTO, 2010. International Trade Statistics 2009,

- $\quad$ http://www.wto.org/english/res_e/statis_e/its2009_e/its09 merch trade_product e.ht $\underline{\mathrm{m}}$

- Yllmaz, 2003. “Turkey's Competitiveness in the European Union: A Comparison with Five Candidate Countries - Bulgaria, The Czech Republic, Hungary, Poland, Romania - and the EU15", Ezoneplus Working Paper, 12, p.13 


\title{
Rekabet Politikası Ekseninde Avrasya Ekonomileri
}

\author{
M. Okan Taşar, Selçuk Üniversitesi \\ Savaş Çevik, Selçuk Üniversitesi
}

\section{Abstract \\ Eurasian Economies in Context of Competition Policy}

Global economy, especially after 1990 have had a liberal approach to structural transformation and reveal the effectiveness of "liberalization" is defined as the process. Together with the global financial crisis started to be discussed this process with a more intense competition and the growing importance of the concept of expanding the size of the country in terms of a systematic policy of competition policy with all the other words are required.

Within the general framework of the so-called Eurasia in the Turkic World in this transformation to create new institutional structures and market mechanisms are working. Decades of an ongoing economic system and a complex new system into the market place, this transformation is absolutely raises a number of structural problems. Yet even liberal economies have experienced economic crises at the regional and global environment is taken into account, and ideally a fully functioning market institutions does not occur.

In this context, competition policy and sub-elements should be defined. Rationalized in terms of market economy should be set to the required qualifications. As for this purpose, work on the first section describes the conceptual background and will be shaped. In the following section, Turkic World Economies mainly as provided in the development process of market reforms and competition policies are introduced, which arise in the functioning of a market economy, or "market failures" will be discussed.

JEL Codes: L51, L43, P21

\section{Rekabet Politikası}

Rekabet; talebin ve teknolojinin özellikleriyle belirlenen siparişe etkin biçimde uyum sağlayabilmek için piyasanın güncel biçimlerini, üretim yapılarını ve organizasyon modellerini uygulama süreci olarak tanımlanabilmekte ve bu anlamıyla; mübadele şartlarını ve rakiplerin davranışlarını dikkate alan aktörler arasındaki etkileşim olarak ortaya çıkmaktadır. Ancak rekabet diğer taraftan; ekonomik aktörlerin sahip oldukları bilgi ve donanımlar bakımından aralarında mevcut uyumsuzluklarla belirginleșen aktif bir rol oynama süreci olarak nitelendirilmekte ve belirlenmiş stratejilerin bir sonucu olarak şekillendirilen sanayi yapıları ve işletme organizasyon biçimleri arasındaki farklılıklarla açıklanmaktadır (Erdut, 1998). Kısaca bağımsız ekonomik birimlerin kendi ekonomik başarıları için birbirlerini karşılıklı olarak etkilemeleri ve ekonomik birimler arasındaki yarış olarak tanımlanan rekabet; yönlendirme, kaynak dağılımını gerçekleştirme ve teknolojik gelişme fonksiyonlarını beraberinde taşımaktadır. $\mathrm{Bu}$ fonksiyonların birlikte sağlanması durumu ise; "etkin" ve "fonksiyonel rekabet" olarak nitelendirilmektedir (Erkan, 1987). Ekonomik büyüme için önemli bir terim olan ekonomik etkinlik; teknolojik gelişmeye ivme kazandırmakta ve piyasa ekonomilerinde bireysel özgürlüklerin gerçekleştirilmesine bağlanmaktadır (Möschel,1989).

Serbest piyasa ekonomilerinde rekabet sürecinin taşıdığı önem nedeniyle bu süreci kesintiye ya da zaafa uğratacak eylemlerin veya işlemlerin önlenmesi ayrı bir anlam ifade etmekte ve rekabet ortadan kaldırmaya yönelik girişimlerin hukuki düzenlemelerle engellenmesi söz konusu olmaktadır. Rekabet hukuku olarak nitelendirilen bu düzenlemeler; hükümetler tarafindan kullanılan özelleştirme, deregülasyon-regülasyon, sübvansiyon ve yabancı sermaye politikaları gibi bir dizi ölçü ve araçlarla şekillendirilerek, rekabet politikasını oluşturmaktadır. Oldukça geniş bir çerçevede, ulusal ve uluslararası gelişmelerden fazlasılyla etkilenen rekabet politikaları; rekabet sürecinin işletilmesini sağlayan bir araç olarak değil, ekonomiyi gelişen 
şartlara uyarlayan, firma ve ülke ekonomilerinin rekabet güçlerini arttıran bir politika bütünü olarak değerlendirilmelidir (Aktan ve Vural, 2004).

\subsection{Rekabet Politikasının Amacı}

Rekabet politikasının temel amacı; piyasa sisteminin fonksiyonel işlerliği için gerekli olan rekabet hukuku ile ilişkili ortamın hazırlanması, düzenlemelerin içeriğinin bireysel faaliyetlere uygulanması ve dinamik rekabet sürecinin geliştirilmesidir (Erkan, 1987). Bu noktada rekabet sürecinin geliştirilmesine ve etkinleştirilmesine yönelik olarak, rekabet politikasının iki belirgin amacı: (1) herhangi bir firmanın, istismar edebileceği büyüklük ve şartlarda bir piyasa gücünü elde etmesinin önlenmesi, (2) piyasa başarısızlıklarının en aza indirgenmesine katkı sağlayacak rekabet kurallarının oluşturulması ve uygulanması olarak ortaya çıkmaktadır (Aktan ve Vural, 2004).

Sadece rekabeti engelleyici eylemlerin ortadan kaldırılmasına yönelik uygulamaların yer aldığı bir rekabet politikası, öncelikle fonksiyonel olmaktan uzaklaşmaktadır. Rekabet politikalarının rekabet kurallarını oluşturarak üretimle ilgili yanlış bilgilendirme, gizli bilgi sızdırılması, yalan ve karalama faaliyetleri, firma logo ve markalarının kötüye kullanımı, damping uygulamaları gibi "haksız rekabet" işleyişinin engellenmesi fonksiyonel bir rekabet politikasının en önemli şartıdır. Bu noktada rekabet kuralları; rekabet edenleri korumakla birlikte ekonomik etkinliği arttıracak rekabet işleyişini gerçekleştirmek amacına da yönelik olmalidir.

Dolayısıyla rekabet politikalarının en belirgin amacı rekabeti arttırmak, piyasa ekonomisine işlerlik kazandırarak ekonomik etkinliği gerçekleştirmektir. Rekabet; üretimde kaynak dağılımında ve tüketimde etkinliği sağlamakta, yenilik ve teknolojik gelişmeleri uyarmakta, gücün tek bir elde toplanmasını önleyerek paylaşımı dengelemekte ve bu fonksiyonları nedeniyle piyasa ekonomileri açısından vazgeçilmez bir kavram haline gelmektedir (Taşar, 2008).

Rekabet politikalarının oluşturulmasında ise; yasal yetkilerle donatılmış kişi veya kurumlar, karar birimleri olarak nitelendirilmekte ancak bu karar birimlerinin doğrudan belirleyici birimler olduğu çıkar ve baskı gruplarının ise bu noktada "dolaylı belirleyici birimler" olarak tanımlandığı görülmektedir. Dolayısıyla rekabet politikasını belirleyen doğrudan belirleyen birimler; kanun koyucu veya yasama, ilgili yasaları işleten yürütme organı, rekabet hukuku mevzuatını izleyen yargı örgütü olmak üzere şekillenmekte ancak bu birimler arasında koordinasyon zaafiyetlerinin giderilmesine yönelik olarak düzenleyici kurullar (regulatory board) da yer almaktadır. Dolaylı olarak etkileyen birimler ise; çıkar ve baskı grupları olarak ortaya çıkmaktadır. Serbest piyasa ekonomilerinde bu birimler, etkinlik dereceleri açısından farklılıklar gösterseler de bütün ekonomiler açısından her biri ortak unsurlar olarak nitelendirilmektedir.

\subsection{Rekabet Politikasının Etkinliği ve Rekabetin Ölçümü}

Rekabet politikası ekonomide yer alan en güçlü aktörlerin davranışları üzerine getirilen kısıtlamaları ifade ettiği için, aktörlerin sahip oldukları ekonomik gücü, kendi çıkarlarına veya toplum zararına yönelik olarak kullanmalarını engelleyebilmektedir. Ayrımcılığın ve imtiyazların rekabet politikası çerçevesinde objektif kriterlerle ortadan kaldırılması; serbest piyasa ekonomisinin işleyişini kolaylaştırmakta ve devlet-ekonomi ilişkisini düzenleyebilmektedir. Devlet müdahalelerinin yol açtı̆̆ rantların dengeli dağılımı ve rant kollamanın yol açtığı kaynak israfının giderilmesi ve daha da önemlisi yolsuzlukların önlenmesi, rekabet politikasının objektif ve bilimsel sınırlamalarıyla mümkün olabilmektedir. Ayrıca rekabet politikasının etkinliği; yönetim anlayış ve uygulamalarında "kalite"nin yükseltilmesi anlamını taşımaktadır. Rekabet politikası; rekabet kültürünün oluşturulmasını, rekabet kültürünün kurumsallaşmasını sağlamakta, rekabet politikasının etkin bir şekilde uygulanmasını kolaylaştırırken, aynı zamanda rekabet gücü yüksek firmaların oluşturduğu bir sektörel yapıyı ortaya çıkarmaktadır (Kaldırımcı, 2003). 
Ekonomilerde rekabet politikasının etkinliğini ölçmede kullanılan yaklaşımlar genel olarak rekabet ölçümünü esas almakta ve yoğunlaşma oranı (seller concentration ratio), mal ve hizmet farklılaștırması ve giriș serbestisi olmak üzere üç göstergeyle tanımlanmaktadırlar. Yoğunlaşma oranı teknik olarak; belli sayıda büyük firmanın veya sektördeki en büyük firmaların toplam satışlar içerisindeki paylarının yüzde olarak hesaplanmasıdır. (Altay ve Aydoğuş, 2003). Ürün farklılaştırması olarak nitelendirilen ikinci ölçüt daha çok reklam kavramıla özdeșleșmekte ve firmaların reklam yoluyla ürünlerini tüketici algılamasında farklı kılmaya ve rekabeti ortadan kaldırmaya yönelik girișimleri içermektedir. Reklam harcamalarının sektörel dağılımları, herhangi bir sektörde reklam harcamalarının artması ya da bir firmanın reklam harcamalarının olağan dıșı artışı, rekabetin azalması ve rekabet ölçümleri açısından anlamlı olabilmektedir. Üçüncü ölçüt ise; ilgili sektörlere başka firmaların girişleri önünde herhangi bir yasal ya da fiili bir engelin bulunup bulunmadığıdır. Ekonomide sektörel kısıtlamaların fazlalığ rekabetin eksikliğini gösterme açısından önemli olabilmektedir.

Ekonomilerde rekabet ortamının yoğunluğunun ve etkinliğinin ölçümünde kurumsal düzeyde incelemeler de gerçekleştirilmektedir. International Institute for Management Development (IMD) rekabet ortamını ve rekabet gücünü; başta GSYİH, enflasyon, patent sayısı gibi rekabet gücünün ölçülebilir boyutlarını ortaya koyan maddi kriterler olmak üzere, eğitim düzeyi, değer sistemleri, bireylerin motivasyonları gibi maddi olmayan kriterlerden de oluşturulan sekiz ana başlıkta ve 250 alt kriterle ölçmektedir Aktan ve Vural, 2004). Benzer analiz ve ölçümlerin gerçekleştirildiği bir diğer önemli kurumsal yapı ise "World Economic Forum" ve yayınlamış olduğu "The Global Competitiveness Report" başlıklı yıllık raporlardır. Cenevre merkezli raporların hazırlanmasında farklı ülkeler ve ülke gruplarının ekonomi ve iş dünyasını oluşturan mikro ve makro ölçekli birimlerinin beklentileri ve yorumları kullanılarak bir endeks haline dönüştürülmesi esas alınmaktadır. Küresel Rekabet Gücü Endeksi (Global Competitiveness Index GCI) olarak ifade edilen ölçümler rekabet kavramının içeriğini oluşturan unsurlar üzerine şekillendirilmektedir.

Ekonomi literatürü, "ulusların zenginliği”ni belirleyen faktörleri özellikle Neo-Klasik yaklaşımlarla anlamaya çalışmakta ve oldukça karmaşık bir kavram olan rekabeti; sermaye, altyapı, eğitim, teknoloji, makro ekonomik istikrar, iyi yönetişim, hukuk, şeffaflık, kurumsallaşma, firma stratejileri, talep ve arz özellikleri ve piyasa büyüklüğü gibi çok sayıda faktörle tanımlamaktadır. 2009-2010 Küresel Rekabet Raporu rekabet kavramını; (1) Kurumsallaşma, (2) Altyapı, (3) Makro ekonomik istikrar, (4) Sağlık ve Zorunlu eğitim, (5) nitelikli eğitim, (6) Mal Piyasalarının Etkinliği, (7) İşgücü piyasalarının etkinliği, (8) Finans piyasalarının çeşitliliği, (9) Teknoloji birikimi ve kullanımı, (10) Piyasaların büyüklüğü ve genişliği, (11) İş çeşitliliğii, (12) Yenilikçi girişimler olmak üzere 12 esas faktör üzerine kurgulamaktadır. $\mathrm{Bu}$ faktörlerden kurumsal, altyap1, makro istikrar ve sağlık-eğitim gibi unsurlar ana unsurlar olarak tanımlanmakta, etkinliğe dayalı olan unsurlar ise; nitelikli eğitim, verimli ya da etkin mal, emek ve finansal piyasalar, teknoloji, piyasa büyüklüğü gibi unsurlardan oluşmaktadır. Üçüncü grup unsurlar yenilikçi yaklaşımlar, iş, mal ve hizmet çeşitliliği olarak gruplandırılmaktadır (Global Competitiveness Report, 2010).

\section{Avrasya Ekonomilerinin Görünümü}

Küresel Rekabet Raporu 2009-2010; 133 ülkede piyasa ekonomisi işleyişinin temel unsurları olarak nitelendirilen ve ülkelerin rekabet güçlerinin ölçümü açısından bir gösterge olarak oluşturulan 12 ana faktörde ortaya çıkan değişikliklerin, olumlu ya da olumsuz değerlendirilmesi ve puanlanmasıyla ortaya çıkmaktadır. Ülkeler Gayrı Safi Yurtiçi Hasılalarına göre 1. Așama, 2. Așama ve 3. Așama ülkeleri olarak tanımlanmakta, bir grup ülke ise geçis ülkeleri olarak ortaya konulmaktadır. GSYH'sı 2000 \$'ın altındaki ülkeler 1. Așama ülkesi olarak gruplandırılmakta ve Avrasya ekonomilerinden Kırgızistan ve Tacikistan bu grupta yer almaktadırlar. Azerbaycan ve Kazakistan gibi ülkeler 2000-3000 \$ aralığında yer almakta ve 2. Aşamaya geçiş ülkeleri olarak gösterilmektedirler. Türk Dünyasının 9000-17000 
\$ GSYH aralığındaki tek ekonomisi ise Türkiye'dir ve 3. Aşamaya geçiş ekonomisi olarak nitelendirilmektedir.

\begin{tabular}{|c|c|c|c|c|c|c|}
\hline \multirow[t]{2}{*}{$\begin{array}{l}\text { Avrasya } \\
\text { Ülkeleri }\end{array}$} & \multicolumn{2}{|c|}{$\begin{array}{c}\text { Temel } \\
\text { Unsurlar }\end{array}$} & $\begin{array}{l}\text { Geliştirilmiş } \\
\text { Dayalı }\end{array}$ & $\begin{array}{l}\text { Etkinliğe } \\
\text { Unsurlar }\end{array}$ & Yenilikçi & Unsurlar \\
\hline & Sira & Skor & Sira & Skor & Sira & Skor \\
\hline Azerbaycan & 50 & 4.63 & 71 & 4.03 & 56 & 3.71 \\
\hline Kazakistan & 74 & 4.27 & 69 & 4.04 & 78 & 3.43 \\
\hline Kırgızistan & 126 & 3.40 & 111 & 3.36 & 128 & 2.80 \\
\hline Tacikistan & 116 & 3.51 & 123 & 3.22 & 109 & 3.06 \\
\hline Türkiye & 69 & 4.34 & 54 & 4.16 & 58 & 3.70 \\
\hline
\end{tabular}

Tablo 1. Avrasya Ekonomilerinin 2009-2010 Küresel Rekabet Endeksi İçerisindeki Siralama ve Skorları Kaynak: The Global Competitiveness Report 2009-2010'dan derlenmiștir.

12 esas unsur üzerine şekillendirilen Küresel Rekabet Endeksi (GCI) ana hatlarıyla: temel (basic) unsurlar, geliştirmiş etkinliğe yönelik (efficiency) unsurlar ve yeniliğe dayalı (innovation) unsurlar olmak üzere ifade edilmektedir.

\subsection{Azerbaycan}

Küresel Rekabet Raporu 2009-2010'a göre Azerbaycan 4.3'lük bir skorla 133 ülke arasında 51. sırada yer almaktadır. Bir önceki dönem ölçümü esas alındığında Azerbaycan; 4.1 skor ve 69. sıradan önemli bir gelişme göstermekte ve piyasa rekabeti açısından belirli bir mesafe almış olduğu görülebilmektedir. Ancak ülkenin en önemli sorunları arasında yolsuzluk olgusu gösterilmekte, yoğun bürokrasi, vergisel düzenlemeler, altyapı eşitsizlikleri ve verimsiz devlet bürokrasisi önemli bir yer tutmaktadır (Global Competitiveness Report, 2010).

Azerbaycan'ın idari regülasyonlara yönelik algılaması rekabet açısından avantaj oluştururken, hükümet politikalarının şeffaflığı ve kamu fonlarında oluşan sapmalar dikkat çekici olumsuzluklar olarak ortaya çıkmaktadır. Rekabet hukuku ve anti-tröst uygulamaların etkinliği açısından Azerbaycan ekonomisi 116. Sırada yer almakta ve genel ortalamadan büyük ölçüde sapma göstermektedir. Aynı şekilde Küresel Kriz açısından önem finansal güvenliğe yönelik regülasyonlarda da yetersiz kalındığı görülmektedir (Global Competitiveness Report, 2010). Küresel finansal krizin uluslararası kredi kaynaklarına erişimi zorlaştırması, gelişmiş ekonomilerde azalan talebin piyasaları daraltması ve özellikle enerji piyasalarında yaşanan istikrarsızlıklar, gerek Azerbaycan gerek diğer Avrasya ekonomileri açısından olumsuz makro ekonomik sonuçları beraberinde getirmektedir (Taşar, 2009).

\subsection{Kazakistan}

Kazakistan, 2008-2009 Küresel rekabet indeksinde 4.1 skorla 67. sırada yer alırken 20092010 indeksinde 133 ülke içerisinde aynı skorla aynı sırada yer almaktadır. Azerbaycan gibi 2. Aşama geçiş ülkesi olarak nitelendirilen Kazakistan; makro ekonomik istikrar açısından olumlu bir süreç izlerken, kurumsal gelişim ve finansal piyasalar anlamında rekabet gücünü tam olarak yerleştirememiştir. Avrasya ekonomilerinin genelinde gözlemlenen yolsuzluk algılaması Kazakistan açısından da en önemli sorun olarak değerlendirilmektedir. Enflasyon önemli bir makro ekonomik istikrarsızlık kaynağı olarak görülmekte ve Kazakistan ekonomisine yönelik beklentilerde ikinci önemli sorun olarak nitelendirilmektedir. Kurumsallaşma ve altyap1 başlıklarında rekabet açısından avantaj sağlayan faktörlerin bütününde olumlu bir görünüm sergileyemeyen Kazakistan, makro ekonomik istikrar başlığında sadece kamu borçları ve bütçe açıkları noktasında rekabet gücü açısından avantajlı olarak algılanmaktadır (Global Competitiveness Report, 2010).

Genel kamu borcunun GSMH'ya oranı dikkate alındığında Kazakistan en düşük değere sahip ülke olarak ortaya çıkmakta, Kırgızistan ve Tacikistan gibi ülkeler ise kamu borç stoku riskli olan ekonomiler olarak nitelendirilebilmektedir. Kazakistan'da kamu borcunun vergi 
gelirlerine oranı 1lımlı bir düzeyde seyrederken, Kırgızistan'da kamu borç stokunun vergi gelirlerine oranı 3 kata yakın, bir başka Avrasya ekonomisi olan Tacikistan'da ise 3 katından fazla seyretmektedir (Çevik, 2010).

\subsection{Kırgızistan ve Tacikistan}

Türk Dünyası ekonomileri içerisinde Tacikistan'la birlikte Küresel Rekabet endeksinde en düşük skorlara sahip olan Kırgızistan genel sıralamada istikrarlı olarak 123. sırada yer almaktadır. Rekabet açısından zayıf altyapı, makro ekonomik istikrarsızlık ve daha da önemlisi siyasi istikrarsızlığın beraberinde taşıdığı toplumsal gerilimler, Kırgızistan için tehlikeli boyutlara tırmanmaktadır. Küresel Rekabet Raporu 2009-2010'a göre GSYİH's1 2000\$'1n altında olduğu için Tacikistan gibi 1. Aşama ülkesi olarak nitelendirilen Kırgızistan'ın en önemli sorun algılamasının ilk sırasında yolsuzluk yer alırken ikinci en önemli sorun olarak politik istikrarsızlık gösterilmektedir. Diğer 1. Aşama ülkesi Tacikistan'da ise; en önemli makro ekonomik sorun finansal kaynaklara erişim olarak değerlendirilmekte ve diğer Avrasya ekonomilerinden daha yoğun bir şekilde vergi oranlarına yönelik olumsuz algılamalar gözlenmektedir. Yolsuzluk algılaması ise; tüm Avrasya ekonomilerinin ortak sorunu olarak Tacikistan'da da varlığını ortaya koymaktadır (Global Competitiveness Report, 2010).

Tacikistan altyapı olarak endekste yer alan ülkeler arasında en düşük skorlara sahip olan ekonomilerden birisi olarak görülmekte, makro ekonomik istikrar başlığının en önemli unsurlarından birisi olan bütçe açıklarının rekabet gücü üzerinde olumsuz etkide bulunduğu ileri sürülmektedir (Global Competitiveness Report, 2010).

\subsection{Türkiye}

Son olarak Türkiye 131 ülke için oluşturulan 2007-2008 raporunda 4.2'lik bir skorla 53 . sırada yer alırken, 134 ülkeli 2008-2009 raporunda 4.1'lik skorla 63. sıraya gerilemiş, 20092010 Raporunda ise; 4.2'lik bir skorla 61. sırada gösterilmiştir. Skor açısından istikrarlı bir çizgi izlenmekte ancak sıralamada özellikle 2007'ye göre olumsuz bir değişiklik gözlenmektedir (Global Competitiveness Report, 2010). Türkiye açısından önem arz eden Avrupa Birliği (AB) üyelik hedefi esas alındığında da, 1996-2005 döneminde özellikle son geniş̧lemeyle üye olan ülkelerin bile gerisinde kaldığı açık bir şekilde gözlenmektedir (TÜSİAD, 2006). Bu durum; Türkiye açısından rekabet sürecinin işlemesinde ve rekabet gücünün geliştirilmesinde çok fazla bir değişiklik olmadığı halde endekste yer alan diğer ülkelerin piyasa ekonomisi algılamasının hızla geliştiğini göstermesi açısından önem arz etmekte, Türkiye'nin bu gelişim çizgisinin uzağında kaldığının işaretlerini vermektedir. En önemli ekonomik sorun diğer ülkelerden oldukça farklı bir şekilde vergisel regülasyonlar ve vergi oranları olarak kabul edilmektedir. Türk Dünyası ekonomileri içerisinde 3. Aşamaya geçiş ülkesi olarak nitelendirilen tek ülke olan Türkiye'nin sorun algılamasında; etkin olmayan kamu bürokrasisi ve tek parti iktidarına rağmen politik istikrarsızlığın 3. ve 4. sırada gösterilmesi oldukça anlamlı ve önemlidir. Aynı şekilde Avrasya ülkelerinin ortak sorunu olarak nitelendirilen yolsuzluk olgusunun Türkiye açısından son sıralara gerilemesi ise önem taşımaktadır (Global Competitiveness Report, 2010).

\section{SONUÇ}

2009-2010 Küresel Rekabet Endeksinde Türkiye açısından finansal piyasalar ve anti-trust politikalarla rekabet hukuku, rekabet için avantaj sağlayacak şekilde olumlu bir gelişme göstermektedir. Etkin anti-trust politikalar başlığında Türkiye 45. sırada yer alırken, finansal piyasa çeşitliliğinde 40. Sırada gösterilmektedir. Bu noktada; 2001 Krizi sonrasında, Güçlü Ekonomiye Geçiş Programı çerçevesinde gerçekleştirilen ekonomi politikaları ve özellikle bankacılık sektörüne yönelik regülasyonların, Küresel Finansal Kriz sürecinde sağladığ 1 olumlu etki ya da katkı Türkiye açısından net bir şekilde ortaya çıkmaktadır. Ancak diğer Avrasya ekonomileri açısından rekabet işleyişinin geliştiğini ileri sürebilmek fazla mümkün 
görünmediği gibi, rekabet gücünün uluslararası sıralamalar açısından umut verici olmadığı özellikle serbest piyasa ekonomisine geçiş açısından dezavantajyarattığı ortaya çıkmaktadır. Özellikle Türkiye hariç yolsuzluk olgusunun en önemli sorun olarak algılanması geleceğe yönelik iyimser beklentileri olumsuz etkilemektedir.

\section{KAYNAKÇA}

- Aktan, Coşkun Can ve İstiklal Y. Vural. 2004. Yeni Ekonomi ve Yeni Rekabet, TISK Yayın No:253, Ankara, s. 103.

- Altay Oğuzhan ve Osman Aydoğuş. 2003. "Türk Bankacılık Sektöründe Piyasa Yapısı ve Rekabet”, Rekabet Düzenlemeler ve Politikalar Kongresi, Rekabet Kurumu Yayın No. 0162, Ankara, s.152.

- Çevik, Savaş. 2010. "Geçiş Ekonomilerinde Kamu Maliyesi ve Mali Sistem Reformları”, Avrasya Etüdleri, TiKA, Sayı: 37, Ankara, s. 90.

- Erdut, Zeki. 1998. Rekabetin İşgücü Piyasasına Etkisi, Türk Ağır Sanayi ve Hizmet Sektörü Kamu İşverenleri Sendikası Yayını, Ankara, s.1.

- Erkan, Hüsnü. 1987. Sosyal Piyasa Ekonomisi, Konrad Adenaeur Vakfı Türkiye Temsilciliği Yayını, İzmir, s.38.

- Kaldırımcı, Nurettin. 2003. "Rekabet ve Yönetim İlişkisi”, Rekabet Düzenlemeler ve Politikalar Kongresi, Rekabet Kurumu Yayın No. 0162, Ankara, s.152.

- Möschel, Wernhard. 1989. "Competition Policy from an Ordo point of View", German Neo-Liberals and the Social Market Economy, New York, s. 146.

- Taşar, M. Okan. 2008. Piyasa Ekonomilerinde 3R: Rekabet, Regülasyon ve Reform, Sayram Yayınları, Konya, s.38.

- Taşar, M. Okan. 2009. "Finansal Regülasyonlar ve Küresel Kriz Sürecinde Türk Dünyası Bankacılık Sistemlerinin Yeniden Yapılandırılması", Avrasya Etüdleri, TIKA, Sayı: 36, Ankara, s. 33.

- TÜSİAD Sabancı Üniversitesi Rekabet Forumu. 2006. Türkiye Küresel Rekabet Raporu, İstanbul, s.33.

- World Economic Forum 2010. The Global Competitiveness Report 2009-2010, Geneva, ss.8-14-12-78-90-187-279. 


\title{
Türk Cumhuriyetlerinin Ulusal Güçlerinin Entegrasyon İçi ve Küresel Düzeyde Pazarlanması
}

\author{
Muhittin Karabulut, Beykent Üniversitesi \\ Tuğba Karabulut, İstanbul Ticaret Üniversitesi
}

\section{Abstract \\ Marketing of the National Power of the Turkic Republics in the Integration and Global Levels}

The purpose of the paper: The purpose of this paper is to enhance the power and its sustainability of the synergies within the Turkic Republics (TRs7) including Turkey and to develop the integration of marketing activities within the near and far a competitive global environment with the FTA (the free trade area). With this in mind, the content of this paper would be as follows: The current states of physical, human, economic/financial, technical information systems of Turkic Republics that make up the national factors are examined. Likewise, the level of attractiveness of the global environment among the Turkic Republics is analyzed. As levels of power and attractiveness of this opportunity and threat assessments are possible, the Turkic Republics in search of integration such as the FTA, the environment and global approach focuses on the possible marketing strategies.

JEL Code: M31

\section{Türk Cumhuriyetleri ve Olası Serbest Ticaret Bölgesi}

$\mathrm{Bu}$ çalışmamızda, eski ve yeni Türk Cumhuriyetleri’nin serbest bir ekonomik bölge oluşturabilme ve ulusal kaynaklarını kendi aralarında ve küresel pazarda rekabetçi olarak pazarlayarak ulusal büyüme, kalkınma ve toplumsal refahlarını birlikte arttırabilme potansiyeli değerlendirilmeye çalışılmaktadır. Bu konuda, yeni Türk Cumhuriyetleri'nin kapitalizm sürecini öğrenme aşamasında olmaları, yer altı ve yer üstü kaynaklarının genelde mevcut ve potansiyeli yüksek zenginliği, özel sektörün ve satın alma gücünün zayıflığı ve fiziki/coğrafi pazara açılma engellerinin bulunması vb. durumlar, bu ülkelerin tek başlarına küresel pazarda faktör koşullarını kendi lehlerine dönüştürme konusunda nispeten yetersiz kalmalarının toplumsal refahı geciktirme etkisi yarattığı söylenebilir. Fazla uzun olmasa da Türkiye'nin, kapitalizmi öğrenme sürecine daha önce başlamış ve muhtelif deneyimler yaşamış olması, yeni Türk Cumhuriyetleri için bir "test pazarı" oluşturarak öğrenme süreçleri aşamalarını kısaltabilir.

Bu çalışmada, Türk Cumhuriyetleri'nin ulusal mevcut ve potansiyel kaynaklarının rekabetçi üstünlüğünü sağlayarak toplumsal refahlarını arttırabilmeleri için küresel rekabetçi bir konuma ve "ürüne" dönüşebilmeleri beklenir. Bu ülkelerin serbest bir ticaret bölgesi oluşturmaları ve bu entegre ulusal güçlerinin yeniden konumlandırılması ile oluşturacakları yeni imajla kendi aralarında, çevre ve küresel pazarda, yaratılabilecek sinerjinin orijin etkisiyle mevcut ve yeni ürün ve markalarını rekabetçi bir konuma eriştirerek pazarlamaları gereği üzerinde durulmaktadır.

Sovyetler Birliği’nin dağılmasından sonra bağımsızlıklarını kazanan (1990-1991) yeni Türk devletlerinin kendi aralarında ve Türkiye ile duygusal yaklaşımlar ve ikili bazı anlaşmalar dışında, örgütsel bir bütünlük sergileyemedikleri söylenebilir. Böylesi bir bütünlükten yoksunluk, Türk Cumhuriyetleri (TC7: Azerbaycan, Kazakistan, Kırgızistan, Özbekistan, Tacikistan, Türkiye ve Türkmenistan) için kendi aralarında ve küresel ölçekte bir sinerji kaybı ve geciken refah değeri olarak nitelendirilebilir. Nitekim birçok devlet, ekonomik (NAFTA gibi) veya ekonomik ve siyasi birlik (Avrupa Birliği=EC gibi) temelinde birleşmeye çalışmaktadır. Bu konuda, yeni Türk Cumhuriyetleri ve İslam ülkeleri ekonomik veya siyasi bir 
güç oluşturabilecek sistematik bir bütünlük sergileyememektedirler. Buna karşın, petrol üreticisi ülkelerle gelişen (emerging) ülkelerin dünya GSMH içindeki payı giderek artarken $A B D$ ve $A B$ 'nin payı trend görünümlü olarak azalmaktadır (Lane and Milesi-Ferretti, 2007). $\mathrm{Bu}$ durum, küresel ölçekte bir gelir kayması, klasik üretim ve tüketim merkezlerinin giderek sorunlu hale dönüșeceği anlamına da gelir. Bu trendin bir diğer anlamı da TC7'nin Avrupa ve ABD pazarının daralması, doğusundaki rekabetçi güçlerin ise artması beklenebilir.

TC7'nin ulusal faktörlerini kendi aralarında, yakın çevre ülkelerde ve küresel pazarda rekabetçi değerlerle pazarlayabilmeleri için birlikte bir güç oluşturmaları gereği varsayımından hareketle iki varsayımda bulunabiliriz:

a. Türk Cumhuriyetleri (TC7) kendi aralarında bir serbest ticaret bölgesi/birliği (STB) oluşturamazlar.

b. Türk Cumhuriyetleri kendi aralarında bir serbest ticaret birliği/STB oluşturabilirler.

TC7'nin bir STB oluşturamazlar varsayımını düşündürebilecek hususlar şu şekilde belirtilebilir:

a. Başarısız Sovyetler Birliği deneyimi ve bunun geride bıraktığı yoksunluklar,

b. Fiziki/coğrafi engeller (tam bir sürdürülebilir birlik için Türkiye ile veya Türkiyesiz en büyük engel),

c. Birleşik Devletler Topluluğu/BDT, bazı politik ve askeri işbirlikleri, Türkiye'nin AB üyelik girişimi ve gümrük birliği (olası tepkiler),

d. Gelişmiş ve nispeten kaynak farklılıkları, hatalı kısa ve uzun dönemli fayda- maliyet analizleri,

e. Serbest ticari bölge oluşturma konusunda misyon, vizyon, amaç ve motivasyon noksanlıkları,

f. Kendi ve bazı komşularıyla bazı iç ve sosyo-politik sorunları,

g. STB misyonu ve vizyonunu uygulamaya aktaracak entegre önderlik noksanlığı,

h. Çevresel ekonomi-politik engeller vb.

TC7'nin bir serbest ticaret birliği/STB oluşturabilirler alternatif varsayımını geçerli kılabilecek hususlar ise, şu şekilde belirtilebilir:

a. Türk Cumhuriyetleri'nin potansiyel gücü, sinerji kayıpları yaşamaktadır (Türkmenistan gazı örneği) ve kaynakları, kendi aralarında, çevre ülkelerde ve küresel ölçekte yeterince değerlendirilememektedir,

b. Kaynaklarının ve potansiyel güçlerinin rekabetçi olarak değerlendirilememesi ilgili ülkeler ve vatandaşları için refah ve yaşam kalitesi kaybı yaratabilmektedir,

c. STB'nin gerçekleştirilmesi halinde oluşacak global güç, iç ve çevresel fiziki engellerle politik çevresel engellerin aşılmasını kolaylaştırabilir,

d. Bugün TC7'nin bir kaçı birbirlerinin lehçelerini anlamasalar da ortak bir tarihi geçmiş, uygun sosyo-kültürel birliktelik ve benzerliklerle coğrafi yakınlık bulunmaktadır. Uluslararası pazarlamada, bu kültürel benzerlik ve yakınlık başlı başına önemli bir etkendir. Nitekim ekonomik olgular, sadece arz ve talebin değil kültürel bir evrim sürecinin de sonucudur (Goldschmidt, 2006).

e. STB, TC7'lerin mevcut ikili ilişkilerini daha da anlamlı hale getirebilir ve diğer bölgesel birilikler karşısında pazarlık/rekabet gücünü arttırabilir: Böylesi bir birlikle $A B$, Türkiye üzerinden Çin sınırına erişebileceği gibi, TC7, Türkiye üzerinden $A B$ ve diğer pazarlara erişebilir.

f. STB halinde, TC7'nin gelişmiş farklılıklarını önleyici finansal ve ekonomik dar boğazların aşılmasında iyileştirici programlar geliştirip yürürlüğe koyabilir. Esasen bu, böylesi bir birlikteliğin çalışabilmesi için de gereklidir. Nitekim AB, Doğu Avrupa Ülkeleriyle $\mathrm{AB}$ arasındaki gelişmişlik farklarını gidermek için, etkin işbirliği, 
ekonomik ve sosyal hayatta reform, -aşamalı-serbest rekabet, yapısal fonlar, modern teknoloji transferi vb. içeriğe sahip böylesi bir programı yürürlüğe koymuştur (Zaman, 2008).

g. Halkın yaşam kalitesi ve ülkelerin refah düzeyini arttırmak ve kaynaklarının sömürülmesini veya atıl durumda kalmasını önleme güdüsü ve kültürel birliktelik, STB misyonu ve vizyonunu uygulamaya aktaracak entegre önderliğe rehberlik edebilecek ve iç sorunların aşılmasını da kolaylaştırabilecek önemli bir etkendir (*).

TC7 için STB, bu ülkelerin üretim faktör ve kaynaklarına rekabetçi işlerlik kazandırabilmek ve bunun sürdürülebilirliğini sağlamak açısından elzem olduğu söylenebilir. Böylesi bir STB, bu ülke kaynak ve faktörlerine akışkanlık sağlayarak, ürün ve markalarına yönelik orijin özellikli yeni bir güven kimliği, imaj ve rekabetçi bir konum kazandırabilecektir. TC7'nin Porter'ın ulusal rekabetçi üstünlük faktörleri (Porter, 1990) arasında saydığı faktör şartlarından yer altı ve üstü kaynakları, kısa ve uzun vadede, genelde, zengin bir görünüm çizmesine rağmen, bunları harekete geçirecek diğer bir üstünlük fakörü olan destek endüstriler yeterli olmadığı gibi, gelirden kaynaklanan iç talep şartları da nispeten zayıftır. Öte yandan diğer bir faktör şart olarak nitelendirilebilecek firma stratejileri, örgütsel yapı ve rekabetçi güç, genelde kapitalizm sürecine yeni geçilmesi nedeniyle nispeten zayıftır. Firmaları üstün başarıya eriştiren faktörler arasında sayılabilecek (McKinsey'in 7-S modeli) strateji, sistem, örgütsel yapı, insan kaynakları ve bunların küresel rekabetçi hünerleri ve paylaşılan örgütsel kültürel değerler (Peters and Waterman,1984) itibariyle de nispeten yetersizlikler olduğu açıktır. Öte yandan, TC7’lerin, devlet ve diğer kurumların ulusal üstünlüğü firmalar eliyle arttırıcı destekleyici tutumlarının da nispeten kısıtlı olduğu söylenebilir.

Avrupa ekonomik topluluğu/AET, NAFTA, ASEAN ve Gulf İşbirliği Konseyi vb. örneklerinde de görüldüğ̈̈ gibi, güçlü bir misyon, vizyon ile politik motivasyonla uzun vadeli fayda ve maliyet analizleriyle ortak refah ve yaşam kalitesini arttırıcı bölgesel serbest ticaret anlaşmalarının uygun bir süreç izlenmesi halinde başarılı oldukları görülmektedir. $\mathrm{Bu}$ süreç amaç, gümrük/tarifeler, ürünsel kaynakların ve yatırım/ortaklık sermaye hareketlerinin mobilitesi, özel ilgi, kendi para politikalarına özen, orijin esaslı ekonomik politikaların koordinasyonu, birliğin entegrasyon düzeyi, gümrük birliğine (Gulf, gümrük birliği çalışmalarına 21 -2002'de-, ortak pazar çalışmalarına 26 yıl sonra erişebilmiştir; ancak günümüzde bu sürenin daha kısa olması beklenir. Nitekim, 50 yıldan beri $\mathrm{AB}$ kapısında bekletilen Türkiye değil, 1991'den sonra bağımsızlığına kavuşan ve daha elverişsiz koşullarda olan Doğu Avrupa ülkeleri AB'ye alınmıştır.) doğru mevcut ve gelecek ticari faaliyetlerin entegre koordinasyonu biçiminde gerçekleştirilebilir. Sonuçta OECD performans göstergeleri değerlendirmelerine de konu olduğu gibi, ilk aşamada şu hususlar gerçekleştirilebilir: İç ve dış ticaretin arttırılması, kendi aralarında ve diğer yabancı sermaye akışının artması, ortak yatırımların gerçekleştirilmesi ve yeni-teknolojilerin artması. Gulf'de bu göstergelerde başarı sağlanmıştır (Hossain and Naser, 2008). Daha ziyade coğrafi yakınlığı olan devletlerin serbest ticaret ve gümrük birlikleri oluşturduğu belirtilirken, AB'nin Güney Kore ile serbest ticaret birliği oluşturmak üzere olduğu da görülmektedir(**).

\section{Türk Cumhiriyetleri ve Serbest Ticaret Birliği}

Türk Cumhuriyetleri/TC7'nin, küresel ölçekte hak etmeleri gereken refah düzeyine erişebilmeleri için, mevcut ve potansiyel ekonomik güçlerinin kendi aralarında ve küresel pazarlarda rekabetçi değerde akışkan hale dönüştürülmesi gerekir. Yeni Türk devletlerinin lojistik sorunları, başlangıçtaki mali ve yönetimsel deneyim yetersizlikleri, kendi aralarındaki ekonomik ilişkilerde ve küresel pazarlarda etkinliklerini sınırlayabilmektedir.

Türk cumhuriyetleri, genelde, birincil veya ikincil komşularının fiziki/coğrafi ve politik kıskacında bulunmaktadır. Bu kelepçenin ekonomi-politik amaçlarla sıkılması veya önemli bir dış ticaret ortağının krize girmesi haline, birçok örnekte görüldüğü gibi (Türkmenistan-Rusya, Azerbaycan-Ermenistan/Rusya, Rusya krizinde Kazakistan ekonomisindeki daralma vb.), ilgili 
ülkede, "fırtınalar" yaratılabilmektedir. Türkiye, bu kelepçenin kırılmasında, çok önemli bir rol oynayabilme potansiyeline sahiptir.

TC7'nin oluşturabilecekleri bir serbest ticaret bölgesi/birliği (STB), bir tür ekonomik alt yap1 entegrasyonu /"piggyback" etkisiyle yaratılabilecek sinerjiyle bu ülkelerin kaynaklarının küresel rekabetçi değerde akışkanlığı sağlanarak refah düzeyleri arttırılabilir. TC7- STB oluşumu, bu ülkelerin tıpkı bir ürün/marka gibi, imaj ve "marka" değerini rekabetçi olarak arttırabilecektir. Bu bakımdan, TC7'nin rekabetçi toplam faktör yetkinliği iyileştirilerek kendi iç pazarında ve küresel alanda rekabetçi değeri iyileştirilebilmelidir. STB gerçekleştirilebilirse, bu ülkelerin küresel pazarda "ütülmeleri" (kaybedenlerden olma durumları) ve sadece "petrol, gaz, inşaat ve maden" /PGiM olarak görülmeleri de nispeten önlenebilecektir. Ülkelerin küresel rekabetçi değerde kaynaklarının doğru ve entegre bir biçimde harekete geçirilebilmesi için STB etkin örgütsel işleyişi yanında, asıl unsurun rekabetçi teknolojilere, mikro ölçekte özendirici uygun girişimci yatırımlara, bunların düzeyine, verimliliğine (Economidio, et al., 2006), işbirliklerine, uygun pazarlama kanalı ve faaliyetlerine ihtiyaç olabilecektir. Mikro ölçekli girişimlerde doğru girişim, ortaklık ve stratejik işbirlikleriyle bunların etkin yönetimi birlikte başarılabilmelidir. (Karabulut ve Karabulut, 2010). Makro açıdan doğru oluşturulan ve etkin işletilen entegre büyüklüğün/STB'in daha iyi olabilmesi için mikro ölçekte küçüklerin de (girişimcilerin ve firmaların) doğru ve etkin çalışabilmesi gerekir.

Entegrasyon teorileri açısından konu irdelenecek olursa, ülkeler arasında organik ve yapısal entegrasyon, ekonomik büyüme faktörlerinin sinerjik entegrasyonuyla kısa ve uzun dönemde büyümenin, ekonomik yararın (üretim ve refahın) ve ülke refahının arttığı görülmektedir (Theodoropoulos and Vojinovic, 2005). Bilindiği gibi, uluslar arası ekonomik eksenli entegrasyonları aşamaları serbest ticaret bölgesi, gümrük birliği, ortak pazar ve ekonomik birlik (Kegan and Green, 2008) ve nihayet siyasi birlik sürecini izleyebilmektedir. AB (Avrupa Birliği), bunu siyasi birlik aşamasına da aktarmıştır. Azerbaycan'ın AB'ye ve DTÖ (Dünya Ticaret Örgütüne) kabul için yaptığı girişimlerde ilk aşamada entelektüel mülkiyet/kanunlar, uluslar arası ticaret/standardizasyon/teknik sistemleri, kalite sertifikasyon uyumu ve prosedürleri ve yatırım rejimi, vergi vb düzenleme istekleri ve özellikle DTÖ ile muhtelif çalışma gurupları görüşmeleri, soru ve cevap listeleriyle karşılaşmış ve on yıllık bir süreçte (1996-2006) ABD destekli çalışmalara rağmen, Azerbaycan'ın ekonomik ve politikada yeni bir anlayış düzlemine geçmesi gerektiği sonucuna varılmıştır (Kavass, 2008).

Türk Cumhuriyetlerinin ulusal güç faktörlerini oluşturan faktör koşullarının küresel ölçekte pazarlanabilmesi için bunların öncelikle kendi aralarında örgütlü ekonomik bir birliğe dönüşerek bir güç oluşturmaları, bu gücün yeniden konumlandırılması, üretkenliklerini teknolojik /ARGE esaslı olarak yenilenmeleri, STB faktörlerine ve ürünlerine dönük orijin imajı kuvvetlendirilebilmelidir. Yeniden konumlandırılmış bu birleşik ekonominin kendi içinde ürün ve yatırım akışkanlığının sağlanması ve çıktıların küresel alana rekabetçi değerlerle sunumu gerçekleştirilerek ülke refahlarının ve vatandaşlarının yaşam kalitesinin arttırılması beklenir. Böylesi yeni bir ekonomik gücün oluşturulabilmesi için ülkeler arasında tarihi bir geçmişin ve nispeten uygun bir sosyo-kültürel atmosferin olduğu ve bu atmosferi değerlendirecek vizyoner politik önderlere, demokratik kolektif önderliklere ve ortak bir iradeye ihtiyaç olduğu söylenebilir. Böylesi bir iradenin ortaya konulması halinde, her ülke, birer ekonomik stratejik birim olarak ele alınıp ülkeler kaynakları ve üretkenliklerinin "portföy" tarzı genel bir yönlendirme ve iç ve küresel pazarlama yaklaşımı sergilenebilir.

STB ile TC7'nin küresel ölçekte yeniden konumlandırılmaları sağlanarak, yetkin arz kaynağ olarak imajları güçlendirilerek "akışkanlıkları" arttırılabilecektir. Böylesi bir yeniden konumlandırma ve yaratılacak imaj, bu ülkeler orijinli ürünlere olan talebi olumlu bir biçimde etkileyerek küresel ölçekte ürünleri jenerik konumdan marka düzeyine erişerek "terfilerini" sağlayabilecektir. TC7- STB içi pazarlamada, tüketicilerin ilgili ürünlere ve markalara olan güven geliştirilerek ithalat etkileri de azaltılabilecektir. Bu terfi durumunu, son çeyrek asırda Türkiye'nin kendi iç ve dış pazardaki "Türk Malı/markasına" olan güven "endeksi" gelişmelerinden de görebilmekteyiz. Öte yandan, bu günlerde, Çin'in, “ucuz ve kalitesiz” ürün 
üreten ülke imajını terfi ettirme sürecine girdiğini ve küresel markaları üretme gücü ve yeteneğini ön plana çıkararak ülke orijinini iyileştirme sürecine girdiğini görüyoruz.

TC7'lerin kaynaklarını ve ürünlerini pazarlayabilmeleri rekabetçi bir ürün haline dönüşmeleri beklenir. Bu ürünün çekirdeğini, ilk aşamada, serbest ticari bölgesi-birliği oluşturabilir. Böylesi bir birlikte, TC7’ler bir portföy olarak değerlendirilebilir. Bu birliğin oluşturulma ve yayılma süreci şu aşamalardan geçebilir:

Birinci aşama: Türk Cumhuriyetleri Serbest Ticaret Bölgesi Birliği/TC-7 STB

İkinci aşama: Avrasya eksenli genişleme-TC7-STB ve AVRASYA

Üçüncü aşama: TC7-STB ve AB ve Küresel Pazar (***).

Birinci aşama: TC7-STB

1. STB pazarı ve ekonomik politikaları entegre edecek bir misyon, vizyon, amaç ve iradenin ortaya konularak STB örgütünün ve organlarının oluşturulması,

2. Bu vizyon ve irade tek millet-çok devlet eksenine dayalı STB'inde daha iyi bir ekonomi ve toplumsal refah için ülkeler içi/arası etkileşimle kaynaklarının stratejik ve sistematik olarak akışkan hale dönüştürülmesi ve küresel rekabetçi güçlerinin arttırılmas1,

3. Bu vizyon doğrultusunda mevcut durumun değerlendirilmesi, STB'in kuvvetli ve zayıf yönleriyle birliğe ilişkin fırsat ve tehditlerin irdelenmesi,

4. STB'in birlik içi ve dışı kısa, orta ve uzun vadeli ekonomik stratejilerin geliştirilmesi,

5. Kısa vadede başta eğitim olmak üzere sosyal ve kültürel alanlarda kültürel birlik anlayışının kuvvetlendirilmesi ve sivil toplum kuruluşlarının (STK) geliştirilip kuvvetlendirilmesi,

6. Kısa ve orta vadede birlik içi kaynakların ve teknolojilerin reorganize edilmesi ve küresel rekabetçi konumlarının arttırılması ve bu amaçla ortak fon, ARGE, proje ve yatırımların geliştirilmesi,

7. Kısa ve orta vadede entelektüel sermayenin geliştirilmesi ve STB içi akışkanlığının arttırılması ve birlik içi bilgi sistemlerini entegre edebilecek ve kıyaslı araştırmalar yapacak bir (TC7-STBStat)kurumun kurulmas1,

8. Sosyal ve ekonomik entegrasyon faaliyetleriyle küresel rekabetçi projeleri finanse edecek ve sürdürülebilirliği sağlayabilecek şekilde, ülkelerin GSYİH nispetinde katılımlarıyla bir STB yatırım bankasının (bu banka uluslar arası kaynak sağlamak için proje geliştirmelere ve teminat sağlanmasına destek de olabilir) kurulması,

9. STB içinde ürünlerin tek pazar eksenli mobilitesini arttıracak zaman eksenli ve aşamalı liberal düzenlemelerin geliştirilmesi,

10. STB'in mikro ve sektörel ölçekte küresel rekabetçi stratejik birimler oluşturarak bunların ürünlerini geliştirmelerinin özendirilmesi ve hedef pazarlarda rekabetçi değerlerle pazarlanmasına destek sağlanması. Bu konuda TC7, müşteri değer zincirinde çok önemli birer ilk aşama stratejik ortağı olabilecek potansiyele sahiptir. $\mathrm{Bu}$ potansiyel bu zincirin dağıtım aşamasında, oluşturulacak stratejik ortaklıklarla ek değer sağlayıcı bir düzleme terfi ettirilebilir.

STB örgütünün oluşturulmasında vizyon, amaç ve iradenin ortaya konulması vakti gelmiş ve geçmektedir. Bu gecikmede başlıca aksaklıklar şu şekilde belirtilebilir:

1. Osmanlı'nın bu coğrafyadan ziyade (16.yy ikinci yarısında Karadeniz ile Hazar'ın birleştirilmesi girişimi tamamlanamamıştır) yönünü başlangıçtan itibaren Batı'ya çevirmesi ve XVII. yy.'dan itibaren de mevcut konumunu korumaya çalışması,

2. Türkiye Cumhuriyeti'nin uniter devlet yapısını geliştirme sürecinde "yurtta sulh cihanda sulh" yaklaşımıyla komşularını tedirgin edebilecek yaklaşımlardan uzak durmas1, 
3. Sovyetlerin bu devletler üzerinde üççeyrek asırlık hegemonyası,

4. 1990-1991 yılından itibaren bağımsızlığını kazanan Türk devletlerinin varoluş çabasına girişmeleri,

5. Türkiye'nin, 1994'ten itibaren ekonomik krizlerle uğraşması ve bu oluşumlara duygusal destekleri dışında sistematik ve organize bir katkıda bulunamaması ve yapılan maddi katkıların da ilgili ülkelerde çarpan ve hızlandıran etkisi yaratacak şekilde kullanılamaması,

6. Rusya'nın güç kaybını giderip Birleşik Devletler Topluluğu/BDT girişiminde bulunarak inisiyatifi yeniden ele almas1,

7. Türkiye'nin, Batı kaynaklı ve enerji odaklı ortak girişimler ve dil-kültür odaklı çabalar dışında, ilişkileri tarafların girişimcilerinin inisiyatifine bırakması, vb.

8. Bu "ayrılıklara" son verilmesi ve ülkeler kaynaklarının ortak refahın artırılmasına doğru bir biçimde tahsis edilmesi ve bunların etkin bir biçimde kullanılması beklenir.

Yaklaşık iki yüz milyon nüfusa, bir buçuk trilyon dolar GSYİH'ya (ppp) ve kıskanılacak kadar zengin yer altı ve üstü doğal kaynaklara sahip Türk Cumhuriyetleri'nde (****) STB için öncelikle vizyoner önderliklere ihtiyaç olduğu söylenebilir. Küresel ölçekte refah düzeyi arttırılmış “Tek millet çok devlet" vizyonu etrafında, durup bir değerlendirme yapılarak mevcut durumda nerede olunduğu ve yakın ve uzak gelecekte nerede olunması gerektiğine cevap aranabilmelidir. $\mathrm{Bu}$ soruya cevap verilemediği takdirde, ülkelerin doğal kaynakları egemen güçlerin kontrolü altına girebilir ve daha önceleri ve halen birçok ülke örneğinde olduğu gibi, doğal kaynakları zengin, halkı fakir, refahı düşük ve düşük refahtan bile yeterli payı alamayan halklar, iç karışıklıklarla birbirine düşman ve bölünmüş topluluklar ortaya çıkabilir. Hatta Ruanda/Afrika örneğinde olduğu gibi (Kotler, et al, 2008), 1rk ve din farklılığı olmayan bir ülkenin, kendi halkının bir bölümünün ticaret, diğer bölümünün tarımla uğraşmalarını bir ayrımcılık haline getirilip birbirlerine kırdırıldığı bile görülebilmektedir. Buna karşılık, vizyoner önderler sayesinde, AB (Avrupa Birliği), kendi içlerindeki uzun süreli muhtelif savaşlara rağmen, "kömür ve çelik" birlikteliği "çekirdeği”" etrafında, yirmi yedi ülkeli beş yüz milyonluk bir birliğe doğru gitmektedir.

AB oluşumu, 1952 Paris antlaşması ve bunu izleyen 1958 Roma Antlaşması esas alınacak olursa, en azından yarım asırlık bir süreçtir ve bir ortak Avrupa pazarı kurmak üzere yola çıkılmıştır (DTM, 1996). Varılan bugünkü aşamada bile, EC başkanı (2008 krizi sonrasında birlik başkanı, Eylül 2010 başlarında) yaptığı bir açıklamada, "ya birlikte kurtulur veya birlikte batarı" demekteydi.

STB'in kuvvetli yönleri ve bazı firsatlar (****) şu şekilde belirtilebilir:

1. Ortak geçmiş/tarih, dil, kültür ve coğrafi sınırdaşlık (Türkiye hariç, Nahcivan veri alınacak olursa),

2. Birçok ülkede, başta enerji olmak üzere, doğal rekabetçi kaynaklar,

3. Eğitilmiş ve yeniden eğitilebilir genç insan gücü,

4. GSYİH'ya göre borçlanma nispetinin düşüklüğü (Türkiye hariç),

5. Bazı ülkelerde (Azerbaycan, Kazakistan, Özbekistan ve Türkmenistan) dış ticaret fazlası,

6. TC7-STB içi pazarın geliştirilebilirliği,

7. Alt yapı yatırımlarının birlikte gerçekleştirilebilirliği,

8. İletişim ve hava ulaşımının nispi uygunluğu ve geliştirilebilirliği,

9. Ortak girişimlerin ve franchasing tarzı büyüme potansiyelinin varlı̆̆

10. TC7-STB içi girdi kaynaklarına duyulan ihtiyaç,

11. Küresel pazarlara birlikte açılabilme olanakları,

12. TC7-STB'in yakın bir gelecekte dünyanın en büyük ekonomisi haline dönüşmesi 
beklenen Çin ve Hindistan pazarında aktif rol üstlenmesi olanaklı hale gelebilecektir $\mathrm{vb}$.

TC7-STB'in zayıf yönleri ve bazı tehditler ise:

1. Ülke düzeyinde mevcut bağlantıları ve taahhütleri ve bu bağlantıların muhalefetleri,

2. Alt yapı ve lojistik sorunları ve karadan Türkiye erişiminde politik-fiziksel engeller,

3. GSYİH ve fert başına düşen gelir (min 2.000\$- max. 11.000\$ ppp olarak) yetersizlikleri ve gelir dağılımı dengesizlikleri (GINII endeksi),

4. Sektörel farklılıklar (tarım alanında \%6-44; sanayi \%16-64; hizmetler \%34-65). Ancak, bu farklılıklar STB içi pazarı dinamik hale getirebilir.

5. Nüfusa ve GSYİH'a nispetle bütçe düşüklükleri ve Türkiye örneği büyük bütçe açıkları,

6. Bazı ülkelerin (Türkmenistan örneği) GSYİH’ya göre yatırım yetersizlikleri,

7. Bazı ülkelerde (Kırgızistan ve Türkiye) yüksek düzeyde işsizlik,

8. Bazı ülkelerde (Kırgızistan, Tacikistan ve Türkiye) ihracatın ithalatı karşılama nispetinin azalmas1,

9. Türkiye ve nispeten Kazakistan hariç, dış ticarete konu olan ürün hattı darlığı (enerji ve maden dışı, Kırgızistan ve Tacikistan hariç) ve genelde rekabetçi teknolojik ürün yetersizlikleri,

10. ARGE harcamaları yetersizlikleri,

11. Çocuk ölümlerinin nispi yüksekliği,

12. Çevresel sorunlar ve petro-kimyasal kirlilik,

13. Bazı ülkelerde GSYİH'a göre düşük eğitim harcamaları,

14. Sivil toplum kuruluşu/STK eksiklikleri, bazı sosyal guruplara ve STK'na bazı ülkelerde, komşuluk ilişkilerine zarar verecek kadar muhalif olma,

15. Gümrük mevzuatlarının farklılığı ve sınır geçişleri yolsuzlukları,

16. Uluslar arası örgütlere üyelik ve ilişkilerde deneyim ve lobi noksanlıkları,

17. Rüşvet, yolsuzluk ve kayırmacılıkların ortalama vatandaş aleyhine, gelişmiş ülke standartlarının üstünde yer alması,

18. Önceki bağlantı ve anlaşmaları (Türkiye'nin $\mathrm{AB}$ ve gümrük birliği, diğer Cumhuriyetlerin BDT),

19. Kendi güçlerini algılamada ve dişa yönelimlerde yetersizlikler,

$\mathrm{Bu}$ dengesizlik ve yetersizlikler (zayıflıklar), STB'in çözmek zorunda olacağı sorunlara ve tehditlere ilişkin gündemi de oluşturacaktır vb.

Öte yandan TC7'nin önemli bir bölümü, yer altı ve üstü doğal kaynakları itibariyle zengin ve fakat ekonomik olarak fakir bir görüntü çizmekte, ekonomik reformları henüz tamamlayamamış, özel sektörü yeterince geliştirilememiş, kontrollü dış ticaret rejimiyle devlete kontrolünde bir ekonomi olma özelliklerini nispeten (özel sektörün GSYİH içinde pay1 \%25-30 payla (****) koruyabilmektedirler (Badykova, 2005). Tacikistan örneğinde olduğu gibi, iç kaynak ve tasarruf yetersizlikleri, büyüme için yabancı yatırımlara olan ihtiyacı arttırmaktadır. TC7'de, bir kaçı dışında (Kazakistan ve nispeten Azerbaycan ve Kırgızistan) uygun bir iç yatırım atmosferi görülmemektedir. Orta Avrupa örneğinde olduğu gibi, GSYİH/büyümenin \%10-12 düzeyinde gerçekleştirilebilmesi için yatırımların GSYİH'nın \%25-30'u düzeyinde olması beklenir (Asadov, 2007). Öte yandan, bazı TC7'de yatırımdan önce bütçe hazırlama, fonksiyonel, idari ve ekonomik kategorilerle bakımından hazırlanma, içerik ve raporlamaları bakımından da sorunlar olduğu görülmektedir (Makhmutova, 2007). Bu sorunların TC7-STB'nin, gerçekleşmesi sonrasında, ortak çalışmalarıyla kısa sürede aşılabilmesi beklenir. 


\section{Türk Cumhiriyetleri ve Serbest Ticaret Birliği Stratejisi}

TC7 eksenli STB eksenli bir sistem, bir üst örgüt ve politikalar oluşturulabilir, örgütsel yapının ve ticari akışkanlığın işleyişi sağlanabilirse, firma ölçeğinde, bu akışkanlığı harekete geçirebilecek bürokrasisi asgariye indirilmiş özendirici politika ve uygulamalara ihtiyaç olabilecektir.

Mevcut ve potansiyel güç değerlendirmeleri dikkate alınacak olursa, TC7-STB için "tek pazar" olma olanakları nispeten çekici hale gelmektedir. Nitekim bir ulusun refahı değerlendirilirken şu dört faktör göz önünde tutulabilmektedir: Doğal (yer altı ve üstü) sermaye, insan sermayesi/verimliliği, sosyal sermaye (toplumu oluşturan aile, kurum ve örgütler) ve fiziki sermaye (donanım değerleri) (Kotler, Jatusripitak ve Maesincee, 2005). TC7'ler arasında bir slogan haline gelen "tek millet, çok devlet" yaklaşımı dikkate alınacak olursa, Porter ve McKinsey S-7 modellerinde de belirtildiği gibi, insan sermayesiyle sosyal ve fiziki/donanım sermayesinin, STB girişiminin gerçekleşmesi sonrasında, iyileştirilmesi gerekecektir. Böylesi bir STB ile TC7 için ülkelerin stratejik konumları ve üretim faktörlerinin küresel rekabetçi değerle pazarlanabilme olanakları geliştirilebilecektir. Diğer bir deyişle TC7'lerin alt ve kurumsal yapılarıyla yatırım, endüstri, ticaret politikalarının geliştirilmesi için stratejik bir adım atılmış olacaktır. Böylesi bir adım, TC7-STB bünyesinde yer alan ve alacak olan mevcut ve yeni girişim ve şirketlerin ulusal refahları arttırıcı stratejileri için elverişli bir ortam sağlayabilecektir. Bu amaçla STB olarak, oluşturulacak örgütler ve çalışma guruplarıyla şu analiz yapılabilmelidir:

1. TC7'lerin her birinin ülke içi ve STB içi rekabetçi yapıları ile küresel rekabetçi yapının analizi,

2. TC7 ve küresel güç ve trendlerin olası etkilerinin analizi,

3. TC7STB'nin kapasite ve yeteneklerinin analizi (Kotler, Jatusripitak ve Maesincee, 2005-geliştirme-),

4. Özel sektörün üretim ve pazarlama yetenekleri ve olası stratejilerinin analizi.

Küresel güç ve trendlerin etkisi altında bulunan TC7-STB'nin fiziki kaynaklarının rekabetçi olarak işletilebilirliği, beşeri, mali/ekonomik ve teknik gücünün, bu gün için, genelde, nispeten "vasat" olduğu, iç ve yakın çevresel hedef pazarlarının çekiciliğinin de nispeten vasat olduğu dikkate alınacak olursa, ilk aşamada, yakın gelecekteki potansiyel güç doğrultusunda rekabetçi olarak yeniden konumlandırılarak hedef pazarlar için orijin etkisini güçlendirici bir stratejinin seçilmesi gerektiği söylenebilir. Yeniden konumlandırılmış entegre ülke faktörleri, firma ölçeğinde, genelde, ürün ve marka olarak çeşitlendirme ve farklılaştırma eksenli stratejilerin seçilmesi beklenir.

Olası STB iç pazarının nispi çekiciliği ve ülkelerin fiziki, beșeri, mali ve teknik güçlerinin nispi konumu dikkate alındığında, TC7-STB için orta vadede ortalama düzeyde çeşitlilik sağlayıcı eksenli bir refah artıșına dönük bir "tek pazar" oluşturulması ve orta vadede bunun diğer AVRASYA ülkelerine doğru açılımının sağlanması ve tarihi "ipek yolunun” işlerliğinin sağlanması mümkün olabilir. Bu coğrafyada gelișmiş bir TC7-STB, doğal kaynaklarının etkin işletimine, ortak refahın arttırılmasına ve olası iç ve çevresel politik çekișmelerde caydırıcılığa da katkı sağlayabilir. Bu coğrafyada, olası fiziki engellerin aşılabilmesi için İran'ın ve Gürcistan’ın kazanılması, küresel fiziki/lojistik akıșkanlığı arttırabilecektir.

Entegrasyon içi ve dışı rekabetçi pazarlamada, TC7'ler, çevre ve küresel olası müşteriler için arz değer zincirinde müşteri değeri yaratıcı iyi bir stratejik ortak haline dönüştürülebilirler. Bu durum, ilgili ülkelerin üretim faktörlerinin, ürün ve markalarının rekabetçi olarak değerlendirilmesine çok önemli bir katkı sağlayabilecektir. Böylesi bir katkı, firma ve ülkelerin ölçek ekonomisi için olumlu bir baz etkisi yaratabilecektir. Bu etkiyi arttırmada, dağıtım kanallarının ve lojistik yapının yeniden oluşturulması olanağı bulunabilir. Bunun sonunda, hem miktar, hem de ilgili ürün ve markaların fiyat stratejilerini de olumlu etkileyebilecektir. 


\section{Sonuç}

Bu çalışmada, olmazı değil, olabilirliği dikkate alarak alternatif varsayıma destek olmak üzere TC-7STB'in oluşturulması gereği üzerinde durulmuştur. Böylesi bir birliktelik için, öncelikle demokratik kolektif bir önderliğe ve doğru bir örgütsel oluşuma ihtiyaç olduğu söylenebilir. Bunun gerçekleşmesi, fiziki/coğrafi engellerin aşılmasına olumlu katkı yapması beklenir. TC7-STB'nin gerçekleşmesi halinde, bu ülkelerin küresel alanda yeniden konumlandırılarak orijin imajlarının terfi edebileceği, faktör değerlerinin sinerjileri arttırılarak kendi iç, çevre ve küresel pazarlarda rekabetçi olarak daha akışkan hale dönüşebileceği, bunun da ülkelerin büyüme ve toplumsal refah düzeylerini arttırabileceği, mikro ölçekte firmalarının yeni girişim, ortaklık ve yatırımlarla ürün ve markalarının bünye içi, çevresi ve küresel pazarlarda pazarlama strateji ve faaliyetlerini iyileştirebileceği söylenebilir.

\section{Kaynaklar}

- Asadov, P., 2007. "Foreign Investment and Economic Reform in Tajikistan", Problems of Economic Transition; 2007, 50, 6, p. 32-83.

- Badykova, N., 2005. "Regional Cooperation in Central Asia: A View from Turkmenistan", Problems of Economic Transition; Dec2005, Vol. 48 Issue 8, p62-95

- $\quad$ Economidio, C., Lei, V. and Netz, J.S., 2006. International Advances in Economic Research, 12, pp. 435-448

- Goldschmidt, N., 2006. “Culture and Economics”, Intereconomics, 2006, pp. 176-188

- Hossain, and Naser, 2008. "Trade and Regional Integration: Analysis of the Effectiveness in the GCC", International Journal of Islamic and Middle Eastern Finance and Management, 1, 2, pp. 95-112.

- Kavass, I.I., 2008. “Azerbaijan's Path towards WTO Accession: Political Concerns, Technical Difficulties, National Attitudes (1997-2006). An Essay in the Form of a Country Report", Review of Central \& East European Law, 33, 3, pp. 343-384.

- Karabulut, M. ve Karabulut, T., 2010, Küresel Yönetim ve Pazarlama, İstanbul: Papatya Yayın.

- Keegan W.Jhoss. and Green, M.C., 2008. Global Marketing, Pearson Int. Press, NJ, pp. 78-93.

- Kotler, P., Jatusriptak, S. and Maesincee, S., 2005. Ulusların Pazarlanması, (Çev.: Buğdaycı), 2. Baskı, T. İş Bankası Kültür Yay., İstanbul.

- Lane, P.R. and Milesi-Ferretti, G.M., 2007. "Europe and Global Imbalances", Economic Policy, 22, 51, pp. 519-573.

- Makhmutova, M., 2007. "The Budget Process in Caspian Countries: The Experience of Kazakhstan and Azerbaijan", Problems of Economic Transition, 50, 4, 24-65.

- $\quad$ Peters, T.J. and Waterman, R.H., 1984. In Search of Excellence, Warner Books, NY.

- Porter, M.E., 1990. The Competitive Advantage of Nations, The Macmillian Press Ltd, London.

- Şafak, Z., Bir Millet Altı Devlet, Hürriyet-i.g., 17.9.2010

- Theodoropoulos, T.E. and Vojinovic, B., 2005. "The Modern Theory of the Synergic Integration of the Factors of Growth in an Economic Union for Europian Corporations, “' Our Economy (Nase Gospodarstvo), 51, 1/2, pp. 90-95.

- Zaman, 2008. "Economic Effects of CEE Countries Integration into the European Union, Petroleum - Gas University of Ploiesti Bulletin”, Economic Sciences Series, 60, 4, pp. 45-54.

- $\quad$---, Avrupa Birliği ve Türkiye, DTM- Avrupa Birliği Genel Müdürlüğü, 1996 
- $\quad$---, CIA- The Factbook ülke -internet- verileri ve muhtelif DTM ve İGEME ülke raporlar1

• - ---, AB-Güney Kore Anlaşması Türkiye’ye “Darbe”, Milliyet (i.g.), 19.9.2010

(*) Bugünkü durumu, 10. Türk Dili Konuşan Ülkeler Devlet Başkanları Zirvesi ile ilgili şu haber pek güzel yansitıyor: "Cumhurbaşkanı Abdullah Gül zirveye katılmayan Özbekistan'a, "Sizi de aramızda görmek istiyoruz" mesajı verdi. Çırağan Sarayı'nda dün yapılan zirveye hazırlık çalışmaları sırasında ve dışişleri bakanları buluşmasında çalışma dili olarak "İstanbul Türkçesi”" kullanılırken, Gül'ün devlet başkanlarıyla düzenlediği ortak basın toplantısında Gül dışındaki devlet başkanları Rusça konuştu. Açılışta konuşan Gül, şunları söyledi: "Biz artık bir milletiz ama 6 tane de devletiz. Bundan büyük bir gurur ve onur duyuyoruz. Türkçe konuşan ülkeler arasındaki hedef halkların menfaati, bölgesel işbirliği, istikrar ve huzur. Gözden rrak olursak gönülden de rrak oluruz. Göz göze, yan yana olduğumuzda, senede birkaç kez toplandığımızda, yan yana oturup istişareler yaptığımızda, gönüllerimizdeki yerlerimiz de daha güçlü devam edecek. Ortak davaya sahip çıkmaya yönelik siyasi irademiz tam. Sinerjimiz bu oluşumun itici gücü olacak." (Şafak, 17.9.2010)

(**) Avrupa Birliği ile Güney Kore arasında 6 Ekim'de imzalanacak Serbest Ticaret Anlaşması'nın, Türkiye'yi olumsuz yönde etkileyeceği bildirildi. $A B$ Haber'e konuşan uzmanlar Türkiye'nin, en önemli iki sektörü otomotiv ve tekstil alanlarında 1996 'da AB ile tesis edilen Gümrük Birliği anlaşmasının ardından elde ettiği tüm kazançların, AB-Güney Kore Serbest Ticaret Anlaşması sonrası yok olacağını ifade ediyorlar. Uzmanların AB Haber'e aktardığına göre, AB-Güney Kore Serbest Ticaret Anlaşmasının Türkiye'ye çok büyük bir etkisi olacak. Türkiye ile Güney Kore arasında Serbest Ticaret Anlaşması olmadığından dolayı Kore malları Türkiye'ye $\mathrm{AB}$ üzerinden sıfır gümrük ile girerken Güney Kore'nin, Türkiye ile Serbest Ticaret Anlaşması imzalamaya yanaşmadığı için Türk mallarının Kore'ye gümrükle gireceği belirtiliyor... Bu arada, aynı uzmanlar, Türkiye ile Güney Kore arasında Serbest Ticaret Anlaşması görüşmelerinin ilk raundunun yapıldığına işaret ederlerken Türkiye'nin Gümrük Birliği sayesinde elde ettiği avantajların bir bir yok olduğuna dikkati çekiyorlar.

(***)İkinci ve üçüncü aşama: TC7-STB ile AVRASYA ve AB eksenli genişleme, bu bir başka çalışmanın konusunu oluşturacaktır.

$(* * * *) \mathrm{Bu}$ değerlendirmeler CIA- The Factbook ülke verileri ve muhtelif DTM ve İGEME ülke raporlarından hareketle geliştirilmiştir. 


\title{
Turizm Sektörünün İstihdam Yaratmadaki Yeri ve 2009 Krizinin Türkiye Turizm İstihdamına Etkileri
}

\author{
Didar Sarı, Sakarya Üniversitesi \\ Zefure Uçar, Sakarya Üniversitesi
}

\begin{abstract}
The Tourism Sector at Creating Employment and the Effects of 2008 Global Crisis on Turkey's Tourism Employment
\end{abstract}

Tourism is one of the largest sectors in the world, providing over 235 million employment oppurtunities in global platform and having 9,2\% of GDP (WTTC, 2010:a). The seasonal nature of tourism industry, rapid changes in working conditions, formal lacks in work contracts of many small businesses etc. are the complicating factors at providing stable employees in the sector (Eurostat et al., 2008:50). Despite these difficulties, in the tourism sector, -which's making positive effects with its labour intensive nature and multiplier effects in various industries-, new job opportunuties influencing positively to the region's and countries' economic structure and even the overall economic structure. According to the barometer published by UNWTO, 2009 Global Economic Crisis effected tourism industry globally negatively with $4,2 \%$ decline at the number of incoming tourists and tourism revenues from $\$ 942$ million to $\$ 852$ million* at 2009 (UNWTO, 2010:a). On the data of Turkey, 3,2\% decline at tourism revenues despite $2 \%$ growth at the number of incoming tourists is attracting attention(UNWTO, 2010:b). By 2008, the direct employment that created Travel\&Tourism Industry in Turkey is occured as 436.6 thousands while it's estimated that it'll rise to 443.1 thousands in 2009 and to 447.5 thousands in 2010 (WTTC, 2010:b).

In this paper, creating employment of tourism sector and the importance of it is emphasized while it's aiming to analyse the effects of 2009 Global Economic Crisis to Turkey's Tourism Employment via secondary data.

JEL Codes: J21, G01

\section{Giriș}

Sosyo-kültürel getirilerinin yanında, makro-ekonomik değişkenler üzerindeki olumlu etkileri ile 21.yüzyılın vazgeçilmez sektörleri arasında yer alan turizm, küresel ekonomide önemli bir konuma sahiptir. Teknolojik işsizliğin artış seyri gösterdiği bu dönemde, emek-yoğun sektörlerin başında gelen turizm, istihdam açığı sorununun çözümünde anahtar faktör rolünü oynamaktadır.

2009 Küresel Ekonomik Krizi ile birlikte sarsılan ekonomilerde, oluşan en büyük sorunlar arasında yer alan istihdam açığı, turizm sektöründe de önemli ölçüde etkisini hissettirmiştir. Bununla birlikte istihdam yaratmada reel büyüme oranındaki düşüşe karşın pozitif rakamları korumayı başaran Türkiye turizm sektörünün önümüzdeki yıllarda bu alanda da artış seyrine girmesi beklenmektedir.

2009 Krizi'nin Türkiye turizm istihdamında yarattığ 1 etkilerin analiz edilmesini amaçlayan çalışmamızda, bu bağlamda ilk olarak sektörün ekonomideki yerine yer verilerek önemine değinilmiş, ardından krizin küresel ölçekte turizm sektöründe oluşturduğu etkiler incelenmiştir. Son olarak krizin Türkiye turizm istihdamına etkilerine yer verilen çalışmamızda ikincil verilerden yararlanılmıştır.

\section{Turizm Sektörü ve Ekonomideki Yeri}

Gelişmekte olan ülkeler başta olmak üzere, birçok ekonomide lokomotif sektör konumunda 
olan turizm, endüstri ülkelerinin çoğunluğunun ekonomilerinde de en hizlı büyüyen alan olan hizmetler sektörünün ana birimini oluşturmaktadır (Theobald, 2005:5). Öyle ki turizm; 'Telekomunikasyon' ve 'Bilgi Teknolojileri'yle birlikte 21. yüzyıl küresel ekonomisine yön veren 3 sektör arasında yer almaktadır (Crouch ve Ritchie, 1999:138).

Şüphesiz, turizm endüstrisinin sağladığı en olumlu etki öncelikle ekonomi üzerinde görülmektedir. Başlıca turizm destinasyonlarında, milli gelirdeki artış, gelen turist sayısındaki artışa paralel olarak ilerlemekte; turizmde uzmanlaşmayan diğer ülkelere kıyasla istihdam ve büyümede çok daha hızlı bir gelişmeyi beraberinde getirmektedir (Capo ve Vale, 2008:201). Gelir ve harcamaların doğrudan ve dolaylı olarak sağladığı etkilerle turizm, ödemeler dengesinden istihdama kadar uzanan geniş bir ölçekle oldukça stratejik makro ekonomik etkilere sahiptir.

Dünya seyahat ve turizm örgütünün hazırladığı 2010 yılı raporunda, küresel krizin yol açtığı daralmaya rağmen, sektörün 2009 yılı itibariyle küresel bazda milli hasılanın \%9,4'ünü oluşturduğu görülmektedir. 2010 yılında, seyahat ve turizm endüstrisinin yarattığ 1 tahmini toplam hasıla \%9,2'ye gerilerken; 'doğrudan' milli hasıla, toplam hasılanın \%3,2'sini oluşturarak 1,986 milyar\$ olarak gerçekleşmiştir (WTTC, 2010c:3).

Küresel bazda toplam ihracat gelirinin \%10,9'una karşılık gelen 1,936 milyar dolarlık ihracat geliri sağlayan sektör, kamu harcamalarının \%3,8'ini oluşturmaktadır (WTTC, 2010c:4).

\subsection{Turizm ve İstihdam İlişkisi}

Hizmeti sağlayan ve alanın insan olduğu turizm sektörü, istihdam yaratma politikasına öncelik vermek isteyen hükümetler için ideal alanlar arasında sıralanmaktadır. Öyle ki turizm, dünya genelinde istihdam yaratmada ilk sirada gelen sektör konumunu alacaktır (UNWTO News, 2010:14). Buna karşın turizm sektöründe istihdam talebi türev; diğer bir deyişle türetilmiş taleptir. Turistik ürün ve hizmetlere talep olduğu sürece sektörde işgücü talebi olacaktır (Tribe, 2004: 261). Bu durum, sezonun yüksek olduğu dönemlerde turizm istihdam talebini arttırmakta, buna karşın düşük olduğu dönemlerde talebi de düşürerek turizmin yol açtığı sayılı olumsuz etkilerden olan 'mevsimlik işsizlik' sorununa neden olmaktadır.

Çok sayıda alt sektörle ilişki içinde bulunduğu bilinen turizmin üç farklı biçimde istihdam yarattığı görülmektedir (Rowe vd.,2002:20).

Konaklama, yiyecek-içecek ve seyahat işletmeleri ile turizm büroları, hava trafik kontrolörleri gibi turizm alanında faaliyet gösteren kamu kuruluşları, sektörde 'doğrudan istihdamı' oluşturmaktadır. Bir diğeri turizme hizmet veren alt sektörlerde oluşan 'dolaylı istihdam'dir.

Şekil 1. Seyahat\&Turizm Endüstrisi İstihdamı (Türkiye)



Kaynak: WTTC, 2010c

Doğrudan İstihdam

Doğrudan\&Dolaylı İstihdam

Havayolu, otel, liman vs. gibi turizm amaçlı kullanılacak tesislerin inşası sırasında sağlanan istihdam, turizm işletmelerinde sunulacak kimi ürünleri üreten tesislerin sağladığ 1 istihdam vs. sektörün yarattığı dolaylı istihdam örneklerindendir. Son olarak turizmden elde edilen gelirin diğer sektörlerde yatırım haline dönüştürülmesiyle gerçekleşen 'uyarılmış istihdam' etkisinden bahsetmek mümkündür. 
Şekil 1'de 2010 yılı itibariyle Türkiye'deki Seyahat ve Turizm Endüstrisinde sağlanan istihdam yapısı görülmektedir.

2010 yılında seyahat ve turizm endüstrisinin yarattı̆ğ tahmini ‘doğrudan' istihdamın, küresel bazda toplam istihdamın \%2,8'ini oluşturan 81,913,000 olduğu tahmin edilmiştir. 10 Yıllık trendlere bakıldığında ise;bu rakamın \%3,2'ye yükselmesi beklenirken; 2010 yılında turizmin istihdam içerinde yarattığı tahmin edilen toplamda $\% 8,1$ oranındaki doğrudan ve dolaylı istihdamın, 2020 yılında \%9,2'ye ulaşarak 303,019,000 olarak gerçekleşeceği öngörülmektedir (WTTC, 2010c:3).

\section{Küresel Ekonomik Krizinin Turizm Sektörüne Etkileri}

Finans krizi olarak Amerika'da başlayıp, kısa sürede küresel bir ekonomik kriz haline dönüşen 2009 krizinin, 1929 büyük buhranının ardından yaşanan en büyük kriz olduğu düşünülmektedir (Gurria, 2008). ABD konut piyasasında fiyatların sürekli artış eğiliminde olması ve bu durumun devam edeceği beklentisiyle bütün kredi türleriyle varlıklarının üzerinde borçlanmaya giden tüketiciler krizin çıkış noktasını oluşturmuştur. Bankaların, karlılıklarını arttırdığ 1 düşüncesiyle, kredi taleplerine olumlu cevaplar vermelerinin ardından, kötü borç olarak da tanımlanan bu kredi türlerinin konut fiyatlarının düşüşe geçmesi ile geri ödenmesinde güçlük yaşanması ve borsada ipotek kredisi türevlerinin değer kaybetmesi ile küresel ekonominin en büyük krizlerinden biri meydana gelmiştir (Hiç, 2009). Reagan döneminden itibaren finans sektörü üzerindeki denetimin zayıflatılmış olması, bankalar ve finans kuruluşlarının iflasına zemin hazırlamıştır (Krugman, 2009). Bankaların toksik varlıklara karşı duyduğu güvensizlik ve kredi taleplerini büyük ölçüde geri çevirmeleri ise reel sektörde fon akışını yavaşlatarak likidite sorunu yaşatmıştır.

Kriz, etkilerini dünya genelinde tüm sektörlerde olduğu gibi turizmde de önemli ölçüde hissettirmiştir. 2009 yılı uluslararası turizm tahmini gelirlerinin 2008 yılında gerçekleşen 942 milyon\$'ın altında kalarak 852 milyon\$ olarak açıklanması, ekonomik krizin sektör üzerinde yarattığı olumsuz etkinin göstergesi niteliğindedir. Reel olarak döviz kuru dalgalanmaları ve enflasyon açısından bakıldığında ise, turizm gelirlerinin $\% 5,7$ oranında düştüğü görülmektedir (WTTC, 2010c:1).

Bir önceki yıla göre 2009'da uluslararası turist hareketlerinde \%4,3 oranında küçülme yaşayan sektörde, Afrika haricindeki bütün destinasyonlara varışlarda düşüş yaşanmıştır. Kuzey Avrupa (-\%6), Güney ve Orta Akdeniz (-\%4), Orta ve Doğu Avrupa (-\%10) ve Güney Amerika (-\%1)'da yaşanan daralmalara karşın, Kuzey Afrika ve Sahara bölgelerinde \%2-\%4 oranında büyüme gerçekleşmiştir.

Şekil 2.Uluslararası Turist Varışları, Aylık Değişim

Dünya

(\% Değişim)

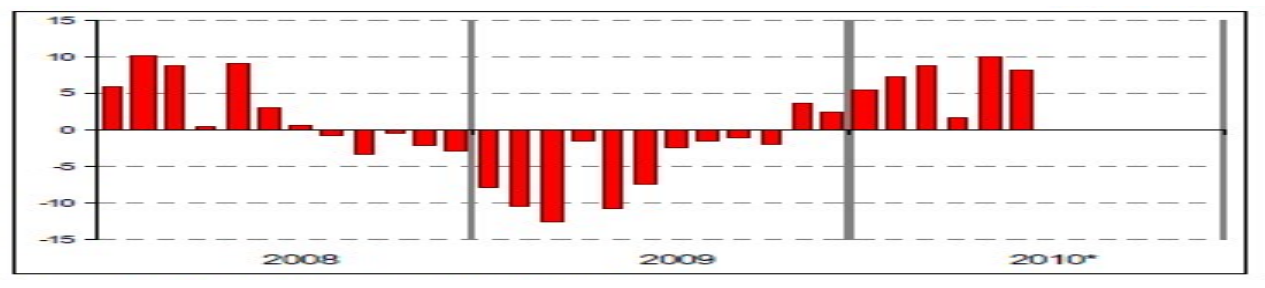

Kaynak: Dünya Turizm Örgütü (UNWTO)

Turizm gelirlerine bakıldığında, dünya genelinde bütün destinasyonlarda düşüş yaşandığı gözlenmektedir. Göreli olarak daha iyi koşullarda olan Asya Pasifik ve Ortadoğu bölgelerinde dahi gelirlerde $\% 1$ ve $\% 3$ oranında düşüş oluşmuştur. Bölgesel olarak ise Okyanusya ve Kuzeydoğu Asya $\% 5$ ve \%1 oranında reel artış gösteren bölgelerdir. Negatif eğilime rağmen Kuzey Avrupa, Güney Asya, Karayipler, Güney Amerika ve Kuzey Afrika kriz karşısında 
turizm sektöründe dünya ortalamasının üzerinde bir gelişim göstermişlerdir (UNWTO, 2010b).

2010 yılının ilk yarısına ait tahminler incelendiğinde ise, 2009 yılında diğer bölgelerden ayrılarak pozitif yönlü ilerleme kaydeden Afrika bölgesinin bu dönemde de hissedilir oranda büyüme kaydeden tek destinasyon olduğu görülmektedir. Güney Afrika'nın, FIFA'nın düzenlediği dünya kupasına ev sahipliği yapması Afrika destinasyonu imajına büyük fayda sağlamıştır. Amerika kıtasına bakıldığında sektörde ortalama \%7 oranında büyüme görülürken, Nisan ayında İzlanda'da oluşan kül bulutlarının hava taşımacılık tarihinin en büyük krizini yaşattığ Avrupa destinasyonunun ortalama büyümesi ise \%2 düzeyinde kalmıştır (UNWTO, 2010c). 2009 yılına kıyasla sevindirici oranlarda büyümeler gerçekleşmesine rağmen, Dünya Turizm Örgütü verilerin dikkatli yorumlanması konusunda uyarıda bulunmaktadır. Öyle ki, 2009 yıllının ilk yarısına göre \%7'lik büyüme kaydedilen uluslararası turist hareketleri 384 milyondan 420 milyona yükselmiştir. Buna karşın bu rakam; 429 milyon olarak gerçekleşen 2008 yılının ilk yarısının \%2 gerisinde bulunmaktadır. Bu durum küresel krizin yol açtığı daralmanın büyük oranda sona erdiğini göstermekle birlikte; 2008 y1lı verileri göz önünde bulundurulduğunda reel büyümenin istenilen düzeyde olmadığına işaret etmektedir.

Küresel ekonominin genelinde olduğu gibi turizm endüstrisinde de toparlanmanın kademeli olarak gerçekleşmesi beklenmektedir. WTTC tahminlerine göre $\% 0,5$ oranında gerçekleşen büyümenin, 2010 yılının ikinci yarısından itibaren önemli oranda hızlanarak 2011'de \%3,2 olarak kaydedileceği düşünülmektedir (WTTC, 2010c:3).

\section{Küresel Ekonomik Krizi’nin Türkiye Turizm İstihdamına Yansımaları}

2009 y1lı tahmini turist varışlarında bir önceki yıla oranla \%2 büyüme kaydeden Türkiye'nin 25,5 milyon varışla, uluslararası turizm pazarında 7.sırada yer aldığı görülmektedir. Buna karşın, tüm destinasyonlarda olduğu gibi krizin etkileriyle turizm gelirlerinde 2008'e kıyasla \%3,2 düşüş yaşayan Türkiye, 21,3 milyar dolarla 9.sırada yer almaktadır (UNWTO, April 2010:7).

\section{Şekil 3. Türkiye Seyahat ve Turizm Endüstrisi İstihdamı ('000 bin işgücü)}

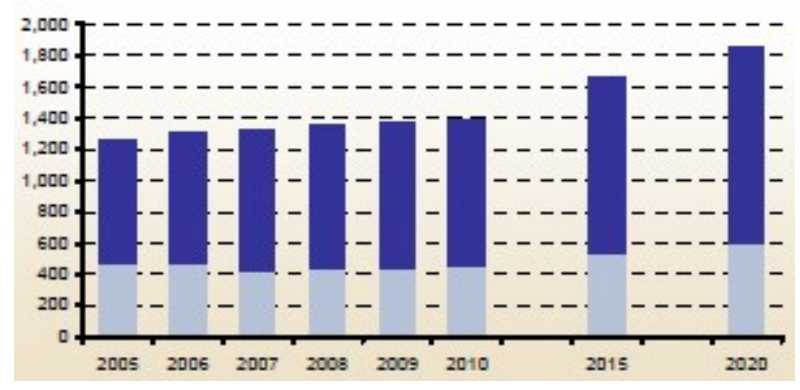

Kaynak: WTTC, 2010c $\square$ Doğrudan İstihdam

Doğrudan \&Dolaylı İstihdam

Tablo 1'de görüleceği üzere, 2008 yılında turizm endüstrisinin Türkiye ekonomisine sağladığı doğrudan istihdam 436.6 bin olarak gerçekleşirken; küresel krizin getirdiği olumsuz etkilerle sektörün istihdam yaratmadaki reel artış hızı azalmasına karşın, sektörün sağladığı 'doğrudan istihdam'ın 2009'da 443.1 bine; 2010 yılında ise ülkedeki toplam istihdamın \%2.1'ini oluşturarak 447.5 bine yükselmesi öngörülmektedir.

İlişkide bulunduğu alt sektörlerle ve uyarılmış etkilerle dolaylı istihdam sağlamada önde gelen sektörlerden olan turizmin, Türkiye'de 2010 yılında yaratacağ $1 \% 6,4$ oranındaki doğrudan ve dolaylı toplam istihdamın, 1,389 bin'den, 2020 yılında 1,847 bine yükselerek $\% 7,2$ oranında gerçekleşmesi beklenmektedir. 
Tablo 1. Türkiye Seyahat ve Turizm Endüstrisi Istihdam Oranları

\begin{tabular}{|c|c|c|c|c|c|c|c|c|}
\hline & $\begin{array}{c}2008 \\
(, 000)\end{array}$ & $\begin{array}{c}\text { Toplam } \\
\text { İstihdam } \\
\text { a Oranı } \\
\mathbf{( \% )}\end{array}$ & $\begin{array}{c}\mathbf{2 0 0 9} \\
(, 000)\end{array}$ & $\begin{array}{c}\text { Toplam } \\
\text { İstihdam } \\
\text { a Oran1 } \\
\mathbf{( \% )}\end{array}$ & $\begin{array}{c}\mathbf{2 0 1 0} \\
(, 000)\end{array}$ & $\begin{array}{c}\text { Toplam } \\
\text { İstihda } \\
\text { ma } \\
\text { Oran1 } \\
\mathbf{( \% )}\end{array}$ & $\begin{array}{c}\mathbf{2 0 2 0} \\
(, 000)\end{array}$ & $\begin{array}{c}\text { Toplam } \\
\text { İtihdama } \\
\text { Oran1 (\%) }\end{array}$ \\
\hline $\begin{array}{c}\text { Doğrudan } \\
\text { İstihdam }\end{array}$ & 436,6 & 2,1 & 443,1 & 2,1 & 447,5 & 2,1 & 592,5 & 2,3 \\
\hline $\begin{array}{c}\text { Doğrudan \& } \\
\text { Dolaylı } \\
\text { İtihdam }\end{array}$ & 1,361 & 6,4 & 1,375 & 6,5 & 1,389 & 6,4 & 1,847 & 7,2 \\
\hline
\end{tabular}

Kaynak: WTTC 2010c'den derlenmiştir

*(Tahmin)

WTTC'nin 2020 yılı tahminleri, Türkiye'de turizm sektörünün yarattığı doğrudan istihdamın, toplam istihdam içerisinde alacağı payın artarak \%2,3'e ulaşacağını ve yaklaşık 593 bin kişiye istihdam sağlayacağını göstermektedir.

2009 Küresel Ekonomik Krizi’nin Türkiye Turizm Sektörü üzerindeki etkilerini görebilmek için reel istihdam ve gayrisafi milli hasıladaki (GSMH)reel büyüme rakamlarını görmek için Tablo 2'yi incelemek fayda sağlayacaktır.

Tablo 2. Türkiye Seyahat ve Turizm Endüstrisi İstihdamı Reel Büyüme Oranları

\begin{tabular}{|c|c|c|c|c|c|c|c|}
\hline & $\mathbf{2 0 0 5}$ & $\mathbf{2 0 0 6}$ & $\mathbf{2 0 0 7}$ & $\mathbf{2 0 0 8}$ & $\mathbf{2 0 0 9}$ & $\mathbf{2 0 1 0}$ & $\mathbf{2 0 2 0}$ \\
\hline Doğrudan İstihdam & -6.7 & -1.6 & -8.5 & 3.3 & 1.5 & 1.0 & 2.8 \\
\hline GSMH & 8 & -7.3 & 6.6 & 0.6 & 7.1 & -3.3 & 3.9 \\
\hline Doğrudan\&Dolaylı İstihdam & -4.5 & 3.6 & 1.6 & 2.5 & 1.0 & 1.0 & 2.9 \\
\hline GSMH & 6.4 & -2.0 & 1.4 & -1.2 & -1.3 & -2.1 & 4.5 \\
\hline
\end{tabular}

Kaynak: WTTC, 2010c'den derlenmiştir

*(Tahmin)

2008 yılının ardından sektördeki doğrudan ve dolaylı istihdam oranlarının 2010 tahminleri dahil olmak üzere devamlı düşüş seyrinde olması, sektörün yarattığı istihdamda azalan oranlı artış olduğuna işaret etmektedir.

\section{Sonuç}

1929 Büyük Buhranının ardından küresel ekonominin yaşadığı en büyük kriz kabul edilen 2009 krizi, etkilerini dünya genelinde ve makro ekonominin bütün değişkenleri üzerinde oldukça yıkıcı biçimde hissettirmiştir.

Büyüme oranlarındaki düşüşün ardından küçülmeye giden ekonomilerde karşılaşılan en büyük sorunlardan olan istihdam açığı, emek-yoğun çalışan turizm sektöründe de kendisini göstermiştir. 2008 yılının ardından yarattığı doğrudan ve toplam istihdam sayılarındaki artışın devam ettiği sektöre reel olarak bakıldığında doğrudan istihdamın 2009 ve 2010'da giderek düştüğü, doğrudan ve dolaylı toplam istihdamın ise 2009'daki düşüşün ardından stabil kaldığ1 gözlenmektedir. Buna karşın, WTTC tarafından yayınlanan 2020 yılı trendlerine göre sektörün kendi bünyesi ile alt ve yan sektörlerde yaratacağı istihdamın artış seyrine girerek önemli ölçüde büyüyeceği öngörülmektedir. 


\section{KAYNAKÇA}

- Capo ve Vale, 2008. “The Macroeconomic Contribution of Tourism” Editörler: Ramos ve Jimenez, Tourism Development: Economics, Management and Strategy, Nova Science Publishers, New York, s.201-227.

- Crouch ve Ritchie, 1999. "Tourism, Competitiveness, and Societal Prosperity", Journal of Business Research, 44, s. 137-152.

- $\quad$ Eurostat, Oecd, Unwto ve Un, 2008. Tourism Satellite Account: Recommended Methodological Framework (TSA: RMF 2008), http://unstats.un.org/unsd/statcom/doc08/BG-TSA.pdf

- Gurria, 2008. From the Financial Crisis to the Economic Downturn: Restoring Growth is a Key Challange, http://www.oecdobserver.org/news/fullstory.php/aid/2753/

- Hiç, 2009. Küresel Ekonomik Kriz ve Türkiye, Beykent Üniversitesi Yayınevi, İstanbul.

- $\quad$ Krugman, Reagan Did It, 2009.

http://www.nytimes.com/2009/06/01/opinion/01 krugman.html

- $\quad$ Liu, (Edit.) 2006. Tourism Management, Nova Science Publishers, New York.

- Lucas, 2004. Employment Relations in the Hospitality and Tourism Industry, Routledge, London.

- Nickson, 2007. Human Resource Management for the Hospitality and Tourism Industries, Butterworth-Heinemann, Cornwall.

- Riley ve Szivas, 2002. Tourism Employment, Channel View Publications, UK.

- Rowe, Smith ve Borein, 2002. Career Award Travel and Tourism, Cambridge University Press, Cambridge.

- Theobald, 2005. "The Meaning, Scope and Measurement of Travel and Tourism" Editör: William F. Theobald, Global Tourism, Elsevier, Burlington, s.5-25.

- Tribe, 2004. The Economics of Recreation, Leisure and Tourism, Elsevier, Oxford.

- Unwto (United Nations World Tourism Organization), 2010a. World Tourism Barometer, International Tourism 2009, http://www.unwto.org/facts/eng/pdf/barometer/UNWTO_Barom10_2_en_excerpt.pdf.

- Unwto (United Nations World Tourism Organization), 2010b. World Tourism Barometer, International Tourism Receipts 2009, http://www.worldtourism.org/facts/eng/pdf/barometer/UNWTO_Barom10_update_ap ril_en_excerpt.pdf.

- Unwto (United Nations World Tourism Organization), 2010c. World Tourism Barometer: Interim Update, August 2010, http://www.unwto.org/facts/eng/pdf/barometer/UNWTO_Barom10_update_august_en _excerpt.pdf.

- Unwto (United Nations World Tourism Organization), UNWTO News, 1/2010.

- Wttc (World Travel and Tourism Council), 2010a. http://www.wttc.org, 29.06.2010.

- Wttc (World Travel and Tourism Council), 2010b.

http://www.wttc.org/eng/Tourism_Research/Economic_Research/Country_Reports/Tu rkey_l

- Wttc (World Travel and Tourism Council), 2010c. Travel\&Tourism Economic Impact, Executive Summary, s.3, http://www.wttc.org/bin/pdf/original_pdf_file/2010_exec_summary_final.pdf. 


\title{
Ekonomik Kriz Dönemlerinde Turizm ve Seyahat Endüstrisinin Tutumu
}

\author{
Perihan Paksoy, Beykent Üniversitesi \\ Nurdan Çolakoğlu, Beykent Üniversitesi
}

\begin{abstract}
Due to economic crises, tourism and travel industry can come to a standstill and the international travel can slow dowm. A common believe among tourism experts is that the financial crisis can damage the tourism industry evenly. In contrast, a closer inspection of tourism statistics indicates that this is not always the case. Hence, while some tourism segments are severely damaged, others demonstrate unique stability and firmness. For instance even after crisis 2008, tourism receipts of Austria and Australia demonstrated a positive growth. In this article the researchers analyse the impact of economic crises on tourism in Turkey and worlwide and try to come up with suggestions. Consequently it is apparent that with the reduced numbers of people travelling for holiday, countries that rely on tourism need to broaden their appeal and try to attract different visitors in addition to their traditional holiday makers and tourism establishments need to adapt themselves to changing conditions and modify themselves according to changing tourist behaviours during crises.
\end{abstract}

JEL Code: L83; G01

\section{Giriş}

Ekonomik krizleri ekonomideki karar birimleri olan hane halkı yani bireyler, firmalar ve devletin davranış ve faaliyetlerinde iç ve dış konjonktür nedeni ile meydana gelen ani ve beklenmeyen değişimler olarak ifade edebilmek mümkündür. Kronik ve yüksek enflasyon, devalüasyon, hükümetlerin radikal para politikaları, dış ticaret dengesizlikleri, giderek artan iç ve diş borç vb. ekonomik krizi doğuran etkenlerden başlıcalarıdır (Apak; Aytaç;2009:17).

Krizlerin yaşandığı dönemlerde ve ülkelerde bütün sektörlerde olduğu gibi turizm sektöründe de etkilenme kaçınılmazdır.

Turizm talebinde etkili olan başlıca ekonomik faktörleri özetlemek ve bunlara bazı ikincil unsurlar ilave etmek gerekirse, ailenin harcanabilir gelir seviyesinin, turist gönderen ülkede aile gelirini etkileyen vergi sisteminin yapısının, turizm dışındaki mal ve hizmetlerin fiyatlarının, ülkedeki faiz oranlarının, turist gönderen ve turiste ev sahipliği yapan ülkelerdeki enflasyon ve döviz kuru seviyesinin, seyahat maliyetlerinin, ekonomik krizler v.b. unsurların turizm talebini belirleyen ana ve tali ekonomik faktörler olduğu söylenebilir (Ryan; 2003:39) $\mathrm{Bu}$ tanımlamadan da anlaşılacağı üzere, ekonomik krizler turizm sektörünü etkileyen faktörlerden biri olarak sıralanmıştır.

Turizm ve seyahat endüstrisi, ekonomik belirsizlik ve dalgalanmalara basit bir sebepten dolayı açıktır. Seyahat ve turizm ihtiyari harcama gerektirir. Zorunlu bir harcama değildir. Ve zorlu ekonomik zamanlarda insanlar yaşam, yiyecek, barınak ve temel aile ihtiyaçların karşılamak için nakit tasarrufunda bulunurlar. Yağcı (2003) turizmde satın alma davranışlarını etkileyen faktörler arasında ekonomik gücü sıralamış ve ekonomik krizin olduğu bir ortamda mavi tura çıkma gibi planların orta ve uzun dönem belirsizliklerinden dolayı ertelenebileceği örneğini vermiştir. Ancak, bu turizmin tamamen durduğu anlamına gelmez.

Her aile harcamalarını öncelikle daha zaruri ve öncelikli gördüğü mal ve hizmetler üzerine yapar ve eğer bu tür harcamaların dışında aile bütçesinde boş zamanların değerlendirilmesi için bir meblağ kalırsa, ilgili aile turizm hizmeti satın almaya yönelebilir. (Oktayer; 2007: 22) 


\section{Krizler ve Turizm Sektörü}

Turizm sektöründe krizler birincil nedenlere yani sektörün kendi dinamiklerinden kaynaklanan nedenlere dayalı gerçekleştiği gibi, ikincil nedenlere yani sektör dışında gerçekleşen olaylara bağlı olarak da oluşabilmektedir.

Turizm krizlerinin özellikleri aşağıda gösterildiği şekilde sıralayabiliriz: (Özkul, 2001: 47)

- Birincil ve ikincil nedenlere sahiptirler,

- Ekonomik nedenlere dayanmasalar da sonuçları ekonomik değer taşır,

- Belirli birikimler sonucu ortaya çıkarlar,

- Zaman içerisinde tekrarlayabilirler,

- İç ve dış kaynaklı gerçekleşebilirler,

- Belirtilerin sergilendiği bir ön sürece (kriz öncesi), sonuçların etkili olduğu bir işlerlik sürecine (kriz sırası) ve etkilerin giderek azaldığı bir son sürece (kriz sonrası) sahiptirler,

· Çözümleri ve etkileri yönünden kısa, orta ve uzun dönemli olabilirler.

\section{Türkiye'de Yaşanılan Krizlerin Turizme Etkisi}

Türkiye'de turizmin krizden nasıl etkilendiğini belirlemek için Türkiye'deki krizlerin kronolojisine de dikkat çekmek faydalıdır.

1980-1999 yılları arasında Türkiye'nin kriz yıllarına damgasını vuran dünya ekonomisindeki gelişmelere dikkat çekilecek olursa (Kazgan);

- 1982: Büyük borçlu Latin Amerika ülkelerinin borç ödeyemez duruma düşmesi ile dünyada büyük borç krizinin patlaması,

- 1987: Kasım ayında New York borsasının çökmesi, izleyen yaygın banka iflasları ile ABD ekonomisinin uzun süreli (1987-91) durgunluğa girmesi,

- 1990: Tokyo borsasının çökmesi, Japonya'da finansal kırılganlığın ortaya çıkması ve uzun süreli durgunluk,

- 1990-91: Irak’a ambargo ve izleyen Körfez Savaş1; bölgeden turist ve sermaye kaçışı,

- 1992-93 (yaz ayları): Avrupa paraları aleyhine spekülasyon sonucu Türkiye'ye rakip ülkeler paralarının devalüasyonu; ABD'ye sermaye kaçışı; ABD'de hızlı, AB'de yavaş büyüme; doların değerlenmesi,

- 1997-99: Uzak Doğu ve Güneydoğu Asya ülkelerinde kriz; bu ülkeler ve GOÜ’den sermaye kaçışı; petrol fiyatının çökmesi; ülke paralarında büyük çaplı devalüasyonlar; dünya pazarının daralması,

- 1998: Asya krizinin Rusya'ya intikali ve Rusya'nın moratoryum ilanı; bölgeden sermaye kaçışı ve kredi faizlerinin artışı; rublenin devalüasyonu; Rusya pazarının daralması gibi çok kısa bir zaman dilimi içinde Dünya'nın çeşitli bölgelerinde önemli krizlerin yaşandığ 1 görülmektedir.

Türkiye'de 1978, 1994 ve 2001 yıllarında önemli sayılabilecek finansal krizler görülmüştür.

Ayrıca Asya ve Rusya krizi de Türkiye'yi önemli ölçüde etkilemistir. 1978 yılında yaşanan, daha doğrusu 1980 öncesi Türkiye'de yasanan krizler daha çok Türkiye'de mal ve emek piyasalarının gelişmediği, döviz piyasası ile para piyasalarının mevcut olmadıgı ortamlarda doğmuş olan krizlerdir.

Türkiye'de turizm hamlesinin başladığı 1980 yılından 1999 yılına kadar olan yirmi yıllık döneme ait yabancı ziyaretçi sayıları ve yabancı ziyaretçi harcamaları incelendiğinde (Tablo 1); 1980 yılında 1.288 bin turistin geldiği ve 326 milyon dolarlık dış turizm geliri elde edildiği görülmektedir. 1989 yılına gelindiğinde 10 yılda toplam 24,3 milyon yabancı turistle, 11,6 milyar dolarlık dış turizm geliri elde edildiği söylenebilir. İkinci 10 yıllık dönem olan 1990- 
1999 yılları arasında da rakamların katlanarak büyüdüğü görülmektedir: 1990-1999 döneminde birinci 10 yılın rakamları neredeyse üçe katlanmıştır.

Yabancı turist sayısı 74,4 milyon, dış turizm geliri 49,8 milyar dolar olarak gerçekleşmiştir. Bununla birlikte yıllar itibari ile yabancı ziyaretçi sayısı değişimlerine bakıldığında; 1982 yılında gelen ziyaretçi sayısı bir önceki yıla oranla \%1 gerilerken, 1986 yılında \%8,5 gerileme, 1993 yılında \%8,1 gerileme ve 1999 yılında \%23,4 gerileme gözlenmektedir. Özellikle 1999 yılındaki ziyaretçi sayısı düşüşünde Dünya'da meydana gelen Asya krizinin yanı sıra Türkiye'de meydana gelen 17 Ağustos depreminin de etkili olduğu söylenebilir.

\begin{tabular}{|c|c|c|c|c|}
\hline Yıllar & $\begin{array}{c}\text { Yabancı Ziyaretçi } \\
\text { Sayısı (Bin kişi) }\end{array}$ & $\begin{array}{c}\text { Değişim } \\
\mathbf{\%}\end{array}$ & $\begin{array}{c}\text { Yabancı Ziyaretçi } \\
\text { Harcaması (Milyon \$) }\end{array}$ & $\begin{array}{c}\text { Değişim } \\
\text { \% }\end{array}$ \\
\hline $\mathbf{1 9 8 0}$ & 1288 & $*$ & 326 & $*$ \\
\hline $\mathbf{1 9 8 1}$ & 1405 & 9,1 & 381 & 16,9 \\
\hline $\mathbf{1 9 8 2}$ & 1391 & -1 & 370 & $-2,9$ \\
\hline $\mathbf{1 9 8 3}$ & 1625 & 16,8 & 411 & 11,1 \\
\hline $\mathbf{1 9 8 4}$ & 2117 & 30,3 & 840 & 104,4 \\
\hline $\mathbf{1 9 8 5}$ & 2614 & 23,5 & 1482 & 76,4 \\
\hline $\mathbf{1 9 8 6}$ & 2391 & $-8,5$ & 1215 & -18 \\
\hline $\mathbf{1 9 8 7}$ & 2855 & 19,4 & 1721 & 41,6 \\
\hline $\mathbf{1 9 8 8}$ & 4172 & 46,1 & 2355 & 36,8 \\
\hline $\mathbf{1 9 8 9}$ & 4459 & 6,9 & 2556 & 8,5 \\
\hline $\mathbf{1 9 9 0}$ & 5389 & 20,9 & 2705 & 5,8 \\
\hline $\mathbf{1 9 9 1}$ & 5517 & 2,4 & 2654 & $-1,9$ \\
\hline $\mathbf{1 9 9 2}$ & 7076 & 28,3 & 3639 & 37,1 \\
\hline $\mathbf{1 9 9 3}$ & 6500 & $-8,1$ & 3959 & 8,8 \\
\hline $\mathbf{1 9 9 4}$ & 6670 & 2,6 & 4321 & 9,1 \\
\hline $\mathbf{1 9 9 5}$ & 7726 & 15,8 & 4957 & 14,7 \\
\hline $\mathbf{1 9 9 6}$ & 8614 & 11,5 & 5650 & 13,9 \\
\hline $\mathbf{1 9 9 7}$ & 9689 & 13 & 7008 & 23,9 \\
\hline $\mathbf{1 9 9 8}$ & 9752 & 0,6 & 7177 & 2,4 \\
\hline $\mathbf{1 9 9 9}$ & 7464 & $-23,4$ & 5193 & $-27,6$ \\
\hline
\end{tabular}

Tablo 1: 1980-1999 yılları arası Türkiye’ye gelen yabancı ziyaretçi sayısı ve yabancı ziyaretçi harcaması. Kaynak: TÜRSAB

Yabancı ziyaretçi harcamaları değişimi incelendiğinde 1986 yılında ziyaretçi sayısının \%8,5 azalmasına karşılık yabancı ziyaretçi harcamalarının \%18 azaldığı görülmektedir. Dikkat çekici bir diğer nokta da 1991 yılında Türkiye'ye gelen yabancı ziyaretçi sayısında bir önceki yıla oranla \%2,4 artış olurken, harcamalarda \%1,9 azalma gerçekleşmiş olmasıdır. Yine 1999 yılında ziyaretçi sayısı \%23,4 azalırken, yabancı ziyaretçi harcamaları \%27,6 azalma göstermiştir.

Kazgan 1998 Rusya krizi ve rublenin devalüasyonu hem mal hem hizmet (başta giyim eşyası, turizm ve taşıma) pazarını daraltırken sermaye kaçışına da ivme vermiştir; 1999'un ilk yarısında A. Öcalan'ın yakalanmasını izleyen Alman kamuoyu tepkisiyle turist gelişinin durması 1999 yılı turist sayısında azalmaya neden olmuştur (Kazgan). 


\begin{tabular}{|c|c|c|c|c|}
\hline Yıllar & $\begin{array}{c}\text { Sayısı } \\
\text { (Bin kişi) }\end{array}$ & $\mathbf{\%}$ & $\begin{array}{c}\text { Harcaması } \\
\text { (Milyon \$) }\end{array}$ & \% \\
\hline $\mathbf{2 0 0 0}$ & 10412 & 39 & 7636 & 47 \\
\hline $\mathbf{2 0 0 1}$ & 11569 & 11 & 8090 & 5,9 \\
\hline $\mathbf{2 0 0 2}$ & 13247 & 14,5 & 8481 & 4,7 \\
\hline $\mathbf{2 0 0 3}$ & 14030 & 5,3 & 9677 & 14,1 \\
\hline $\mathbf{2 0 0 4}$ & 17517 & 24,8 & 12125 & 25,3 \\
\hline $\mathbf{2 0 0 5}$ & 21124 & 20,6 & 13929 & 14,8 \\
\hline $\mathbf{2 0 0 6}$ & 19819 & $-6,2$ & 12553 & $-9,8$ \\
\hline $\mathbf{2 0 0 7}$ & 23341 & 17,7 & 13990 & 11,4 \\
\hline $\mathbf{2 0 0 8}$ & 26337 & 12,8 & 16761 & 19,8 \\
\hline $\mathbf{2 0 0 9}$ & 27077 & 2,8 & 15853 & $-5,4$ \\
\hline
\end{tabular}

Tablo 2: 2000-2009 yılları arası Türkiye'ye gelen yabancı ziyaretçi sayısı ve yabancı ziyaretçi harcaması. Kaynak: TÜRSAB

2000-2009 döneminde ise rakamlar sırasıyla 182,9 milyon kişi ve 154,5 milyar dolar gelir şeklinde gerçekleşmiştir. Turizm sektörünün 30 yıllık geçmişinde elde ettiği kazanımlar toplam 281,7 milyon yabanc1 turist ve 216 milyar dolar diş turizm geliri olmuştur. Tablo 2 incelendiğinde 2006 yılında yabancı ziyaretçi sayısı \%6,2 azalma gösterirken, aynı yıl yabancı ziyaretçi harcamaları da \%9,8 azalmıştır. Dünyada 2008 krizinin yaşanmasının ardından 2009 yılında Türkiye'ye gelen yabancı ziyaretçi sayısında $\% 2,8$ 'lik küçük bir artış yaşanmasına rağmen yabancı ziyaretçi harcamaları $\% 5,4$ oranında gerilemiştir.

\section{Dünyada Turizm ve Krizin Etkisi}

Birleşmiş Milletler Dünya Turizm Örgütü’nün (BMDTÖ) Bakü'de düzenlediği 49. BMDTÖ Avrupa Komisyonu Toplantısında uluslararası seyahat hareketinin 2009 yılında yüzde 2 düzeyinde azalacă̆ı, Avrupa'da ise daralmanın yüzde 3 civarında olacağı beklentisi hakimdi. (Tursab, 2009).

2008 yılında başlayan durgunluğun, yolculuk talebini etkileyen en fazla etkiyi 2009 yılında gösterip göstermediğini bir ölçüde ortaya koymak amacıyla dünyada en çok turist alan 10 ülkeye gelen turist sayıları ve turizm geliri açısından en yüksek gelire sahip 10 ülke incelenmiş ve 2008- 2009 verileri karşılaştırılmıştır. Tablo 3’te görüleceği üzere; 2008 yılında 79,3 milyon kişi ve dünyada \%8,6’lık bir pay ile Fransa birinci sırada yer almaktadır. ABD 58 milyon kişi ile ikinci sırada, İspanya ise 57,3 milyon kişi ile üçüncü sırada yer almıştır. Fransa'nın hemen arkasından gelen ABD ile arasında 19 milyon kişi gibi azımsanmayacak bir üstünlüğün olması dikkat çekicidir. 2008 yılı verileri itibari ile Türkiye en çok turist alan 10 ülke sıralamasında 25 milyon kişi ile 8 . sırada yer almıştır.

\begin{tabular}{|c|c|c|c|}
\hline & & & Turist Sayısı \\
\hline No & Ülke & Milyon Kişi & Dünyadaki Payı (\%) \\
\hline 1 & Fransa & 79,3 & 8,6 \\
\hline 2 & $\mathrm{ABD}$ & 58,0 & 6,3 \\
\hline 3 & İspanya & 57,3 & 6,2 \\
\hline 4 & Çin & 53,0 & 5,7 \\
\hline 5 & İtalya & 42,7 & 4,6 \\
\hline 6 & İngiltere & 30,2 & 3,3 \\
\hline 7 & Ukrayna & 25,4 & 2,8 \\
\hline 8 & Türkiye & 25,0 & 2,7 \\
\hline 9 & Almanya & 24,9 & 2,7 \\
\hline 10 & Meksika & 22,6 & 2,5 \\
\hline \multicolumn{2}{|c|}{ Dünya Toplamı } & 922 & \\
\hline
\end{tabular}

Örgütü, * Günübirlikçiler hariç 
2009 yılında dünyada en çok turist alan 10 ülke incelendiğinde (Tablo 4); bir önceki yıl siralamada 8. sirada yer alan Türkiye'nin 7. sıraya, 9. sirada yer alan Almanya'nın ise 8. siraya yükseldiği görülmektedir. 2008 verileri ile 7. sırada yer alan Ukrayna 2009 yılında listeden düşmüș, onun yerini 9. sırada Malezya almıștır. Tablo 4 incelendiğinde 2009 y1lında ilk onda yer alan ülkelerden Türkiye ve İtalya hariç hepsinde bir önceki yıla göre düşüş yaşandığ 1 görülmektedir. Türkiye bir önceki y1la göre \%2'lik bir artış ile en çok artıșı yakalayan ülke konumundadır. İtalya'da ise artıș oranı $\% 1,2$ 'dir. Turist sayısındaki en büyük azalma ise $\% 8,9$ ile İspanya'da yaşanmıștır. İspanya'yı \%7,3'lük düşüs ile İngiltere izlerken, Fransa'da azalma \%6,4 olarak gerçekleșmiștir. Bu tabloda bir diğer önemli gelișme Malezya'nın 2009 yılında daha önceki seneler ilk 10 ülke içerisinde yer almadığı halde turist varışları arasında 9.sırada yer almasidır.

\begin{tabular}{|c|c|c|c}
\hline \multicolumn{4}{|c|}{} \\
Turist Sayısı \\
\hline No & Ülke & Milyon Kişi & Önceki yıla göre değişim (\%) \\
\hline 1 & Fransa & 74,2 & $-6,4$ \\
\hline 2 & ABD & 54,9 & $-5,3$ \\
\hline 3 & İspanya & 52,2 & $-8,9$ \\
\hline 4 & Çin & 50,9 & $-3,9$ \\
\hline $\mathbf{5}$ & İtalya & $\mathbf{4 3 , 2}$ & $\mathbf{1 , 2}$ \\
\hline 6 & İngiltere & 28,0 & $-7,3$ \\
\hline $\mathbf{7}$ & Türkiye & $\mathbf{2 5 , 5}$ & $\mathbf{2 , 0}$ \\
\hline 8 & Almanya & 24,2 & $-2,8$ \\
\hline 9 & Malezya** & 23,6 & $* *$ \\
\hline 10 & Meksika & 21,5 & $-4,9$ \\
\hline
\end{tabular}

Tablo 4: 2009 verileri ile Dünya'da en çok turist alan 10 ülke Kaynak: Dünya Turizm Örgütü + Euromonitor, **2008 yllında ilk onda yok

Dünya'da turizm geliri en yüksek 10 ülkeye bakıldığında turist sayısı bakımından ikinci sırada yer almasına rağmen gelir sıralamasında birinci olan ABD görülmektedir. 110,1 milyar dolarlık turizm geliri ile ABD dünya turizm gelirlerinin \%11,7'lik kısmını almaktadır. Yine turist sayısı açısından üçüncü sırada görülen İspanya, gelir sıralamasında 61,6 milyar dolar ile ikinci olurken, turist sayısı ile birinci olan Fransa, turizm geliri açısından ancak üçüncü sırada yer almıştır. Bu veriler, Fransa'ya giden turist sayısının çok olmasına rağmen bu ülkeye gelen turistlerin $\mathrm{ABD}$ ve İspanya'ya giden turistlere oranla daha az para harcadıklarını göstermektedir. Türkiye, turizm geliri açısından en yüksek gelire sahip ülkeler arasında, 22 milyar dolar ile 9. sırada yerini almıştır.

\begin{tabular}{|c|c|c|c|}
\hline \multicolumn{2}{|c|}{} & \multicolumn{2}{c|}{ urizm Geliri } \\
\hline No & Ülke & Milyar Dolar & Dünyadaki Payı (\%) \\
\hline 1 & ABD & 110,1 & 11,7 \\
\hline 2 & İspanya & 61,6 & 6,5 \\
\hline 3 & Fransa & 55,6 & 5,9 \\
\hline 4 & İtalya & 45,7 & 4,8 \\
\hline 5 & Çin & 40,8 & 4,3 \\
\hline 6 & Almanya & 40,0 & 4,2 \\
\hline 7 & İngiltere & 36,0 & 3,8 \\
\hline 8 & Avustralya & 24,7 & 2,6 \\
\hline 9 & Türkiye & 22,0 & 2,3 \\
\hline 10 & Avusturya & 21,8 & 2,3 \\
\hline \multicolumn{2}{|c|}{ Dünya Toplamı } & $\mathbf{9 4 4}$ & \\
\hline
\end{tabular}

Tablo 5: 2008 verileri ile Dünya'da turizm geliri en yüksek 10 ülke. Kaynak: Dünya Turizm Örgütü 
Bütün Dünya'da 2008 krizinin yaşanmasının ardından 2009'da turizm gelirlerindeki değişmeler Tablo 6'da verilmiştir. 2008 yılında 9. sırada yer alan Türkiye, 2009 yılına gelindiğinde turizm gelirleri sıralamasında 10. siraya düşmüş, Avusturya ise 10. sıradan 9. sıraya yükselmiştir. İlk onda yer alan diğer ülkelerin turizm gelirleri sıralamasında ise bir değişme yaşanmamışıtır. Dikkat çeken bir diğer nokta ise turist sayıları açısından ilk onda yer almayan Çin, Avustralya ve Avusturya'nın, turizm geliri açısından ilk onda yer almasıdır. Bu da bu ülkelere giden turist sayısının az olmasına rağmen gelirlerinin fazla olduğunu göstermektedir. Çin fuar ve kongre turizmi ile Avusturya kayak turizmi gelirlerleri ile Avustralya da alternatif turizm anlayışı ile gelirlerini yükseltebilmiş olmalarıdır.

\begin{tabular}{|l|l|c|c}
\hline \multicolumn{2}{|c|}{ Ülke } & Milyar Dolar & Ourizm Geliri \\
\hline $\mathbf{N o}$ & ABD & 94,2 & $-14,4$ \\
\hline 1 & İspanya & 53,2 & $-13,6$ \\
\hline 2 & Fransa & 48,7 & $-12,4$ \\
\hline 3 & İtalya & 40,2 & $-12,0$ \\
\hline 4 & Çin & 39,7 & $-2,7$ \\
\hline 5 & Almanya & 34,7 & $-13,2$ \\
\hline 6 & İniltere & 30,1 & $-16,4$ \\
\hline 7 & Avustralya & $\mathbf{2 5 , 6}$ & $\mathbf{3 , 6}$ \\
\hline $\mathbf{8}$ & Avusturya & $\mathbf{2 3 , 0}$ & $\mathbf{4 , 5}$ \\
\hline $\mathbf{9}$ & Türkiye & 21,3 & $-2,3$ \\
\hline 10 & &
\end{tabular}

Tablo 6: 2009 verileri ile Dünya'da turizm geliri en yüksek 10 ülke. Kaynak: Dünya Turizm Örgütü

Tablo 6 incelendiğinde turizm gelirlerindeki en büyük düşüşün \%16,4 ile İngiltere'de olduğu görülmektedir. İngiltere'yi \%14,4 ile ABD, \%13,6 ile İspanya, \%13,2 ile Almanya izlemektedir. Yaşanan krizin olumsuz etkilerine rağmen 2009 yılında turizm gelirlerini arttıran iki ülkenin varlığg gözlenmektedir. Bu ülkeler; bir önceki yıla göre \% 4,5 büyüme ile Avusturya ve \%3,6 artış ile Avustralya'dır. Türkiye'de bir önceki yıla oranla ağırlanan turist sayısı \%2 artış göstermesine rağmen, bu artışın gelirlere yansımadığ 1 ve turizm gelirlerinde $\% 2,3$ 'lük bir düşüş yaşandığı görülmektedir. Aynı şekilde İtalya da bir önceki yıla oranla turist sayısını $\% 1,2$ arttırmış, ancak gelirlerinde \%12'lik bir azalma yaşamıştır. Bu da insanların turistlik amaçlarla yaptıkları gezileri sürdürmelerine rağmen, gittikleri ülkelerdeki harcamalarını kıstıkları anlamina gelmektedir.

\section{Sonuç}

1980-2009 yılları arasında geçen 30 yıl boyunca Türkiye'ye gelen turist sayıları ve elde edilen turizm gelirleri incelendiğinde, çeşitli yıllarda görülen azalmaların genellikle Dünya'da ya da Türkiye'de meydana gelen ekonomik krizlerle ilişkili olduğu görülmektedir.

Bütün Dünya'yı etkisi altına alan 2008'de yaşanmaya başlayan ve etkileri halen devam eden Global Ekonomik krizin Türkiye'de ve Dünya'da turist sayıları ve turizm gelirleri üzerindeki etkisinin ölçülmesi amacıyla, Dünya'da en çok turist alan 10 ülke ve en çok turizm gelirine sahip olan 10 ülke incelenmiş ve bu ülkelerin gerek turist sayısı gerekse turizm geliri açısından 2008 den 2009'a geçildiğinde genel eğilim olarak azalma yaşadıkları tespit edilmiştir. (2008 krizi sonrası Avusturya ve Avustralya turizm gelirlerini hariç tutarak). Oysa ki bu ülkelerin 2006, 2007, 2008 yıllarına ait turizm geliri verilerine bakıldığında yıldan yıla artan bir eğilim bulunmaktadır.

Geçmişte yaşadığımız ekonomik krizler ya da 11 Eylül saldırılarındaki gibi terör olayları sonrasında tecrübe ettiğimiz üzere kriz zamanları ve hemen sonrasında insanlar seyahat etmeye devam ederler fakat bu ekonomik canlılık dönemlerinden daha farklı şekilde gerçekleşir. Ekonomik dalgalanmalarda hayatta kalacak olan ve hatta bazen kriz sonrası ilerleyen aylarda 
işleri daha iyiye gidecek olan turizm ve otelcilik işletmeleri gerçekten kendini kriz ortamına adapte edebilenler olacaktır. Ekonomik dalgalanmalarda her zaman kazananlar ve kaybedenlerin olması doğaldır.

Kisa ve orta vadede seyahatin daha az harcama yapma eğiliminde olan gezginler tarafindan yapılması nerdeyse emin olduğumuz bir gerçektir. Daha sıkı bir bütçeye adapte olan turizm ve otelcilik işletmeleri hizmetlerini sürdürmekte başarılı olmaya devam edeceklerdir. Kriz zamanlarında piyasanın lüks ürün ve hizmetlere olan talebinin düşeceği; düşük maliyetli veya sağladığı hizmetin değeri ile iyi algılanan ürün ve hizmetlere talebin artacağı beklenilmektedir.

Havayolları ve oteller özellikle hızla bu eğilime adapte edebilmelidir. Döviz durgunluklarında, avantajlı döviz kurlarına sahip destinasyonlardan yararlanabilirler. ABD dolarının ve Euro'nun değerindeki dalgalanmaların Amerikalı, Avrupalı ve Japonların yurtdışına seyahate devam etmesinde olduğu gibi. Hükümetlerde uluslararası hava seyahat maliyetinin şişirilmesine neden olan vergileri gözden geçirerek global turizm endüstrisine yardımcı olabilirler.

Bütün sektörlerde olduğu gibi turizm sektörünün de Global Ekonomik krizden etkilendiği söylenmekle birlikte, diğer sektörlere oranla ne ölçüde etkilendiğinin araştırılması da bir başka araştırmanın konusu olacaktır.

\section{Kaynakça}

- Apak, Sudi; Aytaç, Ayhan, 2009. “Küresel Krizler”, Avcıol Basım Yayın, İstanbul.

- Hakan, Özkul, 2001. “Krizlerin Turizm Üzerindeki Etkileri/Turizm Kriz İlişkisi”, 2. Ulusal Türkiye Turizmi Sempozyumu Tebliğler Kitabı, İzmir

- Kazgan, Gülten 2001. “Türkiye’de Ekonomik Krizler: (1929-2001) Nedenleri ve Sonuçları Üzerine Karşılaştırmalı Bir İrdeleme”, İstanbul Bilgi Üniversitesi, DEGEV Türkiye İş Bankası

- Oktayer, Susam \& Çak, 2007. “Türkiye'de Turizm Ekonomisi”, İstanbul Ticaret Odası Yayınları

- $\quad$ Ryan, Chris, 2003. Recreational Tourism: Demand and Impacts (2nd ed.) Channel View Publications, Clevedon

- Yağcı, Özcan 2003. Turizm Ekonomisi, Detay Yayıncılık, Ankara

- WTO, Compendium of Tourism Statistics, Madrid, 2010 Edition

- "UNWTO World Tourism Barometer June 2009". UNWTO World Tourism Barometer (World Tourism Organization) 7 (2). June 2009. http://unwto.org/facts/eng/pdf/barometer/UNWTO_Barom09_2_en_excerpt.pdf.

- UNWTO World Tourism Barometer January 2010. 8. World Tourism Organization. January 2010. http://unwto.org/facts/eng/pdf/barometer/UNWTO_Barom10_1_en_excerpt.pdf.

- $\quad$ http://www.tursab.org.tr/dosya/933/5 933 4917192.ppt (Ekim 2010 tarihinde alınmıştır.)

- $\quad$ www.euromonitor.com/Travel_And_Tourism (Ekim 2010 tarihinde alınmıştır.) 


\title{
Кыргызстан: трудный путь к оздоровлению
}

\author{
Турар Койчуев, академик, Кыргызско-Турецкий университет «Манас», \\ Кыргызстан \\ Turar Koychuev, Kyrgyz-Turkish Manas University
}

\begin{abstract}
Kyrgyzstan: The Hard way to Recovery

The paper analyzes the reasons of the overturn in the power in April 2010, considers the economical difficulties, the country is facing on, the present condition of the economy and its perspectives. It indicates the priorities of the Kyrgyz foreign economic activity. The problems of governing over the economy and social-economical policies are considered.

The world economic crisis, undoubtedly, has influenced on the economy of the country. Reduction of international financial resources decreased inflow of foreign investments in the country. The financial crisis influenced on the demand of our export. The import of manufacturing and consumer goods decreased, whereas our republic is very dependent from import. The crisis influenced on technological modernization and renewal of production. In addition, the crisis in our country could provoke to growth of corruption.

Nevertheless all these negative conditions could move us to positive solutions. The economy of the country must find effective methods for using internal investments, accumulate them in government and private founds for this could secure the economy in risky situations. It is time to create efficient system of ruling over the economy and activity of the Kyrgyz Republic.
\end{abstract}

JEL codes: A10, P20

\section{1 Причины апрельского (2010) переворота во власти.}

Какие же условия, предпосылки и факторы обусловили очередной апрельский (2010 г.) переворот во власти Кыргызской Республике?

Отсутствие стабильности и устойчивости в развитии экономики. В реальном секторе экономики, наиболее пострадавшем в 1991-2005 гг., не произошло весомых позитивных изменений и он продолжал терять свою значимость, в особенности в промышленности. Рабочие места не увеличивались, а сокращались фактически, а не по зафиксированным данным, безработица возрастала. Численность трудовых мигрантов, выезжающих за пределы республики не убавлялась. Оживление и экономический рост отдельных годов «замещался» стагнацией или спадом в другие годы. В среднем в 2005-10 гг. темпы роста ВВП не превысили темпы 2000-05 гг. Не произошло и прогрессивных, привлекательных и предпочтительных структурных изменений, в которых отразились бы комплексность развития, технологическое обновление, инновационная направленность и социальная ориентированность. Сохранялось ущербное состояние экономики. По ВВП в расчете на душу населения республика в странах СНГ занимает одно из последних мест, а в мире входит в число 12-ти самых отсталых стран.

Как следствие неполноценной экономики уровень жизни населения остается невысоким. За чертой бедности, по официальным статистическим данным, находится одна пятая часть населения страны. Фактически удельный вес бедного населения гораздо выше. Разрыв в уровнях жизни между богатыми, среднедостаточными и бедными резко возрастает. Богатые слои в численности населения занимают малый удельный вес, но в размеры их доходов многократно превышают доходы других слоев. Практически большая часть населения находится за чертой бедности, их доходы позволяют им только сводить концы с концами. Среднего достатка люди, которые должны бы составить «костяк» социальной структуры населения и доходы которых должны бы обеспечить 
социально-приемлемый уровень жизни, составляют меньшую чем бедную часть населения, и из этого слоя только меньшая группа способна войти, при благоприятных условиях экономики, в слой богатых, а большая группа озадачена тем, чтобы не упасть и не оказаться среди бедных. Малый и средний бизнес не стал еще надежно работающим. Неуверенное движение экономики и рост цен отражаются на уровне доходов и потребительских расходов всего населения. Оно не богатеет, а беднеет.

На фоне мало-производящей экономики и бедности населения в стране расцвела коррупция. Происходит криминализация общества. Коррупция поглотила все эшелоны власти. Молчаливо взаимосогласованная, взаимосвязанная коррупционная политика власти подменила истинную цель государства, которая должна обеспечить процветание экономики во имя блага народа, и корыстные цели власть имущих взяли верх. Государство и власть практически стали государством и властью для властьимущих. Чтобы защитить эту «антинародную» картину, власть начала сращиваться с криминалом, когда он начал входить, ногой открывая двери, в государственные структуры в качестве высоких чинов. Захват чужого имущества силовыми приемами, принуждение к отказу от имущества, заказные убийства бизнесменов, государственных чиновников, клановые разборки соперничающих криминальных группировок стали обыденным явлением. Атмосфера стала появляться и охватывать не властьдержащую и криминальную среду, но и шире ту среду, которая не имеет доступа к власти, не является богатой, из которой можно выжать и не относится к криминальной, в которой каждая группировка опасается и подозрительно смотрит на группировку рядом, потенциального конкурента.

Государственное управление социально-экономическим развитием в реальности отсутствует. Ни одна декларированная программа развития не реализована. Не приняты кардинальные, эффективные меры по совершенствованию управления. Шла имитация. Если что-то менялось, то в сторону утверждения личной власти, кланового окружения. Демократические принципы менялись диктаторскими методами и механизмами. Внедрялась неработающая система управления, а разлагающая и антисостоятельная, в которой легко свершать корыстные замыслы. Кадры управления составлялись в основном только из избранного круга своих. К власти на разных уровнях и в аппараты управления привлекались неквалифицированные, неопытные, а порой вообще не имеющие отношения к данной деятельности люди. Такая порочная практика развращала систему власти и вызывала недоверие к ней, разочарование в ее деятельности и «готовила» почву не восприятия.

Власть не просто плохо управляла или вовсе не управляла, а стала «покушаться» на жизненные интересы населения, которое и так живет в стесненных условиях. Резкий, необоснованный рост тарифов на потребление электроэнергии и другие коммунальные услуги, выдуманные платы за мифические услуги связи, на железнодорожном транспорте подвели население к той черте, когда до «взрыва» возмущения не хватало только детонатора и пороха.

Стремление к личной власти и диктаторские замашки привели к тому, что президент стал шаг за шагом освобождаться от близости во власти тех соратников, которые вместе с ним стояли у Белого дома в 2005 году. И они стали один за другим переходить в оппозицию. Вот это движение в Кыргызстане от власти в оппозицию и обратно от оппозиции во власть показывает, что эти смены во власти свершались, не ради республики и народа, а ради власти как таковой. Ведь, никто не замышлял и не менял государственно-политическое устройство республики, а происходила смена персон. А поскольку это происходило нецивилизованно и не в правовом поле, а насильственно, то эту смену персон можно классифицировать как переворот, но поддержанный обществом. Но в это перевороте не столько вина оппозиции, сколько власти, злоупотреблявшей положением. Власть взяла курс на силовые методы борьбы с оппозицией и стала арестовывать лидеров оппозиции одних за другими, далее перешла к силовым методам разгона митингующих за свои права, используя силовые структуры, спецназ и 
снайперов. Предполагаемый митинг у Белого дома 7 апреля 2010 мог завершиться мирным исходом, если бы не снайперские пули с крыш Белого дома и появление жертв.

Сегодня нереально и неправомерно ждать от новой власти решения всех накопившихся экономических и социальных проблем. Ей надо политически честно и прозрачно, морально чисто, последовательно и неукоснительно, организовано и решительно обеспечить политическую стабильность.

Новое правительство должно состоять из единомышленников, бескорыстных, чистоплотных, честных, умных и мудрых, а не заниматься «драчкой». Амбиции должны быть отброшены, власть не должна забывать свою ответственность перед страной и народом.

И дальше уже должна пойти продуманная, кропотливая, основательная, постоянная работа по укреплению демократии, подъема экономики и уровня жизни народа, достижению человекориентированной, ставящей интересы страны и народа превыше всего, системы государственной власти, обеспечивающей стране политическое и социальное спокойствие и способствующей созданию благополучия и процветанию народа.

Необратимость процессов, направленных на демократизацию общественной жизни республики, зависит от общественной активности социальных слоев населения и от того, достойные ли личности придут к власти. Надо восстановить и защищать конституционно провозглашенную демократию. Общество должно стать активным. Законы должны исключить возможность поворота к авторитаризму, защищать процесс демократизации и они (законы) должны соблюдаться неукоснительно, всеми без исключения. Никому никаких особых прав. Перед законом все должны быть равны. Акцентированно подчеркиваю: у нас не было революций как в 2005-м, так и в 2010-м году, а были общественные массовые митинги и народ сместил с высших государственных постов лиц, не оправдавших доверия народа и злоупотреблявших высоким должностным положением, проводивших политику утверждения личной или клановой диктатуры, отхода от демократических принципов и нарушая конституционный курс к демократизации.

Поскольку речь идет не о революциях, не о смене государственно-правового, общественно-политического и социально-экономического строя и что все это надо строить сначала, а каких-то особых этапах, имеющих политическое значение, нет просто необходимости говорить. Нужна «ежедневная», постоянная работа по обеспечению стабильности и устойчивости движения на пути к демократизации. Гарантом защиты демократизации и выбранного пути развития являются законы и их неукоснительное исполнение, социальная солидарность, активная позитивная деятельность во всех областях жизнедеятельности, общественный контроль над деятельностью власти, отчетность власти перед обществом, установление эффектного и действенного канала взаимосвязи и партнерства «общество- власть». Народ Кыргызстана может объединить осознание и ответственность каждого гражданина республики за судьбу страны, народа и своей семьи, выраженные в чувстве патриотизма.

\section{2 Преодоление экономических трудностей}

Мировой финансовый кризис, безусловно, повлиял на экономику страны. Во-первых, сокращение финансовых ресурсов и спад производств у иностранных партнёров ограничили приток иностранных инвестиций, что обусловили свертывание тех или иных проектов развития, связанных с иностранными инвестициями.

Во-вторых, финансовый кризис может повлиять на востребованность нашего экспорта. Партнер постарается сохранить связи с крупными партнерами. Наш экспорт настолько структурно беден и незначителен, что без него смогут обойтись, а для нас это отразится 
весьма болезненно.

В-третьих, сократился импорт и производственных, и потребительских товаров, что обусловило сокращение производства и обеспеченность населения потребительскими товарами упала, которая и без этого низкая и потому относительно велико импортирование. Более того, продолжающиеся поступать импортные товары будут предлагаются уже по более высоким ценам.

В-четвёртых, кризис повлиял на технико-технологическое обновление и модернизацию производств на современном уровне, технический и технологический уровень производства в республике по большому счёту не выдерживает критику.

В-пятых, если не будет действенной борьбы с коррупцией, кризис может спровоцировать «вспышку» роста коррупции.

Но, как не парадоксально, из указанных негативов можно вынести позитивные выводы:

Во-первых, искать, находить и использовать эффективные направления, методы и формы использования собственных инвестиций, аккумулируя их в государственных и частных фондах, которые в рискованных ситуациях обеспечат дееспособность экономики.

Во-вторых, кризис - сигнал к тому, что пора экспортируемое сырьё (а мы вывозим в основном сырьё), перерабатывать у себя и экспортировать продукт переработки. Это дороже и выгоднее нам, а, главнее, восстанавливаем связи между своими сырьевыми и перерабатывающими отраслями.

В-третьих, сокращение импорта потребительских товаров (и продовольственных, и непродовольственных), может, наконец, «вынудит» нас к тому, чтобы мы у себя восстановили то, что было, и создавали новые производства, которые будут работать на народ. У нас есть ресурсы, чтобы собственное население накормить, одеть, обуть, обеспечить жильём.

В-четвертых, мы должны у себя создавать научно-исследовательские, изыскательские, проектные, экспериментально-внедренческие инженерные центры и соответствующие производства, нацеленные на производство новой техники и применение новых технологий. Разумеется, по всем отраслям экономики невозможно это осуществить, но по отраслям, имеющим для республики приоритетное значение, и по технике и технологиям, использование которых возможно во многих производственных процессах и во многих отраслях, нужно создавать такие комплексы и центры. Без них невозможно говорить о действенном развитом промышленном облике республики. В советское время Кыргызстан имел развитое многоотраслевое машиностроение, которое нами потеряно.

И, наконец, в-пятых, перед угрозой ухудшения экономической безопасности, а, значит, социальной стабильности, и шире национальной безопасности, борьба с коррупцией должна стать более жесткой, непримиримой и результативной.

В 2009 году влияние мирового экономического кризиса на развитие экономики Кыргызстана оказалось заметным и чувствительным. Свою негативную роль сыграло сильная зависимость от импорта ряда товаров производственного и потребительского характера.

Внешнеторговый оборот в январе-ноябре 2009 года сократился по сравнению с соответствующим периодом 2008 года на 25,4 процента, тогда как в 2008 году к 2007 году увеличился в 1,5 раза. Экспортные поставки в 2009 году к 2008 году снизились на 21,4 процента, а в 2008 году к 2007 году наблюдался рост в 1,5 раза. Импортные поступления уменьшились на 26,8 процента, а в 2008 году к 2007 году возросли в 1,5 раза.

Экспортные поставки республики по видам предпочтительно не отличались. Сократился импорт как важных для производства машин, оборудования и механизмов, 
нефтепродуктов, природного газа и угля, так и потребительских товаров и продовольствия, столь необходимых для обеспечения потребности в них. Объем поступлений пшеничной муки в натуральном выражении в январе-ноябре 2009 года составил лишь 66,1 процента объема соответствующего периода 2008 года. Фруктов - 64 процента; пива - 82,5 процента; сигарет и сигар - 73,4 процента, каменного угля - 70,2 процента; природного газа - 39,1 процента; проката черных металлов - 99,2 процента; новых легковых автомобилей 39,3 процента; автомобилей бывших в употреблении - 32,8 процента. Уменьшились поставки лесоматериалов, оборудования для электросвязи, медикаментов, предметов одежды и одежных принадлежностей и т.д.

В 2009 году по сравнению с 2008 годом внешние инвестиции уменьшились на 15 процентов и в общей сумме инвестиций их доля составила 25,8 процента против 36 процентов в 2008 году. Резко сократились прямые иностранные инвестиции - на 55,3 процента и составили всего 44,7 процента уровня 2008 года.

Как результат, произошло уменьшение и спад темпов экономического роста, снижение уровня жизни населения. ВВП в 2009 году по сравнению с 2008 годом возрос всего на 2,3 процента против 8,4 процента в 2008 году к 2007 году. Объем промышленной продукции сократился на 6,4 процента по сравнению с 2008 годом, тогда как в 2008 году по сравнению с 2007 годом был увеличен на 14,9 процентов. Уменьшились темпы роста в сфере услуг.

Уровень жизни населения остается проблемным. Повышение номинального уровня заработных плат и пенсий «сопровождается» ростом цен на продовольственные и потребительские товары. В результате величина прожиточного минимума в четвертом квартале 2009 года по сравнению с соответствующим периодом 2008 года снизилась на 4,7 процента, а по сравнению с МПБ 2008 года на 14,7 процента. Среднегодовая величина прожиточного минимума за 2009 год по отношению МПБ 2008 года снизилась на 8,: процента.

Если индекс потребительских цен в 2008 году к 2007 году составил 124,5 процента, то в 2009 году к 2088 году 106,8 процента. Скажем, удалось несколько «обуздать» инфляцию. Но не потому, что были предприняты и приняты в полной мере эффективные экономические методы механизмы. Причина, может быть, и в том, что произошел спад в основополагающей отрасли реального сектора экономики - промышленности, снизились темпы роста в других отраслях, в следствие чего уменьшились доходы не имеющей собственность, а зарабатывающей части населения и в целом уровень жизни населении снизился, денежных запасов у большинства населения нет, у сельского населения, а оно составляет большинство, в известной мере полунатуральный хозяйственный уклад, - и все это обусловило сокращение спроса на рынке на товары. Экономический спад произошел в экономике страны переживавшей не экономический бум и не увереностабильное состояние, а неустойчивость, нестабильность и невысокий уровень развития. От одного уровня неразвитости экономики, а значит, и спроса «спустились» к другому уровню неразвитости.

Экономика республики так и не приобрела стабильности и устойчивости развития. Сравним годовые темпы роста ВВП в 2003-2009 гг.: 2003 г. - 107,0\%; 2004 г. - 107,0\%; 2005 г. $-99,8 \%$; 2006 г. - 103,1\%; 2007 г. - 108,5\%; 2008 г. - 108,4\%; 2009 г. - 102,3\%. Относительно высокие темпы прерываются спадами или резким снижением темпов роста. Нет стабильности в динамике, что свидетельствует о слабой устойчивости экономики. На экономику влияют, как уже отмечено, политическая нестабильность и мировые процессы в экономике. Спад экономики в 2005 г. и незначительное повышение темпов в 2006 г. объясняются мартовскими событиями 2005 г. в политической жизни страны. Снижение темпов роста в 2009 г - это следствие влияния мирового финансово- экономического кризиса. Апрельские события 2010 года создали новую политическую ситуацию в республике. Покинул страну и второй Президент республики. Более того, против него заведено уголовное дело. С него снят иммунитет, и 
он отстранен от должности Президента. Политическая обстановка неспокойная. Естественно, что она отразилась на состоянии экономики и её движению трудно будет ожидать обнадеживающих результатов в 2010 году. Становится привычным делом через каждые 5 лет совершать «революции»...

А экономика может прийти в состояние ещё большей проблемности, чем сегодня. С тем имеющимся экономическим потенциалом и достигнутыми результатами до 2010 года, республика в своем развитии, если не будут приняты существенные меры по экономике и решительные действия по обеспечению политической стабильности, не достигнет прорывных успехов и останется в существующем ущербном положении. Сделаем некоторые сопоставления, чтобы не быть голословными.

\section{3 Что нас может ожидать ?}

Среднегодовые темпы ВВП в 2003-2009 годы составили 105,1\%. ВВП суммарно составил в текущих ценах 196.4 млрд. сомов или по среднемесячному курсу валют (1 долл. $=42,89$ сомов) достиг 4,6 млрд. долл. США. Условно представим цены 2009 г. как постоянные (a, значит, сопоставимые), как и постоянными курсы валют, и сделаем прогнозные расчеты ВВП на 2015, 2020, 2025, 2030 годы. Возьмем 2 варианта: 5\% прирост и $10 \%$ прирост ВВП.

\begin{tabular}{|c|c|c|c|c|c|c|}
\hline Годы & \multicolumn{3}{|c|}{ при 5\% приросте } & \multicolumn{3}{c|}{ при 10\% приросте } \\
\cline { 1 - 7 } & $\begin{array}{c}\text { Общий } \\
\text { рост, \% }\end{array}$ & $\begin{array}{c}\text { ВВП 2009г. } \\
\text { в } \\
\text { млрд.долл }\end{array}$ & $\begin{array}{c}\text { Прогно3 } \\
\text { млрд.долл. }\end{array}$ & $\begin{array}{c}\text { Общий } \\
\text { рост, \% }\end{array}$ & $\begin{array}{c}\text { ВВП 2009 } \\
\text { г. в } \\
\text { млрд.долл }\end{array}$ & $\begin{array}{c}\text { Прогно3 } \\
\text { млрд.дол } \\
\text { л. }\end{array}$ \\
\hline 2015 & 130,6 & 4,6 & 6,0 & 160 & 4,6 & 7,4 \\
\hline 2020 & 156,1 & 4,6 & 7,2 & 210 & 4,6 & 9,7 \\
\hline 2025 & 181,6 & 4,6 & 8,3 & 260 & 4,6 & 12,0 \\
\hline 2030 & 207,1 & 4,6 & 9,5 & 310 & 4,6 & 14,3 \\
\hline
\end{tabular}

Таблица 1. Прогноз ВВП

Среднегодовой рост населения в 2003-2009 гг. составил 100,7\%. Представим условно, что этот среднегодовой рост сохранится в 2010-2030 гг. В этом случае к 2015 году численность населения (за 6 лет) достигнет 5,6 млн. человек, к 2020 г. (за 11 лет) - 5,78 млн. человек, к 2025 г. (за 16 лет) - 5,97 млн. человек, к 2030 г. (за 21 лет) - 6,16 млн. человек.

Прогнозные расчеты ВВП на душу населения показывают, какой суммы они достигнут при 5\%-х и 10\%-х среднегодовых темпах прироста ВВП:

\begin{tabular}{|c|c|c|}
\hline Годы & при 5\% с/г темпе прироста & при $10 \%$ с/г темпе прироста \\
\hline 2015 & 1071 & 1321 \\
\hline 2020 & 1246 & 1678 \\
\hline 2025 & 1390 & 2003 \\
\hline 2030 & 1542 & 2321 \\
\hline
\end{tabular}

Таблиияа 2. ВВП на душу населения (в долл. США)

1542 доллара США на душу населения, при 5\% среднегодовом росте означает, что ВВП в 2030 году на душу населения в месяц составит 128,5 долларов, если взять сегодняшний курс доллара к рублю, 5848 сомов. При 10\% среднегодовом росте, в 2030 году ВВП на душу населения в месяц составит 193,4 доллара, или 8799 сомов. При обеих 
вариантах республика остается в группе стран с доходами ниже среднего уровня. Человеку для жизни от указанных сумм ВВП на душу населения на руки выпадет еще меньше денег. При 5\% среднегодовом росте ВВП, если исходить из сложившегося соотношения душевого дохода населения и душевого ВВП (денежные доходы составили $63 \%$ от ВВП), ежемесячный доход населения в расчете на человека к 2030 году составит 3684 сомов, при $10 \%$ среднегодовом росте - 5543 сомов. На эти суммы невозможно нормально прожить не только в 2030 году, но и сейчас (в 2009 г. прожиточный минимум на душу населения составил 3263 сома). А к 2030 году стоимость жизни будет заметно возрастать.

Конечно, расчеты носят условный характер. Во-первых, цены будут меняться. В каких темпах и масштабах - на 20 лет, трудно предвосхищать. ВВП 2030 г.в текущих ценах в какую сумму выйдет и в сопоставимых ценах 2009 г. какого объема достигнет неизвестно. Курс валюты (доллар к сому) тоже не останется неизменным. Улучшится экономическое развитие - курс будет положительным для Кыргызстана, ухудшится курс будет негативным. Но те расчеты, которые мы делаем условно, в какой-то мере дают возможность предположения, что нас может ожидать при неизменных условиях и вариантах темпов роста. Они как бы отражают возможность, которая случится, если мы не сделаем прорыва в структуре экономики, применении науки и технологий, улучшении человеческого фактора и совершенствовании управления. Расчеты показывают, что экономика остается по-существу ущербной, недееспособной. ВВП в расчете на душу населения и при $5 \%$ среднегодовом росте ВВП. и при $10 \%$ росте остается в пределах, характеризующих страну с доходами ниже среднего уровня. Получается, что республика обречена на незавидное состояние экономики, с чем общество не может и не должно смириться.

И это при том, что по сравнению с 2009 г. в 2030 г. ВВП при 5\%-ом среднегодовом росте возрастет в 2,06 раза, при 10\%-ом - в 3,10 раза. Население возрастет в 1,15 раза. Предполагать, что в стране возможны более высокие среднегодовые темпы роста (скажем, по 15\% или по 20\%), нереально.

\section{4 О приоритетах во внешнеэкономическом сотрудничестве.}

Если взять в целом социально-экономическое развитие Кыргызстана, не выделяя его отдельные, частные, конкретные проблемы, регионы, отрасли и направления развития, то в возрождении, обновлении и модернизации экономики республика однозначно будет использовать мировой опыт и углублять, расширять мировые связи.

С учетом новых политических и экономических реалий, необходимо будет выделить конкретные приоритеты в отношениях с внешними партнерами, оценивая заинтересованность сторон. Иначе отношения не могут стать реальными и прочными.

С точки зрения масштабов прозводств и объема выпускаемых и поставляемых товаров Кыргызстан не может представить себя перед внешними партнерами незаменимым партнером. Поэтому напрашивается вопрос: чем конкретно может заинтересовать Кыргызстан? Второй вопрос: какие проблемы экономического развития Кыргызстану прежде всего надо решать и для этого в чем он нуждается и в какой мере тот или иной внешний партнер мог бы содействовать решению этих вопросов.

Возрождение промышленного производства, разумеется на современном инновационном уровне, является важнейшей и трудноразрешимой собственными силами задачей. За годы независимости из-за экономически непродуманной политики, особенно в начальные 1991-1995 годы, Кыргызстан практически потерял промышленность. Без воссоздания этой промышленной основы всей экономики, невозможно обеспечить ее дальнейшее развитие, динамику, стабильность, устойчивость, самодостаточность и гарантию благоприятной будущности. 
Мы много говорим о необходимости перехода на инновационный путь, об использовании информационных технологий, нанотехнологий. Все совершенно справедливо. Нет возражений. Но давайте спросим себя: в каких отраслях прежде всего возможно действительное их внедрение ?..

Инновационный путь, информационные технологии, нанотехнологии - это создание и использование новых машин и механизмов, оборудований и приборов, других технических средств и материалов, уникальных технологий и методов и средств управления нанотехнологическими процессами.

Чтобы иметь эти машины и механизмы, оборудования и приборы, другие технические средства и материалы, нужно иметь развитую промышленную, еще конкретнее индустриальную основу. Если нет индустриальной основы развития экономики и наблюдается спад без того слабой экономики, то где внедрять и куда внедрять нанотехнологии ?

Кыргызстану предстоит задача возрождения реальной экономики, ее индустриальной основы и перехода на этом возрождении к нано и информационным технологиям. В каких областях удастся решать одновременно, а в каких-то потребуется последовательность.

Собственными научно-техническими, инженерными силами Кыргызстану сегодня эти задачи в полной мере и эффективно поднять не под силу. По большому счету, не вдаваясь в детали, возрождение реального сектора экономики и научно-технического потенциала страны представляет собой для Кыргызстана как бы всеобщий приоритет при определении своих отношений с иностранными партнерами.

При выборе партнеров нужно учитывать исторически сложившиеся политические и экономические связи, их масштабы и глубину, идентичность путей и моделей общественного и экономического развития, взаимную садаптированность функционирования экономик, возможности расширения и углубления экономического сотрудничества, степень политического доверия между государствами. Конечно, с учетом реальной суверенности государства, требований рынка целесообразно найти взаимовыгодные формы сотрудничества: торговли, инвестиционных и финансовокредитных связей, создания совместных производств, использования ресурсов труда и интеллектуального кадрового потенциала, совместного освоения природных ресурсов.

Для Кыргызстана чрезвычайно важное значение имеет освоение гидроэнергетических ресурсов. Гидроэнергетика - важнейшая базовая отрасль. Ее достойное развитие позволило бы покрывать внутренние потребности и образовать крупную экспортную поставку.

Хотя Кыргызстан является горной страной, обладает минеральными ресурсами, представляющими интерес в мире для использования в современных отраслях, он не в состоянии в полной мере освоить их из-за крупной недостаточности собственных инвестиций и в силу сложных горно-геологических условий их залегания. Совместное создание горнопромышленного комплекса - это безальтернативный шанс формирования крупной валютообразующей экономической структуры, которая плюс даст ход возникновению сопряженных отраслей и переработке материалов и созданию машин и механизмов.

Экономически заметной может стать золотодобыча. К освоению месторождений золота нужно подходить глубоко продуманно. Не раздавать месторождения по многим иностранным частным компаниям, а создать многопрофильную отечественную золотодобывающую и золотоперерабатывающую промышленность. Золотодобывающая и золотоперерабатывающая промышленность должна быть в руках государства. Это основа создания устойчивого потока золотовалютного фонда страны.

Страна должна обеспечить свою продовольственную безопасность. Оснащение сельского хозяйства современной техникой, улучшение системы мелиорации и 
орошения, использование качественных сортов сельскохозяйственных культур и пород скота, более рациональная структура прозводства позволили бы обеспечить продовольственную безопасность и увеличить экспорт качественных, экологичных продуктов питания.

Есть возможность освоения живописной природы, ее климатических условий для развития туризма, ее биоресурсы - сырьевая база для экологичной фармацевтики.

Кыргызстан нуждается в подготовке кадров для науки, образования, здравоохранения, культуры, реального сектора экономики и различных сферы услуг. Подготовка их за рубежом серьезная проблема.

\section{5 О научной базе социально-экономической политики}

Если экономическая дееспособность страны низка, социальное благополучие не обеспечено, сильное расслоение населения по жизненному уровню с преимущественной долей бедного населения, социально-экономическая справедливость слаба, социальная защита и поддержка не чувствуются, значит, социально-экономическая политика государства была неверной, действия власти недейственными, она оказалась неспособной и сместили свои усилия на корыстные цели удержания власти и обеспечения личного благополучия.

Переход к рыночной экономике естественным образом обусловил повышенный и усиленный интерес к ее теоретическим проблемам. Формирование принципиально новой системы финансовой, кредитной и банковской сфер, выбор подходов к образованию цен и налоговой политике, установление экономических отношений между хозяйствующими субъектами, утверждение механизмов взаимоотношений между государством и хозяйствующими субъектами, определение взаимоотношений между работодателями и наемными работниками, организация социальной защиты и поддержки населения, - все это требует глубокого теоретического обоснования, обновления теоретических подходов. Между тем, при рассмотрении и решении этих важных организационных, институциональных, структурных, нормативных вопросов и экономических инструментариев государственные (соответствующие) органы не всегда опираются на фундаментальную теоретическую основу. А, отсюда, принятие решения не всегда оказываются удачными. В особенности теоретически убедительно не обоснованы вообще экономические, силы рассматривать шире, в том числе рыночные, если рассматривать уже, методы, механизмы, рычаги воздействия на соответствующие экономические процессы. Коснемся некоторых моментов.

Теоретически ничем не обоснована, практически вредна политика невмешательства государства в экономику вообще, отторжение экономики от планового подхода. Объединение всех экономических субъектов и формирование их в единый целостный хозяйственный комплекс страны невозможны без усилий государства, комплексного планового подхода. Другое дело, каким должен быть плановый подход в условиях свободной, открытой, рыночной экономики, в отличие от директивной плановой экономики советского периода.

План рыночной экономики должен предпологающим и предлагающим возможный лучший вариант, инициирующим и стимулирующим, прогнозирующим ожидаемую картину, дающим в руки экономических субъектов информацию об ожидаемом и аналитику экономических процесов.

Особую тревогу вызывает резкое расслоение населения по уровню доходов. Незначительная часть населения относится к очень богатым; другая незначительная часть - к устойчиво состоятельным; третья часть - к неустойчиво и нестабильно состоятельным; четвертая часть - со стабильным средним доходами; пятая часть - с нестабильными средними доходами; шестая часть - к бедному населению; седьмая часть 
- к крайне бедному населению.

Первые - эти уже состоявшиеся олигархи, которые воспользовались властью и приближенностью к ней во времена дикой приватизации и коррумпированы. В такой развивающейся, несамодостаточной, бедной стране как, Кыргызстан, невозможно вырасти в «честного» олигарха.

Вторая - из властных структур с высокими зарплатами и другими источниками, среднего предпринимательства, которые освоили рынок и успешно функционируют, но в известной мере они были, возможно, связаны с «покровительством» власти и «услугами» теневой экономики.

Третьи - из власти не очень высокого ранга, среды среднего и мелкого предпринимательства, еще не в полной мере усвоившие рынок, потому успехи сопровождаются неудачами.

Четвертые - из власти со стабильной зарплатой, определенного круга социальной среды, мелкого предпринимательства с самодостаточными доходами.

Пятая - работники социальной сферы в преимущественной степени, нерентабельно работающие мелкие предприниматели, пенсионеры, наемные рабочие.

Шестые - из социальной сферы, наемные работники с очень низкими заработками, пенсионеры с очень низкими пенсиями, безработные.

Повышение доходов населения с низкими и средними доходами: содействие в трудоустройстве, пересмотр тарификации, правильное (обоснованно и общественно приветствуемое) определение допустимых разрывов в размерах доходов и политика сокращения резких различий в доходах (дифференцированно рассматривая по социальным категориям), - должны выпровить непривлекательное резкое расслоение по уровню доходов. Иначе социальный взрыв неизбежен....

Введя качественные структурные изменения в экономику, используя новые технические и технологические способы, высокодееспособный человеческий ресурс, эффективные методы организации и управления, добиваясь сравнительного уменьшения затрат и используя энергосберегающие, материалосберегающие, трудосберегающие технологии и методы, можно и нужно обеспечить максимальные результаты из реально возможных вариантов и добиваться стабильности и устойчивости развития в полном смысле этих качеств экономики.

Пора перейти к таким устремлениям и действиям, чтобы национальной традицией и особенностями политики Кыргызской Республики стали заметные, прорывные подъемы в развитии через каждые 5 лет и укрепление согласия в обществе, партнерства власти и общества.

Конечно, надо жить не иллюзиями, а быть устремленными вперед, при этом реально и трезво оценивая свой потенциал. В обозримом будущем страна не может войти в группу высокоразвитых стран. И такая задача не может быть поставлена. Но, по мировым меркам, задача достижения стабильности и устойчивости развития и серединного уровня ВВП в расчете на душу населения (т.е. войти в группу стран с доходами серединного уровня (с тенденцией движения к выше среднего уровню), чтобы обеспечить общественно приемлемый уровень жизни народу, должна быть поставлена. Исторически в мировом развитии место Кыргызстана к концу XXI века, по всей вероятности, будет в группе стран с доходами выше среднего уровня. Для Кыргызстана это будет явным успехом, если добьемся. 


\title{
Банковская система Украины в условиях преодоления последствий мирового экономического кризиса
}

\author{
Валентина Орлова, Донецкий национальный университет экономики и \\ торговли имени Михаила Туган-Барановского, Украина \\ Valentina Orlova
}

\begin{abstract}
The banking system of Ukraine after global economic crisis of 2008

In the modern market models state plays the most significant role in the functioning of economic mechanism. It ensures control of total money supply, regulates movement of cash flows, and realizes accumulation and investment of financial resources, crediting different trades and people.

In transition from socialist model of economics to market economy a precondition for the start of reformation of economic relations is multi-branch state banking system.

In the beginning of 1990-s creation of such banking system began in Ukraine. However, crisis situation in economics that developed in 2008 has shown how imperfect and unadapted to the regularities of market economy was banking system in Ukraine.

Now Ukrainian economics like world economy is recovering. However, the problem of growing treasury deficit and national debt becomes issue of the day for the Government as drastic, not predicted variations of foreign currency are able to make an impact on loan market.

The article describes history of building Ukrainian banking system starting from market reforms. It gives analysis of the reasons that have caused collapse of the banking system under conditions of the global economic crisis of 2008. It also evaluates prospects for further development of banking sector in Ukraine.
\end{abstract}

JEL codes: G01, G21, G28

\section{1 Постановка проблемы}

Актуальность проблем реализации кредитно-денежной системы Украины в современных условиях не вызывает сомнений. Прежде всего, это связано с необходимостью проведения сбалансированной антиинфляционной политики в условиях девальвации национальной валюты, а также с необходимостью обеспечения субъектов хозяйствования кредитными ресурсами, что в условиях угасающего финансового кризиса является важнейшим условием выживания и развития. В этой связи особенно важным вопросом становится не только выработка денежно-кредитной политики и ее важной составляющей - банковской политики, но и четкая их реализация с учетом проводимых антикризисных мероприятий, направленных на совершенствование денежно-кредитной системы.

Традиционно денежно-кредитная система рассматривается в 2-х аспектах: функциональном и институциональном.

С позиции функционального аспекта, кредитная система представляет собой совокупность кредитных отношений, форм и методов кредитования.

С позиции институционального аспекта, кредитная система представляет собой совокупность кредитных институтов, которые создают, аккумулируют и предоставляют денежные средства в соответствии с основными принципами кредитования.

Теория и практика свидетельствуют о том, что составляющей частью кредитной системы является банковская система, представляющая совокупность разнообразных видов банков и других кредитных учреждений, институций, которая существует в той 
или другой стране в определенный исторический период и функционирует в пределах единого финансового механизма.

Следует отметить, что банковская система Украины также представляет собой совокупность разнообразных видов банков и разнообразных видов банковских учреждений тесно взаимосвязанных и является составляющей частью кредитной системы.

До провозглашения независимости банковская система Украины являлась составляющей частью своеобразного монобанка Советского Союза, что присуще унитарным странам с командно - административной экономикой. В частности, к началу 1991 года в Украине функционировала банковская система, в состав которой входили филиалы, отделения и учреждения союзных государственных специализированных банков и Госбанка, а также ряд новых акционерных коммерческих банков.

Исследования показали, что принятый в марте 1991 года Закон Украины «О банках и банковской деятельности» способствовал созданию в Украине двухуровневой банковской системы. На базе Украинской республиканской конторы Госбанка СССР был создан Национальный банк Украины (НБУ), как Центральный банк страны. В соответствии с действовавшим законодательством, государственные специализированные банки получили новый статус, превращаясь быстрыми темпами в новые деловые банки акционерной, частной и кооперативной форм собственности, а также банки с участием иностранного капитала.

Современная структура банковской системы Украины, экономические, организационные и правовые основы создания, деятельности, реорганизации и ликвидации банков регулируется действующим Законом Украины «О банках и банковской деятельности» ( с изменениями и дополнениями). (Закон, 2000).

По данным Национального банка Украины в «Реестре банков, их филиалов и представительств, валютных бирж и финансово-кредитных учреждений», по состоянию на 01.05.2010 год из общего количества зарегистрированных в 2005 - 2010 г.г. 195 банков, в числе действующих числятся лишь 176 банков. Кроме того в Реестре зарегистрировано 51 банк с иностранным капиталом, среди которых 18 со стопроцентным иностранным капиталом. При этом за последние три года (2008 - 2010) количество банков с участием иностранного капитала увеличилось лишь на одну единицу (Национальный Банк Украины, 2010). В определенной степени это свидетельствует о недостаточной комплексности политики по преодолению последствий финансового кризиса в Украине.

Вопросами развития банковской системы и преодоления банковского кризиса много внимания уделяют известные ученые, такие как В. М. Геец, Н. М. Шелудько, А. П. Вожежов, А. Л. Ведеев, Д. А. Митяев, А. А. Папаика и другие.

Однако в литературе все же недостаточно освещены отдельные важные проблемы развития банковской системы в посткризисный период.

Учитывая вышеизложенное, целью статьи является выявление направлений повышения эффективности банковской системы в условиях преодоления последствий мирового финансового кризиса, а также разработка предложений относительно дальнейшего совершенствования банковской деятельности в посткризисный период.

\section{2 Изложение основного материала}

В истории развития банковских систем различных стран известно несколько их видов: двухуровневая банковская система, централизованная монобанковская система, уникальная децентрализованная банковская система, Федеральная резервная система США.

В большинстве стран с рыночной экономикой существует двухуровневая структура 
банковской системы.

Первый уровень банковской системы образует Центральный банк страны, который выполняет следующие функции:

- осуществляет эмиссию национальных денежных знаков, организует их обращения и изъятия из обращения, определяет стандарты и порядок ведения расчётов и платежей;

- проводит общий надзор за деятельностью кредитно - финансовых учреждений страны и исполнение финансового законодательства;

- предоставление кредитов коммерческим банкам;

- выпускает и проводит погашение государственных ценных бумаг;

- $\quad$ управляет счетами правительства, осуществляет зарубежные финансовые операции;

- осуществляет регулирование банковской ликвидности с помощью традиционных для центрального банка методов воздействия на коммерческие банки: проведения политики учетной ставки, операций на открытом рынке с государственными ценными бумагами и регулирование норматива обязательных резервов коммерческих банков.

В большинстве стран с рыночной экономикой и двухуровневой банковской системой функции центральных банков в основном совпадают, но есть, естественно, и отличия. Например, во главе банковской системы Франции, которая характеризуется жестким банковским надзором и кредитным контролем, а также преобладанием государственных кредитных институтов, стоит Министерство финансов Франции. То есть Центральный банк Франции - Банк Франции - наряду с двумя другими институтами, которые осуществляют контроль за деятельностью коммерческих банков, находится под руководством Министерства финансов.

Банк Франции обладает монополией на эмиссию банкнот, но его задачи как банка государства ограничены, так как многие банковские операции выполняет само Казначейство Франции.

Помимо двухуровневой структуры банковской системы, существует децентрализованная Федеральная Резервная Система (ФРС США). Ее возглавляют 12 федеральных резервных банков в различных регионах страны, задачей которых является контроль за деятельностью банков - членов ФРС и определение кардинальных направлений монетарной политики США. Членами ФРС является $40 \%$ всех коммерческих банков, но остальные коммерческие банки работают «на свой риск и страх».

Банковская система Украины представляет двухуровневую систему и Центральным банком Украины является Национальный Банк - единый эмиссионный центр государства, государственный орган денежно - кредитного и валютного регулирования, надзора за коммерческими банками. НБУ является экономически самостоятельным органом, осуществляющим расходы за счет собственных доходов в пределах утвержденной Советом НБУ сметы, однако получение прибыли не есть целью его деятельности. Согласно Конституции Украины основной функцией деятельности НБУ является обеспечение стабильности национальной денежной единицы - гривны.

При всем многообразии функций, НБУ, как орган банковского регулирования и наблюдения НБУ с целью обеспечения финансовой надежности банков не только осуществляет государственную регистрацию и лицензирование банков, но и устанавливает для них обязательные экономические нормативы, регламентирующие капитальную базу банков, их ликвидную позицию, кредитный риск, риск инвестирования и риск открытой валютной позиции. 
Проведенное нами исследование состояния банковской системы Украины в условиях длительного мирового кризиса, отсутствия четко установленных его причин и разработки, эффективных мер преодоления последствий позволяют сделать следующие выводы. Во-первых, на протяжении 2001-2004 годов в Украине наблюдалась эндогенная модель развития банковской системы. Высокий уровень высоколиквидных средств, значительное снижение доли проблемных кредитов, значительное превышение средств, привлеченных от населения, над полученными кредитами, а также довольно низкая доля средств нерезидентов в пассивах банков.

Следует отметить, что в этот период в Украине значительно возросли темпы кредитования, как правило, за счет ресурсов, привлеченных от населения, а также наметился рост объемов средств на счетах субъектов хозяйственной деятельности.

Однако в 2005 - 2006 годах банковская система Украины переориентировалась на экзогенную модель развития, что резко изменило ситуацию. В этот период кредитная активность банков получила признаки «бума», основанного на иррациональных ожиданиях. Фактически клиентам банков довольно часто предоставлялись кредиты, платежи по которым значительно превышали их доходы. Это в конечном итоге вызывало необходимость обращаться за новыми кредитами с целью избежания дефолта. То есть в этот период в Украине начало доминировать спекулятивное и Понти - финансирование, которое значительно возросло в 2007 - 2008 годах. Это в значительной мере связано и с привлечением банками в значительных объемах краткосрочных средств от нерезидентов.

На наш взгляд это стало катализатором кризиса в финансово - кредитной системе и прежде всего в банковской системе, которая оказалась неспособной функционировать в условиях открытых систем и противостоять глобальным кризисным явлениям. В этот период, естественно требовалось соответствующее государственное вмешательство в деятельность банков с целью недопущения всеобъясняющего финансового кризиса.

Исследования показывают, что Украина не имела на этот момент эффективных инструментов относительно регулирования вливания в экономику иностранного капитала, краткосрочных иностранных инвестиций и, естественно, сдерживания спекулятивного финансирования (Геец, 2010). Как следствие, неспособность банковской системы противостоять внутренним и внешним негативным факторам обусловили значительные потери в целом экономики и банковской системы Украины в частности в период мирового кризиса.

Анализ макроэкономической ситуации в Украине показал, что улучшение макроэкономики, а так же меры, принятые Национальным банком Украины оказали позитивное влияние на состояние банковской системы и способствовали созданию необходимых условий для возобновления кредитования всех сфер экономики. Согласно данным Государственного Комитета статистики Украины в настоящее время в стране наметился экономический рост. Например только за І квартал 2010 года ВВП возрос на $4,8 \%$, а за 5 месяцев - на $6,1 \%$. Международный валютный фонд прогнозирует рост ВВП в Украине на 3,7\% в 2010 году и на 4,1\% в 2011 году (Национальный Банк Украины, 2010).

По данным НБУ наметилась стабилизация обменного курса и снижение уровня инфляции. Например, в мае 2010 года индекс инфляции составил 99,4\%, учетная ставка НБУ снизилась на 9,5\%, что способствует созданию необходимых условий в процессе кредитования заемных банков (Национальный Банк Украины, 2010а).

Наметилась определенная стабилизация и в банковской системе, что проявляется в укреплении доверия к банкам и возобновления их ресурсной базы, повышения уровня ликвидности и платежеспособности.

Например, начиная со второго полугодия 2009 года, объем средств, привлеченных банками от физических лиц, значительно возрос. Положительные тенденции получили признание, и в 2010 году их объем увеличился на 22,6 млрд. грн. или на 10,8 \% , а по 
состоянию на 01.06.2010 г. составлял 232,7 млрд.грн. или 30,7\% от обязательств банков Украины. Динамика кредитов, предоставленных банками физическим лицам и объемов средств, привлеченных от физических лиц, отражена на рис. 1.
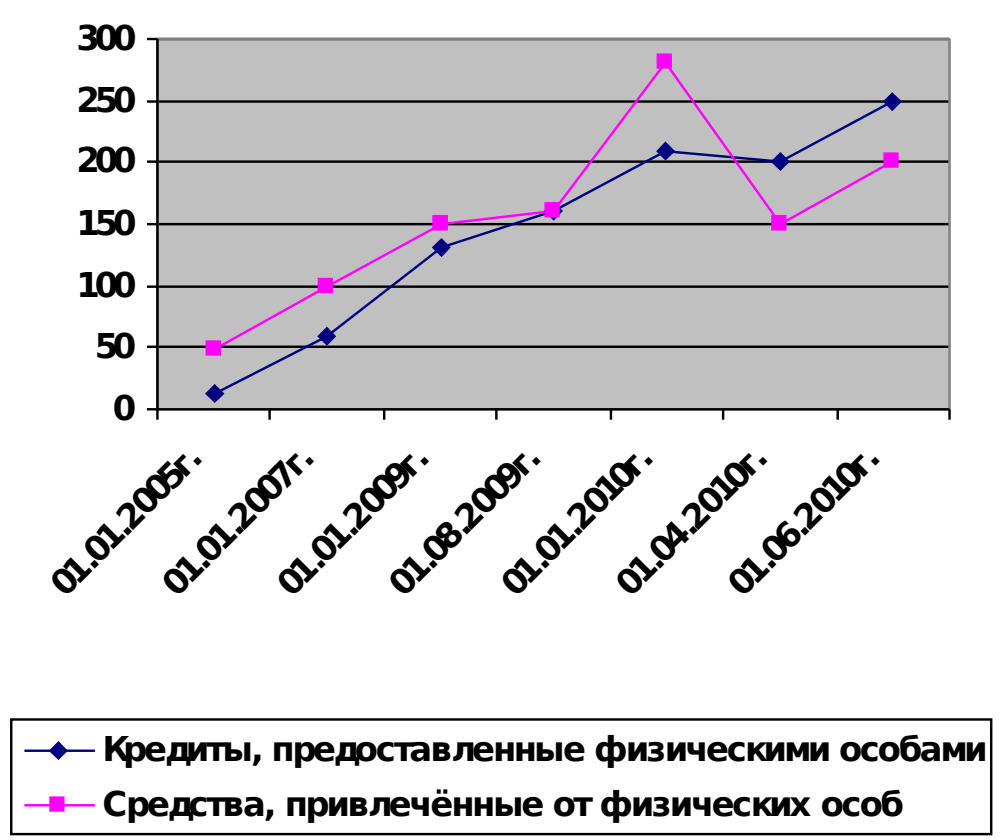

\section{Рисунок 1. Динамика кредитов, предоставленных банками физическим лицам и объемы средств, привлеченных от физических лиц.}

Одной из особенностей мирового финансового кризис на 2008 - 2009 года является то, что решение проблем ликвидности банков в подавляющем большинстве стран не гарантировало возобновление финансирования реального сектора экономики. При этом, как показывают исследования, проблема состоит в том, что снижается стремление к риску не только у банков, но и у заемщиков. В отдельных отраслях экономики Украины на протяжении 2009 года субъекты хозяйствования демонстрировали очень низкий спрос на кредиты не смотря на значительное снижение ставок (Папаика, 2008). В таких условиях, не смотря на повышение уровня ликвидности и капитализации, дальнейшее развитие банковской системы будут сдерживать высокие риски в деятельности банков, а также рост объемов непогашенных заемщиками кредитов. Естественно, в связи с необходимостью формирования дополнительных резервов банковская система ощущает рост убытков. Учитывая вышеизложенное становиться очевидным то, что цель и механизмы поддержки банковской системы со стороны государства, требуют усовершенствования.

\section{3 Выводы}

Рассмотрение основных проблем развития банковской системы Украины в условиях преодоления последствий мирового экономического кризиса показало, что потери банковской системы страны и довольно сложенный процесс выхода из банковского кризиса, а также высокие риски, низкая кредитная активность банков и субъектов хозяйствования, малоэффективное участие государства в повышении стабильного функционирования банковской системы, требуют усовершенствования методов и форм 
регулирования глобального финансового кризиса. На наш взгляд целесообразно:

- более активно применять динамичное резервирование на возмещение возможных текущих и долгосрочных ожидаемых потерь;

- обеспечить на государственном уровне создание методического обеспечения и разработку инструментов сдерживания режима спекулятивного финансирования и повышения запаса ликвидности банков;

- учитывая международный опыт усовершенствовать порядок капитализации банков при непосредственном участии государства;

- решить на государственном уровне вопрос о создании государственного агентства по работе с проблемными активами банков.

\section{ЛИТЕРАТУРА}

- Закон Украины «О банках и банковской деятельности» №2121В-Ш-ВР от 07.12.2000г. http://www.zakon1.rada.gov.ua (Украина).

- Национальный банк Украины, 2010. «Основные показатели деятельности банков по состоянию на 1 июля 2010 года», Вестник Национального банка Украинь,, 174, с. $\underline{33-67}$ (Украина).

- $\quad$ Геец В., 2010. «Формирование и развитие финансового кризиса 2008 - 2009 годов в Украине». Экономика Украины, 573, с. 5-15 (Украина).

- Национальный Банк Украины, 2010. «Основные показатели деятельности банков Украины по состоянию на 01.05.2010 г.», Вестник Национального банка Украины, 172, с. 44 (Украина).

- Папаіка О. О., Кононенко А. Ф., Орлова В. О., Грицак О. В., Попова І. В., Арбузов С. Г., Тодосейчук Г. С., Мелентьева О. В., 2008. Кредитування 1 контроль: Навч.посібник. ДонНУЕТ, Донецьк (Украина). 


\title{
Развитие здравоохранения и экономический рост.
}

\author{
Дамира Джапарова, КТУ "Манас" \\ Damira Japarova, Kyrgyz-Turkish Manas University
}

\begin{abstract}
Development in Health Sector and Economic Growth: Case of Kyrgyzstan

In this article health seen as an indicator that reflects the level of socio-economic development. Progress is ensured not by the rate of growth of production, and quality of life. In this work showed the correlation between the cost of health care and economic growth. Reforming health care in Kyrgyzstan has a goal to increase the availability and quality of care. Found the main problems: lack of funds for health and inefficient use. We conclude that fiscal insurance system in our country, does not affect the quality of care.
\end{abstract}

JEL Codes: I11, I18

Развитие здравоохранения и экономический рост находятся в сложной диалектической взаимосвязи. Государственные расходы, перераспределяя доходы через налоговую систему и социальные выплаты, увеличивает потребительский спрос и способствуют экономическому росту. Однако по мере увеличения государственных расходов начинают усиливаться признаки их отрицательного влияния. Это рост налогового бремени, отсюда - снижение нормы сбережений и инвестиций. Стремление скрыть доходы расширяет теневую экономику. Следует отметить, рост государственных расходов без увеличения налогов сопровождается хроническим бюджетным дефицитом и создает условия для инфляции.

Определенный запас здоровья, знаний, навыков человека, которые используются в сфере общественного производства, в макроэкономике выступая как человеческий капитал, является главным фактором и стратегическим ресурсом экономического развития государства. Он способствует повышению производительности труда и росту доходов. По оценкам экспертов Всемирного банка, в развитых странах доля человеческого капитала в структуре национального богатства на душу населения (в долларах США) составляет от 68 до 76\% (Здоровье нации, 2002). В структуре национального богатства развитых стран все большая доля ВВП приходится на невещественное богатство, которое формируется в значительной степени за счет вложений в «человеческий капитал». Оно включает затраты на образование, профессиональное обучение, охрану здоровья и культуру и другие социальные расходы. Этот процесс отражает возрастающую роль человеческого капитала в современном развитии общества( Бушуев и т.д., 2008). В связи с этим здоровье населения является одним их важнейших показателей, характеризующих уровень социально-экономического развития страны.

Существует довольно тесная взаимосвязь между потенциалом здоровья населения и экономическим ростом. Исследования ученых показывают, что ущерб от заболеваемости, инвалидности и смертности населения очень значителен. Так, по расчетам ряда специалистов, экономический ущерб от потери здоровья населения России в начале 2000 года составлял около 65 млрд долл. США[ Комаров, 2008].

Индекс развития человеческого потенциала, разработанный в рамках Программы развития ООН можно считать обобщающим показателем, характеризующим качество жизни людей в той или иной стране. В его основе лежит идея, о том, что главная цель социального и экономического прогресса состоит не в ускорении развития экономики, а в обеспечении каждому человеку возможностей реализовать свой потенциал, вести здоровую, полноценную и творчески активную жизнь. Согласно данным Всемирной организации здравоохранения, Карибская комиссия по здравоохранению установила, что 
увеличение расходов на здравоохранение в Тринидаде и Тобаго на 1 процент привело через два года к увеличению потоков прямых иностранных инвестиций на 3 процента (Состояние макроэкономики, 2006). Согласно оценкам, примерно одна треть долговременного экономического роста Мексики в период с 1970 по 1995 год обусловлена улучшением состояния здоровья населения (Диафука Сайла-Нгита, 2005). Проведенное в Китае исследование показало, что в течение ближайших 15 лет совокупная факторная производительность, которая, в частности, будет зависеть от состояния здоровья работников, будет играть все более важную роль в поддержании высокого экономического роста. В связи с этим в сектор здравоохранения направляется значительная доля ВВП, $(4,6 \%)$. Такая политика способствует способствует также повышению уровня занятости и будет стимулировать увеличение норм потребления, в Китае (Office of the WHO).

Итак, динамика человеческого капитала становится важной характеристикой социально-экономического развития страны. И здравоохранение должно стать неотъемлемой частью общей национальной стратегии развития. Учитывая, что экономический рост может обернуться бедой для общества, считают, что необходимо использовать показатель, учитывающий и такие факторы как экологическая обстановка, социальное напряжение, здоровье нации.

Здравоохранение как отрасль общественного хозяйства имеет особые формы экономических отношений, нарушающих действие рыночного механизма. Во первых, часть медицинских услуг обладает свойствами «общественных благ». В ряде стран имеются проблемы инфекционных заболеваний (в том числе туберкулеза и ВИЧ/СПИДа), от которых страдают преимущественно люди молодого возраста. И медицинские услуги, оказываемые при этом являются объектом коллективного потребления. Противо-эпидемиологические мероприятия становятся достоянием больших групп населения. В связи с тем что медицинская услуга предоставляется конкретому лицу и полезный эффект ощущают другие люди, имеет место «внешний эффект», получаемый общестом в целом. Так, прививки против туберкулеза ограничивают распостранение этого заболевания. Поэтому в сфере здравоохранения распределение ресурсов не всегда происходит на основе платежеспособного спроса и предпринимательских мотивов, а для удовлетворения потребностей общества. В связи с этим противоэпидемиологические медицинские услуги финансирутся из государственного бюджета, что характеризует нарушение рыночного механизма. Следует отметить, что такими свойствами общественного блага обладает лишь незначительная часть медицинских услуг.

В отличие от обычных рынков, в здравоохранении производитель, а не потребитель определяет объем и цену предоставляемых услуг. Поскольку больной человек не обладает знаниями, необходимыми для определения нужных его лечения, ему сложно выбрать врача и лекарственные препараты, перечень и объем медицинских услуг. Врачи имеют возможность увеличить объем и виды услуг, выбирая, не очень нужные, или совсем ненужные для выздоровления больного. Таким образом, врачи не только определяют и предлагают медицинские услуги, но и формируют спрос на них.

Врачи стационара например, могут увеличить объем услуг и тем самым обеспечить загрузку имеющихся мощностей (коечного фонда, медицинского оборудывания и пр.) и в конечном итоге - увеличить свой доход. Поэтому, имея возможность увеличить используемые ресурсы, не заинтересованы в рациональном их использовании. В связи с этим финансирование отрасли и работа лечебно-профилактических учреждений осуществляется на основе нормативов, устанавливаемых и спускаемых до каждого медицинского учреждения органами государственного управления. Однако в таких условиях нет мотивации труда и экономических стимулов, а также нет возможности оценки его результатов. Иначе говоря, в сфере медицинских услуг в государственных лечебных учреждениях нет полноценных экономических отношений. Это привело к 
тому, что управление отечественным здравоохранением строилось и продолжает осуществляться преимущественно на административных методах. Таким образом, информационная ассиметрия создает условия формирования затратного механизма в здравоохранении.

Спрос на медицинские не зависит от уровня его доходов пациентов. Напротив, человек имеющий более высокие доходы, меньше нуждается в медицинской помощи, так как качество его жизни позволяет иметь хорошее здоровье. Напротив, наибольшую потребность в медицинской помощи имеют лица с низким доходом, и для обеспечения равного доступа к медицинским услугам, со стороны государства, требуется корректировка рыночного механизма распределения ресурсов в пользу стариков, детей, лиц с низким доходом, хронических больных, и активное вмешательства государства. Учитывая риск заболевания и связанные с ним затраты, человек в ситуации неопределенности, чтобы избежать больших единовременных затрат, вносит определенную суммы в общий страховой фонд и получают возможность лечиться за счет собранных средств. Чтобы обеспечить доступ населения к страховым и медицинским услугам, требуются различные формы государственного регулирования.

В экономической литературе на протяжении многих лет здравоохранение рассматривалось как отрасль «непроизводственной сферы» и согласно такому представлению медицинские работники не участвуют в создании национального дохода, а лишь потребляют ее. И в этих условиях ресурсы этой сферы деятельности образуются согласно «остаточному» принципу финансирования. Организаторы здравоохранения оценивали объем средств на содержание медицинских учреждений без поиска альтернативных вариантов вложения ограниченных ресурсов. В таких условиях невозможно получить ответы на вопросы: строить или реконструировать больницу, лечить пациента в стационаре или в поликлинике, взять нового врача, или больше заплатить работающему врачу. В итоге имеет место перегрузка стационаров, недооценка возможностей амбулаторно-поликлинических учреждений, что ведет к большим экономическим потерям. Результатом всего этого является низкая эффективность использования ресурсов и непрофессиональное отношение медицинских работников к своим обязанностям, а также поборы. Все эти недостатки связаны с тем, что здравоохранение как и другие отрасли услуг имеют экономическое начало, а также свою специфику. Непризнание этого влечет за собой уравниловку, низкое качество медицинской помощи, и в конечном итоге, низкий социальный эффект. С 1996 г. здравоохранение республики на основе реформирования и изменений законодательной базы здравоохранения, произошел переход от государственной медицины к бюджетностраховой. Введена система обязательного медицинского страхования и в 2009 г. системой ОМС охвачено 76,7\% населения.

С началом реализации Национальной программы "Манас таалими" (2006-2010 гг.) введены кардинальные изменения в финансирование сектора здравоохранения: бюджет здравоохранения аккумулирован на республиканском уровне, внедрено формирование бюджета здравоохранения на программной основе, что позволило в 2006-2007 гг. расширить объем бесплатных медицинских услуг, предоставляемых по программе государственных гарантий для беременных женщин, детей в возрасте до 5 лет, пенсионеров в возрасте 70 лет и старше, провести выравнивание финансирования регионов, ввести сельский коэффициент для поддержки сельского здравоохранения. Появились новые механизмы формирования и исполнения бюджета организаций здравоохранения через систему Единого плательщика: в стационарах - за пролеченный случай, на первичном уровне как подушевое финансирование.

Консолидированный бюджет сектора здравоохранения республики на 2009 год составил 5 494,8 млн. сомов, что на 11,5\% больше объема утвержденного бюджета 2008 года. И бюджет Фонда ОМС системы Единого плательщика составил соответственно 4161,3 млн. сомов или 16,4\% на больше, чем в 2008 году. Из республиканского бюджета 
поступило - 2998,3 млн. сомов, из местного бюджета - 750,7 млн. сомов, из средств ОМС - 1024,8 млн. сомов, от населения в виде сооплаты - 218,8 млн. сомов, специальные средства республиканского бюджета - 92,2 млн. сомов и местного бюджета41,3 млн. Сомов (Министерство здравоохранения, 2010). Несмотря на то, что финансирование в Кыргызстане осуществляется нарастающими темпами и государство тратит на здравоохранение из года в год больше, ощутимой пользы пока нет. Бюджетностраховая система, которая сложилась на сегодняшней день, мало влияет на качество оказания медицинской помощи. Средства, полученные организациями здравоохранения в порядке сооплаты населения, не подлежат налогообложению и изъятию в государственный бюджет, используются на дополнительную заработную плату и отчисления в Социальный фонд КР, мероприятия, связанные с обеспечением лечебнодиагностического процесса и питание пациентов. Согласно системе Единого плательщика средства от сооплаты поступают в единый фонд, а за тем согласно отчету первичных медицинских учреждений (больниц) за прошлый год о количестве пролеченных больных перераспределяются стационарным отделениям. Ввиду ограниченности ресурсов в стационарах осуществляется жесткая экономия средств, поступиших по системе Единого плательщика. Поскольку эффективные средства лечения стоят дороже, врачи вынуждены приобретать более дешевые препараты на лечение. Такой подход преждевременно обрекает больного, независимо от размера его материального вклада на некачественное лечение, если оно ограничится только средствами, предоставляемыми медицинскими учреждениями.

Вместе с тем сложившийся уровень сооплаты за медицинские услуги не покрывает всех расходов на пациента, что вынуждает медицинских работников компенсировать затраты на лечение из кармана пациента. Кроме того, необходимо признать, что в республике сохраняется практика неофициальных выплат непосредственно медицинскому персоналу. Пациенты кроме установленной сооплаты дополнительно вносят плату за медикаменты, а также нередко осуществляют неофициальные платежи «подарки» врачам, другому медицинскому персоналу и, непосредственно, денежные вознаграждения (особенно, плата за операции). Кроме того, очень часто врач направляет больного в определенную аптеку или лабороторную клинику, имея при этом долю от стоимости проданных пациенту лекарств, или платы за лабороторные исследования, в которых даже если нет необходимости. Хотя $20 \%$ НДС с лекарств сняты, но на самом деле они не стали дешевле. Все это свидетельствует о том, что больной с введением сооплаты вынужден теперь многократно оплачивать одну и ту же медицинскую услугу, в итоге не имея гарантию на полное выздоровление. Оплата больноо части затрат на собственное лечение на наш взгляд, является более справедливым путем привлечения пациента для для его лечения. Поэтому, по совокупности этих причин было бы целесообразно вместо фиксированных соплатежей по отношению к медицинской помощи ввести сооплату по отношению к лекарствам, т.е. оплачивать часть стоимости лекарств, использованных при лечении больного (Практика например, Турции).

Врачи заинтересованные в реальном выздоровлении своего пациента, сами вынуждены рекомендовать дополнительные более качественные и дорогостоящие препараты и платные медицинские услуги. И здесь у него есть возможность злоупотреблять своим преимущественным положением - определять спрос на медицинские услуги.. Кроме того, указанная методика установления норм далеко не соответствует $50 \%$ реальных затрат на лечение больного. Даже одинаковый тип заболевания для разных категорий больных разного возраста и состояния организма требует индивидуального подхода лечения и соответственно дифференцированнных затрат. Согласно существующей методике, вместо получения реальной материальной поддержки со стороны государства одни пациенты вынуждены покрывать расходы других больных. Остается низким заработная плата медицинских работников, уровень заработной платы врачей только в 2007 г. приблизился к минимальному 
потребительскому бюджету, а у среднего и младшего медицинского персонала он продолжает составлять немногим более 50\%.В настоящее время даже непрерывное повышение заработной платы медицинских работников позволяет едва покрывать минимальный потребительский бюджет, что и объясняет реальную причину неофициальной платы медицинских услуг. При таком уровне заработной платы трудно говорить о присутствии реальной мотивации к труду( Министерство здравоохранения, 2010).

Прежде чем приступить к факторам стимулирования труда в этой сфере раскроем современные принципы оплаты труда медицинских работников. Размер заработной платы определяется, исходя из должностного оклада, рассчитанного на базе Единой тарифной сетки и разрядных коэффициентов, и начисляется с учетом выполнения нормы рабочего времени. При начислении заработной платы применяются надбавки и доплаты к должностным окладам работников здравоохранения. Надбавки предусмотрены: за продолжительность непрерывной работы, за сложность, напряженность и качество работы, а также ученую степень. Доплаты к должностным окладам осуществляются: за совмещение профессий, расширение зон обслуживания и увеличения объема выполняемых работ, а также врачам-руководителям. Формирование фонда оплаты труда организаций здравоохранения, работающих в системе Единого плательщика, осуществляется за счет: средств государственного бюджета; средств обязательного медицинского страхования; специальных средств; средств сооплаты. Самое главное следует учесть, что фонд оплаты труда в стационарах определяется на основе затрат прошлого года за «пролеченный случай», что далеко не соответствует «пролеченности» больного. Лечение осуществляется путем использования твердых нормативов, где из нескольких альтернатив закладываются минимальные затраты лечения больного. Отсюда возникает вопрос: где реальный источник материального стимулирования хорошей работы врача? В производстве фонд материального поощрения формируется за сч ет прибыли. В медицине источником поощрения выступает заранее определяемый на основе учета прошлых затрат фонд оплаты труда. И по логике увеличение стимулирующей части должно проходить за счет основной части оплаты труда, что согласно метематике: от перемены мест слагаемых, сумма фонда оплаты труда остается неизменной. В этой связи, поскольку в медицине нет прибыли в качестве источника поощрения может быть использовать часть специальных средств, образованных за счет платных услуг? При этом важнейшим и единственным критерием оценки труда медицинского работника является состояние здоровья пациента после проведения соответствующих медицинских мероприятий. Следует отметить, что при начислении заработной платы, как и во всех бюджетных структурах страны, не учитывается уровень инфляции. И повышение оплаты труда представляет собой лишь частичную компенсацию роста цен.

Следующим источником финансирования являются платные услуги: официальные и неофициальные. Последние не проходят через каналы государственного перераспределения и поступают в медицинские организации в форме прямой оплаты медицинских услуг. Сегодня в Кыргызстане имеют место следующие формы личных расходов на медицинскую помощь - прямая покупка лекарственных средств, платные медицинские услуги по полной стоимости и неформальные т.е. незаконные платежи за услуги. С нашей точки зрения неформальные платежи в медицине то есть, то что платят врачу, не следует считать «взяткой». В условиях отсутствия механизма регулирования, данная плата выступает как не регулируемое государством дополнение к рыночной цене, что невозможно отменить или уничтожить. Единственный способ приведения их в какие-то рамки, формы - это их легализация. Тем более часть платных услуг вышла из тени.

Платные медицинские услуги способствовали активному внедрению новых медицинских технологий. Более интенсивно стала использоваться материально- 
техническая база, кадровые ресурсы и т.д. Конечно, это снимает остроту бюджетного дефицита переходного к рынку периода. Однако, здесь возникли серьезные проблемы. Во первых, платные медицинские услуги оказались вне сферы управляющего воздействия государства (прейскуранты есть, но они устарели, объем услуг не предусмотрен). Во-вторых, появилась тенденция использования государственного сектора для оказания платных услуг. Т.е. платные услуги осуществляются на базе государственных медицинских учреждений. В этой связи имеют место необоснованные госпитализации в государственной больнице, в так называемых платных палатах. В связи с ними появилась проблема неэффективного использования ресурсов здравоохранения и дополнительные расходы коммунальных услуг. Все это противоречит оптимизации стационарной помощи. Чем больше объемы платных услуг, тем больше коечный фонд. Во многом из-за платных услуг возникают лишние мощности учреждений, которые связаны с большими затратами. То есть, платные услуги в данном случае снижают эффективность использования ресурсов.

\section{Литература}

- Здоровье нации, как парадигма экономического и социального развития. Проблемы ответственности бизнеса. Аналитический доклад Совета Федерации Федерального Собрания РФ, 2002.

- Бушуев В. В., Голубев В. С., Коробейников А. А., Селюков Ю. Г. Человеческий капитал для социогуманитарного развития. - М.: «ИАЦ Энергия», 2008. - 96 с.

- Комаров Ю.М. Здравоохранение США: уроки для России. - М.: НПО Медсоцэкономинформ Министерства здравоохранения РФ, 1998.

- По материалам Status of Macroeconomics and Health (Состояние макроэкономики и здравоохранения) - Непал, 2006г;

- По материалам доклада Rwanda Macroeconomics and Health Project Country Report (Доклад по Проекту в сфере макроэкономики и здоровья Руанды), подготовленного Диафукой Сайла-Нгитой, Колумбийский университет, и Целевой группой Руанды по макроэкономике и здоровью, 2005 год.

- Office of the WHO Representative in China/Social Development Department of China State Council Development Research Centre, op. cit.

- Данные Министерства здравоохранения КР.2010г. 


\title{
Новый Подход к Инвестиционным Коэффициентам
}

\author{
Anarkul Urdaletova, Kyrgyz-Turkish Manas University, Kyrgyzstan \\ Syrgak Kıdıraliev, American University of Central Asia, Kyrgyzstan
}

\begin{abstract}
A New Approach to Investment Coefficients

The future business success and, in general, economic growth clearly depend on current investment decisions.

However, sometimes investment projects are deemed acceptable without thorough analysis of all possible alternatives. Or sometimes the wrong interpretation of the results of investment analyses has place.

The purpose of this article is to form a new point of view on various investment coefficients.

The classic books in the finance and investment area teach us that the net present value method - NPV - is the best existing framework for analysis of investment's cash flows. But in some cases NPV, however, creates several problems as, for example, disinvestment. In order to eliminate this shortcoming in our report we introduce a new investment coefficient. An important feature of the report is the new approach to the calculation of traditional investment coefficients, based on recurrence relations.
\end{abstract}

JEL codes: G11

Успех бизнеса в будущем зависит от тех инвестиционных решений, которые принимаются сегодня. Тем не менее, иногда инвестиционные проекты одобряются без тщательного анализа имеющихся альтернатив. Даже в тех случаях, когда анализ проводится, полученная информация не всегда способствует принятию правильных решений, потому что информация не была обработана нужным образом.

Цель данной работы - сформировать новый взгляд на различные инвестиционные коэффициенты. В классических книгах (Besley S., Brigham E.F., 2003: 475-525;

Bierman H, Smidt S., 1992: 50-180) говорится, что NPV наилучший из инвестиционных коэффициентов. Но, мы намерены показать, что в отдельных случаях, использование NPV для принятия решения действительно может способствовать снижению капиталовложений. Для того чтобы избавиться от этого недостатка, в работе предлагается новый инвестиционный коэффициент. Кроме того, для уравновешивания ситуации предлагаем отказаться от использования коэффициента индекс рентабельности. Важной особенностью работы является новый подход к вычислению традиционных инвестиционных коэффициентов, основанный на рекуррентных соотношениях

Говоря об анализе инвестиционных проектов, мы имеем в виду следующую ситуацию: необходимо решить, стоит ли вкладывать деньги в размере $C F_{0}$ в начальный момент времени, если это вложение должно вызвать денежные потоки (cash flows) $C F_{1}, C F_{2}, \ldots$, $C F_{N}$, которые возникают в конце каждого последующего периода времени:

\begin{tabular}{|c|c|c|c|c|c|}
\hline Периоды времени & 0 & 1 & 2 & $\ldots$ & $\mathrm{N}$ \\
\hline Денежные потоки & $-C F_{0}$ & $C F_{1}$ & $C F_{2}$ & $\ldots$ & $C F_{N}$ \\
\hline
\end{tabular}

(Обычно, денежный поток определяется как сумма чистого дохода (прибыли) и амортизации за соответствующий период). Для того чтобы иметь основу для анализа инвестиционных коэффициентов напомним и по новому взглянем на основные определения.

\section{1 Период возврата (payback period)}

показывает, сколько времени понадобится, для того чтобы к инвестору вернулись 
деньги, вложенные в проект.

Для того чтобы вычислить коэффициент «период возврата» будем последовательно вычислять значения кумулятивных денежных потоков (cumulative cash flow - $\boldsymbol{C C F}_{\boldsymbol{m}}$ ) по формуле

$$
C \boldsymbol{C F}_{m}=\mathrm{CCF}_{m-1}+\boldsymbol{C F}_{m},
$$

при $\boldsymbol{C} \boldsymbol{C F}_{\boldsymbol{0}}=\mathbf{-} \boldsymbol{C F}_{\boldsymbol{0}}$, до тех пор пока $\boldsymbol{C} \boldsymbol{C F}_{\boldsymbol{m}}$ не станет неотрицательным.

Если это произошло при $\boldsymbol{m}=\boldsymbol{i}$, период возврата равен

$$
\boldsymbol{i}-\boldsymbol{C C F}_{i} / \boldsymbol{C F}_{\boldsymbol{i}},
$$

если же $\boldsymbol{C C F}_{\boldsymbol{m}}$ отрицателен при всех значениях $\boldsymbol{m}=\mathbf{1}, 2, \ldots, \boldsymbol{N}$, то считается, что проект плохой - не окупаемый. (Номер $\boldsymbol{i}$ в формуле (2) есть номер периода, в котором инвестор возвращает все деньги взятые на проект, отношение $C C F_{i} / C F_{i}$ указывает на часть периода с номером $\boldsymbol{i}$, в которой проект начинает приносить прибыль. При этом предполагается, что денежный поток $C F_{i}$ равномерно распределен внутри периода с номером $\boldsymbol{i}$.)

Например, для проекта приведенного далее, кумулятивные денежные потоки становятся неотрицательными, начиная с 3-го периода:

\begin{tabular}{|c|c|c|c|c|c|}
\hline Периоды времени & 0 & 1 & 2 & 3 & 4 \\
\hline Денежные потоки $\boldsymbol{C F}_{\boldsymbol{m}}$ & -100 & 40 & 50 & 40 & 20 \\
\hline $\begin{array}{c}\text { Кумулятивные денежные } \\
\text { потоки } \boldsymbol{C C}_{\boldsymbol{m}}\end{array}$ & -100 & -60 & -10 & 30 & 50 \\
\hline
\end{tabular}

Поэтому, период возврата равен $3-(30 / 40)=2,25$ года.

Главное преимущество коэффициента период возврата - простота.

К сожалению, он имеет существенные недостатки. Для того чтобы продемонстрировать главные из них приведем

\begin{tabular}{|c|c|c|c|c|c|}
\hline Годы & 0 & 1 & 2 & 3 & 4 \\
\hline Денежные потоки А1 & -100 & 10 & 20 & 70 & 40 \\
\hline Денежные потоки А2 & -100 & 80 & 10 & 10 & 40 \\
\hline
\end{tabular}

\section{Пример 1}

Несложно увидеть, что период возврата (3 года) для проектов A1 и А2 одинаков. Но вряд ли стоит говорить, что эти проекты эквивалентны. Каждый, кто имеет понятие о стоимости денег во времени выберет проект А2.

Для того чтобы показать, что при учете стоимости денег во времени проект А1 лучше, чем проект А2 используем улучшенный вариант коэффициента период возврата Дисконтированный Период возврата с учетом стоимости капитала (payback period with cost of capital- PP(k)), который можно вычислить по формуле (2), используя обобщение формулы (1):

$$
C C F_{m}=C C F_{m-1}(1+k)+C F_{m},
$$

$\boldsymbol{C} \boldsymbol{C \boldsymbol { F } _ { \boldsymbol { 0 } }}=-\boldsymbol{C F}_{\boldsymbol{0}}, \boldsymbol{k}-$ стоимость капитала.

Предположим, что стоимость капитала равна 14\% и вычислим значения кумулятивных денежных потоков для проекта А1:

$C C F_{1}=-100(1+0,14)+10=-104, \quad C C F_{2}=-104(1+0,14)+20=-98,56$,

$C C F_{3}=-98,56(1,14)+70=-42,3584, \quad C C F_{4}=-42,3584(1,14)+40=-8,288576$.

Вычисления показывают, что при стоимости капитала 14\% проект не окупается.

Вычислим значения кумулятивных денежных потоков для проекта А2:

$C C F_{1}=-100(1+0,14)+80=-34, \quad C C F_{2}=-34(1+0,14)+10=-28,76$,

$C C F_{3}=-28,76(1,14)+10=-22,7864, \quad C C F_{4}=-22,7864(1,14)+40=14,023504$.

Отсюда, по формуле (2), получаем, что период возврата с учетом стоимости капитала равен $4-(14,023504 / 40)=3,65$ года. 
Итак, коэффициент период возврата с учетом стоимости капитала показывает, то что должно иметь место: проект А2 лучше, чем проект А1.

К сожалению, коэффициент, называемый период возврата с учетом стоимости капитала, так же как и простой период возврата имеет существенный недостаток: он не учитывает денежные потоки, которые имеют место после возврата затраченных денег.

\begin{tabular}{|c|c|c|c|c|c|c|}
\hline Годы & 0 & 1 & 2 & 3 & 4 & 5 \\
\hline$C F$ проекта В & -317 & 100 & 100 & 100 & 100 & 10000 \\
\hline$C F$ проекта $\mathbf{C}$ & -317 & 200 & 200 & 200 & 200 & 200 \\
\hline
\end{tabular}

Пример 2

Период возврата с учетом стоимости капитала при $10 \%$ интереса для проекта $\mathbf{B}-4$ года, для проекта $\mathbf{C}$, конечно меньше, но вряд ли можно говорить о том, что проект $\mathbf{C}$ лучше.

\section{2 Чистая приведенная стоимость проекта - NPV}

Коэффициент период возврата с учетом стоимости капитала является удобным и широко используемым в практической деятельности. Он позволяет определить как приемлемость проекта - если период возврата меньше длительности проекта, то он приносит выгоду, так и оценить рискованность проекта - чем меньше период возврата, тем ниже риск. Но, как отмечено выше, он имеет существенный недостаток - не учитывает денежные потоки, которые имеют место после возврата затраченных денег. Для того чтобы избавиться от этого недостатка будет логично рассматривать коэффициенты, которые учитывают все денежные потоки.

Самым лучшим, с теоретической точки зрения (об этом говорится почти во всех учебниках по финансам, инвестициям и т.п.) коэффициентом подобного рода, является коэффициент называемый чистой приведенной стоимостью проекта - NPV (Net Present Value).

\begin{tabular}{|c|c|c|c|c|}
\hline Годы & 0 & 1 & 2 & 3 \\
\hline Денежные потоки & -100 & 60 & 40 & 20 \\
\hline
\end{tabular}

зная, что стоимость капитала $k=12 \%=0,12$.

\section{Пример 3 Вычислим NPV проекта D}

Для этого вычислим кумулятивный денежный поток последнего периода $C C F_{N}$, который будем называть конечным значением - TV (terminal value) проекта:

$$
C C F_{1}=-100(1+0,12)+60=-112+60=-\$ 52 .
$$

$C C F_{2}=-52(1+0,12)+40=-18,24 ; \quad C C F_{3}=-18,24(1+0,12)+20=-0,4288$.

Итак, при $k=12 \%$ TV проекта равно $-0,4288$.

Вычислим исходное значение этого числа:

$$
-0,4288 /(1+0,12)^{3}=-0,3052 \text { денежных единиц. }
$$

Это число $(-0,3052)$ есть чистая приведенная стоимость проекта $\mathbf{D}$ при стоимости капитала $12 \%$ - $\mathrm{NPV}_{\mathrm{D}}(12 \%)$.

Как нужно понимать этот результат? Знак минус указывает на то, что при указанных условиях проект является убыточным, и фирма должна его отвергнуть. Но, наряду с обычными коммерческими проектами, существуют проекты, которые должны быть обязательно осуществлены. Представьте себе, что проект D - это проект связанный с очисткой города от мусора. В этом случае число $(-0,3052)$ укажет на минимальную величину трансферта, который должен выделить город для того чтобы побудить какуюлибо фирму взяться за этот проект.

Если стоимость капитала равна $10 \%$, то соответствующие значения накопленных 
денежных потоков:

$$
\begin{gathered}
C C F_{1}=-100(1+0,10)+60=-110+60=-50 . \\
C C F_{2}=-50(1+0,10)+40=-15 ; \quad C C F_{3}=-15(1+0,10)+20=3,5 .
\end{gathered}
$$

Следовательно, $\quad \mathrm{NPV}_{\mathrm{D}}(10 \%)=3,5 /(1+0,10)^{3}=2,63$.

Это число можно трактовать следующим образом: пусть на осуществление проекта D претендуют несколько фирм и объявлен соответствующий тендер. Тогда, 2,63 денежных единиц - это максимум, который может предложить фирма желающая получить этот проект.

Если использовать язык формул, то конечное значение TV запишется в виде

$$
T V=\left(-C F_{0}\right)(1+k)^{N}+\sum_{m=1}^{N} C F_{m}(1+k)^{N-m}
$$

а NPV, соответственно

$$
N P V=\frac{T V}{(1+k)^{N}} .
$$

Несложно увидеть, что формулу (4) легко переписать в виде

$$
N P V=\left(-C F_{0}\right)+\sum_{m=1}^{N} C F_{m}(1+k)^{-m},
$$

обычно используемом при вычислениях NPV. Но по нашему мнению, вычисление NPV через последовательное вычисление кумулятивных денежных потоков более предпочтительно. При использовании этой техники вычислений можно более эффективно использовать калькулятор - на каждом шаге используется результат предыдущих вычислений, имеющийся на дисплее, а также, одновременно с вычислением конечного значения TV можно определить величину периода возврата с учетом интереса.

\section{3 Внутренняя норма доходности проекта - IRR.}

Далее, имеет смысл постараться найти ответ на вопрос: При каком значении стоимости капитала $\boldsymbol{k}$ конечное значение проекта TV (и NPV) равно 0 ?

Это число называется внутренней нормой доходности проекта -

\section{- IRR (Internal Rate of Return).}

\begin{tabular}{|c|c|c|c|c|c|}
\hline Годы & 0 & 1 & 2 & 3 & 4 \\
\hline Денежные потоки & -10 & 2 & 3 & 6 & 5 \\
\hline
\end{tabular}

Предположим, что ставка интереса $k=20 \%=0,2$.

Пример 4. Вычислим IRR проекта Е:

Тогда,

$$
\begin{array}{lr}
C C F_{1}=-10(1+0,2)+2=-12+2=-\$ 10 ; & C C F_{2}=-10(1+0,2)+3=-9 ; \\
C C F_{3}=-9(1+0,2)+6=-4,8 ; & C C F_{4}=-4,8(1+0,2)+5=-0,76 .
\end{array}
$$

Итак, при $k=20 \%$ TV проекта не намного меньше нуля. Следовательно, IRR должно быть несколько меньше этого значения $\boldsymbol{k}$.

Поэтому, повторим вычисления, взяв $k=18 \%$ :

$$
\begin{array}{ll}
C C F_{1}=-10(1+0,18)+2=-11,8+2=-9,8 ; & C C F_{2}=-9,8(1+0,18)+3=-8,564 ; \\
C C F_{3}=-8,564(1+0,18)+6=-4,11 ; & C C F_{4}=-4,11(1+0,18)+5=0,15 .
\end{array}
$$

Теперь мы получили положительное число. Следовательно, значение IRR находится между $18 \%$ и $20 \%$. 
Применив линейную интерполяцию, определим что IRR проекта $\mathbf{E}$, приблизительно, равна $18 \%+(2 \% / 0,91) 0,15=18,33 \%$.

Использовав полученное значение и повторив вычисления, можно получить и более точное значение IRR, но этого делать не стоит, так как сами исходные данные - значения денежных потоков - являются предположительными.

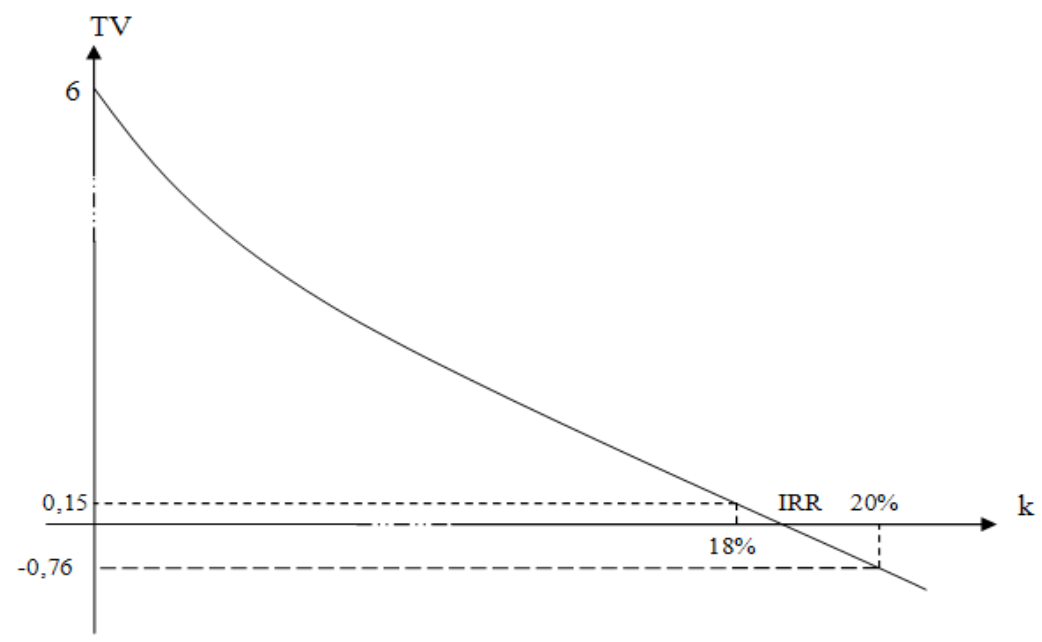

\section{4. Чистая будущая стоимость проекта}

Предположим, что фирма рассматривает инвестиционный проект $\mathbf{F}$, считая что стоимость капитала равна $20 \%$.

\begin{tabular}{|c|c|c|c|c|c|}
\hline Годы & 0 & 1 & 2 & 3 & 4 \\
\hline Денежные потоки & -10 & 7 & 6 & 2 & 1 \\
\hline
\end{tabular}

Вычислим накопленные денежные потоки:

$$
C C F_{1}=(1+0,2)(-10)+7=-5 ; \quad C C F_{2}=(1+0,2)(-5)+6=0 .
$$

Обратите внимание, в конце 2-го периода произошло знаменательное событие деньги, взятые на осуществление проекта, возвращены в полном объеме.

Следовательно, деньги, которые фирма получит в следующем периоде

$$
C C F_{3}=(1+0,2)(0)+2=2,
$$

можно реинвестировать - вложить в другие проекты.

С этого момента, вместо стоимости капитала $(k)$, следует рассматривать ставку реинвестирования!

Она, конечно, может равняться стоимости капитала, но это совсем не обязательно. Обычно, ставка реинвестирования больше чем стоимость капитала - фирма занимает деньги на проект при ставке интереса $k$, рассчитывая получить доход описываемый более высокой ставкой.

Закончим пример, предполагая, что ставка реинвестирования равна стоимости капитала: $\quad C C F_{4}=(1+0,2)(2)+1=3,4$.

Итак, к моменту окончания проекта, если все предположения окажутся верными, фирма, осуществившая проект $\mathbf{G}$, станет богаче на 3,4 единиц. Дисконтировав $3,4 /$ $(1+0,2)^{4}=1,63996 \quad$ найдем чистую приведенную стоимость проекта - NPV.

Отметим, что при вычислении NPV стоимость капитала и ставка реинвестирования считаются одинаковыми.

По аналогии с NPV, предлагаем назвать число 3,4 чистой будущей стоимостью проекта - NFV(Net Future Value). Если стоимость капитала и ставка 
рефинансирования совпадают, то NFV равно TV.

При вычислении NFV стоимость капитала и ставка рефинансирования не обязаны совпадать!

Поэтому, если доходность инвестиций фирмы равна 25\%, то NFV составит

$$
(1+0,25)(2)+1=3,5 \text {. }
$$

Настало обосновать очень серьезное утверждение, которое было сформулировано в водной части: в отдельных случаях, использование NPV для принятия решения может способствовать снижению капиталовложений.

\begin{tabular}{|c|c|c|c|c|c|c|}
\hline Годы & 0 & 1 & 2 & 3 & 4 & 5 \\
\hline Денежные потоки & -100 & 70 & 60 & 50 & 40 & -123 \\
\hline
\end{tabular}

\section{Пример 5. Рассмотрим проект G, считая что стоимость капитала равна $20 \%$}

Вычислим накопленные денежные потоки и получим, что

$$
\text { NPV проекта } \quad-3 /(1+0,2)^{5}=-1,2 \quad \text { отрицательна. }
$$

Поэтому, согласно правилам использования чистой приведенной стоимости - NPV проект нужно отвергнуть.

Но, если учесть то, что деньги, полученные по итогам 3-го и далее периодов, принадлежат фирме, то к накопленным денежным потокам в 4-м и далее периодах следует применять ставку реинвестирования.

Если ставка реинвестирования равна 22\%, то исправленные накопленные денежные потоки (Adjustable Cumulative Cash Flows - ACCF) будут равны

$$
A C C F_{4}=(1+0,22)(50)+101=100 ; \quad A C C F_{5}=(1+0,22)(101)-123=0,22 .
$$

Итак, мы получили, что если ставка реинвестирования равна $20 \%$, а стоимость капитала 22\%, то NFV проекта равна 0,22 денежные единицы. Другими словами, если ставка реинвестирования больше или равна $22 \%$, то проект, который согласно правилу NPV должен быть отвернут, оказывается прибыльным. Можно говорить о том, что все дело в отрицательном денежном потоке последнего периода. Да, это так. Но в последнее время, в связи с все возрастающими требованиями к экологическим и социальным составляющим проектов, таких проектов становится все больше и больше. (Предполагается, что после окончания проекта должна быть проведена рекультивация территории, часть работников должна получить выходное пособие и т.n.)

Использование коэффициента NFV особенно актуально для развивающихся стран, где разница между стоимостью капитала и ставкой реинвестирования может быть очень значительной. К примеру, в Кыргызстане существует большая разница между депозитными ставками и ставками, под которые банки выдают кредиты. Для подтверждения, приведем выписку из таблицы основных макроэкономических показателей Кыргызской Республики:

\begin{tabular}{|c|c|c|c|c|c|c|}
\hline & 2003 & 2004 & 2005 & 2006 & 2007 & 2008 \\
\hline Ставка \% по ссудам & 26,06 & 24,56 & 25,41 & 25,59 & 28,7 & 30,1 \\
\hline Ставка \% по вкладам & 3,48 & 3,52 & 4,03 & 3,64 & 5,8 & 6,3 \\
\hline
\end{tabular}

Поэтому, если при анализе проекта используется только стоимость капитала, то есть коэффициент NPV, то, теоретически, многие весьма выгодные инвестиционные проекты могут быть отвергнуты.

\section{ЛИТЕРАТУРА}

- Besley S., Brigham E.F. (2003) Priciple of Finance. South-Western Thomson Learning. 475-525

- Bierman H, Smidt S. (1992) The Capital Budgeting Decision. Economic Analysis of Investment Projects. Macmillan Co. New York. 50-180 


\title{
Türkiye'nin Orta Asya Ülkeleriyle Ticareti: Almanya ve İran'la Karşılaştırmalı Bir Analiz
}

\author{
Abdüllatif Çeviker, Gaziantep Üniversitesi \\ H. Murat Mutlu, Gaziantep Üniversitesi \\ İsmail Taş, Gaziantep Üniversitesi
}

\section{Abstract \\ Turkey's Trade with Central Asian Countries: A Comperative Analysis with Iran and Germany}

In this study, composition and volume of goods traded will be analyzed by using proportions and trends, to determine the level of commercial partnership of Turkey, Iran and Germany with central Asian countries. Moreover, Turkey's relative position against Iran and Germany will be determined and introduced by using technological structure of export and import data. In the study covering the years of 1999-2008, data for the foreign trade at the level of the SITC 2 was collected from COMTRADE.

According to the findings, approximately $70 \%$ of Turkey's exports to Central Asia occur lower and middle technology product groups but Germany's exports consist of medium and high technology product groups. Iran's exports from the region include primary, source based and low-tech product group. Turkey and Germany's import from the region is dominated by raw material product groups. Iran's structure of import is similar with export structure.

JEL Codes: F14, F15

\section{Giriş}

Tedarik ve tüketim piyasası olarak büyük potansiyeli ve Uzak Asya- Avrupa eksenindeki lojistik önemi nedeniyle Orta Asya ülkeleri tüm dünyanın ilgisini çekmektedir. Türkiye gibi birçok ülke, bölge ile ekonomik ilişkilerini geliştirmek adına kapsamlı politikalar geliştirerek uygulamaktadır. Bu çalışmanın amacı bölge ile tarih, kültür ve coğrafya temelinde ortaklığ bulunan Türkiye'nin Orta Asya ile gerçekleştirdiği ticaretin boyutlarını ve niteliğini incelemektir.

Çalışmada, Orta Asya (Merkezi Asya) tanımlaması içinde genellikle Kırgızistan, Özbekistan Kazakistan, Türkmenistan, Tacikistan yer almakla birlikte, Türkiye'nin dış ilişkilerinde önemli yeri olan Azerbaycan da gruba dahil edildi. Türkiye'nin bu ülkelerle ticari ilişkilerini boyut ve nitelik bakımından açıklığa kavuşturmak için Almanya ve İran ile mukayese yoluna gidildi. Avrupa Birliği'nin Orta Asya ile ilişkilerinde belirleyici olan Almanya, Çin ve Rusya'dan sonra bölgenin üçüncü büyük ticaret ortağıdır. Orta Asya'ya ekonomik nüfuzu hedefleyen ve bunun için spesifik politikalar geliştiren Almanya, bu doğrultuda ticaretini hayli geliştirdiği Kazakistan'ı bölgeye açılan bir kapı olarak görmektedir (Peyrouse, 2009). Sayısı azalmakla birlikte, 200 bin Alman nüfusu (MRGI, 2008) Almanya Kazakistan arasında önemli düzeyde sosyal ve kültürel ortaklığın temelini oluşturmaktadır. İran ise Orta Asya ile ilişkileri bakımından Türkiye ile oldukça benzeşmekte ve günümüzde bölgenin önemli siyasi ve ekonomik güçlerinden biridir. Eskiden beri Orta Asya'da önemli bir aktör olmak isteyen İran, son yıllarda öncelikle uluslararası izolasyondan kurtulmasına yardımcı olmak için bölge devletleri ile siyasi ilişkileri geliştirmek, ticaret ve yatırım hacmini genişletmek istemektedir. İran bir yandan bölge ile ilişkilerini geliştirmek isterken diğer yandan da enerji tabanlı sektörlerde rekabet avantajını korumak amacıyla enerji kaynaklarına erişim hakkını korumayı da hedeflemektedir (Maleki, 2006). Açıkça seslendirilmese de İran ve Türkiye arasında bölgesel güç olma yarışının varlığı göz önünde tutulursa, araştırma bulguları bu yarışın yönü ve geleceği hakkında önemli bilgiler sunacaktır. Genel olarak bakıldığında, bu çalışma 
Türkiye'nin Orta Asya'da rekabet avantajına dayanak olan kültürel yakınlık ve teknolojik üstünlük faktörleri açısından gelişmekte olan İran ve gelişmiş Almanya gibi iki rakip karşısında göreli durum ortaya çıkarmaya çalışacaktır.

Nüfusunun çoğununun Türk asıllı unsurlardan meydana gelen Orta Asya ile Türkiye arasında köklü tarihi ve kültürel bağlar bulunmaktadır. Bölge ülkelerinin bağımsılıklarını tanıyan ilk ülkelerden olan Türkiye ile bölge arasında 1992'de kurulan ticari ilişkiler sonraki yıllarda giderek gelişmiştir (Solak, 2003; Akmeşe ve Çetin, 2009). 2000'ler sonrası başta Kazakistan ve Azerbaycan olmak üzere enerji kaynakları açısından Hazar bölgesinin artan önemi Türkiye ile bölge arasındaki ilişkilere ivme kazandırmıştır. Özellikle Bakü-Tiflis-Ceyhan Boru Hattı'nın devreye girmesi ve bu hatta Türkmen ve Kazak enerji hatlarının da eklenme olasılığı Türkiye ile bölge arasında ilişkilerin derinleşmesinde önemli katkı sağlamıştır (Kılıç, 2009). Türkiye ile bölge arasında ticari ilişkilerin niteliğini çözümlemek amacıyla Birleşmiş Milletler Uluslararası Ticaret Veri Tabanından (Comtrade) sağlanan veriler teknolojik yoğunluğuna göre sınıflandırıldı. Böylece elde edilen araştırma sonuçları ülkelerin hangi teknolojik seviyede ürünler ithal ya da ihraç ettiklerine bakarak bu ülkelerin teknolojik düzeyleri hakkında bilgi vereceği gibi dış ticaret performansını yöneten karar alıcılar için önemli bir hareket noktası olacaktır.

\section{Türkiye-Orta Asya Ticari İlişkilerinin Karşılaştırmalı Analizi}

\subsection{Türkiye ve Orta Asya Arasında Dış Ticaretin Miktarı ve Oransal Payı}

Türkiye'nin bölge ülkeleriyle yaptığı dış ticaret 2004 yılından sonra milyar doları aşmış ve düzenli bir şekilde artarak 2008 y1lında ithalat 4,4; ihracat ise 3,9 milyar dolara ulaşmıştır. Türkiye dönem içinde ithalatını 9,6 kat, ihracatını ise 6,8 kat artırmıştır. Almanya dönem içinde ithalatını yaklaşık 9,3, ihracatını 6,1 kat artırarak 2008 yılında ithalatını 9,4 ve ihracatını 4,1 milyar dolara ulaştırmıştır. Türkiye ile Almanya'nın 2008 yılında bölgeye yaptığı ihracat hemen hemen aynı iken, Almanya'nın bölgeden yaptığı ithalat Türkiye'nin yaklaşık iki katı kadardır. Bu farkın oluşmasında Almanya'nın Kazakistan ile olan sıcak ilişkileri önemli rol oynamıştır. İran'ın ise bölgeye yönelik ithalat ve ihracatı 300-680 milyon dolar arasında dalgalanmıştır.

Türkiye, Almanya ve İran'in toplam diş ticaretinde

Orta Asya'nın payı \%

\begin{tabular}{|c|c|c|c|c|c|c|}
\cline { 2 - 8 } \multicolumn{1}{c|}{} & \multicolumn{2}{c|}{ Türkiye } & \multicolumn{2}{c|}{ Almanya } & \multicolumn{2}{c|}{ İan } \\
\cline { 2 - 7 } \multicolumn{1}{c|}{} & ITH & İHR & İTH & İHR & İTH & İHR \\
\hline 1999 & 1,13 & 2,18 & 0,21 & 0,12 & 1,62 & 1,79 \\
\hline 2000 & 1,19 & 2,08 & 0,28 & 0,13 & 3,02 & 1,65 \\
\hline 2001 & 0,72 & 1,83 & 0,30 & 0,16 & 2,28 & 2,35 \\
\hline 2002 & 0,97 & 1,77 & 0,30 & 0,18 & 1,64 & 1,90 \\
\hline 2003 & 0,98 & 1,97 & 0,32 & 0,19 & 2,15 & 1,90 \\
\hline 2004 & 1,03 & 1,96 & 0,40 & 0,21 & 1,91 & 1,28 \\
\hline 2005 & 1,13 & 1,98 & 0,47 & 0,24 & 1,77 & 1,15 \\
\hline 2006 & 1,49 & 2,40 & 0,55 & 0,27 & - & 1,25 \\
\hline 2007 & 1,65 & 2,79 & 0,62 & 0,30 & - & - \\
\hline 2008 & 2,19 & 2,97 & 0,78 & 0,28 & - & - \\
\hline
\end{tabular}

Orta Asya'nın toplam dış ticaretinde

Türkiye, Almanya ve İran'ın Payı \%

\begin{tabular}{|c|c|c|c|c|c|}
\hline \multicolumn{2}{|c|}{ Türkiye } & \multicolumn{2}{|c|}{ Almanya } & \multicolumn{2}{c|}{ İran } \\
\hline İTH & İHR & İTH & İHR & İTH & İHR \\
\hline 5,49 & 3,73 & 6,35 & 8,16 & 3,40 & 1,66 \\
\hline 4,80 & 3,75 & 6,12 & 8,04 & 3,91 & 2,40 \\
\hline 4,06 & 1,69 & 6,31 & 8,29 & 3,99 & 2,11 \\
\hline 4,48 & 2,69 & 7,72 & 8,03 & 3,80 & 1,81 \\
\hline 5,21 & 2,87 & 7,99 & 8,15 & 3,61 & 2,32 \\
\hline 4,92 & 3,01 & 7,55 & 8,53 & 2,27 & 1,88 \\
\hline 4,74 & 2,81 & 7,58 & 7,87 & 2,24 & 1,46 \\
\hline 5,22 & 3,15 & 7,79 & 7,64 & 2,00 & 0,00 \\
\hline 5,74 & 3,21 & 7,74 & 7,49 & - & - \\
\hline 6,00 & 3,47 & 6,23 & 7,36 & - & - \\
\hline
\end{tabular}

Tablo 1: Türkiye, Almanya, Iran Ve Orta Asya Arasında Ticaretin Karşılıklı Payları (19992008). Kaynak: Trade Map verilerinden hazırlanmıştır.

Türkiye'nin toplam dış alımları içinde Orta Asya ülkelerinin oransal ağırlığı 1999 yılında $\% 1,13$ iken, bu oran on yıl içinde neredeyse ikiye katlanarak \%2,19'a ulaşmıştır. Bu durum söz konusu zaman zarfında Orta Asya'nın bir tedarik piyasası olarak Türkiye için öneminin 
arttığının göstergesidir. İhracatta ise oransal pay artışı, ithalatta olduğu kadar artmamıştır. Fakat Almanya ile Orta Asya ülkelerini bu açıdan karşılaştırdığımızda, Almanya'nın ithalatı içinde Orta Asya'nın oransal ağırlığı dönem içinde üç kattan fazla artarken, ihracatı ise iki kattan fazla artmıştır. Bu durum Almanya'nın Orta Asya ile ticari ortaklık düzeyinin Türkiye'den daha fazla derinleștirdiği anlamına gelmektedir. İran'ın 1999-2006 yılları arasında bölgeden dıș alımlarına bakıldığında ise istikrarsız bir seyir, ihracatında ise dalgalanmakla birlikte azalma eğilimi gözlenmektedir.

Ticari ilişkilere Orta Asya açısından bakıldığında, bölgenin toplam ithalatı içinde Türkiye'nin aldığı pay 1999'da \%5,49 iken, bu oran 2006 yılına kadar azalan eğilim sergilemiş 2007 ve 2008 yıllarında artarak \%6 ya ulaşmıştır. Bölgenin Türkiye'ye yaptığ 1 ihracat ise, Türkiye'nin 2001 kriz y1lı istisna tutulursa, \%3,2 dolaylarında seyretmiştir. Bölge ülkelerinin toplam ithalatı içinde Almanya'nın payı dönem içinde hafifçe artma eğilimi gösterirken, toplam ihracatın içindeki payı azalma eğilimi göstermektedir. Bölge ülkelerinin İran'dan yaptığı ithalatın oransal ağırlığı ise 1999-2006 yılları içinde düşme eğilimi göstermiştir.

\subsection{Türkiye ve Orta Asya Arasında Dış Ticaretin Yapısı}

Türkiye ve Orta Asya arasında ticaretin yapısal çözümlemesinde teknolojik yoğunluğa odaklanılmıştır. Bilindiği gibi teknolojik gelişme uzun dönem ekonomik büyümenin önemli kaynaklarından biridir. Teknolojik gelişme ile birlikte yeni ürünler, yeni üretim biçimleri veya yeni pazarlar yaratılırken birim girdi başına çıktıda artış gerçekleşir. Yaklaşık bütün ekonomik görüş akımları teknolojik gelişmenin, büyüme sürecinde önemli rol oynadığını kabul ederler (Archibugil ve Michie, 1998). Ayrıca yaygın kabul gören büyüme kaynaklarından bir diğeri ise ihracattır. Büyüme kaynağı olarak teknolojik gelişme ve ihracat bir arada düşünüldüğünde ihracat yapısının teknolojik yoğunluğu büyüme sorunsalı çerçevesinde dikkat çeken bir konudur.

İhracat yapısının büyüme üzerine etkisine bakıldığında ise, teknoloji yoğun ürünlerden oluşan bir ihracat yapısının, düşük teknoloji yoğunluklu yapıdan daha fazla etkili olduğu söylenebilir. Öncelikle belirtmek gerekir ki ürün ve süreç yeniliklerinin sıkça görüldüğü sektörler, genellikle teknolojik olarak durgunluk içindeki sektörlerden daha fazla talep artışıyla karşılaşır (Lall, 2000). Dünya ticaretinin en dinamik ürünlerinin enformasyon ve iletişim teknolojileri ürünleri olmasını bu açıdan değerlendirmek gerekir. Yenilikçi sektörlerin talep potansiyelinin yüksek olduğu gibi bu piyasalarda geleneksel ya da düşük teknolojili ürün piyasalarının aksine yeni rakiplerle karşılaşma olasılığı da düşüktür. Çünkü bu alanlarda üretim için gereken beşeri ve finansal sermaye ile diğer kaynaklar, teknolojik yetenek gibi nispeten kıt olmadığından yeni rakipler her zaman hazırdır. Üreticilerin yeni rakiplerle karşılaşmama isteği aynı zamanda düşük fiyat politikasını ve doğal olarak düşük kar marjlarını zorunlu kılar. Bunun aksine teknoloji yoğun ürünler piyasasında üreticiler yeni rakiplerin potansiyel tehdidine karş1 daha dayanıklıdır. Teknoloji yoğun ürünler piyasasında fikri mülkiyet hakları ve yüksek kaliteli işgücü ihtiyacından kaynaklanan piyasaya giriş engelleri yanında üreticiler, mevcut oyuncular karşısında da esnek üretim avantajı sayesinde talep yapısında meydana gelen değişimlere daha kolay uyum sağlar. Öte yandan ileri teknoloji üretim/ihracat yapısının bir takım dışsal faydaları da vardır. Bunlar arasında kendi içinde yenilik yaratma potansiyelinin yüksekliği ve yenilikçi tamamlayıcılık yolu ile düşük teknolojiyle üretim yapılan sektörlerde de verimlilik artışı sağlaması sayılabilir.

Belirli bir ülkenin dış piyasalarda ileri teknoloji alanında avantaj sahibi olması, bir başka değişle uzmanlığının bulunması o ülkenin dış ticaret performansını da olumlu etkiler (Archibugil ve Michie, 1998). Uzmanlaşma düzeyi ya da yenilikçilik ile performans arasında etki mekanizması incelendiğinde üç bağlantı göze çarpmaktadır. Birincisi üretim yöntemiyle ilgili bir süreç yeniliği maliyetleri düşürdüğünden üreticiye önemli bir rekabet avantajı kazandırır. Ticarete konu üründe yaratılan küçük yenilikler kaliteyi artırdığından hem iç hem de dış piyasalarda talep düzeyini yükseltir. Büyük yenilikler ise üreticisine kısa bir süre bile olsa tekel konumu ve buna bağlı olarak olağandışı karlar sağlar. Tüm bunlar göz önünde 
tutulduğunda yüksek teknolojinin belirleyici olduğu ihracat yapısının uluslar arası piyasalarda rekabet gücünü artırdığı ve farklı kanallardan büyüme üzerinde etkili olduğu görülebilir.

Çalışmada Lall (2000) tarafından Pavit (1984) ve OECD (1994)'nin yaptığı tasnif denemelerine dayanarak hazırlanan sınıflandırma kullanılmıştır. Tablo 2'de Türkiye, Almanya ve İran'ın Orta Asya ile ticaretinin teknolojik yoğunluğa göre bileşim ve değişimi görülmektedir.

\begin{tabular}{|c|c|c|c|c|c|c|c|c|c|c|}
\hline \multicolumn{6}{|c|}{ TÜRKIYYE } & \multicolumn{5}{|c|}{ (Milyon \$) } \\
\hline & \multicolumn{2}{|c|}{ Hammadde } & \multicolumn{2}{|c|}{ Kaynak Temelli } & \multicolumn{2}{|c|}{$\begin{array}{c}\text { Düşük } \\
\text { Teknoloji }\end{array}$} & \multicolumn{2}{|c|}{ Orta Teknoloji } & \multicolumn{2}{|c|}{$\begin{array}{l}\text { Yüksek } \\
\text { teknoloji }\end{array}$} \\
\hline & İHR & İTH & İ̈HR & İTH & İHR & İTH & İHR & İTH & İHR & İTH \\
\hline 1999 & 41,8 & 380,6 & 136,5 & 16,2 & 182,8 & 46,9 & 163,1 & 17,1 & 35,9 & 0,4 \\
\hline 2000 & 31,3 & 475,5 & 121,6 & 66,0 & 172,7 & 70,3 & 180,1 & 32,0 & 42,2 & 0,6 \\
\hline 2001 & 32,4 & 185,1 & 123,2 & 54,8 & 146,6 & 41,5 & 194,1 & 12,4 & 48,8 & 2,3 \\
\hline 2002 & 42,3 & 333,2 & 126,0 & 52,2 & 195,8 & 77,3 & 208,9 & 32,7 & 37,2 & 0,7 \\
\hline 2003 & 49,8 & 7,1 & $\overline{16}$ & 86 , & 293,3 & 130,1 & 44,0 & 0,3 & 53,1 & 5,6 \\
\hline 2004 & 60,8 & 2,4 & 1 & 10 & 428,9 & 159,2 & 8 & 3,8 & 72,0 & 1,8 \\
\hline 2005 & $\overline{0,0}$ & 5,3 & 2 2. & 166 & 509,3 & 180,5 & ,2 & 3,1 & 76,2 & 0,7 \\
\hline 5 & 0,2 & 79,0 & $\overline{30}$ & 208 & 672,2 & 58,0 &, 2 & 120,2 & 11,8 & $\overline{2,1}$ \\
\hline 7 & 2,6 & 8,9 & 44 & 279,2 & 08,0 & 290,2 & 0 & 77,8 & 56,5 & 0,7 \\
\hline 2008 & 5,6 & 2972,8 & 672,4 & 547,6 & 1329,1 & 244,1 & 1546,7 & 146,2 & 192,5 & 0,3 \\
\hline \multicolumn{11}{|c|}{ ALMANYA } \\
\hline 1999 & 28,3 & 767,1 & 62,7 & 33,5 & 67,3 & 11,2 & 267,0 & 54,1 & 79,2 & 14,7 \\
\hline 2000 & 16,9 & 34,5 & 51,4 & 35,2 & 70,3 & 12,9 & 389,9 & 44,7 & 91,2 & 2,0 \\
\hline 2001 & 18,8 & 241,7 & 70,3 & 35,6 & 78,9 & 15,1 & 194,1 & 43,7 & 137,5 & $\overline{7,3}$ \\
\hline 2002 & 21,5 & 1362,9 & 75,3 & 29,0 & 92,3 & 20,9 & 631,6 & 45,8 & 128,2 & 3,3 \\
\hline 2003 & 27,6 & 1800,1 & 105,2 & 34,5 & 128,3 & 19,3 & 787,6 & 29,4 & 229,1 & 3,2 \\
\hline 2004 & 27,0 & 2653,2 & 128,3 & 79,5 & 174,2 & 28,1 & 1057,7 & 20,9 & 384,6 & 12,0 \\
\hline 2005 & 32,1 & 3392,5 & 150,2 & 133,0 & 216,8 & 24,0 & 1206,9 & 41,8 & 608,9 & 10,6 \\
\hline 2006 & 61,5 & 4746,3 & 231,7 & 146,5 & 248,0 & 29,6 & 1627,6 & 41,1 & 650,0 & 12,5 \\
\hline 2007 & 55,1 & 6113,6 & 288,5 & 208,7 & 337,1 & 328,9 & 2184,6 & 113,4 & 984,8 & 12,1 \\
\hline 2008 & 76,7 & 87 & 354,2 & 188,6 & 398,4 & 269,1 & 2247,2 & 347,3 & 790,3 & 9,8 \\
\hline \multicolumn{11}{|c|}{ İRAN } \\
\hline 1999 & 3,7 & 26,1 & 112,7 & 16,7 & 131,5 & 99,5 & 55,6 & 56,1 & 4,5 & 6,4 \\
\hline 2000 & 54,0 & .5 & 20,4 & 19,9 & 209,6 & 208,5 & 79,3 & 124,6 & 2,9 & 5,9 \\
\hline 2001 & 40,8 &, 5 & 134,3 & 18,2 & 296,2 & 162,0 & 86,5 & 137,1 & 2,4 & 4,3 \\
\hline 2002 & 39,5 & 97,0 & 133,5 & 21,7 & 279,7 & 137,1 & 80,1 & 76,2 & 1,5 & 2,0 \\
\hline 2003 & 59,6 & 103,5 & 153,9 & 70,7 & 304,4 & 218,3 & 113,1 & 157,0 & 2,4 & 1,7 \\
\hline 2004 & 59,8 & 115,3 & 131,8 & 210,2 & 279,3 & 129,4 & 94,4 & 172,7 & 4,0 & 1,7 \\
\hline 2005 & 95,7 & 134,4 & 165,0 & 231,0 & 297,8 & 190,2 & 121,5 & 126,5 & 5,1 & 1,3 \\
\hline 2006 & 129,4 & 34,3 & 184,6 & 26,3 & 296,5 & 128,4 & 169,2 & 107,3 & 5,6 & 1,0 \\
\hline
\end{tabular}

Tablo 2: Türkiye, Almanya ve Iran'ın Orta Asya ile Ticaretinin Teknolojik Yoğunluğuna Göre Bileşimi. Kaynak: Comtrade veri tabanından elde edilen verilerle hazırlanmıştır. 


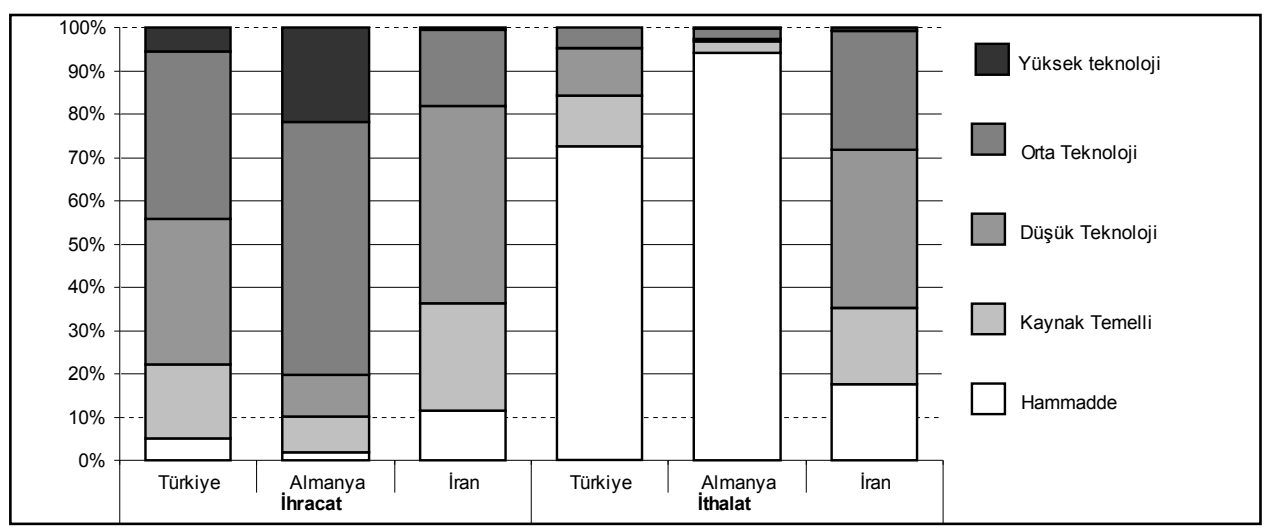

Şekil 1: Türkiye, Almanya ve Iran'ın Orta Asya Ülkeleriyle Dış Ticaretinin Yapısı (1999-2006 ortalama)

Şekil 1 Türkiye, Almanya ve İran'ın Orta Asya'ya dönük dış ticaretinin teknolojik yoğunluğa göre yapısını göstermektedir. Hammadde ticaretinin üç ülkenin ihracatında önemli bir payı bulunmamakta, fakat Türkiye ve Almanya ithalatının sırasıyla \%72,5 ve \%94 gibi çok önemli bir kısmını hammadde şeklinde gerçekleştirmektedir. Türkiye'nin bölgeye doğru kaynak temelli ürünler ihracatının \%17,2'sini, Almanya'nın \%8,12'sini oluştururken, İran'ın $\% 24,74$ 'ünü oluşturmaktadır. Türkiye'nin kaynak temelli ürün ithalatı toplamı içinde \%11,7'lik pay alırken, bu oran Almanya'da \%2,72, İran'da ise \%17,66'dır.

Düşük teknoloji ürünlerinin Türkiye ve görece İran açısından daha önemli bir mal grubu görülmektedir. Türkiye ihracatının \%33,6'sını, İran \%45,62'sini Almanya ise \%9,7'sini bu alanda yapmaktadır. İthalata bakıldığında ise Türkiye'nin payı \%11 iken, İran'ın payı \%36 olarak gerçekleşmiştir. Düşük teknoloji ürünleri Almanya'nın ithalatında ihmal edilebilecek bir düzeydedir. Beklendiği gibi Orta teknoloji ürünleri, Almanya ihracatının \%58,4 ile en büyük bir kısmını oluşturmaktadır. Türkiye'nin de ihracatının en büyük kısmını oluşturmakta, fakat bu oran \%38,6 olarak gerçekleşmiştir. İran ise orta teknoloji alanında ihracatının \%17,4'ünü, fakat ithalatının \%27,5'ini gerçekleştirmiştir. Bu oran Türkiye ve Almanya için \%4,6 ve \%2,3 gibi düşük düzeylerde gerçekleşmiştir. Yüksek teknoloji grubuna giren ürünler Türkiye ihracatının \%5,63'ünü oluştururken Almanya ihracatının \%21,85'ini oluşturmaktadır. İran ise ihracatının \%0,62'si gibi küçük bir payını gerçekleştirmiştir. Her üç ülkenin de Orta Asya ülkelerinden gerçekleştirdiği ithalat içinde ileri teknoloji ürünlerinin payı sırasıyla \%0,11, $\% 0,26$ ve $\% 0,70$ olarak düşük düzeyde gerçekleşmiştir.

\section{Sonuç}

Türkiye'nin Orta Asya ile gerçekleştirdiği ticaretin boyutlarını ve niteliğini incelemeyi amaçlayan bu çalışmada ulaşılan sonuçlar iki başlık altında değerlendirilebilir. Birincisi, Türkiye ve bölge ülkeleri arasındaki dış ticaretin miktarı, karşılıklı oransal payları ve bunların değişiminden elde edilen sonuçlara genel olarak bakıldığında dönem içinde Türkiye ve Orta Asya ticareti dengeli bir şekilde artan bir seyir izlemekle birlikte, ticaret ortağı olarak birbirleri karşısında göreli önemleri eşit değildir. Türkiye'nin toplam ithalatı içinde söz konusu altı ülkenin aldığı pay 2008 yılı için \%2,19 iken, bu ülkelerin toplam ithalatı içinde Türkiye'nin payı \%6 olmuştur. Bu durum tedarik piyasası olarak Türkiye'nin Orta Asya karşısında yaklaşık 3 kat daha fazla önemli olduğunu göstermektedir. Bu eşitsizlik düzeyi 1999'dan 2008'e kadar geçen sürede azalmakla birlikte, ticari ilişkiyle ilgili yerleşik bir karakteristik gibi gözükmektedir. Aynı bağlamda Almanya-Orta Asya ticaretine bakıldığında ise tipik bir gelişmiş-az gelişmiş ticari ilişki modeli görülebilir. Orta Asya karşısında Türkiye ve Almanya'nın önemi karşılaştırıldığında Türkiye'nin tedarikçi olarak Almanya'yı yakından takip ettiği gözlenmiştir. Almanya'nın bölgeden yaptığı büyük miktarda ham petrol ithalatı nedeniyle 
Orta Asya ülkelerinin ihraç piyasası olarak Türkiye'nin görece ağırlığı düşüktür.

İkinci olarak dış ticarete konu ürünlerin teknolojik yoğunluğa göre sınıflandırılması sonucu elde edilen bulgulardan hammadde grubu ile ilgili olarak dikkat çeken unsurlardan birinin Almanya ithalatının \%95'ini bu gruba giren ürünlerden yapmasıdır. Türkiye ise bu anlamda Almanya ile benzeşmekle birlikte ithalatı içindeki payı daha azdır. Genellikle emek yoğun üretilen kaynak temelli ürünlerin üretiminde sermaye, ölçek, beceri faktörleri avantaj doğursa da önemli olan hammadde kaynağının mevcudiyetidir. Dolayısıyla rekabeti etkileyen faktörün doğal kaynağın varlığı, taşıma maliyetleri ve kısmen kaynağın üretime hazırlanmasında kullanılan teknolojidir. Dolayısıyla bu gruba giren ürünlerde avantajların dışsal faktörler tarafından belirlendiği söylenebilir. Bu noktada İran'ın çimento ihracatını lojistik maliyet avantajından kaynaklandığı söylenebilir.

Düşük teknoloji ürünler tekstil, giyim, toprağa dayalı ürünler ve basit eşyalar gibi istikrarlı, dünya coğrafyasına yayılmış teknolojilere sahiptirler. $\mathrm{Bu}$ teknoloji grubunda üretim için gereken sermaye genellikle düşük olduğundan, ürün maliyetinin belirleyicisi emek fiyatıdır. Doğal olarak fiyat farklılaştırması temelindeki rekabette en önemli unsur da ücretler genel seviyesi olmaktadır. Bu piyasalara giriş engelleri genellikle düşük olduğundan oyuncuların karlılık düzeyi bilinçli olarak düşük tutulmaktadır. Burada endüstri grubunun karlılık düzeyinde marka ve tasarım faktörü üzerinde önemli görülmektedir. (Lall, 2000) Türkiye'nin ihracatının önemli bir kısmını düşük teknoloji grubunda yapıyor olması sürdürülebilir bir rekabet avantajına sahip olmak için bir yandan ücretleri baskı altında tutarken diğer yandan marka, tasarım gibi unsurlara ağırlık vermesi gerektiği şeklinde yorumlanabilir. Öte yandan bu alanda en çok ihraç edilen malın hal1-kilim olması tasarım faktörünün Türk üreticileri tarafından kullanıldığını doğrular niteliktedir. Fakat akılda tutulması gerekenin düşük teknoloji ürün piyasalarında yeni rakiplerin her zaman kolayca Türkiye'nin karşısına çıkabileceğidir. Bu noktada izlenmesi gereken stratejinin bir yandan fiyatta rekabet gücüne sahip olmak için ücret avantajına güvenmek yerine maliyet düşürücü proses yeniliklerine kaynak tahsis etmek, diğer yandan marka tasarım ikilisine yatırım yapmak olacaktır. Fakat nihayetinde en önemlisi ilgili sektörün orta ve yüksek teknolojiye bakan yönünü geliştirmek olacaktır.

Türkiye'nin diğer önemli ihraç ürünleri grubu ise Orta teknoloji ürünleridir. Olgun ekonomilerde endüstrinin kalbi konumunda olan orta teknoloji grubu komplike üretim yöntemlerine ihtiyaç duyar (Lall, 2000). Bu teknoloji grubunda yoğun (AR-GE) faaliyetleri ve uzun öğrenme sürecinin gerektiği eğitimli işgücüne ve ciddi ekonomik kaynaklara ihtiyaç duyar. Böyle olunca önemli piyasaya giriş engelleri ve kar potansiyelini içinde barındırır. Türkiye bu grupta ihracatının önemli bir kısmını beyaz eşya olarak gerçekleştirmektedir. Ancak bu ürün grubunun sağladığ 1 katma değerin düşük olduğu ve taşıma maliyetlerinin yüksekliği dikkate alındığında ihracat karlılığı açısından olumsuz bir durum yaratmaktadır. Türkiye'nin orta teknoloji grubundaki bu gelişimi kendisine yüksek teknoloji ürünleri üretimi için gerekli teknolojik altyapı birikimi sağlayacaktır.

Yüksek teknolojili ürünler, araştırma geliştirme maliyetlerinin yüksek olduğu ve hızla değişebilen teknoloji grubudur. Bu grupta üretim yapılabilmesi için ülkede karmaşık bir teknolojik altyapı, yüksek düzeyde teknik beceri, firmalar arasında, firmalarla üniversiteler ve araştırma enstitüleri arasında yakın etkileşimi sağlayan ve planlayan ulusal yenilik sistemini gerektirir. Bununla birlikte elektronik gibi bazı ürünlerin nihai montajında emek yoğun üretime ihtiyaç duyarlar ve yüksek ağırlık değer oranları sayesinde ürünün düşük ücretli üretim alanlarında üretilmesi ekonomi sağlar. Bu tür ürünler farklı üretim maliyeleri yüzünden, üretim sürecinin farklılaştırılmasından dolayı uluslararası entegrasyon sistemine öncülük eder. Elektronik dışında yüksek teknoloji ürünleri (uçak, hassas aletler, eczacilık ekipmanları) beceri düzeyi, teknolojisi ve tedarikçi ağları yüksek olan ekonomilerde kalıcı olurlar (Lall, 2000). Bu noktada ele alınan her ülkenin yüksek teknoloji ürünleri olarak ne ihraç ettiği ayrıntılı olarak incelenmelidir. Çünkü bu grupta Türkiye ve Almanya'nın en büyük ihracat kalemleri telekomünikasyon cihazlarıdır. Ancak bu konu ile ilgili doğru saptamalar için alt grupların da dikkate alan analizlere ihtiyaç vardır. 


\section{KAYNAKÇA}

- Peyrouse, 2009. "Bussiness and Trade Relation Between EU and Central Asia" EUCAM Working Paper No:1 http://www.ceps.eu/book/business-and-traderelationships-between-eu-and-central-asia

- MRGI, 2008. "World Directory of Minorities and Indigenous Peoples - Kazakhstan : Germans," http://www.unhcr.org/refworld/docid/49749cfb28.html

- Maleki, 2006. "Iran, Central Asia, and Afghanistan: Recent Developments" Central Asia-Caucasus Institute \& Silk Road Studies Program Joint Center, http://www.silkroadstudies.org

- Solak, 2003. “Türkiye Orta Asya Cumhuriyetleri Dış Tcaret İlişkilerinin Gelişimi”, Marmara Üniversitesi I.I..B.F Dergisi, 18/1, s.70.

- $\quad$ Akmeşe ve Çetin, 2009. “2008 Dünya Ekonomik Krizinin Türkiye Ekonomisi Ve Türk-Azeri Ekonomik İlişkileri Üzerindeki Etkileri” Journal of Azerbaijani Studies, vol 12, p 55

• Kılıç, 2009. “Türkiye - Türk Dünyası İlişkileri: 1991-2009”, Uluslarası Stratejik Araştırmalar Kurumu, http://www.usakgundem.com

- Trademap, 2010. Trade statistics for international business development, http://www.trademap.org/

- Archibugil ve Michie, 1998. "Technical Change, Growth and Trade: New Departures in Institutional Eoconomics" Journal of Economic Survey, vol 12, no 3

- Lall, 2000. "The Technological Structure and Performance of Developing Country Manufactured Exports, 1985-98" Oxford Development Studies, 28: 3, p. 337 - 369

- Pavitt, 1984. "Sectoral Patterns of Technical Change: Towards A Taxonomy And A Theory", Research Policy”, 13, p. 343-373.

- Comtrade, 2010. United Nations Commodity Trade Statistics Database, http://comtrade.un.org/ 


\title{
Türkiye ile Orta Asya Türk Cumhuriyetleri Arasındaki Endüstri-İçi Ticaretin Analizi
}

\author{
Murat Ozan Başkol, Uludağ Üniversitesi
}

\begin{abstract}
Intra-Industry Trade between Turkey and Central Asian Turkic Republics

Intra-industry trade is the simultaneous export and import of goods within the same industry. The aim of this study is to examine the share of intra-industry trade in Turkey's foreign trade with Central Asian Turkic Republics within the period 1992 to 2009. For this purpose this paper calculates Grubel-Lloyd index by using the data SITC Rev.3 at 3 digit.
\end{abstract}

JEL codes: F10, F12, F14

\section{Giriş}

Uluslararası iktisat teorisi, birincil mallar ile mamul mallar arasındaki bir başka ifadeyle endüstriler arasındaki dış ticaretin nedenlerini analiz eder. Ancak ülkeler arasında birbirleriyle çok kolay ikame edilebilen aynı endüstrinin farklılaştırılmış mallarının ticareti de yapılmaktadır. Günümüzde sanayileşmiş ülkeler arasındaki toplam ticaretin önemli bir kısmı aynı endüstrinin farklılaştırılmış mallarının ticareti, endüstri-içi ticaret, şeklindedir. OECD tarafından yapılan bir çalışmada toplam mamul mal ticareti içinde endüstri-içi ticaretin payı 1996-2000 döneminde Fransa'da \%77,5, Kanada'da \%76,2, İngiltere'de \%73,7 ve ABD'de $\% 68,5$ olarak hesaplanmıştır. (OECD, 2002)

Ülkemizin dış ticaretinde endüstri-içi ticaretin payını belirlemeye yönelik çalışma-lar son yıllarda artmış olmakla birlikte hala yeterli düzeyde değildir. Söz konusu çalışmalar ağırlıklı olarak ülke bazlı çalışmalar şeklinde olup genellikle ülkemizin Avrupa Birliğiyle yaptığı dış ticaret içinde endüstri-içi ticaretin payını analiz etmeye yöneliktir. Gönel'in çalışması (2001) ülkemizin Orta Asya Türk Cumhuriyetleri ile dış ticaretinde endüstri-içi ticaretin payını analiz etmesi açısından önemlidir. Gönel çalışmasında 1992-1997 dönemi için fasıllara göre iki basamaklı dış ticaret verilerinden hareket etmiş ve Orta Asya Türk Cumhuriyetleri için bulduğu endüstri-içi ticaret endeks değerlerini AB için hesapladığı endeks değerleriyle karşılaştırmıştır. Söz konusu çalışmada Orta Asya Türk Cumhuriyetleri için endeks değeri 1992'de \% 3,3 ve 1997 'de \% 6,3; Avrupa Birliği içinse 1992'de \%26,9 ve 1997'de \% 27,2 olarak hesaplanmıştır. AB ile Orta Asya Türk Cumhuriyetleri kıyaslan-dığında Orta Asya Türk Cumhuriyetleri'nin payı oldukça düşüktür (Gönel,2001).

$\mathrm{Bu}$ çalışmanın amacı, ülkemiz ile Orta Asya Türk Cumhuriyetleri arasındaki endüstri-içi ticareti analiz etmektir. Bu amaç doğrultusunda 1992-2009 dönemi için ülkemizle Orta Asya Türk Cumhuriyetleri arasındaki endüstri-içi ticaret endeks değerleri, TÜİK veri tabanından elde edilen Standart Uluslararası Ticaret Sınıflandırması (SITC) 3 basamaklı dış ticaret verileri düzeyinde, Grubel-Lloyd endeksi kullanılarak hesaplanacaktır.

\section{Endüstri-içi ticaret ve ölçülmesi}

Endüstri-içi ticaret, faktör girdileri ve tüketim açısından birbirine yakın ikame mal-ların eşanlı ithalat ve ihracatı olarak tanımlanmaktadır.(Tharakan ve Calfat,1996) Endüstri-içi ticaret aynı endüstriye ait malların hem ihraç hem de ithal edilmesidir. Bir başka ifadeyle endüstri-içi ticaret ülkelerin örneğin neden otomobil ihraç ederken aynı zamanda ithal ettikleri sorusuna cevap aramaktadır.

Endüstri-içi ticaretin ortaya çıkışı, 1960'lı yıllarda Verdoorn ve Balassa'nın gümrük birliği oluşturulduktan sonra endüstri-içi uzmanlaşmanın arttığı yönündeki bulgu-larına 
dayanmaktadır. Verdoorn ve Balassa'nın çalışmaları önemli olmakla birlikte endüstri-içi ticaretin sistematik biçimde ortaya konulması Grubel ve Lloyd'un çalışmasıyla olmuştur. Grubel ve Lloyd'un çalışması gerek farklılaştırılmış malların dış ticaretine teorik bir bakış açısı sergilemesi gerekse de endüstri-içi ticaretin ölçüm yönteminin ortaya konul-ması bakımından önemlidir. Endüstri-içi ticareti açıklamaya yönelik ortaya konan teorik modellerin asıl gelişimi ise A.Dixit ve J.Stiglitz ve K.Lancester'ın tüketici tercihlerini ve ölçek ekonomilerini genel denge modeli içinde șekillendirmeleri ve P.Krugman ve K.Lancester'ın bu modelleri açı bir ekonomi temelinde uygulamalarıyla olmuştur. (Greenaway ve Milner, 1986) Endüstri-içi ticaretin nedenini monopolcü rekabet ve oligopol piyasası özelinde inceleyen aksak rekabet modelleri olduğu kadar endüstri-içi ticareti Hecksher-Ohlin teoremi varsayımları dahilinde açıklayan çalışmalarda mevcuttur.

Endüstri-içi ticaret hesaplamalarında genellikle Grubel-Lloyd Endeksi kullanıl-maktadır. Grubel Lloyd Endeksini şu şekilde gösterebiliriz:

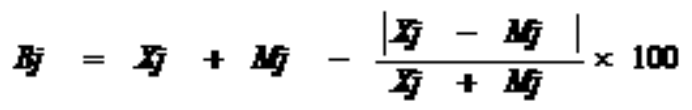

$B_{\mathrm{j}}$; ülkenin $\mathrm{j}$ ürünündeki endüstri-içi ticaret endeks değerini, $\mathrm{X}_{\mathrm{j}}$ ve $\mathrm{M}_{\mathrm{j}}$ ülkenin $\mathrm{j}$ ürünündeki ihracat ve ithalat değerini göstermektedir. Endeks değeri yüz ya da yüze yakın bir değer alıyorsa $\mathrm{j}$ ürünündeki dış ticaretin endüstri-içi ticaret, sıfırsa ya da sıfıra yakın bir değer alıyorsa endüstriler arası ticaret şeklinde olduğu kabul edilmektedir. Grubel-Lloyd Endeksi, endüstri-içi ticaretin toplam dış ticaret içindeki payını göstermektedir. Ancak endüstrilerin dış ticaret hacminin toplam dış ticaret hacmi içerisindeki nispi ağırlıkları farklıdır. Dolayısıyla her endüstrinin alt ürün gruplarının toplam dıș ticaret hacmi içerisindeki ağırlıklarını belirleyerek söz konusu alt ürün gruplarının endeks değerleriyle çarpmak ve bulunan değerleri toplamak bize endüstri-içi ticareti ağırlıklı ortalama cinsinden verecektir.

$$
\overline{B j}=\sum \mathcal{V}_{j}>B_{j} w_{j}=\frac{X j+M j}{\sum X j+\sum M j}
$$

Endüstri-içi ticaret hesaplamalarında karşılaşılan en önemli güçlük, toplulaştırma düzeyinin seçimiyle ilgilidir. Kategorik toplulaştırma (categorical aggregation) bir ülkeye ait dış ticaret istatistiklerinde farklı üretim fonksiyonlarına sahip malların aynı endüstri içerisinde yer almaları ve bu verilerin söz konusu endüstrinin eşanlı ithalat ve ihracat değer-lerini yansıtmasının bir sonucu olarak ortaya çıkmaktadır (Gray,1979). Toplulaştırma dü-zeyinin seçimi daha doğru bir endüstri-içi ticaret endeks değerinin hesaplanması açısından önemlidir. Toplulaştırma düzeyi, ürün sınıflandırmasında temel alınan basamak sayısına bağlı olarak birden beşe kadar değişik biçimlerde ortaya çıkmaktadır. En yüksek toplu-laştırma düzeyi 1, en düşük toplulaştırma düzeyi ise 5 basamaklı toplulaştırma düzeyidir. Ürün sınıflandırmasındaki basamak sayısının azaltılması, toplulaştırma düzeyinin artması-na, basamak sayısının arttırılması ise ayrıştırma düzeyinin artmasına ve dolayısıyla toplu-laştırma seviyesinin azalmasına yol açmaktadır. Şöyle ki 5 SITC kodlu kimya sanayini 2 basamaklı olarak tanımladığımızda 7 alt sektör, 3 basamaklı olarak ele aldığımızda 33 alt sektör için analiz yapmak mümkündür. Dolayısıyla bir ülke için endüstri-içi ticaret endeksi hesaplanırken çalışma açısından belirlenmesi gereken en temel nokta, çalışmanın hangi basamak düzeyinde yapılacağıdır. Çünkü 1-2 basamaklı verilerin seçilmesi durumunda hesaplanan endeks değeri olması gerekenden daha yüksek çıkacaktır.

\section{Türkiye ile Orta Asya Türk Cumhuriyetleri Arasındaki Dış Ticaretin Yapısı}

Ülkemizin Orta Asya Türk Cumhuriyetleriyle arasındaki dış ticaret hacmi artmaktadır. Nitekim 1992 yılındaki dış ticaret hacmi 274,6 milyon \$ iken 2009 yılında 6,3 milyar \$'a ulaşmıştır. Orta Asya Türk Cumhuriyetleriyle dış ticaret hacmimiz artmasına karşın toplam 
ihracatımız ve toplam ithalatımızda söz konusu ülkelerin payı küçüktür. Toplam ihracatımız içerisinde Orta Asya Türk Cumhuriyetlerinin payı 1992 yılında \% 1,3 iken bu oran 2009'da \% 3,3'e yükselmiștir. Toplam ithalatımız içinde Orta Asya Türk Cumhuriyetlerinin payı 1992'de \% 0,4 ve 2009'da \% 2,2'dir. Orta Asya Türk Cumhuriyet-lerine 1992'de yaptı̆̆ımız 185,4 milyon \$'lık ihracatın 67,6 milyar \$'1 (\% 36'sı), 2009'da yaptı̆̆ımız 3,4 milyar \$'lık ihracatın 3,1 milyar \$'1 (\% 92'si) mamul mallar şeklindedir (Tablo 1). Mamul mallar ihracatının önemli bir kısmı özellikle başlıca sınıflara ayrılarak işlenmiș mallar (6) ve makine ve ulașım araçları (7) sektörüne aittir. 1992'de başlıca sınıflara ayrılarak ișlenmiș mallar ihracatının payı \% 4 iken bu oran 2009 yılında \% 32,3'e ulaşmıștır. 1992'de makine ve ulaşım araçları ihracatının payı \% 17 iken bu oran 2009 yılında \% 27,8'e ulaşmıştır.

\begin{tabular}{|c|c|c|c|c|c|c|c|c|c|}
\hline & $\mathbf{1 9 9 2}$ & $\mathbf{1 9 9 3}$ & $\mathbf{1 9 9 4}$ & $\mathbf{1 9 9 5}$ & $\mathbf{1 9 9 6}$ & $\mathbf{1 9 9 7}$ & $\mathbf{1 9 9 8}$ & $\mathbf{1 9 9 9}$ & $\mathbf{2 0 0 0}$ \\
\hline $\mathbf{0 - 4}$ & 117.8 & 165.9 & 110.6 & 203.3 & 267.1 & 271.7 & 224 & 147.6 & 126.7 \\
\hline $\mathbf{5 - 8}$ & 67.6 & 284.5 & 318.9 & 341.8 & 480.1 & 636.1 & 610.9 & 426.0 & 445.7 \\
\hline Toplam & 185.4 & 450.4 & 429.5 & 545.1 & 747.3 & 907.8 & 834.9 & 573.6 & 572.4 \\
\hline & $\mathbf{2 0 0 1}$ & $\mathbf{2 0 0 2}$ & $\mathbf{2 0 0 3}$ & $\mathbf{2 0 0 4}$ & $\mathbf{2 0 0 5}$ & $\mathbf{2 0 0 6}$ & $\mathbf{2 0 0 7}$ & $\mathbf{2 0 0 8}$ & $\mathbf{2 0 0 9}$ \\
\hline $\mathbf{0 - 4}$ & 116.8 & 111.1 & 121.1 & 143.2 & 165.5 & 190.4 & 238.3 & 314.8 & 283 \\
\hline $\mathbf{5 - 8}$ & 440.4 & 508.2 & 777.9 & 1051.0 & 1243.7 & 1791.2 & 2636.1 & 3434.6 & 3114 \\
\hline Toplam & 557.3 & 619.3 & 899.1 & 1194.3 & 1409.2 & 1981.6 & 2874.5 & 3749.4 & 3397 \\
\hline
\end{tabular}

Tablo 1: Orta Asya Türk Cumhuriyetleriyle İhracatımız

Orta Asya Türk Cumhuriyetlerinden 1992 yılında yaptığımız ithalat 89,2 milyon \$ iken 2009 yılında bu rakam 2,8 milyar \$'a ulaşmıştır. Söz konusu ülkelerden yaptığımız ithalatta mamul mal ithalatının payı örneğin 2006'da \% 70'i bulsa da ithalatın önemli bir kısmı 0-4 mal grubuna aittir. Örneğin 1992 yılında yaptığımız ithalatın \% 85'i 0-4 mal grubuna aittir. (Tablo 2)

\begin{tabular}{|c|c|c|c|c|c|c|c|c|c|}
\hline & $\mathbf{1 9 9 2}$ & $\mathbf{1 9 9 3}$ & $\mathbf{1 9 9 4}$ & $\mathbf{1 9 9 5}$ & $\mathbf{1 9 9 6}$ & $\mathbf{1 9 9 7}$ & $\mathbf{1 9 9 8}$ & $\mathbf{1 9 9 9}$ & $\mathbf{2 0 0 0}$ \\
\hline $\mathbf{0 - 4}$ & 76.2 & 149.5 & 155.9 & 190.4 & 181.4 & 193.5 & 229.9 & 284.3 & 393 \\
\hline $\mathbf{5 - 8}$ & 13.0 & 40.4 & 33.7 & 96.8 & 122.6 & 205.9 & 219.0 & 172.9 & 235 \\
\hline Toplam & 89.2 & 189.9 & 189.6 & 287.2 & 304.0 & 399.4 & 448.9 & 457.2 & 628 \\
\hline & $\mathbf{2 0 0 1}$ & $\mathbf{2 0 0 2}$ & $\mathbf{2 0 0 3}$ & $\mathbf{2 0 0 4}$ & $\mathbf{2 0 0 5}$ & $\mathbf{2 0 0 6}$ & $\mathbf{2 0 0 7}$ & $\mathbf{2 0 0 8}$ & $\mathbf{2 0 0 9}$ \\
\hline $\mathbf{0 - 4}$ & 154.3 & 211.0 & 274.9 & 365.7 & 463.4 & 582.9 & 1009.8 & 2391.6 & 1708 \\
\hline $\mathbf{5 - 8}$ & 128.1 & 256.7 & 348.3 & 579.8 & 804.0 & 1384.4 & 1659.4 & 1886.8 & 1165 \\
\hline Toplam & 282.5 & 467.7 & 623.3 & 945.6 & 1267.4 & 1967.4 & 2669.2 & 4278.5 & 2874 \\
\hline
\end{tabular}

Tablo 2: Orta Asya Türk Cumhuriyetleriyle Ithalatımız

Orta Asya Türk Cumhuriyetlerinden yaptığımız ithalatın sektörel dağılımı açısından baktığımızda, 0-4 mal grubunda gerçekleşen ithalatın 2002 yılına kadar akaryakıt hariç yenilmeyen hammaddeler (2), 2003 yılından sonra ise mineral yakıtlar, yağlar ve alkali ürünler (3) ağırlıklı olduğunu görmek mümkündür. Orta Asya Türk Cumhuriyetlerinden yaptığımız mamul mallar ithalatı başlıca sınıflara ayrılarak işlenmiş mallar (6) ağırlıklıdır. 2006 yılında yaptığımız mamul mal ithalatının toplam ithalat içindeki payı \% 70 iken başlıca sınıflara ayrılarak işlenmiş mallar sanayinin payı \% 66'dır.

\section{4 Çalışmanın yöntemi ve bulguları:}

1992-2009 dönemi için ülkemizle Orta Asya Türk Cumhuriyetleri arasındaki endüstri-içi ticaret endeks değerleri, TÜİK veri tabanından elde edilen Standart Uluslararası Ticaret Sınıflandırması (SITC) 3 basamaklı dış ticaret verileri düzeyinde, Grubel-Lloyd endeksi kullanılarak hesaplanmıştır.

Ülkemizin dış ticaretinde endüstri-içi ticaretin payı artmakla birlikte dış ticaret yapımızın 
hala endüstriler arası bir yapıya sahip olduğunu söylemek mümkündür. Ülkemiz için hesaplanan endüstri-içi ticaret endeks değerlerini Tablo 3'den görmek mümkündür. 1992'de \% 26,9 olan endeks değeri 2009 yılında \% 42,1'e ulaşmıştır.

\begin{tabular}{|c|c|c|c|c|c|c|c|c|}
\hline $\mathbf{1 9 9 2}$ & $\mathbf{1 9 9 3}$ & $\mathbf{1 9 9 4}$ & $\mathbf{1 9 9 5}$ & $\mathbf{1 9 9 6}$ & $\mathbf{1 9 9 7}$ & $\mathbf{1 9 9 8}$ & $\mathbf{1 9 9 9}$ & $\mathbf{2 0 0 0}$ \\
\hline 26.9 & 25.6 & 28.5 & 28.1 & 29.6 & 30.4 & 32.6 & 36.0 & 33.5 \\
\hline $\mathbf{2 0 0 1}$ & $\mathbf{2 0 0 2}$ & $\mathbf{2 0 0 3}$ & $\mathbf{2 0 0 4}$ & $\mathbf{2 0 0 5}$ & $\mathbf{2 0 0 6}$ & $\mathbf{2 0 0 7}$ & $\mathbf{2 0 0 8}$ & $\mathbf{2 0 0 9}$ \\
\hline 38.2 & 34.6 & 36.6 & 38.5 & 39.7 & 39.4 & 40.6 & 41.7 & 42.1 \\
\hline
\end{tabular}

Tablo 3: Türkiye için Hesaplanan Endüstri-içi Ticaret Endeks Değerleri

Sektörel düzeyde baktığımızda ise, 1980 sonrası dönemde özellikle başlıca sınıflara ayrılarak işlenmiş mallar (6) ve makine ve ulaşım araçları (7) sektöründe endüstri-içi ticaretin önemli olduğu görülmektedir (Başkol,2005). Başlıca sınıflara ayrılarak işlenmiş mallar (6) endüstrisinin payı 1980'de \% 2,2; 1990'da \% 10,8, 2000'de \% 11,5, 2004'de \% 11,1 ve 2009 'da \% 10,5 olarak gerçekleşmiştir. Makine ve ulaşım araçları (7) endüstrisi açısından 1980 yılında \%1,3 olan endeks değeri,1990'da \% 3,8'e 2000'de \% 11,7'ye ve 2009'da \%15,8'e yükselmiştir. Kimyasallar ve çeşitli mamul eşya endüstrilerinin endüstri-içi ticaretteki payı ise azdir.

\begin{tabular}{|c|c|c|c|c|c|c|c|c|c|}
\hline & $\mathbf{1 9 9 2}$ & $\mathbf{1 9 9 3}$ & $\mathbf{1 9 9 4}$ & $\mathbf{1 9 9 5}$ & $\mathbf{1 9 9 6}$ & $\mathbf{1 9 9 7}$ & $\mathbf{1 9 9 8}$ & $\mathbf{1 9 9 9}$ & $\mathbf{2 0 0 0}$ \\
\hline $\mathbf{0 - 4}$ & 0.006 & 0.013 & 0.008 & 0.003 & 0.012 & 0.005 & 0.005 & 0.008 & 0.016 \\
\hline $\mathbf{5 - 8}$ & 0.011 & 0.014 & 0.032 & 0.018 & 0.028 & 0.026 & 0.025 & 0.031 & 0.031 \\
\hline TOPLAM & 0.017 & 0.027 & 0.040 & 0.021 & 0.040 & 0.031 & 0.030 & 0.039 & 0.047 \\
\hline & $\mathbf{2 0 0 1}$ & $\mathbf{2 0 0 2}$ & $\mathbf{2 0 0 3}$ & $\mathbf{2 0 0 4}$ & $\mathbf{2 0 0 5}$ & $\mathbf{2 0 0 6}$ & $\mathbf{2 0 0 7}$ & $\mathbf{2 0 0 8}$ & $\mathbf{2 0 0 9}$ \\
\hline $\mathbf{0 - 4}$ & 0.017 & 0.011 & 0.015 & 0.021 & 0.022 & 0.018 & 0.016 & 0.018 & 0.019 \\
\hline $\mathbf{5 - 8}$ & 0.045 & 0.036 & 0.059 & 0.046 & 0.047 & 0.042 & 0.037 & 0.041 & 0.044 \\
\hline TOPLAM & 0.062 & 0.047 & 0.074 & 0.067 & 0.069 & 0.060 & 0.053 & 0.059 & 0.063 \\
\hline
\end{tabular}

Tablo 4: Orta Asya Türk Cumhuriyetleri için hesaplanan EITT Endeks Değerleri

Tablo 4'de Orta Asya Türk Cumhuriyetleri için Grubel-Lloyd endeksi kullanarak elde edilen endeks değerlerini görmek mümkündür. Orta Asya Türk Cumhuriyetleriyle aramızda gerçekleşen dış ticaretin endüstriler arası nitelikte olduğu görülmektedir. 1992'de \% 1,7 olan endeks değeri 2009 yılında \% 6,3'e ulaşmıştır. Söz konusu zaman diliminde en yüksek endüstri-içi ticaret değeri 2003 yılında \% 7,4 olarak gerçekleşmiştir.

Pazar yapısı, ürünün kalite ve nitelik bakımından farklılaştırılabilmesi, ölçek eko-nomilerinin gerçekleştirilebilmesi, üretim sürecinin aşamalara ayrılabilmesi gibi özellik-lere dayalı olarak mamul mallarda endüstri-içi ticaret ortaya çıkmaktadır (Küçükahmetoğlu, 2002). Endeks değerlerini sektörel düzeyde incelediğimizdeyse beklenildiği üzere özellikle mamul mallarda (5-8) endüstri-içi ticaretin daha yoğun olduğunu görmek mümkündür. Örneğin 2003'de endeks değeri \%7,4 iken bunun \%5,9'luk kısmı, 2009'da endeks değeri \% 6,3 iken bunun \% 4,4'lük kısmı mamul mallar kökenlidir. Özellikle Orta Asya Türk Cumhuriyetleriyle aramızdaki endüstri-içi ticaretin önemli kısmı başlıca sınıflara ayrılarak işlenmiş mallar endüstrisine (6) aittir. Örneğin 2003'de başlıca sınıflara ayrılarak işlenmiş mallar endüstrisinin endeks değeri \%3,7, 2009 y1lında \% 3,2 olarak gerçekleşmiştir. 


\begin{tabular}{|c|c|c|c|c|c|c|c|c|c|}
\hline & $\mathbf{1 9 9 2}$ & $\mathbf{1 9 9 3}$ & $\mathbf{1 9 9 4}$ & $\mathbf{1 9 9 5}$ & $\mathbf{1 9 9 6}$ & $\mathbf{1 9 9 7}$ & $\mathbf{1 9 9 8}$ & $\mathbf{1 9 9 9}$ & $\mathbf{2 0 0 0}$ \\
\hline $\mathbf{G L} \geq \mathbf{0 , 7 5}$ & 5 & 3 & 4 & 3 & 3 & 3 & 5 & 6 & 7 \\
\hline $\mathbf{0 , 7 5}>\mathbf{G L} \geq \mathbf{0 , 5 0}$ & 3 & 8 & 5 & 9 & 7 & 6 & 5 & 6 & 5 \\
\hline $\mathbf{0 , 5 0}>\mathbf{G L} \geq \mathbf{0 , 2 5}$ & 8 & 5 & 7 & 12 & 12 & 14 & 9 & 14 & 14 \\
\hline $\mathbf{G L}<\mathbf{0 , 2 5}$ & 165 & 205 & 215 & 210 & 225 & 226 & 235 & 218 & 224 \\
\hline & $\mathbf{2 0 0 1}$ & $\mathbf{2 0 0 2}$ & $\mathbf{2 0 0 3}$ & $\mathbf{2 0 0 4}$ & $\mathbf{2 0 0 5}$ & $\mathbf{2 0 0 6}$ & $\mathbf{2 0 0 7}$ & $\mathbf{2 0 0 8}$ & $\mathbf{2 0 0 9}$ \\
\hline $\mathbf{G L} \geq \mathbf{0 , 7 5}$ & 8 & 7 & 6 & 4 & 5 & 7 & 6 & 7 & 6 \\
\hline $\mathbf{0 , 7 5}>\mathbf{G L} \geq \mathbf{0 , 5 0}$ & 4 & 4 & 9 & 9 & 6 & 7 & 6 & 5 & 3 \\
\hline $\mathbf{0 , 5 0}>\mathbf{G L} \geq \mathbf{0 , 2 5}$ & 18 & 14 & 14 & 8 & 14 & 13 & 12 & 11 & 13 \\
\hline $\mathbf{G L}<\mathbf{0 , 2 5}$ & 208 & 215 & 213 & 224 & 223 & 221 & 224 & 230 & 226 \\
\hline
\end{tabular}

Tablo 5: Orta Asya Türk Cumhuriyetleri için hesaplanan G-L endeks değerlerinin dağılımı

Her yıl için hesapladığımız EİT endeks değerlerini $\mathrm{GL} \geq 0,75 ; 0,75>\mathrm{GL} \geq 0,50 ; 0,50>\mathrm{GL} \geq 0,25$ ve GL $<0,25$ olarak 4 bölüme ayırmak mümkündür. Grubel Lloyd endeks değeri 0,25 'den küçük olan sektörlerde dış ticaret yapısının endüstriler arası nitelikte olduğu düşünülmektedir (Erlat ve Erlat, 2003). Ele alınan dönem boyunca endeks değeri 0,25'den küçük olan sektörlerin toplam sektörler içerisindeki payı \% 90'lar ile ifade edilebilir ki bu da bize Orta Asya Türk Cumhuriyetleriyle aramızdaki dış ticaret yapısının endüstri-içi ticaretten ziyade endüstriler arası nitelikte olduğunu göstermektedir. (Tablo 5)

\begin{tabular}{|c|c|c|c|c|}
\hline \multicolumn{2}{|c|}{ 1992-1997 } & \multicolumn{2}{c|}{$\mathbf{1 9 9 8 - 2 0 0 3}$} & 2004-2009 \\
\hline SITC No. & GL Endeksi & SITC No. & GL Endeksi & SITC No. \\
\hline 652 & 67,8 & 655 & 68,7 & 523 \\
\hline 684 & 49,2 & 733 & 56,2 & 575 \\
\hline 611 & 43,6 & 523 & 53,1 & 674 \\
\hline 651 & 37,4 & 684 & 51,4 & 655 \\
\hline 574 & 35,2 & 891 & 47,6 & 684 \\
\hline 654 & 32,8 & 674 & 47,4 & 891 \\
\hline
\end{tabular}

Tablo 6: Dönemler itibarıla en yüksek G-L endeks dĕgerine sahip sektörler

1992-2009 dönemi için hesaplanan G-L endeks değerleri 3 alt dönemin ortalaması olarak Tablo 6'da verilmiştir. 3 alt dönemin ortalamasının verilmesinin ana amacı, daha sağlıklı bir analiz yapabilmektir. Şöyle ki hesaplanan endeks değerleri incelendiğinde sektörlere ait değerlerin bazı yıllarda oldukça yüksek düzeyde endüstri-içi ticaretin varlığına işaret ederken bazı yıllarda endüstriler arası ticaret yapısının ön plana çıkmasıdır. Bundan kaçınmak gayesiyle 1992-1997, 1998-2003 ve 2004-2009 dönemleri belirlenmiş ve bu dönemde ön plana çıkan sektörler Tablo 6'ya aktarılmıştır. Tablo 6'ya göre, 1992-1997 döneminde pamuklu mensucat(652) sektöründe yoğun olarak endüstri-içi ticarete rastlan-mıştır. 1998-2003 dönemindeyse, örme mensucat(655), metalleri dövme, çekiçleme sure-tiyle işlemeye mahsus takım tezgahları (733), diğer inorganik kimyasal maddeler (523) ve alüminyum ve alüminyumdan çubuk, profil, tel, saç, şerit, boru vb. (684) sektörlerinde yoğun endüstri-içi ticaret söz konusudur. 2004-2009 ortalaması olarak diğer inorganik kimyasal maddeler (523), propilen ve diğer olefinlerin polimerleri(575), demir veya alaşımsız çelikten kaplanmış yassı hadde mamulleri(674), örme mensucat(655) ve alüminyum ve alüminyumdan çubuk, profil, tel, saç, boru vb.(684) sektörlerinde yoğun endüstri-içi ticarete rastlanmıştır.

1992-2009 döneminin geneli için ortalamalar bazında bir değerlendirme yapacak olursak, alüminyum ve alüminyumdan çubuk, profil, tel, saç, boru vb.(684) sektöründe G-L endeksi $\% 51,3$; örme mensucat(655) sektöründe G-L endeksi \% 50,6; diğer inorganik kimyasal maddeler (523) G-L endeksi \% 47,9; demir veya alaşımsız çelikten kaplanmış yassı hadde 
mamulleri(674) sektöründe G-L endeksi \% 41,7 ve diğer maddelerden dokunmuş mensucat (ipek, yün, vb.) sektöründe G-L endeksi \% 35,6 olarak gerçekleşmiştir.

\section{Sonuç:}

Ülkemizin dış ticaretinde endüstri-içi ticaretin payını belirlemeye yönelik çalışma-lar son yıllarda artmış olmakla birlikte hala yeterli düzeyde değildir. Bu konuda yapılan her çalışmanın ülkemizde endüstri-içi ticaret yazınının gelişmesine bir katkı sağlayacağı açıktır. 1992-2009 dönemi için Türkiye ile Orta Asya Türk Cumhuriyetleri arasındaki dış ticaret endüstriler arası niteliğiyle dikkat çekmektedir. Ele alınan dönem boyunca endüstri-içi ticaretin payı artmış bile olsa hala endüstrilerin çok önemli bir kısmında endüstri-içi ticaretten bahsetmek mümkün değildir.

\section{Kaynakça}

- Başkol, Murat Ozan,2005. "Endüstri-içi Ticaret Teorisi Açısından Dış Ticaret Yapımızın Değerlemesi”, Yayımlanmamış Doktora Tezi, Uludağ Üniversitesi Sosyal Bilimler Enstitüsü

- $\quad$ Erlat Güzin and Haluk Erlat, 2003. "Measuring Intra-Industry Trade and Marginal Intra-Industry Trade", Russian and East European Finance and Trade, Vol:39, No:6, pp. 5-38

- Gönel Feride Doğaner, 2001."How Important Is Intra-Industry Trade Between Turkey and Its Trading Partners:A Comparison Between the European Union and Central Asia Turkic Republics", Russian and East European Finance and Trade, Vol:37,No:4, pp.61-76

- Gray,Peter.1979 “Intra-Industry Trade:The Effects of Different Levels of Data Aggregation" içinde Herbert Giersh, On The Economics of Intra-Industry Trade, Tübingen:Mohr

- Greenaway David and Chris Milner, 1986. The Economics of Intra-Industry Trade, Oxford:Basil Blackwell

- Grubel Herbert ve Peter J.Lloyd,(1975) Intra-Industry Trade:The Theory and Measurement of International Trade in Differentiated Products, London:MacMillan

- Küçükahmetoğlu Osman,2002."Endüstri-içi ticaret ve Türkiye”, Iktisat, Işsletme ve Finans, Sayı:190, ss.34-50

- OECD,2000."Intra-Industry and Intra-Firm Trade and the Internationalisation of Production" OECD Economic Outlook, No:71

- Tharakan P.K.M. ve G.Calfat,1996."Empirical Analyses of International Trade Flows" iç. David Greenaway (ed.) Current Issues in International Trade, Second Edition, London:MacMillan Press. 


\title{
Geçiş Sürecindeki Türk Cumhuriyetlerinde Ekonomik Büyüme ve İhracat İlişkileri
}

\author{
Selahattin Sarı, Beykent Üniversitesi \\ Cevat Gerni, Gebze Yüksek Teknoloji Enstitüsü \\ Kemal Değer, Karadeniz Teknik Üniversitesi \\ Ö. Selçuk Emsen, Atatürk Üniversitesi
}

\begin{abstract}
Relationship Between Exports and Economic Growth in Turkic Republics in Transition Process

After the collapse of the Eastern Bloc in 1991 the newly independent Turkic republics have experienced a transition recession that is relatively more severe and longer as compared to the case of the Central and Eastern transition economies. The lack of political and socio-economic institutional infrastructure needed for transition is argued as the key factor of this process. The efforts of these countries to integrate with the world markets by force of economic liberalization, the term which is used as the synonym of the transition, constitute the pivot. In the process of liberalizing the commodity markets exports and imports take the most important place. With the process of transition, in the Turkic republics, the production linkages, in other words input interdependencies, which had been formed during Soviet era, broke out and hence production bottlenecks and hyperinflations occurred. While negative supply shocks are expected to overcome in the years 2000s, it is also expected that exports and economic growth relationships as the result of market economy and trade liberalization barely arise. This study concerns the exports and economic growth relationships which forms a trivet of liberalization applications in the Turkic republics. Nevertheless, there is a vest literature that suggests that for exports and outward-orientation to effectively affect economic growth a country should attain a minimum level of development. In this context, the relationships between exports and economic growth in the Turkic republics will be investigated using panel data causality and cointegration tests.
\end{abstract}

JEL Codes: F14, F43

\section{Giriş}

Liberalizmin ve ekonomik anlamda da dışa açık bir anlayışın ekonomik büyümeyi ve refahı artıracağı görüşünün temelinde klasik iktisatçılar yer almaktadır. Klasik iktisatçılara göre, iç piyasaları sınırlı olan ekonomilerde yüksek ve sürdürülebilir büyümeyi sağlayacak ölçekte üretimin desteklenmesi güçtür. Dolayisıyla bu tür ekonomilerin serbest ticaret altında dinamik karşılaştırmalı üstünlüklere göre üretimde bulunmaları yararlı olacaktır. Bunu gerçekleştirmek için ekonomiyi uluslararası yapı ile bütünleştirecek bir dış ticaret rejimi uygulamasının ve buna bağlı oluşacak kaynak tahsisinin dünya ölçeğindeki talep tarafından belirlenmesine izin verilmesinin sistemin temel dinamiği olduğu kabul edilir. Dolayısıyla böyle bir stratejinin doğal amacı sanayileşme ve büyümenin sağlanabilirliğidir ve bunun için gerekli dinamizmin de iç talepten ziyade dış talepten gelen bir yapılanma ile gerçekleşeceği ileri sürülür (Çelebi, 1991: 33). 1970'lerin sonunda ulusal kalkınmacılık anlayışının krize girmesi ve 1980'lerin sonunda da Doğu Bloku'nun çökmesiyle birlikte, klasik bakış açısına sahip dışa açılmanın faziletleri yeniden gündeme gelmeye başlamıştır. Böylece dışa açık ve strateji olarak ihracatayönelik modeller uygulanırken, 20. yüzyılın son çeyreğinde gelinen noktada bu uygulamalarda belirli kalkınmışlık düzeyinde olma gerekliliği de koşul olarak ileri sürülür olmuştur (Han ve Kaya, 2006: 245; Sun ve Parikh, 2001: 187-188).

Diğer taraftan liberal anlayışa karşıt görüşlerin temelini oluşturan List, ithal ikameciliği 
savunarak, korumacılığın sanayileşme için temel teşkil etmesi gerektiğini savunmuştur. $\mathrm{Bu}$ görüşünde de serbest ticaretin aynı kalkınmışlık düzeyinde bulunan ülkeler arasında yararlı olacağını; buna karșılık farklı kalkınmışlık düzeyine sahip ülkeler arasında yararlarının olmadığını ileri sürmüștür. Bu çerçevede Sanayi İnkılâbı'nın ilk olarak gerçekleștiği İngiltere'yi yakalamaya çalışan diğer ülkelerin birçoğunda serbest ticaretin İngiltere yararına olduğu; göreceli olarak daha az kalkınmış ülkelerin lehine olmadığını ifade etmiştir (Chang, 2004: 20).

Dışa açılma üzerine yukarıda kısaca özetlenen lehte ve aleyhte görüşlere karşılık, 1980'lerde ortaya çıkan Yeni Büyüme Teorileri ile dışa açıklık modellenmiş ve ampirik olarak da test edilmeye başlanmıştır. Genel olarak uzun dönem büyümenin lokomotifi olarak teknoloji yayılımının önemine vurgu yapan içsel büyüme modelleri, dış ticarete açık ülkelerin daha yüksek kararlı/istikrarlı büyüme oranlarına sahip olacağı iddiasındadırlar (Grossman ve Helpman, 1990: 796).

\section{Literatür Özeti}

İhracat ve ekonomik büyüme ilişkilerini ele alan ampirik literatür oldukça geniştir. Bir kısım çalışmalar ihracata dayalı büyüme görüşünü destekler nitelikte sonuç verirken, bir kısmında da ihracat ve büyüme arasında anlamlı ilişkilere ulaşamamıştır. Öte yandan bazı çalışmalarda ise ihracatın ekonomik büyümeyi olumsuz etkilediğine dair bulgulara ulaşmıştır (Konu ile ilgili ayrıntılı literatür için bkz: Ahmad ve Kwan, 1991; Edwards, 1993; Ghartey, 1993; Love, 1994; Giles ve Williams, 2000; Medina-Smith, 2001; Subasat, 2002; Abou-Stait, 2005). Genel olarak literatür değerlendirildiğinde, ihracat ve büyüme arası ilişkilerde klasik bakış açsısı dışında bulguların yakalanmasının altında, çalışmalarda ele alınan ülke, dönem ve yöntem farklılıklarının bulunduğu ileri sürülmektedir. Bununla birlikte bazı çalışmalar ise ihraç edilen ürünlerin niteliği ve çeşitliliğine vurgu yaparak, ihracata dayalı büyümenin ancak belirli bir sanayileşme düzeyine sahip ülkelerde ortaya çıkacağını ileri sürmektedir (Subasat, 2002). "Minimum kalkınmışlık düzeyi" olarak ifade edilen bu hipoteze göre ihracatın yurtiçi ekonomide pozitif dışsallık ve verimlilik etkilerine yol açabilmesi için ülkenin belirli bir sanayileşme ve kalkınma düzeyine sahip olması gerekmektedir. Diğer bir deyişle, farklı ülke ve bölgelerde ekonomik büyüme üzerine ihracatın farklılaşan etkisi ekonomik yapı ve kalkınmışlık düzeyine bağlı olacaktır. Ayrıca bu etki, ekonomilerdeki yapısal değişim ve ekonomik kalkınmanın dinamik bir etkileşim sürecini de içermektedir (Sun ve Parikh, 2001: 188). Dolayısıyla az gelişmiş ve gelişmekte olan ülkelerde ihracata dayalı büyüme süreçlerinin ancak ülkeler belirli bir sanayileşme düzeyine sahipse ve ekonomik yapıda önemli yapısal dönüşümleri sağlamışsa ortaya çıkacağı kabul görmektedir (bkz. Giles ve Williams, 2000; Santos-Paulıno, 2005; Emsen ve Değer, 2007).

Bu çalışmada, 1991 yılında eski demir perde olarak tanımlanan SSCB'nin çökmesi sonucu siyasal anlamda bağımsızlığını kazanmış bulunan Türk Cumhuriyetlerindeki ihracat ve ekonomik büyüme arasındaki ilişkiler incelenecektir. Türk Cumhuriyetlerinin mevcut yapısı dikkate alındığında, gerek siyasal, gerekse sosyo-ekonomik anlamda yetersizlikleri bünyelerinde taşıdıkları açıktır. Dolayısıyla bu çalışmaya temel teşkil edecek olan literatür araştırması da, konuyu daha çok gelişmekte olan ülkeler özelinde ele alan çalışmalardan oluşturulmuştur (Tablo 1).

\begin{tabular}{|c|c|c|c|c|}
\hline Yazar(lar) & Ülke(ler) & Yöntem & Değişkenler & Özet Bulgular \\
\hline Yucel & Türkiye (1998- & $\begin{array}{c}\text { Eş } \\
\text { bütünleşme ve } \\
\text { nedensellik } \\
\text { testleri. }\end{array}$ & $\begin{array}{c}\text { Finansal gelişme, } \\
\text { ticari açıllk ve } \\
\text { ekonomik büyüme } \\
\text { ilişkileri. }\end{array}$ & $\begin{array}{c}\text { Ekonomik büyüme üzerine } \\
\text { dişa açıklik pozitif ve buna } \\
\text { karşlik finansal gelişme } \\
\text { negatif etkilere sahiptir. }\end{array}$ \\
\hline $\begin{array}{c}\text { Awokuse } \\
(2008)\end{array}$ & $\begin{array}{c}\text { Arjantin, } \\
\text { Kolombiya ve } \\
\text { Peru. }\end{array}$ & $\begin{array}{c}\text { Nedensellik } \\
\text { testleri. }\end{array}$ & $\begin{array}{c}\text { İhracat, ithalat ve } \\
\text { ekonomik büyüme } \\
\text { ilişkileri. }\end{array}$ & $\begin{array}{c}\text { İhracat ve büyüme } \\
\text { arasında nedensel ilişki } \\
\text { yakalanamazken; ithalata } \\
\text { dayall ihracat ve büyüme }\end{array}$ \\
\hline
\end{tabular}




\begin{tabular}{|c|c|c|c|c|}
\hline & & & & $\begin{array}{l}\text { ilişkilerinin varlığ } 1 \text { tespit } \\
\text { edilmiştir. }\end{array}$ \\
\hline $\begin{array}{c}\text { Yang } \\
(2008)\end{array}$ & $\begin{array}{c}30 \text { ülke; 9’u } \\
\text { OECD, 10’u } \\
\text { Asya, 1'i } \\
\text { Afrika ve 10'u } \\
\text { Latin Amerika. } \\
\text { (1958-2004) }\end{array}$ & $\begin{array}{l}\text { Panel veri } \\
\text { analizleri. }\end{array}$ & $\begin{array}{l}\text { İhracat, Reel döviz } \\
\text { kuru ve ekonomik } \\
\text { büyüme ilişkileri. }\end{array}$ & $\begin{array}{l}\text { İhracat büyümesinin } \\
\text { ekonomik büyümesinden } \\
\text { daha hızlı olduğu } \\
\text { ekonomilerde bunun } \\
\text { besleyen bir kur } \\
\text { politikasının varlığ tespit } \\
\text { edilmiştir. }\end{array}$ \\
\hline $\begin{array}{c}\text { Ibrahim } \\
(2002)\end{array}$ & $\begin{array}{c}\text { Hong Kong, } \\
\text { Güney Kore, } \\
\text { Malezya, } \\
\text { Filipinler, } \\
\text { Singapur ve } \\
\text { Tayland. } \\
\text { (1964-1993) } \\
\end{array}$ & $\begin{array}{l}\text { Zaman serisi } \\
\text { analizleri }\end{array}$ & $\begin{array}{c}\text { Ekonomik büyüme, } \\
\text { emek, sermaye ve } \\
\text { ihracat. }\end{array}$ & $\begin{array}{l}\text { Filipinler dışında, ele } \\
\text { alınan ülkelerde dışa } \\
\text { yönelimin büyüme } \\
\text { üzerinde anlamlı ve pozitif } \\
\text { etkilerinin olduğu } \\
\text { belirlenmiştir. }\end{array}$ \\
\hline $\begin{array}{l}\text { Vohra } \\
(2001)\end{array}$ & $\begin{array}{l}\text { Hindistan, } \\
\text { Pakistan, } \\
\text { Filipinler, } \\
\text { Malezya, } \\
\text { Tayland. } \\
\text { (1973-1993) }\end{array}$ & $\begin{array}{c}\text { Eş } \\
\text { bütünleşme } \\
\text { testleri ve } \\
\text { regresyon } \\
\text { analizleri. }\end{array}$ & $\begin{array}{c}\text { Reel üretim, emek, } \\
\text { sermaye ve ihracat } \\
\text { ilişkileri. }\end{array}$ & $\begin{array}{l}\text { Düşük gelirli Hindistan } \\
\text { dişındaki orta gelirli } \\
\text { ülkelerde ihracat ve } \\
\text { ekonomik büyüme } \\
\text { arasında istatistiki açıdan } \\
\text { anlamlı ve pozitif } \\
\text { ilişkilerin olduğu tespit } \\
\text { edilmiştir. }\end{array}$ \\
\hline $\begin{array}{l}\text { Sun ve } \\
\text { Parikh } \\
(2001)\end{array}$ & $\begin{array}{c}\text { Çin'in } 29 \\
\text { bölgesi. (1985- } \\
1995)\end{array}$ & $\begin{array}{l}\text { Panel veri } \\
\text { analizleri. }\end{array}$ & $\begin{array}{l}\text { Ekonomik büyüme, } \\
\text { emek, sermaye, } \\
\text { doğrudan yabancı } \\
\text { sermaye, } \\
\text { ekonominin dişa } \\
\text { açıklığ1 ve ihracat. }\end{array}$ & $\begin{array}{l}\text { Ekonomik büyümede } \\
\text { ihracatın ve yabancı } \\
\text { sermaye girişlerinin } \\
\text { istatistiki açıdan anlamlı ve } \\
\text { pozitif etkilerinin olduğu } \\
\text { tespit edilmiştir. }\end{array}$ \\
\hline $\begin{array}{l}\text { Medina- } \\
\text { Smith } \\
(2001)\end{array}$ & $\begin{array}{c}\text { Kostarika } \\
(1950-1997)\end{array}$ & $\begin{array}{l}\text { Zaman serisi } \\
\text { analizleri }\end{array}$ & $\begin{array}{l}\text { Reel üretim, emek, } \\
\text { sermaye ile mal ve } \\
\text { hizmet ihracatı. }\end{array}$ & $\begin{array}{l}\text { Ekonomik büyümede } \\
\text { ihracatın ve sermaye } \\
\text { birikiminin anlamlı } \\
\text { etkilerinin olduğu } \\
\text { anlaşılmıştır. }\end{array}$ \\
\hline
\end{tabular}

Tablo 1. Gelişmekte Olan Ülkeler Üzerine Literatür Özeti

Tablo 1'de verilen literatür özetinden açıkça anlaşılacağı üzere çalışmaların büyük bir kısmı ihracata dayalı büyüme lehinde bulgu vermiştir. Bununla birlikte ihracata dayalı büyümeyi desteklemeyen bulgular da söz konusudur. Dolayısıyla genel literatürde olduğu gibi gelişmekte olan ülkeleri ele alan literatürde de farklılaşan bulgular söz konusudur.

\section{Ekonometrik Yöntem ve Ampirik Bulgular}

Bu çalışmada reel ihracat (RX) ve reel hasıla (RGDP) ilişkileri, geçiş sürecinde bulunan 5 Türk Cumhuriyeti (Azerbaycan, Kazakistan, Kırgızistan, Özbekistan ve Türkmenistan) özelinde nedensellik ve eş-bütünleşme analizleri kullanılarak irdelenecektir. Bu çerçevede söz konusu ülkelerin 1990-2008 arası döneme ait verileri, Dünya Bankası'nın "World Development Indicators" isimli veri tabanından alınmıştır. Çalışmada Eviews 6 paket programı kullanılarak bu 5 ülkeye ait verilerden hareketle Granger nedensellik testlerinin yanında değişkenler arası uzun dönemli ilişkileri veren eş-bütünleşme testleri de yapılmıştır.

Türk Cumhuriyetlerinde ihracat ve ekonomik büyüme ilişkilerinin nedensellik ve eşbütünleşme analizler ile belirlenmesinden önce değişkenlerin birim kök içerip içermedikleri Levin, Lin ve Chu (2002) tarafından geliştirilen testle belirlenmeye çalışılmıştır. Tablo 2, logaritmik forma dönüştürülen değişkenlere ait değerlerin sabitli ve trendli bir yapıda durağanlık sınama sonuçlarını göstermektedir. 


\begin{tabular}{|l|c|c|}
\hline Değişkenler & İstatistik & Olasılık \\
\hline LRX & -1.432 & 0.076 \\
\hline LRGDP & -7.409 & 0.000 \\
\hline
\end{tabular}

Tablo 2. Levin, Lin ve Chu Birim Kök Test Sonuçları

Tablo 2'deki bulgulara göre bütün değişkenlerin seviye değerlerinde durağan oldukları anlaşılmaktadır.

Çalışmada öncelikle iki değişken arasındaki nedensel ilişkilerin yönünü tayin etmeye yardımcı olan Granger nedensellik testine yer verilecektir. Granger nedensellik testleri için aşağıdaki eşitlikler kullanılmıştır:

$$
\begin{aligned}
& \operatorname{LRX}_{\mathrm{i}, \mathrm{t}}=\alpha_{0}+\beta_{1} R X_{\mathrm{i}, \mathrm{t}-1}+\beta_{2} R X_{\mathrm{i}, \mathrm{t}-2}+\beta_{3} L R G D P_{i, t-1}+\beta_{4} \operatorname{LRGDP}_{\mathrm{i}, \mathrm{t}-2}+\mathrm{e}_{\mathrm{t}} \\
& \mathrm{LRGDP}_{\mathrm{i}, \mathrm{t}}=\alpha_{0}+\beta_{1} R G D P_{i, t-1}+\beta_{2} R G D P_{i, t-2}+\beta_{3} \mathrm{LRX}_{\mathrm{i}, \mathrm{t}-1}+\beta_{4} \mathrm{LRX}_{\mathrm{i}, \mathrm{t}-2}+\mathrm{e}_{\mathrm{t}}
\end{aligned}
$$

Yukarıdaki eşitliklerin tahmininden elde edilen katsayılara uyarlanan Wald sınaması neticesinde iki değişken arası nedenselliğin yönünü veren sonuçlar, Tablo 3'de sunulmaktadır.

\begin{tabular}{|l|c|c|c|}
\hline Sıfır Hipotezi & $\begin{array}{c}\text { Gözlem } \\
\text { Sayısı }\end{array}$ & $\begin{array}{c}\text { F } \\
\text { İstatistiği }\end{array}$ & Olasılık \\
\cline { 1 - 1 } LRX, LRGDP'nin Nedeni Değildir & \multirow{2}{*}{82} & 1.390 & 0.255 \\
\cline { 1 - 1 } \cline { 4 - 4 } LRGDP, LRX'in Nedeni Değildir & & 18.893 & 0.000 \\
\hline
\end{tabular}

Tablo 3. Granger Nedensellik Test Sonuçları

Tablo 3'deki bulgulara göre ülkenin hasıla düzeyinden ihracata doğru tek yönlü nedensel ilişkiler söz konusudur. Elde edilen bu sonuç, Türk Cumhuriyetlerdeki ihracat performansının ekonomik büyümeyi uyarıcı etkilere neden olamadığını ortaya koymaktadır. Böyle bir sonuç, yukarıda belirtilen "minimum kalkınmışlık düzeyi" olgusuyla örtüşmektedir. Ele alınan ülkelerde genel anlamda üretim ve özelde de sanayileşme düzeyinin yetersizliğinin yanı sıra ihraç edilen ürünlerin ağırlıkla petrol, doğalgaz, tarım ve madencilik ürünleri gibi geriye bağlantıları zayıf ilksel nitelikte olması, Türk Cumhuriyetlerinde ihracattan kaynaklanan büyüme etkilerinin yakalanamamasının nedenleri olarak değerlendirilebilir. Öte yandan değişkenler arası uzun dönemli ilişkilerin varlığı, Pedroni eş-bütünleşme testi ile araştırılmış ve sonuçlar Tablo 4'de verilmiştir.

\begin{tabular}{|l|c|c|}
\hline \multirow{2}{*}{ Değişkenler } & \multicolumn{2}{|c|}{ LRGDP ve LRX } \\
\cline { 2 - 3 } & A ğır. İst. & Olasılık \\
\hline Panel v-Statistic & 1.680 & 0.047 \\
\hline Panel rho-Statistic & -1.624 & 0.052 \\
\hline Panel PP-Statistic & -3.170 & 0.001 \\
\hline Panel ADF-Statistic & -2.973 & 0.002 \\
\hline
\end{tabular}

Tablo 4. Pedroni Eş-Bütünleşme Test Sonuçları

Tablo 4'deki sonuçlara göre LRX ve LRGDP değişkenleri güçlü bir şekilde eş-bütünleşiktir. Yani bu iki değişken benzer trendleri takip etmektedirler. Dolayısıyla elde edilen bu bulgu, çalışmada kısa dönemde anlamlı nedensellik ilişkisi yakalanamamış olmasına karşılık, Türk 
Cumhuriyetlerinde büyüme ile ihracat arasında uzun dönemli ilişkiyi ortaya koyması açısından önemlilik arz eder. Daha açık bir ifadeyle, ele alınan ülkelerde kısa dönemde ihracat büyümenin belirleyicisi değilken, uzun dönemde aksi bulgular verdiği görülmüștür. $\mathrm{Bu}$ açıdan değerlendirilirse, Türk Cumhuriyetlerinde büyümeyi ve kalkınmayı hızlandırıcı makro ve mikro politikalara ağırlık verilmesi gerekliliği açıktır.

\section{Sonuç ve Değerlendirme}

İhracat ve ekonomik büyüme ilişkilerinin klasik iktisattan da önce özellikle Merkantilizme kadar dayanan bir geçmişinin olduğu bilinmektedir. Klasik ekol ise Merkantilizmden farklı olarak, sadece ihracatçılığı değil, ithalatçılığı da öven, dolayısıyla liberalizmi ve buna bağlı olarak ortaya çıkan refah ilişkilerine ağırlık veren ekol konumundadır. Ancak, I. Dünya Savaşı sonrasında bayındırlık harcamalarının gereği olarak Klasik düşüncenin temel sacayağı olan altın para sistemine dönülememesinin yansımaları arasında görülen 1929 Bunalımı, Keynezyen iktisadı doğuran olgu olmuştur. Klasiklerin aksine, belirli koşullarda müdahaleciliğe cevaz veren Keynezyen düşünce, 1929 Bunalımından çıkışta etkin reçeteleri ortaya koyarken, dünya ticaretindeki daralmaları telafi etme yönündeki devalüasyon uygulamaları da rekabetçi devalüasyonları beraberinde getirmiştir. II. Dünya Savaşı sonrası iki kutuplu dünyada liberalizmi ve müdahaleciliği savunan ikili yapı, özellikle 1970'lerde Asya ekonomilerinin yükselmesi ve buna karşılık demir perde ülkelerinde büyümenin durağanlaşmasıyla birlikte, Klasik ve uzantısı konumdaki ekollerin dünya ölçeğinde ağırlık kazanmalarına yol açarken, Berlin Duvarının çökmesi ve demir perdenin yıkılmasıyla bu düşünce tekrar hakim ekol konumuna geçmiştir.

Dolayısıyla dışa açıklık ve büyüme arasındaki ilişkiler, teorik tartışmalardan bir adım daha öteye kayarak hem büyüme modellerine dahil edilmiş hem de ampirik testlerle sınanır olmuştur. Bu çalışmada da, eski demir perde içerisinde yer alan ve bloğun çökmesiyle birlikte hakim düşünce liberal ekonomi politikalarına yönelim içerisinde bulunan Türk Cumhuriyetlerinde ihracat ve ekonomik büyüme ilişkileri araştırılmıştır. Yapılan analizler sonucunda, kısa dönemde ekonomik büyümeden ihracata doğru tek yönlü bir nedensellik tespit edilebilmiştir. Elde edilen bu bulgu, literatürdeki “minimum kalkınmışlık düzeyi” hipotezi ile tutarlılık göstermektedir. Yani bu hipoteze göre Türk Cumhuriyetlerinde ihracatın belirli bir sanayileşme ve kalkınma düzeyine eriştikten ve ekonomik anlamda yapısal dönüşümleri gerçekleştirdikten sonra ancak büyüme etkilerine yol açacağına işaret etmektedir. Dolayısıyla üretim düzeyinde belirli bir olgunluğu yakalayamamış ekonomilerin dışa açılmaları ihracatçı bir yapı doğurmadığı gibi, tüketim kalıplarını da bozarak ithal tüketim cennetlerine dönüştüğü gözlenmektedir. İthalatın giderek artığı bir yapıda finansmanının gerçekçi gelir kaynağı olan ihracat kalemleriyle sağlanamaması hem ticaret hadlerinde bozulmaya hem de dış borçlanmanın kısa zamanda devasa boyutlara ulaşmasına yol açmaktadır.

Kısa dönemde ihracattan kaynaklanan büyüme etkilerinin yakalanamaması yanında, iki değişken arasında uzun dönemli ilişkilerin varlığı Pedroni eş-bütünleşme testi ile belirlenmiştir. Elde edilen bu bulguya göre ise, Türk Cumhuriyetlerindeki uzun dönem büyüme bu ülkelerin ihracat kapasitesinden bağımsız değildir. Aynı şekilde Türk cumhuriyetlerinin uzun dönem ihracat potansiyelleri bu ülkelerin üretim düzeylerindeki gelişmelere bağlı olacaktır. Dolayısıyla etkin büyüme ve kalkınma politikaları önem arz etmektedir.

\section{Kaynakça}

- $\quad$ Abou-Stait, Fouad (2005), “Are Exports the Engine of Economic Growth? Application of Cointegration and Causality Analysis for Egypt, 1977-2003”, African Development Bank, Economic Research Working Paper Series, No: 76.

- $\quad$ Ahmad Jaleel and Andy C. C. Kwan (1991), "Causality between Export and Economic Growth: Empirical Evidence from Africa”, Economics Letters, 37 (3): 243248. 
- Awokuse, Titur O. (2008). "Trade Openness and Economic Growth: Is Growth Export-led or Import-led”, Applied Economics, 40: 161-173.

- Çelebi, Işın (1991). Dışa Açık Büyüme ve Türkiye, e Yayınları, İstanbul.

- Chang, Ha-Joon (2004). Kalkınma Reçetelerinin Gerçek Yüzü, (Çev. Tuba Akıncılar Onmuş), İletişim Yayınları, İstanbul.

- $\quad$ Edwards, Sebastian (1993). "Openness, Trade Liberalization, and Growth in Developing Countries”, Journal of Economic Literature”, XXXI: 1358-1393.

- $\quad$ Emsen, Ö. Selçuk ve M. Kemal Değer (2007). "İktisadi ve Siyasal Liberalizasyon ve Ekonomik Büyüme İlişkileri: Geçiş Ekonomileri Üzerine Panel Veri Analizi”, Atatürk Üniversitesi İiBF Fakültesi Dergisi, 21 (2): 161-195.

- Ghartey, Edward E. (1993), "Causal Relationship between Exports and Economic Growth: Some Empirical Evidence in Taiwan, Japan and the U.S.”, Applied Economics, 25 (9): 1145-1152.

- Giles, Judith A. and Cara L. Williams (2000). Export-led Growth: A Survey of the Empirical Literature and Some Noncausality Results Part 1, Econometrics Working Paper EWP0001, (http://web.uvic.ca/econ/ewp0001.pdf) (Aralık 2005).

- Grossman, Gene M. and Elhanan Helpman (1990). "Comparative Advantage and Long Run Growth”, The American Economic Review, 80 (4): 796-815.

- Han, Ergül ve A. Ayşen Kaya (2006). Kalkınma Ekonomisi Teori ve Politika, Nobel Yayın Dağıtım, Ankara.

- Ibrahim, Izani (2002). “On Exports And Economic Growth”, Jurnal Pengurusan, 21: 3-18.

- $\quad$ Levin, A., C. F. Lin and C. Chu (2002), "Unit Root Tests in Panel Data: Asymptotic and Finite-Sample Properties", Journal of Econometrics, 108(1): 1-24.

- Love, Jim (1994), "Engines of Growth: The Export and Government Sectors", World Economy, 17 (2): 203-218.

- Medina-Smith, Emilio J. (2001). "Is The Export-Led Growth Hypothesis Valid For Developing Countries? A Case Study of Costa Rica", Policy Issues in International Trade and Commodities Study Series No. 7, New York.

- Santos-Paulino, Amelia U. (2005). "Trade Liberalisation and Economic Performance: Theory and Evidence for Developing Countries”, World Economy, 28: 783-821.

- Subasat, Turan (2002), "Doess Export Promotion Increase Economic Growth? Some Croos-Section Evidence", Development Policy Review, 20 (3): 333-349.

- Sun, Haishun and Asho Parikh, (2001). "Exports, Inward Foreign Direct Investment (FDI) and Regional Economic Growth in China”, Regional Studies, 35 (3): 187-196.

- Vohra, Rubina (2001). "Export and Economic Growth: Further Time Series Evidence from Less-Developed Countries", IAER, 7 (3): 345-350.

- Yang, Jie (2008). An Analysis of So-Called Export-led Growth, IMF Working Paper, $\mathrm{WP} / 08 / 220$.

- Yucel, Fatih (2009). "Causal Relationships between Financial Development, Trade Openness and Economic Growth: The Case of Turkey", Journal of Social Sciences, 5 (1): $33-42$. 


\title{
Türk-Ermeni Sınırının Açılmasının Ülke Ekonomileri Üzerindeki Olası Etkileri Üzerine Bir Araştırma
}

\author{
Ersan Bocutoğlu, Karadeniz Technical University \\ Emre Bulut, Karadeniz Technical University
}

\begin{abstract}
An Investigation of Potential Effects of Opening of Turkish-Armenian Border on the Turkish and Armenian Economies
\end{abstract}

Turkish-Armenian border has been closed due to Nagorno-Karabagh question since 1993. The fact that the $20 \%$ of Azerbaijan territory is under Armenian invasion has prevented investigation of potential economic effects of Turkish-Armenian border on related parties so far from being a research agenda. In this study a descriptive approach is adopted since statistical data in hand is inappropriate for an econometric investigation. Long run advantages that an open border brings to Turkey are alternative highway, railway and pipeline routes to Caspian Sea basin and Central Asia while short run advantages are economic gains to Turkish border provinces and port cities connected with Armenia. The long run and short run benefits are vital for Armenia whose economy is agrarian, dependant heavily on foreign trade and foreign aids, experienced high transportation costs, unstable, poor and loosing population although the population data does not reflect the real situation. For Armenia, an open border means a direct territorial connection to European Union (EU), new employment opportunities, up to $23 \%$ fall in transportation costs, trans-border pipeline benefits, a flourished foreign trade, and increasing material well being. Consequently the opening of Turkish-Armenian border is strongly advised for it is beneficial to the related parties under the assumption that a resolution on AzeriArmenian conflicts is reached.

JEL Codes: A10, R41, F02

\section{Giriş}

Türkiye-Ermenistan sınırının açılması son dönemde gerek Avrupa Birliği (AB) ve Amerika Birleşik Devletleri'nde (ABD) gerekse taraflar arasında gündeme getirilen bir konu olmuştur. 10 Ekim 2009 tarihinde Zürih’te, “Türkiye Cumhuriyeti ve Ermenistan Cumhuriyeti Arasında Diplomatik İlişkilerin Geliştirilmesine Dair Protokol"de vurgulanan hususlardan biri de ortak sınırın açılması olmuştur. İki ülke arasındaki sınırın açılması siyasi, kültürel ve ekonomik alanlara etki edebilecektir. Türkiye ve Ermenistan arasındaki sınırların kapatılmasından sonra, iki ülke arasındaki ilişkilerin siyasi boyutu üzerine çok sayıda çalışma yapılmış bu nedenle ilişkilerin ekonomik yönü daima ikinci planda kalmıştır. Bu çalışma, konunun ekonomik boyutu üzerinde durmaktadır.

Bildiride, Türkiye-Ermenistan sınırının açılmasının iki ülkenin ulaştırma, transit taşımacılık, demiryolları, bölgesel kalkınma, turizm, dış ticaret ve sınır ticareti üzerine olası etkilerine değinilmiştir.

\section{Türkiye-Ermenistan Sınırın Açılmasının Ulaştırma, Transit Taşımacılık ve Demiryollarına Etkisi}

Türk-Ermeni sınırı, doğu-batı bağlantısında en verimli güzergâh durumundadır. TürkiyeErmenistan-Azerbaycan demiryolu ve karayolu sistemi bağlantıları, Hazar havzası ve dünya pazarları arasındaki en uygun doğu-batı ulaşım güzergâhını sağlamaktadır. (European Parliament, 2007). Bu bağlamda sınırın açılması daha uygun maliyetle ulaşım ve ticaret yapılmasına olanak sağlayabilecektir. 
Sınırın açılmasıyla ve 1992 yılına kadar faaliyette bulunan Bakü-Gümrü-Kars demiryolu sisteminin yeniden faaliyete geçirilmesiyle, Ermeni demiryolu sistemi, Akyaka-Gümrü bağlantısıyla, Türkiye'yi Kafkasya, Rusya Federasyonu ve Orta Asya'ya geçiş sağlayarak Rus demiryolu ağıyla birleștirecektir. Kars ile İstanbul'u bağlayan demiryolunun son durağı olan Akyaka, Trans-Kafkasya demiryolu sitemine geçiş sağlayan Gümrü'ye bağlanmaktadır. Gümrü, Nahçıvan içinden geçen ve Ermenistan-İran sınırı boyunca uzanan Erivan-Culfa-Bakü ve Erivan-Sevan-Dilian-Gazakh-Bakü hatlarını içeren, diğer demiryolları ile bağlantılıdır. Öte yandan, Karadeniz-Akdeniz limanlarının ve demiryollarının birleștirilmesi sonucu olușturulan güzergâh, Anadolu ve Hazar havzasını bağlayan en uygun maliyetli güzergâh konumundadır (Gültekin, 2004).

Sınırın kapalı olması, Ermenistan'ın kuzey-güney (Rusya-İran-Türkiye) ve doğu-batı (Türkiye-Azerbaycan-Orta Asya) ekseni boyunca uzanan transit güzergâhların merkezi olmasından elde edebileceği avantajlardan faydalanamayacağı anlamına gelmektedir (European Parliament, 2007).

Türkiye, Gürcistan ve İran güzergâhlarını kullanarak Azerbaycan ve Orta Asya'ya ulaşmaktadır. Hâlbuki Türkiye-Ermenistan ve Ermenistan-Azerbaycan sınırlarının açık olması durumunda en kısa güzergâhı sunan Ermenistan, transit ülke olarak kullanılacaktır. Aynı şekilde Ermenistan, doğu ve batı sınırları kapalı olduğundan dolayı dünyanın geri kalan kısmına ulaşımda uzun güzergâhları kullanmaktadır. Ermenistan için Orta Asya'ya ulaşımda en kısa güzergâh Azerbaycan'dır. AB'ne ulaşım da ise en kısa güzergâh Türkiye'nin transit ülke olarak kullanılmasıdır. Aynı zamanda yüksek liman maliyetlerinden ötürü Gürcü limanlarının değil de Karadeniz limanlarının kullanılması Ermenistan için daha avantajlı olabilecektir.

Türkiye-Ermenistan sınırın açılmasıyla, iki ülke arasındaki bağlantılar, Iğdır'da bulunan Alican sınır kapısı ve Kars'ta bulunan Doğu Kap1 (Akyaka) sınır kapısı aracılığıyla gerçekleştirilecektir. Alican sınır kapısı sadece karayolu geçişlerine olanak sağlarken, Doğu Kapı sınır kapısı karayoluna ek olarak demiryolu geçişlerine de olanak sağlamaktadır.

Sınırın kapalı kalması ve açılması durumundaki söz konusu bu güzergâhlardan, Trabzon, Iğdır, Kars ve Ardahan ile Erivan arasındaki mesafeler Tablo 1'de gösterilmektedir.

\begin{tabular}{|c|c|c|c|c|}
\hline \multirow[t]{2}{*}{ Şehirler } & \multicolumn{3}{|c|}{ Sınırın Kapalı Kalması Durumu } & \multirow{2}{*}{$\begin{array}{ll}\text { Sınırın Açık Olması } \\
\text { Durumu } \\
\text { Akyaka } & \\
\text { Sınır } & \\
\text { Kapıs1 } & \\
\text { (Kars) } & \\
\end{array}$} \\
\hline & $\begin{array}{l}\text { Sarp } \\
\text { Sinır } \\
\text { Kap1s1 } \\
\text { (Artvin) }\end{array}$ & $\begin{array}{l}\text { Türkgözü } \\
\text { Sinır } \\
\text { Kapısı } \\
\text { (Ardahan) }\end{array}$ & $\begin{array}{l}\text { Aktaş } \\
\text { Sinır } \\
\text { Kapısı } \\
\text { (Ardahan) }\end{array}$ & \\
\hline Trabzon & 843,8 & 870,7 & 596,9 & 564 \\
\hline Ĭgdır & $1.023,5$ & 753,3 & 483,6 & 280 \\
\hline Kars & 895,6 & 606,7 & 326,6 & 207,9 \\
\hline Ardahan & 789,5 & 562,4 & 289,1 & 273,2 \\
\hline
\end{tabular}

Tablo 1: Türkiye-Ermenistan Sınırın Kapalı ve Açık Olması Durumlarında Türkiye'nin Bazı Şehirleri ve Erivan Arasindaki Mesafeler (Km)

Burada Tablo 1 ve aşağıdaki bilgilerin yardımıyla, Türkiye-Ermenistan sınırın kapalı ve açık olması durumlarına göre iki ülke arasında yapılan dış ticaretteki taşıma maliyetleri ve sınırın açılmasıyla sağlanan maliyet avantajları hesaplanmaktadır.

Trabzon'da faaliyette bulunan N1 Uluslararası Nakliyat Şirketi'nden alınan bilgilere göre 22 Ocak 2010 tarihi itibariyle mazotun litresi Türkiye'de 2,9 TL, Batum'da 1,3 TL ve Tiflis'te 1,2 TL'dir. Türkiye'den Erivan'a gidilirken Batum'a, Batum'dan da Tiflis'e yetecek kadar mazot alınır. Tiflis'ten ise Erivan'a gidilip, aynı güzergâhtan Trabzon'a dönmeye yetecek kadar mazot alınır. Erivan mazotu diğer şehirlere nazaran daha ucuz olmasına rağmen kalitesi düşük olduğundan tercih edilmemektedir. N1 şirketin tırları $100 \mathrm{~km}$ 'de ortalama olarak 30 litre mazot 
harcamaktadır. Öte yandan, tırlara her $50.000 \mathrm{~km}$ 'de bir motor bakımı yaptırılmakta ve ortalama 500 TL ödenmektedir. Lastik bakımı ise her $250.000 \mathrm{~km}$ 'de bir yaptırılmakta ve 9.120 TL ödemektedir. Bir tırın değeri yaklaşık olarak 195.000 TL olup 1 milyon km kullanılabilmektedir. Şirket, şoförlerine 700 TL maaş vermektedir ve bu şoförler ayda ortalama $10.000 \mathrm{~km}$ mesafe kat etmektedirler. Şoförlere seyahatleri sırasında kişisel ihtiyaçları ve tırların masrafları için aylık yaklaşık olarak 6.720 TL harçlık verilmektedir. Gürcistan sınırından Ermenistan'a girerken karayolu geçiş ücreti olarak ortalama 521,5 TL ödemektedirler. Ayrıca tırlar, araç başına ücret, pasaport kontrolü, vb. maliyetleri içeren ve ortalama 74,5 TL'ye tekabül eden bir masrafa da katlanmaktadırlar.

Bu bilgilere göre, sınırın kapalı ve açık olması durumlarına göre Trabzon ve Erivan arasında yapılan ticarette yakıt ve gümrük maliyetleri Tablo 2'de gösterilmektedir.

\begin{tabular}{|l|c|c|c|}
\hline \multirow{2}{*}{} & \multicolumn{3}{|c|}{ Kapalı Sınır } \\
\cline { 2 - 4 } & $\begin{array}{c}\text { Harcanan } \\
\text { Mazot } \\
\text { Miktarı (Litre) }\end{array}$ & $\begin{array}{c}\text { Mazotun } \\
\text { Litre } \\
\text { Fiyatı } \\
\text { (TL) }\end{array}$ & $\begin{array}{c}\text { Toplam } \\
\text { Maliyet } \\
\text { (TL) }\end{array}$ \\
\hline Trabzon-Batum Arası & 59,91 & 2,9 & 173,73 \\
\hline Batum-Tiflis Arası & 115,11 & 1,3 & 149,64 \\
\hline Tiflis-Erivan Arası & 78,12 & 1,2 & 93,74 \\
\hline Karayolu Geçiş Ücreti (TL) & \multicolumn{3}{|c}{521,5} \\
\hline Gümrük Maliyetleri (TL) & \multicolumn{3}{|c}{14,5} \\
\hline Toplam Maliyet (TL) & \multicolumn{3}{|c}{1013,11} \\
\hline
\end{tabular}

Tablo 2: Sinırın Kapalı ve Açık olması Durumlarına Göre Trabzon ve Erivan Arasında Yapllan Ticarette Yakıt ve Gümrük Maliyetleri

Tablo 2'de görüldüğü üzere kapalı sınır söz konusuyken, Erivan'a toplam yakıt maliyeti 417,11 TL olmaktadır. Dönüş yolu da hesaplandığında, Erivan'dan Trabzon'a yakıt maliyeti 303,78 TL olmaktadır. Karayolu geçiş ücreti ve gümrük içerisindeki masraflar da hesaplanıldığında, kapalı sınır durumunda Trabzon-Erivan arasında yapılan ticarette 1.316,89 TL maliyet söz konusudur. Açık sınır söz konusu olduğunda Trabzon-Erivan arasında, maliyet unsuru olarak sadece harcanan yakıt söz konusu olacağından dönüş yolu ile birlikte toplam maliyet 981,36 TL olacaktır.

Öte yandan, Trabzon-Erivan arasında yapılan ticarette ortaya çıkacak olan diğer maliyet unsurları Tablo 3'te gösterilmektedir.

\begin{tabular}{|l|c|c|c|}
\hline \multirow{2}{*}{ Maliyetler } & \multicolumn{2}{|c|}{ Kapalı Sınır } & Açık Sınır \\
\cline { 2 - 4 } & $\begin{array}{c}\text { Km Başına } \\
\text { Maliyet (TL) }\end{array}$ & $\begin{array}{c}\text { Toplam } \\
\text { Maliyet (TL) }\end{array}$ & $\begin{array}{c}\text { Km Başına } \\
\text { Maliyet (TL) }\end{array}$ \\
\hline Motor Bakımı Masrafı & 0,01 & 16,87 & 0,01 \\
\hline Lastik Bakımı Masrafı & 0,03 & 50,62 & 0,03 \\
\hline Yıpranma Payı & 0,19 & 320,64 & 0,19 \\
\hline Şoför Maaş1 & 0,07 & 118,13 & 0,07 \\
\hline Şoför Harçlı̆̆1 & 0,67 & $1.130,69$ & 0,67 \\
\hline Toplam (TL) & 0,97 & $1.636,95$ & 0,97 \\
\hline
\end{tabular}

Tablo 3: Sinırın Kapalı ve Açık olması Durumlarına Göre Trabzon ve Erivan Arasında Yapılan Ticarette Diğer Maliyetler

Tablo 3'teki, km başına maliyetlerin nasıl hesaplanıldığına ayrı ayrı değinilirse; motor bakımı masrafı için $500 \mathrm{TL} / 50.000 \mathrm{~km}$; lastik bakımı masrafı için $9.120 \mathrm{TL} / 250.000 \mathrm{~km}$; yıpranma payı için $195.000 \mathrm{TL} / 1.000 .000 \mathrm{~km}$; şoför maaşı için $700 \mathrm{TL} / 10.000 \mathrm{~km}$; şoför harçlı̆̆ 1 için $6.720 \mathrm{TL} / 10.000 \mathrm{~km}$ gibi bir hesaplama söz konusudur. Toplam maliyet 
hesaplamaları ise bulunan km başına maliyetlerin, Türkiye-Ermenistan sınırın kapalı ve açık olması durumlarında gidiș-dönüș yolu göz önünde bulundurularak Trabzon-Erivan arasındaki mesafelerle (kapalı sınır söz konusuyken mesafe 1.687,6 km, açık sınır söz konusuyken mesafe 1.128 km'dir) çarpılmasıyla elde edilmiştir.

Tablo 2 ve Tablo 3'deki veriler bir arada değerlendirildiğinde, Türkiye-Ermenistan sınırın kapalı kalması durumunda yapılan ticarette toplam 2.953,84 TL'lik bir maliyet söz konusu iken, sınırın açılması durumunda yapılacak olan ticarette toplam maliyet 2.075,52 TL'ye düşebilecektir. Bu durumda, birim fiyatı 10 TL olan 100 birim mal Trabzon'dan Erivan'a ihraç edilirse, kapalı sınır söz konusu iken birim başına maliyet 29,5 TL, toplam maliyet ise 39,5 TL olmaktadır. Öte yandan, sınırın açılması durumunda ise birim başına maliyet 20,75 TL, toplam maliyet ise 30,75 TL olacaktır. Yani sınırın açılması durumunda yapılacak olan maliyet tasarrufu yaklaşık olarak \% 23 olacaktır (Bulut, 2010).

\section{Türkiye-Ermenistan Sınırın Açılmasının Bölgesel Kalkınmaya Etkisi}

Ermenistan, doğu ve batı sınırların kapalı olmasından dolayı ulaşım güzergâhlarının ve enerji koridorlarının bir parçası olamamaktadır ve gerek bölgesel (Bakü-Tiflis-Ceyhan petrol boru hattı, Bakü-Tiflis-Kars demiryolu hattı ve Bakü-Tiflis-Erzurum doğalgaz boru hattı) gerekse de uluslararası projelerin (TRACECA) dışında kalmaktadır. Erivan, söz konusu projelerde Tiflis'in yerini alabilecekken, sınırların kapalı olmasından dolayı bu avantajdan yararlanamamaktadır. Söz konusu projeler, hem Türkiye'nin bölge üzerindeki etkisini artıracaktır hem de barış ve istikrarın bölgeye gelmesini sağlayacaktır (Laçiner, 2002).

Ermenistan, sınırların açılmasının etkisiyle, enerji ve taşımacılık altyapısını geliştirerek, $A B$, Güney Kafkasya, Türkiye, Karadeniz, Rusya ve İran arasındaki projelerde birlikte çalışma imkânı elde edecektir ve bu durumdan önemli avantajlar sağlayabilecektir. Benzer durumlar başta Kars ve Iğdır olmak üzere Türkiye'nin doğu şehirleri için de geçerlidir. Sınır açıldığında Ermenistan'da yaşanacak hareketlilik, Türkiye'nin batıdaki şehirlerine nazaran geri kalmış olan bu sınır şehirlerini de bölgesel anlamda olumlu yönde etkileyebilecektir.

Ayrıca, Anadolu ve Ermenistan arasında direkt bir bağlantının sağlanması, Trabzon limanını geliştirecek, Trabzon-Erzurum-Iğdır-Erivan karayolu ekseninin, Trabzon'u bölgesel bir transit liman haline dönüştürme potansiyeli nedeniyle, Trabzon'un Poti ve Batum gibi demiryolu bağlantısı bulunan ve önemli yatırımları çeken Gürcü limanlarıyla rekabet etme olanağı sağlayabilecektir. (European Parliament, 2007).

\section{Türkiye-Ermenistan Sınırın Açılmasının Turizme Etkisi}

Ermenistan'ın 2007 yılında elde ettiği turizm geliri 333 milyon ABD Dolarıdır. 2007 yılı içinde Ermenistan'a giden toplam turist sayısı ise 510.287 kişidir. Ermenistan'a giden turistler ortalama olarak 20 gün kalmakta ve kişi başına ortalama olarak 705 ABD Doları harcamaktadır. Söz konusu 510.287 kişinin yaklaşık olarak 6.120 kişisini Türkiye'den Ermenistan'a giden turistler oluşturmaktadır (Armenian Tourism Development Agency, 2008). $\mathrm{Bu}$ bağlamda yukarıdaki veriler kullanılarak bir hesaplama yapıldığında; Türkiye'den giden turistler Ermenistan'a yılda ortalama 4.314.600 ABD Doları (6.120 X 705) birakmaktadırlar. $\mathrm{Bu}$ tutar, toplam Ermeni turizm gelirlerinin \% 1,29'una, Ermenistan GSYİH'sının ise \% 0,04'üne tekabül etmektedir.

Türkiye-Ermenistan sınırın açılmasıyla Ermenistan'a geçmek isteyen Ermeni'lerin sayılarının en azından 10.000 'i bulacağı varsayıldığında yukarıda hesaplanan söz konusu gelir 7.050.000 (10.000 X 705) ABD Doları olacaktır. Bu durumda Ermenistan'ın turizm gelirleri ise 335.735.400 ABD Doları olacaktır. Bu bağlamda 7.050.000 ABD Dolarlık gelir, toplam Ermeni turizm gelirlerinin \% 2,09'una, Ermenistan GSYİH'sının ise \% 0,07'sine tekabül edecektir. Yani, Türkiye-Ermenistan sınırının açılması, turizm gelirlerinin \% 0,8 oranında artmasına neden olarak, Ermenistan'ın GSYİH'sını \% 0,03 oranında artırabilecektir (Bulut, 2010). 


\section{Türkiye-Ermenistan Sınırın Açılmasının Dış Ticarete ve Sınır Ticaretine Etkisi}

Ermenistan'ın kapalı sınırları, komşularının çoğunluğu (Türkiye ve Azerbaycan) ile arasındaki ticareti ortadan kaldırmaktadır. Kapalı sınırlar, İran'daki ana merkezlere olan en kısa güzergâhın Türkiye ve Nahcivan topraklarından geçmesinden dolayı, Ermenistan'ın Kuzeybatı İran ile olan ticaretini de ciddi şekilde sinırlandırmaktadır. Ermenistan'ın, Türkiye ve Azerbaycan ile ilişkilerini geliştirmesi ve bölgeye olan altyapı bağlantılarını iyileştirmesi halinde bölgesel ticaret sayesinde daha zengin bir hale gelmesi mümkündür. Aksi takdirde altyapısı zayıf, istikrarsız ve çevresini tehdit eden bir ülkenin uluslararası ticaretten çok fazla beklentisi olmaması gerekir (Laçiner, 2002).

Öte yandan, Ermenistan'ın gerek doğu gerekse de batı sınırının açılması, ticarette hem Türkiye hem de Azerbaycan topraklarını kullanmasına ve Akdeniz limanlarına inmesine olanak sağlayacaktır. Böylece ekstra taşıma maliyetlerinden kurtulabilecektir. Bu durumda ticaret hacmini artırabilme imkânına kavuşabilecektir. Türkiye tarafından bakıldığında ise, Sınırın açılmasıyla, başta doğu şehirleri olmak üzere, Türkiye, yeni bir ihracat pazarı kazanabilecektir. Ermenistan'la ticaretin artması Türkiye'nin dış ticareti bakımından çok önemli olmamakla birlikte, Türkiye'nin doğu şehirlerinden Ermenistan'a yapılan ihracattaki artışlar, Türkiye'nin doğusundaki yerel ekonomiler için çok önemli olabilecektir. Sınırın açılması Ermenistan için ise hayati derecede önem arz etmektedir. Sınırın açılmasıyla birlikte Ermenistan'ın, sadece Türkiye'nin doğu şehirleriyle olan ticaretinde bir artış gerçekleşmeyecek aynı zamanda üçüncü ülkelere olan transit ticaret de artabilecektir. Ermeni-Avrupa Politika ve Hukuki Danışmanlık Merkezi yöneticisi Tigran Jrbashyan'a göre, sınırın açılması durumunda kısa vadede toplam Ermeni ihracatında \% 5,23'lük, toplam Ermeni ithalatında ise \% 4,71'lik bir artış olabilecektir. Jrbashyan, orta vadede ise, söz konusu oranları sirasıly \% 17,73 ve \% 12,95 olarak öngörmektedir (Jrbashyan ve diğerleri, 2007). Ayrıca 2009 yılında 4 milyar dolarlık ihracat gerçekleştiren Doğu Anadolu İhracatçılar Birliği, Doğu Kapı ve Alican sınır kapılarının açılmasıyla birlikte, Ermenistan üzerinden Asya'ya daha kısa ve güvenli ulaşım ile BDT ülkelerine sıfır gümrükle ihracat yapma şansı doğabileceğinden, ihracatın 6 milyar doları aşacağını öngörmektedir.

Sınır Ticaretinin Düzenlenmesine İlişkin 16.05.2009 tarih ve 2009/14451 sayılı Bakanlar Kurulu Kararı ile Sınır ticareti, illerin ihtiyaçlarının bir kısmının sınır komşusu ülkelerden ithalat yoluyla daha düşük maliyetle karşılanması ve bu illerden ihracatın artırılması suretiyle söz konusu illere ekonomik ve ticari canlılık kazandırılması amacıyla yapılan ticari işlemleri ifade etmektedir. Buradan hareketle, Türkiye-Ermenistan sınırın açılması ve sınır ticaretin başlaması, başta Kars olmak üzere Iğdır'a ekonomik anlamda bir hareketlilik getirecektir.

\section{Sonuç}

Ermenistan, doğu ve batı sınırları kapalı olan ve denizlere komşuluğu bulunmayan bir ülke konumunda olup, dünyanın geri kalan kısmına uzun güzergâhların kullanılmasıyla ulaşabilmektedir. Bu bağlamda, Türkiye ve Ermenistan arasındaki bağlantılar, Gürcistan ve İran topraklarının kullanılmasıyla sağlanmaktadır. Fakat bu iki güzergâh da Ermenistan'a, Türkiye topraklarının kullanılması durumunda, Türkiye'nin sunacağı avantajları sunamamaktadır. Bu güzergâhlarının kullanılması taşıma maliyetlerini yaklaşık \%23 oranında arttırarak ticarete konu malların fiyatlarını yükseltmektedir.

Sınırın kapalı olması, Ermenistan'ın Türkiye'nin sınır bölgeleriyle direkt olarak ticaret yapmasını engellemektedir. Türkiye-Ermenistan sınırına ek olarak Ermenistan-Azerbaycan sınırının da kapalı olması, Ermenistan'ın komşularıyla ve çevre ülkelerle olan ticaretini önemli miktarda azaltmıştır. Bununla birlikte, Ermenistan, dış ticarette en önemli ortağı olan Rusya'ya ulaşımda, Gürcistan ve Rusya arasındaki anlaşmazlıklardan dolayı, sıkıntı çekmektedir. Bu nedenle Ermenistan, Türkiye'deki karayolu, demiryolu ve deniz yolu bağlantılarına ihtiyaç 
duymaktadır.

Ermenistan, doğu ve batı sınırlarının kapalı olmasından dolayı, Trans-Kafkasya demiryolu ağının merkezinde bulunmasına rağmen, demiryolu hattını tam anlamıyla kullanamamaktadır. Bununla birlikte, Türkiye'nin Kafkasya'ya açılan tek demiryolu bağlantısının Ermenistan'da bulunması, Türkiye'nin de demiryollarından sağlayacağı avantajlardan faydalanamaması anlamina gelmektedir.

Öte yandan, sınırın açılmasıyla, Ermenistan artık bölgesel ve uluslararası projeler içinde kendisine yer bulabilecek ve bölgesel anlamda kalkınabilme firsatını yakalayabilecektir.

Sınırın açılmasından Türkiye'nin sağlayacağı uzun dönemli avantajlar; Hazar Denizi ve Orta Asya'ya kara, demiryolu ve boru hatları bağlantısında alternatif güzergâhlara kavuşması, kısa dönemli avantajlar ise başta sınır illeri olmak üzere Ermenistan bağlantılı liman kentlerinin ticari kazanımlarıdır. Ermenistan bakımından, Türkiye sınırının açılması, Avrupa Birliği’ne doğrudan ulaşım, transit ülke kazanımları, yeni istihdam imkânları, düşük ulaşım maliyetleri, boru hattı kazançları, dış ticaretin gelişmesi ve refah seviyesinin yükselmesi anlamına gelmektedir.

$\mathrm{Bu}$ çalışmada, Türkiye-Ermenistan sınırının açılmasının politik koşulları üzerinde durulmamış, iki ülke arasındaki kapalı bir sınırın açılmasının doğuracağı olası ekonomik etkiler konusunda ortaya çıkabilecek senaryolar gözden geçirilmiştir. Her ne kadar bilimsel araştırma, incelediği konuyu zaman, mekân ve bilimsel disiplin açısından sınırlandırarak gerçeğin sadece sınırlı bir boyutu üzerinde yoğunlaşmayı yöntem olarak benimsese de, sosyal olguların birbirinden soyutlanarak incelenmesi, ulaşılacak sonucun açıklayıcı gücünü sınırlandırır. $\mathrm{Bu}$ nedenle Türkiye-Ermenistan sınırının açılması konusu, reel uluslararası politik konjonktürden ayrıştırılıp, salt ekonomik yönleri üzerinde yoğunlaşarak ele alınamaz ve Azerbaycan'ın razı olmayacağı bir çerçevede irdelenemez.

Sınırın açılmasının Türkiye ve Ermenistan bakımından sağlayacağı avantajlar dikkate alındığında, Azerbaycan'ın desteğini almak koşulu ile Türkiye-Ermenistan sınır kapısının açılması kuvvetle önerilir. Ulusal çıkarları güvenlik bakımından Rusya'ya, medeni değerleri bakımından Avro-Atlantik dünyasına bağlı olan Ermenistan için sınırın açılması, ulusal çıkarlarındaki paradoksal yapının çözülmesine yardım edecektir. İstikrarlı bir Güney Kafkasya Bölgesi'nin, Türkiye'yi Kafkasya'daki ve Türkistan'daki Türk Cumhuriyetleri'ne yaklaştırma potansiyeli taşıdığı hususunun altının bir kere daha çizilmesinde yarar vardır.

\section{Kaynakça}

- Armenian Tourism Development Agency, 2008. Tourism Investment Handbook, Erivan: ATDA Publications, p. 22-26.

- Bulut, 2010, Türkiye-Ermenistan Sınırının Açılmasının Olası Ekonomik Etkileri Üzerine Bir Araştırma, Yayımlanmamış Yüksek Lisans Tezi, Karadeniz Teknik Üniversitesi Sosyal Bilimler Enstitüsü, p. 59-62, 80-81.

- European Parliament, 2007. The Closed Armenia-Turkey Border: Economic and Social Effects, Including Those On The People; and Implications For The Overall Situation In The Region, Brussels: EP Publications, p. 13, 17, 21-22.

- Gültekin, 2004. From War Economies To Peace Economies In The South Caucasus. International Alert Publications, London.

- Jrbashyan, vd, 2007. " Study Of The Economic Impact On The Armenian Economy From Re-Opening The Turkish-Armenian Borders. Implications for External Trade", Proceedings Of The International Conference On The Economic and Social Consequences Of Opening The Armenia-Turkey Border, p. 84.

- Laçiner, 2002. "Türkiye-Ermenistan İlişkilerinde Sınır Kapısı Sorunu ve Ekonomik Boyutu”, Ermeni Araştırmaları Enstitüsü, 6, p. 57, 61. 


\title{
A Study on the Entry Strategies Related with Risk Management of Turkish Companies to the Emerging Economies
}

\author{
Duygu Anıl Keskin, Istanbul University \\ Ibrahim Anil, Marmara University \\ Cem Canel, University of North Carolina Wilmington
}

\begin{abstract}
There is a wide literature about companies' entry-modes (acquisition and greenfield) and ownership preferences (JV and WOS) that they use while investing abroad. In terms of these entry- modes, the explanation capacity of Institutional Theory, Transaction Cost Theory and Resource Dependency Theory have been measured by several studies. However, when these strategies are evaluated separately their explanation capacity decreases. Therefore, new approaches are used. One of these new approaches by Dunning states that the explanation capacity of these theories would be enhanced by integrating them. Dunning argues that these theories would be integrated by accepting that ownership advantages would be assessed as resource dependency theory, location advantages would be assessed as institutional theory and internalization advantages would be assessed as transaction cost theory. This Eclectic approach is used in this study in terms of the interactions of three different approaches.

Entry modes with multiple theories would be more effective than a single theory in order to explain the entry modes of these companies. In this study, entry strategies of Turkish companies to the Russia Federation, Balkan Countries and Central Asia are explained, compared and discussed in terms of these theories. The aim of this study is to contribute to the relevant literature by understanding which entry strategy would explain the behavior of Turkish companies while investing in other developing countries.
\end{abstract}

JEL Code: M10

\section{Theoretical Framework}

Previous studies, which are about entry and ownership modes of firms, show that the companies use four different modes in terms of their FDI. There are JV and WOS ownership mode, Greenfield and Acquisition entry mode. According to the different approaches, which are explained below, firms prefer different entry and ownership modes.

\subsection{Institutionalist Approach}

According to Gatignon and Anderson (1998, pg.315) country risks generally consist of the political, legal, cultural and economic environment of the country and there is a relationship between these factors and the stability of commercial activities. They argue that the more the risk increases the companies may choose JV because JV gives the possibility to be more flexible in risky environments. The study of Kim and Hwang (1992, pg.35) confirms those arguments by indicating that multinational companies prefer JV entry mode when country risk is high.

Another factor that leads the companies to prefer JV as an entry mode is that the cultural distance between the host country and the country of the investor company. According to several studies (Kogut and Singh, 1988; Gatignon and Anderson, 1988; Erramilli and Rao, 1993; Meyer, 2001 and Tsai and Cheng, 2004) when the cultural distance is high, investor companies prefer to enter by using JV. However, Brouthers and Brouthers (2000) report that there is not any significant relationship between cultural distance and entry mode of Japanese firms that investing in Western Europe. Finally, Anıl and Çakır (2010, pg.11-12) found out that 
when firms are fully aware of the similarities between the business styles and the local culture of the country in question, they prefer JVs. However, the study reveals no meaningful connection between the cultural similarity and the preference of entry mode (Greenfield or acquisition).

\subsection{Transaction Cost Approach}

This approach argues that the organization and the administration structure reducing the transaction costs are the key elements of entry modes of companies (Zhao et al., 2004, pg.526). When the costs of protection against opportunist behavior, performance monitoring and adaptation of production technologies are high, the firm would prefer an internal administration structure (WOS) (Luo, 2001, pg.445,. Meyer and Peng (2005, pg.603),Williamson, 1985)

Several studies in this field (e.g. Gatignon and Anderson, 1988; Padmanabhan and Cho, 1996; Delios and Beamish, 1999; Makino and Neupert, 2000; Luo, 2001; Brouthers, 2002; Tsai and Cheng, 2004) point out that when the firm's asset specificity is high, it is more likely to prefer JV rather than WOS. However, it could be said that there are some exception of this situation. For example, Padmanabhan and Cho (1996, pg.48) argue that When technological deficits in the transition economies are taken into account, an R\&D-intensive firm may prefer to have full control in order to protect its proprietary expertise and/or to use it optimally. They also report that R\&D-intensive Japanese firms generally prefer whole ownership (WOS) in their foreign investments. In addition, since in some conditions the institutional structure cannot protect the intellectual capital of firms, technology-intensive firms prefer to internalize (WOS) their transactions that requires advanced technology (Meyer 2001, pg.360).

Sometimes uncertainty plays an important role on the entry mode choosing process. Especially when uncertainty renders contracts ineffective and leads the partners to be exposed to delays, WOS is preferred (Brouthers and Hennart, 2007, pg. 403).

Transaction cost theorists report that the firm's old experience in the host country or in the international areas has a significant effect on the entry and ownership mode choosing process. In terms of this argument, firms have a significant international experience would prefer to WOS since they do not need to local partners (Dikova and Wittelloostuijn, 2007, pg.1016; Padmanabhan and Cho, 1999, pg.27; Gatignon and Anderson, 1988; Delios and Beamish, 1999; Tsai and Cheng, 2004). Firm's international experience also affects acquisition greenfield dilemma (Larimo, 2003, pg.794).

\subsection{Resource Based Approach}

According to Brouthers and Hennart (2007, pg.404) firms' organizational abilities related to the resources could be used as an advantage in the international markets. Moreover, sometimes firms want to enter international markets in order to gain some key resources. In terms of this argument it could be said that while selecting their partners firms from developing markets are more eager to share the financial assets, technical abilities, abstract assets and expertise of their partners; on the other hand, firms from developed markets emphasize the unique competence, market knowledge and access to the market of more than one partner (Hitt et.al.,2000, 461463). In addition, developed markets' firms use their own resources in order to obtain competitive advantage and they prefer to work with partners which have core competence, local market experience and opportunity for entering to the market; however, developing markets' firms search for partners which they can learn organizational and technical abilities.

Meyer et. al. (2009, pg.62) point out that firms that enter to developing economies prefer to use JV strategies when the institutional conditions of these economies are weak because they can access to important resources by using this strategy. On the other hand, when the institutions are stronger and the market activity is higher, they choose acquisition strategy.

Under the conditions that there are no local partners for the firms that need to obtain new resources in the new market, according to Anand and Delious (1997, pg.582), acquisitions are the only solution. 
When the technological abilities of a firm are treated as a resource, firms that have technological abilities would prefer to greenfield strategy for a few reasons. First of all the local firms do not have sufficient technological ability to present to firms that have stronger technological capacity. Secondly, if the acquirer has superior technological competences, transfer of these competences to the acquire company may be difficult or impossible because of the organizational inertia, i.e. the resistance of the workers within the acquired firm to the changes that would result from the acquisition process.

Finally, the size of a firm is regarded as an important antecedent of competitive advantage of the firm (Ekeledo and Sivakumar, 2004, pg.78). According to the some researcher (e.g. Buckley and Casson, 1976; Terpstra and Yu, adapted from Kumar, 1984, 1988, pg.35; Chang and Rosenzweig, 2001, pg.756) big companies are good at eliminating the risks and costs relating to foreign direct investments and have greater advantage in balancing disadvantageous positions. It is also argued that the larger the investment firm, the greater the acquisition competence of the firm (Kogut and Singh, 1988, pg.420; Larimo 2003, pg.801.)

\subsection{Eclectic Approach}

This approach, also entitled OLI (Ownership, Location, Internalization) argues that the firms choose the most convenient entry mode to the international markets and while doing that they evaluate the firms' own ownership advantages (Resourca Based Theory), host country's position (Institutional Theory), and the internalizing advantages (Transaction cost Theory) of integrating the operations within the firm (Tatoglu and Glaister, 1998, pg.284).

In their study, Agarwal and Ramaswami (1992, pg.20-21) analyze the impact of mutual mutual relations among the firm's property (ability to develop differentiated product, its magnitude and international experience), the firm's position (potential of the market and its investment risk) and the firm's internalizing advantages (risks regarding the contract) in the firm's preferred market entry modes (exportation, licensing, JV, WOS). The results of this study show that most of the small firms which are not experienced enough in international markets prefer to use JV as a entry mode because JV agreements give a chance to share the risks, the costs and also complementary assets and abilities of the partner firm. However, big firms which are already experienced enough in international markets prefer to use WOS since they want to expand markets with lower potential and realize their profit targets. In addition, according to this study when the contractual risks of the firms which have the ability developing differentiated products are considered high, firms are apt to use WOS.

According to several researchers (e.g. (Hoskisson et al., 2000; Luo, 2001; Wright et al., 2005; Meyer and Peng, 2005; Brouthers and Hennart, 2007) there are more than one factors that affect the firms' preferences in terms of entry modes especially in the developing economies and that's why it is not possible to explain firm behavior of international companies by using only one theory or approach. Under the light of this assumption it could be argued that since Dunning's Eclectic Approach covers all other theories and approaches it has a more explicative framework (Brouthers and Hennart, 2007).

At last but not least it should be noted that this theoretical framework does not consist of the differences between managers in terms of risk perception. Since the key decision makers' risk perception would alter from one person to one another it could affect the entry mode choice of firms.

\section{Findings}

The third part of questionnaire format using for Institutional Theory18 scales; of location selection factors; that was developed by Glaister and Tatoğlu (1998) was used in order to identify the realities regarding these firms, and the questionnaire was given to 107 firms and 169 facilities in 7 countries (Bulgaria, Romania, Uzbekistan, Kazakhstan, Turkmenistan, 
Kyrgyzstan and Russia). For this study one question; "to have the advantage of being the first to enter the market" was added to the questionnaire form. The fourth part of questionnaire format using for Transaction cost Theory 13 scales of internalizing advantages of integrating the operations of firms and fifth part of questionnaire format using 7 scales of ownership advantages of firms was used. The values of the criteria which were measured by the questionnaire forms according to 5-point likert scale and averages of the points were as follows;

\subsection{Findings About the Expainatory Capacity of Instutional Theory}

\subsubsection{The Relationship Between Type of Investment and Ownership Pattern with Location Selection Factors}

Our finding shows differences of nineteen location selection determinats in terms of the type of investment. It is seen that convictions about the growth rate of the economy, the degree of unionization and the purchasing powers of customers affect preferences in regard to Greenfield or acquisition. That is, there is a significant difference between two groups at the level of significance is 0.05 . Accordingly, firms who perceive "Geographical Proximity", "the growth rate of economy" and "Level of Unionization" as high prefer the greenfield investment type.

Other finding shows differences of nineteen location selection determinats in terms of the ownership patterns. There is just one significant difference in terms of the preferences about capital structure (type of ownership). It is "Level of Industry Competition" and firms who percieve it as high prefer WOS.

\subsubsection{The Relationship Between Ownership Pattern whit the Cultural Familiarity}

There is a significant difference between WOS and JV groups about "similarity level of local cultures" and "similarity level of ways of business" at 0.05 significance level. Accordingly, firms that have high levels of perception about the similarity of local cultures and similarity of ways of business prefer JV ownership. There is no significant difference between "corporate culture" and "similarity of business ethics" in terms of ownership pattern.

There is a significant difference between WOS and JV patterns in terms of newly formed variable which is derived by the means of cultural variables above. JV is preferable in high levels of cultural familiarity.

Additionally, the relationship between cultural familiarity and mode of entry is analyzed but any significant difference cannot be determined.

\subsubsection{The Relationship Between Type of Investment and Ownership Pattern on Risk Taking}

The risk-taking behavior of traditionally internationalized firms is explained by a correlation with the amount of expected inputs (Buckley and Casson, 1981; Chakrabarti, 2001). Buckley et al., (2007) verified that the phenomenon of highly risk-laden direct capital investments ventured by China is also true for the foreign investments by Turkish firms. All of the Turkish firms, except for one operating in Uzbekistan, work at high performance. It is seen that they have made their investments without considering the risk aspect (Demirbağ et al. 1998), which verifies the findings of previous studies. No correlation has been found between UNCTAD's data on the total investment countries receive and the data of the Undersecretaries of Treasury of the Turkish Republic. Same is true for risk factor data and COFACE risk index data.

Based on these results, there is no statistically significant difference was found between the averages of benefiting from economies of scale, better resource and capacity use, qualified and privileged access to inputs, presence in new markets, opportunity for rapid entry into markets, investment profitability, harmony with Turkish government policy, cost of contracting and implementation, avoiding the risk of misusing production information, ensuring sufficient quality control, insufficient legislation on patent and license rights, inability to make technology transfers through licensing and patents, and in agencies and licensing with the 
ownership pattern and type of investment. Only one relation was found implementation cost of contracts with type of investment. Firms who percieve cost of contracts as high prefer greenfields. The level of significance is 0.05 .

Those who claimed that it was unimportant expressed that they accepted the risk in order to achieve the required outcome, whereas those that regarded it as highly important said that this factor ensures a non-competitive environment and so this aspect was very important in order to sustain the same environment.

\subsection{Findings About the Expainatory capacity of Resource Based Theory}

According to our results, there is no statistically significant difference was found between the averages of International experience, Brand and product image, Practicing level of technology and managerial information, Experience in markets of the chosen country, Quality of staff improvement program, Staff quality and Product differentiation and development skills with ownership pattern and type of investment. Independent $\mathrm{T}$ tests are used to see if there is any significant difference between entry mode groups (acquisition or green field) for all items in group of ownership advantages. Only one relation was found that international experience with type of investment Results show significant difference for them. Firms who percieve their international experience as high, they prefer greenfields. The level of significance is 0.05 .

\subsection{Findings About the Expainatory capacity of Transaction Cost Theory}

Independent $\mathrm{T}$ tests are used to see if there is any significant difference between entry mode groups (acquisition or green field) for all items of internalization advantages which consist of; 4.1. benefiting from economies of scale, 4.2. better resource and capacity use, 4.3. qualified and privileged access to inputs, 4.4. presence in new markets, 4.5. opportunity for rapid entry into markets, 4.6. investment profitability, 4.7. harmony with Turkish government policy, 4.8. cost of contracting and implementation, 4.9. avoiding the risk of misusing production information, 4.10. ensuring sufficient quality control, 4.11. insufficient legislation on patent and license rights, 4.12. inability to make technology transfers through licensing and patents, 4.3. difficulties of agencies and licensing implementations. Reliability analysis is executed for this group of internalization; that consists thirteen items. Cronbach Alpha statistics is calculated as 0.7153 . These items are used for factor analysis and four factors are emerged. KMO measure of sampling adequacy is calculated as 0.6690 and explained variance is 69.5680 per cent by factors.

Group internalization results show significant difference for only cost of contracts item. Variances are assumed equal because of Levene's test and the significance level is estimated as 0.039 for mean difference. As a result, mean difference between groups is statistically significant at level 0.05 .

\subsection{Findings About the Expainatory capacity of Eclectic Theory}

Dunning's Eclectic Approach's arguments in terms of advantages that are related to the country and company it could be said that the following factors have an impact on the decision of the Turkish companies: having a factory in EU, taking the advantage of being first mover, entering international markets, buying a cheap facility in terms of privatization. Hence, in this study which tries to explain the entrance behavior of the companies from different sectors, sizes and from different entrance years, it has been found that Eclectic Approach is more exploratory than other theories. All of these conditions have an impact more or less on the decision of Turkish companies decicons. İn addition to this factors Eclectic theory has been covering other three theories via İLO approach. That means (L) location selection factors of "Geographical Proximity", "the growth rate of economy" and "Level of Unionization" firms who perceive as high prefer the greenfield investment type. There is just one significant difference in location selection factor, terms of the preferences about capital structure (type of 
ownership). It is "Level of Industry Competition" and firms who percieve it as high prefer WOS. Finally, firms that have high levels of perception about the similarity of local cultures and similarity of ways of business prefer JV ownership.

(O) Ownership factors of international experience; Firms who percieve their international experience as high, they prefer greenfields.

(I) Internalization factors of "Implementaion cost of contract" which Firms who percieve cost of contracts as high prefer greenfields.

\section{Conclusions}

This study analyzed which entry (Greenfield/ acquisition) and ownership (JV/WOS) styles are used by one developing country's firms (Turkey) during the entrance process to another developing countries. By doing that various theoretical aspects, Institutional Theory, Transaction Cost Theory, Resource Dependency Theory and Dunning's Eclectic Approach (OLI) which covers first three theories with additional factors, has been used. Despite of the wideness of research that deals with the entrance styles of the developed countries' companies and their entrance process to the developing countries, there are relatively few studies that deal with the entrance styles of developing countries' companies that enter other developing countries. Thus, this study aims to contribute filling this gap.

In this study it has been found that none of the relevant theories could explain the entrance behavior of Turkish companies alone; but, each of them partially explains it. As a result, it could be said that Dunning's Eclectic Approach is more explanatory than other theories.

Although Institutional Theory argues that in the countries where uncertainty and cultural distances are high companies would choose JV, all of the Turkish companies analyzed and has been found similar results. in this study. Moreover, these companies indicate that they did not care about the transaction costs because the conditions were similar to Turkey.

\section{References}

- Agarwal and Ramaswami.(1992).Choice of Foreign Market Entry Mode: Impact of Ownership, Location and Internalization Factors. Journal of International Business Studies. 23.1, 1-27.

- Anand and Delios. (1997). Location Specificity and The Transferability of Downstream Assets to Foreign Subsidiaries. Journal of International Business Studies. 28.3, 579-603.

- Anand and Delios. (2002). Absolute and Relative Resources as Determinants of International Acquisitions. Strategic Management Journal. 23.2, 119-134.

- An1l, Cakir and Canel. (2010). A Comparison of Inward and Outward Foreign Direct Investment Determinants in Turkey. Southeast Decision Sciences Institute Fortieth Annual Conference, Wilmington, Proceedings Book. 528-542.

- Barkema and Vermeulen. (1998). International Expansion Through Start-Up or Acquisition: A Learning Perspective. Academy of Management Journal. 41.1, 7-26.

- Brouthers,(2002). Institutional, Cultural and Transaction Cost Influences on Entry Mode Choice and Performance. Journal of International Business Studies. 33.2, 203221.

- Brouthers and Brouthers. (2000). Acquisition or Greenfield Start-Up? Institutional, Cultural and Transaction Cost Influences. Strategic Management Journal.21.1, 89-97.

- Brouthers, Brouthers and Werner. (1996). Dunning's Eclectic Theory and The Smaller Firm: The Impact of Ownership and Locational Advantages on The Choice of Entry-Modes in The Computer Software Industry. International Business Review. 5.4, 
377-394.

- Brouthers, K. D. and J. F. Hennart. (2007). Boundaries of the Firms: Insights From International Entry Mode Research. Journal of Management. 33.3, 395-425.

- Buckley, Clegg, Cross, Liu, Voss And Zheng (2007) “The Determinants of Chinese Outward Foreign Direct Investment”, Journal of International Business Studies, 38

- Chakrabarti, A. (2001), "The Determinants of Foreign Direct Investment: Sensitivity Analyses of Cross-country Regressions”, Keyklos, Vol.54

- Chang and Rosenzweig. (2001). The Choice of Entry Mode in Sequential Foreign Direct Investment. Strategic Management Journal. 22.8, 747-776.

- Delios and Beamish. (1999). Ownership Strategy of Japanese Firms: Transactional, Institutional, and Experience Influences. Strategic Management Journal. 20.10, 915933.

- Demirbag, Tatoglu and Glaister. (2008). Factors Affecting Perceptions of the Choice between Acquisition and Greenfield Entry: The Case of Western FDI in an Emerging Market. Management International Review. 48.1, 5-38.

- Dikova and Witteloostuijn. (2007). Foreign Direct Investment Mode Choice: Entry and Establishment Modes in Transition Economies. Journal of InternationalBusiness Studies. 38.6,1013-1033.

- Dunning, (1993). Multinational Enterprises and The Global Economy. Wokingham, UK: Addison-Wesley.

- Ekeledo and Sivakumar. (2004). International Market Entry Mode Strategies of Manufacturing Firms and Service Firms: A Resource-Based Perspective. International Marketing Review. 21.1, 68-101.

- Erramilli and Rao. (1993). Service Firms'International Entry-Mode Choice: A Modified Transaction-Cost Analysis Approach. Journal of Marketing. 57.3, 19-38.

- Erramilli, Agarwal and Dev. (2002). Choice Between Non-Equity Entry Modes: An Organizational Capability Perspective. Journal of International Business Studies. 33.2, 223-242.

- Gatignon and Anderson. (1988). The Multinational Corporation's Degree of Control over Foreign Subsidiaries: An Empirical Test of Transaction Cost Explanation. Journal of Law, Economics, and Organization. 4.2, 305-336.

- Hennart and Larimo. (1998). The Impact of Culture on the Strategy of Multinational Enterprises: Does National Origin Affect Ownership Decisions?. Journal of International Business Studies. 29.3, 515-538.

- Hitt, Dacin, Lewitas, Edhec and Borza. (2000). Partner Selection in Emerging and Developed Market Contexts: Resource-Based and Organizational Learning Perspectives. Academy of Management Journal. 43.3, 449-467.

- Hoskisson, Eden, Lau and Wright. (2000). Strategy in Emerging Economies. Academy of Management Journal. 43.3, 249-267.

- Kim and Hwang. (1992). Global Strategy and Multinationals' Entry Mode Choice. Journal of International Business Studies. 23.1, 29-53.

- Kogut and Singh. (1988). The Effect of National Culture on the Choice of Entry Mode. Journal of InternationalBusiness Studies. 19.3, 411-432.

- Larimo, (2003). Form of Investment by Nordic Firms in World Markets. Journal of Business Research. 56.10, 791-803.

- Luo (2001). Determinants of Entry in an Emerging Economy: A Multilevel Approach. Journal of Management Studies. 38.3, 443-472. 
- Makino and Neupert. (2000). National Culture, Transaction Costs, and the Choice Between Joint Venture and Wholly Owned Subsidiary. Journal of International Business Studies. 31.4, 705-713.

- Meyer (2001). Institutions, Transaction Costs, and Entry Mode Choice in Eastern Europe. Journal of International Business Studies. 32.2, 357-367.

- Meyer and Peng. (2005). Probing Theoretically into Central and Eastern Europe: Transactions, Resources, and Institutions. Journal of International Business Studies. 36.6, 600-621.

- Meyer, Estrin, Bhaumik and Peng. (2009). Institutions, Resources, and Entry Strategies in Emerging Economies. Strategic Management Journal. 30.1, 61-80.

- Padmanabhan, and Cho. (1996). Ownership Strategy for a Foreign Affiliate: An Empirical Investigation of Japanese Firms. Management InternationalReview. 36.1, 45-65.

- Padmanabhan and Cho. (1999). Decision Specific Experience in Foreign Ownership and Establishment Strategies: Evidence from Japanese Firms. Journal of International Business Studies. 30.1, 25-41.

- Tatoglu and Glaister. (1998). Determinants of Foreign Direct Investment in Turkey. Thunderbird International Business Review. 40.3, 279-314.

- Tsai and Cheng. (2004). Asset Specificity, Culture, Experience, Firm Size and Entry Mode Strategy: Taiwanese Manufacturing Firms in China, South-East Asia and Western Europe. International Journal of Commerce \& Management. 14.3/4, 1-27.

- Williamson, (1985). The Economic Institutions of Capitalism. New York: Basic Books.

- Wright, Filatotchev, Hoskisson and Peng. (2005). Guest Editors' Introduction: Strategy Research in Emerging Economies: Challenging the Conventional Wisdom. The Journal of Management Studies. 42.1, 1-33.

- Zhao, Luo and Suh. (2004). Transaction Cost Determinants and Ownership-Based Entry Mode Choice: A Meta-Analytical Review. Journal of International Business Studies. 35.6, 524-544 


\title{
Competition in the Banking Sector in the Czech Republic
}

\author{
Daniel Stavárek, Silesian University \\ Iveta Řepková, Silesian University
}

\begin{abstract}
The paper estimates the level of competition of the banking industry in the Czech Republic during the period 2000-2008. We apply Panzar-Rosse model on data from banks comprising almost $90 \%$ of the market. We found that the market was alternately in equilibrium and disequilibrium, which demonstrates a dynamic development of the Czech banking sector. While the market can be described as perfectly competitive during the period 2000-2004, the intensity of competition decreased after joining the EU in 2004 and the market can be characterized as one of monopolistic competition in 2004-2008.

Publication of this paper was supported by the Czech Science Foundation (project GACR 402/08/0067) and Student Grant System of Silesian University (project SGS 25/2010).
\end{abstract}

JEL codes: D40, G21

\section{Introduction}

Sound competition in the banking market is of great economic importance because it lowers prices and improves quality, thereby contributing to the prosperity of consumers and companies alike. Competition fosters innovative behavior, forces banks to improve their efficiency, thus promoting the access of households and firms to financial services and external finance, and thereby enhancing economic growth (Bikker, et al., 2007).

The literature on the measurement of competition can be divided into two major streams: structural and non-structural approaches. The structural approach to the measurement of competition embraces the Structure-Conduct-Performance paradigm (SCP) and the efficiency hypothesis. The two former models investigate whether a highly concentrated market causes collusive behavior among the larger banks resulting in superior market performance, and whether it is the efficiency of larger banks that enhances their performance. These structural models link competition to concentration. Non-structural models for the measurement of competition, namely the Iwata model (Iwata, 1974), the Bresnahan model (Bresnahan (1982) and Lau (1982)), and the PanzarRosse model (Panzar and Rosse, 1987), were developed in reaction to the theoretical and empirical deficiencies of the structural models. These New Empirical Industrial Organisation (NEIO) approaches test competition and the use of market power, and stress the analysis of banks' competitive conduct in the absence of structural measures (Bikker and Haaf, 2000, p. 17).

The aim of the paper is to examine the degree of competition within the Czech Republic banking industry during the period 2000-2008. The Czech Republic's financial system is traditionally bank-based and banks play an important role in the economy on the side of corporations and business as well as households. Furthermore, the banking sector in the Czech Republic went through serious crisis in late 1990s followed by a period of consolidation that included, among others, failures of small banks, privatization of large state-owned banks combined with their recapitalization and cleaning their loan portfolios. The Czech Republic joined the European Union in 2004 and the banking sector cannot stand apart from the ongoing process of financial integration within the European Union. Therefore, the analysis of competition in industry with so many important development milestones is of high interest. 


\section{Panzar-Rosse Model}

The method developed by Panzar and Rosse (1987) determines the competitive behavior of banks on the basis of the comparative static properties of reduced-form revenue equations based on cross-section data. Panzar and Rosse show that if their method is to yield plausible results, banks need to have operated in a long-term equilibrium, while the performance of banks needs to be influenced by the actions of other market participants. The model assumes a price elasticity of demand, $e$, greater than unity, and a homogeneous cost structure. To obtain the equilibrium output and the equilibrium number of banks, profits are maximized at the bank as well as the industry level. That means, first, that bank $i$ maximizes its profits where marginal revenue equals marginal cost:

$$
R_{i}{ }^{\prime}\left(x_{i}, n, z_{i}\right)-C_{i}{ }^{\prime}\left(x_{i}, w_{i}, t_{i}\right)=0 \text {, }
$$

where $R_{i}$ is the total revenue,

$C_{i}$ is the total expenses,

$x_{i}$ is the output of bank $i$,

$n$ is the number of banks,

$w_{i}$ is a vector of $\mathrm{m}$ factor input prices of bank $i$,

$z_{i}$ is a vector of exogenous variables that shift the bank's revenue function,

$t_{i}$ is a vector of exogenous variables that shift the bank's cost function.

In equilibrium, the zero profit constraint holds at the market level:

$$
R_{i}^{o}\left(x^{o}, n^{o}, z\right)-C_{i}^{o}\left(x^{o}, w, t\right)=0 \text {. }
$$

Variables marked with ${ }^{\circ}$ represent equilibrium values. Market power is measured by the extent to which a change in factor input prices is reflected in the equilibrium revenues earned by bank $i$. Panzar and Rosse define a measure of competition, the $H$ statistic as the sum of the elasticities of the reduced form revenues with respect to factor prices:

$$
H=\sum\left(\frac{\partial R_{i}^{o}}{\partial w_{k_{1}}}\right)\left(\frac{w_{k_{1}}}{R_{i}^{o}}\right) \text {. }
$$

The estimated value of the $H$ statistic ranges between $\infty<H \leq 1$. Table 1 summarizes the discriminatory power of $H$.

\begin{tabular}{c|c}
$\mathrm{H} \leq 0$ & Monopoly equilibrium or perfect cartel \\
\hline $0<\mathrm{H}<1$ & Monopolistic competition \\
\hline $\mathrm{H}=1$ & Perfect competition
\end{tabular}

\section{Tab. 1 Panzar-Rosse H statistic}

An important feature of the $H$ statistic is that it must be performed on observations that are in long-run equilibrium, as suggested in previous studies such as Bikker and Haaf (2002), Claessens and Laeven (2004), Casu and Girardone (2006), Matthews, et al. (2007), Fu (2009) and Rezitis (2010). This suggests that competitive capital markets will equalize riskadjusted rates of return across banks such that, in equilibrium, rates of return should be uncorrelated with input prices (Matthews, et al., 2007, p. 2030). The equilibrium test is carried out with the return on assets (or equity), replacing bank revenue as the dependent variable in the regression equation for the $H$ statistic. The $E$ statistic is derived from the equilibrium test and measures the sum of elasticities of rate of return with respect to input prices (Fu, 2009). If the $E$ statistic is equal to zero, it indicates long-run equilibrium, while $E<0$ reflects disequilibrium. Table 2 summarizes the discriminatory power of $E$ statistic.

\begin{tabular}{c|c}
$\mathrm{E}=0$ & Equilibrium \\
\hline $\mathrm{E}<0$ & Disequilibrium
\end{tabular}




\section{Methodology and Data}

Several specifications of the Panzar-Rosse model have been used in empirical literature. One of the crucial differences among studies is the definition of the dependent variable applied in the estimation of $H$ statistic. Chan, et al (2007), Pawlowska (2005), Deltuvaite (2007) or Lee and Nagano (2008) use interest income (revenues). Alternatively, Hempell (2002), Bikker, et al. (2009) or Rezitis (2010) apply a total income or net income (de Rozas, 2007). Some authors analyze the competition in banking using a combination of more than one equation. For example, Chun and Kim (2004) or Fu (2009) have total revenues and interest revenues as dependent variables.

The dependent variable in Eq. (4) chosen for the present paper is defines total revenue to total assets, rather than only the interest part, in order to account for the fact that the importance of non-interest income has increased greatly in recent years in the Czech Republic's banking sector. This view is supported, among others, by Casu and Girardone (2006), Pererera, et al. (2006) and Rezitis (2010), who argue that in a more competitive environment, the distinction between interest and non-interest income becomes less relevant, as banks are competing on both forms. The existence of accounting differences across countries is an additional argument in favor of having a comprehensive view of bank revenues. And the dependent variable is divided by total assets in order to account for size differences as suggested by Casu and Girardone (2006).

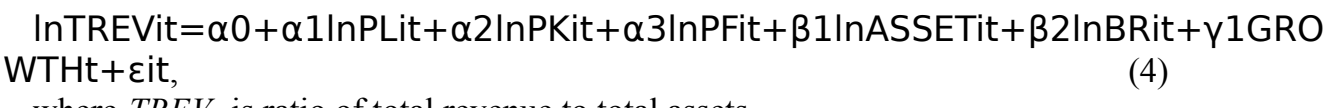

where $T R E V_{i t}$ is ratio of total revenue to total assets,

$P L_{i t}$ is ratio of personnel expenses to number of employees,

$P K_{i t}$ is ratio of other expenses to fixed assets,

$P F_{i t}$ is ratio of annual interest expenses to total loanable funds (deposits + tradable securities + subordinated instruments).

Bank-specific and market-specific variables include:

$A S S E T_{i t}$ is sum of total assets,

$B R_{i t}$ is he ratio of the number of branches of a bank to the total number of branches of all banks,

$\mathrm{GROWTH}_{t}$ is the annual real GDP growth rate, $i$ denotes the bank $(i=1, \ldots, N), t$ denotes time $(t=1, \ldots, T)$.

$P L_{i t}, P K_{i t}$ and $P F_{i t}$ correspond to the three input prices, i.e., labor, capital and funds. Consistently with the intermediation approach, we assume that banks use all the three inputs. Other explanatory variables are chosen to account for bank-specific and market-specific factors. Similar variables are used also in Chun and Kim (2004), Matthews, et al. (2007), Fu (2009) or Rezitis (2010).

The total asset variable $\left(A S S E T_{i t}\right)$ is included to take account of possible scale economies. The ratio of the number of branches of each bank to the total number of branches of the whole banking industry variable $\left(B R_{i t}\right)$ is used in order to account for bank size. Branching has been viewed as a means for maintaining market share by providing consumers with close-quarter access to financial services, mitigating to some extent price competition. The market-specific variable $\left(G R O W T H_{t}\right)$ is incorporated to control for the possible impact of macroeconomic factors on bank performance. It is well known that the profitability and revenue of a bank is highly sensitive to the business cycle. Bad debts and nonperforming loans vary positively with the business cycle, and accounting conventions mean that the timing of a default does not invariably coincide with the turning point of the recession, so bank performance may lead or lag the business cycle. Hence, the final equations to be estimated also include a pure time series variable, real GDP growth rate. All variables are expressed in logarithmic form.

The model assumes a one-way error component as described by 
$\varepsilon i t=\mu i+\vartheta i t$

where $\mu \mathrm{i}$ denotes the unobservable bank-specific effect and $\vartheta$ it denotes a random term which is assumed to be IID. The $\mathrm{H}$ statistic is given by

$H=\alpha 1+\alpha 3+\alpha 3$.

For obtaining equilibrium conditions the model is defined as follows:

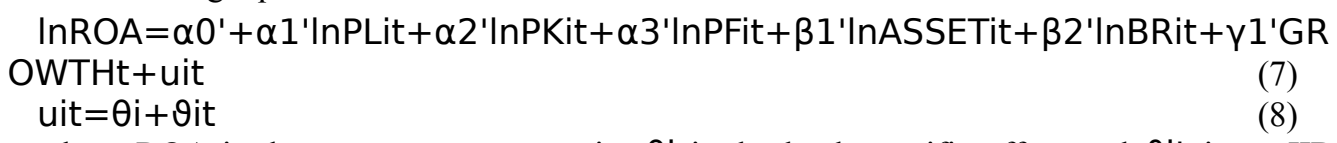

where ROA is the return on assets ratio, $\theta i$ is the bank-specific effect and $\vartheta i t$ is an IID random error. The banking market is deemed to be in equilibrium if

$\mathrm{E}=\alpha 1^{\prime}+\alpha 2^{\prime}+\alpha 3^{\prime}=0$

The dataset used in the analysis covers all major Czech banks of the period 2000-2008 and has been collected from the annual bank reports and BankScope database. Over the sample period, the sample banks controlled on average about $87 \%$ of the Czech banking market with the remaining share controlled by branches of foreign banks in the Czech Republic and "special" credit institutions (building societies, State banks of special purpose, and others). The dataset consists of 15 banks over 9 years. Due to some missing observations we have an unbalanced panel of 129 bank-year observations. To allow for heterogeneity across the banks, we use an error-component model, with the bank-specific error components estimated as fixed effects.

\section{Empirical Analysis and Results}

The empirical analysis begins with a test for market equilibrium. Since the Czech Republic's banking sector went through dynamic development during the period of estimation it would be very ambitious to test only for equilibrium over the full sample. Instead, we run regressions of two 5-year sub-periods with 2004 as an overlap and also a rolling regression of a 4-year window in order to reveal periods of market disequilibrium. Table 3 reports the results of estimation of Eq. (7). To conserve the space only elasticities required to the equilibrium test (Eq. 9) are presented.

The results suggest that market equilibrium over the whole estimation period is questionable. On the other hand, the market was in equilibrium in most of the sub-periods. As argued in Matthews, et al. (2007) the restriction that $E=0$ (market equilibrium) is necessary for the perfect competition case but not for the monopolistic competition case.

\begin{tabular}{c|c|c|c|c|c|c} 
& InPL & InPK & InPF & Sum & H0: $\mathbf{E}=\mathbf{0}$ & Eq./Diseq. \\
\hline $2000-2008$ & 0.0341 & -0.0025 & -0.0004 & 0.0312 & $F(1,108)=19.14^{\text {a }}$ & Diseq. \\
\hline $2000-2004$ & 0.0585 & -0.0009 & 0.0024 & 0.0600 & $F(1,52)=25.96^{\mathrm{a}}$ & Diseq. \\
\hline $2004-2008$ & 0.0095 & -0.0063 & -0.0052 & -0.0020 & $F(1,50)=0.0745$ & Eq. \\
\hline $2000-2003$ & 0.0577 & -0.0029 & 0.0072 & 0.0620 & $F(1,37)=23.162^{\text {a }}$ & Diseq. \\
\hline $2001-2004$ & 0.0387 & -0.0165 & -0.0053 & 0.0169 & $F(1,38)=0.8334$ & Eq. \\
\hline $2002-2005$ & 0.0452 & -0.0192 & -0.0060 & 0.0020 & $F(1,39)=0.9185$ & Eq. \\
\hline $2003-2006$ & 0.0113 & -0.0193 & -0.0116 & -0.0196 & $F(1,39)=5.0855^{\text {b }}$ & Diseq. \\
\hline $2004-2007$ & 0.0039 & -0.0047 & -0.0069 & -0.0077 & $F(1,38)=1.1499$ & Eq. \\
\hline $2005-2008$ & -0.0006 & -0.0036 & -0.0009 & -0.0051 & $F(1,35)=0.5334$ & Eq.
\end{tabular}

Tab. 3 Equilibrium tests (rolling sample) dependent variable $\ln R O A{ }^{a, b}$ denote significance at $1 \%$ and $5 \%$ level

Next, we can proceed with estimation of Eq. (4) and calculation of the $H$ statistic as in Eq. (6). The results presented in Table 4 show substantial differences between the sub-periods used. The common elements are only statistically significant effects of price of labor and bank size. However, the respective coefficients changes noticeably from one sub-period to the other 
( $\ln P L$ decreased, $\ln A S S E T$ increased). Price of funds was significant over the full sample and in the first sub-period (before joining the EU) demonstrating an ability of banks to offset more expensive funds by higher revenues. Number of branches seems to be significant determinant of total revenues in the second sub-period. The positive coefficient suggests that positive effects of maintaining a proximity to customers dominate the increased cost of higher branch network. Such a result confirms a return of customers' preferences to standard face-to-face banking in brick-and-mortar branches.

\begin{tabular}{l|c|c|c} 
Variable & $\mathbf{2 0 0 0}-\mathbf{2 0 0 8}$ & $\mathbf{2 0 0 0}-\mathbf{2 0 0 4}$ & $\mathbf{2 0 0 4}-\mathbf{2 0 0 8}$ \\
\hline Intercept & $2.7642^{\mathrm{a}}(3.4354)$ & $6.2587^{\mathrm{a}}(4.1462)$ & $2.1224^{\mathrm{c}}(1.8940)$ \\
\hline $\ln P L$ & $0.7605^{\mathrm{a}}(5.8285)$ & $0.8629^{\mathrm{a}}(4.3226)$ & $0.4889^{\mathrm{a}}(3.3419)$ \\
\hline $\ln P K$ & $-0.0881(-1.4079)$ & $-0.0926(-1.2440)$ & $0.1399(1.2296)$ \\
\hline $\ln P F$ & $0.2077^{\mathrm{a}}(4.3668)$ & $0.2055^{\mathrm{a}}(3.0636)$ & $0.0729(1.3269)$ \\
\hline $\ln A S S E T$ & $0.5934^{\mathrm{a}}(9.2126)$ & $0.2976^{\mathrm{b}}(2.2535)$ & $0.6537^{\mathrm{a}}(7.4535)$ \\
\hline $\ln B R$ & $-0.0120(-0.3250)$ & $0.0603(1.0225)$ & $0.1803^{\mathrm{a}}(2.7076)$ \\
\hline GROWTH & $-0.7810(-0.5244)$ & $-0.9515(-0.2811)$ & $-1.1818(-0.9179)$ \\
\hline & & & \\
\hline $\mathrm{H} 0: \mu \mathrm{i}=0$ & $F(14,108)=$ & $F(14,52)=9.5400^{\mathrm{a}}$ & $F(14,50)=14.341^{\mathrm{a}}$ \\
& $14.282^{\mathrm{a}}$ & & \\
\hline $\mathrm{H} 0: \mathrm{H}=0$ & $F(1,108)=30.365^{\mathrm{a}}$ & $F(1,52)=15.234^{\mathrm{a}}$ & $F(1,50)=15.296^{\mathrm{a}}$ \\
\hline $\mathrm{H} 1: \mathrm{H}=1$ & $F(1,108)=3.9343^{\mathrm{c}}$ & $F(1,52)=0.0093$ & $F(1,50)=4.0841^{\mathrm{b}}$ \\
\hline $\mathrm{H}$ & 0.8801 & 0.9758 & 0.7017
\end{tabular}

Tab. 4 Test of competitive conditions dependent variable $\operatorname{lnTREV.}{ }^{a, b, c}$ denote significance at $1 \%, 5 \%$ and $10 \%$ level, $t$-values in parentheses

A significance test on the sum of the input elasticities show that the $H$ statistic lies between zero and unity in the full sample and second sub-period. By contrast, the $H$ statistic in the first sub-period is not significantly different from unity. Thus, we can conclude that the Czech banking market can be characterized as one of monopolistic competition in 2000-2008 and 2004-2008 but as the market with perfect competition in 2000-2004. In other words, there is evidence that intensity of competition decreased over the estimation period.

\section{Conclusion}

The aim of the paper was to estimate the level of competition in the Czech banking market during the period 2000-2008. Applying the Panzar-Rosse model we came to conclusion that the competitive conditions worsened over time analyzed. Whereas the banking market during the first sub-period 2000-2004 (before joining the EU) was found to be perfectly competitive the structure of monopolistic competition was revealed during the second sub-period 2004-2008 (after joining the EU). More concetely, the $H$ statistic computed for the full sample is 0.8801 , the $H$ statistic for the first sub-period is 0.9758 , and the $H$ statistic for the second sub-period 0.7017 .

\section{References}

- Bikker and Haaf, 2000. "Measures of competition and concentration in the banking industry: a review of the literature", De Nederlandsche Bank Research Series Supervision no. 27.

- Bikker and Haaf, 2002. "Competition, concentration and their relationship: an empirical analysis of the banking industry", Journal of Banking and Finance, 26, p. 2191-2214.

- Bikker, et al., 2007. "The Impact of Market Structure, Contestability and 
Institutional Environment on Banking Competition”, Utrecht School of Economics Working Papers no. 07-29.

- Bikker, et al., 2009. "Assessing Competition with the Panzar-Rosse Model: The Role of Scale, Costs, and Equilibrium”, Utrecht School of Economics Discussion Paper Series 09-27.

- Bresnahan, 1982. "The Oligopoly Solution Concept is Identified”, Economics Letters, 10, p. 87-92.

- Casu and Girardone, 2006. "Bank Competition, Concentration and Efficiency in the Single European Market”, Manchester School, 74, p. 441-468.

- Chan, et al, 2007. "Bank Competition in New Zealand and Australia“, In Centre for Financial Studies Banking and Finance Conference, p. 22.

- Chun and Kim, 2004. "The Effect of Financial Restructuring on the Degree of Competition in the Korean Banking Industry", Kumamoto Gakuen University Working Paper no. 16.4.

- Claessens and Laeven, 2004. "What Drives Bank Competition? Some International Evidence", Journal of Money, Credit, and Banking, 36, p. 563-584.

- Deltuvaite, 2007. "The Impact of Concentration on Competition and Efficiency in the LithuanianBanking Sector“, Engineering Economics, 54, p. 7-19.

- De Rozas, 2007. "Testing for Competition in the Spanish Banking Industry: The Panzar-Rosse Approach Revisited", Banco de Espan̆a Documentos de Trabajo no. 0726.

- Fu, 2009. "Competition in Chinese Commercial Banking”, Banking and Finance Review, 1, p. 1-16.

- Hempell, 2002. "Testing for Competition Among German Banks“, Deutsche Bundesbank Discussion paper 04/02.

- Iwata, 1974. "Measurement of Conjectural Variations in Oligopoly", Econometrica, 42, p. 947-966.

- Lau, 1982. "On Identifying the Degree of Competitiveness from Industry Price and Output Data”, Economic Letters, 10, p. 93-99.

- Lee and Nagano, 2008. "Market Competition Before and After Bank Merger Wave: A Comparative Study on Korea and Japan”, Pacific Economic Review, 13, p. 604-619.

- Matthews, et al., 2007. "Competitive conditions among the major British banks", Journal of Banking and Finance, 31, p. 2025-2042.

- Panzar and Rosse, 1987. “Testing for 'Monopoly' Equilibrium”, Journal of Industrial Economics, 35, p. 443-456.

- Pawlowska, 2005. "Competition, Concentration, Efficiency, and their Relationship in the Polish Banking Sector”, National Bank of Poland Working Papers no. 32.

- Pererera, et al., 2006. "Competition and structure of South Asian banking: a revenue behaviour approach", Applied Financial Economics, 16, p. 789-801.

- Rezitis, 2010. "Evaluating the state of competition of the Greek banking industry", Journal of International Financial Markets, Institutions and Money, 20, p. 68-90. 


\title{
Global Crisis And Its Effects in Developed and Emergent Countries - "The Bottom Of The Pyramid" as an Innovation Resource
}

\author{
Irma Shyle, Polytechnic University of Tirana \\ Elenica Pjero, University of Vlora "Ismail Qemali"
}

\begin{abstract}
The economists forecast that in the next 5 years the average annual growth of the global economy will be smaller than the average rate in the past 15 years. This reinforce more than ever the problem of the restricted resources management and discovery of the best possible ways to improve and increase the population welfare.

It is raised the question: To serve 5 milliard people in the world (with less than $2 \$$ per day) is: Moral responsability? High level of intelect? Business opportunity?

Is it the time for companies to enter in the Bottom of the Pyramid markets? Is it the Bottom of the Pyramid the source of the innovation? Why are these markets attractive?
\end{abstract}

JEL Codes: E01, D31, M20

\section{Introduction}

Maybe it was not believed that the entire world would have been fallen in a crisis situation after the big depression. Because of the global crisis, it is obviously seen a decline in the market volume but an increase in its value, for the only fact of the extremely growth of the prices. For many countries in the world, import and export were declined, and foreign direct investments were also declined in the emergent countries. There are also social effects of the gloabl crisis in all countries. Albania, as part of the world felt the effects of the crisis, beginning from the decrease of the incoming flow of the emigrants money, who are now unemployed, till to exports decrease pace. It is important to be mentioned that Albania is an emergent country and its main activities are: agriculture, tourism, construction and emigrants remittance. The world experience has shown that heavy industries and those of automibiles are more vulnerable from the crisis, so Albania is less sensitive in this case.

In Albania, one in two persons is poor and one in 20 persons is extremely poor. Some years ago, companies will be directed to the consumers category with average and high income, eleminating and even ignoring low income category (less than $2 \$ /$ day). This market segmentation with income less than 2\$/day represent the so-called The Bottom of the Pyramid. This segment is considered as unsuitable and non-profitable market.

Today if population is segmented by income, it will be clear that $2 / 3$ of them, which is the great part of the market, has less than $2 \$$ per day. The world crisis deepen more the gap between the rich and the poor people. For a market segment to be effective, it must be considerable. The bottom of the Pyramid market size is significative. It is important to be informed in details about this segment specifications, the ability to enter in the market, the neccessary capacity and disponibility to enter to this market.

\section{Global crisis effects}

The world economy is mired in the worst financial crisis since the Great Depression. What first appeared as a sub-prime mortgage crack in the United States housing market during the summer of 2007 began widening during 2008 into deeper fissures across the global financial landscape and ended with the collapse of major banking institutions, precipitous falls on stock markets across the world and a credit freeze. These financial shockwaves have now triggered a 
full-fledged economic crisis, with most advanced countries already in recession and the outlook for emerging and other developing economies deteriorating rapidly, including those with a recent history of strong economic performance.

The crisis has already had a severe impact on global commodity markets with far-reaching implications for the prospects of the developing world at large. Commodity prices have been highly volatile during 2008. Most prices surged in the first half of 2008, continuing a trend that had begun in 2003. Trends in world market prices reversed sharply from mid-2008, however. Oil prices have plummeted by more than 60 per cent from their peak levels of July to November. The prices of other commodities, including basic grains, also declined significantly. In the outlook, most of these prices are expected to even out further along with the moderation in global demand.

Growth of world trade decelerated to 4.3 per cent in early 2008, down from 6.4 per cent in 2007, owing mainly to a decline in imports by the United States. United States imports, which account for about 15 per cent of the world total, have registered a decline in every quarter since the fourth quarter of 2007 and dropped as steeply as 7 per cent in the second quarter of 2008. Growth in the volume of world trade had dropped to about 3 per cent by September 2008, to about one third of the rate of growth a year earlier. In the outlook, global trade is expected to weaken further in 2009. Owing to their limited exposure to the mortgage market derivatives that brought down major banks in the United States and Europe, financial systems in most developing countries initially seemed shielded from any direct impact from the international financial crisis.

Growing risks have emerged through other channels, however, as investors have started to pull back resources from emerging market economies and other developing countries as part of the deleveraging process of financial institutions in the developed countries.

Unlike in recent years when the spread varied significantly across regions and countries to indicate investor discrimination among country-specific risks, the latest surge has been uniform, suggesting that contagion and aversion to investing in emerging markets has taken hold among investors. Spreads are expected to remain high in 2009, as the strains in global credit markets linger and also as capital flows to emerging market economies are projected to drop further.

Our society is facing a financial crisis, an economic crisis, and as recent research is increasingly showing, a humanitarian crisis. Recession has hit the entire world. Wherever we go everybody is talking about it and each and every trade is affected by it.

The declining quality of work opportunities, barriers to employment, exploitation and the failure of income support programs to protect families from debilitating poverty impact everyone. While the country's increasing rates of incarceration impact communities of color disproportionately, our willingness to punish formerly imprisoned people indefinitely affects all of our lives negatively, as we make it impossible for them to contribute to our common wellbeing. The marginalization of poor immigrants of color helps to pull down labor standards for everyone, making work increasingly precarious for all workers. In the larger economic picture, the creation of populations who are unemployed and underemployed at far higher rates than the societal norm, and who remain locked out of stable employment, contributes to the country's overall levels of inequality. High levels of inequality are predictive of the overall lack of a robust national economy. Removing barriers to equal employment for whole populations of people is one very obvious way to begin dismantling inequality in employment and help rebuild the national economy.

In this recession, poverty could grow massively. As the economic crisis continues, deep recession could push $25 \%$ of middle-class families into more serious financial distress. The danger is higher for families of color, with $33 \%$ of Blacks and $41 \%$ of Latinos at risk of falling out of the middle class and into poverty (J. Huezo et al. 2009) According to the Bureau of Labor Statistics, eight of the 10 occupations projected to generate the most jobs by 2016 are 
low-wage jobs in the service sector (A. Bernhardt and C. Owens, 2009). These are precarious jobs that will make more and more workers extremely vulnerable to even small economic fluctuations.

While developed countries are experiencing some of the sharpest economic contractions, households in developing countries are much more vulnerable, and likely to experience acute negative consequences, both in the short- and long-term. (Justin Yifu Lin, 2009)

Declining growth rates combined with high levels of initial poverty leave many households in developing countries highly exposed to the crisis. Vulnerability is heightened if, at the same time, governments are constrained in cushioning the impacts due to limited institutional capacity and fiscal resources.

When the financial crisis first broke, it was thought that developing countries in general would not be affected because their financial sector was not fully integrated in the global financial system. But now as the crisis has

entered the second stage and problems in the real sector have emerged, it has become clear that developing countries will also be seriously affected by the downturn.

Between 2002 and 2007, these countries grew rapidly because of global trade expansion and the large inflows of private capital, including foreign direct investment (FDI), the increase in remittances and the surge in commodity prices. In fact, in 2007, private capital flows to the developing countries amounted to $\$ 1.2$ trillion, a six-fold increase compared to the beginning of the decade, thanks in part to the rise in FDI which responded to the higher export earnings of the resource-rich developing countries. These higher earnings, in turn, were made possible by higher world commodity prices. Also, workers' remittances expanded three times to $\$ 328$ billion over the same period. Now, with the crisis taking its toll, it is estimated that total FDI and private capital flows will decline from $\$ 1.2$ trillion in 2007 to $\$ 363$ billion this year. As a result of declining exports and reduced capital inflows, the developing countries may encounter a financing gap of between $\$ 352$ billion to $\$ 635$ billion. Moreover, remittances are likely to fall by 7.3 percent in 2009 to the level of $\$ 305$ billion.

The GDP growth rate in developing countries in 2009 is forecast to drop to 1.2 percent, a sharp decline from 8.1 percent of growth rate in 2007 and 5.9 percent growth rate in 2008. This decline alone will cause more than 30 million workers to lose their jobs according to the United Nations International Labour Organization, and of course, poverty will rise. In fact, if we don't do anything, this may just be the start of the worst scenario.

New estimates for 2009 suggest that lower economic growth rates would trap 53 million more people in poverty, those living on less than $\$ 1.25$ a day than was expected prior to the crisis. If the $\$ 2$-a-day poverty line is used, 65 million will stay trapped. If the recession protracts, more and more people will fail to get out of poverty.

As Robert Zoellick, World Bank Group President, has said, "The global economic crisis threatens to become a human crisis in many developing countries unless they can take targeted measures to protect vulnerable people in their communities."

Critical to protecting households in countries exposed to the crisis will be the ability of governments to cope with the fallout of the downturn: to finance programs that create jobs, ensure the delivery of core services and infrastructure, and provide safety nets. Yet, only onethird of the exposed countries have the fiscal capacity (i.e., ability to expand fiscal deficits) to render significant countercyclical spending. In countries with limited fiscal capacity it is imperative that assistance be provided via grants and concessional financing wherever possible. Moreover, one-third of the countries with a reasonable amount of fiscal capacity are aid dependent, and will also require external support to finance increased spending.

\section{The crisis effects in South-Eastern Europe}

All economies in South-eastern Europe continued to grow at relatively robust rates in the 
order of 5 per cent or higher in 2008, with the exception of Croatia which had 3.8 per cent. Growth in 2008 continued to be largely driven by domestic demand, underpinned by rising real wages, strong FDI inflows and domestic credit expansion. However, in the course of the year, and with the escalation of the global financial crisis, these growth factors started to lose steam and will weaken further in 2009. Hence, a further moderation in the pace of growth to about 4.5 per cent for the region as a whole is expected in the baseline scenario for 2009 , down from 5.2 per cent in 2008 .

Inflation accelerated in South-eastern Europe in the first half of 2008, driven by surging world food and energy prices, strong domestic demand and rising real wages. The acceleration was quite pronounced in Bosnia and Herzegovina, Croatia, Serbia and the Former Yugoslav Republic of Macedonia. However, during the second half of the year, inflationary pressures weakened as world commodity prices started to fall from their highs and domestic inflationary pressures subsided. Given the overall domestic and global macroeconomic prospects, this trend is likely to gain further ground in 2009.

Employment conditions improved in all South-eastern European economies along with the continued dynamic economic performance in much of 2008. Nonetheless, unemployment rates remain very high (about 16 per cent on average); only Croatia has a single-digit rate of unemployment. Nevertheless, positive labor market developments are expected to continue in 2009 as a result of new investments in production capacity and the implementation of infrastructure projects. In Croatia, though, the rate of unemployment may increase in response to weaker performance of the tourism industry.

The general government budgets in most South-eastern European economies have become more balanced and were fortified by higher tax revenue following strong economic growth in recent years. There was some fiscal loosening in a number of countries in 2008, in part because of their electoral cycle. Fiscal deficits are expected to widen as a result of the economic slowdown and anticipated expected fiscal responses in 2009 , but larger deficits do not pose an immediate threat to macroeconomic stability.

In contrast, there was a notable tightening of monetary policy in 2008, partly in response to rising inflationary pressures. Central banks increased their policy rates in Albania, Serbia (in stages) and the Former Yugoslav Republic of Macedonia, while mandatory reserve requirements were increased in Bosnia and Herzegovina and Croatia. The domestic monetary tightening was coupled with deteriorating conditions of access to international financial markets. The rising cost of credit is likely to further dampen economic activity in the region.

Against the backdrop of strong domestic demand and weakening import demand in the important European markets, imports by South-eastern European economies generally outpaced their exports in 2008. As a result, both trade and current-account deficits continued to widen in all countries and, in a number of cases, have reached alarming proportions. Financing these deficits up until the 2008 crisis did not pose a problem, but financing conditions have been changing for the worse, forcing a downward adjustment in domestic demand. The restraining effect of unfavorable financing conditions is likely to increase further in 2009 and the deficits may decline somewhat in the short run.

\section{The poor as victims or as resilient and important consumers?}

Coming on the heels of the food and energy security crises, the global financial crisis will most likely substantially set back progress towards poverty reduction and the Millennium Development Goals. The tightening of access to credit and weaker growth will cut into public revenues and limit the ability of developing country Governments to make the necessary investments to meet education, health and other human development goals.

Unless adequate social safety nets are in place, the poor will no doubt be hit the hardest. An estimated 125 million people in developing countries were already driven into extreme poverty 
because of the surge in global food prices since 2006.

In the global economy, lasting competitive value is no longer assured by natural resources, human talent, or even core competencies. In these areas, the world is indeed flat. Sustaining innovative solutions and beating the competition is about tapping software and digital applications to wire customer knowledge into the core systems of the firm and measure customer behavior through smart analytics. And this can be done at lower costs and in faster time frames than many understand. The rise of global supply chains in Asia, Eastern Europe and the West are highly competitive, fearless, and bubbling with new approaches driven by the young and ambitious upstarts of the next business generation. Coming to terms with the implications of this transformation is both urgent and inevitable for the survival of businesses (C.K Prahalad and M.S Krishnan, 2008). CEOs, senior executives, and managers of every level face an imperative to understand that to form strategy and execute it they must renew their knowledge of business processes, information technology, and data analysis. To win in the competitive landscape defined by creating one consumer experience at a time, decision makers must develop a "whole new mind" for understanding their global supply, logistics and communications networks.

The focus of young people and young professionals on sites such as My Space, YouTube, and Facebook suggest that a whole generation of consumers are growing up expecting to be treated as unique individuals, and will have the skills and the propensity to engage in a market place defined by customer co-creation. Value for them is not about traditional ideas of quality. That is a given. They want to be involved in shaping their own experiences.

Similarly, the imperatives of access to talent, speed, and cost will drive most firms towards this new global resourcing. By forging the 'always on' network, firms can engage customers and employees emotionally and intellectually in the mission of the firm, minute by minute, day by day.

As Prahalad writes: "From cement to jet engines, from children's toys to delivery of parcels to your home or office by UPS, all industries are going through this transformation. This transformation is not a choice." (C.K. Prahalad, 2008)

While there is a strong demand among the urban poor for better services and quality goods, as well as a demonstrated ability to pay for those services and goods, the failure of the private sector to provide adequate services and goods is in fact a contributor to poverty. Because of the deliberate exclusion of the urban poor from mainstream urban market systems, they live in very high cost economies. For instance, slum dwellers without access to municipal water pay 4 to 100 times as much as their middle and upper class counterparts. They also pay $30 \%$ to $50 \%$ more for food items that are sold in small unit packages.

The availability, accessibility and affordability of private sector goods and services are bound to change the situation of the urban poor and in turn address some of the challenges facing urban centers today. By expanding the global market system to include the urban poor would provide new markets for the private sector and at the same time create opportunities for poor communities. For example, the wireless telecommunication industry in Africa and Asia has been able to create a sustainable win-win situation for the private sector and the urban poor. Mobile communication allows an incredible whole range of new ways to conduct business for the small slum-based entrepreneurs. This industry has created systems and channels that have increased availability of affordable mobile phone service for the poor without creating cost structures that translate to higher prices for the poor. Instead it has opened and created new business possibilities for the poor through access to technology, which a few years back was considered the prerogative of the middle and upper class (Auclair C, 2008).

\section{Bottom of the pyramid}

In 1932, the phrase "bottom of the pyramid" was used by former United States President 
Franklin D. Roosevelt in a radio address to his country that was in the midst of the Great Depression. He said, "These unhappy times call for the building of plans that rest upon the forgotten, the unorganized but the indispensable units of economic power (plans) that put their faith once more in the forgotten man at the bottom of the economic pyramid". It is almost an ominous coincidence that 80 years hence, we are also in the midst, although hopefully at the tail end, of a global crisis. It is apparent that President Roosevelt's statement is as relevant for us today, as it was then. Indeed, it is in adequately and appropriately serving and strengthening the sectors that we will be able to build a solid base for economic growth and development.

"If we stop thinking of the poor as victims or as a burden and start recognizing them as resilient and kreative entrepreneurs and value-conscious consumers, a whole new world of opportunity will open up". (C.K. Prahalad, 2008)

Popularized by C.K. Prahalad, the Bottom of the Pyramid concept which contends that poor people should be seen as potentially profitable customers rather than mere charity cases has caught on fast in the past few years. While some organizations have taken notice and reaped benefits, the bottom of the pyramid has been largely ignored by most. Multinationals and even local companies are yet to be convinced there is a large enough profitable market. For long time the MNC have the idea that the poor cannot be the segment who they can be focus. The reasons are given to the table (C. K. Prahalad and Stuart Hart, 2002).

\begin{tabular}{|c|c|}
\hline Assumption & Implication \\
\hline $\begin{array}{c}\text { The poor are not our target customers; they } \\
\text { cannot afford our products or service }\end{array}$ & $\begin{array}{c}\text { Our cost structure is a given; with our cost } \\
\text { structure, we cannot serve the BOP market }\end{array}$ \\
\hline $\begin{array}{c}\text { The poor do not have use for products sold in } \\
\text { developed countries }\end{array}$ & $\begin{array}{c}\text { We are committed to a form over functionality. } \\
\text { The poor might need sanitation, but can't } \\
\text { afford detergents in formats we offer. } \\
\text { Therefore, there is no market in the BOP. }\end{array}$ \\
\hline $\begin{array}{c}\text { Only developed countries appreciate and pay } \\
\text { for technological innovations. }\end{array}$ & $\begin{array}{c}\text { The BOP does not need advanced technology } \\
\text { solutions; they will not pay for them. } \\
\text { Therefore, the BOP cannot be a source of } \\
\text { innovations }\end{array}$ \\
\hline $\begin{array}{c}\text { The BOP market is not critical for long-term } \\
\text { growth and vitality of MNCs }\end{array}$ & $\begin{array}{c}\text { BOP markets are at best an attractive } \\
\text { distraction. }\end{array}$ \\
\hline $\begin{array}{c}\text { Intellectual excitement is in developed } \\
\text { markets; it is very hard to recruit managers for } \\
\text { BOP markets }\end{array}$ & $\begin{array}{c}\text { We cannot assign our best people to work on } \\
\text { market development in BOP markets }\end{array}$ \\
\hline
\end{tabular}

Table 1. The Dominant Logic of MNCs as It Relates to BOP

The numbers are clearly against the views of such companies. More than half the world's population lives on less than US\$ 2 a day. There is striking disparity between the rich and the poor with over $76.6 \%$ of the private consumptions made by 2 richest deciles of the world's population.

The distribution of wealth and the capacity to generate incomes in the world can be captured in the form of an economic pyramid. At the top of the pyramid are the wealthy, with numerous opportunities for generating high levels of income. More than 4 billion people live at the BOP on less than $\$ 2$ per day.

For more than 50 years, the World Bank, donor nations, various aid agencies, national governments, and, lately, civil society organizations have all fought the good fight, but have not eradicated poverty.

While various quarters shudder at the thought of the three crises mentioned there also laid limitless opportunities for enterprises, governments and entrepreneurs. The financial crisis maybe associated with closures and companies going bankrupt, but it must be kept in mind that 
some of the best known companies have thrived while some were born during such times. Companies should be tough in anticipation of tough times. They should seize the downturn opportunities gear-up for the upturn.

The BOP three pillar principles posses the following questions to the private sector:

- Are the goods and services in the market available to the poor?

- How accessible and at the disposal of the poor are these goods and services?

- Can the poor afford what is being proposed to them by the markets?

If managers do not recognize this trend and get organized to compete in this new environment, they are likely to be left behind. Businesses will need to ceaselessly improve flexibility and efficiency and transparency in all IT and customer-facing processes. Ultimately, the race for the future will be won by those who deliver a unique customer experience at the lowest cost.

The crisis saw failure and closures of thousands of businesses worldwide, record unemployment, declines in consumer wealth estimated in the trillions of U.S. dollars, substantial financial commitments incurred by governments, and most notably significant decline in economic activity around the globe. Now many economists, political leaders, bankers and other market commentators are jubilantly declaring the worst is over and everything is ok again. These same analysts who were oblivious to the looming financial debacle are ignoring evidence which corroborate that this marks only the beginning of larger impending global crisis.

Beyond the global recession, the world also needs to brace for more crises in the coming years. MTI Consulting' CEO Hilmy Cader states "We are not out of the woods yet-the worst is yet to come! We still need to deal with the impact and aftershocks of the financial meltdown and the long term changes it has brought about. Also the world, particularly the emerging and developing nations should be on guard to face a greater impacting Eco Credit Crisis and Bottom of the Pyramid Crisis" (Hilmy Cader, 2009).

Economies and enterprises should also be cautious of long term changes and implications that maybe brought about by the crisis. Consumer's tendency to save and avoid large debt will become more popular leading to long term drop in consumption. Government spending will also reduce in the long term which coupled with reduced private consumption will slow down investment.

As we recover from the global financial crisis we are faced with the greater imminent danger- the Eco Credit Crisis. The world's fast growing population is using up resources at an unprecedented level, significant part of which is not being renewed and is causing irreparable damage to the environment. If we continue to live on the Earth Ecological credit, by 2030 we need the equivalent of 2 planet resources to keep up our lifestyle.

Hilmy Cader stated "It must be kept in mind that unlike the economic recession, governments cannot bailout enterprises from the emerging credit crisis."

With the world's population expected to shoot to 9 Billion by 2040, it is now up to governments and enterprises around the world to take responsibility-what is being done is certainly not enough (James Leape, 2009)!

One of the real threats to sustainable urbanization is urban poverty. It establishes a sophisticated and intricate system that results in a vicious cycle of poverty where conventional market economics condemns millions to poverty, while awarding a few with prosperity. The World Bank affirms that over 3 billion people live on less than $\$ 2.50$ a day, and with the recent global crisis, this number is bound to grow unprecedentedly.

\section{Twelve Principles of Innovation for BOP Markets (C.K Prahalad, 2005)}

1. Focus on price performance of products and services. Serving BOP markets is not just 
about lower prices. It is about creating a new price-performance envelope. Quantum jumps in price performance are required to cater to BOP markets

2. Innovation requires hybrid solutions. BOP consumer problems cannot be solved with old technologies. Most scalable, price-performance-enhancing solutions need advanced and emerging technologies that are creatively blended with the existing and rapidly evolving infrastructures.

3. As BOP markets are large, solutions that are developed must be scalable and transportable across countries, cultures, and languages. How does one take a solution from the southern part of India to the northern part? From Brazil to India or China? Solutions must be designed for ease of adaptation in similar BOP markets. This is a key consideration for gaining scale.

4. The developed markets are accustomed to resource wastage. For example, if the BOP consumers started using as much packaging per capita as the typical American or Japanese consumer, the world could not sustain that level of resource use. All innovations must focus on conserving resources: eliminate, reduce, and recycle. Reducing resource intensity must be a critical principle in produkt development, be it for detergents or ice cream.

5. Product development must start from a deep understanding of functionality, not just form. Marginal changes to products developed for rich customers in the United States, Europe, or Japan will not do. The infrastructure BOP consumers have to live and work in demands a rethinking of the functionality anew. Washing clothes in an outdoor moving stream is different from washing clothes in the controlled conditions of a washing machine that adjusts itself to the level of dirt and for batches of colored and white clothes.

6. Process innovations are just as critical in BOP markets as produkt innovations. In developed markets, the logistics system for accessing potential consumers, selling to them, and servicing products is well-developed. A reliable infrastructure exists and only minor changes might have to be made for specific products. In BOP markets, the presence of a logistics infrastructure cannot be assumed. Often, innovation must focus on building a logistics infrastructure, including manufacturing that is sensitive to the prevailing conditions. Accessing potential consumers and educating them can also be a daunting task to the uninitiated.

7. Deskilling work is critical. Most BOP markets are poor in skills. The design of products and services must take into account the skill levels, poor infrastructure, and difficulty of access for service in remote areas.

8. Education of customers on product usage is key. Innovations in educating a semiliterate group on the use of new products can pose interesting challenges. Further, most of the BOP also live in "media dark" zones, meaning they do not have access to radio or TV. In the absence of traditional approaches to education-tradicional advertising - new and creative approaches, such as video mounted on trucks and traveling low-cost theatrical productions whose job it is to demonstrate product usage in villages, must be developed.

9. Products must work in hostile environments. It is not just noise, dust, unsanitary conditions, and abuse that products must endure. Products must also be developed to accommodate the low quality of the infrastructure, such as electricity (e.g., wide fluctuations in voltage, blackouts, and brownouts) and water (e.g., particulate, bacterial, and viral pollution).

10. Research on interfaces is critical given the nature of the consumer population. The heterogeneity of the consumer base in terms of language, culture, skill level, and prior familiarity with the function or feature is a challenge to the innovation team. 
11. Innovations must reach the consumer. Both the highly dispersed rural market and a highly dense urban market at the BOP represent an opportunity to innovate in methods of distribution. Designing methods for accessing the poor at low cost is critical.

12. Paradoxically, the feature and function evolution in BOP markets can be very rapid. Product developers must focus on the broad architecture of the system - the platform - so that new features can be easily incorporated. BOP markets allow (and force) us to challenge existing paradigms. For example, challenging the grid- based supply of electricity as the only available source for providing good-quality, inexpensive energy is possible and necessary in the isolated, poor BOP markets.

Despite the idea of serving the poor profitably being with us for over a decade, little has been done to demonstrate the true calling of the private sector, as the entity of risk takers who utilize existing market opportunities to create wealth. While the skepticism of many in the private sector is based is real, the reality of the BOP latent potential is real too. By dedicating more investments into research and development, forming alliances and partnerships with BOP entrepreneurs the road to unleashing the full potential of the BOP market will be realized in our live time.

The private sector is bound to benefit from serving and working with the BOP populace. The synergy created in the process is what will translate into a research ground where innovations and ideas will be developed tested and implemented before being moved up to other markets and segments of the urban society. The bottom-up approach to the creation and development of solutions to the urban challenge will place the private sector on a track of sustainability and offer real benefits to the wider society. The challenges that rapid urbanization present us with makes it imperative that we create working models and framework that will enable the private sector to tap into the reservoir of the whole society, including the BOP to come up with economic solutions to the economic problems that threaten the very fabric of urban living today.

\section{Conclusions and Recommendations}

In the world we live today, businesses and top executives must understand what differentiates their companies from others and must understand the needs of the consumers in their markets. If these two ingredients are understood, a business can develop a strategic plan to create a market niche and develop their customer base to be successful. Development of this information along with the development of the internal business processes can lead to some form of a competitive advantage in the market. The businesses and their representatives are directly responsible for the patterns of purchases (in the long run) of each of their customers. How they (the customers) will react within certain situations is largely due to the education and supplying the customer with enough data and tools to proficiently inform them of what is to be completed and within what context and timeframe. Understanding the customer and their reactions to the environment will prolong the life of the relationship between businesses and their customers.

Our society is facing a financial crisis, an economic crisis, and as recent research is increasingly showing, a humanitarian crisis. Recession has hit the entire world. Wherever we go everybody is talking about it and each and every trade is affected by it. If the recession protracts, more and more people will fail to get out of poverty.

The Bottom of the Pyramid approaches offers the private sector an opportunity to lead the way towards urban economic and social

transformation in the $21^{\text {st }}$ century. What is fundamentally required is the elicitation of the adventurous spirit of the sector to push the frontiers of market economics to new heights. The risk-taking attitude of the entrepreneurs of the industrials revolution who opened the wells of wealth to humanity through inventions and innovations needs to be relived in our times. 
Getting the right combination of scale, technology, price, sustainability, and usability requires that managers start with a "zero-based" view of innovations for the BOP markets. Managers need a new philosophy of innovation and product and service delivery for the BOP markets. The 12 principles that constitute the minimum set of a philosophy of innovation are critical to understand and apply. Needless to say, they challenge the existing assumptions about product and market development. By forcing managers in large enterprises to rethink and reexamine their assumptions about form and functionality, about channels and distribution costs, BOP markets can serve as catalysts for new bursts of creativity. The biggest advantage is often in challenging the capital intensity and the managerial cost structures that have been assumed in MNCs.

Innovation in BOP markets can reverse the flow of concepts, ideas, and methods. Therefore, for an $\mathrm{MNC}$ that aims to stay ahead of the curve, experimenting in BOP markets is increasingly critical. It is no longer an option.

\section{References}

- Bernhardt and C. Owens, 2009. "Rebuilding a Good Jobs Economy," The Nation, 30 March 2009 edition

- Auclair C. 2008. How can the Bottom of the Pyramid Approach Work for the Slums? The Habitat Debate, 14,

- Bender, Paul S. 1976 "Design And Operation of Customer Service Systems", American Management Association, New York.

- Steven M. Bragg, 2006 "Outsourcing: A guide to: selecting the correct business unit, negotiating the contract, maintaining control of the process ", John Wiley \& Sons, Inc., New Jersey

- C. K. Prahalad and Stuart Hart 2002, 'The Fortune at the Bottom of the Pyramid, Strategy + Business', 26,

- C.K Prahalad, 2004. 'The Fortune at the Bottom of the Pyramid", Wharton School Publishing,

- C.K Prahalad and M.S Krishnan, 2008. "The New Age of Innovation", McGrawHill, London

- $\quad$ Foxall, Gordon 1991. "Consumer Psychology in Behavioural Perspective", Journal of Economic Psychologie, 12, 544-547

- J. Huezo et al., 2009). “The State of the Dream 2009: The Silent Depression," United For a Fair Economy,

- PRLog Press Release 2009, After the Global Financial Crisis... expect more, http://prlog.org/10373858

- Applied Research Center 2009, Race and Recession, http://arc.org/downloads/2009 race recession

- UN-HABITAT 2007. Business for Sustainable Urbanization, Challenges and Opportunities,

- World Bank 2009, Weathering the Global Economic Crisis: Lessons for Emerging Markets, http://worldbank.org/DEC/weathering-the-global-economic-crisis

- United Nations 2009, World Economic Situation and Prospects 2009, http://www.un.org/esa/policy/wess/wesp

- United for a Fair Economy 2009, State of the dream 2009: The silent Depression, www.faireconomy.org/dream. 


\title{
Is Origin Denomination an Important Marketing Strategy? The Case of Spanish Wine Industry
}

\author{
Luis Navarro Elola, Universidad de Zaragoza España \\ Jesús Pastor Tejedor, Universidad de Zaragoza España \\ Ana Clara Pastor Tejedor, Universidad de Zaragoza España \\ Adrian Archanco Olcese, Universidad de Zaragoza España
}

\begin{abstract}
This investigation work consists on an analysis with the model European Customer Satisfaction Index (ECSI), in order to know the influence that has belonging to an Origin Denomination in the wine sector. So, we've made a marketing research directed to the particular case of Somontano's Wine Origin Denomination which acts as an "umbrella" brand for many wineries of Aragón (Spain). Simultaneously these wineries have their wines under different brands. This study tries to find out if to belong to a DO benefits the wineries. Possibly "strong" wineries improve the image of Somontano's DO and other wineries of the zone. Young wineries benefit themselves with the image old ones have earned. It brings us to a question about if DO Somontano and their customers satisfaction are related or not. Model ECSI allows us to determine consumers' satisfaction aabout a certain product or service. It also demonstrates the relations existing between satisfaction and other factors that take part on purchase.
\end{abstract}

JEL codes: C12, D12, M31

\section{Introduction}

Although we all know that wine is a very present and important product in numerous countries, it is also something much more complex. It is not just another agrarian product.

A great number of people depend direct and indirectly on wine, but we dare to say it brings a "problem" with itself; wine is considered food and spirit at the same time. It has to be taken into account everything which is behind a wine bottle: the fight of the winegrowers to get wine considered as food because of its beneficial and highly demonstrated properties for health opposing the consideration of spirit it is sometimes given, as if it were simple liquor.

This corresponds with the image of the wine consumers have: they consider wine as a healthy drink and look for good quality.

But, when buying wine, what do consumers have into account, the DO or the price? Are flavor and DO the most influential factors in the decision between two wines?

In this study we try to answer these and other questions analyzing the influence the DO has in wine sector.

Present international wine market is in a new consumption dimension; and it is because its evolution has been very different according to two different categories of wine. The table wine, valued like caloric product and of daily consumption, has been losing market share vs. quality wine protected under the DO, with more important cultural components.

Some fundamental characteristics could be stood out therefore to explain why wine consumers are after quality wines:

- Slow convergence of the consumption ratios per capita between countries: homogenization between producer and no producer countries.

- Increase of the rivalry with other drinks that act like substitute products, occupying the traditional place of wine in daily life.

- The world-wide wine production is characterized in addition by the existence to two 
models (the traditional producers and the emergent ones) with some differences:

- European production is mainly based on DO and very regulated indicators of quality. The production in new producing countries is much more liberalized, and they are after strong marks and varietal wines.

- European model tries to obtain competitive advantage through the quality. However, the strategy of the emergent countries companies is based on getting a lower and homogeneous quality.

The administrative concession of a DO to a certain geographic zone, not only tries to protect the name of the region, it also implies the creation and application of a regulation that ensures a quality product.

The DO can be considered as a "collective or umbrella brand", protecting smaller brands but giving them total freedom to develop their communication and marketing policies.

Due to the existing general ignorance among the usual or potential consumers, it would be said that in many cases the DO is not able to assure "confidence to the consumers". This consumers' degree of ignorance and the great emphasis that different institutions are doing in the subject of the DO, has lead us to the accomplishment of an empirical investigation.

\section{The wine sector}

\subsection{Wine in the international context}

World-wide wine market has as the most important players the European Union countries. This is because the three first producing countries of the world, France, Italy and Spain "play in their team". France and Italy are also two of the three first consumers.

World-wide wine consumption, which increased between 1956 and 1980 from 190 million of hl to 290 million of hl, suffered an important recession between 1985 and 1995, year in which it became stabilized in 225 million of hl. Recently, there has been a slight increase until around 244 present million of hl (according to data of 2008 from the OIV).

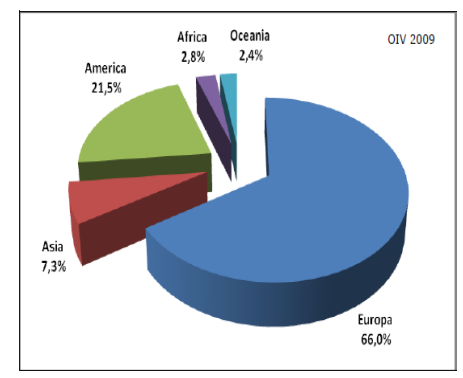

Figure 1 World consumption of wine. 2008 Fuente: OIV

\begin{tabular}{|l|r|r|}
\hline PAIS & prev. 2008 & en $\%$ \\
\hline FRANCIA & 31750 & $13,0 \%$ \\
\hline ESTADOS UNIDOS & 28516 & $11,6 \%$ \\
\hline ITALIA & 26000 & $10,6 \%$ \\
\hline ALEMANIA & 20747 & $8,5 \%$ \\
\hline CHINA & 13671 & $5,6 \%$ \\
\hline REINO UNIDO & 13483 & $5,5 \%$ \\
\hline ESPAÑA & 12790 & $5,2 \%$ \\
\hline RUSIA & 11000 & $4,5 \%$ \\
\hline ARGENTINA & 10677 & $4,4 \%$ \\
\hline RUMANIA & 5404 & $2,2 \%$ \\
\hline TOTAL MUNDIAL & $\mathbf{2 4 4 8 9 7}$ & \\
\hline
\end{tabular}

This world-wide wine consumption decrease in the last 20 years, although it is recovering step by step, is caused by the diminution of the consumption per capita of these three producer and traditionally consuming countries.

Consumption in the "new producing countries" is relatively low, overall in those with a lack of winery tradition, which gets to them to export a high percentage of its production.

These new producers, with clear exporting vocation, have been increasing market share even in the European traditional producers markets. So that, nowadays is very common to find a place for original wines from these countries in the European stores. 


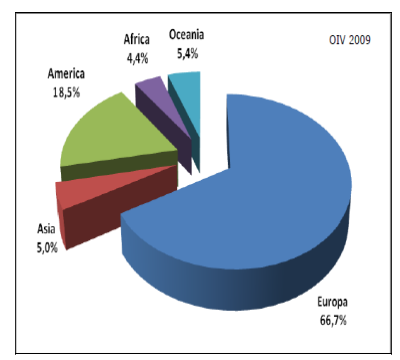

\begin{tabular}{|l|r|r|}
\hline PAIS & prev. 2008 & en \% \\
\hline ITALIA & 48633 & $18,1 \%$ \\
\hline FRANCIA & 41429 & $15,4 \%$ \\
\hline ESPAÑA & 34630 & $12,9 \%$ \\
\hline ESTADOS UNIDOS & 19200 & $7,1 \%$ \\
\hline ARGENTINA & 14677 & $5,5 \%$ \\
\hline AUSTRALIA & 12431 & $4,6 \%$ \\
\hline CHINA & 12000 & $4,5 \%$ \\
\hline SUDAFRICA & 10261 & $3,8 \%$ \\
\hline ALEMANIA & 9991 & $3,7 \%$ \\
\hline CHILE & 8683 & $3,2 \%$ \\
\hline TOTAL MUNDIAL & $\mathbf{2 6 9 0 1 8}$ & \\
\hline
\end{tabular}

Figure 2 World production of wine. 2008 Fuente: OIV

\section{Methodology}

Elaborating a causal relations model we are going to be able to establish the connection between different latent variables as client's satisfaction, loyalty, expectations, etc. But we need to assure if this model will be useful.

\subsection{European index of satisfaction of the client (ECSI)}

Model ECSI measures the satisfaction of the client in the field of the perceived quality of the services, providing a global level of the satisfaction and explaining the relations of causality with its components

\subsection{Causal definition of the variables of the model and its relations}

The first step to make the ECSI is to define the latent variables and its relations:

Expectations: level of reference that consumer of the product or service waits for, before buying it. The expectation has a direct influence on the service' perceived quality, on the service's value and on client's satisfaction.

Perceived quality: component key that determines the satisfaction of the client; it influences satisfaction through two routes:

1. Perceived quality "hardware" or quality of the "product": "hard" nucleus of the service as far as the generic characteristics of the service that is offered.

2. Perceived quality "software" or quality of the "service": specific aspects of the benefit of the service like customized attention, distribution, information services, etc.

Value of the service: relation between quality and price clients have after the received service. It acts as a link between perceived quality and satisfaction.

Image of the service: evaluates the image consumers have about our brand and company. In the model it is an exogenous or independent variable with direct influence on all the others.

Satisfaction of the client: it is the resulting variable that evaluates the attitude or psychological state of the consumer after its experience with the service.

Fidelización of the client: it is the variable of yield of the satisfaction index and measures the capacity that has the company to retain its clients, based on the level reached in that index. 


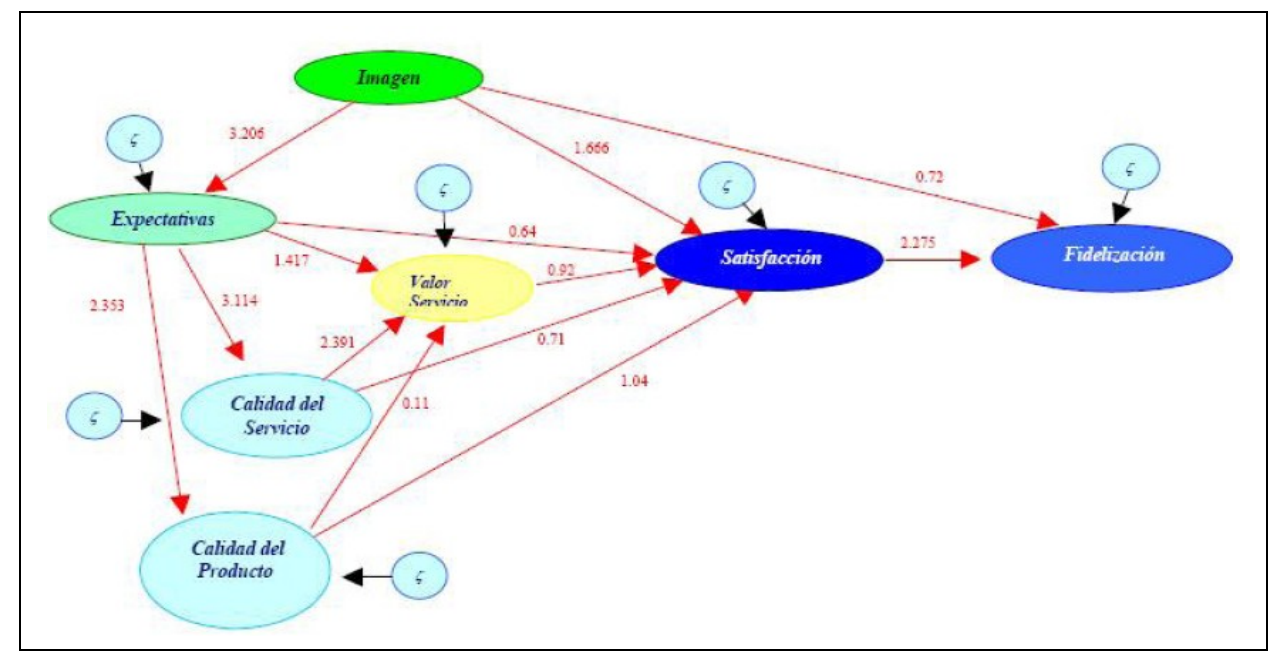

Figure 3 Model ECSI

\section{Questionnaire DO Somontano}

A questionnaire has been developed on the DO Somontano to see if the application of this type of models is guessed right in the sociological investigations or not.

$83 \%$ of the 224 people asked consume wine. So, we are going to work with this $83 \%$ in order to know their preferences, tastes, valuations, and other aspects on the denominations of origin, and more concretely on the DO Somontano.

Most of them assure they consume wine under a DO, which takes to us to corroborate that consumers look for specific requirements like quality. $82 \%$ of the people asked in our poll (152 people) usually consumes DO Somontano, 18\% doesn't.

In our study $48 \%$ assert that they ask their relatives or friends about wine when they buy some. As wine is a nutritional product, it is normal that the person who has tasted it is the one that can give better reference.

Purchase places are even more important. They are not only a place where you can buy wine, they are also a very useful advertising place where consumers can value the information that will make them to chose one product or another.

Department stores, with a 39\%, are the more visited purchase places followed by specialized stores $(27 \%)$ which receive a more "professional" client looks for a more specific product. Small supermarkets receive the $19 \%$ of the wine consumers maybe because of their accessibility. Therefore it could be a great idea to try to promote this channel.

In a society where aesthetic and design are considered as an important added value the wine sector does not want to remain aside. It is also true that as a nutritional product, its content is more important than its container. But if we have a good image, and face we will make a very big point in front of our rivals.

And as we can see, $50 \%$ give "some" or "enough" importance to the design. $21 \%$ consider design as not very important and an $8 \%$ consider it as a very important issue.

\section{Results}

The usefulness of structural equations models for social investigation is the contribution to a global vision of the aspects of the studied phenomenon, in contrast to another type of statistical tools which are focused in the individual analysis of each factor. They also reduce the amount 
of information that must be analyzed, in order to group the relations between a great number of variables.

Referring to causality study, the function of structural equations models is not to corroborate the causal relations between the different variables, but to provide its analysis and decision making.

\section{Conclusions}

Model ECSI let us to determine the consumer's satisfaction with a product or service. It also demonstrates the relations between satisfaction and other factors that take part in the purchase. Therefore, apart from giving value to these variables, it lets us to analyze their relations and the importance of their causality.

We can obtain several conclusions from the questionnaire like consumer's loyalty: more than $80 \%$ usually consumes wine from the DO Somontano. It comes to say that consumers trust DO and their brands.

Price usually has no influence in the choice between one DO and another. Flavor and DO are the more influent factors in the purchase of a certain wine. In a word, products earn an extra quality point when consumers have the guarantee of a DO.

It is also necessary to emphasize the importance consumers give to the bottle and label design. Although it is not a determining characteristic, it can mark the difference between two similar products. So that we don't have to neglect the design, because clients, pay attention to it and it also helps them to choose the wine.

Knowing the final destiny of the DO Somontano's wines consumption, helps us to know better our clients, and the purpose after the purchase of our product. This way we can focus our products on the necessities of our consumers. Thereby and according to the article "Genome of the wine consumer in Spain " we should consider that there are six different kinds of wine consumers: traditional, anxious city dweller, trendy, routinist, occasional interested, and social. Here, we have a very good target to work in.

From this results, we can conclude that belonging to a DO is a clear commercial expansion strategy that impels a mark and a type of wine praising its characteristics and properties giving technical, commercial and overall advertising support putting its region (Somontano in this case) in the map.

A perfect symbiosis arises here: regions take advantage from their wine's good image in order to develop around them a very attractive tourism for everyone.

The benefit for the DO is that many people would come to know its wines and DO Somontano knows that people consume wine when they know that wine. Somontano wants consumers agreed to the image it wants to transmit: quality.

\section{References}

- Bisquerra, R.,1989 Introducción conceptual al análisis multivariable, Barcelona.

- Carreras, 1999 Fundamentos Metodológicos de la Evaluación. La evaluación postpositiva: E.C.S.I., Tesis doctoral, Facultad de Ciencias Políticas y Sociología, Universidad Complutense de Madrid.

- Foguet, Cenders y Gallart, (2000): Modelos de Ecuaciones Estructurales Editorial La Muralla SA, Madrid.

- Hernández Calzada y Mendoza Moheno, 2008: "Decisiones de compra a partir del reconocimiento de la DO: caso del vino en la ciudad de Salamanca", Universidad de Salamanca.

- Rey, 2009 “El vino español en 2008”, Asamblea general de la Federación Española del Vino. 


\title{
Global Food Prices, Agricultural Transformation and Food Security in Central Asia
}

\author{
Kamiljon T. Akramov, International Food Policy Research Institute, \\ Washington, DC, USA
}

\begin{abstract}
This paper addresses the impact of global food prices on domestic food prices, the short-term policy responses, and major constraints on long-term food security in Central Asian countries. A surge in domestic food price inflation in Central Asian countries was almost perfectly simultaneous with the spike in international food prices. The transformation of the region's agriculture since 1991 has changed the structure of agricultural production and led to reallocation of more land to food crops, improving food security in the region and mitigating the negative consequences of rising global food prices. The paper argues that the further improvement of food security in the region requires concerted efforts from governments to remove existing constraints on agricultural productivity and regional cooperation and trade.
\end{abstract}

JEL codes: Q18, O24, O57

\section{Introduction}

As a result of both internal (land reform and agricultural policy) and external (trade) factors, food security in Central Asia has improved significantly since the mid 1990s. However, the recent surge in global food prices shows that Central Asian countries, especially Kyrgyzstan and Tajikistan, are still vulnerable to external shocks. Short-term policy responses by national governments in the region varied according to whether a given country is a net exporter or net importer. The geography of wheat production and consumption - the most important item in region's food consumption - is such that the capacity to export surplus production over domestic consumption is far more concentrated in Kazakhstan while other countries of the region are net importers. The remoteness of the region, poor infrastructure and other difficulties with access to global markets give Kazakhstan a unique position in the regional cereal market. It is one of the world's largest grain exporters and major exporter of wheat to its Central Asian neighbors Kyrgyzstan, Tajikistan, Turkmenistan and Uzbekistan. In this regard, the introduction of export restrictions on wheat in 2008 by the government of Kazakhstan created additional problems for other countries of the region, who were already struggling with high food prices.

The negative consequences of surging global food prices and Kazakhstan's restrictions on wheat exports would have been more severe if the agricultural sector in the region had not been restructured after 1991. The major reforms after 1991 included liberalization of agricultural prices and markets, farm restructuring, property rights reform and transition to individual farming. Although all Central Asian countries implemented such reforms to some degree, the intensity and extent of the reforms varied across these countries. This paper addresses three aspects of food security in Central Asia, including the impact of global food crisis on domestic food prices, the short-term policy responses taken by national governments, and major constraints on long-term food security in the region.

\section{Global Food Crisis and Domestic Food Prices in Central Asia}

According to United States Department of Agriculture (USDA)'s food security assessments, every country in Central Asia, except Tajikistan, has been food secure since the early 2000s. However, recent surge in global food prices had a significantly negative impact on food security in the region, which was evident in rising domestic inflation and growing numbers of 
food insecure people. The spike in domestic food price inflation in Central Asia was almost perfectly simultaneous with the surge in international food prices. Reflecting the surge in global food prices, year-on-year food price inflation in most of the region accelerated sharply and jumped into double digits from the second half of 2007 and stayed high through September 2008 , when it started to decline closely reflecting global food price trends. The escalation of domestic food price inflation was especially pronounced in Kyrgyzstan, where the food price index was up almost 40 percent on a year-on-year basis in October 2007, and hit peak of 48 percent in June 2008, and moderated to 20 percent in December 2008. The acceleration of food price inflation was less pronounced in Uzbekistan, where the government has pursued a policy of cereal self-sufficiency since the early 1990s and has made extensive use of price controls.

Increasing global food prices even influenced the Kazakhstan's domestic food market, one of the world's major exporters of high-quality grain. Kazakhstan's food price inflation reached double digits in August 2007 and then quickly accelerated to 25-26 percent on a yearon-year basis in the fourth quarter of 2007. Given surging global food prices and accelerating domestic inflation, the government felt that large, sudden increase in foreign demand might divert wheat from domestic markets and result in further increases in domestic food prices. This led to the Kazakh government's decisions initially to impose export tariffs on wheat in February 2008, and later to enforce a temporary suspension on wheat exports in April 2008 (Mitra and Josling, 2009). Kazakhstan's decision to restrict wheat exports, echoing the moves of other wheat exporters (that is, Russia, Argentina, and Ukraine), caused international prices of high-quality wheat to surge by 25 percent in one day on February 25, 2007(HIS Global Insight, 2008) . Overall, international food prices might have increased by about 20 percent as a result of the temporary export restrictions (Ivanic and Martin, 2008). The impact of global food crisis was more pronounced in Central Asia's net cereal importers. According to USDA's annual food security assessments, in three Central Asian countries, including Kyrgyzstan, Turkmenistan, and Uzbekistan, food consumption for the lowest income quintile fell below the nutritional target in 2007. In Tajikistan, the most vulnerable country in the region, about 80 percent of population fell below the nutritional target during the same time period. Overall, Tajikistan's 2007 distributional food gap — the amount of food needed to raise consumption in every income quintile to the minimum nutritional target — was estimated at 29 kilograms per person in grain equivalent (USDA, 2008).

National governments in the region introduced various short-term policy measures to mitigate the negative impacts of rising food prices. These included reduced taxes and import duties on selected food grains (Kyrgyzstan and Tajikistan), targeted food subsidies for low income people (Kyrgyzstan), and subsidies for agricultural producers (Kyrgyzstan, Tajikistan and Uzbekistan) (ADB, 2008). Administrative price control measures and targeted social assistance programs have been in place for some time in Uzbekistan. In Tajikistan and Turkmenistan, governments also implemented measures to increase domestic grain production (USDA, 2008). These negative consequences would have been more severe if the agricultural sector in the region had not been transformed during transition period. The next section discusses the characteristics of the salient agricultural transformation that has occurred in Central Asia.

\section{Agricultural Transformation and Food Production}

The agricultural sector helps to improve food availability by increasing food production. Prior to 1991, the agricultural sector in the region was dominated by large-scale inefficient socialist farms. The reasons for persistent inefficiency of collective farms are well documented in the literature and include soft budget constraints, excessive agency problems and transaction costs. Therefore, the need for transition from a collective farming based on a command economy to private farming based on a market agricultural system was necessary (Lerman, et al., 2004). 
The transformation of the agricultural sector began in the early 1990s and continues to the present day. The major elements of this transformation includes: (1) liberalization of prices and the removal of direct government intervention in agricultural decision-making; (2) land reform and farm reorganization; and (3) formation of market and collective-action institutions (Rozelle and Swinnen, 2004). There are, however, important differences among individual countries in terms of the pace of transformation and the resulting farm structure. According to the World Bank's agrarian reform metric, Kyrgyzstan belongs to the advanced reformer group, with an average reform score of 7.2; this was significantly higher than those of its neighbors in Central Asia, which were rated as moderate (Kazakhstan, with an average score of 6.2) or slow (Tajikistan, 4.4 and Uzbekistan, 4.8) reformers (Csaki, et al, 2006).

In the beginning of the transition (1991-1992), Kyrgyzstan quickly liberalized its agricultural markets and prices, and, after four years (1995), started the distribution of agricultural land to farmers giving them land use certificates for up to 99 years. These land use certificates granted five legal rights to individual farmers, namely the rights to transfer, exchange, sell, lease, and use the land certificate as collateral for credit. Later, in 1998, there was a country-wide referendum that adopted a constitutional amendment that allowed private land ownership. Currently, agricultural land may be owned by the state, by citizens of Kyrgyzstan who are at least 18 years old and have permanently resided in rural areas for at least two years, and by agricultural cooperatives. The agricultural land may be leased out, sold or donated, but must be used exclusively for the purposes of agricultural production. The land shares and parcels may be traded for other land shares or parcels, but only within the boundaries of a given local government. Thus, although land reform is not yet complete, Kyrgyzstan has made significant progress in privatizing land and creating markets for agricultural land (Akramov and Omuraliev, 2009).

Other countries in the region lagged in the implementation of agrarian reforms and generally still do not recognize private property rights to agricultural land, with some minor exceptions. Kazakhstan restricts private land ownership to small household plots of up to 0.2 ha, whereas Uzbekistan and Tajikistan basically retain full state ownership of land (Lerman, et al, 2004). Overall, Kazakhstan has adopted the principle of state ownership of agricultural land with private use and transfer rights under long-term (up to 99-year) leases. Nevertheless, the government still seems to favor large agricultural enterprises, and very little (less than $10 \%$ ) of the farmland is cultivated by individual farmers. The agricultural sector was neglected from the 1990 s up to the early 2000s, when the government introduced a price-support system for wheat and other agricultural products (Pomfret, 2008). In Tajikistan, land remains in exclusive state ownership and land reform is restricted to reallocation of state-owned agricultural land among producers through the mechanism of land use rights. Land use rights can be transferred and individuals have the right to withdraw from the collective farm to establish private (dehkan) farms. In order to exercise this right, they must obtain approval from the farm chairman and the district government, and take on responsibility for a portion of the debt accrued by the former state or collective farm. Nevertheless, currently, households and private (dehkan) farms control almost two-thirds of total farmland in the country (Lerman and Sedik, 2008).

In Uzbekistan, the principle of exclusive state ownership of land, which does not allow private land ownership either by individuals or collectives, is in place. Currently, there are three types of farms in the country: corporate farms, peasant farms and household plots. The district governments allocate land to these three types of agricultural producers along with the right of inheritance, but without any rights to sell, transfer, or exchange. Despite the restricted land reform, the farm structure in the country has gradually changed away from collective toward peasant farming (Lehrman, 2008). This transformation took place step by step and the government also gradually reduced price and market distortions in agriculture by introducing reforms aimed at reducing the negative incentives for farmers (Pomfret, 2008).

The evidence suggests that agricultural reforms had important impacts on agricultural production and food security in the region. First, the net effect of agricultural reforms was a 
dramatic shift in the distribution of agricultural land use in favor of private farms. In turn, the changes in the distribution of agricultural land by farm type led to significant modifications in the structure of agricultural production. This impressive shift in the composition of agricultural production does not simply reflect the changes in the composition of land holdings across different farm types. The evidence suggests that private farms are more productive than collective farms (Lerman, 2008; Akramov and Omuraliev, 2009). As a result, agricultural growth and production recovered in all Central Asian countries. Second, agricultural reforms allowed farmers to improve their resource allocation based on market conditions and the profitability of particular crops. This led to more diverse production systems and substantial changes in cropping patterns by increasing the land devoted to food crops significantly (Lerman, 2008; Akramov and Omuraliev, 2009). The changes in crop patterns in favor of food crops played an important role in improving food security by substantially increasing per capita food availability. Finally, evidence from cross-section household surveys in Kyrgyzstan, Tajikistan and Uzbekistan suggest that agricultural reforms probably had a positive impact on household income by making more land available to rural households and giving decisionmaking power to individual farmers (Lerman, 2008; Lerman and Sedik, 2008).

\section{Constraints on achieving food security in Central Asia}

The brief overview of the region's agricultural reforms and growth provided in the previous section showed that land reform and individualization of agriculture led to the recovery of agricultural production and enhanced food security in the region. However, the evidence suggests that there remain several constraints on achieving higher and sustained levels of agricultural growth and food production in the region. First, de-collectivization of agriculture significantly diminished the agency problem and significantly improved incentives for farmers throughout the region. Nevertheless, farmers in most of Central Asia still make their production decisions based on distorted prices and are unable to benefit from higher international prices for their products despite being exposed to higher input prices. Moreover, some governments in the region continue to intervene in farmers' decision making with respect to crops and markets (Lerman, 2008; Pomfret, 2008).

Second, transition to a market-based agriculture in Central Asia was accompanied by a significant decline in agricultural public expenditures, leading to a noticeable deterioration in the quality of rural infrastructure and the availability of agricultural services. This negative impact was perhaps most damaging for the irrigation infrastructure, a major component of the region's agricultural production. De-collectivization created an institutional vacuum because no organization was responsible for the operation and maintenance of the on-farm irrigation networks. This has led to poor upkeep of the existing infrastructure. The governments supported by donors tried to mitigate the problem by introducing an irrigation service fee and through establishment of water users associations (WUA). However, institutional reform in the irrigation sector was significantly slower than land reform, and irrigation facilities had already largely deteriorated by the time irrigation reforms were introduced. Moreover, the WUAs are still weak and financially unsustainable, due to problems with the collection of service fees, incongruities between formal and informal rules, power abuse, rent seeking, information asymmetry, and distrust between community members (Akramov and Omuraliev, 2009).

Third, land reform and individualization of agriculture contributed to the fragmentation of land use. Due to their limited size, private smallholder farms cannot afford to purchase costly agricultural machinery. Without capital to replace and maintain existing equipment, the agricultural machinery fleet deteriorated in Central Asia, resulting in "de-mechanization" of the agricultural sector (World Bank, 2009). The recovery of agricultural production and strong growth suggests that negative impact so far has been offset by improvements in labor efforts and resource allocation. However, this may have important implications for long-run productivity. In this regard, consolidation of land use is an important policy direction for 
Central Asian countries. The experience of market economies shows that leasing can play an important role in land consolidation (Lerman et al., 2004). Further, the evidence suggests that small farmers can make use of scale economies by establishing trade and service cooperatives, which allows them to share the burden of capital expenditures by creating a machinery pool (Lerman, et al, 2004). The development of such cooperatives requires appropriate legal basis and institutional reforms and promotion of service cooperatives may be a promising direction for fostering improvements in farmers' access to agricultural machinery and services. However, some Central Asian countries (for example, Uzbekistan) are leaning towards formal government-sponsored land consolidation programs based on enlargement of farm size by fiat instead of the market-driven process. This may create significant problems for food security and poverty reduction because it may lead to the consolidation of agricultural land in the hands of a few well-connected and wealthy farmers while many others may become landless.

Fourth, farmers need new services, such as agricultural advisory and marketing, to fully exploit the new economic paradigm of the market economy. Unfortunately, the agrarian reforms in Central Asia were inconsistent, and this dimension of the transition to market-based individual farming was mostly neglected during the earlier phases of transition. As a result, only a fraction of region's individual farmers have access to such services. For example, in Kyrgyzstan, only one-fifth of farmers have access to advisory services. Only 2-3 percent of farmers use marketing, information or legal services (Akramov and Omuraliev, 2009). Finally, remoteness of the region from major international ports lead to high transport costs and the lengthy transit time needed for international shipments to and from Central Asia, which is a major constraint for achieving sustainable food security in the region. Thus, food security in the region can be significantly improved by enhancing regional cooperation and trade. This requires collaborative efforts from governments to remove existing barriers, such as tariffs and quantitative restrictions, as well as restrictions on the movements of goods and transport across borders and through territories of the neighboring countries.

\section{Conclusion}

The spike in international food prices in 2007-2008 had a significant impact on domestic food prices in the region. Short-term policy responses by national governments in the region varied according to whether the country is a net exporter or importer of food. The net importers faced an additional problem with food security because some net exporters introduced temporary restrictions on cereal exports. The negative consequences of rising global food prices would have been more severe if the agricultural sector in the region was not restructured during transition. The reform led to more diverse production systems and substantial changes in cropping patterns, with a significant increase in the land area devoted to food crops, such as wheat, vegetables, potatoes and fruits. This played an important role in improving food security by increasing per capita food availability.

Nevertheless, the recent surge in global food prices showed that Central Asian countries, especially Kyrgyzstan and Tajikistan, are still vulnerable to external shocks. In order to increase and sustain the agricultural growth rates and levels of food production, the Central Asian countries need concerted efforts to remove remaining constraints in the sector. First and foremost, remaining distortions in agricultural markets and prices should be removed. Another essential problem is that transition to a market-based agriculture in Central Asia was accompanied by a significant decline in agricultural public expenditures, leading to a noticeable deterioration in irrigation infrastructure and the availability of agricultural machinery and services. Thus, the governments and donors have to make collaborative efforts to address these shortcomings by channeling additional public resources to the sector as well as by creating new market-based mechanisms. Further, additional reforms are needed with respect to property rights and institutional changes. These reforms should generate proper marketbased incentives for agricultural land consolidation, and improve the market and collective 
action institutions, such as WUAs and cooperatives. Finally, the evidence suggests that longterm food security can be significantly improved by enhancing regional cooperation and trade. Thus, the Central Asian countries need to remove existing barriers on both regional and international movements of agricultural and food products.

\section{References}

- Akramov, K. and N. Omuraliev, 2009. Institutional Change, Rural Services, and Agricultural Performance in Kyrgyzstan. Discussion Paper 175, Washington, DC: International Food Policy Research Institute.

- Asian Development Bank (ADB), 2008. Food Prices and Inflation in Developing Asia: Is Poverty Reduction Coming to an End? Manila, Phillipines.

- Csaki, C., Kray, H. and S. Zorya, 2006. The Agrarian Economies of Central-Eastern Europe and the Commonwealth of Independent States: An Update on Status and Progress in 2005. World Bank ECSSD Working Paper 46, Washington D.C.

- HIS Global Insight, 2008. Wheat Prices Leap 25\% as Kazakhstan Joins List of Countries Restricting Exports, http://www.ihsglobalinsight.com/SDA/SDADetail11647.htm.

- Ivanic, M. and Martin, W., 2008. Implications of higher global food prices for poverty in low-income countries, Agricultural Economics 39 (Supplement), p 405.

- Lerman, Z., Csaki, C. and G. Feder, 2004. Agriculture in Transition: Land Policies and Evolving Farm Structures in Post-Soviet Countries, Lexington Books, Oxford, UK

- Lerman, Z. and D. Sedik, 2008. The Economic Effects of Land Reform in Tajikistan. Report prepared for European Commission under the EC/FAO Food Security Programme.

- Lerman, Z., 2008. Agricultural Development in Central Asia: A Survey of Uzbekistan, Eurasian Geography and Economics, 49(4), p. 481.

- $\quad$ Mitra, S. and T. Josling., 2009. Agricultural Export Restrictions: Welfare Implications and Trade Disciplines, International Food and Agricultural Trade Policy Council Position Paper, Washington, D.C.

- $\quad$ Pomfret, R., 2008. Kazakhstan, In Eds. Anderson, K. and J. Swinnen, Distortions to Agricultural Incentives in Europe's Transition Economies, Washington DC: World Bank.

- Rozelle, S. and J.F.M. Swinnen, 2004. Success and Failure of Reform: Insights from the Transition of Agriculture. Journal of Economic Literature, XLII (2), p404.

- United States Department of Agriculture (USDA), 2008. Food Security Assessment 2007. Agriculture and Trade Report GFA 19. Washington, D.C.

- World Bank, (2009) Farm Mechanization: A New Challenge for Agriculture in low and Middle Income ECA Countries. Washington, DC: World Bank. 


\title{
The Management Of The Agricultural Structure Of Russia While Maintaining Food Security In The Era Of Globalization
}

\author{
Irina Soldatova, South Federal University \\ Viktor Ovchinnikov, South Federal University \\ Michail Chernishev, South Federal University \\ Nicolay Kuznesov, Rostov State University of Economics
}

\begin{abstract} and are caused by the following:

1. considerable increase of threshold value of the criteria of domestic

market saturation by import output, for example, - meat;

2. low level of paying capacity of the population for food stuff;

3. price disproportion at the markets of agricultural, fish output and

food stuff on one side and material-technical resources on the other;

4. disturbance of stability of financial-credit system;

5. insufficient level of development of domestic market infrastructure;

6. moral and physical aging of material-technical basis of

agro-industrial and fishery complexes;

7. insufficient level of innovation and investment activities;

8. reduction of national genetic resources.
\end{abstract}

The main object of this paper is the food safety of the Russian Federation - it is such a state of the country's economy when food independence of the Russian Federation is provided, physical and economic availability of food stuffs, corresponding to the requirements of Russian Federation legislation in safety and quality, is guaranteed for the population of the country. Realization of Russia's national interests in this field is a key problem. Guarantee of food safety is connected with the overcoming of negative factors which have a complex character

JEL codes: Q 18

\section{Introduction}

The main theme of this report is food safety of Russia. This such condition of the state economy, when

- Food independence of the country is provided;

- Physical and economic utility of food products is guaranteed by the state and

- Corresponds to requirements of the legislation of the Russian Federation in safety and quality.

Food independence - ability of agrarian sector of the country to provide manufacturing, storage, processing and delivery to the population foodstuffs principal views, in quantity and the assortment necessary for an active healthy life. Food safety is not provided if manufacture of a foodstuff makes less than 75-80 \%, according to physiological norms.

Food safety of Russia is considered provided if, in case of the receipt termination in the country of foodstuff from abroad, there is no food crisis.

In Russia it should be made:

Potato - $95 \%$, 
Grain, milk and milk food - $90 \%$;

Salt food - $85 \%$;

Meat and meat products - $85 \%$,

Fish and fish products, sugar, vegetable oil - $80 \%$.

\section{Two basic approaches in food safety}

Under the forecast of the international organisations the world situation on food safety the next decade will become aggravated. In the developed states exists two basic approaches in food safety:

The first - a priority in support of the national agricultural manufacturer (country EC),

The second - equal support of agricultural manufacturers and consumers of food (USA).

It is offered to use support of manufacturers and foodstuffs consumers in Russia.

All slides, schemes, tables are taken from official sources of the Ministry of Agriculture and the foodstuffs.
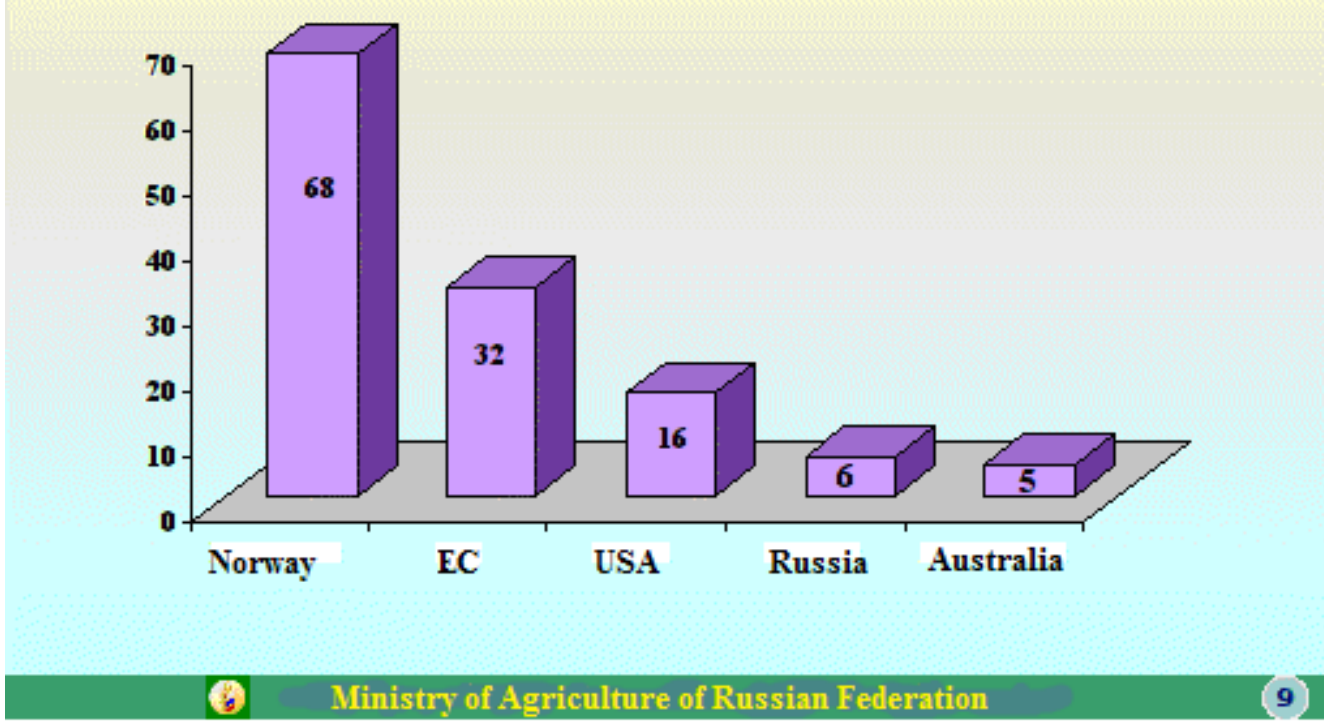

Slide 1. Level of support of agricultural manufacturers (In recalculation on 1 rouble of made production)

The budget of agricultural manufacturers in Russia (a slide 1) is less than in the USA - in 2,7 times, in countries EC - in 5,4 times. Natural environmental conditions in Russia for manufacture of agricultural production are much more difficult.

Problems of food safety become more important in world trade regulation. The Russian economists, name «food safety» «food independence», because of essential economic dependence of Russia in import of food and raw materials.

Growth of manufacture of agricultural production in Russia was accompanied by growth of import of the foodstuffs. The import volume has reached 35,2 bln. dollars, and the negative balance of export and import has made 25,8 bln. dollars (fig. 1.). Import growth goes much faster than export growth. 

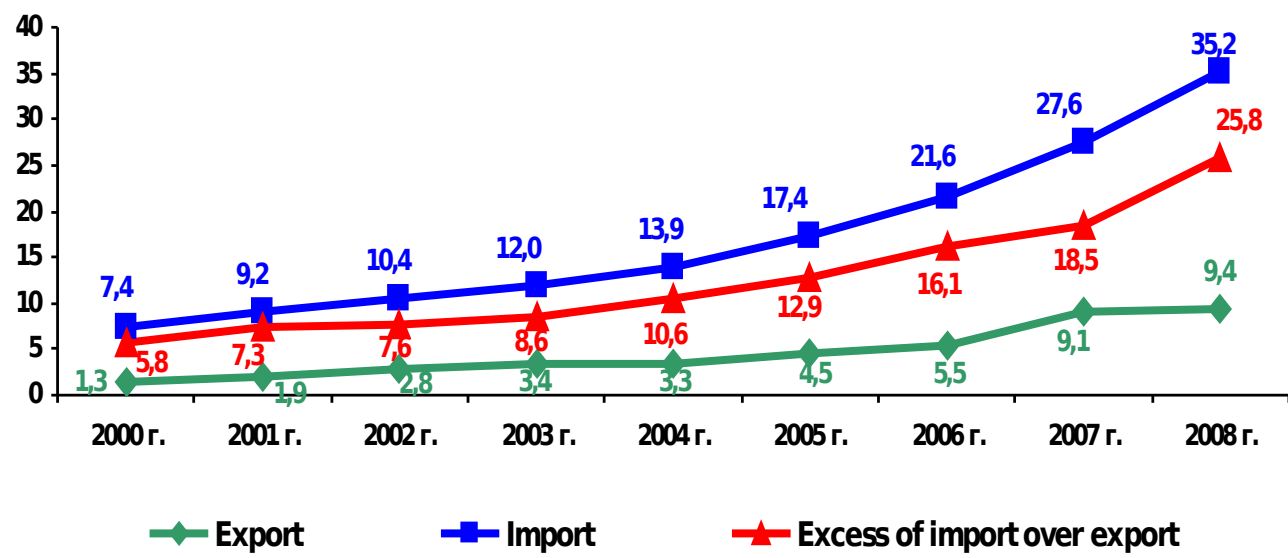

Drawing 1. Export and import of agricultural production and the foodstuffs, bln. dollars of the USA

Volumes of import of meat fresh and frozen, dairy products (tab. 1) have considerably increased. The basic increase in value of import has occurred at the expense of increase of average contract prices practically on all articles of food. In 1,3 times contract prices of meat fresh and frozen, and also fowl have increased.

\begin{tabular}{|l|r|r|r|r|}
\hline $\begin{array}{l}\text { Kinds of the agricultural production and } \\
\text { the foodstuffs }\end{array}$ & 2006 & 2007 & 2008 & $\begin{array}{l}\text { 2008 year in } \\
\% 2007\end{array}$ \\
\hline $\begin{array}{l}\text { Articles of food and agricultural raw } \\
\text { materials (except textile), bln. dollars of } \\
\text { the USA }\end{array}$ & 21,6 & 27,6 & 35,2 & 127,3 \\
\hline Meat fresh and frozen (meatless birds) & 1411,4 & 1489,4 & 1710,8 & 114,9 \\
\hline Fowl fresh and frozen & 1282,5 & 1294,9 & 1223,8 & 94,5 \\
\hline Fish fresh and frozen & 686,1 & 870,2 & 881,1 & 101,2 \\
\hline Milk and cream condensed & 145,3 & 130,6 & 160,2 & 122,6 \\
\hline Oil creamy and other dairy fats & 165,0 & 123,5 & 140,0 & 113,5 \\
\hline Oil sunflower & 100,0 & 131,9 & 111,9 & 84,8 \\
\hline Sugar-raw & 2629,4 & 3410,4 & 2417,6 & 70,9 \\
\hline Sugar-raw & 349,7 & 296,1 & 165,1 & 55,8 \\
\hline Sugar-raw & 1187,4 & 1260,2 & 1288,4 & 102,2 \\
\hline
\end{tabular}

Table 1: Import of principal views of articles of food and agricultural raw materials to the Russian Federation, thousand ton

That is, high import dependence of the country by separate kinds of agricultural production and the foodstuffs remains. At the expense of import $36 \%$ of commodity resources today are formed. Sharply there is a problem of dependence on import in the market of cattle-breeding production. The share of import in commodity resources of meat is estimated in $41 \%$, milk - in $27 \%$. Import of pork from the beginning of 2009 has grown on $29 \%$, and dried milk - almost in 2 times.

Growth of internal manufacture of meat not to the full covered increase of consumer demand of the population that was reflected in increase in volumes of its import (fig. 2). 


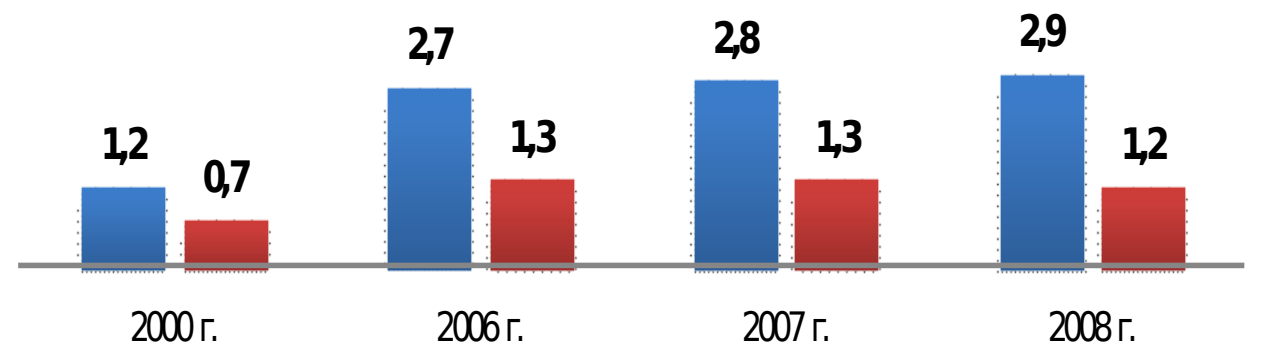

мясо всехвидов

Meat of all kinds мясо птицы

Meat of fowl

Drawing 2. Meat import of everything, including fowl, million $m$

Relative density of import in formation of the general resources of meat and meat products (in recalculation on meat) has made in $200733,2 \%$, in $2008-32 \%$ at a target indicator of 34 $\%$.

Import of meat fresh and frozen has developed at 1711 thousand level $\mathrm{T}$ that on $14,9 \%$ more than in 2007, including: beef - 871,6 thousand т (10,2 \%), pork - 822,1 thousand т $(19,6 \%)$. Fowl import has decreased on 5,5\% to 1223,8 thousand tons.

In 2008 dried milk import has increased on $21,3 \%$, oils creamy - on $8,1 \%$, cheeses and cottage cheese - on 5,8\%. In recalculation on milk it has been delivered dairy production of 7315,3 thousand т. The share of import dairy production in its general resources has made 17,6 $\%$ against $17,3 \%$ in 2007.

All it increases dependence of the food market and seriously infringes upon interests of the Russian agriculture.

The governmental policy in sphere of a guarantee of products of food should include necessarily risks and agricultural production threats.

It includes, for example, such factors as deficiency of competent staff, price disproportion, modern systems of supervision on the state of the market of manufacture etc.

To come nearer to level of the developed countries to us it is necessary to solve simultaneously some the interconnected and capital-intensive problems:

1. Technological modernisation of agriculture and the food-processing industry, sphere of industrial service of agrarian and industrial complex;

2. Formations of personnel potential of the branch, capable to master an innovation;

3. Work on manufacture restoration on the thrown agricultural grounds;

4. Creation a modern social infrastructure of rural territories (habitation, roads, etc.).

The guarantee of safety of foodstuff is connected with overcoming of following negative factors:

1. Substantial growth of threshold value of criteria of a saturation of home market by import production, for example, meat;

2. Low level of payment ability of the population for a foodstuff;

3. Not stability of system of the financial credit;

4. Insufficient level of development of an infrastructure of home market;

5. Moral and physical ageing of a material condition agroindustrial and a fishery complex; 
6. Insufficient level of an innovation and investment actions;

7. Reduction of national genetic resources;

8. Probable expansion of production of biological fuel from agricultural production and raw materials;

9. Shortage of competent staff.

\section{Conclusion}

The problem of food safety dares in the world, in the country and regional aspect.

In Rome, on November, 16th, 2009 in the Declaration of the World summit on food safety five principles of the Akvilsky initiative on food safety are confirmed:

- Investment in realisation of national plans on food safety;

- Strategic coordination of actions at global level, country level, regional aspect;

- The universal approach to maintenance of food safety, that is a combination of urgent;

_ Measures of the help to long-term efforts on agricultural production development;

- Increase of a role and efficiency of institutes;

- Maintenance of steady investment in agriculture and food safety.

The Ministry of Agriculture and the foodstuffs of Russia has developed the Doctrine of food safety. In the Doctrine the conventional recommendations of FAO about a share of import and stocks of food resources are considered.

Doctrine main objective is self-maintenance of the country with qualitative agricultural production, raw materials and the foodstuffs at level not less than $80-90 \%$ from requirement. At the Summit the concrete contribution of Russia to strengthening of global food safety at the expense of stable growth of manufacture of grain and the accruing volume of its export has been noted. For today Russia is included into a three of the largest world suppliers of wheat.

The next 10-15 years in Russia it is planned to finish manufacture of grain to 120-125 million tons a year that will allow to provide stable export at level of 30-40 million tons.

Within the limits of the Doctrine of food safety reduction of import of meat to $18 \%$ by 2012 , that is almost twice in comparison with 2008 is predicted. Internal manufacture of meat should grow on $25 \%$ or on one and a half million tons, milk - to 33 million tons, import on milk will be reduced by 2012 to $16,6 \%$.

As a result of realisation of a series of measures on agriculture development, by 2012 in separate directions the stage import replacement (fowl, pork, grain, a potato, vegetable oil) and saturation of home market by domestic production production is finished.

Export of agricultural production, raw materials and the foodstuffs has made 9,39 bln. dollars of the USA and has grown in comparison with 2007 on $0,32 \mathrm{bln}$. dollars of the USA, or on 3,3 $\%$ (fig. 3).

Regional, dominating features of support in agrarian sector become one of the important forms of management of a state policy of agriculture. 


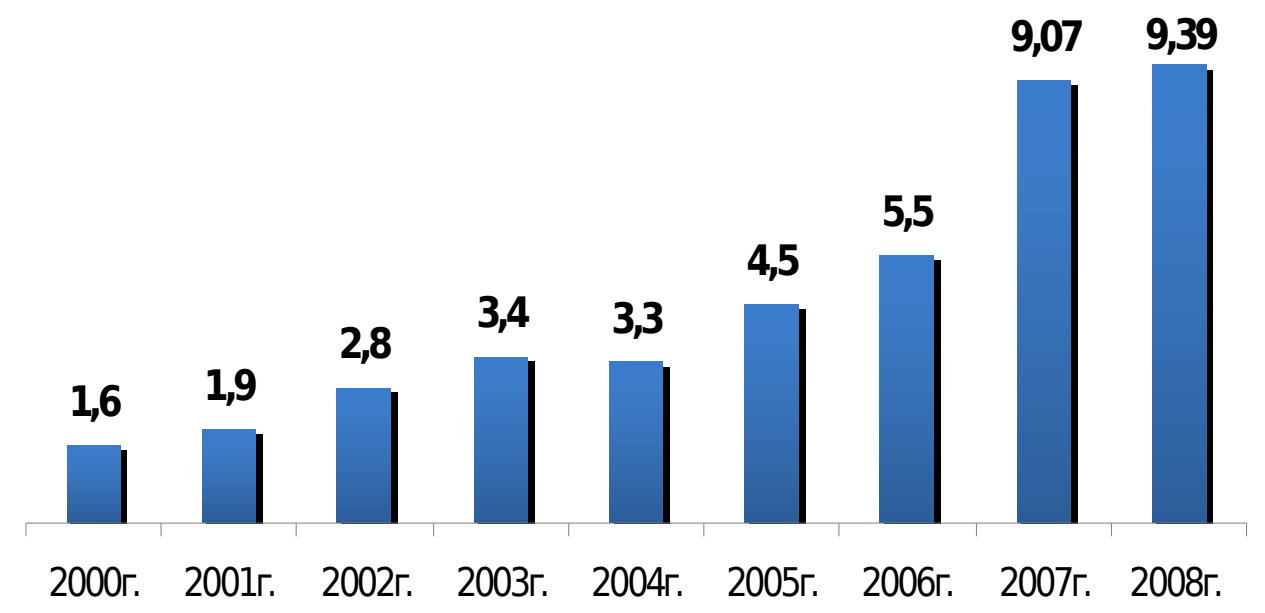

Drawing 3. Export of agricultural production and the foodstuffs, bln. Dollars of the USA

Efficiency of a regional policy proves to be:

- In flexibility,

- High possibilities in management,

- In use of budgetary funds.

The leading part at the decision of a problem of food safety should be taken away to a regional government.

The project of the Rostov region should be spent in following directions:

- Safety of area in the foodstuffs, in quantitative and qualitative aspect;

- Quality check of foodstuff of the population;

- Economic suitability of the foodstuffs.

In the world, the country and in region management of agriculture with a view of advancement to food safety, should be co-ordinated necessarily with food independence.

\section{References}

- E.Skrynnik «The National report« on a course and results of realisation in 2008 of a government program of development of agriculture and regulation of the markets of agricultural production, raw materials and the foodstuffs on 2008 - $2012 »$, Moscow, 2009

- E.Skrynnik About the total Declaration of the World summit on food safety, Rome, on November, $16^{\text {th }}$

- $\quad$ E.Srynnik Performance at panel session on agrarian questions at the Petersburg international economic forum, 6/18/2010, St.-Petersburg

- The decree of the President of the Russian Federation from January, 30th, 2010 № 120 «About the statement of the Doctrine of food safety of the Russian Federation»

- The order of the Government of the Russian Federation from March, 17th, 2010 № 376-r «The Plan of measures on realisation of positions of the Doctrine of food safety of the Russian Federation»

- Krftherina Sierra, Vice President, Sustainable Development The World Bank «Russian Agriculture Post Crisis» Friday, June 18, 2010 St. Petersburg International 


\section{Economic Forum}

- $\quad$ Russia agribusiness report, London, Q3 2010 Including 5-year industry forecasts by BMI Part of BMI's Industry Report \& Forecasts Series Published by: Business Monitor International Publication date: May 2010

Table 2. Performance of the basic indicators characterising realisation of government program in 2008

\begin{tabular}{|c|c|c|c|}
\hline Basic indicators & plano & fact & $\begin{array}{l}\text { feasibility, } \\
\%,\end{array}$ \\
\hline $\begin{array}{l}\text { 1. An index of production of agriculture } \\
\text { in economy of all categories (in the } \\
\text { comparable prices), } \%\end{array}$ & 103,8 & 110,8 & 7,0 \\
\hline $\begin{array}{l}\text { 2. An index of production of animal } \\
\text { industries in economy of all categories } \\
\text { (in the comparable prices), } \%\end{array}$ & 104,8 & 103,4 & $-1,4$ \\
\hline $\begin{array}{l}\text { 3. An index of production of plant } \\
\text { growing in economy of all categories (in } \\
\text { the comparable prices), } \%\end{array}$ & 102,9 & 117,6 & 14,7 \\
\hline $\begin{array}{l}\text { 4. An index of physical volume of } \\
\text { investments into a fixed capital of } \\
\text { agriculture, } \%\end{array}$ & 115,0 & 97,5 & $-17,5$ \\
\hline $\begin{array}{l}\text { 5. Had resources of house economy in a } \\
\text { countryside (on a member of an } \\
\text { economy in a month), rbl. }\end{array}$ & 7085,0 & 7752,1 & 109,4 \\
\hline $\begin{array}{l}\text { 6. A share of the Russian manufacture in } \\
\text { formation of resources, } \% \text { : } \\
\text { Meat and meat products (in } \\
\text { recalculation on meat) }\end{array}$ & & & \\
\hline $\begin{array}{l}\text { Milk and milk food (in recalculation } \\
\text { on milk) }\end{array}$ & $\begin{array}{l}61,1 \\
78,3\end{array}$ & $\begin{array}{l}60,8 \\
77,8\end{array}$ & $\begin{array}{r}-0,3 \\
-0,5\end{array}$ \\
\hline \multicolumn{4}{|l|}{$\begin{array}{l}\text { 7. Factor of updating of principal views } \\
\text { of agricultural machinery in the } \\
\text { agricultural organisations, } \% \text { : }\end{array}$} \\
\hline Tractors & 5,2 & 5,4 & \\
\hline Combines grain-harvesting & 7,4 & 8,9 & 0,2 \\
\hline Combines & 11,8 & 11,9 & $\begin{array}{l}1,5 \\
0,1\end{array}$ \\
\hline $\begin{array}{l}\text { 8. Power security of the agricultural } \\
\text { organisations on } 100 \text { hectares of an area } \\
\text { under crops, h.p. }\end{array}$ & 134,0 & $145,3^{*}$ & 108,5 \\
\hline $\begin{array}{l}\text { A labour productivity index in economy } \\
\text { of all categories, } \%\end{array}$ & 104,8 & 113,0 & 8,2 \\
\hline
\end{tabular}




\title{
Food Demand Analysis of Indonesian Households: Do They Eat Better or Smoke When They Get Richer?
}

\author{
Evita Hanie Pangaribowo, University of Bonn
}

\begin{abstract}
Pursuing food security is one of the main Indonesian government's agendas. Indonesian government has been successful in maintaining aggregate food production and supply, yet this achievement has not been transferred to household level. The government has formulated several models of food security and established Food Security Council to mitigate the food insecurity. Direct cash aid has been provided since 1998. Nevertheless, poverty and food security remain. This failure might be due to the lack of knowledge on household food expenditure patterns which vary across income groups and regions. Using the richness of Indonesia Family Life Survey, this study analyzes the responsiveness of Indonesian households to food prices, incomes, and other socioeconomic factors. The study employs Quadratic Almost Ideal Demand System model and also accounts for demographic effects and regional differences. Food demand behavior varies significantly between urban and rural households as well as income groups, but not Java and non Java households. The poorest households consume more staple food and adult goods while the richest households consume more meat and snack and dried food. As shown by expenditure elasticity, the poorest will transfer their extra resources on adult goods instead of transferring this income into more nutrient foods. This finding reveals one of evidences behind the failure of government policies and intervention on food security. Hence, direct cash aid might still be wasteful in the absence of providing relevant knowledge on nutrition issues.
\end{abstract}

JEL Code: D11, D12

\section{Introduction}

Indonesia government has put food security as one of the main agenda in development. The national data shows that the calorie availability and consumption are $3035 \mathrm{kcal}$ per capita and $2015 \mathrm{kcal}$ per capita, respectively. This level is above the recommended energy availability and consumption which is $2200 \mathrm{kcal}$ per capita and $2000 \mathrm{kcal}$ per capita (Ministry of Agriculture, 2007). Despite food security pursued by Indonesian government through maintaining aggregate production and supply, this achievement has not been transferred to household level. There are still around 32 percent of households are food insecure where they consume less than dietary recommended (Rusastra, et al., 2008). In addition, there are around 30 per cent of Indonesian children have an inadequate nutritional status as represented by the high incidence of underweight and stunting (Schmidt, 2002). Those available evidences show that food insecurity in Indonesia was not a problem of aggregate (national) food availability (Tabor, et al., 1999). In fact, food insecurity is still found in the presence of the ongoing rice for the poor program.

Those problems indicate that there exists fundamental issue is still unfolded, for instance food demand behavior. Knowledge on household food consumption behavior is essential to understand how the household responds to price and income. Understanding food consumption pattern, particularly how this pattern differs across income groups is important for appropriate policy direction to mitigate food insecurity. In fact, there are abundant works on food demand pattern in Indonesia. Nevertheless, those studies either used cross sectional data (Chernichovsky and Meesook, 1984; Pitt and Rosenzweig, 1985, Pitt and Rosenzweig 1986, Ravallion 1990, Skoufias 2003) or ignored any impacts of demographic factors (Widodo 2006). Those studies hence do not capture changing policies that affect households' profiles which then affect their consumption patterns. Using the rich dataset of Indonesian Family Life Survey, this study is the only panel data study on food demand in Indonesia done to date. More 
importantly, in the case of Indonesia, this study will account for nonlinearity of Engel Curve in food demand which will be accomplished by modeling food demand using appropriate econometrics techniques.

The organization of this paper is as follow. The first section is introduction and followed by a brief description of the empirical model in section two. The data used in this study will be outlined in section three. Section four is results and discussion. Section five is to conclude.

\section{The Quadratic Almost Ideal Demands System Model}

This study will employ a basic model of consumption function. The consumption behaviour is likely to be affected by prices and income. Aside from that, household food demand behavior will also likely be influenced by demographic factors such as household size and composition as well as rural urban differences. In the demand analysis, most studies examine demand behavior using complete demand system. System of demand equation models consumer demand in a way that the system specifies the allocation of total expenditures for all goods in the budget. This model is more favorable since it generates income and price elasticity and satisfies the restriction in demand theory. The complete demand system employed in this study is Quadratic Almost Ideal Demand System (QUAIDS) (Banks, et al., 1997). QUAIDS is an extension from Almost Ideal Demand System (Deaton and Muellbauer, 1980). QUAIDS includes higher order of expenditure term to capture the nonlinearity of Engel Curve. The QUAIDS model is presented as follow:

$$
\begin{aligned}
& w_{i}=\alpha_{i}+\sum_{j=1}^{x} \gamma_{i j} \ln p_{j}+\beta_{i} \ln \left\{\frac{m}{P(p)}\right\}+\frac{\lambda_{i}}{b(p)}\left[\ln \left\{\frac{m}{P(p)}\right\}^{2}+\sum_{i=1}^{2} \partial_{i} D_{i t}^{k}+u_{i}^{k}\right. \\
& \ln P(p)=\alpha_{0}+\sum_{j=1}^{x} \alpha_{i} \ln p_{i}+\frac{1}{2} \sum_{i=1}^{x} \sum_{j=1}^{x} \gamma_{i j} \ln p_{i} \ln p_{j}
\end{aligned}
$$

where:

$\mathrm{W}_{\mathrm{i}}$ is expenditure share of food all food items

$\mathrm{m}$ is expenditure of all food

$p_{i}$ is price of food group $i$

$p_{j}$ is price of food group $j$

$\mathrm{D}$ is a set of household characteristics including household size, urban/rural, dummy female headed household, education of household head, Java/Non Java.

\section{Data}

The data used in this research is Indonesian Family Life Survey Data (IFLS). IFLS is a longitudinal socioeconomic and health survey conducted in 1993, 1997, 2000 and 2007 (RAND, 2006). IFLS collects data on individual respondents, their families, their households, the communities in which they live, and the health and education facilities they use. The first wave of IFLS was administered in 1993 interviewing 7,224 households. The second wave of IFLS sought to re-interview the same respondents in 1997. The next wave, IFLS3, was fielded on the full sample in 2000. The latest wave of IFLS was fielded in 2007. In IFLS4, like earlier waves, it re-interviews all target households, plus new split-off households that contained at least one target respondent. The total number of observations in this study is 16,836 households. There are approximately 5600 households for each wave.

In this study, food demand is mainly derived from consumption module of the household questionnaire. Food expenditure of food items is used since IFLS does not provide quantity consumed by household. The recall period of these food expenditures is one week. All of these food expenditures will be aggregated into eight food groups: staple food, vegetables and fruit, meat and fish, dairy product, oils, adult goods, snack and dried food and other food. Other food 
includes food away from home. Aside from food expenditure, prices are also key variables in modeling demand. Fortunately, IFLS also provides detailed information from the communities in which IFLS households are located and from the facilities that used by the households. The information in the community level includes prices data collected from shops and main markets in the enumeration area. With the absent of quantity data in consumption as what is the situation of IFLS, prices data from community questionnaire is preferable (Deaton and Zaidi, 2002).

\section{Results and Discussion}

The results from descriptive statistics show that there is a huge gap between the poorest and the richest household (Tabel 1, Appendix). The mean income per capita of the poorest is 119802.4 rupiahs while the richest mean income per capita is almost ten times higher (905482.6 rupiahs). The household head's level of education from the richest group is 11 years while the poorest is less than 3 years. Staple food is the major food expenditure followed by meat and fish. The high share expenditure of staple food is typical of developing countries. It is also found that expenditure for snack and dried food has increased which indicates that Indonesian households start to shift to fast and ready food. Disaggregated by income groups, it is evident that the poorest dominant expenditure is staple food and less likely to spend for dairy product (Figure 2). In addition, the consumption of adult goods is even higher than the consumption of diary product. On the other hand, the dominant food expenditure of the richest group is snack and dried food, followed by meat and fish. In terms of geographical aspect, urban households consume more snack and dried food and dairy product while rural household eat more staple. This pattern indicates that most of richer households reside in urban areas. Interestingly, the expenditure for vegetables, meat and fish, oil and adults are almost uniform.

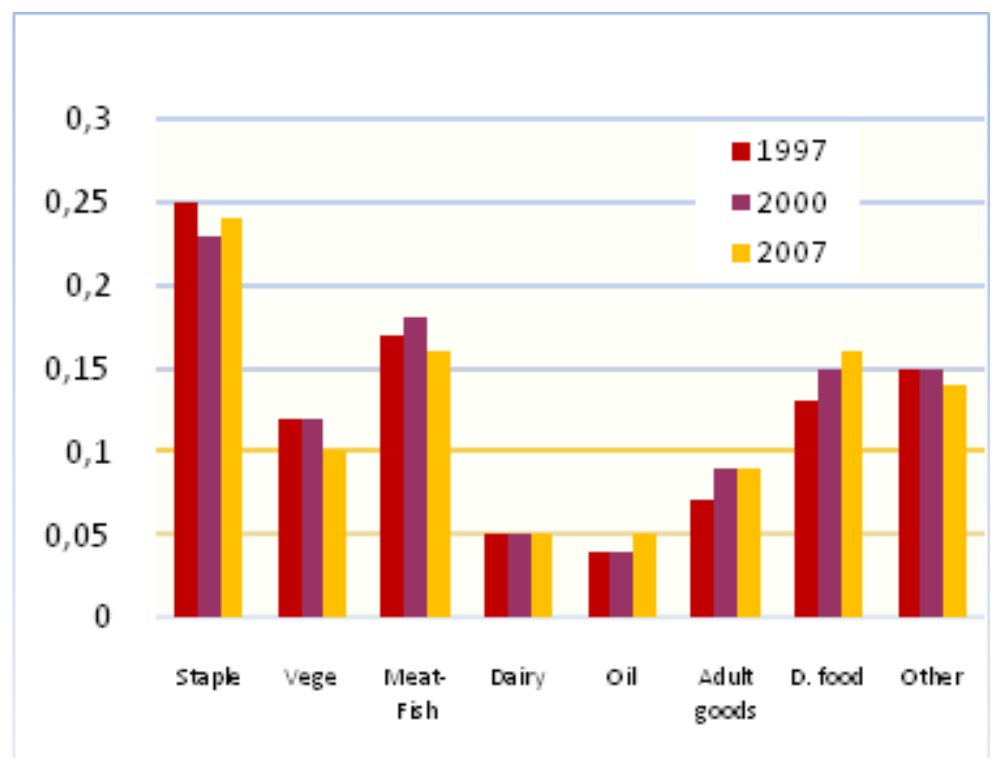

Figure 1. Food Consumption Trend 


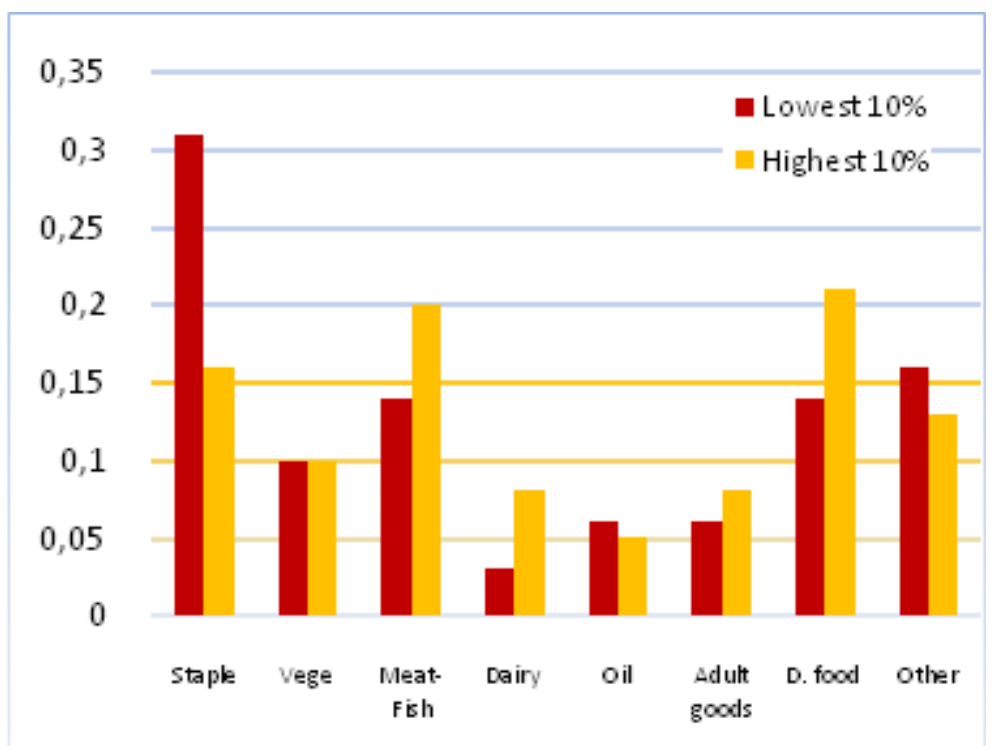

Figure 2. Food Consumption by Income

The QUAIDS model shows that the quadratic term of food expenditure for all food groups is significant. This result implies the nonlinearity of Engel curve with respect to total food expenditure for all food groups. Furthermore, QUAIDS allows the possibility of normal commodity changing to luxury or luxury goods becoming normal. When a commodity has positive sign of expenditure and negative sign of higher order of expenditure term, this commodity is considered a luxury good at low levels of expenditure and necessity at high levels (Banks, et. al, 1997). Vegetables and dairy product are following this pattern. In terms of household characteristics, it is revealed that household size and household head education are significant for all food expenditure. The larger the household size, the more the household consumes staple food while the reverse fact applied for meat and fish and dairy product. This finding explains that larger household tends to choose cheaper calorie food source rather than more nutrient food such as meat and fish and dairy product. The household head education also has a positive and significant effect for meat and fish and dairy product expenditure. How the household responds to price and income change is explained from the expenditure and price elasticities derived from QUAIDS model.

From the pooled sample, all expenditure elasticities are positive which means that the eight food groups are categorized as normal good. Staple food, oils and other food are expenditure inelastic while vegetables, meat and fish, dairy product, adult goods and snack are expenditure elastic. Expenditure elasticity for dairy product is the highest among eight food groups. This finding points out that the increase of income shifts the consumption pattern from staple food to more meat, poultry, eggs, and dairy products. Even though this pattern is a good sign for Indonesia where more people will consume more nutrient food, the health problems as a consequence of this dietary change should also be anticipated.

The results also show that expenditure elasticities vary across income groups. Expenditure elasticity for staple food is elastic for the poorest group. Interestingly, expenditure elasticity for adult goods of the poorest is the highest. This fact confirms the poorest group in Indonesia spend high share of their budget for tobacco. It is reported that 70 per cent of the smoker are the poor which means that the poor is the main contributor for government revenue from tobacco (Suara Media, 2010). This finding indicates that the extra resource earned by the poorest might not be transferred to more nutrient food rather they might utilize this additional income for adult goods consumption. The Indonesian Consumer Foundation reported that there was a misused of direct cash aid from government. Instead of transferring into more 'human 
capital' expenditure, more than 50 per cent of the direct cash aid was spent for smoking (Kompas, 2009). In this case, the aid fungibility is evident. On the other hand, the richest group will be more responsive to dairy product and dried food as their income rise while expenditure elasticity for staple food and vegetables is inelastic. Comparing between urban and rural, expenditure elasticity for staple food is slightly higher in urban than rural. Both urban and rural households are expenditure elastic for meat and fish, dairy product, adult goods, and dried food. Rural household are more elastic for meat and fish and dairy product, while urban household more elastic for snack and dried food.

The result also shows that the own price elasticities are as expected. For pooled sample, among eight food groups, only meat and fish is price elastic. However, when we disaggregate by income group, the poorest is price elastic for vegetables, meat and fish, dairy products and adult goods. This means that the poorest household responds more than proportionately to the prices change of these foods. Based on geographical aspect, urban households are price inelastic for all food groups while rural households are responsive to the change of vegetables, meat and fish and adult goods.

The expenditure and price elasticities show that food demand behavior varies across income groups and urban-rural. The QUAIDS model which also elaborates the demographic variables in this study provide more precise estimate for expenditure and price elasticity. The fact that the poorest are more responsive to adult goods where extra resource exists has explained the failure of government intervention.

\section{Conclusion}

This paper presents an analysis of food demand behavior of Indonesian household. In the case of Indonesia, this study is the first food demand analysis using QUAIDS which elaborate household characteristics and geographical aspects. There are significant different pattern of food demand across income groups. For the pooled sample, staple food, oils and food away from home are necessities while vegetables, meat and fish, dairy products and adult goods are luxuries. Based on income group, it is found that expenditure elasticity on adult goods is very elastic for the poorest household while the richest households are expenditure elastic on dairy product. This result shows that poorest households will transfer their extra resources on adult goods instead of transferring this income into more nutrient foods. In terms of price responsiveness, meat and fish is price elastic for the pooled sample. However, the poorest households are price elastic for all food groups except staple and dried food. These findings show that in a developing country with wide income disparity and rural urban gap like Indonesia, a comprehensive analysis of food demand which account those differences is essential to get a better understanding of household demand behavior and to reshape the food policy direction.

\section{References}

- Ministry of Agriculture, 2007. Sustainable Food Security Development in Indonesia: Policies and Its Implementation, http://www.unescap.org/LDCCU/Meetings/HighLevel-RPD-food-fuel-crisis/PaperPresentations/C2-FoodSecurity/ASuryana-DOA-Indonesia-FoodSecurity.pdf

- Rusastra, I. W., Napitupulu, T. A., and Bourgeois, R., 2008. The Impact of Support for Imports in Food Security in Indonesia, Bogor: UNESCAP-CAPSA, p.52.

- Schmidt, M. K., Muslimatun, S., West, C. E., Schultink, W., Gross, R., and Hautwast, J. G. A., J. 2002. "Nutritional Status and Linear Growth of Indoensian Infants in West Java are Determined More by Prenatal Environment than Postnatal Factors", Journal of Nutrition, 132, p. 2202. 
- Tabor, S.R., Dillon, H.S. and Sawit, M., 1999. "Understanding the 1988 food crisis: supply, demand or policy failure?" in Proceedings of International Seminar on Agricultural Sector During the Turbulence of Economic Crisis: Lessons and Future Directions, http://www.adelaide.edu.au/cies/papers/iwp9913.pdf

- Chernichovsky, D. and O.A. Meesook, 1984. Patterns of Food Consumption and Nutrition in Indonesia, World Bank Staff Working Paper 670, World Bank, Washington, D.C.

- $\quad$ Pitt, M. M., and Rosenzweig, M. R., 1985. Health and Nutrient Consumption Across and Within Farm Household, The Review of Economics and Statistics, 67(2), p. 212.

- $\quad$ Pitt, M. M., and Rosenzweig. M. R., 1986. 'Agricultural Prices, Food Consumption, and Health and Productivity of Farmers,' in Inderjit Singh, Lyn Squire, and John Strauss (eds.), Agricultural Household Models: extensions, applications, and policy, Washington D. C.: The World Bank.

- Ravallion, M., 1990. "Income Effects on Undernutrition”, Economic Development and Cultural Change, 38(3), p. 489.

- Skoufias, E, 2003. "Is the Calorie-Income Elasticity Sensitive to Price Changes? Evidence from Indonesia", World Development, 31(7), p. 1291.

- Widodo, T., 2006. Demand Estimation and Household's Welfare Measurement: Case Studies on Japan and Indonesia, http://harp.lib.hiroshimau.ac.jp/bitstream/harp/1956/1/keizai2006290205.pdf

- $\quad$ Banks, J.; Blundell, R., and Lewbel, A., 1997. "Quadratic Engel Curves and Consumer Demand", The Review of Economics and Statistics, 79(4), p. 527-539.

- Deaton, A., and J. Muellbauer, 1980. “An Almost Ideal Demand System”, American Economic Review 70(3), p. 312-336.

- RAND, 2006. IFLS3 Public Release, http://www.rand.org/labor/FLS/IFLS/ifls3.html

- Deaton, A. and Zaidi, S, 2002. Guidelines for constructing consumption aggregates for welfare analysis. LSMS Working Paper 135, World Bank, Washington D.C.

- Suara Media, 2010. Pengguna Rokok Mayoritas Orang Miskin, http://www.suaramedia.com/berita-nasional/19121-lm3-heran-pengguna-rokokmayoritas-orang-miskin.html

- Kompas, 2009. Uang BLT Habis buat Merokok, http://bisniskeuangan.kompas.com/read/2009/02/26/19191949/Uang.BLT.Habis.buat. Merokok

Appendix

\begin{tabular}{cccccc}
\hline Variables & Pooled & Poorest & Richest & Rural & Urban \\
\hline Household size & 4.37 & 2.59 & 5.3 & 4.22 & 4.56 \\
Education of HH Head & 6.34 & 2.68 & 10.78 & 4.86 & 8.04 \\
Age of Household Head & 51.12 & 59.01 & 50.55 & 51.09 & 51.15 \\
$\begin{array}{c}\text { Proportion of Male } \\
\quad \text { Headed }\end{array}$ & 0.80 & 0.56 & 0.88 & 0.81 & 0.79 \\
Proportion of Farm & 0.40 & 0.46 & 0.19 & 0.62 & 0.15 \\
$\quad$ Household & 294658.2 & 119802.4 & 905482.6 & 225928.4 & 376758 \\
Income per capita & & & & & \\
\hline
\end{tabular}

Table 1. Summary Statistics of Selected Demographic Characteristics 


\begin{tabular}{cccccc}
\hline & All & Poorest & Richest & Urban & Rural \\
& Samples & & & & \\
\hline Staple & 0.7564 & 1.0152 & 0.8623 & 0.7866 & 0.7566 \\
& $(0.0083)$ & $(0.0424)$ & $(0.0356)$ & $(0.0135)$ & $(0.0104)$ \\
Vegetables & 1.0532 & 0.9967 & 0.8380 & 1.0362 & 1.0659 \\
& $(0.0094)$ & $(0.0639)$ & $(0.0288)$ & $(0.0164)$ & $(0.0130)$ \\
Meat and Fish & 1.1475 & 1.0358 & 1.0494 & 1.0876 & 1.1771 \\
& $(0.0079)$ & $(0.0549)$ & $(0.0228)$ & $(0.0142)$ & $(0.0109)$ \\
Dairy & 1.3025 & 1.2800 & 1.1246 & 1.2017 & 1.4078 \\
& $(0.0140)$ & $(0.1240)$ & $(0.0377)$ & $(0.0779)$ & $(0.0208)$ \\
Oils & 0.8879 & 0.7960 & 1.0744 & 0.9292 & 0.8625 \\
& $(0.0115)$ & $(0.0712)$ & $(0.0511)$ & $(0.0220)$ & $(0.0151)$ \\
Adult Goods & 1.0667 & 1.3568 & 0.9849 & 1.0378 & 1.1030 \\
& $(0.0159)$ & $(0.1327)$ & $(0.0560)$ & $(0.1326)$ & $(0.0205)$ \\
Dried Food & 1.1586 & 0.9091 & 1.0876 & 1.1163 & 1.1097 \\
& $(0.0125)$ & $(0.1021)$ & $(0.0311)$ & $(0.1015)$ & $(0.0177)$ \\
Other & 0.9131 & 0.9138 & 1.0143 & 0.9160 & 0.9065 \\
& $(0.0070)$ & $(0.0465)$ & $(0.0241)$ & $(0.0118)$ & $(0.0094)$ \\
$\mathrm{N}$ & 15442 & 1408 & 1408 & 7189 & 8253 \\
\hline
\end{tabular}

Table 2. Expenditure Elasticities

\begin{tabular}{cccccc}
\hline & ll Samples & Poorest & Richest & Urban & Rural \\
\hline Staple & -0.7706 & -0.9473 & -0.8080 & -0.6827 & -0.8380 \\
& 0.0324 & 0.1081 & 0.1460 & 0.0642 & 0.0391 \\
Vegetables & -0.9580 & -1.0703 & -0.7772 & -0.8483 & -1.0297 \\
& 0.0160 & 0.0654 & 0.0488 & 0.0228 & 0.0231 \\
Meat and Fish & -1.0032 & -1.1402 & -1.1228 & -0.9202 & -1.0532 \\
& 0.0331 & 0.1510 & 0.0979 & 0.0496 & 0.0454 \\
Dairy & -0.9771 & -1.2391 & -1.0179 & -0.9419 & -0.9961 \\
& 0.0367 & 0.1786 & 0.0986 & 0.0542 & 0.0535 \\
Oils & -0.7367 & -0.7757 & -0.6215 & -0.7981 & -0.6891 \\
& 0.0292 & 0.0981 & 0.1221 & 0.0454 & 0.0390 \\
Adult Goods & -0.9451 & -1.2450 & -1.1954 & -0.7940 & -1.0255 \\
& 0.0438 & 0.1868 & 0.1439 & 0.1268 & 0.0526 \\
Dried Food & -0.9374 & -0.7680 & -0.9453 & -0.9649 & -0.9043 \\
& 0.0181 & 0.0954 & 0.0419 & 0.0411 & 0.0287 \\
Other & -0.9495 & -0.7258 & -0.8961 & -0.9037 & -0.9676 \\
& 0.0230 & 0.0874 & 0.0740 & 0.0357 & 0.0305 \\
$\mathrm{~N}$ & 15442 & 1408 & 1408 & 7189 & 8253 \\
\hline
\end{tabular}

Table 3. Marshallian Own Price Elasticity 


\title{
Cooperative Milk Farms of Germany: Position and Perspectives under the Conditions of Globalization
}

\author{
Igor Tonkoshkurov, Khakassia State University named after Nikolaj Katanov, \\ Russia
}

\begin{abstract}
The article considers the analysis of cooperative milk farms in German. Special attention is paid to influence of globalization on development of cooperative farms in the milk production. Cooperatives are going to become one of the most attractive forms of businesses. In German decreased the number of cooperatives during last decade. However their structure is getting more complicated and improved.
\end{abstract}

JEL code: Q13

\section{Introduction}

Traditionally, Germany has a considerable part of the world milk market. During the last decade (1999-2009) some changes took place in the processes around milk production, primarily structural changes. The main goal of this article is to research the current condition of cooperatives in German milk production and in so doing determine the major perspective their development.

Since the 1980s, structural issues began to develop in the German milk production process and throughout the EU. Milk production experiences pressure both from demand and supply. The supply in European Union includes about $15 \%$ of the total volume [1]. Arrangements of agrarian reform have led to a reduction of government assistance on the demand side. These occurrences complicate the position of producers of milk industry, and they can be compensated for by economic efficiency upgrading of production.

\section{Cooperative milk farms in Germany: Present situation}

Only cooperative enterprises have more opportunities in such situations because cooperatives have opportunity to reduce some costs rapidly on account of combined purchases of raw material and fodder, seeds, appointments, equipment, etc. Therefore the part of milk, which is processed by cooperative farms in Germany, increased $60 \%$ in recent years [2]. At that time the number of cooperative milk enterprises processing milk was reduced by $50 \%$. Cooperatives take part in more profound specialization and cooperation of production. Such enterprise structures combined with the practice of varied forms of creation, process and sale of production is more economical. The three global factors for the consolidation of the milk industry are as follows:

- first, cost reduction by combined purchases of raw material and fodder, seeds, appointments, equipment;

- $\quad$ second, development and appearance of new markets; big producers unite different national markets under one „roof" of their enterprise, which allows the optimization of research-and-development spending and business expansion schemes as well as the reduction of marketing and advertising costs. Such big corporations have a significant part of the global market, a considerable client base, and excellent reputations; therefore, it is difficult for separate enterprises to enter new markets without taking part in the process of cooperation;

- and, third, the necessity of continual innovation. The strongest competition in the global markets require the German producers of milk products to continually refine 
the production process, as well as the production of new kinds of milk products. This requires big investments that separate small and mid-sized enterprises cannot put into practice. Only big producers have an opportunity to invest in innovative projects and productive-technological research initiatives. For that matter cooperative unions render considerable assistance to their members by supporting scientific-practical symposiums and conferences, workshops, flows of technological knowledge, and so on.

Data about the cooperative German farms are showed in table 1. The federal state of Bavaria (the regional union is located in Munich) has remained the milk production center for many years. However it is of note that the role of regional unions in the federal states of NordrheinWestfalen (Munster) and Niedersachsen (Hannover) increased greatly during the last decade. Institut für Genossenschaftswesen im Centrum für Angewandte Wirtschaftsforschung Westfälische Wilhelms-Universität (The Institute of Cooperation at the University of Münster) provides the greatest contribution in the development of cooperation in agriculture and the milk industry. This Institute manages many production projects and collaborates actively with regional enterprises and associations.

\begin{tabular}{|l|c|c|c|c|c|}
\hline $\begin{array}{c}\text { Regional } \\
\text { Union }\end{array}$ & $\begin{array}{c}\text { Milk } \\
\text { working } \\
\text { enterprises }\end{array}$ & $\begin{array}{c}\text { Delivery } \\
\text { cooperatives of } \\
\text { milk products }\end{array}$ & $\begin{array}{c}\text { Other } \\
\text { Products } \\
\text { and Costs }\end{array}$ & Total & $\begin{array}{c}\text { Return } \\
\text { (million } \\
\text { euro) }\end{array}$ \\
\hline Hannover & 20 & 26 & 10 & 56 & 3.664 \\
\hline Oldenburg & 2 & 4 & 3 & 9 & 461 \\
\hline Munster & 3 & 4 & & 7 & 3.298 \\
\hline Karlsruhe & 1 & 2 & 4 & 7 & 200 \\
\hline Stuttgart & 6 & 22 & & 28 & 851 \\
\hline Munich & 28 & 147 & & 175 & 2.286 \\
\hline Dresden & 2 & 6 & & 8 & - \\
\hline Total: & 62 & 211 & 17 & 290 & 10.760 \\
\hline
\end{tabular}

Table 1 The quantity of cooperative milk enterprises and their return in year 2008, by region [3]

Five enterprises compose over $70 \%$ of the German cooperative dairy market (table 2 ). The biggest corporation is Bremen's «Nordmilch», which has more than one-quarter of the entire return.

\begin{tabular}{|l|c|}
\hline \multicolumn{1}{|c|}{ Kind of enterprise-member of cooperation } & Return (million euro) \\
\hline Milk process enterprises & 10.031 \\
\hline including: & 2.522 \\
\hline Nordmilch AG, Bremen & 2.200 \\
\hline Humana Milchunion eG, Eversvinkel & 1.240 \\
\hline Hochwald Nahrungsmittel GmbH, Talfang & 1.000 \\
\hline Bayernland eG, Nurnberg & 619 \\
\hline Milchunion Hocheifel eG, Pronsfeld & 729 \\
\hline Milk production delivery cooperatives & 10.760 \\
\hline Total: & \\
\hline
\end{tabular}

Table 2 Return of cooperative milk farms by enterprise for 2008 [4]

During 1999-2008, the number of dairy farmers reduced significantly - over 39\% - through processes of conglomeration. This reduction involved both large enterprises and individual dairy farms. In spite of total reduction of milk cows by $12 \%$, the quantity of cows per owner increased by an average of $44 \%$ [5]. This fact witnessed the integration of milk production enterprises and reduction of individual farms and private households. Theoutput of milk and 
milk products was reducedas the number of dairy farms and cattle declined. This was connected with increase in the productivity of the milk market by $19 \%$ from 1999 until 2009. Also it is of note that dairy consumption grew $13 \%$. Furthermore, there was an increase in the output of sour-milk products $(16 \%)$ and cheeses $(25 \%)$. At the same time a reduction took place in the production of condensed milk (by $+25 \%$ ), butter (by - $5 \%$ ) and milk products (by - 31\%) [6]. The biggest rate of increase was in the production of sour-milk products (such as milk drinks, kefir, yogurts, puddings, and so on) in these latter years.

\section{Globalization of the milk production}

The conditions of globalization provide for the continual expansion of sales areas. The main consumers of EU milk productions include the USA, Russia, Algeria, Saudi Arabia, Japan and Switzerland. According to experts' evaluations, by the year 2050 the number of world inhabitants will approach 9 billion people. In connection with the main centers of demographic growth, situated in Africa and Asia, cooperatives have to displace priorities in global sales to these regions. During the period of 2004 until2008, the export of milk production from the EU to Russia, Indonesia and China nearly doubled. As for other countries, their return volumes did not indicate considerable change.

If the global market continues at the same rate as 2009 , it could overcome the deficit of years from 2004 to 2006, when the consumption of milk production exceded their production. During 2001-2008, milk output increased by 944 million ton (13.8\%), and in consumption of 909 million $(13.37 \%)$. Per capita milk consumption increased as well. Underdeveloped regions in Asia, Africa and Latin America remains low with a ration of $0.28 \mathrm{~kg}$ per day per man.

\begin{tabular}{|c|c|c|c|c|c|c|c|c|}
\hline Rate & $\begin{array}{l}200 \\
1\end{array}$ & $\begin{array}{l}200 \\
2\end{array}$ & $\begin{array}{l}200 \\
3\end{array}$ & $\begin{array}{l}200 \\
4\end{array}$ & $\begin{array}{l}200 \\
5\end{array}$ & $\begin{array}{l}200 \\
6\end{array}$ & $\begin{array}{l}200 \\
7\end{array}$ & $\begin{array}{l}200 \\
8\end{array}$ \\
\hline $\begin{array}{l}\text { Production } \\
\text { (million ton) }\end{array}$ & $\begin{array}{l}589 \\
6\end{array}$ & $\begin{array}{l}601 \\
9\end{array}$ & $\begin{array}{l}614 \\
6\end{array}$ & $\begin{array}{l}626 \\
0\end{array}$ & $\begin{array}{l}645 \\
1\end{array}$ & 6612 & $\begin{array}{l}671 \\
0\end{array}$ & $\begin{array}{l}684 \\
0\end{array}$ \\
\hline $\begin{array}{l}\text { consumption } \\
\text { (million ton) }\end{array}$ & $\begin{array}{l}589 \\
1\end{array}$ & $\begin{array}{l}598 \\
2 \\
\end{array}$ & $\begin{array}{l}614 \\
6 \\
\end{array}$ & $\begin{array}{l}627 \\
8 \\
\end{array}$ & $\begin{array}{l}647 \\
8 \\
\end{array}$ & 6631 & $\begin{array}{l}671 \\
0 \\
\end{array}$ & $\begin{array}{l}680 \\
0 \\
\end{array}$ \\
\hline $\begin{array}{l}\text { difference } \\
\text { (million ton) }\end{array}$ & +5 & +37 & $\overline{0}$ & -18 & -27 & -19 & 0 & +40 \\
\hline $\begin{array}{l}\text { per capita } \\
\text { consumption } \\
\text { (kg/year) }\end{array}$ & $\begin{array}{l}95 \\
8\end{array}$ & $\begin{array}{l}96, \\
1\end{array}$ & $\begin{array}{l}97, \\
5\end{array}$ & $\begin{array}{l}98, \\
4\end{array}$ & $\begin{array}{l}100 \\
4\end{array}$ & $\begin{array}{l}101 \\
6\end{array}$ & $\begin{array}{l}101, \\
6\end{array}$ & $\begin{array}{l}101 \\
7\end{array}$ \\
\hline
\end{tabular}

Table 3 Dynamics of production and consumption of milk in the world for years 2001-2008 [7]

At present, the role of government in regulation milk markets is significant (particularly in the determination milk quotas). The basic trend in development of the dairy industry in years to come is the reduction of state influence. Crucial arrangements in this direction include the reduction of trade obstacles (for example, imports) and markets liberalization. The arrangements at the level of the World Trade Organization have a special role in determining this direction.

It is necessary to note, that liberalization, in turn, leads to internationalization of markets around their geographic arrangements. It also increases the dependence of agrarian markets upon other markets (namely, energy and financial markets). Furthermore, we must always consider the instability and inequality of global markets. In this respect the cooperatives have to adapt their structures to market conditions and their various particularities. 


\section{Conclusion.}

Accordingly, only development of cooperative attitudes between enterprises in the process of globalization is a response to changing economic conditions. The cooperation leads to secure enterprises' juridical and economical independence in order to compete with the biggest producers successfully. In this context it is important to note, that the amalgamation of businesses is dependent uponcost-benefit analyses. The amalgamation process needs particular transaction costs, including costs for legal and advisory services, audit, valuation of assets, elaboration of social plans for personnel, and so on. Therefore it is necessary to understand the current situation by careful research of enterprises and trends in their development, all the while considering the process of development of regional and global markets, as well as the state of current world finances.

The main recommendations for further development of milk cooperative farms in Germany under the conditions of globalization are as follows: 1) further perfection of production quality; 2) reduction of production unit quantity; 3) search of new markets; and 4) selection of most effective sales area. The preservation of long-term competitive ability of milk cooperative farms, as well as of meat farms, is connected with considerable investments. Buildup of ownership capital therein acquires the paramount meaning.

\section{References}

- M. Nüssel „Mehr Markt in der Agrarwirtschaft. Herausforerungen und Konsequenzen für die Raiffaisen-Genossenschaften“, Zeitschrift für das gesamte Genossenschaftswesen. - 2006. - Band 56, Heft 2, s. 170.

- M. Nüssel „Mehr Markt in der Agrarwirtschaft. Herausforerungen und Konsequenzen für die Raiffaisen-Genossenschaften“, Zeitschrift für das gesamte Genossenschaftswesen. - 2006. - Band 56, Heft 2, s. 170.

- „Milchmarkt im Umbruch - Situation und Perspektiven aus Sicht der genossenschaftlichen Milchwirtschaft", in Deutscher Raiffeisenverband e. V., Hohenheim, 2009.

- „Milchmarkt im Umbruch - Situation und Perspektiven aus Sicht der genossenschaftlichen Milchwirtschaft", in Deutscher Raiffeisenverband e. V., Hohenheim, 2009.

- $\quad$ Statistische Daten - Wirtschaftliche Bedeutung, http://raiffeisen.de.

- Geschäftsbericht 2008, in Deutscher Genossenschafts- und Raiffeisenverband e.V., Berlin, 2009.

- „Milchmarkt im Umbruch - Situation und Perspektiven aus Sicht der genossenschaftlichen Milchwirtschaft", in Deutscher Raiffeisenverband e. V., Hohenheim, 2009. 


\section{Author Index}

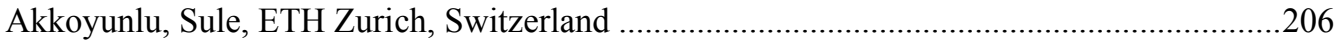

Akramov, Kamiljon, International Food Policy Research Institute, USA …….......................433

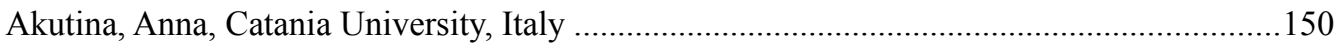

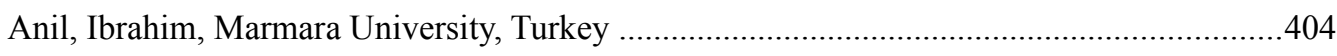

Anil Keskin, Duygu, Istanbul University, Turkey ...............................................................404

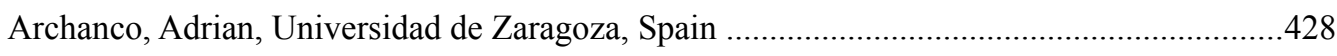

Ascarya, Ascarya, Central Bank of Indonasia, Indonesia .....................................................252

Ay, Ahmet, Selçuk University, Turkey ………...........................................................14, 289

Aykaç Alp, Elçin, Yıldız Technical University, Turkey ......................................................... 191

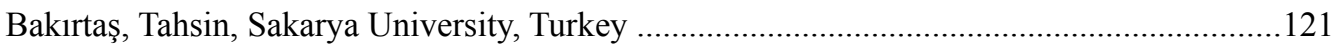

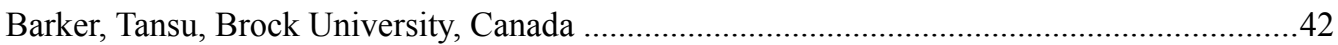

Başdaş, Ülkem, Middle East Technical University, Turkey .......................................................92

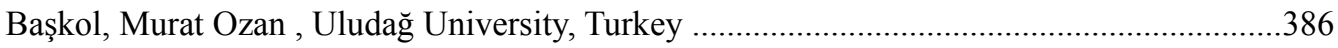

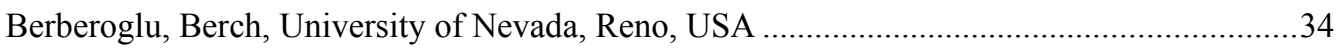

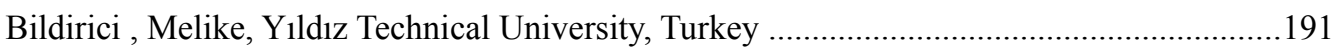

Birol, Özlen Hiç, Boğazici University, Turkey ………......................................................... 110

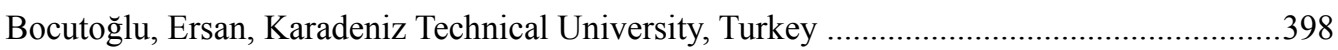

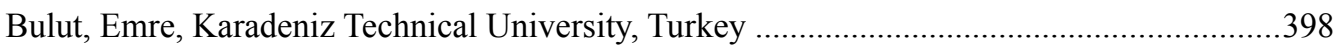

Canel, Cem, University of North Carolina, Wilmington, USA …............................................404

Çelik, Ahmet Alkan, Beykent University, Turkey ................................................................. 136

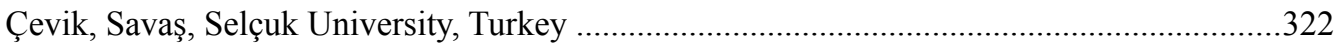

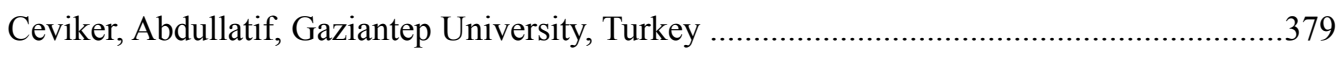

Chernishev, Michail, South Federal University, Russia .........................................................439

Chiran, Ruxandra Ionela, Bucharest Academy of Economic Studies, Romania ..................... 143

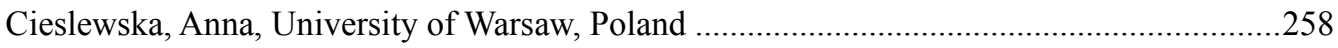

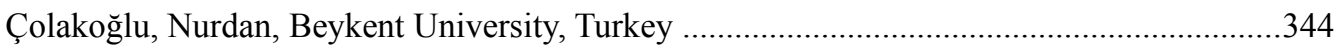

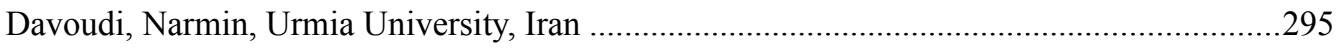

Dedeoğlu, Dinçer, Bahçeşehir University, Turkey ....................................................................129

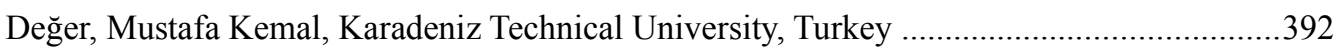

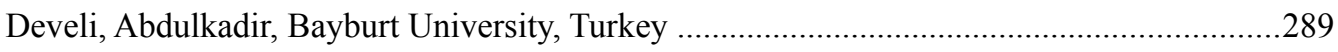

Djurovic, Gordana, University of Montenegro, Montenegro ...............................................201

Elmas, Bekir, Erzurum Atatürk University, Turkey .............................................................. 183

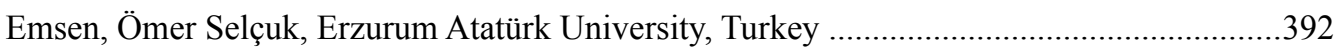

Erdoğan, Savaş, Selçuk University, Turkey ……………........................................................ 14

Erzurumlu, Ömer Yaman, Doğus University, Turkey ...........................................................232

Esen, Ömer, Erzurum Atatürk University, Turkey ................................................................. 183



Ganiyev, Junus, Kyrgyz-Turkish Manas University, Kyrgyzstan ............................................ 82

Gazioğlu, Şaziye, University of Aberdeen, United Kingdom ................................................92

Gedikli, Ayfer, Kırklareli University, Turkey ..................................................................... 173

Gerçeker, Mustafa, Selçuk University, Turkey ..................................................................... 14 


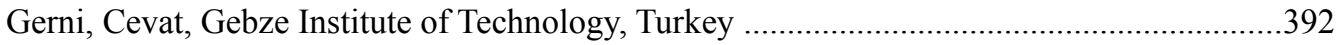

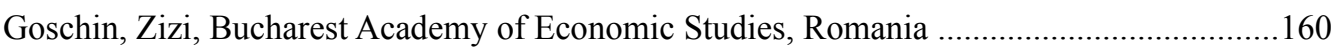

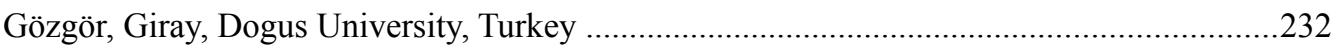

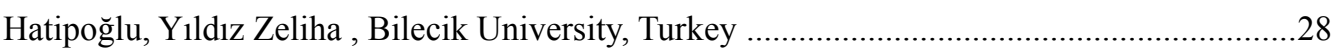

Haydaroğlu, Ceyhun, Bilecik University, Turkey ………....................................................217

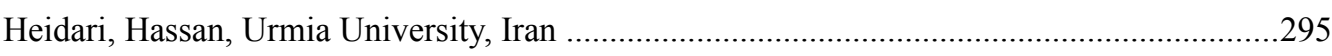

İkizlerli, Deniz, Durham University, United Kingdom ......................................................240

Ileanu, Bogdan, Bucharest Academy of Economic Studies, Romania .....................................154

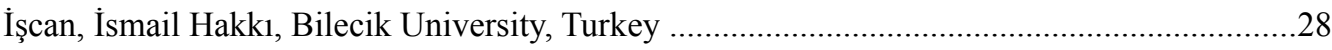

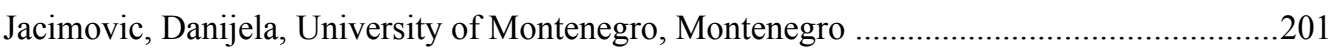

Japarova, Damira, Kyrgyz-Turkish Manas University, Kyrgyzstan ........................................367

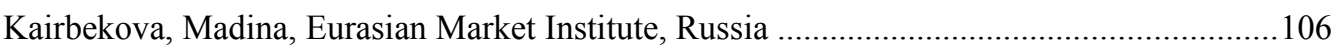

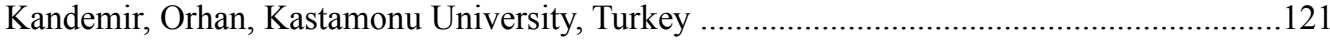

Karaağaç, Alper, Okan University, Turkey .......................................................23, 115, 277

Karaalp, Hacer Simay, Pamukkale University, Turkey ......................................................... 315

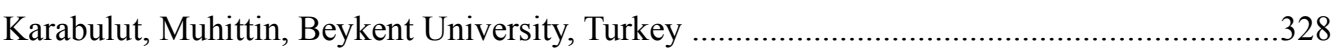

Karabulut, Tuğba, Istanbul Commerce University, Turkey ……..........................................328

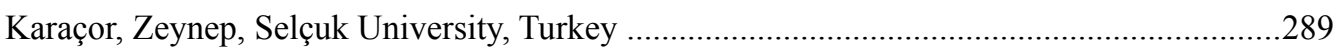

Karapınar, Esra, Zirve University, Turkey ..................................................................... 75

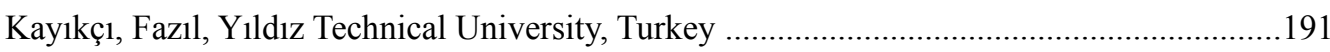

Kıdıraliyev, Sirgak, American University of Central Asia, Kyrgyzstan .................................373

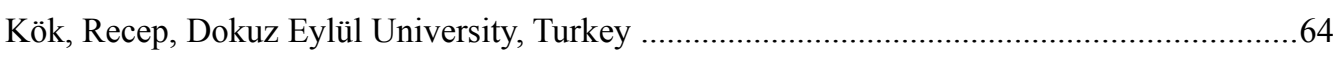

Koychuev, Turar, Kyrgyz-Turkish Manas University, Kyrgyzstan .........................................351

Kuznesov, Nicolay, Rostov State University of Economics, Russia ........................................439

Marşap, Akın, Istanbul Aydin University, Turkey ..........................................................5, 207

Mukhammedov, Abu, University of International Business, Kazakhstan .................................106

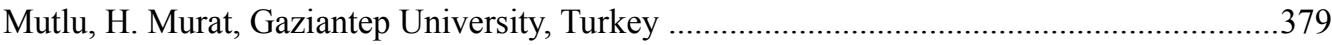



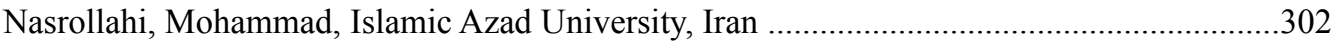

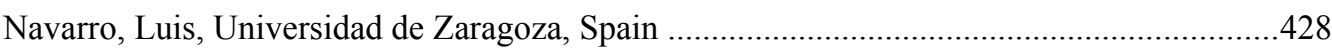

Önden, Ismail, Okan University, Turkey ………............................................23, 115, 277



Orlova, Valentina, Donetsk National University of Economics and Trade, Ukraine ................361



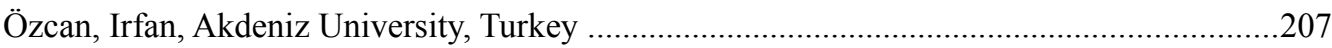

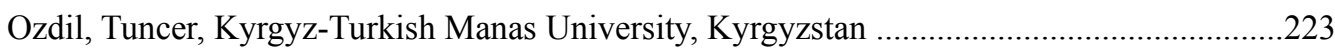

Özer, Bilal, Okan University, Turkey ….........................................................23, 115, 277

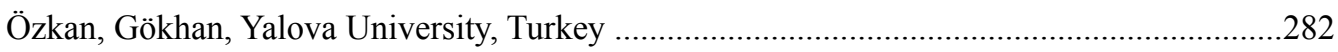



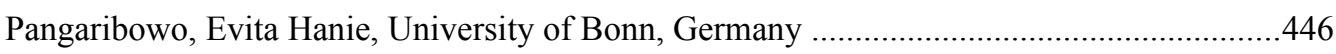

Pastor, Ana Clara, Universidad de Zaragoza, Spain .............................................................428

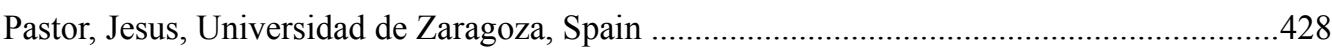


Pirimbayev, Jusup, Kyrgyz-Turkish Manas University, Kyrgyzstan ........................................82

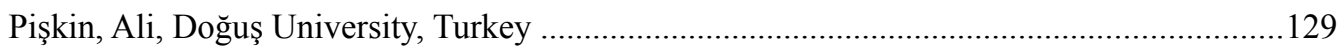

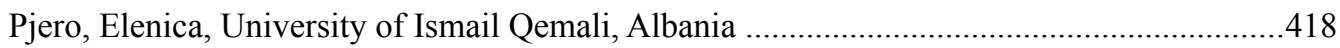

Polouček, Stanislav, VŠB-Technical University of Ostrava, Czech Republic ............................98

Popa, Aura, Bucharest Academy of Economic Studies, Romania ...........................................160

Rad, Nataliya, Donetsk National University of Economics and Trade, Ukraine ......................247

Rapkova, Iveta, Silesian University, Czech Republic ..........................................................412

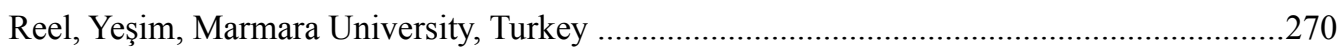

Roman, Mihai, Bucharest Academy of Economic Studies, Romania ............................154, 160

Roman, Monica, Bucharest Academy of Economic Studies, Romania ....................................154

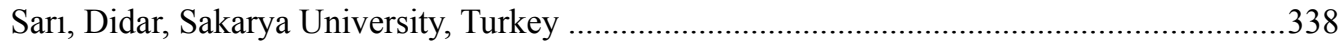

Sarı, Selahattin, Beykent University, Turkey .........................................................136, 392

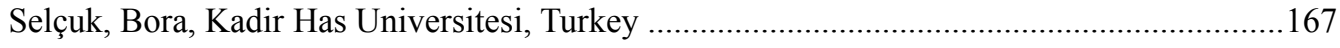

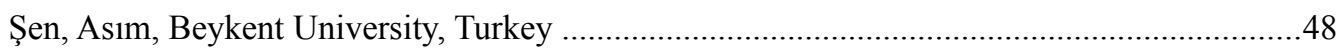

Shyle, Irma, Polytechnic University of Tirana, Albania ........................................................

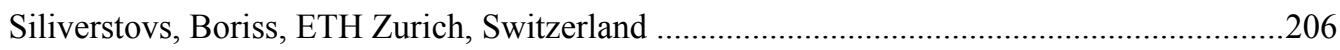

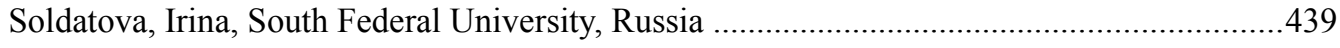

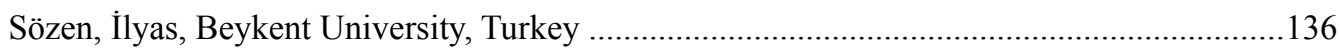

Stavarek, Daniel, Silesian University, Czech Republic .......................................................412

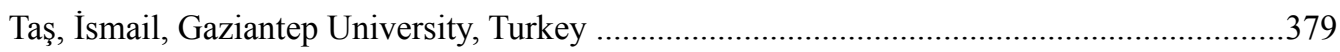

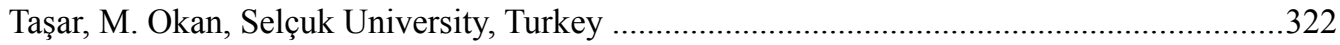

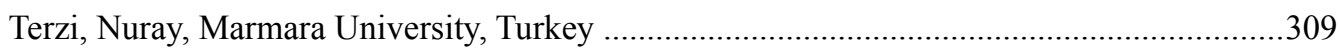

Tonkoshkurov, Igor, Khakassia State University named after Nikolaj Katanov, Russia .........453

Turdalieva, Ainura, Kyrgyz-Turkish Manas University, Kyrgyzstan .....................................223

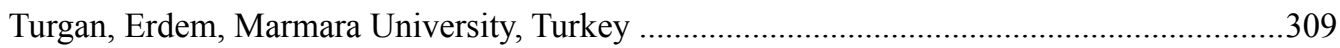

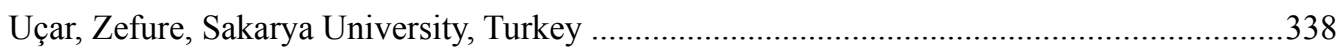

Ulku, Numan, Central European University, Hungary ......................................................240

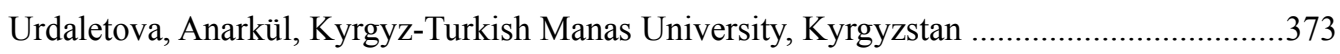

Wieslhuber, Carmen, University of Regensburg, Germany ...................................................59

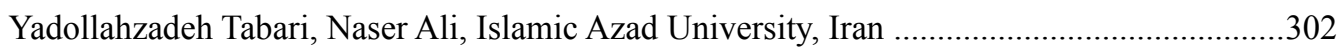

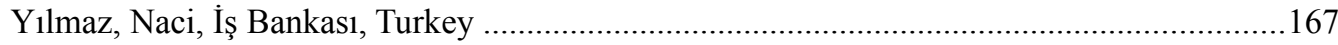

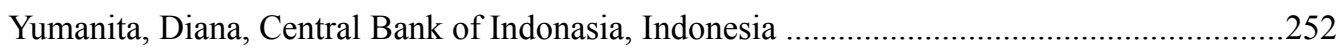

Zarplı, Çağdaş, Bilecik University, Turkey ………............................................................217

Zeynalov, Vidadi, Azerbaijan State Economic University, Azerbaijan .....................................264 
